Petroleum Geology of the

Northern Part of the

Arctic National Wildlife Refuge,

Northeastern Alaska

U.S. GEOLOGICAL SURVEY BULLETIN 1778

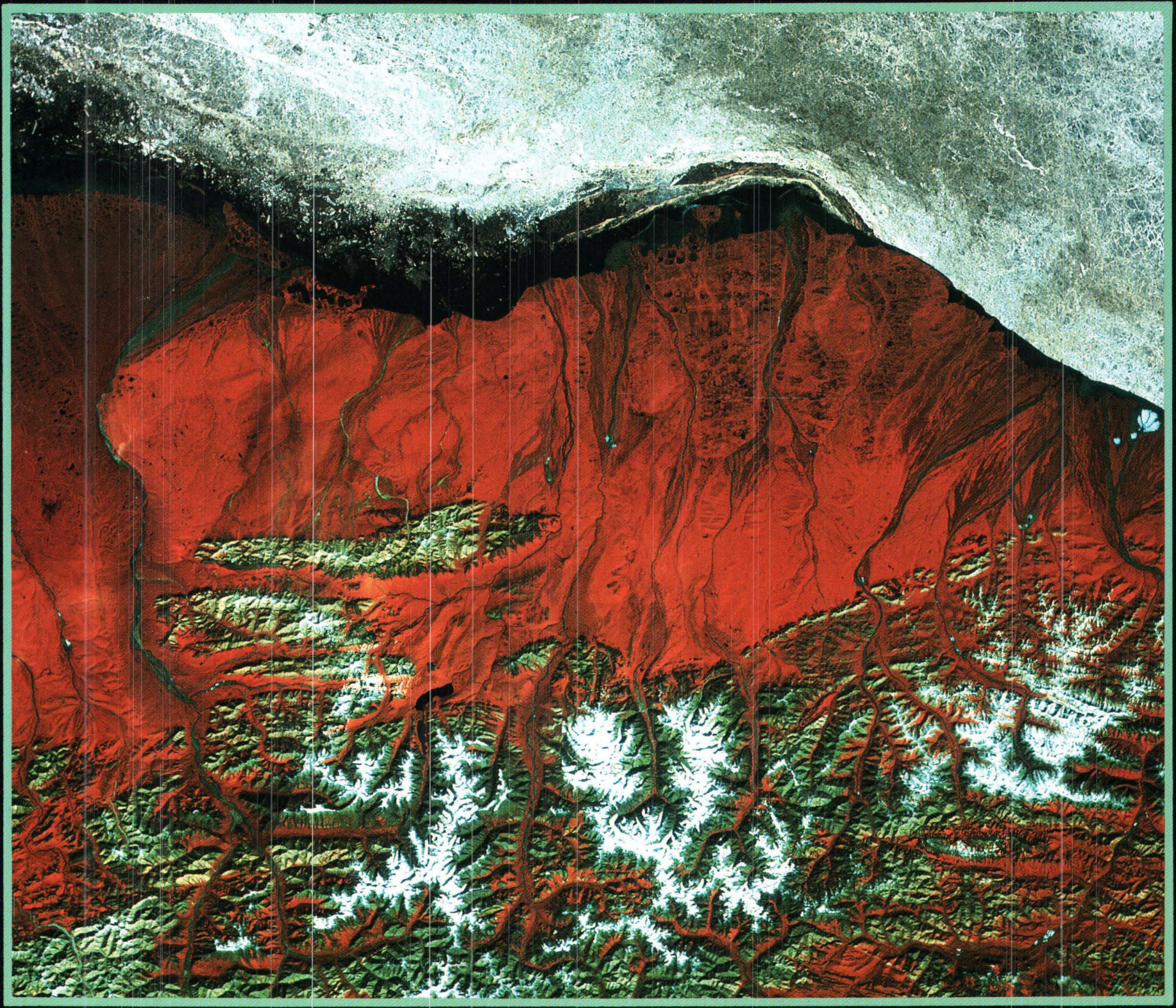




\section{COVER}

Most of the northern part of the Arctic National Wildlife Refuge between the Canning River (left) and the Kongakut River (right) is shown in this five-scene Landsat digital mosaic image. Scale is approximately 1:1 140000 ( 1 inch $=18$ miles). The highest peaks in the entire Brooks Range are shown here (snow-capped mountains, lower center) adjacent to the foothills, coastal plain (including the 1002 area), and ice-covered Beaufort Sea (top). Landsat multispectral scanner bands 421 were used to produce this color infrared composite image, provided by William Acevedo, Geographic Investigations Section, Western Mapping Center, U.S. Geological Survey, Menlo Park, California. 
Petroleum Geology of the Northern Part of the Arctic National Wildlife Refuge, Northeastern Alaska

KENNETH J. BIRD and LESLIE B. MAGOON, Editors 


\section{DEPARTMENT OF THE INTERIOR}

DONALD PAUL HODEL, Secretary

\section{U.S. GEOLOGICAL SURVEY}

Dallas L. Peck, Director

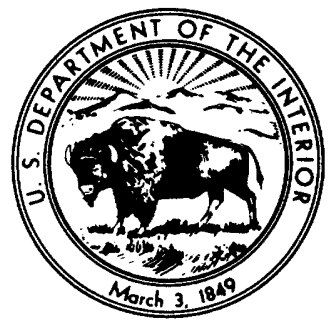

For sale by the

Books and Open-File Reports Section

U.S. Geological Survey

Federal Center, Box 25425

Denver, CO 80225

Library of Congress Cataloging-in-Publication Data

Petroleum geology of the northern part of the Arctic National

Wildlife Refuge, northeastern Alaska.

(U.S. Geological Survey Bulletin 1778)

Bibliography

Includes Index

1. Petroleum-Geology-Alaska-Arctic National Wildlife

Refuge. I. Bird, Kenneth J. II. Magoon, Leslie B. III. Series.

QE75.B9 No. 1778

[TN870.5]

$557.3 \mathrm{~s}$

$87-600246$

$\left[553.2^{\circ} 82^{\circ} 097986\right]$ 


\section{FOREWORD}

The mission of the U.S. Geological Survey is to provide up-to-date geologic, topographic, and hydrologic information that can contribute to the wise management of the nation's natural resources and promote the health, safety, and well-being of its people. In keeping with our mission, this report sets out the petroleum geology data used in assessing the oil and gas resources of the coastal plain (1002 area) portion of the Arctic National Wildlife Refuge (ANWR) in northeastern Alaska.

In the Alaska National Interest Lands Conservation Act (ANILCA) of 1980, Congress called for a detailed and comprehensive evaluation of the fish and wildlife and energy values of the 1002 area, which contains about 8 percent of the total area of the ANWR. Specifically, the ANILCA authorized the Secretary of the Interior:

1. To conduct a comprehensive, continuing baseline study of the fish and wildlife resources of the 1002 area,

2. To develop guidelines for, initiate, and monitor a surface geological and seismic exploration program for oil and gas, and

3. To prepare a report to Congress that would describe the fish and wildlife resources of the 1002 area; identify and estimate the volume and area of potential hydrocarbon resources; assess the potential impact of development; discuss the transportation of oil and gas; review the national need for domestic sources of oil and gas; and recommend whether further exploration, development, and production of oil and gas should be allowed, and if so, what additional legal authority is necessary to avoid or minimize adverse effects on the environment.

The Geological Survey and the Bureau of Land Management, through a formal agreement, assisted the Fish and Wildlife Service, which is the lead agency in the evaluation of the ANWR. The former two agencies provided technical expertise in reviewing industry-proposed geophysical and geological exploration plans, in conducting geologic studies, in assessing the hydrocarbon potential of the 1002 area, and in compiling the formal report to Congress, which contained a brief and nontechnical summary of the geology and resource assessment of the coastal plain.

This publication is offered as a supplement to the Secretary of the Interior's report to Congress. Together with a separately published geologic map of the northern part of the ANWR (Bader and Bird, 1986), it provides the complete and detailed technical information that was only summarized in the congressional report. Its 23 individually authored chapters, by scientists of the Geological Survey and the Bureau of Land Management, are based on studies conducted over a five year period. The authors not only give the detailed geologic information developed and utilized in the oil and gas resource assessment, but also provide a description of assessment techniques and results. Also included are govemment interpretations of selected raw data from the industry seismic exploration program-a program authorized by the ANILCA and regulated by the Fish and Wildlife Service.

Finally, all of these studies derive from a foundation of geologic knowledge and information representing nearly eight decades of investigations in northeastern Alaska, primarily by the Geological Survey and for a variety of goals within our mission.

Dallas L. Peck

Director 


\section{CONTENTS}

Foreword, by Dallas L. Peck III

Abstract, by Kenneth J. Bird and Leslie B. Magoon 1

Chapters

1. Introduction $\mathbf{3}$

Comelius M. Molenaar

2. Principles of petroleum geology and exploration methods 7

Cornelius M. Molenaar

3. Regional geologic setting and history of petroleum exploration $\mathbf{1 7}$

Kenneth J. Bird and Jeffrey W. Bader

4. Surficial geology, permafrost, and physical processes 27

Max C. Brewer

5. Stratigraphy 37

Kenneth J. Bird and Cornelius M. Molenaar

6. Quaternary seismic stratigraphy of the inner continental shelf north of the

Arctic National Wildlife Refuge 61

Stephen C. Wolf, Peter W. Barnes, Douglas M. Rearic, and Erk Reimnitz

7. Petroleum reservoir rocks $\mathbf{7 9}$

Kenneth J. Bird, Sarah B. Griscom, Susan Bartsch-Winkler, and Dennis M. Giovannetti

8. Petrography and diagenesis of the Ledge Sandstone Member of the Triassic

Ivishak Formation 101

Robert K. Marinai

9. Petrology of Cretaceous and Tertiary reservoir sandstones in the

Point Thomson area 117

Donald L. Gautier

10. Petrology and reservoir potential of the Jago River Formation $\mathbf{1 2 3}$

Hugh McLean

11. Thermal maturity, richness, and type of organic matter of source-rock units

Leslie B. Magoon, Phillip V. Woodward, Arthur C. Banet, Jr., Sarah B. Griscom, and Theodore A. Daws

12. Geochemistry of surface oil shows and potential source rocks

Donald E. Anders, Leslie B. Magoon, and Sister Carlos Lubeck

13. Relationship of clay mineralogy, thermal maturity, and geopressure in wells of the Point Thomson area 199

Donald L. Gautier, Kenneth J. Bird, and Virginia A. Colten-Bradley

14. Horizontal-gradient magnetic and helium surveys 209

Kimberley I. Cunningham, Alan A. Roberts, and Terrence J. Donovan

15. Gravity interpretation of the coastal plain 219

Stephen L. Robbins 
16. Seismic-reflection data processing 225

W. James Leinbach, Jr., John J. Miller, and Myung W. Lee

17. Seismic-reflection data acquisition, processing, and interpretation 235

Richard L. Foland and Douglas J. Lalla

18. Structure of pre-Mississippian rocks beneath the coastal plain

Michael A. Fisher and Terry R. Bruns

19. Regional structure of rocks beneath the coastal plain 249

Terry R. Bruns, Michael A. Fisher, W. James Leinbach, Jr., and John J. Miller

20. Structural style and framework geology of the coastal plain and adjacent Brooks Range 255

John S. Kelley and Richard L. Foland

21. Structure of the continental shelf north of the Arctic National Wildlife Refuge 271

Arthur Grantz, David A. Dinter, and Raymond C. Culotta

22. Assessment of in-place oil and gas resources 277

Gordon L. Dolton, Kenneth J. Bird, and Robert A. Crovelli

23. Economically recoverable oil resources 299

James E. Callahan, Gary W. Brougham, and Robert J. Bascle

References cited 309

Index 325

\section{PLATES}

[In pocket]

1. Well correlation sections showing selected data, northeastern Alaska.

2. Gravity and aeromagnetic maps of $\mathbf{1 0 0 2}$ area and vicinity, Arctic National Wildlife Refuge, Alaska.

3. Selected seismic lines, synthetic seismograms, and structural feature map on top of pre-Mississippian rocks, 1002 area, Arctic National Wildlife Refuge, Alaska.

4. Selected seismic lines across the 1002 area, Arctic National Wildlife Refuge, Alaska.

5. Generalized tectonic map and sections of the Sadlerochit and Shublik Mountains area, and seismic profiles 84-14 and 84-24, 1002 area, Arctic National Wildlife Refuge, Alaska.

\section{FIGURES}

1.1. Index maps showing ANWR and adjacent areas 4

2.1-2.4. Diagrams illustrating:

2.1. Geologic time scale 8

2.2. Sequences of hydrocarbon generation 9

2.3. Four types of hydrocarbon traps $\mathbf{1 1}$

2.4. Paths of seismic waves 13

2.5. Seismic profile example 14

3.1. Map of North Slope, Mackenzie Delta, and Beaufort Sea areas showing major structural features, rock sequences, and oil and gas fields 18

3.2. Columnar sections comparing the stratigraphy of the northern part of the ANWR, the Prudhoe Bay area, and the Mackenzie Delta area 21

3.3. Schematic cross sections of the North Slope and Mackenzie Delta 
4.1. Schematic diagram showing effect of surface features on distribution of permafrost

4.2. Map showing distribution of surficial deposits in the 1002 area 34

5.1. Stratigraphic column for the northem part of ANWR 38

5.2. Geologic map of the 1002 and adjacent areas showing locations of Cretaceous and Tertiary outcrops 39

5.3. Photographs of outcrops of Katakturuk Dolomite, Lisburne Group, pre-Mississippian basement complex, Kavik and Ledge Sandstone Members of Ivishak Formation, Kingak Shale, pebble shale unit, and Arctic Creek facies 41

5.4. Diagram showing Ellesmerian stratigraphic relations in ANWR 42

5.5-5.9. Photographs of outcrops showing:

5.5. Stratigraphy in Katakturuk Canyon, fossiliferous limestone and calcareous shale in lower part of Shublik Formation, and Karen Creek Sandstone 44

5.6. Type section of Kongakut Formation, pebble shale unit, Kemik Sandstone, and Ledge Sandstone Member of Ivishak Formation 46

5.7. Kemik Sandstone, Kingak Shale, pebble shale unit, Hue Shale, Paleocene(?) turbidites, and Katakturuk Dolomite 49

5.8. Pebble shale unit, Hue Shale, gamma-ray zone, and Inoceramus zone $\mathbf{5 0}$

5.9. Canning Formation turbidites and mudstone $\mathbf{5 2}$

5.10. Diagram showing Brookian stratigraphic relations in ANWR $\mathbf{5 4}$

5.11. Columnar section of Cretaceous and lower Tertiary(?) rocks in Ignek Valley 56

5.12. Correlation section from Ignek Valley to nearby wells $\mathbf{5 8}$

6.1-6.6. Maps of:

6.1. Study area 62

6.2. USGS tracklines in Canning River-Barter Island area

6.3. Geologic units on seafloor of Camden Bay 65

6.4. Contours on horizon $A^{\prime}$ in Camden Bay area 66

6.5. Subsurface structures northwest of Barter Island 67

6.6. USGS tracklines in Jago Lagoon-Demarcation Bay area

Seismic profiles showing:

$6.7-6.10$.

6.7. Area northwest of Demarcation Bay along trackline 26-83 68

6.8. Area northeast of Barter Island, using uniboom data from trackline 34-81 and $7 \mathrm{kHz}$ data from trackline $33-81 \quad 69$

6.9. Middle inner shelf along trackline $35-81$, showing possible gas-charged sediments $\mathbf{7 0}$

6.10. Seaward-dipping reflections truncated at seafloor along tracklines 33-81 and 36-81 $\mathbf{7 1}$

6.11. Map of geologic units above horizon B along the inner shelf between Jago Lagoon and Demarcation Bay $\mathbf{7 2}$

6.12. Seismic profiles of possible Holocene sediment accumulations offshore along tracklines 35-81 and 36-81 73

6.13. Map of tracklines and thickness of Holocene(?) sediments in Demarcation Bay $\mathbf{7 4}$

6.14. Landsat imagery of Demarcation Bay area 75

6.15-6.17. Maps of:

6.15. Tracklines and thickness of Holocene(?) sediments in Beaufort Lagoon $\mathbf{7 6}$

6.16. Distribution and depth below sea level of horizon A between Jago Lagoon and Demarcation Bay $\mathbf{7 7}$

6.17. Locations of profiles A and B of figure $6.18 \quad 78$

6.18. Profiles A and B showing topographic gradient and its relation to horizon A 78

6.19. Cross section through Canning River delta and Flaxman Island $\mathbf{7 8}$

7.1. Map of Ellesmerian rocks subcropping beneath the Lower Cretaceous unconformity

7.2. Map of pre-Mississippian carbonate rocks in northeastern Alaska 86

7.3. Diagram showing correlations of pre-Mississippian (basement complex) rocks

7.4. Photograph and photomicrographs of potential reservoir rocks in ANWR 88

7.5. Map showing truncation and (or) onlap edge of Endicott Group 91

7.6. Map showing Lisburne Group isopachs in northeastern Alaska 92

7.7. Diagram showing correlations of Lisburne Group sections and well penetrations adjacent to ANWR coastal plain 93 
7.8. Map showing isopachs of the Ledge Sandstone Member, Ivishak Formation 95

7.9. Ternary diagram showing detrital grain composition of selected sandstone units 96

7.10-7.12. Maps showing:

7.10. Distribution and thickness of Karen Creek Sandstone in northeastern Alaska

7.11. Isopachs of Kemik Sandstone and Thomson sand of local usage in northeastern Alaska 97

7.12. Distribution of outcrops of Canning, Sagavanirktok, and Jago River Formations and thickness of Sagavanirktok Formation in northeastern Alaska 99

8.1. Map showing location of measured sections and wells 101

8.2. Diagram showing columnar stratigraphic sections of Ledge Sandstone Member 104

8.3. Ternary diagrams of detrital grain composition of Ledge Sandstone Member 105

8.4. Photomicrographs of the Ledge Sandstone Member 106

8.5. Diagram showing burial history of the Ivishak Formation and diagenetic history of the Ledge Sandstone Member 107

8.6-8.8. Photomicrographs of the Ledge Sandstone Member showing:

8.6. Siderite and quartz/chert dissolution $\mathbf{1 1 0}$

8.7. Enhanced porosity caused by siderite dissolution $\mathbf{1 1 2}$

8.8. Pore space filled by authigenic quartz, kaolinite, ankerite, and dead oil 114

9.1-9.3. Scanning electron micrographs of:

9.1. Clean, well-sorted, highly porous reservoir sandstone of the Thomson sand of local usage 118

9.2. Monocrystalline quartz in the Thomson sand of local usage 119

9.3. Detrital dolomite in the Thomson sand of local usage 119

9.4. Ternary diagram showing framework mode for Canning Formation sandstones

9.5. Ternary diagram showing proportions of lithic fragments for sandstones of the Canning Formation 121

10.1. Ternary diagrams showing detrital grain compositions of Jago River Formation sandstones 124

10.2. Photomicrographs of Jago River Formation sandstones $\mathbf{1 2 5}$

11.1. Flow chart of geochemical analyses included in this report 128

11.2. Van Krevelen diagram used to determine type of organic matter 129

11.3. Diagram showing stages of thermal organic evolution $\mathbf{1 3 0}$

11.4. Graphs used to evaluate the amount, type, and stage of organic matter $\mathbf{1 3 0}$

11.5. Map showing thermal maturity of the pebble shale unit 133

11.6. Diagrams summarizing the organic geochemistry of the Shublik Formation

11.7. Diagrams summarizing the organic geochemistry of the Kingak Shale 138

11.8. Geochemical analyses of the Ignek Valley section $\mathbf{1 3 9}$

11.9-11.11. Diagrams summarizing the organic geochemistry of the:

11.9. Pebble shale unit 140

11.10. Hue Shale 142

11.11. Canning Formation $\mathbf{1 4 4}$

11.12. Diagram showing vitrinite reflectance, geothermal gradients, and hydrocarbon thresholds for eight wells in the Point Thomson area 147

11.13. Lopatin diagram showing time of thermal maturity for Point Thomson area 149

11.14. Lopatin diagram showing time of thermal maturity for the Kavik area 151

11.15. Map showing maturity levels on the pre-Mississippian unconformity in the northern ANWR area 152

12.1. Map showing locations of outcrop samples in this study $\mathbf{1 8 3}$

12.2. Map showing locations of oil samples in this study $\mathbf{1 8 4}$

12.3. Map showing surface and subsurface oil and gas occurrences, stratigraphic column showing position of oil seeps and oil-stained rocks, and diagram comparing API oil gravity with gas-oil ratio (GOR) in the Point Thomson area 185

12.4. Chromatograms for immature and mature rocks 190

12.5. Plot of $\mathrm{C}_{15+}$ hydrocarbon content versus organic-carbon content for ANWR rocks 192

12.6. Chromatograms for ANWR oils 194

12.7. Ternary diagram comparing distributions of saturate hydrocarbons, aromatic hydrocarbons, and nonhydrocarbons in ANWR oils 196 
12.8-12.10. Plots of:

12.8. $\delta^{13} \mathrm{C}$ aromatic hydrocarbons versus $\delta^{13} \mathrm{C}$ saturate hydrocarbons and $\delta^{13} \mathrm{C}$ saturate hydrocarbons versus $\mathrm{C}_{19} / \mathrm{C}_{23}$ tricyclic terpane ratio 197

12.9. $\delta^{13} \mathrm{C}$ saturate hydrocarbons versus saturate hydrocarbons / aromatic hydrocarbons ratio 198

12.10. Hopane $/ C_{23}$ tricyclic terpane ratio versus $C_{19} / C_{23}$ tricyclic terpane ratio 198

13.1-13.3. Diagrams showing:

13.1. Well logs, mud weights, acoustic transit times, and bottomhole temperatures of Point Thomson Unit-1 well 200

13.2. Well logs, mud weights, acoustic transit times, and bottomhole temperatures of Point Thomson Unit-2 well 201

13.3. Vitrinite reflectance and temperature of maximum pyrolytic yield with depth in Point Thomson Unit-1 well 204

13.4. X-ray diffractogram of tuff or tuffaceous shale from Point Thomson Unit-2 well 205

13.5. Diagram showing relative abundances of clay minerals in the Point Thomson Unit-1 and Unit-2 wells 206

13.6. X-ray diffractograms of shales from Point Thomson Unit-1 and Unit-2 wells 207

14.1-14.7. Maps of 1002 area showing:

14.1. Areas of helium and magnetic surveys 210

14.2. Sample localities for helium survey 212

14.3. Contours of helium concentrations in permafrost greater than two standard deviations above backround 213

14.4. Contours of helium concentrations in permafrost with possible fault anomalies removed 214

14.5. Regional helium gradient contours 215

14.6. Contours of first-order residuals above regional helium gradient 216

14.7. Comparison of first-order residual helium with longitudinal-difference magnetic anomalies 217

15.1. Diagram showing rock density averages by stratigraphic unit from 14 wells 221

15.2-15.7. Gravity models showing observed and calculated values along:

15.2. Profile $A-A^{\prime} \quad \mathbf{2 2 2}$

15.3. Profile $B-B^{\prime} \quad \mathbf{2 2 2}$

15.4. Profile $C-C^{\prime} \quad 223$

15.5. Profile $D-D^{\prime} \quad 223$

15.6. Profile $E-E$ ' 224

15.7. Profile $F-F^{\prime} \quad 224$

16.1. Flow chart of seismic processing by the USGS 227

16.2. Typical seismic-reflection field records 228

16.3. Illustration of common-depth-point gather 229

16.4. Earth models illustrating seismic velocity analysis with flat reflector and dipping reflector 229

16.5-16.7. Seismic displays of:

16.5. Velocity analysis for multivalued velocity problem $\mathbf{2 3 0}$

16.6. Velocity analysis for extremely good reflections 231

16.7. Stacked section 232

17.1. Map showing seismic line locations, wells, and land boundaries in the 1002 area

17.2. Seismic-reflection records showing noise bursts and noise suppression 238

17.3. Map showing outcrop limits of the Lower Cretaceous unconformity, the Marsh Creek anticline, and seismic line 84-14 239

17.4. Diagram showing development of Marsh Creek triangle zone 239

17.5. Map showing location of inferred erosional edges of the Endicott and Lisburne Groups 240

17.6. Diagram showing seismic response in the frozen-unfrozen coastal transition zone

18.1. Cross section from unmigrated seismic-reflection data in western 1002 area $\mathbf{2 4 6}$

18.2. Cross sections from unmigrated seismic-reflection data in western 1002 area $\mathbf{2 4 6}$

19.1. Map of ANWR showing structural zones and seismic lines processed by USGS 250

19.2. Diagram showing time-depth conversion curve of three wells 251 
19.3. Map showing near-surface structural trends in the Brookian sequence

20.1. Map showing study area in northeastern Alaska 256

20.2. Diagram showing stratigraphic position of major thrust faults 257

20.3. Map showing distribution of large anticlines cored by pre-Mississippian rocks $\quad 259$

20.4. Diagrams showing structural discontinuity along the pre-Mississippian unconformity 260

20.5. Diagrams showing the distribution of strata in the Marsh Creek and Sunset thrust sheets and generation of a duplex 260

20.6. Map showing areal distribution of the Kingak Shale $\mathbf{2 6 1}$

20.7. Photograph and sketch showing imbrication of the Kemik Sandstone 262

20.8. Diagram showing relations and nomenclature of a duplex 264

20.9. Photograph of footwall cutoff in the Kemik Sandstone 264

20.10. Diagram showing how the roof thrust could cut up-section 265

20.11. Diagram showing triangle zones produced by imbrication 265

20.12. Photograph of detachment folds in the Lisburne Group $\mathbf{2 6 8}$

20.13. Diagram showing the geologic relations across mountain front 269

21.1-21.4. Maps of northern Alaska and Beaufort Sea showing:

21.1. Major structural features $\mathbf{2 7 2}$

21.2. Structure contours on detachment-fault surface $\mathbf{2 7 3}$

21.3. Structure contours on late Eocene unconformity $\mathbf{2 7 4}$

21.4. Isopachs of late Wisconsin or Holocene sedimentary prism and location of Quaternary fold axes, active faults, and earthquake epicenters 275

21.5. Diagram showing average reflection time as a function of depth 276

22.1. Stratigraphic column showing interval of each of the seven plays assessed 278

22.2-22.8. Maps, generalized cross sections, assessment data forms, and estimated resources and pool sizes for:

22.2. Topset play $\mathbf{2 8 0}$

22.3. Turbidite play $\mathbf{2 8 1}$

22.4. Thomson/Kemik play 282

22.5. Undisturbed Pre-Mississippian play 284

22.6. Imbricate Fold Belt play 285

22.7. Folded Ellesmerian/Pre-Mississippian play 286

22.8. Undeformed Ellesmerian play $\mathbf{2 8 8}$

22.9. Data form for play-analysis method, annotated 289

22.10. Flow chart of analytic method of play analysis $\mathbf{2 9 0}$

22.11. Diagram showing a typical cumulative probability curve 291

22.12-22.14. Probability curves showing:

22.12. Estimated in-place oil and total gas resources of the 1002 area 292

22.13. Estimated in-place oil for each of the seven plays assessed 293

22.14. Estimated in-place gas for each of the seven plays assessed 293

22.15. Map and diagram showing land blocks A-D of the 1002 area and estimated in-place oil and gas resources 294

23.1. Input form for prospect-specific analysis $\quad \mathbf{3 0 0}$

23.2. Map showing seismically mapped prospects in the 1002 area 301

23.3. Flow chart showing reutine for PRESTO drilling simulation 304

23.4. Flow chart showing routine for calculating resources using PRESTO 305

23.5. Histogram showing conditional, economically recoverable resources of eight largest prospects compared with recoverable reserves in producing fields 307

\section{TABLES}

1.1. Exploratory wells drilled adjacent to ANWR 5

1.2. List of contractors and services rendered in the ANWR 1002 exploration program of 1984 and $1985 \quad 6$

3.1. Oil and gas discoveries through 1985 for the North Slope, Mackenzie Delta, and Beaufort Sea 
4.1. $\quad$ Extreme and average annual temperatures at Barter Island and Umiat 28

4.2. Average temperatures and thaw index, Barter Island and Umiat, 1976-84 28

4.3. Winter river water depths at selected locations in the 1002 area in $1973 \quad \mathbf{3 3}$

6.1. $\quad \mathrm{R} / \mathrm{V}$ Loon and R/V Karluk log data for seismic tracklines for the area from the Canning River to Demarcation Bay, Alaska (exclusive of side-scan sonar)

7.1. Summary of thickness determinations for selected stratigraphic units in northeastern Alaska $\mathbf{8 2}$

7.2. Summary of thickness, porosity, and permeability of potential reservoir rocks in and adjacent to the ANWR coastal plain 84

7.3. Fluid recovery from some potential reservoir rocks in wells adjacent to the ANWR coastal plain $\mathbf{8 5}$

7.4. Porosity and permeability measurements of carbonate rocks of the pre-Mississippian basement complex in and adjacent to ANWR 90

7.5. Porosity determinations of dolomite samples of the Lisburne Group from three measured sections in ANWR 94

7.6. Petrographic summary of selected sandstones in northeastern Alaska $\mathbf{9 8}$

8.1. Modal analyses from thin-section point counts of sandstone of the Ledge Sandstone Member of the Ivishak Formation 103

9.1. Names, locations, and cored intervals of wells sampled for this study 117

10.1. Compositional point-count data for the Jago River Formation 124

11.1. Wells adjacent to the ANWR for which geochemical data are available 132

11.2. Geochemical summary for outcrop and well information in and adjacent to the 1002 area for the Sadlerochit and Lisburne Groups and the Kayak Shale 134

11.3. Geochemical summary for well and outcrop information for the Shublik Formation in and adjacent to the 1002 area 136

11.4. Geochemical summary for well and outcrop information for the Kingak Shale in and adjacent to the 1002 area 137

11.5. Geochemical summary for well and outcrop information for the pebble shale unit in and adjacent to the 1002 area 141

11.6. Geochemical summary for well and outcrop information for the Hue Shale in and adjacent to the 1002 area $\mathbf{1 4 3}$

11.7. Geochemical summary for well and outcrop information for the Canning Formation in and adjacent to the 1002 area 145

11.8. Geochemical summary for well and outcrop information for the Sagavanirktok Formation in and adjacent to the 1002 area 146

11.9. Calculation of present-day time-temperature index (TTI) values for the Point Thomson Unit-1 well 148

11.10. Calculation of present-day time-temperature index (TTI) values for the Beli Unit-1 well 150

12.1. Geochemical data for rock outcrops, oil-stained outcrops and surface seeps in ANWR, and oil samples from the Prudhoe Bay area and NPRA 182

12.2. Oil and gas recovered from wells adjacent to ANWR 193

13.1. Subsurface fluid pressures measured during formation tests in two wells in the Point Thomson area 202

13.2. Subsurface temperatures for two wells in the Point Thomson area 202

13.3. Analyses performed on samples from two wells in the Point Thomson area $\mathbf{2 0 3}$

13.4. Abundance and ordering of clays from two wells in the Point Thomson area 203

14.1. Population statistics for helium concentrations measured in the ANWR coastal plain helium survey area $\mathbf{2 1 8}$

15.1. Densities derived from gamma-gamma density well logs in 14 wells adjacent to the ANWR that were used in modeling gravity profiles $A-A^{\prime}$ to $F-F^{\prime}$ in the 1002 area 222

16.1. Reflection seismic lines on and adjacent to the Arctic National Wildlife Refuge recorded and processed by GSI in 1984-1985 225

16.2. Dynamite recording parameters for the 1984 GSI seismic survey on and adjacent to the Arctic National Wildlife Refuge 226

16.3. Vibroseis recording parameters for the 1984 and 1985 GSI seismic surveys on and adjacent to the Arctic National Wildlife Refuge 226 
17.1. Parameters of seismic data acquisition in the ANWR area in 1984-1985

17.2. Wells utilized in determining formation velocities in the 1002 area 242

17.3. Formation velocities derived from analysis of acoustic logs from wells adjacent to the 1002 area $\mathbf{2 4 2}$

17.4. Time-depth conversion equation 243

22.1. Summary of 1985 USGS/BLM assessment of in-place oil and gas resources in the ANWR 1002 area 292

22.2. Comparison of estimated in-place oil and gas resources and pool sizes in ANWR coastal plain by the USGS in 1980 and 1985294

23.1. Data on petroleum prospects in the 1002 area $\mathbf{3 0 2}$

23.2. Reservoir volume parameters used in estimating recoverable oil in the 1002 area assessment $\quad \mathbf{3 0 3}$

23.3. Undiscovered, conditional, economically recoverable oil resources in the 1002 area 306

23.4. Distribution of estimated unconditional mean recoverable oil resources by blocks in the 1002 area $\quad 306$

\section{APPENDIXES}

11.1. Geochemical indicators for thermal maturity, type, and richness of source rocks for rock units penetrated by wells 153

14.1. Determination of helium background level 218

22.1. Glossary for oil and gas appraisal data form 295

Any use of trade names in this report is for descriptive purposes only and does not imply endorsement by the USGS. 


\section{PETROLEUM GEOLOGY OF THE NORTHERN PART OF THE ARCTIC NATIONAL WILDLIFE REFUGE, NORTHEASTERN ALASKA}





\title{
Petroleum Geology of the Northern Part of the Arctic National Wildlife Refuge, Northeastern Alaska
}

\author{
By Kenneth J. Bird ${ }^{1}$ and Leslie B. Magoon, ${ }^{1}$ Editors
}

\section{Abstract}

These 23 individually authored chapters by Geological Survey, Bureau of Land Management, and associated scientists relate the geologic data used in assessing the oil and gas resources of the coastal plain part of the $76,890-\mathrm{km}^{2}$ (19-million acre) Arctic National Wildlife Refuge (ANWR) in northeastern Alaska. The assessment and its report to Congress were called for by the Alaska National Interest Lands Conservation Act of 1980. This publication serves as a supplement to the report to Congress by providing complete and detailed technical information, not included in that report, concerning hydrocarbon source rocks, thermal history, reservoir rocks, traps (and seals), and the timing of hydrocarbon generation. The amounts of oil and gas in the study area are estimated by using assessment techniques that assign probabilities on the basis of these factors.

The assessment area lies in the northeasternmost part of Alaska between the Brooks Range and the Arctic Ocean. Nearby major oil-bearing areas include Prudhoe Bay to the west and the Mackenzie Delta to the east. The assessment area consists of treeless, tundra-covered plains and rolling hills, and it covers some $6,070 \mathrm{~km}^{2}$ (1.5 million acres) or about 8 percent of the ANWR. It is an arctic desert with permafrost as thick as $600 \mathrm{~m}(2,000$ $\mathrm{ft}$ ) and few bedrock exposures. Although this region is seismically the most active part of northern Alaska, the number of earthquakes and their magnitudes are small compared with southern Alaska.

The ANWR coastal plain is part of the Arctic Alaskan tectonic plate, which includes all of the Alaskan North Slope and parts of adjacent areas. Although the position of this plate relative to other plates in preCretaceous time is uncertain, the position and movement of the ANWR part of the plate in Cretaceous and Tertiary time can be described as a complex interplay among several large-scale tectonic features and processes. These include (1) a continental margin and tectonic hinge line formed by rifting during Early Cretaceous time, (2) a progradational Late Cretaceous to Holocene clastic wedge, (3) northward-directed Eocene

\footnotetext{
${ }^{1}$ U.S. Geological Survey, Menlo Park, Calif.
}

to Holocene thrust faulting, and (4) late Cenozoic continental-margin collapse along north-dipping listric normal faults. The coastal plain area is underlain by as much as $7 \mathrm{~km}(23,000 \mathrm{ft})$ thickness of Cretaceous and Tertiary sedimentary rocks that overlie a Lower Cretaceous unconformity. All but the northwestern quarter of the area, which is undeformed, is involved in an east- and northeast-trending, north-verging imbricate fold and thrust-fault system related to Brooks Range deformation.

Rocks with petroleum potential in the coastal plain area are mostly younger than Devonian and are divided into an older sequence (Ellesmerian) of Mississippian to Early Cretaceous age and a younger sequence (Brookian) of Cretaceous and Cenozoic age. Basement rocks consist of Precambrian to Devonian metasedimentary rocks with minor amounts of igneous rocks. South of the coastal plain, the Ellesmerian sequence is about $1 \mathrm{~km}(3,300 \mathrm{ft})$ thick and is composed of nearly equal amounts of carbonate and clastic rocks. These rocks record marine and nonmarine deposition along a slowly subsiding continental margin in which the land lay to the north and the sea lay to the south. Ellesmerian reservoirs are the primary oil-producing rocks in the Prudhoe Bay area. The Lower Cretaceous unconformity truncates the Ellesmerian sequence and older rocks northward across the coastal plain. This unconformity is believed to limit the occurrence of Ellesmerian rock units in much of the northern part of the coastal plain area. The Brookian sequence consists of as much as $7 \mathrm{~km}(23,000 \mathrm{ft})$ thickness of marine and nonmarine siliciclastic deposits representing debris shed from the ancestral Brooks Range. The locus of deposition initially was in a foredeep basin adjacent to the ancestral Brooks Range and, then, migrated northeasterly across a subsiding basement ridge and rifted margin. The Brookian sequence provides the deep burial and attendant heat necessary for hydrocarbon maturation in both Ellesmerian and Brookian source rocks on the North Slope.

The most likely petroleum reservoir rocks beneath the coastal plain are intrabasement carbonate rocks, Ellesmerian sandstone similar to that of the Kemik Sandstone or Thomson sand of local usage, and Brookian turbidite sandstone in the Canning Formation or deltaic sandstone in the Sagavanirktok and Jago River Formations. Ellesmerian reservoir rocks are expected to 
occur in the southern parts of the coastal plain, but their distribution is difficult to map. The low porosity and permeability of most rocks observed in outcrops may be improved in the subsurface by development of secondary porosity, possibly in proximity to the Lower Cretaceous unconformity, or by the occurrence of abnormally high fluid pressures that inhibit compaction and cementation.

Oil seeps and oil-stained rocks on the ANWR coastal plain indicate that thermally mature petroleum source rocks are present. Measured helium and aeromagnetic anomalies, which are attributed to hydrocarbon microseepages near the surface, may indicate that oil and gas accumulations are present. Analyses suggest that three types of oil, named after nearby geographic features, are present: (1) Jago, (2) Manning, and (3) Kavik. None are similar to oil from the Prudhoe Bay area. The Brookian Hue Shale is the only oil-prone source rock in the coastal plain area and is the likely source of the Jago oil. Other rock units analyzed are considered gas prone, although preCretaceous rocks in the Brooks Range could not be evaluated because of their high levels of thermal maturity. With a present-day geothermal gradient of about $30{ }^{\circ} \mathrm{C} / \mathrm{km}\left(1.6^{\circ} \mathrm{F} / 100 \mathrm{ft}\right)$, hydrocarbon-generation thresholds on the coastal plain are estimated to be as follows: oil generation between depths of 3.7 and $6.9 \mathrm{~km}$ $(12,000-22,500 \mathrm{ft})$, condensate generation between 6.9 and $8.5 \mathrm{~km}(22,500-28,000 \mathrm{ft})$, and gas generation below $8.5 \mathrm{~km}(28,000 \mathrm{ft})$. Oil generation probably began about 50 million years ago at the southern edge of the coastal plain and progressed northward, reaching the coastline about 10 million years ago. Clay-mineral transformation and abnormal fluid-pressure development accompanied the onset of oil generation.

Seismic data indicate that many more structures (potential hydrocarbon traps) are present on the coastal plain than previously suspected. Stratigraphic or combination structural and stratigraphic traps may also be present but have not been identified. Two types of structural traps are present: short-wavelength folds and long-wavelength folds. Short-wavelength folds, which are commonly highly faulted and involve mostly Brookian rocks, are more numerous. These structures may number in the hundreds, but they are small relative to the 4.8 by $9.6 \mathrm{~km}$ ( 3 by $6 \mathrm{mi}$ ) seismic survey grid, and four-way closure is difficult to demonstrate. The Marsh Creek anticline is interpreted to be an intensely deformed anticlinorium or triangle zone, rather than being a simple anticline. The short-wavelength structures overlie one or more regionally extensive low-angle faults that structurally detach them from long-wavelength, moderately faulted structures composed mostly of preBrookian rocks. Twenty-six of these structures have been mapped, and the largest is about $920 \mathrm{~km}^{2}$ (227,000 acres) in area with $3 \mathrm{~km}(10,000 \mathrm{ft})$ of vertical closure. Other structures, smaller than the seismic grid, may also be present. These 26 structures provide the basis for estimating economically recoverable oil resources in this study.

The timing of hydrocarbon generation relative to the formation of traps is judged to be favorable for the retention of oil in the coastal plain area. Structural traps are believed to have formed before, during, and after oil generation and migration. Beneath the northern part of the coastal plain and offshore, oil generation and the formation of structures are probably still occurring.

The evaluation of hydrocarbon resources of the study area was accomplished in two stages: (1) an assessment of in-place oil and gas resources based on a play-analysis method, and (2) a separate assessment of economically recoverable oil based on a prospect-specific method. Estimates of in-place oil and gas are (1) a 95 percent chance for more than 4.8 billion barrels of oil (bbo) and 11.5 trillion cubic feet of gas (tcfg); (2) a 5 percent chance for more than 29.4 bbo and $64.5 \mathrm{tcfg}$; and (3) a mean estimated resource of 13.8 bbo and $31.3 \mathrm{tcfg}$. Estimates of economically recoverable oil for the 26 structures (mentioned above) are a 95 percent chance of $0.6 \mathrm{bbo}$, a 5 percent chance of $9.2 \mathrm{bbo}$, and a mean of 3.2 bbo. Natural gas was not considered economically recoverable in this study.

Acknowledgments-We thank the contributing authors of this publication and the personnel of the Geological Survey, Bureau of Land Management, and Fish and Wildlife Service whose conscientious team effort resulted in the successful completion of the oil and gas assessment. C.M. Molenaar is acknowledged for his leadership throughout this undertaking. His extensive field experience in the ANWR, and adjacent parts of the North Slope, provided the geologic foundation for many of the studies; for many newcomers to the geology of the ANWR, he patiently served as instructor and guide. The timely submittal of manuscripts for this publication and the report to Congress is in large part the result of his gentle but persistent reminders. Special thanks are accorded to S.B. Griscom for her considerable efforts early in the process of organizing and editing this publication. We gratefully acknowledge the assistance of A.C. Christiansen, T.A. Coit, B.V. Fulop, N. Scott, P.A. Swensen, L.M. Wood, and P.V. Woodward, whose efforts were crucial in meeting the publication deadlines. 


\title{
Chapter 1.
}

\section{Introduction}

\author{
By Cornelius M. Molenaar ${ }^{1}$
}

\section{INTRODUCTION}

This publication presents the results of a multifaceted study of the geology of the coastal plain and adjacent areas of the Arctic National Wildlife Refuge (ANWR) and estimates of its yet to be discovered oil and gas resources. The purpose of these studies was to collect and evaluate geologic data in order to assess the petroleum potential of a specific area of the ANWR coastal plain as mandated by Congress in section 1002(h) of the Alaska National Interest Lands Conservation Act (ANILCA), Public Law 96-487, December 2, 1980. The specified land area is referred to as the 1002 area in this publication (fig. 1.1).

This report serves as an appendix to the congressional report on the ANWR 1002 area (Clough and others, 1987) by supplying technical geologic and assessment details not found in that report. Because this publication is intended for a broader readership than just earth scientists, the following chapter describes in layman terms the principles of petroleum geology and exploration methods.

\section{GENERAL SETTING}

The 1002 area comprises about $6,270 \mathrm{~km}^{2}(1.55$ million acres), or about 75 percent of the total coastal plain of the ANWR. These lands lie north of the Brooks Range and are bounded on the north by either the Beaufort Sea or the southern boundary of the Kaktovik Inupiat Corporation (KIC) lands. The western boundary is formed by the Canning and Staines Rivers, and the eastern boundary is the Aichilik River. The southern boundary follows township lines. Although referred to overall as coastal plain, some of the topography (especially in the southern part) consists of broad, lowrelief foothills, which are dissected by numerous northand northeast-flowing streams and rivers. Some hills rise

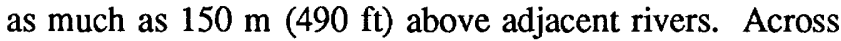

\footnotetext{
${ }^{1}$ U.S. Geological Survey, Denver, Colo.
}

the 25 to $55 \mathrm{~km}$ (16 to $34 \mathrm{mi}$ ) breadth of the area, the general elevation ranges from at or near sea level on the north to about $300 \mathrm{~m}(1,000 \mathrm{ft})$ on the south. Many small, shallow lakes are present in poorly drained localities, especially in the eastern part of the area.

Except for very small willow trees or bushes along river valleys in the southern part of the area, the coastal plain is treeless and is covered by tundra-type vegetation. Loosely consolidated sand, mud, gravel, or a soil zone underlies much of the vegetated cover. Unlike most of the coastal plain west of the ANWR, consolidated older rocks are exposed along several of the larger streams and rivers (see geologic map by Bader and Bird, 1986). This is attributed to the more recent and more intense folding in the 1002 area than in areas to the west. Permafrost, perennially frozen ground, is present throughout the area, probably to a depth of 300 to $600 \mathrm{~m}$ $(1,000$ to $2,000 \mathrm{ft})$. During the summer, the ground thaws to a depth of $0.5 \mathrm{~m}(1.5 \mathrm{ft})$ or less (see chap. 4).

The mountain belt south of the 1002 area is made up of several east-trending subranges of the Brooks Range. From north to south, the western subranges are the Sadlerochit Mountains, the Shublik Mountains, and the Third and Fourth Ranges of the Franklin Mountains (fig. 1.1B). The Romanzof Mountains are south of the eastern half of the coastal plain. The highest peaks of the entire Brooks Range are in this general area with the highest being Mt. Chamberlin at 2,749 $\mathrm{m}(9,020 \mathrm{ft})$. Most of the peaks along the immediate mountain front range in elevation from 900 to $1,800 \mathrm{~m}(3,000$ to 6,000 $\mathrm{ft})$. The abrupt topographic relief along the mountain front is due to the contrast in resistance to erosion between the more resistant, older sedimentary and igneous rocks of the mountains and the less resistant, younger sedimentary rocks of the coastal plain and foothills area.

The larger valleys in the mountains were carved by glaciers during the Pleistocene, and remnant glaciers are still present around the higher mountain peaks. At times during the past, glaciers in some of the larger valleys extended into the coastal plain area, as indicated by the presence of morainal material. 

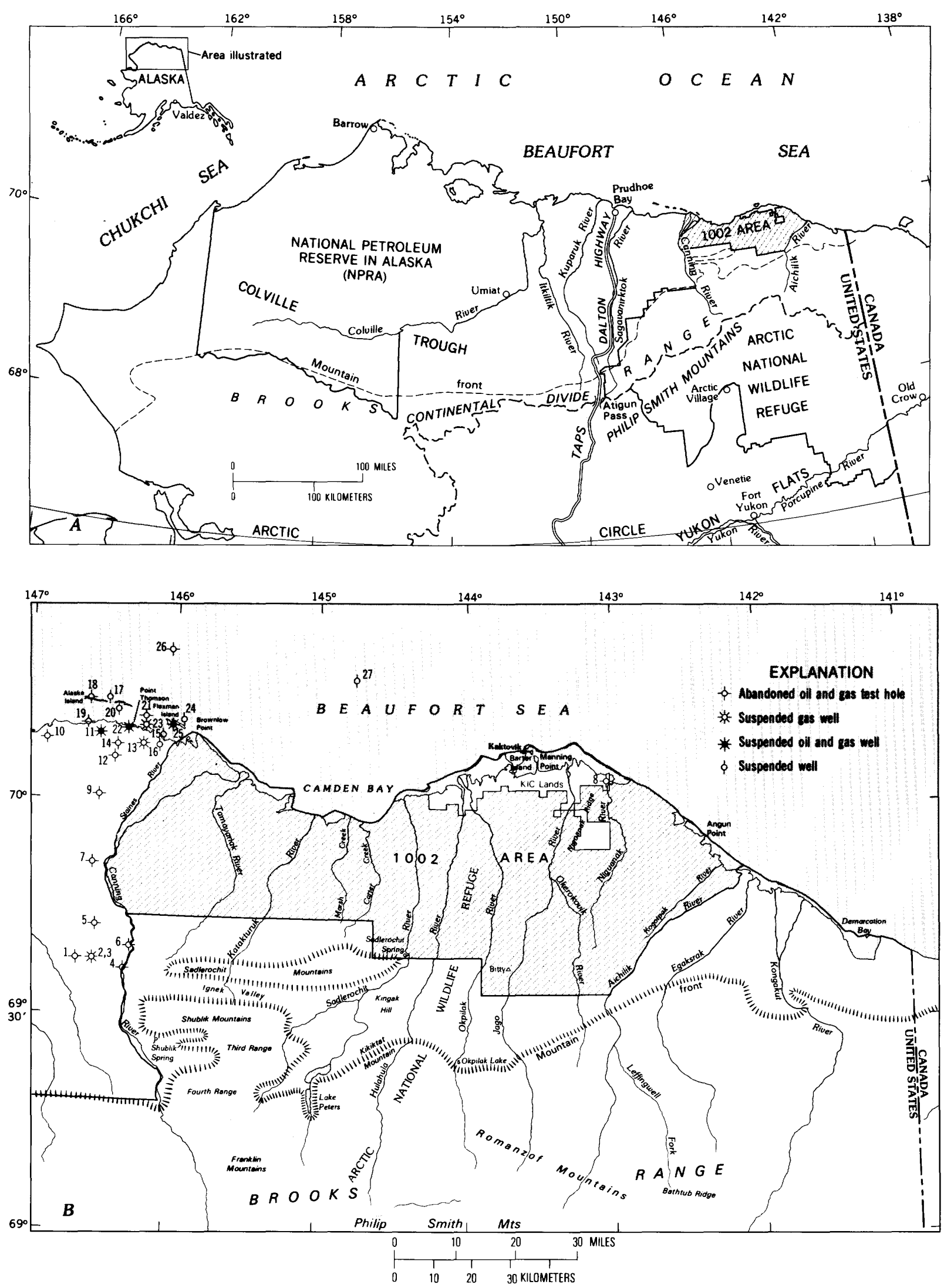

Figure 1.1. Index maps showing location of study area. A, Northern Alaska, showing ANWR and 1002 area. $B$, Enlargement of 1002 area. KIC, Kaktovik Inupiat Corporation. 


\section{PREVIOUS WORK}

The earliest geological investigations of the ANWR area were by Leffingwell (1919) between 1906 and 1914. Much of his work involved studying ice and permafrost features along the coast and mapping the coastline, but he did make several reconnaissance trips inland, where he examined bedrock exposures in the Sadlerochit Mountains area. His general stratigraphic observations led to the naming of several geologic formations, and these names still are used today. Another early survey was the geologic reconnaissance associated with the Alaska-Canada boundary survey from the Porcupine River to the Arctic Ocean reported by Maddren (1912).

Table 1.1. Exploratory wells drilled adjacent to ANWR
Reconnaissance and detailed geological investigations by the U.S. Geological Survey (USGS) were begun in the general area during the summer of 1947 , continued intermittently through 1961 , and then almost continuously from 1966 to 1985 . Geologists from the oil industry, the U.S. Bureau of Land Management (BLM), the State of Alaska, and various universities have also conducted geological field work in the ANWR. Industry has drilled 27 exploratory and development wells to the west and north of the ANWR (table 1.1).

\section{CURRENT WORK}

As provided by ANILCA sections 1002(a), (d), and (e), regulated exploration (including seismic surveys)

[See figure 1.1B for well locations; \#, well information not available to the U.S. Geological Survey for this study]

\begin{tabular}{|c|c|c|c|c|c|c|c|c|}
\hline \multirow[t]{2}{*}{ Well } & \multirow[t]{2}{*}{ Company } & \multirow[t]{2}{*}{ Well name and number } & \multicolumn{5}{|c|}{ Total depth location } & \multirow{2}{*}{$\begin{array}{c}\text { Total depth } \\
\text { (ft) }\end{array}$} \\
\hline & & & Sec. & $\mathrm{T}$. & $\mathrm{R}$. & Latitude & Longitude & \\
\hline 1. & Atlantic Richfield Co. & Kavik Unit-2 & 11 & $3 \mathrm{~N}$ & $22 \mathrm{E}$ & & & 7,500 \\
\hline 2. & Pan Am. Petroleum Corp. & Kavik-1 & 7 & $3 \mathrm{~N}$ & $23 \mathrm{E}$ & & & 9,564 \\
\hline 3. & Atlantic Richfield Co. & Kavik Unit-3 & 8 & $3 \mathrm{~N}$ & $23 \mathrm{E}$ & & & 5,850 \\
\hline 4. & Exxon Corp. & Canning River Unit A-1 & 19 & $3 \mathrm{~N}$ & $24 \mathrm{E}$ & & & 8,874 \\
\hline 5. & Mobil Oil Corp. & Beli Unit-1 & 8 & $4 N$ & $23 \mathrm{E}$ & & & 14,632 \\
\hline 6. & Exxon Corp. & Canning River Unit B-1 & 32 & $4 N$ & $24 \mathrm{E}$ & & & 10,803 \\
\hline 7. & Exxon Corp. & Alaska State J-1 & 23 & $6 N$ & $22 \mathrm{E}$ & & & 13,644 \\
\hline 8. & Chevron USA Inc. & $\mathrm{KIC}-1^{\#}$ & 1 & $8 \mathrm{~N}$ & $36 \mathrm{E}$ & & & 15,193 \\
\hline 9. & Union Oil Co. of Calif. & E. de K. Leffingwell-1 $1^{\#}$ & 25 & $8 \mathrm{~N}$ & $22 \mathrm{E}$ & & & 14,824 \\
\hline 10. & Humble Oil and Refining Co. & East Mikkelsen Bay State-1 & 7 & $9 \mathrm{~N}$ & $21 \mathrm{E}$ & & & 15,205 \\
\hline 11. & Exxon Corp. & Point Thomson Unit-2 & 3 & $9 N$ & $22 \mathrm{E}$ & & & 14,117 \\
\hline 12. & Mobil Oil Corp. & West Staines State-2 & 25 & $9 \mathrm{~N}$ & $22 \mathrm{E}$ & & & 13,171 \\
\hline 13. & Exxon Corp. & Alaska State C-1 & 14 & $9 \mathrm{~N}$ & $23 \mathrm{E}$ & & & 13,761 \\
\hline 14. & Mobil Oil Corp. & West Staines State 18-9-23 & 18 & $9 \mathrm{~N}$ & $23 \mathrm{E}$ & & & 13,329 \\
\hline 15. & Phillips Petroleum Co. & North Staines River-1 & 5 & $9 \mathrm{~N}$ & $24 \mathrm{E}$ & & & 14,266 \\
\hline 16. & Mobil Oil Corp. & Staines River State-1 ${ }^{\#}$ & 19 & $9 \mathrm{~N}$ & $24 \mathrm{E}$ & & & 13,238 \\
\hline 17. & Sohio Petroleum Co. & Alaska Island-1 & 2 & $10 \mathrm{~N}$ & $22 \mathrm{E}$ & & & 15,222 \\
\hline 18. & Sohio Petroleum Co. & Challenge Island-1 & 8 & $10 \mathrm{~N}$ & $22 \mathrm{E}$ & & & 13,587 \\
\hline 19. & Exxon Corp. & Point Thomson Unit-4 & 29 & $10 \mathrm{~N}$ & $22 \mathrm{E}$ & & & 15,074 \\
\hline 20. & Exxon Corp. & Alaska State F-1 & 18 & $10 \mathrm{~N}$ & $23 \mathrm{E}$ & & & 14,316 \\
\hline 21. & Exxon Corp. & Alaska State D-1 & 23 & $10 \mathrm{~N}$ & $23 \mathrm{E}$ & & & 13,050 \\
\hline 22. & Exxon Corp. & Point Thomson Unit-1 & 32 & $10 \mathrm{~N}$ & $23 \mathrm{E}$ & & & 13,298 \\
\hline 23. & Exxon Corp. & Point Thomson Unit-3 & 35 & $10 \mathrm{~N}$ & $23 \mathrm{E}$ & & & 14,125 \\
\hline 24. & Exxon Corp. & Alaska State G-2 & 25 & $10 \mathrm{~N}$ & $24 \mathrm{E}$ & & & 16,527 \\
\hline 25. & Exxon Corp. & Alaska State A-1 & 27 & $10 \mathrm{~N}$ & $24 \mathrm{E}$ & & & 14,206 \\
\hline 26. & Union Oil Co. of Calif. & Hammerhead prospect ${ }^{\#}$ & & & & $70^{\circ} 21^{\prime} 52.6^{\prime \prime} \mathrm{N}$ & $146^{\circ} 1^{\prime} 27.9^{\prime \prime} \mathrm{W}$ & 8,034 \\
\hline 27. & Shell Western E \& P, Inc. & Corona prospect $\#$ & & & & $70^{\circ} 18^{\prime} 52.6^{\prime \prime} \mathrm{N}$ & $144^{\circ} 45^{\prime} 31.6^{\prime \prime} \mathrm{W}$ & (Drilling) \\
\hline
\end{tabular}


was allowed in the 1002 area during the 1984 and 1985 winter seasons, and surface geological investigations were allowed in the ANWR, both inside and outside the 1002 area, in order to provide the geological and geophysical information necessary to evaluate the area's oil and gas resources. During the first year's seismic program, 760 line mi were surveyed. Because the 1984 seismic survey revealed a complex subsurface structure, a second season of seismic surveying, comprising 692 line $\mathrm{mi}$, was allowed in order to better evaluate the area's hydrocarbon potential. During these seismic surveys, gravity measurements were made at selected stations along the seismic lines, and many of the 75- to 100 -ft-deep shot holes were sampled for paleontological and geochemical analyses. The contractors and services provided in the industry exploration program of 1984 and 1985 are listed in table 1.2. In addition, 15 oil companies or groups, as well as USGS and BLM parties, also conducted surface geological studies in and adjacent to the 1002 area during the 1984 and 1985 seasons.

Table 1.2. List of contractors and services rendered in the ANWR 1002 exploration program of 1984 and 1985

\begin{tabular}{ll}
\hline \multicolumn{1}{c}{ Contractor } & \multicolumn{1}{c}{ Service } \\
\hline Geophysical Service Inc. & Seismic survey \\
Geophysical Service Inc. & Gravity survey \\
International Technology, Inc. & Gravity survey \\
Brown and Ruth, Inc. & Shot-hole geochemistry \\
Micropaleo Consultants, Inc. & Shot-hole paleontology \\
\hline
\end{tabular}




\title{
Chapter 2.
}

\section{Principles of Petroleum Geology and Exploration Methods}

\author{
By Cornelius M. Molenaar ${ }^{1}$
}

\section{INTRODUCTION}

Ever since the first oil well in the United States was drilled near Titusville, Pennsylvania, in 1859, the science of petroleum geology has steadily advanced and methods of petroleum exploration have become increasingly sophisticated. In the early days, test wells were commonly located near oil seeps or on obvious surface-expressed anticlines. The more obvious geologic structures have now been drilled, and remaining prospects are more difficult to detect; these difficulties have helped spur the great advances in geologic concepts and exploration methods that have been made, especially in the last 15 or 20 years.

To assist the lay reader, this chapter briefly reviews the many facets of petroleum geology and the methods used in exploring for crude oil and natural gas, or petroleum as they are collectively known. Although the discussion is not specific to the Arctic National Wildlife Refuge (ANWR), the general concepts are applicable. Details of the geology and of the oil and gas resource assessment of the ANWR are discussed in following chapters.

There are many good reference publications on the different aspects of petroleum geology, a few of which are listed at the end of each section in this chapter.

\section{PETROLEUM GEOLOGY}

Petroleum is a general term for all naturally occurring hydrocarbons, whether gaseous, liquid, or solid. Natural gas, the common term for gaseous hydrocarbons, is composed mainly of methane, with lesser amounts of "heavier" gases, such as propane and butane. Crude oil, the common term for the liquid phase, is actually a complex mixture of various types of hydrocarbons, known as paraffins, naphthenes, and aromatics, and of nonhydrocarbons, known as resins and asphaltenes. Solid hydrocarbons, the familiar "tar" or asphalt, usually occur at or near the Earth's surface and

\footnotetext{
${ }^{1}$ U.S. Geological Survey, Denver, Colo.
}

are residual hydrocarbons formed by the escape of the "lighter" fractions from the oil. Chemical variations in petroleum are primarily due to differences in the source material, thermal history, and distances the petroleum may have moved or migrated.

The prevailing theory for the origin of petroleum is that it is one of the products of thermal transformation of biogenic material buried with rock and mineral debris (sediments) in a sedimentary basin. Oil and gas accumulations result when organic-carbon-rich (source) rocks are subjected to sufficient heat and geologic time (maturation) to generate petroleum, which then moves (migrates) from the source rocks to porous (reservoir) rocks that are overlain by impermeable (sealing) rocks in a geometrical arrangement preventing the escape of oil and gas (a trap). All of the steps in this process are critical, interrelated factors that may or may not occur in a particular sedimentary basin.

Useful references on petroleum geology are Link (1982), Perrodon (1983), and Selley (1982).

\section{Sedimentary Basin}

A sedimentary basin is a large area of the Earth's surface that has subsided and allowed the accumulation of great thicknesses of sedimentary material. The history of sedimentary basins is usually measured in tens of millions of years. In their early stages, these basins are usually water-filled, elongate depressions (seaways or lakes) with dimensions measured in tens to hundreds of miles. Ultimately, they are filled with sediments a few thousand to greater than $30,000 \mathrm{ft}$ thick. Some basins have a complex history with multiple episodes of subsidence, sedimentary filling, uplift, deformation, and erosion. Sedimentary basins may form along the margins of continents (crustal plates) or within continents. Those basins along continental margins form where plates pull apart from, slide past, or collide with one another. The origins of intraplate basins are not well understood. Subsidence is believed to be related to a combination of crustal cooling and loading. Loading may be caused by (1) deposition of sediments, (2) water, resulting from a rise in sea level, or (3) thrusting of one earth slab on top of another. 
The North Slope or Colville basin, of which the coastal plain of the ANWR is a part, was originally about $300 \mathrm{~km}$ (200 mi) wide and covered the entire width of northern Alaska $(1,000 \mathrm{~km}, 600 \mathrm{mi})$, extending into Canada on the east and the Chukchi Sea on the west. It is a complex basin with multiple episodes of subsidence, uplift, erosion, and deformation.

The age of a sedimentary basin is important because geologically old basins (Precambrian) generally have less organic material (poor source rocks) and are more likely to have experienced extreme heating and deformation, making preservation of oil and gas deposits unlikely. Worldwide, most oil and gas deposits occur in rocks younger than 570 million years (fig. 2.1). This segment of geologic time coincides with the rise and predominance of complex, multicellular life forms.

Useful references on sedimentary basins are Biddle and Christie-Blick (1985) and Miall (1984).

\section{Sedimentary Rocks}

Sedimentary rocks are formed by the consolidation of muds, sands, or gravels that are transported into a basin by streams or the wind, or that are formed by the accumulation of lime or silica particles produced by biologic activity. As the deposits gradually accumulate in greater and greater thicknesses, interstitial water is forced out of the pore spaces as the sediment grains assume a tighter packing, and cementing material (commonly calcium carbonate) binds the grains together. The sediment then becomes a sedimentary rock. Gravels become conglomerate, sands become sandstone, and muds become mudstone or shale. In carbonate sediments, lime mud and particulate carbonate grains are cemented, usually by calcium carbonate that precipitates out of circulating pore water, and become a carbonate rock termed either limestone or dolomite, depending on

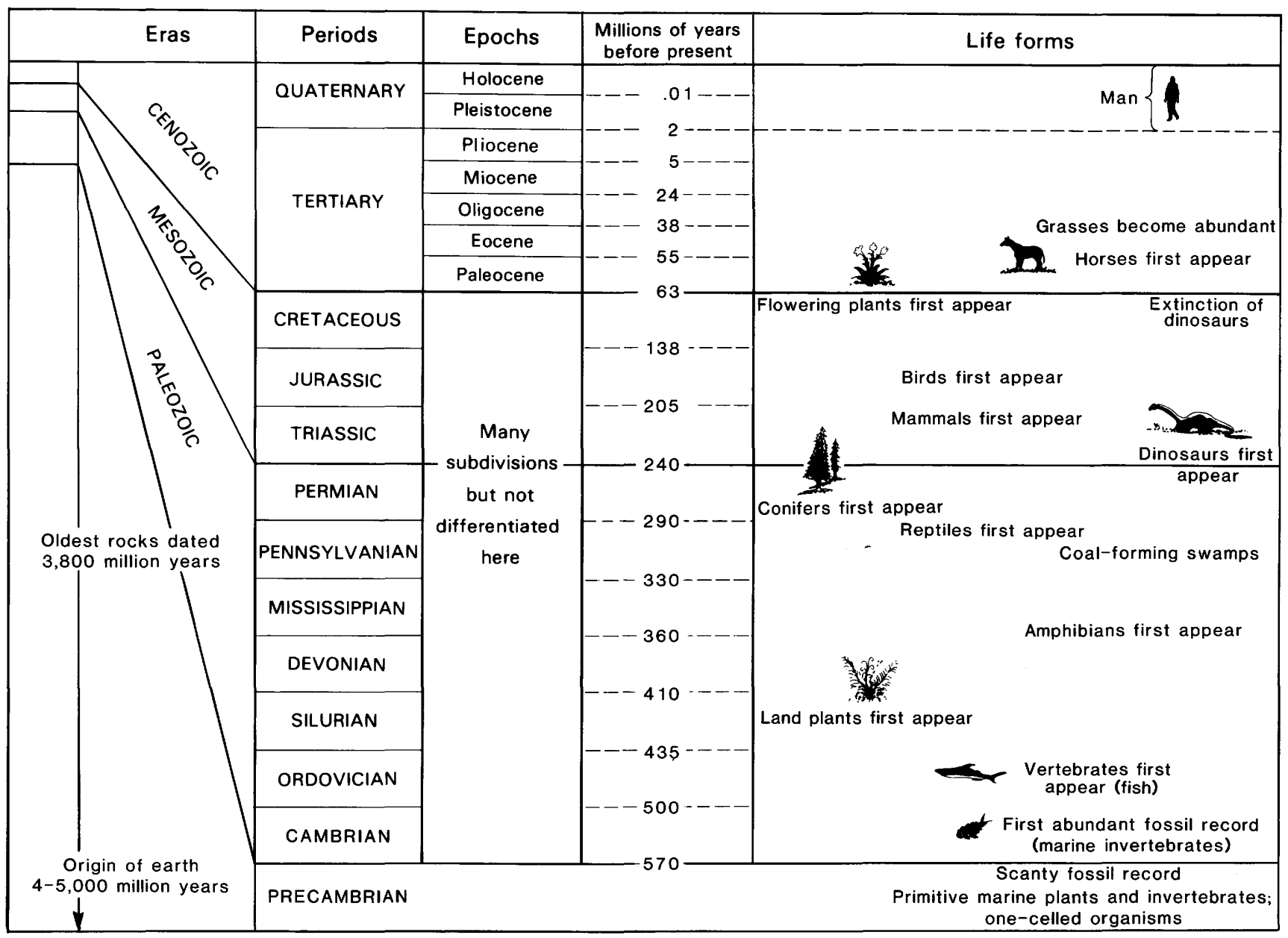

Figure 2.1. Geologic time scale and approximate age in millions of years. Time scale in years is based on radioactive decay rates of certain elements and is not linear. Columns show divisions of geologic time throughout Earth's history. These divisions, based on evolution and extinction of different life forms, also tend to reflect major tectonic events (structural disturbances) around the world. 
the amount of magnesium present. Different rock types are the basis for subdividing thick sedimentary rock sequences into mappable rock units called formations. Geologically related formations may be lumped together into groups, or a formation may be subdivided into smaller units called members. Naming rock units is essential for communication purposes.

Useful references on sedimentary rocks are Blatt and others (1980), Friedman and Sanders (1978), Reading (1986), and Selley (1976).

\section{Petroleum Source Rocks}

Petroleum source rocks are sedimentary rocks rich enough in organic matter to generate petroleum. The organic matter usually consists of some combination of (1) land-derived (terrestrial) material mostly comprised of plant remains such as pollen, spores, leaf cuticles, and other material, which is washed into a basin together with rock and mineral particles by streams and rivers, and (2) aquatically derived (marine or lacustrine) material comprised of plants and animals, generally microscopic in size, that live in the ocean or in lakes. The organic matter sinks to the seafloor with the finer silt and clay particles, where it is incorporated into the sediments. If the bottom water of a basin has poor circulation and consequently low oxygen content, thus making the environment uninhabitable for bottomdwelling scavengers, the organic matter is preserved and becomes a constituent of the sediments. When compacted, these sediments become organic-carbon-rich shales or limestones and are potential source rocks. The lower limit for a potential source rock is usually considered 0.5 weight percent organic matter, while greater than 2 percent organic matter is considered a rich potential source rock. Some very rich source rocks contain greater than 5 percent organic matter. The weight percent and type of organic matter (terrestrial or marine) in a sediment can be determined by laboratory analyses.

The type of organic matter and its thermal history determine the type of petroleum that is generated. Woody or inertinitic (coaly) material generates only methane gas, whereas herbaceous, algal, and marine plant materials usually generate oil. To generate oil or "thermal" gas, the potential source rock must be heated, usually by deep burial, to certain threshold temperatures for a minimum period of time. Source rocks heated to less than sufficient temperatures for oil generation are known as immature or potential source rocks, those heated to sufficient temperatures are known as mature source rocks or oil source rocks, and those subjected to extreme temperatures are known as overmature or postmature source rocks. The first petroleum products generated are the heavier oils. As the source rock is heated to higher temperatures (buried deeper) for longer periods, the lighter oils are generated; at still higher temperatures, only methane gas is generated (fig. 2.2). The complete sequence of generation usually occurs over a temperature range of 65 to $175^{\circ} \mathrm{C}\left(150-350^{\circ} \mathrm{F}\right)$, a timespan of millions of years, and a depth range of $2,400-5,500 \mathrm{~m} \quad(8,000-18,000 \mathrm{ft})$. At greater temperatures and depths, the chances for petroleum occurrence are greatly diminished.

In addition to being generated by thermal processes, gas known as biogenic methane gas can be created by the action of bacterial consumption of organic matter at lower temperatures than are required for thermal gas generation. Swamp gas is a common example of this process. The Kenai gas field in southern Alaska is biogenic methane.

Useful references on petroleum source rocks and geochemistry are Hunt (1979), Tissot and Welte (1984), and Waples $(1981,1985)$.

\section{Reservoir Rocks}

A reservoir rock is one that is sufficiently porous and permeable so that its contained fluids can be "produced," that is, extracted. Sandstone, conglomerate, and carbonate rocks are the most common petroleum

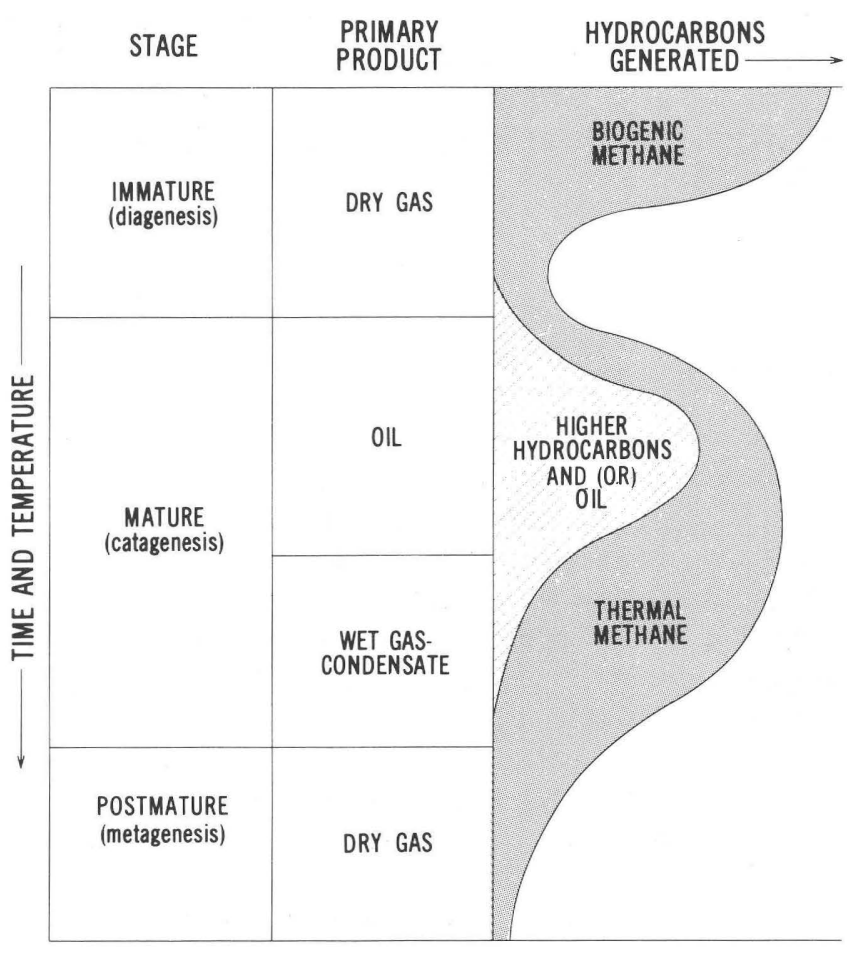

Figure 2.2. Sequences of hydrocarbon (petroleum) generation as temperature increases (from Rice and Claypool, 1981). 
reservoir rocks. But these rock types do not always form reservoirs because they may have lost much of their original porosity and permeability. For example, unconsolidated sand, such as that found on a beach, may have 40 percent porosity ( 40 percent of the total volume of the sand is pore space). Compaction and cementation by minerals that precipitate from fluids moving through the sand will greatly reduce this pore space. Any alteration of chemically unstable types of sand grains (such as feldspar, volcanic rock fragments, or certain other nonquartz grains) by fluids moving through the system lessens the porosity and permeability even more. Thus, the sandstone may end up with greatly diminished reservoir properties and may become so cemented that it is not an effective reservoir. In some cases, however, open fractures in an otherwise low-permeability sandstone, or even in a nonreservoir shale or siltstone, can provide the necessary interconnections for the system to become an effective reservoir. Porosity may also be created by dissolution of mineral cements or grains by a fluid with a different chemical composition moving through the rock. Porosity developed in this way is known as secondary porosity. Porosity in the main reservoir rock in the Prudhoe Bay field is an example of secondary porosity.

The changes that a sediment undergoes from the time of deposition to the present-day sedimentary rock are called diagenetic effects, or diagenesis. By studying thinly ground slices of the rock (thin sections) under a microscope, geologists not only can determine the composition of the rock but also can reconstruct or interpret its diagenetic history.

Useful references on reservoir rocks and diagenesis are Roehl and Choquette (1985) and Scholle $(1978,1979)$.

\section{Petroleum Traps}

As petroleum is generated, pressure increases within the source rock and forces the petroluem into the fluid system of the basin. Being lighter than water (the other fluid in the system), oil moves upward, generally along tilted, more permeable carrier beds, until it either seeps out at the surface or meets a barrier (trap) that stops its flow. Petroleum traps are of three types: structural, stratigraphic, and a combination of these two.

Structural traps are formed by folding (bending) or faulting (breaking) of the reservoir-rock layers. When the layers are arched (folded) so that they tilt in opposite directions, they are called anticlines (fig. 2.3A). The top or crest of the fold is called the anticlinal axis; to be a trap, the anticlinal axis must also tilt in opposite directions, forming a dome. Many of the large fields of California, the Middle East, and the Rocky Mountains occur in anticlinal traps.
A fault trap is formed by the juxtaposition of the reservoir bed against an impermeable formation, such as shale across a fault (fig. 2.3B). Sometimes, however, the fault plane or fractures associated with the fault provide avenues of escape for the petroleum. Many Gulf Coast fields associated with salt domes or growth faults are fault traps.

Structural traps, especially anticlinal traps, are easiest to find and are likely to produce petroleum at several levels. They are often evident at the surface or can be found relatively easily with geophysical methods, especially seismic techniques.

Stratigraphic traps are formed when a reservoir bed terminates as a result of internal changes within the rock sequence. One kind of stratigraphic trap is formed when a reservoir bed thins to zero thickness or grades into impermeable strata (fig. 2.3C). Many oil fields with carbonate reservoirs, such as those of the Permian basin of West Texas and eastern New Mexico, the Aneth field of southeastern Utah, the Silurian reef fields of Michigan, and the Devonian reef fields of Alberta, Canada, are stratigraphic traps. Another type of stratigraphic trap, called an unconformity trap, is formed when tilted strata, including reservoir beds, are truncated by erosion and subsequently covered by impermeable deposits such as shale (fig. 2.3D). The giant East Texas field is this type of trap. Stratigraphic traps are subtle, may have only one producing zone, and are difficult to find. However, they can be prolific petroleum producers.

Combination traps require both structural and stratigraphic features to complete the trap. An example is a plunging anticline in which the reservoir rock terminates up the plunge of the anticlinal axis. The updip termination provides the stratigraphic component, and the anticlinal reversal of the plunging anticline provides the structural component. Combination traps may be subtle and as difficult to find as stratigraphic traps. They too can be prolific petroleum producers. The giant Prudhoe Bay field is the result of a combination anticlinal-unconformity type of trap.

Useful references on traps are Braunstein (1976), Halbouty (1970, 1981, 1982), and King (1972).

\section{Summary}

The factors involved in the making of an oil or gas field are (1) petroleum source rocks, (2) sufficient heat or depth of burial to transform the organic matter into petroleum, (3) carrier beds to move the generated petroleum, (4) traps in which the petroleum can move no farther, (5) adequate reservoir beds from which the petroleum can be produced, and (6) proper timing of petroleum generation and migration relative to trap formation. These six factors must be considered in evaluating the petroleum potential of an area. 


\section{PETROLEUM EXPLORATION METHODS}

Petroleum exploration is a risky business; as a general rule, only two or three of every 20 exploratory wells find economically recoverable oil or gas. Even more revealing are the statistics on significant discoveries-discoveries greater than 1 million barrels of recoverable oil or 6 billion $\mathrm{ft}^{3}$ of recoverable gas. Between 1946 and 1979, the rate of significant discoveries declined from slightly more than three to less than two for every 100 exploratory wells drilled (Johnston, 1986). To reduce the risk, a modern petroleum exploration program evaluates each of the six factors necessary for the occurrence of a petroleum accumulation (see above) by integrating geological, geochemical, and geophysical data with ever-increasing sophistication. Such a program generally includes surface outcrop studies and subsurface studies of any nearby wells, including paleontological and geochemical analyses of well and outcrop samples, seismic surveys, gravity surveys, magnetometer surveys, and several other less-used types of surveys. Additionally, in some areas drilling is done in off-structure positions purely for stratigraphic information. All these studies and surveys yield different types of information that relate to the six factors. A petroleum assessment or exploration program

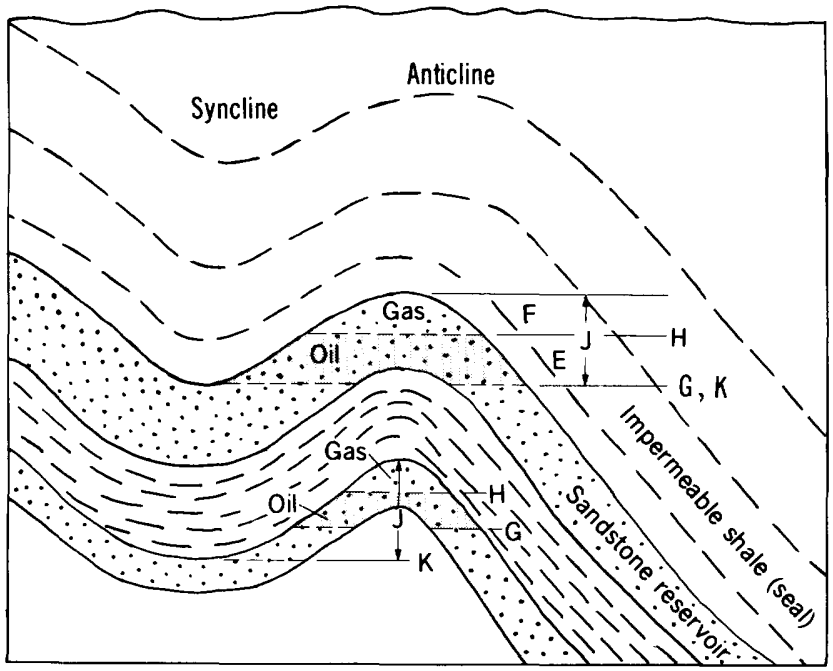

A

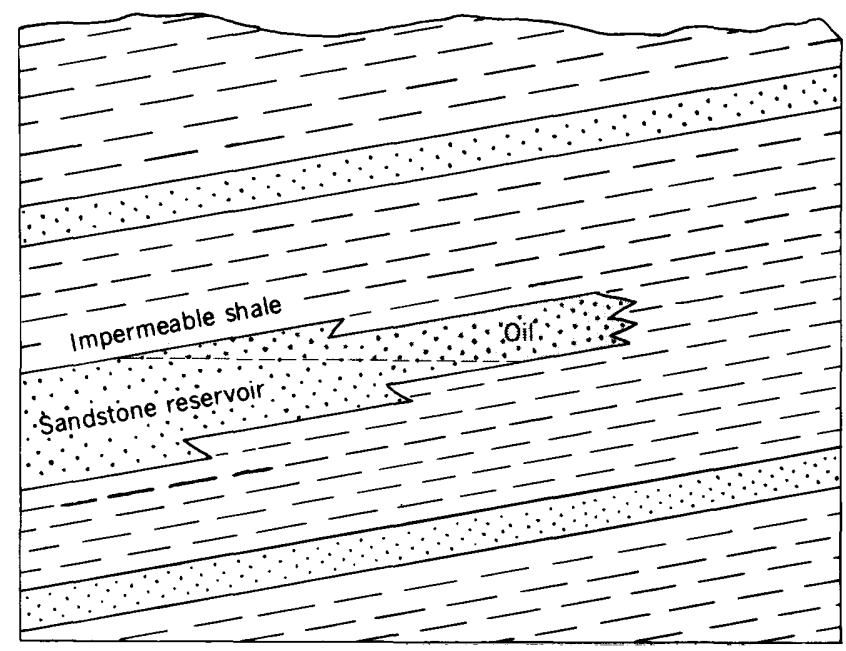

C

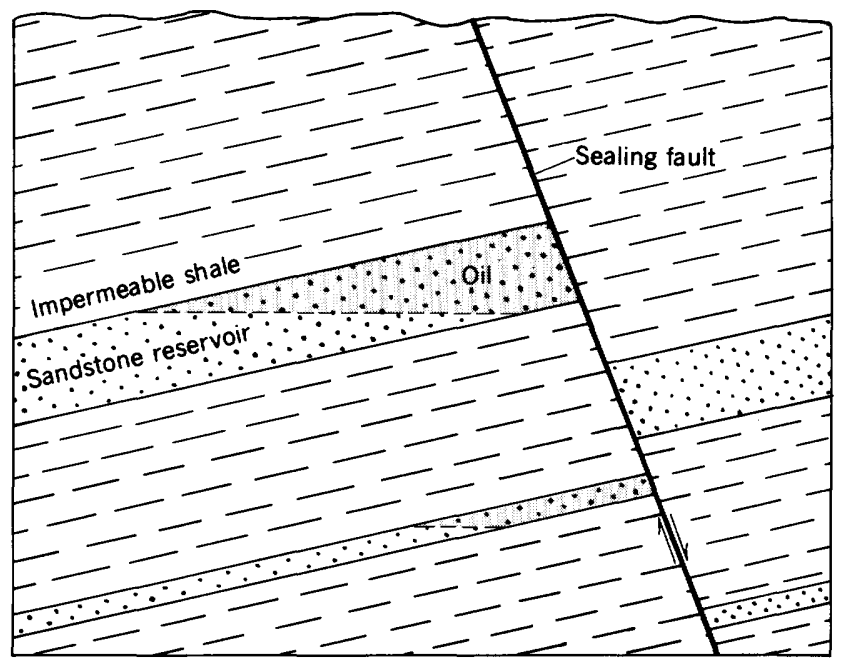

B

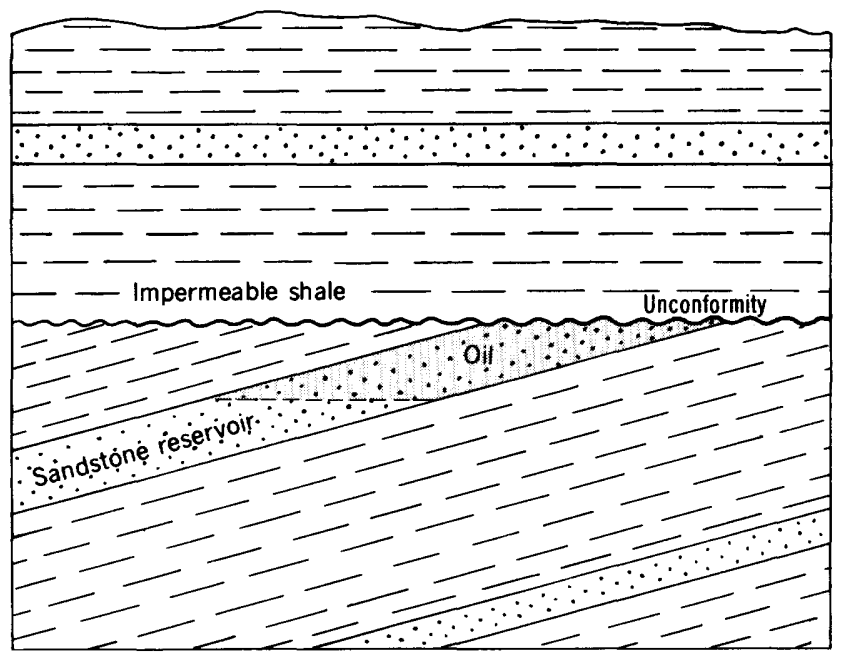

D

Figure 2.3. Schematic diagram showing four basic types of hydrocarbon traps. Shaded area is oil accumulation. A, Anticlinal or domal trap. E, oil column; F, gas column; G, oil-water contact; H, gas-oil contact; J, vertical closure of structure; $\mathrm{K}$, spill point, which does not correspond to oil-water contact if trap is not full. $B$, Fault trap. Arrows on fault indicate direction of relative movement. $C$, Stratigraphic pinch-out trap. $D$, Unconformity trap. 
that does not attempt to evaluate each of the factors is incomplete. The ultimate goal of an exploration program is to identify and drill indicated traps (prospects). Drilling is the only sure method to determine if a petroleum accumulation actually exists.

Useful references providing an overview of petroleum exploration methods are Curtis and others (1981) and Hyne (1984).

\section{Surface and Subsurface Geological Studies}

Surface and subsurface geological exploration, which includes analysis of stratigraphy, structure, paleontology, and geochemistry, is generally the first method used in unexplored (frontier) areas because such studies are less costly than geophysical surveys and drilling and can yield a great deal of important information about the rocks likely to be present in the subsurface. In prospective areas where the bedrock is exposed and the surface structure can be mapped, drillable prospects can be directly located; many of the early fields in the Rocky Mountains and California were found by this method. Bedrock is not exposed in many areas of the ANWR, however, and data gathered from rocks exposed in adjacent areas, such as the Brooks Range and its foothills, are extrapolated into the covered areas, such as the coastal plain of the ANWR. Surface geological studies include (1) determining the order and age of the stratigraphic sequence, (2) measuring the thickness of various stratigraphic units, (3) making sedimentologic studies to determine depositional environments, (4) sampling different rock units for age, reservoir, and source-rock analysis, and (5) determining the structural style and timing of any deformation.

Studies of nearby wells are also very important. Borehole measurements (well logs) provide information on the character of the sedimentary section, such as lithology (rock type), rock-unit thickness, reservoir quality, and presence of potential petroleum source rocks. Examination and analysis of cores and drill cuttings yield information on the presence of oil "shows" (oil-stained samples or other indications of petroleum encountered while drilling). In addition, well samples are analyzed for fossil content and source-rock quality. Examination of outcrop and well samples for microfossils is necessary for dating and correlating rock units. Geochemical analyses of shale samples yield information on organic richness, type of organic material (oil prone versus gas prone), and thermal maturity (have they been buried deep enough to generate petroleum or have they been buried so deep as to be overmature?). In addition, analyses of oils collected from surface seeps or from wells may provide information on which rocks were the source for the oil.

Subsurface geologic structure is not always indicated by surface outcrops. In this situation and in those in which rock outcrops are poor or entirely absent, such as the 1002 area, geophysical prospecting is used. Three commonly used methods are seismic, gravity, and magnetic surveys. The latter two provide general information on large-magnitude structural features and rock types. Because this information is not as detailed as that provided by seismic methods, it is seldom used in selecting drilling sites.

\section{Seismic Surveys}

Seismic surveys are the most often used of the geophysical methods because they provide the most useful results. A seismic survey gathers subsurface geologic information by recording impulses from an artificially generated shock wave. The two fundamental types of seismic surveys are refraction and reflection. The refraction method was used more commonly during the 1930's and is used for determining the larger features and structures of sedimentary basins. The reflection method gives a more direct and detailed picture of the subsurface structure than the refraction method and is used almost exclusively in petroleum exploration today. Results are easily translated into geological terms, although the methods and techniques used for acquiring, processing, and interpreting the data are very complicated and expensive. The seismic survey of the 1002 area used the reflection method exclusively.

The common procedure for seismic-reflection surveys on land consists of creating artificial shock waves and recording the resultant seismic energy as it arrives at groups (arrays) of vibration detectors (seismometers or geophones) on the surface. These geophone arrays are connected by electrical cable to an instrument truck that receives and records the seismic signals. Seismic energy reaches the geophones by several different routes. One signal spreads over the ground as a surface wave. Another travels along a subsurface layer and is refracted to the surface. The third and most important signal travels downward until it reaches an abrupt change in rock character and is then reflected back to the surface (fig. 2.4).

The geophones are spaced at intervals $(34 \mathrm{~m}$ (110 ft) apart in most of the ANWR survey) along a line extending 3-5 km (2-3 mi) from the energy input point (shothole or vibrator station). The signals from the geophones are recorded electronically in an instrument vehicle. By repeating this process with a series of shots (spaced $67 \mathrm{~m}(220 \mathrm{ft})$ apart in most of the ANWR survey) along the long line of geophones and progressively moving the entire line ahead, a seismic profile is made by plotting the arrival times of the sound (or acoustic) waves from various reflectors under each shotpoint. This is called the common-depth-point (CDP) method. 
The type of seismic-reflection survey is usually referred to by the method of generating the shock wave. On land, the most commonly used are the explosive (or dynamite) and vibrator methods, both of which were used in the 1002 area.

Historically, explosives have been the most widely used way to generate seismic shock waves. With this method, 2-45 kg (5-100 lb) of explosive charge are detonated at the bottom of an 8- to 60-m-deep (25-200 ft) hole drilled with a truck-mounted drill. This method was used in the 1002 area during the first season of data collection.

The vibrator (or Vibroseis-a registered trademark of Continental Oil Company) method was used on the coastal plain for the second season of data collection and is replacing the explosive method in many areas. A typical operation uses three or four large trucks or tractors, each equipped with a vibrator pad mounted between the front and rear wheels, and four or five support vehicles. The vibrator pads (about $1.2 \mathrm{~m}^{2}, 4 \mathrm{ft}^{2}$ ) are lowered to the ground, and vibrators on all trucks then vibrate simultaneously, being triggered electronically from the recorder truck. After the reflections are recorded, the trucks are moved forward a short distance and the process is repeated.

A seismic profile covering many miles of traverse shows the various reflectors as flat, sloping, curving, or broken depending on the structural configuration (fig. 2.5). The reflectors are recorded in time (seconds or microseconds). Therefore, the velocity of the acoustic wave traveling through the different rock

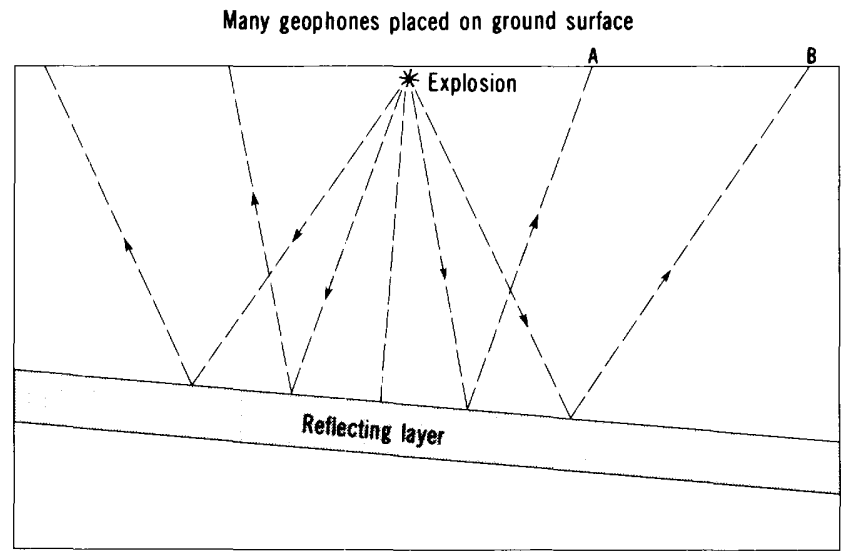

Figure 2.4. Paths of seismic waves from dynamite explosion near surface to reflecting rock layer and back to surface. Arrival time of reflected seismic wave at geophone $B$ is a fraction of a second later than at geophone A. Hence the reflection for geophone B is plotted slightly lower on the seismic profile than for geophone A. formations must be known or approximated to convert time to depth. This velocity can be obtained from the reflection data itself if structural complications are not too severe, or from velocity surveys in nearby wells if such data are available. Structure-contour maps and rock-thickness maps are made from the significant reflecting horizons-those that can be correlated from one seismic line to another. Because of the many variations in the magnitude of the reflected seismic energy, poor continuity or lack of reflectors, poorly known velocities, and complex structure, such as is present in the 1002 area, much interpretive skill is involved in mapping the subsurface structure. Where the rocks are relatively undeformed and the seismic records are of high quality, valuable information on probable rock types, environments of deposition, and lateral relationships can be obtained from careful interpretation of the seismic records. Such studies are called seismic stratigraphy.

Useful references on seismic methods and interpretation are Anstey (1982), Berg and Woolverton (1985), Dobrin (1960), and Sheriff (1980).

\section{Gravity and Magnetic Surveys}

Gravity and magnetic surveys are two separate methods that provide regional information on the presence and general thickness of sedimentary rocks, and perhaps on the presence and extent of some of the larger structures and faults. Gravity and magnetic measurements are plotted on maps and contoured to show trends. Gravity surveys measure small differences in the Earth's gravitational field that are caused by small differences in the density of various types of rocks. This is generally done with small portable instruments called gravimeters. With these sensitive instruments, measurements are taken along profiles across an area with stations spaced from less than $1 \mathrm{~km}(0.6 \mathrm{mi})$ to 5 $\mathrm{km}$ (3 mi) apart. After correcting for latitude and topographic effects and adjusting the data to a common base level, one can interpret any remaining differences as reflecting variations in the density of the underlying rocks. By modeling the thicknesses and densities of different kinds of rocks (sedimentary, igneous, or metamorphic) that may underlie the area-shale (least dense), sandstone (more dense), limestone (more dense), and their underlying nonsedimentary basement rocks (usually most dense)-an approximate configuration of the basin can be determined.

Magnetic surveys are often used to supplement gravity surveys. These surveys utilize relatively small, airborne or portable ground-based instruments called magnetometers. The instruments measure slight variations in the Earth's magnetic field caused by small variations in the magnetic properties of the different kinds of rocks that make up the Earth's crust. Generally, 
magnetic surveys show the approximate configuration of the basin by the contrast between the usually more magnetic basement rocks and the overlying, less magnetic sedimentary rocks. In the 1002 area, however, most basement rocks are similar in magnetic character to the overlying sedimentary rocks.

A useful reference on gravity and magnetic methods is Dobrin (1960).

\section{Other Types of Surveys}

Several other types of surveys have been useful in solving special problems or in providing specific information on a particular basin. These include electrical, magnetotelluric, and radiation surveys (see Dobrin, 1960).

Two relatively new methods have been used in parts of the coastal plain area of the ANWR. These methods, sometimes referred to as direct-detection methods, involve measuring the horizontal magnetic gradient and the helium content of soil samples, respectively (see chap. 14). Both methods measure small changes in the near surface caused by hydrocarbon microseepages, which commonly occur over hydrocarbon accumulations. The horizontal-gradient magnetometer survey, made with low-flying aircraft, measures small changes in the horizontal gradient of the Earth's magnetic field that are related to near-surface magnetic minerals formed by chemical reduction of ferric iron to ferrous iron by petroleum microseepage. The helium survey analyzes near-surface borehole samples (about 1 $\mathrm{m}$ ( $3 \mathrm{ft}$ ) deep) for helium content. Helium is a byproduct of radioactive decay of certain elements, some of which are associated with petroleum. Thus, anomalously high helium content in soil samples may indicate petroleum microseepages.

\section{Stratigraphic Test Wells}

In some undrilled areas, such as some offshore basins, a well will be drilled in a position least likely to find petroleum for the sole purpose of obtaining stratigraphic, geochemical, and geophysical information on the rocks present in the basin. These wells are called stratigraphic tests or, in the case of the offshore areas, COST (continental offshore stratigraphic test) wells.

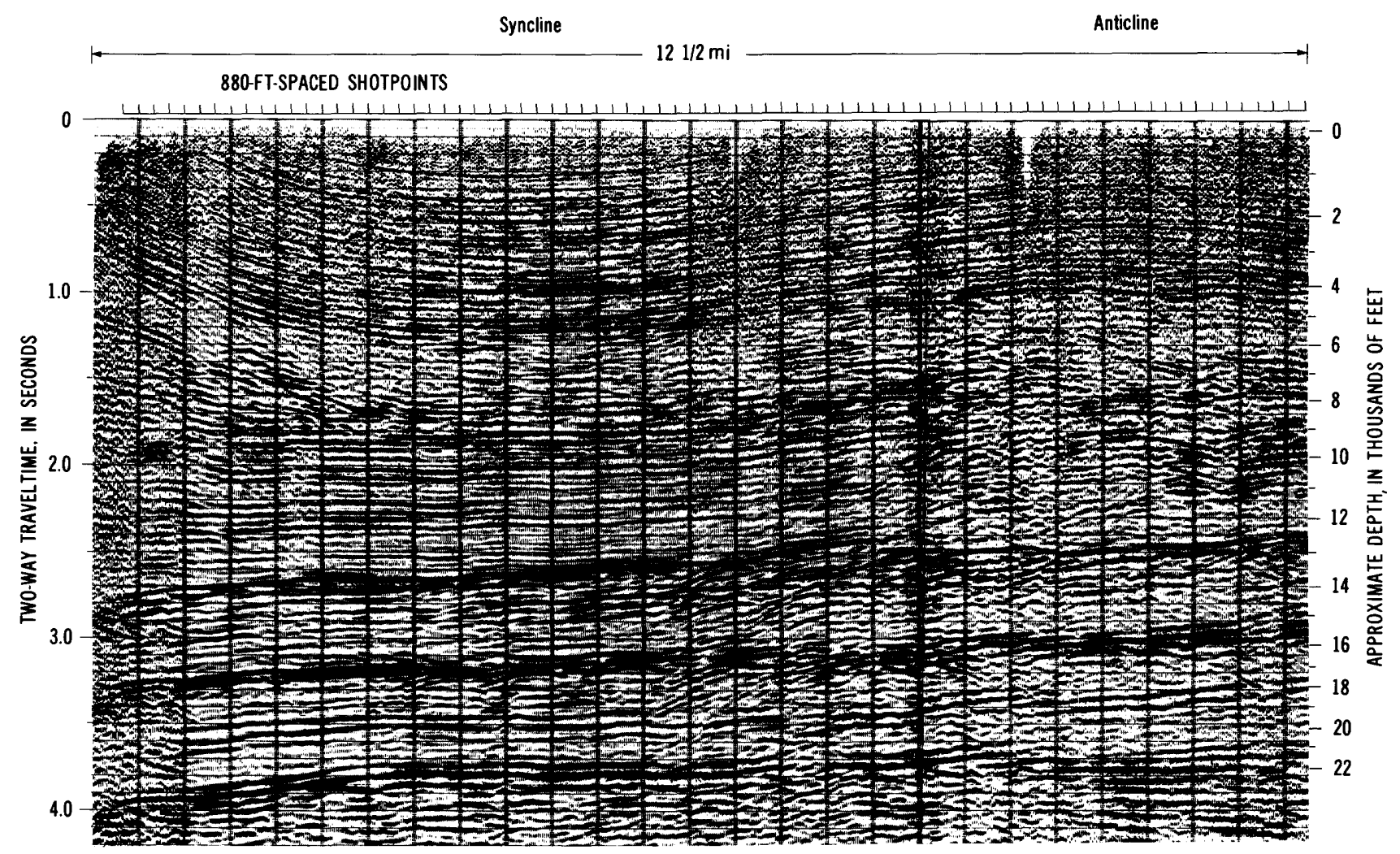

Figure 2.5. Seismic profile showing how seismic data are displayed. An anticline, syncline, and flank of another anticline are shown, from right to left, in shallower beds. (Example is from line 80-77-G in central North Slope $12 \mathrm{mi}$ west of Umiat.) 
Cuttings and core samples are examined for rock type, microfossils, source- and reservoir-rock characteristics, and oil indications. However, examination of drill cuttings is only one part in evaluating the strata penetrated by the drill. At intervals during the drilling and after reaching the final depth, various types of geophysical or mechanical measurements of the borehole are conducted by lowering instruments on a cable into the borehole. The resulting measurements are called well logs. The most common are electrical (resistivity and spontaneous potential), gamma-ray, acoustic, neutron, density, and caliper surveys. Each log records certain characteristics of the strata penetrated; the suite of logs reveals much about rock type, thickness, acoustic velocity, density, porosity, and fluid content.

\section{Summary of Exploration Methods}

All of the exploration methods discussed provide information important in assessing the petroleum potential of an area. Certainly, surface and subsurface studies, seismic surveys, and stratigraphic tests (if appropriate to the evaluation program) are extremely important. All information gathered is considered in making petroleum evaluations or in locating drill sites. Ultimately, however, the presence or absence of commercial petroleum accumulations cannot be ascertained without drilling one or more wells on the different types of prospects, depending on the complexity of the structure and of the stratigraphy. There are many examples of prospects or areas that were rated as having very high potential that proved to be nonproductive when they were drilled. A recent example is the Mukluk structure in the Beaufort Sea, which was drilled in 1983. Other examples are the Barrow high near Point Barrow and the Colville high on the Colville River delta west of Prudhoe Bay. Both structures originally looked more promising than the later-drilled Prudhoe Bay structure. This demonstrates that areas must continually be reassessed as new data become available, because not all factors necessary to make an oil field are precisely known. This uncertainty adds to the exploration risk and results in differences in exploration strategy, bidding, and the range of estimates of petroleum potential. 



\title{
Chapter 3.
}

\section{Regional Geologic Setting and History of Petroleum Exploration}

\author{
By Kenneth J. Bird ${ }^{1}$ and Jeffrey W. Bader ${ }^{1}$
}

\section{INTRODUCTION}

In the northeastern part of Alaska occupied by the Arctic National Wildlife Refuge (ANWR), the Brooks Range reaches its greatest elevation and is nearly twice as wide as elsewhere, whereas the foothills and coastal plain belt (the 1002 area) are reduced to a fraction of their width farther west. The North Slope, adjacent continental shelves, part of northeastern Siberia, and most of the Brooks Range (including its extension into Canada) are part of a single crustal plate. Its relationship to adjacent plates prior to Cretaceous time is uncertain, and thus it is considered a suspect terrane (Coney and Jones, 1985). Several regional, intraplate geologic trends overlap or converge in the northern part of the ANWR and account for a geologic complexity not found elsewhere on the North Slope. As previously noted by Mast and others (1980), the ANWR coastal plain has geologic similarities to both nearby petroleumbearing areas-the Prudhoe Bay area to the west and the Mackenzie Delta-Beaufort Sea area to the east.

This paper places the 1002 area in its regional geologic context and shows its relationship to nearby petroleum-bearing areas. While large amounts of oil and gas have already been discovered in these areas, their petroleum exploration history offers an example of the amount of time involved in the exploration and development of oil and gas resources in frontier regions that is measured in decades.

\section{REGIONAL SETTING}

\section{Arctic Alaska Plate}

The North Slope, the adjacent continental shelves, most of the Brooks Range and its extension into Canada (the British Mountains), and part of northeastern Siberia are all considered part of a continental plate herein referred to as the Arctic Alaska tectonic plate (fig. 3.1 , inset). This plate consists of a basement of Precambrian to Middle Devonian metasedimentary rocks of both deep- and shallow-marine origin, volcanic rocks,

\footnotetext{
${ }^{1}$ U.S. Geological Survey, Menlo Park, Calif.
}

and scattered granitic plutons dated as Devonian. Unconformably overlying the basement are two sedimentary sequences: (1) a south-facing passive margin sequence (Ellesmerian) of Mississippian to Early Cretaceous age derived from a landmass that lay to the north, and (2) a foredeep and northward-facing passive margin sequence (Brookian) of Cretaceous and Tertiary age derived from the Brooks Range orogenic highlands to the south.

The boundaries of the plate are only approximately located and poorly understood (Churkin and Trexler, 1980; Coney and Jones, 1985; Hubbard and others, 1987). The Arctic Alaska plate is bordered (1) on the north by oceanic crust of the Arctic Ocean basin (Canada basin), the boundary of which is postulated to lie north of a tectonic hinge line (fig. 3.1) beneath the continental slope (Grantz and May, 1983; chap. 21); (2) on the east by the North American plate, the boundary of which is marked by a zone of northeast-trending strikeslip faults in northwestern Canada (McWhae, 1986; Hubbard and others, 1987); and (3) on the south and west by allochthonous terranes (Churkin and Trexler, 1980; Coney and Jones, 1985), the boundary of which is marked in Alaska by the structurally complex Brooks Range, composed in its southern parts of an enormous stack of north-vergent nappes that Coney and Jones $(1985$, p. 276$)$ provisionally regard as being composed of four separate terranes.

The Arctic Alaska plate is considered a suspect terrane (Coney and Jones, 1985) because (1) it is difficult to demonstrate that continental crust of any sort lay where Alaska is today in pre-Cretaceous time, and (2) because the pre-Cretaceous geology of the Arctic Alaska plate cannot be traced directly into adjacent areas. Plate tectonic reconstructions in the western Arctic are made more difficult by the absence of clearly discernible magnetic lineations in the seafloor of the Canada basin. Utilizing other lines of evidence has led to numerous plate reconstructions for the Arctic Ocean basin and adjacent plates. (See summaries by Lawver and others (1984) and Nilsen (1981) and the recent reports by Green and others (1982), McWhae (1986), and Hubbard and others (1987)). These various reconstructions have in common the postulate of hundreds of kilometers of translational and (or) rotational motion-motion that occurred during Cretaceous time. However, they restore 


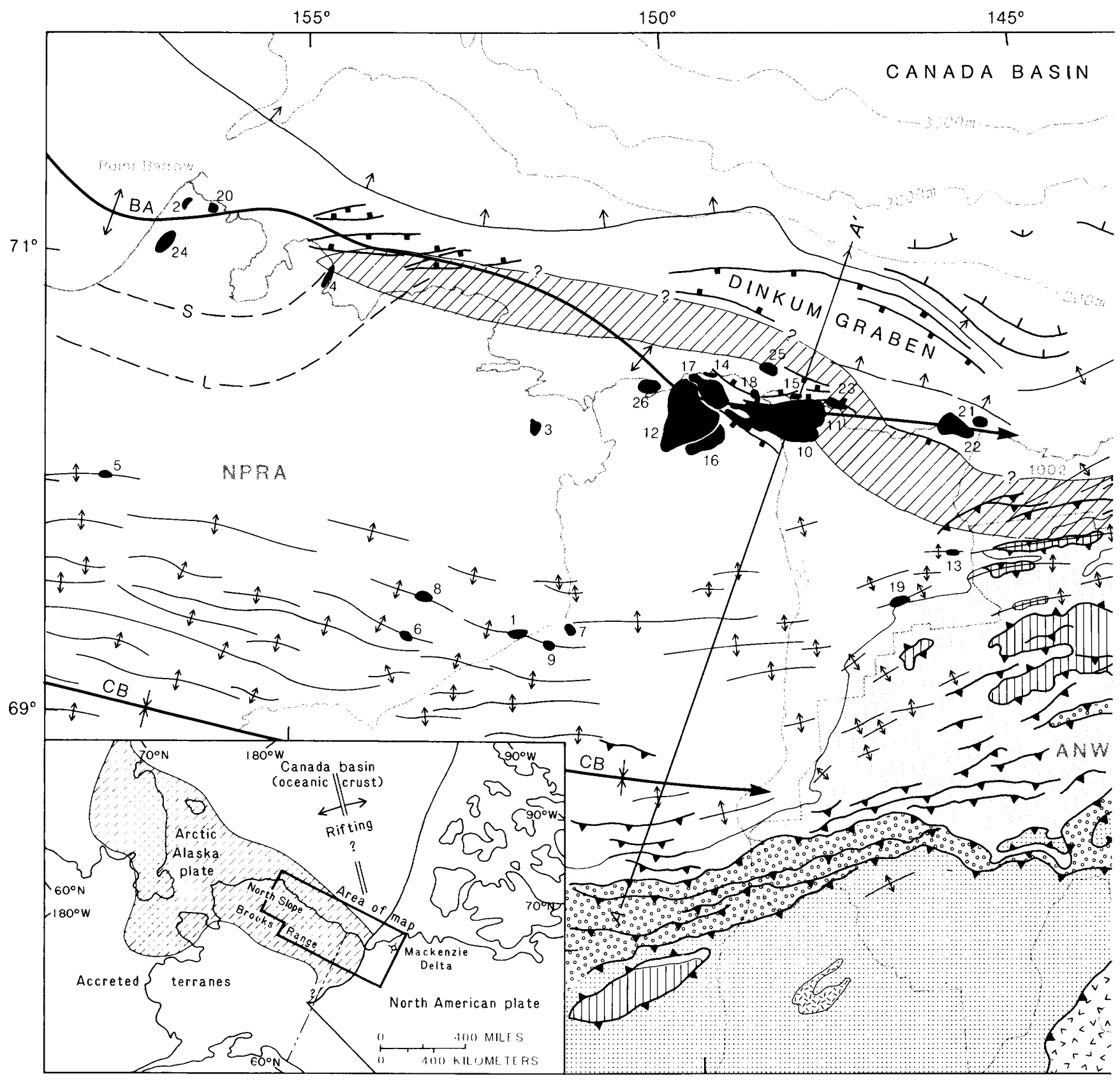

EXPLANATION

Autochthonous and parautochthonous rocks Tertiary and Cretaceous sedimentary rocks-Brookian sequence

Cretaceous to Mississippian sedimentary rocks-Ellesmerian sequence

एZA

Zone of truncation--Developed in Mississippian through Triassic part of Ellesmerian sequence beneath the so-called Lower Cretaceous uncontormity

पI Pre-Mississippian rocks

涩涩 Granitic intrusive rocks

Figure 3.1. Regional geologic setting of the 1002 area and adjacent oil-bearing areas, Prudhoe Bay and Mackenzie Delta, showing relationship to tectonic plates (inset; modified from Churkin and Trexler, 1980),

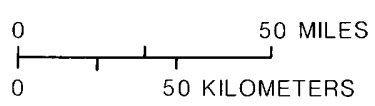

Allocthonous rocks of the Brooks Range

Late Devonian clastic-wedge deposits (Kanayut Conglomerate) and adjacent strata

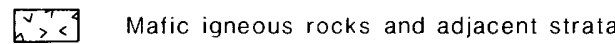

Other metasedimentary rocks 


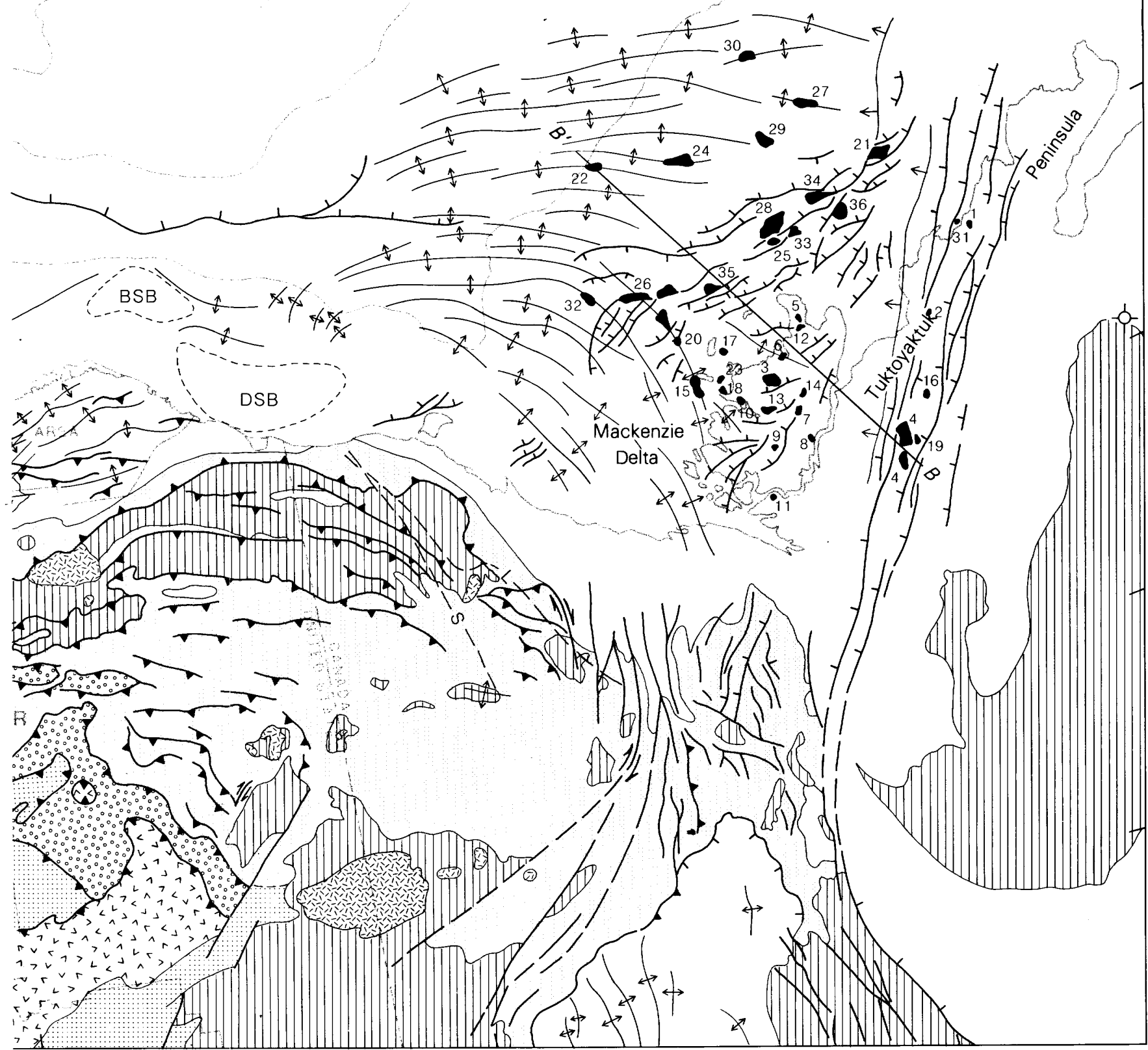

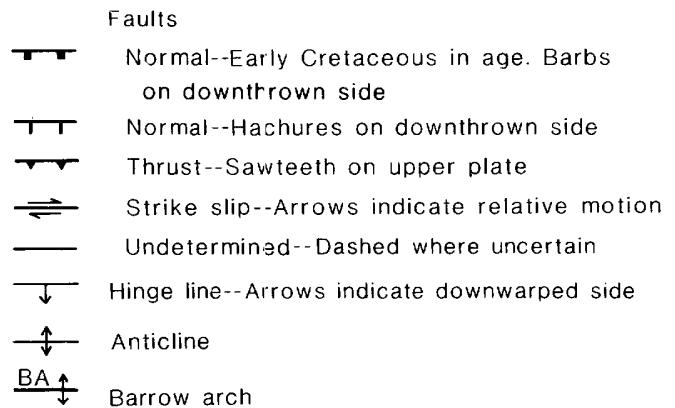

data are from Craig and others (1985) and Grantz and May (1983) for Alaska and Dixon and others (1985) and J.R. Dietrich (Geological Survey of Canada, written commun., 1985) for Canada. Onshore data are from

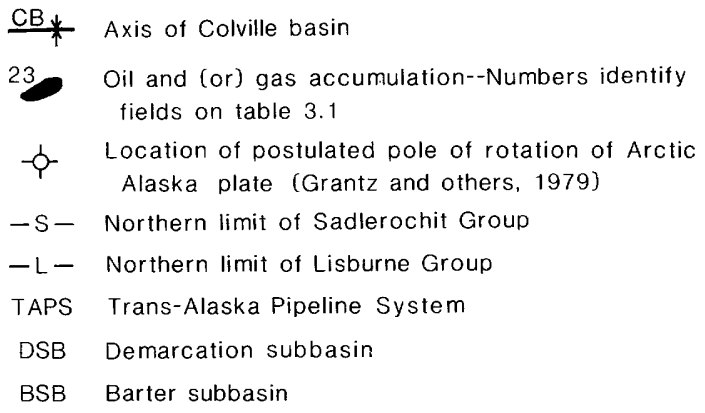

Norris (1984) for Canada and Bader and Bird (1986), Nilsen and others (1980), and various U.S. Geological Survey geologic quadrangle maps for Alaska. See fig. 3.3 for sections $A-A^{\prime}$ and $B-B^{\prime}$. 
the Arctic Alaska plate to diverse locations such as adjacent to parts of Arctic Canada, the northern Cordillera of Canada, or the proto-Pacific Ocean south of present-day Alaska.

One of the oldest and widely accepted models explaining the origin of Arctic Alaska is the rifting and rotation of the Arctic Alaska plate away from Arctic Canada about a pivot near the Mackenzie Delta (Carey, 1958; Tailleur, 1973; Mull, 1982; Grantz and May, 1983; fig. 3.1). This hypothesis accounts for (1) the inferred Cretaceous age of the Canada basin, (2) the fit of the restored blocks (with respect to bathymetry, gravityanomalies, and geology of Late Paleozoic and younger rocks), and an apparent linkage with deformation in the Brooks Range, in which the amount of tectonic shortening was inferred to decrease from west to east (Mull, 1982). Problems with this hypothesis include structural and metamorphic differences between Devonian and older rocks across the restored boundary between Canada and Alaska, opposition of mid-Paleozoic sediment transport directions, a similar amount of tectonic shortening throughout the Brooks Range, and the cause of Tertiary (postrotational) deformation in northeastern Alaska and northwestern Canada. To accommodate these problems, the hypothesis may be modified to include as much as $2,000 \mathrm{~km}(1,200 \mathrm{mi})$ of left-lateral displacement of the Arctic Alaska plate in mid-Paleozoic time from a site north and east of Ellesmere Island (Sweeney, 1982; Eisbacher, 1983), a cause of Brooks Range deformation unrelated to or only partly related to rotational opening of the Canada basin, and causes of Tertiary deformation that may be external to the Arctic Alaska plate (Moore and others, 1985b).

\section{Geologic Complexity of the Northern ANWR}

The geologic complexity of the northern part of the ANWR, as described in the accompanying papers of this volume, is not found elsewhere on the North Slope. This complexity results from the particular overlap and composition of the sedimentary sequences and the convergence of several intraplate structural features.

Stratigraphic features that contribute to the geologic complexity of the ANWR are as follows. PreMississippian carbonate and quartzite units many kilometers thick provide a rigid basement in the northern part of the ANWR that is unknown in the subsurface to the west. The erosional northern limit of Ellesmerian rocks, related to rift-margin uplift, projects into the coastal plain area (fig. 3.1), thus restricting the occurrence of these relatively competent rocks that include both source and reservoir rocks for petroleum at Prudhoe Bay. In contrast to the relatively thin Ellesmerian rocks beneath the coastal plain, Brookian clastic rocks are very thick, relatively incompetent, and show pronounced lateral facies changes related to northeasterly progradation. At least one regional unconformity, provisionally dated as Eocene, is known within this sequence.

Structural features that contribute to the complexity of the ANWR are from north to south, a tectonic hinge line, a southeast-trending basement ridge (Barrow arch), and a fold and thrust belt (Brooks Range and adjacent foothills)(fig. 3.1). The tectonic hinge line, the Barrow arch, and a system of associated normal faults are features located generally north of Alaska that are believed to be related to Early Cretaceous rifting and (or) later subsidence (Grantz and May, 1983). The tectonic hinge line marks the area where prerift continental crust dips sharply seaward toward transitional and oceanic crust (chap. 21) and the Barrow arch, the line of inflection where the regional southward-dipping basement surface is downwarped and downfaulted to the north in response to rifting and later subsidence. All of these features trend east-southeast and project into the northern part of the ANWR.

The fold and thrust belt trends eastward across most of northern Alaska. At about $149^{\circ} \mathrm{W}$. longitude, just east of the trans-Alaska pipeline system (TAPS), it makes a pronounced northward bulge (fig. 3.1). Onshore, structural axes are curvilinear, northeast- and east-trending in Alaska and southeast-trending in Canada. Offshore, in Brookian rocks, structural axes are broadly parallel to onshore trends, suggesting a genetic relationship. The eastern Brooks Range was previously interpreted to show relatively little telescoping and mostly vertical uplift (Mast and others, 1980; Mull, 1982). A more recent interpretation (Rattey, 1985), however, estimates more than $400 \mathrm{~km}(250 \mathrm{mi})$ of telescoping, an amount comparable to that of the western and central Brooks Range (Mayfield and others, 1983; Butler and others, 1985). Deformation is thin skinned but, unlike the western and central Brooks Range, involves significant amounts of the basement rocks (Rattey, 1985; Vann and others, 1986; chaps. 17-20).

Observations from the Mackenzie Delta coupled with those in and adjacent to the ANWR suggest that this region experienced at least three episodes of deformation during the Cenozoic: (1) early Tertiary (Paleocene and Eocene) thrust faulting and folding in the northern ANWR (chap. 20) and diapiric folding and faulting in the Mackenzie Delta and offshore (Dixon and others, 1985), (2) middle Tertiary (early Miocene) extensional faulting in the Mackenzie Delta and offshore area (Dixon and others, 1985), and (3) late Tertiary and Quaternary (Pliocene to Holocene) folding and faulting in the northern ANWR and offshore (chaps. 17-21). Only the western part of the coastal plain and the area offshore are experiencing present-day deformation (chap. 21).

The stratigraphic similarities of the northern ANWR and adjacent oil-bearing areas are illustrated in 
figure 3.2. Stratigraphic columns for the Prudhoe Bay region, the northern part of the ANWR, and the Mackenzie Delta region show that the ANWR has both an Ellesmerian sequence and a Brookian sequence similar to those of the Prudhoe Bay area. The Brookian sequence in the ANWR is thicker and the Ellesmerian sequence thinner than those at Prudhoe Bay. The Mackenzie Delta region has a very thick Brookian sequence and an abbreviated Ellesmerian sequence limited to Jurassic and younger strata.

\section{HISTORY OF PETROLEUM EXPLORATION AND DEVELOPMENT OF ADJACENT AREAS}

\section{North Slope-Beaufort Sea Area}

\section{General Setting and Geology}

The North Slope-Beaufort Sea area includes land north of the Brooks Range drainage divide and the offshore area extending to the edge of the continental

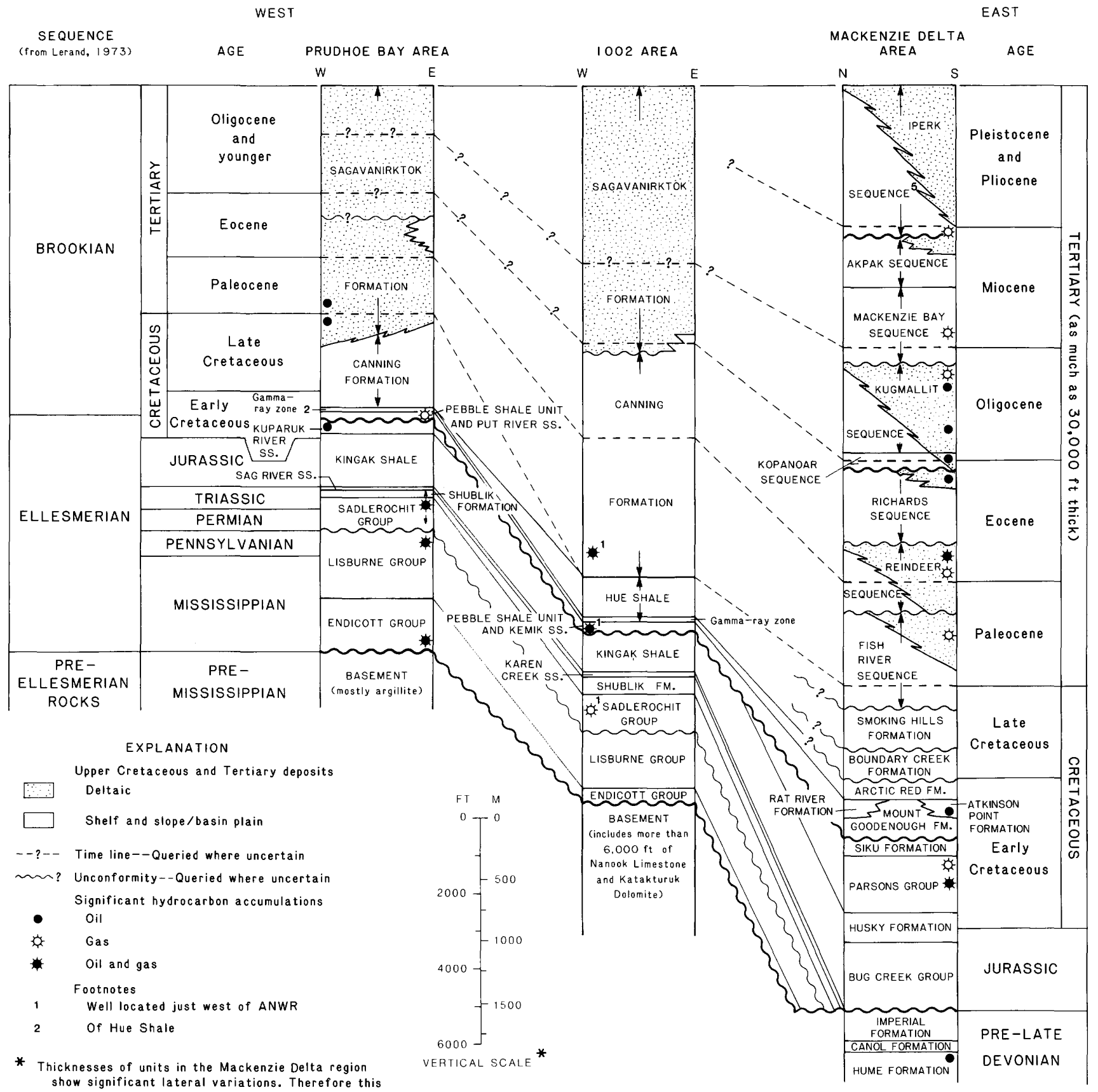

Figure 3.2. Generalized columnar sections illustrating stratigraphic similarities between northern part of the ANWR and adjacent oil-bearing areas, Prudhoe Bay and Mackenzie Delta. 
shelf at a water depth of about $200 \mathrm{~m}(700 \mathrm{ft})$. This region is underlain by Paleozoic to Cenozoic petroleumprospective sedimentary rocks, which are generally subdivided into lower and upper sequences. The lower sequence (Ellesmerian) consists of Mississippian to lowermost Cretaceous sandstone, shale, and carbonate rocks that were deposited in a basin in which the land area lay to the north (the area of the present-day Arctic Ocean) and the sea lay to the south. These rocks, which only locally are more than $3 \mathrm{~km}(10,000 \mathrm{ft})$ thick, are faulted to varying degrees and with older rocks form the Brooks Range. The upper sequence (Brookian) consists of a very thick section (more than $7.6 \mathrm{~km}, 25,000 \mathrm{ft}$ ) of Lower Cretaceous to Holocene sandstone and shale. These rocks represent erosional debris shed from the ancestral Brooks Range and deposited in a subsiding, troughlike basin adjacent to the range. These sediments gradually filled the basin and, in a series of migrating deltaic wedges, built northward and eastward across a submerged ridge and into the deeper parts of the Beaufort Sea (fig. 3.3A).

\section{Drilling History}

The North Slope is unique among United States petroleum basins because of the Federal Government's long involvement in petroleum evaluation and exploration there (Bird, 1981). The first North Slope well was drilled in 1944 by the U.S. Navy in the National Petroleum Reserve in Alaska (NPRA) (then called Naval Petroleum Reserve No. 4). From 1944 to 1981 the Navy and USGS drilled 66 exploratory wells, most of which are located in the NPRA. The first industry well was drilled by Colorado Oil and Gas Corporation in 1963, and through 1984 a total of 205 onshore and offshore industry wells had been drilled. The first offshore well, located on a natural barrier island, was drilled by BP Alaska Inc. in 1975. A total of 37 offshore exploratory wells had been drilled through 1984. The area initially available to industry for drilling was limited to the lands between the NPRA and the ANWR. Later, lands became available west of the NPRA and offshore. The NPRA was opened for leasing in 1981. In early 1985 and continuing in 1986, an exploratory well was drilled on Kaktovik Inupiat Corporation lands adjacent to the 1002 area (well no. 8, fig. 1.1B).

\section{Hydrocarbon Discoveries}

The first discovery was made by the U.S. Navy in 1946 in the third year of exploration, after drilling 17 wells and shallow core tests. Through 1984, 234 onshore and 37 offshore government and industry exploratory wells have resulted in the discovery of 22 oil and gas fields onshore and 3 offshore. Although many of the fields are noncommercial by current North Slope standards, the total ultimate recovery from all the fields is estimated to be nearly 13 billion barrels of oil and more than 37 trillion $\mathrm{ft}^{3}$ of gas (see fig. 3.1, table 3.1). The first hydrocarbon production was in 1949, when the government produced natural gas for local use at Barrow. Commercial oil production from the Prudhoe Bay field began in 1977 with the completion of the trans-Alaska pipeline - almost 10 years after the field was discovered. The Prudhoe Bay and Kuparuk River fields, the two leading U.S. oil producers, were supplying 1.67 million barrels of oil per day in 1984 , or about 20 percent of the total U.S. production. Development of the Lisburne and Endicott fields is underway. In 1985, Milne Point field was put on production. Oil and gas have also been discovered in the Flaxman Island and Point Thomson areas, both less than $16 \mathrm{~km}(10 \mathrm{mi})$ from the northwest corner of the 1002 area (Nos. 21 and 22, fig. 3.1 and table 3.1). The areal extent of these accumulations is unknown, and it is possible that one or both may extend into the 1002 area.

\section{Mackenzie Delta-Beaufort Sea Area}

\section{General Setting}

The Mackenzie Delta-Beaufort Sea area, as described by Procter and others (1984), includes the onshore Mackenzie Delta, the Tuktoyaktuk Peninsula, and that part of the offshore area extending to the edge of the continental shelf at a water depth of approximately $200 \mathrm{~m}$ (700 ft). The region is underlain by deltaic sandstones and shales of Mesozoic and Cenozoic age that thicken rapidly to more than $12 \mathrm{~km}(39,000 \mathrm{ft})$ a short distance seaward from the present delta. These beds overlie faulted Paleozoic rocks stepping down steeply beneath the Mesozoic and Cenozoic cover. The Paleozoic rocks rise to the surface and are exposed in the southern part of the area. The basin contains a series of Mesozoic and Cenozoic depocenters. Thick Upper Cretaceous to Holocene clastic sediments were deposited in a series of migrating deltaic wedges, which built out over the passive-type margin of the southern Beaufort Sea (fig. $3.3 B)$.

\section{Drilling History}

The first well in this region was drilled onshore east of the Tuktoyaktuk Peninsula in 1962. By the end of 1984, a total of 170 wells had been drilled (J.R. Dietrich, Geological Survey of Canada, oral commun., 1985). Exploration for oil and gas in this region has progressed from onshore drilling to drilling in shallow water $(0-26 \mathrm{~m}, 0-85 \mathrm{ft})$ from artificial islands, to drilling in water depths greater than $26 \mathrm{~m}(85 \mathrm{ft})$ from drillships and floating platforms. The first onshore well was drilled in 1962, the first shallow-water offshore well in 1973, and the first deeper water offshore well from a drillship in 1976. 


\section{Hydrocarbon Discoveries}

The first discovery was made in 1970 after more than eight years of exploration and drilling 21 dry holes. Through 1984, 114 onshore wells and 56 offshore wells had resulted in the discovery of 18 oil and gas fields onshore and 18 offshore (see fig. 3.1, table 3.1). Recoverable hydrocarbon reserves for all but the two reported 1985 discoveries (table 3.1) total 740 million barrels of oil and 10 trillion $\mathrm{ft}^{3}$ of gas. Reserves for individual fields are reported for only 5 of the 34 fields; reserves of the remaining fields are estimates. The wide spectrum of reserve estimates for oil and gas in this region reflects the many geological complexities and the sparcity of definitive drill-stem tests. These estimates are conservative and certainly subject to significant change (Procter and others, 1984). One such significant change occurred in 1986 when Gulf Canada Resources Ltd. announced that evaluation of test data from recently drilled delineation wells in the Amauligak field (No. 34, table 3.1) supported their earlier reserve estimates of 700 to 800 million barrels of oil (Oil and Gas Journal, 1986). In early 1987, the company announced development plans for this field that include water-borne production starting as soon as 1988 followed in about four years by construction of a crude oil pipeline up the Mackenzie River valley (Oil and Gas Journal, 1987).

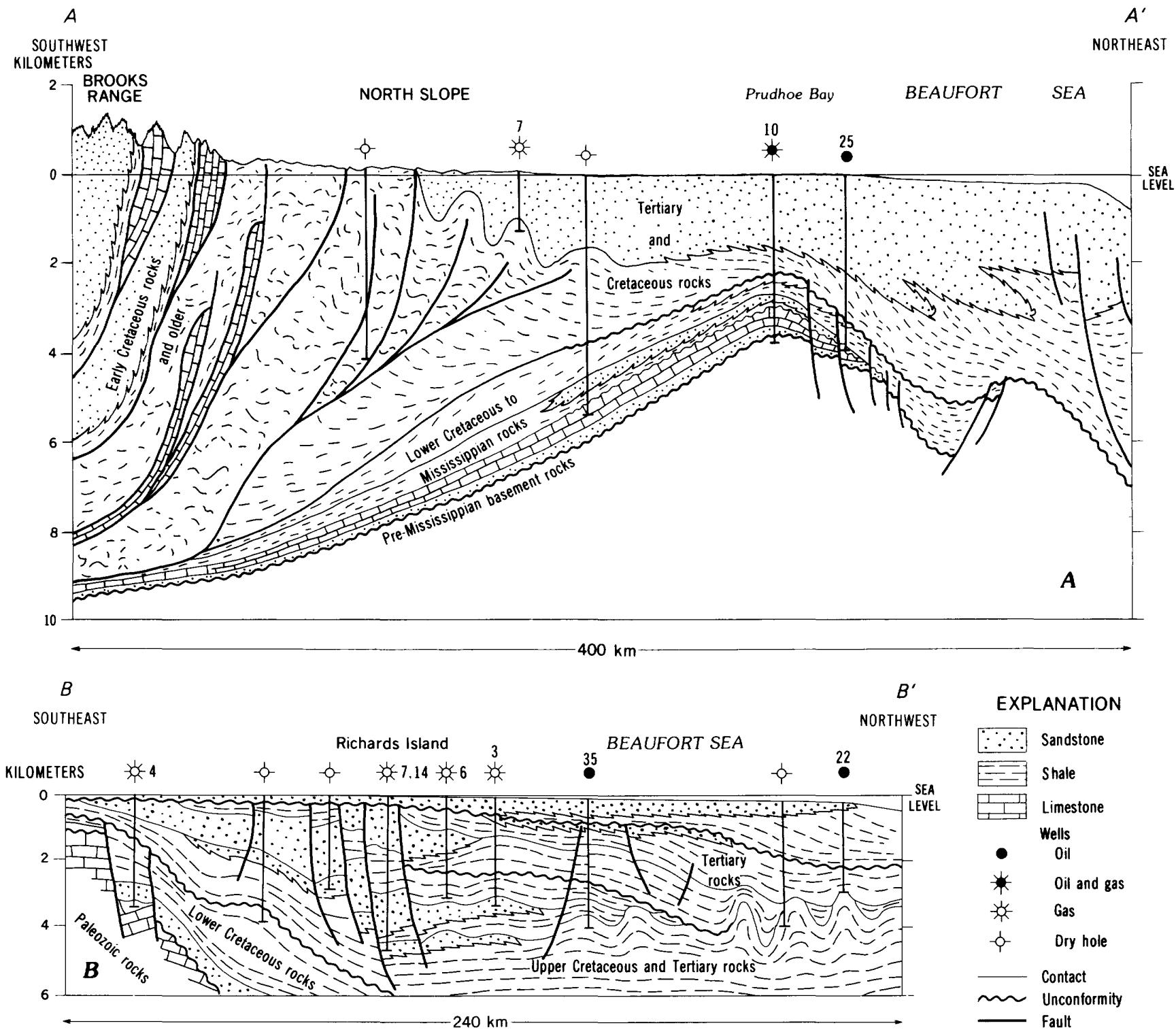

Figure 3.3. Sections showing schematic stratigraphic relations. $A$, North Slope of Alaska. $B$, Mackenzie Delta (from Procter and others, 1984). See figure 3.1 for location of sections. Numbers correspond to oil and gas fields in table 3.1. 
Table 3.1. Oil and gas discoveries through 1985 for the North Slope, Mackenzie Delta, and Beaufort Sea

[Field numbers correspond to locations shown on figure 3.1; field sizes on North Slope-Beaufort Sea from Bird (1981), Van Dyke (1980), Werner (1984), several issues of the Oil and Gas Joumal, and the Alaska Oil and Gas Conservation Commission (1985); field sizes and totals for Mackenzie Delta-Beaufort Sea from Procter and others (1984); -, oil or gas not present; n.a., oil or gas present, amount unknown; *, recoverable oil in millions of barrels; **, recoverable gas in billions of cubic feet; + , heavy oil and tar deposits with a total estimated amount of in-place oil of $26-44$ billion barrels (Werner, 1984); ++, oil and gas totals do not include discoveries made in 1985]

\begin{tabular}{|c|c|c|c|c|c|c|c|c|}
\hline \multirow[t]{2}{*}{ No. } & \multicolumn{3}{|c|}{ North Slope-Beaufort Sea } & \multirow[t]{2}{*}{ Year } & \multirow[t]{2}{*}{ No. } & \multicolumn{3}{|c|}{ Mackenzie Delta-Beaufort Sea } \\
\hline & Field & Oil* & Gas** & & & Field & Oil* & Gas** \\
\hline 1 & Umiat & 70 & n.a. & 1946 & & & & \\
\hline 2 & South Barrow & - & 25 & 1949 & & & & \\
\hline 3 & Fish Creek & n.a. & - & 1949 & & & & \\
\hline 4 & Simpson & 10 & n.a. & 1950 & & & & \\
\hline 5 & Meade & - & 15 & 1950 & & & & \\
\hline 6 & Wolf Creek & - & n.a. & 1951 & & & & \\
\hline 7 & Gubik & - & 150 & 1951 & & & & \\
\hline 8 & Square Lake & - & 45 & 1952 & & & & \\
\hline 9 & East Umiat & - & n.a. & 1963 & & & & \\
\hline 10 & Prudhoe Bay & 9,600 & 28,500 & 1968 & & & & \\
\hline 11 & Lisburne & 210 & 800 & 1968 & & & & \\
\hline 12 & Kuparuk & 1,480 & 640 & 1969 & & & & \\
\hline 13 & Kavik & - & n.a. & 1969 & & & & \\
\hline 14 & Milne Point & 100 & n.a. & 1969 & & & & \\
\hline 15 & Gwydyr Bay area & 80 & n.a. & 1969 & & & & \\
\hline 16 & West Sak & + & - & 1969 & & & & \\
\hline 17 & Ugnu & + & - & 1969 & & & & \\
\hline \multirow[t]{3}{*}{18} & North Prudhoe & 75 & n.a. & 1970 & 1 & Atkinson & - & n.a. \\
\hline & & & & 1971 & 2 & Mayogiak & n.a. & - \\
\hline & & & & 1971 & 3 & Taglu & 45 & 2,400 \\
\hline \multirow[t]{9}{*}{19} & Kemik & - & n.a. & 1972 & 4 & Parsons & 23 & 2,200 \\
\hline & & & & 1972 & 5 & Ivik N.E. & n.a. & - \\
\hline & & & & 1972 & 6 & Mallik & & n.a. \\
\hline & & & & 1973 & 7 & Ya Ya S. & - & n.a. \\
\hline & & & & 1973 & 8 & Reindeer & - & n.a. \\
\hline & & & & 1973 & 9 & Titalik & - & n.a. \\
\hline & & & & 1973 & 10 & Niglintgak & 23 & 800 \\
\hline & & & & 1973 & 11 & Kugpik & n.a. & - \\
\hline & & & & 1973 & 12 & Ivik S.W. & n.a. & - \\
\hline \multirow[t]{3}{*}{20} & East Barrow & - & 19 & 1974 & 13 & Kumak & n.a. & n.a. \\
\hline & & & & 1974 & 14 & Ya Ya N. & n.a. & - \\
\hline & & & & 1974 & 15 & Adgo & n.a. & n.a. \\
\hline \multirow[t]{5}{*}{21} & Flaxman Island & n.a. & n.a. & 1975 & 16 & Imnak & n.a. & \\
\hline & & & & 1975 & 17 & Pelly & - & n.a. \\
\hline & & & & 1976 & 18 & Garry S. & n.a. & n.a. \\
\hline & & & & 1976 & 19 & Kamik & n.a. & - \\
\hline & & & & 1976 & 20 & Netserk & - & n.a. \\
\hline
\end{tabular}


Table 3.1. Oil and gas discoveries through 1985 for the North Slope, Mackenzie Delta, and Beaufort Sea-Continued

[Field numbers correspond to locations shown on figure 3.1; field sizes on North Slope-Beaufort Sea from Bird (1981), Van Dyke (1980), Werner (1984), several issues of the Oil and Gas Joumal, and the Alaska Oil and Gas Conservation Commission (1985); field sizes and totals for Mackenzie Delta-Beaufort Sea from Procter and others (1984); -, oil or gas not present; n.a., oil or gas present, amount unknown; *, recoverable oil in millions of barrels; **, recoverable gas in billions of cubic feet; + , heavy oil and tar deposits with a total estimated amount of in-place oil of $26-44$ billion barrels (Wemer, 1984); ++, oil and gas totals do not include discoveries made in 1985]

\begin{tabular}{|c|c|c|c|c|c|c|c|c|}
\hline \multirow[t]{2}{*}{ No. } & \multicolumn{3}{|c|}{ North Slope-Beaufort Sea } & \multirow[t]{2}{*}{ Year } & \multirow[t]{2}{*}{ No. } & \multicolumn{3}{|c|}{ Mackenzie Delta-Beaufort Sea } \\
\hline & Field & Oil* & Gas** & & & Field & Oil* & Gas** \\
\hline \multirow{2}{*}{22} & Point Thomson & 350 & 5,000 & 1977 & 21 & Ukalerk & - & n.a. \\
\hline & & & & 1977 & 22 & Nektoralik & n.a. & n.a. \\
\hline \multirow[t]{5}{*}{23} & Endicott & 375 & 731 & 1978 & 23 & Garry N. & n.a. & n.a. \\
\hline & & & & 1978 & 24 & Kopanoar & n.a. & - \\
\hline & & & & 1978 & 25 & Isserk & n.a. & - \\
\hline & & & & 1979 & 26 & Tarsiut & 150 & 85 \\
\hline & & & & 1979 & 27 & Nerlerk & n.a. & - \\
\hline \multirow[t]{6}{*}{24} & Walakpa & - & n.a. & 1980 & 28 & Issungnak & 100 & 2,500 \\
\hline & & & & 1981 & 29 & Koakoak & - & n.a. \\
\hline & & & & 1982 & 30 & Kenalooak & - & n.a. \\
\hline & & & & 1982 & 31 & W. Atkinson & - & n.a. \\
\hline & & & & 1983 & 32 & Pitsiulak & n.a. & n.a. \\
\hline & & & & 1983 & 33 & Itiyok & n.a. & n.a. \\
\hline 25 & Seal Island & 300 & n.a. & 1984 & 34 & Amauligak & n.a. & n.a. \\
\hline \multirow[t]{2}{*}{26} & Colville Delta & n.a. & n.a. & 1985 & 35 & Nipterk & n.a. & n.a. \\
\hline & & & & 1985 & 36 & Amerk & - & n.a. \\
\hline Totals ++ & & 12,650 & 36,765 & & & & 740 & 10,170 \\
\hline
\end{tabular}

\section{Summary}

The 1002 area lies near the northeastern edge of the Arctic Alaska tectonic plate between the Prudhoe Bay and Mackenzie Delta oil-bearing areas. The relationship of this plate to other plates in the Arctic is unknown in pre-Cretaceous time, but it may have traveled as much as $2,000 \mathrm{~km}(1,200 \mathrm{mi})$. Intraplate structural and stratigraphic features combine in the 1002 area to produce a geologic complexity unknown elsewhere on the North Slope. The post-Devonian stratigraphy of the 1002 area is intermediate between the nearly equal thicknesses of Ellesmerian and Brookian rocks of the Prudhoe Bay area and the thick Brookian and relatively thin Ellesmerian rocks of the Mackenzie Delta area. Stratigraphic truncation, a system of normal faults, and hinge lines related to Early Cretaceous rifting project into the 1002 area, where they are overridden by and incorporated into a Cenozoic fold and thrust belt.

Numerous oil and gas fields are known from the North Slope and the Mackenzie Delta. Oil exploration dates from the 1940's on the North Slope and the 1960's in the Mackenzie Delta region. At the end of 1984, the amount of estimated recoverable oil for the North Slope was about 13 billion barrels and for the Mackenzie Delta about 1-2 billion barrels. In both regions, the time between first exploration and commercial production is measured in decades. 



\title{
Chapter 4.
}

\section{Surficial Geology, Permafrost, and Physical Processes}

\author{
By Max C. Brewer ${ }^{1}$
}

\section{INTRODUCTION}

The 1002 area is within the tundra-covered Arctic Coastal Plain Province, the only extension of the Interior Plains of North America in Alaska (Wahrhaftig, 1965). Except for scattered bedrock outcrops in about 4 percent of its area, the 1002 area is covered by a thin mantle of unconsolidated, frozen sediments of Cenozoic

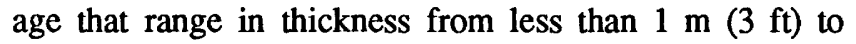
about $30 \mathrm{~m}(100 \mathrm{ft})$. The outcrops are mainly poorly consolidated Tertiary siltstone, mudstone, sandstone, and conglomerate in the Marsh Creek and middle Jago River areas; a few minor outcrops of Cretaceous and Jurassic shales along the lower Jago River; and Cretaceous and Jurassic shale near the Niguanak River and in the Sadlerochit Spring area.

Oil seeps have been found in the Manning Point area, about $10 \mathrm{~km}(6 \mathrm{mi})$ north of the 1002 area, and near Angun Point, within the 1002 area. Oil-stained sandstones are found in outcrops near the middle reaches of the Katakturuk River; and oil-bearing sands and shales having an odor of oil occur in outcrops along the lower Jago River, about $16 \mathrm{~km}(10 \mathrm{mi})$ south of Barter Island (chap. 12).

Despite the arctic climate prevailing during the Pleistocene, glaciers were absent from about 90 percent of the 1002 area. A large valley glacier formed a piedmont lobe that extended approximately $20 \mathrm{~km}(12$ $\mathrm{mi}$ ) into the area along the Canning River and probably about $11 \mathrm{~km}(7 \mathrm{mi})$ along the Tamayariak River. Smaller valley glaciers extended about $6 \mathrm{~km}(4 \mathrm{mi})$ into the area along the Hulahula River, just across the 1002 area boundary along the Jago River, and $3 \mathrm{~km}(2 \mathrm{mi})$ along the Aichilik River. Glacial fluvial deposits and eolian materials are widespread, even in unglaciated areas.

The Beaufort Sea coastline, with its narrow beaches, is low lying, gradually receding, and irregular in shape. It has numerous points, many offshore shoals, mudflats, spits, bars, and low-lying barrier islands behind which are shallow lagoons. The coastline is punctuated by deltas, the most pronounced being those of the Canning, Hulahula-Okpilak, Jago, and Aichilik Rivers.

\footnotetext{
${ }^{1}$ U.S. Geological Survey, Anchorage, Alas.
}

Tides are small; the diurnal tide rarely exceeds $0.3 \mathrm{~m} \mathrm{(1}$ $\mathrm{ft})$, and the maximum annual tide is less than $1 \mathrm{~m}(3 \mathrm{ft})$. Wind tides occasionally exceed the maximum lunar tides during periods of open water, particularly in late September - early October. The coast is characterized by bluffs commonly 1 to $2 \mathrm{~m}$ ( 3 to $7 \mathrm{ft}$ ) high, locally as high as $8 \mathrm{~m}(26 \mathrm{ft})$. The $15-\mathrm{m}(50 \mathrm{ft})$ contour is generally $2-3 \mathrm{mi}$ inland, except at Barter Island, which is only about $5 \mathrm{~km}(3 \mathrm{mi})$ wide but is higher than $15 \mathrm{~m}$ $(50 \mathrm{ft})$ in the central area. In the low-lying Canning River delta, a comparable elevation is found about $13 \mathrm{~km}$ (8 mi) inland.

Lagoons and bays are generally shallow, 1 to 4 m (3 to $13 \mathrm{ft}$ ) deep, except in Camden Bay, where the $5-\mathrm{m}(16 \mathrm{ft})$ depth contour is within about $180 \mathrm{~m}$ (200 yd) of shore. Camden Bay offers the best reasonably deep, protected harborage along the Arctic coast of Alaska.

\section{CLIMATE}

The climate of the 1002 area is arctic marine, having extremely low winter temperatures and short, cool summers. Persistent winds occur throughout the year. Blizzards are frequent during the long, dark winter. Along the coast the climate is moderated by the sea and is less extreme. Meteorological data are limited; those of most value for this study are the marine data from Barter Island (Kaktovik) (see fig. 1.1B) and the data from Umiat (to the west and about $120 \mathrm{~km}$ (75 mi) inland), which has more of an arctic continental climate. Umiat is the closest area for which inland climate records exist. The recorded extreme temperatures and the average annual temperatures for both stations (table 4.1), however, do not indicate any significant differences between the arctic marine and continental climates and thus effectively mask the important parameters. The maximum and minimum temperatures are of very short duration, often only minutes, and thus do not really affect either the environment or man's activities.

The average monthly temperatures, however, can markedly affect the environment and man's activities. From year to year the average monthly temperatures, especially in winter, can vary widely. At Barter Island, the average January temperature was -15.3 
${ }^{\circ} \mathrm{C}\left(+4.5^{\circ} \mathrm{F}\right)$ in 1981 and $-29.9^{\circ} \mathrm{C}\left(-21.8^{\circ} \mathrm{F}\right)$ in 1983. At Umiat, the average January temperature was $-24{ }^{\circ} \mathrm{C}$ $\left(-11.2{ }^{\circ} \mathrm{F}\right)$ in 1982 and $-41.2^{\circ} \mathrm{C}\left(-42.2{ }^{\circ} \mathrm{F}\right)$ in 1984. In summer, variations are less pronounced but more important because the accumulation of the degree days above freezing (thaw index) greatly influences the depth of thaw in the soil, the rate of the melting of ice on water bodies, and the growth and reproduction of plants. Some of the important average monthly temperature data and temperature-related parameters are tabulated below (table 4.2). The thaw indices indicate that approximately three times as much heat energy is usually received at the ground surface in the Umiat area than at Barter Island during the summer months. Because the difference in the departure from the norm is most important, the effects of an unusually warm summer can be relatively greater at Barter Island than in the Umiat area.

In the Arctic, the chill factor is more important than the air temperature in evaluating the temperature's effect. Strong winds of $48 \mathrm{~km} / \mathrm{h}(30 \mathrm{mi} / \mathrm{h})$ coupled with cold temperatures $\left(-37.2{ }^{\circ} \mathrm{C},-35.0{ }^{\circ} \mathrm{F}\right)$ produce chill temperatures sometimes colder than $-73.3^{\circ} \mathrm{C}\left(-99.9^{\circ} \mathrm{F}\right.$; Selkregg, 1975). The average wind-chill factor at Barter Island during February 1984 resulted in a temperature of $-62.2^{\circ} \mathrm{C}\left(-80.0^{\circ} \mathrm{F}\right)$ from an ambient temperature of -36.2 ${ }^{\circ} \mathrm{C}\left(-33.2^{\circ} \mathrm{F}\right)$ with a wind speed of $24.9 \mathrm{~km} / \mathrm{h}(15.5$ $\mathrm{mi} / \mathrm{h})$.

Precipitation over the 1002 area is light but frequent; it occurs as drizzle in the summer and as light snow in the winter. Published summaries indicate that the annual precipitation at Barter Island averages 15.95 $\mathrm{cm}$ (6.28 in) and has ranged from $7.44 \mathrm{~cm}(2.93 \mathrm{in})$ in 1974 to $31.04 \mathrm{~cm}(12.22 \mathrm{in})$ in 1955 . Average summer precipitation is $1.32 \mathrm{~cm}(0.52 \mathrm{in})$ in June, $2.57 \mathrm{~cm}(1.01$ in) in July, and $2.77 \mathrm{~cm}(1.09$ in) in August. The reported remaining $9.30 \mathrm{~cm}$ (3.66 in) generally occur as snow throughout the rest of the year. Rainfall rarely exceeds $1.3 \mathrm{~cm}(0.5 \mathrm{in})$ in any one day (three times in

Table 4.1. Extreme and average annual temperatures at Barter Island and Umiat

\begin{tabular}{ccc}
\hline $\begin{array}{c}\text { Recorded } \\
\text { maximum } \\
\left({ }^{\circ} \mathrm{F}\right)\end{array}$ & $\begin{array}{c}\text { Recorded } \\
\text { minimum } \\
\left({ }^{\circ} \mathrm{F}\right)\end{array}$ & $\begin{array}{c}\text { Average annual } \\
\text { temperature }\left({ }^{\circ} \mathrm{F}\right) \\
\text { during 1976-84 }\end{array}$ \\
\hline Barter Island ${ }^{1}$ \\
\hline 78 (July 78) & -59 (Feb 50) & +10.4 \\
\hline \multicolumn{3}{c}{ Umiat $^{2}$} \\
\hline 85 (July 77) & -65 (Feb 77) \\
2 Maximum and minimum for 1955-84. \\
Maximum and minimum for 1967-84.
\end{tabular}

the last 15 years). On the North Slope, the relative humidity is generally high during the summer -80 to 95 percent along the coast. During winter it falls to about 60 percent. Absolute humidity in winter is generally low, often 5 to 20 percent.

Snow can occur at any time on the 1002 area, although snowfall is greatest during September-November and in January, with a lesser fall in May. Ablation becomes important during May, and melting begins in late May and is largely completed by early June. Winds continually redistribute snowdrifts, baring inland ridgetops and drifting in the valleys, with drifts adjacent to stream cutbanks sometimes becoming 6 m (20 ft) deep. Higher microsites, such as tussock tops and "high-centered" polygons, are frequently exposed with hard-packed snow drifted between them. Felix and others (1986), who traveled with the seismic crews in the spring of 1985, noted that the area west of the Sadlerochit River had significantly less snow than the eastern part of the 1002 area. According to numerous measurements taken throughout the 1002 area from January to May, average depths of snow actually accumulated on the ground were $30 \mathrm{~cm}$ (12 in) in 1984 and $23 \mathrm{~cm}$ (9 in) in 1985; measured depths ranged from $0 \mathrm{~cm}(0 \mathrm{in})$ to at least $81 \mathrm{~cm} \mathrm{(32} \mathrm{in)} \mathrm{(Felix} \mathrm{and} \mathrm{others,}$ 1986).

During 1955 to 1984 , the recorded average seasonal snowfall at Barter Island was $106.9 \mathrm{~cm}(42.1$ in); the minimum was $50.6 \mathrm{~cm}$ (19.9 in) in 1980-81, and the maximum was $181.4 \mathrm{~cm}$ (71.4 in) in 1961-62. Because the wind blows almost continuously, the snow crystals are broken up and pack much like fine sand, and the snow often develops a density of about $0.4 \mathrm{~g} / \mathrm{cm}^{3}$. Snowfall has been reported from average depths of snow measured on the ground and converted to 10 in of snow, equal to 1 in of water; thus, the actual winter precipitation is believed to be about four times the 9.30 $\mathrm{cm}$ (3.66 in) officially reported (Black, 1954).

Easterly winds predominate most of the year in the 1002 area. However, during January through April

Table 4.2. Average temperatures and thaw index, Barter Island and Umiat, 1976-84

\begin{tabular}{lcr}
\hline & $\begin{array}{c}\text { Barter } \\
\text { Island }\end{array}$ & Umiat \\
\hline Average temperature ( ${ }^{\circ} \mathrm{F}$ ): & & \\
Coldest month & -33.1 (Feb. 84) & -42.1 (Jan. 84) \\
Warmest month & 42.9 (Aug. 79) & 58.0 (Jul. 79) \\
& & \\
\multicolumn{3}{l}{ Thaw index (degree days above freezing): } \\
Maximum (summer) & 793 & 2,183 \\
Minimum (summer) & 456 & 1,371 \\
Average (summer) & 549 & 1,671 \\
\hline
\end{tabular}


westerly winds are often associated with peak gusts and storms. The windiest month usually is January (mean $15.0 \mathrm{mi} / \mathrm{h}$ ), and the calmest month is July (mean 10.7 $\mathrm{mi} / \mathrm{h}$ ). The peak gust (westerly) recorded at Barter Island was $75 \mathrm{mi} / \mathrm{h}$ in January 1980 . Ice storms or occasionally heavy rains occur in October and January. The coastal part of the 1002 area can be subjected to storms rolling in from the Beaufort Sea during the openwater season. Even though Barter Island, the barrier islands, the shallow lagoons, and often nearby sea ice provide some shelter to coastal areas, these storms can cause severe erosion of the coastline.

In the 1002 area, particularly along the coastline and up to $8 \mathrm{~km}(5 \mathrm{mi})$ inland, fog frequently reduces visibility. Three types of fog occur within the 1002 area:

1. Advection fog-occasional during warmer months when relatively warm, moist air moves over a cold surface such as sea ice.

2. Steam fog (and "sea smoke")—during openwater season when the difference between air and water temperatures is great; most extensive over open leads in ice-covered sea.

3. Ice fog - more frequent during winter, when moisture is released into cold, calm air (below about -30 $\left.{ }^{\circ} \mathrm{C}\left(-20^{\circ} \mathrm{F}\right)\right)$, forming ice crystals; reduced by persistent winds.

Along the coast, fog occurs most frequently during summer. At Barter Island, it reduces visibility to $10 \mathrm{~km}(6 \mathrm{mi})$ or less about 27 percent of the time during May-September, reaching a maximum of 31.5 percent in August. Fog occurs an average of 10 percent of the time during the rest of the year. Inland, Umiat has fog about 15 percent of the time during September-May, and less than 10 percent of the time during June-August.

Stratus clouds are prevalent in the Arctic during summer months, often persisting for weeks. The base of these clouds is often below $200 \mathrm{~m}(700 \mathrm{ft})$. At Barter Island and Umiat, skies are cloud covered 54 percent of the year.

In the winter, blowing snow and whiteouts can create conditions in which neither shadows nor horizon nor clouds are discernible, and in which depth perception and orientation are lost. At Barter Island, blowing snow reduces visibility to $10 \mathrm{~km}(6 \mathrm{mi})$ or less about 10 to 22 percent of the winter. This is in addition to loss of visibility caused by fog.

At Barter Island, the sun is continuously above the horizon from May 15 to July 27 and continuously below the horizon from November 24 to January 17. In winter, when the sun is not more than $6^{\circ}$ below the horizon, twilight permits many activities; at the latitude of Barter Island, moonlight can be an important source of illumination. In the 1002 area, twilight amounts to 6 or 7 hours in late November and is reduced to about 3 hours by December 21 .
The arctic winter is characterized by frequent temperature inversions. Whereas the lower atmospheric air temperature normally decreases with increasing altitude, in a temperature inversion, colder air is overlain by a warmer air layer. Surface temperatures are warmer during the summer, and thus fewer inversions occur; and for those inversions that do occur, their base generally is above the ground surface.

Freezeup normally begins in early to midSeptember. Drier areas begin freezing first, sometimes cycling between freeze and thaw for several days. Wet tundra and ponds freeze over next, then lakes and rivers and protected shallow lagoons. In wet areas, as many as eight weeks may be required to completely freeze the "active layer" (the layer above the permafrost that annually freezes and thaws; Brewer, 1958a). A sudden cold snap, particularly if accompanied by wind, can cause all areas to freeze over within a day or two. Freezeup on the sea depends on late-summer water temperatures, nearness of the ocean icepack, winds, and prevailing air temperatures. Generally, at least the nearshore sea areas are iced over by early to midOctober.

Ice thickness is determined by numerous factors, including thickness and insulating value of the snow cover. Data from the Arctic coast indicate ice

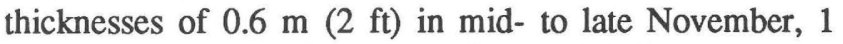

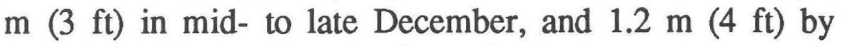
mid- to late January. At the end of winter, the average maximum thickness of seasonal sea ice and freshwater lake ice is about $1.8 \mathrm{~m}$ (6 ft; Brewer, 1958b). Near the cutbank of a river or a sea bluff, where deep snowdrifts may occur, the ice may be only 0.4 to $0.5 \mathrm{~m}$ (16 to 20 in) thick, whereas in the middle of the river it may be $1.8 \mathrm{~m}(6 \mathrm{ft})$ thick. Similarly, should the winter temperatures remain average or even mild with a very light snowpack, the ice may be as much as 2.3 to $2.4 \mathrm{~m}$ $(7.5$ to $8 \mathrm{ft})$ thick.

In the 1002 area, the ground is frozen until early June. Rivers fed from melting snow in the foothills may start to flow as early as mid-May. Ponds, lakes, lagoons, and nearshore sea ice begin to melt in early June. Ice on deeper lakes may not completely melt until early to mid-July. Ice breakup in coastal lagoons and nearshore areas depends on runoff from the land, offshore grounding, and ocean currents. Where runoff is negligible, melting follows a pattern similar to that in deeper lakes. Melting off river mouths is markedly different: freshwater runoff begins in late May, depositing river sediments on top of the ice (Walker, 1973); channels are often cut on both the top and bottom of the ice surfaces, and large holes may be cut through by river waters draining in a swirling, fast-cutting manner. Nearshore, land-fast sea ice often does not completely melt in place but instead floats away, beginning as early as late June. 


\section{PERMAFROST}

Permafrost is defined as a thickness of soil or other superficial deposit (even of bedrock) at a variable depth beneath the surface of the Earth in which a temperature below freezing $\left(0^{\circ} \mathrm{C}, 32^{\circ} \mathrm{F}\right)$ has existed continuously for a long time (from two years to tens of thousands of years; Muller, 1947). It may include soil, rock, minerals, interstitial and massive ice (the latter as wedges or, less frequently, lenses), organic matter, or other materials both naturally occurring and those buried by man. Permafrost is often considered to be synonymous with "perennially frozen ground"; however, it need not be "frozen hard," because the material could contain water having an elevated salinity, as is often found in the NPRA, or could contain liquid hydrocarbons, such as oil seeps found in northern Alaska. Because of confining pressures, such as at the base of permafrost, the contained water could have a depressed freezing point. Or, because of low water content and particle-surface forces, the material could be unfrozen. The volume of ice in permafrost soils, particularly in the first few tens of feet below the ground surface, can be several times the volume of the mineral components; it can even approximate pure ice. At the other extreme, some gravel may contain little, if any, ice.

Except for a small area at Sadlerochit Spring, which flows year round, the 1002 area is believed to be completely underlain by permafrost.

The minimal permafrost-temperature data available for Barter Island suggest an average permafrost temperature of -7.9 to $-9{ }^{\circ} \mathrm{C}$ (17.8 to $15.8{ }^{\circ} \mathrm{F}$; M.C. Brewer, unpubl. data). Similar temperatures have been found in a series of shotholes extending from the coast inland for $32 \mathrm{~km}(20 \mathrm{mi})$ in the 1002 area (T.E. Osterkamp, oral commun., 1986). Temperatures also vary with season and depth (Brewer, 1958a, fig. 3). Near Barrow, at a depth of $21.3 \mathrm{~m}$ (70 ft), where annual change is negligible (Brewer, 1958a), permafrost temperatures range from about $-0.5^{\circ} \mathrm{C}\left(31^{\circ} \mathrm{F}\right)$ under the ocean to about $-7.5{ }^{\circ} \mathrm{C}\left(18.5{ }^{\circ} \mathrm{F}\right)$ beneath sandy unvegetated beaches to about $-9.5^{\circ} \mathrm{C}\left(15^{\circ} \mathrm{F}\right)$ under dry tundra areas to a minimum of about $-10.6^{\circ} \mathrm{C}\left(12.9^{\circ} \mathrm{F}\right)$ under very wet, low-centered, polygonal tundra areas (Brewer, 1976). Similar temperatures and variations in temperature are believed to occur throughout the 1002 area.

The greatest reported thickness of permafrost in Alaska is about $685 \mathrm{~m}(2,250 \mathrm{ft})$ near Prudhoe Bay (Lachenbruch and others, 1987), believed to result from an anomalous thermal conductivity because of the unusually thick gravel in that area. Permafrost thickness decreases markedly in all directions within a few miles. In the NPRA, the maximum known thickness is $405 \mathrm{~m}$ $(1,330 \mathrm{ft})$, inland near Barrow (Brewer, 1958a). At Umiat the thickness ranges approximately from 213 to $322 \mathrm{~m}$ (700 to 1,055 ft; Brewer, 1958c). No wells have been drilled through the permafrost in the 1002 area; about 15 $\mathrm{km}$ (9 mi) south of the southwest corner of the 1002 area, at the Canning River Unit-1 well, the measured permafrost thickness is $283 \mathrm{~m}$ (928 ft) (Lachenbruch and others, 1987). The thickness of the active layer ranges from less than 0.3 to $1.5 \mathrm{~m}(<1$ to $5 \mathrm{ft})$ and averages about $0.6 \mathrm{~m}(2 \mathrm{ft})$.

Depending on their depths and areal extents, lakes and rivers influence the shape of the permafrost table. Shallow lakes freeze to the bottom and are directly underlain by permafrost. Deep lakes greater than $2 \mathrm{~m}(7 \mathrm{ft})$ deep typically do not freeze to the bottom and consequently are underlain by a thaw bulb in the permafrost table (Brewer, 1958a, b). Shallow rivers and creeks freeze to the bottom, with the permafrost table usually a few inches to a few feet beneath. Some deeper rivers, such as the Canning, may have unfrozen pockets of water in deeper parts $(2 \mathrm{~m}(7 \mathrm{ft})$ or more at freezeup) but may be frozen to the bottom in shallower areas. Thus, the permafrost table beneath a river may be very irregular. The effects of surface features on distribution of permafrost are shown in figure 4.1.

Studies of seawater and borehole temperatures in the Mackenzie Bay, Flaxman Island, Prudhoe Bay, Harrison Bay, and Barrow areas (fig. 1.1) indicate that subsea permafrost occurs in the nearshore area of the Beaufort Sea (Brewer, 1955a) and probably extends in a thin layer out to water depths approximating $152 \mathrm{~m}$ (500 $\mathrm{ft}$ ). Subsea temperatures range from approximately 30.1 ${ }^{\circ} \mathrm{F}$ at $4.6 \mathrm{~m}(15.0 \mathrm{ft})$ below sea bottom in the Chukchi Sea off Barrow (Brewer, 1955a, 1958a) to $29.5^{\circ} \mathrm{F}$ at 6.8 m $\left(22.3 \mathrm{ft}\right.$ ) in Harrison Bay off Atigaru Point to $29.3{ }^{\circ} \mathrm{F}$ at $5.4 \mathrm{~m}(17.7 \mathrm{ft})$ in Prudhoe Bay off Reindeer Island (the latter two temperatures from Osterkamp and Harrison, 1985). Permafrost temperatures in the nearshore Beaufort Sea parallel mean annual bottomwater temperatures (Selkregg, 1975), approximately 31.1 ${ }^{\circ} \mathrm{F}$ to $30.8^{\circ} \mathrm{F}$ for the Chukchi Sea, and $30.0^{\circ} \mathrm{F}$ to 29.7 ${ }^{\circ} \mathrm{F}$ for the Beaufort Sea. Where the water in the shallow nearshore areas freezes to the bottom, the permafrost temperatures decrease markedly, and the permafrosttemperature profiles are similar to those found on land (Osterkamp and Harrison, 1985). Farther east, eroded pingos occur well offshore in Mackenzie Bay.

Few data are available concerning (1) the amounts of ice in subsea sediments, (2) whether the ice is mostly interstitial, and (3) whether, at least nearshore, a significant portion of it occurs as ice wedges. Information is also lacking regarding near-surface variability in ice content resulting from shoreline regression (about $1 \mathrm{~m}(3.3 \mathrm{ft}$ ) per year) (Leffingwell, 1919; MacCarthy, 1953) because of migrating spits, bars, and barrier islands, and because of warmer water inflow from major rivers.

Permafrost-related stream data for the 1002 area are sparse. However, data from the Shaviovik River, 56 $\mathrm{km}(35 \mathrm{mi})$ west of the ANWR, are pertinent because the Shaviovik has many characteristics common to most 
rivers in the 1002 area, with the exceptions of the Canning and Aichilik Rivers. It is shallow and has many bars, few potholes, heavy spring runoff, summer lowand high-water periods, and low water at freezeup. The average annual temperature in shallow sediments beneath the Shaviovik (Brewer, 1958a) is about $5.4^{\circ} \mathrm{F}$ warmer than beneath adjacent well-drained tundra, although well below the freezing point of freshwater. Measurements from the upper part of the geothermal profile beneath a narrow sand bar in midriver do not indicate any unfrozen zones in the river channel on either side of the bar in late winter. Temperature data for the 4.6- and 7.6-m (15 and $25 \mathrm{ft}$ ) depths suggest that water is present in the channel at the time of freezeup, which delays the freezing process. Temperature profiles through and beneath shallow lakes are similar. Apparently, shallow rivers freeze to the bottom; sands and gravels in the river bottoms rest on permafrost and by early November usually are also frozen.

Ice wedges form when the upper few feet of ground, exposed to temperatures well below freezing, contract and crack, usually in a polygonal pattern. Hoarfrost is formed in these cracks and is cemented by the spring meltwater, which leaves a vertical stringer of ice. This ice limits summer expansion of warming permafrost, displacing the adjacent mineral soils upward; repeated cracking and widening of the ice wedges over many years eventually results in elevated ridges of material on each side of the wedges (Lachenbruch and others, 1962).

Polygonal ground is the common surface feature in the 1002 area. Most polygons range in diameter from 10 to $60 \mathrm{~m}$ ( 30 to $200 \mathrm{ft}$ ) and are easily recognized on the surface; some in the southern part of the 1002 area are masked by tussock-type tundra. Usually each polygon is separated from adjacent polygons by ice wedges a few inches to several feet wide at the permafrost table. These ice wedges are 3-6 m (10-20 ft) deep and are interconnected. Some small streams may have originated by the melting of a long series of ice wedges. Beaded streams, with the beads located at the intersections of ice wedges, follow this pattern.

Most polygonal areas in the 1002 area contain "low-centered" polygons, characterized at the outer edges by upthrust ridges that impede drainage from the polygon and give the enclosed area a rice-paddy appearance.

Where slopes near streams or some lake banks allow drainage, "high-centered" polygons may occur. These polygons originate in the same manner as lowcentered polygons, but during exceptionally warm

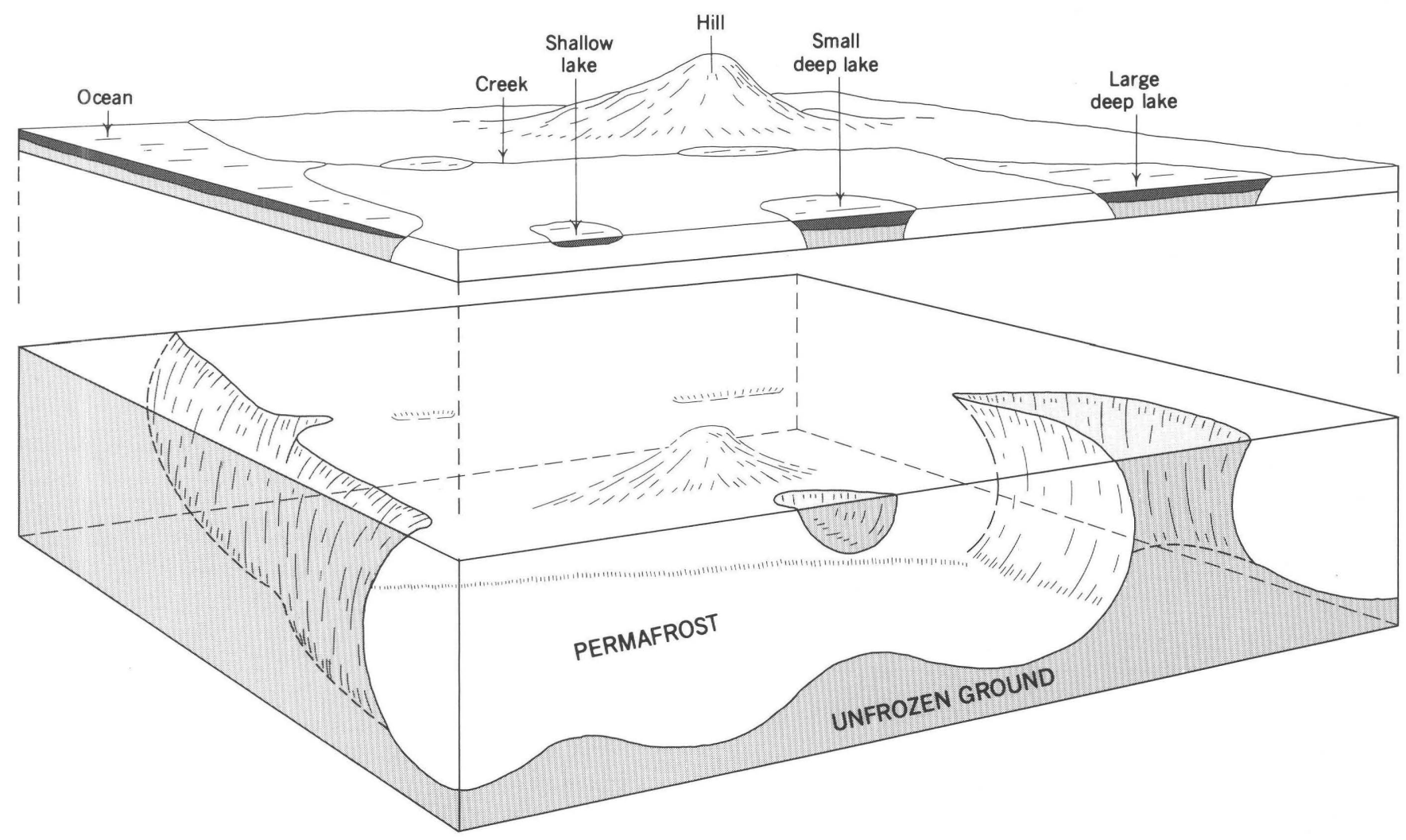

Figure 4.1. Schematic representation of effect of surface features on distribution of permafrost in continuous permafrost zone. From Lachenbruch and others (1962). 
summers with deeper thaw, the tops of the ice wedges melt, water drains off, and the soil and tundra slump into the voids. The slumping, when continued over tens of years, produces ditches between the polygons, thus leaving the polygons as erosional remnants separated by partially filled voids.

\section{SOILS AND OTHER RELATED MATERIALS}

The 1002 area is crossed by numerous northflowing rivers that have their headwaters in the glaciated mountains rising about $10-20 \mathrm{~km}(6-12 \mathrm{mi})$ south of the area's southern boundary. Outwash plains, active flood plains, river terraces, and eolian deposits resulting from winds during glaciation characterize much of the 1002 area, which has a thin mantle of unconsolidated (although frozen) sediments about 1 to $30 \mathrm{~m} \mathrm{(3} \mathrm{to} 100 \mathrm{ft}$ ) thick.

The valleys of larger streams are underlain by large quantities of coarse sand and gravel. These include the valleys of the Canning, Tamayariak, Katakturuk, Sadlerochit, Hulahula, Okpilak, Jago, Okerokovik, Kogotpak, and Aichilik Rivers. These rivers, especially the Canning, Sadlerochit, Hulahula, Jago, and Aichilik, are heavily braided and have extensive unvegetated gravel bars. Gravel also occurs in the southern part of the 1002 area between the Canning River and Marsh Creek, along the tops and flanks of ridges between the Katakturuk and Sadlerochit Rivers, and on spits and bars along the Beaufort Sea coastline. On the spits and bars, the deposits range from fine- to medium-grained sandy gravel to sand. Granular deposits typically present in stream valleys range from coarse- to medium-grained sandy gravels with cobbles along the southern boundary of the 1002 area. Downstream toward the Beaufort Sea, the materials become progressively finer grained; in the deltaic areas, they range from fine- to medium-grained sandy gravels to silt. Sand dunes occur in the deltas of the Canning, Hulahula-Okpilak, and Jago Rivers. Extensive mudflats are found in front of the Canning, Okpilak, Jago, and Aichilik deltas. Numerous sizable sandy shoals are prominent between the deltas of the Sadlerochit and Okpilak Rivers.

Soils in the 1002 area are poorly developed, are frequently water saturated, and can generally be classed as tundra soils, bog soils, or sand dunes. They tend to be sticky claylike soil in the beginning process of leaching (except in better drained dune areas) because of cold ground temperatures, the presence of permafrost, and the thinness of the "active layer." Polygonal patterning is well developed throughout the area, although surface expressions tend to be more pronounced adjacent to breaks in slope, especially those associated with drainage. A soils study in the valleys of the upper Okpilak and Jago Rivers (Brown and Tedrow, 1964) reported mineral uniformity in the soils, with quartz and feldspar each amounting to 40-50 percent in the sands, and heavy-mineral suites consisting of opaques, epidote, tourmaline, chlorite, actinolite, zircon, and minor amounts of other minerals. In view of the geomorphic history of the 1002 area, this type of mineral composition may be assumed to prevail there (Brown and Tedrow, 1964).

Except in the sand dunes, on ridgetops, and in unvegetated gravel areas, much of the 1002 area is covered by a 2 - to 5 -cm-thick (1 to 2 in) organic mat of living vegetation overlying a fibrous layer containing sand, silt, and small cobbles. That fibrous layer, in turn, overlies mineral soils of loam, silt, or sand. In welldrained areas, thaw progresses to greater depths, and mineral soils near the base of the "active layer" may have a pronounced brownish appearance owing to an accumulation of well-humified organic matter.

\section{WATER RESOURCES}

Water resources in the 1002 area are very limited and are confined to the surface. The estimated 250 - to 300 -m-thick ( 800 to $1,000 \mathrm{ft}$ ) impermeable permafrost layer precludes obtaining nonsaline water from within this zone. Although no wells penetrate the permafrost zone in the 1002 area, any water that might occur beneath that zone probably would be brackish or at least moderately saline (Cederstrom and others, 1953; Hopkins and others, 1955; Brewer, 1958a, b, 1974; Williams, 1970).

Lakes are a major source of, and storage for, water on the North Slope coastal plain; however, only a few large lakes occur in the 1002 area. A few shallow thaw lakes are found near the coast east of the Canning River delta and east of the Hulahula-Okpilak River delta, the latter being on Native lands and outside the 1002 area. Except for two near the Canning River delta, the lakes each cover less than $2.6 \mathrm{~km}^{2}\left(1 \mathrm{mi}^{2}\right)$; most have basins less than $2 \mathrm{~m}(7 \mathrm{ft})$ deep and freeze to bottom by late winter. These shallow lakes could provide a source of potable water in early winter.

Rapid spring snowmelt (10-14 days) causes water to accumulate on and flow over the river ice, fracturing and rapidly eroding it. Large chunks of ice break loose from the banks and bottoms of the river and float downriver. In constricted areas, ice may lodge, causing jams and extensive spring flooding, particularly in the deltas. Even if this does not occur, the rivers run very full because of the rapid snowmelt. Surface runoff often resembles sheetflow because of the frozen ground. Suspended-sediment content is very high, perhaps 75 percent of the annual transport (Walker, 1973), and river banks are severely eroded, with higher cutbanks often being undercut. By the third or fourth week in June, rivers may subside to summer low-water stages. Late 
summer and fall rains may rapidly bring the rivers to one or more flood stages. Warm weather may also cause the rapid rise of glacial rivers such as the Hulahula, Jago, and Okpilak. Low water prevails at the time of freezeup; by midwinter, most rivers in the 1002 area go dry or freeze to bottom throughout most of their length, with the possible exception of a few basins or "potholes" near the mouth of the Canning and perhaps one or two other major rivers. Even early in the freezeup period, if the basins or potholes in the lower Canning are connected to the sea, water may be brackish because of seawater intrusion. The Canning River has not been intensively studied, but comprehensive studies of the Colville River (approximately 3.5 times the length and 11 times the drainage basin of the Canning) show that streamflow even ceases in that river during winter, and saltwater intrusions eventually reach as far as $58 \mathrm{~km}$ (36 mi) upstream (Walker, 1973).

Data from water-availability studies for the proposed Alaska Natural Gas Pipeline are shown in table 4.3. These data were obtained $19-43 \mathrm{~km}(12-27 \mathrm{mi})$ inland, approximately along the midsection of the 1002 area, and suggest that in winter, rivers in the 1002 area are not a potential source of water for industrial use. Note that water depths beneath ice do vary throughout the length of these rivers. Water is available in some local areas, providing overwintering habitat for fish.

Several springs occur along the northern edge of the eastern Brooks Range. The largest of these is

Table 4.3. Winter river water depths at selected locations in the 1002 area in 1973

[Data from U.S. Department of the Interior (1976, p. 99)]

\begin{tabular}{lcccc}
\hline River & $\begin{array}{c}\text { Date } \\
\text { sampled/ } \\
\text { observed } \\
\text { (mo /d) }\end{array}$ & $\begin{array}{c}\text { Thickness } \\
\text { of ice }\end{array}$ & $\begin{array}{c}\text { Water } \\
\text { depth }\end{array}$ & $\begin{array}{c}\text { Approximate } \\
\text { straight-line } \\
\text { distance upstream } \\
\text { (ft) }\end{array}$ \\
\hline Canning & $4 / 18$ & 7.54 & 0 & 19.8 \\
(downstream) & $11 / 05$ & 1.15 & 0 & 14.0 \\
Tamayariak & $11 / 07$ & 0 & 0 & 14.0 \\
$\quad$ Do. & $11 / 07$ & 0 & 1.15 & 13.0 \\
Katakturuk & $11 / 07$ & 0 & 0 & 11.8 \\
Sadlerochit & $11 / 07$ & .03 & 0 & 18.9 \\
Hulahula & $4 / 18$ & 0 & 0 & 21.7 \\
Do. & $11 / 08$ & 0 & .82 & 19.2 \\
Jago & $4 / 18$ & 0 & 0 & 26.7 \\
Do. & $11 / 07$ & .85 & 0 & 26.7 \\
Okerokovik & $11 / 07$ & 0 & .66 & 25.7 \\
Aichilik & $11 / 07$ & 2.16 & 0 & 19.8 \\
\hline
\end{tabular}

Sadlerochit Spring, just inside the southern boundary of the 1002 area (fig. 4.2). The spring flows year round; its rate of discharge and water temperature are variable. This spring has had a reported discharge of $21.2 \mathrm{ft}^{3} / \mathrm{s}$ (Craig and McCart, 1974) and a temperature of $43{ }^{\circ} \mathrm{F}$. Discharges of $37 \mathrm{ft}^{3} / \mathrm{s}$ (U.S Fish and Wildlife Service, U.S. Geological Survey, and U.S Bureau of Land Management, 1983) and $88.3 \mathrm{ft}^{3} / \mathrm{s}$ (Williams, 1970) and temperatures of $55^{\circ} \mathrm{F}$ (U.S Fish and Wildlife Service, U.S. Geological Survey, and U.S. Bureau of Land Management, 1983) and $52{ }^{\circ} \mathrm{F}$ (Williams, 1970) also have been reported.

Numerous small springs have been reported from indirect evidence on rivers or in valleys south of the 1002 area where large icings have been observed (U.S. Fish and Wildlife Service, U.S. Geological Survey, and U.S. Bureau of Land Management, 1983; Williams, 1970). Selected physical parameters have been measured for some springs (U.S. Fish and Wildlife Service, 1982). Icings (aufeis), especially those reported on rivers, require investigation to determine whether they result from discharge from true springs or are the result of meltwater in areas having a relatively steep gradient.

The availability of freshwater in the 1002 area varies greatly with season and locality. Although water usually can be obtained within a reasonable distance from rivers and streams during the summer, there is virtually no water during the winter except that occurring as snow and ice.

Turbidity from suspended sediments impairs water quality. Suspended-sediment concentrations are highest in the major streams and rivers during spring breakup and late summer and fall high-flow periods (U.S. Fish and Wildlife Service, U.S. Geological Survey, and U.S. Bureau of Land Management, 1983). During lowflow periods, most streams are almost clear. However, the Canning, Hulahula, Okpilak, Jago, and Aichilik Rivers are somewhat turbid owing to glacial inflow from tributaries (U.S. Fish and Wildlife Service, U.S. Geological Survey, and U.S. Bureau of Land Management, 1983). Some shallow lakes are turbid during the summer, when wind and wave action disturb bottom sediments. Aside from periods of turbidity, the water in most rivers and lakes is virtually colorless. Tea-colored water, resulting from high concentrations of dissolved organic materials, occurs in some smaller tundra streams and ponds.

Water quality in lakes and streams is lessened in winter because salts and dissolved organic material are excluded from the downward-growing ice (U.S. Department of the Interior, 1976). The concentrations of those materials depend on the ratio of water to ice as the ice thickens. Water in lakes and river pools that freeze nearly to the bottom is usually unpotable by late winter.

Dissolved oxygen is at or near saturation in lakes and streams during summer. Under winter ice cover, dissolved-oxygen levels can be severely depressed 
owing to lack of aeration and the extended darkness that limits photosynthesis (U.S. Fish and Wildlife Service, U.S. Geological Survey, and Bureau of Land Management, 1983).

Coliform-bacteria counts in lakes and ponds peak in early June because of the "washing action" of surface runoff. A secondary peak follows in mid- to late summer in areas where large concentrations of waterfowl arrive for molting and staging (Boyd and Boyd, 1963).

Because of the lack of freshwater for industrial use within the 1002 area, the adjacent marine waters must be viewed as a water resource. Lagoons begin breakup in early June with an influx of fresh, silt-laden, relatively warm water from river and stream runoff and snowmelt. Much of this water initially flows over the top of the sea ice; silt deposits as thick as $10-15 \mathrm{~cm}$ (4-6 in) and thinning seaward have been observed on the ice (Walker, 1973). Overflows can continue for several kilometers offshore until they meet cracks in the ice. In shallow lagoons (less than about $2 \mathrm{~m}(7 \mathrm{ft})$ deep), the ice is often frozen to bottom, and water may puddle on top until the ice becomes free and floats. Moats form along the shore in early June, and by early to mid-July the lagoons are generally ice free. Freezeup begins again in late September-early October.

By the time the lagoons are ice free, the influx of freshwater, coupled with some ocean-current flushing of hypersaline brines formed beneath the ice during the winter, often drastically reduces salinity from a normal 32-33 parts per thousand (ppt) to $<10$ ppt. Salinity gradually increases during the balance of the summer owing to the influx of marine water through inlets and the lowered discharges of freshwater.

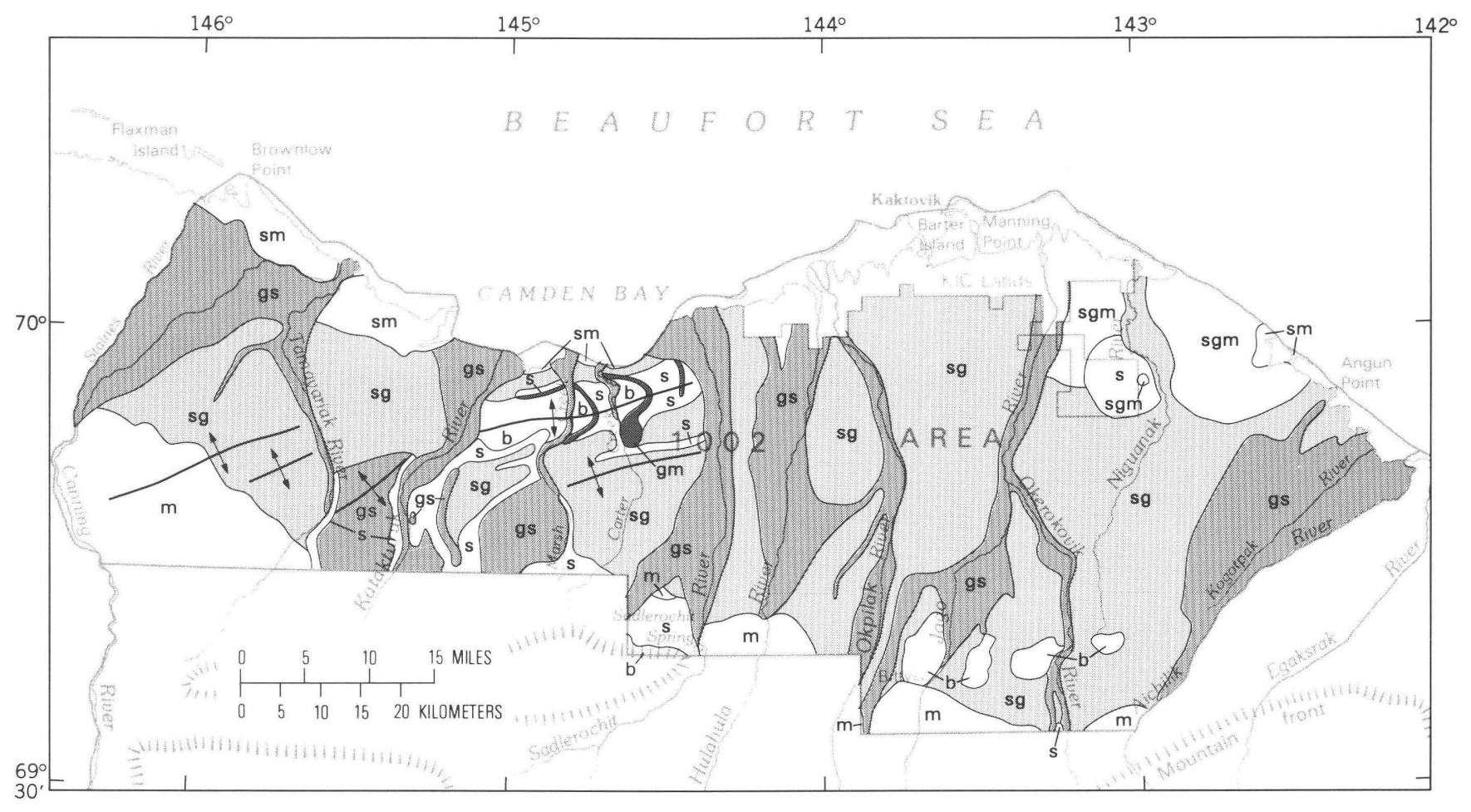

EXPLANATION
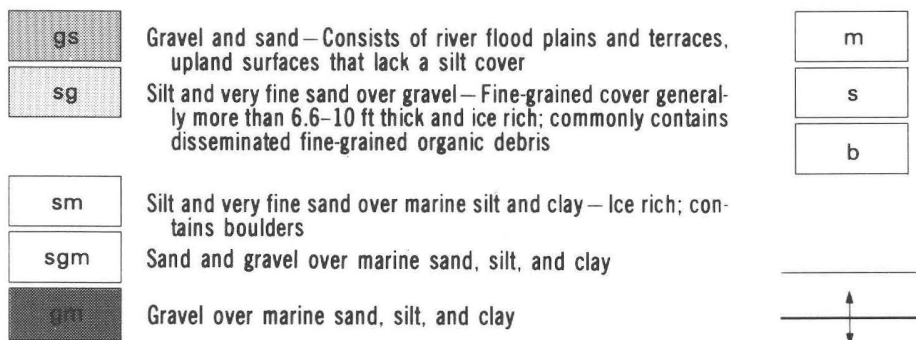

Morainal deposits-Composed of compact, silty, bouldery till Slope deposits-Variable composition, ranging from silt to bedrock rubble Bedrock

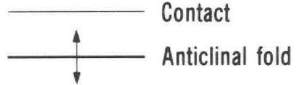

Figure 4.2. Generalized surficial deposits of the 1002 area, indicating surface materials only and not what could be borrowed for fill. Geology by Carter and others (1986). 


\section{EROSION AND MASS MOVEMENT}

Water and wind are the major shapers of the landscape of the 1002 because of the ice-rich permafrost, unconsolidated sediments, and exposed river channels, deltas, and offshore bars and barrier islands. Water causes the most erosion, especially during spring breakup. It flushes heavy sediment loads onto the sea ice (Walker, 1973); undercuts high banks and ice-rich terraces, which causes frozen blocks of soil to fall into the rivers; and builds deltas and mudflats. Even though the results of lateral erosion are obvious in the multichannel braiding of the major rivers, stream gradients across the 1002 area demonstrate the potential for vertical erosion. Gradients range from approximately $3.7 \mathrm{~m} / \mathrm{mi}(12 \mathrm{ft} / \mathrm{mi})$ on the Canning River to $9 \mathrm{~m} / \mathrm{mi}(30$ $\mathrm{ft} / \mathrm{mi})$ on the Hulahula and Aichilik to $12.3 \mathrm{~m} / \mathrm{mi}(40$ $\mathrm{ft} / \mathrm{mi}$ ) on the Katakturuk and Sadlerochit to about 15.2 $\mathrm{m} / \mathrm{mi}(50 \mathrm{ft} / \mathrm{mi})$ on Marsh Creek, which cuts through ridges of Tertiary sandstone and conglomerate.

Erosion along the coast and offshore during open water is less obvious. Leffingwell (1919) and MacCarthy (1953) suggested that bluffs and beaches erode at a rate of approximately $1 \mathrm{~m} / \mathrm{yr}(3 \mathrm{ft} / \mathrm{yr})$; Leffingwell also reported an extreme shoreline recession rate of more than $9 \mathrm{~m} / \mathrm{yr}(30 \mathrm{ft} / \mathrm{yr})$. Wiseman and others (1973) measured $50 \mathrm{~m}(164 \mathrm{ft})$ of bluff erosion on the east end of Pingok Island, west of Prudhoe Bay, during three weeks in 1972; this was also an extreme. Beach erosion varies greatly from place to place and year to year along the entire Beaufort coast, depending on storm intensites and the nearness of pack ice. Erosion on the order of 1 to $2 \mathrm{~m} / \mathrm{yr}$ ( 3 to $6 \mathrm{ft} / \mathrm{yr}$ ) may be the average. Erosion and deposition of eroded sands and gravel also produces barrier-island or spit migration. This occurs especially where no established vegetation mat exists. Such migration can introduce major variations in the temperature and thickness of subsea permafrost.

Thaw lakes elongated north-south are characteristic of the Arctic coastal plain farther west, but they are not a pronounced feature in the 1002 area, where the few small lakes (except in the CanningTamayariak delta) are oriented either randomly or somewhat east-west. Because prevailing winds are not greatly different, the general absence of north-south orientation suggests that the small thaw lakes found there are enlarged more by thermal erosion than by mechanical (current) erosion.

Although precipitation over the 1002 area is light, in summer the soils are frequently water saturated because (1) evaporation rates are low, (2) the permafrost barrier prevents water loss to underground aquifers, and (3) irregularities in the permafrost table impede surface drainage. Despite the fact that saturation is usually conducive to solifluction and creep or slump in areas of steeper terrain, the surface impact of these processes is not widespread in the 1002 area because of its generally coarser material. However, once the surface is disturbed, these processes can become active, especially along coastal bluffs, terrace escarpments, lake margins, and ridge slopes. Locally, along a stretch of the Katakturuk River and near Marsh and Carter Creeks, landslides have occurred in weathered and poorly indurated Tertiary shale, siltstone, and sandstone. In all areas having exposed mineral soil and any appreciable slope, the soil migrates gradually downslope because of seasonal frostjacking of individual soil grains.

Wind erosion is generally confined to the deltas of the Canning, Hulahula-Okpilak, and Jago Rivers (where active dunes are found along their western banks) and to sandy river bluffs, exposed bars in braided rivers, and exposed spits and barrier islands. Though considered to be a summer phenomenon, wind erosion actually occurs during much of the year in exposed areas along river bluffs and on barrier islands.

\section{SEISMICITY}

Earthquakes of magnitude 6 and larger on the Richter scale of intensity are potentially destructive; earthquakes of magnitude 5 could cause damage locally. There has been some earthquake activity in the 1002 area, but historically the level of this activity has been reported to be low (U.S. Department of the Interior, 1976 , p. 84), with at least six shocks (five of them offshore) with magnitudes greater than 4.0 having occurred between the mid-1960's and the mid-1970's. The reported epicenters were located within about $65 \mathrm{~km}$ (40 mi) of the 1002 area between longitudes $143^{\circ} \mathrm{W}$. and $146^{\circ} \mathrm{W}$., with an uncertainty in epicenter locations estimated at about $40 \mathrm{~km}$ ( $25 \mathrm{mi}$ ). (See fig. 21.4 for locations of earthquake epicenters.)

More recent work (Grantz and others, 1983a) suggests that the area is tectonically more active than previously reported. This activity is often interpreted to be caused by slumping on the Beaufort Sea continental shelf and slope. Grantz and others (1983a) have reported for the period 1966-78 what appears to be 38 earthquakes of magnitudes 3.6 to 4.7 and 1 earthquake of magnitude 5.3 with epicenters ranging from about $13 \mathrm{~km}$ $(8 \mathrm{mi})$ to about $56 \mathrm{~km}(35 \mathrm{mi})$ offshore from the 1002 area; 6 earthquakes of magnitudes 3.6 to 4.7 with epicenters near the coast; and 10 earthquakes of magnitudes 3.6 to 4.7 either within the 1002 area or within about $40 \mathrm{~km}(25 \mathrm{mi})$ of its landward boundaries. The estimated epicenter location accuracy was reported to be about $5 \mathrm{~km}(3 \mathrm{mi})$ onshore and to range between 5 and $48 \mathrm{~km}$ (3 and $30 \mathrm{mi}$ ) offshore. Folding has affected Quaternary deposits in the area (Carter and others, 1986), and this could conceivably be related to seismically active faults at depth.

As seismically active faults are possible, earthquake potential within or adjacent to the 1002 area may be specified as a maximum expectable earthquake of magnitude 5.5 (U.S. Department of the Interior, 1976, 
p. 86; Page and others, 1972). The maximum expectable earthquake is the largest earthquake that may reasonably be expected to occur.

\section{AIR QUALITY}

Relatively few long-term air-quality data are published for Arctic Alaska. Most of the measurements, including those for selected pollutants, have been made at the Naval Arctic Research Laboratory (NARL) at Barrow and appear to be apropos for Barter Island and the 1002 area because of similar air-mass movement, location, physiographic setting, and lack of industrialization.

The North Slope air is generally of very good quality, and the air at Barrow has been described as the purest in the nation (Burro, 1973). The low levels of pollutants that do occur generally result from natural sources and natural atmospheric reactions. In recent years, however, there have been reports of Arctic haze, with the suggestion that some pollutants originate from the Ural Mountains (U.S.S.R.) industrial complex. Locally, particulate-matter content may be very high because of windblown dust from beaches, sand bars, and sand dunes, because of salt spray near the coast, or because of industrial operations such as road traffic at Prudhoe Bay. Low concentrations of carbon monoxide have been measured (Cavanagh and others, 1969), ranging from 0.055 to 0.250 parts per million (ppm) and averaging $0.090 \mathrm{ppm}$, with the trend toward an increase during the past 20 years. Carbon-dioxide concentrations show an annual cycle (Kelley and Weaver, 1966; National Oceanic and Atmospheric Administration,
1975). Concentrations are higher during the winter and under the snow (Kelley and Weaver, 1966), and they are at their minimum in August, corresponding closely to the maximum vegetative bloom on the tundra.

The effects of human activity on air quality are localized, being restricted mostly to the vicinity of villages and to the Prudhoe Bay/Kuparuk area, and are strongly dependent on local meteorological conditions and topography.

Strong temperature inversions on the coastal plain, particularly during the winter, often begin near ground level and hinder vertical air circulation and mixing. An inversion, if coupled with low, near-surface wind speeds, can produce prolonged stagnant air conditions, especially in areas having topographic obstructions such as hills and mountains. Although inversions are common in the 1002 area, persistent surface winds tend to prevent air stagnation.

\section{NOISE}

Ambient noise levels over most of the 1002 area are low and result predominantly from natural sources or processes. During the winter, the principal sounds are those associated with the wind. Noise carries considerable distances (but not upwind), especially during calm, cold $\left(-40^{\circ} \mathrm{F}\right)$ conditions because of the increased air density. Water noises, including those of wave action, occur during the summer. Manmade sounds are confined to village activities and to some isolated activities, such as hunting. Other manmade sources include those from aircraft, vehicles, and equipment operations. 


\title{
Chapter 5.
}

\section{Stratigraphy}

\author{
By Kenneth J. Bird ${ }^{1}$ and Cornelius M. Molenaar ${ }^{2}$
}

\section{INTRODUCTION}

The coastal plain and mountains of the Arctic National Wildlife Refuge (ANWR) are underlain by sedimentary and igneous rocks many thousands of meters thick. These rocks probably represent as much as a billion years of geologic time, but those with petroleum potential are mostly younger than Devonian (360 Ma) in age. The rocks are grouped into sequences to emphasize the major features and important geologic events. Sequences are assemblages of formations and groups, separated either by unconformities or depositional contacts, that identify suites of rocks of fundamentally different origins and commonly different compositions (Norris, 1985a). Four or five sequences may be present in the coastal plain and mountains of the ANWR. Only the upper two sequences are considered prospective for petroleum. These are the Ellesmerian sequence of Mississippian to earliest Cretaceous age and the Brookian sequence of Early Cretaceous to Quaternary age (fig. 5.1). The older sequences are combined in the discussion of pre-Mississippian rocks. General comments on petroleum reservoir- and source-rock qualities are made in this chapter; more detailed information is contained in other chapters of this publication.

\section{PRE-MISSISSIPPIAN ROCKS}

Pre-Mississippian rocks in the mountains adjacent to the ANWR coastal plain consist of as many as three sequences ranging in age from Precambrian to Devonian. Most of these rocks have been subjected to deep burial, heating, and deformation to such an extent that they are generally not considered prospective for indigenous oil or gas and are referred to in this report as the basement complex. However, some rocks in this assemblage have sufficient porosity for an oil or gas accumulation under conditions where hydrocarbons generated in younger (post-Devonian) source rocks could migrate into these older reservoir rocks. These conditions apparently exist in the Alaska State F-1 and

\footnotetext{
${ }^{1}$ U.S. Geological Survey, Menlo Park, Calif.

2 U.S. Geological Survey, Denver, Colo.
}

Alaska Island-1 wells on the barrier islands north of Point Thomson (wells 20 and 17 , respectively, figs. $1.1 B$, 5.2 ), where oil and gas have been recovered from basement rocks. Similar conditions may occur elsewhere, and therefore these rocks must be considered in discussions of the petroleum potential of the coastal plain.

The pre-Mississippian rocks in northeastern Alaska consist of metamorphosed sedimentary rocks with locally significant amounts of volcanic and intrusive igneous rocks. These rocks are extensively exposed in the northeastern Brooks Range, including the southern part of the Mount Michelson and Demarcation Point quadrangles, and in the core areas of the Shublik and Sadlerochit Mountains; they are also penetrated by numerous wells along the coast west of the ANWR. All rocks of this assemblage lie unconformably beneath Mississippian or younger rocks.

The geologic complexity of these rocks is indicated by the mapping of at least 40 different rock units in the Demarcation Point quadrangle, mostly south and east of the eastern half of the 1002 area (Reiser and others, 1980). As noted by Moore and others (1985), these include both miogeoclinal lithologies such as quartzite and carbonate rocks, and various eugeoclinal lithologies such as radiolarian chert, argillite, volcanogenic graywacke, and mafic to intermediate volcanic rocks. These pre-Mississippian rocks have been interpreted as a conformable stratigraphic succession (Dutro and others, 1972; Norris, 1985b) or as faultbounded tectono-stratigraphic terranes (Moore and others, 1985). In northeastern Alaska, Dutro and others (1972) have identified as many as six different sequences in the pre-Mississippian rocks. In the adjacent part of the Yukon Territory of Canada, Norris (1985b) subdivided these rocks into seven informal lithostratigraphic units. Two unconformities are reported within the Precambrian, a third at the top of the Precambrian, and a fourth at the base of the Middle(?) Devonian. Volcanic rocks are of Precambrian, Cambrian, and Ordovician age, whereas intrusive igneous rocks are of Silurian or Devonian age (Sable, 1977). The thickness of the basement complex is unknown but is very thick. Norris (1985b) estimates that the Precambrian part of this assemblage alone is more than $13.4 \mathrm{~km}(44,000 \mathrm{ft})$ thick and, in spite of locally intense deformation, dips generally southwest. 


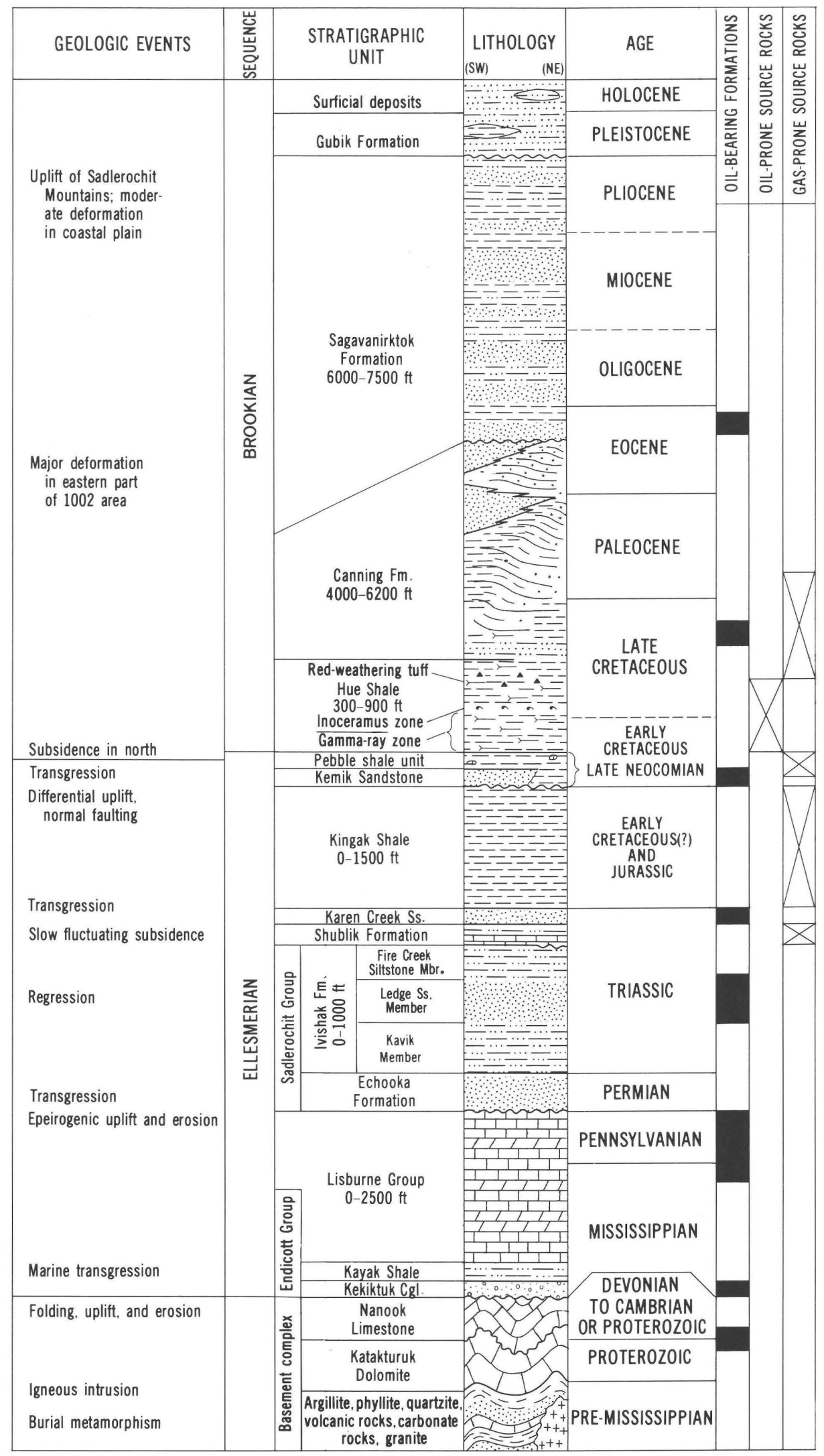

EXPLANATION

\begin{tabular}{|c|c|}
\hline & \\
\hline & Conglomerate \\
\hline & Sandstone \\
\hline$\cdots \cdots \cdots$ & Siltstone \\
\hline$=1=$ & Shale \\
\hline | $1 \frac{1}{1}$ & Limestone \\
\hline 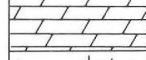 & Dolomite \\
\hline $\begin{array}{l}++++ \\
+++++ \\
++\end{array}$ & Granite \\
\hline$\ulcorner\succ$ & Bentonite \\
\hline$\Delta \Delta \Delta$ & Siliceous \\
\hline & Concretion \\
\hline$a$ & Inoceramus \\
\hline
\end{tabular}

Figure 5.1. Generalized stratigraphic column for northern part of the ANWR showing significant geologic events, oilbearing formations west of ANWR (see chap. 7), and potential source rocks (see chaps. 11, 12). Vertical scale is not uniform. Hue Shale may range into the Paleocene in parts of this area. 

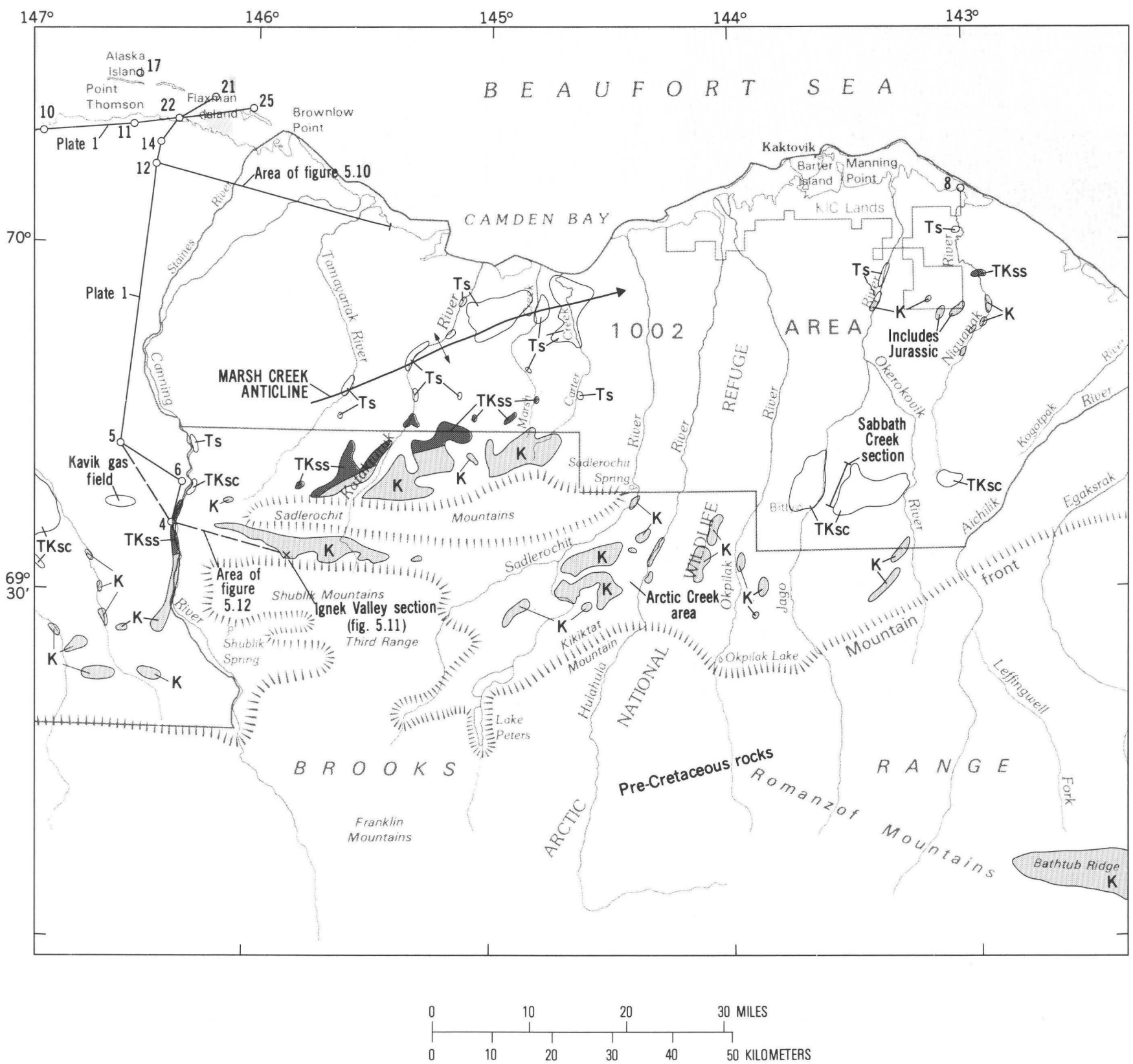

\section{EXPLANATION}

Ts Tertiary sedimentary rocks

Paleocene and uppermost Cretaceous sedimentary rocks

\begin{tabular}{|c|}
\hline TKsc \\
\hline$K$ \\
\hline
\end{tabular}

Shallow marine and nonmarine sedimentary rocks and conglomerate

Deep-water marine sandstone and shale

Cretaceous sedimentary rocks

Drill hole-Well name and number explained on table 1.1

Figure 5.2. 1002 area and adjacent mountains of the ANWR showing areas of Cretaceous and Tertiary outcrops and locations of figures 5.10, 5.11, 5.12, and plate 1. Mountains consist of pre-Cretaceous rocks except where indicated. 
A thick section of pre-Mississippian carbonate rocks in the basement complex is exposed in the Shublik and Sadlerochit Mountains. These rocks, which could be important reservoirs for oil and gas, are called the Nanook Limestone and the Katakturuk Dolomite (Dutro, 1970). The Katakturuk Dolomite, which is probably Proterozoic in age and consists predominantly of lightgray vuggy dolomite (fig. $5.3 A)$, is about $1,070 \mathrm{~m}(3,500$ $\mathrm{ft}$ ) thick in the Shublik Mountains. About $3,000 \mathrm{~m}$ $(10,000 \mathrm{ft})$ is exposed in the Sadlerochit Mountains, but this section may be repeated by faults. The Nanook Limestone, which is Late Proterozoic or Early Cambrian to Early and (or) Middle Devonian in age, crops out in the Shublik Mountains, where it overlies (probably disconformably) the Katakturuk Dolomite (Blodgett and others, 1986). It is about $900 \mathrm{~m} \mathrm{(3,000} \mathrm{ft)} \mathrm{thick} \mathrm{and}$ consists of nearly equal amounts of fine-grained limestone and medium- to coarse-grained, partly vuggy, stromatolitic dolomite.

In addition to pre-Mississippian carbonate rocks exposed in the mountains, as much as $100 \mathrm{~m}(330 \mathrm{ft})$ of carbonate rocks, some with reservoir potential, occur in a basement complex composed predominantly of argillite in wells in the Point Thomson-Flaxman Island area northwest of the 1002 area (pl. 1, fig. 7.3). Seismic data indicate that these rocks may also extend into the 1002 area. The age of the argillite and carbonate rocks is poorly known. They may be Ordovician and Silurian, similar to paleontologically dated argillite in the Prudhoe Bay and Point Barrow areas (Carter and Laufeld, 1975) or they may be Proterozoic, if the suite of radiometric (K-Ar) ages (547-584 Ma) from argillite in the West Staines State 18-9-23 well date the metamorphism of these rocks (Drummond, 1974, p. 802).

Seismic data from the 1002 area add to our knowledge of the large-scale structure of the preMississippian rocks. Fisher and Bruns (chap. 18) show the presence of a broad east-west-trending asymmetric antiform beneath the western part of the 1002 area. South-dipping reflections are nearly horizontal, whereas north-dipping reflections are steep relative to the preMississippian unconformity. Outcrop data suggest that the south-dipping reflections may originate from bedding. Outcrops of pre-Mississippian rocks in the mountains south of the western 1002 area have an east-west grain and are almost universally south-dipping (Reiser, 1970, p. K4). J.S. Kelley (U.S. Geological Survey, oral commun., 1985) reports that the angle of dip of these rocks is about 15 degrees relative to the preMississippian unconformity.

Norris (1985b) interprets the Precambrian rocks (his Neruokpuk Formation) in the northern Yukon Territory of Canada to comprise a deep-water slope sequence, deposited in large part by turbidity currents, shed from a provenance that was sedimentary and perhaps metamorphic. He hypothesizes that these rocks are the thick, distal slope equivalent of the platformal deposits of the upper Tindir Group, now $450 \mathrm{~km}$ (280 $\mathrm{mi}$ ) to the south. In contrast, Moore and others (1985) interpret the pre-Mississippian rocks of northeastern Alaska to represent several tectono-stratigraphic terranes assembled by accretionary processes along an active continental margin prior to Middle Devonian time.

Rocks of the basement complex in the ANWR encompass a long, poorly understood period of geologic time during which marine and probably nonmarine sediments accumulated in one or more sedimentary basins adjacent to active volcanoes. Several periods of uplift and erosion are indicated by unconformities, and at least one period of mountain building is indicated by the intrusion of granitic rocks.

\section{ELLESMERIAN SEQUENCE}

The Ellesmerian sequence was named by Lerand (1973) for Mississippian to Jurassic sedimentary rocks in Arctic Canada. Grantz and others (1975) applied the name to rocks of similar age in northern Alaska. These rocks record marine to nonmarine deposition along a slowly subsiding continental margin in which the land area was to the north and the seaway was to the south. In the Sadlerochit Mountains, the sequence may reach a thickness of $900 \mathrm{~m}(3,000 \mathrm{ft})$. A schematic diagram of the Ellesmerian rocks exposed in the mountains south of the 1002 area is given in figure 5.4.

A regional unconformity that developed during mid-Neocomian time across an uplift associated with the rifted margin of the Arctic Alaska plate in northernmost Alaska truncates older rocks northward. This unconformity, referred to herein as the Lower Cretaceous unconformity, is of great importance to the petroleum potential of the 1002 area because it controls the northern distribution of most Ellesmerian reservoir rocks (see chap. 7). In addition, the shale overlying the unconformity may provide a seal and source rock for truncated reservoirs. Most of the pre-Cretaceous Ellesmerian rocks may have been removed by erosion under the Lower Cretaceous unconformity in much of the 1002 area (pl. 1, fig. 7.1). However, they could be preserved in pre-unconformity down-dropped blocks in the 1002 area, although seismic data neither support nor preclude this possibility. Because these rocks are probably present in at least part of the 1002 area, they are described in ascending order as follows.

\section{Endicott Group}

The Endicott Group, the basal unit of the Ellesmerian sequence, unconformably overlies the basement complex. In the mountains south of the 1002 area, it consists of Mississippian clastic and carbonate rocks generally assigned to three formations: the Kekiktuk Conglomerate, the Kayak Shale, and the 


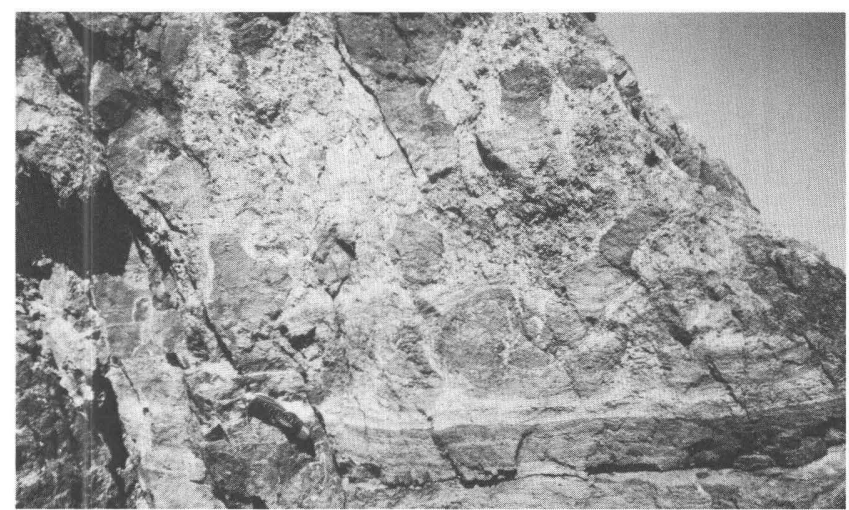

$\boldsymbol{A}$

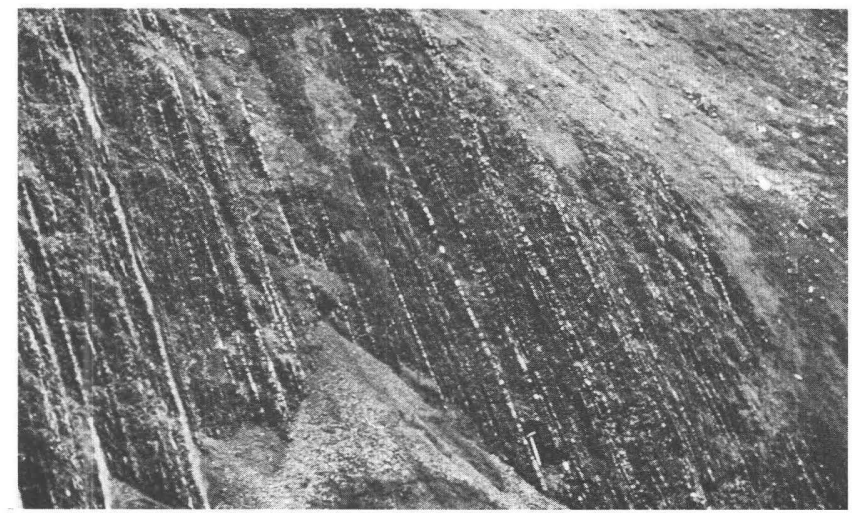

C

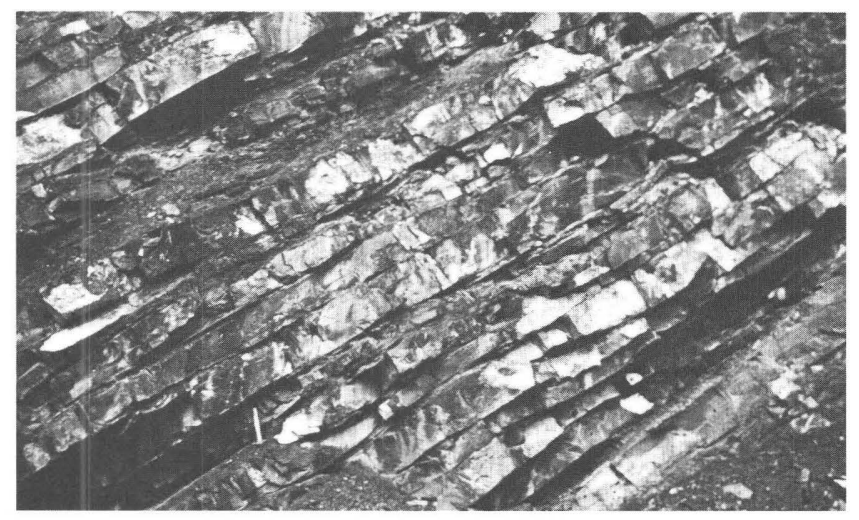

$\boldsymbol{E}$

Figure 5.3. Outcrops. A, Algal heads in Proterozoic Katakturuk Dolomite exposed on ridge above Hue Creek, north side of Shublik Mountains ( $\mathrm{SW}^{1 / 4} \mathrm{sec}$. 6, T. 2 N., R. 26 E.). Pocket knife for scale (lower-left center). $B$, South-dipping Lisburne Group unconformably overlying pre-Mississippian basement complex, here composed of Neruokpuk Quartzite and near-vertical mafic igneous dike(?) (prominent dark ridge). View eastward (secs. 5-8, T. 3 N., R. 31 E.). $C$, Steeply north-dipping Kavik Member of Ivishak Formation, Sadlerochit Group, exposed on Marsh Creek, north flank of Sadlerochit Mountains (sec. 19, T. 4 N., R. 30 E.). D, Massive beds of Ledge Sandstone Member of Ivishak Formation,

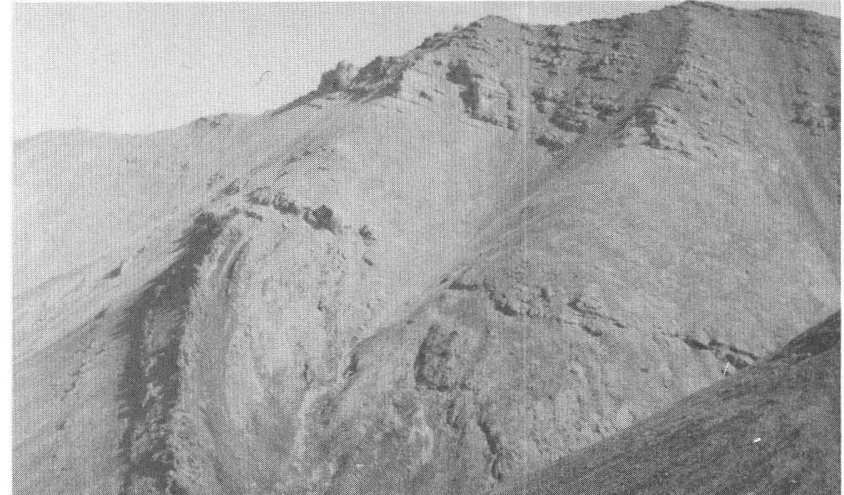

$\boldsymbol{B}$

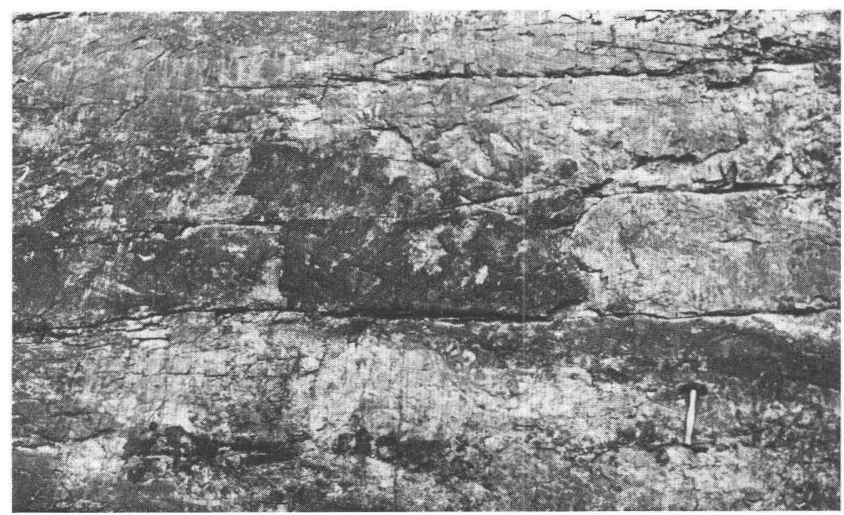

D

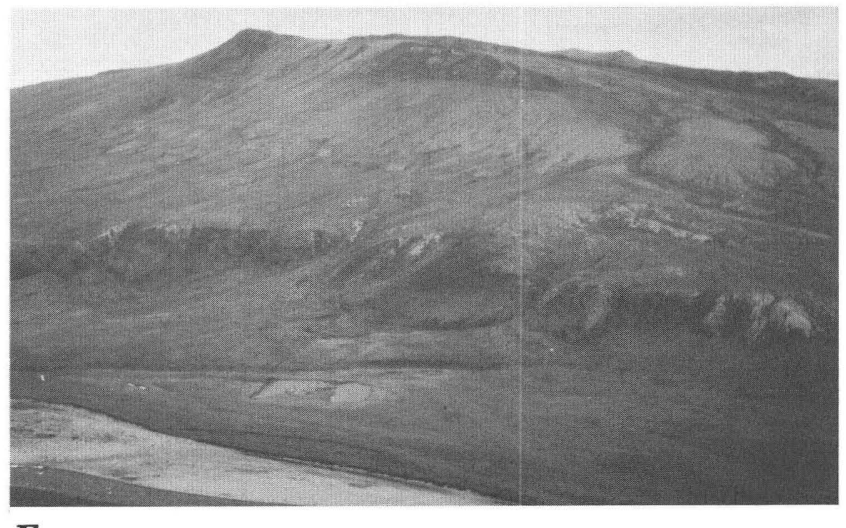

$F$

Sadlerochit Group, exposed along Fire Creek at east end of Shublik Mountains (sec. 15, T. 2 N., R. 28 E.). E, Medium-bedded Ledge Sandstone Member of Ivishak Formation, Sadlerochit Group, exposed along Fire Creek at east end of Shublik Mountains (sec. 15, T. 2 N., R. 28 E.). $F$, Kingak Cliff viewed from the air southeasterly across the Sadlerochit River (secs. 1, 2, 11, 12, T. 2 N., R. 30 E.). Contact between Kingak Shale and pebble shale unit (no Kemik Sandstone) is near base of hill (probably in lower scarp). Slope and hill above are shale and sandstone of Arctic Creek facies. Photographs $C, D$, and $E$ by R.K. Marinai. 
Itkilyariak Formation. These rocks range in thickness from a few meters or less to more than $600 \mathrm{~m}(2,000 \mathrm{ft})$. Thickness variations may be caused by differential subsidence during deposition or by truncation beneath the Lower Cretaceous unconformity. The Endicott Group may be missing from parts of the 1002 area for either or both reasons.

The Kekiktuk Conglomerate is composed of as much as $137 \mathrm{~m} \mathrm{(450} \mathrm{ft)} \mathrm{of} \mathrm{nonmarine} \mathrm{conglomerate,}$ sandstone, shale, and minor amounts of coal in outcrops. It is discontinuous in the mountains south of the 1002 area and, where present, is the basal formation of the group (Brosgé and others, 1962). This formation and the overlying Kayak Shale and (or) Itkilyariak Formation are much thicker in local downwarpings such as the elongate, half-graben that extends from just east of Prudhoe Bay southeasterly toward the ANWR as interpreted from well data (fig. 7.5). At its type section west of Lake Peters, $48 \mathrm{~km}$ (30 mi) south of the 1002 area, the Kekiktuk Conglomerate is $80 \mathrm{~m} \mathrm{(262} \mathrm{ft)} \mathrm{thick.}$ Nilsen (1981) reports that this section consists of a basal breccia 1 to $3 \mathrm{~m} \mathrm{(3-10} \mathrm{ft}$ ) thick, overlain by finingupward couplets of conglomerate and sandstone $58 \mathrm{~m}$ $(190 \mathrm{ft})$ thick, succeeded by fining-upward cycles of conglomerate, sandstone, and shale $20 \mathrm{~m}$ (66 ft) thick that gradually pass into marine and tidal deposits of the Kayak Shale. Conglomerate clasts are compositionally mature, being composed of quartz, chert, and quartzite. Nilsen interprets the lower $60 \mathrm{~m}(197 \mathrm{ft})$ of this section as representing deposits formed mostly by braided streams, and the upper $20 \mathrm{~m} \mathrm{(66} \mathrm{ft)} \mathrm{of} \mathrm{the} \mathrm{section} \mathrm{as}$ representing deposits formed mostly by meandering streams. The Kekiktuk contains oil and gas in the Endicott field, located about $16 \mathrm{~km}(10 \mathrm{mi})$ east of Prudhoe Bay (Behrman and others, 1985).

The Kayak Shale either gradationally overlies the Kekiktuk or, where the Kekiktuk is absent, unconformably overlies the basement complex (Brosgé and others, 1962). The Kayak consists of dark-gray marine shale, generally with minor amounts of interbedded sandstone near the base and increasing amounts of interbedded limestone and dolomite toward the top. This formation may be thin or absent, as in the Sadlerochit Mountains area (fig. 5.3B), or as much as $400 \mathrm{~m}(1,300 \mathrm{ft})$ thick. Microfossils and megafossils from limestone interbeds indicate that the Kayak Shale is Late Mississippian (Meramecian) in the northern part of the ANWR (Armstrong and Mamet, 1977; Brosgé and others, 1962). The Kayak Shale grades upward and laterally into the Lisburne Group.

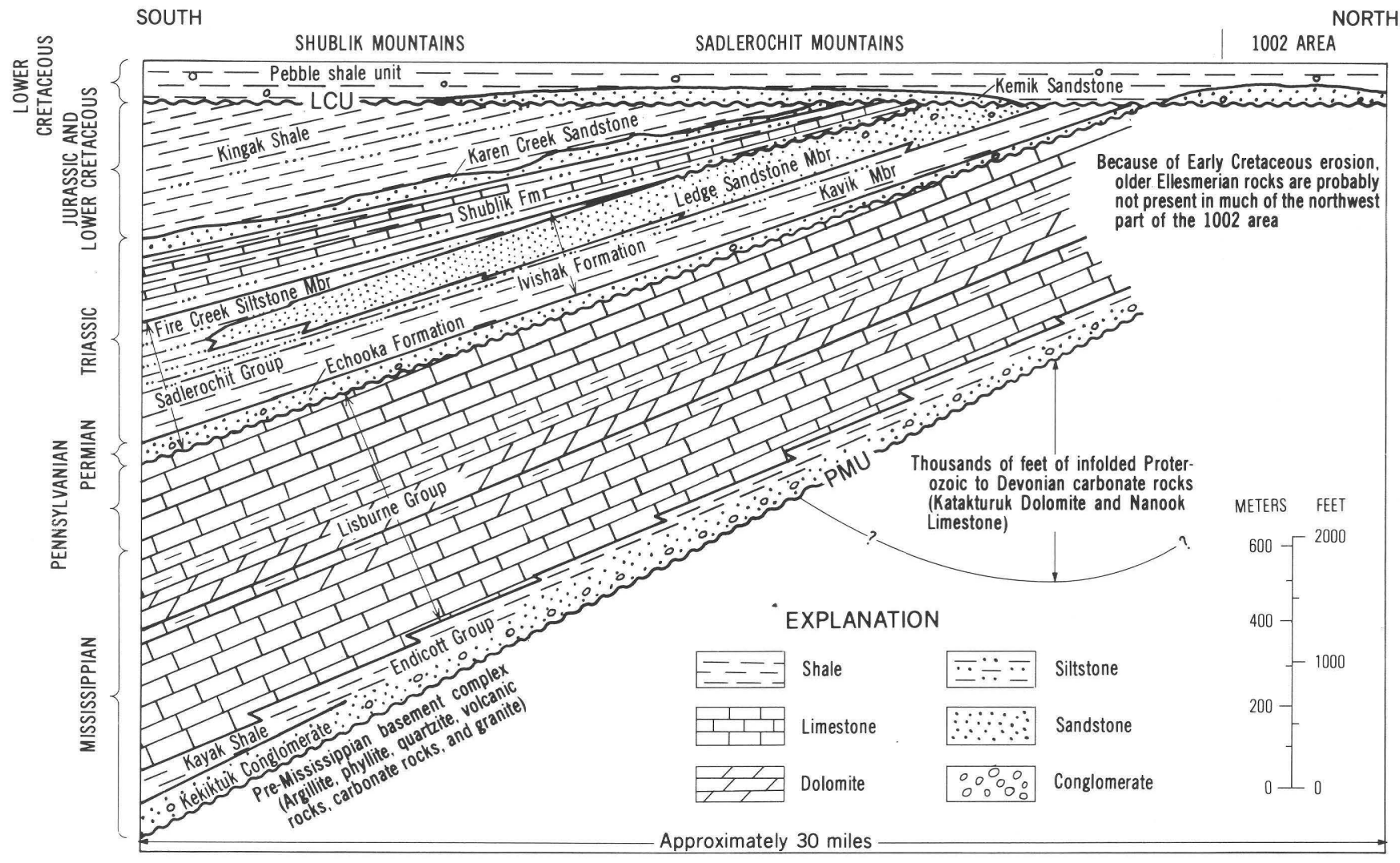

Figure 5.4. Diagrammatic section showing stratigraphic relations of the Ellesmerian sequence along mountain front in the ANWR. LCU, Lower Cretaceous unconformity; PMU, pre-Mississippian unconformity. 
The Itkilyariak Formation is a rock unit of similar stratigraphic position and lithology to the Kayak Shale and is distinguished primarily by its red color. It occurs in outcrop only in scattered, small areas of the northernmost northeastern Brooks Range, where it may be as much as $45 \mathrm{~m}(150 \mathrm{ft})$ thick. In the subsurface west of the ANWR, it reaches thicknesses greater than $150 \mathrm{~m}$ (500 ft)(Mull and Mangus, 1972). Well data west of the ANWR (pl. 1) indicate that the Kayak Shale grades laterally (northward) and upward into the Itkilyariak Formation. Its basin-margin position, lateral relations, and lithology all suggest that the Itkilyariak Formation represents a mixed, marine-nonmarine depositional environment, probably in large part tidal-flat deposition in an arid climate (Bird and Jordan, 1977).

Rock types, thicknesses, and stratigraphic relations of the Endicott Group in the northern part of the ANWR indicate a northern landmass bordered on the south by a swampy coastal plain traversed by streams or rivers emptying into a sea that lay farther south. Through time, subsidence continued and the seas transgressed the landmass, which caused these depositional environments to shift northward.

\section{Lisburne Group}

The Mississippian and Pennsylvanian Lisburne Group is composed of limestone with lesser amounts of dolomite and minor amounts of shale and sandstone. It occurs throughout the northeastern Brooks Range and in the subsurface as far west as the National Petroleum Reserve in Alaska (fig. 1.1A), where it is as young as Permian (Bird, 1978; Molenaar and others, 1986). It is absent in wells in the Point Thomson area because of truncation by the Lower Cretaceous unconformity, and it may also be missing from part of the 1002 area. Generally, the Lisburne gradationally overlies the Kayak Shale and is unconformably overlain by the Sadlerochit Group. Locally, however, the Lisburne Group may lie directly on pre-Mississippian basement rocks (fig. 5.3B) or on a very thin Endicott Group, as in the Sadlerochit Mountains area and perhaps some of the 1002 area. This relationship may be important in seismic-reflection interpretations in the 1002 area. The prominent seismic reflection from the top of the basement complex (chaps. 17 - 20) may be absent in areas where the Lisburne lies directly on the basement because of insufficient acoustic contrast between these two rock units.

The Lisburne in the outcrop belt is composed of 430 to $855 \mathrm{~m}(1,400$ to $2,800 \mathrm{ft})$ of Upper Mississippian to Middle Pennsylvanian cherty limestone and dolomite (Armstrong, 1972; Armstrong and Mamet, 1975, 1977; Wood and Armstrong, 1975). The lower part of the Lisburne, known as the Alapah Limestone, consists of medium-gray, recessive-weathering limestone and dolomite. The upper part, known as the Wahoo
Limestone, consists of light-gray, massive and resistantweathering limestone with minor amounts of dolomite (figs. 5.3B, 5.5A). Dolomite and dolomitic limestone in the Lisburne may have good porosity. At Prudhoe Bay, the Lisburne contains oil and gas. Comparison of the Lisburne at Prudhoe Bay with the northernmost Lisburne outcrops in the ANWR (Armstrong and Mamet, 1974) shows a remarkable similarity in thickness, rock type, rock sequence, and age.

Stratigraphic relations, rock types, and fossils indicate that the Lisburne was deposited in a clear, relatively warm, shallow sea. The gradation from predominantly clastic sedimentary rocks (Endicott Group) to predominantly carbonate rocks (Lisburne Group) indicates continued subsidence and a significant reduction in the amount of terrigenous sediment reaching the sea. The formation of intertidal to supratidal dolomite during Late Mississippian time indicates a minor regression of the sea. From the latest Mississippian to the Middle Pennsylvanian, sedimentation kept pace with subsidence and produced thick, shallow-water, bioclastic limestones. Regional upwarping, sometime between the Middle Pennsylvanian and the Early Permian, resulted in a retreat of the sea and the development of an erosional unconformity at the top of the Lisburne.

\section{Sadlerochit Group}

The Sadlerochit Group crops out throughout the northeastern Brooks Range and occurs in the subsurface to the west. It is absent because of Early Cretaceous erosion evident in northern coastal wells from a few kilometers (miles) east of Prudhoe Bay eastward to the Point Thomson area and perhaps throughout most of the 1002 area (pl. 1, fig. 7.1). The Sadlerochit Group unconformably overlies the Lisburne Group (fig. 5.5A) and is overlain either by the Shublik Formation or, in the area of truncation, by the Lower Cretaceous informally named pebble shale unit (fig. 5.6B, C). The Sadlerochit is composed of as much as $380 \mathrm{~m}(1,250 \mathrm{ft})$ of shallow-marine sandstone, siltstone, and shale. Detterman and others (1975) subdivided these strata into two formations, the basal Echooka Formation of Early and Late Permian age and the overlying Ivishak Formation of Early Triassic age. The Ivishak has been further subdivided into three members named the Kavik, Ledge Sandstone, and Fire Creek Siltstone Members. Reports by Detterman (1970, 1974, 1976, 1984a, b) provide the following details.

The Echooka Formation consists of 45 to $137 \mathrm{~m}$ (150 to $450 \mathrm{ft}$ ) of sandstone and siltstone in the northern mountains of the ANWR. Locally, channels are cut into the upper part of the Lisburne Group and are filled with chert-pebble conglomerate (Detterman and others, 1975). Reiser and others (1971) observed some of these 
channels near the east end of the Shublik Mountains (sec. 16, T. 2 N., R. 28 E.). These conglomerates probably represent fluvial deposition during the development of the erosional unconformity between the Echooka Formation and the Lisburne Group. The overlying sandstone and siltstone typical of the Echooka Formation comprise the basal marine transgressive deposits formed during the northward advance of the sea across the eroded platform composed of Lisburne Group carbonate rocks.

The Kavik Member of the Ivishak Formation abruptly overlies the Echooka Formation. It consists of 30 to $122 \mathrm{~m}$ (100 to $400 \mathrm{ft}$ ) of dark-colored, laminated to thin-bedded, silty shale and siltstone (fig. 5.3C). These rocks represent prodelta deposits that thicken southward and grade upward into the massive deltaic sandstones of the Ledge Sandstone Member. The Ledge ranges in thickness from $30 \mathrm{~m}(100 \mathrm{ft})$ to more than $175 \mathrm{~m}$ (575 $\mathrm{ft}$ ) and consists of northward-thickening and coarsening sandstone beds with thin siltstone interbeds (fig. 5.3D, E). Sedimentary structures, burrows, and occasional fossils indicate a shallow-marine environment of deposition. The sandstone has low porosity because of silica cementation (see chap. 8). This low porosity contrasts with the high porosities in equivalent sandstones - the main oil-producing reservoir-in the Prudhoe Bay field. The Ledge Sandstone Member grades upward into the northward-thinning Fire Creek Siltstone Member. This member is composed of as much as $30 \mathrm{~m}(100 \mathrm{ft})$ of siltstone and argillaceous

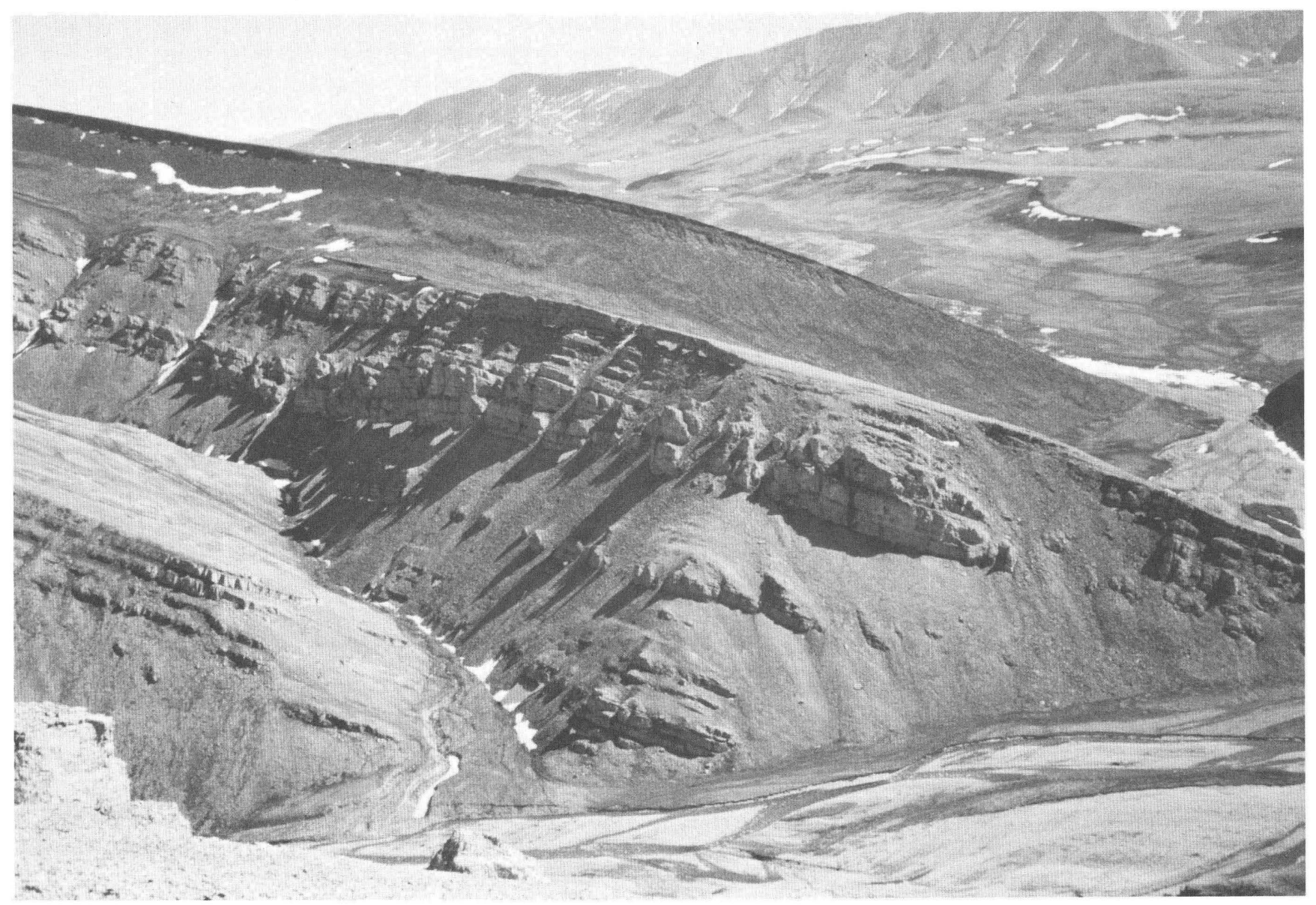

$\boldsymbol{A}$

Figure 5.5. Outcrops. A, View southeastward across Katakturuk Canyon into upper Ignek Valley. Resistant ledges (foreground) are Lisburne Group unconformably overlain by Sadlerochit Group forming the smooth recessive slope and resistant ridge-capping unit, the Ledge Sandstone Member of the Ivishak Formation. Valley floor beyond the ridge is underlain by Kingak Shale, and Kemik Sandstone forms the low, sinuous ridge across the valley. Shublik Mountains in distance. Photograph by K.F. Watts. $B$, Fossiliferous limestone and calcareous shale in lower part of Shublik Formation at Fire Creek near east end of Shublik Mountains (NE1/4 sec. 15 , T. 2 N., R. 28 E.). C, Karen Creek Sandstone near Fire Creek at east end of Shublik Mountains (SW1/4 sec. 11, T. 2 N., R. 28 E.). 
sandstone, deposited during a deepening of the sea. It is missing along the north flank of the Sadlerochit Mountains, where it and probably some of the Ledge Sandstone Member have been removed by Early Cretaceous erosion (fig. 5.6B, C). The Fire Creek Siltstone Member is gradationally overlain by the Shublik Formation.

The Sadlerochit Group represents renewed subsidence of the basin and uplift of the northern landmass. Transgressive marine deposits at the base of the group records this subsidence. Following deposition of offshore muds, regressive deltaic deposits indicate uplift in the source area. The change from deltaic sandstone to finer grained siltstone deposition indicates continued subsidence and (or) a wearing down of the source area.

\section{Shublik Formation}

The Shublik Formation, of Middle and Late Triassic age, is a distinctive dark-colored unit primarily consisting of fossiliferous limestone and calcareous shale (fig. 5.5B). It conformably overlies the Sadlerochit Group, except in some of the northernmost outcrops, where Detterman and others (1975) interpret the contact to be disconformable. The Shublik crops out along the mountain front and occurs in the subsurface to the west. It is 90 to $150 \mathrm{~m}$ (300 to $500 \mathrm{ft}$ ) thick in the outcrop belt and depositionally thins to the north in the subsurface west of the 1002 area. It is missing in a large area extending from near Prudhoe Bay eastward to the Point Thomson area because of truncation by the Lower Cretaceous unconformity (pl. 1, fig. 7.1). It is also probably missing from a large part of the 1002 area for the same reason.

The Shublik consists of four vertically separated facies: a lower siltstone, a fossiliferous limestone, a mudstone, and a calcareous siltstone (Detterman and others, 1975; Tourtelot and Tailleur, 1971). Phosphatic nodules and cements are common just above and below the limestone facies. The Shublik is rich in organic carbon and is considered to be an important source rock for Prudhoe Bay oil (Seifert and others, 1979; Magoon and Bird, 1985).

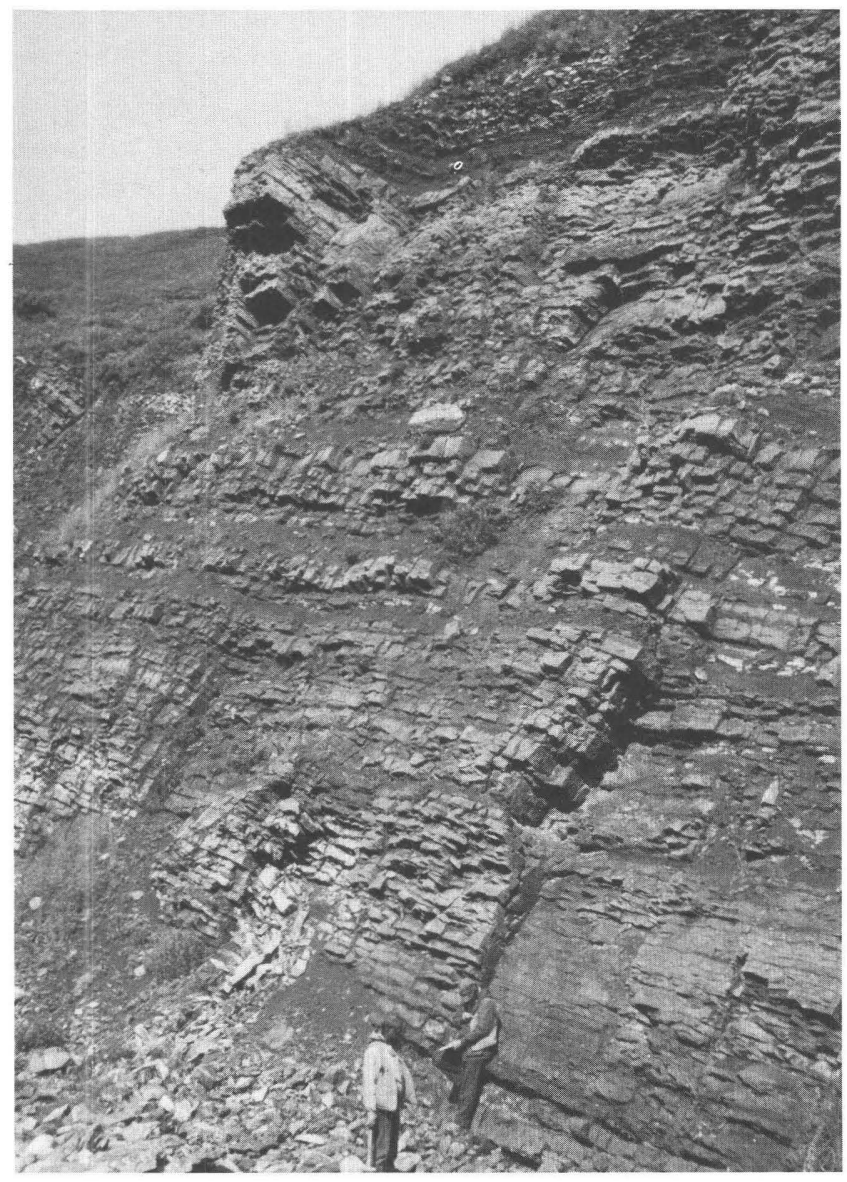

$B$

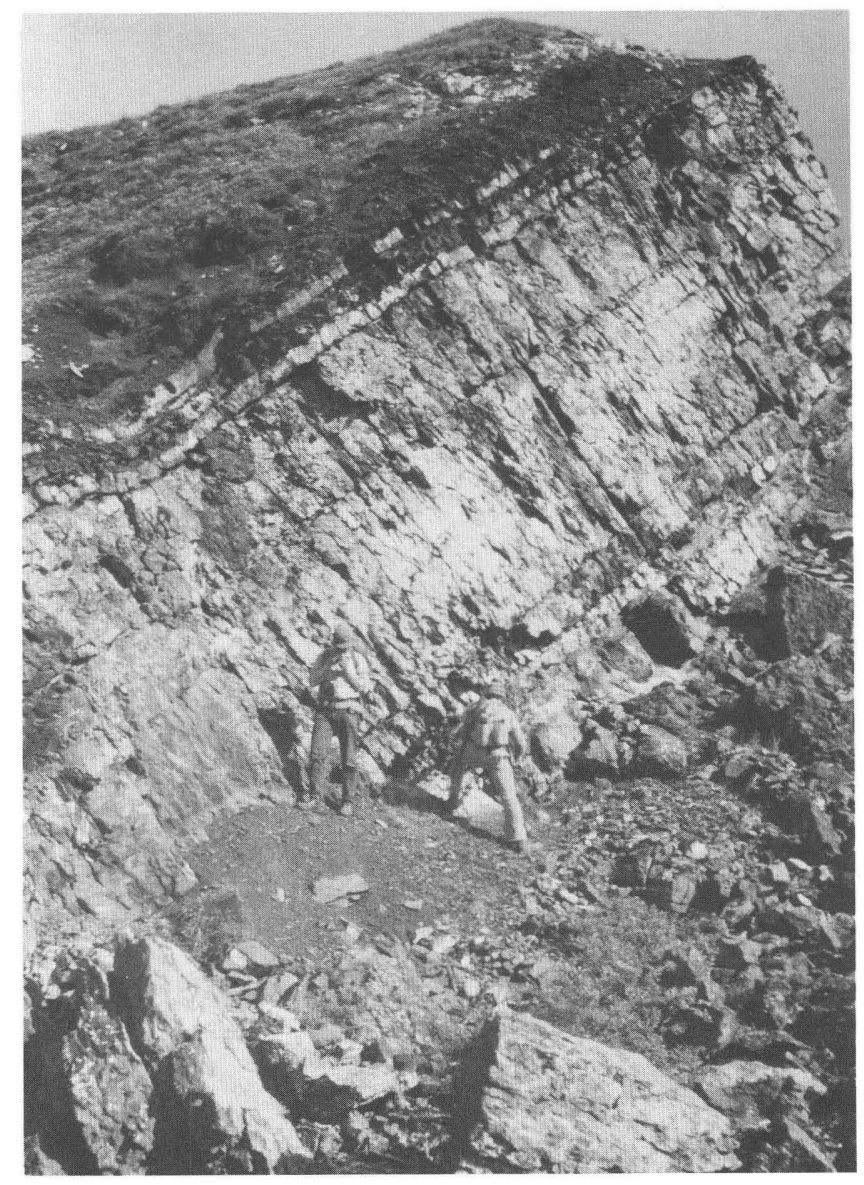

C

Figure 5.5. Continued. 
The Shublik Formation represents continued subsidence of the basin following Sadlerochit deposition. Fine-grained clastic and chemical sedimentation predominated then in a sea rich with organisms. A minor regression of the sea is recorded at the top of the Shublik by deposition of the overlying Karen Creek Sandstone.

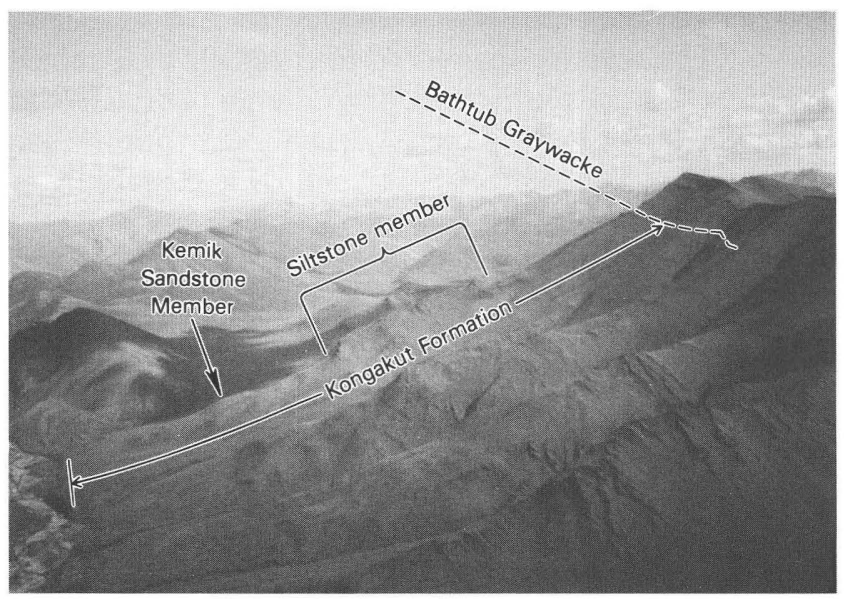

$\boldsymbol{A}$

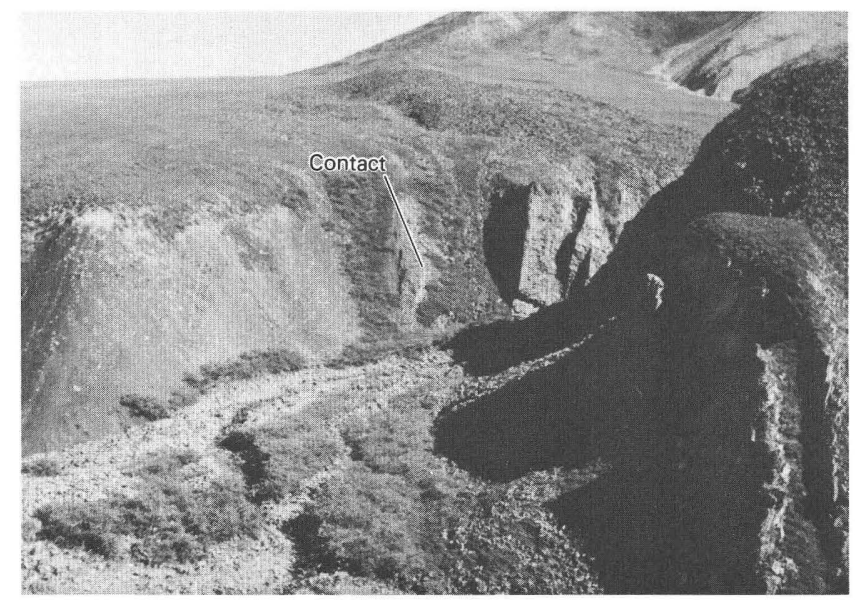

$B$

Figure 5.6. Outcrops. $A$, View to east along north side of Bathtub Ridge. Type section of Kongakut Formation is along ridge near center of photograph. $B$, Pebble shale unit and thin basal Kemik Sandstone unconformably overlying Ledge Sandstone Member of Ivishak Formation (Sadlerochit Group) at Marsh Creek on north side of Sadlerochit Mountains (sec. 19, T. 4 N., R. 30 E.). $C$, Close-up of $B$. Man's hand is on contact. $D$, Kemik Sandstone, $30 \mathrm{~m}$ (100 ft) thick, in Ignek Valley on southeast side of syncline in lower part of photograph $5.7 A\left(\mathrm{~W}^{1 / 2}\right.$ sec. 2 , T. 2 N., R. 27 E.).

\section{Karen Creek Sandstone}

The Karen Creek Sandstone of Late Triassic age is a gray, resistant, quartzitic sandstone that conformably overlies the Shublik Formation over most of its outcrop area. The Karen Creek crops out along the mountain front from a few kilometers east of the Aichilik River to

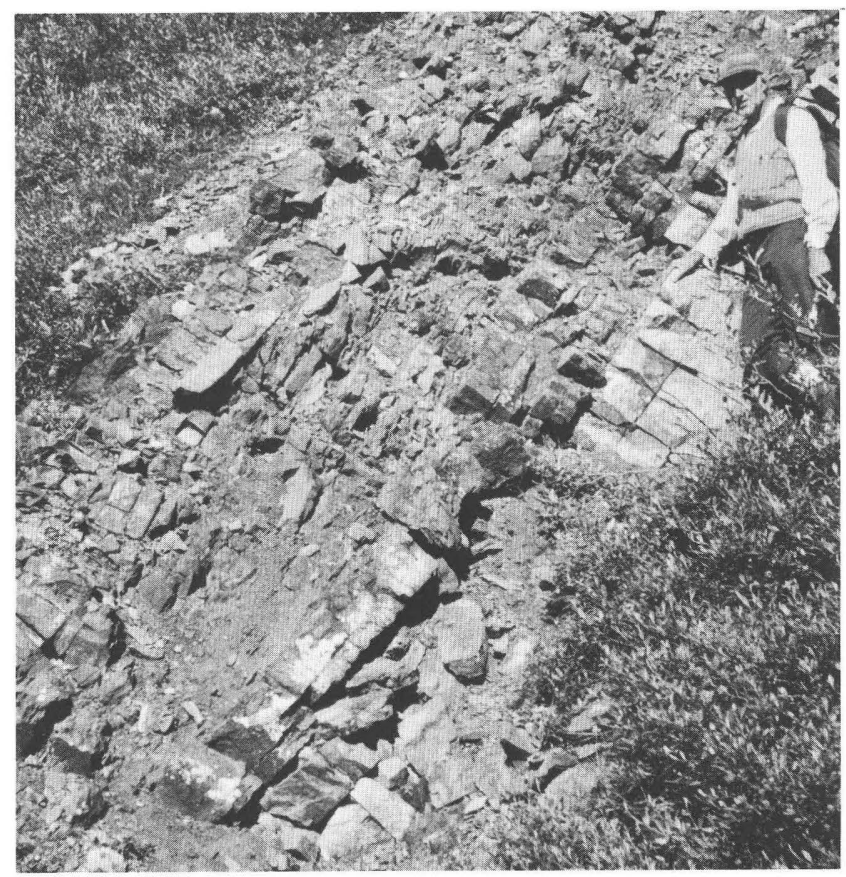

C

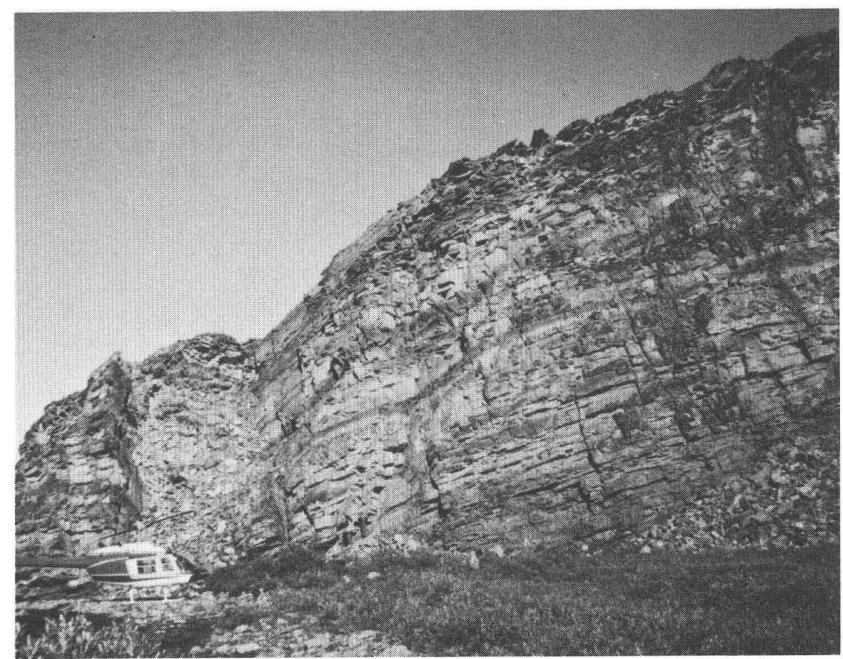

D 
west of the Canning River. It ranges in thickness from 3 m (10 ft) on the Kavik River southwest of the 1002 area to about $38 \mathrm{~m}(125 \mathrm{ft})$ along the mountain front near the Jago and Aichilik Rivers (Detterman and others, 1975). It is very hard in outcrops, consisting primarily of wellcemented, very fine to coarse silt-size quartz grains. Burrows and bioturbation are common, and the bedding is thick to massive (fig. 5.5C). Bivalve fossils indicate a Late Triassic (Norian) age for the Karen Creek Sandstone.

Marine fossils, bioturbation, bedding features, and the widespread distribution of the Karen Creek Sandstone indicate deposition over a broad, shallow shelf. Thickness variations are probably due to the marine currents responsible for depositing the sand, rather than indicating a source direction. Regional considerations, as well as the quartzose composition, indicate that the Karen Creek had a northern source.

The Karen Creek Sandstone is not considered a good reservoir rock because of its very fine grained texture, cementation, and generally limited thickness. However, the Sag River Sandstone, with which the Karen Creek is correlative, is oil productive in some wells in the Prudhoe Bay area and contains gas in the Kavik field.

\section{Kingak Shale}

The Kingak Shale, of Jurassic and Early Cretaceous (Berriasian-Valanginian) age, is a thick, marine shale that conformably overlies the Karen Creek Sandstone. The Kingak crops out discontinuously along the mountain front, around the Sadlerochit Mountains, and in one small part of the 1002 area west of the Niguanak River (labeled Jurassic on fig. 5.2). Detterman and others (1975) reported thicknesses ranging from 45 to $365 \mathrm{~m}$ (150 to $1,200 \mathrm{ft}$ ) in the Ignek Valley area and at least $427 \mathrm{~m}(1,400 \mathrm{ft})$ along the Aichilik River. Keller and others (1961) reported a thickness of about $900 \mathrm{~m}(3,000 \mathrm{ft})$ at Kemik Creek, west of the Canning River. In general, the Kingak thins to the north because of truncation by the Lower Cretaceous unconformity (fig. 5.4). In the Marsh Creek area, immediately north of the Sadlerochit Mountains, the Kingak has been totally removed under the unconformity. However, it is present again about $2 \mathrm{~km}(1 \mathrm{mi})$ north on a thrust plate that has been transported farther north than the block where the Kingak is missing. Much of the thickness variation of the Kingak is probably due to structural repetition by thrust faults (see chap. 20). The Kingak Shale exposed in the Niguanak River area, from which Middle Jurassic (Bajocian) megafossils were collected (Reiser and others, 1980), is also thought to have been transported from the south and uplifted by thrust faults.

The Kingak Shale consists primarily of darkgray to black, fissile, noncalcareous, clayey to silty shale and lesser amounts of siltstone. The siltstone and silty shale constitute the middle part of the formation, and ironstone concretions are common to rare throughout the formation (Detterman and others, 1975). The uppermost (Lower Cretaceous) part of the Kingak contains rare, matrix-supported, fine to very fine quartz grains (Molenaar, 1983) and very rare chert and limestone pebbles. Parts of the Kingak may be potential source rocks for petroleum.

The Kingak Shale is interpreted to have been deposited in outer-shelf, slope, and basinal depositional environments. Fossil data indicate ages ranging from the Early Jurassic to the Early Cretaceous with some missing fossil zones within the thick unit. The missing zones may represent times of little or no deposition rather than erosional unconformities. Regional considerations, including shallow-marine tongues of quartzose sandstone that pinch out to the south in northern coastal areas between Prudhoe Bay and Point Barrow, indicate that sandstones in the Kingak had a northern source (Molenaar, 1981; Carman and Hardwick, 1983). In the Mackenzie Delta area to the east, the Kingak or ageequivalent units generally had a southeastern source (Poulton, 1982). However, there has been considerable differential plate movement between northeastern Alaska and the Mackenzie Delta area since the Kingak was deposited. Although direct evidence is lacking, the area of separation of the present-day northern-source Kingak from the southeastern-source Kingak is thought to be east of the Alaska-Canada border (Poulton, 1982, p. 16; Balkwill and others, 1983, p. 17). If this line of separation was within the 1002 area, the distribution of Jurassic and younger potential reservoir sandstones would be affected east of the line.

An interesting sidelight on the Kingak Shale is that the upper part of the type section consists of Albian(?) or younger Brookian turbidites (fig. 5.3F). The Kingak was named by Leffingwell $(1919$, p. 119) for exposures extending from the upper part of Camp 263 Creek on the south side of the eastern part of the Sadlerochit Mountains, across the Sadlerochit River, and up to the resistant sandstone bed capping Kingak Cliff (Mt. Michelson C-2 quadrangle). Apparently, Leffingwell thought that the resistant sandstone bed was what is now called the Kemik Sandstone, which overlies the Kingak Shale at the head of Ignek Valley, $24 \mathrm{~km}(15 \mathrm{mi})$ west. Actually, the top of the Kingak is near the base of Kingak Cliff, south of the Sadlerochit River, where it is overlain by the pebble shale unit. The Kemik Sandstone is not present. The slope above, which Leffingwell described as "dirty green" shale, consists of bentonitic shale and thin-bedded sandstone rubble capped by a thick amalgamated turbidite sandstone bed, all of which we include in the Arctic Creek facies (to be discussed). In addition, a sole thrust fault of large displacement is probably present within the Kingak Shale. This would explain the absence of the Kemik Sandstone to the southeast and the juxtaposition of the Arctic Creek facies 
and the Jago River Formation with unlike facies to the west mentioned in the discussion of those units.

Morgridge and Smith (1972) and Jones and Speers (1976) considered the Kingak Shale as a possible source for the oil in the Prudhoe Bay field. Seifert and others (1979) demonstrated geochemically that the Kingak Shale was a major source rock for the oil in the Prudhoe Bay field.

\section{Kemik Sandstone and Pebble Shale Unit}

Erosion of an uplifted segment of the rifted margin of the Arctic Alaska plate resulted in removal of much of the Ellesmerian sequence in northernmost Alaska during mid-Neocomian time (figs. 3.1, 5.4, pl. 1). Subsequent subsidence of this northern uplift resulted in northward transgression of the sea in late Neocomian time and deposition of the discontinuous Kemik Sandstone and the associated, informally named pebble shale unit (Molenaar and others, 1987). Detterman and others $(1975$, p. 21) included these units-their Kemik Sandstone Member and pebble shale member, respectively-in the lower (but not basal) part of the Kongakut Formation, a 600-1,200-m-thick (2,000$4,000 \mathrm{ft}$ ) section of predominantly shale and siltstone that crops out in the Bathtub Ridge area $56 \mathrm{~km}(35 \mathrm{mi})$ south of the mountain front (figs. 5.2, 5.6A). Because only the Kemik Sandstone Member and pebble shale member, as well as parts of the clay shale member (upper part of the Kingak Shale) of this thick formation, are present along the mountain front and coastal plain (Molenaar, 1983, p. 1072), Molenaar and others (1987) recommended (1) that the Kongakut Formation be geographically restricted from the area along the mountain front and coastal plain, (2) that the Kemik in this area be raised to formational rank and called the Kemik Sandstone, and (3) that the pebble shale member should likewise be raised to formational rank in this area and called the pebble shale unit. The Kemik Sandstone is widely distributed along the mountain front and in wells in the coastal plain west of the ANWR. The term "pebble shale unit" is used in this report for the unit throughout the mountain front and coastal plain. Photographs of outcrops relating to the Kemik Sandstone, pebble shale unit, and overlying Brookian rocks are shown in figures 5.6 to 5.9.

The Kemik Sandstone and pebble shale unit rest on progressively older formations from south to north (fig. 5.4, pl. 1). On the north side of the Sadlerochit Mountains, they rest on the Permian and Triassic Sadlerochit Group (fig. $5.6 B, C$ ), and in wells in the Staines River-Point Thomson area immediately northwest of the ANWR, they rest on the basement complex (pl. 1). Although the Kemik Sandstone and pebble shale unit are separated by a regional unconformity from the underlying major part of the Ellesmerian sequence in northernmost Alaska, they are included in the Ellesmerian sequence because they were derived from a northern source.

\section{Kemik Sandstone}

The Kemik Sandstone, of Hauterivian (Early Cretaceous) age, crops out around the Sadlerochit Mountains (figs. 5.5A, 5.6D, 5.7A) and in a southwesterly extending band along the foothills as far as the Echooka River, $65 \mathrm{~km}$ (40 mi) southwest of the Sadlerochit Mountains (Molenaar, 1983, p. 1070). It also occurs in several wells along the foothills as far as $112 \mathrm{~km}(70 \mathrm{mi})$ west of the Canning River. To the south, the Kemik apparently pinches out as the underlying unconformity dies out (Molenaar, 1983, p. 1071). The Kemik unit is not known to crop out southeast and east of the Sadlerochit Mountains except in the Bathtub Ridge area, $97 \mathrm{~km}(60 \mathrm{mi})$ to the southeast. The Kemik Sandstone of the foothills belt is apparently not connected with the Kemik Sandstone Member of the Kongakut Formation of the Bathtub Ridge area; however, the presence in both of the ammonite Simbirskites indicates that they are both Hauterivian in age (Detterman and others, 1975, p. 25; Molenaar, 1983, p. 1072).

In the foothills outcrop belt of the ANWR, the Kemik Sandstone is generally one sandstone body ranging in thickness from a few feet to about $30 \mathrm{~m}$ (100 ft) (fig. 5.6D). Locally, as on the north and south sides of the Sadlerochit Mountains, two or more separate sandstone beds crop out. These, however, are considered to be repeats of a single bed by imbricate thrust faults. Similar fault repetitions of the Kemik Sandstone are interpreted in the Canning River Unit A-1 well near the Canning River west of the Sadlerochit Mountains and the Kemik-1 well $42 \mathrm{~km}$ (26 mi) to the southwest (Bird, 1982). The Kemik Sandstone consists of fine- to very fine grained, well-cemented, noncalcareous sandstone in medium to thick beds. The medium- or dark-gray color probably is due to intermixed clay. The sand grains are composed mostly of quartz and chert, and they were

Figure 5.7. Outcrops. A, View to west of Ignek Valley. Resistant bed in valley bottom is the Kemik Sandstone, which unconformably overlies the Kingak Shale (covered). Pebble shale unit overlies Kemik and is mostly covered. Light-toned outcrops in valley are bentonitic shales of Hue Shale. Sadlerochit Mountains on right and Shublik Mountains on left. $B$, Aerial view of Ignek Valley section (fig. 5.11), the type section of the Hue Shale, on west side of Hue Creek. Pebble shale unit (overturned) is dark outcrop in center of photograph. Hue Shale is light-toned outcrop. Tight syncline in lower part of photograph is in Paleocene(?) turbidites. Southdipping Katakturuk Dolomite of Shublik Mountains is thrust against Mesozoic rocks. 


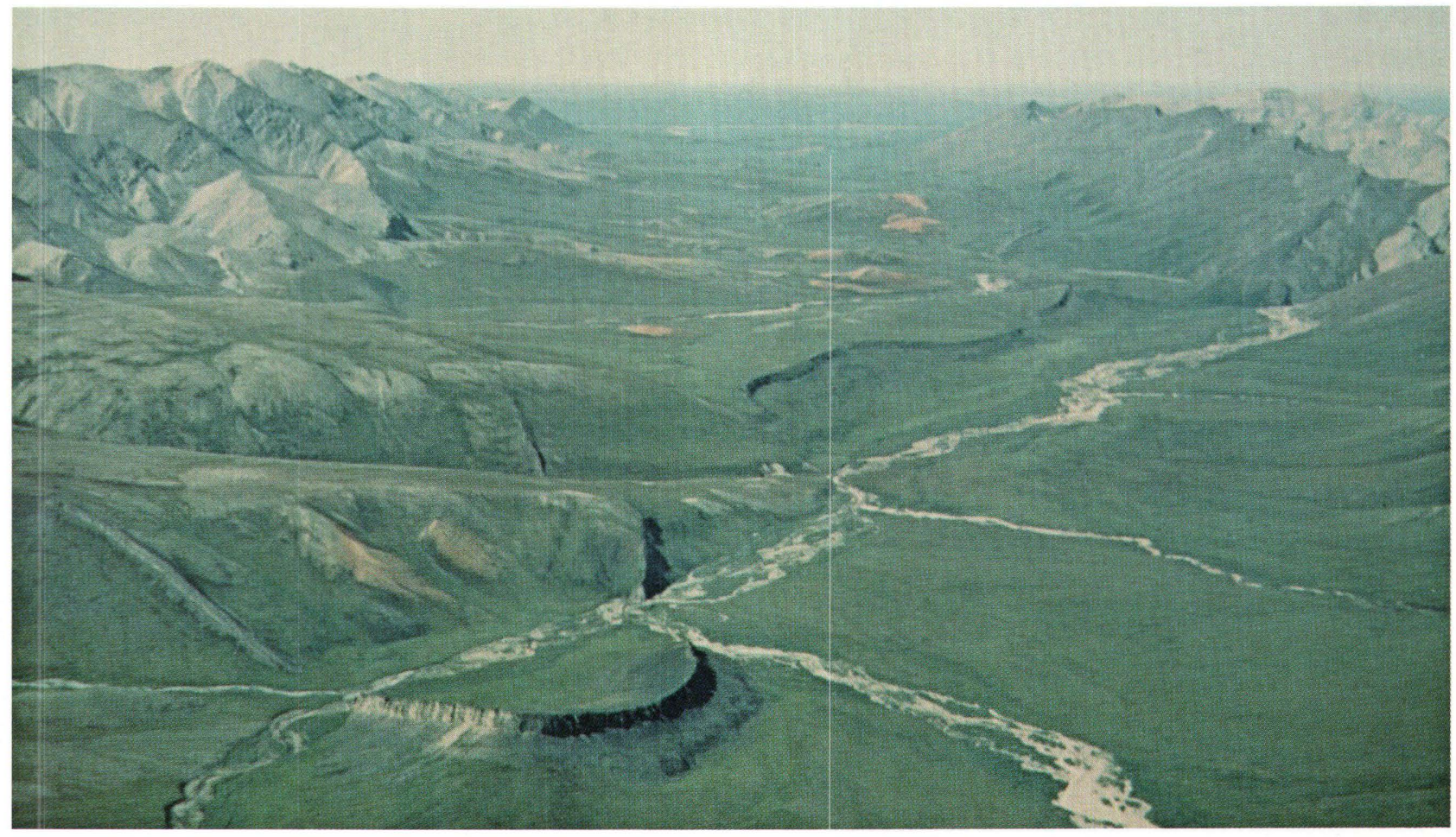

A

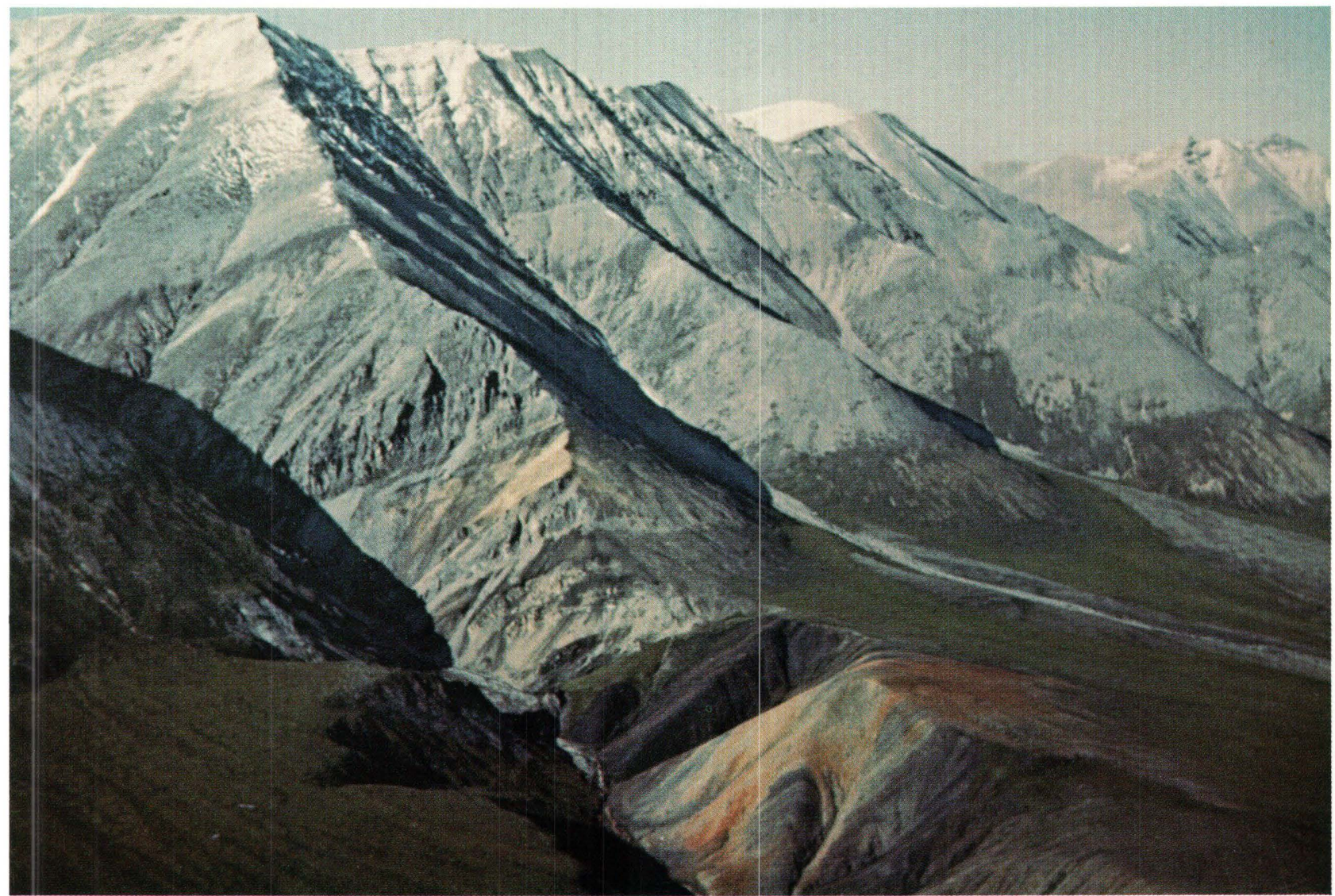




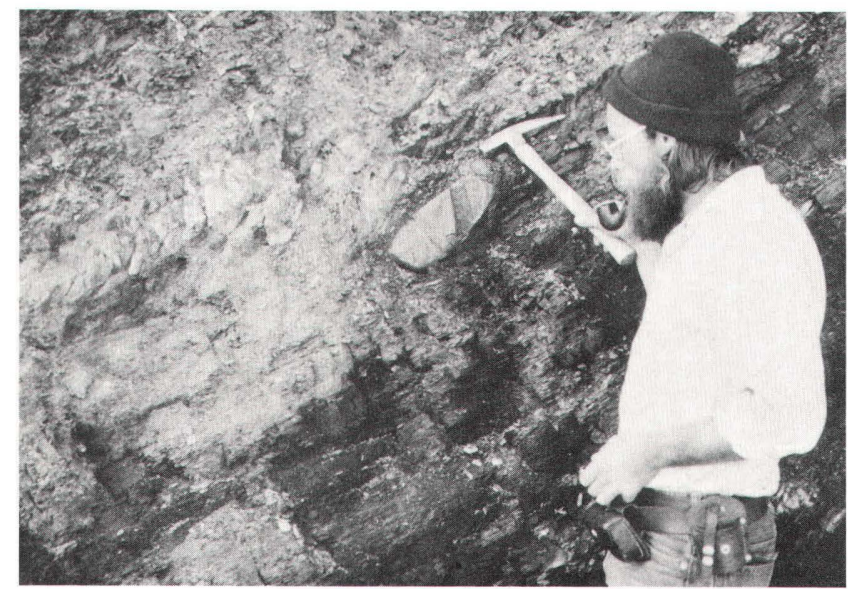

$\boldsymbol{A}$

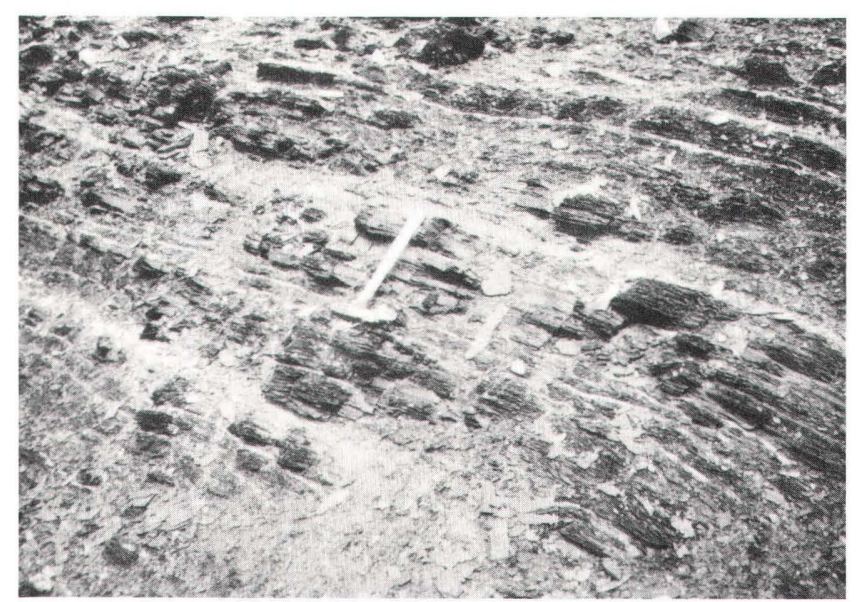

C

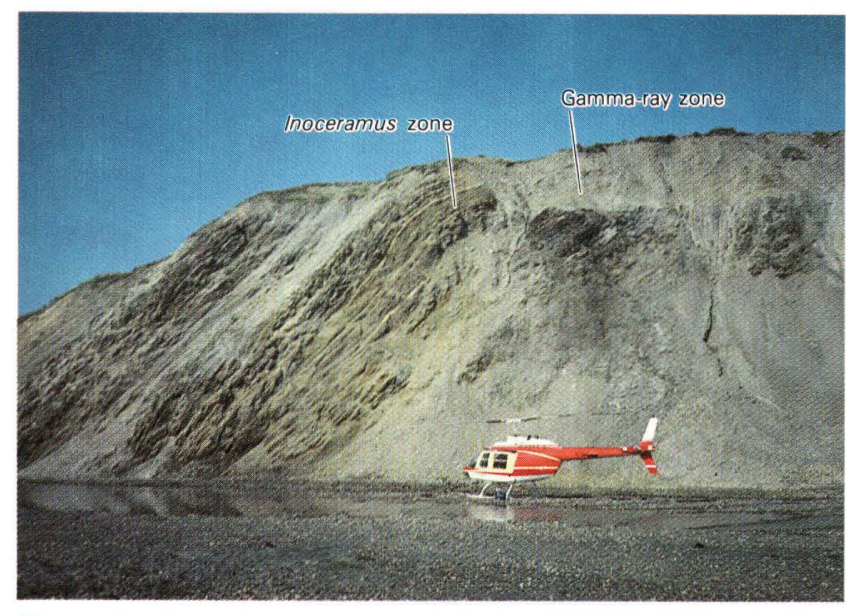

$\boldsymbol{E}$

Figure 5.8. Outcrops. $A$, Large cobble in upper part of pebble shale unit ( $\mathrm{W}^{1 / 2} \mathrm{sec}$ s7, T. 3 N., R. 25 E.). $B$, Pebble shale unit and Hue Shale on west side of Hue Creek, Ignek Valley section (fig. 5.11; NE $1 / 4$ sec. 6, T. 2 N., R. 26 E.). Arrows on fault indicate direction of relative movement. $C$, Interbedded fissile black shale and bentonite of gamma-ray zone, Ignek Valley section. $D$,

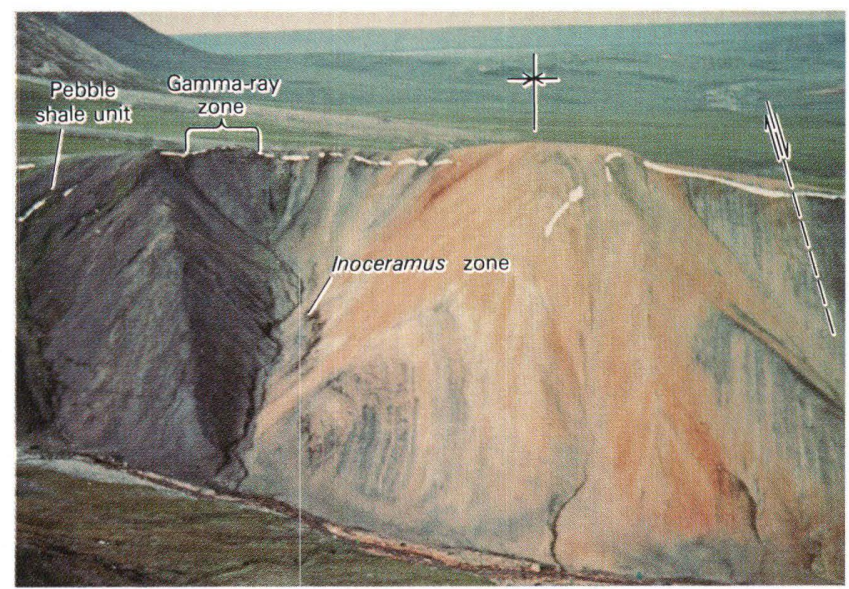

$B$

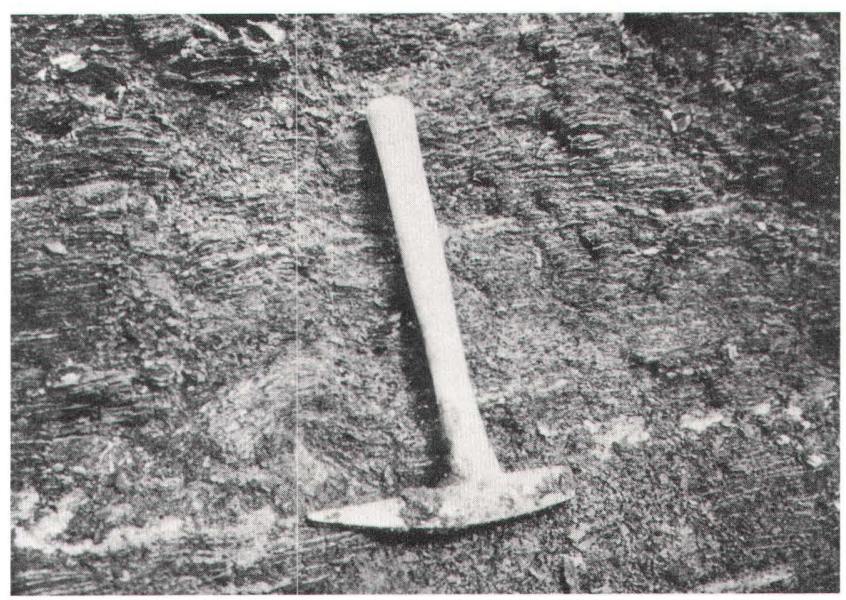

D

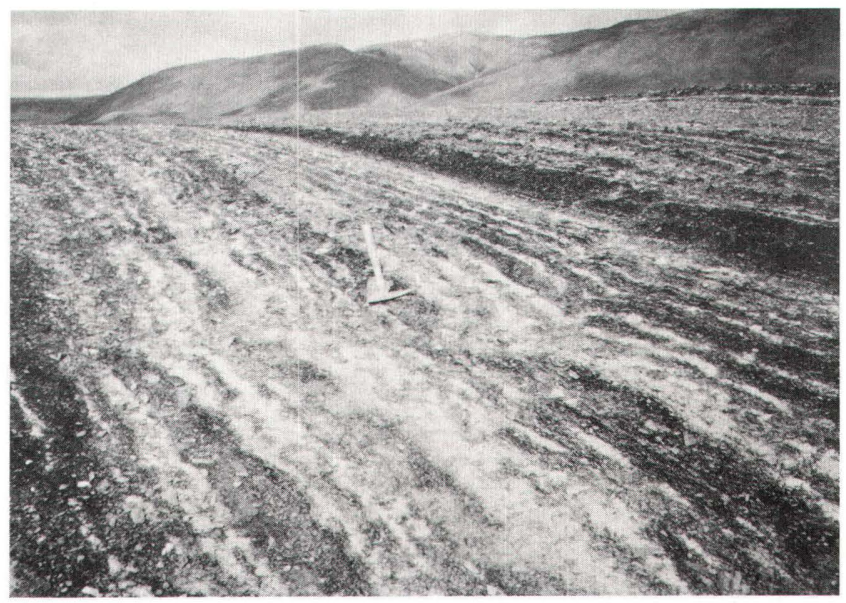
$\boldsymbol{F}$

Prismatic shell fragments (thin light bands) of inoceramids, Inoceramus zone at Ignek Valley section. $E$, Cretaceous section exposed along Jago River showing Inoceramus zone overlying gamma-ray zone (NE $1 / 4 \mathrm{sec}$. 4, T. 6 N., R. 35 E.). $F$, Interbedded black shale and bentonite of Hue Shale above Inoceramus zone, Ignek Valley section. 
probably derived from the Sadlerochit and Lisburne Groups that were being eroded to the north. Thin beds of pebble conglomerate are common at and near the base of the Kemik Sandstone in outcrops around the Sadlerochit Mountains.

Bedding features, scattered fossils, and trace fossils indicate a shallow-marine origin for the Kemik Sandstone. Its distribution, variable thickness, and relation with the underlying unconformity suggest that it was deposited on a broad shelf associated with a transgressing sea-probably as large offshore bars during a stillstand of the transgression. The Thomson sand, a unit of local usage that is penetrated by wells in the Point Thomson area, is a thick conglomeratic sandstone unit that is stratigraphically correlative with the Kemik Sandstone. It is a lenticular sandstone body that attains a thickness of at least $90 \mathrm{~m}(300 \mathrm{ft})$ and is of good reservoir quality. The conglomerate consists of pebble- to boulder-size clasts of dolomite, which suggests that it is of local derivation-probably from pre-Mississippian rocks of the basement complex (see chap. 9).

\section{Pebble Shale Unit}

The pebble shale unit either overlies the Kemik Sandstone or, where the Kemik Sandstone is absent, unconformably overlies the Kingak Shale or older rocks. It crops out around the Sadlerochit Mountains (figs. 5.6 5.8), in the Arctic Creek area, along the mountain front near the Okerokovik River, and west of the Niguanak River on the coastal plain. In the Sadlerochit Mountains area, the pebble shale unit is 60 to $90 \mathrm{~m}$ (200 to $300 \mathrm{ft}$ ) thick and consists of dark-gray to black, noncalcareous, clayey to silty shale containing minor scattered, rounded and frosted, quartz grains. Common to rare, matrixsupported chert and quartzite pebbles or granules and very rare cobbles (fig. 5.8A) occur throughout the pebble shale unit. Commonly, there is a concentration of pebbles at the base. Ironstone concretions are also common. The depositional origin of the rare pebbles and quartz grains scattered throughout the pebble shale unit is not clear. Undoubtedly, the pebble shale unit as a whole represents slow deposition, especially in the upper part. The scattered pebbles and quartz grains may have been rafted in by shore ice, kelp, or tree roots.

The upper contact of the pebble shale unit is placed at the base of a highly radioactive bentonitic shale. This contact is readily apparent on gamma-ray well logs. In outcrops, the upper contact is placed at the change from the generally nonbentonitic shale below to the interbedded shale and bentonite above. Previously, Bird (1982) and Molenaar (1981) included the highly radioactive shale in the pebble shale unit in the subsurface to the west. Molenaar and others (1987) now consider the highly radioactive shale to be a distal condensed deposit related to the Brookian sequence, and hence it should be separated from the underlying pebble shale unit.
The pebble shale unit is Hauterivian to Barremian (Early Cretaceous) in age, based on foraminiferal and palynologic data. Megafossils are very rare or absent thoughout the unit. Interpreted as an offshore deposit associated with the northwardtransgressing sea, it is part of the northerly derived Ellesmerian sequence. The uppermost undated part, however, may represent very slow deposition associated with the Brookian sequence, because the northern source area had subsided and had ceased to be a source by latest Neocomian time (Grantz and May, 1983).

Some workers consider the pebble shale unit to be a source rock for at least some of the oil in the Prudhoe Bay field (Morgridge and Smith, 1972; Jones and Speers, 1976; Seifert and others, 1979). In the ANWR area, the pebble shale unit is a gas-prone source rock (chaps. 11, 12).

\section{BROOKIAN SEQUENCE}

The Brookian sequence consists of thick, northeasterly prograding, basinal, basin-slope, shallowmarine, and nonmarine shelf deposits derived from the ancestral Brooks Range orogenic belt to the south and southwest. The Brooks Range orogeny may have started in Jurassic time, and certainly the mountain belt was a dominant source during earliest Cretaceous time. However, except for a thin section of shale and bentonite, significant deposition from this source did not occur in the coastal plain area of northeastern Alaska until Late Cretaceous and Tertiary time, because the deeper part of the Colville basin that lay to the south was a trap for almost all the southerly and southwesterly derived sediments (Molenaar, 1983, p. 1078). The thin (90 to $300 \mathrm{~m}, 300$ to $1,000 \mathrm{ft}$ ) condensed section of Aptian(?) (Lower Cretaceous) to Upper Cretaceous organic-carbon-rich shale and bentonite in northeastern Alaska is considered to represent clay and ash particles from the Brookian source that settled out of suspension, probably in deep water. The total Brookian sequence is as much as $4,000 \mathrm{~m}(13,000 \mathrm{ft})$ thick in wells irnmediately northwest of the ANWR (fig. 5.10, pl. 1).

Formational terms used in this report for Brookian rocks follow those recently proposed by Molenaar and others (1987). Five separate units are discussed: (1) the Hue Shale, a distal condensed shale facies; (2) the Arctic Creek facies, a turbidite facies that crops out southeast and east of the Sadlerochit Mountains and is coeval with part of the Hue Shale; (3) the Canning Formation, a thick prodelta slope-shale facies with turbidites in the lower part; (4) the Jago River Formation, a thick, predominantly nonmarine facies that crops out in the southeastern part of the 1002 area and is coeval with part of the Canning Formation; and (5) the Sagavanirktok Formation, a thick, shallow-marine and nonmarine, deltaic and coastal-plain facies (fig. 5.10). 


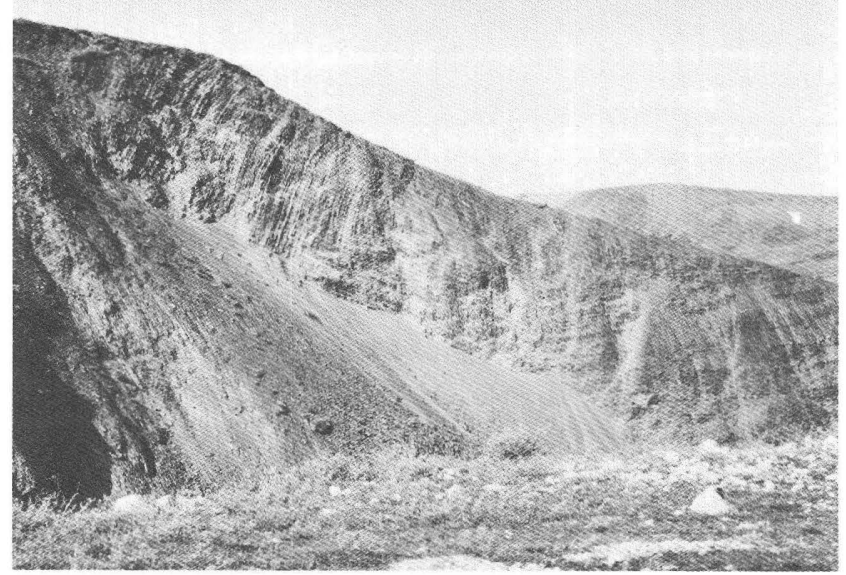

$\boldsymbol{A}$

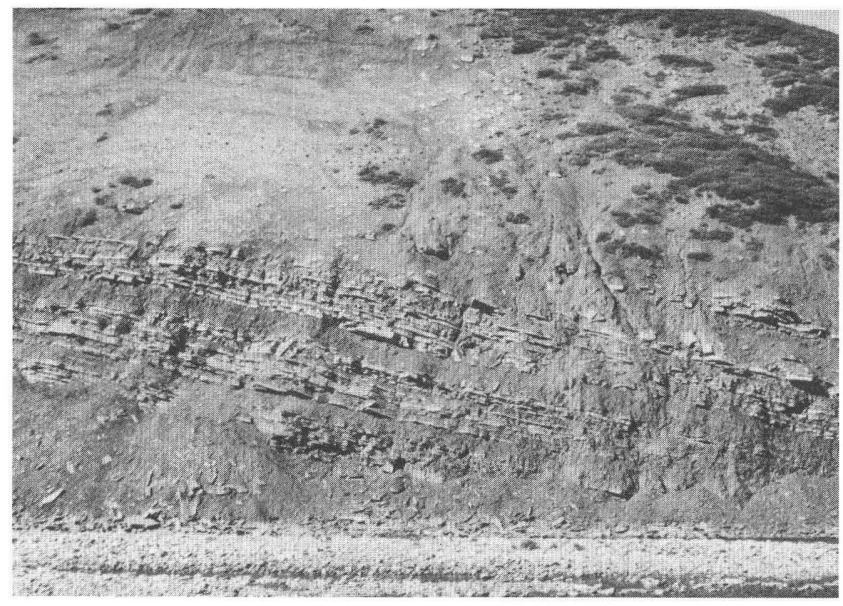

B

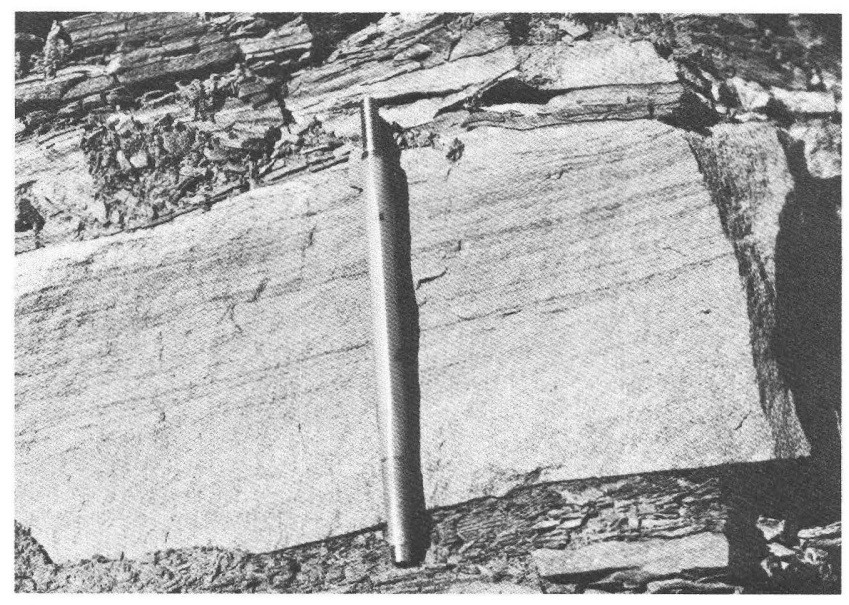

C

Figure 5.9. Outcrops. $A$, Paleocene(?) turbidites of Canning Formation in syncline, Ignek Valley section (fig. 5.11). $B$, Paleocene turbidites along Katakturuk River north of Sadlerochit Mountains (sec. 11, T. 4 N., R. 27 E.). $C$, Close-up of turbidite sandstone bed of Canning Formation showing Bouma $\mathrm{b}, \mathrm{c}$, and $\mathrm{d}$ bedding sequence. Pencil is about $14 \mathrm{~cm}(6 \mathrm{in}$.) long (sec. 11, T. 4 N., R.

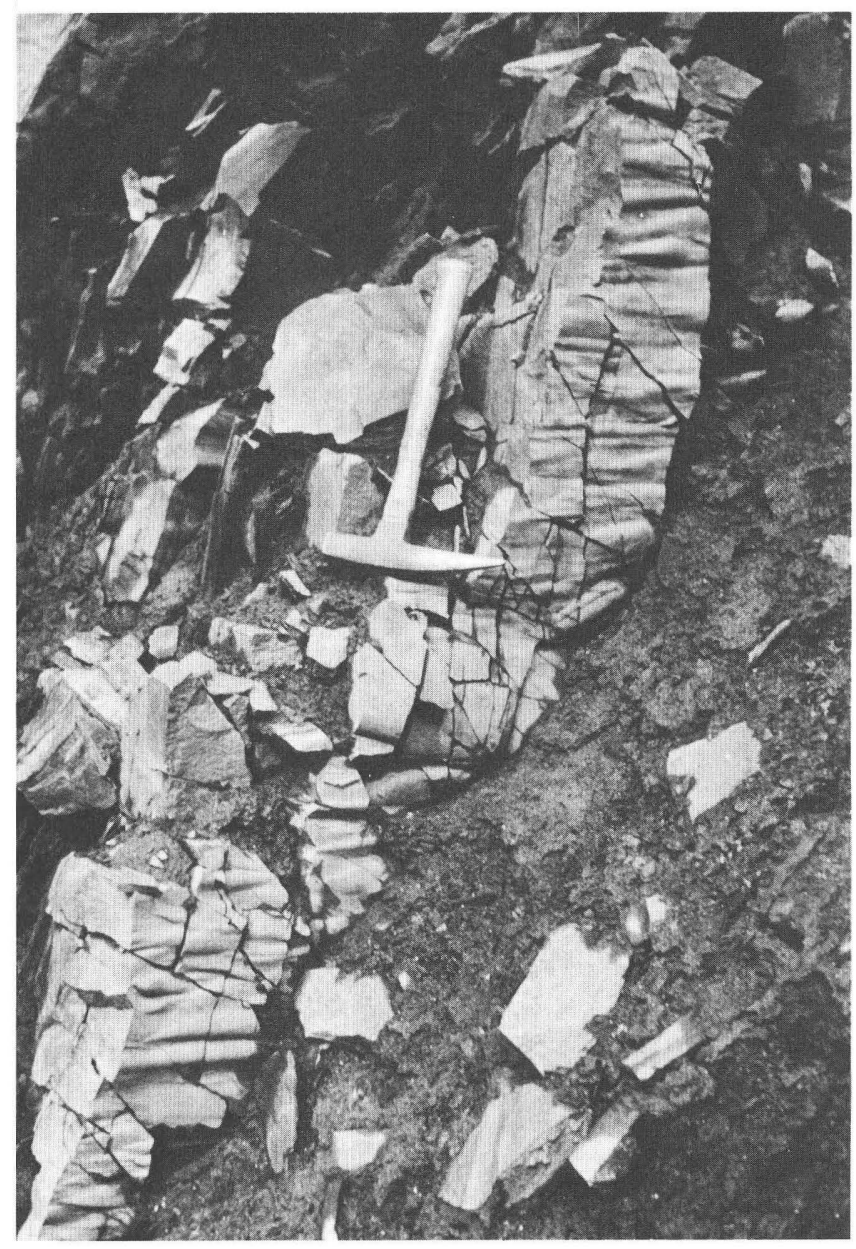

D

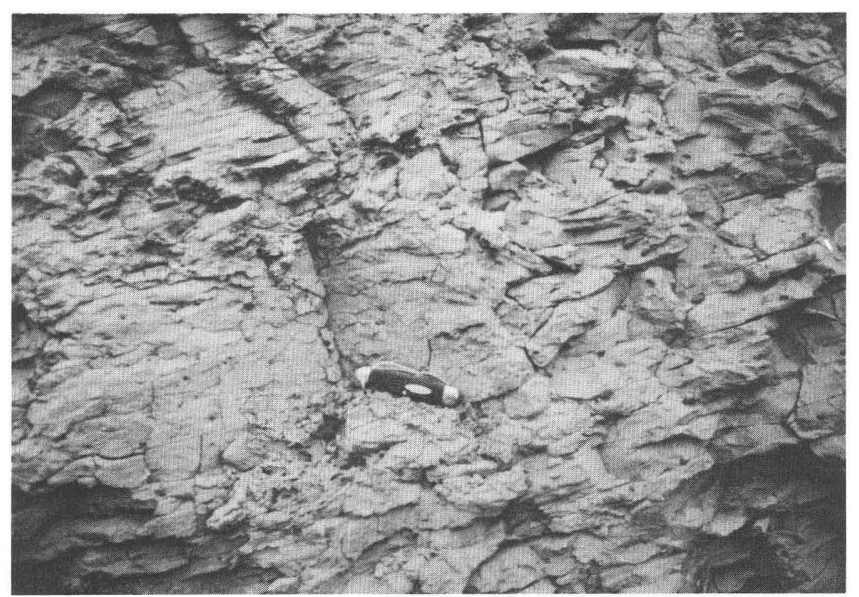

$\boldsymbol{E}$

27 E.). $D$, Flute casts at base of probable Maestrichtian turbidites of Canning Formation in Ignek Valley ( $\mathrm{NE}^{1 / 4}$ sec. 1 , T. 2 N., R. 26 E.). Current direction is from left to right (east). $E$, Eocene mudstone of Canning Formation showing common matrix-supported chert pebbles (S1/2 sec. 25 , T. 8 N., R. 36 E.). 
The Hue Shale and Canning Formation are terms proposed by Molenaar and others (1987). Most Brookian units are diachronous, and recognition of the units and their corresponding facies is useful in discussing stratigraphy throughout the eastern North Slope. The stratigraphic and temporal relations of Brookian rocks between Prudhoe Bay and Flaxman Island and along the west side of the 1002 area are shown in plate 1 .

\section{Hue Shale}

The Hue Shale was named by Molenaar and others (1987) for a section of brightly colored shale, bentonite, and tuff exposed along the ridge immediately west of Hue Creek at the base of the Shublik Mountains on the south side of Ignek Valley (figs. 5.2, 5.7B, 5.8B). The Hue Shale crops out on both sides of the Sadlerochit Mountains and in the Jago and Niguanak River areas in the 1002 area (figs. 5.2, 5.8E). It also occurs throughout the subsurface of the coastal plain and can be traced in coastal wells as far west as the Colville River (pl. 1; Molenaar and others, 1986). Farther west in the NPRA, the lithologic equivalent of the Hue Shale is the highly radioactive shale interval, generally less than $45 \mathrm{~m}$ (150 $\mathrm{ft}$ ) thick, that is included in the pebble shale unit in that area (Molenaar, 1981; Bird, 1982).

The Hue Shale conformably overlies the pebble shale unit and is conformably overlain by the Canning Formation (to be discussed). It is $222 \mathrm{~m}$ (730 ft) thick at the type section, although a fault of probable small displacement cuts out some of the section. The Hue Shale and adjacent strata at the type section are shown in a columnar section in figure 5.11. A correlation of this section with nearby wells is shown in figure 5.12.

The thickest well penetration is in the West Staines State-2 well, where the Hue Shale is about 300 m $(1,000 \mathrm{ft})$ thick (fig. 5.10, pl. 1). The Hue Shale is much thinner in the island wells north of Point Thomson, and it is missing altogether, probably as a result of submarine scouring at the base of the overlying Canning Formation, in the Alaska State A-1 and D-1 wells on Flaxman Island (pl. 1, fig. 7.3).

In most outcrops, the Hue Shale consists of less than $300 \mathrm{~m}(1,000 \mathrm{ft})$ of black, fissile, noncalcareous, clay shale, bentonite, and tuff ranging in overall age from Aptian(?) (Early Cretaceous) to Campanian or Maestrichtian (Late Cretaceous). At the type section, the formation is Aptian(?) to Campanian in age. Regionally, its top is diachronous, being older to the west and younger to the north and east (pl. 1). In the West Staines State-2 well, the uppermost part is probably Maestrichtian. Based on the diachronous pattern of the upper part becoming younger to the north and east, it may be as young as Paleocene in the subsurface in northern parts of the ANWR (fig. 5.10).

The base of the Hue Shale is placed at the base of the bentonitic shale or bentonite beds above the nonbentonitic pebble shale unit. This coincides with the base of a highly radioactive shale zone, about 30 to $45 \mathrm{~m}$ $(100$ to $150 \mathrm{ft}$ ) thick (fig. 5.8B, C, E). This zone is easily detected on gamma-ray logs in wells and by gamma-ray scintillometers on outcrops (figs. 5.11, 5.12), and in the Prudhoe Bay-Kuparuk areas, it has been informally called the gamma-ray zone (GRZ) (Tailleur and others, 1978) or the highly radioactive zone (HRZ) (Carman and Hardwick, 1983). As previously mentioned, Bird (1982) and Molenaar (1981) included the GRZ in the pebble shale unit in the subsurface to the west. In addition to fissile black shale and bentonite, rare matrix-supported, frosted quartz grains also occur in the lower part of the zone. Micropaleontologic data from wells indicate that the GRZ is, at least in part, Albian (Early Cretaceous) in age. Farther west in the Prudhoe Bay-Kuparuk field area, Carman and Hardwick (1983) have reported an Aptian to Albian age for this zone on the basis of dinoflagellates and radiolarians.

A 6- to 8-m-thick ( 20 to $25 \mathrm{ft}$ ) bed rich in prismatic shell material of the bivalve Inoceramus immediately overlies the GRZ. This bed weathers rusty brown and consists of interlayered dark-gray shale and Inoceramus prisms, which appear as veins of prismatic calcite (fig. 5.8D). Although individual inoceramids cannot be recognized, stringers of the shell material indicate some of the bivalves were almost $1 \mathrm{~m}(3 \mathrm{ft})$ across. Like the GRZ, this bed occurs over a wide area and can be identified on almost all lithologic logs of wells east of Prudhoe Bay. In the outcrop area, it is recognized in several localities on both sides of the Sadlerochit Mountains and in the Jago and Niguanak River areas of the 1002 area (fig. 5.8B, E). The association of this distinctive unit with underlying and overlying euxinic, organic-carbon-rich shale and bentonite, together with its widespread distribution, suggests that it was deposited in water depths well below wave base and possibly in bathyal depths. Perhaps the water conditions were less toxic at the time, and the inoceramids were able to flourish. Inoceramids are more tolerant than other bivalves of oxygen-deficient water (W.A. Cobban, U.S. Geological Survey, oral commun., 1985). In any case, conditions must have provided a special ecological niche. Although age data on this bed are lacking in the outcrop area, based on well correlations west of Prudhoe Bay, it is probably Cenomanian (Late Cretaceous) in age (Molenaar and others, 1986).

Above the Inoceramus zone is about $53 \mathrm{~m}$ (175 $\mathrm{ft}$ ) of interbedded black, fissile shale and bentonite in which bentonite beds are more abundant and thicker than other parts of the Upper Cretaceous section (fig. 5.8F). Fossil fish remains occur in this interval. This part of the section, which is probably coeval with the bentoniterich Seabee Formation and the lower part of the Schrader Bluff Formation of the central North Slope, is well exposed along the banks of the Jago and Niguanak 
Rivers (sec. 4, T. 6 N., R. 35 E. and sec. 9, T. 6 N., R. 37 E.) as well as at the type section at Hue Creek in Ignek Valley (figs. 5.2, 5.7B, 5.11). Above this unit and

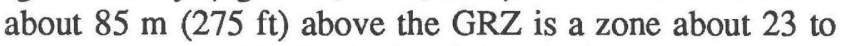
$30 \mathrm{~m}$ (75 to $100 \mathrm{ft}$ ) thick of interbedded black shale, bentonite, and hard indurated tuff. The tuff is light gray and consists of silt or smaller size particles in a fused groundmass. Detterman and others (1975, p. 34) described it from thin section as a devitrified welded tuff composed of 90 percent glass shards. It weathers bright

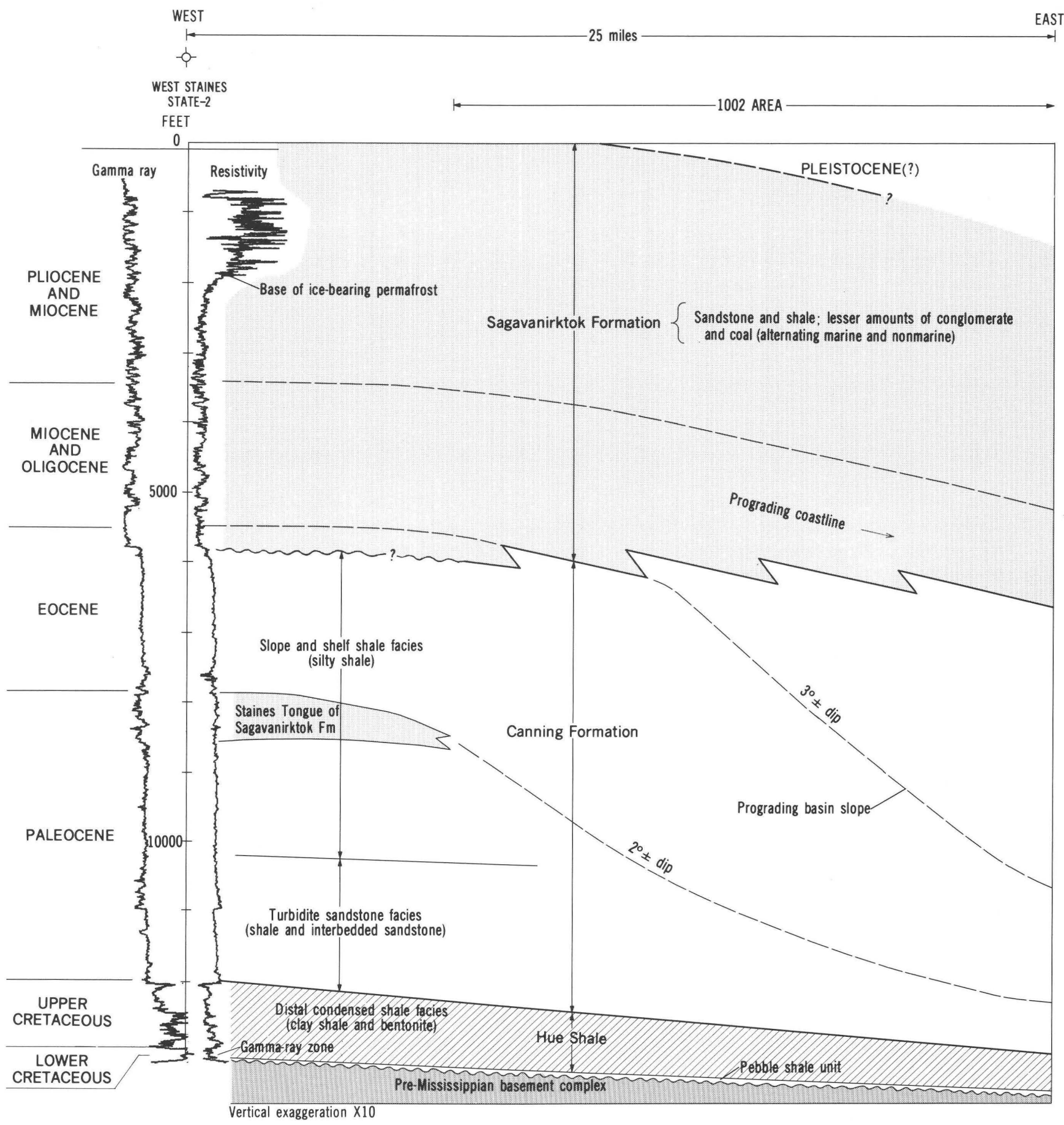

Figure 5.10. Diagrammatic section based on seismic profile 84-1 (p1. 4) showing stratigraphic relations of the Brookian sequence between West Staines State-2 well and northwest corner of ANWR. Dashed lines represent time lines. Depths on well log are in feet. Ages are based on micropaleontologic data. Dips indicated on clinoform beds are with respect to overlying topset beds. See figure 5.2 for location of section. 
red and is conspicuous in rubble outcrops on the north and south sides of the Sadlerochit Mountains. The red coloration is due to surface oxidation and is restricted to a thin rind on rubble outcrops. As many as four red zones crop out north of the Sadlerochit Mountains, but these occurrences are interpreted to be due to fault repetitions of one zone. Palynological data from an $11-\mathrm{m}$

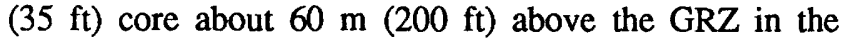
West Staines State 18-9-23 well (south of Point Thomson) indicate a Santonian to Campanian age for this zone. Recognition of the different parts of the Hue Shale is helpful in unraveling complex structures in the outcrop belt because the Hue Shale acts as glide planes for thrust faults.

The upper $76 \mathrm{~m}(250 \mathrm{ft})$ of the Hue Shale at the type section is less fissile, medium- to dark-gray, silty shale and contains matrix-supported chert and quartzite pebbles in the upper half. This part of the section is less organic-carbon rich and is transitional with the overlying Canning Formation. In outcrops, the contact is placed at the first occurrence of sandstone or siltstone interbeds. In the subsurface, the contact is placed at the point of increased gamma-ray deflection in the Hue Shale on gamma-ray logs (fig. 5.10, pl. 1).

The Hue Shale is a distal, condensed shale facies deposited on the north side of the Colville basin, on the Barrow arch, and probably on the area north of the arch. The condensed nature of the Hue Shale is evident when its $300 \mathrm{~m}(1,000 \mathrm{ft})$ or less thickness representing Aptian(?) to Campanian or Maestrichtian time is compared with the greater than $5,000 \mathrm{~m}(16,000$ $\mathrm{ft}$ ) of Albian to lower Campanian rocks south of Umiat (Molenaar and others, 1986, 1987). Lying below largescale clinoform beds of the Canning Formation, at least the upper part of the Hue Shale is a deep-water (bathyal or deeper) deposit. The remaining major part, however, may have been deposited in shallower water depths because of possible subsidence after their deposition. When considered with the underlying pebble shale unit, which represents shoreline conditions at its base (Kemik Sandstone), these units apparently represent deposition during a time when the rate of subsidence was greater than the rate of sedimentation.

The Hue Shale is organic-carbon rich in its lower part (commonly greater than 4 percent organic carbon) and is considered to be a very good to excellent oil-prone source rock (fig. 5.11).

\section{Arctic Creek Facies}

The Arctic Creek facies is a thick section of complexly deformed, largely undated, in part bentonitic shale and turbiditic sandstone that occurs southeast and east of the Sadlerochit Mountains (fig. $5.3 F$ ) as far as the Okerokovik River. A thickness of about $1,100 \mathrm{~m}(3,600$ $\mathrm{ft}$ ) was calculated for a south-dipping section of these rocks along a tributary of the Okerokovik River (secs. 4,
5, and 8, T. 2 N., R. 36 E.), but repetition by faulting cannot be ruled out. The middle Albian ammonite Paragastroplites spiekeri (McLearn) was found at two localities in the upper Arctic Creek area (fig. 5.2; Detterman and others, 1975, p. 29). Fourteen samples of the Arctic Creek facies from widely scattered locations that were analyzed for foraminifers were barren. Because of high thermal maturation levels, no samples were analyzed for palynomorphs. Inoceramids were observed in nonbentonitic turbidite beds on the west bank of the Hulahula River, but a collection proved to be inadequate for age determination.

Based on their bentonitic character, Molenaar (1983, p. 1075) considered the undated turbidites of the Kingak Cliffs and Kingak Hill area near Arctic Creek (fig. $5.3 F$ ) to be Campanian or Maestrichtian in age. Because the characteristic Hue Shale is not present between these turbidites and the underlying pebble shale unit, it now seems more likely that these turbidites and those along the foothills to the east are Albian and (or) Cenomanian in age and are here referred to as the Arctic Creek facies. The few groove and flute casts observed indicate deposition by northeast- to east-flowing currents. Intense deformation, however, may have rotated these rocks from their original position. These rocks have probably been thrust northward from the south and are probably not present in the subsurface of the coastal plain to the north. They differ greatly from Albian and Cenomanian rocks included in the Hue Shale around the Sadlerochit Mountains and in adjacent wells to the west (figs. 5.11, 5.12). In addition, the Arctic Creek facies is thermally more mature. Vitrinite reflectance $\left(R_{o}\right)$ values of 6 samples from scattered locations in the Arctic Creek area are between 1.8 and 2.0 , whereas $R_{o}$ values of coeval rocks in Ignek Valley, $48 \mathrm{~km}(30 \mathrm{mi})$ to the west, are 1.0 to 1.1 (fig. 5.11). This indicates that the Arctic Creek facies was more deeply buried and, therefore, may have originated farther south in deeper parts of the basin.

\section{Canning Formation}

The Canning Formation was named by Molenaar and others (1987) for a thick, dominantly shale unit that conformably overlies the Hue Shale and underlies thick, deltaic deposits of the Sagavanirktok Formation (fig. 5.10). Because of discontinuous exposures and structural complications in the outcrop belt, the type section of the Canning Formation was designated as the section penetrated between 1,777 and $3,651 \mathrm{~m}(5,830$ and $11,980 \mathrm{ft})$ in the West Staines State2 well in sec. 25 , T. 9 N., R. 22 E. (figs. 5.2, 5.10). The total thickness, including the 268-m-thick (880 ft) Staines Tongue of the Sagavanirktok Formation, is 1,875 $\mathrm{m}(6,150 \mathrm{ft})$. In other wells immediately west of the ANWR, the Canning Formation is 1,200 to $1,800 \mathrm{~m}$ $(4,000$ to $6,000 \mathrm{ft})$ thick (pl. 1). Farther east, in the structurally complex part of the 1002 area, deformation 


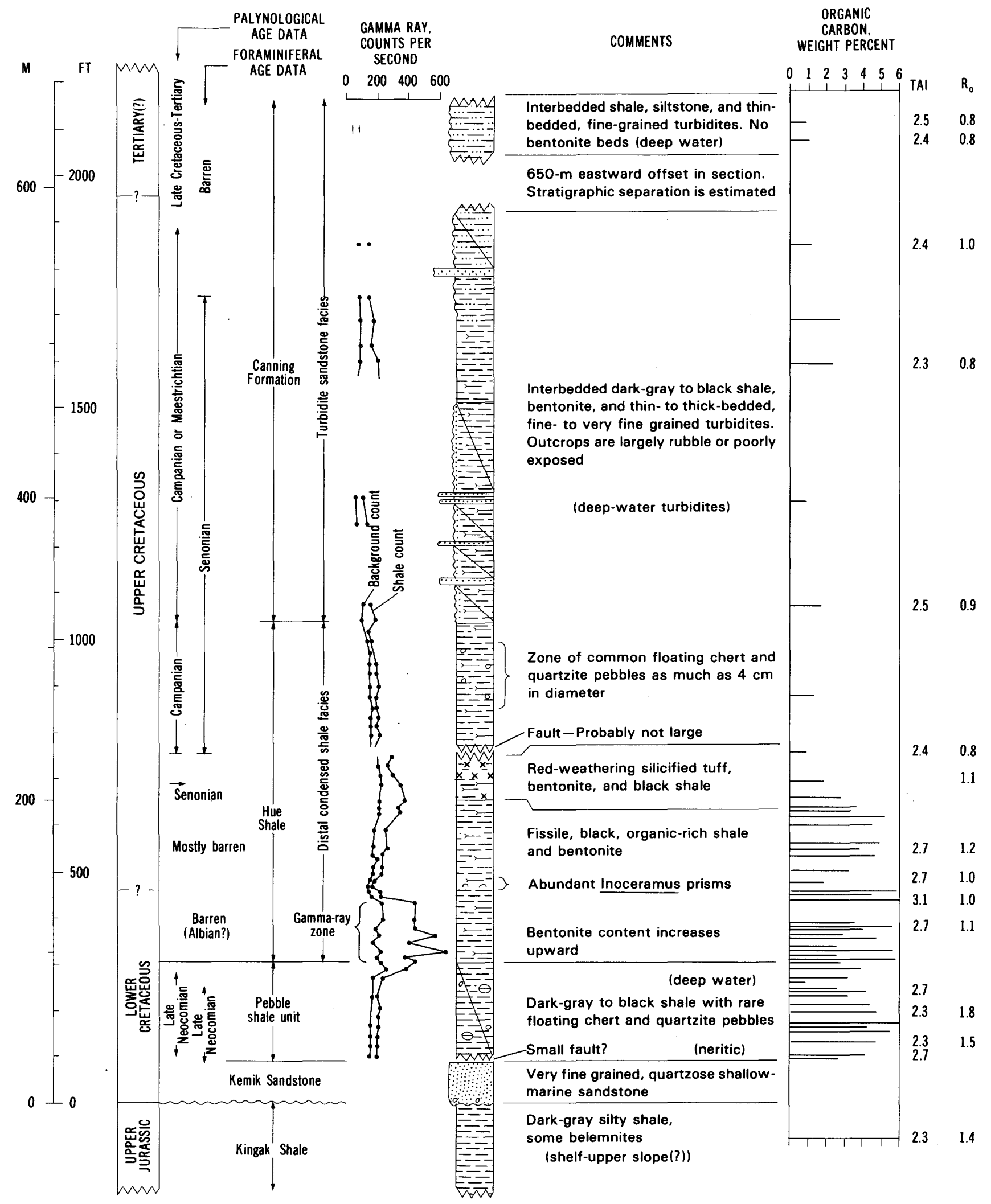

EXPLANATION

\begin{tabular}{|c|c|c|c|c|c|}
\hline$E=$ & Shale & $\because \cdots \cdots$ & Siltstone & n & Shell fragments \\
\hline$\because \because \cdots:$ & Sandstone & $\longleftarrow$ & Bentonite & $x$ & Tuff \\
\hline & Partly covered & $\theta$ & Concretion & 0 & Pebble \\
\hline
\end{tabular}


during Paleocene or Eocene time probably caused thinning and truncation within the formation. At the type well, the Canning Formation is disconformably overlain by the Sagavanirktok Formation, but the disconformity occurs within the Sagavanirktok to the south and west because the formation contacts are at a lower stratigraphic level than the disconformity (pl. 1). Commonly, the upper contact is transitional and is placed at the change from shale to the dominantly sandstone lithologies of the Sagavanirktok Formation. The basal contact of the Canning Formation is placed either at the lowest sandstone or siltstone interbed located above the Hue Shale or, on subsurface logs, at the boundary of decreased gamma-ray, increased resistivity, or decreased transit-time deflection at the top of the Hue Shale.

In the West Staines State-2 well and other wells west of the ANWR, and in outcrops in the western part of the area, the Canning Formation consists of slope and shelf deposits that are subdivided, in ascending order, into (1) a turbidite sandstone facies consisting of lower slope and basinal shale with sandstone interbeds, and (2) a thick slope and shelf shale facies. These facies are coeval with deltaic and coastal plain facies of the Sagavanirktok Formation to the west and southwest (pl. 1).

\section{Turbidite Sandstone Facies}

The turbidite sandstone facies crops out along the Canning River west of and on both sides of the Sadlerochit Mountains (figs. 5.9, 5.11). These rocks consist mostly of dark-gray to gray-brown bentonitic shale and siltstone, with generally thin beds of finegrained with some very fine to medium-grained sandstone. Thin beds of bentonite also occur in the Cretaceous part of the Canning Formation. The sandstone beds are generally less than a few feet thick, although a few amalgamated beds are as thick as $9 \mathrm{~m}$ (30 ft) (Molenaar, 1983, p. 1075). Graded bedding, bottom marks, and Bouma sequences, although not ubiquitous, indicate a turbidity-current origin for these sandstone beds (fig. $5.9 C, D$ ). Groove and flute casts observed in outcrops around the Sadlerochit Mountains indicate deposition by northeast- to east-flowing currents, similar to that of the Arctic Creek facies (fig. 5.9D).

Figure 5.11. Columnar section of Cretaceous and lower Tertiary(?) rocks exposed in Ignek Valley (NE $1 / 4 \mathrm{sec} .6$, T. 2 N., R. 26 E.) showing paleontologic age and hydrocarbon source-rock data, and type section of Hue Shale. TAI, thermal alteration index; $R_{0}$, vitrinite reflectance. Modified from Molenaar (1983). See figure 5.2 for location of section and figures 5.7 to 5.9 for photographs.
The position of the turbidites at or near the base of clinoform beds observed in wells and seismic sections west of the ANWR indicates deposition in water depths ranging from 600 to $1,200 \mathrm{~m}(2,000$ to $4,000 \mathrm{ft})$ or more (fig. 5.10, pl. 1). Little is known of this facies in the structurally disturbed part of the 1002 area to the east.

Around the Sadlerochit Mountains and in wells west of the ANWR, the turbidite sandstone facies (of which sandstone constitutes a very small part) is 300 to $900 \mathrm{~m}(1,000$ to $3,000 \mathrm{ft})$ thick and ranges in age from Campanian or Maestrichtian to Paleocene (fig. 5.10, pl. 1). In the northwestern part of the ANWR, the turbidite facies probably ranges in age from Paleocene to Eocene and possibly Oligocene in the subsurface.

Sandstones of the turbidite sandstone facies are considered to have reservoir potential in the 1002 area. Although they have only poor to fair porosity and are generally thin bedded in the outcrop belt, thicker, more porous beds may occur in the subsurface in the 1002 area. These sandstone beds are discontinuous, which enhances stratigraphic trapping possibilities. Some of the wells in the Point Thomson-Flaxman Island area, immediately west of the northwest comer of the ANWR, have penetrated relatively thick beds or groups of beds that are capable of oil and gas production. In the Jago River and Niguanak River areas of the 1002 area (fig. 5.2), however, there are several outcrops of middle Cretaceous to Eocene shales but few sandstone outcrops.

\section{Slope and Shelf Facies}

The slope and shelf shale facies crops out sparsely in the foothills north of the Sadlerochit Mountains, along the axis of Marsh Creek anticline, and in the northernmost outcrops along the Jago and Niguanak Rivers. It ranges in age from Paleocene to Eocene and possibly Oligocene in the northern part of the 1002 area and consists of medium-gray to graybrown, silty, bentonitic shale with minor thin beds of very fine or fine-grained sandstone. The sandstone beds are turbidites in the lower part of the unit and shelf sandstones in the upper part, where they grade into the overlying Sagavanirktok Formation. Matrix-supported sand grains and pebbles in the silty shale are characteristic of the Eocene part of the sequence (fig. $5.9 E)$. The slope and shelf shale unit is about $1,220 \mathrm{~m}$ $(4,000 \mathrm{ft})$ thick in wells west of the ANWR (fig. 5.10, pl. 1). The thickness is probably different in the structurally deformed part of the 1002 area and the only slightly folded Eocene rocks immediately north. The Eocene rocks apparently postdate much of the deformation in this part of the coastal plain and rest unconformably on older rocks.

At the West Staines State-2 well, the Canning Formation is Paleocene and Eocene in age, based on palynomorph data (fig. 5.10). To the east, the uppermost part of the Canning ranges into the Oligocene, as indicated on seismic line 84-1 (pl. 4). 


\section{Jago River Formation}

The Jago River Formation, which was named by Buckingham (1987), is an anomalously thick section of predominantly nonmarine rocks exposed in the southeastern part of the 1002 area near the Jago River (fig. 5.2). The best exposures are along Igilatvik Creek (Demarcation Point C-5 quadrangle, scale 1:63,360), also known as Sabbath Creek (Detterman and others, 1975; Reiser and others, 1980). Detterman and others (1975) reported a thickness of $3,270 \mathrm{~m}(10,725 \mathrm{ft})$ and Buckingham (1985a, 1987) a thickness of $2,861 \mathrm{~m}(9,387$ $\mathrm{ft}$ ) for this section. It consists of thick units of sandstone, conglomerate, siltstone, and shale with thin beds of coal. Pyroclastic material, which is common in coeval rocks to the west, is absent (Detterman and Spicer, 1981; Buckingham, 1985a).

The Jago River Formation is interpreted as a regressive sequence of shallow-marine siltstone and distributary-channel sandstones in the lowermost part that grades upward into delta-plain and conglomeratic alluvial-plain facies (Molenaar, 1983, p. 1077). These rocks are dated as (1) Paleocene based on pollen (Palmer and others, 1979; Lyle and others, 1980), (2) Late Cretaceous or early Tertiary based on plant fossils (Detterman and Spicer, 1981), and (3) Late Cretaceous in the lower two-thirds of the section and Paleocene in the upper third based on plant fossil determinations by R.A. Spicer (Buckingham, 1985b). On the basis of age and genetic and lithologic similarities, the Jago River Formation is correlated with the Moose Channel Formation of the Mackenzie Delta area, $240 \mathrm{~km}(150 \mathrm{mi})$ to the east (Detterman and Spicer, 1981; Buckingham, 1985a).

The geographic position of the thick section of nonmarine rocks of the Jago River Formation is anomalous with respect to thinner coeval turbidite sandstone facies of the Canning Formation observed in the Sadlerochit Mountains area 64 to $80 \mathrm{~km}$ (40 to 50 $\mathrm{mi}$ ) to the west, unless the nonmarine rocks represent

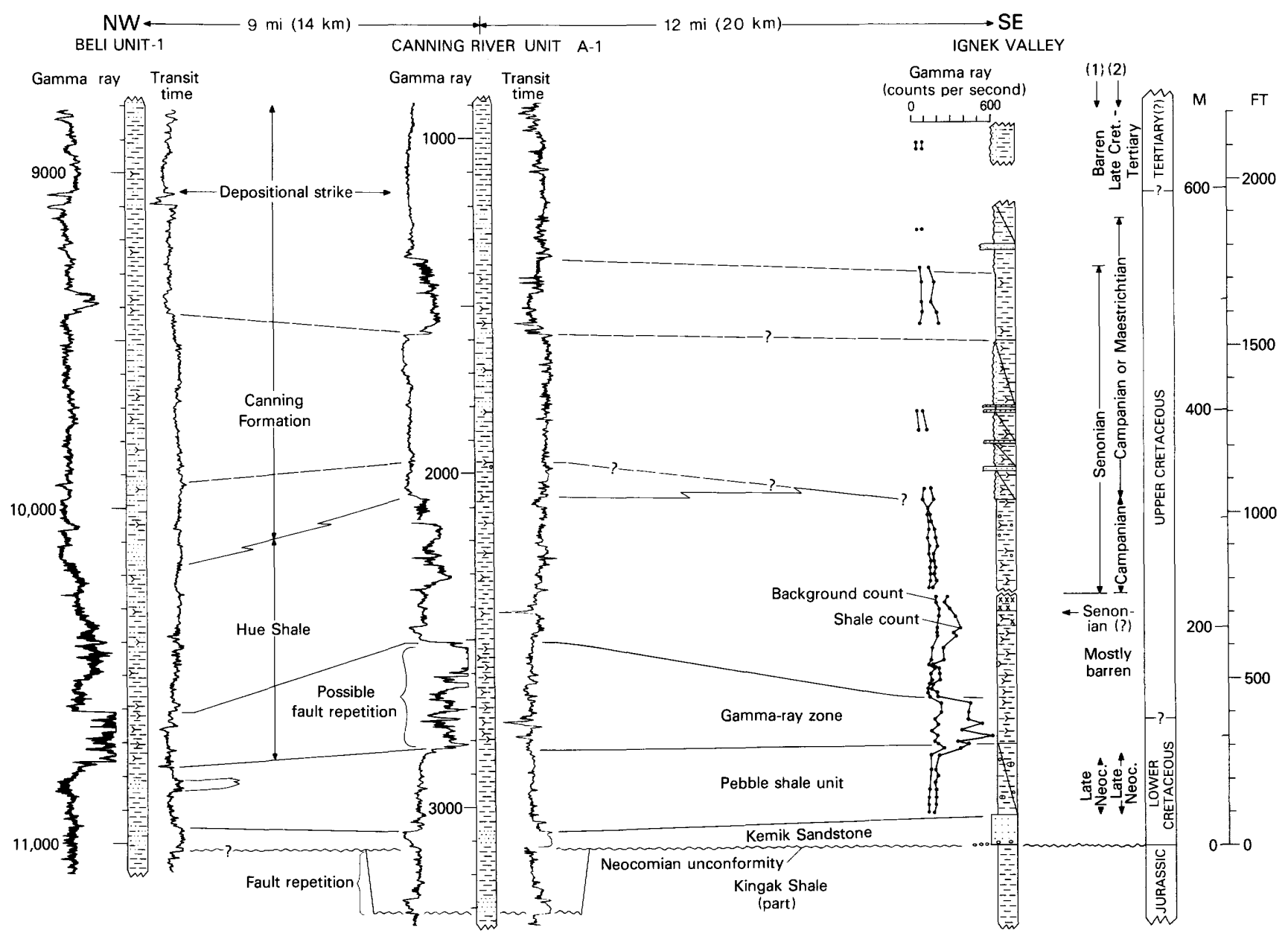

Figure 5.12. Stratigraphic correlation section of Ignek Valley outcrop section (fig. 5.11) and nearby wells. Age data at right of columnar section are based on (1) foraminifers or (2) palynologic data (modified from Molenaar, 1983). Depths on well logs are in feet. See figure 5.2 for location of section and figure 5.11 for explanation of symbols. Dashed line, time line. 
deposition from a closer source to the south or southeast. Indeed, current-direction features observed by Buckingham (1985b, p. 79) indicate general current dispersal directions to the north and northwest. In the Canadian Beaufort Sea, the Dome Petroleum Natsek E56 well, about $145 \mathrm{~km}(90 \mathrm{mi})$ to the east, penetrated $1,569 \mathrm{~m}(5,148 \mathrm{ft})$ (base not penetrated) of Paleocene deltaic rocks, including thick coal beds (Dietrich and others, 1985). These deltaic rocks, which may correlate with the Jago River Formation, must have had a southern or southeastern source.

Another problem of geographic position is that similar thick nonmarine or shallow-marine-equivalent rocks do not crop out in the complexly deformed area 29 $\mathrm{km}(18 \mathrm{mi})$ to the north, where both older and younger rocks are exposed. Possible explanations of this may be (1) that these rocks were cut out by the fault that separates Cretaceous rocks on the south from Eocene rocks to the north along the Jago River; (2) that these strata were deposited in a contemporaneously growing syncline or basin, and thus coeval rocks to the north are much thinner; (3) that the Jago River Formation may be on a far-traveled plate of a thrust fault and was originally a greater distance from the thinner, more distal coeval rocks that crop out to the north; or (4) that rocks equivalent to the Jago River Formation were removed, all or in part, by erosion under an Eocene unconformity in the subsurface to the north. Significant northward displacement by thrust faults is likely because the underlying Arctic Creek facies exposed to the south is also anomalous with respect to coeval rocks to the west. Therefore, the latter two explanations are considered the most plausible.

\section{Sagavanirktok Formation}

The Sagavanirktok Formation is a thick shallow-marine and nonmarine unit overlying and intertonguing with the Canning Formation (fig. 5.10). Parts of the Sagavanirktok crop out along the Canning and Kavik Rivers west of the Sadlerochit Mountains and on the north flank of the Marsh Creek anticline (fig. 5.2). It consists dominantly of fine- to medium-grained sandstone and generally bentonitic shale with lesser amounts of conglomerate and minor coal. On the north flank of the Marsh Creek anticline, where an incomplete thickness of $1,500 \mathrm{~m}(5,000 \mathrm{ft})$ was calculated, the sands and conglomerates are friable (Morris, 1957). In wells adjacent to the northwest corner of the ANWR, the Sagavanirktok is 1,800 to $2,300 \mathrm{~m}(6,000$ to $7,500 \mathrm{ft})$ thick.

The Sagavanirktok Formation conformably overlies the Canning Formation in most places west of the ANWR, but in several wells northwest of the ANWR there is an unconformity at the base of the unit. In this area, a conglomeratic sandstone rests directly on marine shale (fig. 5.10) with no angular discordance. This unconformity may correlate with a late Eocene unconformity in the Mackenzie Delta area (Dietrich and others, 1985) and with the angular unconformity observed in the lower part of the Tertiary section in the Beaufort Sea off the eastern half of the ANWR (Grantz and May, 1983). The unconformity also may be related to compressional tectonics occurring in the 1002 area to the east. Seismic and surface data in the 1002 area indicate that significant tectonism occurred during or immediately prior to Eocene deposition. According to seismic data in the less deformed northwestern part of the 1002 area, however, the unconformity dies out to the east, and the deltaic sequence again rises stratigraphically as it progrades to the east or northeast (fig. 5.10). The unconformity northwest of the ANWR may be the result of a relative drop in sea level, during which the underlying shale was scoured by fluvial or deltaic channels that extended out on the shelf.

In most of the coastal plain of northeastern Alaska, the Sagavanirktok Formation is unconformably overlain by less than $60 \mathrm{~m}(200 \mathrm{ft})$ of the Gubik Formation, which in this area is Pleistocene in age (Detterman and others, 1975, p. 40).

Micropaleontologic data from wells and from outcrops in the uppermost part of the Sagavanirktok Formation (Nuwok Member) on the north flank of the Marsh Creek anticline (Detterman and others, 1975, p. 39) indicate that the main part of the Sagavanirktok is late Eocene to Pliocene or younger in age in and adjacent to the northwestern coastal plain of the ANWR (fig. 5.10). The 268-m-thick $(880 \mathrm{ft})$ Staines Tongue of the Sagavanirktok Formation, which is almost $600 \mathrm{~m}$ $(2,000 \mathrm{ft})$ below the main part of the formation in the West Staines State- 2 well, is mostly Paleocene in age (fig. 5.10, pl. 1).

The base of the Sagavanirktok is diachronous and is older to the west and south. It formerly was considered to be no older than Tertiary in age (Gryc and others, 1951, p. 167; Detterman and others, 1975, p. 39). As a mappable lithologic unit, however, the lowermost part is Late Cretaceous in age at Prudhoe Bay (pl. 1) and in areas to the west and southwest (Molenaar and others, 1986).

Correlation of well-log markers within the Sagavanirktok Formation in wells west of the ANWR indicates uniform deposition on a shelf and delta or coastal plain. Deposition was alternately shallow marine and nonmarine in character as the seaway transgressed and regressed across the area. There probably are several disconformities or hiatuses within the section due to sea-level changes, but the dominant depositional pattern was progradation to the northeast.

Sandstones and conglomerates of the Sagavanirktok Formation would be good reservoirs for petroleum. However, because of the dominance of sandstone in the section, effective seals for traps may be limited (see chap. 7). 



\title{
Chapter 6.
}

\section{Quaternary Seismic Stratigraphy of the Inner Continental Shelf North of the Arctic National Wildlife Refuge}

\author{
By Stephen C. Wolf, ${ }^{1}$ Peter W. Barnes, ${ }^{1}$ Douglas M. Rearic, ${ }^{1}$ and Erk Reimnitz ${ }^{1}$
}

\section{INTRODUCTION}

The transgressive and regressive history of the sea along the Arctic continental margin during glacial periods is poorly understood owing to the limited number of Arctic studies and the limited understanding of Arctic marine geologic processes. Development of this history is needed to interpret the thermal and permafrost regime, to better understand past and future climatic trends, and to assess the present stability of the coast and shelf sediments and the potential for deposits of sand and gravel.

The following report provides a stratigraphic framework based on the interpretation of shallowpenetration (less than $50 \mathrm{~m}, 160 \mathrm{ft}$ ) seismic data. These sediments were deposited during Pleistocene and Holocene time on the inner shelf of the Beaufort Sea between the Canning River and the Canadian border, a shoreline distance of approximately $180 \mathrm{~km}(110 \mathrm{mi})$. The purpose of this study has been to obtain and interpret all available geophysical data, to develop an understanding of the geologic framework that operated during Quaternary time, and to describe the recent geologic history of the area. The report is an eastward extension of an earlier report by Wolf and others (1985) that describes the shallow seismic stratigraphy between Prudhoe Bay and the Canning River (fig. 6.1).

Geophysical data for this study were acquired along approximately $675 \mathrm{~km}(420 \mathrm{mi})$ of tracklines, many of which extended $20 \mathrm{~km}(12 \mathrm{mi})$ seaward from the coast (fig. 6.1). Uniboom and Geopulse seismic systems were used for the shallow seismic surveys. These systems penetrated as deep as $50 \mathrm{~m}(165 \mathrm{ft})$ beneath the seafloor in some areas. Raytheon RTT 1000 and Innerspace bathymetric profiling systems provided bathymetric data as well as high-frequency $(7 \mathrm{kHz})$ subbottom seismic data. Side-scan sonar data, although not a significant part of this report, were acquired with an EG\&G model $259-4100-\mathrm{kHz}$ system and a Klein

\footnotetext{
${ }^{1}$ U.S. Geological Survey, Menlo Park, Calif.
}

$531 \mathrm{~T} 100-$ and $500-\mathrm{kHz}$ system that incorporated a subbottom profiler and microprofiler. A listing of data from vessel logs is shown in table 6.1.

The primary reason for the apparent random line patterns is that the field-work objectives and priorities varied from year to year, as did the sea-ice distribution. The latter is a factor that commonly dictates where and how a particular line can be run. Furthermore, seismic profiles represent only a fraction of the data gathered. Often specific study topics were pursued, involving such additional techniques as underwater photography and video recording, diving operations, sediment and water sampling, coring, ice-gouge studies, and repetitive surveys of certain lines with side-scan and $7-\mathrm{kHz}$ equipment. Furthermore, many tracklines simply represent transit lines from one study site to another, on which only bathymetric data were taken. Reports of results of other studies may be found in Barnes and others (1980), Kempema and others (1981, 1983), Reimnitz and others (1982), and Minkler and others (1982).

\section{PHYSIOGRAPHY}

\section{Coastal Plain}

We briefly describe the coastal-plain physiography in order to provide an insight into the type of terrain encountered by the transgressing sea during the postglacial rise in sea level. A more detailed physiographic description of the entire area may be found in Walker and others (1982). The western part of the coastal plain in this study extends from the Canning River to Barter Island and encompasses Camden Bay. The hills in this area are higher than those on the coastal plain to the east. Because the land rises steeply from the sea, coastal bluffs up to $10 \mathrm{~m}(35 \mathrm{ft})$ in relief can be observed. Stream drainage is well defined across the irregular surface, which is characterized by thaw lakes and ponds. The Canning, Katakturuk, Sadlerochit, Hulahula, and Okpilak Rivers all flow into Camden Bay. Except for the Katakturuk, each river has a delta at the coastline; the largest is associated with the Canning 
River. The hilly coastal plain rises southward from Camden Bay to the Sadlerochit Mountains over a distance of 40 to $50 \mathrm{~km}$ (25 to $30 \mathrm{mi}$ ) (fig. 6.1).

The irregular coastline east of Barter Island consists of many lagoons and bays but is dominated by barrier islands. The coastline is backed by low-lying tundra, with small bluffs reaching heights of about $8 \mathrm{~m}$ $(25 \mathrm{ft})$ near Barter Island. The coastal onshore area east of Barter Island is characterized by gentle slopes ascending from the coast toward the foothills of the Brooks Range some 25 to $50 \mathrm{~km}$ (15 to $30 \mathrm{mi}$ ) to the south. Numerous lakes are interspersed within the hilly terrain. Active and abandoned stream channels have resulted in the formation of a dissected land surface. The largest rivers flowing to the Beaufort Sea in this area are the Aichilik, Egaksrak, and Kongakut, all of which have small deltas at their mouths (fig. 6.1).

The eastern part of the coastal plain is characterized by two large fans to the south and west of Demarcation Bay (fig. 6.1). The Brooks Range lies only $20 \mathrm{~km}(12 \mathrm{mi})$ south of the coastline here, and as a consequence the fans have steep gradients. The largest fan, formed by the Kongakut River, terminates at the coast, which leads to the formation of barrier islands, narrow lagoons, and minor deltas. The smaller fan to the east is somewhat irregular in shape, being cut by Demarcation Bay on the west and having a coastal-plain lake morphology in the central sector.

\section{Offshore Physiography}

The inner shelf of the Beaufort Sea has a gentle seaward gradient, with bathymetric contours that generally are subparallel to the coastline. In Camden Bay, water depths of $40 \mathrm{~m}(130 \mathrm{ft})$ are encountered about $40 \mathrm{~km}(25 \mathrm{mi})$ north of the coastline (fig. 6.2). From Barter Island eastward, the seafloor gradient is twice as steep as that west of Barter Island, and depths reach $40 \mathrm{~m}(130 \mathrm{ft})$ within $20 \mathrm{~km}(12 \mathrm{mi})$ of the coast. Side-scan sonar data show the seafloor to be severely ice gouged throughout the region (Reimnitz and others, 1982). A large offshore ridge with relief of 4 to $8 \mathrm{~m}$ (13 to $26 \mathrm{ft})$ and length of approximately $30 \mathrm{~km}(19 \mathrm{mi})$

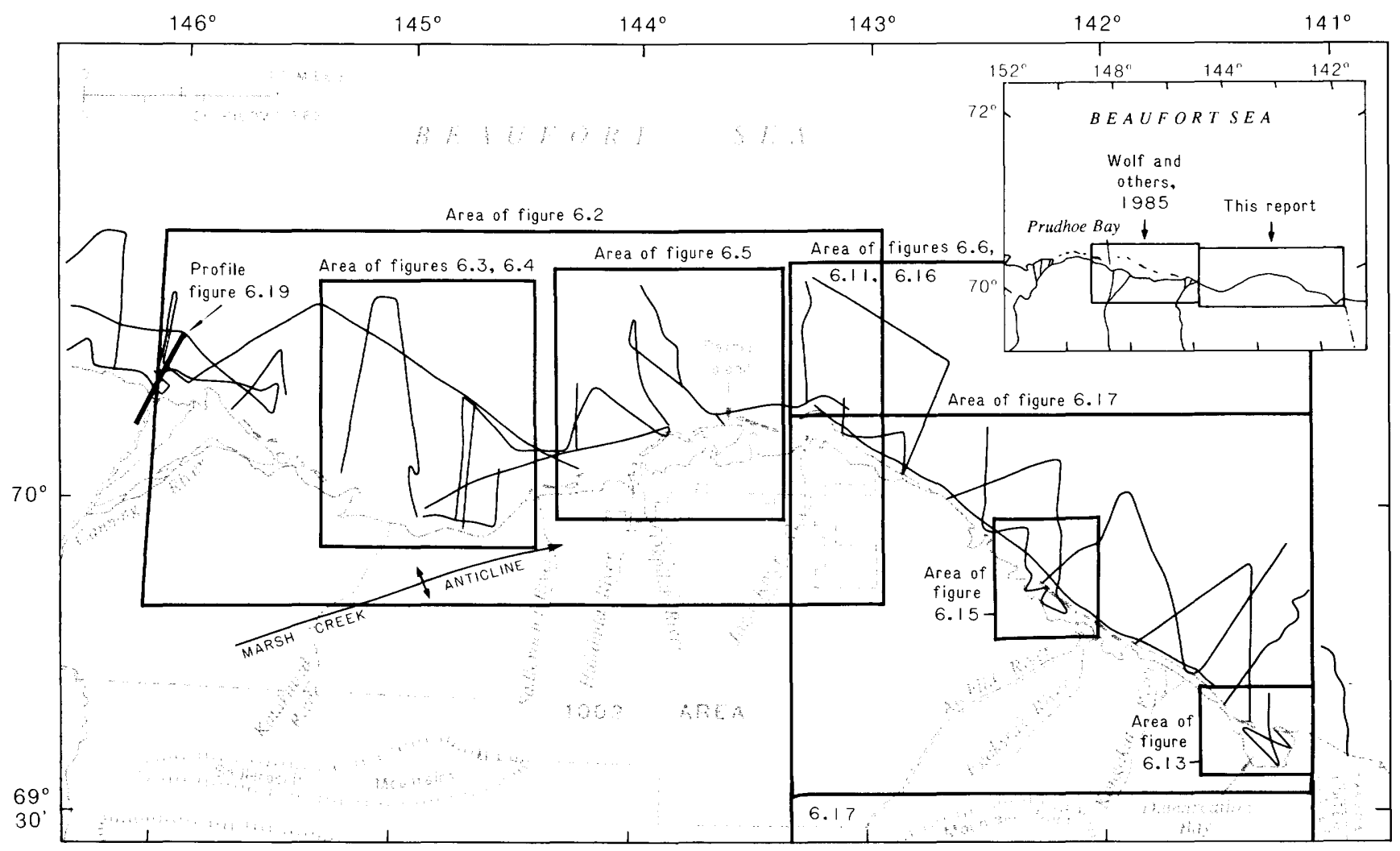

Figure 6.1. Locations of geographic features, other maps, and profile in this report and insert showing location of this study in relation to companion study by Wolf and others (1985). U.S. Geological Survey tracklines are shown in Beaufort Sea. 
Table 6.1. $\mathrm{R} / \mathrm{V}$ Loon and $\mathrm{R} / \mathrm{V}$ Karluk log data for seismic tracklines for the area from the Canning River to Demarcation Bay, Alaska (exclusive of side-scan sonar)

[High-resolution system used; 1972, Minisparker; 1980-82, Uniboom; 1983, Geopulse. n.d., no data]

\begin{tabular}{|c|c|c|c|c|c|c|c|}
\hline \multirow[b]{2}{*}{ Year } & \multirow[b]{2}{*}{ Date } & \multirow[b]{2}{*}{ Line no. } & \multirow[b]{2}{*}{ Julian date } & \multicolumn{2}{|c|}{$\begin{array}{l}\text { High-resolution } \\
\text { seismic data }\end{array}$} & \multicolumn{2}{|c|}{$\begin{array}{l}\text { Subbottom data } \\
\quad(7 \mathrm{kHz})\end{array}$} \\
\hline & & & & Time & Roll no. & Roll time & Roll no. \\
\hline \multirow[t]{7}{*}{1972} & $8 / 30$ & $5-71$ & 242 & $1532-1611$ & 5 & n.d. & n.d. \\
\hline & $8 / 30$ & $6-71$ & 242 & $1615-1648$ & 6 & n.d. & n.d. \\
\hline & $8 / 30$ & $7-71$ & 242 & $1654-1726$ & 7 & n.d. & n.d. \\
\hline & $8 / 30$ & $8-71$ & 242 & $1756-1815$ & 8 & n.d. & n.d. \\
\hline & $8 / 30$ & $9-71$ & 242 & $1950-2018$ & 8 & n.d. & n.d. \\
\hline & $8 / 30$ & $10-71$ & 242 & $2021-2107$ & 10 & n.d. & n.d. \\
\hline & $8 / 30$ & $11-71$ & 242 & $2111-2155$ & 11 & n.d. & n.d. \\
\hline \multirow[t]{6}{*}{1980} & $7 / 19$ & $1-80$ & 201 & n.d. & n.d. & $1245-1530$ & 1 \\
\hline & $7 / 20$ & $2-80$ & 202 & $1305-1455$ & 1 & $1305-1455$ & $1-2$ \\
\hline & $7 / 21$ & $3-80$ & 203 & $0830-1048$ & 1 & 0830-1048 & $2-3$ \\
\hline & $7 / 21$ & $4-80$ & 203 & $1151-1900$ & $1-2$ & $1151-1900$ & $3-4$ \\
\hline & $7 / 22$ & $5-80$ & 204 & $0600-1630$ & 2 & $0600-1630$ & $4-5$ \\
\hline & $7 / 23$ & $6-80$ & 205 & $0900-1915$ & $2-3$ & $0900-1915$ & $6-7$ \\
\hline \multirow[t]{16}{*}{1981} & $7 / 20$ & $8-81$ & 201 & n.d. & n.d. & $0930-1400$ & 3 \\
\hline & $7 / 21$ & $9-81$ & 202 & $0849-1900$ & $1-2$ & 0849-1900 & $4-5$ \\
\hline & $7 / 22$ & $10-81$ & 203 & n.d. & n.d. & $0957-1725$ & $6-7$ \\
\hline & $7 / 23$ & $11-81$ & 204 & $0845-1356$ & $2-3$ & 0845-1356 & $7-8$ \\
\hline & $7 / 24$ & $12-81$ & 205 & $0952-1252$ & 3 & $0952-1252$ & 8 \\
\hline & $7 / 24$ & $13-81$ & 205 & $1338-1825$ & 3 & $1338-1825$ & 9 \\
\hline & $7 / 25$ & $14-81$ & 206 & $0939-1650$ & 4 & $0930-1650$ & $10-11$ \\
\hline & $7 / 27$ & $15-81$ & 209 & $0834-1125$ & $4-5$ & $0834-1125$ & 11 \\
\hline & $8 / 9$ & $31-81$ & 221 & $1735-1900$ & 6 & $1735-1900$ & 23 \\
\hline & $8 / 10$ & $32-81$ & 222 & $1205-1947$ & 6 & $1205-1947$ & $23-24$ \\
\hline & $8 / 11$ & $33-81$ & 223 & $1041-1345$ & 7 & $1041-1345$ & 25 \\
\hline & $8 / 11$ & $34-81$ & 223 & $1604-1902$ & 7 & $1604-1902$ & 26 \\
\hline & $8 / 12$ & $35-81$ & 224 & $1110-1651$ & 8 & $1110-1651$ & $26-27$ \\
\hline & $8 / 13$ & $36-81$ & 225 & $0941-1714$ & $8-9$ & $0941-1714$ & $27-28$ \\
\hline & $8 / 14$ & $37-81$ & 226 & $1124-1425$ & 9 & $1124-1425$ & 29 \\
\hline & $8 / 15$ & $38-81$ & 227 & $0831-1152$ & 10 & $0831-1152$ & 29 \\
\hline \multirow[t]{3}{*}{1982} & $9 / 3$ & $8-82$ & 246 & $1706-2020$ & 2 & n.d. & n.d. \\
\hline & $9 / 5$ & $9-82$ & 248 & $0850-1544$ & $2-3$ & n.d. & n.d. \\
\hline & $9 / 5$ & $10-82$ & 248 & $1545-1855$ & 3 & n.d. & n.d. \\
\hline \multirow[t]{5}{*}{1983} & $8 / 8$ & $26-83$ & 220 & $1450-1800$ & 4 & $1420-1800$ & 3 \\
\hline & $8 / 8$ & $27-83$ & 220 & $1800-2145$ & 5 & $1800-2145$ & 3 \\
\hline & $8 / 9$ & $28-83$ & 221 & $1333-1725$ & 5 & 133301725 & 3 \\
\hline & $8 / 9$ & $30-83$ & 221 & $1925-2000$ & 6 & $1925-2000$ & 4 \\
\hline & $8 / 9$ & $30-83$ & 221 & n.d. & n.d. & $2032-2110$ & 4 \\
\hline
\end{tabular}


trends semiparallel to the coastline from Barter Island southeastward at a distance of 10 to $12 \mathrm{~km}(6$ to $7 \mathrm{mi})$ offshore. This ridge is commonly congested with grounded ice masses, which impede deep-draft ice from flowing onshore (Reimnitz and Maurer, 1978). Seismicreflector data indicate that the ridge is an erosional remnant related to the underlying geology. Similar ridges or shoals were observed in Camden Bay and are related both to the underlying geology and to constructional processes. These ridges are discussed in more detail later in this report.

\section{SEISMIC DATA AND ANALYSES}

All seismic data were interpreted in order to determine reflectors that might be correlated throughout the area. Only two acoustic surfaces, which we have called horizons $\mathrm{A}$ or $\mathrm{A}^{\prime}$ and $\mathrm{B}$, were found to be traceable over most of the study area. The shallower surface (horizon $B$ ) was found to be less continuous than horizon A or A', particularly in Camden Bay; as such, it could not be contoured with any confidence. However, its relationship in depth below seafloor and vertical separation from horizon A was fairly consistent where observed. Nevertheless, sufficiently large areas or gaps existed in the acoustic data for horizon B to make correlation of the horizon from line to line difficult. These gaps are primarily due to wide line spacing, poor resolution, and (or) diminished acoustic impedance resulting from the presence of identical acoustic facies above and below the horizon.

In Camden Bay, the Quaternary stratigraphy is complicated by the presence of complex pre-Quaternary structures, which are discussed later. The stratigraphy east of Barter Island is simple, showing units that are conformable to each other. In the eastern area, however, acoustic units above and below horizons $A$ and $B$ in places show cut-and-fill channels that are only traceable over short distances because of the wide spacing of tracklines. The complex subsurface structures effectively divide each horizon surface into two sections. For the purposes of the following discussion, horizon $\mathrm{A}^{\prime}$ refers to

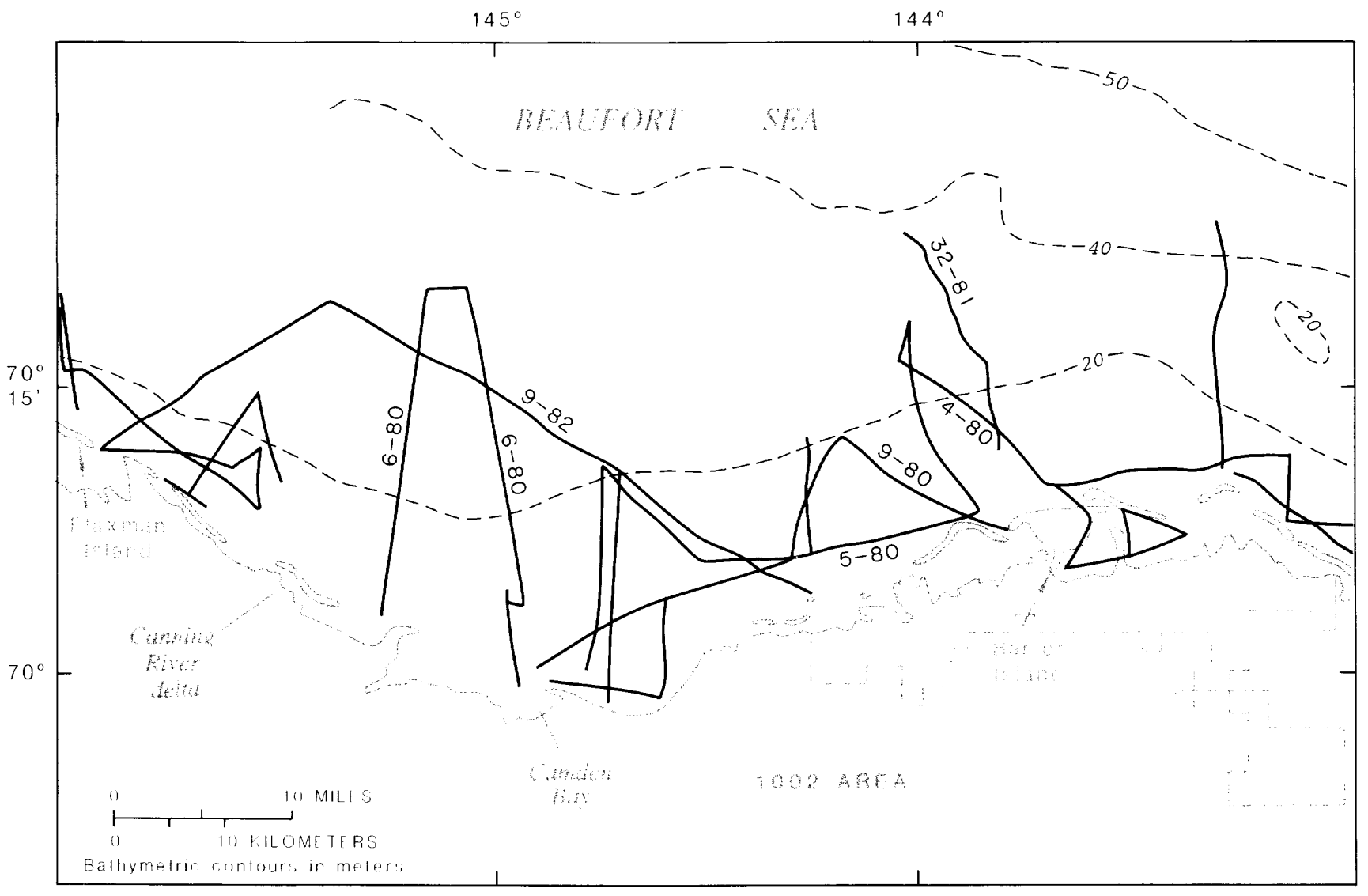

Figure 6.2. Location of U.S. Geological Survey tracklines in Canning River-Barter Island area, Beaufort Sea (1971 to 1982; see fig. 6.1). 
the Camden Bay section and horizon A for the section between Barter Island and Demarcation Bay. Horizon B, for the reasons stated above, is not subdivided. Although surfaces $A$ and $A^{\prime}$ may in fact be equivalent to each other in time of formation and proximity to the coastline, there is a lack of sufficient seismic data to confirm this hypothesis.

Two reflectors that lie above horizons $\mathrm{A}, \mathrm{A}^{\prime}$, and $B$ throughout the area are actively being destroyed by intense ice gouging, particularly along the seaward margin of the area. These young reflectors have seaward dips along the inner shelf, flatten seaward, and are being truncated at the seafloor over much of the region.

The uppermost acoustic sedimentary sequence, which consists of an acoustically transparent unit, was found in four places in the study area: in Camden Bay, in the central outer part of the study area north of Beaufort Lagoon, in Beaufort Lagoon, and within Demarcation Bay. Very high resolution $(7 \mathrm{kHz})$ data were useful in resolving sediments near the seafloor that were $1 \mathrm{~m}(3 \mathrm{ft})$ or less in thickness.

\section{DESCRIPTION AND SIGNIFICANCE OF ACOUSTIC REFLECTORS}

\section{Canning River to Barter Island}

Tracklines interpreted in this area are concentrated into two groups with little coverage between them; this made correlation from one group to the other difficult. One trackline set is in Camden Bay, centered around line 6-80; the other is north-northwest of Barter Island, centered around line 4-80 (fig. 6.2).

The Camden Bay and Barter Island sets of tracklines exhibit different structures and seismic stratigraphies. The Camden Bay sequence is similar to that described for the region between Barter Island and Demarcation Bay, but horizon $\mathrm{A}^{\prime}$ has more relief than horizon A. Data gaps and complex structural trends near Barter Island prevent the tracing of features from the Canning River to parts east of Barter Island. Therefore, the stratigraphic sequences of the Camden Bay and Barter Island trackline sets are considered separately.

The Camden Bay set lies adjacent to the area that was studied in detail and described by Wolf and others (1985). That report concluded that a broad, subsurface delta system, which overlies relatively flatlying marine sediments, exists immediately west of the present study area.

\section{Camden Bay Area}

The seafloor in Camden Bay is depicted in figure 6.3. Of significant physiographic interest are the long linear ridges that are apparently subparallel to the bathymetric contours. These ridges have no internal reflectors in some cases, but generally they are residual highs composed of eroded, relatively flat-lying sedimentary sequences, much like those north of Barter Island. Ridge $\mathrm{A}$, the long 2-m-high (6 ft) ridge of figure 6.3 , appears to be constructional because it lacks internal reflectors and is situated shoreward of a subsurface structural high. Likewise ridge $\mathrm{B}$, a 1-m-high $(3 \mathrm{ft})$ ridge to the south, also lacks internal reflectors but has sedimentary sequences onlapping on its north and south flanks (fig. 6.3). This configuration suggests that this particular ridge may be a submerged barrier island formed at a lower stand of sea level.

The seaward-dipping seismic unit 3 and the relatively flat-lying units 2 and 1 near the shoreline are remarkably similar to nearshore acoustic units east of

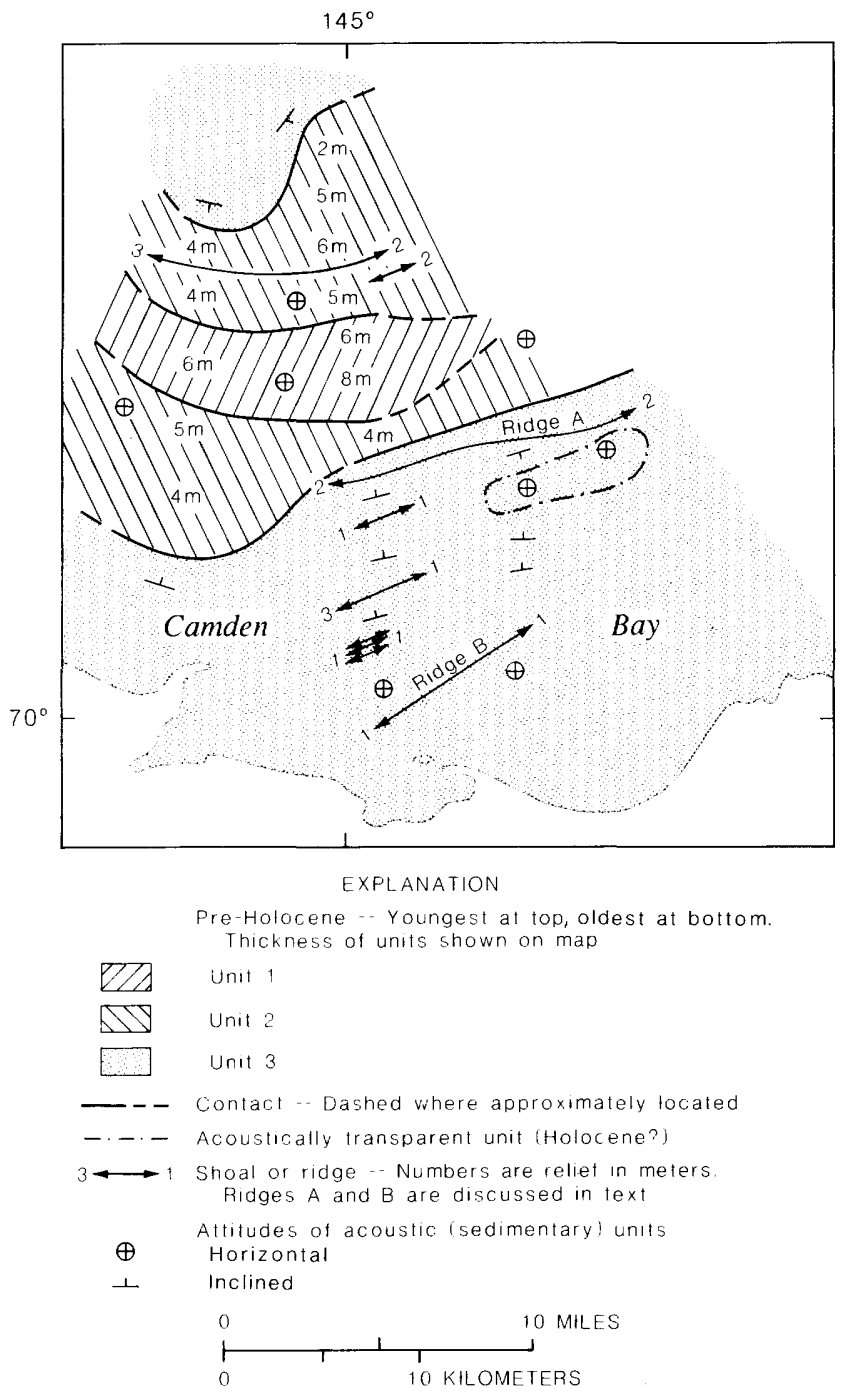

Figure 6.3. Seafloor, showing apparent distribution and attitudes of geologic units in Camden Bay (see fig. 6.1). 
Barter Island. Until further seismic data are acquired, one can assume, on the basis of similar acoustic signatures and distribution, that these units are the same as those described between Barter Island and Demarcation Bay.

An area of acoustically transparent sediment was observed south of ridge A (fig. 6.3). The accumulation is up to $4 \mathrm{~m}(13 \mathrm{ft})$ thick and may represent an area of Holocene deposition. Sediment samples and additional seismic-reflection data are needed to substantiate this hypothesis.

The eastern and southern dips of unit 3 shown in the extreme northern part of the area suggest a subsurface high. This high may represent a near-surface reflection of the deeper Camden anticline (Grantz and others, 1983; chap. 21). Unit 2 to the south rises to the north and crops out both there and on its southem flank (fig. 6.4). The seafloor has a slight northward gradient and is intensely ice gouged.

Except for the area of possible Holocene sediment accumulation and constructional ridges, the entire area, like the region to the east of Barter Island, is undergoing intense ice gouging; the area appears to be a region of little deposition and probably is being eroded.

The contoured surface of horizon $\mathrm{A}^{\prime}$ (fig. 6.4) shows variable relief, unlike the surface of horizon A between Barter Island and Demarcation Bay. Seismic data show reflectors that top lap into the surface and indicate that this surface is an unconformity. The relief, therefore, may reflect directions of surface drainage during the time the erosional surface was formed. The underlying anticlinal high, at depth, to the north of the area may have played a dominant role in controlling relief. Drainage from an ancestral Camden Bay may have been disrupted by a growing Camden anticline and thus forced to flow to the northeast and northwest around the high. The acoustic stratigraphy above and below horizon $\mathrm{A}^{\prime}$ shows a significant number of cut-and-fill channels, which suggests that this region has had an active depositional and erosional history. The equivalent of horizon B was more difficult to resolve in this area than in the region east of Barter Island, perhaps as a result of this increase in depositional and erosional activity and of the topographic influence of the growing anticlinal high on accumulation and removal of sediments. The sequences that top lap into horizon $\mathrm{A}^{\prime}$ and define the near-surface expression of the anticlinal high suggest that sedimentation rates have been less since the formation of horizon $A^{\prime}$ than they were before the events that formed this horizon; however, periods of cutting and filling of channels continued to occur and indicate a history that is similar to the one suggested for the area from Barter Island to Demarcation Bay.

\section{Barter Island Area}

A subsurface map of a sedimentary structure centered approximately $20 \mathrm{~km}(12 \mathrm{mi})$ north of Barter
Island is shown in figure 6.5. The structure consists of a folded and faulted sequence containing two geologic units (units 4 and 5) with differing apparent dips. On seismic records, the angular terminations of beds at this contact suggest that there is an unconformity between the two stratigraphic units. The unit northwest of the contact (unit 5) is anticlinal with evidence of faulting along its southern flank. The unit southeast of the contact (unit 4) appears to lap onto this large structure and is characterized by very slight dips to the southeast.

Outcrops of both stratigraphic units may be present on the seafloor, but seismic and $7-\mathrm{kHz}$ records do not allow their delineation. The presence of this

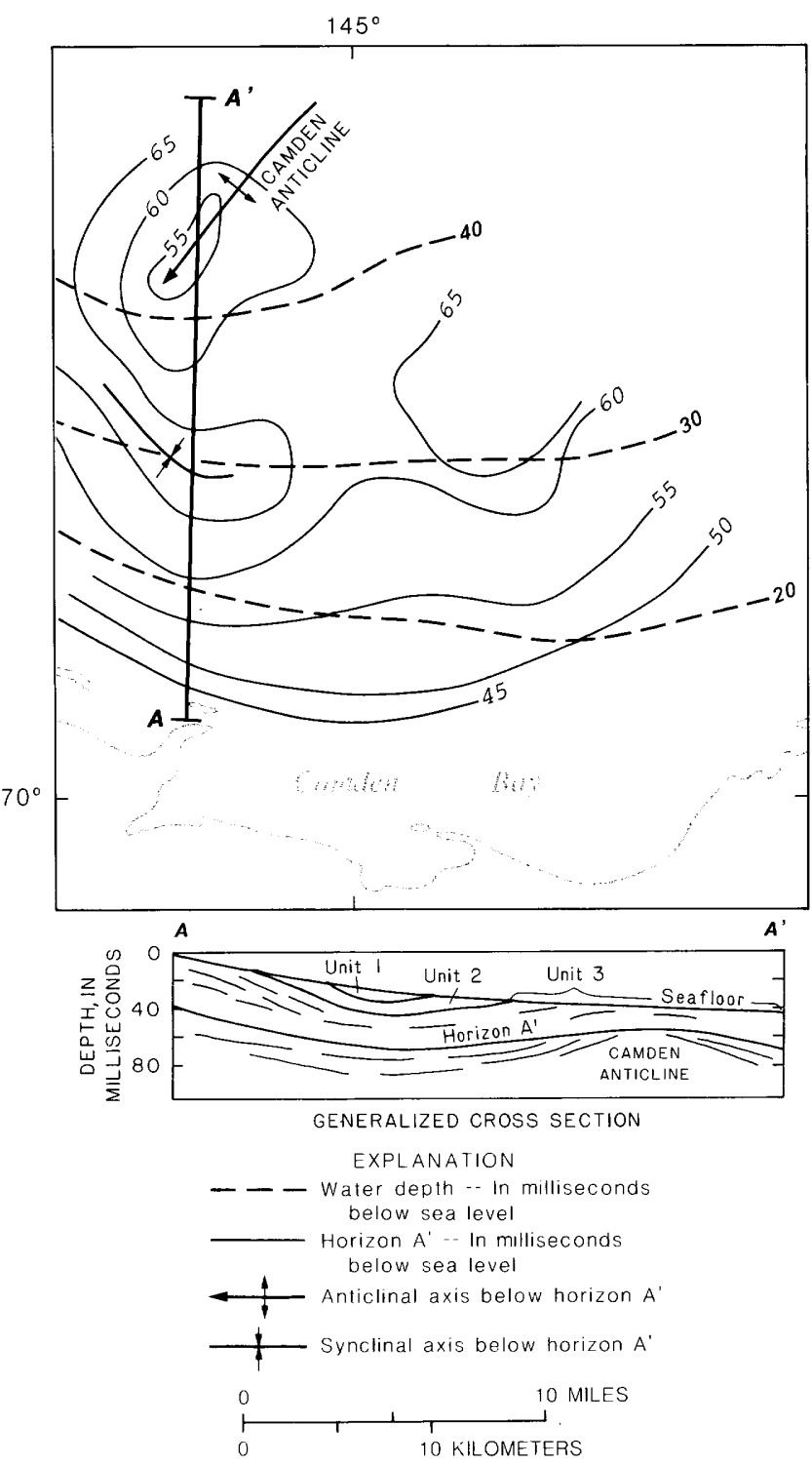

Figure 6.4. Contours on surface of horizon A'. Units 13 refer to figure 6.3 (see fig. 6.1). 
subsurface structure means that horizon $A$ to the east and horizon $A^{\prime}$ to the west must crop out on the seafloor along the flanks of the structure; this in turn suggests that these two different stratigraphic units (units 4 and 5) are much older than horizons A and A'. Additional seismic data will be required to delineate and tie these stratigraphic units together with horizons $A$ and $A^{\prime}$.

A sediment cover of variable thickness overlies this structure. As much as $4 \mathrm{~m}(13 \mathrm{ft})$ of sediment cover occurs above the structure in the southeastern part of this area. Bedding features within this sediment cover are being destroyed by ice gouging. This cover thins near the anticlinal axis.

The series of faults and dips northwest of Barter Island and in the lagoons to the south (fig. 6.5) align well with the northeasterly trend of the Marsh Creek anticline, which lies well to the southwest. Bedrock in the lagoons is close to the lagoon floors and is covered by thin Holocene(?) deposits.

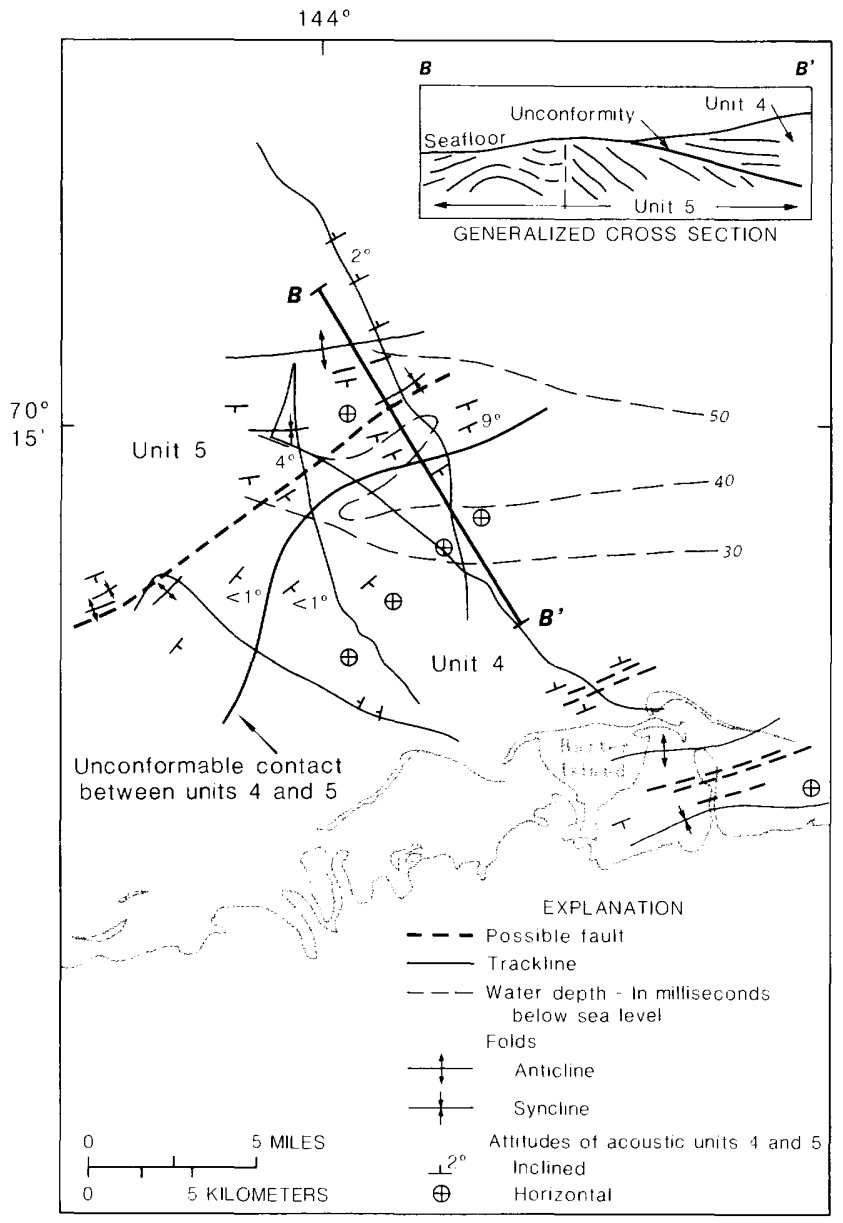

Figure 6.5. Subsurface structures northwest of Barter Island (see fig. 6.1).

\section{Barter Island to Demarcation Bay}

Horizons A and B

USGS trackline coverage provided seismic data to delineate horizons $\mathrm{A}$ and $\mathrm{B}$ throughout much of the Barter Island to Demarcation Bay area (fig. 6.6). Our data extend to water depths of $40 \mathrm{~m}(130 \mathrm{ft})$ and achieve as much as $50 \mathrm{~m}(160 \mathrm{ft})$ subbottom penetration. A representative seismic-reflection profile showing acoustic stratigraphy on the inner shelf between Barter Island and Demarcation Bay is shown in figure 6.7. Here we briefly describe these two horizons.

Horizon $A$. - The most persistent and deepest reflector is horizon A (fig. 6.7). Below horizon A throughout much of the area, the acoustic signal is weak and little bedding is observable. Seaward- (northward) dipping reflectors can be seen top lapping into horizon A on line 34-81 (fig. 6.8). Similar features observed along other seismic lines suggest that horizon A represents an unconformity. Based on interpretations at many onshore-offshore trackline crossings, it appears that horizon $\mathrm{A}$ is approximately 45 to $50 \mathrm{~m}$ (148 to $164 \mathrm{ft}$ ) below the seafloor in water depths of $40 \mathrm{~m}(130 \mathrm{ft})$ along the outer limits of the area surveyed. Horizon A shallows to approximately $30 \mathrm{~m}(100 \mathrm{ft})$ below the seafloor in the midregion at approximately $25 \mathrm{~m}(80 \mathrm{ft})$ water depth. Seismic data are marginal near the coast, which makes it difficult to delineate horizon A.

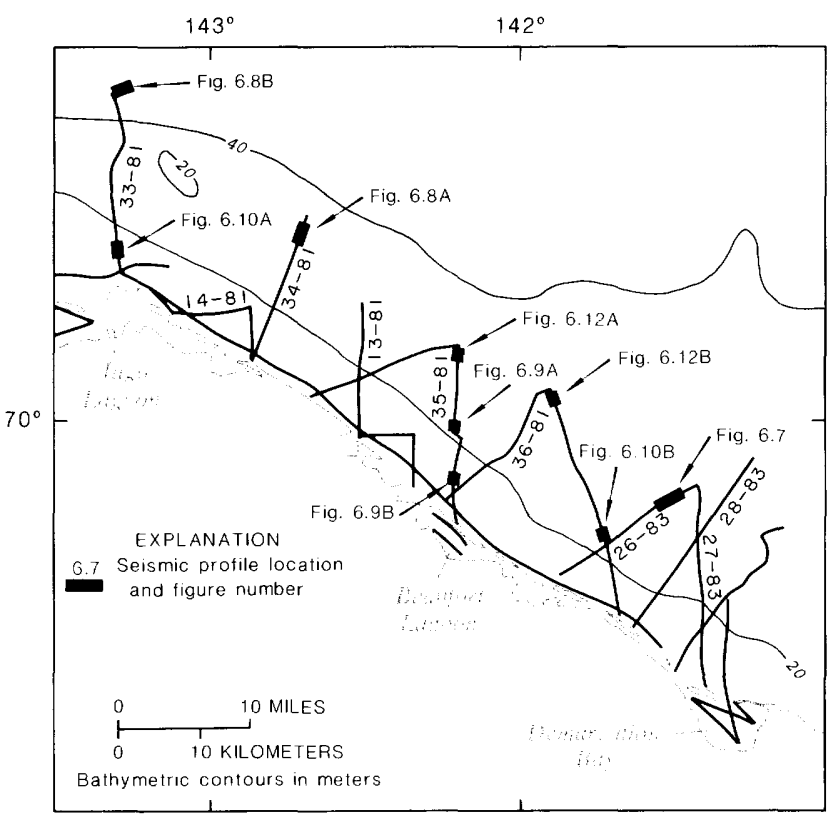

Figure 6.6. Location of U.S. Geological Survey tracklines in the Jago Lagoon-Demarcation Bay area, Beaufort Sea, (1971 to 1983) and segments of lines illustrated in this report (see fig. 6.1). 
Horizon $B$. - The next higher major acoustic boundary, horizon $\mathrm{B}$, was somewhat difficult to resolve as a continuous linear reflector. In general, however, it is seen as the top of an acoustic sequence composed of closely spaced, thinly laminated, coherent reflectors (fig. 6.7). These reflectors are relatively flat lying with local areas of seaward-dipping intemal reflectors. Between horizons A and B is a unit characterized by widespread but persistent reflectors in a homogeneous sequence (fig. 6.8, upper profile).

Horizon B in figure 6.9 (upper profile), as with horizon $\mathrm{A}$ in figure 6.8, indicates that units below are top lapping into the horizon surface. This evidence suggests that horizon B may also be an unconformity. There are numerous examples that support this interpretation. In figure 6.9 (upper profile), horizon A has only subtle suggestions of top-lapping units. In figure 6.9 (lower profile), horizon $A$ is obscured by locally strong multiples. Horizon B, on the other hand, although occasionally blocked by what appears to be gas, has a very high acoustic impedance. This high reflectivity occurs in many areas, especially near the coastline. In general, horizon B lies approximately $15 \mathrm{~m}(50 \mathrm{ft})$ below the seafloor in $40 \mathrm{~m}(130 \mathrm{ft})$ water depth and shallows to $5 \mathrm{~m}(16 \mathrm{ft})$ below the seafloor in $15 \mathrm{~m}(50 \mathrm{ft})$ water depth. Seismic data near the coast are marginal, but it appears that horizon B may crop out near the coastline.

Generally, horizons A and B lie subparallel to the seafloor, with most cut-and-fill channels occurring between the two. The largest channel observed lies below horizon $\mathrm{B}$, with the base defined by horizon $\mathrm{A}$; the channel is situated approximately $10 \mathrm{~km}(6 \mathrm{mi})$ north of Demarcation Bay and was observed on lines 26 to 28 of the 1983 cruise. The channel axis trends west-northwest to east-southeast, is approximately 10 to $12 \mathrm{~km}$ (6 to 7 mi) in width, and has 5 to $10 \mathrm{~m}$ (15 to $35 \mathrm{ft}$ ) of relief. Its relationship to present land features is unclear because the line spacing does not allow us to extend the axis to the east or west.

\section{Units Above Horizon B}

Above horizon B and commonly 5 to $10 \mathrm{~m}$ (15 to $35 \mathrm{ft}$ ) below the seafloor in the outer part of the study area is a third, rather dominant horizon with an irregular surface that occasionally is composed of short, overlapping, horizontal "minireflectors." Near the seafloor between times 1620 and 1630 (fig. 6.8, upper profile), 4 to $10 \mathrm{~m}$ (13 to $33 \mathrm{ft}$ ) below the seafloor, lies an acoustic grouping of tightly spaced, flat-lying

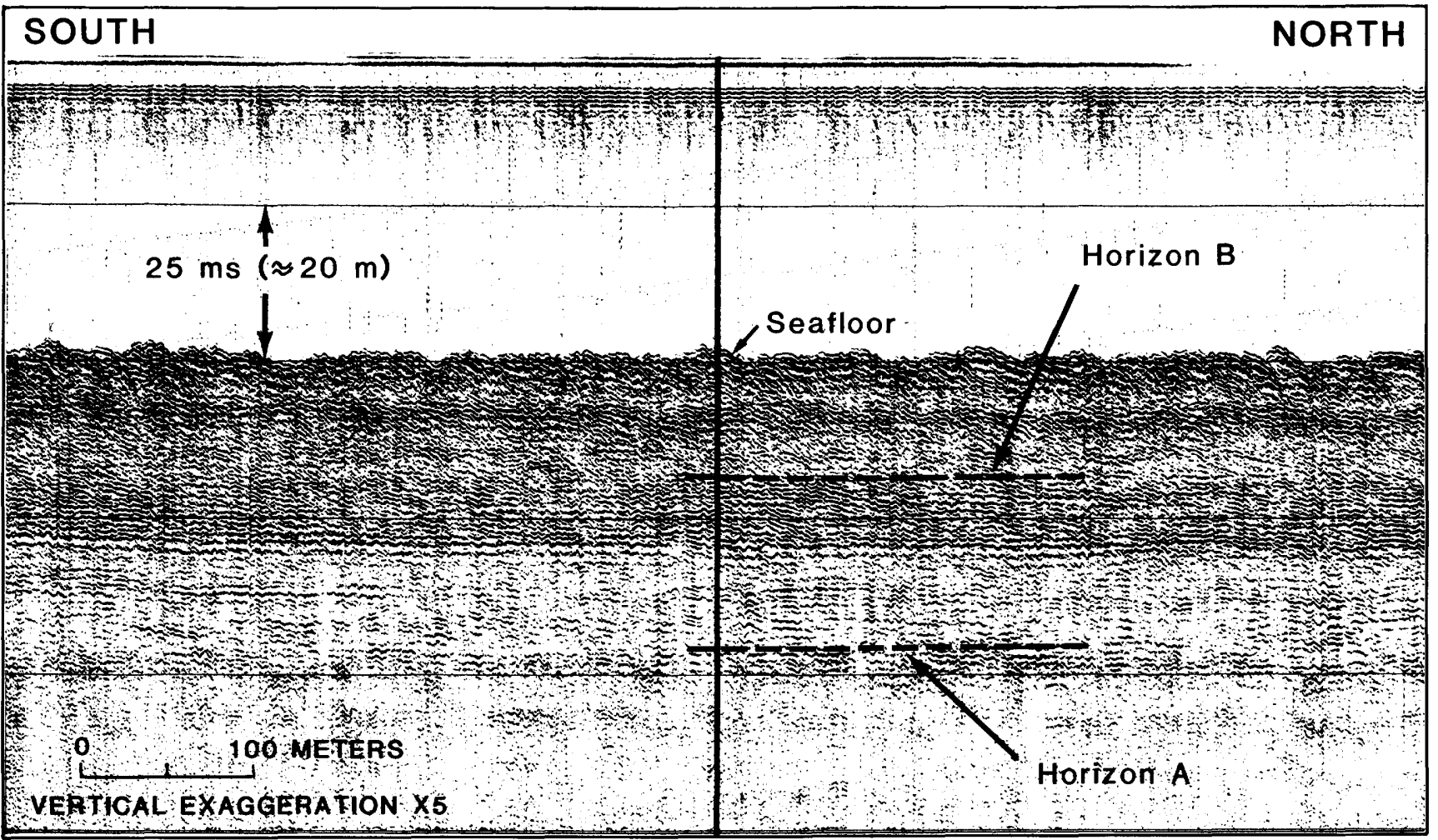

Figure 6.7. Representative seismic section for area northwest of Demarcation Bay in 40-m (130-ft) water depth along trackline $26-83$ (see fig. 6.6). 
reflectors. This grouping phenomenon and the irregular surface previously mentioned have been observed along other lines but not frequently enough to demonstrate the continuity of either. The occasional grouping of reflectors may reflect a change in sediment type from nonbedded to bedded sequences, which lie just below the seafloor in isolated areas.

The $7-\mathrm{kHz}$ record in the lower part of figure 6.8 shows that these bedded units have not been deposited recently but rather are older units that are actively undergoing destruction by intense ice gouging (particularly north of Barter Island, where the gouging penetrates a meter or two down into the seafloor). Ice is acting as a natural "rototiller," destroying previous stratigraphy and homogenizing the upper few meters of the seafloor sediments.

The effects of this scouring can also be demonstrated in the vicinity of the offshore shoals. The topographic high at the north end of figure 6.8 (lower profile) is the inshore flank of a southeast-trending linear shoal north of Barter Island in approximately $50 \mathrm{~m} \mathrm{(160}$ $\mathrm{ft}$ ) of water. During some surveys, this area was
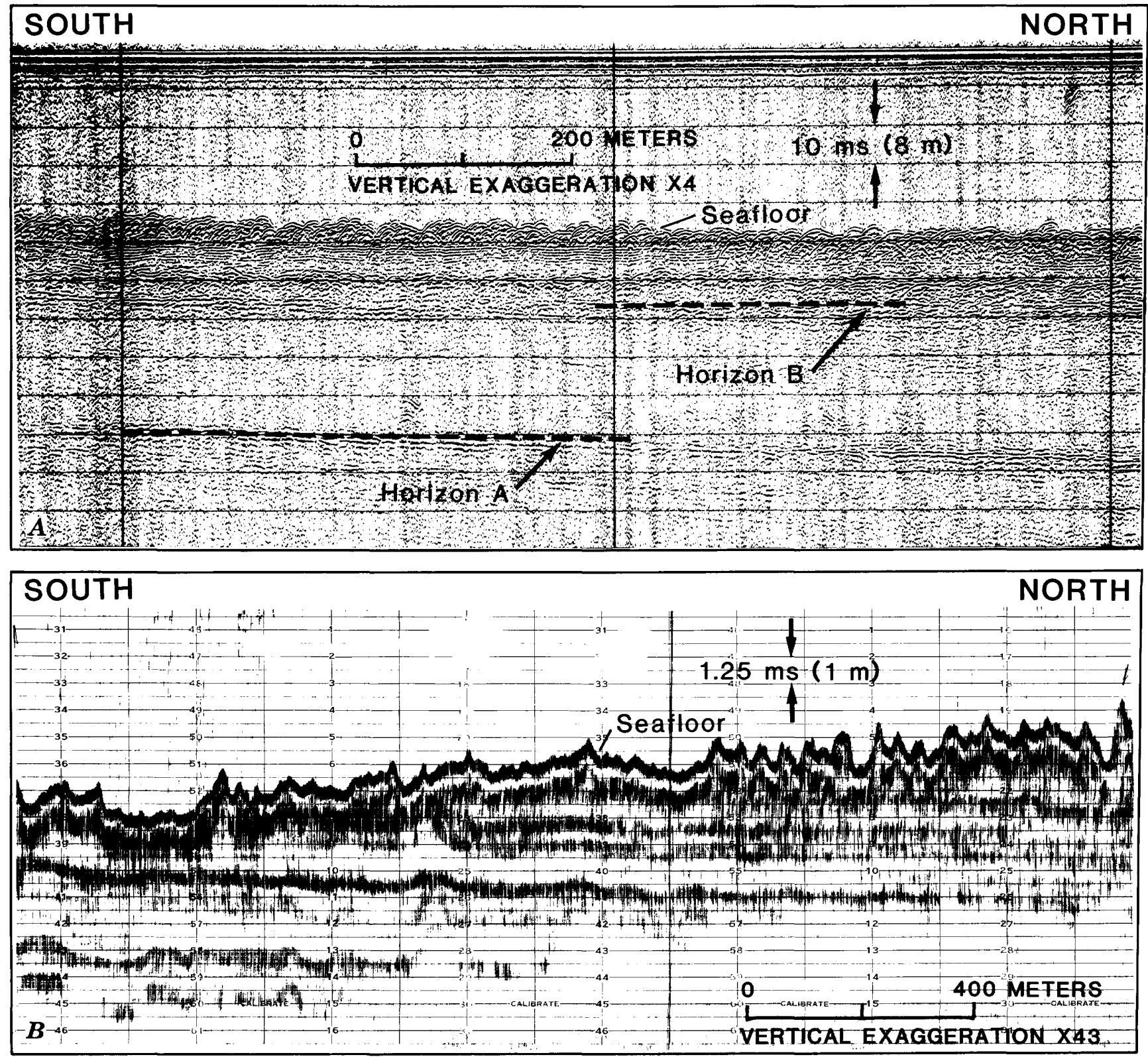

Figure 6.8. Seismic lines from area northeast of Barter Island, Beaufort Sea. A. Uniboom data, line 34-81. B. 7-kHz data, line 33-81. See figure 6.6 for locations. 
congested with large grounded ice masses. Acoustic reflectors within the shoal terminate at or near the seafloor, and in this particular example, at least $4 \mathrm{~m} \mathrm{(13}$ $\mathrm{ft}$ ) of bedded materials to the south have been destroyed and removed from the area. This destruction by ice masses is characteristic throughout the area but is best shown along this shoal. Clearly, recent deposition is not occurring; rather, the data demonstrate that rapid degradation of the inner shelf and removal of sediments from the area is taking place. Excessive removal of sediments from the area may also have been facilitated by stream erosion during periods of low sea-level stands.

Along the inner shelf, there are groups of reflectors that have seaward dips and appear to crop out at the seafloor. Two examples of $7-\mathrm{kHz}$ records illustrating these seaward-dipping reflectors are shown in figure 6.10. Dips along the tracklines are approximately 30 minutes, although the dips vary, which suggests a somewhat variable depositional history. Pinch-outs of north-dipping wedges can be observed in the lower profile of figure 6.10 , especially toward the southern end. These records are representative of others throughout the area. In most cases, the reflectors appear to be truncated at or near the seafloor, with little suggestion of Holocene sediment cover.

The distribution of the reflectors above horizon $B$ is shown in figure 6.11. Geologic units defined by these reflectors are generally horizontal along the coastline. These reflectors grade into the northwestsoutheast-trending belt of seaward-dipping reflectors (unit 3 ), similar to those shown in figure 6.10. Locally, the uppermost reflectors, which define the base of unit 2 , flatten out seaward and are essentially parallel to the sea surface; they range from 0 to $8 \mathrm{~m}(0$ to $26 \mathrm{ft})$ in thickness. As a result of the seafloor having a seaward gradient greater than that of this unit, the basal reflector should crop out farther seaward in some places. In fact, such outcrops do occur in the northwestern part of this
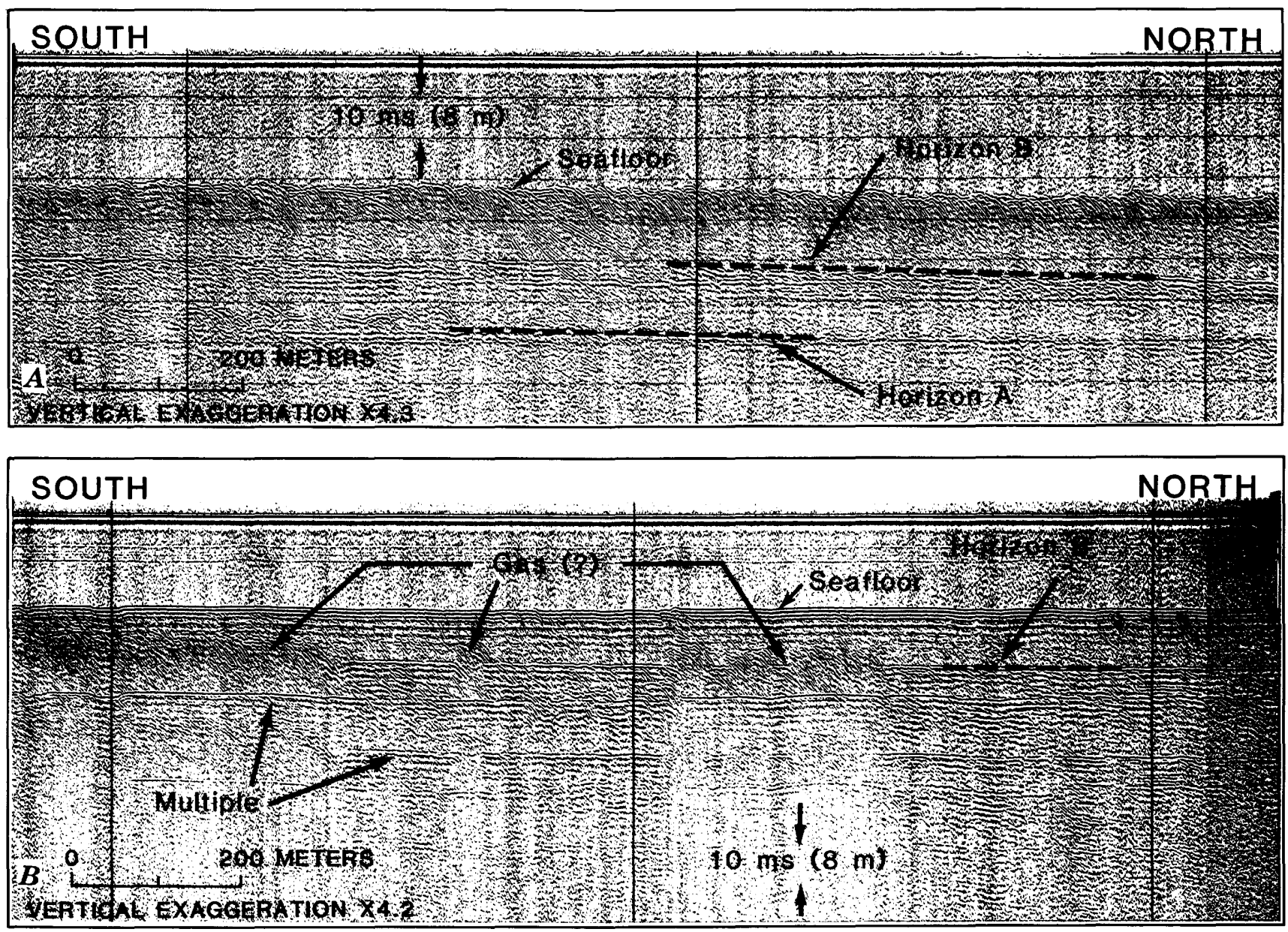

Figure 6.9. Representative middle inner-shelf $(15$ to $25 \mathrm{~m} ; 50$ to $80 \mathrm{ft}$ ) seismic-reflection profiles along trackline 35 81. Possible gas-charged sediments are marked on profile $B$ (see fig. 6.6 for locations). 
area. The unit is actively being destroyed by ice gouging, as shown in figure 6.8. The presence of the offshore linear shoal north of Barter Island accounts for the preservation of the top reflector between the two areas of destruction. Another area of destruction occurs north of Demarcation Bay.

Above these reflectors and within the horizon disturbed by ice gouging, short, discontinuous reflectors that are subparallel to the seafloor occur at relatively consistent depths. Throughout the area, these short reflectors were observed near the seafloor, but a continuous surface as such was not noted. These short reflectors may indicate an acoustic impedance difference that was established within the near-surface sediments as a result of ice keels that penetrated and slid along the subseafloor. It is possible that if conditions of sea level and ice availability remain static over long periods of time, a continuous subsurface reflector may be created by this process. Canadian researchers refer to the area above this reflector as the scour saturation zone (SSZ; Harper and Penland, in press).

\section{Youngest Units (Including Holocene Units)}

In the middle part of the Barter Island to Demarcation Bay area, north of Beaufort Lagoon (figs. $6.6,6.11$ ), the "top-flattening seaward" unit (unit 2) appears to be overlain by an even younger unit. This youngest unit (unit 1) is shown on seismic sections in figure 6.12. In both sections, the unit occurs in about 40 $\mathrm{m}(130 \mathrm{ft})$ of water and appears as a homogeneous, acoustically transparent sequence. On line 36 (fig. 6.12,
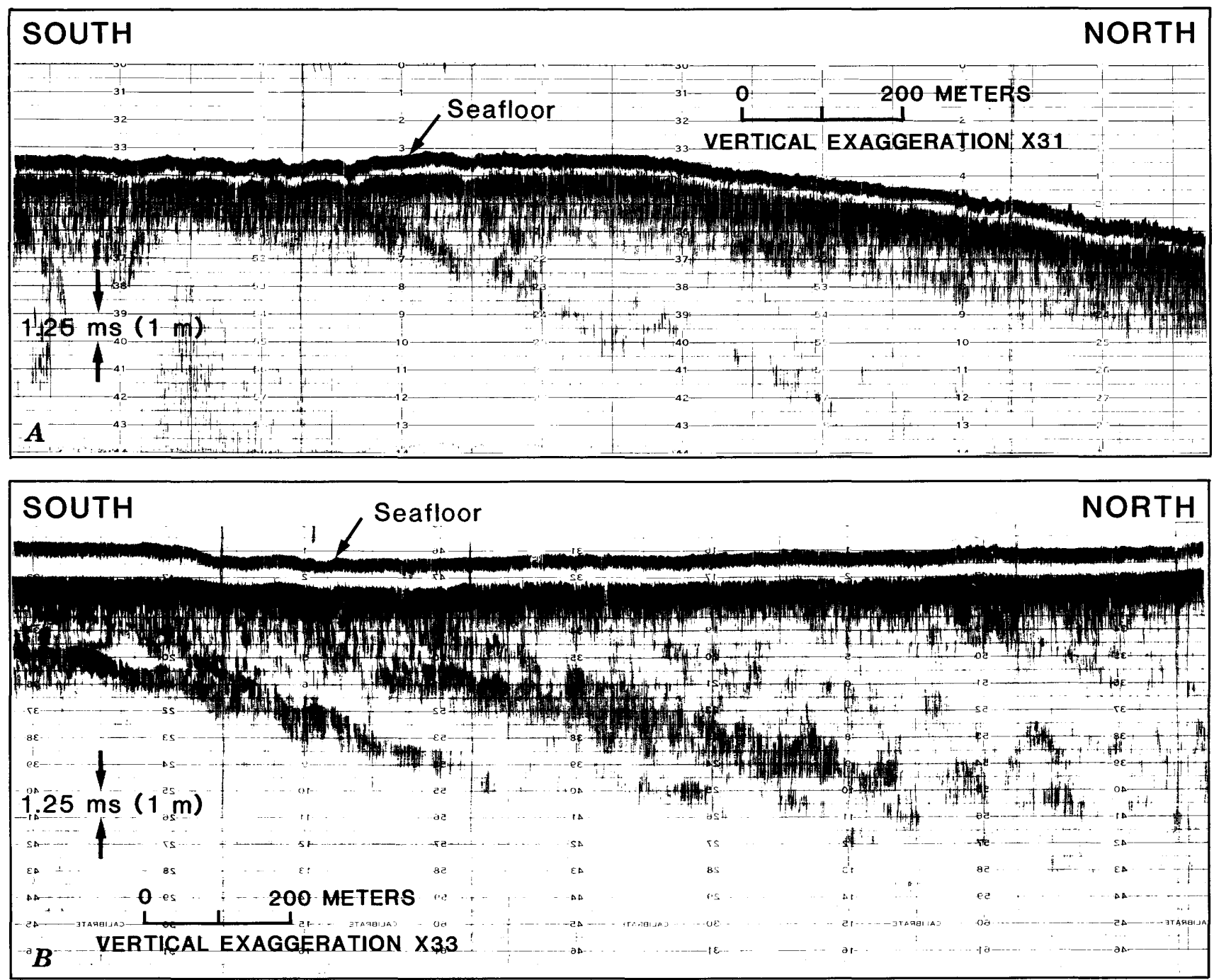

Figure 6.10. Examples of $7-\mathrm{kHz}$ records showing seaward-dipping reflectors that are truncated at seafloor. $A$. Line 33-81. B. Line 36-81. See figure 6.6 for locations. 
lower section) the unit is very thin, but it increases to

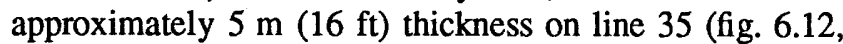
upper section). At least two possible interpretations can be applied to this new unit. Either it is, in fact, a younger Holocene(?) accumulation, or else it may represent a facies within the "top-flattening-seaward" unit described earlier. Line spacing does not permit extension of this unit to the northwest or southeast. The fact that the landward edge of unit 1 appears to be farther inshore than the boundary where ice gouging has destroyed unit 2 below suggests that this accumulation may in fact be a sedimentary facies rather than Holocene sediments. On the other hand, the bathymetric contours, which generally maintain a subparallel trend to the coastline, suggest a slight depression or embayment in this area that might allow the Holocene sediments to accumulate (see fig. 6.6). In general, if inner-shelf accumulations of Holocene materials are to be found, this area would be the most likely.

Holocene sediments are thought by many researchers to be present along barrier islands and in some bays and lagoons. Some unconsolidated Holocene(?) sediments as thick as $4 \mathrm{~m}(13 \mathrm{ft})$ have been found in Demarcation Bay (fig. 6.13). These sediments have been deposited on a surface of hummocky relief rather than on a flat or in a bowllike feature. More than 3 to $4 \mathrm{~m}$ (10 to $13 \mathrm{ft}$ ) of sediments have accumulated inshore of the spits and islands marking the seaward boundary of the bay, particularly along the sand-gravel spit on the northwest side of the bay (fig. 6.13). Outside the bay, the Holocene(?) sediments thin to zero within 1 or $2 \mathrm{~km}(0.6$ to $1.2 \mathrm{mi})$ of the opening. Farther seaward,

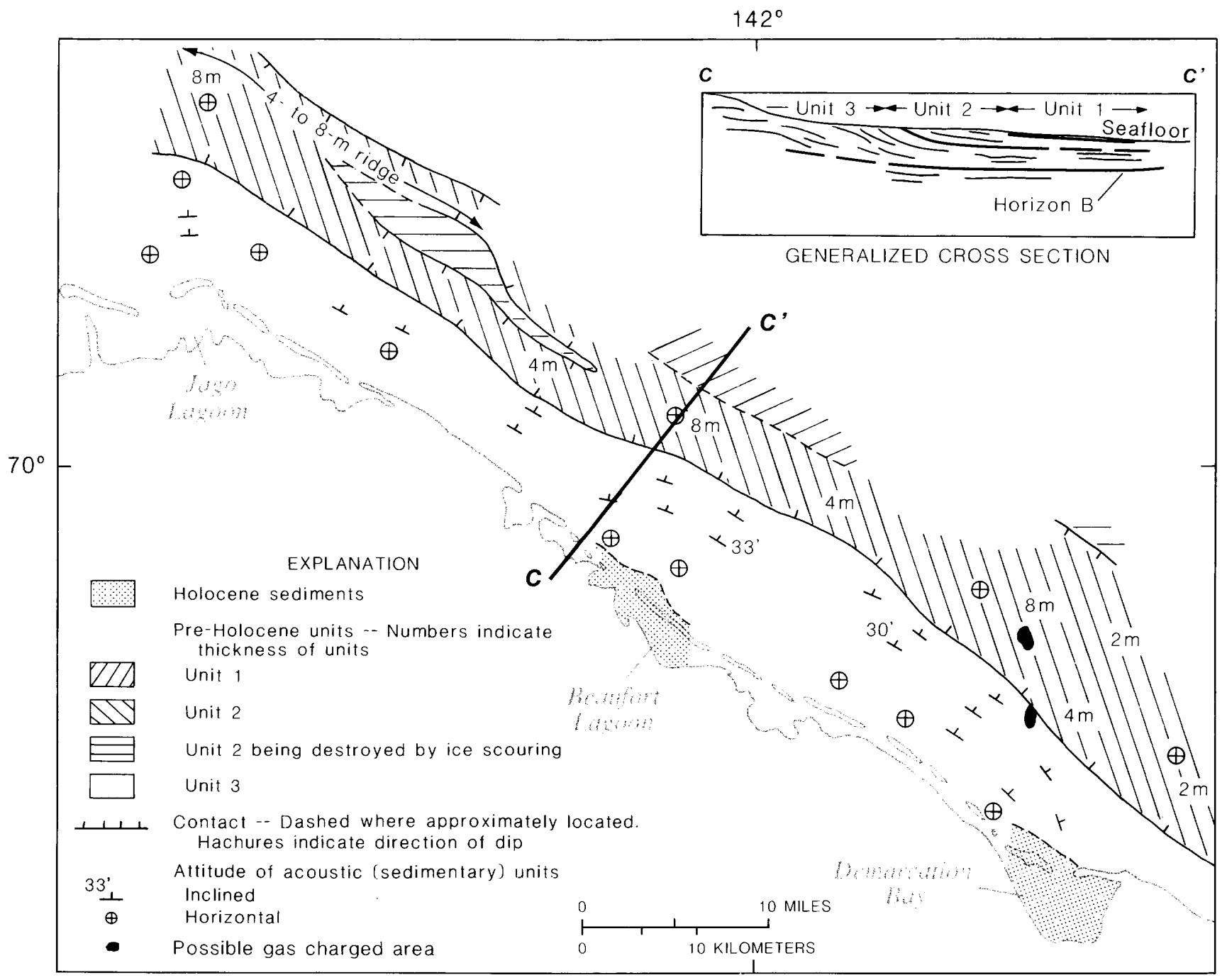

Figure 6.11. Seafloor, showing apparent distribution and attitudes of geologic units above horizon B along the inner shelf between Jago Lagoon and Demarcation Bay (see fig. 6.1). 
the $7-\mathrm{kHz}$ records suggest the truncation of sedimentary units at the seafloor, as discussed earlier. The zero contour marks the transition zone between present-day nearshore deposition and offshore erosion or lack of deposition.

Landsat imagery (fig. 6.14) suggests areas of active Holocene deposition at the terminus of the large fan along the coast west of Demarcation Bay. The light-gray areas in the water indicate turbid water masses trapped behind the barrier islands and partly within Demarcation Bay. False-color imagery shows minor sediment-laden water masses exiting through passes between barrier islands into the Beaufort Sea. The flow of water masses was eastward at the time this image was taken.
Beaufort Lagoon, midway between Barter Island and Demarcation Bay, is another area that appears to have a similar thickness of Holocene(?) sediments (fig. 6.11). In figure 6.15, the thickest deposits include the barrier islands within the contour lines. This suggests, as one might expect, that the barrier islands in this region are Holocene in age and that some Holocene sediments have accumulated subparallel to the islands on both the seaward and lagoonal sides. The transition to an erosional surface again occurs a few kilometers offshore from the barrier islands, similar to the distribution of Holocene(?) sediments in Demarcation Bay. Coincidently, both areas reflect Holocene(?) sediment accumulations of approximately 3 to $4 \mathrm{~m}$ (10 to $13 \mathrm{ft}$ ).
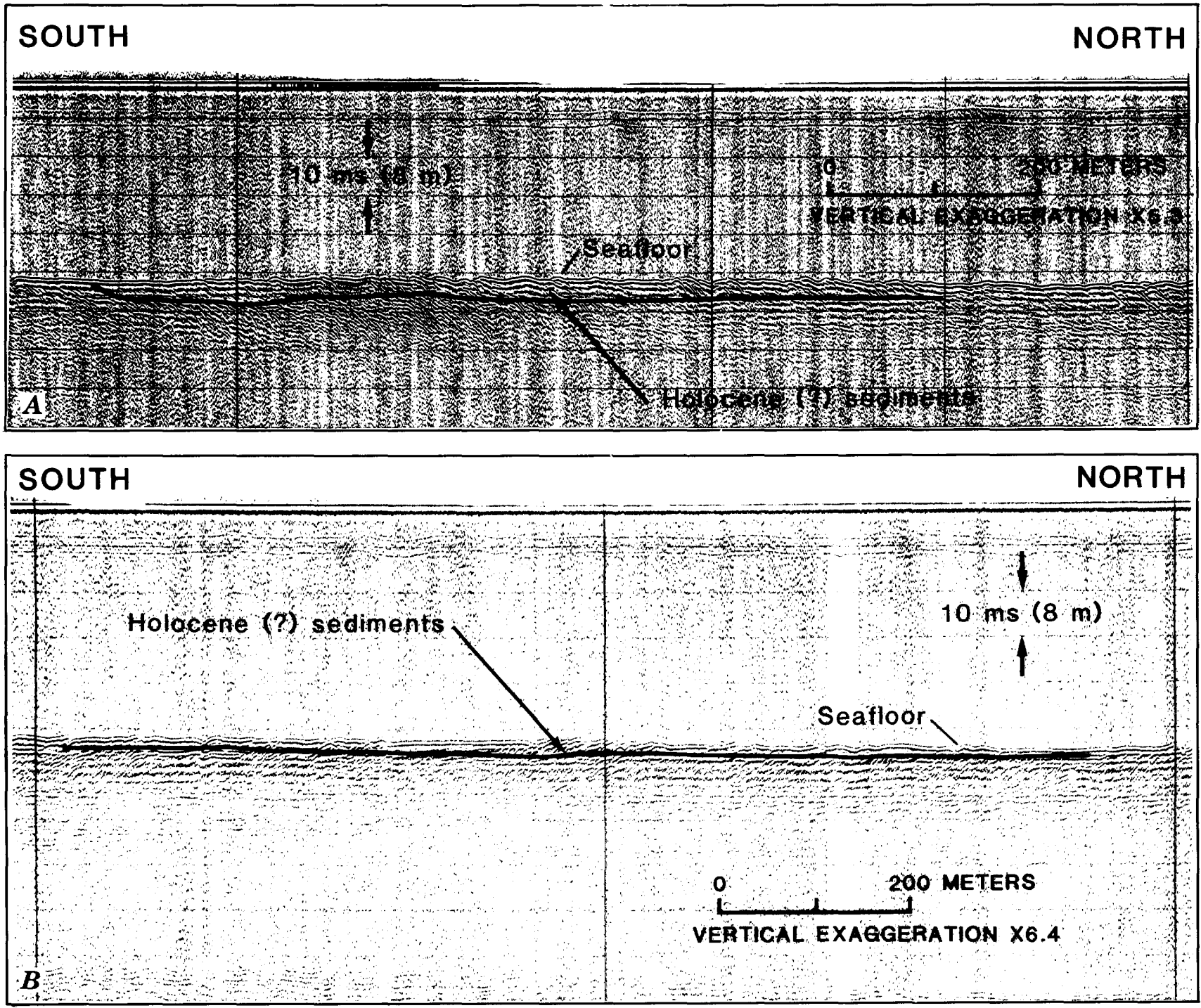

Figure 6.12. Possible Holocene(?) sediment accumulations northeast of Beaufort Lagoon. A. Line 35-81. B. Line 3681. See figure 6.6 for locations. 


\section{Acoustic Anomalies Suggesting Gas}

Horizon B is broken in several places by acoustic signatures that have been interpreted as representing gas-charged sediment accumulations. The areal distribution of these signatures was plotted along seismic tracks where observed, but too few occurrences were seen to make it possible to determine a pattern of distribution or to allow one to identify gas-rich areas. Most nearshore occurrences are generally located near entrances to lagoons or are associated with small deltas, but these occurrences are few and small in size.

The two largest gas-signature areas were observed north of Demarcation Bay (fig. 6.11). The gas signatures do not appear to be of near-surface origin. Their sources may be at depth and are perhaps associated with the broad west-northwest- to east-southeast-trending channel that occurs between horizons A and B north of Demarcation Bay. The seaward signature probably defines the northeast side of the channel, which may represent an older barrier-island complex at depth; these accumulations may have formed from decay of organic matter in lagoonal deposits located inshore (southwest) of the old barrier islands, or instead they may be of thermal origin at depth.

\section{AREAL DISTRIBUTION AND ANALYSIS OF HORIZON A}

Sufficient data exist to permit line-to-line correlation and contouring of horizon A from Barter

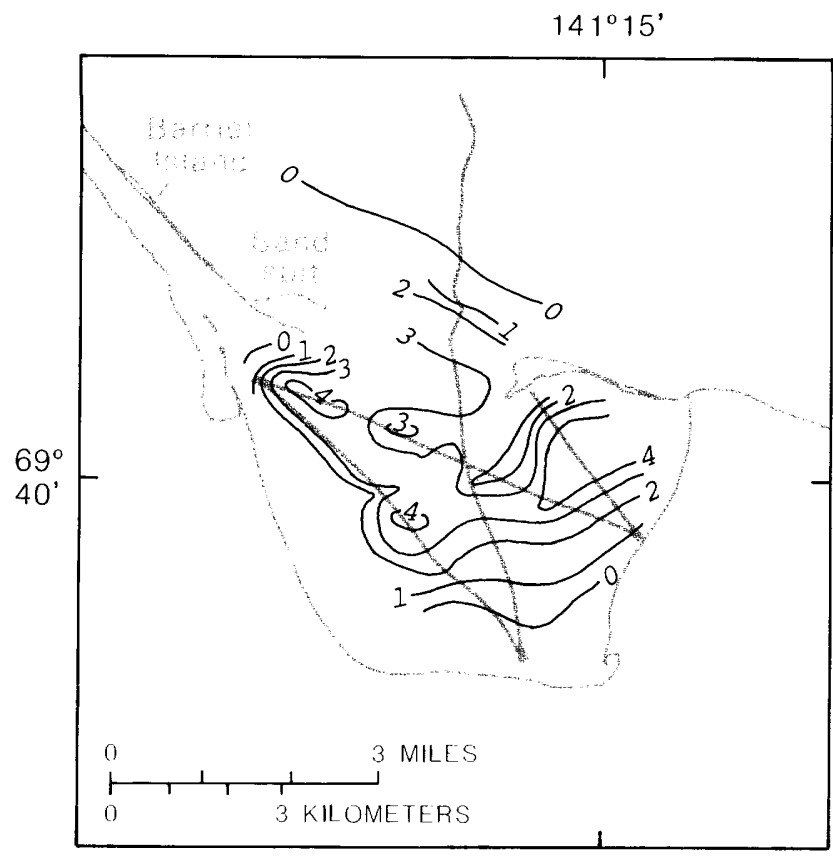

Figure 6.13. Thickness of Holocene(?) sediments (in meters) and tracklines in Demarcation Bay (see fig. 6.1).
Island to Demarcation Bay (fig. 6.16). Water depths and depths to horizon A are given in milliseconds below sea level. As shown, horizon A slopes seaward and generally has contours that parallel the coastline except for an area north of Demarcation Bay, where they turn northeast, forming an embaymentlike feature. Calculated slopes of the horizon are 11 minutes north of Barter Island, 14 minutes north of Beaufort Lagoon, and 17 and 4 minutes north of Demarcation Bay. Stratigraphic thicknesses can generally be calculated by using an approximately $1,600 \mathrm{~m} / \mathrm{s} \quad(5,300 \mathrm{ft} / \mathrm{s})$ sound velocity. This velocity has worked well for the seismic stratigraphy from Prudhoe Bay to the Canning River (Wolf and others, 1985).

The anomalous embayment on the surface north of Demarcation Bay suggests a depressionlike feature or an embayment that existed at the time the surface was formed. It appears that surface drainage at the time of the formation of horizon A was directed toward the northwest. The steep 17-minute nearshore slope probably reflects close proximity to the Brooks Range. For the most part, reflectors above this surface do not suggest tectonic activity or warping through time, as they are generally subparallel to the surface gradient. In general, the acoustic stratigraphy suggests a continuous depositional history, interrupted only twice by widespread erosional cycles represented by horizons A and $B$ and associated cut-and-fill channels within the section.

Two northeast-southwest-trending profiles have been constructed to illustrate the relationship between the gradient of horizon $\mathrm{A}$ and the adjacent land-surface topography (figs. $6.17,6.18$ ). Profile A crosses what was earlier described as coastal-plain physiography, whereas profile B passes through the large fan west of Demarcation Bay and southwest to the base of the Brooks Range. In profile $A$, the land gradient below 50 $\mathrm{m}(160 \mathrm{ft})$ altitude essentially parallels horizon A (fig. 6.18). The profile also suggests that the apparent erosional surface of horizon $A$ crops out at or near the coastline. Horizon B, which is not shown, also crops out near the coastline on some seismic records. These data suggest that sediments deposited onshore during or after those sediments forming horizons A and B offshore must be very thin and must thicken seaward as they approach the inner Beaufort Sea shelf. The sediments at the seafloor of the inner shelf are being actively incised and eroded by ice gouging, which has left what appears to be an area of nondeposition or erosion. Therefore, much of the sediment that was deposited on the inner shelf after the deposition of horizons $\mathrm{A}$ and $\mathrm{B}$ has been removed from the area. One might conclude that minimal amounts of sediment are being deposited on land, that much of the sedimentary material introduced onto the inner shelf is trapped in lagoons, and that any sedimentary material that does reach the inner shelf bypasses it in this area. The profiles and the minimal 
modern sediment accumulations suggest that some of the land features on the coastal plain may, in fact, be old erosional remnants associated with the formation of horizons $\mathrm{A}$ and $\mathrm{B}$.

The land gradient of profile B is more closely parallel to that of the seafloor than to the gradient of horizon A. This observation can readily be explained by the suggestion that the large fan through which this profile passes is a young feature that is actively passing fine-grained sediments toward the Beaufort Sea shelf. If the fanlike structure did not exist, the gradient of horizon $A$ and that of the bedrock underlying the fan surface would be more closely identical, as is the case in profile A.

The 4-minute gradient in profile $B$ reflects the depression or embayment on horizon A (fig. 6.16). The 17-minute gradient of horizon A in this profile compared with the 13-minute gradient in profile A clearly reflects the influence on horizon A of the nearby Brooks Range.

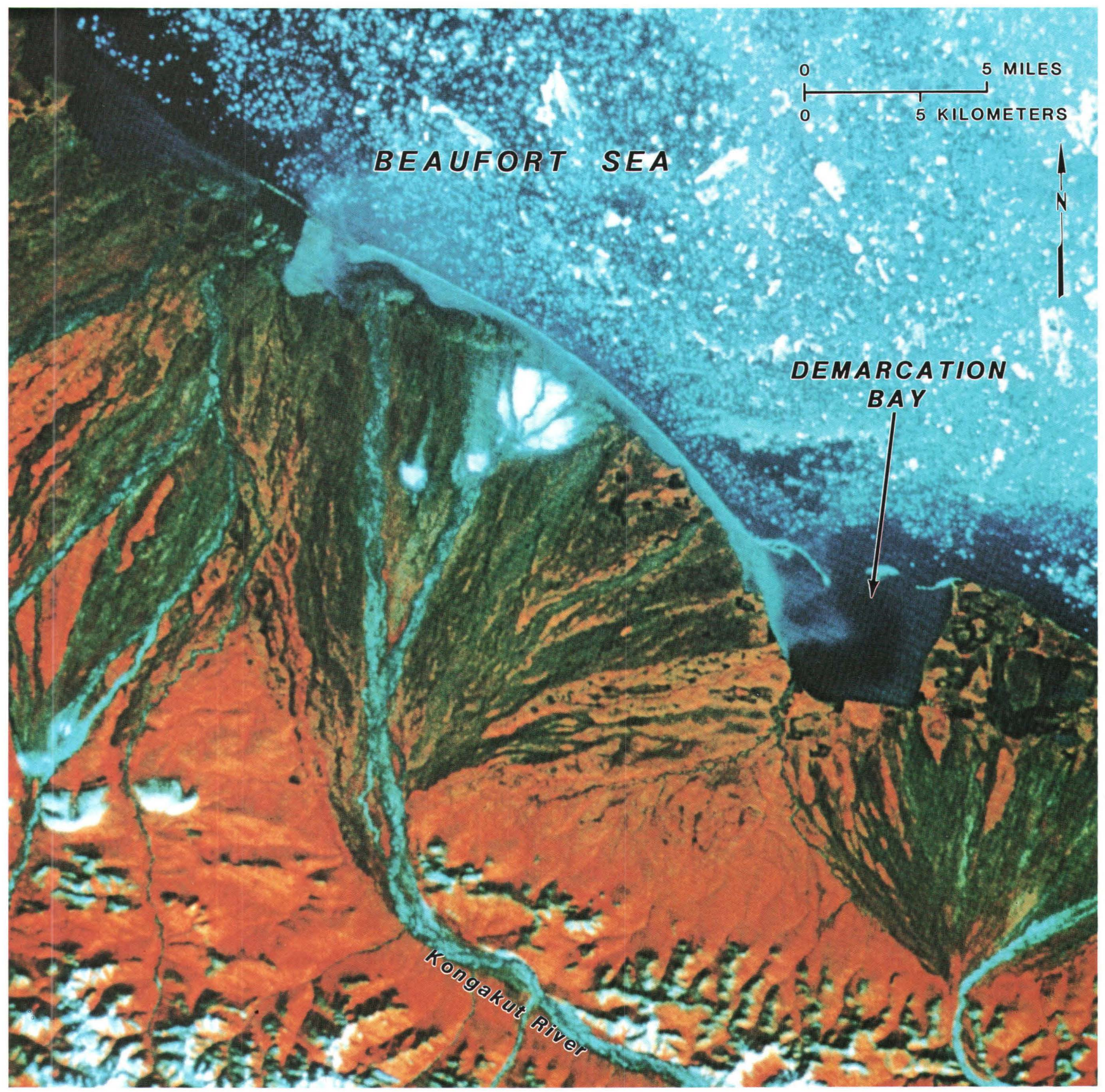

Figure 6.14. Landsat imagery of Demarcation Bay area showing coastline characteristics and adjacent alluvial fans. 


\section{INTERPRETATION AND CONCLUSIONS}

The geometry, depths to horizons A and A', and acoustic sediment sequences above $\mathrm{A}$ and $\mathrm{A}^{\prime}$ to the seafloor (particularly from Barter Island to Demarcation Bay) are similar to features and units described for the area between the Canning River and Prudhoe Bay (Wolf and others, 1985); therefore, the two areas described in this report are thought to have a similar geologic history. In these areas, the sedimentary units are typically composed of deltaic and fluvial outwash materials, both on land and near the coast. These sediments grade into marine fine-grained sediments at the coast and offshore (fig. 6.19).

In the area between the Canning River and Demarcation Bay, terrestrial deposits locally have prograded out onto the shelf, interfingered with marine deposits, and been subjected to two erosional cycles represented by (1) horizon $\mathrm{A}^{\prime}$ and its counterpart horizon A, and (2) horizon B. The seafloor off these areas, like that off the Canning River-Prudhoe Bay area, may also be interpreted as a present-day erosional surface with little or no Holocene deposition.

Fan deltas are described as being alluvial fans that prograde into a standing body of water from an adjacent highland. They are characterized by gravelly, proximal, braided-stream deposits that grade seaward into

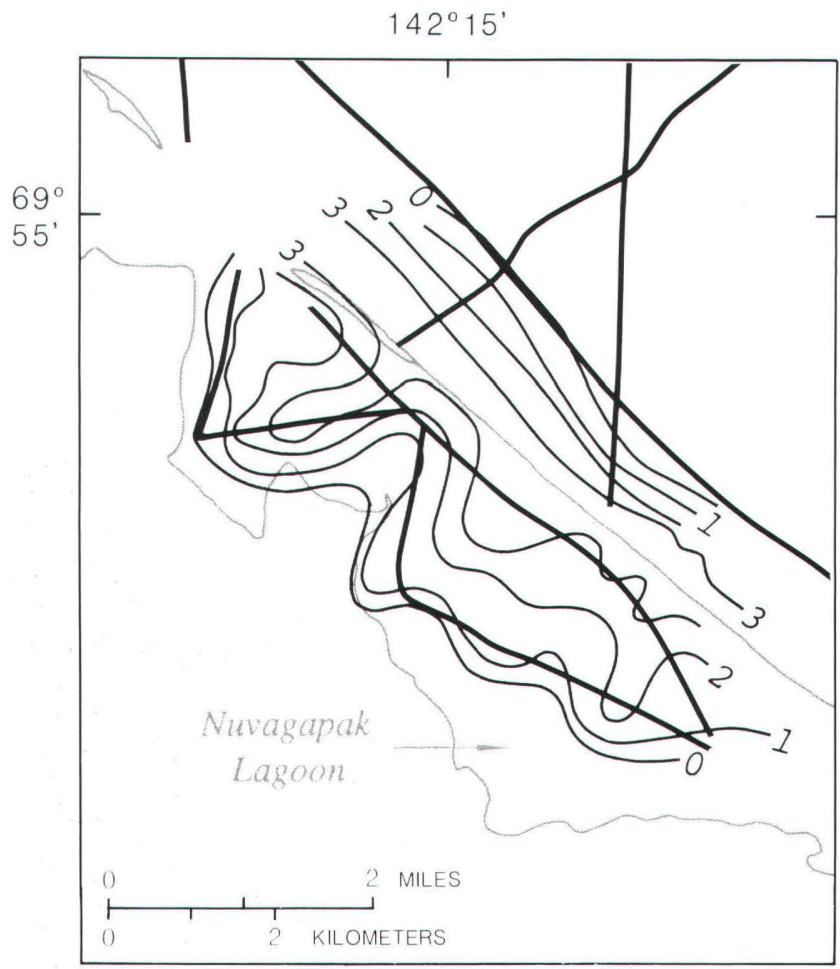

Figure 6.15. Tracklines and thickness of Holocene(?) sediments (in meters) in Beaufort Lagoon, particularly Nuvagapak Lagoon (see fig. 6.1). sandy, distal, braided-stream deposits, into welllaminated sands of the beach-nearshore zone, and finally into burrowed shoreface muds (Wescott and Ethridge, 1980). USGS sediment samples taken from the fanlike structures alongshore and offshore west of Demarcation Bay show gravel barrier islands and nearshore muddy gravels. These sediments grade laterally into clean and muddy sands with pebbles offshore and to sandy mud and soft mud farther offshore. The steep gradient of the fan, the close proximity of the Brooks Range, and the presence of sedimentary textures and structures diagnostic of fan deltas suggest that the large fanlike structure near Demarcation Bay is in fact a fan delta, as described in the literature.

The proximal positions of horizons $\mathrm{A}$ and $\mathrm{A}^{\prime}$ relative to the present-day coastline, their seaward gradient, their depth below sea level, and their relationship to the present-day adjacent land surface all suggest that these horizons may be similar in age and description to surface 3 of Wolf and others (1985) in the Canning River-Prudhoe Bay area.

Horizon A north of Barter Island (fig. 6.16) projects into the offshore sediment sequence described by Grantz and others (1983) as middle and late Pleistocene in age. Borehole data from the Canning River-Prudhoe Bay area suggest that the age of surface 3 is approximately 250 ka (Peggy Smith, U.S. Geological Survey, oral commun., 1984). If we assume that the similarities between horizons $\mathrm{A}, \mathrm{A}^{\prime}$ and surface 3 hold true, these data suggest that horizons $\mathrm{A}$ and $\mathrm{A}^{\prime}$ are middle and late Pleistocene in age.

Likewise, for the same reasons horizon B correlates with surface 4 of Wolf and others (1985) (fig. 6.19) in the Canning River-Prudhoe Bay area. From borehole studies in the western part of that area, surface 4 has an apparent age of 125 ka (Peggy Smith, oral commun., 1984).

A summary of findings of this report is as follows:

(1) By projection of acoustic reflectors onshore, it appears that the Arctic coastal plain in this region may actually be an old surface composed largely of erosional remnants masked by thin Holocene(?) sediments, including those that form the fan delta near Demarcation Bay.

(2) The inner shelf appears to be an erosional surface where sealed outcrops have progradational and inner-shelf marine depositional histories of pre-Holocene age; this surface is presently being subjected to widespread ice gouging.

(3) The inner shelf may contain records of sediments no older than horizon A (250 ka).

(4) Horizon A and the sediments above it have been uplifted and eroded by recent tectonic activity northwest of Barter Island. 
(5) Horizon A ( $250 \mathrm{ka})$ and horizon B ( 125 $\mathrm{ka})$ record lower sea-level stands and the development of unconformities on the inner shelf.

(6) Post-horizon B sediments reach a maximum thickness of $15 \mathrm{~m}(50 \mathrm{ft})$, but the age of the youngest sediments is unknown.

(7) Holocene sediments are believed to be restricted to nearshore barrier islands and lagoons, and those sediments that are presently being introduced onto the inner shelf are bypassing the area.

(8) Offshore ridges are mostly erosional remnants possibly left from subaerial erosion from the last sea-level lowstand. Some ridges in Camden Bay are constructional and appear to be moving shoreward.

(9) Few occurrences of gas-charged sediments were noted. The largest accumulations were in two areas north of Demarcation Bay on the inner shelf.

$142^{\circ}$

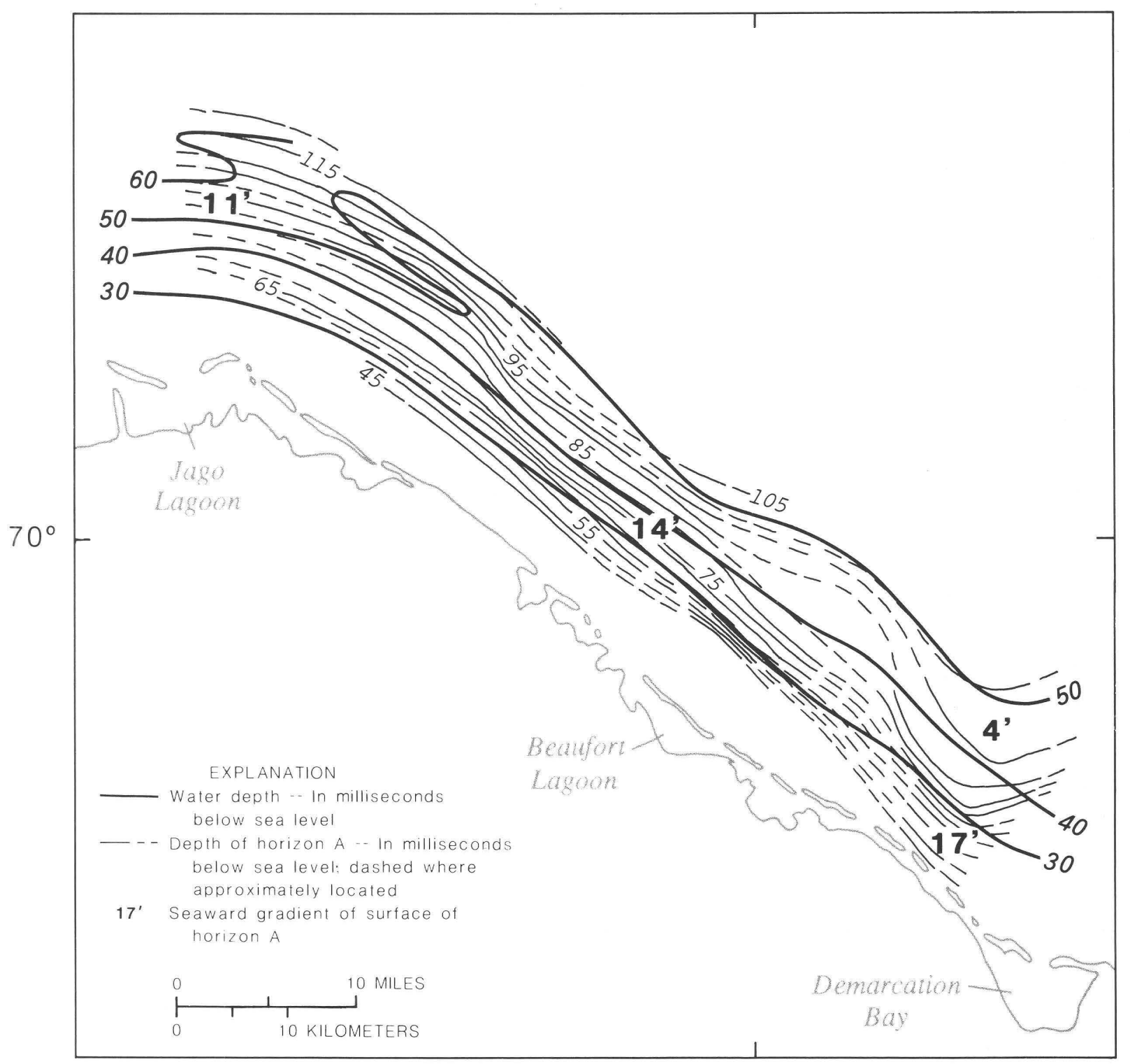

Figure 6.16. Areal distribution and depth below sea level of horizon A between Jago Lagoon and Demarcation Bay (see fig. 6.1). 


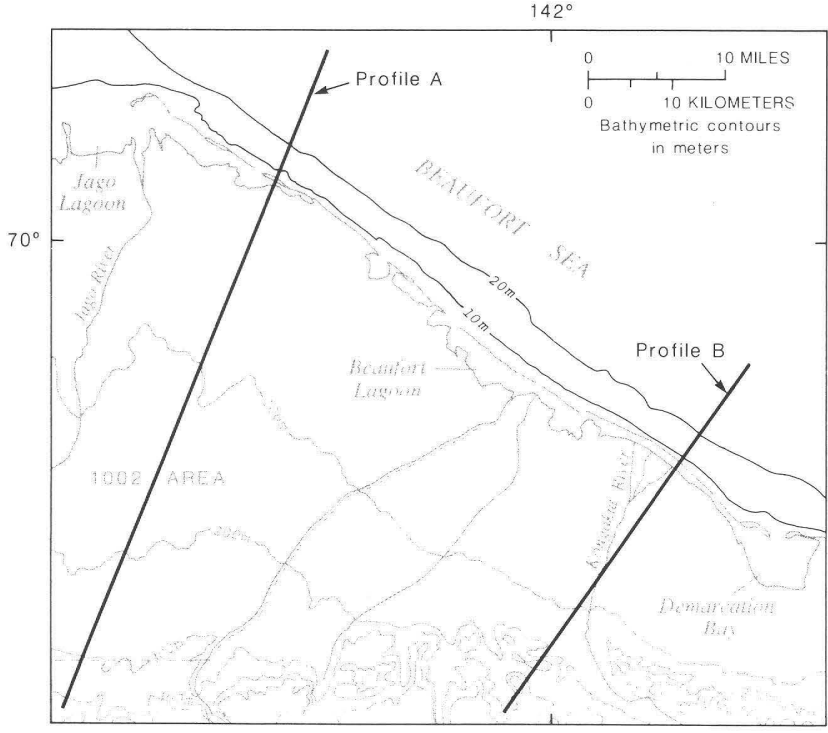

Figure 6.17. Location and orientation of profiles A and B between Jago Lagoon and Demarcation Bay (see fig. 6.1).
SOUTHWEST
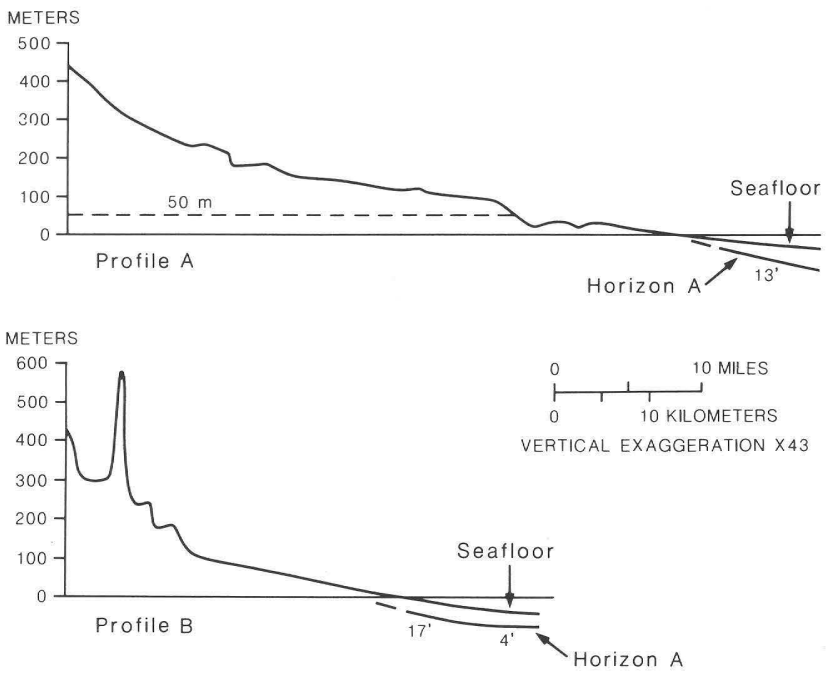

Figure 6.18. Profiles $A$ and $B$, showing topographic gradient and its relation to horizon A. Seaward gradient (in minutes) is shown for surface of horizon A.

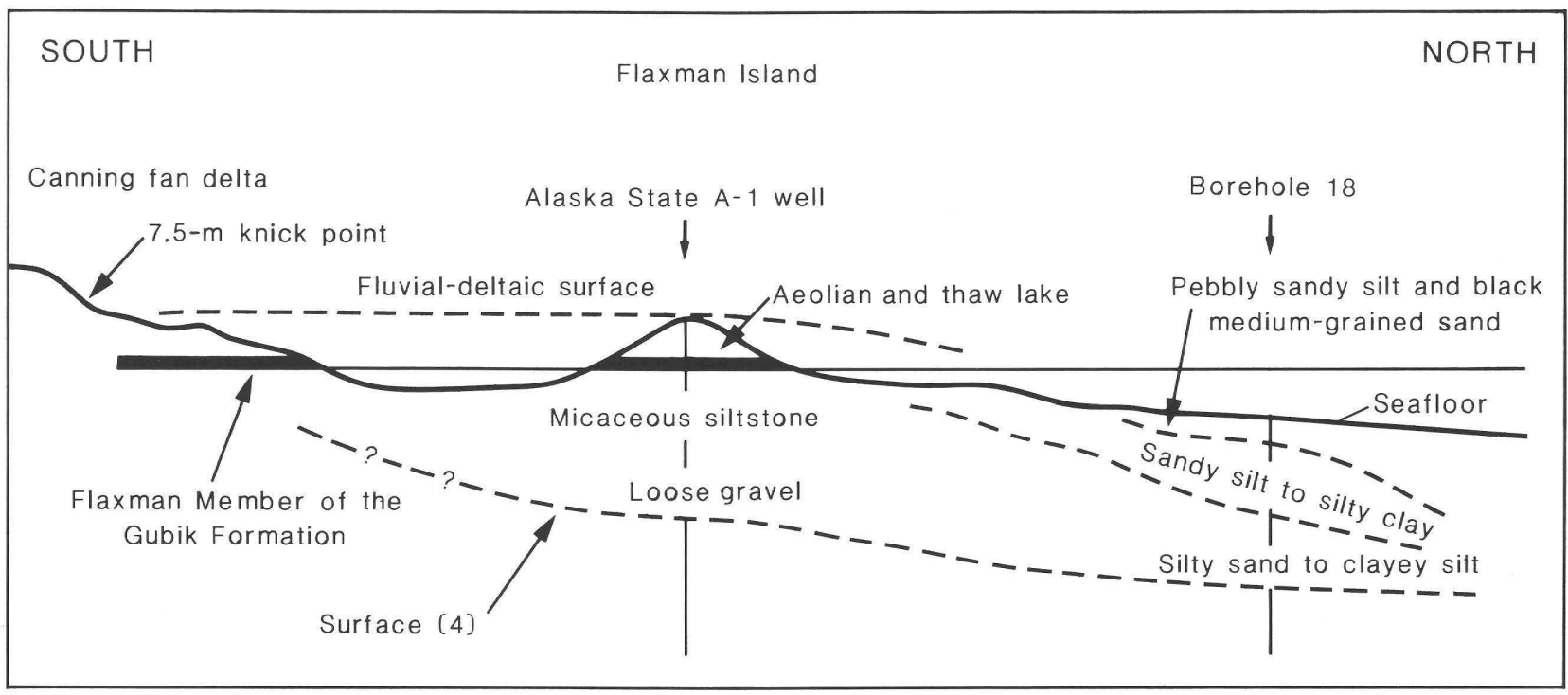

Figure 6.19. Schematic cross section from Canning River fan delta through Flaxman Island to borehole 18 (see fig. 6.1). Modified from Wolf and others (1985). Surface (4) refers to an erosional unconformity that is 125,000 years old. 


\title{
Chapter 7.
}

\section{Petroleum Reservoir Rocks}

\author{
By Kenneth J. Bird, ${ }^{1}$ Sarah B. Griscom, ${ }^{2}$ Susan Bartsch-Winkler, ${ }^{3}$ and Dennis M. Giovannetti ${ }^{4}$
}

\section{INTRODUCTION}

Potential petroleum reservoir rocks in the Arctic National Wildlife Refuge (ANWR) coastal plain may consist of both sandstone and carbonate rocks. This paper summarizes the areal distribution, thickness, composition, porosity, and permeability of these rocks in outcrops and nearby wells. The distribution and characteristics of these rocks in the ANWR subsurface are inferred from seismic interpretation and by projection of regional trends.

Rock units of the Ellesmerian sequence are the reservoirs for all currently productive North Slope oil fields. Therefore, the determination of the areal distribution of potential Ellesmerian reservoir rocks beneath the coastal plain is a most important aspect of this study. Most Ellesmerian rocks may only be present (1) in the southernmost parts of the coastal plain along the so-called Lower Cretaceous unconformity truncation edge, (2) beneath the coastal plain in thrust slices transported from the south, or (3) in areas downfaulted prior to Early Cretaceous erosion. Structural complexity commonly obscures these relations on seismic records, and distant well control leaves much uncertainty about the distribution of these rocks. Regional trends of the truncated edges of the Ellesmerian formations are shown in figure 7.1. Some of these edges can be approximately located in the ANWR outcrops, but their trend is probably shifted northward by an undetermined amount of tectonic transport (chap. 20).

Because of truncation by the Lower Cretaceous unconformity, the potential reservoir rocks most likely to occur in the coastal plain are intrabasement carbonate rocks and sandstones, the Kemik Sandstone, turbidite sandstones in the Canning Formation, and deltaic sandstones in the Sagavanirktok and Jago River Formations. Ellesmerian reservoir rocks are expected to occur at least in the southern parts of the coastal plain, but their northern limits are difficult to map. By analogy with the Point Thomson area northwest of the coastal

\footnotetext{
${ }^{1}$ U.S. Geological Survey, Menlo Park, Calif.

2 U.S. Geological Survey, Woods Hole, Mass.

${ }^{3}$ U.S. Geological Survey, Reston, Va.

${ }^{4}$ ARCO Oil and Gas, Inc. Bakersfield, Calif.
}

plain, all potential reservoirs but the deltaic sandstones may be overpressured.

Data for this evaluation of potential reservoir rocks were obtained from published and unpublished sources as well as from our own analyses. Stratigraphic thicknesses, summarized in table 7.1, are from measured outcrop sections and well penetrations. Porosity and permeability, determined from well logs, laboratory measurements, and visual estimates, are summarized in table 7.2. Significant test results from nearby wells and known oil and gas accumulations are also summarized to provide information on reservoir quality (table 7.3). Many of these tests are also plotted on the well correlation sections in plate 1. Each potential reservoir unit is described below, ordered from oldest to youngest.

\section{BASEMENT COMPLEX}

Potential reservoir rocks in the basement complex of the ANWR coastal-plain area may be carbonate rocks and calcareous sandstones. These rocks are exposed in the mountains south of the coastal plain and are penetrated by wells west of the ANWR (fig. 7.2). In the Sadlerochit and Shublik Mountains, limestone and vuggy dolomite of the Nanook Limestone, Katakturuk Dolomite, and unnamed rocks have a total thickness of more than 1,830 m (6,000 ft) (Dutro, 1970). Elsewhere in outcrop, carbonate rocks are much thinner and are commonly interbedded with clastic or volcanic rocks (Dutro and others, 1972). In the subsurface, vuggy dolomite (presumed to be the Katakturuk Dolomite) is present in the lower $199 \mathrm{~m}(654 \mathrm{ft})$ of the Canning River Unit A-1 well (pl. 1), whereas carbonate rocks several hundred feet thick with minor amounts of quartzite were penetrated in wells in the Point Thomson area (fig. 7.3). Limestone and dolomite are most common in those wells located on the barrier islands north of Point Thomson, although argillite and minor amounts of limestone and chert are encountered in wells located onshore in the Point Thomson area.

The basement rocks on seismic records in the western part of the coastal plain show a fair degree of lateral continuity and only moderate deformation (chap. 18). These observations suggest that reservoir-rock units 
within the basement may be identifiable with seismic data. A demonstration of basement-rock continuity may be the occurrence of carbonate rocks about $46 \mathrm{~m} \mathrm{(150 \textrm {ft } )}$ thick that show similar log characteristics in several wells on the barrier islands north of Point Thomson. Similarities in rock type, thickness, and log response suggest that equivalent strata within the basement complex may have been penetrated in the Alaska State A-1, D-1, and F-1 wells (fig. 7.3).

Most primary porosity in carbonate rock and sandstone in the basement complex was destroyed during a long history of deep burial, heating, and deformation. However, secondary porosity may be present in easily leached carbonate rock or in sandstone with carbonate cement (fig. 7.4A). Outcrop samples of the Nanook Limestone and the Katakturuk Dolomite average less than 5 percent porosity and less than 1-millidarcy (md) permeability (table 7.4). Log calculations from subsurface carbonates penetrated by wells also indicate that porosities are generally less than 5 percent, but that some thin intervals have porosities as high as 25 percent (for example, see figure 7.3 in which low-resistivityreading dolomites of test interval three are calculated to have 20-25 percent porosity). Fractures, which are reported in most basement complex cores, should provide greater permeabilities than those indicated by routine analysis.

Gas and condensate have been recovered from basement rocks in the Alaska Island-1 and Alaska State F-1 wells on the barrier islands north of Point Thomson. Daily flow rates are calculated to be as much as 2.9 million $\mathrm{ft}^{3}$ of gas and 175 barrels of oil, while other wells have flowed water at rates calculated to be as much as 4,800 barrels per day (table 7.3). Abnormally high pressures are encountered in the basement and overlying rocks in the Point Thomson area.

\section{KEKIKTUK CONGLOMERATE}

Potential reservoir rocks in the Kekiktuk Conglomerate consist of nonmarine sandstone and conglomerate. In outcrops adjacent to the ANWR coastal plain, the Kekiktuk is a resistant, massive quartzite as much as $137 \mathrm{~m}$ (450 ft) thick; in wells it may be as much as $585 \mathrm{~m}(1,920 \mathrm{ft})$ thick. However, it is discontinuous in its occurrence overlying the regional Ellesmerian (Mississippian) unconformity. If present in

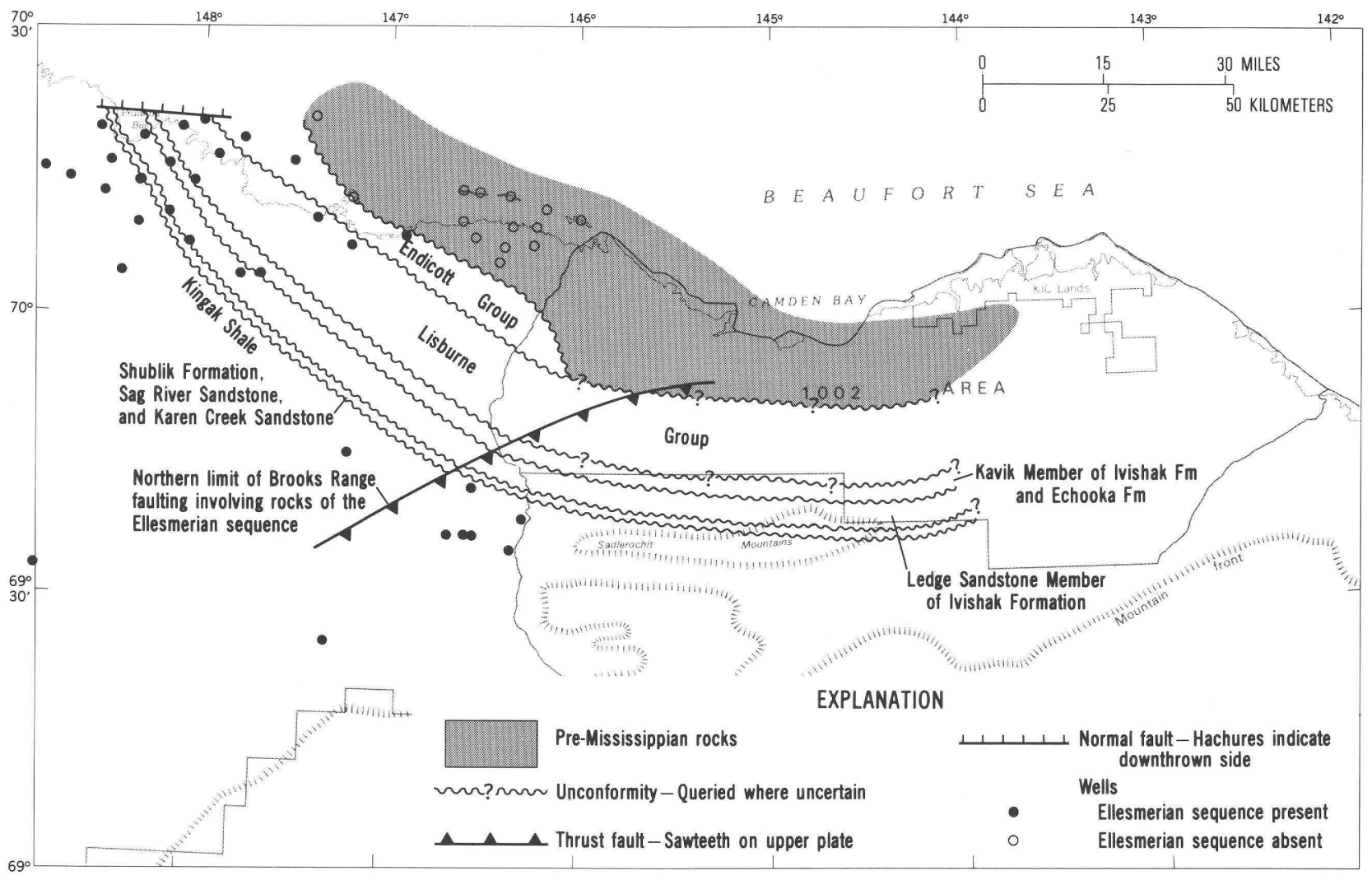

Figure 7.1. Subcrop of the Ellesmerian sequence beneath Lower Cretaceous unconformity in northeastern Alaska. Trends are from Tailleur and others (1978), Jones and Speers (1976), and Van Poollen and Associates and Alaska Division of Oil and Gas (1974) modified by new well information and seismic data (chap. 17). 
the coastal-plain subsurface, the Kekiktuk may be the northernmost of Ellesmerian rock units present beneath the Lower Cretaceous unconformity (figs. 7.1, 7.5).

Sandstone of the Kekiktuk Conglomerate is composed of angular to subangular, medium- to coarsegrained quartz with some chert and rare plagioclase. Matrix and cement consist of quartz silt, quartz overgrowths, sericite, and pyrophyllite. Secondary quartz overgrowths are locally abundant, and interpenetrating grain boundaries are common (Reed and Hemley, 1966; Reed, 1968; fig. 7.4B).

Log-calculated porosities are uniformly less than 5 percent in the Canning River Unit A-1 and Kavik-1 wells. No hydrocarbons were indicated in the Kekiktuk Conglomerate in these wells. However, in the Endicott field near Prudhoe Bay, estimated to contain 375 million barrels of recoverable oil, the Kekiktuk reservoir has diagenetically enhanced average porosities of 18 to 22 percent and permeabilities of 500 to $1,000 \mathrm{md}$ (Behrman and others, 1985). The occurrence of tightly cemented sandstone (quartzite) in outcrops and of porous and permeable sandstone near Prudhoe Bay suggests a possible northward trend of improvement in the Kekiktuk reservoir quality. This improvement may be related to a combination of lesser burial and more favorable conditions for producing secondary porosity in the north.

\section{LISBURNE GROUP}

Potential reservoir rocks in the Lisburne Group consist of dolomite and limestone. In outcrops and wells adjacent to the ANWR coastal plain, the Lisburne Group consists of 430 to $855 \mathrm{~m}(1,400$ to $2,800 \mathrm{ft})$ of Late Mississippian to Middle Pennsylvanian platform carbonate rocks in which dolomite is most common in the Late Mississippian part (figs. 7.6, 7.7, table 7.1). Bird and Jordan (1977) show that in the subsurface west of the ANWR, Lisburne dolomites may have fair to good porosity and that limestones have generally low porosity.

Adjacent to the ANWR coastal plain, dolomite in the Lisburne occurs in beds ranging from less than 1.5 $\mathrm{m}(5 \mathrm{ft})$ thick to massive intervals as much as $21 \mathrm{~m} \mathrm{(70}$ $\mathrm{ft})$ thick and may constitute as much as $183 \mathrm{~m} \mathrm{(600} \mathrm{ft)}$ of the group (fig. 7.7; Armstrong and Mamet, 1977; Wood and Armstrong, 1975). Eight sections adjacent to the ANWR coastal plain (fig. 7.7) show that Lisburne dolomites vary in thickness, amount, and stratigraphic position. These observations suggest that dolomite in the ANWR coastal plain is probably erratic in occurrence with poor lateral continuity.

Porosity in the Lisburne in outcrops and wells adjacent to the coastal plain is best developed in microcrystalline (crystal size less than $30 \mu \mathrm{m}$ ) dolomite. The porosity is intercrystalline or occurs as small, millimeter-size vugs produced by the leaching of fossil fragments (fig. 7.4C). Sedimentary structures, accessory minerals, and microfauna suggest that the microcrystalline dolomite is of early diagenetic origin in an intertidal to supratidal environment. Analysis of Lisburne porosity, based on bulk-density measurements of outcrop samples and acoustic log calculations in wells, shows that not all dolomite is porous; in fact, most dolomite is of low ( $<5$ percent) porosity, but some relatively thin intervals have as much as 20 percent porosity. Outcrop sample porosities (table 7.5) show similar values and distribution when compared with logcalculated porosities in wells (fig. 7.7). Although no permeability measurements have been made, fractures are common in the Lisburne Group and should enhance its effective permeability.

Indications of oil in the Lisburne Group adjacent to the ANWR coastal plain are relatively rare. A few occurrences of dark bitumen (dead oil) are recorded on well logs and have been observed in petrographic thin sections of vuggy dolomite 274 to $396 \mathrm{~m}$ (900 to 1,300 $\mathrm{ft}$ ) below the top of the Lisburne in the eastern Sadlerochit Mountains (figs. 7.4C, 7.7). Oil and gas in the Lisburne is reported from a number of wells west of the ANWR, including the Lisburne oil field (Bird and Jordan, 1977). ARCO Alaska, Inc., reports that the Lisburne field contains about 3 billion barrels of in-place oil and 3 trillion $\mathrm{ft}^{3}$ of in-place gas. Porosity in the Lisburne field reportedly averages about 10 percent and matrix permeability ranges from 0.1 to 2 md (Alaska Oil and Gas Conservation Commission, 1984).

\section{IVISHAK FORMATION}

Potential reservoir rocks in the Ivishak Formation are sandstones, the most abundant of which occur in the Ledge Sandstone Member. The Ledge, which thickens and coarsens northward, is composed of massive, thickly bedded sandstone and conglomeratic sandstone. In wells and outcrops adjacent to the ANWR coastal plain, the Ledge Sandstone Member ranges in thickness from 30 to $175 \mathrm{~m}$ (100 to $575 \mathrm{ft}$ ) (fig. 7.8). Erosion beneath the Lower Cretaceous unconformity has removed the upper part of the Ledge along the north flank of the Sadlerochit Mountains.

In outcrops and wells adjacent to the ANWR coastal plain, the Ledge Sandstone Member is generally a well-sorted, very fine grained to medium-grained, silica-cemented quartzose sandstone that contains as much as 20 percent chert clasts according to Marinai (chap. 8). He reports that other cements include siderite, pyrite, calcite, chlorite, and kaolinite. Petrographic analysis by Cloft (1984) of 94 samples from 5 localities south of the ANWR coastal plain shows that Ledge detrital sand grains are composed of quartz and chert (83 to 100 percent; avg 91 percent), feldspar ( 0 to 4 percent; 
Table 7.1. Summary of thickness determinations for selected stratigraphic units in northeastern Alaska

\begin{tabular}{lrrr}
\hline \multicolumn{1}{c}{$\begin{array}{c}\text { Well or } \\
\text { measured section }\end{array}$} & $\begin{array}{c}\text { Location } \\
\text { Sec--T.-R. }\end{array}$ & $\begin{array}{c}\text { Thickness } \\
\text { (ft) }\end{array}$ & $\begin{array}{c}\text { Data } \\
\text { source }\end{array}$ \\
\hline Sagavanirktok Formation * \\
Beli Unit-1 & $8-4 \mathrm{~N}-23 \mathrm{E}$ & 6,280 & 1 \\
Canning River Unit B-1 & $32-4 \mathrm{~N}-24 \mathrm{E}$ & 3,300 & 1 \\
East Mikkelsen Bay State-1 & $7-9 \mathrm{~N}-21 \mathrm{E}$ & 8,530 & 1 \\
Mikkelsen Bay State 13-9-19 & $13-9 \mathrm{~N}-19 \mathrm{E}$ & 8,400 & 1 \\
Challenge Island-1 & $8-10 \mathrm{~N}-22 \mathrm{E}$ & 5,865 & 1 \\
Alaska Island-1 & $11-10 \mathrm{~N}-22 \mathrm{E}$ & 5,830 & 1 \\
Alaska State F-1 & $17-10 \mathrm{~N}-23 \mathrm{E}$ & 6,895 & 1 \\
Alaska State C-1 & $16-9 \mathrm{~N}-23 \mathrm{E}$ & 8,725 & 1 \\
Point Thomson Unit-1 & $32-9 \mathrm{~N}-23 \mathrm{E}$ & 8,810 & 1 \\
Point Thomson Unit-2 & $3-9 \mathrm{~N}-22 \mathrm{E}$ & 8,560 & 1 \\
Point Thomson Unit-3 & $34-10 \mathrm{~N}-23 \mathrm{E}$ & 8,545 & 1 \\
Point Thomson Unit-4 & $32-10 \mathrm{~N}-22 \mathrm{E}$ & 8,595 & 1 \\
Alaska State A-1 & $27-10 \mathrm{~N}-24 \mathrm{E}$ & 7,600 & 1 \\
West Mikkelsen State-1 & $32-10 \mathrm{~N}-19 \mathrm{E}$ & 8,400 & 1 \\
Alaska State D-1 & $23-10 \mathrm{~N}-23 \mathrm{E}$ & 7,205 & 1 \\
West Staines 18-9-23 & $18-9 \mathrm{~N}-23 \mathrm{E}$ & 8,580 & 1 \\
West Staines State-2 & $25-9 \mathrm{~N}-22 \mathrm{E}$ & 8,490 & 1 \\
Carter Creek & $7 \mathrm{~N}-30 \mathrm{E}$ & $\sim 5,000$ & 2 \\
West Kavik Unit-1 & $20-5 \mathrm{~N}-20 \mathrm{E}$ & 8,700 & 1 \\
Nora Federal-1 & $5-2 \mathrm{~N}-16 \mathrm{E}$ & 7,800 & 1 \\
Lake 79 & $1-8 \mathrm{~N}-17 \mathrm{E}$ & 8,100 & 5 \\
Kadler-1 & $15-9 \mathrm{~N}-16 \mathrm{E}$ & 7,500 & 5 \\
Term Island Y-0196 & $26-11 \mathrm{~N}-18 \mathrm{E}$ & 8,000 & 1 \\
\hline & Jago River Formation & & \\
\hline Sabbath Creek & $3 \mathrm{~N} \mathrm{\&} \mathrm{4N-35E}$ & 11,000 & 3 \\
Sabbath Creek & $3 \mathrm{~N} \& 4 \mathrm{~N}-35 \mathrm{E}$ & 9,387 & 4 \\
\hline
\end{tabular}

Turbidite sandstones in the Canning Formation

Beli Unit-1
Canning River Unit B-1

East Mikkelsen Bay State-1

Alaska Island-1

Alaska State F-1

Alaska State C-1

Alaska State A-1

Alaska State D-1

Point Thomson Unit-1

Point Thomson Unit-2

Point Thomson Unit-3

Point Thomson Unit-4

West Staines 18-9-23

West Staines State-2

\begin{tabular}{lrrr} 
West Staines State-2 & $25-9 \mathrm{~N}-22 \mathrm{E}$ & 74 & 1 \\
\hline & Kemik Sandstone & & \\
\hline Upper Echooka River & $36-1 \mathrm{~S}-18 \mathrm{E}$ & 85 & 6 \\
Upper Shaviovik River & $24-1 \mathrm{~S}-20 \mathrm{E}$ & $>30$ & 6 \\
Fin Creek & $26-1 \mathrm{~N}-21 \mathrm{E}$ & $>110$ & 6 \\
Section 15 & $34,35-1 \mathrm{~N}-23 \mathrm{E}$ & $>5$ & 6 \\
West side Canning River & $6-1 \mathrm{~N}-24 \mathrm{E}$ & $>30$ & 6 \\
West bank Canning River & $30-2 \mathrm{~N}-24 \mathrm{E}$ & $>100$ & 6 \\
Ignek Creek & $27-3 \mathrm{~N}-25 \mathrm{E}$ & 65 & 6 \\
East end Sadlerochit Mts. & $11-3 \mathrm{~N}-31 \mathrm{E}$ & 35 & 6 \\
Ignek Valley & $5,6-2 \mathrm{~N}-26 \mathrm{E}$ & 90 & 6 \\
Bathtub Ridge & $8-4 \mathrm{~S}-41 \mathrm{E}$ & 260 & 3 \\
Ignek Mesa & $5-2 \mathrm{~N}-28 \mathrm{E}$ & $>130$ & 7 \\
Ignek Valley traverse & $26,27-3 \mathrm{~N}-26 \mathrm{E}$ & $>40$ & 8 \\
Ignek Valley loc. 19 & $3-2 \mathrm{~N}-27 \mathrm{E}$ & $>73$ & 8
\end{tabular}

Table 7.1. Summary of thickness determinations for selected stratigraphic units in northeastern AlaskaContinued

\begin{tabular}{|c|c|c|c|}
\hline $\begin{array}{c}\text { Well or } \\
\text { measured section }\end{array}$ & $\begin{array}{l}\text { Location } \\
\text { Sec.-T.-R. }\end{array}$ & $\begin{array}{l}\text { Thickness } \\
\text { (ft) }\end{array}$ & $\begin{array}{r}\text { Data } \\
\text { source }\end{array}$ \\
\hline \multicolumn{4}{|c|}{ Kemik Sandstone - Continued } \\
\hline Canning River Unit A-1 & $19-3 N-24 E$ & 45 & 1 \\
\hline Beli Unit-1 & $8-4 \mathrm{~N}-23 \mathrm{E}$ & 40 & 5 \\
\hline Canning River Unit B-1 & $32-4 N-24 E$ & 35 & 5 \\
\hline West Kavik Unit-1 & $20-5 \mathrm{~N}-20 \mathrm{E}$ & 0 & 5 \\
\hline Kavik-1 & $7-3 N-23 E$ & 30 & 5 \\
\hline Kavik Unit-2 & $11-3 N-22 E$ & 35 & 5 \\
\hline Kavik Unit-3 & $8-3 N-23 E$ & 25 & 5 \\
\hline Kemik-1 & $17-1 \mathrm{~N}-20 \mathrm{E}$ & 290 & 5 \\
\hline Fin Creek-1 & $25-2 \mathrm{~N}-18 \mathrm{E}$ & 160 & 5 \\
\hline Echooka-1 & $32-1 N-16 E$ & 180 & 5 \\
\hline Nora Federal-1 & $5-2 \mathrm{~N}-14 \mathrm{E}$ & 100 & 5 \\
\hline \multicolumn{4}{|c|}{$\begin{array}{ll}\text { Thomson sand } \\
\end{array}$} \\
\hline East Mikkelsen Bay State-1 & $7-9 \mathrm{~N}-21 \mathrm{E}$ & 85 & 1 \\
\hline Mikkelsen Bay State 13-9-19 & $13-9 \mathrm{~N}-19 \mathrm{E}$ & 55 & 5 \\
\hline Challenge Island-1 & $8-10 \mathrm{~N}-22 \mathrm{E}$ & 50 & 1 \\
\hline Alaska Island-1 & $11-10 \mathrm{~N}-22 \mathrm{E}$ & 0 & 1 \\
\hline Alaska State F-1 & $17-10 \mathrm{~N}-23 \mathrm{E}$ & 35 & 1 \\
\hline Alaska State C-1 & $16-9 \mathrm{~N}-23 \mathrm{E}$ & 280 & 1 \\
\hline Point Thomson Unit-1 & $32-9 \mathrm{~N}-23 \mathrm{E}$ & 332 & 1 \\
\hline Point Thomson Unit-2 & $3-9 \mathrm{~N}-22 \mathrm{E}$ & 125 & 1 \\
\hline Point Thomson Unit-3 & $34-10 N-23 E$ & 265 & 1 \\
\hline Point Thomson Unit-4 & $32-10 \mathrm{~N}-22 \mathrm{E}$ & 80 & 1 \\
\hline \multicolumn{4}{|c|}{ Karen Creek Sandstone +} \\
\hline Karen Creek & $11-1 S-30 E$ & 70 & 9 \\
\hline Aichilik River & $16-2 N-37 E$ & 100 & 10 \\
\hline Hula Hula River & $31-2 N-32 E$ & 135 & 10 \\
\hline Fire Creek & $11-2 \mathrm{~N}-28 \mathrm{E}$ & 20 & 7 \\
\hline South side Ignek Valley & $6-2 \mathrm{~N}-26 \mathrm{E}$ & 60 & 7 \\
\hline Beli Unit-1 & $8-4 N-23 E$ & 20 & 1 \\
\hline Canning River Unit A-1 & $19-3 \mathrm{~N}-24 \mathrm{E}$ & 36 & 1 \\
\hline Canning River Unit B-1 & $32-4 \mathrm{~N}-24 \mathrm{E}$ & 32 & 1 \\
\hline West Kavik Unit-1 & $20-5 \mathrm{~N}-20 \mathrm{E}$ & 15 & 1 \\
\hline Kavik-1 & $7-3 N-23 E$ & 30 & 1 \\
\hline Kavik Unit-2 & $11-3 N-22 E$ & 42 & 1 \\
\hline Kavik Unit-3 & $8-3 N-23 E$ & 40 & 1 \\
\hline
\end{tabular}

Ledge Sandstone Member of the Ivishak Formation

Canning River Unit A-1 19-3N-24E

Beli Unit-1

Canning River Unit B-1

$8-4 \mathrm{~N}-23 \mathrm{E}$

West Kavik Unit-1

Kavik Unit-2

Kavik Unit-3

Marsh Creek tributary

Westend Sadlerochit

Southside Sadlerochit

$32-4 \mathrm{~N}-24 \mathrm{E}$

$20-5 \mathrm{~N}-20 \mathrm{E}$

$11-3 \mathrm{~N}-22 \mathrm{E}$

$8-3 \mathrm{~N}-23 \mathrm{E}$

$19-4 \mathrm{~N}-30 \mathrm{E}$

$24-3 \mathrm{~N}-25 \mathrm{E}$

$36-3 \mathrm{~N}-28 \mathrm{E}$

$15-2 \mathrm{~N}-28 \mathrm{E}$

$18-1 \mathrm{~N}-31 \mathrm{E}$

29-1N-28E

Kikiktat Mountain

Eagle Creek

Pogopuk Creek

Upper Sadlerochit River

34-1S-23E

28-1S-28E

9-5S-22E

Marsh Fork Canning River

$19-4 \mathrm{~S}-26 \mathrm{E}$

$12-1 \mathrm{~N}-25 \mathrm{E}$

$\begin{array}{rl}350 & 1 \\ 470 & 1 \\ 422 & 1 \\ 575 & 1 \\ 336 & 1 \\ 326 & 1 \\ 190 & 7 \\ >155 & 7 \\ <375 & 7 \\ 390 & 7 \\ 375 & 7 \\ 180 & 7 \\ 140 & 7 \\ 190 & 7 \\ 100 & 7 \\ 165 & 7 \\ 255 & 7 \\ 205 & 7\end{array}$


Table 7.1. Summary of thickness determinations for selected stratigraphic units in northeastern AlaskaContinued

\begin{tabular}{|c|c|c|c|}
\hline $\begin{array}{c}\begin{array}{c}\text { Well or } \\
\text { measured section }\end{array} \\
\end{array}$ & $\begin{array}{c}\text { Location } \\
\text { Sec.-T.-R. } \\
\end{array}$ & $\begin{array}{c}\text { Thickness } \\
\text { (ft) }\end{array}$ & $\begin{array}{c}\text { Data } \\
\text { source }\end{array}$ \\
\hline \multicolumn{4}{|c|}{ Ledge Sandstone Member of the Ivishak Formation--Continued } \\
\hline Kavik River & $5-2 S-24 \mathrm{E}$ & 300 & 7 \\
\hline Upper Aichilik River & $36-3 S-39 E$ & 180 & 3 \\
\hline Cottonwood Creek & $13-4 S-41 \mathrm{E}$ & 210 & 3 \\
\hline Joe Creek & $21-5 S-45 E$ & $>50$ & 3 \\
\hline Intemational Boundary M-5 & $23-1 N-45 E$ & $>390$ & 3 \\
\hline Egaksrak River & $26-3 N-39 E$ & $>280$ & 3 \\
\hline Aichilik River & $30-2 N-37 E$ & 440 & 3 \\
\hline West Fork Aichilik River & $10-1 S-37 \mathrm{E}$ & 240 & 3 \\
\hline Jago River & $11-1 \mathrm{~N}-35 \mathrm{E}$ & $>130$ & 3 \\
\hline \multicolumn{4}{|c|}{ Lisburne Group } \\
\hline Clarence River & $\begin{array}{r}14-1 \mathrm{~N}-44 \mathrm{E} \\
\text { and } 26-1 \mathrm{~N}-45 \mathrm{E}\end{array}$ & 1,850 & 11 \\
\hline Kongakut River & 21-5S-41E & 2,370 & 11 \\
\hline Egaksrak River \$ & $17-2 \mathrm{~N}-39 \mathrm{E}$ & $-1,500$ & 12 \\
\hline Eastern Sadlerochit Mts. & $7-3 N-31 E$ & 1,700 & 11 \\
\hline Sadlerochit Mountains & $24-3 \mathrm{~N}-27 \mathrm{E}$ & 1,400 & 13 \\
\hline Western Sadlerochit Mts. & $13,24-3 \mathrm{~N}-25 \mathrm{E}$ & 1,450 & 14 \\
\hline Plunge Creek & $\begin{array}{r}36-2 S-24 E \\
\text { and } 19-2 S-25 E\end{array}$ & 2,500 & 14 \\
\hline Marsh Fork & $27,34-3 S-26 E$ & $>2,385$ & 11 \\
\hline Syncline & $7,23-25-3 S-39 \mathrm{E}$ & 2,800 & 11 \\
\hline Ikiakpuk River & $15,22-1 \mathrm{~S}-27 \mathrm{E}$ & 2,100 & 13 \\
\hline Old Man Creek & $23-1 N-32 E$ & 1,400 & 13 \\
\hline Peters Lake & ?-1S-29E & 1,825 & 16 \\
\hline Canning River Unit A-1 & $19-3 N-24 E$ & 2,305 & 5 \\
\hline Beli Unit-1 & $8-4 N-23 E$ & $>2,217$ & 5 \\
\hline Canning River Unit B-1 & $32-4 N-24 E$ & $>1,103$ & 5 \\
\hline West Kavik Unit-1 & $20-5 \mathrm{~N}-20 \mathrm{E}$ & $>2,088$ & 5 \\
\hline Mikkelsen Bay State 13-9-19 & $13-9 \mathrm{~N}-19 \mathrm{E}$ & 1,355 & 5 \\
\hline \multicolumn{4}{|c|}{$\begin{array}{c}\text { Kekiktuk Conglomerate } \\
\end{array}$} \\
\hline Mikkelsen Bay State 13-9-19 & $13-9 \mathrm{~N}-19 \mathrm{E}$ & 1,640 & 5 \\
\hline West Mikkelsen State-1 & $32-10 \mathrm{~N}-19 \mathrm{E}$ & 1,920 & 1 \\
\hline East Mikkelsen Bay State-1 & $7-9 \mathrm{~N}-21 \mathrm{E}$ & 420 & 5 \\
\hline Kavik-1 \& & $7-3 N-23 E$ & $>250$ & 5 \\
\hline Canning River Unit A-1 & $19-3 N-24 E$ & 240 & 5 \\
\hline Clarence River & $14-1 N-44 E$ & 320 & 11 \\
\hline \multirow[t]{2}{*}{ Plunge Creek } & $36-2 S-24 E$ & 30 & 14 \\
\hline & and $19-2 \mathrm{~S}-25 \mathrm{E}$ & & \\
\hline Marsh Fork & $27,34-3 S-26 \mathrm{E}$ & 200 & 11 \\
\hline Okpilak River & $1-1 S-32 E$ & 420 & 15 \\
\hline Section 5 & $27-1 S-29 E$ & $>98$ & 17 \\
\hline Whistler Creek & 28-1S-29E & 295 & 16 \\
\hline 1. This study & \multicolumn{3}{|c|}{ 10. Tourtelot and Tailleur (1971) } \\
\hline 2. Morris (1953) & \multicolumn{3}{|c|}{ 11. Armstrong and Mamet (1975) } \\
\hline 3. Detterman (1984b) & \multicolumn{3}{|c|}{ 12. Armstrong (1972) } \\
\hline 4. Buckingham (1985b) & \multicolumn{3}{|c|}{ 13. Armstrong and Mamet (1977) } \\
\hline 5. Bird (1982) & \multicolumn{3}{|c|}{ 14. Wood and Armstrong (1975) } \\
\hline 6. Molenaar and others (1984) & \multicolumn{3}{|c|}{ 15. Sable (1977) } \\
\hline 7. Detterman (1984a) & \multicolumn{3}{|c|}{ 16. Brosgé and others (1962) } \\
\hline 8. Lyle and others (1980) & \multicolumn{3}{|c|}{ 17. Reed (1968) } \\
\hline \multicolumn{4}{|c|}{ 9. Detterman and others (1975) } \\
\hline \multicolumn{4}{|c|}{$\begin{array}{l}\text { * Thickness may include one or more tongues of Canning Formation. } \\
\text { † Includes subsurface stratigraphic-equivalent Sag River Sandstone. } \\
\$ \text { Modified by estimates of C.M. Molenaar (written commun., 1983). } \\
\text { \& May be a fault-repeated section of Ivishak Formation. }\end{array}$} \\
\hline
\end{tabular}

avg 1 percent), and rock fragments ( 0 to 18 percent; avg 8 percent) (fig. 7.9).

Porosity development in the Ledge Sandstone Member in this area is poor and randomly distributed. Porosity estimates from thin sections and core measurements average about 4 percent, while log calculations average about 7 percent (table 7.2). According to Marinai (chap. 8), the porosity is mostly secondary and primarily due to the dissolution of authigenic siderite; some detrital chert grains are also dissolved. Sandstone textures indicate that siderite formed soon after deposition, and where siderite is dissolved, the precompaction porosity is restored. Because the style of siderite cementation is similar to that found at Prudhoe Bay, similar types of porosity may be found in the ANWR if the conditions for siderite dissolution are present in the subsurface of the coastal plain.

Indications of oil, such as bitumen, are only rarely present in the Ledge Sandstone Member in the area adjacent to the coastal plain. Gas occurs in the Ledge and Sag River Sandstone in the Kavik gas field, about $16 \mathrm{~km}(10 \mathrm{mi})$ southwest of the ANWR coastal plain. In the Prudhoe Bay field, where it is the main oil-producing reservoir, the Ledge displays excellent reservoir characteristics: porosity averages 20 to 30 percent, and permeability ranges from 75 to $4,000 \mathrm{md}$ (Jamison and others, 1980). A large proportion of the porosity in some parts of the reservoir is secondary, the result of leaching of carbonate cements (Melvin and Knight, 1984).

\section{KAREN CREEK SANDSTONE}

Potential reservoir rocks in the Karen Creek Sandstone consist of massively bedded, siliceous quartzose sandstone, which ranges in thickness from 0 to $41 \mathrm{~m}$ ( 0 to $135 \mathrm{ft}$ ) in wells and outcrops adjacent to the ANWR coastal plain (fig. 7.10). The Lower Cretaceous unconformity truncates the Karen Creek Sandstone at the northern edge of the Sadlerochit Mountains. Thus, the Karen Creek Sandstone will probably not occur within most of the subsurface of the coastal plain except possibly on thrust slices brought into the area from the south.

The Karen Creek Sandstone consists of very fine grained sandstone and siltstone composed of angular to well-rounded grains of quartz (45 to 75 percent), chert (10 to 20 percent), and rare plagioclase. Accessory minerals, including phosphate nodules, make up about 5 percent of the rock. The sandstone is primarily cemented with quartz, but calcite, dolomite, and siderite are also reported (Reed, 1968; Detterman and others, 
1975). In the lower part of the formation, where it grades into the underlying Shublik Formation, calcite becomes more abundant and constitutes as much as 10 percent of the rock.

The Karen Creek Sandstone displays low porosity and permeability in wells and outcrops adjacent to the ANWR coastal plain. Log calculations indicate some thin intervals of the Karen Creek may have as much as 15 percent porosity. However, most calculations and a few measurements of core samples show that the average porosity is less than 5 percent and the permeability is less than $1 \mathrm{md}$ (table 7.2).

The subsurface-equivalent of the Karen Creek Sandstone (Sag River Sandstone) is gas bearing in the Kavik gas field, where maximum open-flow rates of as much as 10.5 million $\mathrm{ft}^{3} /$ day of gas have been calculated from test data (table 7.3). It is a minor hydrocarbon reservoir in the Prudhoe Bay field, where porosity values as high as 25 percent and permeability measurements as high as $270 \mathrm{md}$ have been reported (Jamison and others, 1980). In this area, its reservoir quality is improved by mineral leaching near the Lower Cretaceous unconformity (Barnes, 1985).

\section{KEMIK SANDSTONE}

Potential reservoir rocks in this stratigraphic interval include discontinuous bodies of sandstone of local derivation overlying the regional Lower Cretaceous unconformity. Two separate sandstones are known to occur adjacent to the ANWR coastal plain: the Kemik Sandstone and the Thomson sand of local usage. The Kemik Sandstone extends from the east end of the

Table 7.2. Summary of thickness, porosity, and permeability of potential reservoir rocks in and adjacent to the ANWR coastal plain

$[-$, no data $]$

\begin{tabular}{|c|c|c|c|c|c|c|c|c|}
\hline \multirow{2}{*}{$\begin{array}{l}\text { Potential } \\
\text { reservoir } \\
\text { rock }\end{array}$} & \multicolumn{2}{|c|}{$\begin{array}{l}\text { Thickness } \\
\text { (ft) }\end{array}$} & \multirow{2}{*}{$\begin{array}{l}\text { Number of } \\
\text { samples (s) } \\
\text { or wells (w) }\end{array}$} & \multicolumn{2}{|c|}{$\begin{array}{l}\text { Porosity } \\
\text { (pct) }\end{array}$} & \multicolumn{2}{|c|}{$\begin{array}{l}\text { Permeability } \\
\text { (md) }\end{array}$} & \multirow[t]{2}{*}{$\begin{array}{c}\text { Data } \\
\text { source }\end{array}$} \\
\hline & Average & Range & & Average & Range & Average & Range & \\
\hline \multirow[t]{2}{*}{ Sagavanirktok Formation } & 7,555 & $3,300-8,810$ & $17(w)$ & $20-30$ & $5-35$ & - & - & 1,2 \\
\hline & & & $18(s)$ & 17 & $12-23$ & 453 & $2-3,200$ & \\
\hline Jago River Formation & 10,195 & $9,387-11,000$ & $14(s)$ & 4 & $1-6$ & $<1$ & $<1-2$ & $1,2,3$ \\
\hline \multirow[t]{2}{*}{ Canning Formation } & 76 & $0-266$ & $14(w)$ & $12-20$ & $8-28$ & - & - & $1,2,4$ \\
\hline & & & $17(\mathrm{~s})$ & 5 & $<1-11$ & $<1$ & $<1-1$ & \\
\hline \multirow[t]{2}{*}{ Kemik Sandstone } & 80 & $0-290$ & $5(w)$ & 8 & $3-10$ & - & - & 1,2 \\
\hline & & & $20(s)$ & 5 & $1-12$ & 1 & $<1-20$ & \\
\hline Thomson sand & 150 & $0-332$ & $5(w)$ & 16 & $11-25$ & - & $10->1,000$ & 1,4 \\
\hline \multirow[t]{2}{*}{ Karen Creek Sandstone * } & 50 & $0-135$ & $6(w)$ & 5 & $3-10$ & - & - & 1,6 \\
\hline & & & $4(s)$ & $<5$ & $3-5$ & $<1$ & - & \\
\hline Ledge Sandstone & 288 & $100-575$ & $6(w)$ & 7 & $3-15$ & - & - & $1,5,6$ \\
\hline \multirow{2}{*}{$\begin{array}{l}\text { Member of the } \\
\text { Ivishak Formation }\end{array}$} & & & $47(s)$ & $<5$ & $<1-6$ & $<1$ & - & - \\
\hline & & & & & & & & \\
\hline \multirow[t]{2}{*}{ Lisburne Group } & 1,890 & $1,355-2,800$ & $3(w)$ & 10 & $7-19$ & - & - & 1 \\
\hline & & & $89(s)$ & 6.5 & $2-15$ & - & - & \\
\hline Kekiktuk Conglomerate & 610 & $0-1,920$ & $2(w)$ & $<5$ & $1-5$ & - & - & 1 \\
\hline \multirow[t]{2}{*}{ Basement complex } & $>10,000$ & $?$ & $10(w)$ & $<5$ & $1-25$ & - & - & $1,6,7$ \\
\hline & & & $56(s)$ & $<5$ & $1-10$ & $<1$ & $<1-1$ & \\
\hline
\end{tabular}

1. This study

2. Lyle and others (1980)

3. McLean (chap. 10)

4. Gautier (chap. 9)

5. Marinai (chap. 8)

6. Canning River Unit A-1 well file

7. Dutro (1970)

* Includes measurements from subsurface stratigraphic-equivalent Sag River Sandstone. 
Sadlerochit Mountains westward into the subsurface for about $160 \mathrm{~km}(100 \mathrm{mi})$ in a band 16 to $48 \mathrm{~km}(10$ to 30 mi) wide. The Kemik reaches a maximum thickness of nearly $90 \mathrm{~m}$ (300 ft) (fig. 7.11, table 7.1). The Thomson sand occurs in some of the wells in the Point Thomson area. This sandstone body, which is as much as $100 \mathrm{~m}$ $(330 \mathrm{ft})$ thick, is at least $19 \mathrm{~km}(12 \mathrm{mi})$ long and $8 \mathrm{~km}$ ( $5 \mathrm{mi}$ ) wide. It trends east-southeasterly and may extend into the ANWR coastal plain. Other sandstones may also occur within the coastal-plain area. The Kemik Sandstone and the Thomson sand display distinctly different compositions and reservoir characteristics.

The Kemik Sandstone consists of massively bedded, quartz-cemented sandstone composed of very fine grained to fine-grained, well-rounded quartz and chert grains with accessory glauconite, phosphate, sericite, and zircon (fig. 7.4D). Detterman and others (1975) note that the lower $6 \mathrm{~m} \mathrm{(20} \mathrm{ft)}$ of the Kemik

Table 7.3. Fluid recovery from some potential reservoir rocks in wells adjacent to the ANWR coastal plain

[MCFD, thousand cubic feet of gas per day; BOPD, barrels of oil per day; BPD, barrels per day; bbl, barrels; -, no data]

\begin{tabular}{|c|c|c|c|c|c|c|c|c|}
\hline \multirow[b]{2}{*}{ Area } & \multirow[b]{2}{*}{ Well } & \multirow{2}{*}{$\begin{array}{c}\text { Depth } \\
\text { interval } \\
\text { (ft) }\end{array}$} & \multicolumn{2}{|c|}{ Fluid recovery } & \multirow{2}{*}{$\begin{array}{c}\text { Gas/oil } \\
\text { ratio } \\
\text { (GOR) }\end{array}$} & \multirow{2}{*}{$\begin{array}{c}\text { API } \\
\text { gravity } \\
\left({ }^{\circ}\right)\end{array}$} & \multirow{2}{*}{$\begin{array}{l}\text { Length } \\
\text { of test } \\
\text { (h) }\end{array}$} & \multirow[b]{2}{*}{ Remarks } \\
\hline & & & $\begin{array}{c}\text { Gas } \\
(\mathrm{MCFD})\end{array}$ & $\begin{array}{c}\text { Oil } \\
\text { (BOPD) }\end{array}$ & & & & \\
\hline \multicolumn{9}{|c|}{ Canning Formation } \\
\hline \multirow[t]{5}{*}{ Point Thomson } & Alaska State A-1 & $12,565-12,635$ & 2,200 & 2,500 & 864 & 23 & 11.25 & \\
\hline & Alaska State F-1 & $12,008-12,080$ & 116 & 137 & 1,040 & 22 & 16.12 & \\
\hline & Point Thomson Unit-1 & $11,392-11,421$ & 2,250 & 132 & 17,045 & 44 & 11.75 & \\
\hline & Point Thomson Unit-2 & $11,580-11,678$ & 124 & 248 & 500 & 21 & 6 & Stabilized test after acidizing. \\
\hline & West Staines 18-9-23 & $11,650-11,675$ & - & - & - & 27 & - & Flowed oil and gas; $17 \mathrm{bbl}$ recovered. \\
\hline \multirow[t]{2}{*}{ Kavik } & Beli Unit-1 & $8,420-8,435$ & 50 & - & - & - & - & \\
\hline & & $9,055-9,103$ & 210 & - & - & - & - & \\
\hline \multicolumn{9}{|c|}{ Thomson sand } \\
\hline \multirow[t]{5}{*}{ Point Thomson } & Alaska State C-1 & $13,426-13,560$ & 3,400 & 874 & 3,890 & 37 & 24.33 & After acidizing. \\
\hline & Alaska State F-1 & $13,794-13,884$ & 4,235 & 284 & 14,912 & 35 & 92.97 & \\
\hline & Point Thomson Unit-1 & $12,834-12,874$ & 3,860 & 170 & 22,705 & 45 & 7 & \\
\hline & & $12,963-13,050$ & 13,307 & 2,283 & 5,826 & 18 & 18.5 & \\
\hline & Point Thomson Unit-3 & $13,872-13,885$ & 6,348 & 476 & 13,336 & 38 & 9.07 & \\
\hline \multicolumn{9}{|c|}{ Sag River Sandstone } \\
\hline \multirow[t]{2}{*}{ Kavik } & Kavik-1 & $4,252-4,292$ & 10,500 & - & - & - & 16.75 & $\begin{array}{l}\text { Calculated absolute potential } \\
\text { from 4-point test. }\end{array}$ \\
\hline & Kavik Unit-3 & $4,935-5,070$ & 7,400 & - & - & - & 9.5 & $\begin{array}{l}\text { Calculated maximum open } \\
\text { flow from 4-point test. }\end{array}$ \\
\hline \multicolumn{9}{|c|}{ Ledge Sandstone Member of Ivishak Formation } \\
\hline \multirow[t]{2}{*}{ Kavik } & Kavik-1 & $4,748-5,100$ & 44,000 & - & - & - & 17.5 & $\begin{array}{l}\text { Estimated absolute open-flow } \\
\text { potential from 4-point test. }\end{array}$ \\
\hline & Kavik Unit-3 & $5,524-5,850$ & 170,000 & - & - & - & 10 & $\begin{array}{l}\text { Calculated absolute open flow } \\
\text { from 4-point test. }\end{array}$ \\
\hline \multicolumn{9}{|c|}{ Basement complex } \\
\hline \multirow[t]{3}{*}{ Point Thomson } & Alaska Island-1 & $14,997-15,022$ & 2,931 & 175 & 11,270 & $>40$ & 24 & Condensate. GOR estimated. \\
\hline & Alaska State F-1 & $13,940-14,316$ & 2,975 & 152 & 19,572 & 35 & $8 . \dot{6}$ & \\
\hline & Alaska State A-1 & $12,997-13,182$ & - & - & - & - & .48 & $\begin{array}{l}\text { Flowed 4,220 BPD salt water } \\
\quad(40,500 \mathrm{ppm} \text { chlorides). }\end{array}$ \\
\hline Kavik & Canning River A-1 & $8,263-8,874$ & - & - & - & - & .67 & $\begin{array}{l}\text { Flowed 4,800 BPD water } \\
\text { (382 ppm chlorides). }\end{array}$ \\
\hline
\end{tabular}


contains sericitic clay, phosphate, chlorite, 10 to 15 percent feldspar, carbonaceous material, and thin stringers of pebble conglomerate. The entire unit is characterized by the presence of white grains of partially dissolved chert. Outcrop samples analyzed in this study show a detrital grain composition of quartz and chert (81 to 100 percent; avg 90 percent), feldspar ( 0 to 11 percent; avg 4 percent), and rock fragments ( 0 to 13 percent; avg 6 percent) (table 7.6, fig. 7.9).

The porosity of the Kemik Sandstone is as much as 12 percent. The average is 8 percent from log calculations and 5 percent from measurements. Permeability is as much as $20 \mathrm{md}$ and averages about 1 md (table 7.2).

The Thomson sand, which is described in greater detail in chapter 9 , is a fine-grained sandstone that becomes conglomeratic northward. Its composition is uncommon, consisting of detrital dolomite crystals and quartz grains. The sandstone mineralogy, northwardcoarsening grain size, and the presence of dolomite and limestone in the underlying basement rocks indicate that the Thomson sand is of local derivation. Visual estimates and $\log$ calculations indicate porosities of as much as 25 percent with an average of about 16 percent (table 7.2). Permeability is visually estimated by Gautier (chap. 9) to be more than 1,000 md. The high porosity and permeability may result from the combination of abnormally high pressures and the presence of hydrocarbons inhibiting both compaction and cementation.

The Exxon Corporation estimates that the Point Thomson field contains recoverable reserves of 5 trillion $\mathrm{ft}^{3}$ of gas and 350 million barrels of condensate (Oil and Gas Journal, 1984). Flow rates of as much as 13 million $\mathrm{ft}^{3}$ of gas and about 2,300 barrels of oil per day have been measured. Oil recovered from the Thomson sand is mostly $35^{\circ}$ to $45^{\circ}$ API gravity, although one test recovered oil of $18^{\circ}$ API gravity (table 7.3).

\section{CANNING FORMATION}

Potential reservoir rocks in the Canning Formation are sandstone units interpreted to be turbidite deposits. Wells west of the ANWR coastal plain contain a 600 - to 900 -m-thick $(2,000-3,000 \mathrm{ft})$ unit of shale and

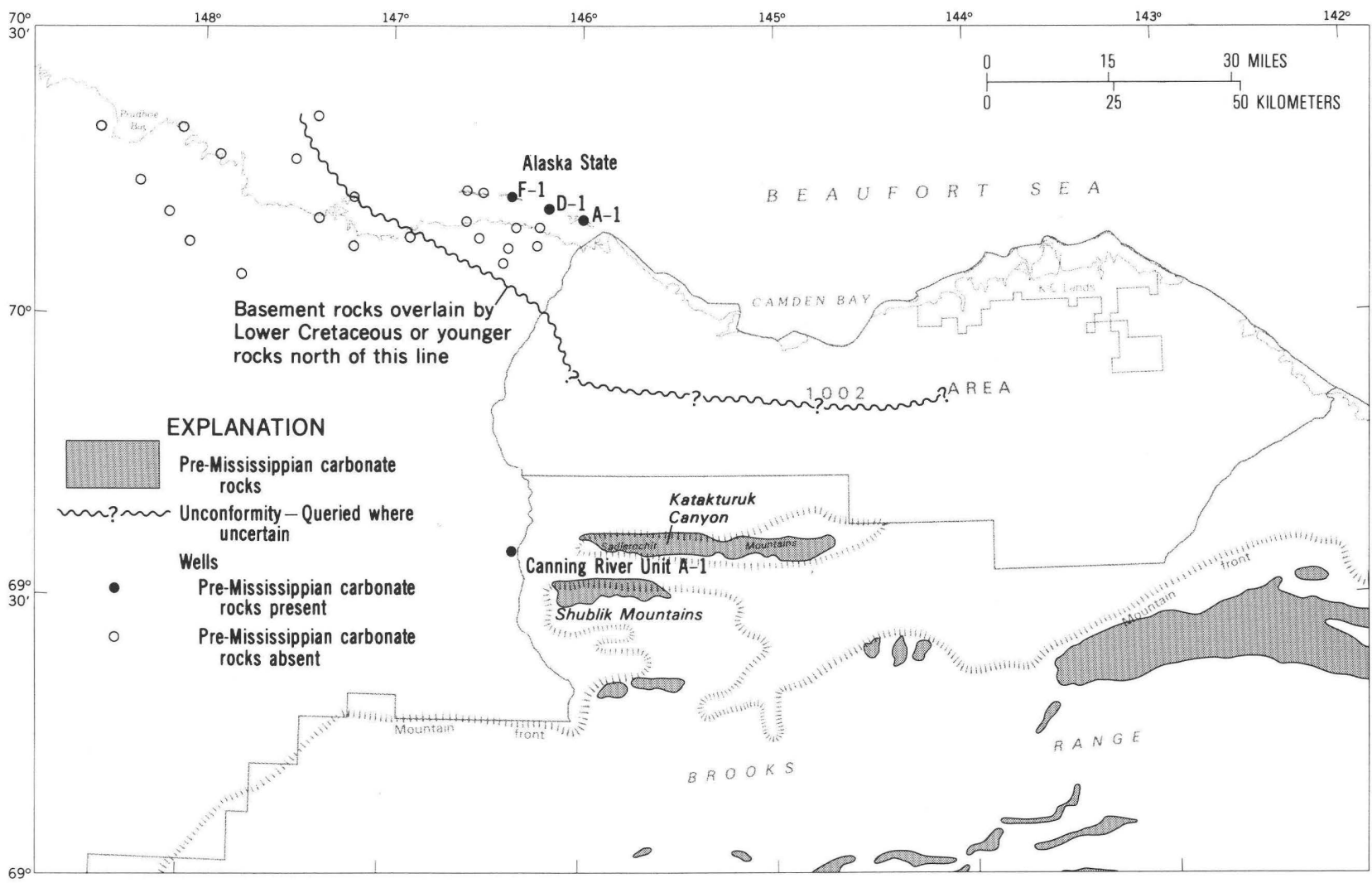

Figure 7.2. Outcrop distribution of pre-Mississippian carbonate rocks and wells that penetrate pre-Mississippian rocks in northeastern Alaska. 
sandstone between an underlying distal, condensed, basinal shale facies (Hue Shale) and an overlying thick, slope and shelf shale facies (chap. 5). These sandstones are generally thin bedded and discontinuous. However, groups of beds as thick as $9 \mathrm{~m}$ (30 ft) occur in outcrop (Molenaar, 1983) and as thick as $21 \mathrm{~m}$ (70 ft) in the
Alaska State A-1 well (fig. 7.3). In 14 wells just west of the ANWR, a count of sandstone beds thicker than $1.5 \mathrm{~m}$ $(5 \mathrm{ft})$ in this facies shows that 3 wells $(21$ percent) have no sandstone and that the remaining 11 wells have 8 to $81 \mathrm{~m}$ ( 27 to $266 \mathrm{ft}$ ) of sandstone, averaging $23 \mathrm{~m}$ (76 ft). In the Point Thomson area, most turbidite sandstone

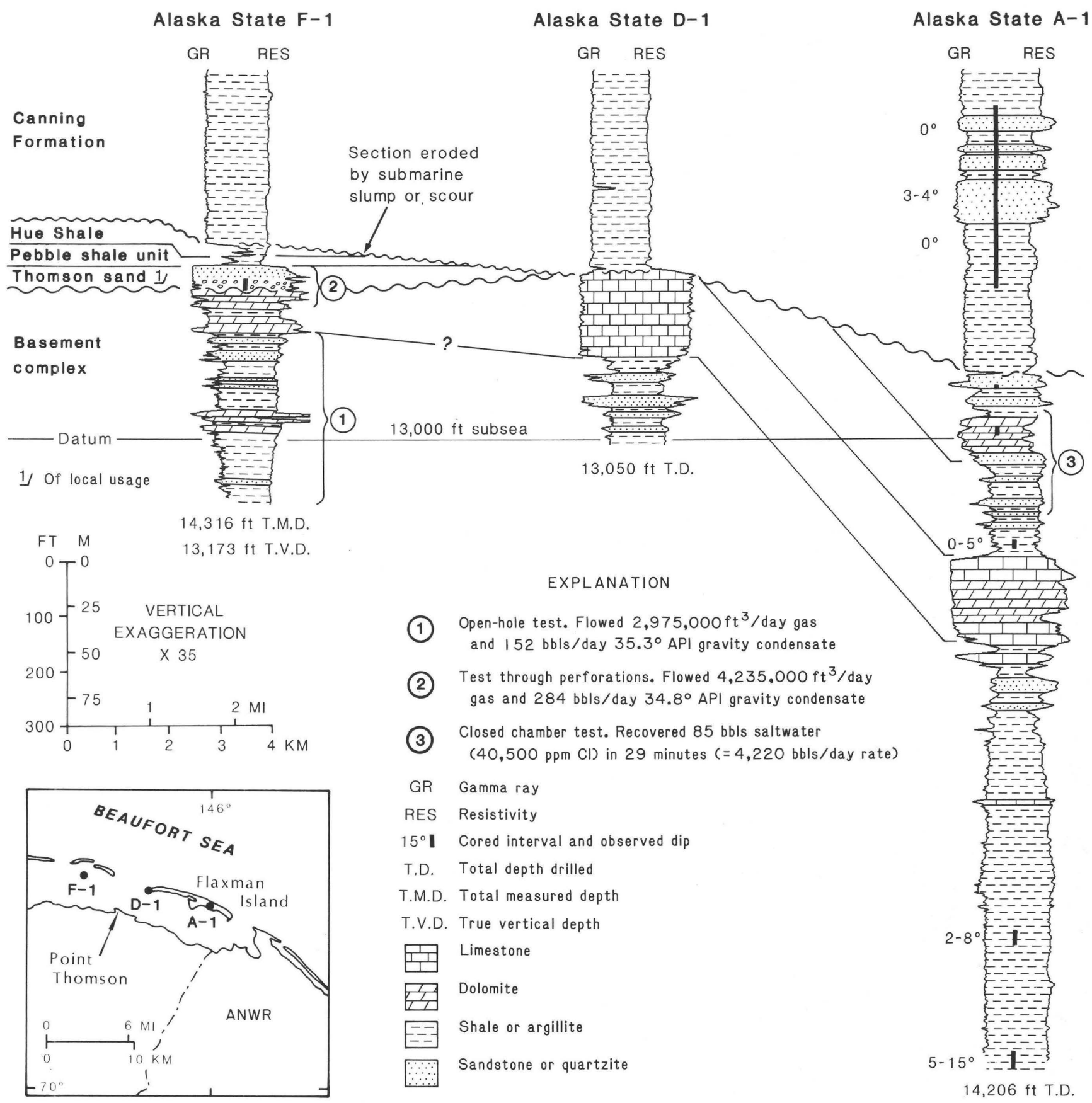

Figure 7.3. Pre-Mississippian (basement complex) rocks penetrated in selected wells on barrier islands north of Point Thomson showing possible correlations. Observed dip in cores and continuity of strata implied by proposed correlations are consistent with seismic data, which show continuity of reflections (chap. 18). 

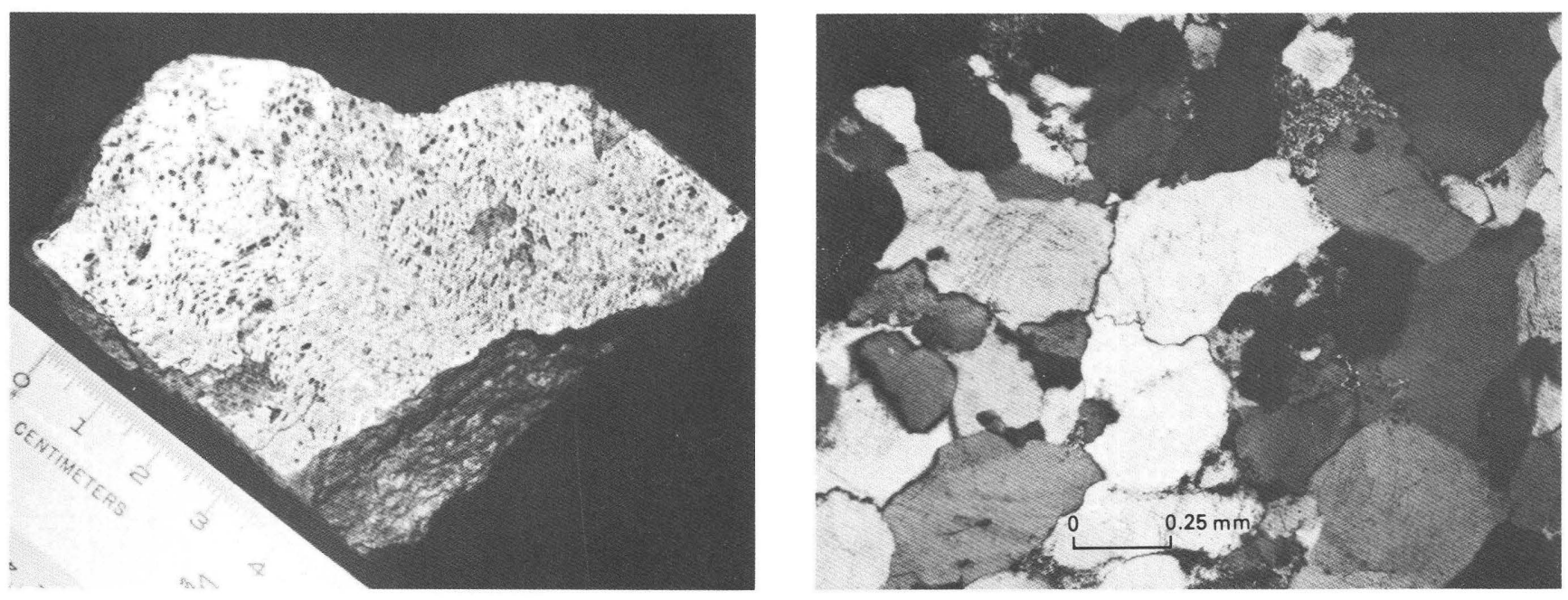

$\boldsymbol{A}$

$\boldsymbol{B}$
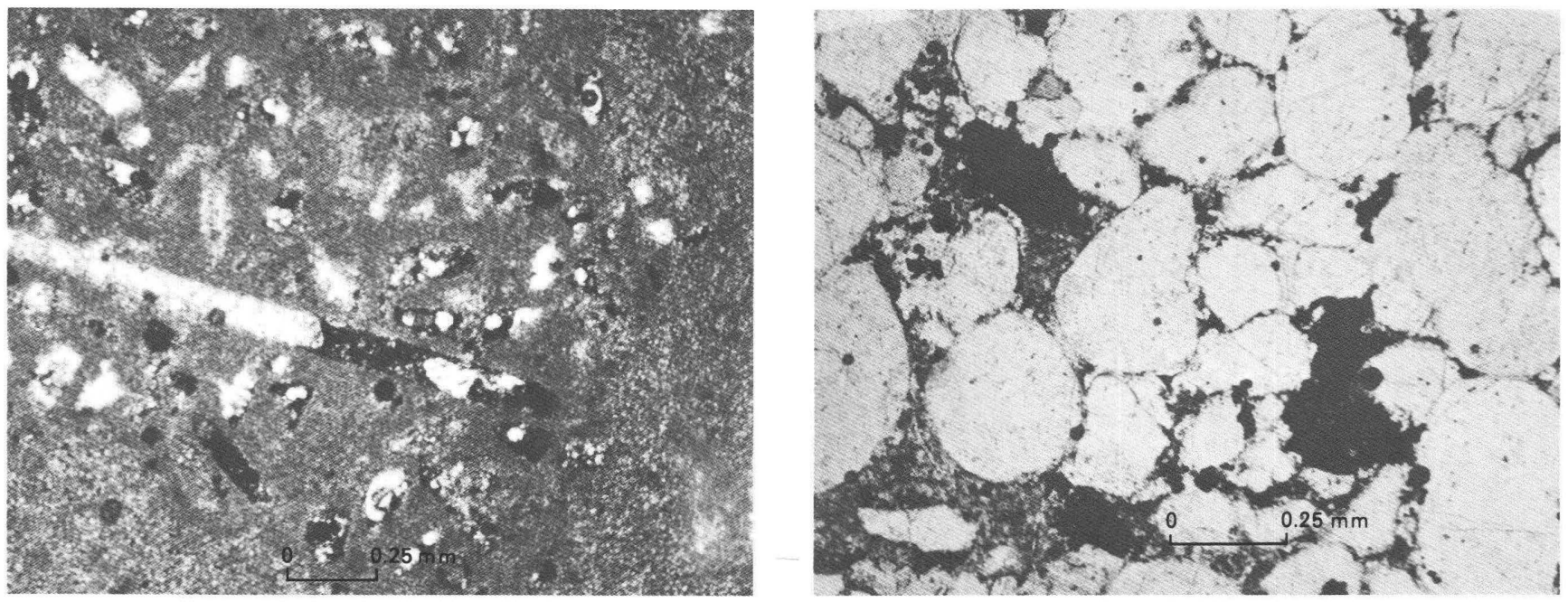

C

$\boldsymbol{D}$
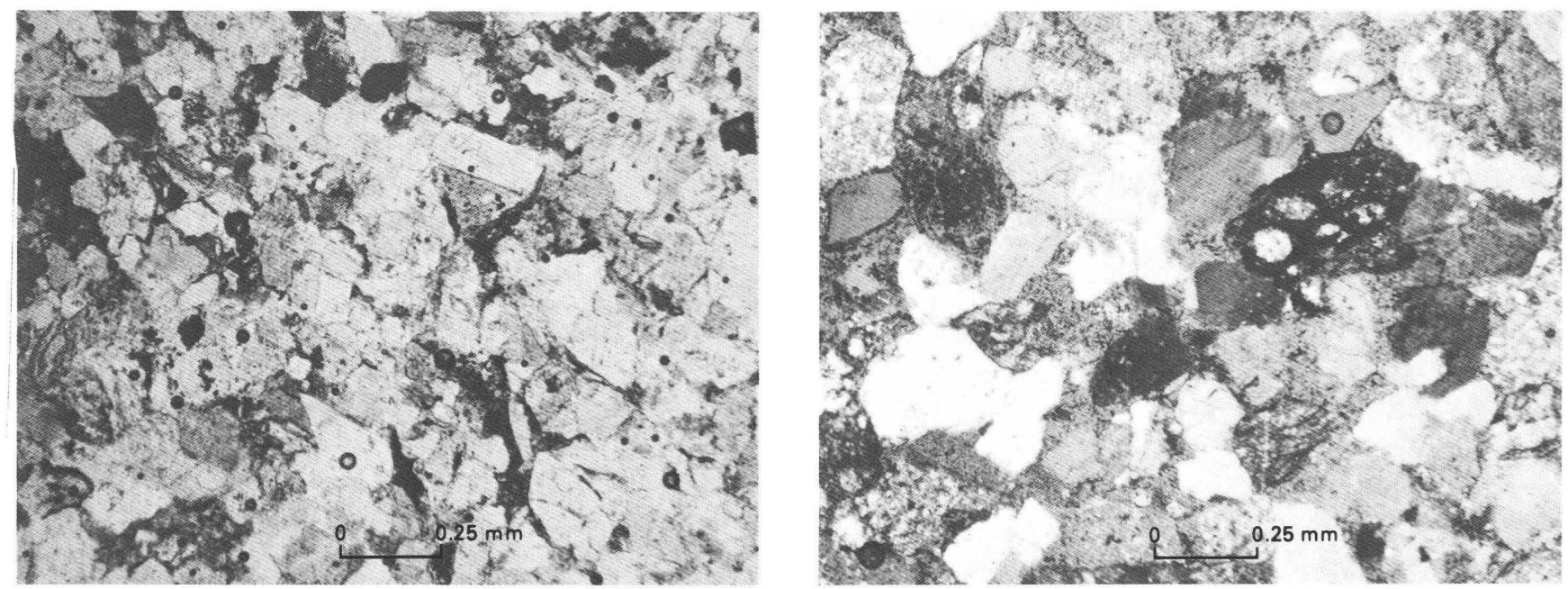
units occur below $3,000 \mathrm{~m}(10,000 \mathrm{ft})$ subsea where abnormal fluid pressures have been measured with gradients of as much as $0.84 \mathrm{psi} / \mathrm{ft}$, nearly double the normal hydrostatic gradient (chap. 13).

The sandstones are mostly fine grained, well sorted, and composed of nearly equal amounts of quartz and sedimentary lithic grains (chap. 9). Petrographic analysis of outcrop samples of these sandstones shows a detrital grain composition of 41 to 75 percent quartz and chert (avg 65 percent), 3 to 22 percent feldspar (avg 7 percent), and 15 to 37 percent rock fragments (avg 28 percent) (table 7.6, figs. 7.4E, 7.9). Porosity in the overpressured sandstone units of the Point Thomson area is 10 to 28 percent and averages about 20 percent as determined from log calculations. These values are somewhat higher than estimates from petrographicsection study (chap. 9). Porosity calculated from logs in normally pressured turbidite sandstones south of the Point Thomson area ranges from 8 to 18 percent and

Figure 7.4. Potential reservoir rocks in ANWR. A, Sample of the Katakturuk Dolomite showing vuggy porosity. Sample (84AMK-30G), collected by C.M. Molenaar in Katakturuk Canyon, measures 3.7 percent porosity and 0.1 md permeability (table 7.4). $B$, Sandstone sample of the Kekiktuk Conglomerate showing well-cemented, low-porosity nature of this rock unit in ANWR area. Sample, 83BR526, was collected by T.E. Moore in SW $1 / 4$ sec. 35, T. 1 S., R. 26 E., Fourth Range. XP. $C$, Microcrystalline dolomite sample of the Lisburne Group from eastern Sadlerochit Mountains, 277 m (910 ft) below top of the Lisburne Group, showing leached-fossil and intercrystalline porosity, some of which contains "dead" oil (black areas). Sample (68A4B+790), collected by A.K. Armstrong from Eastern Sadlerochit Mountains section, is calculated to have 12 percent porosity (table 7.5). PL. D, Sample of the Kemik Sandstone showing characteristic well-rounded grains and generally low porosity. Sample (82AMK-76) was collected near the Kekiktuk River by C.M. Molenaar, sec. 10, T. 2 N., R. 30 E. PL. E, Turbidite sandstone sample from the Canning Formation showing characteristic low porosity because of compaction by labile rock fragments. Sample (80AMK-41D) collected by C.M. Molenaar from outcrop in sec. 11, T. 4 N., R. 27 E., Katakturuk River. PL. F, Sandstone sample of the Sagavanirktok Formation showing relatively coarse grain size, loose packing, and good porosity. Sample (80AMK-31) collected by C.M. Molenaar from outcrop in sec. 33, T. 4 N., R. 24 E. along Canning River. PL. averages about 12 percent. The latter values are better than the 5 percent average porosity measured by Lyle and others (1980) from outcropping turbidites on the coastal plain (table 7.2, fig. 7.12). As observed by Gautier (chap. 9) and Gautier and others (chap. 13), the higher porosity and permeability values in sandstone beds beneath the coastal plain are probably dependent on abnormally high pressures, which inhibit porosity loss by compaction.

Oil and gas occur in several of these sandstones in the Point Thomson area, where flow rates of as much as 2,500 barrels of $23^{\circ}$ API gravity oil and 2.2 million $\mathrm{ft}^{3}$ of gas per day have been measured (table 7.3). The gravity of recovered oils ranges from $21^{\circ}$ to $44^{\circ} \mathrm{API}$, although values of $21^{\circ}$ to $27^{\circ}$ API gravity are most common. Gas-to-oil ratios range from 500 to 17,000 , with most less than 1,000 .

\section{SAGAVANIRKTOK AND JAGO RIVER FORMATIONS}

Potential reservoir rocks in the Sagavanirktok Formation and in the Jago River Formation of Buckingham (1987) are shallow-marine to nonmarine sandstone beds that occur in outcrops on the ANWR coastal plain. The Sagavanirktok Formation is penetrated in wells to the west (fig. 7.12). Both formations are many thousands of feet thick, of which as much as half may consist of sandstone. The sandstones are commonly conglomeratic and occur in beds generally less than $9 \mathrm{~m}$ (30 ft) thick, although groups of beds may be more than $30 \mathrm{~m}$ (100 ft) thick. Although both formations are grossly similar in age, composition, and origin, they differ markedly in reservoir characteristics.

The Sagavanirktok Formation on the ANWR coastal plain and in wells to the west ranges in thickness from 1,006 to $2,685 \mathrm{~m}(3,300$ to $8,810 \mathrm{ft}$ ) (table 7.1). Most of the Sagavanirktok sandstones are medium to coarse grained and friable with relatively good porosity and permeability. The sandstone is composed of 56 to 85 percent quartz and chert (avg 71 percent), 0 to 20 percent feldspar (avg 5 percent), and 14 to 35 percent volcanic and metamorphic lithic fragments (avg 24 percent) (table 7.6, figs. 7.4F, 7.9). Samples with better porosity show evidence of leached grains and cements. Laboratory measurements by Lyle and others (1980) indicate an average porosity of 17 percent and an average permeability of $453 \mathrm{md}$. In wells just west of the ANWR, the log-calculated porosity of these sandstones is generally in the 20 to 30 percent range (table 7.2).

Oil staining is fairly common in the basal part of the Sagavanirktok Formation in the wells adjacent to the coastal plain. One well (Point Thomson Unit-2) shows consistent oil staining throughout an interval about 
Table 7.4. Porosity and permeability measurements of carbonate rocks of the pre-Mississippian basement complex in and adjacent to ANWR

[See figure 7.2 for location of samples]

\begin{tabular}{|c|c|c|c|}
\hline Sample & $\begin{array}{l}\text { Porosity } \\
\text { (pct) }\end{array}$ & $\begin{array}{l}\text { Permeability } \\
(\mathrm{md})\end{array}$ & Source \\
\hline \multicolumn{4}{|c|}{$\begin{array}{l}\text { KATAKTURUK DOLOMITE } \\
\text { Katakturuk Canyon }\end{array}$} \\
\hline 84 AMK-31 & 4.4 & $<0.1$ & 1 \\
\hline 84 AMK-30I & 1.9 & .1 & 1 \\
\hline 84 AMK-30E & 2.3 & $<.1$ & 1 \\
\hline 84 AMK-30G & 3.7 & .1 & 1 \\
\hline 84 AMK-30J & 10.0 & .1 & 1 \\
\hline 84 AMK-30H & .8 & $<.1$ & 1 \\
\hline 84 AMK-30F & .8 & $<.1$ & 1 \\
\hline 84 AMK-23A & 2.0 & .6 & 1 \\
\hline 84 AMK-35 & 6.2 & $<.1$ & 1 \\
\hline B10A1 & 1.8 & $<.1$ & 2 \\
\hline B10A2 & 2.1 & .1 & 2 \\
\hline B10B & 1.6 & $<.1$ & 2 \\
\hline $\mathrm{B} 10 \mathrm{C}$ & 1.7 & $<.1$ & 2 \\
\hline B10D & 1.7 & $<.1$ & 2 \\
\hline $\mathrm{B} 10 \mathrm{~F}$ & 2.0 & .2 & 2 \\
\hline B10G & 2.3 & .2 & 2 \\
\hline B10I & 1.9 & $<.1$ & 2 \\
\hline B10J & 1.8 & $<.1$ & 2 \\
\hline B10L & 1.9 & .1 & 2 \\
\hline $\mathrm{B} 11 \mathrm{~A}$ & 1.4 & $<.1$ & 2 \\
\hline B12B & 2.1 & .7 & 2 \\
\hline B12E & 1.9 & .4 & 2 \\
\hline $\mathrm{B} 12 \mathrm{~F}$ & 1.6 & $<.1$ & 2 \\
\hline B12K & 1.6 & $<.1$ & 2 \\
\hline $\mathrm{B} 12 \mathrm{~N}$ & 1.7 & .1 & 2 \\
\hline B12Q1 & 1.9 & .2 & 2 \\
\hline B12Q2 & 1.8 & $<.1$ & 2 \\
\hline B14A & 2.3 & 1.2 & 2 \\
\hline B14C & 4.1 & .9 & 2 \\
\hline B14G & 1.2 & .2 & 2 \\
\hline $\mathrm{B} 14 \mathrm{~N}$ & 1.9 & .1 & 2 \\
\hline B14O & 1.4 & $<.1$ & 2 \\
\hline B14R & 1.4 & $<.1$ & 2 \\
\hline $\mathrm{B} 100 \mathrm{H}$ & 2.1 & .2 & 2 \\
\hline $\mathrm{B} 100 \mathrm{~K}$ & 1.7 & .1 & 2 \\
\hline B100R & 3.2 & .7 & 2 \\
\hline $\mathrm{B} 101 \mathrm{~F}$ & 3.4 & 1.6 & 2 \\
\hline B101G & 1.7 & .2 & 2 \\
\hline B101J & 1.2 & .1 & 2 \\
\hline B101N & 1.6 & $<.1$ & 2 \\
\hline B102A & 1.4 & $<.1$ & 2 \\
\hline B102B & 1.4 & $<.1$ & 2 \\
\hline B102D & 3.1 & .8 & 2 \\
\hline
\end{tabular}

Table 7.4. Porosity and permeability measurements of carbonate rocks of the pre-Mississippian basement complex in and adjacent to ANWR-Continued

[See figure 7.2 for location of samples]

\begin{tabular}{lccc}
\hline Sample & $\begin{array}{c}\text { Porosity } \\
(\mathrm{pct})\end{array}$ & $\begin{array}{c}\text { Permeability } \\
(\mathrm{md})\end{array}$ & Source \\
\hline \multicolumn{4}{c}{ Canning River Unit A-1, core no. 7 } \\
\hline 8865.2 & 0.4 & $<0.1$ & 3 \\
8866.7 & .6 & $<.1$ & 3 \\
8867.4 & .7 & $<.1$ & 3 \\
8868.6 & 1.1 & $<.1$ & 3 \\
8869.3 & .8 & $<.1$ & 3 \\
8870.4 & .6 & $<.1$ & 3 \\
8871.6 & .3 & $<.1$ & 3 \\
8872.2 & .8 & $<.1$ & 3 \\
8873.2 & .8 & $<.1$ & 3 \\
\hline \multicolumn{4}{c}{ NANOOK LIMESTONE } \\
\hline B13E & \multicolumn{3}{c}{ Shublik Mountains } \\
B17K & 1.8 & $<0.1$ & \\
B18E & 1.2 & .1 & 2 \\
\hline
\end{tabular}

1. This study

2. Dutro (1970)

3. Canning River Unit A-1 well history

The Jago River Formation, about 3,000 m $(10,000 \mathrm{ft})$ thick (table 7.1$)$, is composed predominantly of well-indurated nonmarine sandstone, conglomerate, and shale that crops out in an area $30 \mathrm{~km}$ long by $10 \mathrm{~km}$ wide ( $18 \mathrm{mi}$ by $6 \mathrm{mi}$ ) near the southern boundary of the coastal plain, 24 to $48 \mathrm{~km}$ (15 to $30 \mathrm{mi}$ ) east of the Sadlerochit Mountains (fig. 7.12). McLean (chap. 10) reports that the sandstone is composed of moderately sorted and rounded grains consisting of 17 to 65 percent quartz and chert (avg 33 percent), 0 to 3 percent feldspar (avg 1 percent), and 35 to 82 percent igneous, metamorphic, and sedimentary rock fragments (avg 67 percent) (fig. 7.9). Visible porosity is nearly zero due to compaction; no hydrocarbon indications are visible. Measurements of outcrop samples by Lyle and others (1980) indicate porosities less than 6 percent and permeabilities less than 2 md (table 7.2). Bird and Molenaar (chap. 5) note that these rocks are unusual in thickness and geographic location; their distribution in the subsurface is unknown. Bird and Molenaar favor an original site of deposition farther south than their present location and emplacement by northward thrusting.

\section{SUMMARY \\ SUMMARY} $120 \mathrm{~m}(400 \mathrm{ft})$ thick. The multibillion-barrel heavy-oil accumulations (West Sak and Ugnu) occur in Upper Cretaceous and lower Tertiary deltaic sandstones in the Prudhoe Bay area (Werner, 1984, 1985).
Potential petroleum reservoir rocks in the

ANWR coastal plain probably consist of both sandstone and carbonate rocks. All hydrocarbon-bearing reservoir rocks present in the Prudhoe Bay area (and some that are not) may be present in the coastal plain. However, most 
oil-productive Prudhoe reservoirs are probably restricted to the western and southern parts of the ANWR coastal plain, because in the northern parts of the coastal plain they were probably removed by erosion beneath the Lower Cretaceous unconformity. The reservoir rocks most likely to occur throughout the ANWR coastal plain are intrabasement carbonate rocks and sandstones, sandstones similar to those of the Kemik Sandstone or the Thomson sand, turbidite sandstones in the Canning Formation, and deltaic sandstones in the Sagavanirktok and Jago River Formations. Except for the Sagavanirktok Formation, all potential reservoir rocks in outcrop on or adjacent to the coastal plain have low porosity $(<10$ percent) and permeability $(<20 \mathrm{md})$. By analogy with reservoir rocks in the Prudhoe Bay area, much better porosity and permeability might be developed in pre-Cretaceous reservoir rocks adjacent to the Lower Cretaceous unconformity. Sandstones similar to the Kemik or Thomson units and turbidite sandstones in the Canning Formation may have better porosity and permeability than indicated by the outcrop samples. These improved reservoir characteristics are expected to occur in relatively unfaulted areas where abnormally high pressures may be present; such pressures would inhibit porosity reduction by compaction. The Sagavanirktok Formation, the youngest and least buried potential reservoir, has high porosity and permeability. Because of the relatively high percentage of sandstone in this formation, seals adequate to trap hydrocarbons may be a problem.

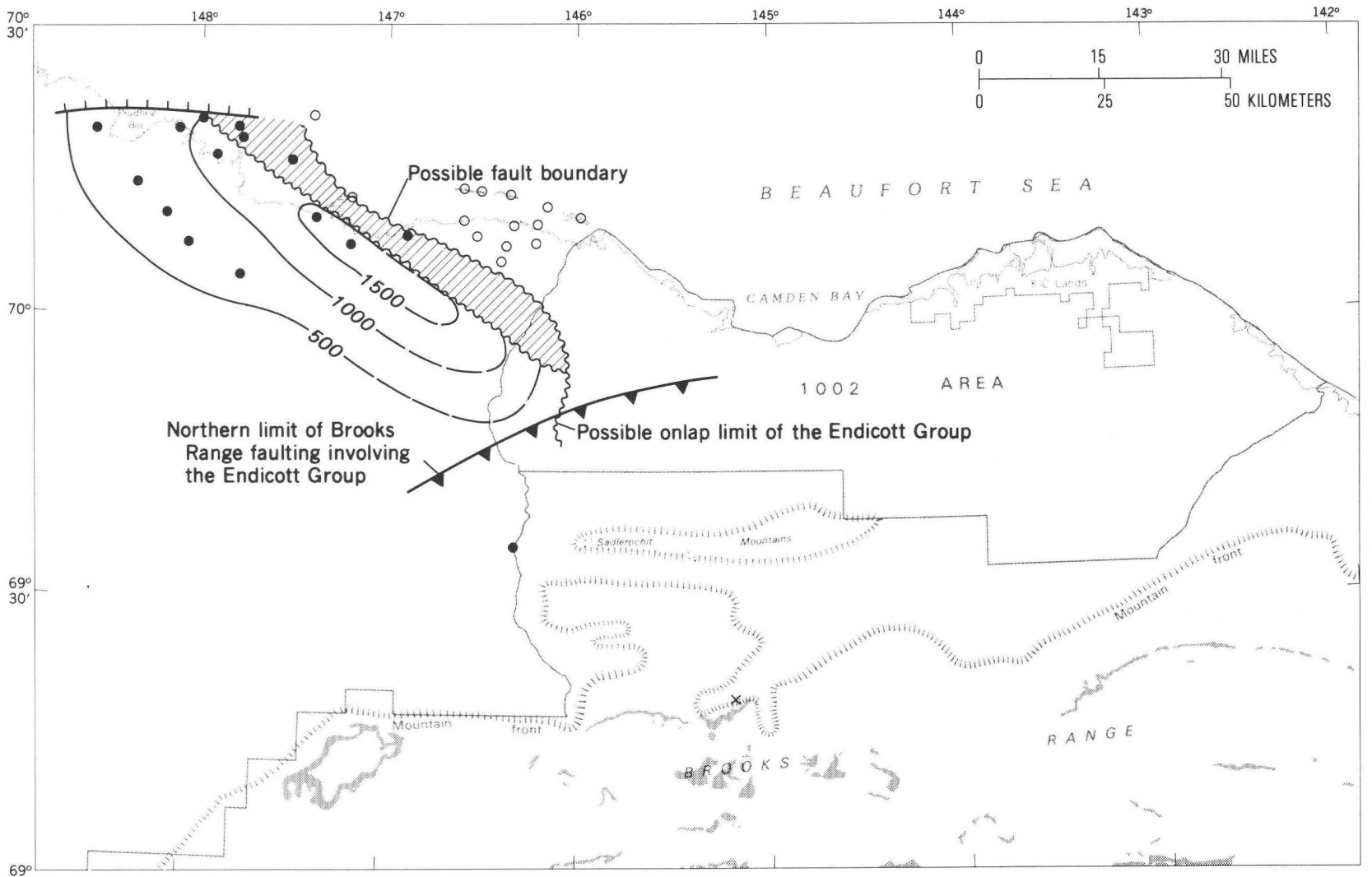

EXPLANATION

7.5
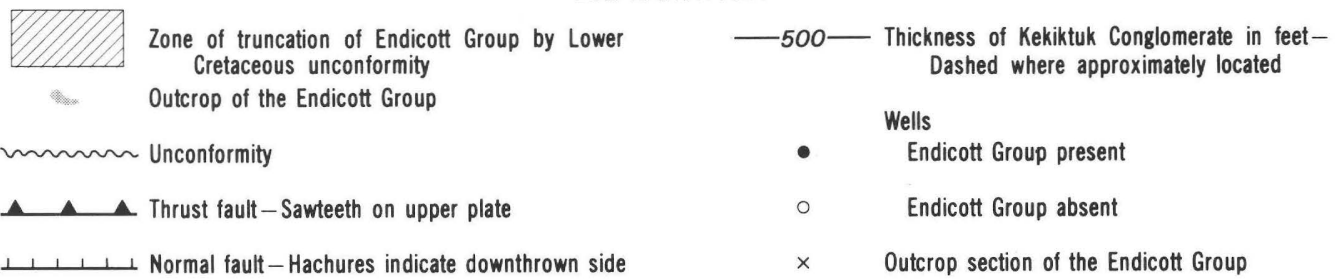

Figure 7.5. Endicott Group truncation and (or) onlap edge, well penetrations, and outcrop distribution in northeastern Alaska. Contours (in feet) show thickness of Kekiktuk Conglomerate. Data points for the Kekiktuk are listed in table 7.1. 


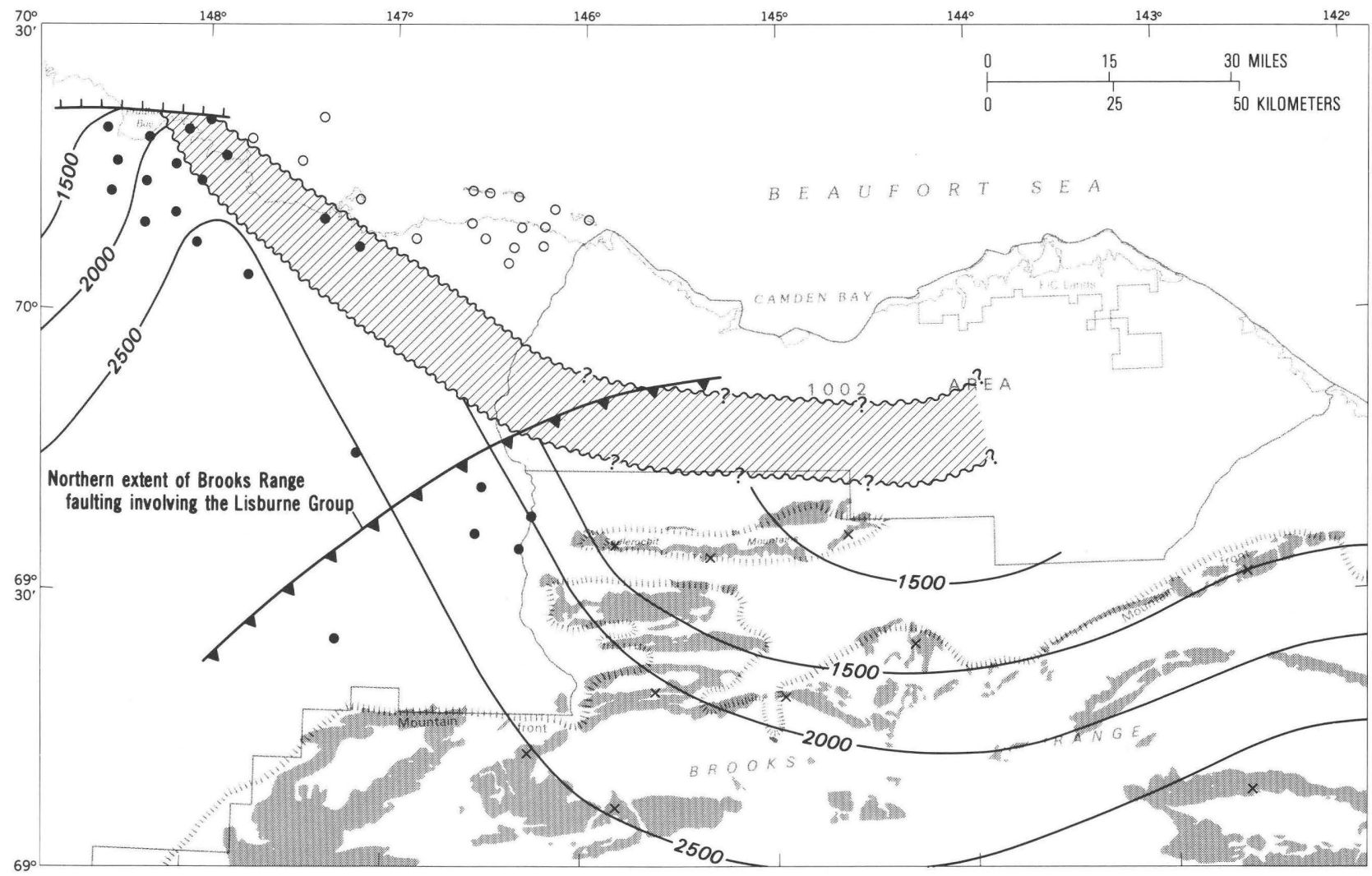

EXPLANATION

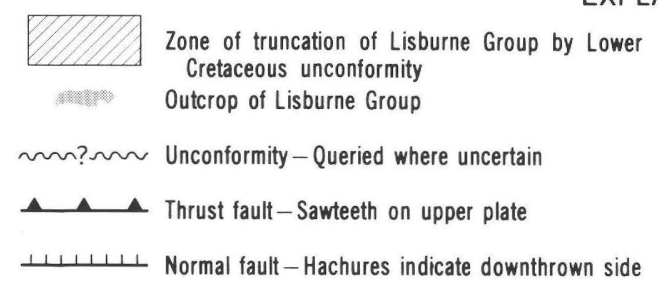

$$
\begin{array}{cc}
\text {-2000 - Thickness of Lisburne Group in feet } \\
\text { Wells } \\
\text { Lisburne Group present } \\
\times \quad \text { Lisburne Group absent } \\
\times \quad \text { Outcrop section of Lisburne Group }
\end{array}
$$

Figure 7.6. Lisburne Group truncation edge, isopachs (in feet), control points, and outcrop pattern in northeastern Alaska. Lisburne data points are listed in table 7.1. 


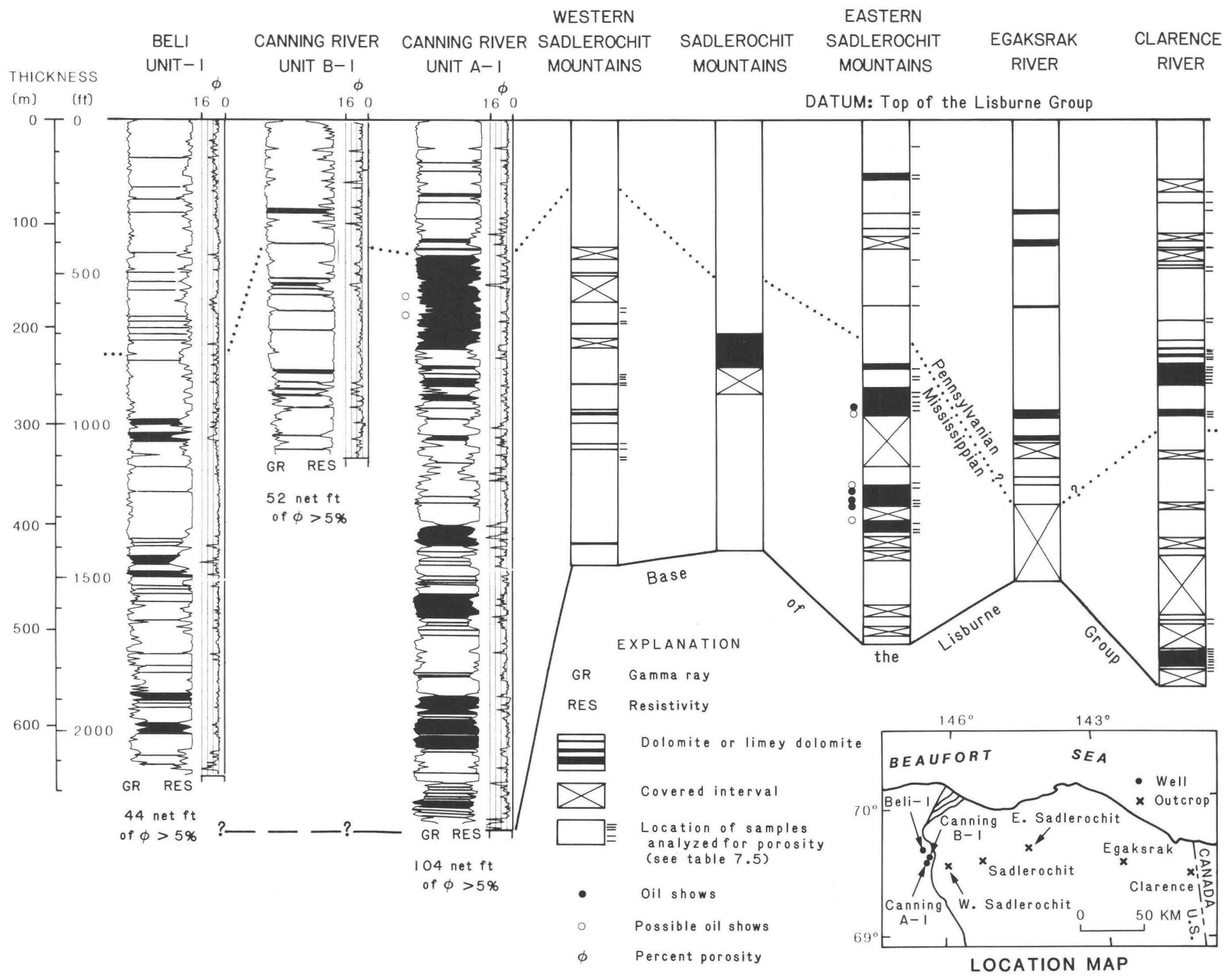

Figure 7.7. Correlation chart of Lisburne Group outcrop sections and well penetrations adjacent to ANWR coastal plain showing distribution of dolomite, porosity determinations, and oil indications. Porosity determinations from outcrops are summarized in table 7.5. Porosity curve for wells was calculated from acoustic log assuming dolomite lithology and is considered valid only for dolomite intervals (darkened). Location of Mississippian-Pennsylvanian boundary is based on foraminiferal determinations by Armstrong and Mamet (1977) for outcrops and by M.B. Mickey (Micropaleo Consultants, Inc., oral commun., 1986). Sources of outcrop sections are listed in table 7.1. 
Table 7.5. Porosity determinations of dolomite samples of the Lisburne Group from three measured sections in ANWR

[Porosity was calculated from bulk density measurements assuming sample was entirely dolomite of density $2.86 \mathrm{~g} / \mathrm{cm}^{3}$. Because samples contain variable but undetermined admixtures of calcite and chert, these are considered maximum porosity values. All samples collected by A.K. Armstrong. See figure 7.7 for location of sections]

\begin{tabular}{|c|c|c|c|}
\hline Sample & $\begin{array}{c}\text { Depth } \\
\text { from top } \\
(\mathrm{ft})\end{array}$ & $\begin{array}{c}\text { Bulk } \\
\text { density } \\
\left(\mathrm{g} / \mathrm{cm}^{3}\right)\end{array}$ & $\begin{array}{c}\text { Calculated } \\
\text { porosity } \\
\text { (pct) }\end{array}$ \\
\hline \multicolumn{4}{|c|}{ Western Sadlerochit Mountains } \\
\hline $69 \mathrm{~A}-1+1005$ & 495 & 2.675 & 6 \\
\hline $69 \mathrm{~A}-1+882$ & 618 & 2.632 & 8 \\
\hline $69 \mathrm{~A}-1+880$ & 620 & 2.662 & 7 \\
\hline $69 A-1+830$ & 670 & 2.642 & 8 \\
\hline $69 A-1+670$ & 830 & 2.666 & 7 \\
\hline $69 A-1+665$ & 835 & 2.679 & 6 \\
\hline $69 A-1+660$ & 840 & 2.688 & 6 \\
\hline $69 A-1+650$ & 850 & 2.602 & 9 \\
\hline $69 A-1+643$ & 857 & 2.762 & 3 \\
\hline $69 A-1+640$ & 860 & 2.652 & 7 \\
\hline $69 \mathrm{~A}-1+555$ & 945 & 2.656 & 7 \\
\hline $69 \mathrm{~A}-1+545$ & 955 & 2.725 & 5 \\
\hline $69 \mathrm{~A}-1+542$ & 958 & 2.780 & 3 \\
\hline $69 \mathrm{~A}-1+520$ & 980 & 2.673 & 7 \\
\hline $69 A-1+515$ & 985 & 2.668 & 7 \\
\hline $69 A-1+500$ & 1,000 & 2.674 & 7 \\
\hline $69 A-1+450$ & 1,050 & 2.680 & 6 \\
\hline $69 A-1+430$ & 1,070 & 2.661 & 7 \\
\hline $69 \mathrm{~A}-1+425$ & 1,075 & 2.719 & 5 \\
\hline $69 \mathrm{~A}-1+410$ & 1,090 & 2.751 & 4 \\
\hline $69 A-1+400$ & 1,100 & 2.633 & 8 \\
\hline $69 \mathrm{~A}-1+130$ & 1,370 & 2.676 & 6 \\
\hline \multirow[t]{2}{*}{$69 \mathrm{~A}-1+120$} & 1,380 & 2.781 & 3 \\
\hline & & Average & 6.2 \\
\hline \multicolumn{4}{|c|}{ Clarence River } \\
\hline $71 \mathrm{~A}-1+265$ & 245 & 2.680 & 6 \\
\hline $71 \mathrm{~A}-1+270$ & 250 & 2.658 & 7 \\
\hline $71 \mathrm{~A}-1+310$ & 290 & 2.650 & 7 \\
\hline $71 \mathrm{~A}-1+376$ & 356 & 2.620 & 8 \\
\hline $71 \mathrm{~A}-1+425$ & 405 & 2.635 & 8 \\
\hline $71 \mathrm{~A}-1+470$ & 450 & 2.650 & 7 \\
\hline $71 \mathrm{~A}-1+478$ & 458 & 2.658 & 7 \\
\hline $71 \mathrm{~A}-2+1780$ & 630 & 2.614 & 9 \\
\hline $71 \mathrm{~A}-2+1765$ & 645 & 2.680 & 6 \\
\hline $71 A-2+1680$ & 730 & 2.708 & 5 \\
\hline $71 \mathrm{~A}-2+1670$ & 740 & 2.660 & 7 \\
\hline $71 \mathrm{~A}-2+1660$ & 750 & 2.650 & 7 \\
\hline $71 \mathrm{~A}-2+1652$ & 758 & 2.705 & 5 \\
\hline $71 \mathrm{~A}-2+1610$ & 800 & 2.598 & 9 \\
\hline $71 \mathrm{~A}-2+1590$ & 820 & 2.671 & 7 \\
\hline $71 \mathrm{~A}-2+1585$ & 825 & 2.420 & 15 \\
\hline $71 \mathrm{~A}-2+1575$ & 835 & 2.525 & 12 \\
\hline $71 \mathrm{~A}-2+1565$ & 845 & 2.715 & 5 \\
\hline
\end{tabular}

Table 7.5. Porosity determinations of dolomite samples of the Lisburne Group from three measured sections in ANWR-Continued

[Porosity was calculated from bulk density measurements assuming sample was entirely dolomite of density $2.86 \mathrm{~g} / \mathrm{cm}^{3}$. Because samples contain variable but undetermined admixtures of calcite and chert, these are considered maximum porosity values. All samples collected by A.K. Armstrong. See figure 7.7 for location of sections]

\begin{tabular}{|c|c|c|c|}
\hline Sample & $\begin{array}{l}\text { Depth } \\
\text { from top } \\
\text { (ft) }\end{array}$ & $\begin{array}{c}\text { Bulk } \\
\text { density } \\
\left(\mathrm{g} / \mathrm{cm}^{3}\right)\end{array}$ & $\begin{array}{c}\text { Calculated } \\
\text { porosity } \\
\text { (pct) }\end{array}$ \\
\hline \multicolumn{4}{|c|}{ Clarence River-Continued } \\
\hline $71 \mathrm{~A}-2+1554$ & 856 & 2.660 & 7 \\
\hline $71 \mathrm{~A}-2+1480$ & 930 & 2.588 & 10 \\
\hline $71 \mathrm{~A}-2+1470$ & 940 & 2.690 & 6 \\
\hline $71 \mathrm{~A}-2+1465$ & 945 & 2.610 & 9 \\
\hline $71 \mathrm{~A}-2+1309$ & 1101 & 2.445 & 15 \\
\hline $71 \mathrm{~A}-2+1220$ & 1190 & 2.553 & 11 \\
\hline $71 \mathrm{~A}-2+800$ & 1610 & 2.640 & 8 \\
\hline $71 \mathrm{~A}-2+790$ & 1620 & 2.580 & 10 \\
\hline $71 \mathrm{~A}-2+715$ & 1695 & 2.745 & 4 \\
\hline $71 \mathrm{~A}-2+710$ & 1700 & 2.662 & 7 \\
\hline $71 \mathrm{~A}-2+700$ & 1710 & 2.800 & 2 \\
\hline $71 A-2+680$ & 1730 & 2.760 & 3 \\
\hline $71 A-2+670$ & 1740 & 2.723 & 5 \\
\hline $71 \mathrm{~A}-2+654$ & 1756 & 2.760 & 3 \\
\hline \multirow[t]{2}{*}{$71 \mathrm{~A}-2+650$} & 1760 & 2.740 & 4 \\
\hline & & Average & 7.3 \\
\hline \multicolumn{4}{|c|}{ Eastern Sadlerochit Mountains } \\
\hline $68 A-4 A+80$ & 80 & 2.490 & 13 \\
\hline $68 A-4 A+170$ & 170 & 2.600 & 9 \\
\hline $68 A-4 A+180$ & 180 & 2.745 & 4 \\
\hline $68 A-4 A+300$ & 300 & 2.741 & 4 \\
\hline $68 A-4 A+340$ & 340 & 2.691 & 6 \\
\hline $68 A-4 A+350$ & 350 & 2.746 & 4 \\
\hline $68 \mathrm{~A}-4 \mathrm{~A}+440$ & 440 & 2.670 & 7 \\
\hline $68 A-4 A+530$ & 530 & 2.689 & 6 \\
\hline $68 A-4 A+600$ & 600 & 2.735 & 4 \\
\hline $68 \mathrm{~A}-4 \mathrm{~A}+800$ & 800 & 2.722 & 5 \\
\hline $68 \mathrm{~A}-4 \mathrm{~B}+822$ & 878 & 2.750 & 4 \\
\hline $68 A-4 B+820$ & 880 & 2.740 & 4 \\
\hline $68 A-4 B+790$ & 910 & 2.505 & 12 \\
\hline $68 A-4 B+780$ & 920 & 2.655 & 7 \\
\hline $68 A-4 B+770$ & 930 & 2.690 & 6 \\
\hline $68 \mathrm{~A}-4 \mathrm{~B}+580$ & 1120 & 2.710 & 5 \\
\hline $68 \mathrm{~A}-4 \mathrm{~B}+525$ & 1175 & 2.680 & 6 \\
\hline $68 A-4 B+510$ & 1190 & 2.710 & 5 \\
\hline $68 \mathrm{~A}-4 \mathrm{~B}+470$ & 1230 & 2.770 & 3 \\
\hline $68 A-4 B+460$ & 1240 & 2.770 & 3 \\
\hline $68 A-4 B+450$ & 1250 & 2.775 & 3 \\
\hline $68 A-4 B+400$ & 1300 & 2.780 & 3 \\
\hline $68 A-4 B+380$ & 1320 & 2.755 & 4 \\
\hline \multirow[t]{2}{*}{$68 A-4 B+370$} & 1330 & 2.695 & 6 \\
\hline & & Average & 5.5 \\
\hline
\end{tabular}




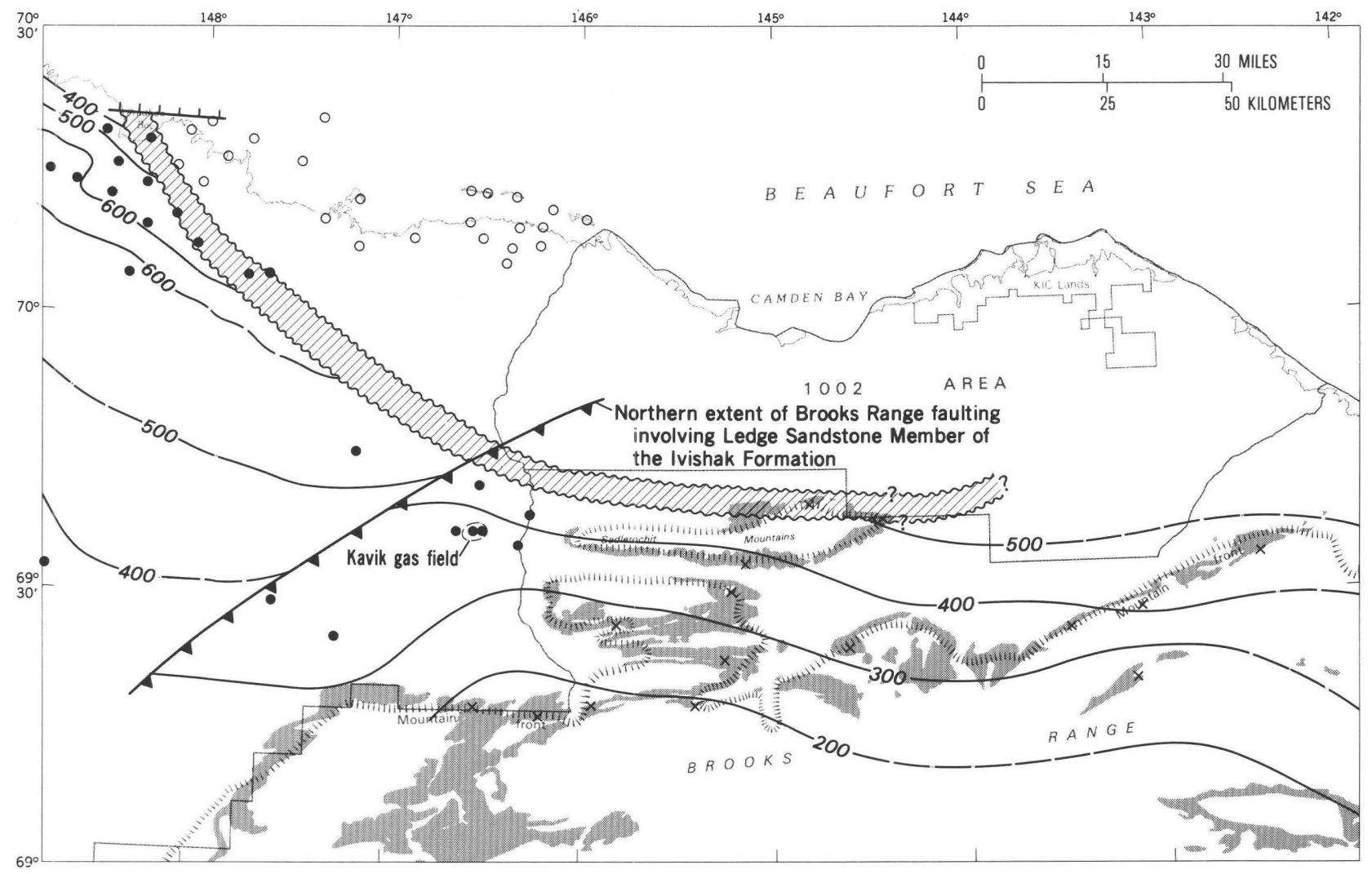

EXPLANATION

Zone of truncation of Ledge Sandstone Member of Ivishak Formation _ - 300 — Thickness of Ledge Sandstone Member in feet-Dashed where approxby Lower Cretaceous unconformity Outcrop of Ledge Sandstone Member

$\sim ? \sim$ Unconformity-Queried where uncertain

- Ledge Sandstone Member present

Thrust fault-Sawteeth on upper plate

- Ledge Sandstone Member absent

Normal fault-Hachures indicate downthrown side

$\times \quad$ Outcrop section of Ledge Sandstone Member

Figure 7.8. Ledge Sandstone Member of Ivishak Formation (Sadlerochit Group) isopachs (in feet) and truncation edge in northeastern Alaska. Outcrop pattern is that of entire Sadlerochit Group. Data points and thicknesses are listed in table 7.1. 


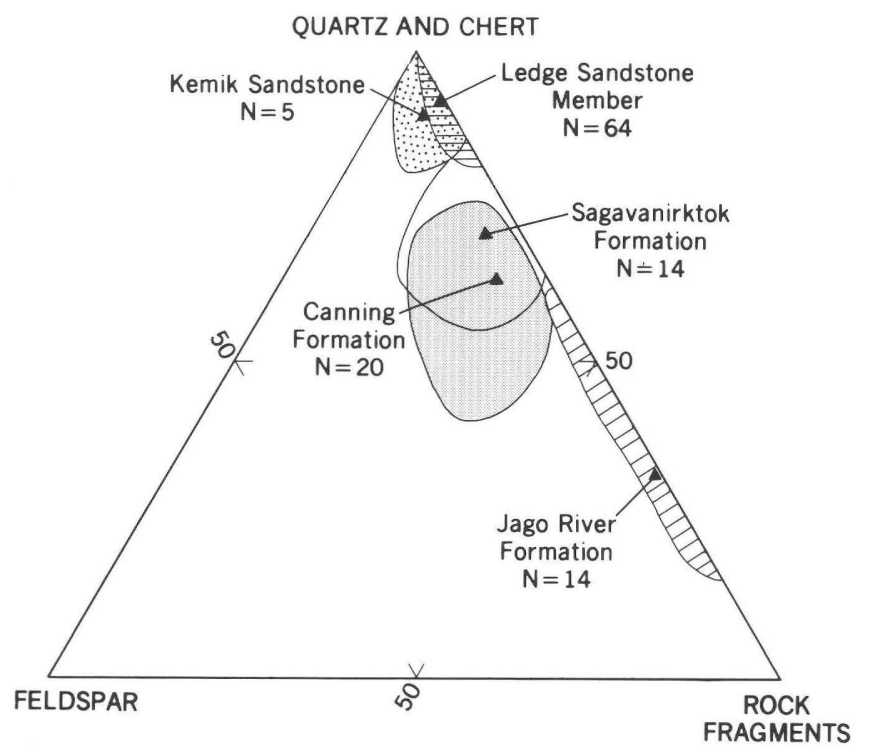

Figure 7.9. Ternary plot illustrating detrital grain composition of selected sandstone units in and adjacent to ANWR coastal plain. Chert has been counted with quartz rather than with lithic grains in order to emphasize potential reservoir properties. All compositions have been normalized by eliminating matrix abundance. Data are from following sources: Ledge Sandstone Member of Ivishak Formation, Cloft (1984); Jago River Formation, McLean (chap. 10); all others, this study (table 7.6). N, number of samples.

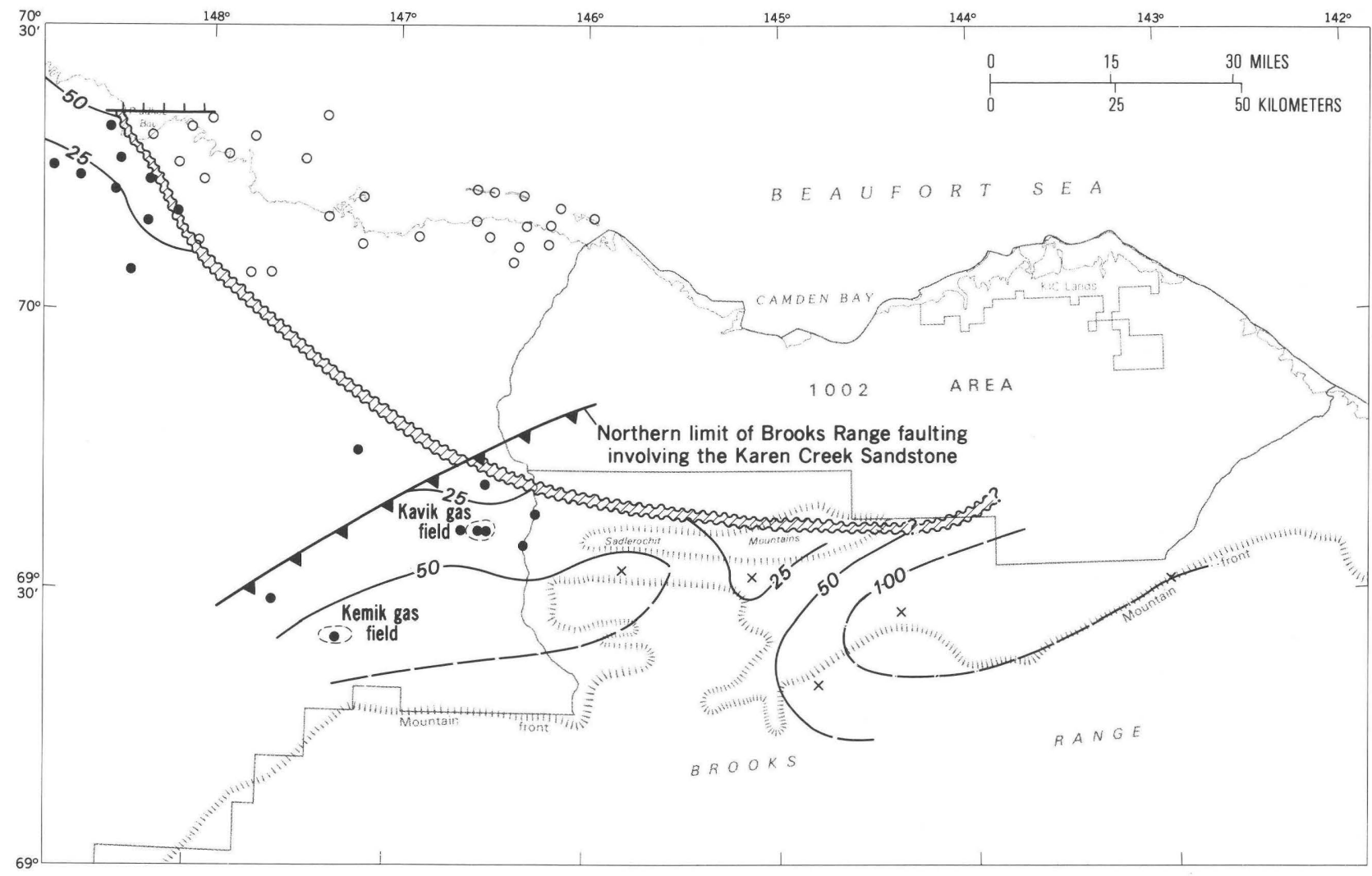

EXPLANATION

Zone of truncation of Shublik Formation and Sag River Sandstone or Karen Creek Sandstone

$\sim \sim \sim$ Unconformity - Queried where uncertain

A_ A Thrust fault-Sawteeth on upper plate

$\perp+\perp, \perp \perp$ Normal fault - Hachures indicate downthrown side

$-50-$ Thickness of Karen Creek Sandstone in feet

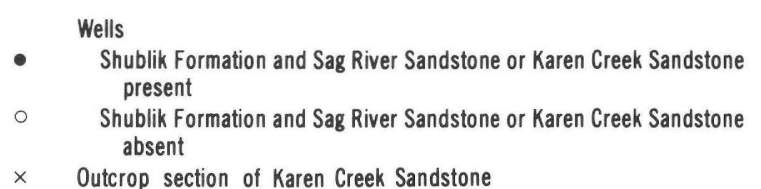

$\times \quad$ Outcrop section of Karen Creek Sandstone

Figure 7.10. Karen Creek Sandstone outcrop pattern, truncation edge, thickness (contours in feet), and control points in northeastern Alaska. See table 7.1 for listing of control points for Karen Creek Sandstone. 


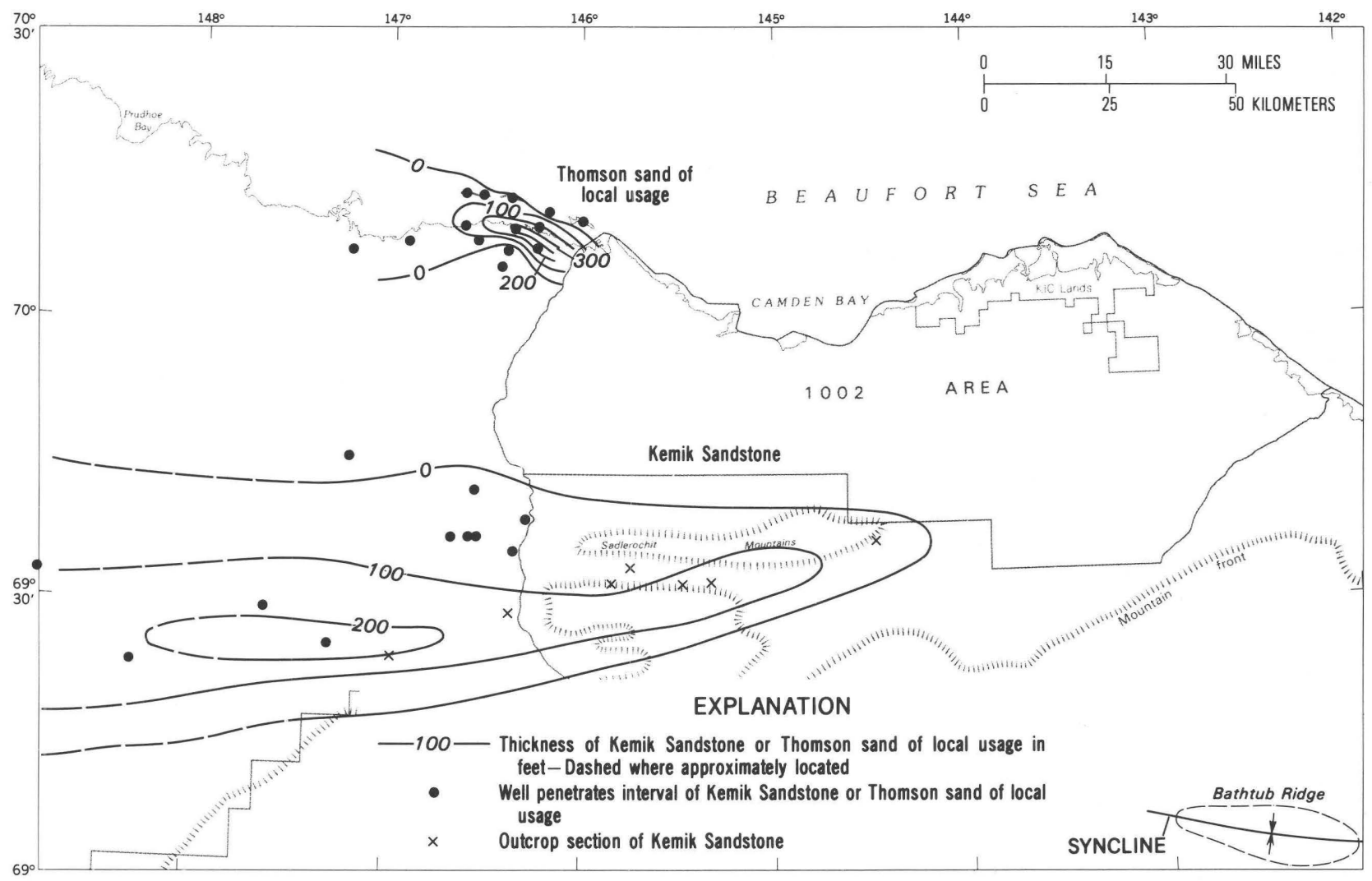

Figure 7.11. Isopachs (in feet) of Kemik Sandstone and Thomson sand of local usage in northeastern Alaska. Data points are listed in table 7.1. 
Table 7.6. Petrographic summary of selected sandstones in northeastern Alaska

[Data, based on 300 counts per sample, are expressed as percentages or ratios. Additional petrographic data are presented in Marinai (chap. 8), Gautier (chap. 9), and McLean (chap. 10). -, no data]

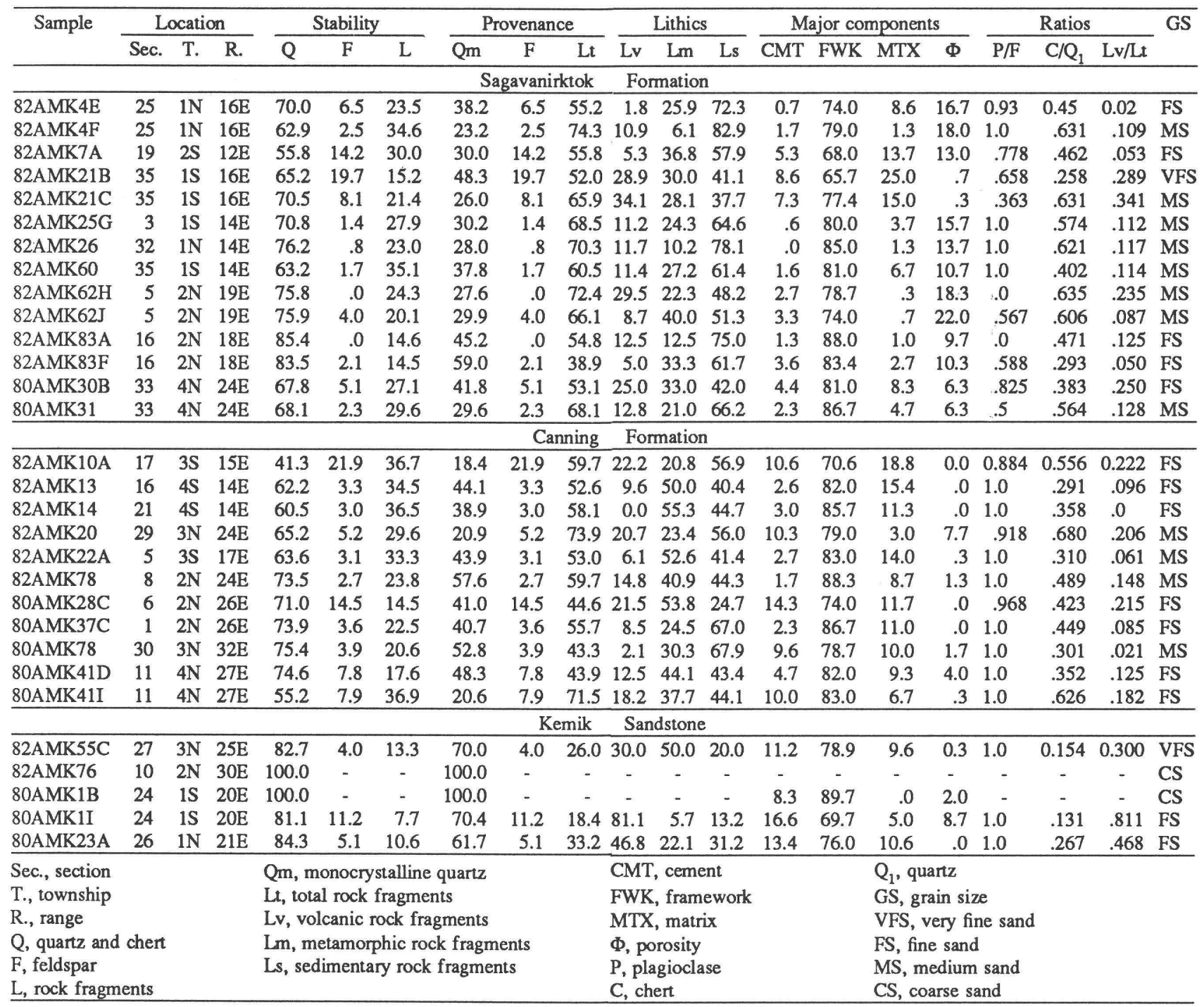




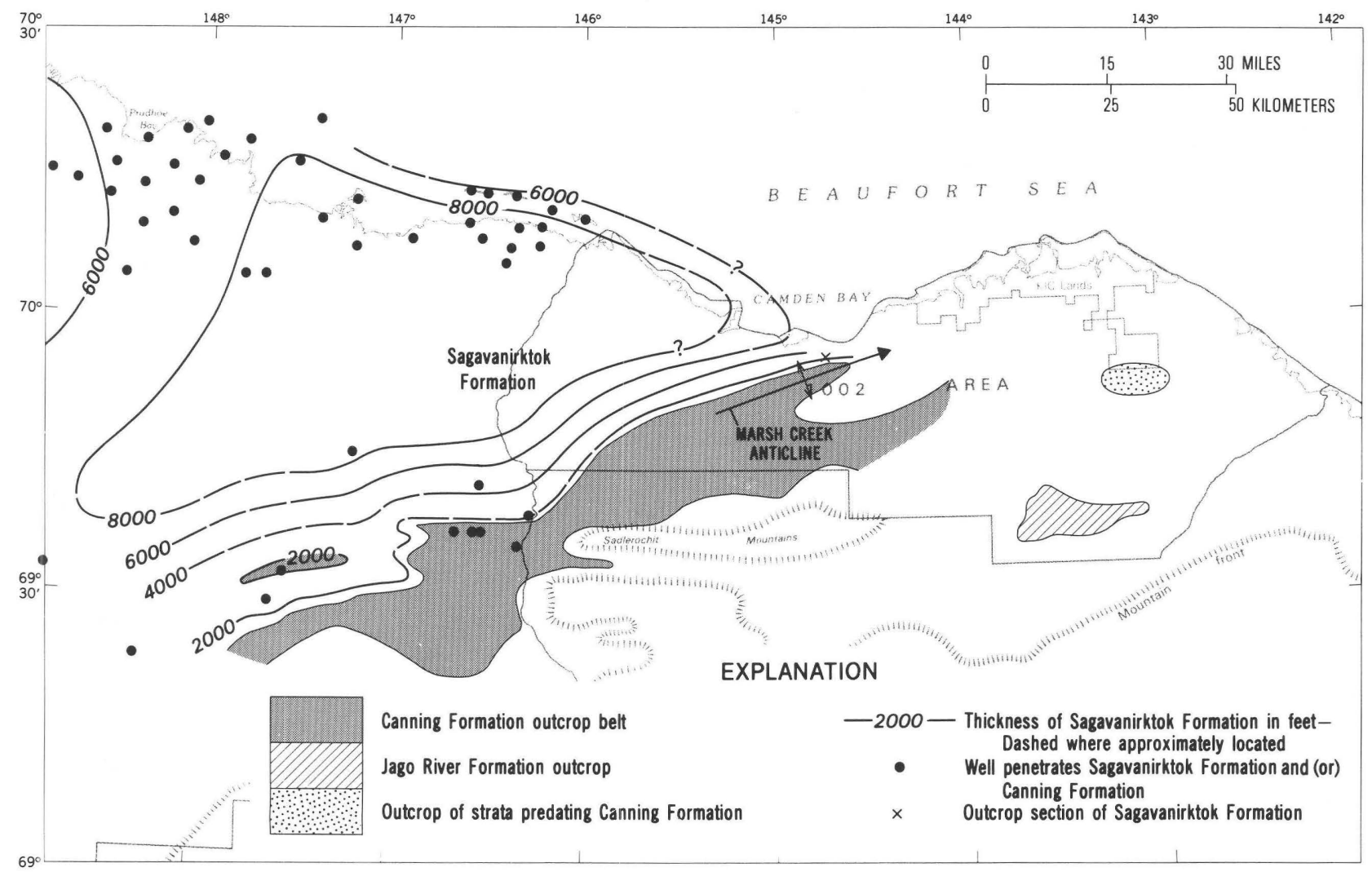

Figure 7.12. Generalized outcrop pattern of the Canning Formation, Sagavanirktok Formation, and Jago River Formation in northeastern Alaska. Isopachs (in feet) are of the Sagavanirktok Formation, which includes one or more tongues of the Canning Formation. See table 7.1 for thicknesses. 



\title{
Chapter 8.
}

\section{Petrography and Diagenesis of the Ledge Sandstone Member of the Triassic Ivishak Formation}

\author{
By Robert K. Marinai ${ }^{1}$
}

\section{INTRODUCTION}

This report documents and describes the diagenesis of the Ledge Sandstone Member, the middle member of the Triassic Ivishak Formation (fig. 5.1), and shows the relationship between diagenetic trends and depositional environments. The diagenesis and depositional environments of the Ledge were compared and contrasted in three measured outcrop sections in the Arctic National Wildlife Refuge (ANWR) south of the coastal plain and in five cores from four wells just west of the ANWR (fig. 8.1). Each of the measured sections is interpreted to be dominated by a different shallowmarine depositional environment, and each displays correspondingly subtle diagenetic differences. The four wells to the west of the ANWR provide only supplemental information to the outcrop sections because of a limited number of cores and a limited amount of core sample from the Ledge Sandstone Member. The depositional environments of these samples could not be directly determined because of the small sample size, generally only a few centimeters. However, projection of regional facies trends and identification of diagnostic mineral assemblages allow an interpretation of the depositional environments of the Ledge in these wells.

\section{PREVIOUS WORK}

The regional setting and stratigraphic nomenclature of the Permian and Triassic Sadlerochit Group is summarized by Bird and Molenaar (chap. 5). Bird and others (chap. 7) provide general thickness, porosity, and compositional data for the Ledge Sandstone Member. Detterman and others (1975) named and described the Ledge Sandstone Member. Cloft (1984) performed a detailed sedimentological study of five measured sections of the Ledge from the ANWR and determined that it was deposited in a variety of shallowmarine environments. Jones and Speers (1976) described the stratigraphy and petroleum geology of the Ivishak Formation and adjacent formations from the subsurface

\footnotetext{
${ }^{1}$ Geonomics Inc., Campbell, Calif.
}

of the Prudhoe Bay oil field, where the Ledge is the main reservoir rock unit. Melvin and Knight (1984) studied the Ivishak in the Prudhoe Bay area and concluded that its diagenesis is largely lithofacies dependent. Van de Kamp (1979) included the Ivishak in a diagenetic study of the northerly derived Ellesmerian sequence from the National Petroleum Reserve in Alaska (NPRA) and from Prudhoe Bay; he concluded that much of its porosity is diagenetically produced.

\section{METHODOLOGY AND SAMPLING PROCEDURES}

Field work-measuring and sampling three stratigraphic sections of the Ivishak Formation-was done in the ANWR during July 1984 as part of a USGS field program. The limited amount of field time only allowed for the measurement and sampling of three sections: Aichilik River, Fire Creek, and Marsh Creek

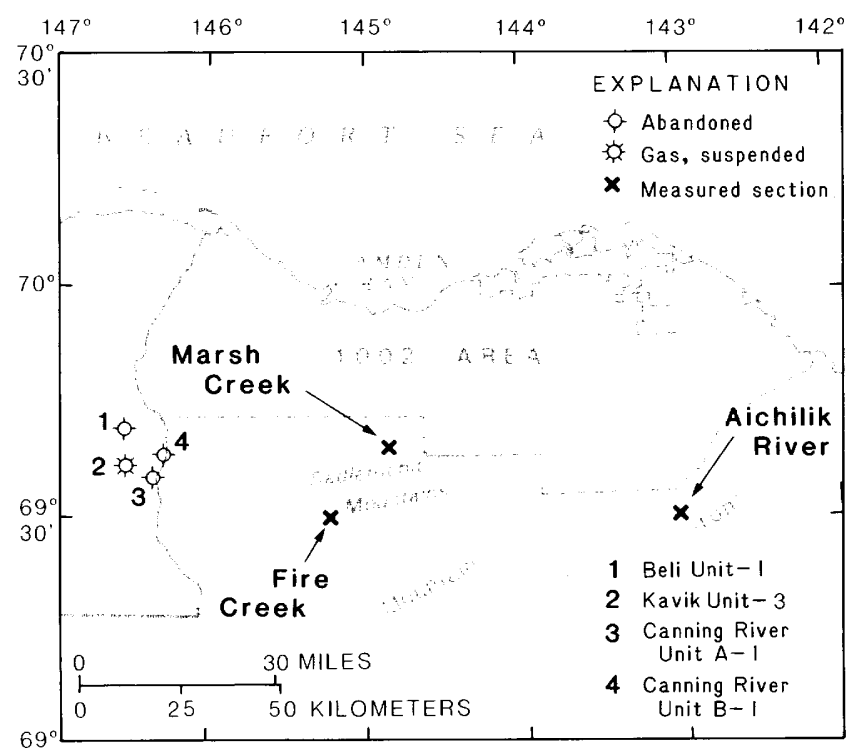

Figure 8.1. Location of measured sections and wells used in this report. 
(fig. 8.1). For this study, a combined total of more than 400 samples were collected from these sections and from four wells located west of the ANWR: Beli Unit-1, Kavik Unit-3, Canning River Unit A-1, and Canning River Unit B-1. The Ledge Sandstone Member at these sections is interpreted to represent a variety of sedimentary environments, which provides an opportunity to determine how the environment of deposition affects diagenesis. Exposures permitting, samples were collected at $10-\mathrm{ft}$ intervals. The availability of core samples from wells was limited to five cores, represented by small chips, one from each foot of core. Sampling of these wells was based solely on the access to the materials of interest. These wells are presumedly located on structures that lie to the west of and that trend with the Sadlerochit Mountains (fig. 8.1; K.J. Bird, U.S. Geological Survey, oral commun., 1986). More than 150 thin sections from the well and outcrop samples were studied to determine the petrology and diagenesis of the Ledge Sandstone Member. Representative specimens were photomicrographed to illustrate the main diagenetic events. Thirty thin sections were point counted, at 300 counts per slide, for modal analysis (table 8.1). X-ray diffraction aided in mineral identification. A scanning electron microscope (SEM) provided morphologic details of authigenic minerals and pore spaces. Spot analysis with a Tracor Electron Dispersion System (EDS) provided positive identification of minerals while using the SEM. Electron microprobe spot analysis of siderite and ankerite yielded quantitative chemical data on these important carbonate cements.

\section{OUTCROP AND CORE DESCRIPTIONS}

The Ledge Sandstone Member in the ANWR represents regressive, shallow-marine, deltaic, and shoreface deposits that were laid down during a period of uplift and erosion of a northern landmass (chap. 5). The three stratigraphic sections and five cores studied are interpreted to represent at least three different environments within the overall regressive Ledge Sandstone Member. The Marsh Creek section represents sediments deposited closest to the source, and the Aichilik River section the most distant, with the Fire Creek section intermediate (Cloft, 1984). A very brief description of the observed diagnostic features for the depositional environments of each of these sections follows. For a more complete treatment, see Cloft (1984).

\section{Depositional Environments of Measured Sections}

\section{Fire Creek Section}

The Ledge at this section (sec. 8, 9, and 16, T. 2 N., R. $28 \mathrm{E}$.) is $111 \mathrm{~m}$ (365 ft) thick and is dominated by very fine grained sandstone with numerous siltstone interbeds and some shale laminae (fig. 8.2A). The base of this section $(0-15.2 \mathrm{~m}, 0-50 \mathrm{ft})$ is dominated by massive, fine- to medium-grained sandstone overlain by parallel-bedded sandstone with normal graded bedding. These beds are interpreted to represent an offshore bar or upper shoreface sequence. Above a 30.5-m (100 ft) covered interval, the next exposed part of the section (45.7-85.3 $\mathrm{m}, \quad 150-280 \mathrm{ft})$ displays highly contorted ball-and-pillow structures overlain by parallel-bedded, wavy, fine-grained sandstones. Above this is fine-grained sandstone with siltstone and claystone lenses and some smoothly undulating bedding. This sequence is interpreted to be delta-front, tidal flat, beach, and deltafringe or shoreface deposits. Above a $10.7 \mathrm{~m}$ (35 ft) covered interval, the next part of the section $(102.1-111.3 \mathrm{~m}, 335-365 \mathrm{ft})$ is dominated by parallelbedded quartz arenites with small lumps of clay overlain by a thin interval of low-angle, planar-tabulate, crossbedded sandstone. Massively bedded sandstone and parallel-laminated siltstone comprise the uppermost part of the section. This sequence is interpreted to represent normal delta-front deposits that were modified by wave action or an upper shoreface sequence.

\section{Marsh Creek Section}

The Ledge at this section (sec. 23, 24, T. 4 N., R. 30 E.) is $71 \mathrm{~m} \mathrm{(232} \mathrm{ft)} \mathrm{thick,} \mathrm{displays} \mathrm{a} \mathrm{basal}$ gradational contact with the Kavik Member, and is truncated by the so-called Lower Cretaceous unconformity (fig. 8.2B). It is estimated that an additional $61 \mathrm{~m}(200 \mathrm{ft})$ of the Ledge is missing due to this truncation (K.J. Bird, U.S. Geological Survey, written commun., 1986). At the base of the Marsh Creek section, from 0 to $27.4 \mathrm{~m}$ ( 0 to $90 \mathrm{ft}$ ), the Ledge is dominated by parallel-bedded sandstone and siltstone with rare marine fossils. These beds are interpreted to represent delta-front sediments. The interval 27.4 to 42.7 $\mathrm{m}$ (90 to $140 \mathrm{ft}$ ) upsection displays a variety of lithofacies that are dominated by parallel-bedded siltstone and ripple marked, wavy-bedded, massive sandstone. These strata are interpreted to represent upper shoreface and offshore bar sequences. From 42.7 to $54.9 \mathrm{~m}$ (140 to $180 \mathrm{ft}$ ) the facies are dominated by planar-tangential crossbedded sandstone, parallel-laminated siltstone, massively bedded sandstone, and disturbed sandstone and siltstone with infrequent ball-and-pillow structures. This sequence is interpreted to represent beach deposits. The uppermost part of the Marsh Creek section, from 54.9 to $70.7 \mathrm{~m}$ (180 to $232 \mathrm{ft}$ ), is massively bedded sandstone, burrowed sandstone and siltstone, and parallel-laminated siltstone beds that are inferred to represent a delta-front or upper shoreface sequence. Rocks from this sequence are truncated by the Lower Cretaceous unconformity and overlain by the Lower Cretaceous pebble shale unit. 


\section{Aichilik River Section}

The Ledge at this section (sec. 22, T. 2 N., R. 37 E.) is $117.4 \mathrm{~m}$ (385 feet) thick. It is the most difficult section to interpret because it is extensively covered (fig. 8.2C). The base of the accessible outcrop from $0-7.6 \mathrm{~m}(0-25 \mathrm{ft})$ displays bioturbation as well as internally deformed laminations suggesting that they probably formed due to slumping on oversteepened slopes. These beds are interpreted to have been deposited in a distal delta-front environment. The interval from 7.6 to $70.1 \mathrm{~m}(25$ to $230 \mathrm{ft})$ is largely covered except for about $4.6 \mathrm{~m}(15 \mathrm{ft})$ of massive sandstone. From 70.1 to $117.4 \mathrm{~m}(230$ to $385 \mathrm{ft})$, the few accessible outcrops in the upper part of the section show interbedded thick sandstones and thinner siltstone and shale strata in a depositional pattern similar to turbidite facies. However, taken in the context of the inferred depositional environments of the other sections, a more likely environment of deposition is a delta fringe.

\section{Core Descriptions}

Access to cored material was extremely limited, and inspection of the core itself was not possible. The following descriptions are based on work done by the American Stratigraphic Company. The Ledge interval from Canning River Unit A-1 (sec. 19, T. 3 N., R. 24 E.) is at 1,436 to $1,573 \mathrm{~m}(4,710$ to $5,160 \mathrm{ft})$ depth, and the cored interval occurs between 1,484 and 1,498 m (4,868 to $4,915 \mathrm{ft}$ ). The Ledge in this core is a moderately sorted, rounded, very fine to medium-grained sandstone and siltstone cemented with quartz and minor amounts of siderite. There are few argillaceous partings and traces of enhanced porosity due to fracturing.

Table 8.1. Modal analyses from thin-section point counts of sandstone of the Ledge Sandstone Member of the Ivishak Formation

[Sample identification: ARV, Aichilik River section; BU, Beli Unit-1; CRA, Canning River Unit A-1; CRB, Canning River Unit B-1; FCK, Fire Creek section; KU3, Kavik Unit-3; MCK, Marsh Creek section. Sample number indicates distance (in feet) below top of section or well. Textural characteristics: So, sorting; Gs, grain size. Sorting classes: M, moderate; MP, moderate to poor, MW, moderate to well; P, poor; VP, very poor; VW, very well; W, well. Grain-size classes: C, coarse sand; F, fine sand; M, medium sand; VF, very fine sand. Framework grains: Qm, monocrystalline quartz; Qp, polycrystalline quartz; C, chert; L, lithic grains, undifferentiated; F, feldspar; G, organics; M, matrix; O, other. Matrix and Cement: Q, quartz; Si, siderite; An, ankerite; K, kaolinite; C, chlorite; A, apatite; B, barite; P, pyrite; S, sphalerite. Framework components: Q, mono- and polycrystalline quartz; F, feldspar; L, lithic fragments including chert. Total components: Fk, framework grains; MC, matrix and cement; P, porosity. All figures are volume percents based on 300 counts per sample. T, trace.]

\begin{tabular}{|c|c|c|c|c|c|c|c|c|c|c|c|}
\hline \multicolumn{2}{|c|}{ Sample } & \multicolumn{2}{|c|}{ Texture } & \multicolumn{8}{|c|}{ Framework grains } \\
\hline \multirow[t]{2}{*}{ Well } & \multirow{2}{*}{$\begin{array}{c}\text { Depth } \\
\text { (ft) }\end{array}$} & & & & & & & & & & \\
\hline & & So & Gs & $Q \mathrm{~m}$ & Qp & C & $\mathrm{L}$ & $\mathbf{F}$ & $\mathbf{G}$ & $\mathbf{M}$ & $\mathrm{O}$ \\
\hline CRB & 8956 & $\mathbf{W}$ & VF-F & 50 & 7 & 25 & $\mathbf{T}$ & 0 & 0 & 2 & $\bar{T}$ \\
\hline CRB & 8962 & MW & $\mathbf{F}$ & 50 & 9 & 10 & 1 & 0 & 0 & 15 & $\mathbf{T}$ \\
\hline CRB & 8967 & MW & $\mathbf{F}$ & 45 & 7 & 22 & $\mathbf{T}$ & 0 & 0 & 12 & 0 \\
\hline BU & 11652 & $\mathbf{P}$ & F-M & 33 & 4 & 20 & 1 & 0 & 0 & 24 & $T$ \\
\hline BU & 11654 & MW & $\mathbf{M}$ & 41 & 2 & 17 & 1 & 0 & 0 & 0 & 0 \\
\hline BU & 11835 & VW & $\mathrm{F}$ & 44 & 10 & 25 & 1 & 0 & 0 & 1 & 0 \\
\hline BU & 11840 & VP & VF-M & 28 & 8 & 47 & 1 & 0 & 0 & 1 & 0 \\
\hline KU3 & 5410 & w & F-M & 45 & 1 & 5 & 0 & 0 & 0 & 0 & 0 \\
\hline KU3 & 5431 & VW & $\mathrm{F}$ & 51 & 9 & 23 & 1 & 0 & 0 & 7 & 0 \\
\hline KU3 & 5440 & $\mathbf{W}$ & F-M & 53 & 12 & 17 & 0 & 0 & 1 & 0 & 14 \\
\hline CRA & 4874 & $\mathbf{M}$ & $\mathbf{F}$ & 43 & 12 & 12 & 1 & $\mathrm{~T}$ & 0 & 0 & 0 \\
\hline CRA & 4876 & $\mathbf{P}$ & VF-M & 38 & 10 & 32 & 2 & 0 & 0 & 0 & 0 \\
\hline CRA & 4881 & VW & F & 47 & 12 & 16 & 2 & $\mathrm{~T}$ & 0 & 0 & 0 \\
\hline CRA & 4892 & $\mathbf{M}$ & $\mathbf{M}$ & 47 & 6 & 27 & $\mathbf{T}$ & 0 & 0 & 1 & 0 \\
\hline CRA & 4898 & MP & F-M & 50 & 6 & 21 & 0 & 0 & 0 & 4 & 0 \\
\hline CRA & 4903 & MW & F-M & 50 & 11 & 26 & $\mathbf{T}$ & 0 & 0 & 4 & 0 \\
\hline CRA & 4909 & MW & F-M & 38 & 18 & 28 & 1 & 0 & 0 & 1 & 0 \\
\hline CRA & 4911 & P & VF-M & 44 & 11 & 25 & 1 & 0 & 0 & 9 & 0 \\
\hline FCK & 230 & VW & F & 46 & 16 & 22 & 2 & 0 & 0 & 4 & $T$ \\
\hline FCK & 250 & $\mathbf{M}$ & $\mathbf{M}$ & 39 & 11 & 34 & 0 & 0 & 0 & 0 & 0 \\
\hline FCK & 260 & P & F-C & 32 & 11 & 45 & 0 & 0 & 0 & 1 & $\mathrm{~T}$ \\
\hline FCK & 305 & M & $\mathbf{M}$ & 55 & 15 & 22 & 3 & 0 & 0 & 0 & 0 \\
\hline FCK & 360 & W & $\mathrm{F}$ & 53 & 11 & 10 & 2 & 0 & 0 & 0 & 0 \\
\hline FCK & 430 & W & F & 48 & 4 & 19 & 4 & 0 & $\mathbf{T}$ & 0 & 0 \\
\hline ARV & 705 & VP & M-C & 17 & 4 & 60 & 2 & 0 & 0 & 0 & 0 \\
\hline ARV & 710 & VP & $\mathbf{M}-\mathbf{C}$ & 18 & 4 & 62 & 3 & 0 & 0 & 0 & 0 \\
\hline ARV & 820 & $\mathbf{W}$ & $\mathbf{M}$ & 47 & 10 & 17 & $\mathbf{T}$ & 0 & 0 & 0 & 0 \\
\hline MCK & 300 & P & M-C & 21 & 1 & 44 & 1 & 0 & 0 & 0 & 0 \\
\hline MCK & 325 & MW & $\mathbf{M}$ & 42 & 8 & 20 & 4 & 0 & 0 & 0 & 0 \\
\hline MCK & 350 & M & F-M & 50 & 6 & 20 & 0 & 0 & 0 & 4 & 0 \\
\hline
\end{tabular}

\begin{tabular}{|c|c|c|c|c|c|c|c|c|c|c|c|c|c|c|}
\hline \multicolumn{9}{|c|}{ Matrix and Cement } & \multicolumn{6}{|c|}{$\frac{\text { Summary }}{\text { Normalized percent }}$} \\
\hline & & & & & & & & & & ame & & & Total & \\
\hline$Q$ & $\mathrm{Si}$ & An & $\mathbf{K}$ & C & $\mathbf{A}$ & B & $\mathbf{P}$ & $\mathbf{S}$ & $\mathbf{Q}$ & $\mathrm{F}$ & $\mathrm{L}$ & $\mathbf{F k}$ & MC & $\mathbf{P}$ \\
\hline 12 & $\mathrm{~T}$ & 0 & 3 & 0 & 0 & 0 & 0 & 0 & 70 & 0 & 30 & 82 & 17 & 1 \\
\hline 7 & 7 & $\mathbf{T}$ & $\mathbf{T}$ & 0 & 0 & 0 & 0 & 0 & 85 & 0 & 15 & 70 & 28 & 2 \\
\hline 3 & 0 & 10 & $\mathbf{T}$ & 0 & 0 & 0 & 0 & 0 & 70 & 0 & 30 & 74 & 26 & $\mathbf{T}$ \\
\hline 3 & 14 & 0 & 1 & 0 & 0 & 0 & 1 & 0 & 65 & 0 & 35 & 57 & 42 & 1 \\
\hline 17 & 0 & 22 & 0 & 0 & $\mathrm{~T}$ & 0 & 0 & $\mathbf{0}$ & 80 & $\mathbf{0}$ & 20 & 61 & 39 & $\mathbf{0}$ \\
\hline 15 & 3 & 2 & 0 & 0 & 0 & 0 & 0 & 0 & 68 & 0 & 32 & 70 & 29 & 1 \\
\hline 9 & 5 & 0 & $\mathbf{T}$ & 0 & 0 & 0 & 0 & 0 & 43 & 0 & 57 & 84 & 13 & 3 \\
\hline 8 & 0 & 35 & 0 & 0 & 0 & 0 & 0 & 0 & 90 & 0 & 10 & 51 & 49 & $\mathrm{~T}$ \\
\hline 8 & $\mathbf{T}$ & 0 & 0 & 0 & 0 & 0 & 1 & 0 & 71 & 0 & 29 & 84 & 16 & $\mathrm{~T}$ \\
\hline $\mathrm{T}$ & 0 & 0 & 0 & 0 & 0 & 0 & 3 & 0 & 79 & 0 & 21 & 82 & 18 & $\mathrm{~T}$ \\
\hline 4 & 19 & 0 & 0 & 8 & 0 & 0 & 0 & 0 & 81 & $\mathrm{~T}$ & 19 & 68 & 32 & $\mathrm{~T}$ \\
\hline 13 & 2 & 0 & 0 & 2 & 0 & 0 & $\mathbf{T}$ & 0 & 58 & 0 & 42 & 82 & 18 & $\mathrm{~T}$ \\
\hline 12 & 2 & 0 & 0 & 7 & 0 & 0 & $\mathbf{T}$ & 0 & 76 & $\mathrm{~T}$ & 24 & 77 & 32 & 1 \\
\hline 11 & 3 & 0 & 0 & 0 & 0 & 0 & $\mathbf{T}$ & 12 & 66 & 0 & 33 & 80 & 20 & 0 \\
\hline 2 & 18 & 0 & 0 & $\mathrm{~T}$ & 0 & 0 & 0 & 0 & 56 & 0 & 44 & 76 & 24 & 0 \\
\hline 5 & 1 & 0 & 0 & 0 & 0 & 0 & 1 & 0 & 61 & 0 & 39 & 87 & 13 & 0 \\
\hline 12 & $\mathbf{T}$ & 0 & 0 & 0 & $\mathbf{T}$ & 0 & $\mathbf{T}$ & 0 & 66 & 0 & 34 & 85 & 15 & 0 \\
\hline 5 & 0 & 0 & 0 & 1 & 0 & 0 & 2 & 0 & 68 & 0 & 32 & 81 & 19 & 0 \\
\hline 8 & $\mathbf{T}$ & 0 & $\mathrm{~T}$ & 0 & 0 & 0 & $\mathrm{~T}$ & 0 & 72 & 0 & 28 & 88 & 12 & $\mathbf{T}$ \\
\hline 13 & 0 & 0 & 0 & 0 & 0 & 0 & 0 & $\mathbf{T}$ & 59 & 0 & 41 & 89 & 9 & 2 \\
\hline 9 & 0 & 0 & 0 & 0 & 0 & 0 & 0 & 0 & 49 & 0 & 51 & 88 & 10 & 2 \\
\hline 4 & 2 & 0 & 0 & 0 & 0 & 0 & 0 & 0 & 74 & 0 & 26 & 94 & 6 & $\mathbf{T}$ \\
\hline 22 & 1 & 0 & 0 & 0 & 0 & 0 & 0 & 0 & 84 & 0 & 16 & 76 & 23 & $\mathbf{T}$ \\
\hline 16 & 5 & 0 & 0 & 0 & 3 & 0 & 0 & 0 & 69 & 0 & 31 & 76 & 23 & 1 \\
\hline 1 & 8 & 0 & 0 & 5 & 0 & 0 & 0 & 0 & 25 & 0 & 75 & 82 & 14 & 4 \\
\hline 3 & 1 & 0 & 0 & 7 & 0 & 0 & 0 & 0 & 77 & 0 & 23 & 72 & 28 & 0 \\
\hline 12 & 4 & 0 & 0 & 5 & 0 & 0 & 0 & 7 & 77 & 0 & 23 & 72 & 28 & 0 \\
\hline 12 & 16 & 0 & 0 & 0 & 5 & 0 & 0 & 0 & 33 & 0 & 67 & 67 & 33 & $\mathbf{T}$ \\
\hline 10 & 2 & 0 & 6 & 0 & 0 & 0 & 0 & $\mathbf{T}$ & 68 & 0 & 32 & 67 & 33 & $\mathrm{~T}$ \\
\hline 2 & 18 & 0 & 0 & $\mathrm{~T}$ & 0 & 0 & 0 & 0 & 56 & 0 & 44 & 76 & 24 & 0 \\
\hline
\end{tabular}


The Ledge from Canning River Unit B-1 (sec. 32 , T. 4 N., R. 24 E.) is present from 2,673 to $2,830 \mathrm{~m}$ $(8,770$ to $9,285 \mathrm{ft})$, and the cored interval is from 2,729 to $2,735 \mathrm{~m}(8,955$ to $8,973 \mathrm{ft})$. It is a moderate- to well-sorted, angular, very fine' to medium-grained sandstone and siltstone. There is no fracturing or porosity.

In Kavik Unit-3 (sec. 8, T. 3 N., R. 23 E.) the Ledge is present from 1,618 to $1,756 \mathrm{~m}(5,310$ to 5,760 $\mathrm{ft}$ ), and the cored interval is from 1,646 to $1,659 \mathrm{~m}$
$(5,400$ to $5,442 \mathrm{ft})$. The upper part of the core contains two 1.5 - to $1.8-\mathrm{m}$-thick ( 5 to $6 \mathrm{ft}$ ) shale sequences. The sandstone is moderate to well sorted, fine to coarse grained, and rounded. Fractures account for minor porosity, and they are commonly filled with dead oil.

The Ledge in Beli Unit-1 (sec. 8, T. 4 N., R. 23

E.) is present from 3,511 to $3,699 \mathrm{~m}(11,520$ to 12,135 $\mathrm{ft})$. The two cores from the Ledge range in depth from 3,550 to $3,556 \mathrm{~m}(11,648$ to $11,666 \mathrm{ft})$ and from 3,605 to $3,609 \mathrm{~m}(11,828$ to $11,842 \mathrm{ft})$. The upper core is
$\boldsymbol{A}$

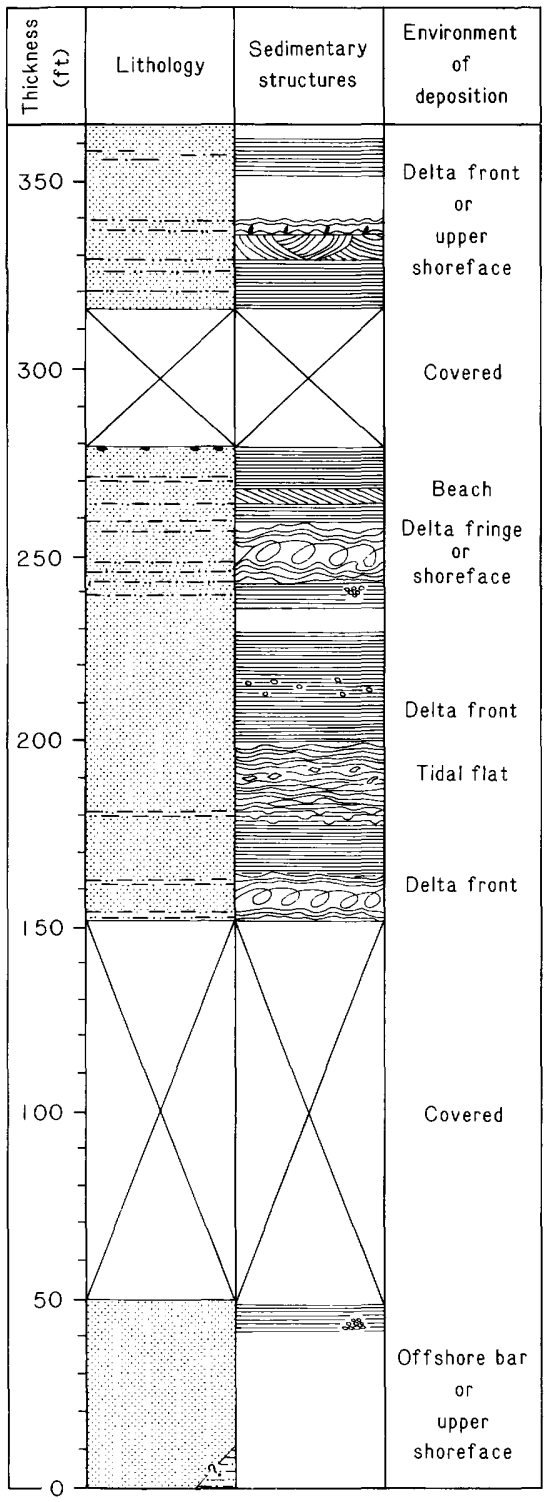

$\boldsymbol{B}$

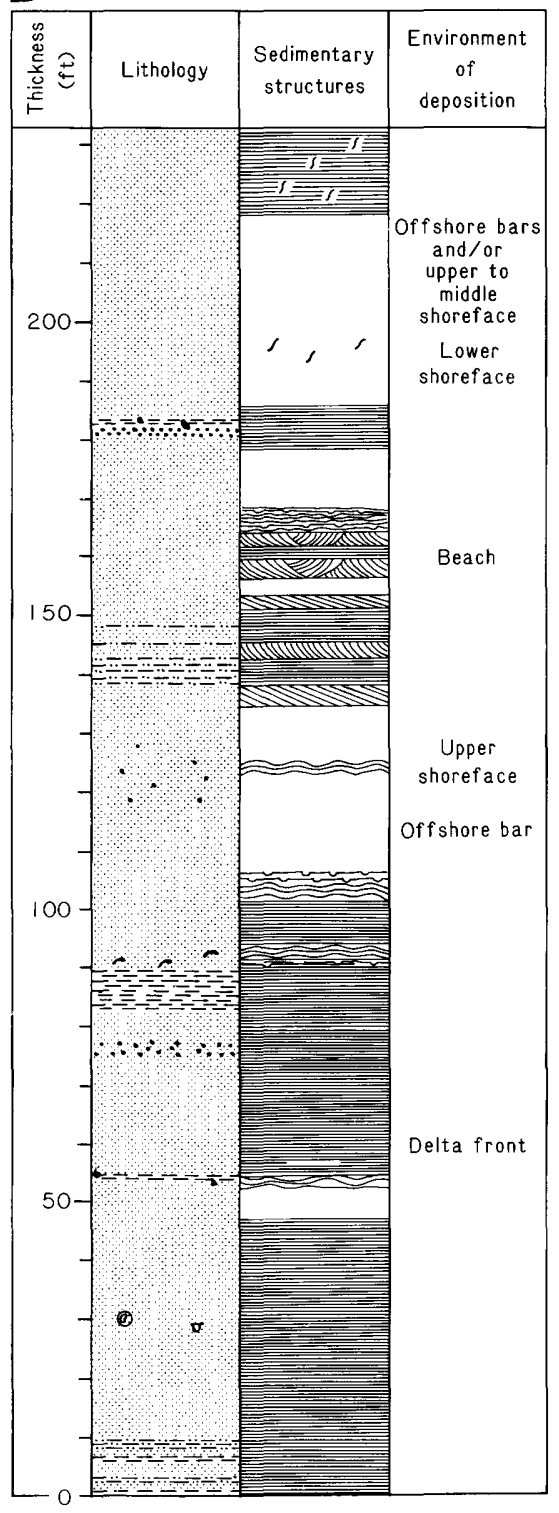

C

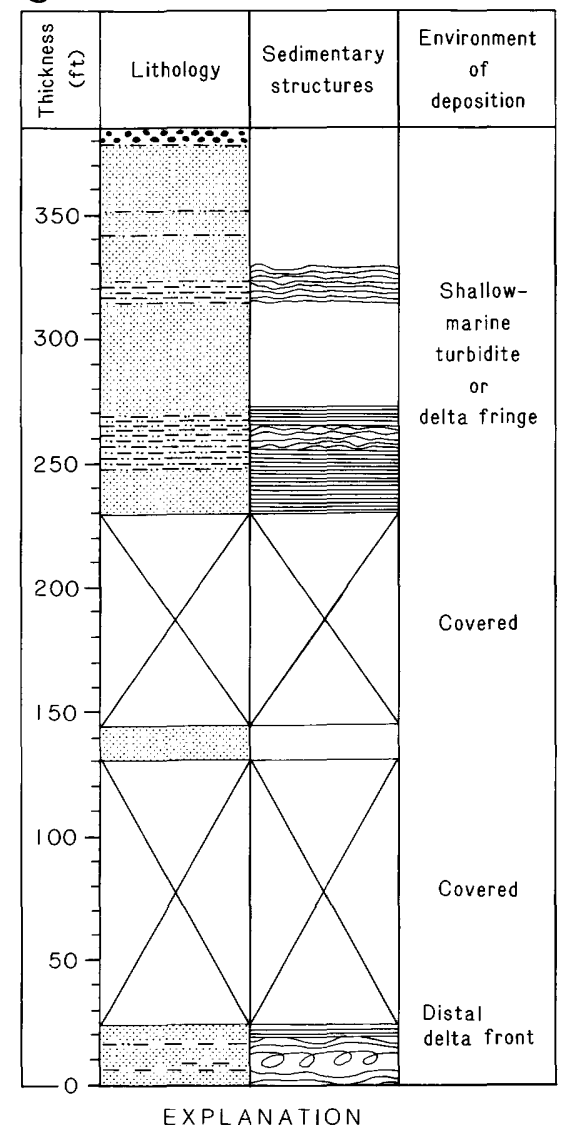

Lithology

Accessories

$\because 0$ Pebbles

re Shell fragments

Es Rootlets

Diflow and ball structures

Sedimentary structures

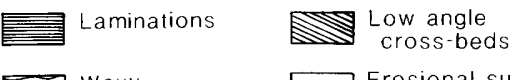

Wavy
laminations

Erosional surface

Bioturbation

Figure 8.2. Stratigraphic sections of Ledge Sandstone Member of Ivishak Formation at $(A)$ Fire Creek, $(B)$ Marsh Creek, and $(C)$ Aichilik River. 
interpreted to occur within the gradational contact with the Fire Creek Siltstone Member of the Ivishak Formation because it is dominated by shales. The sandstone from this core is a poorly sorted, rounded, medium-grained quartz arenite that has minor fracturederived porosity. The lower core is a fine- to coarsegrained, angular to rounded, moderately sorted quartz arenite that is commonly fractured.

\section{PETROGRAPHYY}

The framework mineralogy of the Ledge Sandstone Member is very consistent throughtout the North Slope despite its having been deposited in a variety of depositional environments (Detterman and others, 1975; Van de Kamp, 1979; Melvin and Knight, 1984; Cloft, 1984). It is generally a mature, chert-rich quartz arenite (fig. 8.3) that thickens and coarsens toward the source area (north). It contains as much as 60 percent chert fragments and is angular to well rounded, very well sorted to very poorly sorted, and very fine grained to pebbly conglomeratic. Discrete chert grains are commonly iron stained (fig. 8.4A) and contain pyrite inclusions (fig. $8.4 B$ ), which suggests a hematiteand pyrite-rich source terrane. The angular appearance of quartz grains is due to the abundance of

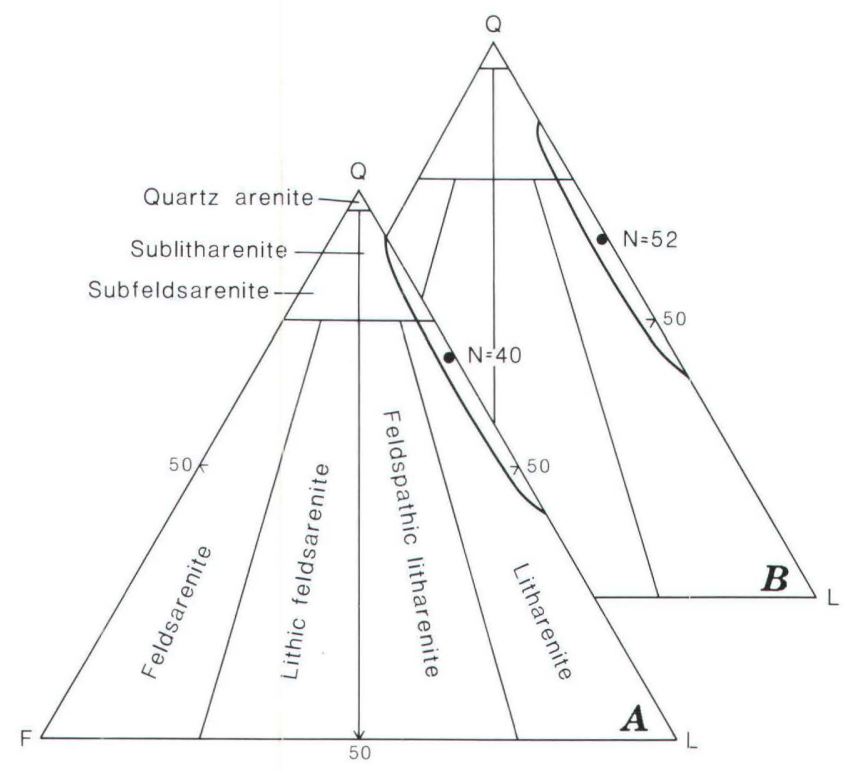

Figure 8.3. Ternary plots of detrital grain composition of (A) 40 samples of Ledge Sandstone Member from ANWR area compared with $(B)$ similar plot based on 52 samples from Ledge-equivalent sandstone from the Prudhoe Bay area (modified from Melvin and Knight, 1984). Compositions are based on 300 counts per slide. Dot indicates average (mean) composition. postdepositional quartz overgrowths and pressure solution as inferred by the contrasting roundness of detrital chert. In the Ledge, chert percentages decrease and sorting increases with decreasing grain size. Shale beds are composed of mainly illite.

The maturity of the Ledge is attributed to its being derived from a very mature source terrane. The sediments represented in this study were deposited in predominantly shallow-marine environments that were subjected to intensive wave and longshore current reworking and redistribution (Cloft, 1984). The reworking of these sediments could have contributed to their maturity. However, modal analysis (Melvin and Knight, 1984) of the lithologic equivalent of the Ledge in the Prudhoe Bay field area (the Ivishak Sandstone of Jones and Speers, 1976) from proximal, nonmarine-facies sediments deposited in alluvial fans and braided streams yield almost exactly the same framework mineralogy as the intensively reworked sediments (fig. 8.3). Therefore, the maturity of the Ledge is interpreted to result from a very mature recycled source rather than from a loss of unstable mineral and rock fragments through mechanical and chemical processes. Authigenic minerals in the Ledge Sandstone Member (in order of abundance) are quartz, siderite, ankerite, pyrite, carbonate fluorapatite, chlorite, kaolinite, and sphalerite. Unlike the uniform framework mineralogy, the authigenic mineralogy exhibits trends suggesting that some of the mineral distribution is facies controlled. In general, chlorite is found in the delta-fringe facies; ankerite, siderite, kaolinite, and sphalerite are common in the facies with shoreline influences, such as beaches, bars, and backbars; and minor amounts of siderite, pyrite, and carbonate fluorapatite are found in the delta-front facies. Precompaction authigenic mineralogy has profoundly affected the late diagenesis and porosity development of the Ledge. The creation of the pore-space network, which makes the rocks lithologically equivalent to the Ledge in the Prudhoe Bay field such excellent reservoirs, is primarily due to the dissolution of authigenic carbonate minerals and unstable rock fragments (Van de Kamp, 1979; Melvin and Knight, 1984). The distribution of these carbonate materials in the ANWR is probably (at least in part) facies controlled.

\section{DIAGENESIS}

The diagenesis of the Ledge from the study area sections follows a long and complex history that in general proceeds as follows: (1) compaction and development of pressure solution (facies independent); (2) pyrite precipitation (delta-front facies); (3) siderite precipitation and quartz/chert dissolution (facies independent); (4) fracturing (facies independent); (5) siderite dissolution (facies independent); (6) carbonate fluorapatite precipitation (delta-front facies); (7) chlorite 


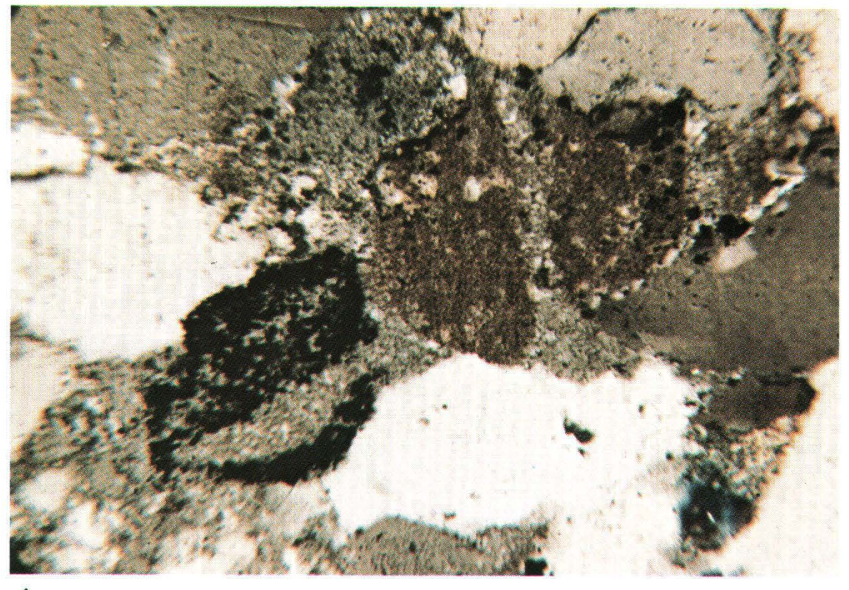

A

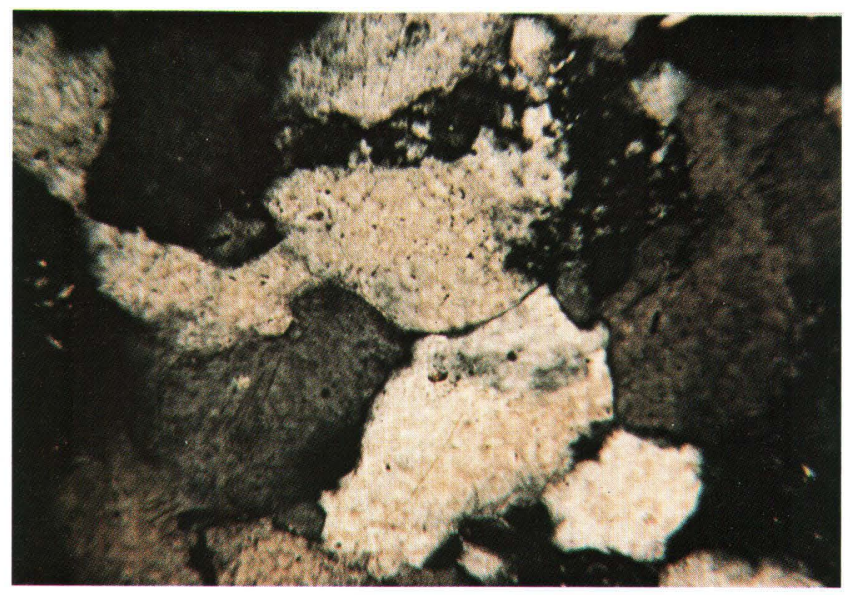

C

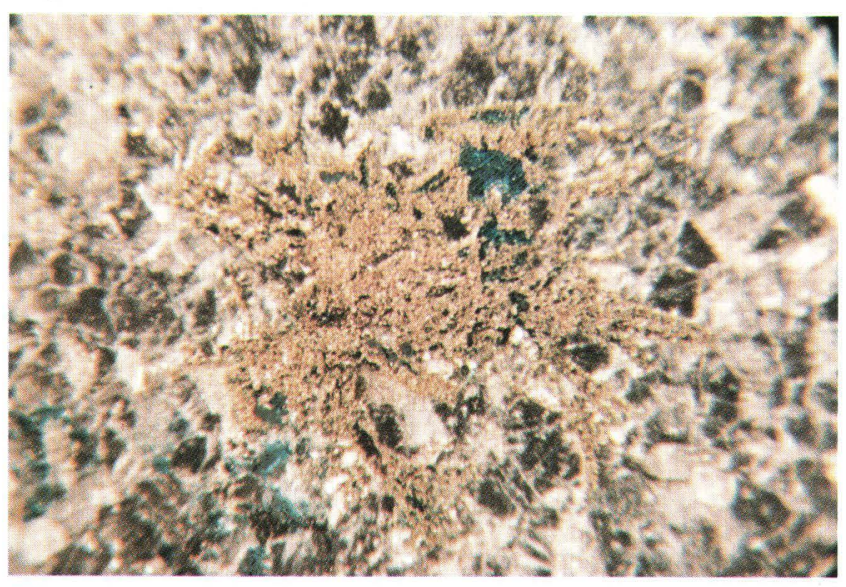

$\boldsymbol{E}$

Figure 8.4. Photomicrographs of the Ledge Sandstone Member. A, Iron-stained chert on right and chert with pyrite inclusions (black in this view) on left, suggesting hematite- and pyrite-bearing source terrane. $10 \mathrm{x} / 1 / 2 \mathrm{XN}$. $B$, Chert with pyrite inclusions, suggesting pyrite-bearing source terrane. $10 x / 1 / 2 X N$. $C$, Sutured and concavoconvex grain contacts and minor pressure solution. Note nearly $120^{\circ}$ grain contacts and severely deformed chert at bottom, indicating maximum compaction. $25 \mathrm{x} / \mathrm{XN}$. $D$,

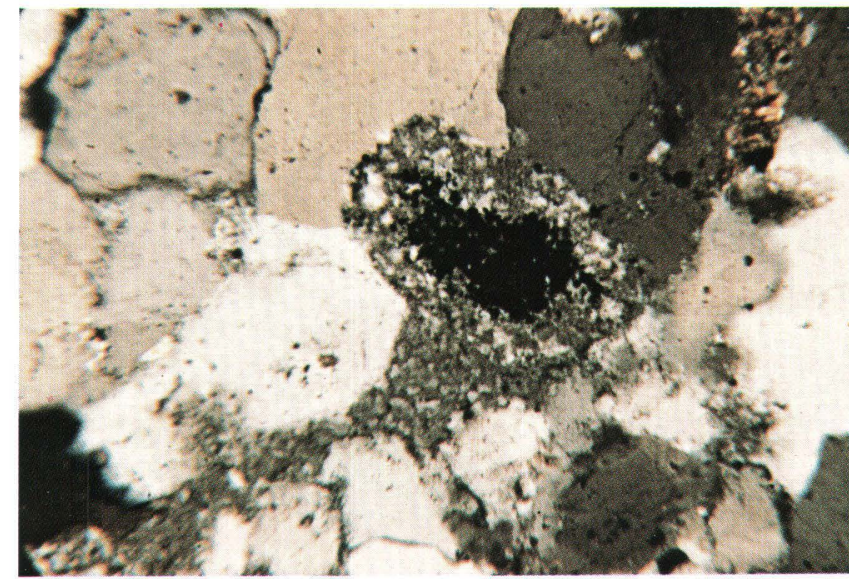

$\boldsymbol{B}$

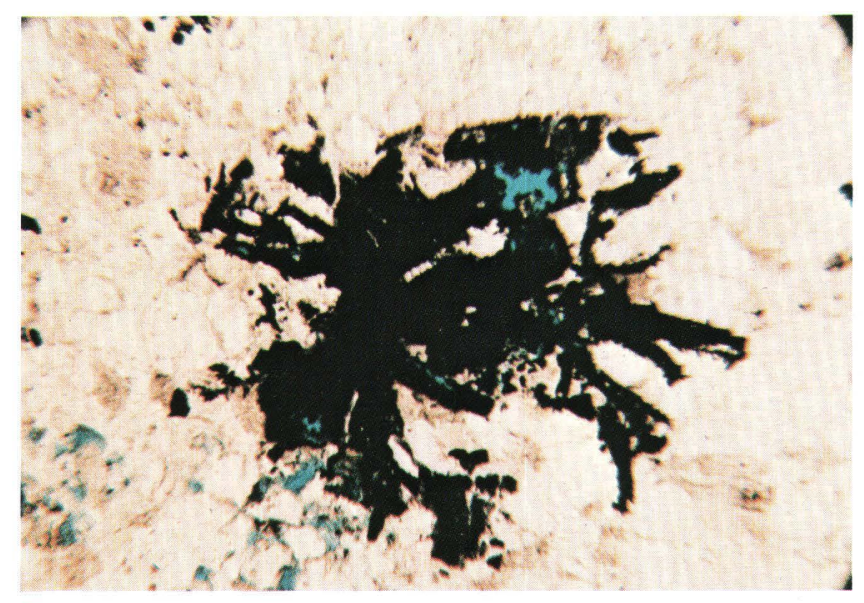

D

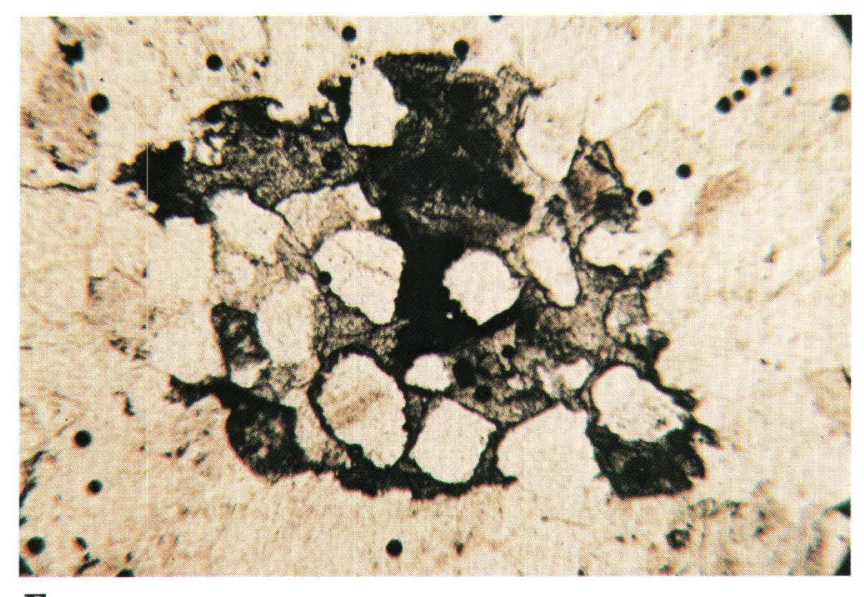
F

Example of an early-formed pyrite concretion. Concretions of this type are most common in delta-front facies. $2.5 \mathrm{x} / \mathrm{PL}$. $E$, Same as $D$, but with reflected light. 2.5x/RL. $F$, Pyrite-cored siderite crystal suggests that precipitation of these continuous iron-bearing phases was early. Preserved open packing within siderite concretions suggests that precipitation of siderite occurred in shallow subsurface. $2.5 \mathrm{x} / \mathrm{PL}$. 
formation (delta-fringe facies); (8) quartz precipitation (facies independent); (9) kaolinite precipitation (shoreface facies); (10) ankerite, pyrite, and sphalerite precipitation (shoreface facies); and (11) organic matter migration. The relative timing of these diagenetic stages is summarized in figure 8.5. This is an idealized sequence, and there may be considerable overlap between some of the steps. For example, compaction and siderite precipitation probably occur simultaneously. Throughout the North Slope, the porosity and permeability of the lithologic equivalent of the Ledge in the Prudhoe Bay area are derived from its diagenesis rather than from its preservation of primary porosity and permeability (Van de Kamp, 1979; Melvin and Knight, 1984). Porosity enhancement due to carbonate dissolution is considered an important diagenetic factor in the Prudhoe Bay field (Melvin and Knight, 1984). Petrographic evidence in some Ledge samples suggests that a similar dissolution event occurred in the ANWR, resulting in enhanced porosity. These pores were subsequently filled, primarily with late authigenic quartz and ankerite, which effectively destroyed the reservoir quality of the Ledge in the ANWR (as represented by the outcrops).

\section{Compaction and Pressure Solution}

Compaction features of the Ledge Sandstone Member in the ANWR consist of grain-to-grain contacts,

$\boldsymbol{A}$

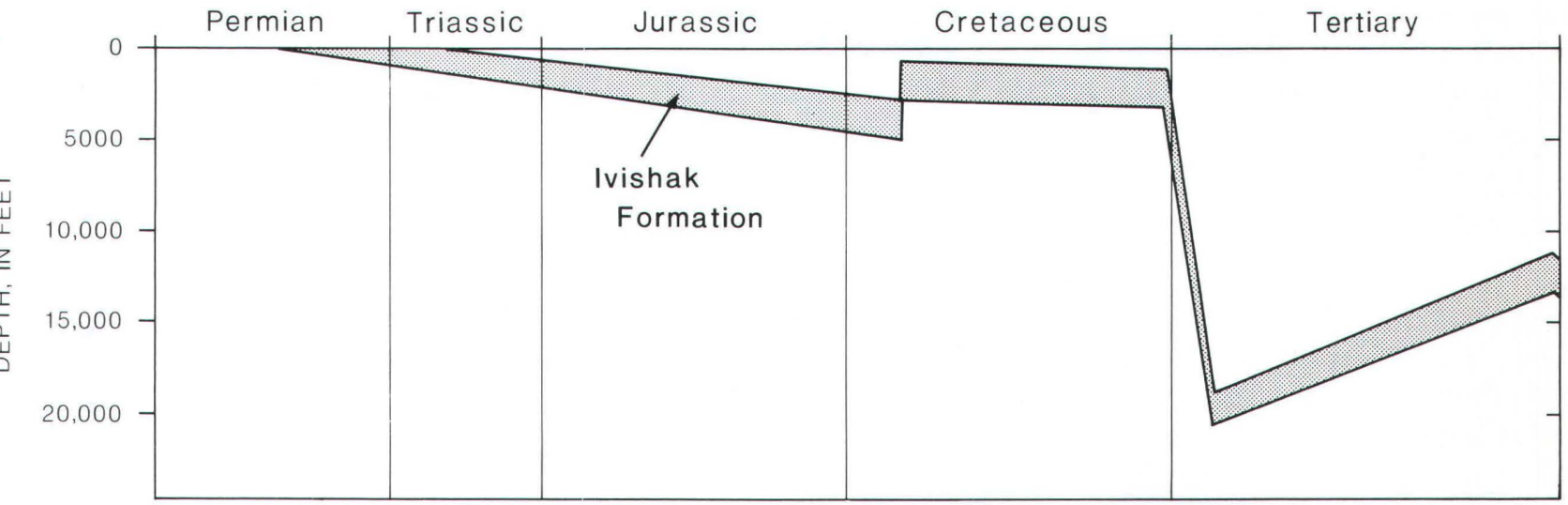

$B$

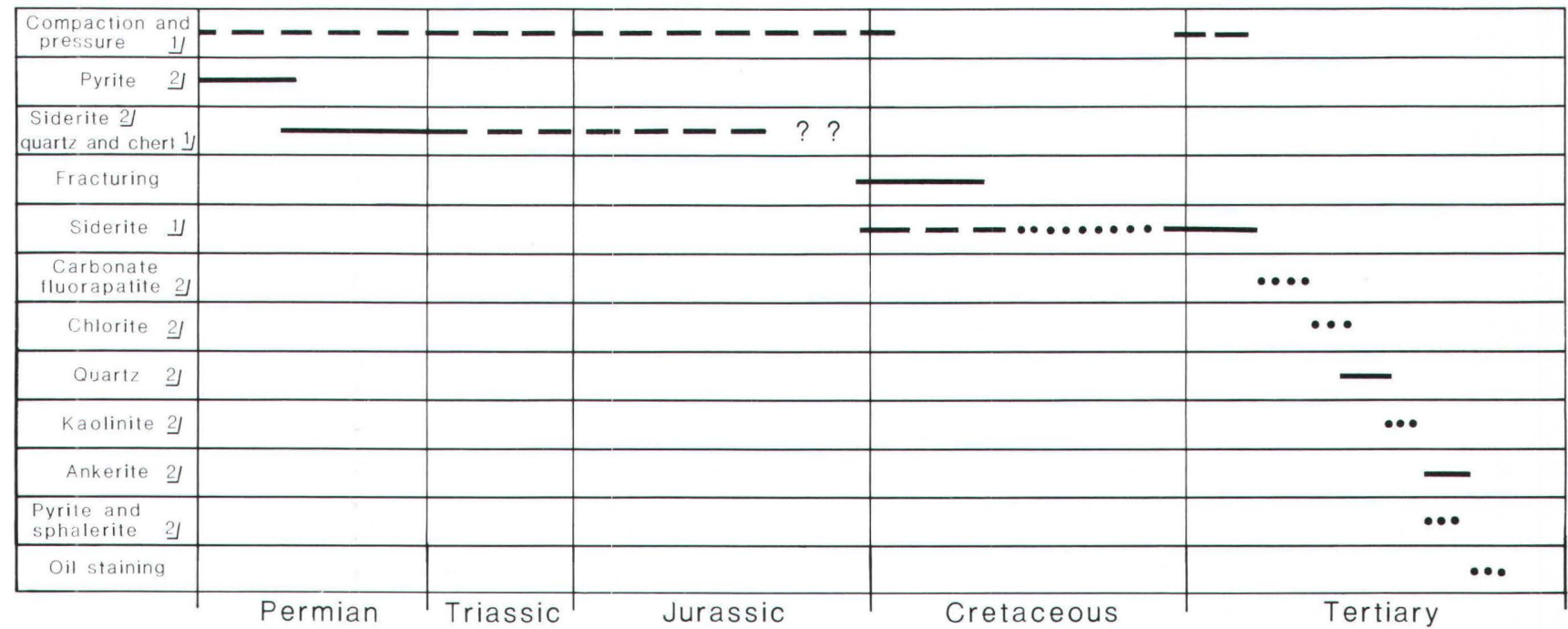

${ }^{1}$ Dissolution.

${ }^{2}$ Precipitation.

Figure 8.5. Burial history of the Ivishak Formation from Beli Unit-1 well $(A)$ and diagenetic history of the Ledge Sandstone Member as inferred from this study $(B)$. Burial-history curve adapted from Magoon and others (chap. 11). Solid line, most abundant; dashed line, less abundant; dotted line, least abundant; ?, questionable occurrence. 
the creation of a pseudomatrix, and the development of some pressure solution. Sutured and concavo-convex grain contacts are common and are believed to be indicative of early compaction. Given the complex structural history of the region (chaps. 18-21), compaction is considered to be a diagenetic force that was active throughout much of the history of the Ledge. Fractured monocrystalline quartz grains, sutured and concavo-convex grain contacts, and pressure solution were commonly observed in fine-grained sandstones (fig. $8.4 C$ ). These textures result from a lack of early cementation, which allows the rock to be compacted. In situ fracturing of quartz results in a polycrystalline appearance, and thus these grains are not useful as provenance indicators. Chert grains are rarely fractured but are commonly plastically deformed. Occasionally, chert is severely deformed and forms a pseudomatrix (Dickinson, 1970). Illitic clay is often associated with this cherty pseudomatrix, and, when present, the combination of the two results in the destruction of any porosity and permeability that the rock may have had.

\section{Pyrite}

Traces of very early authigenic pyrite are present as small concretions in the Ledge (fig. 8.4D,E). Pyrite is present in the delta-front facies sediments and rarely forms the cores of individual siderite crystals (figs. $8.4 F, 8.6 A)$ in some of the shore-system facies sediments. Pyrite concretions preserve the open packing of the framework grains and also predate siderite concretions. This textural evidence, as well as the chemical arguments discussed below, strongly suggest that pyrite formed very early in the history of the Ledge, probably within the first few meters of burial.

Three major factors control the formation of low-temperature authigenic pyrite in sediments: (1) dissolved iron in solution or the presence of minerals that will contribute iron; (2) dissolved sulfate or sulfide present in reducing waters; and (3) sulfate-reducing bacteria in anoxic environments acting on organic matter (Berner and others, 1979). The association between pyrite and siderite, the authigenic mineral phase that follows it, indicates that there was sufficient dissolved iron in early Ledge pore waters for continuous precipitation of these iron-bearing phases. The source of this early iron is not clear. It is obvious that the Ledge was derived from a very mature source that was poor in mafic minerals, which rule these minerals out as an iron source. In addition, ionic iron is frequently below detection limits in normal natural waters (Duchart and others, 1973), which suggests that they also were not the source of iron for pyrite and siderite in the Ledge. Clay reactions involving the transition of smectite to illite occur at diagenetic temperatures and release iron and magnesium into pore waters, thus providing a source of these cations for the iron- and magnesium-bearing authigenic carbonates, ankerite and ferroan dolomite (Boles, 1979). The initiation of these clay reactions requires temperatures of at least 80 to $100{ }^{\circ} \mathrm{C}$ (176 to $212^{\circ} \mathrm{F}$ ) (Hoffman and Hower, 1979; Sredon and Eberl, 1984). According to temperatures attained from siderite oxygen isotopes (see the section "Siderite and Quartz/Chert Dissolution"), as well as textural evidence outlined above, pyrite and siderite in the Ledge precipitated in the shallow subsurface, where these temperatures were probably not attained. Some detrital chert grains in the Ledge are commonly stained reddish brown, which suggests hematite staining and cementation at the source. The weathering of such a hematite-bearing terrane could have provided the iron necessary to form early pyrite and siderite. Therefore, the hypothetical source of iron for these minerals was from the weathering of hematite- and pyrite-bearing metasedimentary rocks similar to the pre-Mississippian argillite penetrated in wells throughout the coastal-plain province west of the ANWR.

Pyrite requires a reducing environment to precipitate. Normal marine bottom waters are generally slightly oxidizing (Drever, 1982), which suggests that pyrite formed in the shallow subsurface, where an anoxic environment is more likely to occur (Bischoff and $\mathrm{Ku}$, 1971). The sulfate ion necessary for pyrite precipitation is able to diffuse into the shallow-marine subsurface (Kaplan and others, 1963), where it is readily available for bacterial reduction (Berner, 1974). Ledge Sandstone Member burial depths greater than the diffusive capability of the sulfate ion may have contributed to sulfate depletion, leading to limited pyrite precipitation. Hydrogen sulfide $\left(\mathrm{H}_{2} \mathrm{~S}\right)$ is the source of the reduced sulfur necessary for the formation of pyrite in shallowmarine sediments. It is derived from the reduction of sulfate by sulfate-reducing bacteria acting on organic matter in anoxic environments (Berner, 1981b). If there is a limited supply of organic matter, than sulfatereducing bacteria, and consequently sulfide and pyrite formation, will also be limited. Organic matter is rarely preserved at any of the measured sections, which implies an initially low organic-matter content. For this reason the small amount of pyrite present in the Ledge is considered to be primarily due to a scarcity of organic matter at the time of its deposition. The presence of early pyrite in the Ledge from the ANWR suggests that the chemical environment present in the early pore waters was dominated by reducing, ferrous iron-rich waters. Sulfate reduction, and therefore pyrite precipitation, was probably largely constrained by the limited organic content of the Ledge. The increasing burial depth of the Ledge may also be partly responsible for decreased sulfate activity due to lack of ionic diffusion into deeper sediments. 


\section{Siderite and Quartz/Chert Dissolution}

Siderite is a ubiquitous authigenic constituent of the Ledge, and its dissolution is important in the porosity-enhancement process in the sandstone (Melvin and Knight, 1984). Its average composition, based on 68-electron microprobe spot analysis, is $\left(\mathrm{Ca}_{0.04} \mathrm{Mg}_{0.18}\right.$ $\left.\mathrm{Fe}_{0.76} \mathrm{Mn}_{0.01}\right) \mathrm{CO}_{3}$, and there may be as much as about 30 percent substitution of $\mathrm{Mg}^{2+}$ for $\mathrm{Fe}^{2+}$ in the siderite crystal lattice. The volumetric proportion of siderite varies widely, from 0 to more than 50 percent of a thin section. Low percentages may be partially due to siderite dissolution. Siderite frequently and extensively replaces chert fragments and marginally replaces monocrystalline quartz grains (fig. 8.6B). It commonly occurs as anhedral to euhedral, poikilotropic concretions (fig. 8.6C) that are frequently compositionally zoned (fig. $8.6 D$ ). Concretions may encompass more than 50 detrital quartz and chert grains. Siderite was observed to border dust rims on detrital quartz grains that were subsequently cemented with syntaxial quartz overgrowths (fig. 8.6E), indicating a prequartz overgrowth time of formation. Detrital phyllosilicate crystals within Ledge argillaceous lamellae are commonly deformed around authigenic siderite crystals (fig. 8.6F).

These textural relationships show that siderite cementation preceded quartz cementation and probably occurred at shallow burial depths. If we use Friedman and O'Neil's (1977) carbonate fractionation curves, stable oxygen isotope values $\left(\mathrm{kO}^{18} \cong 29.50\right)$ for siderites from the Ledge yield temperatures of formation of about 25 to $30{ }^{\circ} \mathrm{C}$ (77 to $86{ }^{\circ} \mathrm{F}$ ) under the assumption of normal marine water compositions. These low temperatures also indicate shallow burial depth at the time of siderite precipitation.

Siderite requires a reducing environment to form (Gautier and Claypool, 1984; Postma, 1982; Pye, 1984). The replacement of quartz by siderite indicates that quartz was dissolved during siderite precipitation. The two most important factors affecting quartz-carbonate solubility are $\mathrm{pH}$ and temperature, with solubility increasing as both temperature and $\mathrm{pH}$ increase (Blatt and others, 1980). The low temperature of siderite precipitation and quartz dissolution rules out temperature as a factor affecting quartz solubility in the Ledge. Therefore, the replacement of quartz by siderite in the Ledge is $\mathrm{pH}$ dependent. Experimental data (Krauskopf, 1956) show that at standard temperatures and pressures, silica solubility is very low between $\mathrm{pH}$ limits of 2 to 8.5. At $\mathrm{pH}$ values higher than 8.5 , silica solubility abruptly increases, attaining values up to $5,000 \mathrm{ppm}$ at a $\mathrm{pH}$ of 11 (Dapples, 1979a). Therefore, siderite replacement of quartz in the Ledge implies the presence of waters with a $\mathrm{pH}$ greater than 8.5. However, waters with this $\mathrm{pH}$ would dissolve quartz regardless of the presence of siderite. This type of widespread quartz dissolution has not occurred in the Ledge, which suggests a microalkaline environment at the quartz-siderite interface with an anomalously high $\mathrm{pH}$. The genesis of such a microenvironment has not yet been determined.

Comparisons between recent reducing environments and the inferred early chemistry of Ledge pore fluids based on Ledge mineralogic assemblages reveal similarities. Bischoff and $\mathrm{Ku}(1970,1971)$ measured the pore fluids of shallow $(<5 \mathrm{~m},<16 \mathrm{ft})$, recent marine-oxidizing and marine-reducing sediments. The waters they collected from anoxic nearshore marine sediments off the coast of Gibraltar were strongly reducing and were marked by sulfate reduction, $\mathrm{Mg}^{2+}$ and $\mathrm{Ca}^{2+}$ depletion, and slight enrichment in $\mathrm{Mn}^{2+}$. These trends resemble the probable chemical environment of the Ledge based on early authigenic mineralogic assemblages and Ledge siderite microprobe analysis. The substitution of $\mathrm{Mg}^{2+}$ for $\mathrm{Fe}^{2+}$ in the siderite crystal lattice may be the mechanism for the depletion of $\mathrm{Mg}^{2+}$ observed by Bischoff and $\mathrm{Ku}$ (1971) in nearshore anoxic pore waters. Magnesium-ion depletion was not observed in marine oxic environments (Bischoff and $\mathrm{Ku}$, 1970). Sulfate reduction in the Ledge is evident from the presence of pyrite. Relatively high concentrations of $\mathrm{Mn}^{2+}$, up to 5 mole percent, in some cores of individual siderite crystals suggest that manganese released into the pore fluids of shallow sediments during reduction of early-formed manganese oxides (Bischoff and $\mathrm{Ku}, 1970$, 1971) was quickly incorporated into the growing siderite concretions.

\section{Fractures}

Fractures were rarely observed in the Ledge from the study area. Mineral associations suggest two fracture sets: (1) fractures associated with siderite dissolution and uncommonly filled with carbonate fluorapatite, and (2) fractures filled with late authigenic carbonate and quartz. These fractures may have formed during either of two periods of uplift, with the first occurring in the Late Jurassic and Early Cretaceous (Grantz and May, 1983), and the second during the middle Cenozoic (chaps. 19 and 20).

Unlike the study area sections, nearly every core that was studied revealed fractures. Thin-section study of fractures from the Beli Unit-1 well shows a relationship between fractures and dissolution of siderite (fig. 8.7A). Carbonate fluorapatite was observed to fill some of the enhanced pores created by this dissolution, which suggests that slightly acidic pore waters moved through these fractures (Krumbein and Garrels, 1952). Late fractures were only very rarely observed and were filled with authigenic quartz and minor carbonate. They probably have had only a minor effect on Ledge diagenesis. 


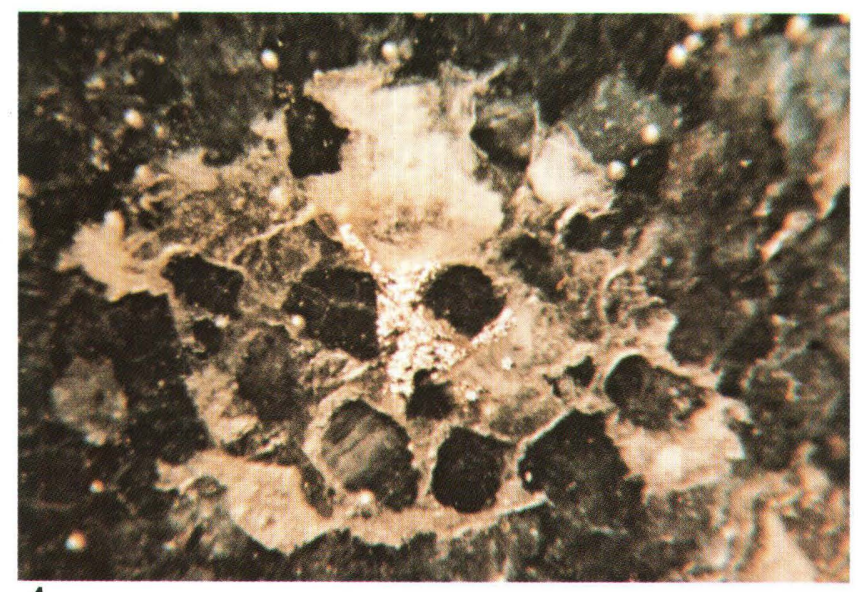

$\boldsymbol{A}$

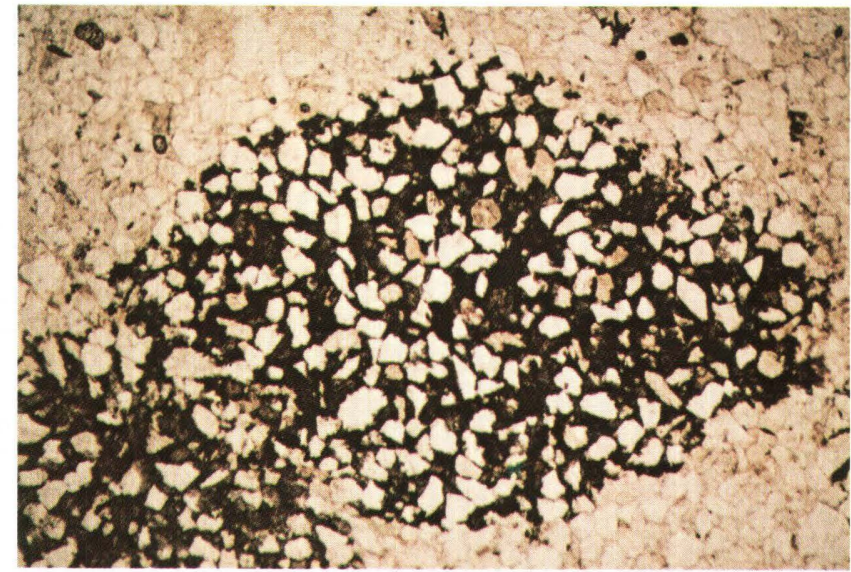

C

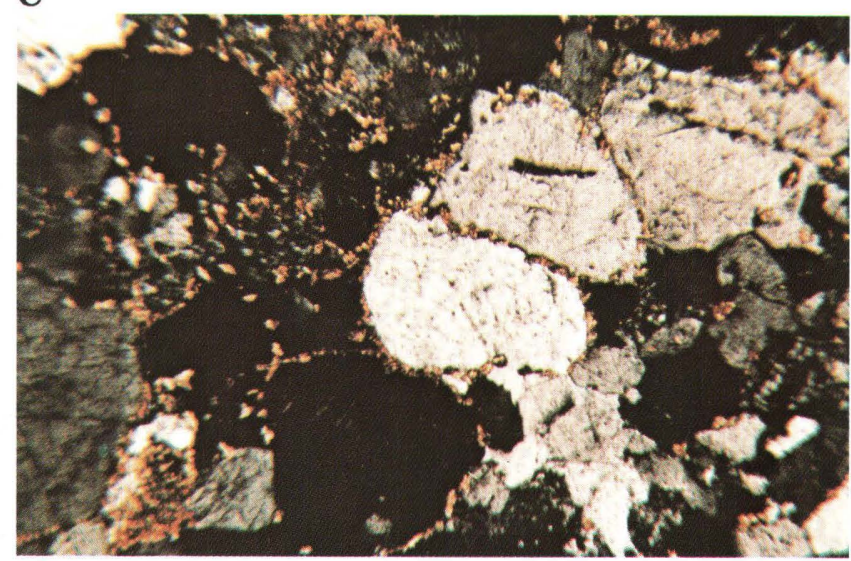

$\boldsymbol{E}$

Figure 8.6. Photomicrographs of the Ledge Sandstone Member. $A$, Same as $8.4 F$, but with reflected light. $B$, Extensive siderite replacement of chert as shown here is common in the Ledge Sandstone Member. Notice how monocrystalline quartz grain at bottom is only marginally replaced. $10 \mathrm{x} / \mathrm{XN}$. $C$, Euhedral, poikilotropic, siderite rhomb. Subhedral to euhedral siderite rhombs similar to this are common throughout the Ledge Sandstone Member. Framework grains within concretion display open packing, especially when contrasted with tight packing of non-siderite-cemented framework grains. Quartz overgrowths are absent within these concretions,

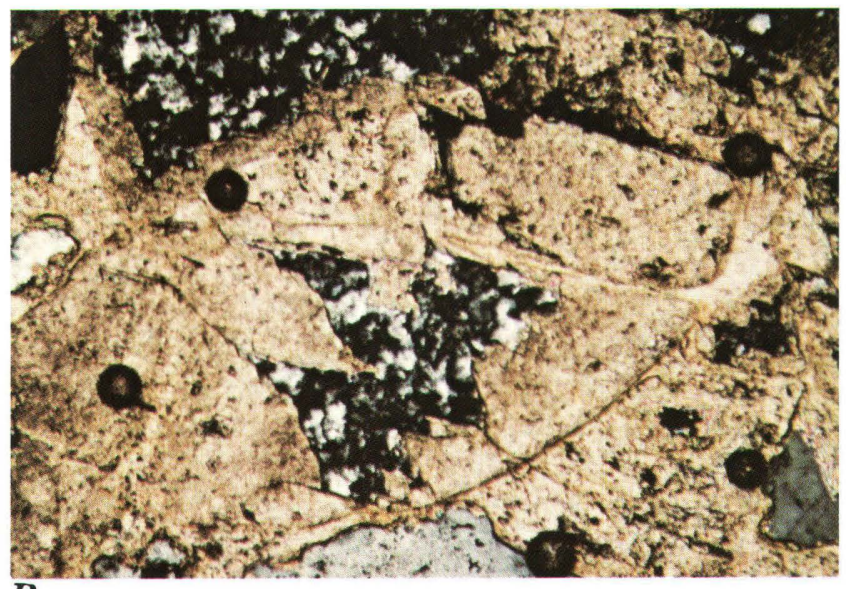

$\boldsymbol{B}$

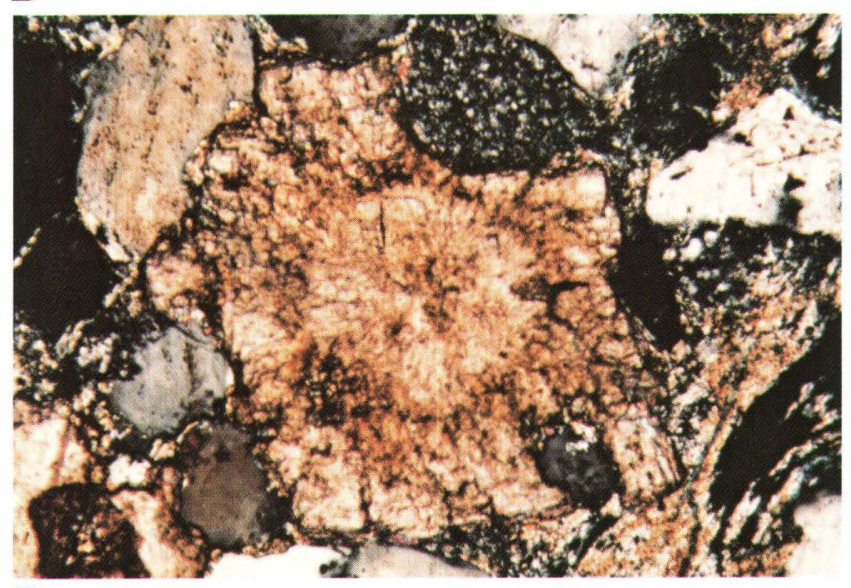

$\boldsymbol{D}$

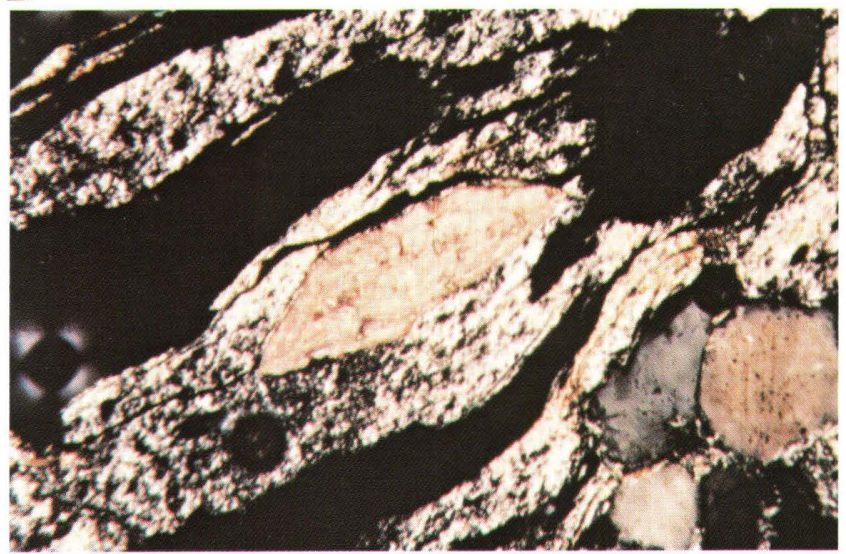

F

indicating pre-quartz formation. These textures suggest that formation of siderite occurred at shallow depths before significant chemical or mechanical compaction. 2.5x/PL. $D$, Zoned siderite crystal. Microprobe analysis of these zones shows varying concentrations of iron and magnesium. Generally, darker areas are more iron rich. $10 \mathrm{x} / \mathrm{XN}$. E, Small, rounded, siderite crystals line detrital grains and indicate a period of siderite precipitation prior to formation of quartz overgrowths. 10x/XN. F, Siderite within argillaceous lamellae. Note how detrital phyllosilicate crystals bend around siderite crystal, suggesting early formation before compaction. 10x/XN. 


\section{Siderite Dissolution}

Textural evidence, corroded and rhombically embayed detrital quartz and chert grains, and remnants of authigenic siderite indicate that dissolution of siderite was common in the Ledge (fig. 8.7B). This dissolution resulted in enhanced pores that were subsequently filled mostly with authigenic quartz, kaolinite, and ankerite. In some samples, minor amounts of enhanced porosity are preserved. Two likely hypotheses for the origin of these acidic fluids are (1) movement of slightly acidic meteoric waters entering into the formation during Late Jurassic and Early Cretaceous subaerial exposure (Van de Kamp, 1979), and (2) movement of acidic formation waters, acidified by acids generated by organic-matter maturation (Schmidt and McDonald, 1979a; Franks and Forester, 1984; Surdam and others, 1984), into and through the formation, probably in Tertiary time.

Evidence for some dissolution due to meteoric influx exists at the Marsh Creek section, the only section studied that was truncated by the Lower Cretaceous unconformity. Slightly corroded siderite remnants occasionally line detrital grains (fig. $8.7 C, D$ ). They have been oxidized and altered to hematite and were protected from further alteration by later syntaxial quartz overgrowths, thereby ruling out oxidation due to Holocene exposure. Because the Ledge at the Marsh Creek section has been truncated by the Lower Cretaceous unconformity, oxidation and partial dissolution of siderite may have occurred during Upper Jurassic and Lower Cretaceous subaerial exposure, when slightly acidic and oxic+ meteoric waters moved into and through the formation (Van de Kamp, 1979). Although some siderite dissolution has occurred at this section, widespread dissolution is not evident, which leads to the conclusion that the unconformity has not had a uniform effect on porosity development in the Ledge.

It is clear that in considering carbonate dissolution in the Ledge, factors other than proximity to the Lower Cretaceous unconformity must be considered. One such consideration is the generation of organic acids during the maturation of organic matter (Schmidt and McDonald, 1979a; Franks and Forester, 1984; Surdam and others, 1984). There is a strong correlation between $\mathrm{CO}_{2}$ generation and secondary-porosity development (Tissot and Welte, 1978; Franks and Forester, 1984). Results of kerogen-maturation experiments showed that both algal and humic kerogen types are capable of generating carbonic and carboxylic acids at about $80{ }^{\circ} \mathrm{C}$ $\left(176{ }^{\circ} \mathrm{F}\right)$ (Tissot and Welte, 1978; Surdam and others, 1984). Illite-smectite reactions also begin at about this temperature (Hoffman and Hower, 1979; Sredon and Eberl, 1984) and are widely acknowledged to facilitate petroleum migration from source to reservoir rocks (Powers, 1967; Burst, 1969; Wilson and Pittman, 1977; Bruce, 1984). The coincidence in time and temperature of organic-acid generation with illite-smectite transition and hydrocarbon generation suggests organic acids could be swept through adjacent sandstones just prior to hydrocarbon generation (Schmidt and McDonald, 1979a; Surdam and others, 1984). For this to occur, however, the source rock must be hydrodynamically linked to the reservoir sandstones (Surdam and others, 1984). The organic-carbon-rich Shublik Formation, which was hydrodynamically linked to the Ivishak Formation, is a possible source for these kinds of acids.

\section{Carbonate Fluorapatite}

$\left(\mathrm{Ca}_{5}\left(\mathrm{PO}_{4}, \mathrm{CO}_{3}, \mathrm{OH}\right)_{3}(\mathrm{~F}, \mathrm{OH})\right)$, carbonate $\begin{array}{r}\text { identified by Xorapatite } \\ \mathrm{X} \text {-ray }\end{array}$ diffraction and EDS techniques, are locally abundant in inferred Ledge delta-fringe and delta-front facies. It occurs as small anhedral to subhedral, enhanced, porefilling crystals (fig. 8.7E), and may account for as much as 7 percent of the total rock volume. In general, apatites can occur over a wide temperature range (Deer and others, 1966; Nriagu and Moore, 1984). Phosphate precipitation is independent of $\mathrm{pE}$ and dependent on $\mathrm{pH}$ (Krumbein and Garrels, 1952). Phosphate solubility is similar to that of calcium carbonate, increasing with decreasing $\mathrm{pH}$ (Krumbein and Garrels, 1952). Thus, the $\mathrm{pH}$ of this system during carbonate-fluorapatite precipitation is determined to be mildly acidic. Samples from the Beli Unit-1 well show a clear temporal relationship between a fracturing event, dissolution of siderite, and the precipitation of carbonate fluorapatite. The relative timing between these events is as follows: (1) fracturing, (2) siderite dissolution, and (3) carbonatefluorapatite precipitation.

Traces of detrital phosphate and phosphatecemented detrital siltstone are present in the Ledge. Primary phosphatic material was also observed in the shoreface facies of the Marsh Creek section. The solution of these phosphatic minerals is not considered the source for the small amount of authigenic phosphate cement because Ledge detrital-phosphate content is very small, and the occurrence of authigenic phosphate is not spatially related to detrital-phosphate concentration. Furthermore, the association of carbonate fluorapatite with fractures suggests that phosphate-rich fluids moved into the Ledge through the fractures. The Shublik Formation is stratigraphically above the Ivishak Formation, contains phosphate beds, and is acknowledged to be one of the main source rocks for North Slope petroleum (Magoon and Bird, 1985). Migration of phosphate-rich fluids from the Shublik into the Ledge through fractures could be responsible for the carbonate fluorapatite in the Ledge. If authigenic phosphate minerals in the Ledge can be used as indicators of fluids derived from the Shublik, then acidic pore fluids traveling through fractures and dissolving carbonate materials prior to phosphate formation can also 
be traced to the Shublik. Since the Shublik is organiccarbon rich (Magoon and Bird, 1985), these acids can be assumed to be organically derived, as discussed in the section on siderite dissolution.

\section{Chlorite}

Chlorite in the Ledge was identified petrographically and through X-ray diffractions. It occurs as detrital grain coatings (fig. $8.7 F$ ) in rocks inferred to represent the more distal delta-front facies. Chlorite is not considered important in either the preservation or destruction of porosity and permeability in the Ledge from the ANWR because of its low volumetric occurrence. No detailed chemical data were gathered on the chlorites. They occur over a wide temperature range, have a widely variant chemical composition, and are not considered diagnostic of any
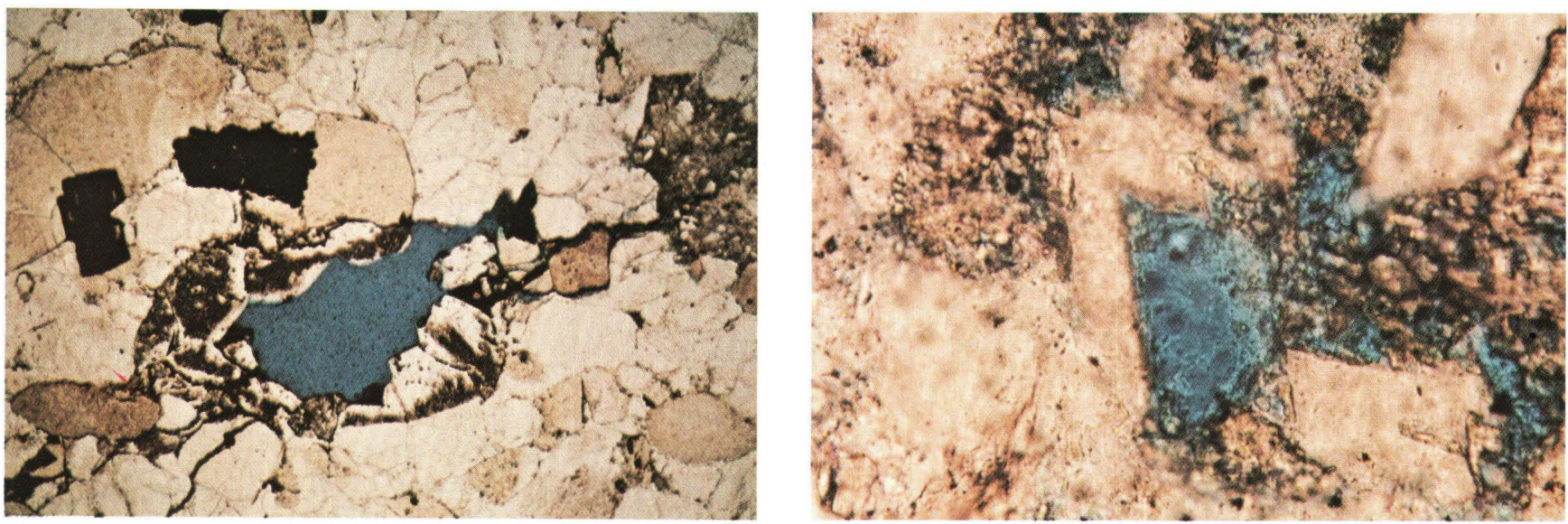

$\boldsymbol{A}$

$\boldsymbol{B}$
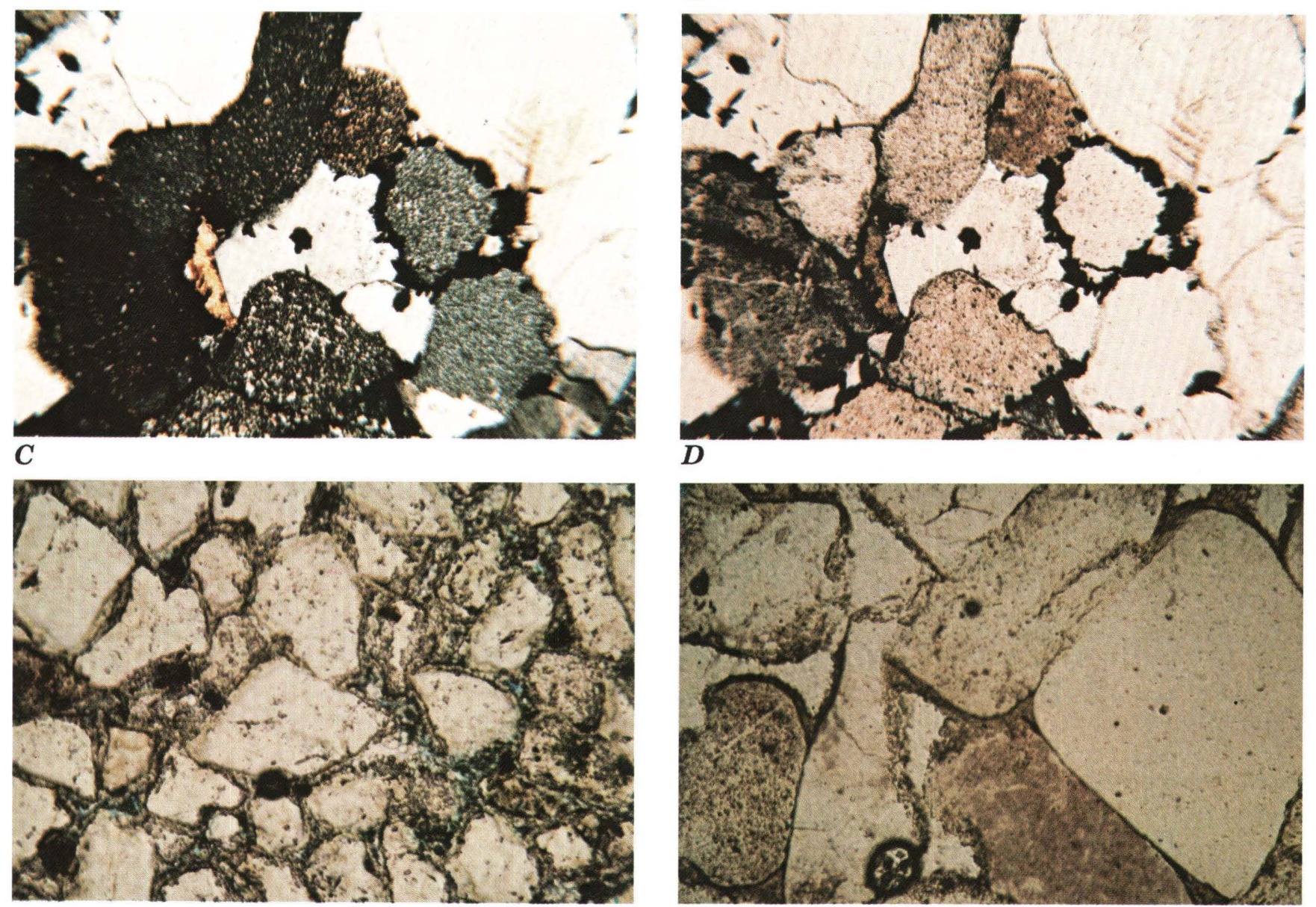
particular environment (Deer and others, 1966). Iron and magnesium necessary for chlorite formation in the Ledge may be derived from siderite dissolution.

\section{Quartz}

Quartz is volumetrically the most important pore-filling cement in the Ledge, occupying as much as 22 percent of the total rock volume. It extensively fills enhanced pores (fig. 8.8A), and there are no apparent facies controls in its distribution. Silica sources for quartz precipitation include dissolved silica resulting from quartz and chert dissolution (Walker, 1960) and silica released during smectite diagenesis (Boles and Franks, 1979). Because quartz precipitation is followed

Figure 8.7. Photomicrographs of the Ledge Sandstone Member. A, Dissolution of siderite associated with fracture, resulting in enhanced porosity. Rhombic embayments and siderite remnants along pore-space perimeter suggest pore was filled with siderite. Iron carbonates at left (opaque in this view due to oxidation to hematite) that are not cut by fracture are not dissolved, suggesting that fractures play an important role in the porosity development of the Ledge Sandstone Member by acting as conduits for acidic fluids. 2.5x/PL. $B$, Enhanced porosity due to siderite dissolution. Extensive rhombic embayment in quartz grain in this view resulted from siderite replacement of quartz and its subsequent dissolution. Note remanent siderite cement in right center strongly suggests this pore was filled with siderite. 25x/PL. C, Quartz cementation after partial siderite dissolution. Siderite in this view has also been oxidized, possibly because of oxic meteoric waters entering into the Ledge Sandstone Member during Late Jurassic and Early Cretaceous subaerial exposure. Quartz overgrowths preserved siderite texture, prohibiting alteration during its current subaerial exposure. Ankerite is adjacent to quartz overgrowth, indicating formation after quartz overgrowth. $25 \mathrm{x} / \mathrm{XN}$. $D$, Same as $C$, but with plane light. Notice iron-stained chert grains. $25 \mathrm{x} / \mathrm{XN}$. E, Carbonate fluorapatite almost completely filling enhanced pores created by dissolution of siderite. Traces of porosity (blue in this view) are preserved. Carbonate fluorapatite was associated with fractures, implying slightly acidic, phosphate-rich pore fluids moving through fractures. 10x/PL. $F$, Authigenic chlorite (dark greenish brown in this view) lining detrital quartz grains that were subsequently cemented with quartz. Note corroded and rhombically embayed chert grains, suggesting siderite replacement of quartz; quartz then filled enhanced pore spaces. 10x/PL. by ankerite precipitaion, which (as explained below) requires elevated temperatures for formation, quartz precipitation did not occur as a result of current subaerial exposure. Wood and Hewett (1984) have proposed a convective fluid-flow model to help explain inorganic diagenetic processes, including authigenic quartz precipitation. Briefly summarized, deeper and warmer fluids will migrate convectively up anticlinal structures. As the fluid moves up the geothermal gradient, its temperature decreases. As noted previously, decreased temperatures result in decreased silica solubilities and increased quartz precipitation.

\section{Kaolinite}

Authigenic kaolinite is restricted to secondary pores formed by the dissolution of siderite in the shoreface facies (fig. 8.8B). It is generally of minor volumetric significance and forms dense crystal aggregates generally less than $0.5 \mathrm{~mm}$ in diameter. Trace amounts of organic matter are trapped within the kaolinite booklets. Aluminum necessary for kaolinite precipitation may be derived from metal-ion complexation by organic acids (Surdam and others, 1984).

\section{Ankerite, Pyrite, and Sphalerite}

Ankerite and traces of pyrite and sphalerite are the last authigenic minerals to precipitate in the Ledge. They most commonly occur in the inferred shoreface systems. Ankerite occupies as much as nearly 40 percent of the total rock volume in some thin sections. Its average composition based on 48-electron microprobe spot analyses is $\left(\begin{array}{lll}\mathrm{Ca}_{0.48} & \mathrm{Mg}_{0.31} & \mathrm{Fe}_{0.19}\end{array} \mathrm{CO}_{3}\right.$. It is a common pore-filling cement (fig. $8.8 \mathrm{C}$ ), and, unlike siderite and early pyrite, does not form discrete concretions nor extensively replace either quartz or chert. No ankerite dissolution was observed. Traces of pyrite and sphalerite are associated with ankerite, which indicates reducing, sulfide-rich waters moving through the Ledge during this time. Oxygen-isotope data from Gulf Coast ankerites indicate that ankerite requires relatively high diagenetic temperatures to form, about 125 to $210^{\circ} \mathrm{C}$ ( 257 to $410{ }^{\circ} \mathrm{F}$; Boles, 1978). It can form either by direct precipitation from the pore waters or from replacement of calcite (Boles, 1978). A source of iron and magnesium necessary for ankerite formation is the release of these cations into pore fluids during the transition of smectite to illite (Boles, 1978; Boles and Franks, 1979). All the ankerite observed in the Ledge occurs within a few feet of relatively thick, illite-rich shale layers, which suggests that this process is responsible for the ankerite in the Ledge. Sphalerite is an uncommon diagenetic mineral. However, numerous 
authors have recorded the presence of relatively high concentrations of dissolved zinc in formation waters of producing oil fields (Lebedev, 1972; Carpenter and others, 1974; Gardner, 1974; Vine and Tourtelot, 1970), and Lebedev (1972) reports sphalerite forming at surface temperatures and pressures.

\section{Organic Migration}

Organic matter, which apparently migrated through the formation after ankerite precipitated, was rarely observed as dead oil or asphalt in some Ledge pores (fig. 8.8D).

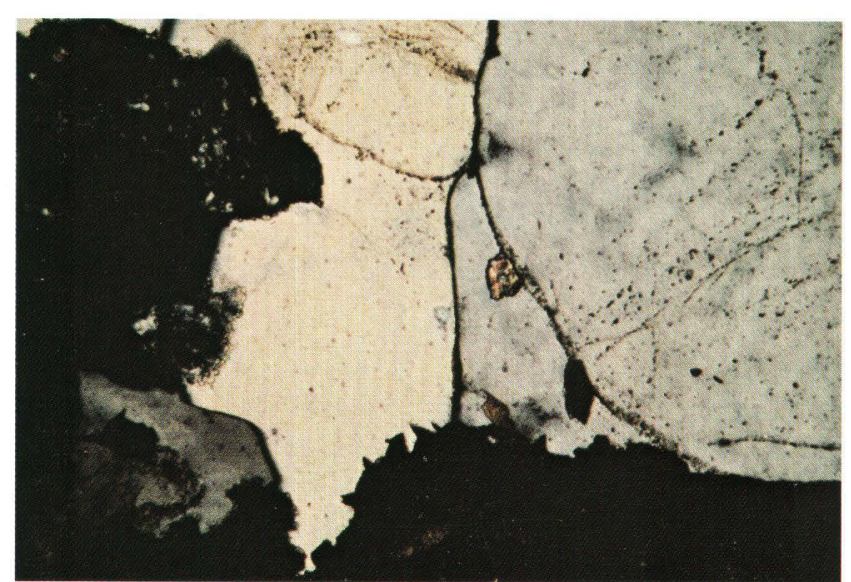

$\boldsymbol{A}$

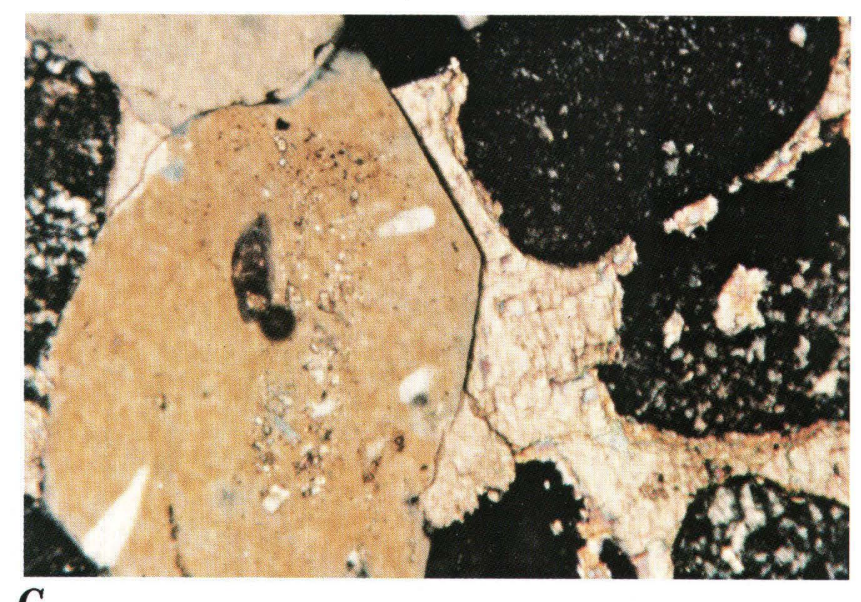

C

Figure 8.8. Photomicrographs of the Ledge Sandstone Member. $A$, Authigenic quartz filling enhanced pore space. Note siderite remnant on quartz dust rim. This texture is common in the Ledge Sandstone Member. $10 \mathrm{x} / \mathrm{XN}$. $B$, Kaolinite filling small pore space. Note how adjacent ankerite, rotated to extinction in this view,

\section{SUMMARY}

The Ledge Sandstone Member is a mature chert-rich quartz arenite. Its mineralogic assemblages strongly suggest it was derived from a hematite- and pyrite-cemented, recycled, foreland-uplift, orogenic provenance (Dickinson and Suczek, 1979). Its lithologic equivalent in the Prudhoe Bay field, the Ivishak Sandstone of Jones and Speers (1976), has excellent, diagenetically created reservoir qualities in that field and good, diagenetically produced, reservoir qualities in the NPRA.

Three prerequisites are necessary for the development of this reservoir: (1) extensive early carbonate cementation, (2) extensive carbonate

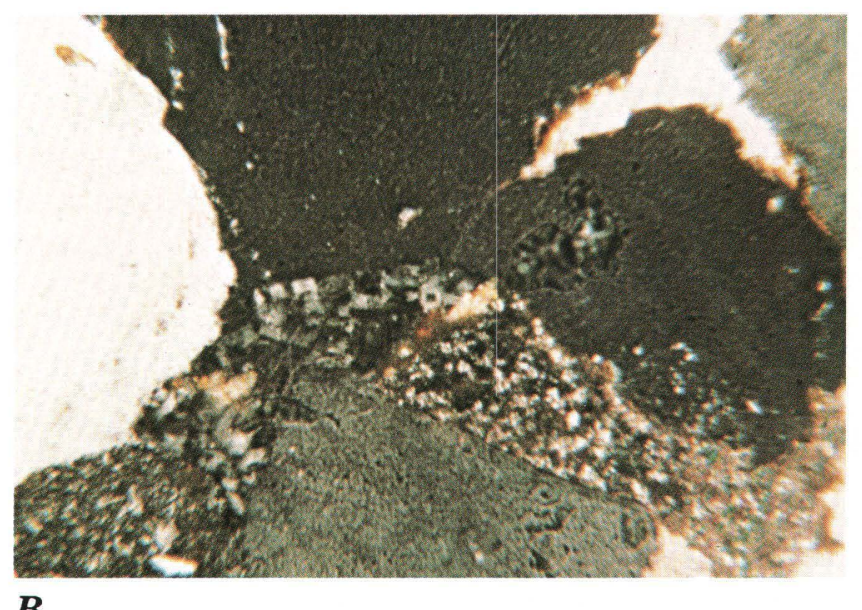

$\boldsymbol{B}$

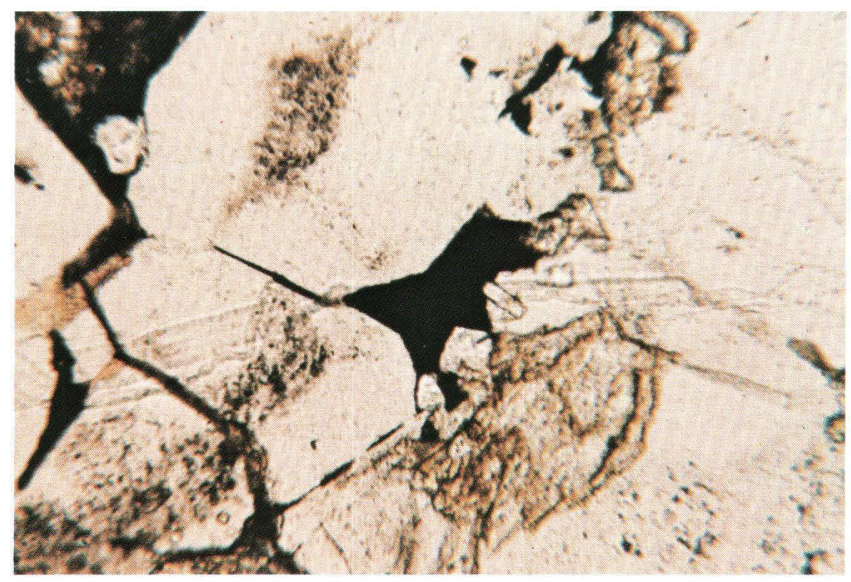

D

appears to be growing over kaolinite, indicating that kaolinite precipitated before ankerite. 10x/XN. $C$, Ankerite cement. Notice euhedral-crystal termination of adjacent quartz overgrowth, indicating that quartz formed before ankerite. $10 x / X N$. $D$, Pore-filling dead oil. 10x/PL. 
dissolution, and (3) limited quartz recementation. Authigenic carbonate minerals-siderite and ankeriteare common in the Ledge from the ANWR. Siderite precipitates early, preserves an open framework, and partially replaces existing quartz and chert grains. Ankerite forms late and fills enhanced pores. The authigenic carbonate distribution appears to be facies related; in general, the more proximal the facies, the higher the percentage of carbonate cement. Dissolution of siderite cement was commonly observed in the Ledge, which indicates the movement of acidic fluids into and through the formation. Fractures observed in outcrop and subsurface samples acted as acidic-fluid conduits. Two likely sources of acidic fluids are either slightly acidic meteoric waters traveling into the formation during the Late Jurassic and Early Cretaceous, when the Ellesmerian sequence was subaerially exposed, or organic and carbonic acids generated during hydrocarbon maturation, possibly from the overlying Shublik Formation during the Tertiary. The presence of extensive (although sometimes partially dissolved) siderite cement at the Marsh Creek section, a section truncated by the Lower Cretaceous unconformity, suggests that the Lower Cretaceous unconformity has not had a uniform effect on porosity development in the Ledge. Enhanced pores are commonly completely filled with authigenic quartz and ankerite. Authigenic quartz precipitation may be due to decreased silica solubilities resulting from fluid movement of warmer, silica-rich waters into cooler sinks. Silica is probably derived from clay diagenesis or dissolution of quartz and chert within the Ledge.

From the data presented in this report, and under the assumption that the Ledge is present beneath the coastal plain, postulates concerning the diagenesis and reservoir quality of the Ledge beneath the coastal plain can be made. The Ledge reservoir quality is dependent upon authigenic carbonate dissolution and therefore upon the initial presence of carbonate cements. The diagenetic trend indicates that carbonate cements are more abundant in the more proximal facies. The cementation pattern in the lithologically equivalent Ivishak Sandstone of Jones and Speers (1976) from the Prudhoe Bay field confirms this trend. Circulation of acidic fluids is necessary for porosity development. The truncation of the Ledge by the Lower Cretaceous unconformity may have affected the porosity and permeability development of the Ledge, but it is not considered critical. Possible sources of the acidic fluids required to dissolve the carbonate minerals are the organic acids generated during maturation of organic matter. Carbonate fluorapatite associated with fractures may indicate that the acidic fluids moving through the fractures originated in the Shublik Formation. Extensive quartz cementation may be a relatively low-temperature phenomenon due to silica-rich solutions moving up a geothermal gradient, precipitating quartz in cooler sinks. Therefore, quartz cementation may not be as great a diagenetic factor in the deep subsurface of the coastal plain. 



\title{
Chapter 9.
}

\section{Petrology of Cretaceous and Tertiary Reservoir Sandstones in the Point Thomson Area}

\author{
By Donald L. Gautier ${ }^{1}$
}

\section{INTRODUCTION}

This chapter illustrates salient aspects of the petrology of two potential petroleum reservoirs of the ANWR coastal plain. Based mainly on observations of core chips and cuttings from wells in the Point Thomson area adjacent to the ANWR (table 9.1), this study focuses on (1) sandstones and conglomerates of the Lower Cretaceous Thomson sand of local usage from the uppermost part of the Ellesmerian sequence, and (2) deep-water marine sandstones of the Canning Formation (Brookian sequence).

These two rock units in the Point Thomson area were selected for investigation because (1) the Thomson sand and the turbiditic sandstones of the Canning Formation occur as hydrocarbon reservoirs in the subsurface of the coastal plain immediately adjacent to the ANWR and, therefore, provide the nearest example of rock units to be expected beneath the ANWR coastal plain; and (2) reliable evaluation of porosity, permeability, pore geometry, diagenetic history, and anticipated reservoir quality can only be conducted from subsurface materials, which are unaffected by surface weathering. The general distribution, petrography, and potential reservoir properties of rocks that crop out in the ANWR are amply treated in chapter 7.

The reservoirs discussed here may be similar to rocks that will actually be encountered beneath the ANWR coastal plain. Petrologic studies of the Thomson sand indicate an unusual composition of abundant detrital carbonate (dolomite) framework grains. Subsurface fluids have induced secondary porosity by partially dissolving the carbonate framework grains, and they have also preserved primary porosity and permeability by inhibiting the formation of authigenic minerals that would otherwise have adversely affected reservoir quality. Consequently, the Thomson is anticipated to have excellent reservoir potential, if present in the ANWR coastal plain.
The turbiditic sandstones of the Canning Formation are rich in argillaceous rock fragments. Under most circumstances, chemical and mechanical diagenesis of such grains would significantly diminish the reservoir properties. However, abnormally high fluid pressures in these sandstones in the Point Thomson area have apparently inhibited normal grain compaction and

Table 9.1. Names, locations, and cored intervals of wells sampled for this study

\begin{tabular}{ccccc}
\hline Well & \multicolumn{3}{c}{$\begin{array}{c}\text { Surface } \\
\text { location }\end{array}$} & $\begin{array}{c}\text { Depth } \\
\text { intervals }\end{array}$ \\
\cline { 2 - 4 } & Sec. & T.N. & R.E. & (ft) \\
\hline West Staines State 18-9-23 & 18 & 9 & 23 & $10,573-10,613$ \\
& & & & $11,655-11,677$ \\
& & & & $11,677-11,707$ \\
& & & & $11,707-11,738$
\end{tabular}

\begin{tabular}{|c|c|c|c|c|}
\hline Alaska State A-1 & 27 & 10 & 24 & $\begin{array}{l}12,427-12,463 \\
12,468-12,557 \\
12,557-12,647\end{array}$ \\
\hline Point Thomson Unit-1 & 32 & 10 & 23 & $\begin{array}{l}12,158-12,178 \\
12,830-12,890 \\
12,890-12,950 \\
12,950-13,009\end{array}$ \\
\hline Point Thomson Unit-2 & 3 & 9 & 22 & $\begin{array}{l}11,676-11,696 \\
11,696-11,756 \\
11,756-11,846\end{array}$ \\
\hline Point Thomson Unit-3 & 34 & 10 & 23 & $\begin{array}{l}13,665-13,695 \\
13,695-13,725 \\
13,725-13,756 \\
13,811-13,871\end{array}$ \\
\hline Challenge Island-1 & 8 & 10 & 22 & $\begin{array}{c}8,237-8,246 \\
13,438-13,464 \\
13,464-13,487\end{array}$ \\
\hline
\end{tabular}

\begin{tabular}{lllll} 
Point Thomson Unit-4 & 32 & 10 & 22 & $14,973-14,986$ \\
\hline
\end{tabular}

\footnotetext{
${ }^{1}$ U.S. Geological Survey, Denver, Colo.
} 
chemical diagenesis. Thus, porosity and reservoir quality are preserved. Similar conditions may exist beneath the ANWR coastal plain.

\section{THOMSON SAND (ELLESMERIAN)}

The Thomson sand, an informally named sandstone unit of local usage that lies below the pebble shale unit, is named for its occurrence in the subsurface near Point Thomson. It has no known outcrops, but well data show that it occurs along a southeast trend from Challenge Island to at least the Canning River. The Thomson ranges in thickness from 0 to more than $110 \mathrm{~m}$ $(350 \mathrm{ft})$ in the Point Thomson area (fig. 7.11). The northwest and southeast limits of the Thomson are not known, but it and related sandstones may extend beneath the coastal plain of the ANWR.

The Thomson sand is stratigraphically correlative with the Kemik Sandstone and like the Kemik, it is of Early Cretaceous (Neocomian) age. At Point Thomson, it unconformably overlies preMississippian basement rocks and is overlain by the Lower Cretaceous pebble shale unit.

The Thomson consists of very fine to very coarse grained, medium-brown to gray, dololithic ( $>50$ percent detrital dolomite) sandstone with thin interbeds of granule to pebble conglomerate. Locally, it includes pebble, cobble, and boulder conglomerate. At Challenge Island, boulders larger than $1.4 \mathrm{~m}(4.5 \mathrm{ft})$ in diameter have been penetrated during coring of the unit. The Thomson displays well-developed, stacked, fining-upward sequences that have been identified in cores and electrical logs.

\section{Sandstone Lithologies}

The dominant lithology of the Thomson sand is well-sorted, very fine grained to fine-grained sandstone, consisting mostly of detrital monocrystalline dolomite occurring as rounded grains and rhombohedral cleavage fragments. Monocrystalline quartz grains and minor amounts of argillaceous lithic fragments are common. A typical framework modal composition is 53 percent detrital dolomite grains, 36 percent monocrystalline quartz grains, and 11 percent sedimentary and metasedimentary rock fragments.

\section{Conglomeratic Lithologies}

The conglomerates of the Thomson sand consist almost entirely of clasts derived from fine-grained sedimentary rocks (fig. 9.1). Dominant among these are granules, pebbles, cobbles, and boulders of dense, coarsely crystalline dolomite showing little evidence of original depositional textures. Dolomite clasts constitute most of the conglomeratic facies. Thomson conglomerates also contain sparse limestone clasts consisting of neomorphic sparite with patches of unrecrystallized micrite, and rare clasts of oolitic limestone.

Siliciclastic grains are also common in the Thomson and include a wide range of argillaceous rock fragments, such as shale, silty shale, and pyritic and siliceous mudrocks with chert and quartz-filled fractures, as well as quartzitic siltstone, shale, and fragments of very fine grained to fine-grained sandstone. Lithic fragments of sandstone range from quartz arenite to lithic arenite or feldspathic arenite with several compositions and textures. All of the siliciclastic lithic fragments are well indurated, display no primary porosity, and have enlarged micalike crystals in place of authigenic or detrital clay minerals. Detrital arenitic clasts commonly have moldic porosity resulting from feldspar dissolution. These detrital lithic grains indicate provenance in a sedimentary tectonic terrane that has undergone temperatures and burial depths nearly sufficient for lowgrade metamorphism.

Conglomeratic facies of the Thomson sand may locally display high porosity (25 percent) and extremely high permeability ( $>1,000$ millidarcies). However, the coarse-grained facies commonly contains intergranular material consisting of well-sorted, detrital-dolomite sandstone, typical of the sandstone facies of the Thomson and presumably derived from the same source. Some conglomerates contain intergranular silty and sandy clay matrix of detrital origin.

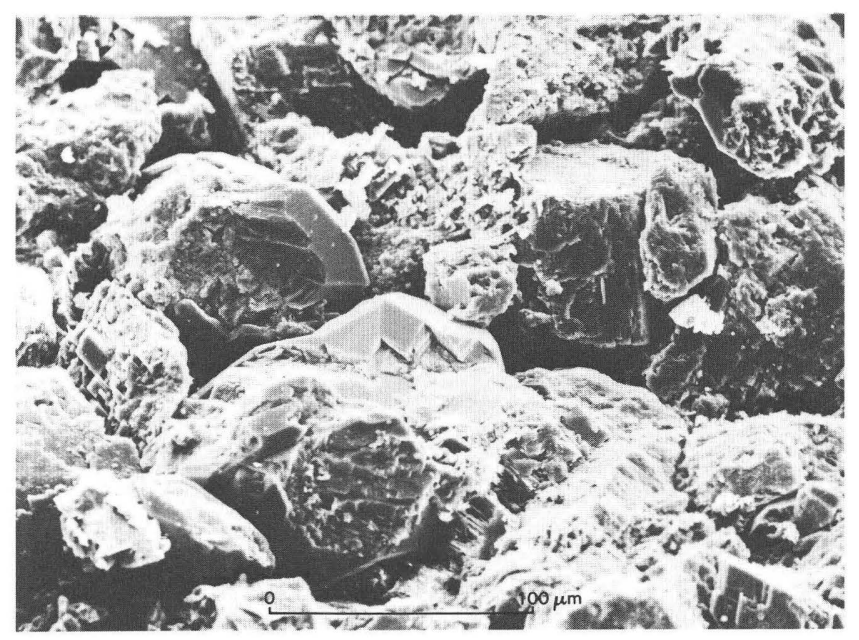

Figure 9.1. Scanning electron micrograph of clean, well-sorted, highly porous reservoir sandstone of the Thomson sand of local usage consisting of detrital dolomite and quartz. Point Thomson Unit-3 well, 13,831-ft depth. 


\section{Diagenesis}

The porosity and permeability of the Thomson sand are very high because the pore networks are generally free of authigenic minerals (minerals formed after deposition) and are open and well connected. Authigenic minerals consist mainly of quartz overgrowths developed on detrital, monocrystalline quartz grains (fig. 9.2) and of sparse euhedral crystals of authigenic dolomite in intergranular spaces. Small amounts of kaolinite occur in some intergranular pores.

Scanning electron microscopy (SEM) of cores of the Thomson reveals that most grains of dolomite, and thus most of the sandstone framework grains, display dissolution textures (fig. 9.3). These dissolution textures are generally similar to those described by Schenk and Richardson (1985) in anhydrite. The dissolution occurs mainly on grain margins and is crystallographically controlled, which results in sharp, angular projections and reentrants (fig. 9.3). Such crystallographically controlled surfaces suggest that dissolution was limited by the surface reaction rate and not by the pore-fluid flow (Berner, 1978, 1981a; Schenk and Richardson, 1985). In contrast to dolomite, grains of monocrystalline quartz display euhedral growth textures, typical of quartz cements formed in crystallographic continuity with existing detrital framework grains (fig. 9.2). Pore spaces are generally free of authigenic clays, although detrital matrix is abundant in some samples from the conglomeratic facies.

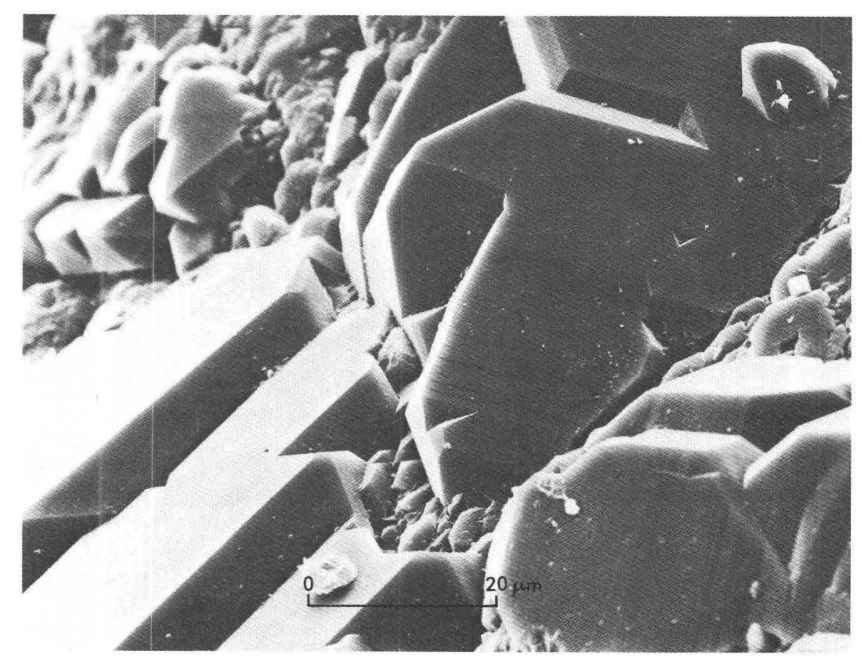

Figure 9.2. Scanning electron micrograph of grain of monocrystalline quartz in the Thomson sand of local usage displaying well-developed overgrowths resulting from quartz precipitation on pre-existing detrital quartz. Point Thomson Unit-3 well, 13,736-ft depth.

\section{Interpretation}

The composition of clasts in the conglomeratic facies of the Thomson sand, in conjunction with the coarse grain sizes of the facies, argues strongly for local derivation from pre-Mississippian lithologies such as those in the basement complex of wells located near Point Thomson. Basement lithologies near Point Thomson reportedly include "dolomite," "carbonate," and "argillite" (fig. 7.3). Scour-and-fill structures, as well as cobble and boulder conglomerates and upward-fining sequences, suggest (but do not prove) a local derivation and significant relief, presumably along the rifted continental margin near the shoreline of the transgressing Early Cretaceous sea. Whether deposition was subaerial in a fluvial setting, in a submarine-channel complex, or in other environments is not known.

The presence of abundant detrital dolomite influences diagenesis in both the conglomeratic and sandstone facies. The ubiquity of dissolution features demonstrates that dolomite has been dissolving in the presence of formation waters in the subsurface. Despite the evident release of cations and bicarbonate from the dolomite, other carbonate minerals have not formed cements. The dissolving dolomite does not provide suitable substrates for crystal growth and has probably inhibited development of intergranular silicate cements. In contrast, quartz grains of the Thomson sand display authigenic, euhedral overgrowths. The scarcity of authigenic phases that formed later than quartz, together with the fresh appearance of the euhedral quartz terminations (fig. 9.2), suggests that quartz may be

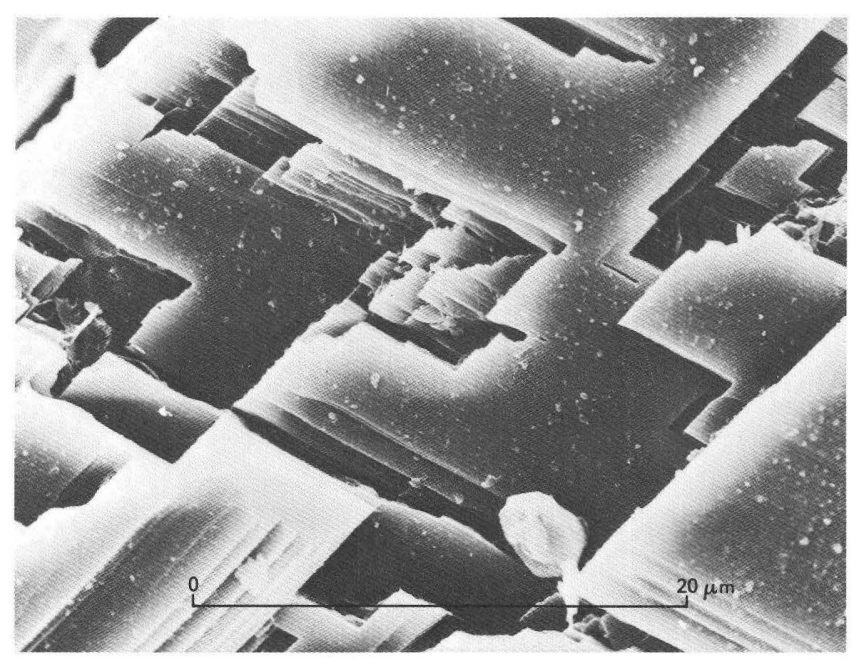

Figure 9.3. Scanning electron micrograph of grain surface of detrital dolomite in the Thomson sand of local usage displaying surficial, dissolution textures. Point Thomson Unit-3 well, 13,831-ft depth. 
precipitating simultaneously with dolomite dissolution. Such simultaneous precipitation and dissolution in the presence of kaolinite and in the absence of carbonate minerals other than dolomite suggests $\mathrm{pH}$ control. Various lines of evidence, including vitrinite reflectance analysis, Rock Eval pyrolysis, and clay-mineral studies (chap. 13), indicate that the Thomson sand and associated shales are thermally submature with respect to the main episode of oil generation. The level of maturation is that of decarboxylation of organic-acid anions, a diagenetic process during which significant $\mathrm{pH}$ effects are expected (Gautier and others, 1985).

\section{Implications for Reservoir Quality}

The sandstones of the Thomson sand have porosities ranging from 5 to 25 percent, with most generally clustering at the higher end of this range. Permeabilities are measured or estimated to lie between 10 and several thousand millidarcies, depending upon lithology. The Thomson contains no significant types or amounts of minerals that react adversely in the presence of drilling fluids, and so deterioration of reservoir quality due to formation damage is not expected. In conclusion, the Thomson sand represents a high-quality, potential reservoir capable of large-scale oil and gas yield. The limiting factor will be the distribution of this reservoir rock beneath the coastal plain.

The Thomson is but one sandstone directly associated with the transgression of the sea over the Lower Cretaceous (Neocomian) unconformity of the North Slope. Stratigraphically similar sands, but perhaps of differing composition and origin, such as the Kemik Sandstone, may also be present beneath the coastal plain of the ANWR. Such sandstones constitute the potentially best reservoirs of the ANWR coastal plain. This high potential is due to (1) the proximity to overlying organic-carbon-rich facies of the Brookian sequence, (2) the obvious possibility of high-quality reservoirs indicated by the Thomson, and (3) the propensity toward secondary porosity and hydrocarbonentrapping permeability barriers commonly associated with such deposits.

\section{CANNING FORMATION (BROOKIAN)}

Marine sandstones constitute a volumetrically small but significant part of the Canning Formation. Relatively thin bedded sandstones are enclosed in marine shales and probably range in age from Cretaceous to Eocene or Oligocene in the coastal plain of the ANWR. Because of their proximity to organic-carbon-rich marine shales and because of their lenticularity and lithologic properties as indicated by wells in the Point Thomson area, these sandstones are considered to be a potential reservoir facies within the coastal plain.

\section{Lithology}

Samples studied include well-sorted sandstones that occur in thin beds with sharp bases and that overlie and fine upward into marine shale. Generally, the sandstones contain a considerable amount of intergranular matrix clays and organic matter. From available samples (core chips), neither the average and maximum thickness of the sandstone beds nor the general configuration of the lithology could be determined. However, at least some samples were clearly from upward-fining units, whereas others were of uniform grain size and generally similar to those described from outcrops of the turbidite sandstone facies of the Canning Formation (chap. 5).

\section{Composition of Sandstones}

Near Point Thomson, the marine sandstones consist of 40 to 60 percent detrital quartz, nearly all of it monocrystalline. The remainder is largely lithic fragments, most of which reflect a sedimentary or metasedimentary (tectonic) provenance (fig. 9.4).

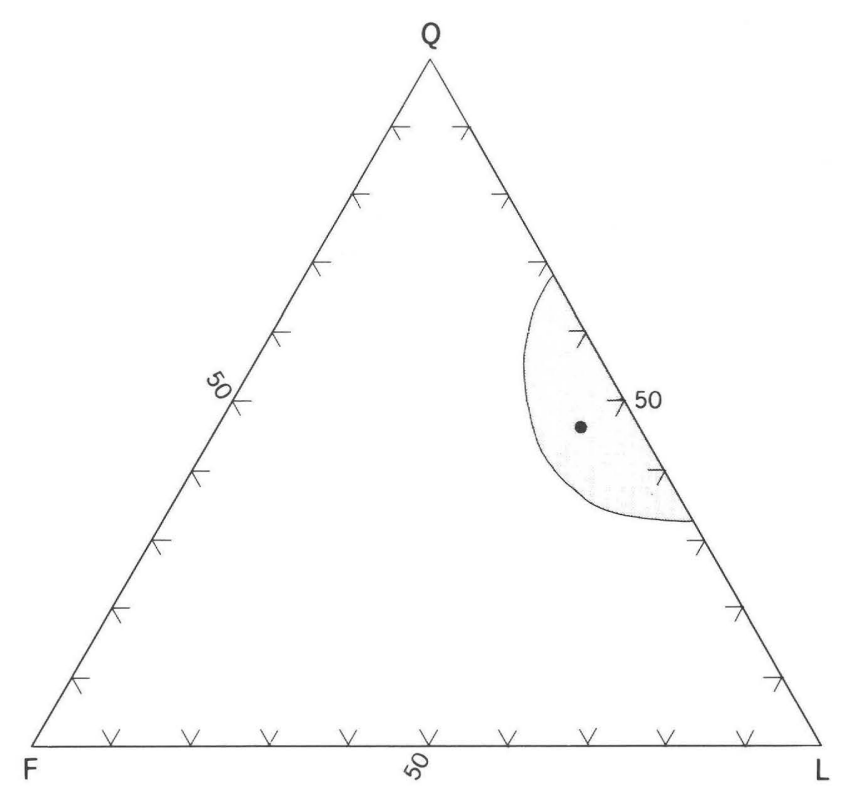

Figure 9.4. Triangular QFL plot showing framework mode for marine sandstones of the Canning Formation. $\mathrm{Q}$, monocrystalline and polycrystalline quartz and quartz chert; F, all feldspars; L, all rock fragments except quartz. Dot indicates typical composition discussed in text. 
Sedimentary lithic grains include chert, siltstone, mudstone, shale, sparse dolomite fragments, and scattered coal(?) grains. Metasedimentary rock fragments are dominated by quartz and white mica in various proportions, commonly with a schistose texture. Volcanogenic lithic fragments are present in some sandstones. Feldspar contents vary considerably, with some samples containing abundant potassium feldspar and a little plagioclase, but feldspars generally constitute no more than a few percent of the total sandstone framework grain mineralogy. In some samples no feldspar is present, and in a few of these, the feldspar was probably never present. However, petrographic observations of moldic porosity resulting from the dissolution of sandstone framework grains leave open the possibility that significant secondary porosity developed through the dissolution of framework grains of feldspar. A typical feldspathic sample (figs. 9.4, 9.5) is composed of monocrystalline quartz (46 percent), sedimentary and metasedimentary lithic grains (23 percent), potassium feldspar (7 percent), polycrystalline quartz (6 percent), volcanic rock fragments' (4 percent), chert (3 percent), and plagioclase ( 2 percent).

\section{Diagenesis}

Interpretations of postdepositional alterations are critical to predictions of reservoir potential of the

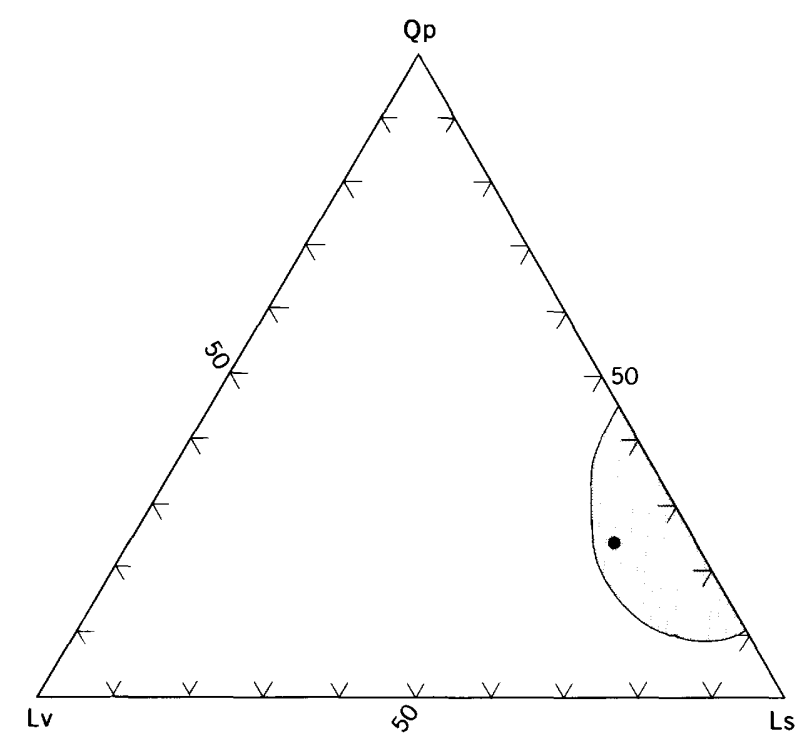

Figure 9.5. Triangular QpLvLs plot showing proportions of polycrystalline lithic fragments for marine sandstones of the Canning Formation (modified from Dickinson, 1970). Qp, polycrystalline quartz and quartz chert; Lv, volcanogenic lithic grains; Ls, sedimentary and metasedimentary lithic grains. Dot indicates typical composition discussed in text. turbidite sandstone facies beneath the coastal plain. Porosity loss due to diagenetic alteration is dominated by ductile-grain deformation and, to a lesser degree, by quartz cementation. Certain sandstones display poikilotopic carbonate cements, including calcite but perhaps more commonly ferroan dolomite (or ankerite?). Many pores are filled with kaolinite, which reduces the intergranular spaces to microporosity. In some samples, pores are lined with authigenic illite or chlorite. Moldic porosity, skeletal-grain porosity, and relict carbonate are commonly observed, attesting to the development of secondary porosity.

The sandstones are associated with shales containing mainly illite or micalike minerals, but also containing kaolin, chlorite, and mixed-layer illite/smectite clay (chap. 13). Preliminary and unpublished data suggest that mineral transformations within the mixed-layer illite/smectite are associated with abnormally high fluid pressure, which is a prevalent phenomenon in the Point Thomson area. In the Texas and Louisiana Gulf Coast basin, temperature-controlled smectite-to-illite transformations are thought to be genetically related to overpressuring. The thick sequence of the Canning Formation, which contains mixed-layer illite/smectite, suggests that abnormally high fluid pressures may commonly exist at depth beneath the ANWR coastal plain.

\section{Interpretation}

Sandstones of the Canning Formation evaluated here are marine deposits that apparently accumulated in 600 to $1,200 \mathrm{~m}(2,000$ to $4,000 \mathrm{ft})$ of water near the base of the basin slope (chap. 5). The principal effects of diagenesis have been (1) the formation of early diagenetic intergranular carbonate cement, some of it subject to dissolution and to the development of secondary porosity; (2) the reduction of porosity by ductile-grain deformation and quartz cementation; (3) the precipitation of kaolinite in open pore spaces; and (4) the formation of secondary porosity, especially moldic porosity, from the dissolution of susceptible framework grains and cements.

The sandstone compositions indicate a provenance different than that observed and reported for sandstones of the Lower Cretaceous Ellesmerian rocks. The complex framework grain composition (figs. 9.4, 9.5) suggests a tectonic derivation (Dickinson, 1970) mainly from sedimentary and metasedimentary terranes, but with admixtures of volcanogenic materials; this interpretation is consistent with an origin in the ancestral Brooks Range to the south and southwest.

\section{Reservoir Potential}

The turbidite sandstone facies of the Canning Formation is a potential reservoir beneath the coastal 
plain. The litharenite framework composition of the sandstones is typical of sandstones that lose effective porosity through significant framework collapse during burial (Nagtegaal, 1978). Indeed, sandstone samples of the Cretaceous-Tertiary Jago River Formation from outcrops near Sabbath Creek in the ANWR, which display a similar composition to the sandstones being considered here, have virtually no visible porosity (see chap. 10). Porosity loss results mainly from the tightly compressed lithic grains, which form a "pseudomatrix." Core-chip samples from Point Thomson have porosities ranging from near zero to approximately 15 percent (estimated by modal analysis). Because the principal porosity loss results from the compaction of ductile framework grains, the net confining pressure exerted upon the sandstone may be critical in the loss or preservation of reservoir porosity (chap. 13).
The Canning Formation displays abnormally high formation pressures near Point Thomson and elsewhere. This overpressuring coincides with mixedlayer clay transformations in thick shale sequences, in which expanding mixed-layer illite/smectite clays are a significant component, and suggests that much of the Canning Formation beneath the coastal plain may also be subject to high formation pressures (chap. 13). Under such conditions, the lithic sandstones of the unit's turbiditic facies may have significant porosity preserved at depth. The possible preservation of porosity in overpressured zones, coupled with the lenticularity of these sandstones and their proximity to organic-carbonrich mudstones, capable of yielding petroleum, presents the possibility of hydrocarbon reservoirs in sandstones of the Canning Formation in the coastal plain. 


\title{
Chapter 10.
}

\section{Petrology and Reservoir Potential of the Jago River Formation}

\author{
By Hugh McLean ${ }^{1}$
}

\section{INTRODUCTION}

The Jago River Formation, named by Buckingham (1987), consists of 2,850 m (9,350 ft) of nonmarine conglomerate, sandstone, siltstone, and coal stringers that are locally exposed along the north-flowing Sabbath Creek (Igilatvik Creek). According to detailed measurements by Buckingham (1985b), only about 566 $\mathrm{m}(1,860 \mathrm{ft})$ are actually exposed over a distance of approximately $10 \mathrm{~km}(6 \mathrm{mi})$. Outcrops are located in $\mathrm{T}$. 3 and 4 N., R. 35 W. (Demarcation Point C-5 quadrangle, scale 1:63,360). Strata at the south end of the outcrop belt dip north approximately $45^{\circ}$ and gradually flatten to about $5^{\circ}$ at the north end of the sequence (C.M. Molenaar, U.S. Geological Survey, written commun., 1986).

Pollen assemblages indicate a Paleocene age (Palmer and others, 1979; Lyle and others, 1980), and plant fossils a Late Cretaceous and Tertiary (Paleocene) age (Detterman and Spicer, 1981), for the Jago River Formation. The sequence is interpreted as a progradational (regressive) succession of fluvio-deltaic strata that were probably derived from the Late Cretaceous uplift of the ancestral Brooks Range (Molenaar, 1983; Buckingham 1985a, b).

Previous work on the Jago River Formation includes generalized columnar sections with porosity and permeability published by Lyle and others (1980) and a more detailed columnar section with age assignments by Detterman (1984b). A detailed study by Buckingham (1985b) of the stratigraphy, sedimentology, and petrology of this formation compares the section with coeval rocks to the west and to the east. A summary of this work is included in Buckingham (1985a).

Outcrop samples of sandstone from the Jago River Formation used in this study were collected by C.M. Molenaar in the summer of 1983; thin sections were point counted and described by the author in 198485.

\section{PETROLOGY}

\section{Composition}

The compositions of 14 sandstone samples were determined petrographically by counting 400 points per slide. Results of the detrital modal analyses are shown in figure 10.1, and raw data are tabulated in table 10.1 . The rocks vary little in composition and texture throughout the section, and they classify as immature litharenites according to the classification of Folk (1968).

The main constituents of the framework grain population are sedimentary and metamorphic rock fragments, especially chert and argillite (fig. $10.2 A, B$ ). Quartz percentages vary in relation to grain size, from as low as 2 percent in coarse-grained rocks to as high as 40 percent in fine-grained rocks. Feldspar (mainly plagioclase) is a minor constituent. The average composition is $\mathrm{Q}_{12} \mathrm{~F}_{1} \mathrm{~L}_{87}$. The population of chert grains includes radiolarian chert, recrystallized chert, and argillaceous chert; together, they constitute the most abundant rock fragments, followed by argillaceous mudstone, tuffaceous mudstone, siltstone, and finegrained silty sandstone (fig. 10.2C). Metamorphic rocks include phyllite, quartzite, marble, and granoblastic textures composed of chlorite, quartz, and feldspar. Other minor constituents include coal, mica, andesitic volcanic rocks, and rare foraminifers (fig. 10.2D). A ternary distribution of rock fragments is shown in figure 10.1, and the composition of the Jago River Formation is compared with other North Slope rocks by Bird and others in chapter 7.

\section{Texture}

Visual estimates of size sorting indicate that most samples are moderately sorted, with fine-grained sandstone slightly better sorted than coarse-grained samples. A prominent texture observed in all of the samples is the tightly appressed (packed) network of framework grains (fig. 10.2E). Ductile rock fragments (especially argillaceous sedimentary grains) suffer widespread interpenetration from adjacent less ductile grains (fig. 10.2F). Matrix averages approximately 13

\footnotetext{
${ }^{1}$ U.S. Geological Survey, Menlo Park, Calif.
} 


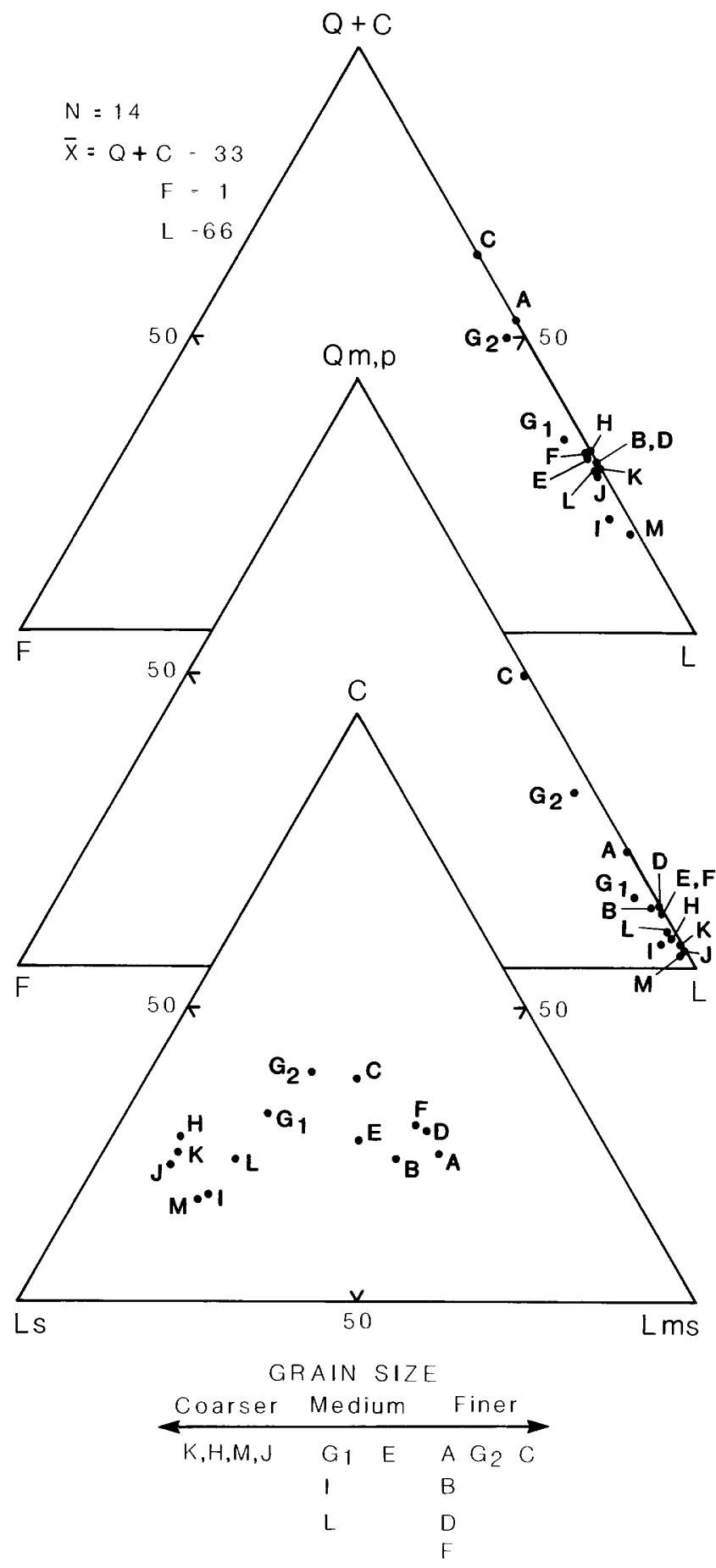

Figure 10.1. Ternary diagrams illustrating detrital grain composition of Jago River Formation sandstones. Letters relate samples and point-count data (based on 400 counts per sample) in table 10.1. Qm,p, quartz, monocrystalline and coarsely polycrystalline; no quartzite; $\mathrm{F}$, plagioclase, nonvolcanic; $\mathrm{L}$, total rock fragments excluding chert; $\mathrm{C}$, chert; Ls, mudstone, siltstone, sandstone, and coal; Lms, phyllite, schist, and quartzite. $\mathrm{N}$, number of samples. $\overline{\mathrm{x}}$, average composition in percent. percent, mainly consisting of pseudomatrix composed of a mixture of clay and chlorite.

\section{Cement}

Grain interpenetration is the major cementing agent rather than minerals precipitated in intergranular spaces (fig. $10.2 E, F$ ). Some samples, however, in the upper part of the section contain as much as 16 percent sparry intergranular cement that replaces sedimentary and metamorphic rock fragments and fills some of the pores.

\section{Provenance}

The abundance and diversity of sedimentary and metasedimentary rock fragments is consistent with a source in the ancestral Brooks Range. Buckingham (1985b, 1987) suggests that the Jago River Formation was derived partly from a collision orogen composed largely of nappes and thrust sheets and partly from a melange orogen composed of chert and volcanic rock. A Brooks Range source is also consistent with the northand northwest-directed paleocurrent flow measured by Buckingham (1985b). The provenance of the Jago River

Table 10.1. Compositional point-count data for the Jago River Formation

[All figures are volume percents; tr, trace; sample $A$ is stratigraphically lowest; $M$ is stratigraphically highest; data based on 400 counts per thin section]

\begin{tabular}{|c|c|c|c|c|c|c|c|c|c|c|c|c|c|c|c|}
\hline Sample & A & B & C & D & $\mathrm{E}$ & $\mathbf{F}$ & G1 & $1 \mathrm{G}$ & 2 & $\mathbf{H}$ & I & $\mathrm{J}$ & $\mathrm{K}$ & $\mathrm{L}$ & M \\
\hline \multicolumn{15}{|l|}{ Quartz } & \\
\hline (mono & 20 & & 40 & 19 & 9 & 8 & 10 & 2 & & 4 & 4 & 3 & 4 & 5 & \\
\hline Plagio & 0 & 0 & $\mathbf{t r}$ & tr & 1 & 1 & 3 & & 2 & tr & 3 & 3 & 0 & tr & \\
\hline Chert & 16 & 14 & 11 & 9 & 15 & 18 & 19 & 1 & 7 & 23 & 14 & 20 & 21 & 20 & \\
\hline \multicolumn{16}{|l|}{ Rock fragments: } \\
\hline Volcanic & 4 & 6 & 6 & 10 & 14 & 15 & 10 & & 7 & 2 & 1 & tr & 1 & tr & \\
\hline Meta & 32 & 27 & 10 & 30 & 22 & 25 & 14 & 1 & 1 & 9 & 15 & 10 & 9 & 16 & 13 \\
\hline Sedime & 17 & 20 & 11 & 17 & 21 & 16 & 27 & 1 & 6 & 52 & 53 & 57 & 54 & 48 & 52 \\
\hline Granoblast & 4 & 4 & 1 & 4 & 5 & 1 & 2 & & 2 & 1 & 2 & $\mathbf{t r}$ & 1 & 1 & \\
\hline \multicolumn{16}{|l|}{ Matrix: } \\
\hline Clay/ch & 7 & 20 & 21 & 11 & 13 & 16 & 15 & 2 & 1 & 9 & 8 & 9 & 0 & 0 & \\
\hline etem & & & & & & & & & & & & & & & \\
\hline Calcite & 0 & 0 & 0 & 0 & 0 & 0 & 0 & 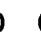 & 0 & 0 & 0 & 0 & 11 & & \\
\hline
\end{tabular}

Normalized percent:

Quartz

Feldspar

$\begin{array}{llllllllllllll}22 & 11 & 45 & 21 & 10 & 10 & 12 & 30 & 4 & 4 & 3 & 4 & 5 & 2\end{array}$

Lithic $\begin{array}{lllllllllllllll}78 & 89 & 55 & 79 & 89 & 89 & 85 & 67 & 95 & 93 & 94 & 96 & 94 & 97\end{array}$

Lithic composition:

Chen

$\begin{array}{llllllllllllll}25 & 24 & 38 & 29 & 27 & 30 & 32 & 39 & 28 & 18 & 23 & 25 & 24 & 17\end{array}$

$\begin{array}{lllllllllllllll}\text { Sedimentary } & 2532 & 31 & 25 & 36 & 26 & 46 & 37 & 62 & 63 & 66 & 64 & 56 & 65\end{array}$ \begin{tabular}{lllllllllllllll} 
Metamorphic & 50 & 44 & 31 & 46 & 38 & 44 & 22 & 24 & 10 & 19 & 11 & 11 & 20 & 18 \\
\hline
\end{tabular} 


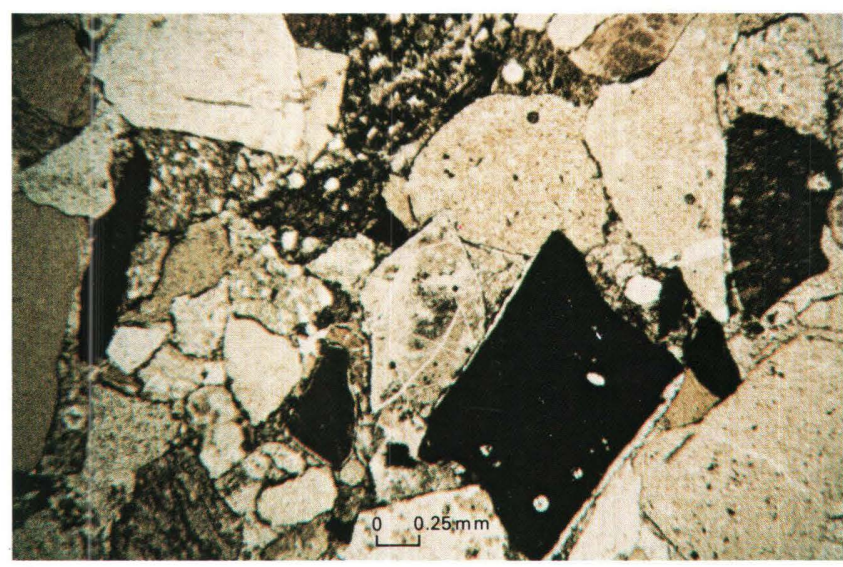

$\boldsymbol{A}$

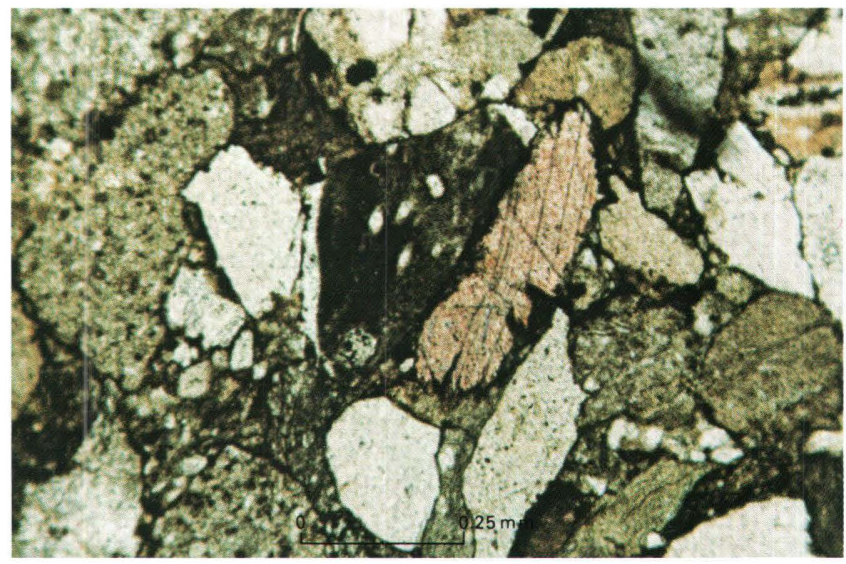

C

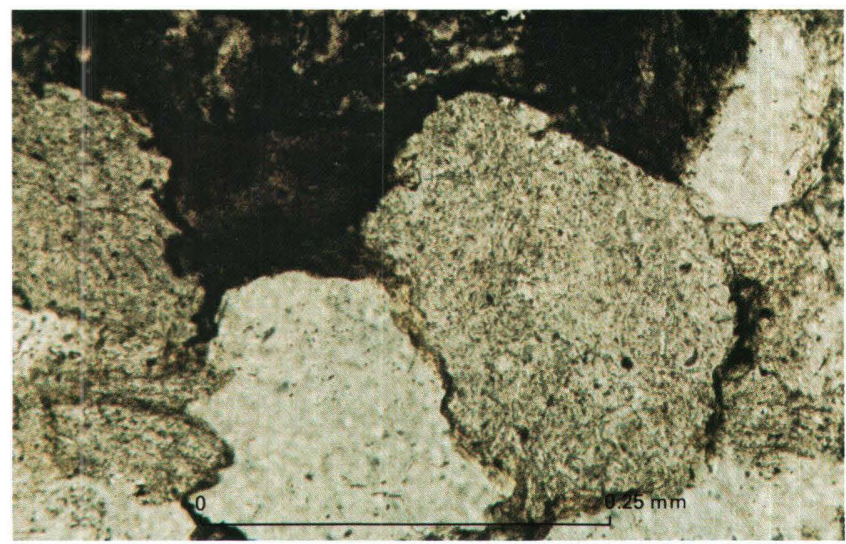

$\boldsymbol{E}$

Figure 10.2. Photomicrographs of Jago River Formation sandstones. Bar scale in each is $0.25 \mathrm{~mm}$. A, Typical lithic arenite of the Jago River Formation. Radiolarian(?) mudstone (center right) is rimmed with authigenic quartz. Note variation in grain size and shape and high packing density. Plane light. $B$, Same as $A$, but with crossed polarizer. Note that radiolarians(?) appear to be recrystallized. $C$, Detrital carbonate (center) in contact with radiolarian(?) mudstone. Note tightly appressed grains, especially sedimentary rock fragment caught

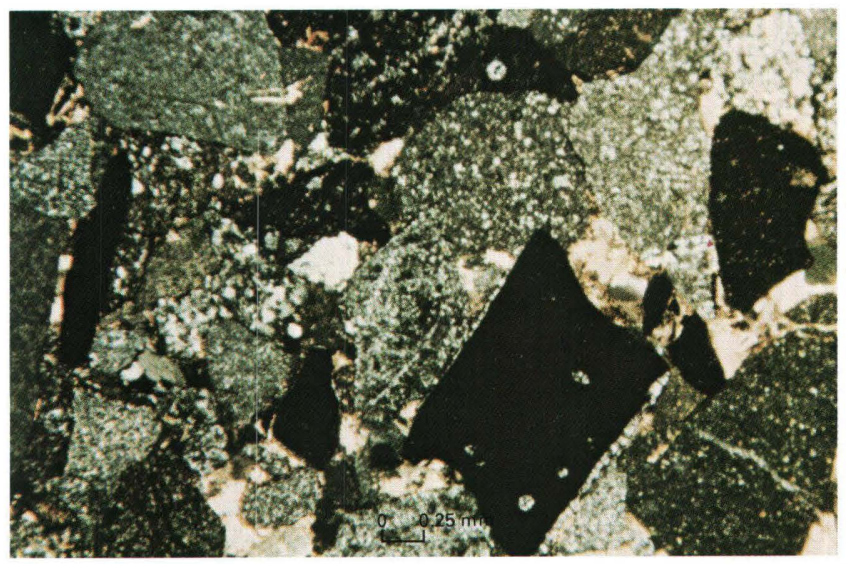

$B$

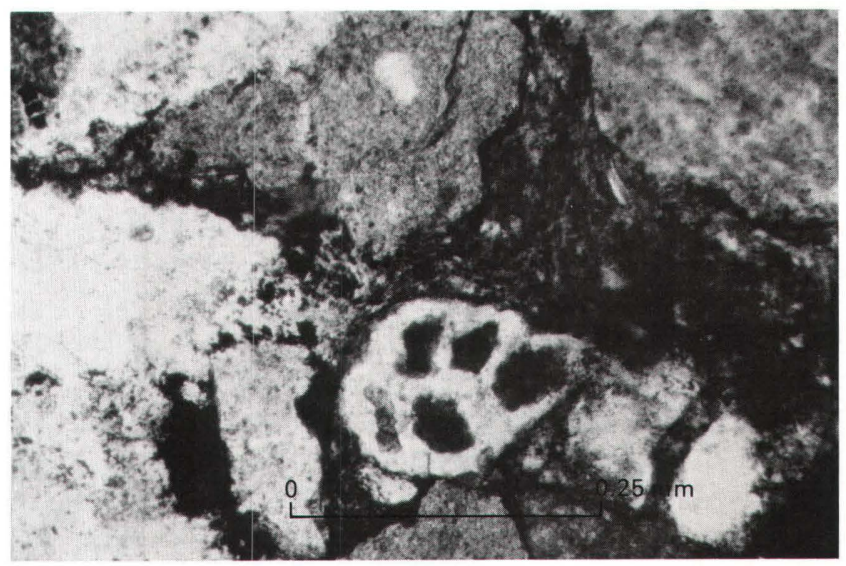

$\boldsymbol{D}$

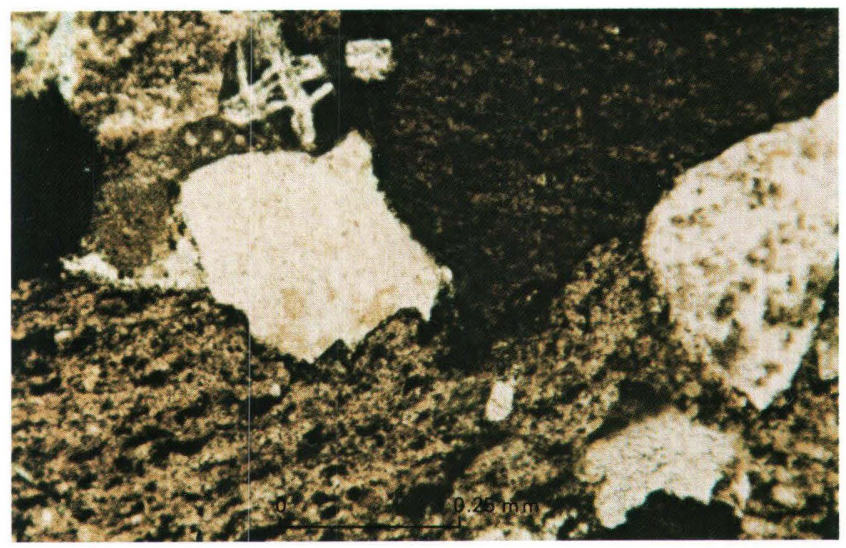

$\boldsymbol{F}$

between two chert grains at bottom center. Plane light. $D$, Rare agglutinated foraminifer with test composed of authigenic silica. Chambers are filled with opaque clay paste. Plane light. E, Chert grain surrounded by other sedimentary rock fragments. Note moderate suturing of grain contacts and absence of authigenic cement. $F$, Highly compacted carbonaceous mudstone (lower left) penetrated by light-colored chert grain. Note interpenetration of grain boundaries and absence of authigenic cement. Plane light. 
Formation might be misinterpreted if there has been abundant recycling of resistant grains such as chert, quartzite, and quartz from Paleozoic strata of the Brooks Range. Such a factor could obscure provenance interpretations.

Buckingham (1985b) compared the Sabbath Creek unit with rocks of similar age both to the west and to the east of the study area; he determined that the Moose Channel Formation, located $270 \mathrm{~km}(170 \mathrm{mi})$ to the east in the Mackenzie Delta, is partly coeval but not correlative with the Jago River Formation. Although both sequences have similar lithofacies and were deposited in similar sedimentary environments, there are minor differences in compositions and paleocurrent directions. The Moose Channel Formation indicates flow to the east and north compared with the westward and northward flow in the Jago River Formation.

The Jago River Formation differs from the Colville Group to the west in that the latter is marine and contains tuffaceous beds and subfeldspathic sandstone. Paleocurrent flow in the Colville Group is reported to be to the northeast (Buckingham, 1985b).

The Jago River Formation also compares poorly with the Sagavanirktok Formation in that the latter contains beds of volcanic ash, bentonite, and lignite, and its upper conglomerate member consists of massive unconsolidated sand, gravel, and volcanic ash. The age of the Sagavanirktok Formation in and adjacent to the coastal plain of the ANWR is Tertiary, and according to
Buckingham (1985b), the formation includes beds as young as Pleistocene.

\section{RESERVOIR POTENTIAL}

The surface outcrop samples of the Jago River Formation were measured for porosity and permeability by Lyle and others (1980). The 14 samples have an average porosity of 3.6 percent and an average permeability of 0.32 millidarcy. These low values reflect the tightly appressed interlocking framework grains, which are observed in thin section (fig. 10.2C, E, F). The original porosity, however, may have been high because there is little evidence of primary clay matrix and the grains tend to be moderately sorted and rounded. Facies analysis by Buckingham (1985b) indicates that Jago River Formation sands were deposited in channel-fill, point-bar, levee, and crevasse splay environments.

Examination of sandstone textures suggests that rocks with an open-packed framework and a high percentage of ductile rock fragments may actually speed the process of mechanical compaction during burial. As burial depths increase, the ductile grains would be rearranged to a close packing configuration and their deformation would fill the surrounding pore space. Thus, the original reservoir potential of the sandstone in the Jago River Formation was probably high, but now is negligible, based on the findings of this study. 


\title{
Chapter 11.
}

\section{Thermal Maturity, Richness, and Type of Organic Matter of Source-Rock Units}

\author{
By Leslie B. Magoon, ${ }^{1}$ Phillip V. Woodward, ${ }^{1}$ Arthur C. Banet, Jr., \\ Sarah B. Griscom, ${ }^{3}$ and Theodore A. Daws ${ }^{4}$
}

\section{INTRODUCTION}

The purpose of this paper is to (1) identify oil or gas source rocks in or adjacent to the coastal-plain area; (2) assess the amount, type, and thermal maturity of organic matter in these rocks; (3) map the amount and thermal maturity of important oil or gas source-rock units; and (4) determine the time of generation of petroleum and the directions in which it was expelled and subsequently migrated.

In order to determine if a particular sedimentary rock is capable of being a source for oil or gas, the organic matter preserved in rocks is evaluated for three attributes: (1) thermal history, (2) organic-matter richness, and (3) kerogen type. Six types of analyses were used to evaluate these attributes: (1) organic-carbon content, (2) thermal analysis, (3) vitrinite reflectance, (4) thermal alteration index, (5) visual kerogen, and (6) $C_{15+}$ hydrocarbon content. Used together, these data are useful in determining the rock units most likely to be sources for oil or gas. Also, by using organic-matter richness and thermal maturity maps in conjunction with geological and geophysical maps, one can determine the geographic location where this oil or gas originates.

After determining and mapping the oil or gas source rocks in and adjacent to the coastal-plain area and interpreting which source rock generated oil or gas, we then reconstruct the burial history for the stratigraphic sections penetrated in the Point Thomson Unit-1 and Beli Unit-1 wells. Along with the present-day geothermal gradient, a Lopatin diagram for these two wells is constructed to determine the most likely time and depth of oil or gas generation in the coastal-plain area.

Recent information on the thermal history of outcrops in the Brooks Range is reported by Brosgé and others (1981) and Harris and others (1983). Subsurface

\footnotetext{
${ }^{1}$ U.S. Geological Survey, Menlo Park, Calif.

2 Bureau of Land Management, Anchorage, Alas.

3 U.S. Geological Survey, Woods Hole, Mass.

${ }^{4}$ U.S. Geological Survey, Denver, Colo.
}

geochemical information on both rocks and oils of the North Slope has been published by Morgridge and Smith (1972), Jones and Speers (1976), Seifert and others (1979), Magoon and Claypool (1981, 1984, 1985, in press), Carman and Hardwick (1983), Magoon and Bird (1985), and Magoon and others (in press). Source-rock information on outcrops used in this study in northeastern Alaska was reported by Palmer and others (1979), Lyle and others (1980), and Molenaar (1983).

The reliability of oil and gas source-rock assessment depends upon "adequate" geochemical characterization of the stratigraphic interval(s) considered; adequate characterization is a sampling problem dependent upon the thickness, areal extent, and internal geochemical variability. The stratigraphic intervals in northeastern Alaska range in thickness from a few hundred to several thousand feet, and most extend across the North Slope.

Sample quality is important for both well and outcrop. Well samples are either drill cuttings, conventional cores, or sidewall cores. Sidewall cores were not available for this study, and very few conventional cores were analyzed. Thus, drill cuttings were used extensively in the Point Thomson and Kavik areas. With cutting samples, a relatively complete geochemical profile may be drawn for each well, but at least three potential problems exist: (1) in an uncased hole, sample material stratigraphically above the drill bit is often "caved," or mixed in, with the sample being drilled; (2) mud additives, such as walnut shells, not removed before analysis may be interpreted as organiccarbon-rich petroleum source rocks; and (3) cutting samples improperly dried under a heat lamp or on a stove (not air dried) are partially cooked and frequently give indications of being an overmature or depleted source rock when the rocks are actually a good source. Outcrop samples are difficult to work with because weathering (oxidation) alters and degrades organic matter (Leythaeuser, 1973; Clayton and Swetland, 1976). Also, owing to poor outcrop exposures, there are fewer outcrop samples available to evaluate a particular stratigraphic 
interval, whereas drill cuttings from a well provide continuous stratigraphic samples.

Samples used to characterize each stratigraphic unit are summarized by unit, but generally, west of the Canning River, the rock samples are from industry exploratory wells; east of the Canning River, the rocks are surface samples from the Brooks Range to the south and from the coastal-plain area to the north. About 1,400 cutting and core samples from wells in the Point Thomson and Kavik areas were analyzed by industry and made public by the State of Alaska Oil and Gas Conservation Commission; in addition, samples from two wells in the Kavik area were analyzed by Geochem Research Inc. (Houston, Texas) under USGS contract. The 558 outcrop samples used in this study were collected by USGS field parties in 1975, 1976, 1978, 1980, and 1982-1984. Additional information for this study has been taken from Palmer and others (1979) and Lyle and others (1980).

\section{GEOCHEMICAL METHODS}

Geochemical methods are separated into three categories as related to the various organic components: organic matter, kerogen, and bitumen analyses. This organization recognizes that sedimentary rock is made up of mineral matter and organic matter; that organic matter includes insoluble organic matter and soluble organic matter, or kerogen and bitumen, respectively; and that bitumen is the precursor to crude oil. Organic-matter analyses include those measurements of both kerogen and bitumen together such as organic-carbon content, elemental analysis, and thermal analysis. Kerogen analyses are only concerned with the solid material in the organic matter and include visual kerogen, thermal alteration index (TAI), and vitrinite reflectance $\left(R_{0}\right)$. Bitumen analyses examine the crude-oil-like or liquid portion of organic matter that can be compared with crude oil. A generalized flow chart of geochemical methods is shown in figure 11.1, and the specific analyses are described below.

\section{Organic-Matter Analyses}

Organic-carbon content (weight percent) is a measure of the amount of organic matter in a rock that originates from either terrestrial or marine organisms. Organic-carbon content alone does not characterize the capacity of a rock to generate oil or gas. The organiccarbon maps presented in this study reflect organicmatter richness on a regional scale. As a matter of approximation, values of less than 0.5 weight percent are considered nonsource (Welte, 1965), 0.5 to 2.0 weight percent are fair potential source rocks, and above 2.0 weight percent are good potential source rocks.
Organic-carbon content is available for every rock sample analyzed in this study.

An elemental analysis measures the amount of elemental carbon, hydrogen, and nitrogen (CHN) in organic matter. The ability of a source rock to generate oil or gas is dependent on the amount of hydrogen or lipid material contained in the organic matter. A source rock with a relatively high hydrogen content will generate large volumes of oil, whereas source rocks with low amounts of hydrogen will generate only gas. A source rock with an $\mathrm{H} / \mathrm{C}$ ratio above 1.0 is oil prone and below 1.0 is gas prone (Tissot and Welte, 1978, 1984; Hunt, 1979). Elemental analyses were performed only on rock units penetrated in the Beli Unit-1 and Canning River Unit A-1 wells and from selected outcrop samples.

Thermal analysis is a fast, inexpensive way to approximately measure the amount, type, and thermal maturity of organic matter in a rock. The two analyses used in this study were TEA-FID (thermal evolution analysis-flame ionization detector; Barker, 1974) and Rock Eval. By gradually heating organic matter included in a powdered rock sample and monitoring the expelled hydrocarbons, peaks are recorded. For both analyses the first two peaks are similar; peak 1 measures the volatile or already-formed hydrocarbons, and peak 2 measures the pyrolyzed hydrocarbons and represents the hydrocarbons thermally cracked or released from the kerogen. Peak 3, from Rock Eval data, represents the oxygen content of the kerogen. TEA-FID analyses for rock units penetrated in the Beli Unit-1 well and outcrop samples are available. Rock Eval analyses are available for rock units penetrated in nine Point Thomson wells, three Kavik wells, and many outcrop samples. Since Rock Eval information is available for all but one well and some outcrop samples, the remainder of the discussion stresses this analysis.

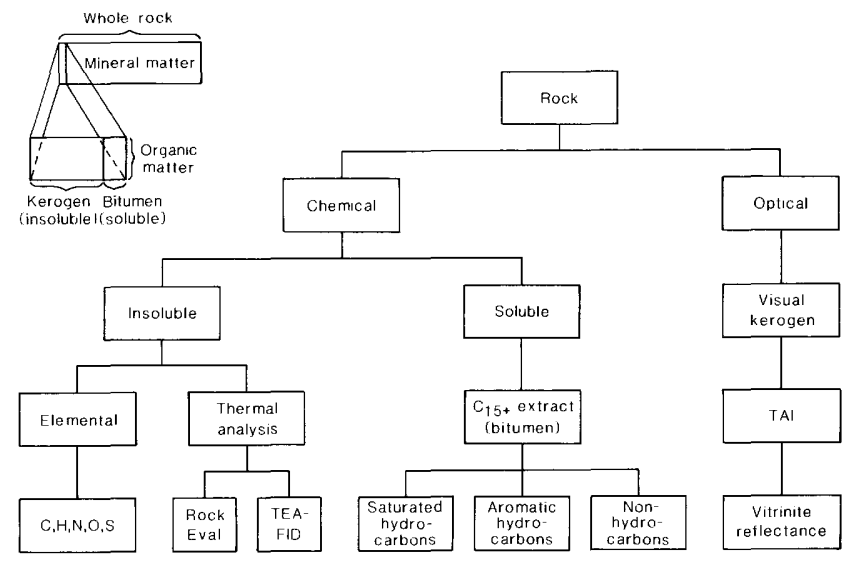

Figure 11.1. Flow chart of analyses included in this report. TAI, thermal alteration index; TEA-FID, thermal evolution analysis-flame inonization detector; $\mathrm{C}$, carbon; $\mathrm{H}$, hydrogen; $\mathrm{N}$, nitrogen; $\mathrm{O}$, oxygen; $\mathrm{S}$, sulfur. 
Rock Eval peaks are designated $S_{1}, S_{2}$, and $S_{3}$ and represent the volatile hydrocarbons, pyrolyzed hydrocarbons, and oxygen (carbon dioxide), respectively. Rock Eval information is interpreted in the following manner. The $S_{1}$ peak is the area of the low-temperature, free-hydrocarbon yield and corresponds to the amount of hydrocarbons vaporized and driven from the sample. The $S_{2}$ peak indicates the organic-matter richness or potential that the sample has for generating hydrocarbons. $S_{2}$ values less than 5 are poor to fair source rocks and above 5 are good source rocks (Clementz and others, 1979). The Rock Eval temperature $\left(T_{\max }\right)$ refers to the temperature of $S_{2}$ when the maximum amount of pyrolytic products are evolved. Temperatures below $435^{\circ} \mathrm{C}\left(815^{\circ} \mathrm{F}\right)$ indicate immature potential source rocks, from 435 to $460{ }^{\circ} \mathrm{C}$ (815 to 860 $\left.{ }^{\circ} \mathrm{F}\right)$, mature, and above $460{ }^{\circ} \mathrm{C}\left(860^{\circ} \mathrm{F}\right)$, overmature (Espitalie and others, 1977b). The ratio of the $S_{2}$ peak to the $S_{3}$ peak is an indicator of whether the organic matter is gas prone or oil prone; values less than 2.5 are gas prone, values between 2.5 and 5 are equally oil prone and gas prone, and values over 5 are oil prone (Clementz and others, 1979). The hydrogen index, $\mathrm{S}_{2}$ /organic-carbon content, identifies the kerogen type; indices around 200 are type III, terrestrial organic matter; indices around 500 are type II, marine organic matter; and indices around 800 are type I, algal organic matter (Espitalié and others, 1977b). Production index, $S_{1} / S_{1}+S_{2}$, is a useful parameter to monitor the level of maturity as well as oil migration into the source rocks. Values less than 0.1 are immature, values between 0.1 and 0.4 are mature, and values over 0.4 are indicative of migrated or indigenous oil (Espitalié and others, 1977b).

Rock Eval information can be plotted on a van Krevelen diagram to indicate organic-matter type (fig. 11.2). On this diagram, the hydrogen index (HI) is compared with the oxygen index (OI, $S_{3}$ /organic-carbon content) to determine if the organic matter included in the rock is type I, II, or III. With higher levels of organic-matter maturity, the $\mathrm{HI}$ and $\mathrm{OI}$ tend toward the origin along the evolution lines indicated and pass through levels of 0.5 and 1.0 percent $R_{o}$ (Tissot and Welte, 1984).

\section{Kerogen Analyses}

Visual kerogen evaluation determines the presence and type of biological material included in the sediments at the time of deposition. The biological material includes amorphous material such as algal bodies; herbaceous material such as pollen, spores, and leaf cuticle; woody material such as the structural elements of plants; and inertinite or black opaque carbonaceous debris. Amorphous and herbaceous material are important constituents of oil source rocks, and woody material and some inertinite are gas source rocks. All of these materials are examined and identified on a kerogen strew slide with a transmitting light microscope. Visual kerogen information is available for three Point Thomson wells, two Kavik wells, the Ignek Valley section, and selected outcrops.

The thermal alteration index (TAI), acquired on the same kerogen strew slide, provides information on thermal maturity. As kerogen experiences higher levels of thermal maturity it undergoes color changes from light yellow to brown to black (Staplin, 1969). An index from 1 to 5 expresses this color change (Bayliss and Magoon, in press). Values below 2.1 are immature, values from 2.1 to 3.3 are mature, and values above 3.3 are overmature (fig. 11.3). TAI data are available on outcrop samples (Palmer and others, 1979) and two Kavik area wells (see table 11.1).

Vitrinite reflectance $\left(R_{o}\right)$ is a measure of the thermal maturity (Castaño and Sparks, 1974). To equate $R_{0}$ values with the generation of oil and gas, other geochemical analyses must be related to $R_{o}$ measurements (Bayliss and Magoon, in press). $R_{0}$ values indicate immature, mature, and overmature source rocks and may be correlated with the three stages of petroleum generation: (1) the diagenetic stage $\left(<0.6\right.$ percent $\left.R_{o}\right)$, where very little oil or thermal gas is generated; (2) the catagenetic stage ( 0.6 to 2.0 percent $R_{0}$ ), where oil,

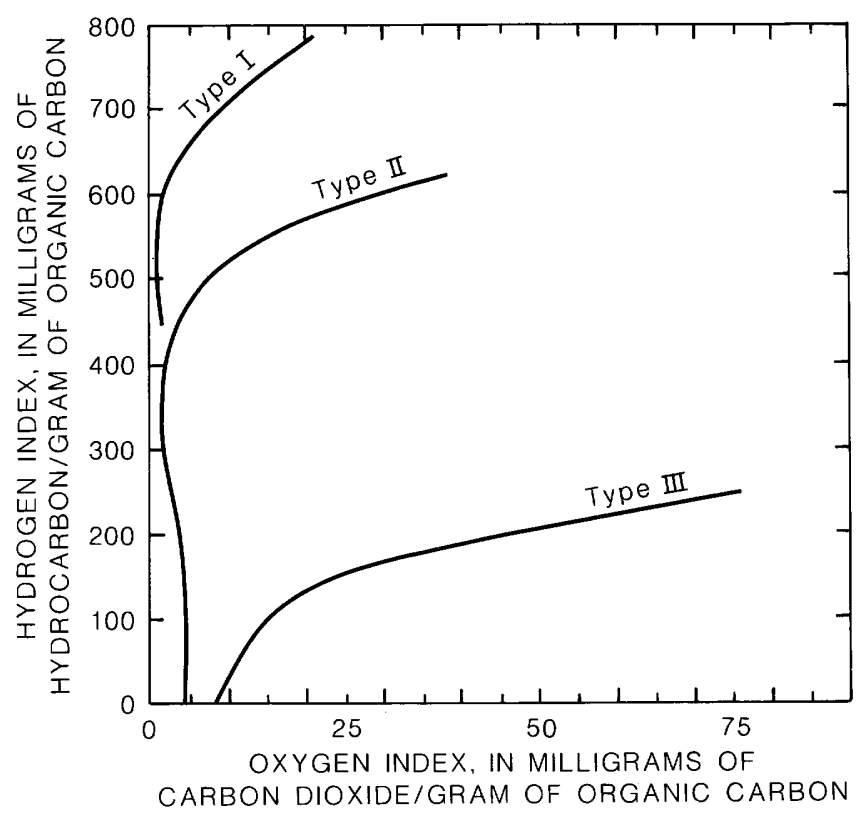

Figure 11.2. Van Krevelen diagram used for Rock Eval and organic-carbon information to determine type of organic matter. Type I, algal or oil prone; Type II, marine or oil prone; Type III, terrestrial or gas prone. 
condensate, and gas are generated and preserved, and (3) the metagenetic stage (above 2.0 percent $R_{o}$ ), where gas is generated and oil is thermally decomposed to gas (Tissot and Welte, 1984). $R_{o}$ values are reported here for nine Point Thomson wells, four Kavik wells, and most outcrop localities.

\section{Bitumen Analyses}

Bitumen, or extractable $\mathrm{C}_{15+}$ hydrocarbon content, is the combined weights of the heavier saturated and aromatic hydrocarbons and nonhydrocarbons (fig. 11.1). This fraction, when expelled from a source rock at maturity, is an important constituent of crude oil. To provide information on the ability of each rock unit to generate hydrocarbons, $\mathrm{C}_{15+}$ hydrocarbon content (HC) is plotted against organic-carbon content (OC; fig. 11.4A). A similar plot by Hunt (1979) shows values of numerous petroleum source rocks compared with those of petroleum-bearing reservoir rocks. The lower line represents the $\mathrm{HC} / \mathrm{OC}$ value of $10 \mathrm{mg} \mathrm{HC} / \mathrm{g} \mathrm{OC}$, or the proposed lower limit of petroleum source rocks. Values that fall between 10 and $70 \mathrm{mg} \mathrm{HC} / \mathrm{g} \mathrm{OC}$ are either type II or type III, and values between 70 and $100 \mathrm{mg} \mathrm{HC/g}$ OC are type II. The type I threshold of $150 \mathrm{mg} \mathrm{HC} / \mathrm{g}$ $\mathrm{OC}$ is not shown on figure $11.4 A$ because type I source rocks are not present in the ANWR. The upper line represents an $\mathrm{HC} / \mathrm{OC}$ value of $100 \mathrm{mg} \mathrm{HC} / \mathrm{g} \mathrm{OC}$ and separates inferred indigenous hydrocarbons (below) from migrated, expelled, or reservoired hydrocarbons (above).

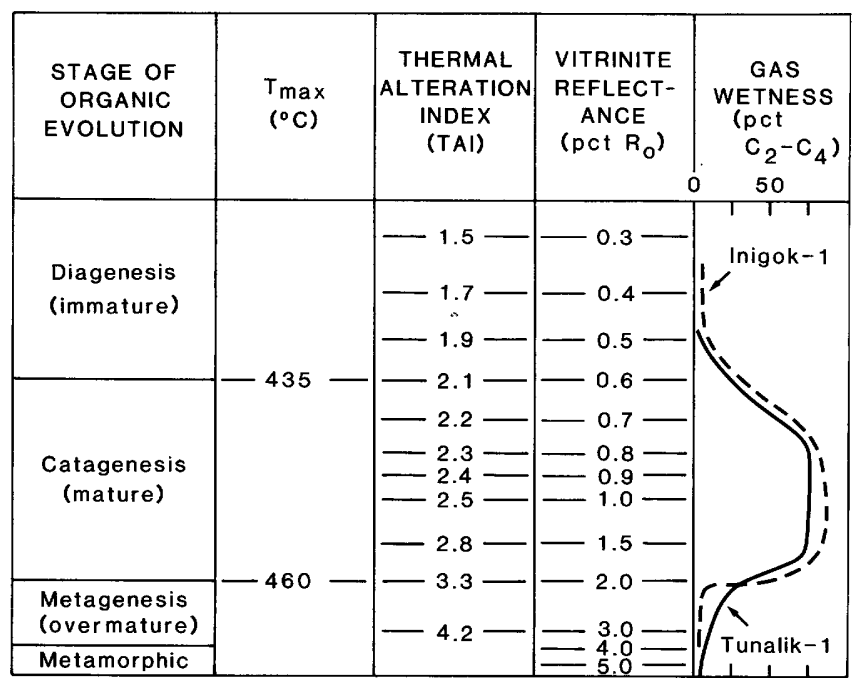

Figure 11.3 Stages of organic evolution calibrated to vitrinite reflectance and gas wetness from two wells in NPRA. Also shown are threshold values for $T_{\max }$ for Rock Eval and TEA-FID, and thermal alteration index.
Organic-carbon content (horizontal axis) is divided into three sections: nonsource if values are less than 0.5 weight percent, fair source for values from 0.5 to 2.0 weight percent, and good source rock for values above 2.0 weight percent.
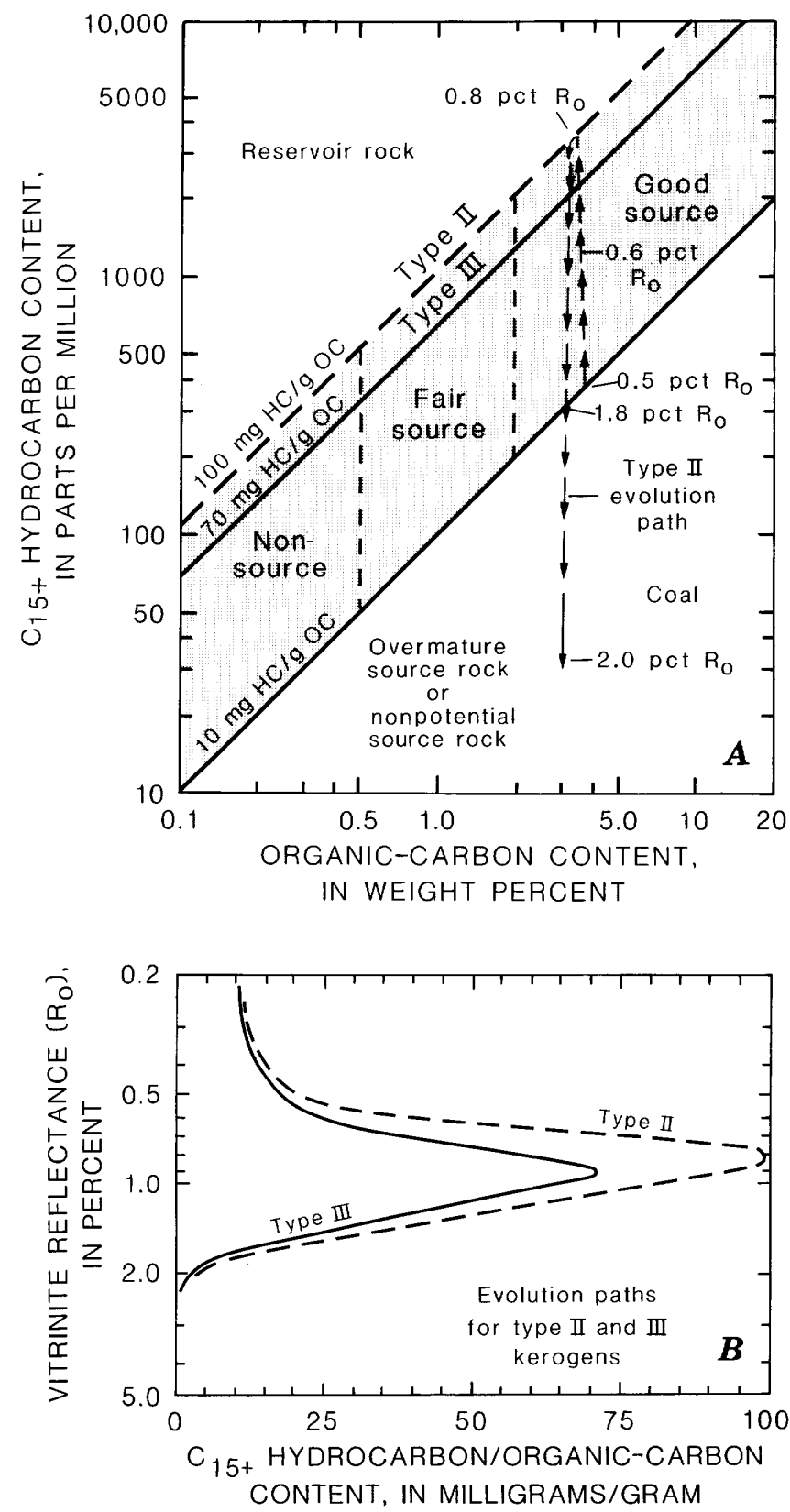

Figure 11.4. Graphs used to evaluate the amount, type, and evolution stage of organic matter. A, Organic-carbon content compared with extractable hydrocarbons. Upper boundary for type II kerogen is shown as a dashed line and for type III as a solid line. Indigenous hydrocarbons plot below dashed line and migrated hydrocarbons above. $B$, Extractable hydrocarbons and organic-carbon content compared with vitrinite reflectance. 
In the subsurface, a source rock going through the three stages of organic evolution varies in hydrocarbon content (fig. 11.4B). With $\mathrm{R}_{\mathrm{o}}$ values less than 0.6 percent the hydrocarbon content ranges from 10 to $20 \mathrm{mg} \mathrm{HC} / \mathrm{g} \mathrm{OC}$. Above 0.6 percent $R_{\mathrm{o}}$, types III and II organic matter generate different amounts of hydrocarbon content at peak generation (70 and $100 \mathrm{mg}$ $\mathrm{HC} / \mathrm{g} \mathrm{OC}$, respectively). The maturity at peak generation is different for each kerogen type ( 0.9 percent $R_{0}$ for type III and 0.8 percent $R_{o}$ for type II). For both source-rock types, all hydrocarbon has been expelled or thermally cracked to gas by 2.0 percent $R_{0}$. A similar maturity path is shown on figure $11.4 A$ for type II organic matter. Solvent extraction information is available for outcrop samples only, as published by Lyle and others (1980) and determined by the USGS laboratory (chap. 12).

\section{GEOCHEMICAL RESULTS}

Framework geochemistry depicts the regional variation by rock unit for the following three attributes: (1) thermal history using percent $R_{o}$, thermal alteration index, and $\mathrm{T}_{\max }$ from Rock Eval; (2) organic-matter richness using organic-carbon content and Rock Eval; and (3) kerogen type using Rock Eval and visual kerogen. This framework geochemisty is restricted to nine stratigraphic units, as follows: Kayak Shale, Lisburne Group, Sadlerochit Group, Shublik Formation, Kingak Shale, pebble shale unit, Hue Shale, Canning Formation, and Sagavanirktok Formation. The geology of these units is described in more detail by Bird and Molenaar (chap. 5). In addition to the geochemical analyses on the outcrop samples in and adjacent to the coastal-plain area, samples from 13 wells in the Point Thomson and Kavik areas are summarized in table 11.1 and displayed in appendices $11.1 \mathrm{~A}$ through $11.1 \mathrm{M}$. Geochemical summaries for all units, from oldest to youngest, are presented in tables and figures.

\section{Regional Thermal History}

The thermal histories of the rocks in the undeformed and deformed zones are quite different, as expressed in the contrasting structural styles on either side of the Marsh Creek anticline. Northwest of the anticline, where units are at maximum burial depth, rock units older than the pebble shale unit dip gently to the south, and the younger deltaic foreset strata of the Canning Formation dip gently to the east. South of the anticline, steep dips, thrusting, and uplift are common to coastal-plain sedimentary rocks. In both areas, the so- called Lower Cretaceous unconformity at the base of the pebble shale unit truncates all units that predate the pebble shale unit to the northeast.

Thermal alteration index, vitrinite reflectance, and Rock Eval data indicate a high thermal history for pre-Tertiary outcrops in the Brooks Range. Because of this high thermal history, the amount and type of organic matter before maturity are difficult to ascertain. Overmature organic matter has lost or expelled most hydrocarbons, leaving behind dark-brown to black kerogen that is difficult to interpret. Exceptions are several outcrops of immature parts of the Hue Shale and Kingak Shale in the Jago River and Niguanak Ridge areas, and marginally mature Kayak Shale in a well in the Point Thomson area. Most Tertiary rocks that crop out in the deformed zone are immature to marginally mature. Vitrinite reflectance data contoured at the Lower Cretaceous unconformity from well information indicate that the undeformed zone is near maximum burial depth, whereas data contoured from well and outcrop information indicate that the deformed zone is uplifted (fig. 11.5). The simple maturity pattern in the deformed zone suggested for the Lower Cretaceous unconformity does not reflect the structural complexity revealed by seismic data (chaps. 17, 19, 20).

\section{Organic-Matter Amount, Type, and Thermal Maturity}

A brief description of the framework geochemistry and of the amount, type, and thermal maturity of the organic material for each rock unit follows. Source rocks are evaluated as being either oil prone or gas prone. This means that the predominant petroleum product for an oil-prone source rock is oil, but some natural gas is also generated and expelled. The reverse is true for a gas-prone source rock.

\section{Kayak Shale}

The Kayak Shale was evaluated using 20 outcrop samples from seven localities in the Brooks Range and 28 samples from a well in the Point Thomson area and two wells in the Kavik area (table 11.2, app. $11.1 A, J, L)$. Organic-carbon content ranges from 0.0 to 2.6 weight percent and averages 1.2 weight percent for outcrop samples, and from 1.4 to 3.5 weight percent and averages 2.3 weight percent for wells. The thermal maturity from vitrinite reflectance data ranges from 0.8 to 4.3 percent $R_{o}$ for both well and outcrop samples. The TAI values for both outcrop and well information ranges from 3.4 to 4.2 , or overmature. The hydrogen index values for both sample types are 100 or less. Visual kerogen indicates similar amounts of amorphous and herbaceous material and woody and inertinitic material. Except for the Point Thomson well, the Kayak 
Shale is too thermally mature in the Brooks Range to evaluate its original source-rock characteristics. Samples from the East Mikkelsen Bay State-1 well are mature $\left(0.8\right.$ pct $\mathrm{R}_{\mathrm{o}}, \mathrm{T}_{\max }=450{ }^{\circ} \mathrm{C}$ ) gas-prone (2.1 wt pct OC, $\mathrm{HI}=100,50 / 50 \mathrm{pct}$ amorphous/woody, Am/Wo) source rocks.

\section{Lisburne Group}

The Lisburne Group was evaluated using 10 outcrop samples from six localities in the Brooks Range and 209 samples from four wells in the Kavik area (table 11.2, app. 11.1J-M). Organic-carbon content, except for one sample at 1.1 weight percent, averages 0.1 weight percent for outcrop samples, and 0.2 weight percent for cutting samples. The thermal maturity from thermal alteration index (TAI) data is about 2.5 from outcrop samples and with an interpolated vitrinite reflectance value from cutting samples of 1.5 percent $R_{0}$. Visual kerogen indicates that amorphous and herbaceous material predominate over woody and inertinitic material. Even for these low organic-carbon contents and high maturities, hydrogen indices for these samples are as high as 213 and average 74 for both outcrop and well information, which probably reflects the presence of small amounts of oil-prone kerogen. This suggests that if the organic content were to increase, the Lisburne would be a good oil-prone source rock. However, the one sample with organic-carbon content of 1.1 weight percent is not overmature, as its hydrogen index is only 11. Therefore, the thermally mature Lisburne Group is not a petroleum source rock in or adjacent to the 1002 area.

\section{Sadlerochit Group}

The Sadlerochit Group was evaluated using 21 outcrop samples from seven localities in the Brooks Range and 102 cutting samples from four wells in the Kavik area (table 11.2, app. 11.1J-M). The organiccarbon content ranges from 0.3 to 1.8 weight percent and averages 0.9 weight percent for outcrop samples and 0.8 weight percent for well cuttings. The thermal maturity from vitrinite reflectance data ranges from 1.2 to 2.2 percent $R_{o}$ in outcrop and from 0.9 to 1.3 percent $R_{o}$ in the wells (table $11.2, \mathrm{pl}$. 1). TAI values range from 2.5 to 3.9 , or mature to overmature. Visual kerogen indicates that the organic material is derived from a terrigenous source area, as the constituents are predominantly herbaceous, woody, and inertinitic. The hydrogen index values from outcrop samples area as high as 50, but they are as high as 437 (Kavik Member of the Ivishak Formation) in the Canning River Unit B-1 well (see table 11.2; individual values exceed 500, app. 11.1M). Low organic-carbon content and a terrigenous source indicate a poor petroleum source rock, except for the samples from the Canning River Unit B-1 well, where good oil-prone type II kerogen is present. Because of the high thermal maturity (1.3 pct $\left.R_{o}, p l .1\right)$, the Kavik Member in the Canning River Unit B-1 well could be the source for the gas in the Kavik area.

\section{Shublik Formation}

The Shublik Formation was evaluated using 56 outcrop samples from 10 localities in the Brooks Range and 14 drill cuttings from 4 Kavik area wells (table 11.3, app. 11.1J-M). Eleven wells west of the Kavik area

Table 11.1. Wells adjacent to the ANWR for which geochemical data are available

[X, data available; -, no data available; Vit. ref., vitrinite reflectance; RE, Rock Eval; TEA-FID, thermal evolution analysis-flame ionization detector, OC, organic carbon; CC, carbonate carbon; TAI, thermal alteration index; VK, visual kerogen; EA, elemental analysis; ST, subsurface temperature]

\begin{tabular}{|c|c|c|c|c|c|c|c|c|c|c|c|c|c|}
\hline Well & $\begin{array}{l}\text { API } \\
\text { No. }\end{array}$ & $\begin{array}{l}\text { Location } \\
\text { Sec.-T.-R. }\end{array}$ & $\begin{array}{c}\text { Total } \\
\text { depth } \\
\text { (ft) }\end{array}$ & $\begin{array}{l}\text { Ap- } \\
\text { pendix }\end{array}$ & $\begin{array}{l}\text { Vit. } \\
\text { ref. }\end{array}$ & RE & $\begin{array}{l}\text { TEA- } \\
\text { FID }\end{array}$ & $\mathrm{OC}$ & $\mathrm{CC}$ & TAI & VK & EA & ST \\
\hline \multicolumn{14}{|c|}{ Point Thomson Area } \\
\hline East Mikkelsen Bay State-1 & $50-089-20002$ & $7-9 \mathrm{~N}-21 \mathrm{E}$ & 15,205 & $11.1 \mathrm{~A}$ & $\mathrm{x}$ & $\mathrm{x}$ & - & $\bar{x}$ & - & - & $\mathrm{X}$ & - & $\bar{x}$ \\
\hline West Staines State-2 & $50-089-20004$ & $25-9 \mathrm{~N}-22 \mathrm{E}$ & 13,171 & $11.1 B$ & $\mathbf{x}$ & $\mathrm{x}$ & - & $\mathrm{x}$ & - & - & $\mathrm{x}$ & - & $\mathrm{x}$ \\
\hline Point Thomson Unit-1 & $50-089-20005$ & $32-10 \mathrm{~N}-23 \mathrm{E}$ & 13,298 & $11.1 C$ & $\mathrm{X}$ & $\mathrm{x}$ & - & $\mathbf{x}$ & - & - & - & - & $\mathrm{x}$ \\
\hline Point Thomson Unit-2 & $50-089-20006$ & $3-9 \mathrm{~N}-22 \mathrm{E}$ & 14,117 & 11.1D & $\mathbf{x}$ & $\mathrm{x}$ & - & $\mathrm{X}$ & - & - & - & - & $\mathrm{x}$ \\
\hline Point Thomson Unit-3 & $50-089-20007$ & $34-10 \mathrm{~N}-23 \mathrm{E}$ & 14,125 & $11.1 E$ & $\mathbf{x}$ & $\mathrm{x}$ & - & $\mathrm{x}$ & - & - & - & - & $\mathrm{x}$ \\
\hline Challenge Island-1 & $50-089-20012$ & $8-10 \mathrm{~N}-22 \mathrm{E}$ & 13,587 & $11.1 F$ & $\mathrm{x}$ & $\mathrm{x}$ & - & $\mathrm{X}$ & - & - & - & - & \\
\hline Alaska State D-1 & $50-089-20015$ & $23-10 \mathrm{~N}-23 \mathrm{E}$ & 13,050 & $11.1 G$ & $\mathbf{x}$ & $\mathrm{x}$ & - & $\mathrm{X}$ & - & - & $\mathrm{x}$ & - & $\mathrm{x}$ \\
\hline Alaska Island-1 & $50-089-20018$ & $11-10 \mathrm{~N}-22 \mathrm{E}$ & 15,222 & $11.1 H$ & $\mathrm{X}$ & $\mathrm{X}$ & - & $\mathbf{x}$ & - & - & - & - & $\mathrm{X}$ \\
\hline Alaska State F-1 & 50-089-20019 & $17-10 \mathrm{~N}-23 \mathrm{E}$ & 14,316 & $11.1 I$ & $\mathrm{X}$ & $\mathrm{X}$ & - & $\mathrm{x}$ & - & - & - & - & $\mathrm{X}$ \\
\hline \multicolumn{14}{|c|}{ Kavik Area } \\
\hline Kavik-1 & $50-179-20001$ & $7-3 \mathrm{~N}-23 \mathrm{E}$ & 9,564 & $11.1 \mathrm{~J}$ & $\bar{x}$ & $\bar{x}$ & - & $\mathrm{X}$ & - & - & - & - & - \\
\hline Beli Unit-1 & $50-179-20002$ & $8-4 N-23 E$ & 14,632 & $11.1 \mathrm{~K}$ & $\mathrm{x}$ & - & $\mathrm{x}$ & $\mathrm{X}$ & $\mathrm{x}$ & $\mathrm{x}$ & $\mathrm{x}$ & $\mathrm{x}$ & $\mathrm{x}$ \\
\hline Canning River Unit A-1 & $50-179-20005$ & $19-3 \mathrm{~N}-24 \mathrm{E}$ & 8,874 & $11.1 L$ & $\mathrm{X}$ & $\mathbf{x}$ & - & $\mathbf{X}$ & $\mathrm{x}$ & $\mathbf{x}$ & $\mathbf{X}$ & $x$ & $\mathrm{x}$ \\
\hline Canning River Unit B-1 & $50-179-20006$ & $32-4 \mathrm{~N}-34 \mathrm{E}$ & 10,803 & $11.1 M$ & $\mathbf{x}$ & $\mathrm{x}$ & - & $\mathrm{x}$ & & - & & - & $\mathrm{x}$ \\
\hline
\end{tabular}


were used for additional control on the organic-carbon contour map (fig. 11.6A). Organic-carbon content from the Prudhoe Bay area to the east of the Jago River and south to the Brooks Range is mapped at a 2.0 weight percent contour interval. West of the Kavik area, the average organic-carbon value for 11 wells is 2.6 weight percent, with a range of values from 1.2 to 5.6 weight percent. The Kavik area wells have organic-carbon contents that average 1.5 weight percent, and the Brooks Range outcrop samples average 1.7 weight percent. This is a decrease of 1 weight percent from Prudhoe Bay to the Brooks Range south of the 1002 area. Vitrinite reflectance values for the Shublik Formation in the Prudhoe Bay area where it is truncated by the so-called Lower Cretaceous unconformity are 0.5 to 0.6 percent $R_{0}$ (fig. 11.5), but they are 1.6 to 3.0 percent $R_{o}$, with TAI values ranging from 2.7 to 3.8 , in outcrop (table 11.3, fig. 11.6B).

Rock Eval data for the Kavik area wells and for the Brooks Range outcrops indicate that the Shublik is mature but has a hydrogen index of less than 50 and thus is not even a type III kerogen (fig. 11.6). Visual kerogen for the Beli Unit-1 well indicate amorphous and herbaceous material is present (table 11.3). The small amounts of $\mathrm{C}_{15+}$ hydrocarbons extracted from overmature outcrop samples cannot be used to evaluate immature or marginally mature organic matter (fig. $11.6 D, E)$. In contrast, the Shublik in the Prudhoe Bay area is a fair to good oil-prone source rock (Seifert and others, 1979; Magoon and Bird, 1985). However, the
Shublik in wells from the Kavik area is gas prone, but in outcrop to the east is so mature that the original organic-matter type cannot be determined.

\section{Kingak Shale}

The Kingak Shale was evaluated using 109 outcrop samples from 22 localities on the coastal plain and in the Brooks Range and 59 drill cuttings from 4 Kavik area wells (table 11.4, app. 11.1J-M). Eight wells west of the Kavik area were used for control on the organic-carbon map (fig. 11.7A). Organic-carbon content for the Kingak Shale is contoured at a 0.5 weight percent interval. West of the Kavik area, the organic-carbon content ranges from 1.4 to 2.8 weight percent, and averages 1.9 weight percent. The organic-carbon content from 4 Kavik wells and 22 outcrop localities averages 1.5 weight percent and ranges from 0.4 to 3.4 weight percent, which represents a decrease of 0.4 weight percent from west to east. Vitrinite reflectance values range from 0.8 to 2.3 percent $R_{0}$ (table 11.4) with individual values as high as 3.0 (fig. $11.7 \mathrm{~B}$ ) in the Brooks Range. The TAI ranges from 2.3 to 3.7 in both well and outcrop. The Kingak Shale in the Ignek Valley section is very mature at 1.4 percent $R_{o}$ (fig. 11.8) and in the Niguanak Ridge is immature at 0.5 percent $R_{o}$ (table 11.4).

Rock Eval analyses indicate that the organic matter in the Prudhoe Bay field area is predominantly oil prone (chap. 12). However, based on Rock Eval data, the hydrogen index is below 150 for wells in the Kavik area

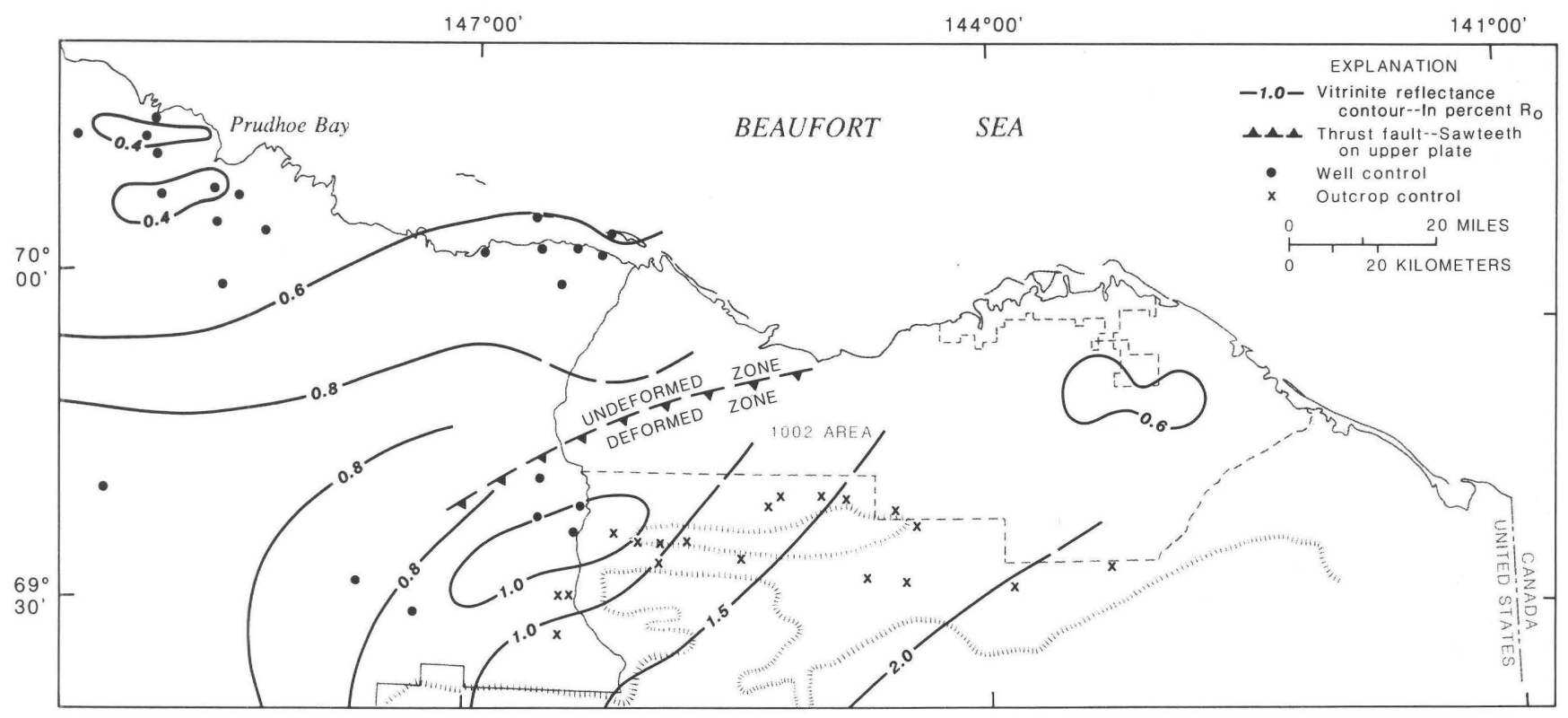

Figure 11.5. Thermal maturity from vitrinite reflectance $\left(R_{o}\right)$ from the basal part of the pebble shale unit, including the Hue Shale west of the Kavik area, on regional Lower Cretaceous unconformity. Effect of faulting is not shown in deformed zone. 
and for outcrop localities in the Brooks Range (see fig. 11.8) and in the Niguanak Ridge, which indicates gasprone organic matter. Visual kerogen indicates that the organic matter originated from a terrestrial source, as it is predominantly herbaceous, woody, and inertinitic with a much lower percentage of amorphous material. The
$\mathrm{C}_{15+}$ hydrocarbon-content values obtained by solvent extraction from outcrop samples indicate that four samples are fair to good petroleum source rocks (table 11.4, fig. 11.7D), but the $\mathrm{C}_{15+}$ hydrocarboncontent/organic-carbon values compared with $R_{0}$ values indicate gas-prone organic matter (fig. 11.7E).

Table 11.2. Geochemical summary for outcrop and well information in and adjacent to the 1002 area for the Sadlerochit and Lisburne Groups and the Kayak Shale

$[-$, not analyzed; ND, no determination; OC, organic carbon; HI, hydrogen index; TEA-FID, thermal evolution analysis - flame ionization detector; Vit. ref., vitrinite reflectance; TAI, thermal alteration index; Am, amorphous; He, herbaceous; Wo, woody; In, inertinite; H/C, hydrogen/carbon]

\begin{tabular}{|c|c|c|c|c|c|c|c|c|c|c|c|c|c|}
\hline \multirow[t]{2}{*}{ Name and No. } & \multirow{2}{*}{$\begin{array}{l}\text { Location } \\
\text { Sec.-T.-R. }\end{array}$} & \multirow{2}{*}{$\begin{array}{l}\text { No. of } \\
\text { samples }\end{array}$} & \multirow{2}{*}{$\begin{array}{l}\mathrm{OC} \\
(w t \\
\mathrm{pct})\end{array}$} & \multirow[t]{2}{*}{$\mathrm{HI}$} & \multirow{2}{*}{$\begin{array}{l}\text { Rock Eval } \\
\mathrm{T}_{\max } \\
\left({ }^{\circ} \mathrm{C}\right)\end{array}$} & \multirow{2}{*}{$\begin{array}{l}\text { TEA-FID } \\
\mathrm{T}_{\max } \\
\left({ }^{\circ} \mathrm{C}\right)\end{array}$} & \multirow{2}{*}{$\begin{array}{l}\text { Vit. } \\
\text { ref. } \\
\text { (pct } \\
\text { Ro }_{0} \text { ) }\end{array}$} & \multirow[t]{2}{*}{ TAI } & \multicolumn{4}{|c|}{$\begin{array}{l}\text { Visual kerogen } \\
\text { (pct) }\end{array}$} & \multirow[t]{2}{*}{$\mathrm{H} / \mathrm{C}$} \\
\hline & & & & & & & & & $\mathrm{Am}$ & $\mathrm{He}$ & Wo & In & \\
\hline \multicolumn{14}{|c|}{ Sadlerochit Group } \\
\hline \multicolumn{14}{|c|}{ WELLS } \\
\hline Kavik-1 & $7-3 \mathrm{~N}-23 \mathrm{E}$ & 19 & 0.9 & 5 & 480 & - & 1.3 & - & - & - & - & - & - \\
\hline Beli Unit-1 & $8-4 N-23 E$ & 17 & .3 & 146 & - & 450 & 1.2 & 2.7 & 27 & 44 & 12 & 16 & - \\
\hline Canning River Unit A-1 & $19-3 \mathrm{~N}-24 \mathrm{E}$ & 44 & .5 & 24 & 460 & - & .9 & 2.7 & 7 & 38 & 28 & 27 & - \\
\hline Canning River Unit B-1 & $32-4 \mathrm{~N} 34 \mathrm{E}$ & 22 & 1.6 & 437 & 430 & - & 1.3 & - & - & - & - & - & - \\
\hline \multicolumn{14}{|c|}{ OUTCROPS } \\
\hline Unnamed & $32-1 \mathrm{~N}-27 \mathrm{E}$ & 1 & 1.5 & 4 & 440 & - & - & - & - & - & - & - & - \\
\hline Fire Creek & $11-2 \mathrm{~N}-28 \mathrm{E}$ & 3 & 1.0 & 1 & 323 & 462 & 1.7 & 2.5 & 0 & 30 & 30 & 40 & - \\
\hline Unnamed & $27-4 \mathrm{~N}-29 \mathrm{E}$ & 5 & .3 & 50 & - & 365 & 1.2 & 2.8 & 0 & 55 & 20 & 25 & - \\
\hline Marsh Creek & $19-4 \mathrm{~N}-30 \mathrm{E}$ & 4 & .6 & 15 & 450 & 380 & 1.9 & 3.6 & 0 & 10 & 45 & 45 & - \\
\hline Unnamed & $30-2 N-38 E$ & 3 & .4 & 1 & ND & - & - & - & - & - & - & - & - \\
\hline Kaluakat River & $22-3 N-40 E$ & 1 & 1.8 & 7 & - & 440 & 2.2 & 3.9 & 33 & 33 & 0 & 34 & - \\
\hline Bathtub Ridge & $6-4 \mathrm{~S}-41 \mathrm{E}$ & 4 & .4 & 16 & - & 350 & - & - & - & - & - & - & - \\
\hline \multicolumn{14}{|c|}{ Lisburne Group } \\
\hline \multicolumn{14}{|c|}{ WELLS } \\
\hline Kavik-1 & $7-3 N-23 E$ & 66 & 0.3 & 92 & 440 & - & 1.8 & - & - & - & - & - & - \\
\hline Beli Unit-1 & $8-4 N-23 E$ & 37 & .1 & 213 & - & 450 & 1.5 & 2.8 & 43 & 33 & 13 & 11 & - \\
\hline Canning River Unit A-1 & $19-3 N-24 E$ & 85 & .2 & 54 & 380 & - & 1.2 & 2.7 & 34 & 45 & 13 & 8 & - \\
\hline Canning River Unit B-1 & $32-4 \mathrm{~N} 34 \mathrm{E}$ & 21 & .1 & - & - & - & 1.5 & - & - & - & - & - & - \\
\hline \multicolumn{14}{|c|}{ OUTCROPS } \\
\hline Unnamed & $36-1 S-26 \mathrm{E}$ & 1 & 1.1 & 11 & - & 352 & - & - & - & - & - & - & - \\
\hline Unnamed & 6-1S-28E & 1 & .1 & 116 & ND & - & - & - & - & - & - & - & - \\
\hline Unnamed & $15-2 \mathrm{~N}-28 \mathrm{E}$ & 4 & .1 & 85 & ND & 474 & - & 2.4 & 25 & 38 & 0 & 37 & - \\
\hline Unnamed & $30-4 N-30 E$ & 2 & .2 & 38 & ND & 420 & ND & 2.6 & 50 & 50 & - & - & - \\
\hline Unnamed & $30-2 N-38 E$ & 1 & .1 & 0 & ND & - & - & - & - & - & - & - & - \\
\hline Unnamed & $36-3 N-39 E$ & 1 & .1 & 60 & - & 383 & - & - & - & - & - & - & - \\
\hline \multicolumn{14}{|c|}{ Endicott Group (Kayak Shale) } \\
\hline \multicolumn{14}{|c|}{ WELLS } \\
\hline East Mikkelsen Bay State-1 & $7-9 \mathrm{~N}-21 \mathrm{E}$ & 10 & 2.1 & 100 & 450 & - & 0.8 & - & 50 & - & 50 & - & - \\
\hline Kavik-1 & $7-3 \mathrm{~N}-23 \mathrm{E}$ & 9 & 1.4 & 1 & - & - & 1.8 & - & - & - & - & - & - \\
\hline Canning River Unit A-1 & $19-3 \mathrm{~N}-24 \mathrm{E}$ & 9 & 3.5 & - & - & 600 & 1.3 & 3.4 & 10 & 36 & 18 & 27 & - \\
\hline \multicolumn{14}{|c|}{ OUTCROPS } \\
\hline Unnamed & $11-1 \mathrm{~S}-26 \mathrm{E}$ & 7 & 1.6 & 10 & - & 425 & 2.5 & 4.0 & 15 & 15 & 30 & 40 & 0.2 \\
\hline Unnamed & $36-1 S-26 \mathrm{E}$ & 1 & .6 & 16 & - & 348 & - & - & - & - & - & - & - \\
\hline Unnamed & $1-1 S-27 E$ & 1 & .0 & ND & ND & - & - & - & - & - & - & - & - \\
\hline Unnamed & $27-1 S-29 E$ & 1 & 2.6 & 11 & - & 448 & 4.3 & 4.2 & 0 & 0 & 50 & 50 & - \\
\hline Unnamed & $7-1 N-32 E$ & 3 & 1.1 & 2 & ND & - & - & - & - & - & - & - & - \\
\hline Unnamed & $32-2 N-38 E$ & 4 & 1.0 & 3 & ND & - & 3.2 & 3.7 & 27 & 36 & 9 & 27 & - \\
\hline Unnamed & $15-3 S-39 E$ & 3 & 1.6 & 1 & ND & - & 4.0 & - & - & - & - & - & - \\
\hline
\end{tabular}



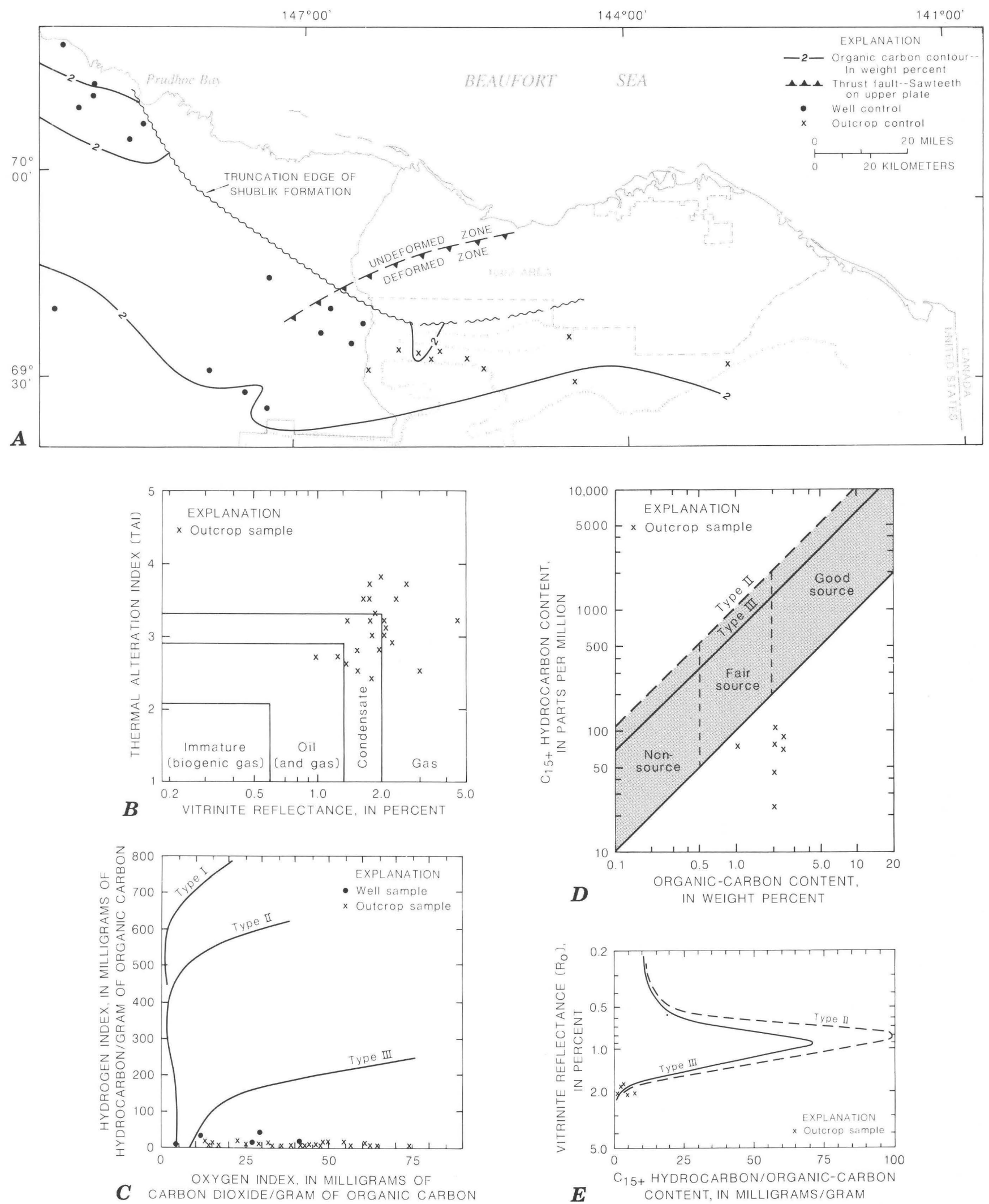

Figure 11.6. Geochemical summary for the Shublik Formation. A, Organic-carbon contour map. $B$, Thermal maturity from vitrinite reflectance and TAI. $C$, Kerogen type from Van Krevelen diagram. $D$, Richness of source rock from $\mathrm{C}_{15+}$ hydrocarbons and organic-carbon content. $E$, Stage of organic evolution. 
In summary, the Kingak Shale in the Niguanak Ridge, in the Brooks Range, and in the wells in the Kavik area is gas prone.

\section{Pebble Shale Unit}

The pebble shale unit was evaluated using 140 outcrop samples from 30 localities and 20 cutting samples from 7 wells in the Kavik and Point Thomson areas (fig. 11.9, table 11.5, app. 11.1A, $B, D, J-M$ ).

The pebble shale unit is 1 weight percent richer in organic-carbon content in the Prudhoe Bay area than in the ANWR coastal plain. West of the Kavik wells, the organic-carbon content for nine wells ranges from 2.4 to 5.1 weight percent and averages 3.3 weight percent. The average organic-carbon content for 7 wells and 30 outcrop localities in and adjacent to the ANWR is 2.4 weight percent and 2.2 weight percent, respectively (table 11.5, fig. 11.9A). Vitrinite reflectance indicates that the pebble shale in the wells adjacent to the 1002 area are marginally mature in the Point Thomson area and at peak maturity in the Kavik area (fig. 11.5). Outcrop information indicates that values range from 0.8 to 3.1 percent $R_{o}$ in the Brooks Range (see fig. 11.8) and average 0.6 percent $R_{0}$ in the Niguanak Ridge. Corresponding values for TAI are 2.5 to 4.2 and 2.1 (table 11.5, fig 11.9B).

Rock Eval information for the Kavik wells and outcrop samples in the ANWR indicate that the pebble shale unit is gas prone (table 11.5, fig. 11.8, 11.10C). Two cutting samples from the East Mikkelsen Bay State-1 well with hydrogen indices over 300 are exceptions and are most likely caved cutting samples from the overlying oil-prone Hue Shale (app. 11.1A). Based on $\mathrm{C}_{15+}$ hydrocarbon content obtained from solvent extraction compared with organic-carbon content, the pebble shale unit is not a source for oil regardless of maturity (fig. $11.9 D, E$ ).

The pebble shale unit within the deformed zone is a gas-prone source rock with thermal maturities that range from immature to very mature. In the undeformed zone, the pebble shale unit is an immature oil-prone source rock in the Prudhoe Bay area (Seifert and others, 1979; Magoon and Bird, 1985) and a marginally mature gas-prone source rock in the Point Thomson area.

\section{Hue Shale}

The Hue Shale was evaluated using 72 outcrop samples from 7 localities in the ANWR coastal plain and 99 drill cuttings from 10 wells in the Kavik and Point Thomson areas (fig. 11.10, table 11.6, app. 11.1A-D, $F$, $I-M)$. West of the Kavik area, the Hue Shale is combined with the pebble shale unit, which was just discussed. From drill cuttings acquired from the Kavik and Point Thomson wells, the organic-carbon content ranges from 1.5 to 3.3 weight percent and averages 2.2 weight percent (table 11.6, fig. 11.10A). Organic-carbon

Table 11.3. Geochemical summary for well and outcrop information for the Shublik Formation in and adjacent to the 1002 area

[-, not analyzed; OC, organic carbon; HI, hydrogen index; RE, Rock Eval $\left(\mathrm{T}_{\max }\right)$; $\mathrm{TF}$, thermal evolution analysis - flame ionization detector ( $\mathrm{T}_{\max }$ ); Vit. ref., vitrinite reflectance; TAI, thermal alteration index; Am, amorphous; He, herbaceous; Wo, woody; In, inertinite; Bit., bitumen; Sat., saturates; Arom., aromatics; NHC, nonhydrocarbons; Elem. ratio, elemental analysis ratios; H, hydrogen; O, oxygen; C, carbon]

\begin{tabular}{|c|c|c|c|c|c|c|c|c|c|c|c|c|c|c|c|c|c|c|}
\hline \multirow[t]{2}{*}{ Name and No. } & \multirow{2}{*}{$\begin{array}{l}\text { Location } \\
\text { Sec.-T.-R. }\end{array}$} & \multirow{2}{*}{$\begin{array}{l}\text { No. } \\
\text { of } \\
\text { sam- } \\
\text { ples }\end{array}$} & \multirow{2}{*}{$\begin{array}{c}\text { OC } \\
\text { (wt } \\
\text { pct) }\end{array}$} & \multirow[t]{2}{*}{$\mathrm{HI}$} & \multirow{2}{*}{$\begin{array}{l}\mathrm{RE} \\
\left({ }^{\circ} \mathrm{C}\right)\end{array}$} & \multirow{2}{*}{$\begin{array}{c}\text { TF } \\
\left({ }^{\circ} \mathrm{C}\right)\end{array}$} & \multirow{2}{*}{$\begin{array}{l}\text { Vit. } \\
\text { ref. } \\
\text { (pct } \\
\mathrm{R}_{\mathrm{o}} \text { ) }\end{array}$} & \multirow[t]{2}{*}{ TAI } & \multicolumn{4}{|c|}{$\begin{array}{l}\text { Visual kerogen } \\
\text { (pct) }\end{array}$} & \multicolumn{4}{|c|}{$\begin{array}{c}\text { Solvent extraction } \\
(\mathrm{ppm})\end{array}$} & \multicolumn{2}{|c|}{ Elem. ratio } \\
\hline & & & & & & & & & Am & $\mathrm{He}$ & Wo & In & Bit. & Sat. & Arom. & $\mathrm{NHC}$ & $\mathrm{H} / \mathrm{C}$ & $\mathrm{O} / \mathrm{C}$ \\
\hline \multicolumn{19}{|c|}{ WELLS } \\
\hline Kavik-1 & $7-3 N-23 E$ & 3 & 1.4 & 9 & 472 & - & 1.2 & - & - & - & - & - & - & - & - & - & - & - \\
\hline Beli Unit-1 & $8-4 N-23 E$ & 2 & 1.4 & - & - & 463 & 0.8 & 2.4 & 50 & 50 & 0 & 0 & - & - & - & - & - & - \\
\hline Canning River Unit A-1 & $19-3 N-24 E$ & 5 & 1.5 & 22 & 425 & - & .9 & - & - & - & - & - & - & - & - & - & - & - \\
\hline Canning River Unit B-1 & $32-4 N-24 E$ & 4 & 1.6 & 33 & 450 & - & 1.0 & - & - & - & - & - & - & - & - & - & - & - \\
\hline \multicolumn{19}{|c|}{ OUTCROPS } \\
\hline Canning River & $16-2 \mathrm{~N}-24 \mathrm{E}$ & 1 & 0.9 & 13 & 442 & - & 2.4 & 3.5 & 44 & 33 & 0 & 22 & 43 & - & - & - & - & - \\
\hline Unnamed & $27-3 \mathrm{~N}-25 \mathrm{E}$ & 2 & 1.5 & 15 & 530 & - & 1.8 & 3.2 & 30 & 50 & 0 & 20 & 137 & 55 & 16 & 60 & - & - \\
\hline Ignek Valley & $6-2 N-26 E$ & 11 & 2.8 & 51 & - & 460 & 1.6 & 2.8 & 35 & 35 & 15 & 15 & - & - & - & - & 0.6 & - \\
\hline Unnamed & $2-2 N-26 E$ & 4 & 1.8 & 10 & 500 & - & 2.0 & 3.1 & 40 & 40 & 0 & 20 & 214 & 87 & 21 & 55 & - & - \\
\hline Unnamed & $30-3 N-27 E$ & 2 & 1.2 & 35 & - & 460 & 2.0 & 2.7 & 30 & 30 & 15 & 15 & - & - & - & - & .5 & 0.05 \\
\hline Unnamed & $6-2 N-28 E$ & 2 & 1.4 & 25 & - & 400 & 1.7 & 3.5 & 0 & 50 & 25 & 25 & - & - & - & - & - & - \\
\hline Fire Creek & $11-2 N-29 E$ & 13 & 1.9 & 10 & 300 & 600 & 2.0 & 3.7 & 20 & 30 & 15 & 35 & 15 & - & - & - & - & - \\
\hline Last Creek & $11-3 N-31 E$ & 13 & 1.4 & 10 & 450 & 417 & 2.1 & 3.8 & 60 & 20 & 10 & 10 & 128 & 31 & 24 & 41 & .4 & - \\
\hline Hula Hula River & $6-1 N-32 E$ & 3 & 2.2 & 6 & ND & - & - & - & - & - & - & - & - & - & - & - & - & - \\
\hline Aichilik River & $21-2 N-37 E$ & 5 & 1.7 & 7 & ND & - & 3.0 & - & - & - & - & - & - & - & - & - & - & - \\
\hline
\end{tabular}


contents from outcrops range from 1.4 to 12.1 weight percent and average 5.9 weight percent. The richest samples of the Hue Shale have organic-carbon contents of 12 weight percent and are from the Niguanak Ridge. The Hue Shale is immature ( 0.4 percent $\left.R_{o}\right)$ on the coastal plain but is mature ( 1.0 percent $\mathrm{R}_{\mathrm{o}}$ ) south of the coastal plain (figs. 11.5, 11.8). TAI values range from 1.6 to 2.7 in both well and outcrop samples (table 11.6, fig. 11.10B).

Rock Eval data in the Point Thomson and Kavik areas indicate type III organic matter, except for two wells (East Mikkelsen Bay State-1 and Alaska State F-1) in the Point Thomson area that encountered type II/III organic matter (table 11.6, fig. 11.10C). Outcrops in the Niguanak Ridge, with hydrogen indices from 265 to 415 , are also oil prone. Visual kerogen indicates that the predominant material is amorphous and herbaceous organic matter, followed by woody and inertinitic material. The $\mathrm{C}_{15+}$ hydrocarbon content compared with organic-carbon content suggests that the Hue Shale unit is a good source rock in the Jago and Niguanak areas (fig. 11.10D). This ratio, when compared with maturity (pct $\mathrm{R}_{\mathrm{o}}$ ), indicates a type II kerogen for two samples which have a ratio of 75 and are immature $\left(0.5 \mathrm{pct} \mathrm{R}_{\mathrm{o}}\right.$; fig. 11.10E). Rock Eval, visual kerogen, and $\mathrm{C}_{15+}$ hydrocarbon content all suggest that the Hue Shale is a mixture of marine and terrigenous organic matter.

The Hue Shale is a good, immature to marginally mature, oil-prone source rock on the coastal plain east of the Jago River and in the subsurface at Point Thomson.

Table 11.4. Geochemical summary for well and outcrop information for the Kingak Shale in and adjacent to the 1002 area

[-, not analyzed; OC, organic carbon; HI, hydrogen index; RE, Rock Eval ( $\left.\mathrm{T}_{\max }\right)$; $\mathrm{TF}$, thermal evolution analysis - flame ionization detector $\left(\mathrm{T}_{\max }\right)$; Vit. ref., vitrinite reflectance; TAI, thermal alteration index; Am, amorphous; He, herbaceous; Wo, woody; In, inertinite; Bit., bitumen; Sat., saturates; Arom., aromatics; NHC, nonhydrocarbons; Elem. ratio, elemental analysis ratios; H, hydrogen; O, oxygen; C, carbon]

\begin{tabular}{|c|c|c|c|c|c|c|c|c|c|c|c|c|c|c|c|c|c|c|}
\hline \multirow[t]{2}{*}{ Name and No. } & \multirow{2}{*}{$\begin{array}{l}\text { Location } \\
\text { Sec.-T.-R. }\end{array}$} & \multirow{2}{*}{$\begin{array}{l}\text { No. } \\
\text { of } \\
\text { sam- } \\
\text { ples }\end{array}$} & \multirow{2}{*}{$\begin{array}{l}\text { OC } \\
(w t \\
p c t)\end{array}$} & \multirow[t]{2}{*}{ HI } & \multirow{2}{*}{$\begin{array}{l}\mathrm{RE} \\
\left({ }^{\circ} \mathrm{C}\right) \\
\end{array}$} & \multirow{2}{*}{$\begin{array}{l}\mathrm{TF} \\
\left({ }^{\circ} \mathrm{C}\right) \\
\end{array}$} & \multirow{2}{*}{$\begin{array}{l}\text { Vit. } \\
\text { ref. } \\
\text { (pct } \\
\text { Ro }_{\mathrm{o}} \text { ) }\end{array}$} & \multirow[t]{2}{*}{ TAI } & \multicolumn{4}{|c|}{$\begin{array}{l}\text { Visual kerogen } \\
\text { (pct) }\end{array}$} & \multicolumn{4}{|c|}{$\begin{array}{l}\text { Solvent extraction } \\
(\mathrm{ppm})\end{array}$} & \multicolumn{2}{|c|}{ Elem. ratio } \\
\hline & & & & & & & & & $\mathrm{Am}$ & $\mathrm{He}$ & Wo & In & Bit. & Sat. & Arom. & NHC & $\mathrm{H} / \mathrm{C}$ & $\mathrm{O} / \mathrm{C}$ \\
\hline \multicolumn{19}{|c|}{ WELLS } \\
\hline Kavik-1 & $7-3 N-23 E$ & 12 & 1.6 & 16 & 460 & - & 1.2 & - & - & - & - & - & - & - & - & - & - & - \\
\hline Beli Unit-1 & $8-4 N-23 E$ & 5 & 2.5 & 96 & - & 455 & 0.8 & 2.4 & 44 & 44 & 11 & 1 & - & - & - & - & - & - \\
\hline Canning River Unit A-1 & $19-3 N-24 E$ & 36 & 1.2 & 43 & - & 455 & .9 & 2.8 & 0 & 38 & 33 & 30 & - & - & - & - & - & - \\
\hline Canning River Unit B-1 & $32-4 \mathrm{~N}-24 \mathrm{E}$ & 6 & 2.3 & 47 & 458 & - & 1.0 & - & - & - & - & - & - & - & - & - & - & - \\
\hline \multicolumn{19}{|c|}{ OUTCROPS } \\
\hline Unnamed & $35-1 N-23 E$ & 6 & 3.4 & 10 & 520 & 585 & 1.7 & 3.2 & 20 & 20 & 30 & 30 & 25 & - & - & - & - & - \\
\hline Unnamed & $6-1 N-24 E$ & 5 & 1.7 & 18 & - & 500 & .8 & 2.5 & 10 & 30 & 30 & 30 & 1,277 & 184 & 205 & 888 & - & - \\
\hline Ignek Valley & $6-2 \mathrm{~N}-26 \mathrm{E}$ & 3 & .8 & 30 & 465 & - & 1.4 & 2.3 & 0 & 27 & 36 & 36 & 364 & 190 & 38 & 60 & - & - \\
\hline Unnamed & $28-3 N-26 E$ & 2 & 2.5 & - & - & - & 1.6 & 3.5 & 10 & 30 & 30 & 30 & 1,654 & 287 & 170 & 1,179 & - & - \\
\hline Unnamed & $25-3 \mathrm{~N}-26 \mathrm{E}$ & 2 & 1.0 & 35 & - & 430 & 1.0 & 2.8 & 35 & 40 & 15 & 10 & - & - & - & - & - & - \\
\hline Ignek Mesa & $6-2 \mathrm{~N}-28 \mathrm{E}$ & 1 & 2.2 & 13 & - & 475 & 1.4 & 2.7 & 44 & 44 & 11 & 0 & - & - & - & - & - & - \\
\hline Fire Creek & $11-2 \mathrm{~N}-29 \mathrm{E}$ & 14 & 1.0 & 35 & 310 & 425 & 2.3 & 3.3 & 0 & 27 & 36 & 36 & - & - & - & - & 0.4 & 0.0 \\
\hline Dodo Creek & $11-2 \mathrm{~N}-29 \mathrm{E}$ & 19 & 1.1 & 4 & 520 & - & - & - & - & - & - & - & - & - & - & - & - & - \\
\hline Unnamed & $25-2 \mathrm{~N}-29 \mathrm{E}$ & 1 & 1.5 & 3 & - & - & - & - & - & - & - & - & - & - & - & - & - & - \\
\hline Marsh Creek & $9-4 N-30 E$ & 6 & 2.0 & 30 & - & 440 & 1.4 & 2.8 & 10 & 30 & 30 & 30 & - & - & - & - & - & - \\
\hline Sadlerochit River & $3-2 N-30 E$ & 1 & .6 & 5 & 300 & - & 1.1 & - & - & - & - & - & - & - & - & - & - & - \\
\hline Unnamed & $25-2 \mathrm{~N}-30 \mathrm{E}$ & 2 & 1.3 & 9 & - & 550 & 1.8 & 3.7 & 10 & 18 & 36 & 36 & - & - & - & - & - & - \\
\hline Unnamed & $32-3 N-31 E$ & 2 & 2.0 & 1 & 30 & - & - & 3.7 & 0 & 20 & 40 & 40 & - & - & - & - & - & - \\
\hline Unnamed & $29-4 \mathrm{~N}-31 \mathrm{E}$ & 7 & .9 & 25 & - & 500 & 1.7 & 2.7 & 0 & 20 & 40 & 40 & 137 & 54 & 40 & 39 & .8 & .2 \\
\hline Unnamed & $14-3 N-31 E$ & 1 & .6 & 27 & - & 370 & - & - & - & - & - & - & - & - & - & - & - & - \\
\hline Sadlerochit Springs & $31-4 N-32 E$ & 1 & 1.6 & 6 & - & 411 & 1.9 & 3.4 & 8 & 42 & 25 & 25 & - & - & - & - & - & - \\
\hline Unnamed & $31-2 \mathrm{~N}-32 \mathrm{E}$ & 3 & .9 & 0 & ND & - & - & - & - & - & - & - & - & - & - & - & - & - \\
\hline Okpilak Creek & $34-2 N-33 E$ & 1 & 1.3 & 0 & ND & - & - & - & - & - & - & - & - & - & - & - & - & - \\
\hline Unnamed & $34-2 N-36 E$ & 8 & .9 & 5 & ND & - & - & - & - & - & - & - & - & - & - & - & - & - \\
\hline Aichilik River & $17-2 \mathrm{~N}-37 \mathrm{E}$ & 16 & .7 & 20 & 400 & ND & 1.8 & 3.6 & 0 & 20 & 40 & 40 & - & - & - & - & - & - \\
\hline Niguanak Ridge & $2-6 N-36 E$ & 6 & 2.9 & 18 & ND & 420 & .5 & - & - & - & - & - & 205 & 65 & 41 & 57 & - & - \\
\hline Bathtub Ridge & $5-4 S-39 E$ & 2 & .4 & 9 & ND & - & - & - & - & - & - & - & - & - & - & - & - & - \\
\hline
\end{tabular}



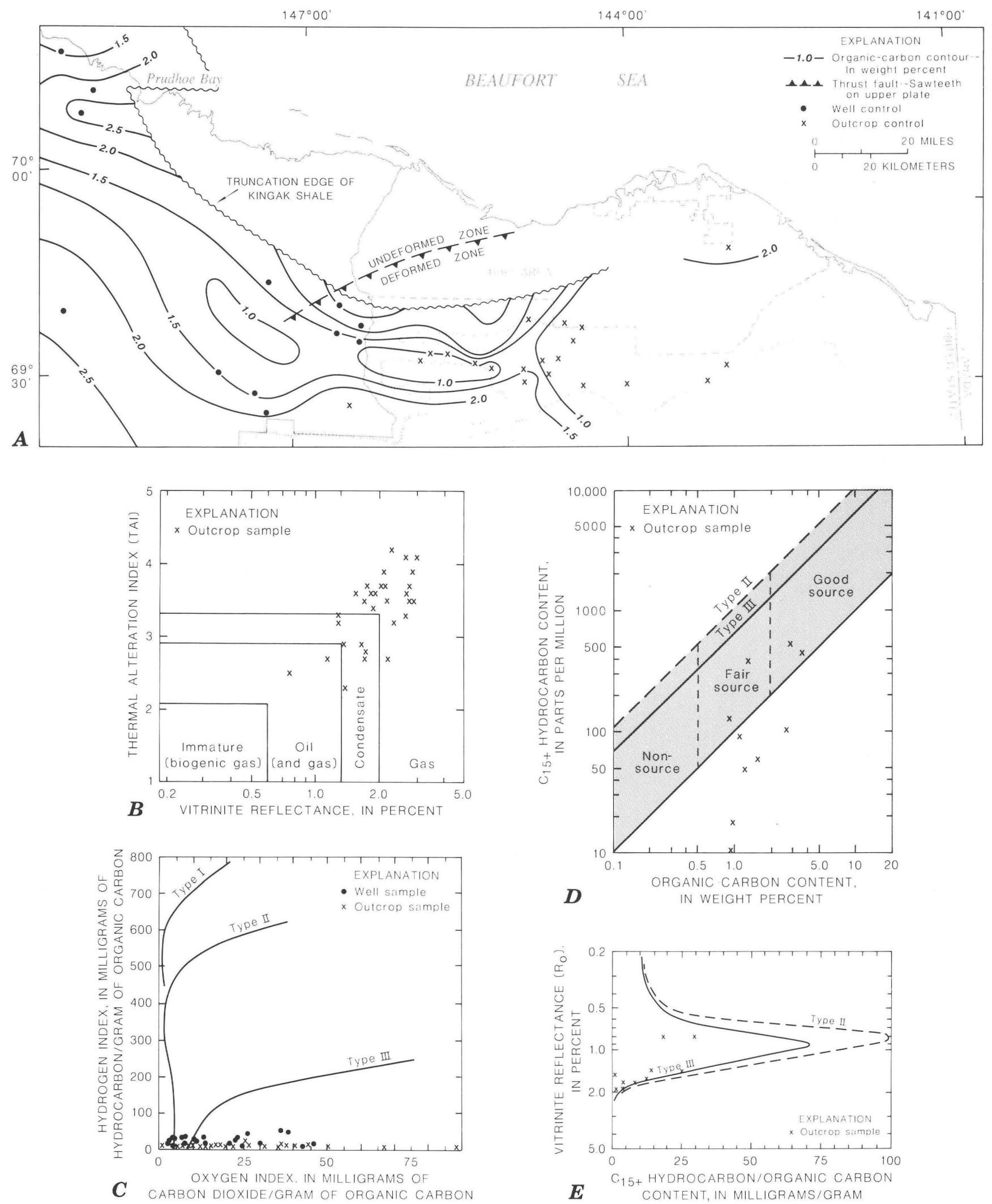

Figure 11.7. Geochemical summary for the Kingak Shale. $A$, Organic-carbon contour map. $B$, Thermal maturity from vitrinite reflectance and TAI. $C$, Kerogen type from Van Krevelen diagram. $D$, Richness of source rock from $\mathrm{C}_{15+}$ hydrocarbons and organic-carbon content. $E$, Stage of organic evolution. 


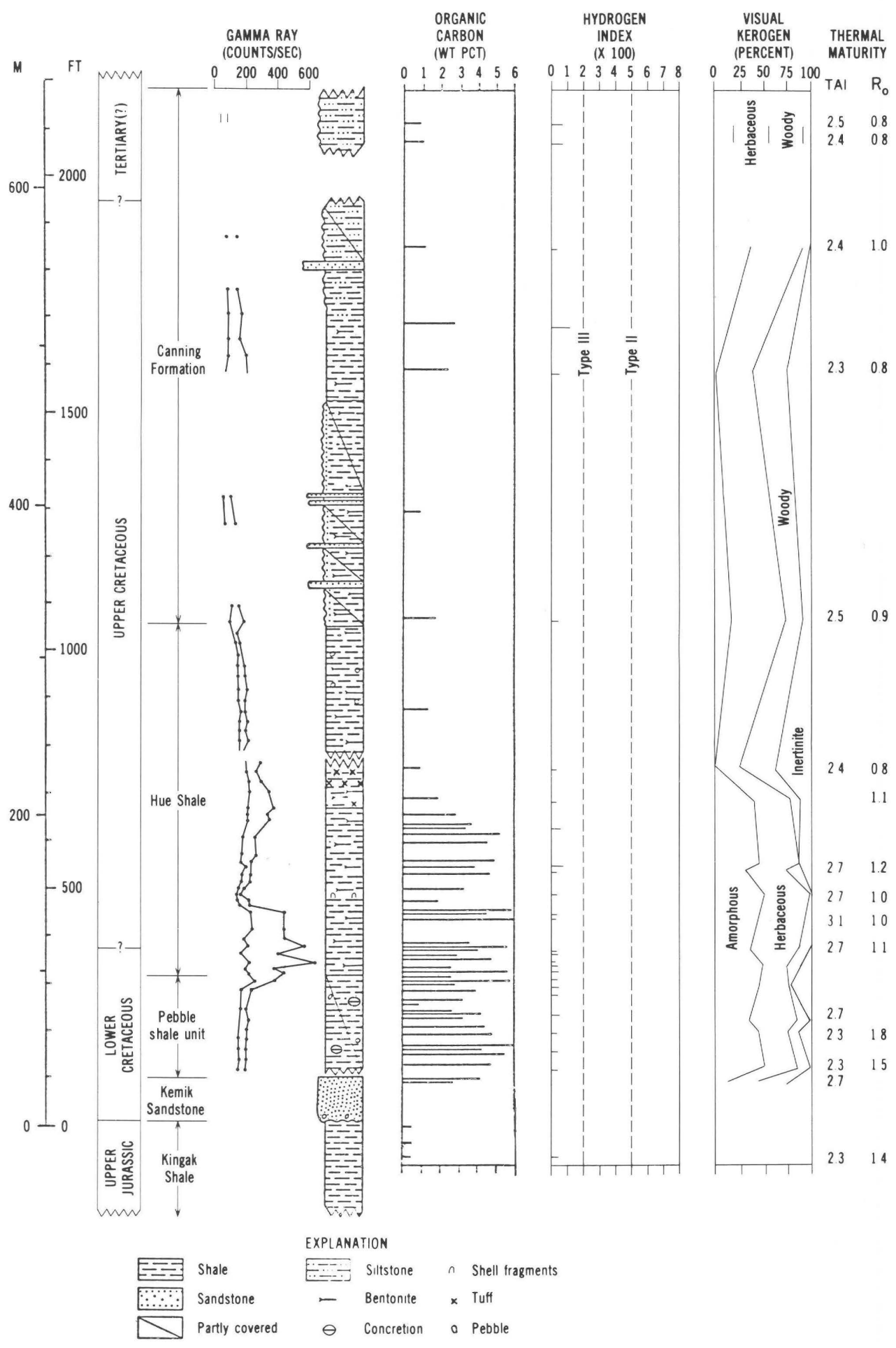

Figure 11.8. Ignek Valley section, showing petroleum geochemical results for organic carbon, hydrogen index from Rock Eval, visual kerogen, thermal alteration index (TAI), and vitrinite reflectance $\left(\mathrm{R}_{\mathrm{o}}\right)$. 

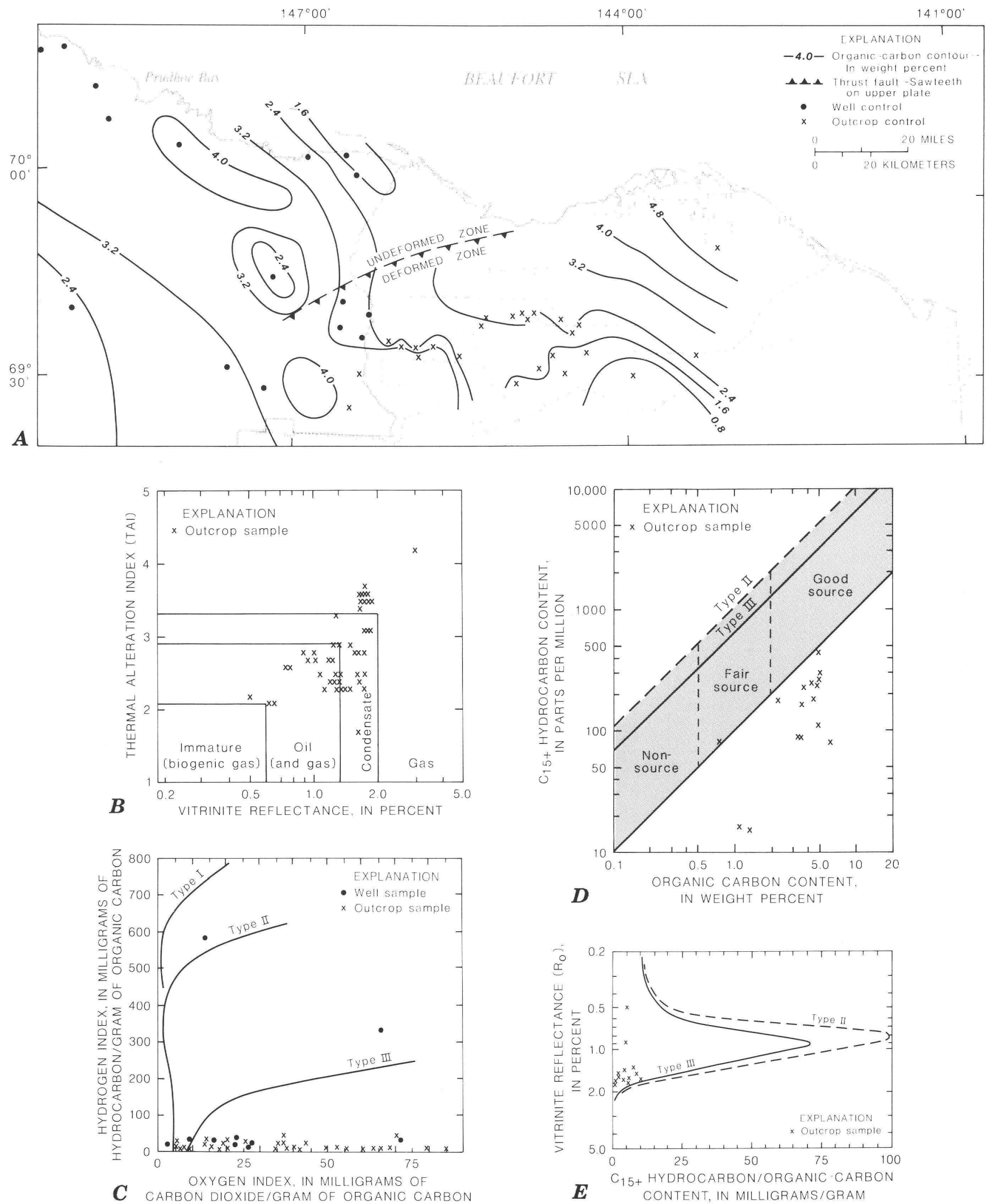

Figure 11.9. Geochemical summary for the pebble shale unit. $A$, Organic-carbon contour map. $B$, Thermal maturity from vitrinite reflectance and TAI. $C$, Kerogen type from Van Krevelen diagram. $D$, Richness of source rock from $\mathrm{C}_{15+}$-saturated hydrocarbons. $E$, Stage of organic evolution. 
Canning Formation

The Canning Formation was evaluated using 79 outcrop samples from 22 localities in the ANWR and 604 drill cuttings from 13 wells from the Kavik and Point Thomson areas (fig. 11.11, table 11.7, app. $11.1 A-M)$. The average organic-carbon content for the
Canning Formation increases to the north (fig. 11.11A). In four wells west of the Kavik area, organic-carbon values range from 0.7 to 1.2 weight percent and average 1.0 weight percent. In wells adjacent to the ANWR, the average organic-carbon content ranges from 0.8 to 1.8 weight percent and averages 1.3 weight percent. Outcrop data have a broad range (0.4 to 6.6 weight percent) and

Table 11.5. Geochemical summary for well and outcrop information for the pebble shale unit in and adjacent to the 1002 area

[-, not analyzed; OC, organic carbon; HI, hydrogen index; RE, Rock Eval ( $\left.\mathrm{T}_{\max }\right)$; $\mathrm{TF}$, thermal evolution analysis - flame ionization detector ( $\mathrm{T}_{\max }$ ); Vit. ref., vitrinite reflectance; TAI, thermal alteration index; Am, amorphous; He, herbaceous; Wo, woody; In, inertinite; Bit., bitumen; Sat., saturates; Arom., aromatics; NHC, nonhydrocarbons; Elem. ratio, elemental analysis ratios; H, hydrogen; O, oxygen; C, carbon]

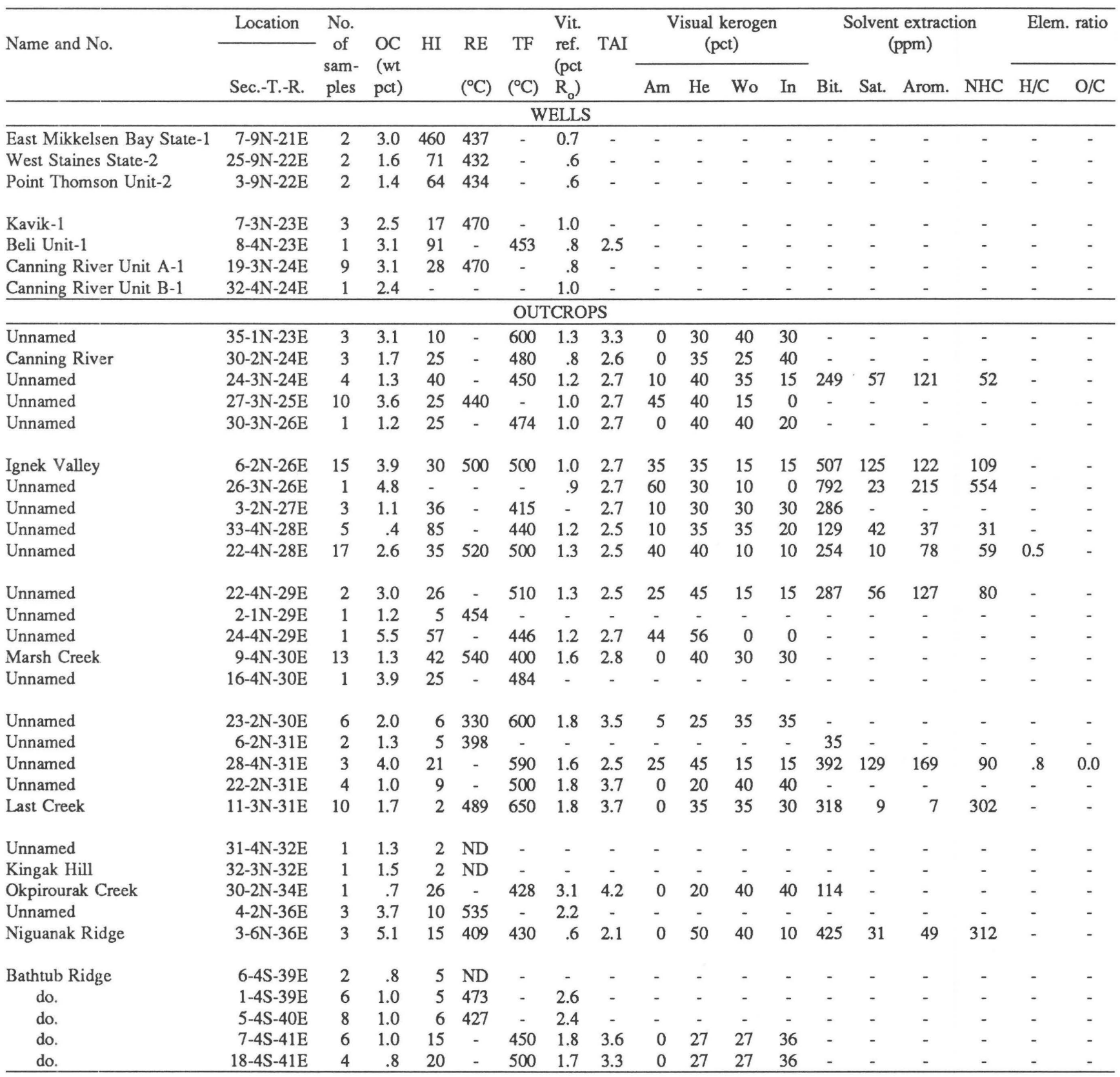



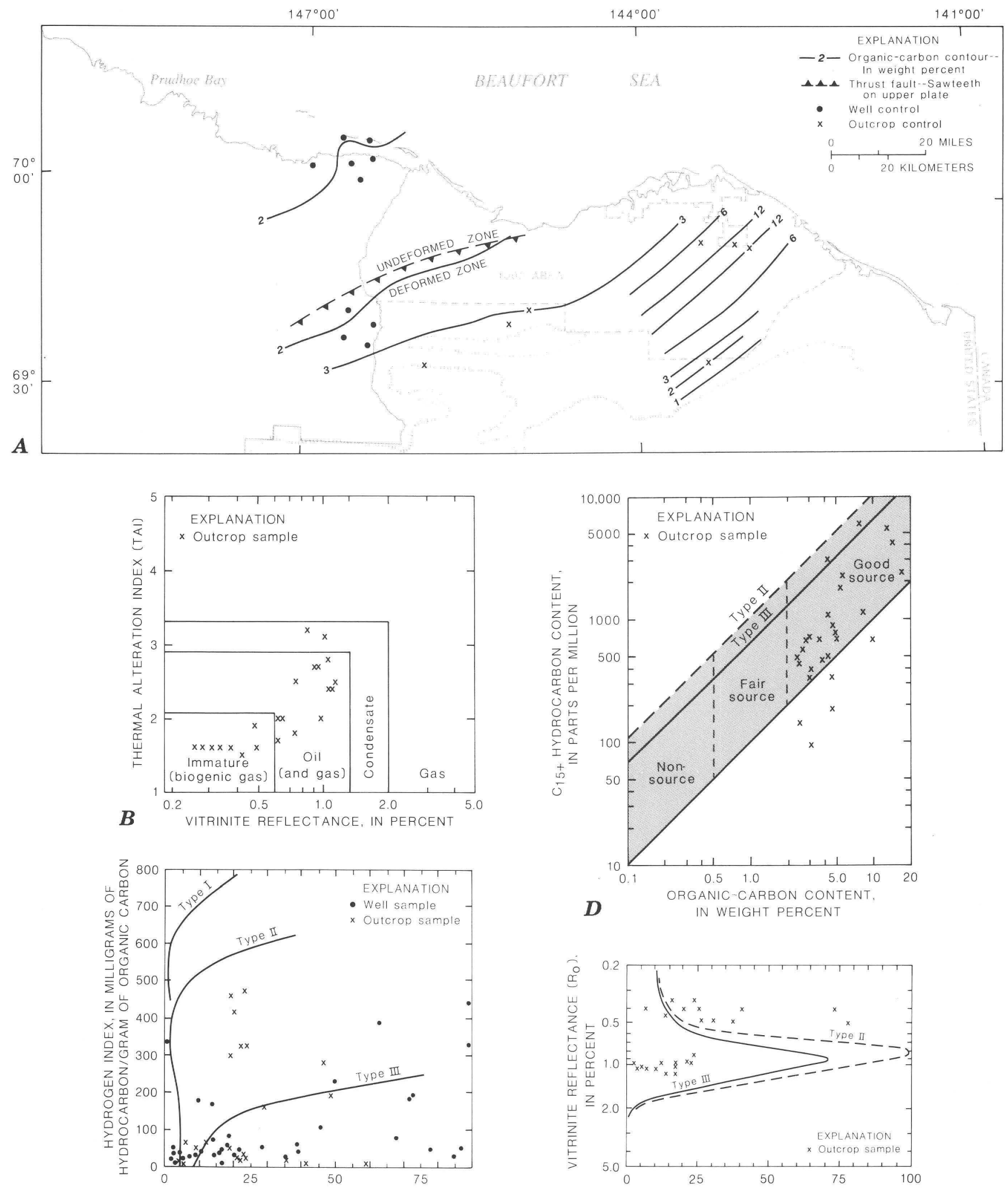

OXYGEN INDEX, IN MILLIGRAMS OF
$\boldsymbol{C}$ CARBON DIOXIDE/GRAM OF ORGANIC CARBON

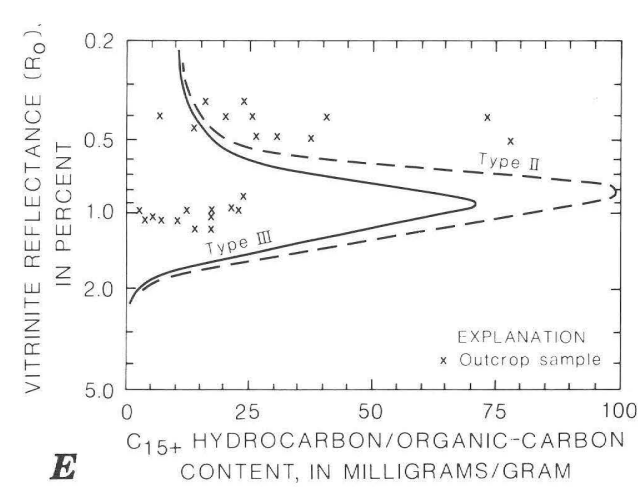

Figure 11.10. Geochemical summary for the Hue Shale. $A$, Organic-carbon contour map. $B$, Thermal maturity from vitrinite reflectance and TAI. $C$, Kerogen type from Van Krevelen diagram. $D$, Richness of source rock from $\mathrm{C}_{15+}$-saturated hydrocarbons. $E$, Stage of organic evolution. 
average 1.9 weight percent organic carbon (table 11.7). Thermal maturity for the Canning Formation ranges from immature to marginally mature in the undeformed zone and mature to very mature in the deformed zone (fig. i1.11, table 11.7).

Rock Eval information from wells and outcrops indicates that the Canning Formation contains type III organic matter (fig. 11.11C). Visual kerogen indicates that the organic matter is of terrestrial origin, as herbaceous and woody material predominate. The $\mathrm{C}_{15+}$ hydrocarbon content compared with organic-carbon content indicates that the Canning Formation is a fair to good source rock (fig. 11.11D). However, samples in the 0.8 to 2.0 percent $R_{\mathrm{o}}$ range indicate that the organic matter is type III. Rock Eval, visual kerogen, and $\mathrm{C}_{15+}$ hydrogen content all indicate a terrigenous source for the organic matter, or type III kerogen.

The Canning Formation contains gas-prone organic matter with a wide range of maturities.

\section{Sagavanirktok Formation}

The Sagavanirktok Formation was evaluated using 51 outcrop samples from 16 localities and 280 drill cuttings from 11 wells in the Kavik and Point Thomson area (table 11.8). The organic-carbon content for the Sagavanirktok Formation from drill cuttings ranges from
0.8 to 3.0 weight percent (excluding the inertinitic 10.8 weight percent value from the Beli Unit-1 well) and averages 1.3 weight percent; for outcrop samples, it ranges from 0.5 to 2.2 weight percent and averages 1.4 weight percent. The thermal maturity ranges from 0.4 to 0.6 percent $R_{o}$ for drill cuttings and 0.3 to 0.9 percent $R_{o}$ for outcrop samples.

Rock Eval data show that the hydrogen index, except for the Beli Unit-1 well, does not exceed 150 for either well or outcrop samples. Visual kerogen indicates that the organic matter is of terrestrial origin, or herbaceous, woody, and inertinitic. The $\mathrm{C}_{15+}$ hydrocarbon content obtained from solvent extraction of six samples ranges from 63 to $217 \mathrm{ppm}$ and averages $140 \mathrm{ppm}$, indicating a fair source rock (sum of saturate and aromatic hydrocarbons, table 11.8).

The Sagavanirktok Formation is an immature to mature, gas-prone source-rock unit containing organic matter of terrestrial origin.

\section{TEMPERATURE AND TIMING OF OIL GENERATION AND PRESERVATION}

A chain of specific geologic events must occur if an oil or gas accumulation is to occur and be preserved. First, an oil or gas source rock, a carrier bed

Table 11.6. Geochemical summary for well and outcrop information for the Hue Shale in and adjacent to the 1002 area

$\left[-\right.$, not analyzed; OC, organic carbon; HI, hydrogen index; RE, Rock Eval $\left(\mathrm{T}_{\max }\right) ; \mathrm{TF}$, thermal evolution analysis - flame ionization detector $\left(\mathrm{T}_{\max }\right)$; Vit. ref., vitrinite reflectance; TAI, thermal alteration index; Am, amorphous; He, herbaceous; Wo, woody; In, inertinite; Bit., bitumen; Sat., saturates; Arom., aromatics; NHC, nonhydrocarbons; Elem. ratio, elemental analysis ratios; H, hydrogen; O, oxygen; C, carbon]

\begin{tabular}{|c|c|c|c|c|c|c|c|c|c|c|c|c|c|c|c|c|c|c|}
\hline \multirow[t]{2}{*}{ Name and No. } & \multirow{2}{*}{$\begin{array}{l}\text { Location } \\
\text { Sec.-T.-R. }\end{array}$} & \multirow{2}{*}{$\begin{array}{c}\text { No. } \\
\text { of } \\
\text { sam- } \\
\text { ples }\end{array}$} & \multirow{2}{*}{$\begin{array}{l}\text { OC } \\
\text { (wt } \\
\text { pct) }\end{array}$} & \multirow[t]{2}{*}{$\mathrm{HI}$} & \multirow{2}{*}{$\begin{array}{l}\mathrm{RE} \\
\left({ }^{\circ} \mathrm{C}\right) \\
\end{array}$} & \multirow{2}{*}{$\begin{array}{l}\mathrm{TF} \\
\left({ }^{\circ} \mathrm{C}\right) \\
\end{array}$} & \multirow{2}{*}{$\begin{array}{l}\text { Vit. } \\
\text { ref. } \\
\text { (pct } \\
\text { Ro }_{\mathrm{o}} \text { ) }\end{array}$} & \multirow[t]{2}{*}{ TAI } & \multicolumn{4}{|c|}{$\begin{array}{l}\text { Visual kerogen } \\
\text { (pct) }\end{array}$} & \multicolumn{3}{|c|}{$\begin{array}{l}\text { Solvent extraction } \\
\text { (ppm) }\end{array}$} & \multicolumn{3}{|c|}{ Elem. ratio } \\
\hline & & & & & & & & & $\mathrm{Am}$ & $\mathrm{He}$ & Wo & In & Bit. & Sat. & Arom. & NHC & $\mathrm{H} / \mathrm{C}$ & $\mathrm{O} / \mathrm{C}$ \\
\hline East Mikkelsen Bay State-1 & $7-9 \mathrm{~N}-21 \mathrm{E}$ & 4 & 2.6 & 498 & 425 & - & 0.7 & - & 100 & - & - & - & - & - & - & - & - & - \\
\hline West Staines State-2 & $25-9 \mathrm{~N}-22 \mathrm{E}$ & 13 & 1.7 & 95 & 425 & - & .6 & - & 50 & - & 50 & - & - & - & - & - & - & - \\
\hline Point Thomson Unit-1 & $32-10 \mathrm{~N}-22 \mathrm{E}$ & 6 & 1.6 & 50 & 430 & - & .7 & - & - & - & - & - & - & - & - & - & - & - \\
\hline Alaska State F-1 & $18-10 \mathrm{~N}-23 \mathrm{E}$ & 1 & 3.3 & 341 & 430 & - & .7 & - & - & - & - & - & - & - & - & - & - & - \\
\hline Kavik-1 & $7-3 N-23 E$ & 20 & 2.1 & 26 & 445 & - & 1.0 & - & - & - & - & - & - & - & - & - & - & - \\
\hline Beli Unit-1 & $8-4 \mathrm{~N}-23 \mathrm{E}$ & 9 & 1.8 & 85 & - & - & .7 & 2.4 & 19 & 47 & 20 & 14 & - & - & - & - & - & - \\
\hline Canning River Unit A-1 & $19-3 \mathrm{~N}-24 \mathrm{E}$ & 23 & 2.9 & 34 & 445 & - & .8 & 2.7 & 16 & 35 & 24 & 25 & - & - & - & - & - & - \\
\hline Canning River Unit B-1 & $32-4 \mathrm{~N}-24 \mathrm{E}$ & 11 & 2.8 & 56 & 440 & - & .9 & - & - & - & - & - & - & - & - & - & - & - \\
\hline Jago River & $4-6 N-35 E$ & 22 & 6.7 & 265 & 400 & 425 & .4 & 1.6 & 50 & 40 & 5 & 5 & 13,442 & 659 & 3,203 & 9,580 & 1.2 & .1 \\
\hline Unnamed & $8-2 N-36 E$ & 3 & 1.4 & 15 & ND & - & 1.8 & - & - & - & - & - & - & - & - & - & - & - \\
\hline Niguanak Ridge & $1-6 N-36 E$ & 3 & 12.1 & 383 & - & 410 & - & - & - & - & - & - & - & - & - & - & - & - \\
\hline Niguanak Ridge & $4-6 \mathrm{~N}-37 \mathrm{E}$ & 9 & 11.5 & 415 & 405 & 412 & .4 & 1.7 & 40 & 40 & 10 & 10 & 8,094 & 2,258 & 1,951 & 3,280 & - & - \\
\hline
\end{tabular}



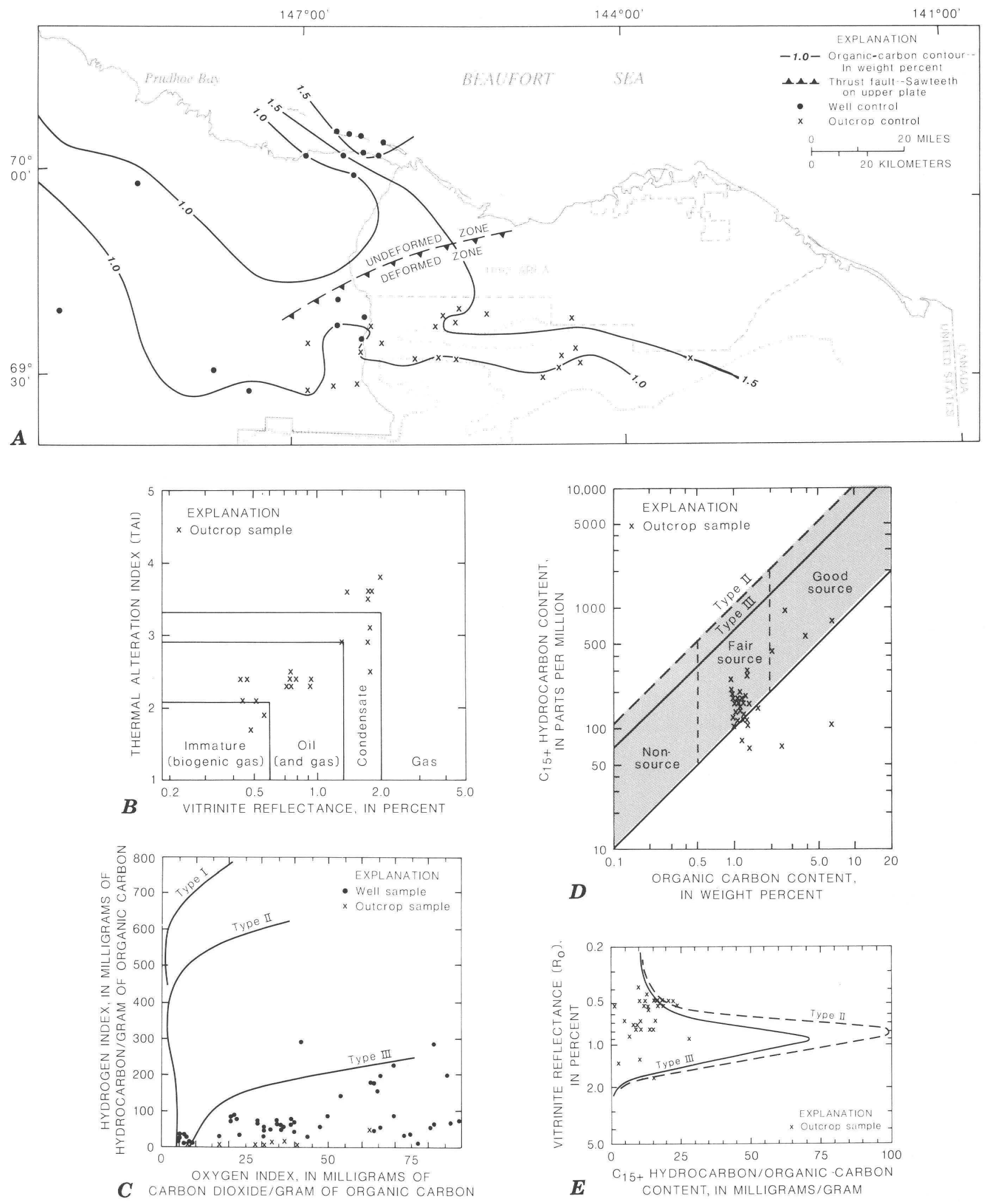

Figure 11.11. Geochemical summary for the Canning Formation. A, Organic-carbon contour map. $B$, Thermal maturity from vitrinite reflectance and TAI. $C$, Kerogen type from Van Krevelen diagram. $D$, Richness of source rock from $\mathrm{C}_{15+}$-saturated hydrocarbons. $E$, Stage of organic evolution. 
or migration path, and a reservoir rock in a trap must be located in time and space in such a way that when oil or gas is generated it can move out of the source rock and into the reservoir rock. Second, the oil that finally accumulates in the reservoir rock must be preserved at temperatures above which little or no bacterial degradation can occur and below which the oil will not be thermally cracked or broken down into natural gas. In these two situations, time and temperature play a vital role in the formation and preservation of oil and gas.

Table 11.7. Geochemical summary for well and outcrop information for the Canning Formation in and adjacent to the 1002 area

[-, not analyzed; OC, organic carbon; HI, hydrogen index; RE, Rock Eval ( $\left.\mathrm{T}_{\max }\right)$; $\mathrm{TF}$, thermal evolution analysis - flame ionization detector ( $\left.\mathrm{T}_{\max }\right)$; Vit. ref., vitrinite reflectance; TAI, thermal alteration index; Am, amorphous; He, herbaceous; Wo, woody; In, inertinite; Bit., bitumen; Sat., saturates; Arom., aromatics; NHC, nonhydrocarbons; Elem. ratio, elemental analysis ratios; H, hydrogen; O, oxygen; C, carbon]

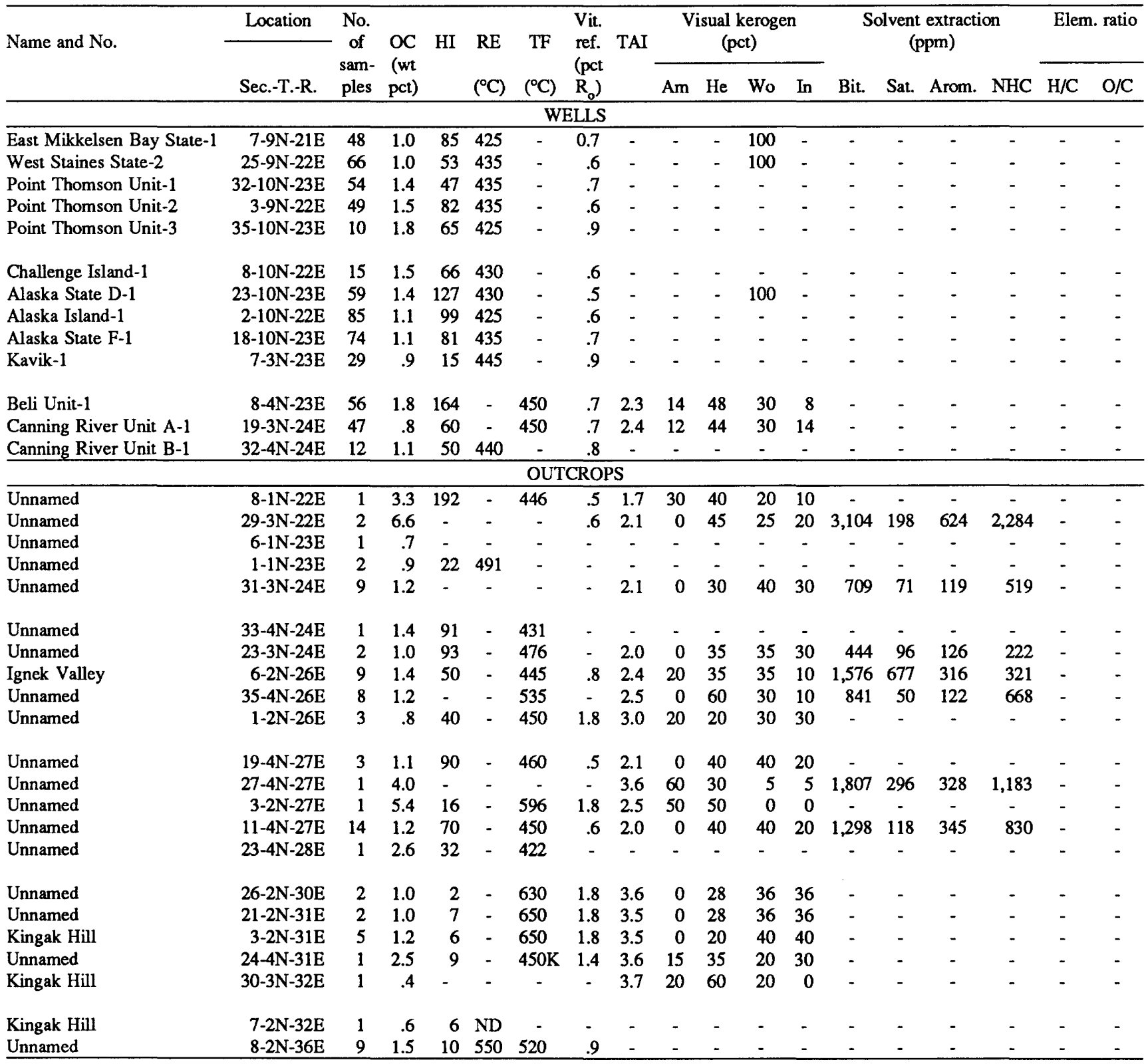




\section{Present-Day Temperature}

In order to estimate the paleogeothermal gradient in an area, the present geothermal gradient must first be determined. For the best possible results, one needs stabilized temperature information from wells that penetrate a stratigraphic section that is presently at maximum burial depth and that has not been uplifted. Wells adjacent to the ANWR in the Point Thomson area have experienced very little, if any, uplift, but no stabilized temperatures are available. The next best temperature data come from bottom-hole temperature measurements acquired during each wireline log survey. A correction is applied to these temperatures to account for the lack of thermal equilibrium between the drilling mud and the formation temperature.
Horner cross plots are used to estimate the temperature of a rock unit at equilibrium (Horner, 1951). Values for three variables are required: (1) recorded bottom-hole temperature, (2) time since circulation stopped for each bottom-hole temperature, and (3) the amount of time the formation was exposed to circulating mud after drilling stopped. This technique is applied to eight wells that are as deep as $4,600 \mathrm{~m}(15,000 \mathrm{ft})$ in the Point Thomson area (fig. 11.12). The corrected values are indicated in appendix $11.1 A-E, G-I$.

A best-fit present-day geothermal gradient to $4,600 \mathrm{~m}(15,000 \mathrm{ft})$ was estimated and then projected to about $8,550 \mathrm{~m}(28,000 \mathrm{ft})$. The present-day geothermal gradient can be compared with $R_{0}$ data to $4,600 \mathrm{~m}$ $(15,000 \mathrm{ft})$ from nine wells in the Point Thomson area. A best-fit $R_{0}$ gradient was estimated and projected to

Table 11.8. Geochemical summary for well and outcrop information for the Sagavanirktok Formation in and adjacent to the 1002 area

[-, not analyzed; OC, organic carbon; HI, hydrogen index; RE, Rock Eval $\left(\mathrm{T}_{\max }\right) ; \mathrm{TF}$, thermal evolution analysis - flame ionization detector $\left(\mathrm{T}_{\max }\right)$; Vit. ref., vitrinite reflectance; TAI, thermal alteration index; Am, amorphous; He, herbaceous; Wo, woody; In, inertinite; Bit., bitumen; Sat., saturates; Arom., aromatics; NHC, nonhydrocarbons; Elem. ratio, elemental analysis ratios; H, hydrogen; O, oxygen; C, carbon]

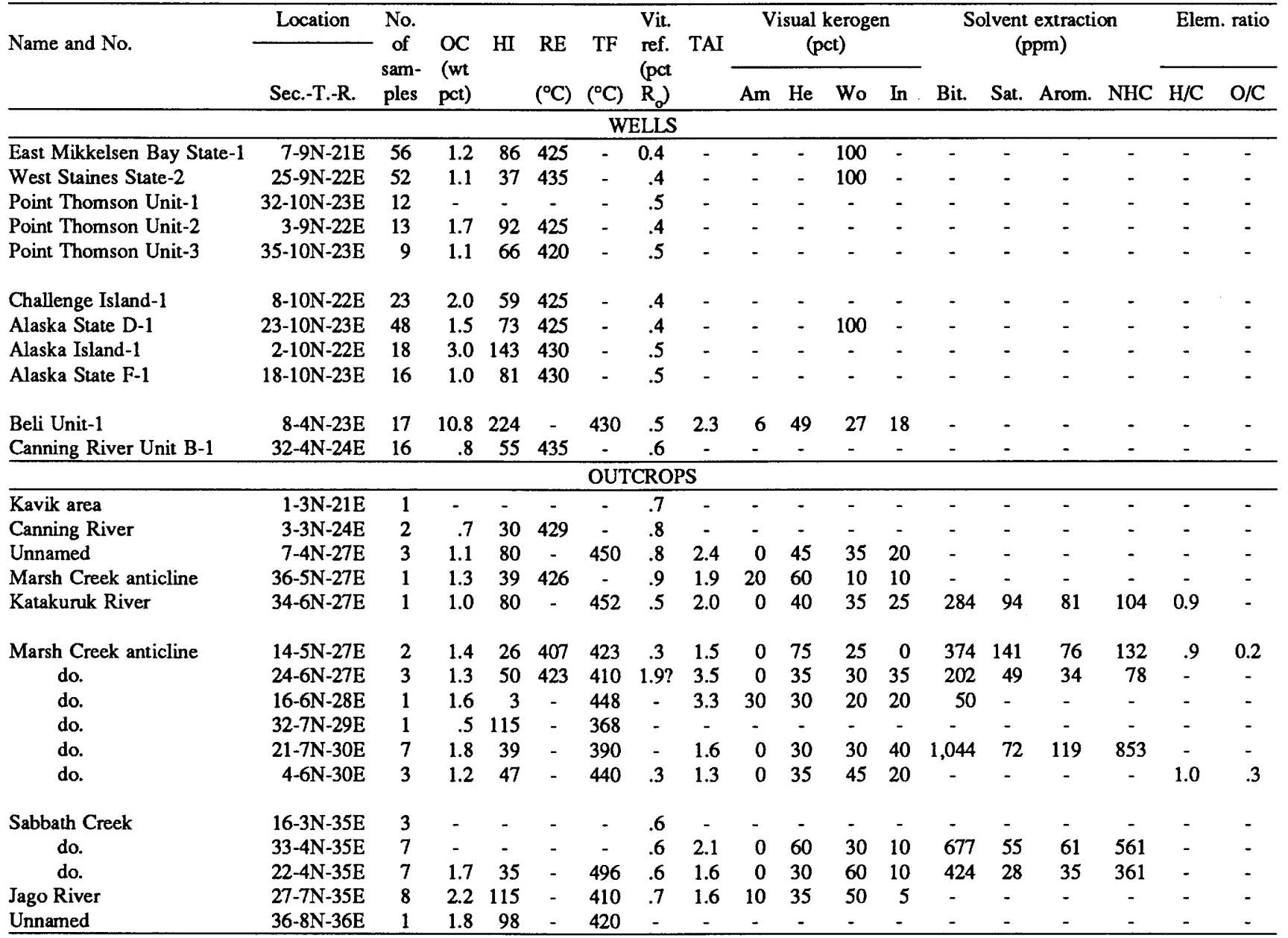


$8,550 \mathrm{~m}(28,000 \mathrm{ft})$ for comparison to the present-day geothermal gradient. Based on these gradients, oil is presently being generated from 3,660 to $6,860 \mathrm{~m}(12,000$ to $22,500 \mathrm{ft}$ ), condensate from 6,860 to $8,550 \mathrm{~m}(22,500$ to $28,000 \mathrm{ft})$, and gas below $8,550 \mathrm{~m}(28,000 \mathrm{ft})$. Threshold values are 0.6 percent $R_{o}$ and $95^{\circ} \mathrm{C}\left(200{ }^{\circ} \mathrm{F}\right)$ for oil, 1.35 percent $R_{0}$ and $190{ }^{\circ} \mathrm{C}\left(375^{\circ} \mathrm{F}\right)$ for condensate, and 2.0 percent $R_{0}$ and $245^{\circ} \mathrm{C}\left(475^{\circ} \mathrm{F}\right)$ for gas.

To compare present-day temperatures directly with $R_{o}$ values, one must understand that the $R_{o}$ values are a product of both time and temperature, not just temperature. In addition, $R_{o}$ values are irreversible,
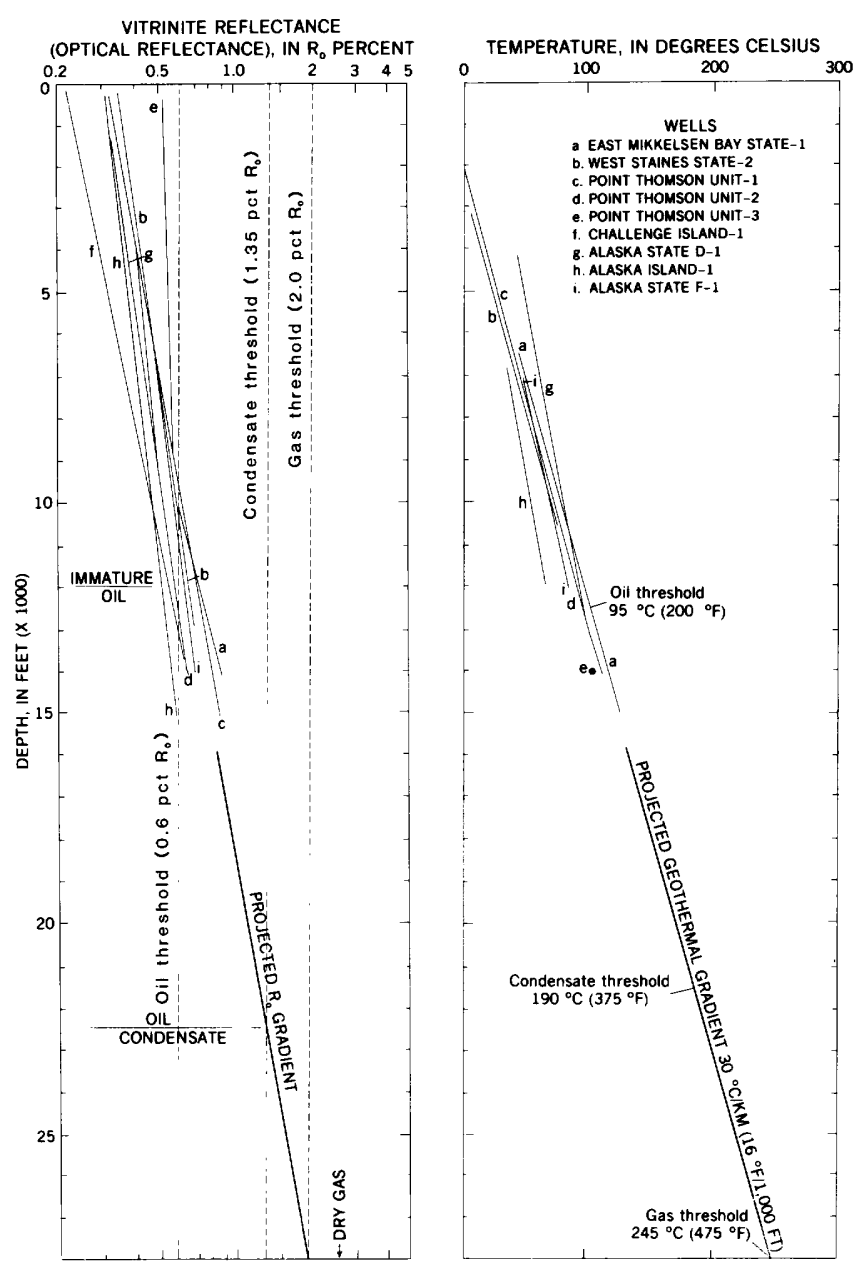

Figure 11.12. Vitrinite reflectance for nine wells and geothermal gradients for eight wells in Point Thomson area. Thresholds for oil, condensate, and gas are 0.6, 1.35 , and 2.0 percent $R_{o^{\circ}}$ respectively, for vitrinite reflectance and $95{ }^{\circ} \mathrm{C}, 190^{\circ} \mathrm{C}$, and $245^{\circ} \mathrm{C}$, respectively, for subsurface temperatures. Depth thresholds are $12,000,22,500$, and $28,000 \mathrm{ft}$. Subsurface temperature plots are corrected using Horner cross plots. Dot, single temperature reading in Point Thomson Unit-3 well. whereas the temperature of rock fluctuates with geologic events, such as burial, erosion, and heat flux.

In summary, present-day geothermal and $R_{o}$ gradients are useful for determining maturity profiles for rocks that are presently at maximum burial depth (as in the undeformed zone) but not in structural settings that have been uplifted or thrusted (as in the deformed zone). The $R_{o}$ gradient is useful, within broad limits, in estimating the amount of uplift.

\section{Lopatin Reconstruction}

First-order reaction kinetics predict that thermal maturation of organic matter is time and temperature dependent (Lopatin, 1971; Waples, 1980). On a relative basis, temperature has 10 times more of an effect on the maturation of source rocks than does time. There are various methods to model the time-temperature dependencies of thermal maturation (Lopatin, 1971; Connan, 1974; Hood and others, 1975; Tissot and Welte, 1978, 1984; Waples, 1980; Zhijun, 1983; Pigott, 1985) that are applicable to basin analyses. Waples' (1980) technique calculates a time-temperature index (TTI), which expands on the Lopatin (1971) method; it is used in this study to determine the geologic time of thermal maturity of the Hue Shale in the Point Thomson and Kavik areas. The Point Thomson Unit-1 and the Beli Unit-1 wells are chosen to be representative for the TTI calculations.

\section{Point Thomson Unit-1 Well}

The burial history for the Point Thomson Unit-1 well was constructed from the geologic ages posted on the well correlation section (pl. 1). The OligoceneMiocene and Miocene-Pliocene stratigraphic boundaries are unclear, unlike the tops for the Paleocene and Eocene sections. The same burial rate was used for the younger Tertiary units as was used for the older Tertiary units. The time scale is from the U.S. Geological Survey (1983). Rock units are those of Bird and Molenaar (chap. 5), and the $R_{o}$ values are estimated from the well display (app. 11.1C). The change in thermal gradient back in geologic time is estimated from trial and error calculation using Waples' (1980) TTI method. The results are shown in table 11.9 and on figure 11.13.

Based on the TTI calculations, the Hue Shale, an oil-prone source rock, was mature enough (beginning 5 million years ago) to generate oil in the late Miocene and early Pliocene in the Point Thomson area. In approximately the same place and time, the pebble shale unit, a gas-prone source rock, was mature enough to generate some gas. 
Table 11.9. Calculation of present-day time-temperature index (TTI) values for the Point Thomson Unit-1 well

[ $\mathrm{r}^{\mathrm{n}}$, rate of maturation for a particular temperature interval; $\Delta$ Time, age at which the rock unit enters that interval minus the age at which it enters the next interval (Waples, 1980)]

\begin{tabular}{|c|c|c|c|c|c|}
\hline $\begin{array}{c}\text { Temperature } \\
\text { interval } \\
\left({ }^{\circ} \mathrm{C}\right) \\
\end{array}$ & $r^{n}$ & $\begin{array}{l}\Delta \text { Time } \\
\text { (m.y.) }\end{array}$ & $\begin{array}{c}\text { Interval } \\
\text { TTI }\end{array}$ & $\begin{array}{l}\text { Age } \\
(\mathrm{Ma})\end{array}$ & $\begin{array}{c}\text { Total } \\
\text { TTI }\end{array}$ \\
\hline \multicolumn{6}{|c|}{ Horizon F } \\
\hline $0-10$ & $2^{-10}$ & 8.0 & 0.0 & 8.0 & 0.0 \\
\hline $10-20$ & $2^{-9}$ & 8.9 & .0 & 16.9 & .0 \\
\hline $20-30$ & $2^{-8}$ & 11.0 & .0 & 28.0 & .1 \\
\hline $30-40$ & $2^{-7}$ & 10.0 & .1 & 38.0 & .1 \\
\hline \multicolumn{6}{|c|}{ Horizon $\mathrm{E}$} \\
\hline $0-10$ & $2^{-10}$ & 2.0 & 0.0 & 2.0 & 0.0 \\
\hline $10-20$ & $2^{-9}$ & 5.4 & .0 & 7.5 & .0 \\
\hline $20-30$ & $2^{-8}$ & 12.1 & .0 & 19.6 & .1 \\
\hline $30-40$ & $2^{-7}$ & 11.0 & .1 & 30.6 & .1 \\
\hline $40-50$ & $2^{-6}$ & 11.9 & .2 & 42.5 & .3 \\
\hline $50-60$ & $2^{-5}$ & 12.5 & .4 & 55.0 & .7 \\
\hline \multicolumn{6}{|c|}{ Horizon D } \\
\hline $0-10$ & $2^{-10}$ & 0.4 & 0.0 & 0.4 & 0.0 \\
\hline $10-20$ & $2^{-9}$ & .5 & .0 & .9 & .0 \\
\hline $20-30$ & $2^{-8}$ & 3.7 & .0 & 4.6 & .0 \\
\hline $30-40$ & $2^{-7}$ & 14.9 & .1 & 19.5 & .1 \\
\hline $40-50$ & $2^{-6}$ & 11.4 & .2 & 30.9 & .3 \\
\hline $50-60$ & $2^{-5}$ & 10.6 & .3 & 41.6 & .6 \\
\hline $60-70$ & $2^{4}$ & 13.5 & .8 & 55.1 & 1.5 \\
\hline $70-80$ & $2^{-3}$ & 2.4 & .3 & 57.5 & 1.8 \\
\hline \multicolumn{6}{|c|}{ Horizon $\mathrm{C}$} \\
\hline $10-20$ & $2^{-9}$ & 0.9 & 0.0 & 0.9 & 0.0 \\
\hline $20-30$ & $2^{-8}$ & .9 & .0 & 1.8 & .0 \\
\hline $30-40$ & $2^{-7}$ & 2.4 & .0 & 4.3 & .0 \\
\hline $40-50$ & $2^{-6}$ & 2.1 & .0 & 6.4 & .1 \\
\hline $50-60$ & $2^{-5}$ & 8.1 & .3 & 14.5 & .3 \\
\hline $60-70$ & $2^{-4}$ & 13.3 & .8 & 27.7 & 1.1 \\
\hline $70-80$ & $2^{-3}$ & 11.4 & 1.4 & 39.2 & 2.6 \\
\hline $80-90$ & $2^{-2}$ & 12.8 & 3.2 & 52.0 & 5.8 \\
\hline $90-100$ & $2^{-1}$ & 10.0 & 5.0 & 62.0 & 10.8 \\
\hline \multicolumn{6}{|c|}{ Horizon B } \\
\hline $0-10$ & $2^{-10}$ & 0.1 & 0.0 & 0.1 & 0.0 \\
\hline $10-20$ & $2^{-9}$ & .1 & .0 & .2 & .0 \\
\hline $20-30$ & $2^{-8}$ & 1.7 & .0 & 1.9 & .0 \\
\hline $30-40$ & $2^{-7}$ & 2.2 & .0 & 4.1 & .0 \\
\hline $40-50$ & $2^{-6}$ & 1.5 & .0 & 5.6 & .0 \\
\hline $50-60$ & $2^{-5}$ & 2.3 & .1 & 7.9 & .1 \\
\hline
\end{tabular}

\section{Beli Unit-1 Well}

The burial history for the Beli Unit-1 well was constructed from the geologic ages for the post-Jurassic rocks noted on the well correlation section (pl. 1). For
Table 11.9. Calculation of present-day time-temperature index (TTI) values for the Point Thomson Unit-1 well Continued

$\left[r^{n}\right.$, rate of maturation for a particular temperature interval; $\Delta$ Time, age at which the rock unit enters that interval minus the age at which it enters the next interval (Waples, 1980)]

\begin{tabular}{rrrrrr}
\hline $\begin{array}{c}\text { Temperature } \\
\text { interval } \\
\left({ }^{\circ} \mathrm{C}\right)\end{array}$ & $\mathrm{r}^{\mathrm{n}}$ & $\begin{array}{c}\Delta \text { Time } \\
(\mathrm{m} . y .)\end{array}$ & $\begin{array}{c}\text { Interval } \\
\text { TTI }\end{array}$ & $\begin{array}{c}\text { Age } \\
(\mathrm{Ma})\end{array}$ & $\begin{array}{r}\text { Total } \\
\text { TTI }\end{array}$ \\
\hline $60-70$ & $2^{-4}$ & 15.2 & 1.0 & 23.1 & 1.1 \\
$70-80$ & $2^{-3}$ & 11.8 & 1.5 & 34.9 & 2.5 \\
$80-90$ & $2^{-2}$ & 11.7 & 2.9 & 46.6 & 5.5 \\
$90-100$ & $2^{-1}$ & 13.9 & 7.0 & 60.6 & 12.4 \\
$100-110$ & $2^{0}$ & 2.4 & 2.4 & 63.0 & 14.9 \\
$90-100$ & $2^{-1}$ & .0 & .0 & 63.0 & 14.9 \\
$100-110$ & $2^{0}$ & .0 & .0 & 63.0 & 14.9 \\
\hline \multicolumn{5}{c}{ Horizon B - continued } \\
\hline $0-10$ & $2^{-10}$ & 8.8 & 0.0 & 8.8 & 0.0 \\
$10-20$ & $2^{-9}$ & 48.2 & .1 & 57.0 & .1 \\
$20-30$ & $2^{-8}$ & .8 & .0 & 57.8 & .1 \\
$30-40$ & $2^{-7}$ & 1.7 & .0 & 59.5 & .1 \\
$40-50$ & $2^{-6}$ & 2.0 & .0 & 61.5 & .2 \\
$50-60$ & $2^{-5}$ & 1.9 & .1 & 63.4 & .2 \\
$60-70$ & $2^{-4}$ & 7.2 & .5 & 70.6 & .7 \\
$70-80$ & $2^{-3}$ & 14.0 & 1.7 & 84.6 & 2.4 \\
$80-90$ & $2^{-2}$ & 11.0 & 2.7 & 95.6 & 5.2 \\
$90-100$ & $2^{-1}$ & 13.2 & 6.6 & 108.8 & 11.8 \\
$100-110$ & $2^{0}$ & 11.2 & 11.2 & 120.0 & 23.0 \\
\hline & & & & &
\end{tabular}

convenience, the burial history for the last 150 m.y. are shown. The ages for the pre-Cretaceous units are from Bird (1982). The $\mathrm{R}_{\mathrm{o}}$ data are from the well display (app. $11.1 K)$, and the amounts of uplift and erosion for the Kingak Shale $(900 \mathrm{~m}, 3,000 \mathrm{ft})$ and the Tertiary $(1,200$ $\mathrm{m}, 4,000 \mathrm{ft}$ ) as shown by the burial paths are judged by K.J. Bird (oral commun., 1986). The results of the TTI calculations are shown in table 11.10 and on figure 11.14. Based on these calculations the Kavik Member (of the Ivishak Formation of the Sadlerochit Group) is mature at $54 \mathrm{Ma}$, or in the early Eocene. The Hue Shale was capable of generating oil at $45 \mathrm{Ma}$, or $40 \mathrm{~m}$.y. before the Hue Shale in the Point Thomson area.

\section{Petroleum Migration}

Petroleum migration from a source rock (primary migration or expulsion) and along a carrier bed or conduit (secondary migration) is assumed to take place very near the time the source rock passes through the stage of catagenesis. The rate at which a source rock passes through catagenesis is determined by its burial 
rate, which is what heats up and matures kerogen. With a slow burial rate through the catagenesis stage, primary and secondary migration will take place over a great amount of geological time; conversely, if burial is rapid, migration will take place over a short period of time. In addition, after petroleum accumulates in a trap, subsequent tectonic activity (folding, thrusting, uplifting) will cause remigration (tertiary migration) from the previous trap to a newly formed trap.

The two structural zones of the 1002 area, undeformed and deformed, indicate at least two styles of petroleum generation, migration, and accumulation. Within the deformed zone, two petroleum systems are possible-one involving the Ellesmerian sequence and the other the Brookian system.

\section{Undeformed Zone}

Rocks to the northwest of the Marsh Creek anticline lie within the undeformed zone (fig 11.5). In this zone, the stratigraphic section is interpreted to be buried to maximum depth.
Based on the $R_{0}$ gradient ( 0.6 percent $R_{0}$ as the threshold of oil generation) and the Hue Shale as the oil source rock, the entire undeformed zone is presently generating oil (fig. 11.15). The present-day structural configuration (pl. 3 ) indicates that all oil and gas should migrate updip toward the Point Thomson area.

The gas in the Point Thomson field that occurs in the Thomson sand of local usage and the basement complex appears to be anomalous because none of the Hue Shale is presently in the zone of gas generation. However, the pebble shale unit immediately overlies the gas-bearing reservoir rocks, and downdip it lies between the pre-Mississippian unconformity and the Hue Shale. Because the pebble shale unit is a gas-prone source rock, it is the most likely source for the gas and condensate in the Point Thomson area; the Hue Shale is the most likely source for the oil in the Canning Formation (chap. 12).

\section{Deformed Zone}

The deformed zone to the southeast of the Marsh Creek anticline is presently thrust faulted, folded, and uplifted. The depth to the top of the oil, condensate,

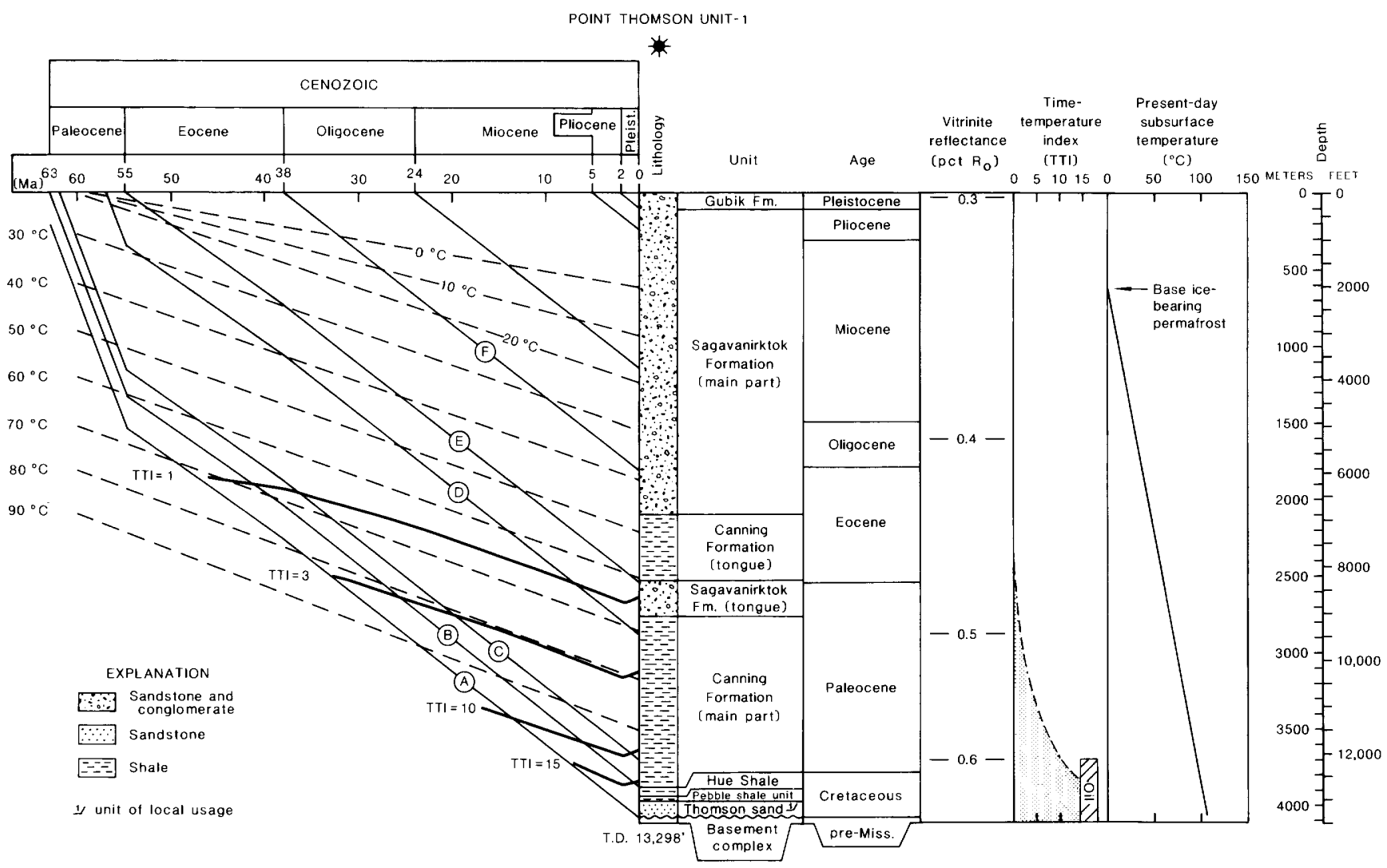

Figure 11.13. Lopatin diagram showing time of thermal maturity $(T T I=10)$ for rock units in the Point Thomson area using Point Thomson Unit-1 well. For example, the top of the Hue Shale reached maturity 5 million years ago. T.D., total depth. Present-day vitrinite reflectance values with corresponding TTI (right edge of stippled pattern). Circled letters A-F refer to horizons listed in table 11.9. 
Table 11.10. Calculation of present-day timetemperature index (TTI) values for the Beli Unit-1 well

$\left[\mathrm{r}^{\mathrm{n}}\right.$, rate of maturation for a particular temperature interval; $\Delta$ Time, age at which the rock unit enters that interval minus the age at which it enters the next interval (Waples, 1980)]

\begin{tabular}{|c|c|c|c|c|c|}
\hline $\begin{array}{c}\text { Temperature } \\
\text { interval } \\
\left({ }^{\circ} \mathrm{C}\right)\end{array}$ & $r^{n}$ & $\begin{array}{l}\Delta \text { Time } \\
\text { (m.y.) }\end{array}$ & $\begin{array}{c}\text { Interval } \\
\text { TTI }\end{array}$ & $\begin{array}{l}\text { Age } \\
\text { (Ma) }\end{array}$ & $\begin{array}{r}\text { Total } \\
\text { TTI }\end{array}$ \\
\hline \multicolumn{6}{|c|}{ Top Sagavanirktok Formation } \\
\hline $0-10$ & $2^{-10}$ & 0.1 & 0.0 & 0.1 & 0.0 \\
\hline 10- 20 & $2^{-9}$ & 1.0 & .0 & 1.1 & .0 \\
\hline $20-30$ & $2^{-8}$ & 1.3 & .0 & 2.4 & .0 \\
\hline $30-40$ & $2^{-7}$ & 1.0 & .0 & 3.4 & .0 \\
\hline $40-50$ & $2^{-6}$ & 1.0 & .0 & 4.4 & .0 \\
\hline $50-60$ & $2^{-5}$ & 1.0 & .0 & 5.4 & .1 \\
\hline $60-70$ & $2^{-4}$ & .7 & .0 & 6.0 & .1 \\
\hline $70-80$ & $2^{-3}$ & 1.0 & .1 & 7.1 & .2 \\
\hline $80-90$ & $2^{-2}$ & 1.2 & .3 & 8.2 & .5 \\
\hline $90-100$ & $2^{-1}$ & 1.3 & .6 & 9.5 & 1.2 \\
\hline $100-110$ & $2^{\circ}$ & 38.1 & 38.1 & 47.6 & 39.3 \\
\hline $90-100$ & $2^{-1}$ & 5.0 & 2.5 & 52.7 & 41.8 \\
\hline $80-90$ & $2^{-2}$ & 6.0 & 1.5 & 58.6 & 43.3 \\
\hline $70-80$ & $2^{-3}$ & 5.9 & .7 & 64.5 & 44.0 \\
\hline \multicolumn{6}{|c|}{ Top Hue Shale } \\
\hline $0-10$ & $2^{-10}$ & 0.5 & 0.0 & 0.5 & 0.0 \\
\hline $10-20$ & $2^{-9}$ & 5.0 & .0 & 5.5 & .0 \\
\hline $20-30$ & $2^{-8}$ & 5.0 & .0 & 10.4 & .0 \\
\hline $30-40$ & $2^{-7}$ & 6.1 & .0 & 16.5 & .1 \\
\hline $20-30$ & $2^{-8}$ & 1.7 & .0 & 18.2 & .1 \\
\hline $10-20$ & $2^{-9}$ & 1.7 & .0 & 19.8 & .1 \\
\hline $0-10$ & $2^{-10}$ & 8.5 & .0 & 28.3 & .1 \\
\hline $10-20$ & $2^{-9}$ & 47.6 & .1 & 75.9 & .2 \\
\hline $20-30$ & $2^{-8}$ & 1.0 & .0 & 76.9 & .2 \\
\hline $30-40$ & $2^{-7}$ & 1.0 & .0 & 77.9 & .2 \\
\hline $40-50$ & $2^{-6}$ & 1.0 & .0 & 78.9 & .2 \\
\hline $50-60$ & $2^{-5}$ & 1.0 & .0 & 79.9 & .2 \\
\hline $60-70$ & $2^{-4}$ & 1.0 & .1 & 80.9 & .3 \\
\hline $70-80$ & $2^{-3}$ & 1.0 & .1 & 81.9 & .4 \\
\hline $80-90$ & $2^{-2}$ & 1.1 & .3 & 83.0 & .7 \\
\hline $90-100$ & $2^{-1}$ & 1.3 & .6 & 84.3 & 1.3 \\
\hline $100-110$ & $2^{\circ}$ & 10.0 & 10.0 & 94.3 & 11.3 \\
\hline $110-120$ & $2^{1}$ & 18.0 & 35.9 & 112.2 & 47.2 \\
\hline $100-110$ & $2^{\circ}$ & 14.1 & 14.1 & 126.3 & 61.3 \\
\hline $90-100$ & $2^{-1}$ & 5.5 & 2.8 & 131.8 & 64.1 \\
\hline $80-90$ & $2^{-2}$ & 6.3 & 1.6 & 138.1 & 65.7 \\
\hline $70-80$ & $2^{-3}$ & 1.9 & .2 & 140.0 & 65.9 \\
\hline
\end{tabular}

and gas maturity thresholds are based on the same preMississippian unconformity (pl. 3, fig. 11.15). Therefore, the burial depths depicted here are minimum because in the Niguanak Ridge, the Kingak Shale and pebble shale unit are at 0.5 percent $R_{o}$. In the Point Thomson area,
Table 11.10. Calculation of present-day timetemperature index (TTI) values for the Beli Unit-1 wellContinued

[ $r^{n}$, rate of maturation for a particular temperature interval; $\Delta$ Time, age at which the rock unit enters that interval minus the age at which it enters the next interval (Waples, 1980)]

\begin{tabular}{|c|c|c|c|c|c|}
\hline $\begin{array}{c}\text { Temperature } \\
\text { interval } \\
\left({ }^{\circ} \mathrm{C}\right)\end{array}$ & $r^{n}$ & $\begin{array}{l}\Delta \text { Time } \\
\text { (m.y.) }\end{array}$ & $\begin{array}{c}\text { Interval } \\
\text { TTI }\end{array}$ & $\begin{array}{l}\text { Age } \\
\text { (Ma) }\end{array}$ & $\begin{array}{r}\text { Total } \\
\text { TTI }\end{array}$ \\
\hline \multicolumn{6}{|c|}{ Top Kingak Shale } \\
\hline $0-10$ & $2^{-10}$ & 5.3 & 0.0 & 5.3 & 0.0 \\
\hline $10-20$ & $2^{-9}$ & 52.6 & .1 & 57.8 & .1 \\
\hline $20-30$ & $2^{-8}$ & 52.6 & .2 & 110.4 & .3 \\
\hline $30-40$ & $2^{-7}$ & 52.6 & .4 & 162.9 & .7 \\
\hline $40-50$ & $2^{-6}$ & 38.5 & .6 & 201.5 & 1.3 \\
\hline $50-60$ & $2^{-5}$ & 5.0 & .2 & 206.4 & 1.5 \\
\hline $60-70$ & $2^{-4}$ & 5.0 & .3 & 211.4 & 1.8 \\
\hline $70-80$ & $2^{-3}$ & 4.8 & .6 & 216.2 & 2.4 \\
\hline $60-70$ & $2^{-4}$ & 1.7 & .1 & 217.9 & 2.5 \\
\hline $50-60$ & $2^{-5}$ & 1.7 & .1 & 219.5 & 2.5 \\
\hline $40-50$ & $2^{-6}$ & 24.9 & .4 & 244.5 & 2.9 \\
\hline $50-60$ & $2^{-5}$ & 31.7 & 1.0 & 276.1 & 3.9 \\
\hline $60-70$ & $2^{-4}$ & 1.0 & .1 & 277.1 & 4.0 \\
\hline $70-80$ & $2^{-3}$ & 1.0 & .1 & 278.1 & 4.1 \\
\hline $80-90$ & $2^{-2}$ & 1.0 & .2 & 279.1 & 4.4 \\
\hline $90-100$ & $2^{-1}$ & 1.0 & .5 & 280.1 & 4.9 \\
\hline $100-110$ & $2^{\circ}$ & 1.2 & 1.2 & 281.2 & 6.0 \\
\hline $110-120$ & $2^{1}$ & 1.3 & 2.6 & 282.5 & 8.6 \\
\hline $120-130$ & $2^{2}$ & 1.5 & 5.8 & 284.0 & 14.4 \\
\hline $130-140$ & $2^{3}$ & 28.2 & 225.7 & 312.2 & 240.2 \\
\hline $120-130$ & $2^{2}$ & 7.8 & 31.2 & 320.0 & 271.3 \\
\hline $110-120$ & $2^{1}$ & 18.1 & 36.2 & 338.1 & 307.5 \\
\hline $100-110$ & $2^{0}$ & 1.6 & 1.6 & 339.7 & 309.1 \\
\hline $110-120$ & $2^{1}$ & .3 & .6 & 340.0 & 309.7 \\
\hline
\end{tabular}

the 0.5 percent $R_{o}$ level is at a burial depth of $3,050 \mathrm{~m}$ $(10,000 \mathrm{ft})$, which implies that the Niguanak area has been uplifted from this depth. Considerable care must be taken in interpreting the thermal history of the deformed zone as it relates to the generation, migration, and accumulation of oil and gas.

Two petroleum systems are present in the deformed zone: the Ellesmerian and the Brookian. The Ellesmerian petroleum system includes the source and reservoir rocks that produced the Prudhoe Bay oil field. This system is south of the truncation edge, or in the southwest corner of the 1002 area, where the so-called Lower Cretaceous unconformity did not remove the Shublik Formation and Kingak Shale, the source of the Prudhoe Bay oil. In the southwest part of the 1002 area and in the Brooks Range, these units are too mature for us to be sure of their original source-rock characteristics, so we cannot entirely eliminate them as sources of oil in 
the 1002 area. However, we do not consider the Shublik or Kingak as likely sources, because no oil in or adjacent to the 1002 area compares with the Prudhoe Bay oil (chap. 12). Also, migration would have had to have taken place in Cretaceous and possibly early Tertiary time, before folding, thrusting, and uplift of the Brooks Range (chap. 20). The geometry of these units during this period would have been such that oil would have migrated updip to the northwest toward the Prudhoe Bay field.

The Brookian petroleum system is almost entirely within the 1002 area. The Hue Shale is the oilprone source rock, the pebble shale unit and the Canning Formation are gas-prone source rocks, and there are several potential reservoir rocks (fig. 5.1; chap. 7). At least two interpretations of the oil-migration history in the deformed area are possible. The first is that structural traps developed after petroleum migration. For this geologic history, the Late Cretaceous and Tertiary prograding delta filled the Hulahula low or basin before thrust faulting and folding occurred. The maximum burial depth would have occurred in Miocene or Pliocene time. With this scenario, structural contours from the Hulahula low would rise gently and would be uninterrupted by folds or faults (no Marsh Creek anticline) to the Point Thomson area on the west and to Canada on the east. Hence, any oil, condensate, or gas that was generated would migrate updip to the Point Thomson area or to Canada. Therefore, any structural traps formed after migration would not be charged with petroleum.

A second scenario for the geologic history in the deformed zone is that the structures formed before petroleum migration. For this geologic setting the Late Cretaceous and Tertiary prograding delta is continually deformed, folded, and faulted as deposition progresses. The maximum burial depth would have occurred prior to uplift, but the preexisting structural traps would have already captured migrating oil and gas. In this particular scenario, the fetch or drainage area for the Point Thomson area is the undeformed area, whereas the fetch for the Marsh Creek anticline and other structures in the

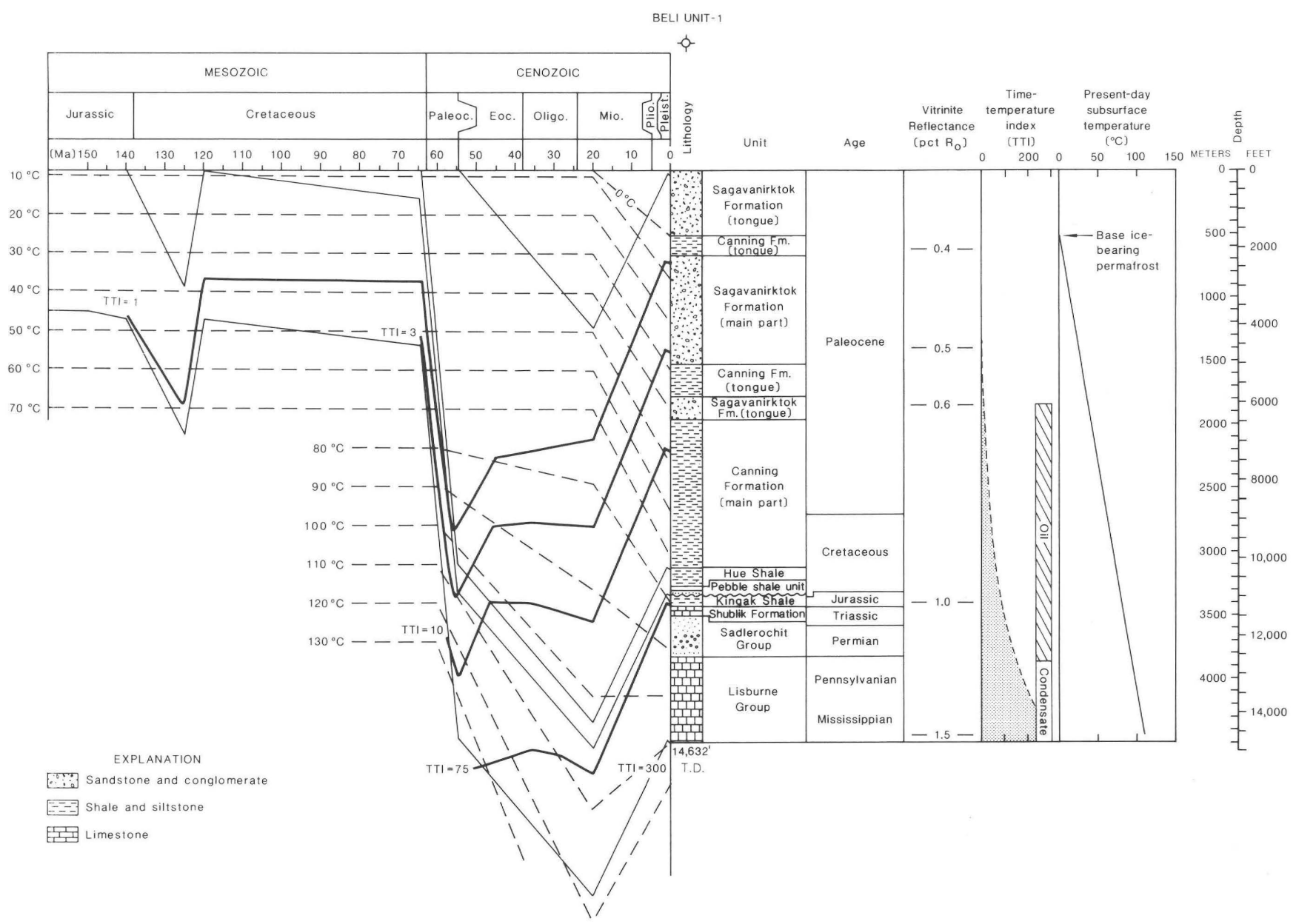

Figure 11.14. Lopatin diagram showing time of thermal maturity (TTI $=10$ ) for rock units in the Kavik area using Beli Unit-1 well. For example, the top of the Hue
Shale reached maturity 45 million years ago. T.D., total depth. Present-day vitinite reflectance values with corresponding TTI (right edge of stippled pattern). 
deformed area would have had to have been filled to spill point before any oil or gas could migrate updip.

\section{CONCLUSIONS}

Organic-carbon content, organic-matter type, and pyrolysis hydrocarbon yield show that all rock units (except the Hue Shale) are predominantly type III organic-matter units. Pre-Cretaceous rocks that crop out in the Brooks Range could not all be adequately evaluated because of the high thermal maturity of their organic matter. The most promising oil source rock within the ANWR coastal plain is the Hue Shale.

The maturity thresholds of oil, condensate, and gas from calculated $\mathrm{R}_{\mathrm{o}}$ gradients in the Point Thomson area are $3,660,6,860$, and $8,530 \mathrm{~m}$, respectively $(12,000$, 22,500 , and $28,000 \mathrm{ft}$ ). These thresholds can be used in the undeformed zone, which is presently at maximum burial depth, but not in the deformed zone, which is presently folded, faulted, and uplifted. In the latter zone the $\mathrm{R}_{\mathrm{o}}$ gradient does, in a broad sense, provide a measure of the uplift.

TTI calculations for the Beli Unit- 1 and Point Thomson Unit-1 wells indicate that maturity first occurred in the south and progressed northward. The Hue Shale matured in the Beli Unit-1 well during the Eocene and in the Point Thomson Unit-1 well in late Miocene and early Pliocene time.

The regional structural configuration of the preMississippian unconformity indicates that the most mature part of the coastal-plain area is the Hulahula low. Based on geochemical information, the Hue Shale is the only oil-prone source rock in the coastal-plain area. The time of structural deformation in the deformed zone is critical to the presence of oil in structures, provided that reservoirs and seals are present. If petroleum migrated before structural development, it would pass through all areas except the Point Thomson area and Canada; however, a more likely interpretation is that petroleum migrated during structural deformation, so it was probably trapped in some of the many structures in the 1002 area.
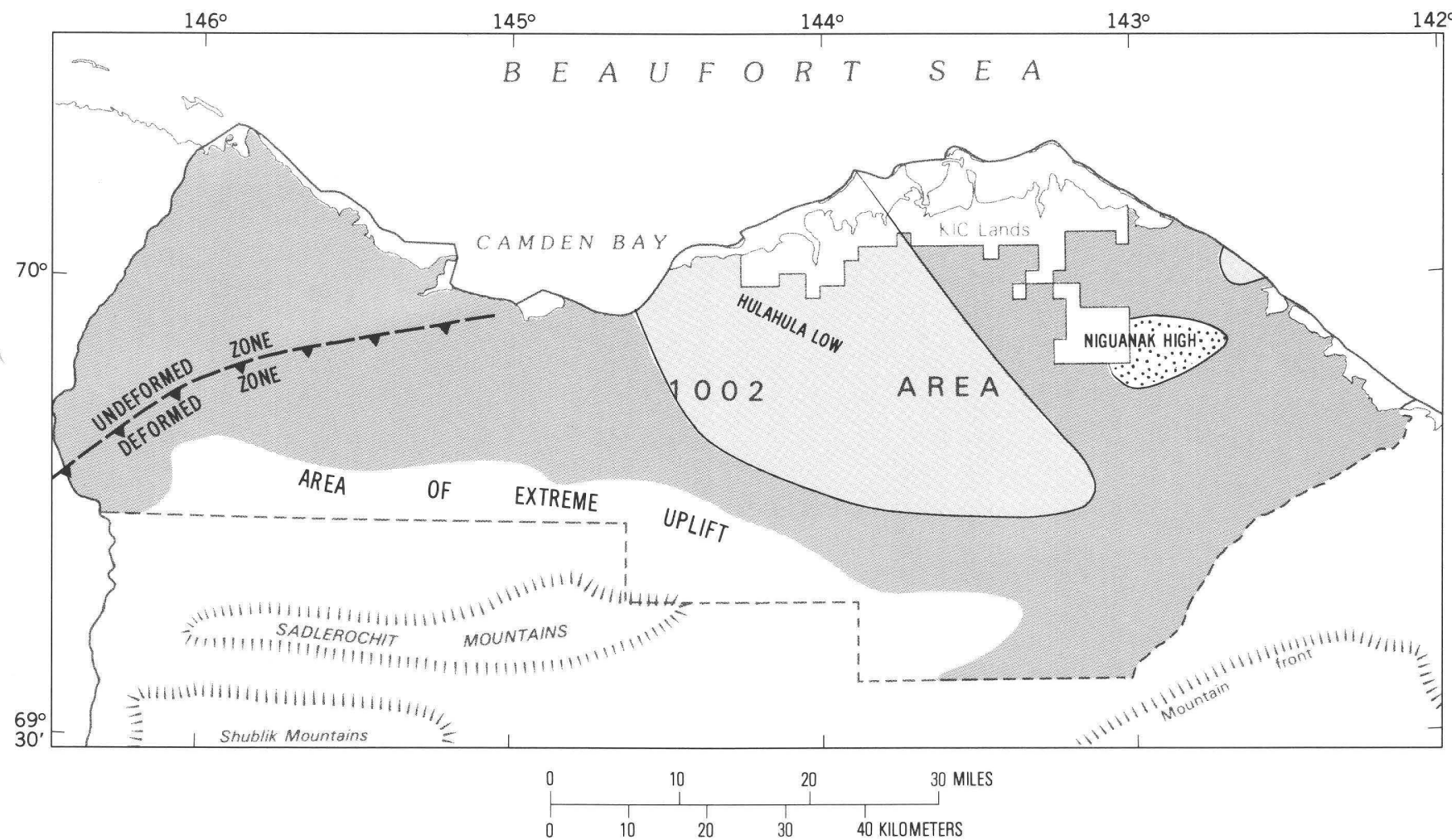

EXPLANATION
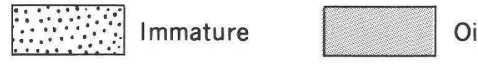

Oil

Condensate

Figure 11.15. Maturity levels based on present-day burial depths in the 1002 area. In undeformed zone, present-day burial depths properly represent the maturity level of the Hue Shale just above unconformity. However, for the deformed zone, burial depths are minimums because of considerable uplift due to thrust faulting and folding. High maturity values for outcrop samples along north flank of Sadlerochit Mountains and in Niguanak area are evidence for this uplift. 


\section{APPENDIX 11.1}

Geochemical indicators for thermal maturity, type, and richness of source rocks for rock units penetrated by wells. UBM, Umiat base and meridian; $\mathrm{KB}$, kelly bushing; TD, total depth. A, East Mikkelsen Bay State-1. $B$, West Staines State-2. $C$, Point Thomson Unit-1. D, Point Thomson Unit-2. $E$, Point Thomson Unit-3. $F$, Challenge Island-1. $G$, Alaska State D-1. $H$, Alaska Island-1. I, Alaska State F-1. J, Kavik-1. K, Beli Unit-1. L, Canning River Unit A-1. M, Canning River Unit B-1.

\section{EXPLANATION}

$\begin{array}{ll}4 & \text { Bottom of casing } \\ \text { LITHOLOGY }\end{array}$

\section{OIL SHOWS}

(from American Stratigraphic Company)

Questionable, no fluorescence in solvent

- Spotted staining, fluorescence in solvent

- Even staining, fluorescence in solvent 


\section{A. EAST MIKKELSEN BAY STATE-1}

INDICATORS OF THERMAL HISTORY

ROCK UNITS PENETRATED

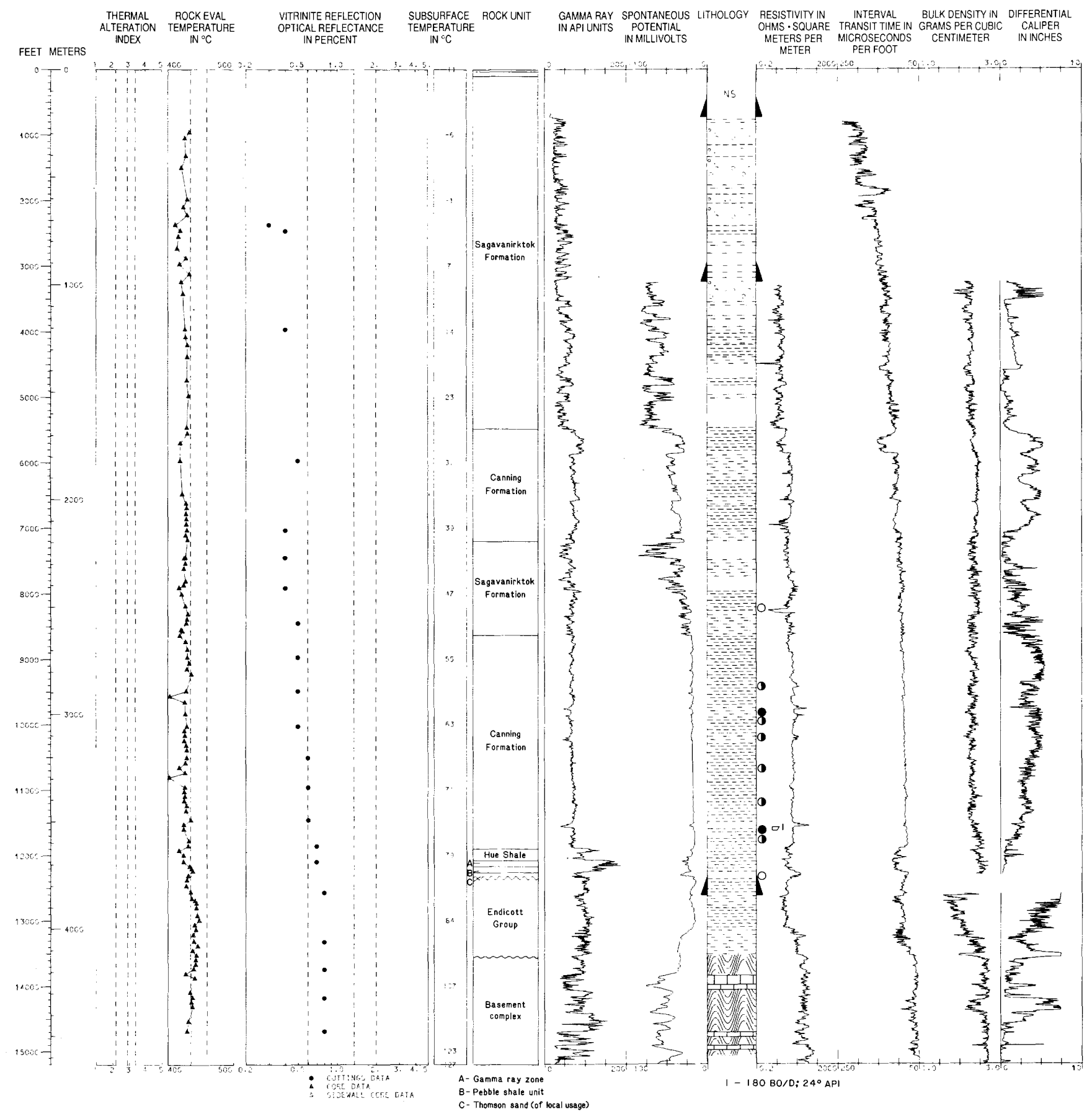




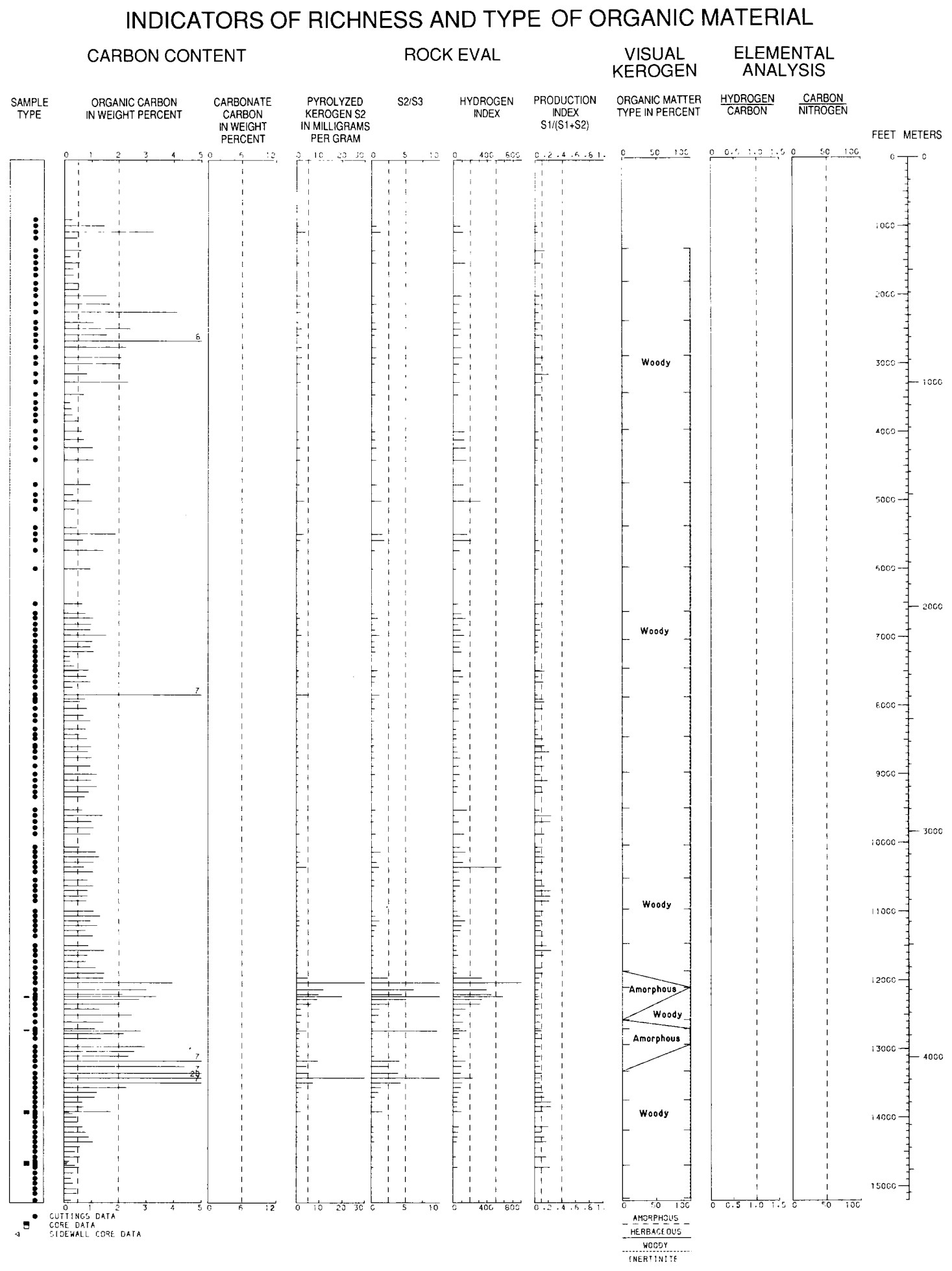




\section{B. WEST STAINES STATE-2}

INDICATORS OF THERMAL HISTORY

ROCK UNITS PENETRATED

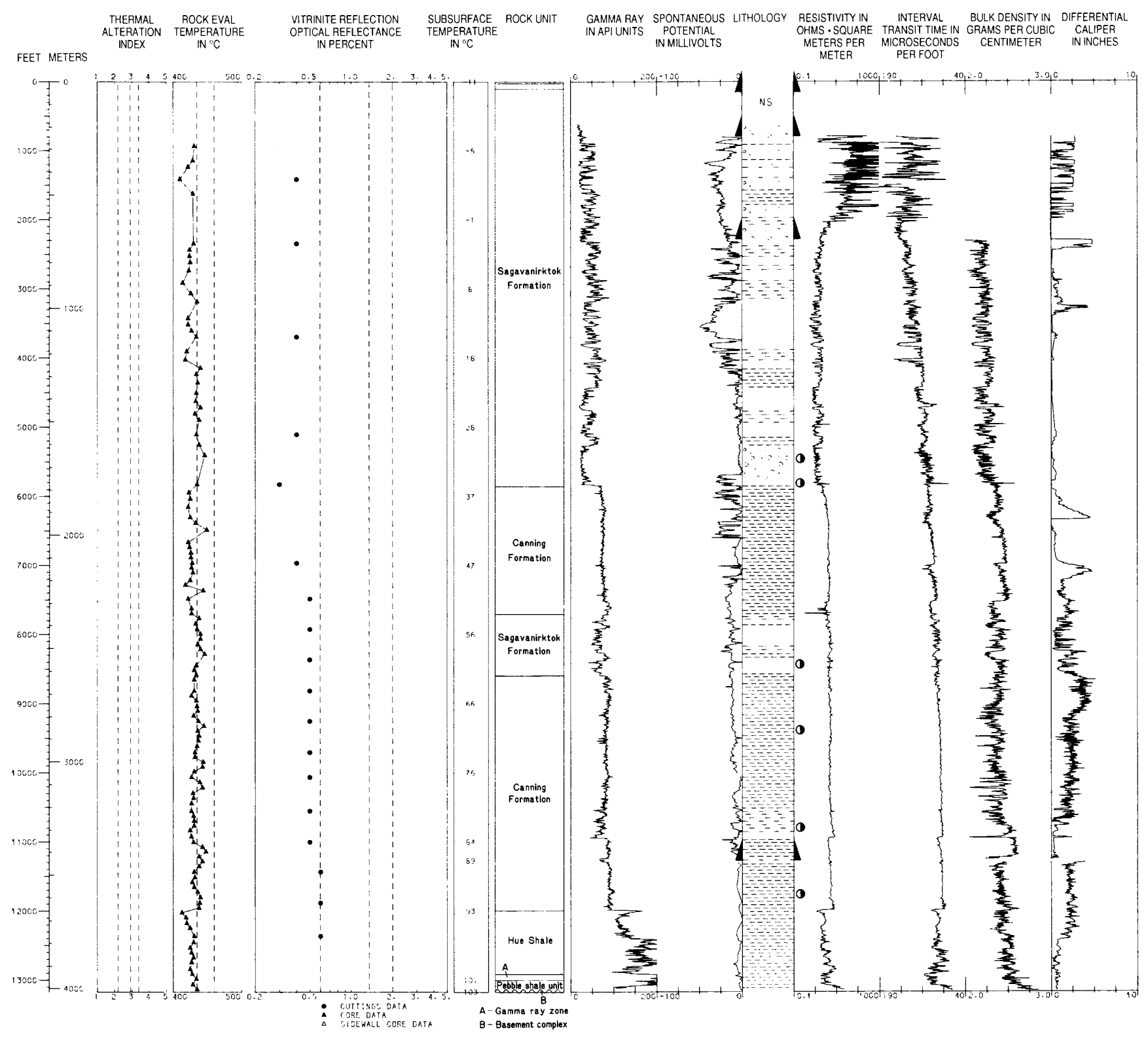




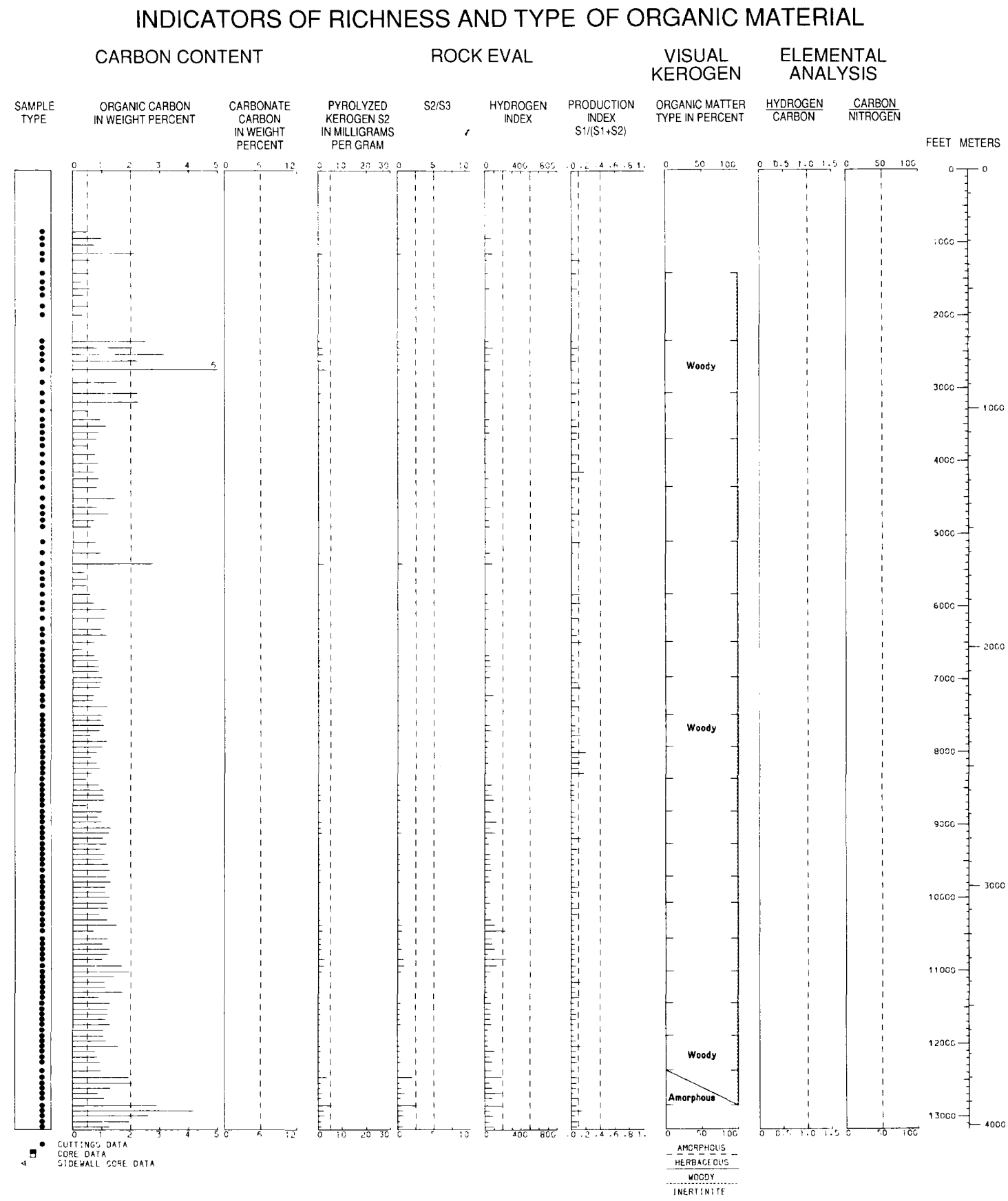




\section{POINT THOMSON UNIT-1}

\section{INDICATORS OF THERMAL HISTORY}

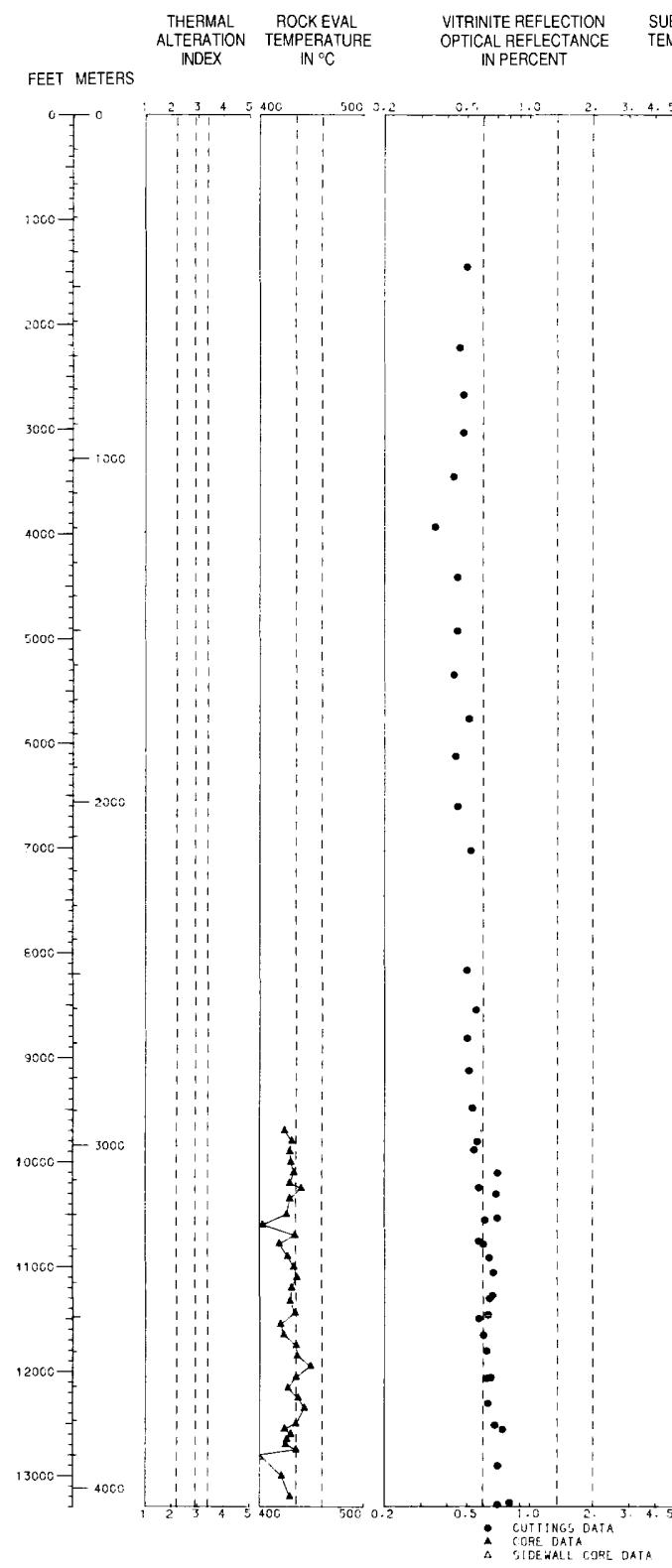

ROCK UNITS PENETRATED

SUBSURFACE ROCK UNIT IN ${ }^{\circ} \mathrm{C}$ INTERVAL BULK DENSITY IN DIFFERENTIAL IN MILLIVOLTS
TRANSIT TIMEIN GRAMS PER CUBIC CALIPER METERS PER MICROSECONOS CENTIMETER IN INCHES

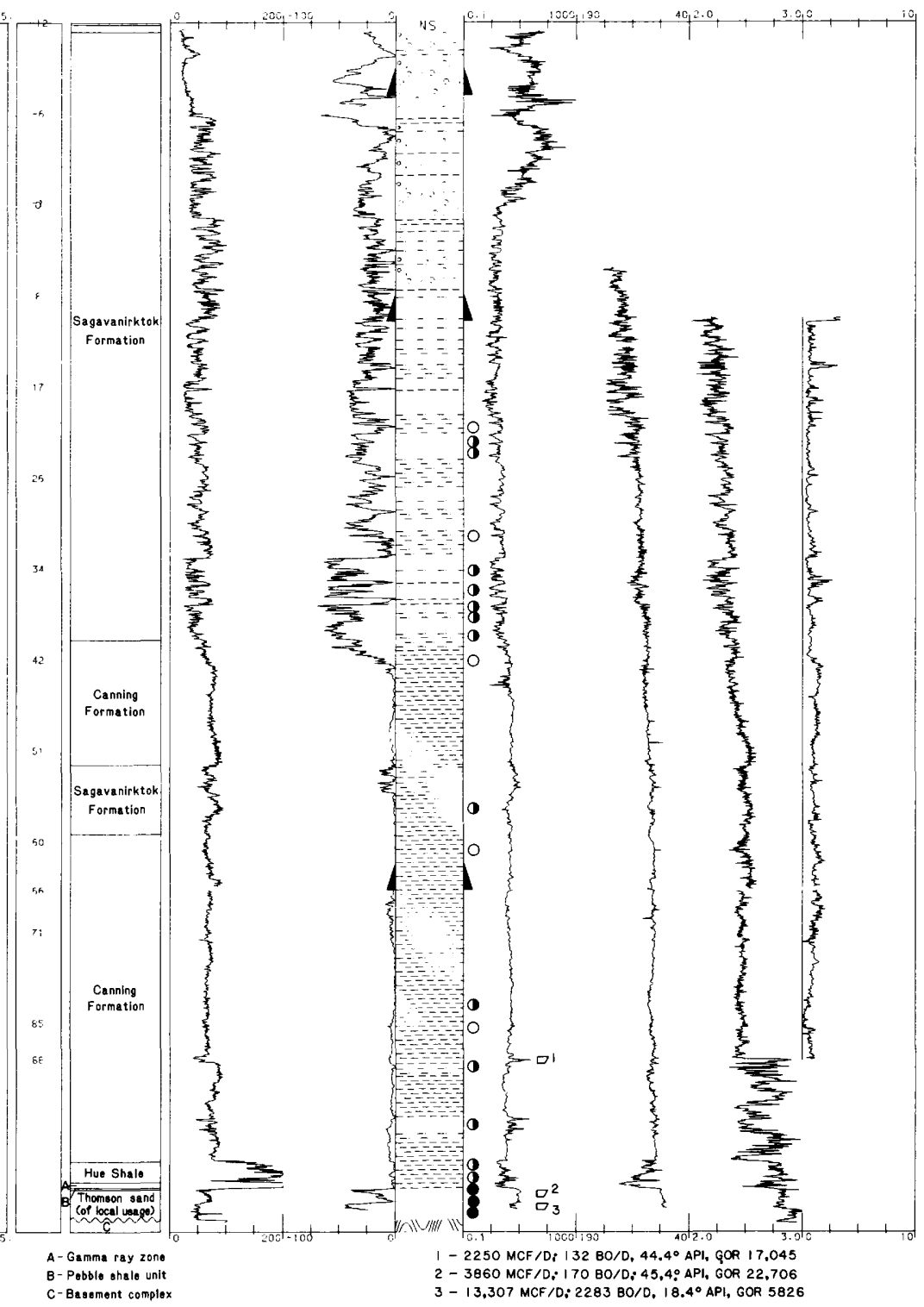




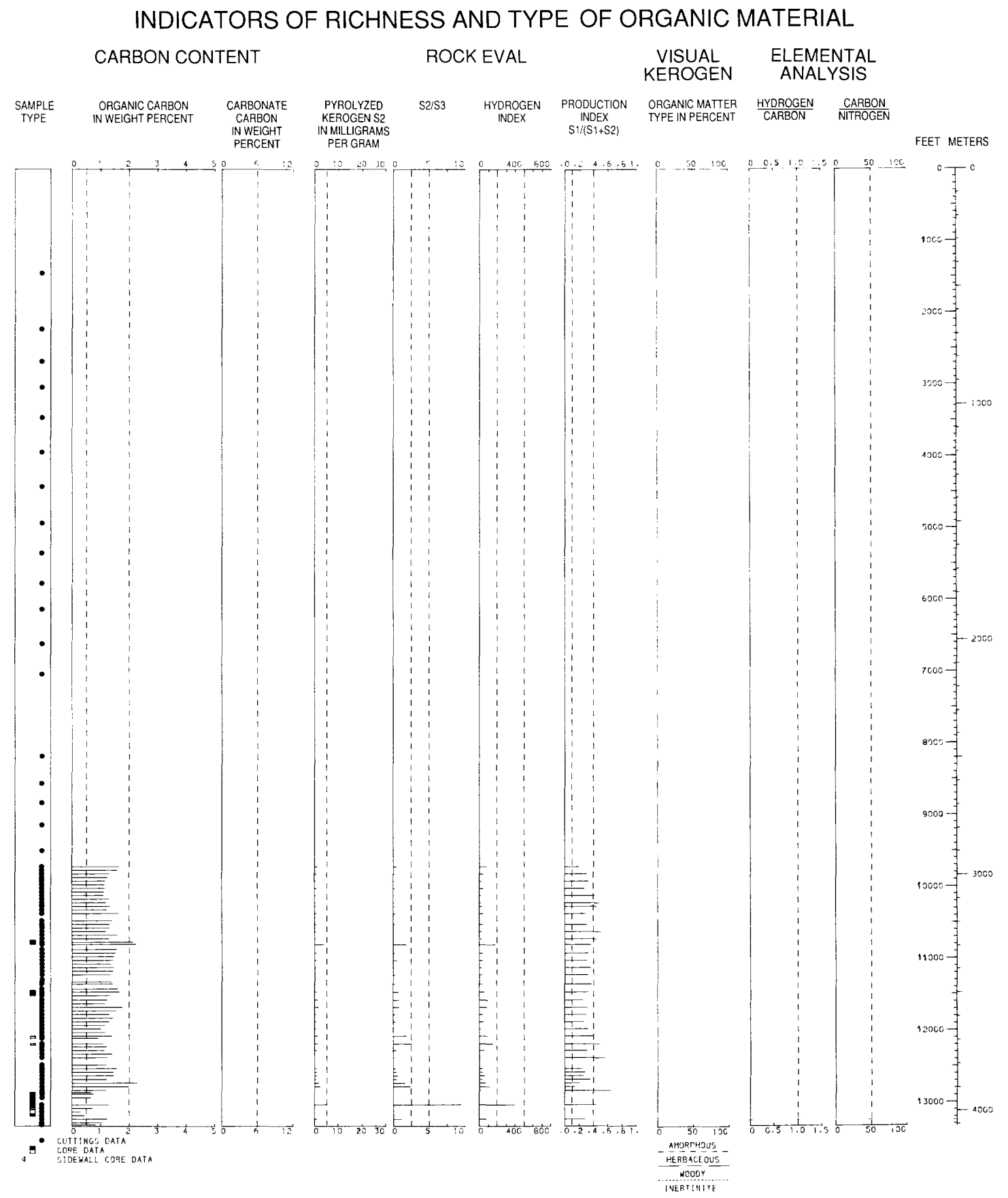




\section{POINT THOMSON UNIT-2}

INDICATORS OF THERMAL HISTORY

ROCK UNITS PENETRATED

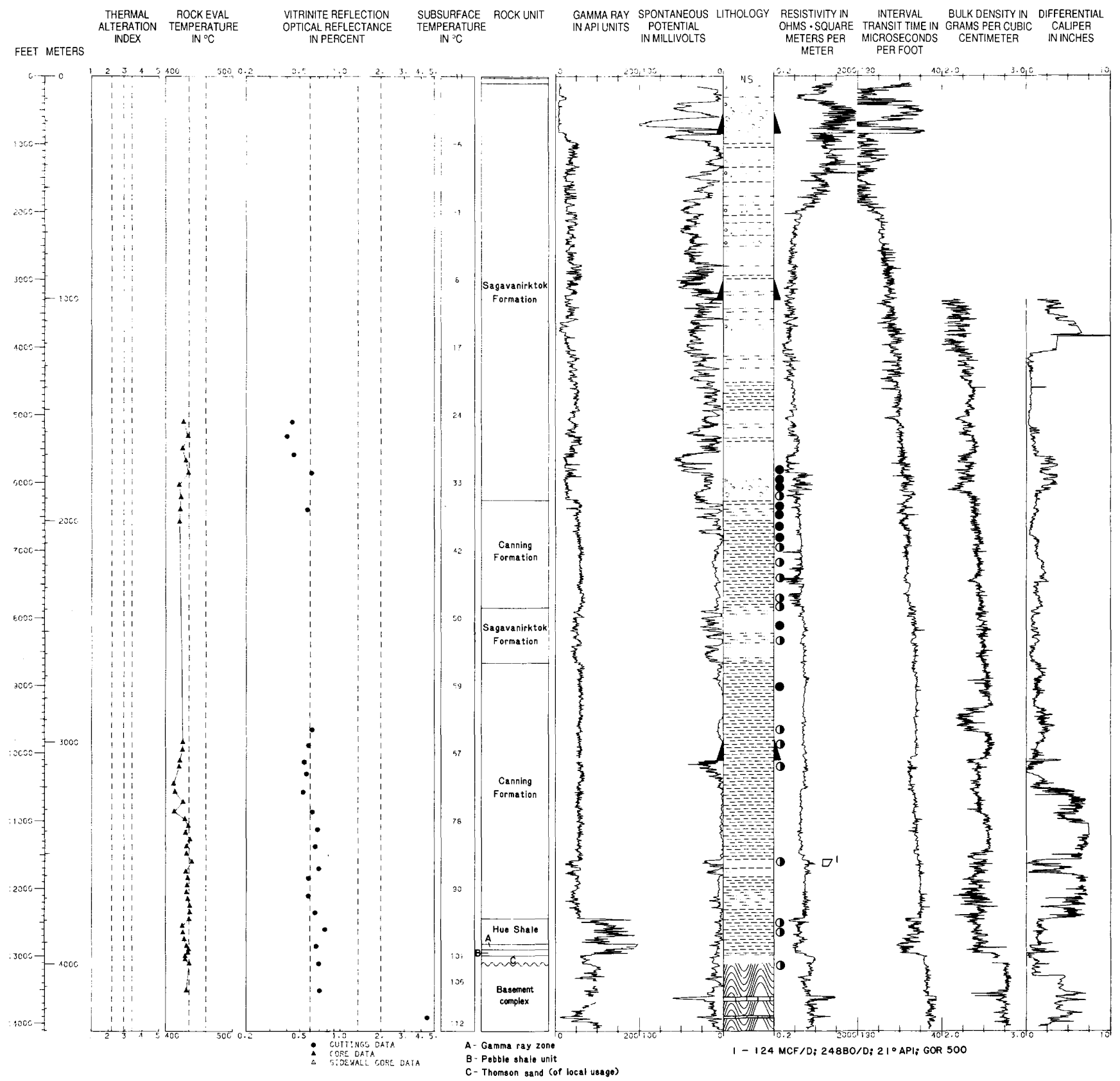




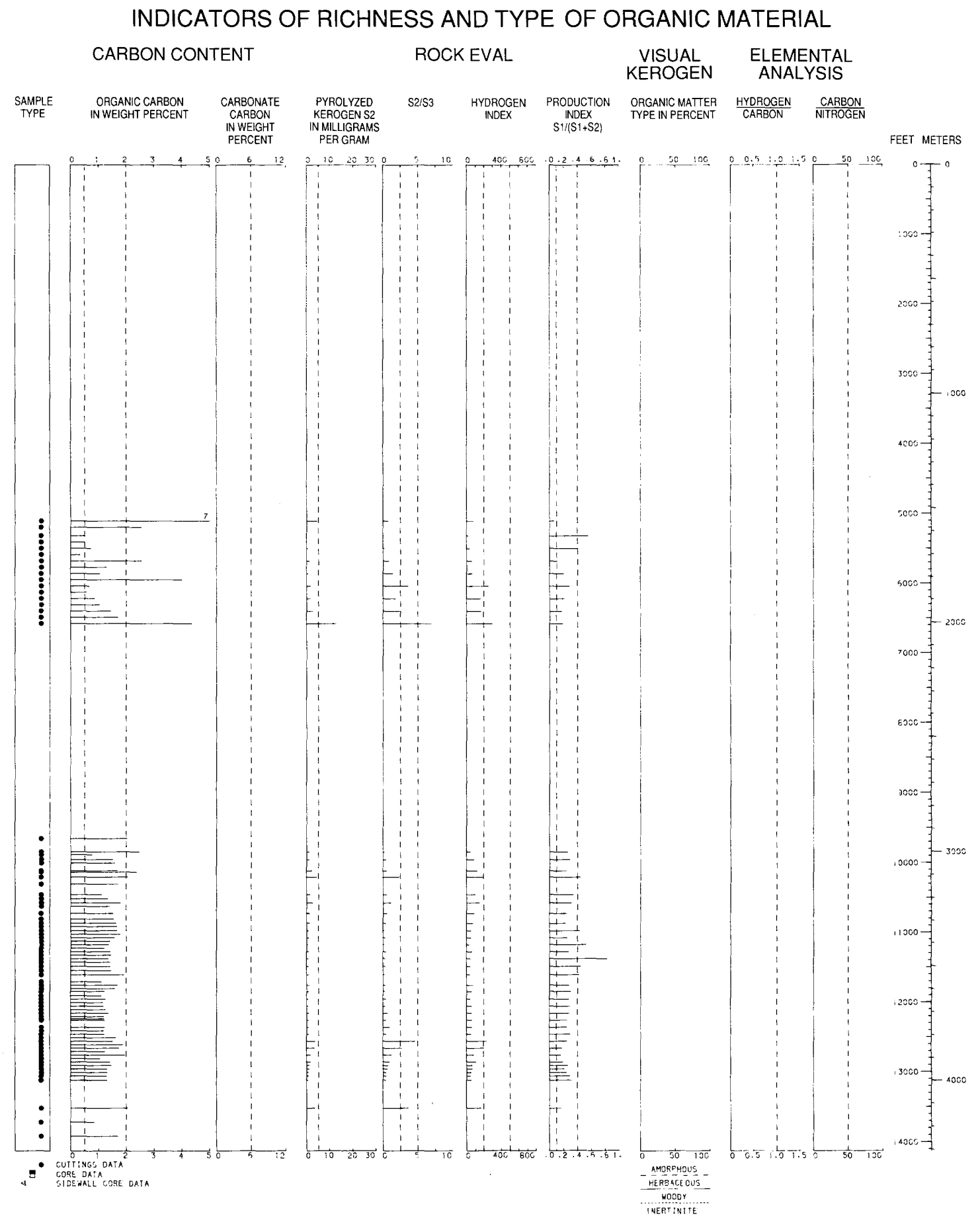




\section{E. POINT THOMSON UNIT-3}

INDICATORS OF THERMAL HISTORY

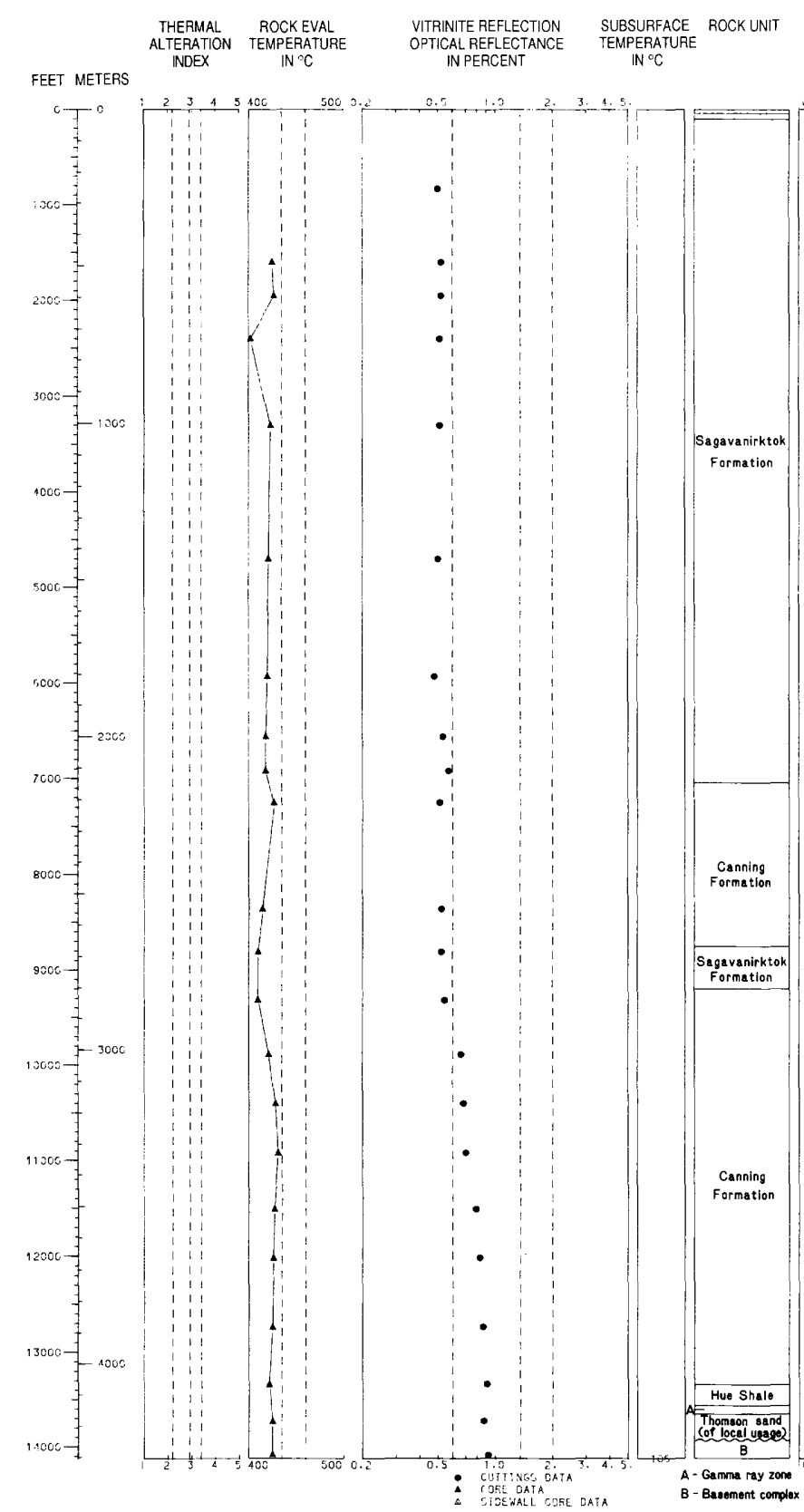

ROCK UNITS PENETRATED

GAMMARAY SPONTANEOUS LITHOLOGY RESISTIVITY IN INTERVAL BULKDENSITY IN DIFFERENTIAL INAPI UNITS POTENTIAL METERSPER MICROSECONDS CENTIMETER IN INCHES

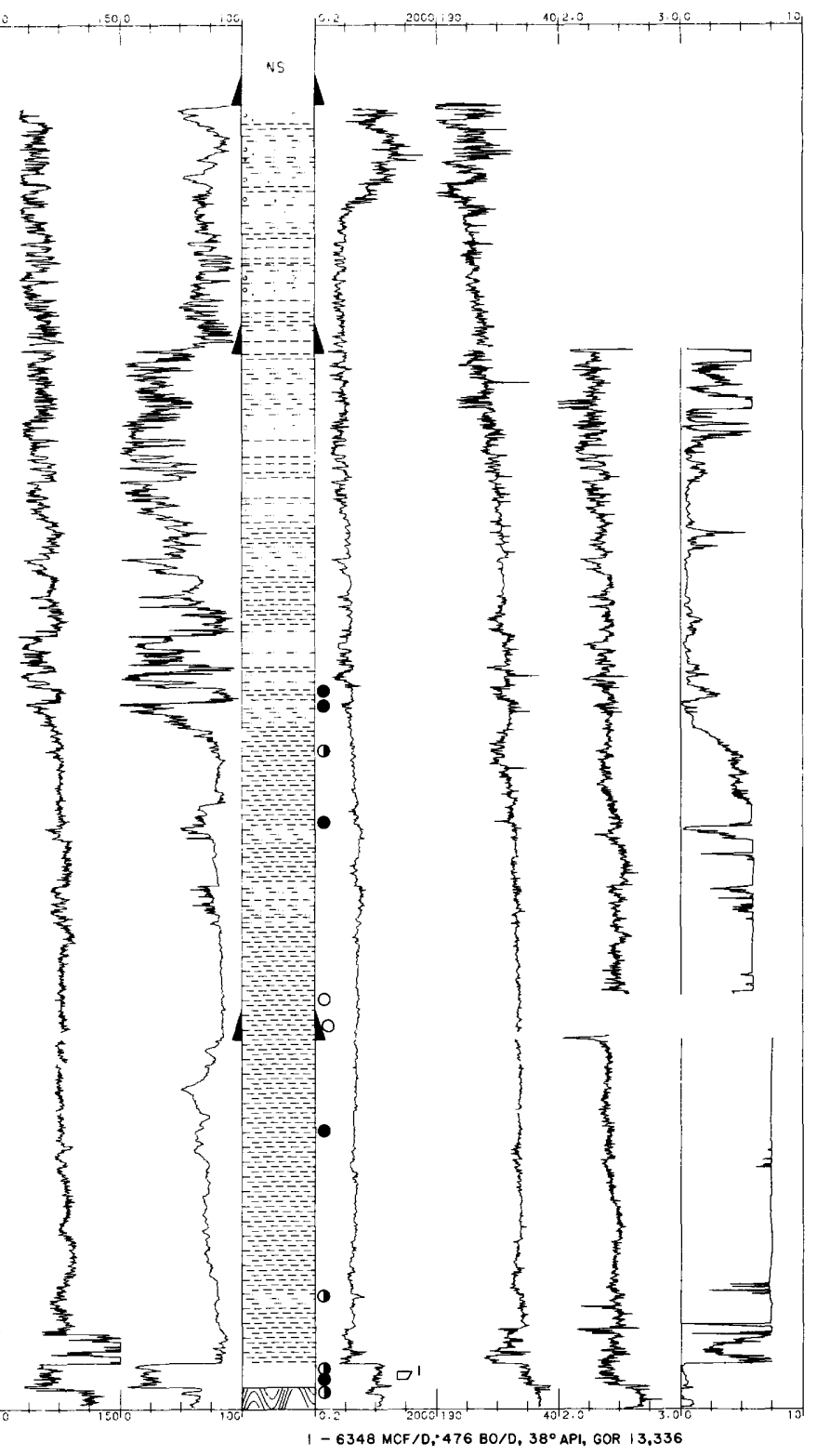




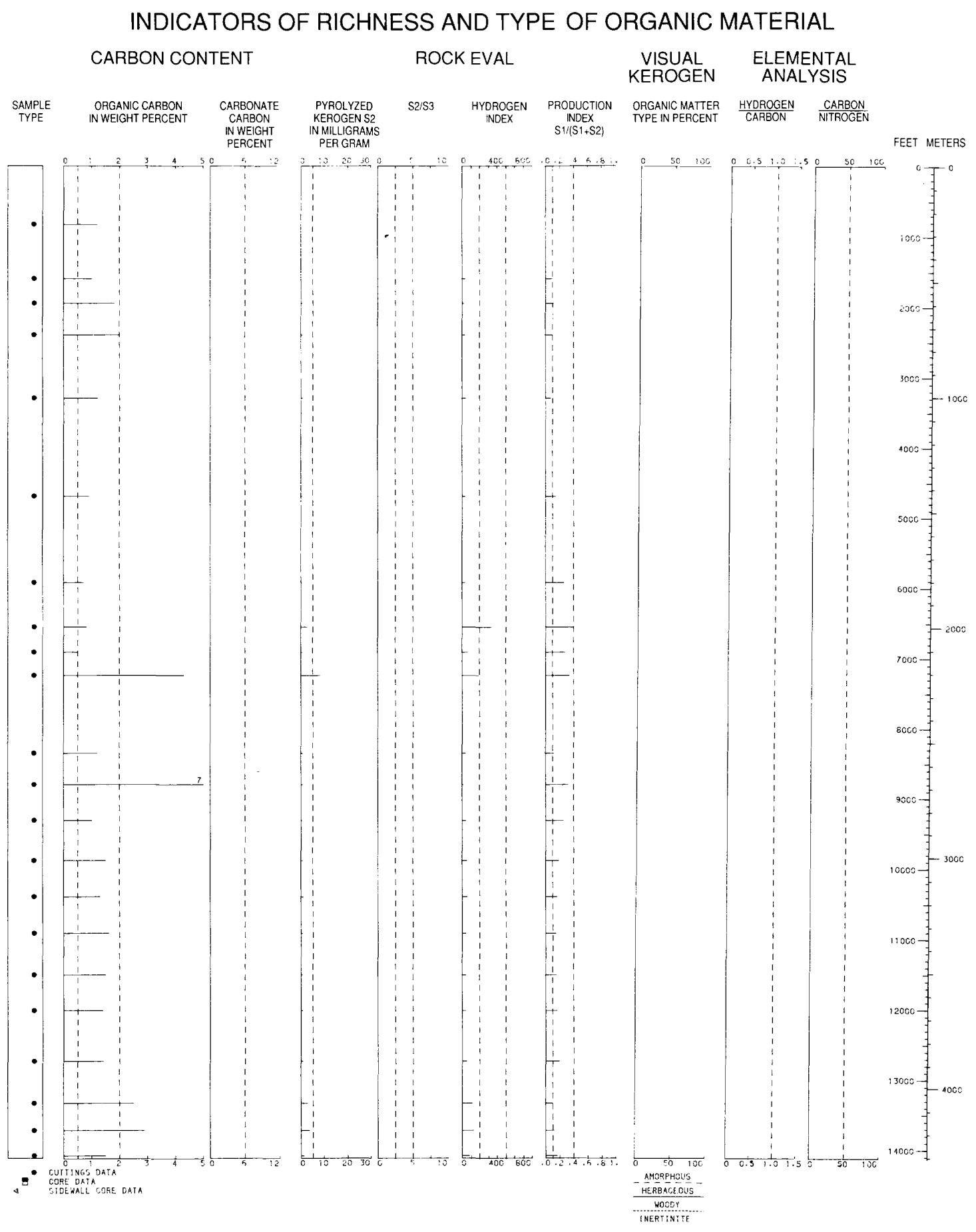


F. CHALLENGE ISLAND-1

INDICATORS OF THERMAL HISTORY

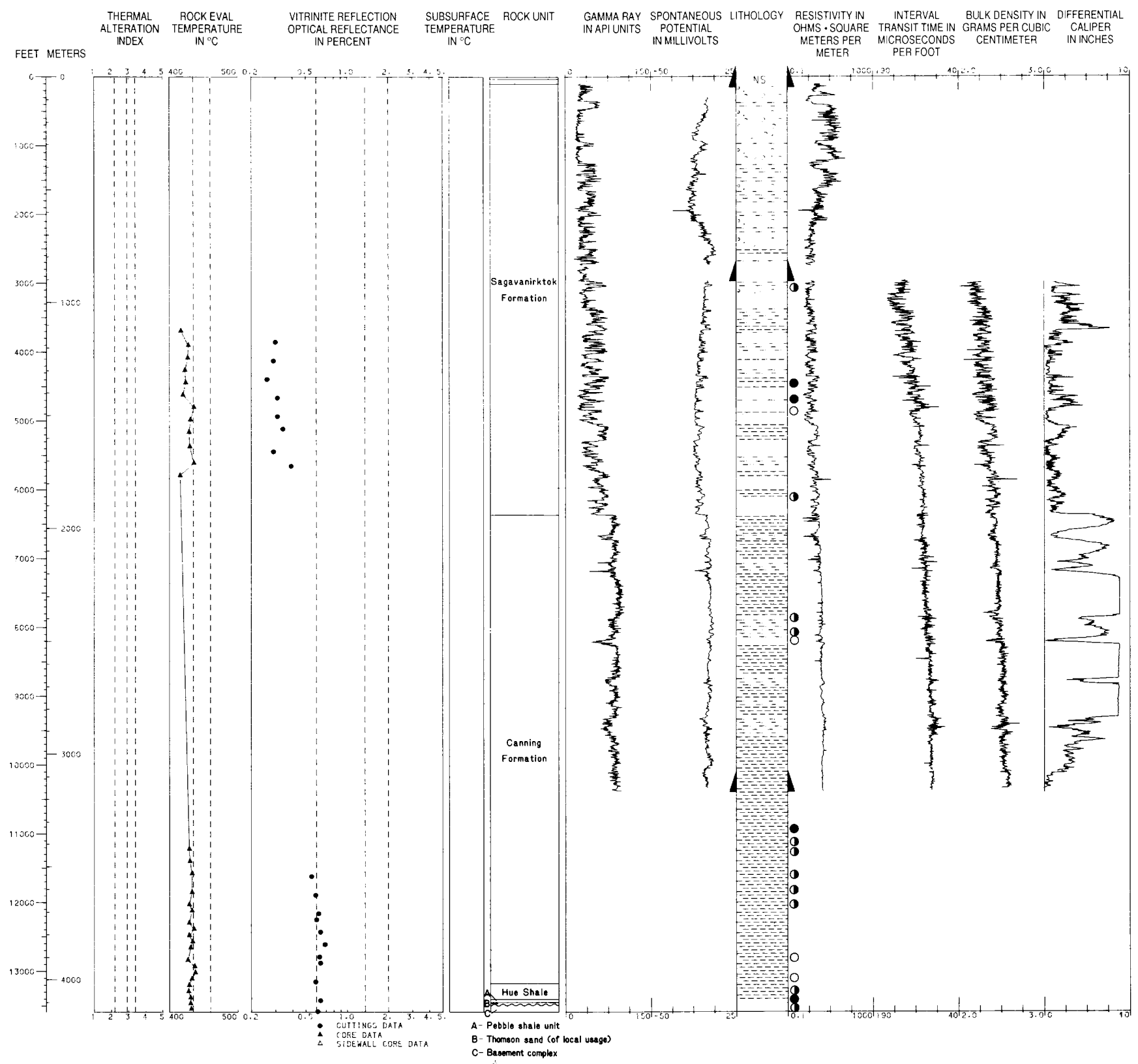




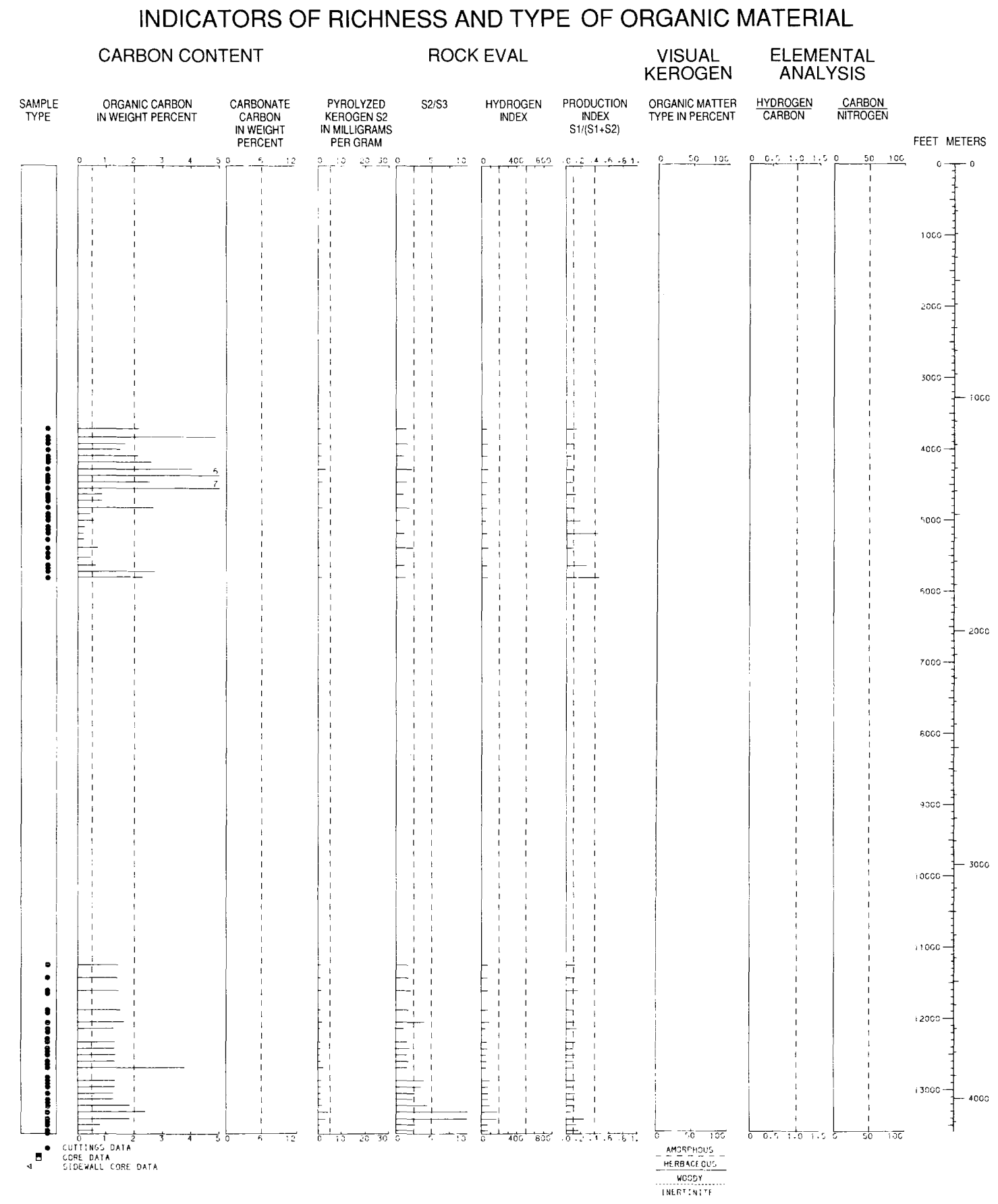


G. ALASKA STATE D-1

INDICATORS OF THERMAL HISTORY

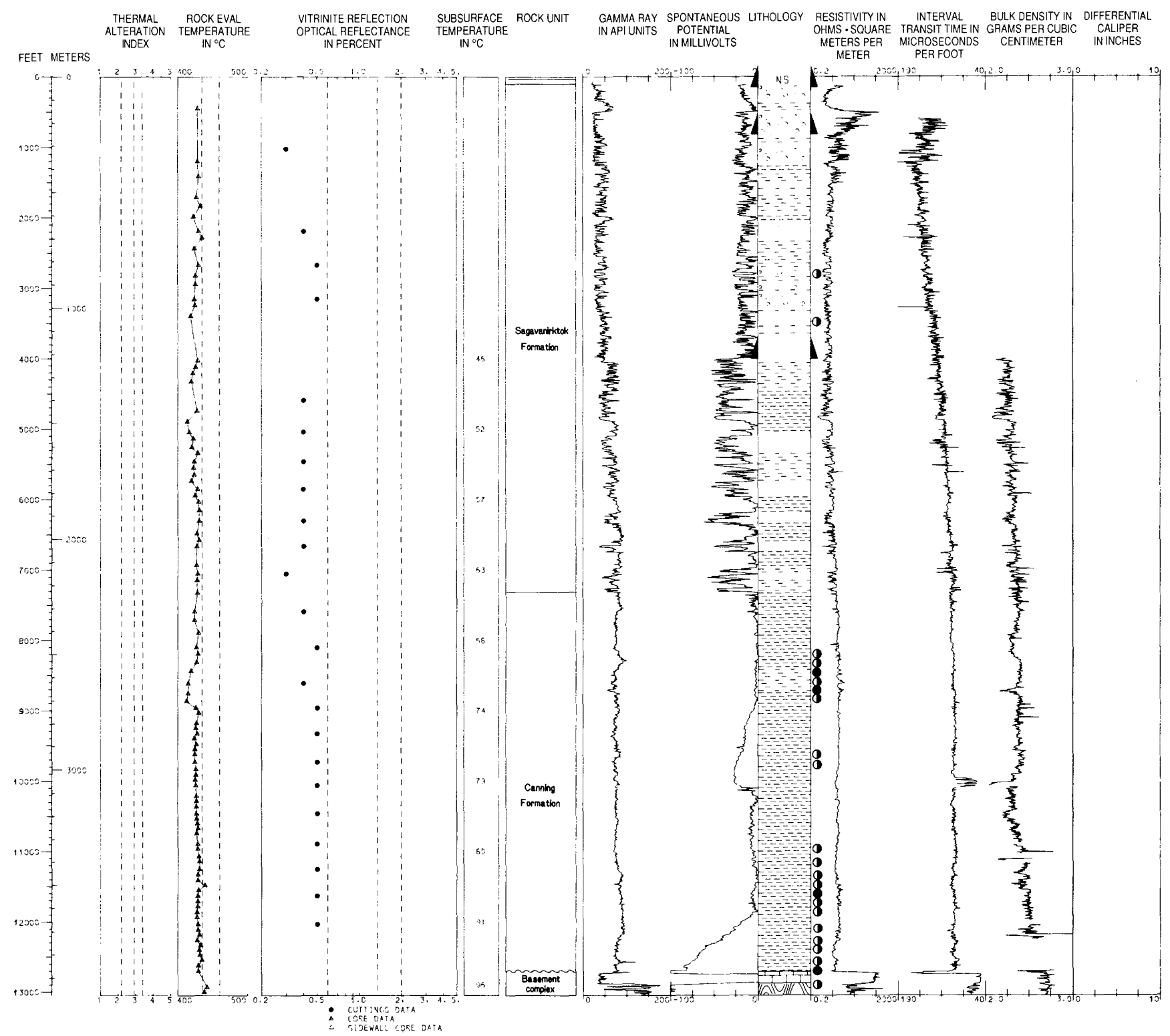




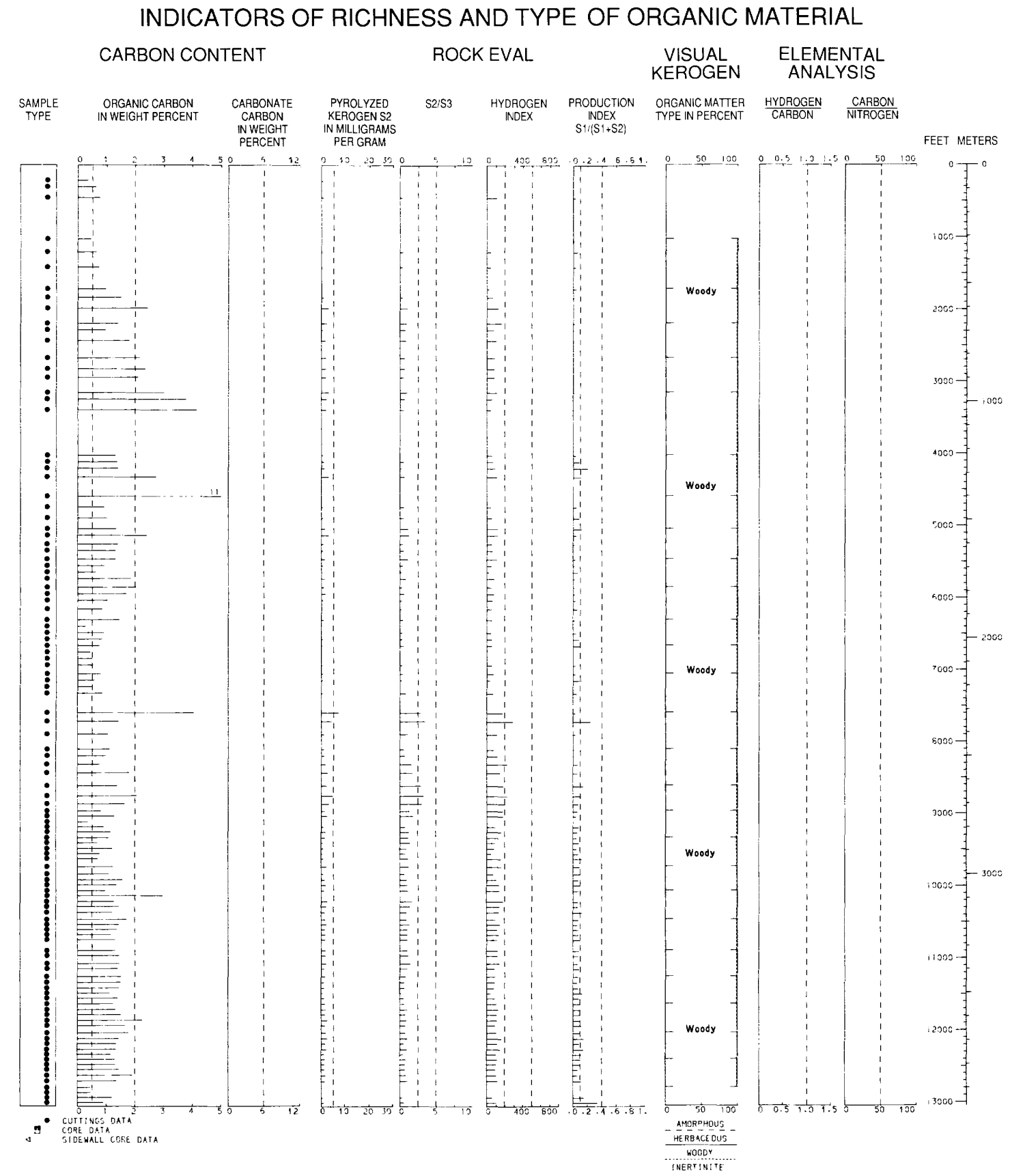


H. ALASKA ISLAND-1

INDICATORS OF THERMAL HISTORY

ROCK UNITS PENETRATED

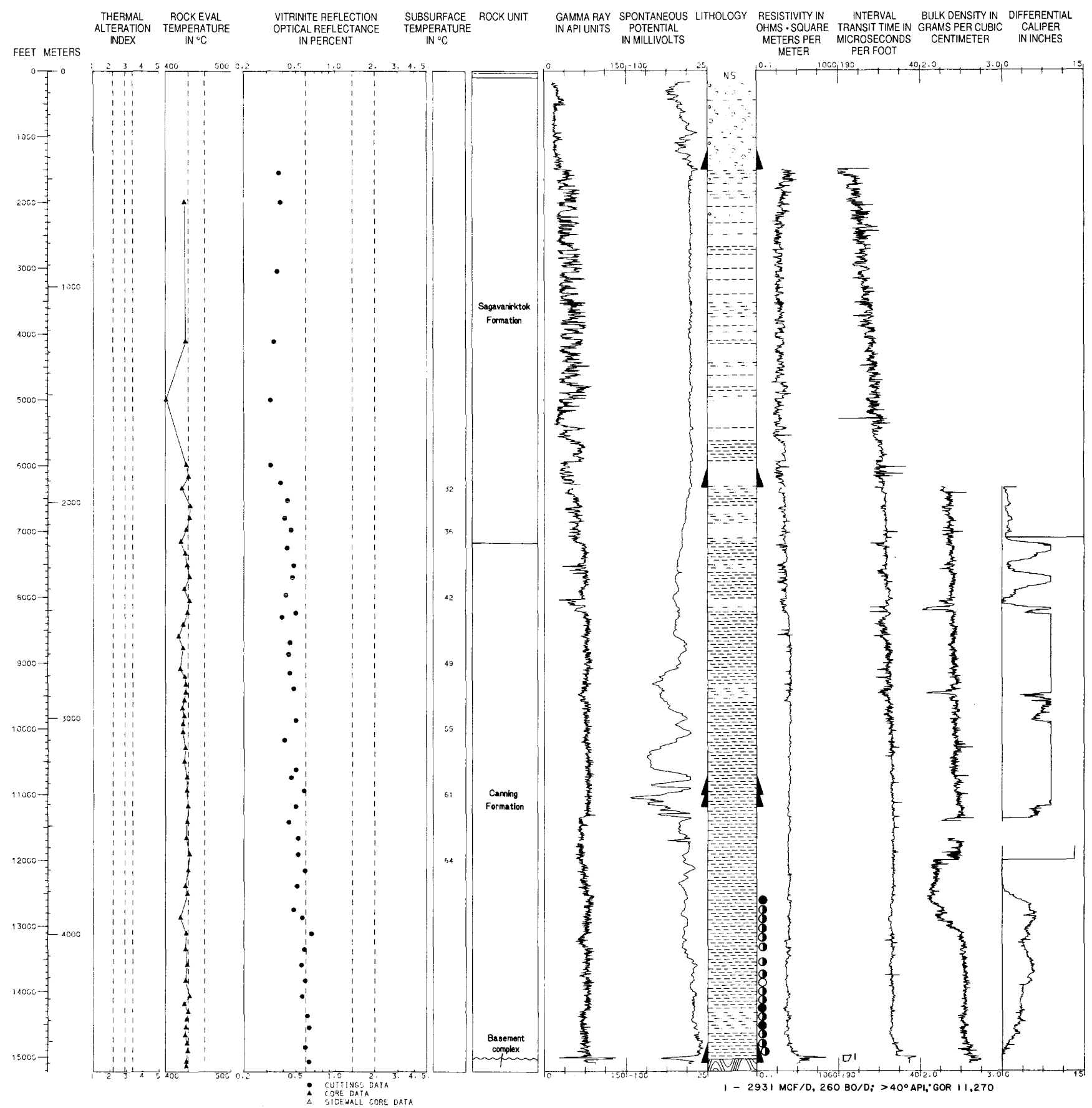




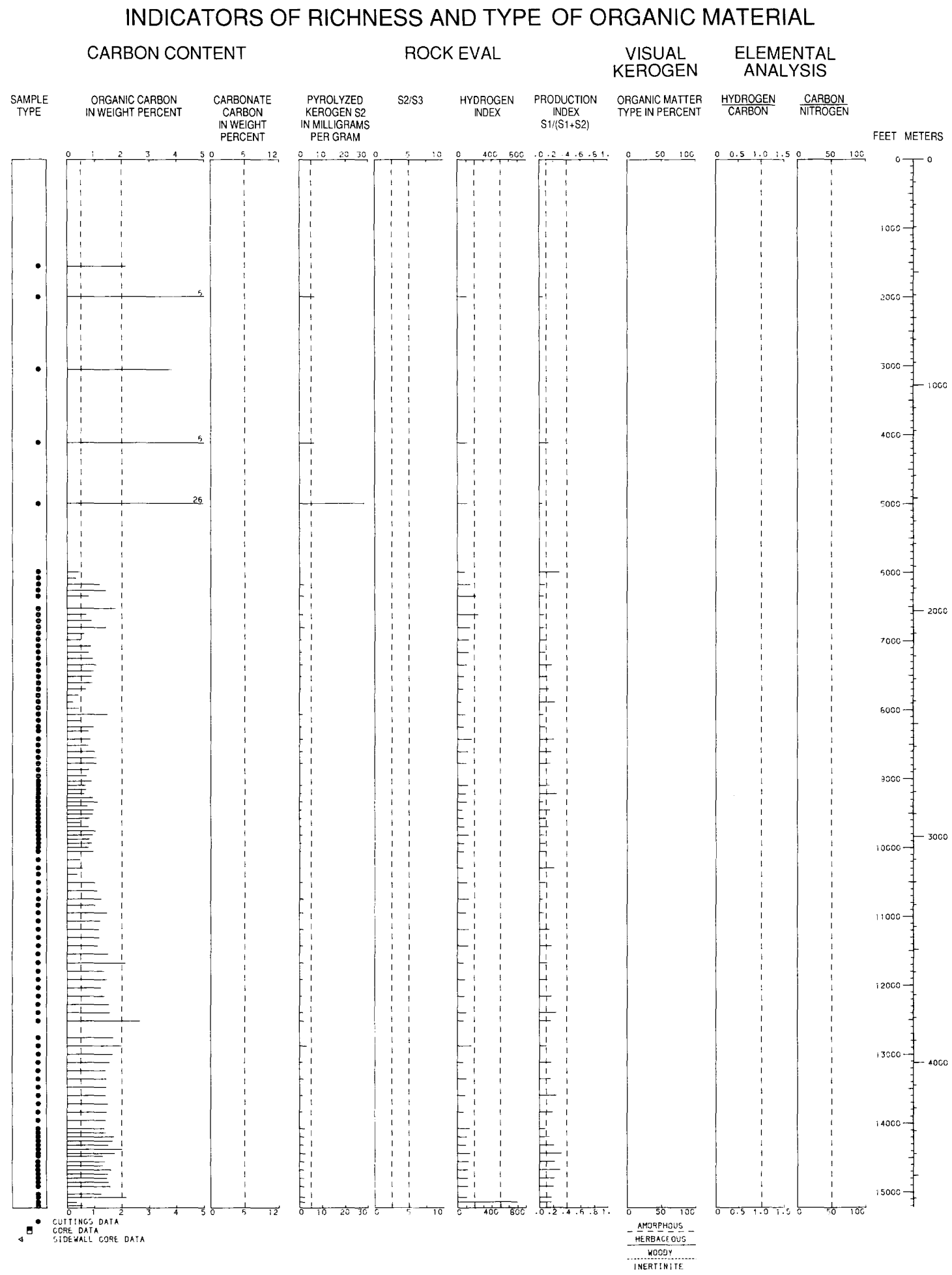




\section{ALASKA STATE F-1}

\section{INDICATORS OF THERMAL HISTORY}

ROCK UNITS PENETRATED

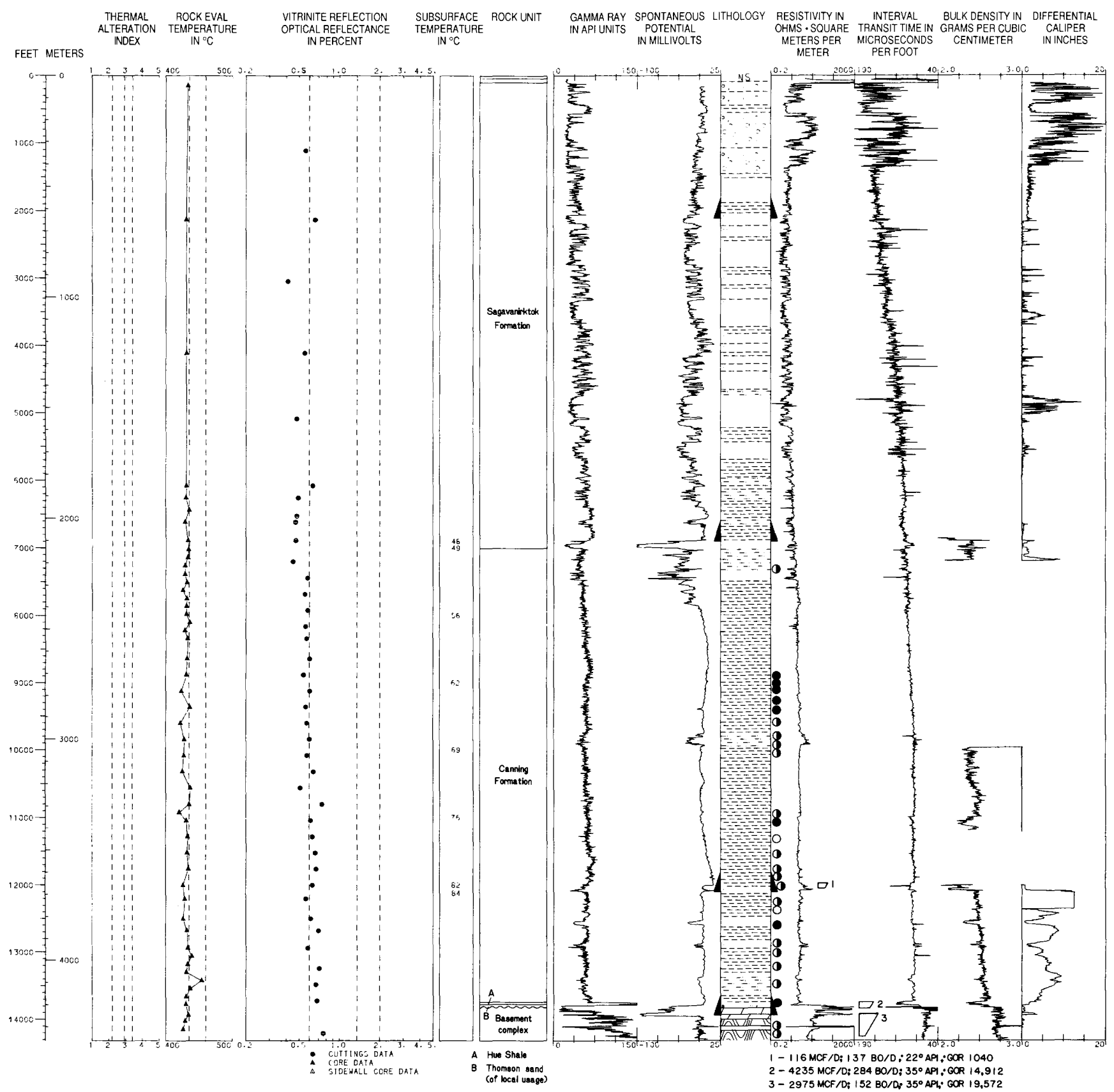




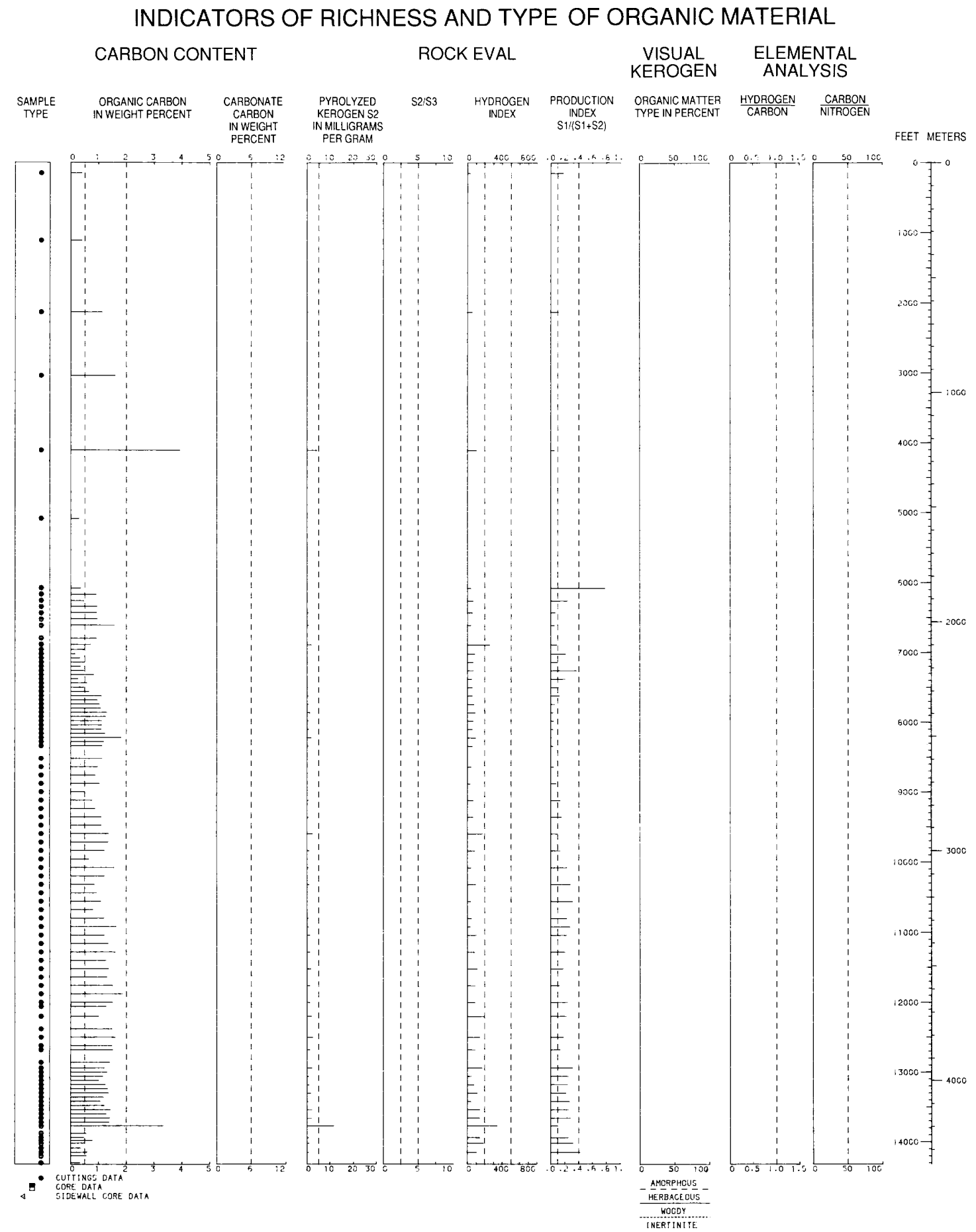




\section{J. KAVIK-1}

INDICATORS OF THERMAL HISTORY

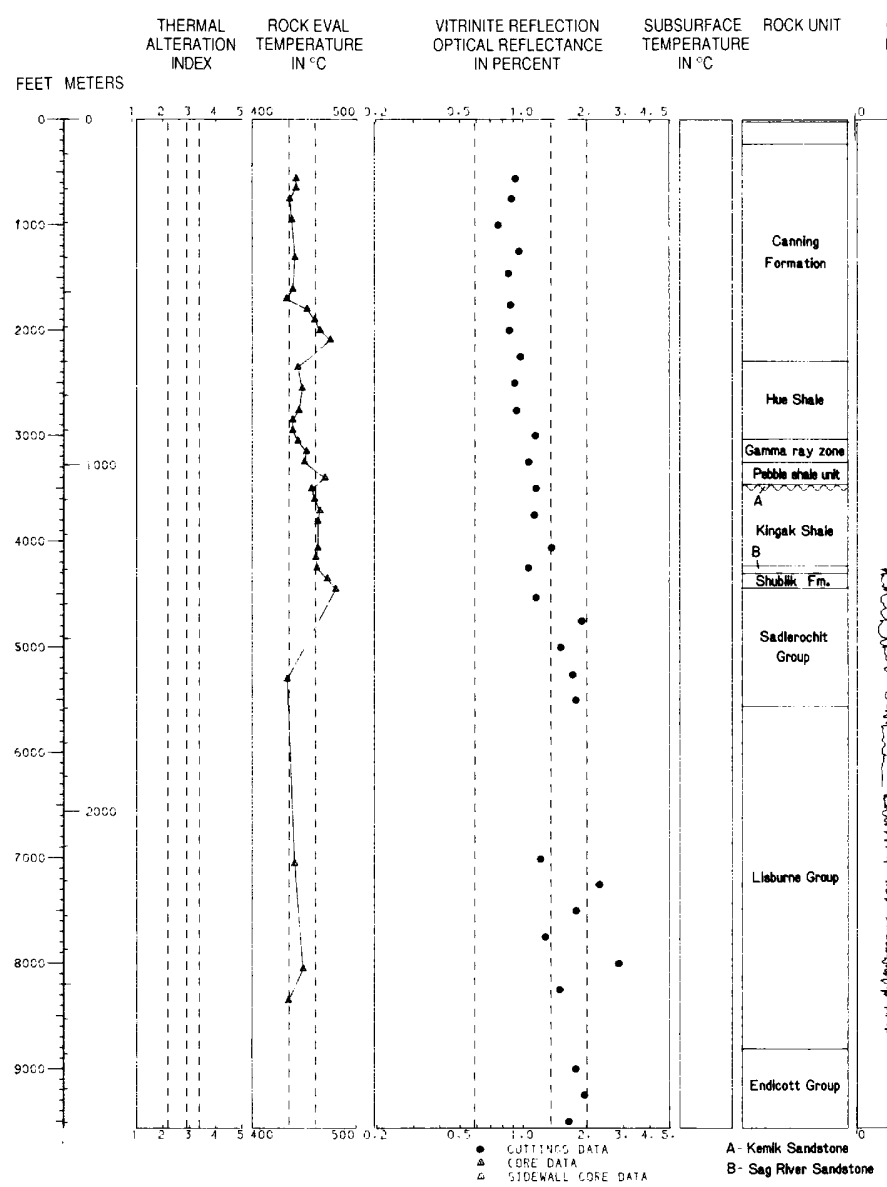

ROCK UNITS PENETRATED

GAMMA RAY SPONTANEOUS LITHOLOGY RESISTIVITYIN INTERVAL BULKDENSITYIN DIFFERENTIAL INAPIUNITS POTENTIAL OHMS - SOUARE TRANSIT TIME IN GRAMS PER CUBIC CALIPER METERS PER MICROSECON

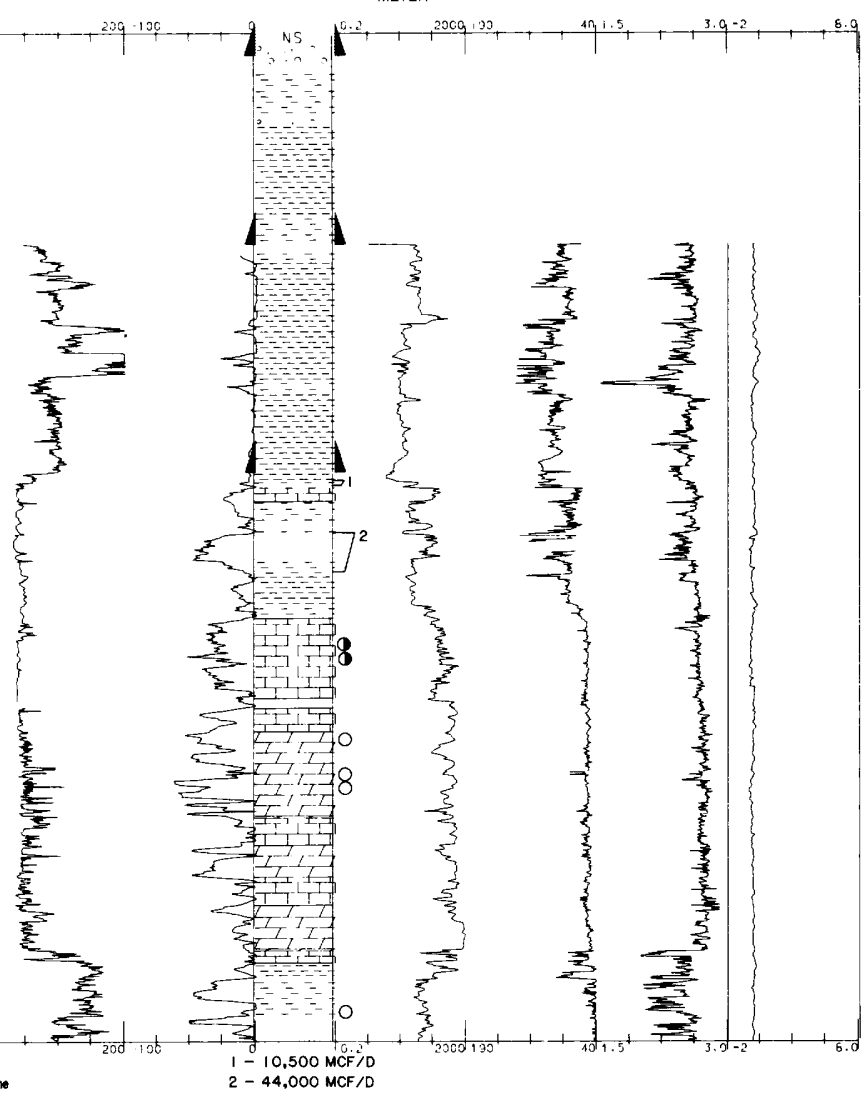




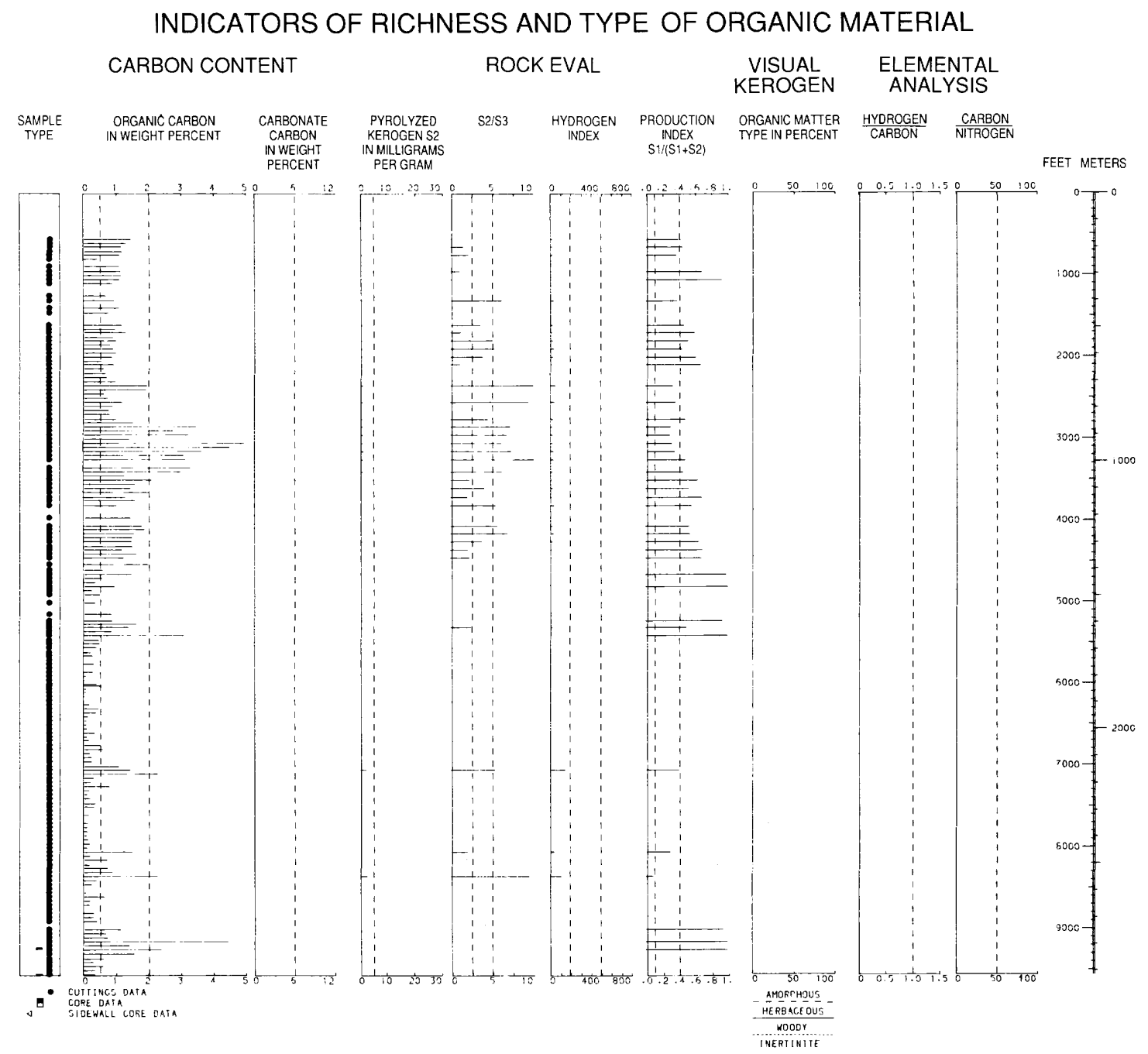




\section{K. BELI UNIT-1}

\section{INDICATORS OF THERMAL HISTORY}

ROCK UNITS PENETRATED

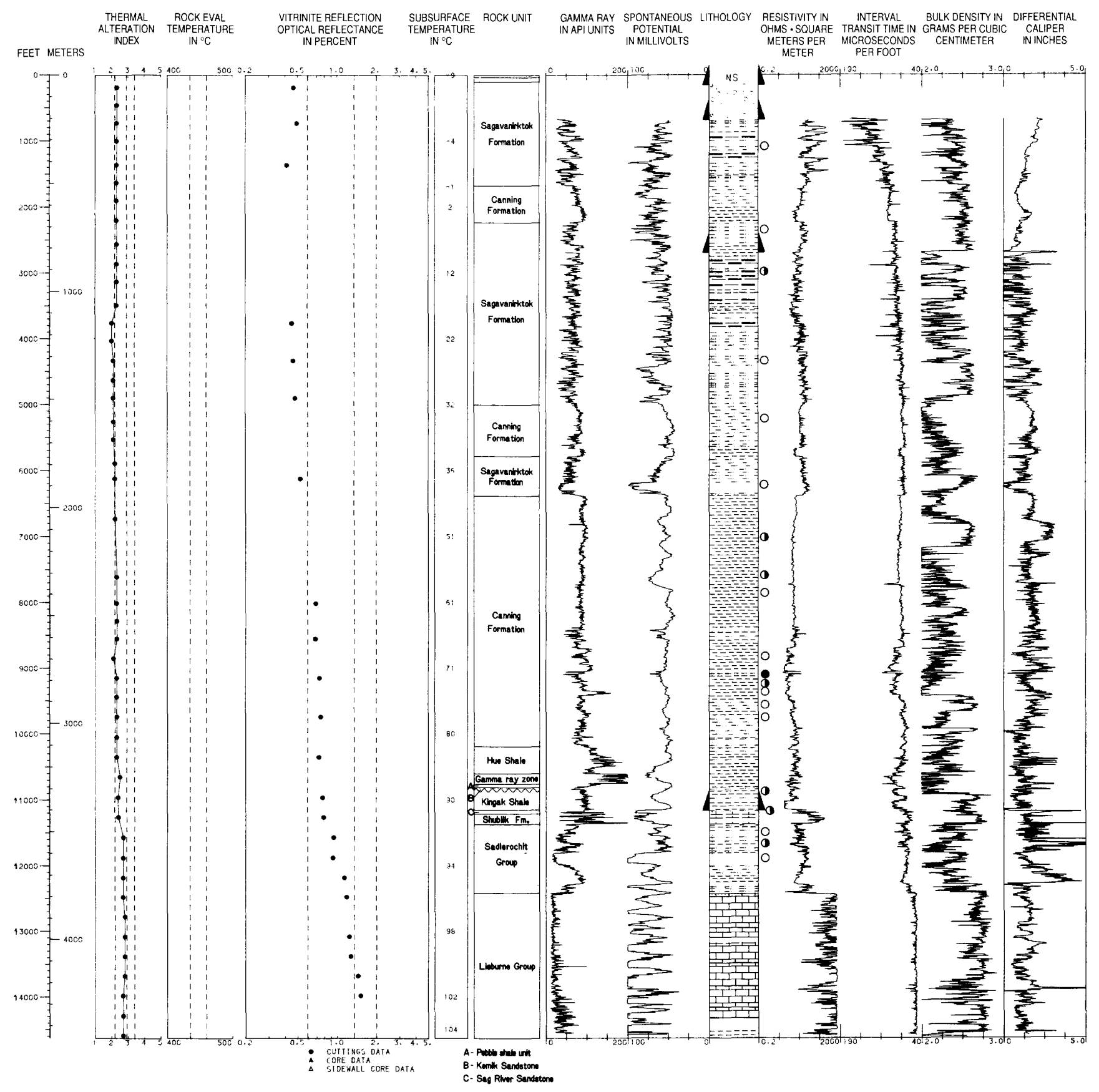




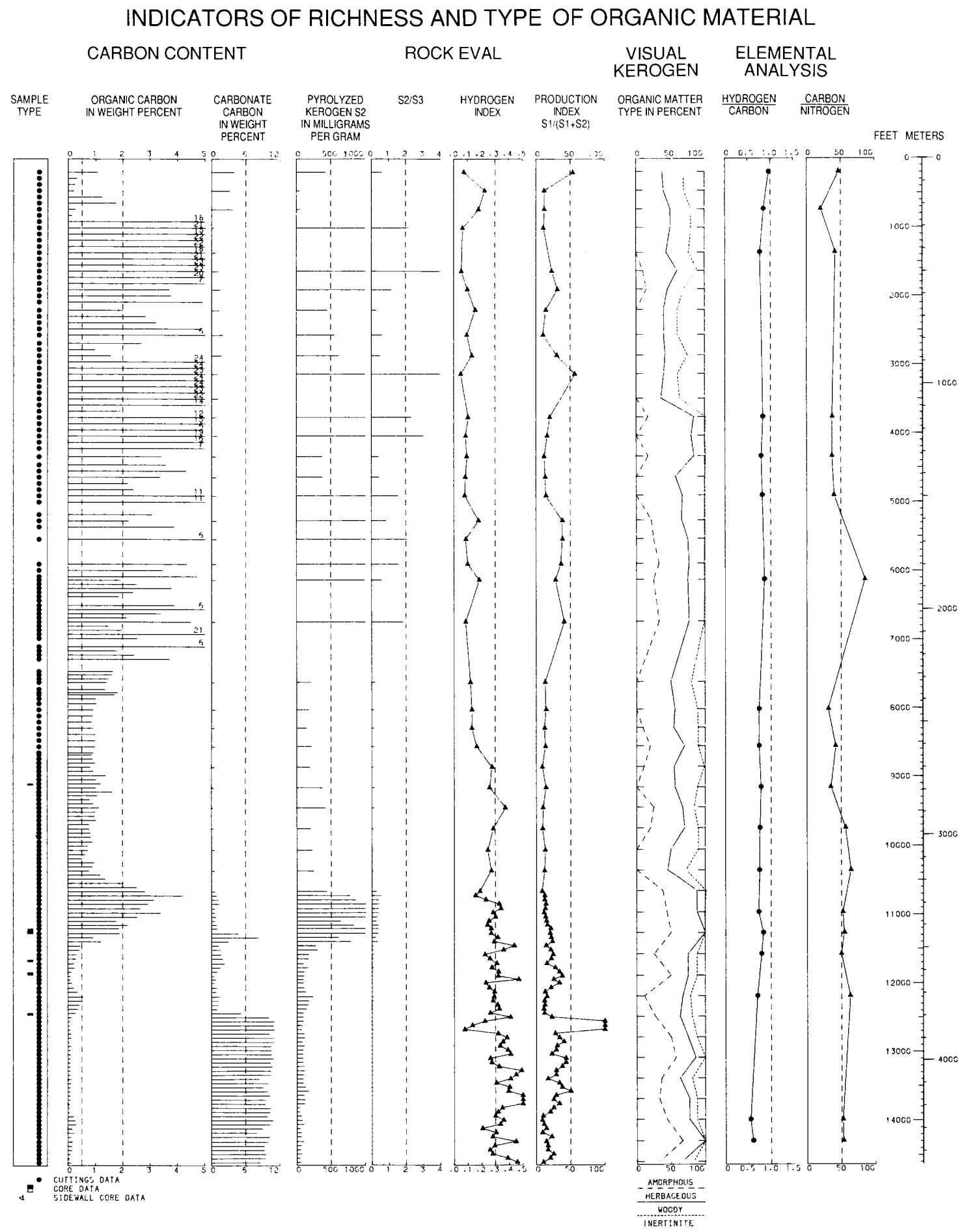




\section{CANNING RIVER UNIT A-1}

INDICATORS OF THERMAL HISTORY

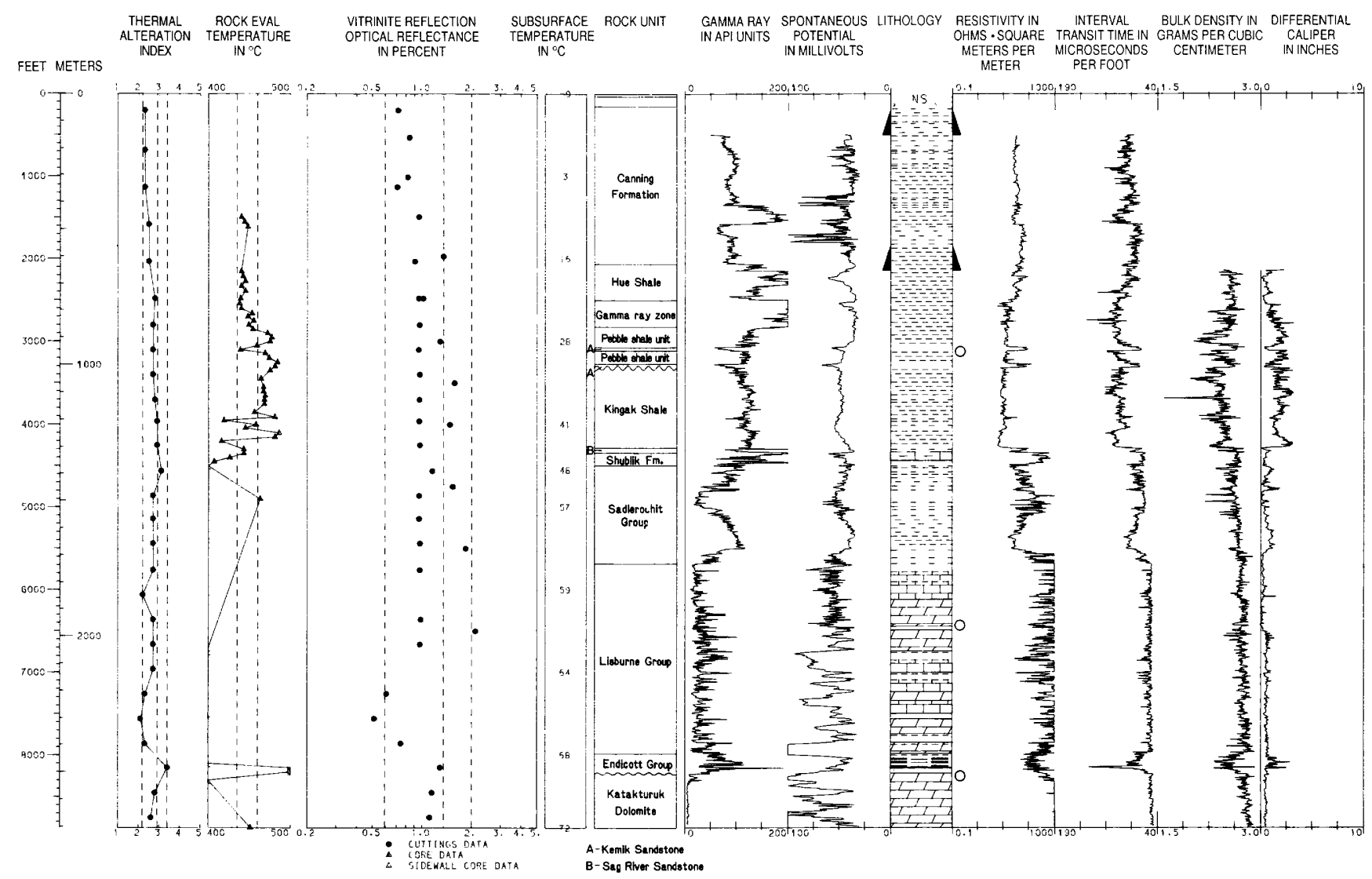




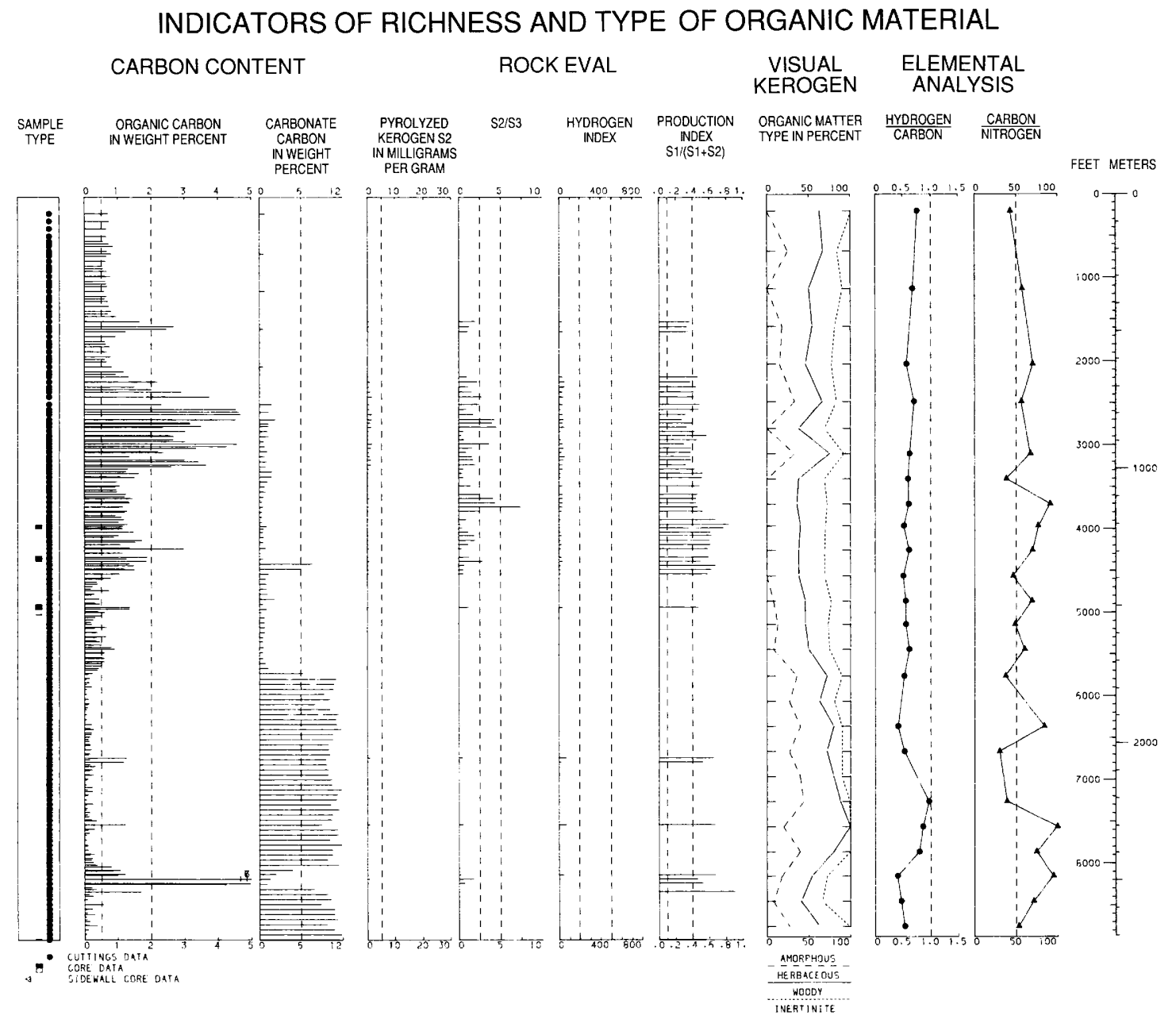


M. CANNING RIVER UNIT B-1

\section{INDICATORS OF THERMAL HISTORY}

ROCK UNITS PENETRATED

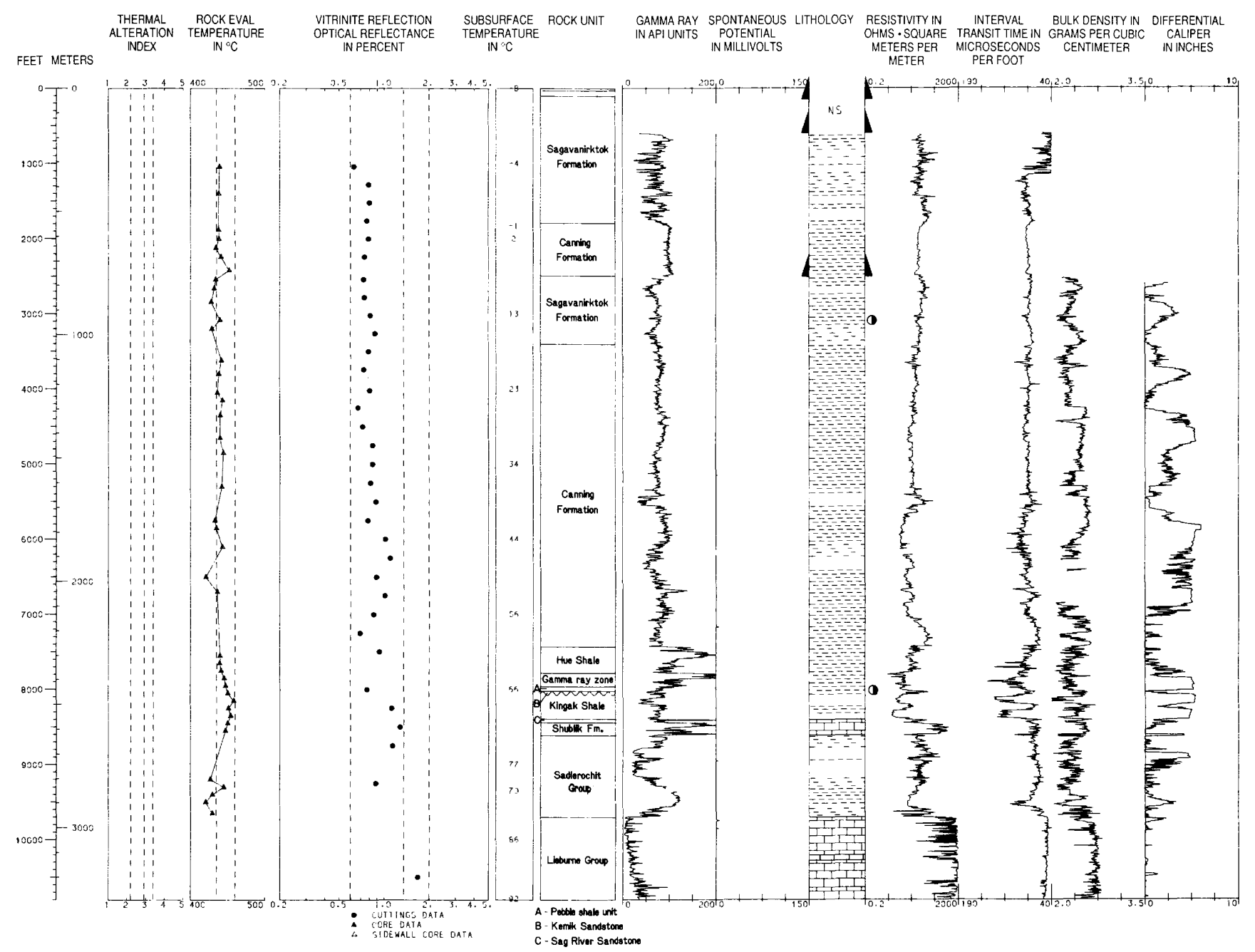




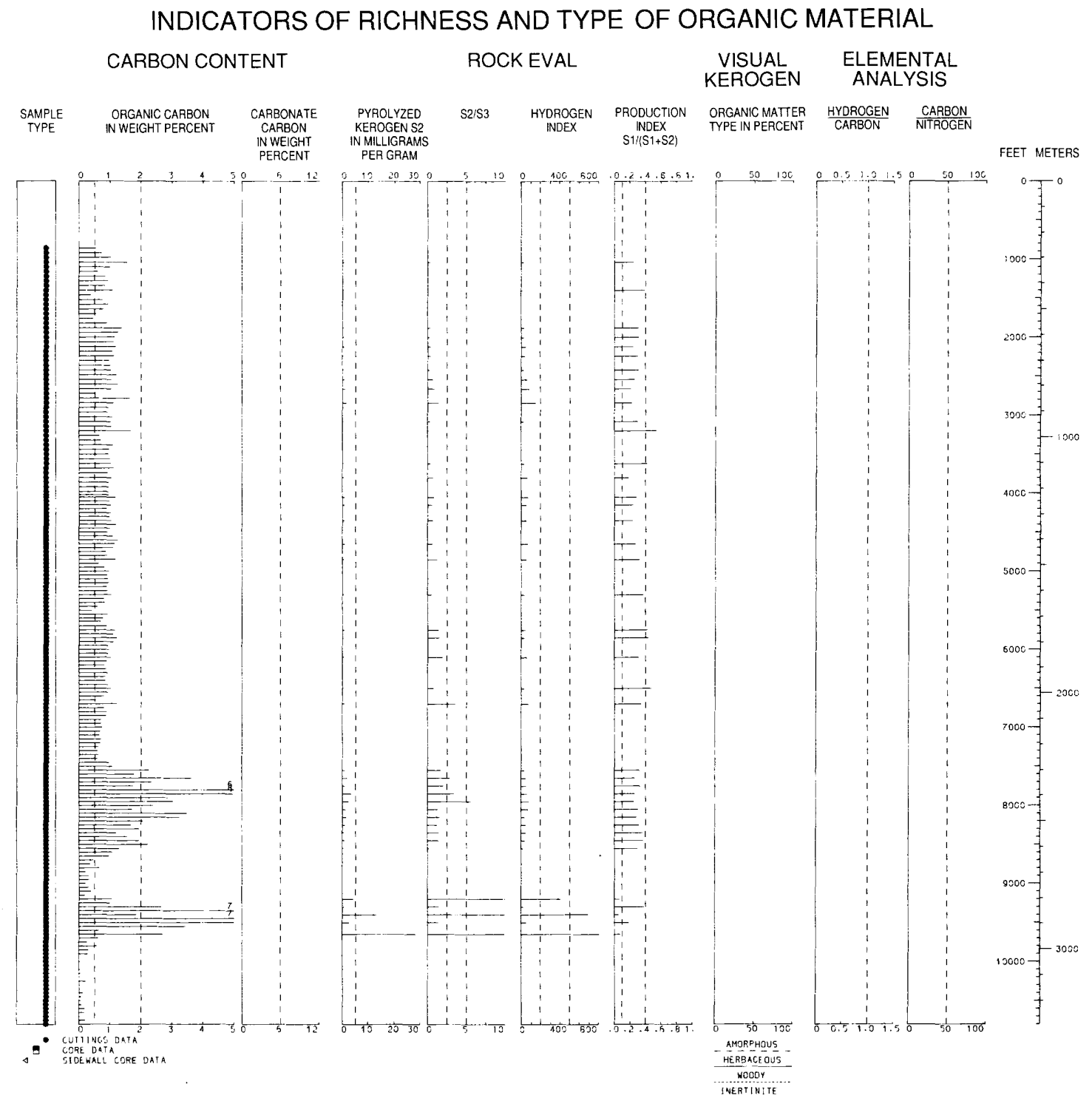




\title{
Chapter 12.
}

\section{Geochemistry of Surface Oil Shows and Potential Source Rocks}

\author{
By Donald E. Anders, ${ }^{1}$ Leslie B. Magoon, ${ }^{2}$ and Sister Carlos Lubeck ${ }^{1}$
}

\section{INTRODUCTION}

Thirteen oil seeps or oil-stained outcrops discovered in or adjacent to the coastal plain of the Arctic National Wildlife Refuge (ANWR) in northeastern Alaska indicate that commercial hydrocarbons may be present in the subsurface. This area is flanked by two important petroleum provinces-the Prudhoe Bay area to the west, which has known recoverable resources of about 13 billion barrels of oil and 37 trillion $\mathrm{ft}^{3}(1$ trillion $\mathrm{m}^{3}$ ) of gas, and the Mackenzie Delta to the east, which has known recoverable resources of about 1 billion barrels of oil and 10 trillion $\mathrm{ft}^{3}\left(0.3\right.$ trillion $\left.\mathrm{m}^{3}\right)$ of gas (table 3.1). The character and source of the hydrocarbons, as well as the geology, in these two adjoining petroleum provinces are distinctly different from each other, which makes direct extrapolation from either side into the ANWR difficult.

Subsurface geochemical information on the North Slope has been published by Morgridge and Smith (1972), Jones and Speers (1976), Seifert and others (1979), Magoon and Claypool (1981, 1984, 1985), Carman and Hardwick (1983), and Magoon and Bird (1985) for both rocks and oils. Palmer and others (1979) and Lyle and others (1980) published results for potential reservoir and source rocks in northeastern Alaska. Molenaar (1983) described the stratigraphy and depositional environments of Cretaceous and lower Tertiary rocks along the foothills of the Brooks Range from the Echooka River on the west to Bathtub Ridge on the east.

The purpose of this study is to determine the source(s) of the ANWR oil seeps and stains and to determine if the oil type(s) is similar to other North Slope oils. These other oil types include the economically important Prudhoe Bay oil and the Kingak oil as characterized by Seifert and others (1979) and Magoon and Claypool (1984), and the National Petroleum Reserve in Alaska (NPRA) oil types as characterized by Magoon and Claypool (1981, in press). The rock samples chosen for detailed geochemical

\footnotetext{
${ }^{1}$ U.S. Geological Survey, Denver, Colo.

2 U.S. Geological Survey, Menlo Park, Calif.
}

analysis are designated high grade by Magoon and others (chap. 11). Oil samples are from seeps or stained rocks on the surface in or adjacent to the ANWR.

Based on geochemical information for nine rock units in the ANWR (chap. 11), 22 outcrop samples from five rock units (Shublik Formation, Kingak Shale, pebble shale unit, Hue Shale, and Canning Formation) were selected for a more detailed source-rock evaluation and for the oil-source rock comparisons. For oil-oil and oil-source rock comparisons, nine oil samples from six surface localities in and adjacent to the ANWR, three NPRA oils, and two Prudhoe Bay oils were used. Oil-oil correlations are based on similarities in carbon isotopes, $\mathrm{C}_{19} / \mathrm{C}_{23}$ tricyclic terpane ratios, hopane/ $\mathrm{C}_{23}$ tricyclic terpane ratios, and saturate/aromatic hydrocarbon ratios; oil-source rock corrrelations are based on similarities in carbon isotopes and $\mathrm{C}_{19} / \mathrm{C}_{23}$ tricyclic terpane ratios.

\section{SAMPLE DISTRIBUTION}

The reliability of oil and gas source-rock assessment depends upon adequate geochemical characterization of the stratigraphic intervals considered. Many more samples were used to characterize each stratigraphic unit than are presented in table 12.1. West of the Canning River, most of the rock samples are from industry exploratory wells and were not available for this study; east of the Canning River, all 22 samples are from outcrops in the Sadlerochit and Shublik Mountains and from the ANWR coastal plain (fig. 12.1).

Five free-oil samples are from the South Barrow gas field (pebble shale oil), the Umiat oil field (Umiat oil), and the Cape Simpson area (Simpson oil), all in the NPRA, and from the Prudhoe Bay oil field (Prudhoe and Kingak oil types). No oil or gas samples from the Point Thomson and Kavik areas were available for this study. In the 1002 and adjacent areas, 13 oil seeps or oilstained rocks are known, but not all were available for this study. Three oil seeps are located along the coast: an unconfirmed seep at the mouth of the Canning River, and two confirmed seeps at Manning Point and Angun Point. One seep at Manning Point has the only occurrence of high API gravity (26.7) oil in the 1002 area. Samples collected from the Angun Point oil seep 
Table 12.1. Geochemical data for rock outcrops, oil-stained outcrops and surface seeps in ANWR, and oil samples from the Prudhoe Bay area and NPRA

[For sample locations, see figures 12.1, 12.2; -, not analyzed; n., negligible; im., immature; do., ditto; OC, organic carbon; HI, hydorgen index; OI, oxygen index; $\mathrm{S}_{1}+\mathrm{S}_{2}$, peak 1 plus peak 2; PI, production index; Bit., bitumen; NHC, nonhydrocarbon; HC, hydrocarbon; $\mathrm{S}$, saturated hydrocarbon; A, aromatic hydrocarbon; $\mathrm{nC}_{17}$, normal paraffin with 17 carbons; $\mathrm{Pr}$, pristane; $\mathrm{Ph}$, phytane; $\mathrm{C}_{19}$ Tri, $\mathrm{C}_{19}$ tricyclic terpane; $\mathrm{C}_{23}$ Tri, $\mathrm{C}_{23}$ tricyclic terpane; Hop, hopane; $\mathrm{C}_{31} \quad \mathrm{Hop}, \quad \mathrm{C}_{31} \quad$ hopane; $20 \mathrm{~S} / 20 \mathrm{~S}+20 \mathrm{R}, \quad \alpha \alpha \alpha \mathrm{C}_{29} 20 \mathrm{~S} / \alpha \alpha \alpha \mathrm{C}_{29} 20 \mathrm{~S}+\alpha \alpha \alpha \mathrm{C}_{29} 20 \mathrm{R} \quad$ steranes; $\Sigma \beta / \Sigma \beta+\Sigma \alpha$, $\beta \beta \mathrm{C}_{29} 20 \mathrm{~S}+\beta \beta \mathrm{C}_{29} 20 \mathrm{R} / \beta \beta \mathrm{C}_{29} 20 \mathrm{~S}+\beta \beta \mathrm{C}_{29} 20 \mathrm{R}+\alpha \alpha \mathrm{C}_{29} 20 \mathrm{~S}+\alpha \alpha \mathrm{C}_{29} 20 \mathrm{R}$ steranes; $\mathrm{C}_{28} / \mathrm{C}_{28}+\mathrm{C}_{29}, \mathrm{C}_{28} 20 \mathrm{R}$ triaromatic/C $2820 \mathrm{R}$ triaromatic $+\mathrm{C}_{29} 20 \mathrm{R}$ monoaromatic steranes]

\begin{tabular}{|c|c|c|c|c|c|c|c|c|c|c|c|c|c|c|c|c|}
\hline \multirow[b]{2}{*}{ Sample } & \multirow{2}{*}{$\begin{array}{l}\text { Rock unit, } \\
\text { well, or } \\
\text { outcrop }\end{array}$} & \multicolumn{6}{|c|}{ Rock Eval } & \multirow{2}{*}{$\begin{array}{l}\text { Vit. } \\
\text { ref. } \\
\text { (pct } \\
\mathrm{R}_{\mathrm{o}} \text { ) }\end{array}$} & \multicolumn{6}{|c|}{ Extraction } & \multicolumn{2}{|c|}{ Isotope } \\
\hline & & $\begin{array}{c}O C \\
\text { (wt pct) }\end{array}$ & $\mathrm{HI}$ & OI & $\begin{array}{l}\mathrm{S}_{1}+\mathrm{S}_{2} \\
(\mathrm{~kg} / \mathrm{t})\end{array}$ & PI & $\begin{array}{l}\mathrm{T}_{\max } \\
\left({ }^{\circ} \mathrm{C}\right)\end{array}$ & & $\begin{array}{c}\text { Bit. } \\
\text { (ppm) }\end{array}$ & $\begin{array}{c}\text { Bit./OC } \\
\text { (pct) }\end{array}$ & $\begin{array}{l}\text { NHC } \\
(\mathrm{ppm})\end{array}$ & $\begin{array}{c}\mathrm{HC} \\
(\mathrm{ppm})\end{array}$ & $\begin{array}{c}\mathrm{HC} / \mathrm{OC} \\
(\mathrm{pct})\end{array}$ & S/A & $\begin{array}{c}\delta^{13} \mathrm{C} \\
S\end{array}$ & $\begin{array}{c}\delta^{13} \mathrm{C} \\
\mathrm{A}\end{array}$ \\
\hline \multicolumn{17}{|c|}{ Outcrop samples from the Arctic National Wildlife Refuge } \\
\hline 1 & Canning Shale & 1.5 & 69 & 90 & 0.76 & 0.03 & 424 & - & 202 & 1.3 & 78 & 83 & 0.6 & 1.4 & -28.6 & -27.7 \\
\hline 2 & do. & 2.7 & 167 & 17 & 4.93 & .04 & 438 & 1.0 & 1,576 & 5.8 & 321 & 993 & 3.7 & 2.1 & -28.7 & -28.5 \\
\hline 3 & Hue Shale & 3.1 & 26 & 41 & .93 & .16 & 432 & 1.0 & 1,012 & 3.3 & 187 & 703 & 2.3 & 1.3 & -27.6 & -27.0 \\
\hline 4 & do. & 5.0 & 48 & 12 & 2.10 & .05 & 435 & 1.2 & 1,220 & 2.4 & 161 & 903 & 1.8 & 3.5 & -25.9 & -26.2 \\
\hline 5 & do. & 15.6 & 505 & 27 & 80.84 & .03 & 404 & - & 8,094 & 5.2 & 3,280 & 4,209 & 2.7 & 1.2 & -28.3 & -27.8 \\
\hline 6 & do. & 8.0 & 429 & 19 & 38.04 & .10 & 411 & - & 8,673 & 10.8 & 1,441 & 6,266 & 7.8 & 1.9 & -29.0 & -28.0 \\
\hline 7 & do. & 14.2 & 456 & 19 & 66.82 & .03 & 406 & - & 9,707 & 6.8 & 3,808 & 5,388 & 3.8 & 1.3 & -28.4 & -28.8 \\
\hline 8 & do. & 5.9 & 324 & 24 & 20.30 & .06 & 409 & .5 & 3,062 & 5.2 & 1,077 & 1,838 & 3.1 & 1.5 & -29.4 & -29.4 \\
\hline 9 & do. & 18.3 & 471 & 23 & 88.40 & .03 & 408 & .5 & 7,500 & 4.1 & 4,202 & 2,392 & 1.3 & .9 & -28.6 & -27.6 \\
\hline 10 & do. & 3.9 & 51 & 12 & 2.60 & .04 & 450 & - & 947 & 2.4 & 182 & 697 & 1.8 & 2.1 & -27.4 & -27.9 \\
\hline 11 & do. & 2.5 & 53 & 38 & .92 & .08 & 431 & 1.0 & 791 & 3.2 & 137 & 583 & 2.3 & 3.1 & -27.1 & -26.9 \\
\hline 12 & do. & 4.6 & 19 & 62 & .79 & .09 & 437 & 1.1 & 715 & 1.6 & 137 & 501 & 1.1 & 2.2 & -27.4 & -26.6 \\
\hline 13 & pebble shale unit & 6.3 & 11 & 90 & .62 & .03 & 405 & .5 & 425 & .7 & 312 & 80 & .1 & .6 & - & -25.2 \\
\hline 14 & do. & 3.5 & 19 & 27 & .59 & .07 & 538 & 1.6 & 254 & .7 & 59 & 88 & .3 & .1 & -25.3 & -22.4 \\
\hline 15 & do. & 4.3 & 24 & 16 & 1.20 & .10 & 502 & 1.8 & 507 & 1.2 & 109 & 247 & .6 & 1.0 & -23.6 & -22.3 \\
\hline 16 & do. & 4.8 & 19 & 18 & .99 & .07 & 526 & 1.5 & 848 & 1.8 & 221 & 439 & .9 & 1.1 & -24.9 & -22.2 \\
\hline 17 & Kingak Shale & 4.5 & 20 & 58 & 1.22 & .25 & 406 & .5 & 2,144 & 4.8 & 392 & 1,323 & 2.9 & 3.6 & -28.9 & -27.6 \\
\hline 18 & do. & 2.7 & 25 & 75 & .73 & .07 & 426 & - & 205 & .8 & 57 & 106 & .4 & 1.6 & -28.3 & -27.3 \\
\hline 19 & do. & .9 & 35 & 27 & .44 & .30 & 462 & 1.4 & 364 & 4.0 & 60 & 228 & 2.5 & 5.0 & -26.3 & -25.5 \\
\hline 20 & Shublik Formation & 2.1 & 17 & 19 & .50 & .06 & 560 & 1.9 & 129 & .6 & 44 & 78 & .4 & 2.9 & -27.3 & -28.1 \\
\hline 21 & do. & 2.1 & 12 & 23 & .36 & .11 & 569 & 2.1 & 214 & 1.0 & 55 & 108 & .5 & 4.1 & -27.4 & -26.7 \\
\hline 22 & do. & 2.5 & 19 & 32 & .42 & .07 & 539 & 1.8 & 137 & .5 & 60 & 71 & .3 & 3.4 & -29.1 & -27.9 \\
\hline \multicolumn{17}{|c|}{ Oils from the Prudhoe Bay area and the National Petroleum Reserve in Alaska } \\
\hline 23 & Kavearak Point- $1^{1}$ & - & - & - & - & - & - & - & - & - & $8.2^{2}$ & $91.8^{2}$ & - & 3.8 & -31.8 & -30.5 \\
\hline 24 & Prudhoe Bay Unit D-3 ${ }^{1}$ & - & - & - & - & - & - & - & - & - & 20.2 & 79.8 & - & 1.4 & -29.6 & -29.1 \\
\hline 25 & Umiat-4 & - & - & - & - & - & - & - & - & - & 1.2 & 98.8 & - & 4.0 & -28.0 & -26.7 \\
\hline 26 & Simpson Shot-Hole & - & - & - & - & - & - & - & - & - & 5.7 & 94.3 & - & 4.1 & -28.4 & -27.5 \\
\hline 27 & So. Barrow- $20^{1}$ & - & - & - & - & - & - & - & - & - & 12.0 & 88.0 & - & 3.1 & -29.1 & -28.7 \\
\hline \multicolumn{17}{|c|}{ Oil-stained outcrops and surface seeps from the Arctic National Wildlife Refuge } \\
\hline 28 & Kavik outcrop & 2.8 & - & - & - & - & - & - & 26,400 & 94.3 & $80.9^{2}$ & $19.1^{2}$ & 18.0 & 3.8 & -26.7 & -27.8 \\
\hline 29 & So. Katakturuk outcrop & .5 & - & - & - & - & - & - & 4,240 & 84.8 & 9.3 & 90.7 & 76.9 & 5.2 & -29.5 & -28.8 \\
\hline 30 & No. Katakturuk outcrop & 2.3 & - & - & - & - & - & - & 20,240 & 88.0 & 73.8 & 26.2 & 23.1 & 2.6 & -29.3 & -28.1 \\
\hline 31 & Angun Point outcrop & 7.9 & - & - & - & - & - & - & 69,520 & 88.0 & 77.9 & 22.1 & 19.4 & 3.0 & -29.0 & -28.1 \\
\hline 32 & Angun Point seep & - & - & - & - & - & - & - & - & - & 73.6 & 24.4 & - & 2.9 & -28.9 & -28.3 \\
\hline 33 & Jago River outcrop & 1.9 & - & - & - & - & - & - & 8,500 & 44.7 & 19.9 & 80.1 & 35.8 & 2.5 & -29.4 & -28.8 \\
\hline 34 & Jago River outcrop & 2.7 & - & - & - & - & - & - & 20,500 & 75.9 & 12.9 & 87.1 & 66.1 & 2.2 & -29.2 & -28.9 \\
\hline 35 & Manning Point seep & - & - & - & - & - & - & - & - & - & 26.8 & 73.2 & - & 5.2 & -28.2 & -27.5 \\
\hline 36 & Manning Point outcrop & 11.0 & - & - & - & - & - & - & 96,400 & 87.6 & 11.7 & 88.3 & 77.4 & 5.4 & -28.4 & -27.6 \\
\hline
\end{tabular}

${ }^{1}$ Depth, in feet, for samples 23, 7,702-7,710;24, 10,417-10,535; 25, 299; and 27, 1,556-1,639.

${ }^{2}$ Amount of NHC and HC reported as weight percent of bitumen for oils, seeps, and stained rocks. 
Table 12.1. Continued

\begin{tabular}{cccccccc}
\hline \multicolumn{7}{c}{ Biomarkers } \\
\hline $\mathrm{nC}_{17} /$ & $\mathrm{Pr} /$ & $\mathrm{C}_{19}$ Tri/ & Hop/ & $\mathrm{C}_{31} \mathrm{Hop}$ & $20 \mathrm{~S} /$ & $\Sigma \beta /$ & $\mathrm{C}_{28} /$ \\
$\mathrm{Pr}$ & $\mathrm{Ph}$ & $\mathrm{C}_{23}$ Tri & $\mathrm{C}_{23}$ Tri & $22 S / 22 \mathrm{R}$ & $20 \mathrm{~S}+20 \mathrm{R}$ & $\Sigma \beta+\Sigma \alpha$ & $\mathrm{C}_{28}+\mathrm{C}_{29}$
\end{tabular}

\begin{tabular}{rrrrrrrr}
\hline & & & & & & & \\
\hline 0.3 & 1.7 & 1.3 & 13.0 & n. & $<0.1$ & im. & 0.1 \\
1.7 & 1.4 & .8 & .8 & 1.5 & .4 & 0.6 & 1.0 \\
2.8 & 1.6 & .6 & .3 & 1.5 & .5 & .6 & 1.0 \\
3.7 & 1.7 & .9 & .6 & 1.3 & .4 & .6 & 1.0 \\
.3 & 1.1 & .4 & 28.0 & .2 & .1 & .4 & .0 \\
& & & & & & & \\
1.5 & 2.0 & .4 & 10.8 & .8 & .4 & .5 & $\mathrm{n}$. \\
.4 & 1.0 & .5 & 22.0 & .3 & .1 & .4 & .0 \\
.2 & 1.5 & .4 & 8.0 & 1.0 & .1 & .3 & .1 \\
.3 & 1.2 & .3 & 19.0 & .2 & .1 & .4 & .0 \\
4.6 & 2.0 & 1.2 & .4 & 1.5 & .5 & .5 & 1.0 \\
& & & & & & & \\
2.9 & 1.8 & 1.4 & .5 & 1.5 & .4 & .4 & 1.0 \\
2.0 & 1.5 & .9 & .3 & 1.5 & .5 & .5 & 1.0 \\
.6 & 3.4 & 3.8 & 114.0 & .5 & $<.1$ & im. & .5 \\
1.9 & 1.3 & .2 & .2 & 1.2 & .3 & .4 & 1.0 \\
2.7 & 2.0 & 2.1 & $\mathrm{n}$. & $\mathrm{n}$. & $\mathrm{n}$. & $\mathrm{n}$. & 1.0 \\
& & & & & & & \\
1.8 & 2.3 & .9 & .7 & 1.5 & 0.5 & .6 & 1.0 \\
1.5 & 1.9 & 1.0 & 13.8 & 0.5 & 0.2 & .4 & .5 \\
.6 & 2.5 & 2.0 & 55.0 & 0.5 & $<0.1$ & im. & .4 \\
2.8 & 1.8 & .4 & .3 & 1.5 & 0.6 & .6 & 1.0 \\
1.6 & 1.2 & .2 & .1 & 1.5 & 0.6 & .6 & 1.0 \\
& & & & & & & \\
1.5 & 1.7 & $\mathrm{n}$. & $\mathrm{n}$. & $\mathrm{n}$. & $\mathrm{n}$. & $\mathrm{n}$. & 1.0 \\
1.6 & 1.3 & .2 & .5 & 1.5 & 0.6 & .7 & 1.0 \\
\hline & & & & & & & \\
\hline
\end{tabular}

\begin{tabular}{crrrrrrr}
\hline 1.4 & 2.5 & .2 & 19.0 & 1.4 & .5 & .5 & - \\
2.0 & 1.5 & $<.1$ & 4.1 & 1.4 & .5 & .5 & - \\
2.0 & 2.2 & 1.9 & 2.3 & 1.2 & .5 & .6 & - \\
n. & 2.1 & .6 & 4.5 & 1.3 & .4 & .5 & - \\
.9 & 1.2 & .2 & .4 & 1.7 & .5 & .6 & - \\
\hline
\end{tabular}

\begin{tabular}{cccccccc}
\hline n. & n. & .1 & n. & n. & n. & n. & n. \\
.4 & 1.3 & .6 & 9.0 & 1.3 & .5 & .5 & - \\
n. & n. & .3 & 13.8 & 1.4 & .4 & .5 & n. \\
n. & n. & .4 & n. & n. & n. & n. & n. \\
n. & n. & .6 & n. & n. & n. & n. & .5 \\
& & & & & & & \\
n. & n. & .5 & 8.4 & 1.4 & .4 & .5 & .6 \\
n. & n. & .5 & 7.1 & 1.2 & .4 & .5 & .5 \\
n. & n. & 2.1 & 15.7 & 1.2 & .4 & .4 & .6 \\
n. & n. & 1.9 & 13.8 & 1.2 & .4 & .4 & .6 \\
\hline
\end{tabular}

were first designated as very heavy asphaltic oils but later samples collected along the coast were found to be oil-saturated sandstones (table 12.1, fig. 12.2).

Six oil-stained sandstones are confirmed; one is located just west of the Canning River in the Kavik area, two along the Canning River, two along the Katakturuk River, and one at the east end of the Sadlerochit Mountains. A brief explanation as to the mode of occurrence of these six oil-stained sandstones is as follows. Northwest of the Kavik gas field, numerous large blocks of oil-saturated conglomeratic sandstone crop out on tundra-covered hills. The two oil-stained sandstones along the Canning River do not contain enough extractable oil for analysis and thus are not included in this study. Oil-stained turbidite sandstone crops out along the north flank of the Sadlerochit Mountains on the Katakturuk River (South Katakturuk) and contains sufficient indigenous oil to be analyzed. Oil-saturated sandstone is also found on the Katakturuk River near the axis of the Marsh Creek anticline (North Katakturuk) and implies leakage of oil from a deep accumulation within this structure. Oil-stained sandstone confirmed by geologists from the State of Alaska is located at the east end of the Sadlerochit Mountains; however, these rocks also are not included in our study.

Oil-stained shale and dolomite is confirmed in four localities. Based on solvent extraction, the Kingak Shale at the base of the Ignek Valley section contains migrated oil. Residual oil was observed in thin sections of dolomite of the Lisburne Group from the east end of the Sadlerochit Mountains (fig. 7.4C). Along the Jago River, oil-stained shale or mudstone has a strong kerosene smell on both sides of a fault; north of the fault, solvent extraction confirms the presence of migrated oil. Solvent extraction data from the Kingak

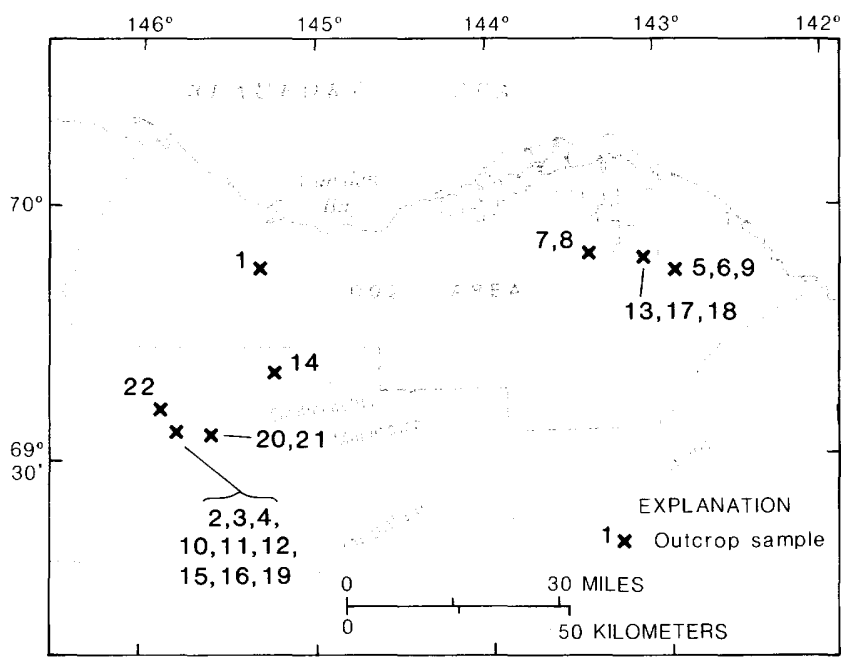

Figure 12.1. Locations of outcrop samples used in this study. Numbers refer to table 12.1 . 
Shale in the Niguanak area indicate the presence of migrated oil that has been biodegraded. The locations of these confirmed and unconfirmed seeps and stains are shown on figure $12.3 A$, and the stratigraphic intervals from which the seeps ooze and from which the stained rock samples were collected are shown on figure $12.3 B$.

\section{GEOLOGIC FRAMEWORK}

The structural framework of the five rock units geochemically evaluated in this report differs on either side of the Marsh Creek anticline. West of the anticline, rocks older than the Canning Formation dip gently to the south and the clinoform strata of the Canning Formation dip gently to the northeast. East of the anticline, rocks in the coastal plain are complexly deformed (chap. 17, $19,20)$. In both areas, an unconformity at the base of the pebble shale unit truncates older rocks, including the Shublik Formation and the Kingak Shale (chap. 5, 7). West of the anticline the area is designated as the undeformed zone, and the area to the east is the deformed zone. A brief description of each rock unit follows.

\section{Shublik Formation}

The Shublik Formation of Middle and Late Triassic age is a distinctive lithologic unit consisting of calcareous, sooty shale and fossiliferous, dark, phosphatic limestone. It crops out in the Sadlerochit and Shublik Mountains and along the mountain front to the east, and it also occurs in the subsurface in the Kavik area. The Shublik has a fetid odor when broken and ranges in thickness from zero, where it is truncated, to $155 \mathrm{~m}$ (510 ft) (Bird, 1985). The Shublik was deposited along a continental margin where upwelling was common (Parrish, 1985).

\section{Kingak Shale}

The Kingak Shale of Early Jurassic to earliest Cretaceous age crops out along the Brooks Range mountain front and occurs throughout most of the subsurface to the west. It consists predominantly of dark-gray marine shale and ranges in thickness from zero where truncated by the so-called Lower Cretaceous unconformity to about $1,200 \mathrm{~m}(4,000 \mathrm{ft})$ in the Colville trough (chap. 5).

\section{Pebble Shale Unit}

The pebble shale unit of Early Cretaceous age is an informal unit and can be mapped across the entire North Slope. In the Sadlerochit and Shublik Mountains, the pebble shale unit is 60 to $90 \mathrm{~m}$ (200 to $300 \mathrm{ft}$ ) thick and consists of dark-gray to black, noncalcareous, clayey to silty shale containing minor scattered, rounded, frosted quartz grains (Molenaar, 1983). The lower part of the unit is considered to be an offshore deposit associated with the northerly transgressing sea, whereas the upper unfossiliferous part may be associated with a very slow, starved-basin deposition.

\section{Hue Shale}

The Hue Shale, which contains a radioactive shale interval at its base, is a distal, condensed shale facies that crops out around the Sadlerochit Mountains and in the Niguanak River area on the ANWR coastal plain. It usually is less than $300 \mathrm{~m}(1,000 \mathrm{ft})$ thick and

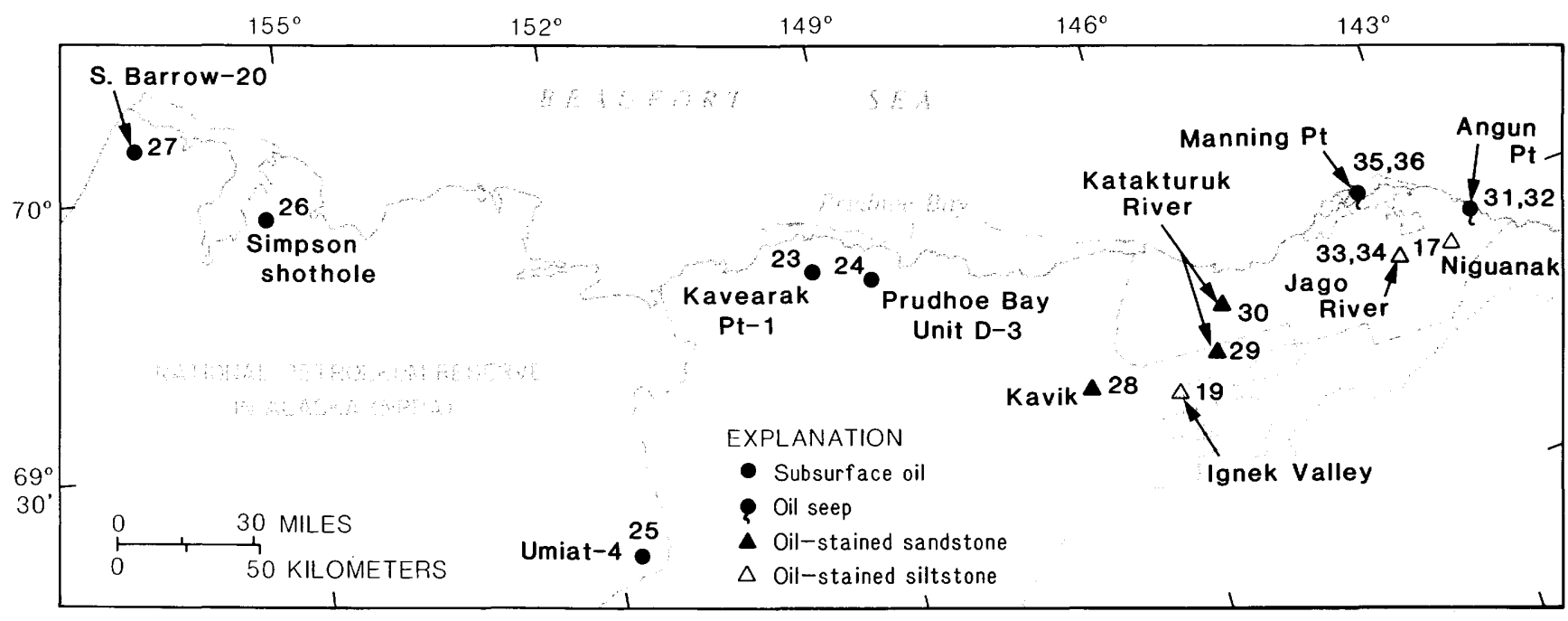

Figure 12.2. Locations of oil samples used in this study. Numbers refer to table 12.1. 


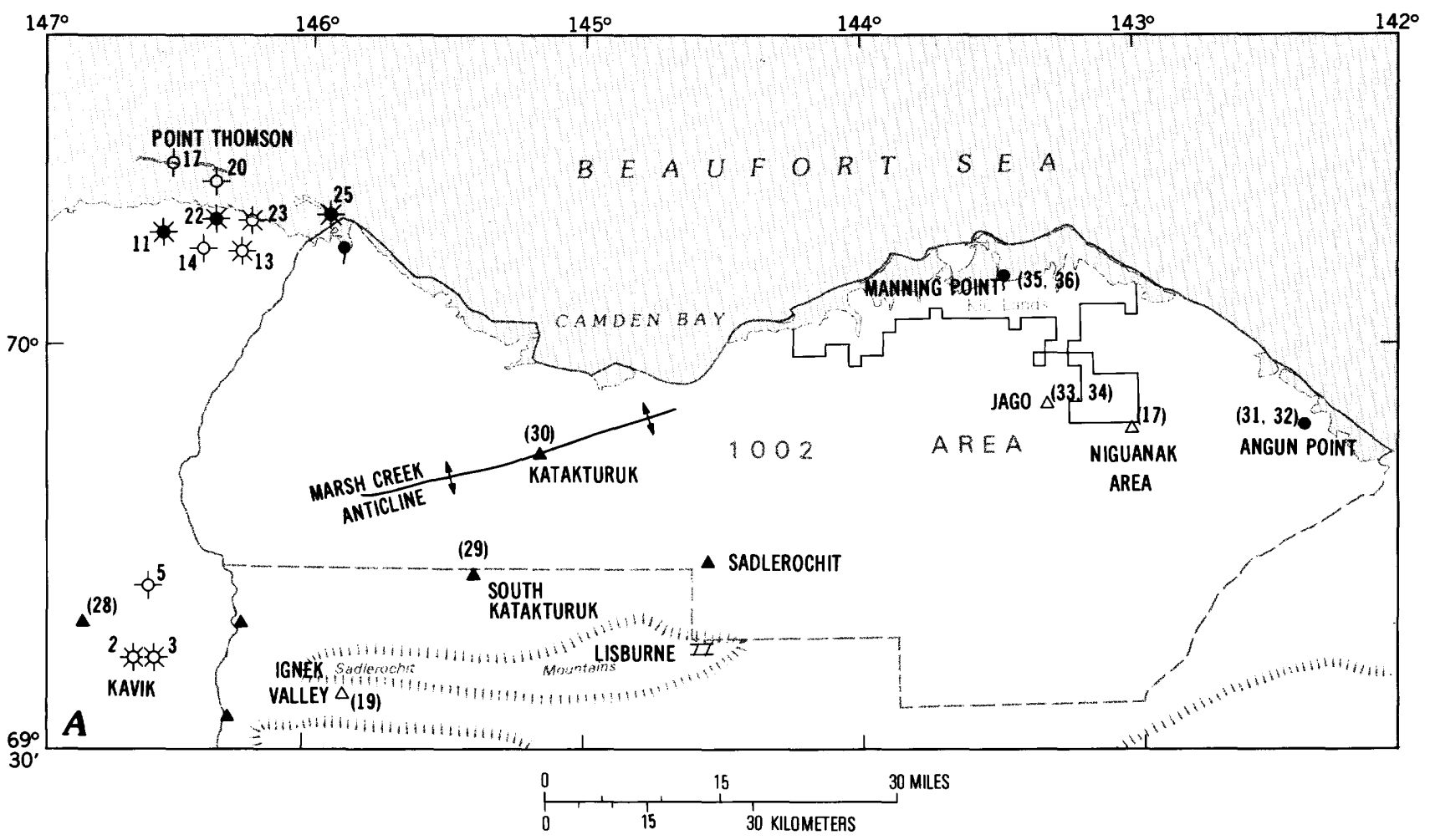

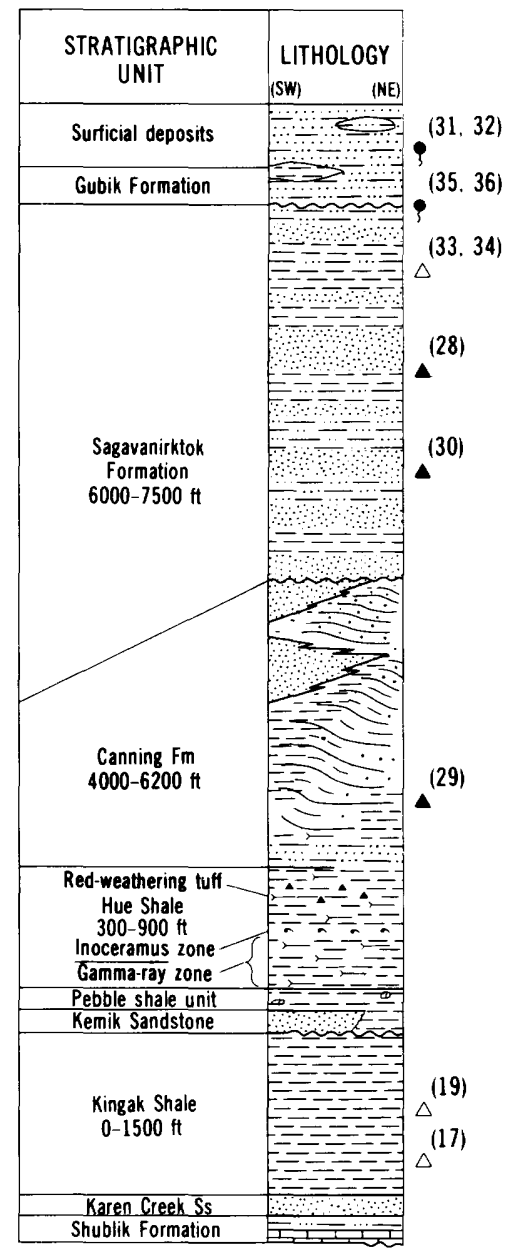

B
EXPLANATION

Oil and gas indications

Well-Numbers are keyed to names in table 1.1

t. 25 Oil and gas. suspended

13 Gas, suspended

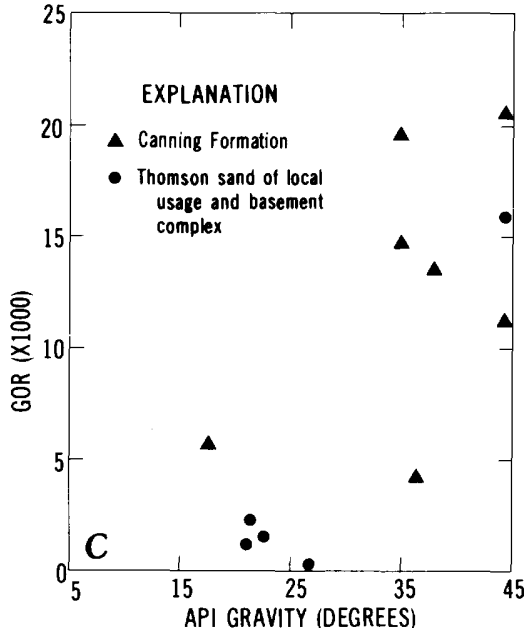

5 Dry hole, abandoned

$b^{17}$ Suspended

Surface-Numbers are keyed to analyses in table 12.1

Oil seep

$\Delta(30) \quad$ Oil-stained sandstone

$\triangle$ (19) Oil-stained shale

II Oil-stained dolomite, not analyzed

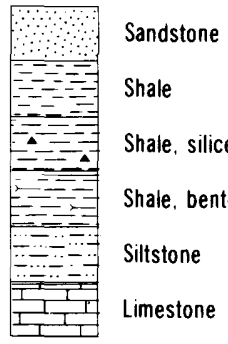

Figure 12.3. $A$, Surface and subsurface oil and gas occurrences in and adjacent to ANWR. $B$, Generalized stratigraphic column showing relative position of oil seeps and stains in and adjacent to ANWR. $C$, API oil gravity compared to gas-oil ratio (GOR) for oil and gas occurrences in Point Thomson area. 
consists of black, fissile, noncalcareous, clay shale and bentonite of Early and Late Cretaceous and Paleocene(?) age (Molenaar and others, 1987; chap. 5).

\section{Canning Formation}

The Canning Formation gradationally overlies the Hue Shale and consists of 1,200 to $1,800 \mathrm{~m}(4,000$ to $6,000 \mathrm{ft}$ ) of dark-gray to gray-brown bentonitic shale and siltstone with thin turbidite sandstone beds in the lower part. It ranges in age from Late Cretaceous to early Tertiary, and it crops out around the Sadlerochit Mountains (Molenaar and others, 1987; chap. 5).

\section{ANALYTICAL METHODS}

The analytical methods used in this study include Rock Eval, organic-carbon content, extractable organic matter, column chromatography, gas chromatography, gas chromatography-mass spectral analysis, carbon isotopes, vitrinite reflectance, and various biomarker ratios. Rock Eval and organic-carbon content are discussed by Magoon and others (chap. 11). The remaining analytical methods are as follows.

\section{Extractable Organic Matter (Bitumen)}

Extractable organic matter (EOM), or bitumen, refers to the amount of organic material exhaustively extracted from a rock with chloroform. Generally, the quantity of bitumen extracted from shales ranges from 20 to $200 \mathrm{mg} / \mathrm{g} \mathrm{OC} \mathrm{(2} \mathrm{to} 20$ weight percent), and depending upon the kerogen type, the hydrocarbons range from 10 to $70 \mathrm{mg} / \mathrm{g} \mathrm{OC} \mathrm{(1-7} \mathrm{weight} \mathrm{percent)} \mathrm{for} \mathrm{type} \mathrm{III,} \mathrm{to} 100$ $\mathrm{mg} / \mathrm{g}$ OC (10 weight percent) for type II, and to 150 $\mathrm{mg} / \mathrm{g}$ OC (15 weight percent) for type I (Tissot and Welte, 1984). The quantity of bitumen and hydrocarbons relative to organic-carbon content usually rises with increasing thermal maturity to a maximum value, then falls during late catagenesis (see chap. 11). As a rule, when bitumen values for shales exceed 20 weight percent per gram of $\mathrm{OC}$, the rock extracted is considered to be oil stained. Metamorphosed shales generally contain less than 0.02 weight percent $(200 \mathrm{ppm})$ bitumen.

\section{Column Chromatography}

A rapid and reproducible fractionation technique for isolating the asphaltene, saturate and aromatic hydrocarbon, and resin fractions of petroleum and sedimentary rock extracts was developed in cooperation with the J. T. Baker Chemical Company using solidphase extraction columns (Baker, 1982). The primary advantages of this new technique are its speed of separation and its simplicity of operation. Molecular- type analysis can be obtained on 10 samples of oil or bitumen extract in less than 30 minutes.

The method is as follows. Using a column adapter (7122-0), connect a 6-mL silica-gel column (7086-6) containing $500 \mathrm{mg}$ of solid phase and a 6-mL cyano $(\mathrm{CN})$ column (7021-7) containing $1,000 \mathrm{mg}$ of solid phase in tandem (silica-gel on bottom) and place in the Baker-10 manifold cover. Wash the columns with 6 $\mathrm{mL}$ of isooctane to activate the solid phases and to cleanse the columns of any adsorbed hydrocarbons. If the columns are washed under vacuum, do not allow them to dry at this stage. Press a column adaptor in the top of the $\mathrm{CN}$ column and attach a tared 3-mL filtration column (7121-3). Place a tared vial into the column rack beneath the column assembly. Accurately weigh $25-40$ $\mathrm{mg}$ of crude oil or bitumen extract, dissolve oil or bitumen in $0.5 \mathrm{~mL}$ of isooctane, and transfer contents to the filtration column. Aspirate the solvent onto the $\mathrm{CN}$ column. Aspirate an additional $5 \mathrm{~mL}$ of isooctane in 1$\mathrm{mL}$ aliquots through the $\mathrm{CN}$-silica-gel column assembly. Release vacuum before columns come to dryness and remove tared vial containing saturated hydrocarbons. Remove the filtration column and adaptor from the $\mathrm{CN}$ column and retain the filtration column for determination of the weight of asphaltenes. Place a second tared vial into the collection rack for recovering aromatic hydrocarbons. Remove the $\mathrm{CN}$ column and adaptor from the silica-gel column and retain for later elution. Wash the silica-gel column with two 1-mL aliquots of $1: 3$ benzene-isooctane. Release the vacuum and remove the silica-gel column. Replace the $\mathrm{CN}$ column (previously removed) onto the manifold and aspirate with two 1-mL aliquots of $1: 3$ benzene-isooctane. Release the vacuum and remove vial containing aromatic hydrocarbons. Place a third tared vial into the collection rack and wash the CN column with $4 \mathrm{~mL}$ of chloroform to remove the resinous (polar aromatic) constituents. Evaporate the solvents from the various vials under dry nitrogen gas or vacuum centrifuge to obtain the $\mathrm{C}_{15+}$ weights. If normal alkanes are to be removed from the saturated hydrocarbon fraction, elution of this hydrocarbon fraction with isooctane or cyclohexane instead of hexane or heptane will save having to evaporate the sample before addition of molecular sieves.

\section{Gas Chromatography (GC)}

Gas chromatograms of the hydrocarbon fractions were obtained using an HP 5880A gas chromatograph equipped with a $60 \mathrm{~m} \times 0.32 \mathrm{~mm}$ fused silica capillary column coated with a 0.25 -micron film thickness of SE54. The gas chromatographic conditions were as follows: inlet temperature was $325^{\circ} \mathrm{C}\left(617^{\circ} \mathrm{F}\right)$, FID detector was $350^{\circ} \mathrm{C}\left(662^{\circ} \mathrm{F}\right)$, carrier gas was $\mathrm{H}_{2}$, column headpressure was $10 \mathrm{psi}$, column initial temperature was $50^{\circ} \mathrm{C}\left(92^{\circ} \mathrm{F}\right)$ at $2 \mathrm{~min}$, program rate 
was $4{ }^{\circ} \mathrm{C} / \mathrm{min}\left(7.2^{\circ} \mathrm{F} / \mathrm{min}\right)$, and column final temperature was $320^{\circ} \mathrm{C}\left(578{ }^{\circ} \mathrm{F}\right)$ at $8 \mathrm{~min}$.

\section{Gas Chromatography-Mass Spectrometry (GC- MS)}

Relative distributions of biomarker compounds (such as tricyclic and pentacyclic terpenoids and saturated and aromatic steranes) preserved in oils, seeps, and rock extracts are very useful in oil-oil and oil-source rock correlation studies and in aiding thermal maturity assessment (Mackenzie, 1984). The distributions of these biomarker compounds in the rock extracts and seeps discussed in this report were determined via GCMS multiple ion detection (MID) techniques. The gas chromatographic conditions were the same as discussed in the preceding GC section, with the exception that the starting temperature was $100{ }^{\circ} \mathrm{C}\left(212^{\circ} \mathrm{F}\right)$, the ending temperature was $340^{\circ} \mathrm{C}\left(644{ }^{\circ} \mathrm{F}\right)$, and the carrier gas was helium. The mass spectrometer used was a Kratos-AEI MS-30 instrument equipped with a Fluke programmable power supply for switching the accelerating voltage during MID. The source pressure was $1 \times 10^{-6}$ torr, the source temperature was $250^{\circ} \mathrm{C}\left(452{ }^{\circ} \mathrm{F}\right)$, the EI voltage was $70 \mathrm{eV}$, and the dynamic resolution was $1200+$ amu.

\section{Carbon Isotopes}

During kerogen catagenesis, hydrocarbons form that are isotopically lighter ( 1 to 4 per mil) than the kerogen from which they are derived. Pooled oil and bitumen formed from these thermally generated hydrocarbons reveal little added isotopic fractionation $(<1$ per mil). As a result of this closeness in carbon isotopic values between oils and the bitumens from which they are derived, carbon isotopes have become a valuable tool in oil-oil and oil-source rock evaluations.

Carbon isotopic values reported in this paper are for the $\mathrm{C}_{15+}$ saturated and aromatic hydrocarbon (HC) fractions of the oils, seeps, and rock extracts. The hydrocarbons were combusted to $\mathrm{CO}_{2}$ in an atmosphere of oxygen and subsequently purified under vacuum by differential temperature transfer. A Finnigan Mat Model 251 mass spectrometer was used to make the isotopic determination. The ${ }^{13} \mathrm{C} /{ }^{12} \mathrm{C}$ ratios are expressed in the usual delta $(\delta)$ notation relative to the Peedee belemnite (PDB) marine carbonate standard.

\section{Thermal Maturity Indicators}

Vitrinite reflectance $R_{o}$, Rock Eval $T_{\max }$, extended hopane $S / R$ pairs, and isomeric ratios of specific saturated steranes and aromatized steranes are all indirect measurements useful in assessing the relative thermal maturity of sedimentary rocks. Changes in reflectance associated with the maceral vitrain, in the temperature of maximum hydrocarbon generation $\left(T_{\max }\right)$ during pyrolysis of the kerogen moiety, and in specific biomarker isomeric ratios are related to temperaturedependent chemical reactions that take place during thermal maturation.

Vitrinite reflectance and $\mathrm{T}_{\max }$ measurements are useful over a large range of thermal maturities, whereas the ratios of specific molecular species are useful over much narrower thermal maturity ranges. For example, the $S / R$ ratios of the extended hopanes are useful thermal maturity indicators up to an equivalent $R_{o}$ of about 0.5 to 0.7 percent (early catagenesis). Extended hopane ratios greater than 1.2 to 1.6 are questionable (Mackenzie, 1984). The $20 \mathrm{~S} / 20 \mathrm{R}$ ratios of the $\alpha \alpha \alpha$-steranes are useful indicators of thermal maturity up to an $R_{\text {o }}$ equivalence of about 1.0 to 1.1 percent. At maximum thermal usefulness, the $20 \mathrm{~S} / 20 \mathrm{R} \alpha \alpha \alpha$-sterane ratio approaches 1.1 to 1.2 percent. The more stable $\alpha \beta \beta-20 \mathrm{~S}$ and $20 \mathrm{R}$ steranes start forming from the $\alpha \alpha \alpha-20 \mathrm{~S}$ and $20 \mathrm{R}$ steranes at a $R_{\mathrm{o}}$ thermal equivalence of about 0.7 percent and reach equilibrium at an $R_{o}$ equivalence of about 1.0 percent. At equilibrium, the ratio of $\alpha \beta \beta$ steranes to the sum of the $\alpha \alpha \alpha$ - and $\alpha \beta \beta$-steranes is about 0.6 to 0.7 . The thermal conversion of the $C_{29}$ (20R) monoaromatic. sterane to the $\mathrm{C}_{28}(20 \mathrm{R})$ triaromatic sterane is useful in estimating thermal maturity of samples to an $R_{o}$ equivalence of about 1.0 percent. Above this maturation level, the monoaromatics very rapidly degrade to the $\mathrm{C}_{21}$ and $\mathrm{C}_{22}$ dealkylated steranes, and the triaromatics degrade to the $\mathrm{C}_{20}$ and $\mathrm{C}_{21}$ dealkylated steranes.

\section{ORGANIC GEOCHEMISTRY OF ROCKS}

\section{Thermal Maturity}

Thermal maturity data for the potential source rocks of the ANWR are not a simple function of the present-day burial depths of the rocks because of Tertiary deformation in much of the area (chap. 11). For example, at the Ignek Valley section, where tectonic events have brought more deeply buried rocks to the surface, the thermal maturity level with respect to hydrocarbon generation is very mature to postmature $\left(\mathrm{T}_{\max }=500+{ }^{\circ} \mathrm{C}\right.$ $\left(902+{ }^{\circ} \mathrm{F}\right), 1.8-2.1$ pct $\left.\mathrm{R}_{\mathrm{o}}\right)$ for the Shublik Formation; very mature $\left(\mathrm{T}_{\max }=462{ }^{\circ} \mathrm{C}\left(830^{\circ} \mathrm{F}\right), 1.4 \mathrm{pct} \mathrm{R}_{\mathrm{o}}\right)$ for the Kingak Shale; very mature $\left(\mathrm{T}_{\max }=500+{ }^{\circ} \mathrm{C}\left(902+{ }^{\circ} \mathrm{F}\right)\right.$, 1.5-1.8 pct $\mathrm{R}_{\mathrm{o}}$ ) for the pebble shale unit; and mature to very mature $\left(\mathrm{T}_{\max }=431-438^{\circ} \mathrm{C}\left(778-820^{\circ} \mathrm{F}\right), 1.0-1.2\right.$ pct $R_{o}$ ) for the Hue Shale and Canning Formation. At the Niguanak River section, $100 \mathrm{~km}(60 \mathrm{mi})$ northeast of 
the Ignek Valley section, on the other hand, the Canning, Hue, pebble shale, and Kingak units are immature to marginally mature $\left(\mathrm{T}_{\max }=404-426^{\circ} \mathrm{C}\left(729-769^{\circ} \mathrm{F}\right), 0.5\right.$ pct $R_{0}$ ). Because of the advanced thermal maturity of the potential source rocks at the Ignek Valley section, the biological markers normally used for oil-source rock correlation (for example, steranes, pentacyclic triterpanes, and aromatized steranes) could not be utilized. The less thermally affected tricyclic terpanes were still useful for correlation purposes.

\section{Organic Matter Type and Quality}

\section{Shublik Formation}

The organic-carbon content of the Shublik Formation in four wells adjacent to the ANWR west of the Sadlerochit Mountains averages 1.5 weight percent and in ANWR outcrops averages 1.7 weight percent (chap. 11). North of the Brooks Range, the Shublik Formation is truncated at the pebble shale unconformity. The Shublik Formation in the Brooks Range is so thermally mature that the organic-matter type cannot be determined. Extrapolation from the NPRA (Magoon and Claypool, 1981) and Prudhoe Bay (Seifert and others, 1979) suggests that the Shublik Formation contains organic matter of at least type II/III. The locations of the three Shublik samples evaluated in this study are the Ignek Valley (table 12.1, samples 20,21) and the west end of the Sadlerochit Mountains (table 12.1, sample 22). The average organic-carbon content for these samples is 2.2 weight percent.

\section{Kingak Shale}

Based on data from 4 Kavik wells and from 22 outcrop localities across the ANWR, the organic-carbon content of the Kingak Shale ranges from 0.7 to 4.5 weight percent and averages 1.3 weight percent (chap. 11). Like the Shublik Formation, the Kingak Shale is truncated by the Lower Cretaceous unconformity in the ANWR coastal plain north of the Brooks Range. In the Niguanak River uplands, the Kingak Shale is present but may have been transported into this region from the south. At the Ignek Valley section, the Kingak Shale is too thermally mature to evaluate the organic-matter type, but in the Niguanak uplands it is marginally mature $(0.5$ pct $R_{o}$ ). Here the organic-matter type, based on hydrogen indices (mg $\mathrm{S}_{2} / \mathrm{g} \quad \mathrm{OC}$ ) and pyrolysis hydrocarbon yields $\left(S_{1}+S_{2}\right)$, is type III. Three samples of the Kingak are used in this study, two from the Niguanak uplands (table 12.1, samples 17, 18), and one from the Ignek Valley section (table 12.1, sample 19). The average organic-carbon content of these samples is 2.7 weight percent.

\section{Pebble Shale Unit}

Organic-carbon content in the pebble shale unit, based on data from 7 wells west of the Canning River and 30 outcrop localities in the ANWR, averages 2.4 weight percent and 2.1 weight percent, respectively (chap. 11). Rock Eval data (hydrogen indices and $S_{1}+S_{2}$ ) indicate that the organic-matter type in the pebble shale unit is predominantly type III. The four samples of the pebble shale unit in table 12.1, whose average organiccarbon content is 4.7 weight percent, are from three localities. The first locality is the Niguanak uplands (table 12.1, sample 13), the second is the north flank of the Sadlerochit Mountains (table 12.1, sample 14), and the last is the Ignek Valley section (table 12.1, samples 15 and 16).

\section{Hue Shale}

Organic-carbon content, based on subsurface data from 10 wells adjacent to the ANWR and surface samples from 7 localities, averages 2.2 weight percent and 5.9 weight percent, respectively (chap. 11). The highest organic-carbon content (avg 12.0 weight percent), is found in the Niguanak and Jago River sections of the eastern ANWR, where the Hue Shale is still thermally immature. South of the Marsh Creek anticline at the foot of the Sadlerochit Mountains, thermally mature samples still run as high as 8.0 weight percent. Ten samples of the Hue Shale with an average organic-carbon content of 8.1 weight percent were examined carefully in this study (table 12.1). Five of the samples are from the Ignek Valley section (samples $3,4,10,11,12$ ), three are from the Niguanak uplands (samples 5, 6, 9), and two are from the Jago River section (samples 7,8 ). Based on hydrogen indices and $S_{1}+S_{2}$ yields, the Hue Shale organic matter at the Niguanak and Jago River (samples 5-9) sections is at minimum a type I/II mix. At Ignek Valley the organic matter of the Hue Shale is too thermally mature to adequately evaluate genetic type, but since this shale is deposited in a deep-water marine environment from the Point Thomson area across the ANWR, the organic matter is probably marine as well in the Ignek Valley area.

\section{Canning Formation}

Organic-carbon content in the Canning Formation, based on data from 13 wells in the Point Thomson and Kavik areas and from 22 outcrops in or adjacent to the ANWR, averages 1.3 weight percent and 1.9 weight percent, respectively (chap. 11). Based on hydrogen indices and pyrolysis hydrocarbon yields, the organic matter in this unit is overwhelmingly type III. Two samples of the Canning Formation having an average organic-carbon content of 2.1 weight percent were used in this detailed study (table 12.1). One 
sample is from the Katakuruk River (sample 1), and the other is from the Ignek Valley section (sample 2).

\section{ROCK RESULTS}

Other geochemical evidence for type III organic matter in the Canning Formation, pebble shale unit, and Kingak Shale is seen in the mass spectral selected ion $(\mathrm{m} / \mathrm{z} 217)$ traces of the sterane biomarkers $(1,13$, and 18 in fig. 12.4A). The high $\mathrm{C}_{29}$ sterane contents relative to $\mathrm{C}_{27}$ and $\mathrm{C}_{28}$ sterane contents in immature rocks from these units suggest a large type III contribution (Huang and Meinschein, 1976).

The material most like petroleum in sedimentary rocks is the solvent extractable bitumen. This bitumen contains both hydrocarbons and nonhydrocarbon constituents that migrate from thermally mature source rocks and become the major component of crude oil. Hunt (1979) demonstrated that the ability of a rock to produce oil was directly related to its extractable hydrocarbon $\left(\mathrm{C}_{15+}\right)$ content and its organic-carbon content. This relationship between extractable hydrocarbons and organic-carbon content in the ANWR rocks is shown in figure 12.5. According to Hunt, rocks containing more than $300 \mathrm{mg} \mathrm{HC/g} \mathrm{OC}$ are reservoir rocks, between 100 to $300 \mathrm{mg} \mathrm{HC} / \mathrm{g}$ OC are oil-stained rocks, with less than $10 \mathrm{mg} \mathrm{HC/g} \mathrm{OC}$ are nonsource rocks, and between 10 and $100 \mathrm{mg} \mathrm{HC/g} \mathrm{OC}$ are potential source rocks if their organic-carbon content exceeds 0.5 weight percent.

Three of the rocks analyzed in the ANWR study contain more than 100 but less than $300 \mathrm{mg} \mathrm{HC} / \mathrm{g} \mathrm{OC}$ (10-30 pct HC/OC, table 12.1, samples $28,30,31$ ) and, by definition, are stained; four of the rocks possess more than $300 \mathrm{mg} \mathrm{HC} / \mathrm{g}$ OC (30 pct $\mathrm{HC} / \mathrm{OC}$, table 12.1, samples 29, 33, 34, 36) and are reservoir rocks (by definition); and nine ANWR rocks (table 12.1, samples 1, $13-16,18$, and 20-22) contain less than $10 \mathrm{mg} \mathrm{HC} / \mathrm{g} \mathrm{OC}$ (1 pct $\mathrm{HC} / \mathrm{OC}$ ) and are nonsource rocks (by definition). ANWR rock samples 2-12, 17, and 19 (table 12.1) contain more than 10 but less than $100 \mathrm{mg} \mathrm{HC} / \mathrm{g} \mathrm{OC}$ (1-10 pct $\mathrm{HC} / \mathrm{OC})$ and are potential source rocks according to the Hunt (1979) model (fig. 12.5).

Though sample 17 is organic carbon rich (4.5 weight percent) and plots as a good source rock in figure 12.5 , the kerogen associated with this sample produces very little hydrocarbon during Rock Eval pyrolysis $\left(\mathrm{S}_{2}=\right.$ $0.9 \mathrm{~kg} \mathrm{HC} / \mathrm{t})$. The production index $(0.25)$ of this immature sample $\left(\mathrm{T}_{\max }=406^{\circ} \mathrm{C}\left(733^{\circ} \mathrm{F}\right), 0.5 \mathrm{pct} \mathrm{R}_{\mathrm{o}}\right)$ suggests that it is oil stained. Gas chromatographic analyses of the saturated hydrocarbon fraction of sample 17 indicates that it is stained by a biodegraded crude oil (fig. 12.4A). This loss of hydrocarbon by biodegradation may account for why sample 17 does not plot as oilstained in figure 12.5 .
Kingak Shale sample 19 from Ignek Valley (fig. $4 B$ ) may also be oil-stained. If the Kingak at Ignek Valley contains the same type III organic matter as is associated with the thermally immature Kingak Shale at the Niguanak Ridge (table 12.1, samples 17, 18), the hydrocarbons extracted from sample 19 are probably not indigenous because the immature Kingak at Niguanak is capable of producing only light hydrocarbons $\left(<\mathrm{nC}_{20}\right)$ during pyrolysis. If Kingak Shale sample 19 is lightly stained ( $\mathrm{PI}=0.3$ ) with migrated oil, it could explain why this sample plots as a source rock in figure 12.5 instead of a nonsource rock.

The ability of a sedimentary rock to produce oillike (liquid) hydrocarbons during catagenesis is generally related to the hydrogen richness of the sample. Whether a hydrogen-rich sample has any economic potential depends on the quantity of organic matter. The only ANWR rocks with sufficient organic carbon content and hydrogen-rich organic matter to be oil source rocks are the type II facies of the Hue Shale. The Canning Formation, pebble shale unit, and Kingak Shale have sufficient organic-carbon content to be oil source rocks, but their organic matter is so hydrogen deficient that the dominant product during catagenesis is gas (table 12.1).

\section{ORGANIC GEOCHEMISTRY OF OILS}

Crude-oil characterization is limited to the information available from wells in the Point Thomson and Kavik areas and to geochemical analyses of two oil seeps and six oil-stained rocks within or adjacent to the 1002 area (fig. 12.3).

\section{Point Thomson and Kavik Areas}

Eight Point Thomson wells recovered oil and gas (table 12.2). Excluding two anomalously low values, the gas-to-oil ratio (GOR) ranges from 3,890 to 22,705 and averages 16,359 (fig. $12.3 \mathrm{C}$ ). The oil gravity ranges from $18^{\circ}$ to $45^{\circ}$ API. Two distinct oil types appear to be contained in these wells. The oil from the Thomson sand of local usage and the basement complex is a $35^{\circ}$ to $45^{\circ}$ API gravity oil with one exception (an $18^{\circ}$ API gravity oil). The $18^{\circ}$ API gravity oil could be caused by biodegradation or deasphalting of the oil by a high proportion of gas. Deasphalting occurs when gaseous hydrocarbons move through an oil column and cause the asphaltic fraction of crude oil to precipitate out.

The second oil type in the Point Thomson area occurs in the turbidite sandstones of the Canning Formation. The GOR is less than 1,100 and the API gravity ranges from $21^{\circ}$ to $27^{\circ}$; one notable exception is an oil with a GOR of 17,045 and an API gravity of $44^{\circ}$. No explanation for this anomaly is apparent, except that the higher gravity oil migrated vertically from the Thomson sand. 
GC

1
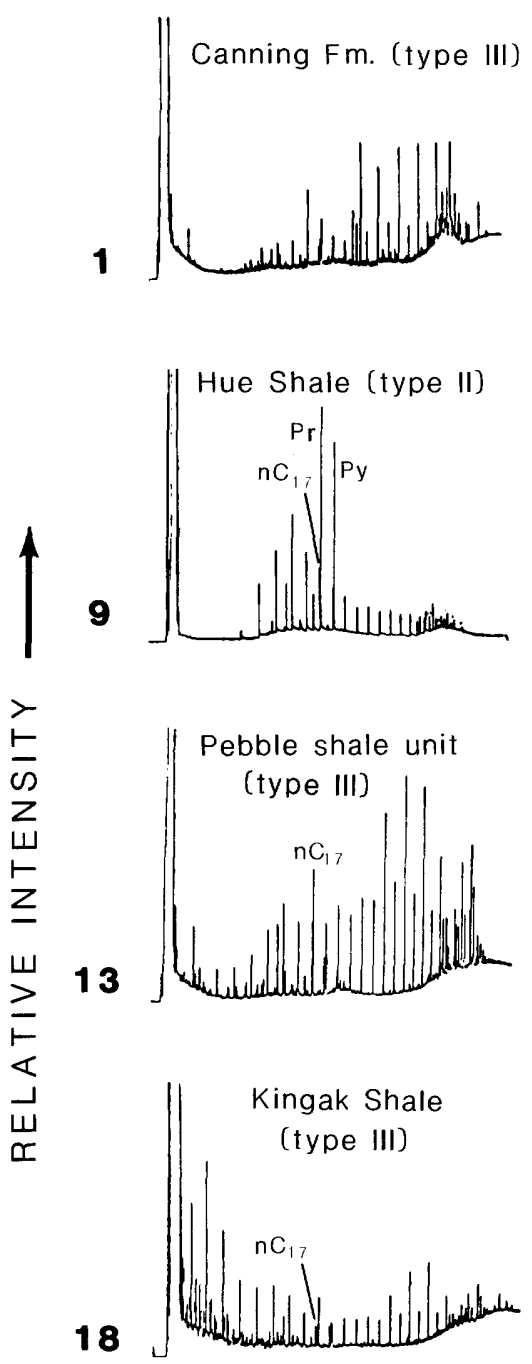

17

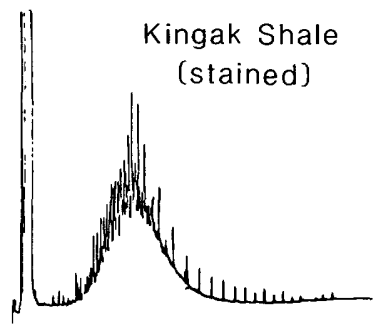

$m / z 191$
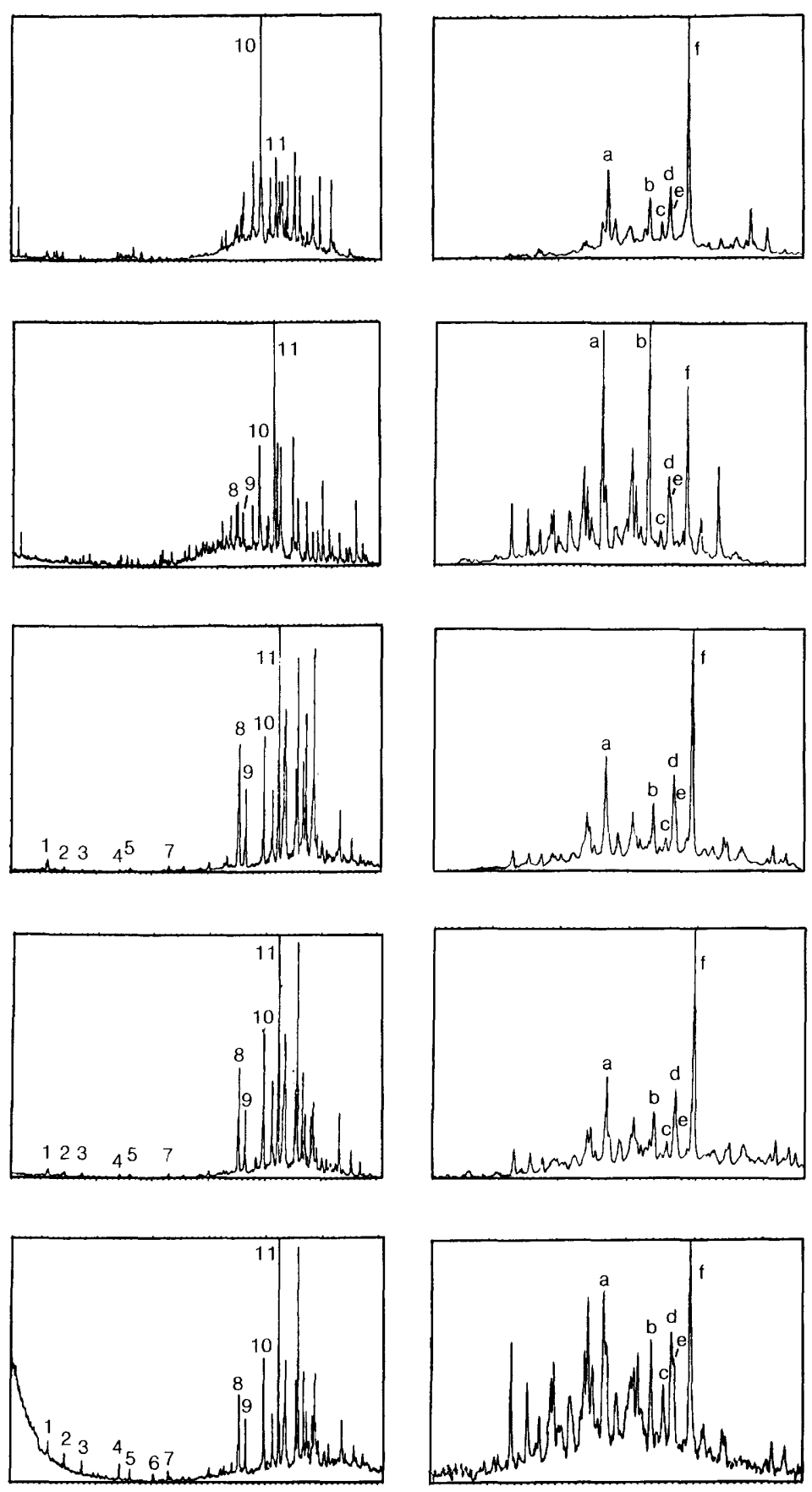

$\boldsymbol{A}$

\section{RETENTION TIME}

Figure 12.4. Gas chromatograms and $m / 2191$ and 217 ion chromatograms for $(A)$ immature and $(B)$ mature rocks. Bold numbers refer to table 12.1. Abbreviations for the GC (gas chromatograph) column: $\mathrm{nC}_{17}$, straight-chained paraffin with 17 carbon atoms; Pr, pristane; Py, phytane; for the $m / z 191$ column: $1, \mathrm{C}_{19}$ tricyclic; $2, \mathrm{C}_{20}$ tricyclic; $3, \mathrm{C}_{21}$ tricyclic; $4, \mathrm{C}_{23}$ tricyclic; $5, \mathrm{C}_{24}$ tricyclic; $6, \mathrm{C}_{25}$ tricyclic; 7, $\mathrm{C}_{26}$ tricyclic;
8, $\mathrm{C}_{27}$ trisnorhopane (Ts); $9, \mathrm{C}_{27}$ trisnorhopane (Tm); $10, \mathrm{C}_{29}$ norhopane; $11, \mathrm{C}_{30}$ hopane; $12, \mathrm{C}_{31}$ homohopane (S,R); for the $\mathrm{m} / \mathrm{z} 217$ column: a, $\mathrm{C}_{27} 14 \alpha$ sterane (20R); b, $\mathrm{C}_{28} 14 \alpha$ sterane (20R); $c, \mathrm{C}_{29} 14 \alpha$ sterane $(20 \mathrm{~S}) ; \mathrm{d}, \mathrm{C}_{29} 14 \beta$ sterane (20R); e, $\mathrm{C}_{29} 14 \beta$ sterane (20S); f, $\mathrm{C}_{29} 14 \alpha$ sterane (20R). 
GC
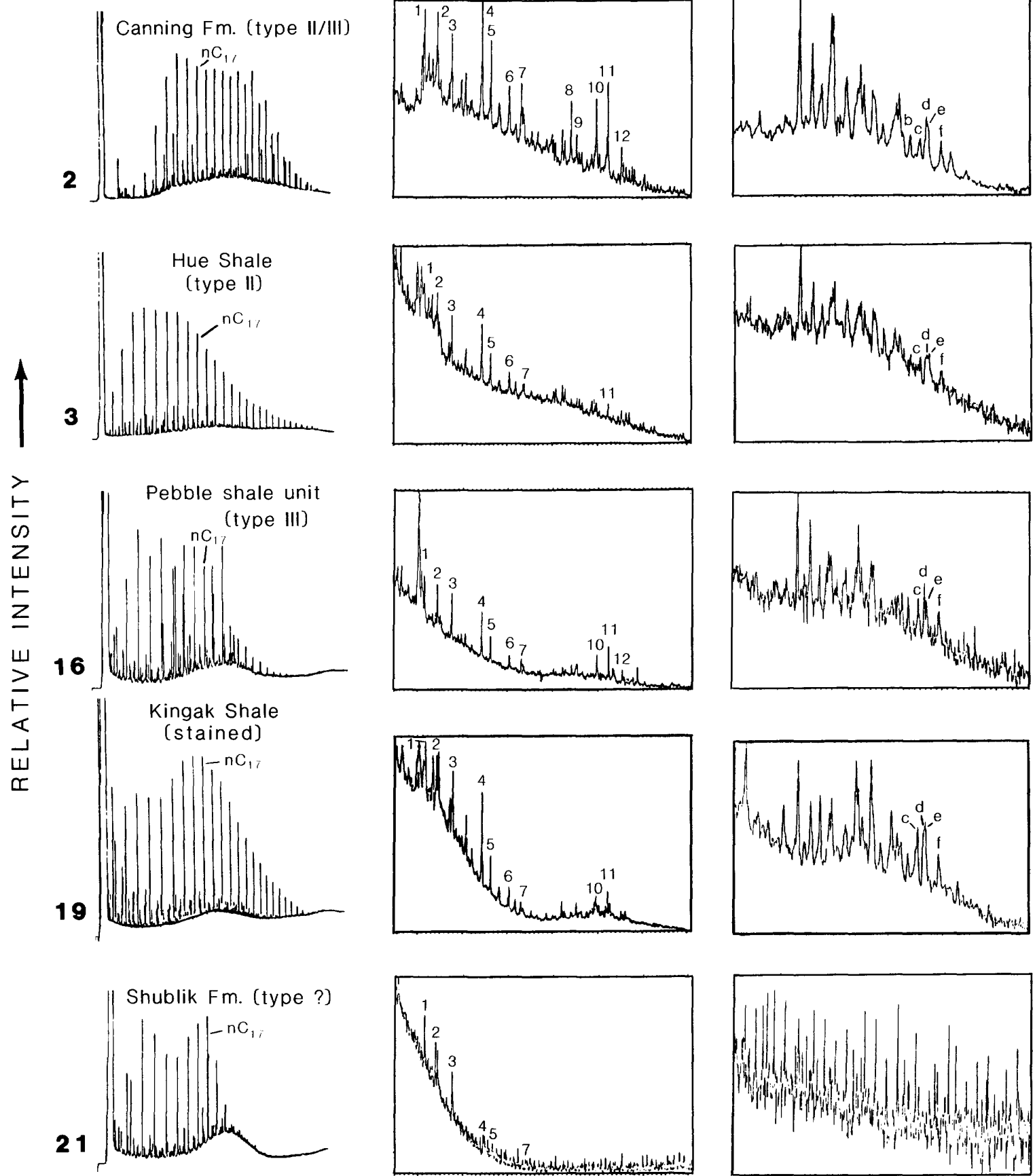

$\boldsymbol{B}$
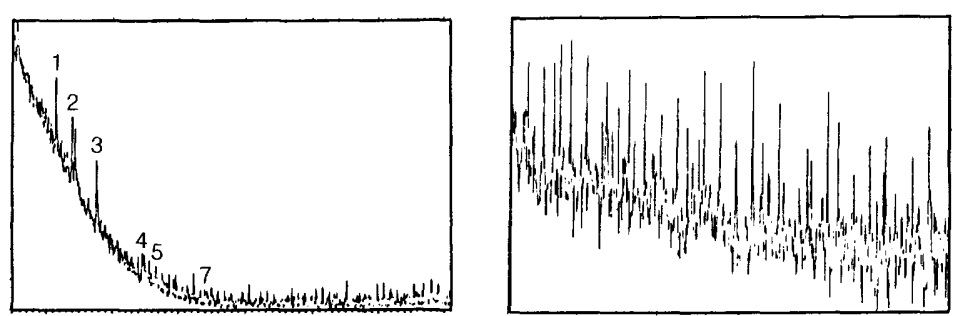

RETENTION TIME

Figure 12.4. Continued. 
The two types of oil in the Point Thomson area are characterized as a $35^{\circ}$ to $45^{\circ}$ API gravity oil with an average GOR of 16,000 and a $21^{\circ}$ to $27^{\circ}$ API gravity oil with an average GOR of 750 . The gaseous higher gravity oil in the Thomson sand and basement complex probably originates from type III organic matter, such as in the pebble shale unit, whereas the lower gravity oil in the Canning Formation probably originates from type II/III organic matter, such as in the Hue Shale.

Three wells in the Kavik area penetrated small gas accumulations (table 12.2). Drill stem tests in the Canning Formation in the Beli Unit-1 well indicated rates of as much as 210 trillion $\mathrm{ft}^{3}$ (tcf)/day (6 trillion $\mathrm{m}^{3} /$ day) gas. In the Kavik-1 and Kavik Unit-3 wells, drill-stem tests in the Karen Creek Sandstone produced up to $10,000 \mathrm{tcf} /$ day ( 280 trillion $\mathrm{m}^{3} /$ day) and up to 170,000 tcf/day $\left(4,800\right.$ trillion $\mathrm{m}^{3} /$ day $)$ gas from the Ledge Sandstone Member (of the Ivishak Formation). The origin of this gas is unknown, but it is suspected to be thermal gas from very mature to overmature source rocks in the Kavik area. Gas recovered from the Canning Formation most likely originated from indigenous type III organic matter, and gas from the

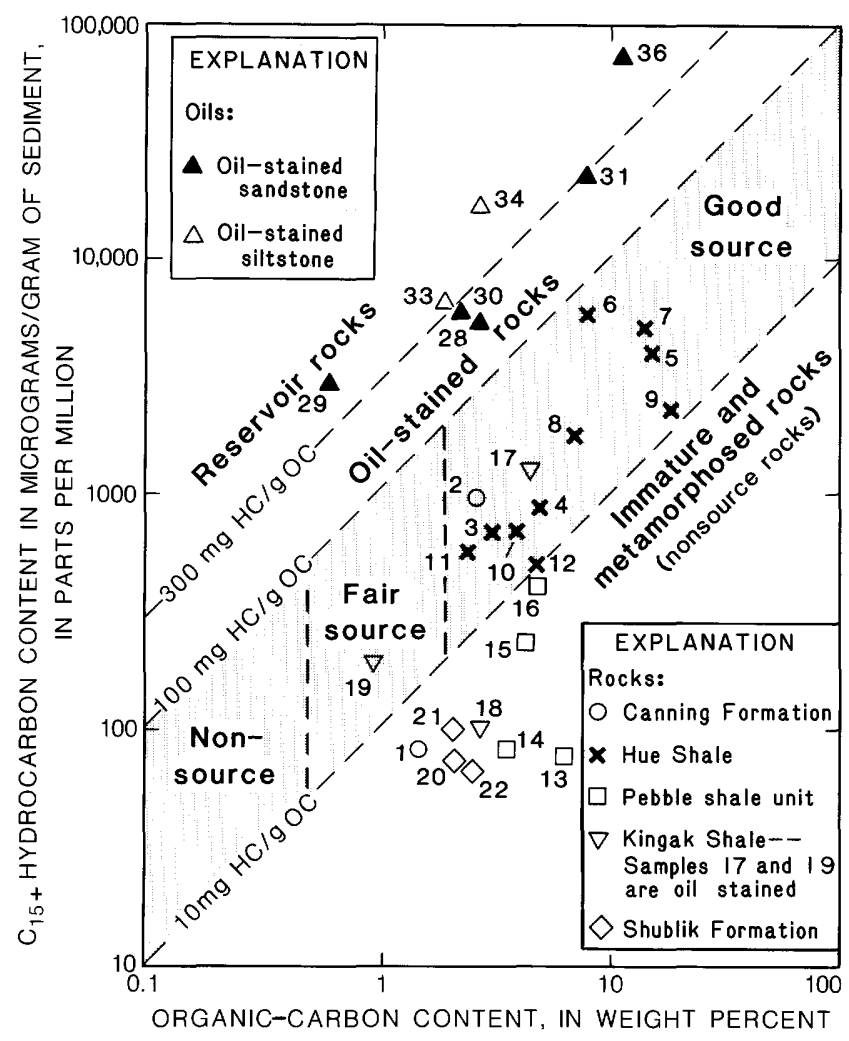

Figure 12.5. $\mathrm{C}_{15+}$ hydrocarbon content versus organiccarbon content for ANWR rocks. Numbers refer to table 12.1.
Karen Creek Sandstone could have come from the Kavik Member of the Ivishak Formation (chap. 11).

\section{Oil Seeps and Oil-Stained Outcrops}

Eleven oil samples have been analyzed from two oil seeps and six oil-stained outcrops within and adjacent to the ANWR coastal plain. The oil-stained shales occur in the Kingak Shale and the Canning Formation, and the oil-stained sandstones occur in the Canning Formation and the Sagavanirktok Formation. The two oil seeps, Manning Point and Angun Point, emanate from the surficial deposits. Except for sample 17 from the Kingak Shale, which was detected in the laboratory, all oil stains were observed in the field (fig. $12.4 A, B$, samples $17-19$ and fig. $12.6 A, B$, samples 28-36).

All of the stained rocks, with the exception of samples 17 and 19, contain abundant hydrocarbons ( $\mathrm{HC} / \mathrm{OC}=18$ to 77 weight percent, table 12.1). The relatively low $\mathrm{HC} / \mathrm{OC}$ value (2.9 weight percent) for sample 17 results from light staining of an organiccarbon-rich, type III rock with a biodegraded crude oil (fig. 12.4A). All of the ANWR oil seeps and stained rocks are biodegraded except samples 19 and 29 (figs. $12.4 A, B, 12.6 A, B)$. When the relative amounts of the saturate and aromatic hydrocarbons and the nonhydrocarbons for the seeps and stains are plotted on a triangular diagram, two clusters occur; one cluster is high in nonhydrocarbons (asphaltics), and the other is high in saturate hydrocarbons (paraffins; fig. 12.7). The asphaltic-type oils (table 12.1, samples 28, 30-32) are severely biodegraded and dominated by heavy hydrocarbons, whereas the paraffinic-type oils (table 12.1, samples 17, 19, 29, and 33-36) are less biodegraded and dominated by light hydrocarbons.

\section{Oil-Oil Correlations}

Carbon-isotope information on the saturate and aromatic hydrocarbon fractions for the seeps and stained rocks in or adjacent to the ANWR (table 12.1, samples 28-36) shows distinct isotopic differences that help to classify the oils into specific types (fig. 12.8A). Carbon isotopes are little affected by biodegradation and weathering processes, so the clustering of values into three distinct groups in figure $12.8 \mathrm{~A}$ has implications as to the origin of these oils. The values for stained samples 17 and 19 were not plotted because their hydrocarbon staining was only slight, which could make the possible effects of the indigenous hydrocarbons on the isotope values of the migrated hydrocarbons large (particularly the aromatic hydrocarbons). Carbonisotopic values for the saturate and aromatic hydrocarbon fractions for the Prudhoe Bay (Seifert and others, 1979; Magoon and Claypool, 1984) and NPRA oil types are also shown for purposes of comparison. Based on isotopic similarities, the Jago River, Katakturuk River, 
and Angun Point oils (fig. 12.8A, table 12.1, samples 29-34) form one ANWR oil type (Jago type), the Manning Point oil (fig. 12.8A, table 12.1, samples 35, 36) forms a second ANWR oil type (Manning type), and the Kavik oil (adjacent to the ANWR; fig. 12.8A, table 12.1, sample 28) forms a third oil type (Kavik type). Isotopically, the Prudhoe Bay area oils (represented by samples 23, Kingak oil, and 24, Prudhoe oil) are unlike any of the northeastern Alaska oils, the South Barrow-20 oil (sample 27, pebble shale oil) is similar to the Jago type, and the Cape Simpson and Umiat oils (samples 25 and 26, Simpson-Umiat oil) are similar to the Manning type.

A comparison of the carbon-isotope values for the saturate hydrocarbon fraction in the ANWR oils with the saturate/aromatic hydrocarbon (S/A) ratios in the oils is shown in figure 12.9. As in the previous plot (fig. 12.8A), the ANWR and Kavik oils in figure 12.9 cluster into the same three groups: Jago, Manning, and Kavik). Sample 29 is the only ANWR oil examined that is not severely biodegraded (fig. 12.6A). Consequently, sample 29 possesses a high S/A ratio and plots to the right of the main body of oils for the Jago type (fig. 12.9). When compared with the other North Slope oils, we find that the Prudhoe Bay oil types and the NPRA
Umiat and Simpson oil types are unlike the ANWR and Kavik oils, but that the pebble shale oil type (South Barrow-20) is like the Jago type.

Although the pentacyclic biomarker, hopane, is missing from some of the more biodegraded northeastern Alaska oils (table 12.1, samples 28, 31, 32), a comparison of the hopane/ $\mathrm{C}_{23}$ tricyclic terpane ratio in the remaining ANWR oils (table 12.1, samples 29, 30, 33-36) with their $\mathrm{C}_{19} / \mathrm{C}_{23}$ tricyclic terpane ratios (fig. 12.10) separates the Manning and Jago types and easily distinguishes the ANWR oil types from other North Slope oils. From table 12.1, the ANWR oils and the Kavearak Point oil (Prudhoe) have hopane/ $\mathrm{C}_{23}$ tricyclic terpane ratios $>7$, whereas the remaining North Slope oils have values $<5$. Most North Slope oils have low $\mathrm{C}_{19} / \mathrm{C}_{23}$ tricyclic terpane ratios that fall in the range 0.1 to 0.6 (table 12.1). Within this narrow range, the Prudhoe Bay, pebble shale, Simpson, Jago, and Kavik oil types cannot be distinguished from each other, but they can be distinguished from the much higher ratios (1.9-2.1) of the Manning and Umiat types.

When the tricyclic terpane distributions $\left(\mathrm{C}_{19} / \mathrm{C}_{23}\right)$ in the ANWR and Kavik oils are plotted against the $\delta^{13} \mathrm{C}$ values for their saturate hydrocarbon

Table 12.2. Oil and gas recovered from wells adjacent to ANWR

$[-$, no information; MCFD, thousand cubic feet of gas per day; BOPD, barrels of oil per day (calculated from flow period)]

\begin{tabular}{|c|c|c|c|c|c|c|}
\hline Well & $\begin{array}{l}\text { Depth } \\
\text { interval } \\
\text { (ft) }\end{array}$ & $\begin{array}{l}\text { Rock } \\
\text { unit }\end{array}$ & $\begin{array}{l}\text { Fluids } \\
\text { recovered }\end{array}$ & $\begin{array}{l}\text { Gas/oil } \\
\text { ratio } \\
\text { (GOR) }\end{array}$ & $\begin{array}{l}\text { API } \\
\text { gravity } \\
\left({ }^{\circ}\right)\end{array}$ & Remarks \\
\hline \multicolumn{7}{|c|}{ Point Thomson area } \\
\hline East Mikkelsen Bay State-1 & $11,552-11,564$ & Canning Fm. & Oil & - & 24 & $180 \mathrm{BOPD}$ \\
\hline Alaska State A-1 & $12,565-12,635$ & Canning Fm. & Oil \& gas & 864 & 23 & 2,200 MCFD; 2,500 BOPD \\
\hline \multirow[t]{3}{*}{ Alaska State F-1 } & $12,008-12,080$ & Canning Fm. & do. & 1,040 & 22 & 116 MCFD; 137 BOPD \\
\hline & $13,794-13,884$ & Thomson sand & do. & 14,912 & 35 & 4,235 MCFD; 284 BOPD \\
\hline & $13,940-14,316$ & Basement complex & do. & 19,572 & 35 & 2,975 MCFD; 152 BOPD \\
\hline \multirow[t]{3}{*}{ Point Thomson Unit-1 } & $11,392-11,421$ & Canning Fm. & do. & 17,045 & 44 & 2,250 MCFD; 132 BOPD \\
\hline & $12,834-12,874$ & Thomson sand & do. & 22,705 & 45 & 3,860 MCFD; 170 BOPD \\
\hline & $12,963-13,050$ & Thomson sand & do. & 5,826 & 18 & 13,307 MCFD; 2,283 BOPD \\
\hline Point Thomson Unit-2 & $11,580-11,678$ & Canning Fm. & do. & 500 & 21 & 124 MCFD; 248 BOPD \\
\hline Point Thomson Unit-3 & $13,872-13,885$ & Thomson sand & do. & 13,336 & 38 & 6,348 MCFD; 476 BOPD \\
\hline Alaska Island-1 & $14,997-15,022$ & Basement complex & do. & 11,270 & $>40$ & 2,931 MCFD; 260 BOPD \\
\hline West Staines State $18-9-23$ & $11,650-11,675$ & Canning Fm. & Oil & - & 27 & 210 BOPD and gas \\
\hline Alaska State C-1 & $13,426-13,560$ & Thomson sand & Oil \& gas & 3,890 & 37 & 3,400 MCFD; 875 BOPD \\
\hline \multicolumn{7}{|c|}{ Kavik area } \\
\hline \multirow[t]{2}{*}{ Kavik-1 } & $4,252-4,292$ & Karen Creek Sandstone & Gas & - & - & 10,500 MCFD \\
\hline & $4,748-5,100$ & Ledge Sandstone Mbr. ${ }^{1}$ & do. & - & - & $44,000 \mathrm{MCFD}$ \\
\hline \multirow[t]{2}{*}{ Kavik Unit-3 } & $4,935-5,070$ & Karen Creek Sandstone & do. & - & - & 7,400 MCFD \\
\hline & $5,524-5,850$ & Ledge Sandstone Mbr. ${ }^{1}$ & do. & - & - & 170,000 MCFD \\
\hline \multirow[t]{2}{*}{ Beli Unit-1 } & $8,420-8,435$ & Canning Fm. & do. & - & - & 50 MCFD \\
\hline & $9,055-9,103$ & Canning Fm. & do. & - & - & 210 MCFD \\
\hline
\end{tabular}

${ }^{1}$ Of Ivishak Formation. 
GC
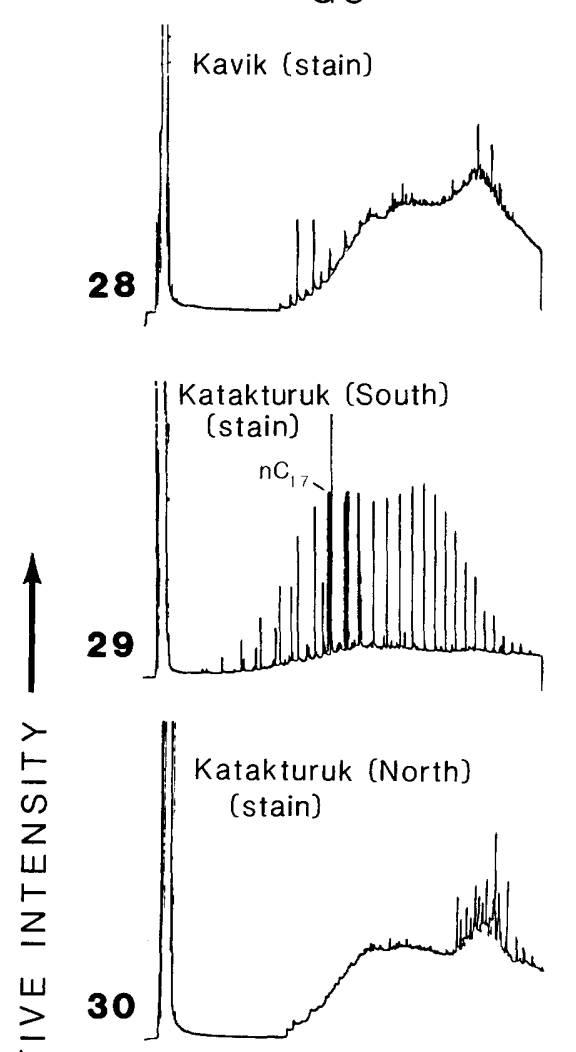

31
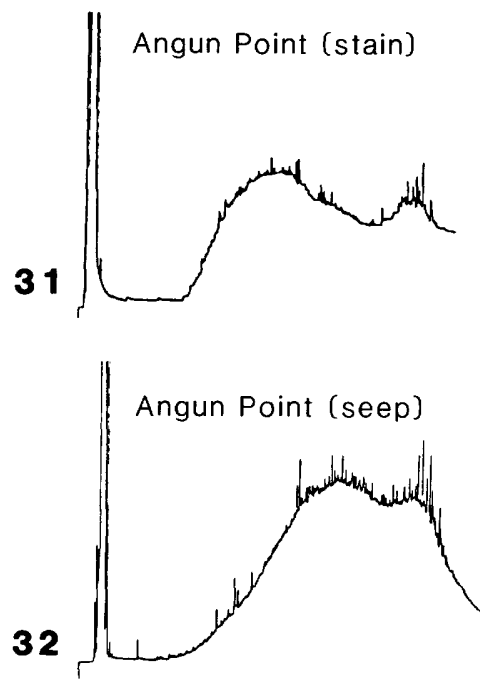

$m / z 191$
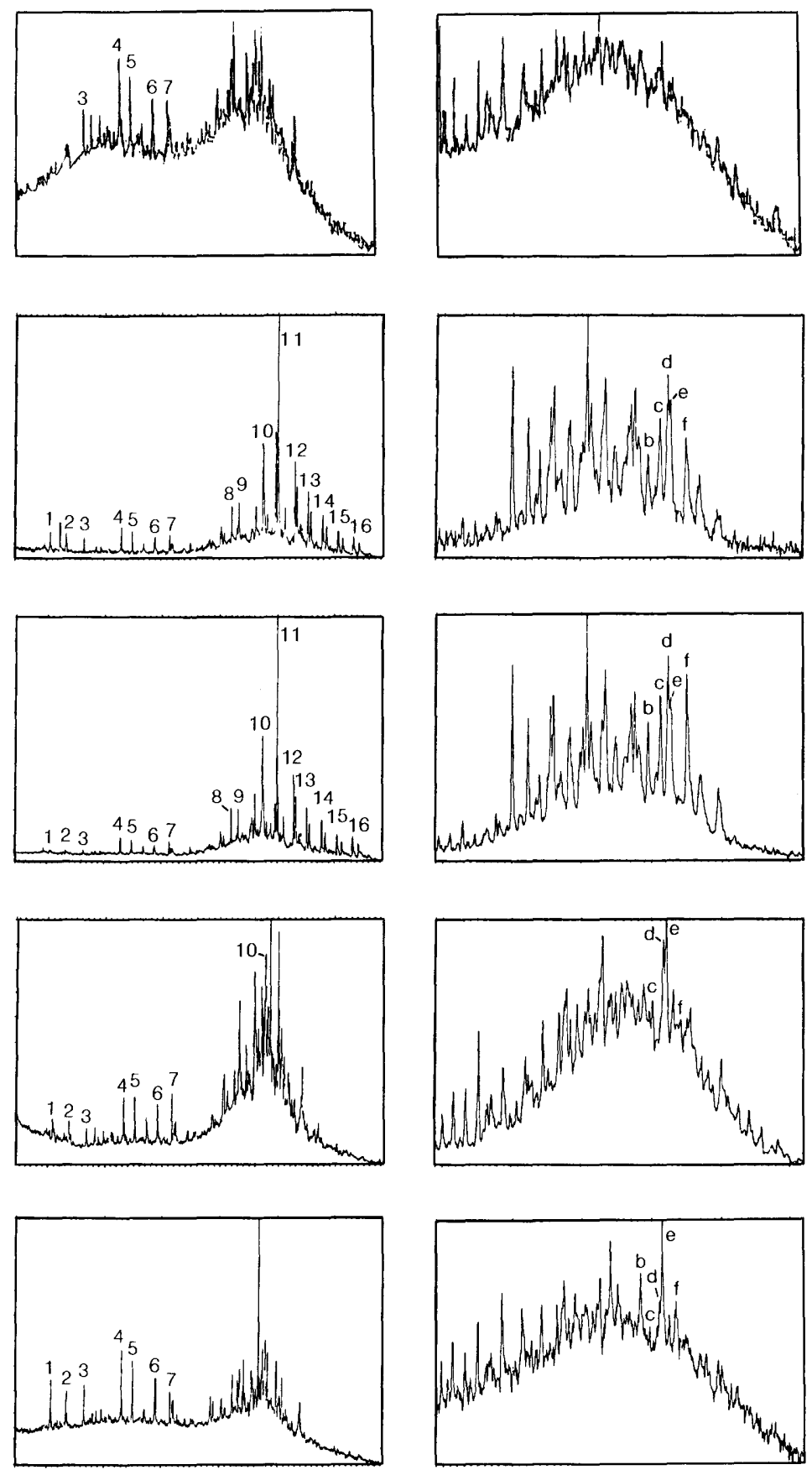

$\boldsymbol{A}$

RETENTION TIME 
GC
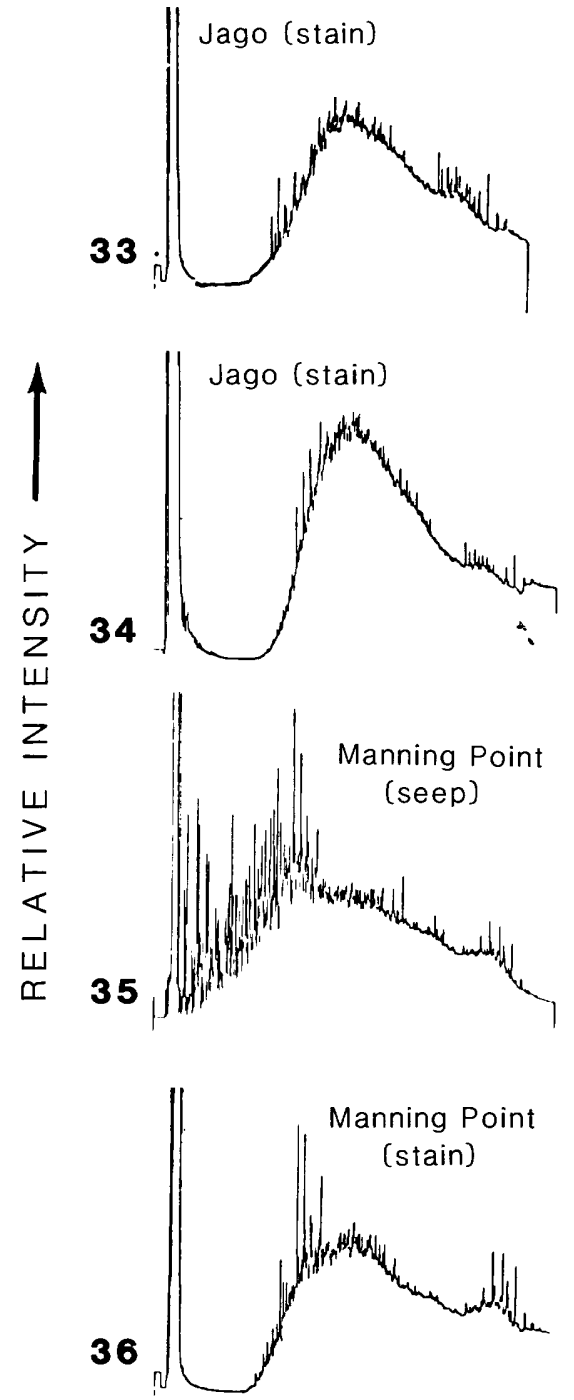

$m / z 191$
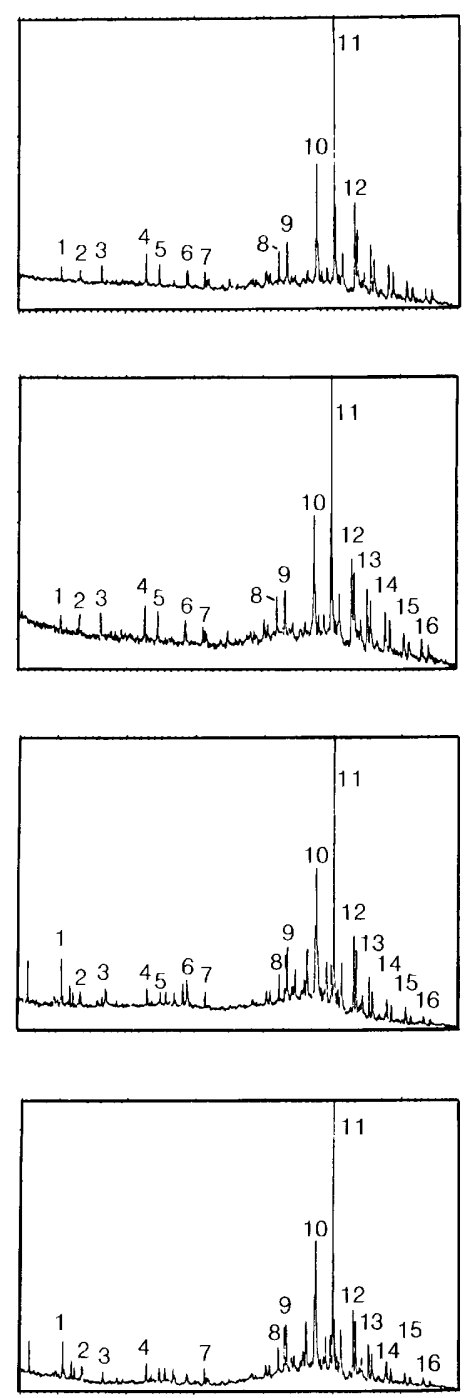

$m / z \quad 217$
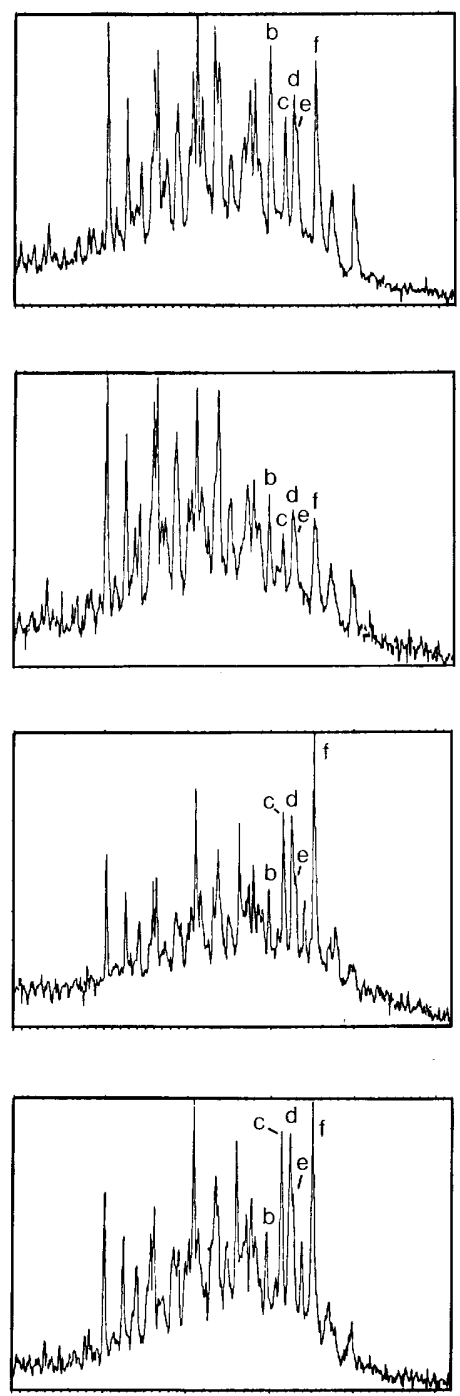

$\boldsymbol{B}$

RETENTION TIME

Figure 12.6. Continued.

fractions, the northeastern Alaska oils again separate (fig. $12.8 B$ ) into three groups: Jago (29-34), Manning (35, 36 ), and Kavik (28).

\section{Oil-Source Rock Correlation}

Oil-source rock correlation is based upon the recognition of compositional similarities and dissimilarities in the oil and rock extracts. Generally, agreement in two or more independent parameters (such as carbon isotopes and biological marker distributions) are necessary to suggest a relationship. Bitumen extracts from five ANWR rock units (Shublik Formation, Kingak
Shale, pebble shale unit, Hue Shale, Canning Formation) were compositionally compared with the ANWR oil types (Jago, Manning, and Kavik) established in the preceding section. The compositional parameters least affected by biodegradation and thermal maturity (such as carbon isotopes of the saturate and aromatic hydrocarbon fractions and $\mathrm{C}_{19} / \mathrm{C}_{23}$ tricyclic terpane ratios) were used for the ANWR oil-source rock correlation study.

The $\delta^{13} \mathrm{C}$ values for the saturate and aromatic hydrocarbon fractions from the ANWR oils and rocks are compared in figure $12.8 C$. In this figure, isotopic data for the Hue Shale and Canning Formation are shown plotted as one group because they are stratigraphically 
adjacent and lithologically similar (Molenaar, 1983). The 3 per-mil shift in isotope values within the Hue Shale and Canning Formation is largely a function of organic-matter type (II, III). The type II facies of these two units (table 12.1 , samples $2,5-9$ ) are isotopically the lightest $\left(\delta^{13} \mathrm{C}=-28.8 \pm 0.5\right.$ for the saturate hydrocarbons, $-28.5 \pm 0.9$ for the aromatic hydrocarbons), forming a cluster of values plotting in the lower quadrant. On the other hand, the type III facies (table 12.1, samples 1, 3, $4,10-12)$ in the Hue Shale and Canning Formation are isotopically the heaviest $\left(\delta^{13} \mathrm{C}=-27.3 \pm 1.3\right.$ for the saturate hydrocarbons, $-27.1 \pm 0.8$ for the aromatic hydrocarbons), forming a cluster of values plotting in the upper quadrant.

Based on carbon-isotopic similarities and dissimilarities between the rocks and oils, only the pebble shale unit can be ruled out as a potential source rock for the ANWR and Kavik oils. The Jago oil type hydrocarbons are isotopically most like the hydrocarbons from the type II facies of the Hue Shale, and the Manning oil type is isotopically similar to the Shublik Formation, Kingak Shale, and Hue Shale. Isotopically, the Kavik oil type hydrocarbons are somewhat different from any of the hydrocarbons in the rock units of the ANWR.

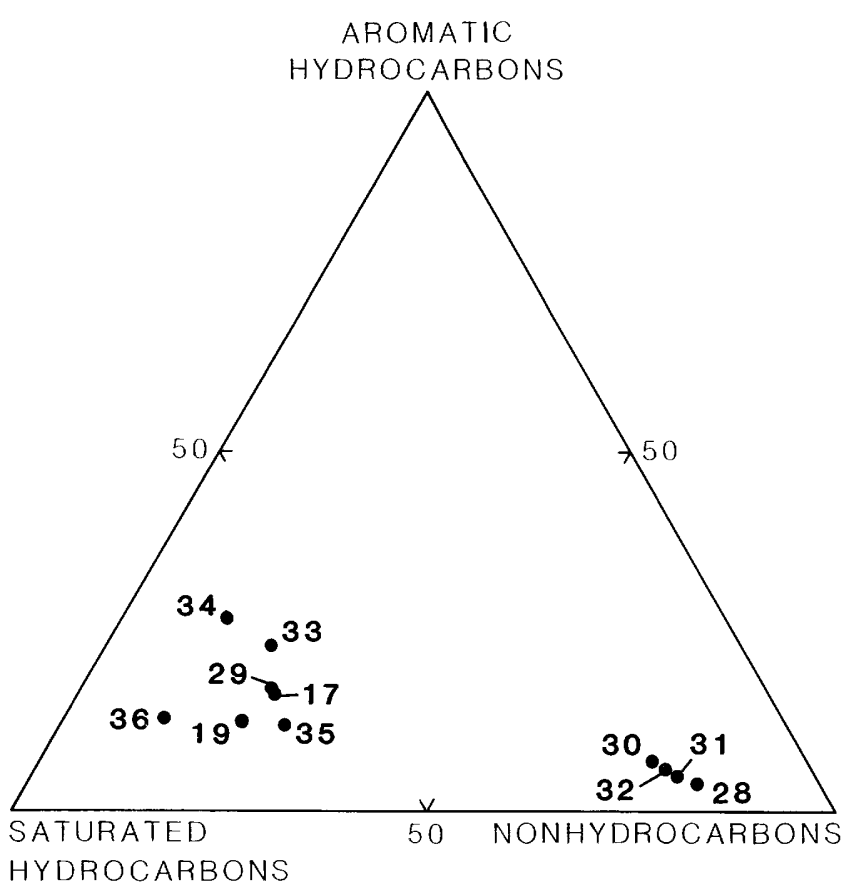

Figure 12.7. Comparison of distributions of saturated hydrocarbons, aromatic hydrocarbons, and nonhydrocarbons (asphaltic) in ANWR oils. Numbers refer to table 12.1 .
In the oil-oil correlation section previously discussed, the plot of the $\delta^{13} \mathrm{C}$ values of the saturate hydrocarbon fraction for the oils versus their $C_{19} / C_{23}$ tricyclic terpane ratios was useful in establishing three genetic oil types in or adjacent to the ANWR (fig. $12.8 B$ ). Comparison of the oils with similar properties in the five rock units (fig. 12.8D) shows the Jago oil type similar to the type II facies of the Hue Shale, the Manning oil possibly similar to the Kingak Shale, and the Kavik oil type dissimilar to any of the rock units.

The high hopane/ $\mathrm{C}_{23}$ tricyclic terpane ratios $(>7)$ that characterize the ANWR oils (table 12.1) are also high $(>8)$ in all of the thermally immature rocks of the ANWR but low $(<1)$ in all of the thermally mature rocks of the ANWR (table 12.1). Because this ratio is not expected to change dramatically during mild oil biodegradation but can change to lower ratios with migration and thermal maturation, the high hopane/ $\mathrm{C}_{23}$ tricyclic terpane ratios in the ANWR and Kavik oils relative to the much lower ratios in the mature rocks of the ANWR suggest that expulsion had to have begun early during catagenesis, and that the distance of migration had to have been short in order for the values in the oils to remain so high.

\section{CONCLUSIONS}

The Shublik Formation, Kingak Shale, pebble shale unit, Hue Shale, and Canning Formation are all sufficiently rich in organic-carbon content to be good source rocks. However, the type II rocks of the Hue Shale are the only rocks in the ANWR with adequate hydrogen-rich kerogen to yield liquid hydrocarbons during catagenesis. The pebble shale unit, Canning Formation, and Kingak Shale at Niguanak are dominated by hydrogen-poor, type III organic matter and yield principally gas during hydrous pyrolysis. The Shublik Formation and Kingak Shale exposures at Ignek Valley could not be adequately evaluated because of the advanced thermal maturity of their organic matter.

The source for the hydrocarbons in the Point Thomson area can only be speculated on. The condensate and gas recovered from the Thomson sand and basement complex is probably derived from the type III organic matter associated with the pebble shale unit, and the oil recovered from the Canning Formation probably came from the Hue Shale. The gas recovered from three wells in the Kavik area is probably of thermal origin from overmature source rocks in the immedidate area.

The characterization of crude oil from surface seeps and oil-stained rocks within or adjacent to the ANWR can be divided into two groups (asphaltic and paraffinic), which are in part the result of biodegradation and weathering. Genetically, the oils within or adjacent to the ANWR form three distinct oil types, based on 


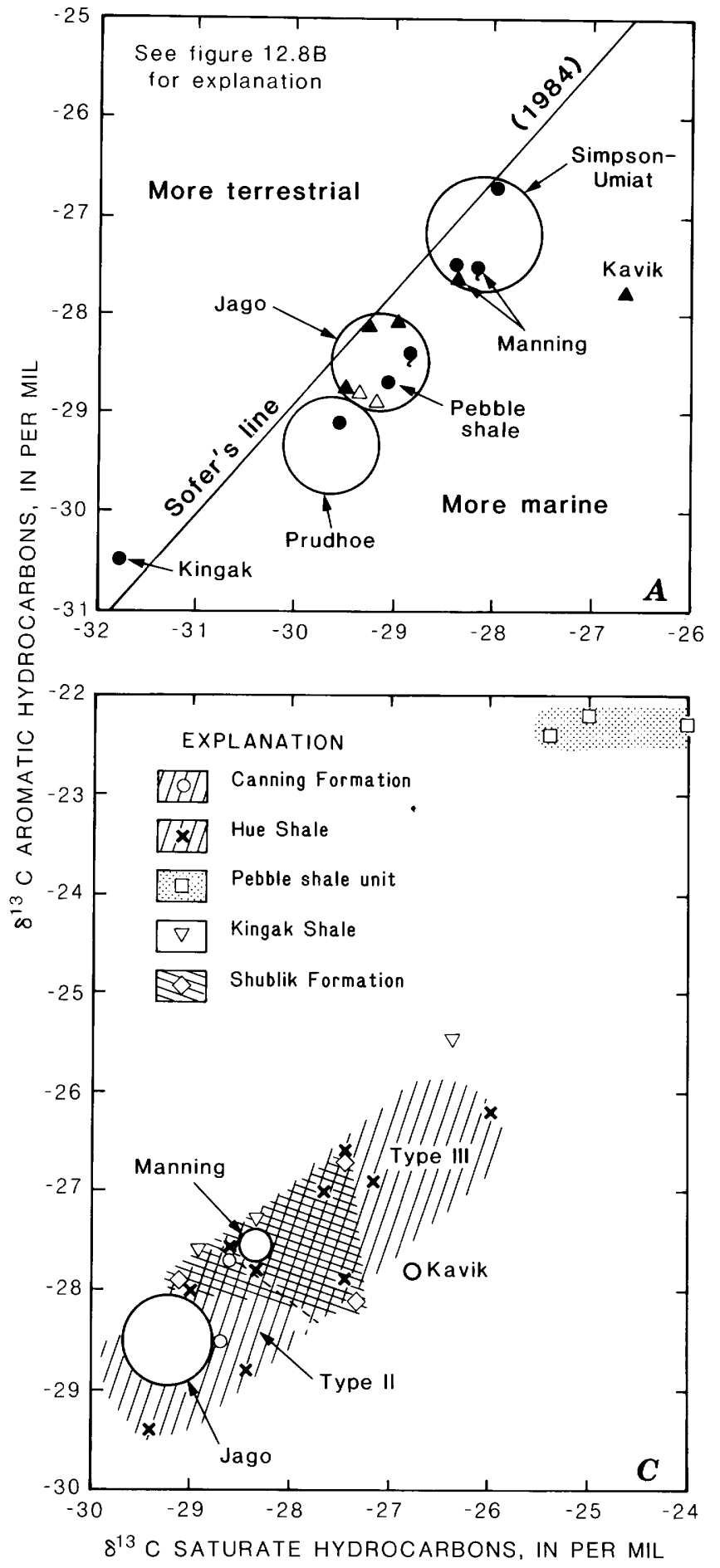

Figure 12.8. $A$, Carbon-isotope distribution for ANWR, NPRA, and Prudhoe Bay (North Slope) oil types. Sofer's line separates marine from nonmarine oils (Sofer, 1984). $B$, Comparison of $\delta^{13} \mathrm{C}$ saturate hydrocarbons with $\mathrm{C}_{19} / \mathrm{C}_{23}$ tricyclic terpane ratio in ANWR, NPRA,

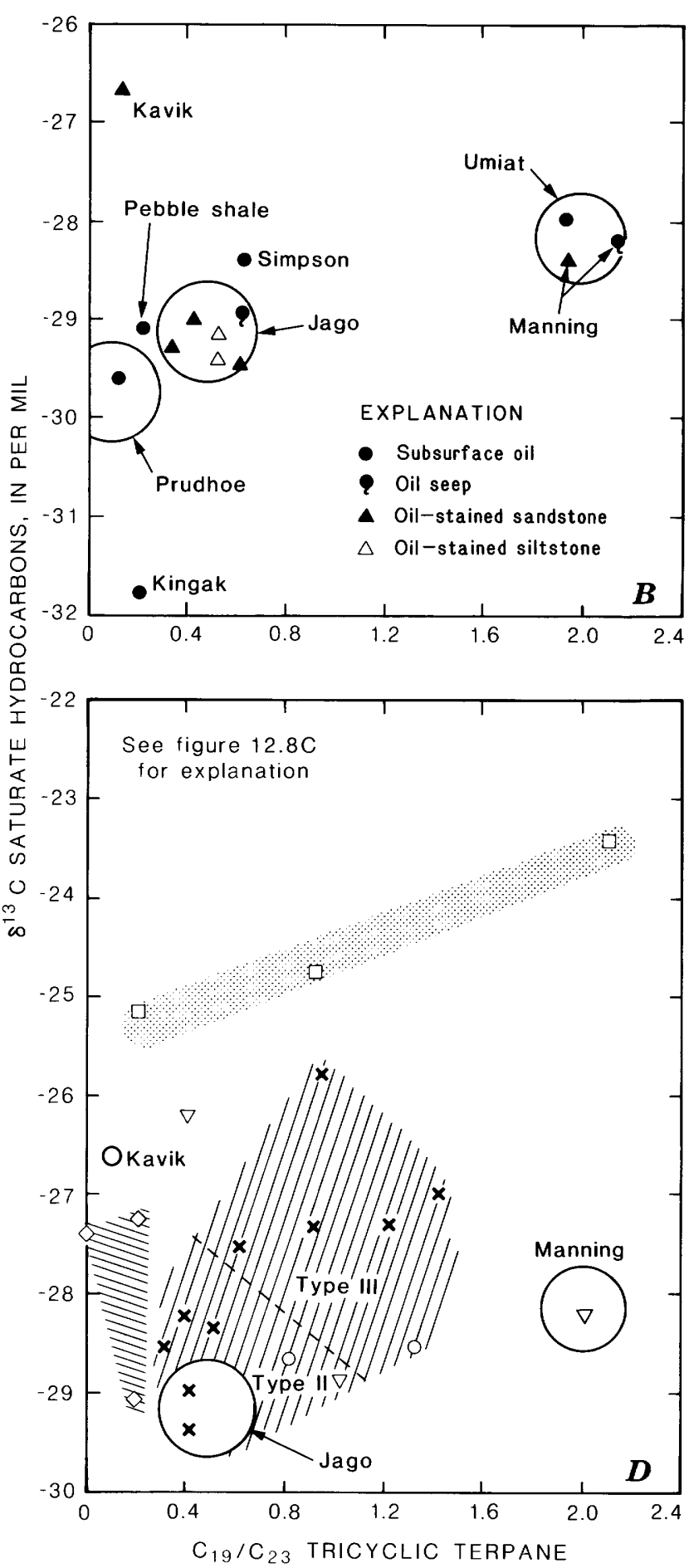

and Prudhoe Bay area oil types. $C$, Carbon-isotope distribution (saturate versus aromatic) in ANWR oils and rocks. $D$, Carbon-isotope $\left(\delta^{13} \mathrm{C}\right.$ saturate hydrocarbon) versus $\mathrm{C}_{19} / \mathrm{C}_{23}$ tricyclic terpane ratio in ANWR oils and rocks. Data listed on table 12.1 . 
similarities or dissimilarities in their carbon-isotope values of the saturate and aromatic hydrocarbons, $\mathrm{C}_{19} / \mathrm{C}_{23}$ tricyclic terpane ratios, hopane/ $\mathrm{C}_{23}$ tricyclic terpane ratios, and saturate/aromatic hydrocarbon ratios. The three oil types are as follows: (1) the Jago oil type, which includes oils from the Katakturuk River area near the Marsh Creek anticline, the Katakturuk River area near the Sadlerochit Mountains, the Jago River area, and the Angun Point adjacent to the Beaufort Sea; (2) the Manning oil type, from Manning Point adjacent to the Beaufort Sea; and (3) the Kavik oil type, from the Kavik River area west of the Canning River. The commercially important Prudhoe Bay oil types of Seifert and others (1979) and the NPRA oil types of Magoon and Claypool

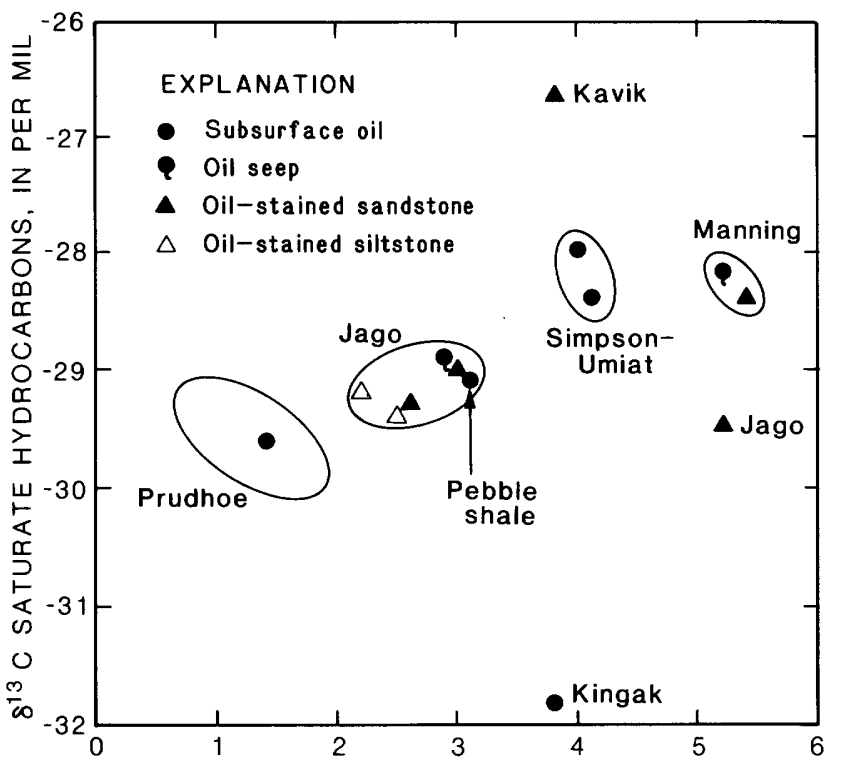

SATURATE HYDROCARBONS/AROMATIC HYDROCARBONS
(1981) do not correlate well with any of the oils found in or adjacent to the ANWR coastal plain. From this observation, it can be assumed that the oils of the ANWR did not have a common origin with the NPRA and Prudhoe Bay oils.

Oil-source rock correlation, based on similarities in carbon-isotope values of the saturate and aromatic hydrocarbon fractions and $\mathrm{C}_{19} / \mathrm{C}_{23}$ tricyclic terpane ratios, suggests that the most promising sourcerock unit for the Jago oil type is the Hue Shale. Chemically, the source rocks for the Manning and Kavik oil types could not be established with the same degree of certainty.

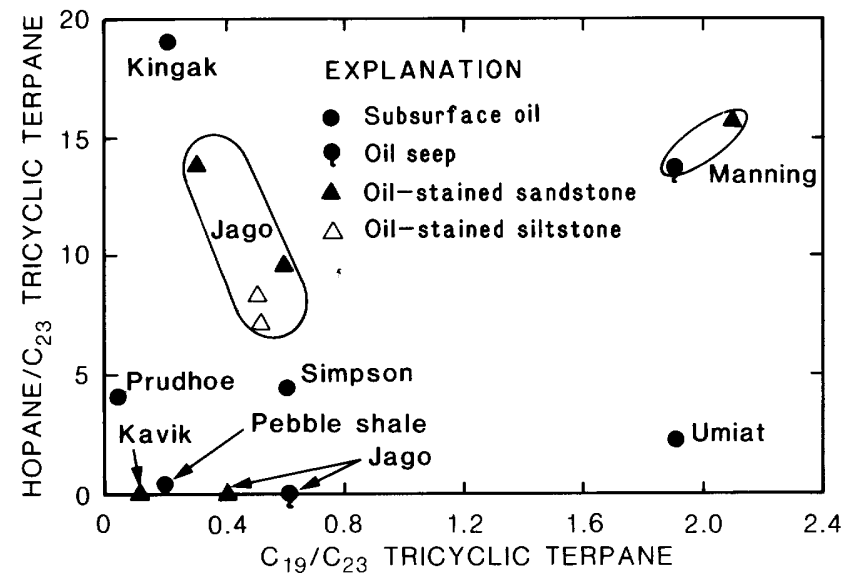

Figure 12.10. Comparison of hopane/ $C_{23}$ tricyclic terpane ratio with $\mathrm{C}_{19} / \mathrm{C}_{23}$ tricyclic terpane ratio in ANWR, NPRA, and Prudhoe Bay area oil types.

Figure 12.9. Comparison of $\delta^{13} \mathrm{C}$ saturate hydrocarbons with saturate/aromatic hydrocarbons ratio in ANWR, NPRA, and Prudhoe Bay area oil types. 


\title{
Chapter 13.
}

\section{Relationship of Clay Mineralogy, Thermal Maturity, and Geopressure in Wells of the Point Thomson Area}

\author{
By Donald L. Gautier, ${ }^{1}$ Kenneth J. Bird, ${ }^{2}$ and Virginia A. Colten-Bradley ${ }^{3}$
}

\section{INTRODUCTION}

Turbiditic sandstones of the Canning Formation are potential reservoir rocks in the coastal plain of the Arctic National Wildlife Refuge (ANWR). In the Point Thomson area immediately adjacent to the northwestern corner of the ANWR, these rocks are rich in lithic grains and thus are especially susceptible to significant loss of porosity and permeability due to overburden stress (chap. 9). Such effects of compaction may be minimized by the presence of abnormal pore-fluid pressures (geopressures) that offset overburden pressure and reduce net confining stress. The presence of geopressures in the Point Thomson area suggests that such porosity preservation may be the case beneath the ANWR coastal plain also. In order to better predict the possibility of geopressures and concomitant porosity preservation in the Canning Formation beneath the coastal plain of the ANWR, more information is needed concerning the nature of the overpressuring and its relationship to basin evolution.

The effort to clarify the relationships between thermally controlled clay-mineral diagenesis and organic-matter transformations on the one hand and permeability, porosity, and abnormal fluid pressures on the other in thick, shaly sedimentary sequences represents a significant research frontier. Studies of shale-sandstone sequences in the United States Gulf Coast (see Hower and others, 1976; Burst, 1969; and many others), the Rocky Mountains (Hoffman and Hower, 1979; Pollastro and Barker, 1984) and elsewhere have suggested a genetic relationship between thermal maturity for hydrocarbons and illitization of mixed-layer illite/smectite (I/S) clay. In the Gulf Coast, the principal transformation of smectite layers in $\mathrm{I} / \mathrm{S}$ to illite layers occurs at a temperature of approximately 80 to $100{ }^{\circ} \mathrm{C}$ (176 to $212^{\circ} \mathrm{F}$ ). There is strong evidence that the illitization reaction is important in the development of geopressures (Kerr and Barrington, 1961; Freed, 1982; Bruce, 1984).

\footnotetext{
${ }_{2}^{1}$ U.S. Geological Survey, Denver, Colo.

2 U.S. Geological Survey, Menlo Park, Calif.

${ }^{3}$ St. Marys College of Maryland, St. Marys City, Md.
}

The North Slope basin near the ANWR in the Point Thomson area provides an additional setting in which to test the relationship between geopressures, organic-matter maturation, clay-mineral transformations, and porosity preservation. The thick Cretaceous and Tertiary shale and sandstone section consisting of the pebble shale unit, the Hue Shale, and the lower part of the Canning Formation provides an ideal natural laboratory for such an investigation. The Canning Formation and underlying units include a thick sequence of marine mudstone that contains relatively abundant I/S clay and significant amounts of organic matter. In addition, wells near the ANWR have both a well-defined transition from normally pressured to abnormally pressured pore fluids and ample sample availability. Accordingly, for the purposes of better predicting porosity-pressure-maturity relationships beneath the ANWR coastal plain, an investigation was undertaken of the clay diagenesis and thermal maturity of the Canning Formation and adjacent rocks in two wells (Point Thomson Unit-1 and Unit-2) in the Point Thomson area.

\section{Pressure and Temperature}

Analysis of data from the Point Thomson Unit-1 and Unit-2 wells indicates the existence of geopressures below about $3,000 \mathrm{~m}(10,000 \mathrm{ft})$ in both wells and relatively low geothermal gradients (figs. 13.1, 13.2).

Pressures in the subject wells are indicated by the acoustic log, by the mud weights used during drilling, and by the pressure measurements made during formation tests. A trend line, hand-fitted to the shaley intervals of the acoustic-log curve in the upper part of the Canning Formation, shows a progressive decrease in acoustic transit time (increasing velocity) with depth to about $3,000 \mathrm{~m}(10,000 \mathrm{ft})$. Below this depth, the transit time remains the same or increases, which causes the curve to depart from the trend line. The point of departure of the acoustic curve from the trend line is generally interpreted as the top of the geopressured interval (Fertl, 1976). At about this same depth, the driller increased the mudweight from $10 \mathrm{lb} / \mathrm{gal}$ to about $15 \mathrm{lb} / \mathrm{gal}$. Direct measurements during formation tests at several depths within the geopressured section show fluid 
pressures well in excess of hydrostatic (table 13.1).

Bottomhole temperatures recorded by maximum-reading thermometers on successive logging runs in the subject wells were corrected by Horner plots as modified by Dowdle and Cobb (1975). To allow for attachment of the thermometer to the cable at the top of the logging tool, the depth of the temperature reading is estimated to be $15 \mathrm{~m}(50 \mathrm{ft})$ less than the depth reached by the logging tool (Blanchard and Tailleur, 1982). The amount of time the formation is exposed to circulating drilling fluids is critical for accurate temperature corrections. However, this information is not routinely available in the Alaska Oil and Gas Conservation Commission (AOGCC) well records. Therefore, the values in table 13.2 (column 5) are estimates based on available records and drilling time recorded on the mud log. These estimates are believed to be conservative, and thus the values are probably low. Corrected temperatures at three points in each well were combined with a temperature estimate $\left(-1{ }^{\circ} \mathrm{C}, 30^{\circ} \mathrm{F}\right)$ at the loginterpreted base of ice-bearing permafrost (T.S. Collett, U.S. Geological Survey, personal commun., 1986; figs. 13.1, 13.2). The profiles are similar in the upper part of each well. Gradients calculated between data points indicate temperatures for the Point Thomson Unit-1 and Unit-2 wells at the top of the abnormally pressured section are $73{ }^{\circ} \mathrm{C}\left(163{ }^{\circ} \mathrm{F}\right)$ and $66^{\circ} \mathrm{C}\left(151^{\circ} \mathrm{F}\right)$, respectively, and increase downward to the top of the

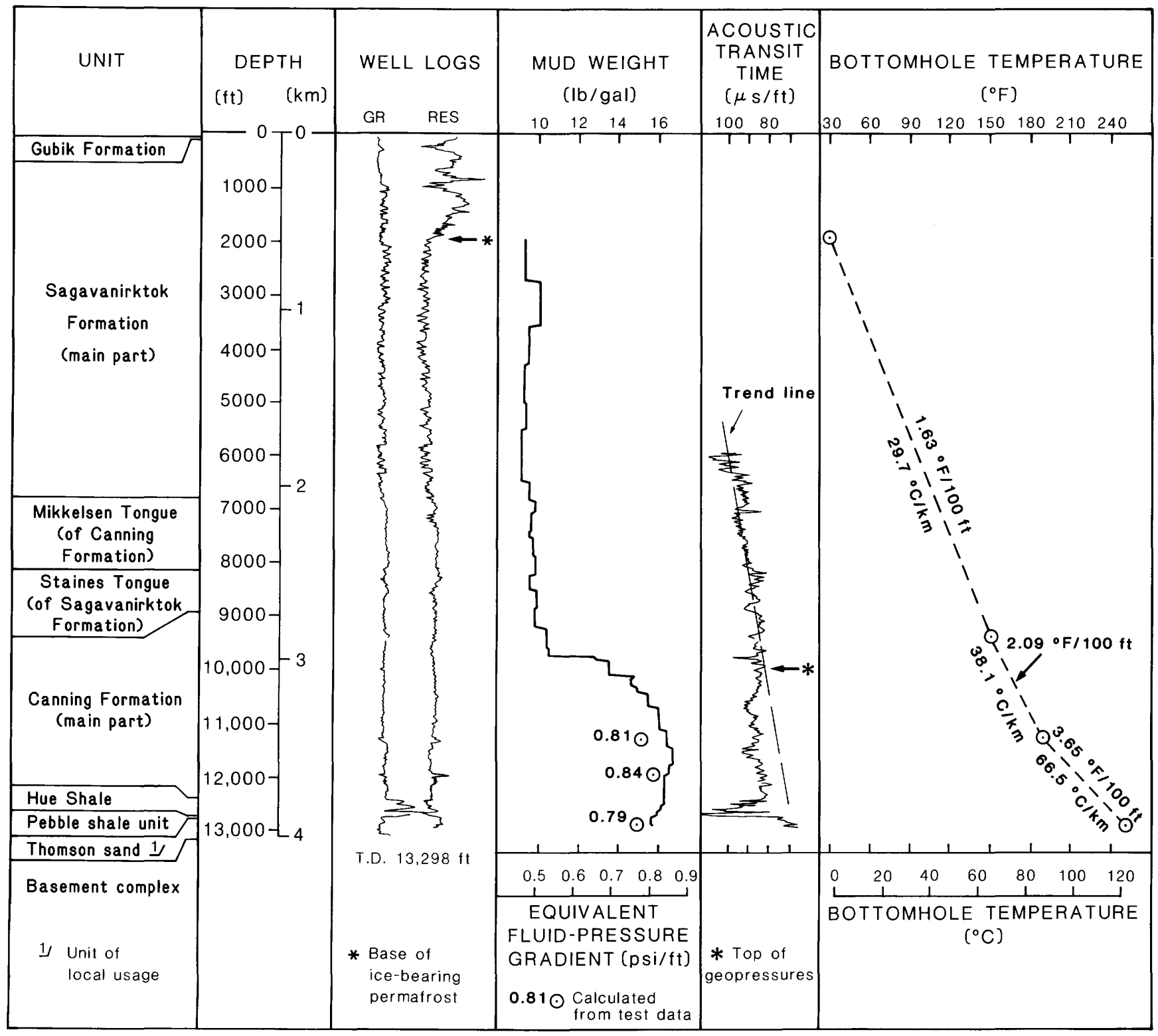

Figure 13.1. Gamma-ray (GR) and resistivity (RES) logs, mud weights used during drilling, acoustic transit time, and corrected bottomhole temperatures of Point Thomson Unit-1 well. T.D., total depth. 
pre-Mississippian basement complex, where they are 124 ${ }^{\circ} \mathrm{C}\left(255^{\circ} \mathrm{F}\right)$ and $105^{\circ} \mathrm{C}\left(221^{\circ} \mathrm{F}\right)$, respectively.

\section{ANALYSIS}

Samples were collected from cuttings of the Point Thomson Unit-1 and Unit-2 wells at the Alaska State well sample facility at Eagle River, Alaska. Shales were selected to encompass normally pressured rock, the transition zone, and the zone of abnormally high pressures. Formation pressures were inferred from mud weights used in drilling and from drill-stem test data. Samples were integrated over approximately $15-\mathrm{m}(50 \mathrm{ft})$ intervals to insure homogeneity. These intervals are listed in table 13.3.

Samples were hand-picked, washed, split, and analyzed by LECO combustion, Rock Eval pyrolysis, and X-ray powder diffraction. Whole-rock X-ray powder diffraction analysis was used to determine general mineralogical composition in preparation for further analysis. Selected samples were disaggregated and the $<2-\mu \mathrm{m}$ and $<0.5-\mu \mathrm{m}$ fractions were separated by means of centrifugation. Oriented clay slides were prepared from each of these fractions and analyzed after airdrying, saturation with ethylene glycol vapor, and heating to 300 ${ }^{\circ} \mathrm{C}\left(542^{\circ} \mathrm{F}\right)$ and to $550^{\circ} \mathrm{C}\left(992^{\circ} \mathrm{F}\right)$. Relative abundances

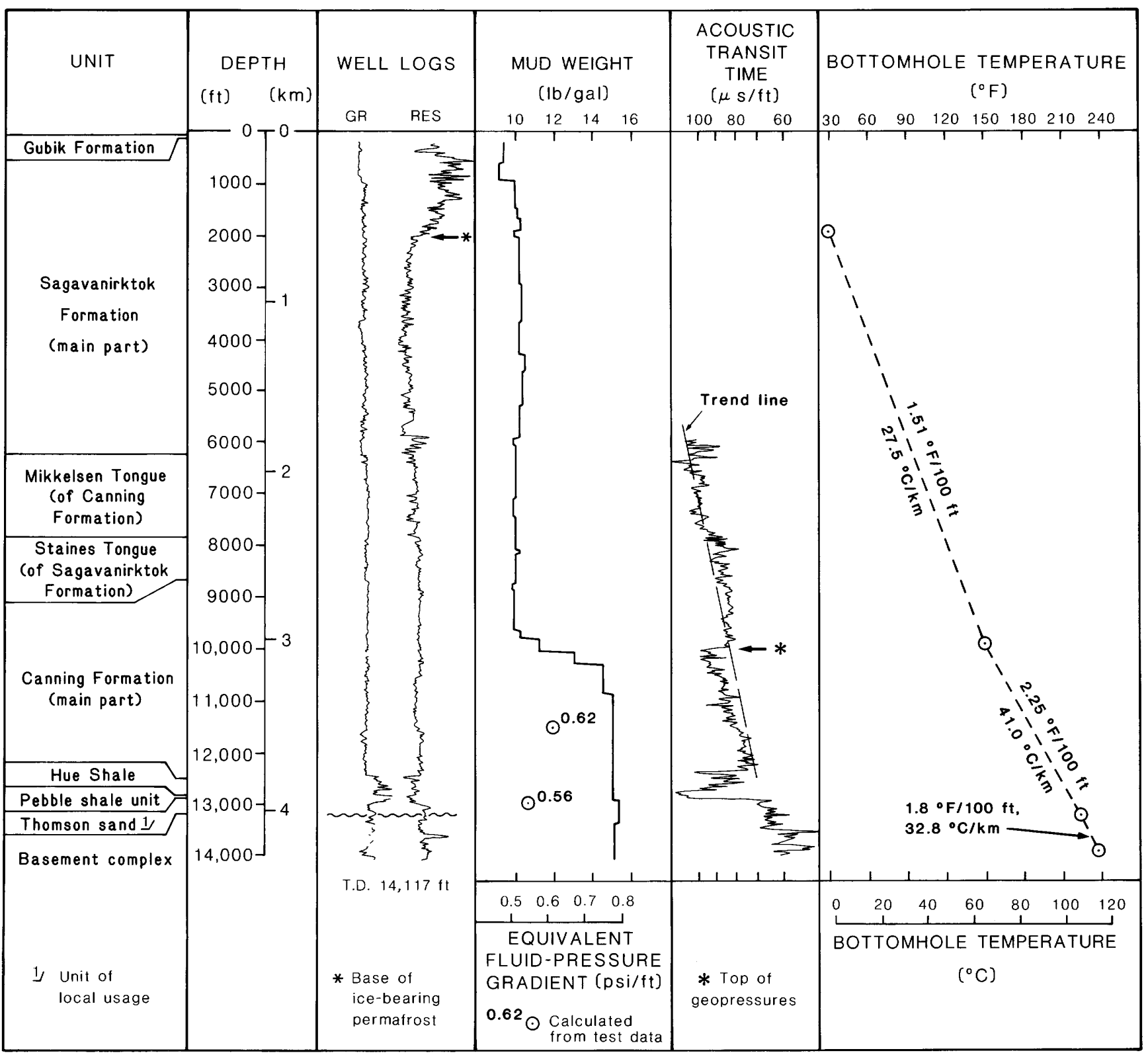

Figure 13.2. Gamma-ray (GR) and resistivity (RES) logs, mud weights used during drilling, acoustic transit time, and corrected bottomhole temperatures of Point Thomson Unit-2 well. T.D., total depth. 
Table 13.1 Subsurface fluid pressures measured during formation tests in two wells in the Point Thomson area

[Maximum pressures are those reported during either initial or final shut-in period]

\begin{tabular}{|c|c|c|c|}
\hline \multicolumn{2}{|c|}{ Depth of pressure gauge } & & \multirow{2}{*}{$\begin{array}{l}\text { Pressure } \\
\text { gradient }\end{array}$} \\
\hline $\begin{array}{l}\text { From kelly } \\
\text { bushing } \\
\text { (ft) }\end{array}$ & $\begin{array}{c}\text { Below ground } \\
\text { surface } \\
\text { (ft) }\end{array}$ & pressure & \\
\hline \multicolumn{4}{|c|}{ Point Thomson Unit-1 } \\
\hline 11,338 & 11,316 & 9,203 & 0.81 \\
\hline 12,007 & 11,985 & 10,118 & .84 \\
\hline 12,937 & 12,915 & 10,160 (est) & .79 \\
\hline \multicolumn{4}{|c|}{ Point Thomson Unit-2 } \\
\hline${ }^{1} 11,580$ & 11,555 & 7,122 & ${ }^{2} 0.62$ \\
\hline 13,020 & 12,995 & 7,234 & .56 \\
\hline
\end{tabular}

${ }^{1}$ Depth of pressure gauge not reported; figure given is upper depth of interval tested.

${ }^{2}$ Value is approximate (and probably a minimum) because depth of pressure gauge was not reported. of clay minerals in the $<2-\mu \mathrm{m}$ fraction were estimated from peak heights and by the methods of Schultz (1964, 1984). Results are listed in table 13.4.

\section{RESULTS}

\section{Organic-Matter Content}

The samples analyzed in this study all contain more than 1.2 weight percent organic carbon (OC). This value is well in excess of the value of 0.5 weight percent OC suggested as being the minimum amount for a potential petroleum source rock (Dow, 1977). The maximum amount of OC in these samples is approximately 2.4 weight percent, with many samples containing in excess of 1.5 weight percent OC. The samples thus contain enough carbon to have served as petroleum source rocks. This finding is supported by the Rock Eval pyrolytic data, which show that some of the samples have hydrocarbon yields in excess of 4,000 ppm. All samples yielded hydrocarbons in excess of $1,500 \mathrm{ppm}$.

The hydrogen index (HI), expressed as milligrams of pyrolytic hydrocarbons per gram of organic carbon ( $\mathrm{mg} \mathrm{S} / \mathrm{g} \mathrm{OC}$ ), is used as an indicator of organic-matter type. Generally, HI values in excess of 400 to 600 are indicative of type II organic matter, whereas $\mathrm{HI}$ values of less than about 100 indicate type III organic matter (Espitalie and others, 1977a). Samples analyzed in this study have $\mathrm{HI}$ values ranging from 31 to

Table 13.2 Subsurface temperatures for two wells in the Point Thomson area

[Data corrected by Horner plot principle as modified by Dowdle and Cobb (1975); estimated thermometer depth after Blanchard and Tailleur (1982); DIL*, Dual Induction-Laterolog; FDC*, Formation Density Log; BHC*, Borehole Compensated Sonic Log; CNL*, Compensated Neutron Log; *, Mark of Schlumberger]

\begin{tabular}{|c|c|c|c|c|c|c|}
\hline \multirow{2}{*}{$\begin{array}{l}\text { Well } \\
\log \end{array}$} & \multirow{2}{*}{$\begin{array}{c}\text { Total } \\
\text { depth } \\
(\mathrm{ft}) \\
\end{array}$} & \multirow{2}{*}{$\begin{array}{c}\text { Thermometer } \\
\text { depth } \\
(\mathrm{ft})\end{array}$} & \multicolumn{2}{|c|}{ Time } & \multicolumn{2}{|c|}{ Temperature } \\
\hline & & & $\begin{array}{l}\text { After circulation } \\
\text { stopped } \\
\text { (h) }\end{array}$ & $\begin{array}{c}\text { Circulation at } \\
\text { thermometer depth } \\
\text { (h) }\end{array}$ & $\begin{array}{l}\text { Observed } \\
{ }^{\circ} \mathrm{C}\left({ }^{\circ} \mathrm{F}\right)\end{array}$ & $\begin{array}{l}\text { Corrected } \\
{ }^{\circ} \mathrm{C}\left({ }^{\circ} \mathrm{F}\right) \\
\end{array}$ \\
\hline \multicolumn{7}{|c|}{ Point Thomson Unit-1 } \\
\hline DIL* & 9,533 & 9,483 & 6 & 4 & $53(126)$ & $67(157)$ \\
\hline FDC* & 9,533 & 9,483 & 10 & 4 & $58(135)$ & $67(157)$ \\
\hline BHC* & 11,399 & 11,349 & 10 & 10 & $78(171)$ & 89 (191) \\
\hline FDC* & 11,399 & 11,349 & 14.75 & 10 & $81(176)$ & 89 (191) \\
\hline DIL* & 13,069 & 13,019 & 10 & 7 & $99(210)$ & $123(252)$ \\
\hline BHC* & 13,069 & 13,019 & 14 & 7 & $105(220)$ & $123(252)$ \\
\hline \multicolumn{7}{|c|}{ Point Thomson Unit-2 } \\
\hline DIL* & 10,102 & 10,052 & 10 & 8 & $59(137)$ & $67(152)$ \\
\hline FDC* & 10,102 & 10,052 & 16.5 & 8 & $62(142)$ & $67(152)$ \\
\hline BHC* & 13,396 & 13,346 & 11 & 14 & $96(204)$ & $109(226)$ \\
\hline FDC* & 13,396 & 13,346 & 17 & 14 & $99(210)$ & $109(226)$ \\
\hline DIL* & 14,117 & 14,067 & 12 & 13 & $105(219)$ & $116(239)$ \\
\hline CNL* & 14,117 & 14,067 & 21 & 13 & $109(226)$ & $116(239)$ \\
\hline
\end{tabular}


222 , which suggests that they contain a mixture of type II and type III organic matter. Samples with HI values of 31 to 100 clearly contain only type III organic matter. In general, samples from the Point Thomson Unit- 2 well have a greater abundance of type II organic matter than do samples from the Point Thomson Unit-1 well. These findings are consistent with observations of visual kerogen that indicate the presence of woody material throughout the Point Thomson Unit-1 well (data available from the AOGCC public well files in Anchorage, Alaska).

\section{Thermal Maturity}

Espitalie and others (1977a) have shown that the temperature at which maximum pyrolytic yield $\left(\mathrm{T}_{\max }\right)$ of hydrocarbons occurs in the laboratory during the Rock

Table 13.3. Analyses performed on samples from two wells in the Point Thomson area

[OC, total organic carbon; Rock Eval, Rock Eval pyrolysis; XRD, X-ray diffraction of whole rock for bulk composition and of two size fractions for clay mineralogy; $x$, analysis performed; -, not analyzed]

\begin{tabular}{|c|c|c|c|c|c|}
\hline \multirow{3}{*}{$\begin{array}{c}\text { Depth } \\
\text { interval } \\
\text { (ft) }\end{array}$} & \multirow{3}{*}{ OC } & \multirow{3}{*}{ Rock Eval } & \multicolumn{3}{|c|}{ XRD } \\
\hline & & & \multirow[t]{2}{*}{ Whole rock } & \multicolumn{2}{|c|}{ Clay mineralogy } \\
\hline & & & & $<2-\mu \mathrm{m}$ & $<0.5-\mu \mathrm{m}$ \\
\hline \multicolumn{6}{|c|}{ Point Thomson Unit-1 } \\
\hline $9000-9050$ & $\mathbf{x}$ & $\mathbf{x}$ & $\mathbf{x}$ & $\mathbf{x}$ & $\mathbf{x}$ \\
\hline $9400-9450$ & $\mathbf{x}$ & $\mathrm{x}$ & $\mathbf{x}$ & $\mathbf{x}$ & $\mathbf{x}$ \\
\hline $9750-9790$ & $\mathbf{x}$ & $\mathbf{x}$ & $\mathbf{x}$ & $\mathbf{x}$ & $\mathrm{x}$ \\
\hline $10,200-10,250$ & $\mathbf{x}$ & $\mathbf{x}$ & $\mathbf{x}$ & $\mathbf{x}$ & $\mathbf{x}$ \\
\hline $10,550-10,600$ & $\mathbf{x}$ & $\mathbf{x}$ & $\mathbf{x}$ & $\mathbf{x}$ & $\mathbf{x}$ \\
\hline $10,950-10,980$ & $\mathbf{x}$ & $\mathbf{x}$ & $\mathbf{x}$ & - & - \\
\hline $11,300-11,333$ & $\mathbf{x}$ & $\mathbf{x}$ & $\mathbf{x}$ & $\mathbf{x}$ & $\mathbf{x}$ \\
\hline $11,600-11,640$ & $\mathbf{x}$ & $\mathbf{x}$ & $\mathbf{x}$ & - & - \\
\hline $11,900-11,950$ & $\mathbf{x}$ & $\mathbf{x}$ & $\mathbf{x}$ & - & - \\
\hline \multicolumn{6}{|c|}{ Point Thomson Unit-2 } \\
\hline $9,000-9,030$ & $\mathbf{x}$ & $\mathbf{x}$ & $\mathbf{x}$ & $\mathbf{x}$ & $\mathbf{x}$ \\
\hline $9,300-9,400$ & $\mathbf{x}$ & $\mathbf{x}$ & $\mathbf{x}$ & - & - \\
\hline $9,600-9,700$ & $\mathbf{x}$ & $\mathrm{x}$ & $\mathbf{x}$ & - & - \\
\hline $9,900-9,960$ & $\mathbf{x}$ & $\mathbf{x}$ & $\mathbf{x}$ & $\mathbf{x}$ & $\mathbf{x}$ \\
\hline $10,200-10,260$ & $\mathbf{x}$ & $\mathbf{x}$ & $\mathbf{x}$ & $x$ & $\mathbf{x}$ \\
\hline $10,900-10,950$ & $\mathbf{x}$ & $\mathrm{x}$ & $\mathrm{x}$ & $\mathbf{x}$ & $\mathbf{x}$ \\
\hline $11,310-11,370$ & $\mathbf{x}$ & $\mathbf{x}$ & $\mathrm{x}$ & - & - \\
\hline $11,650-11,700$ & $x$ & $x$ & $x$ & $x$ & $x$ \\
\hline $12,110-12,140$ & $\mathbf{x}$ & $\mathbf{x}$ & $\mathbf{x}$ & - & - \\
\hline $12,500-12,540$ & $\mathbf{x}$ & $\mathbf{x}$ & $\mathbf{x}$ & - & - \\
\hline $12,700-12,750$ & $\mathbf{x}$ & $\mathrm{x}$ & $\mathbf{x}$ & $x$ & $\mathrm{x}$ \\
\hline
\end{tabular}

Eval analysis is dependent largely upon the level of thermal maturity of the organic matter being analyzed. They suggest that $\mathrm{T}_{\max }$ temperatures in the range of 435 ${ }^{\circ} \mathrm{C}\left(815^{\circ} \mathrm{F}\right)$ to $460^{\circ} \mathrm{C}\left(860^{\circ} \mathrm{F}\right)$ are observed in samples with thermal maturity levels that correspond to the principal zone of petroleum generation. The $T_{\max }$ temperatures from samples analyzed for this report are combined with $\mathrm{T}_{\max }$ data from the AOGCC public well file for purposes of illustration in figure 13.3.

Samples from both wells display general trends toward increasing $T_{\max }$ values with depth (fig. 13.3). Mean random vitrinite reflectance $\left(R_{0}\right)$ data from the AOGCC well file yield a definite trend of increasing $R_{0}$ with depth (fig. 13.3). Mean reflectance values equal to

Table 13.4. Abundance and ordering of clays from two wells in the Point Thomson area

[Determinations by the methods of Schultz $(1964,1978)$; K+C, kaolinite and chlorite; I, discrete illite; I/S, mixed-layer illite-smectite clay; R, degree of ordering in $I / S$; ordering (R) and percent $S$, from diffractograms of both $<2-\mu \mathrm{m}$ and $<0.5-\mu \mathrm{m}$ fractions; -, not determined]

\begin{tabular}{|c|c|c|c|c|c|}
\hline \multirow{2}{*}{$\begin{array}{c}\text { Depth } \\
\text { (ft) }\end{array}$} & \multicolumn{3}{|c|}{ Relative abundance } & \multirow[b]{2}{*}{$\mathbf{R}$} & \multirow{2}{*}{$\begin{array}{c}S \\
\text { in I/S } \\
\text { (pct) }\end{array}$} \\
\hline & $\begin{array}{l}K+C \\
\text { (pct) }\end{array}$ & $\begin{array}{c}\mathrm{I} \\
\text { (pct) }\end{array}$ & $\begin{array}{c}\text { I/S } \\
\text { (pct) }\end{array}$ & & \\
\hline \multicolumn{6}{|c|}{ Point Thomson Unit-1 } \\
\hline $9,000-9,050$ & 40.7 & 42.1 & 16.2 & 0 & $40-60$ \\
\hline $9,400-9,450$ & 40.1 & 38.9 & 21.0 & 0 & - \\
\hline $9,750-9,790$ & 36.1 & 33.6 & 30.3 & 0 & $50-60$ \\
\hline $10,200-10,250$ & 41.7 & 48.0 & 10.3 & 0 & $40-75$ \\
\hline $10,550-10,600$ & 43.1 & 45.5 & 11.4 & 0 & 50 \\
\hline $10,950-10,980$ & 42.6 & 53.1 & 4.3 & - & - \\
\hline $11,300-11,330$ & 42.7 & 49.1 & 8.2 & 0 & - \\
\hline $11,600-11,640$ & 37.0 & 56.0 & 7.0 & - & - \\
\hline $11,900-11,950$ & 33.1 & 47.4 & 29.5 & 1 & - \\
\hline \multicolumn{6}{|c|}{ Point Thomson Unit-2 } \\
\hline $9,000-9,030$ & 48.7 & 48.4 & 2.9 & 0 & - \\
\hline $9,300-9,400$ & 46.6 & 47.0 & 6.4 & 0 & - \\
\hline $9,600-9,700$ & 45.7 & 47.9 & 6.4 & 0 & - \\
\hline $9,900-9,960$ & 41.7 & 47.8 & 10.5 & 0 & 50 \\
\hline $10,200-10,260$ & 46.0 & 47.0 & 7.0 & 0 & 40 \\
\hline $10,500-10,560$ & 43.9 & 49.4 & 6.7 & 0 & 40 \\
\hline $10,900-10,950$ & 34.3 & 60.6 & 5.1 & 0 & $40-80$ \\
\hline $11,310-11,370$ & 35.3 & 55.3 & 9.4 & 0 & 40 \\
\hline $11,650-11,700$ & 43.9 & 48.8 & 16.3 & 1 & $<40$ \\
\hline $12,100-12,140$ & 31.6 & 57.0 & 11.4 & 1 & $<40$ \\
\hline $12,500-12,540$ & 20.7 & 45.7 & 33.6 & 0 & 90 \\
\hline $12,700-12,750$ & 26.4 & 58.9 & 14.7 & 1 & $<40$ \\
\hline
\end{tabular}


0.6 percent and greater, a range generally thought to correspond to the top of the oil-generation window, are observed below a depth of approximately $3,320 \mathrm{~m}$ $(10,900 \mathrm{ft})$ in the Point Thomson Unit-1 well. Rock Eval pyrolysis data generally support this trend, with most samples below $3,320 \mathrm{~m}(10,900 \mathrm{ft})$ having $T_{\max }$ values greater than $430{ }^{\circ} \mathrm{C}\left(806^{\circ} \mathrm{F}\right)$. Note, however, that the $\mathrm{R}_{\mathrm{o}}$ data indicate higher maturity than do the Rock Eval data obtained during this study (fig. 13.3).

Both wells show a significant increase in pore pressure in excess of normal hydrostatic pressure below a depth of approximately $3,000 \mathrm{~m} \mathrm{(10,000} \mathrm{ft)} \mathrm{(figs.} \mathrm{13.1,}$ 13.2). This transition to geopressures occurs somewhat

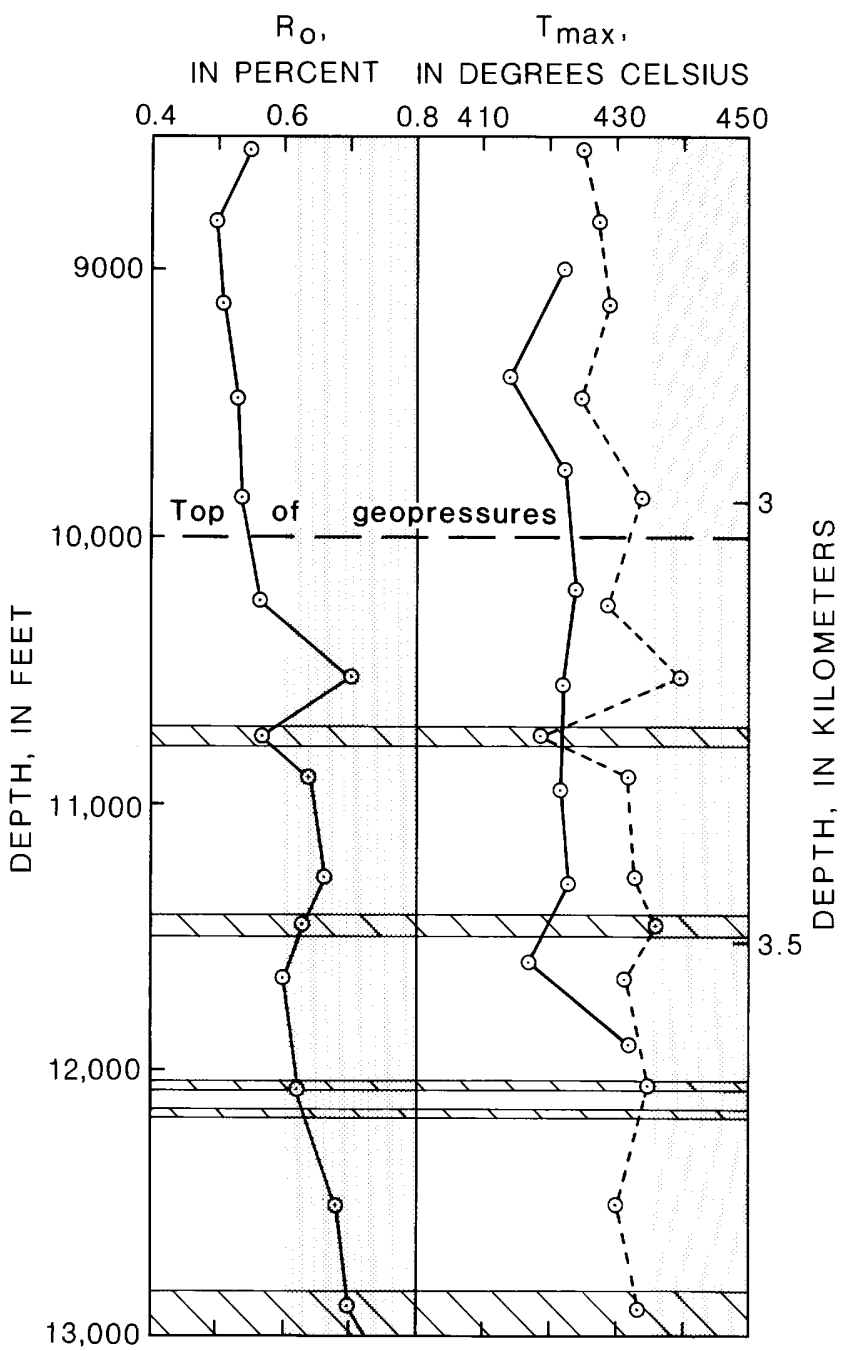

Figure 13.3. Vitrinite reflectance $\left(R_{o}\right)$ and temperature of maximum pyrolytic yield $\left(\mathrm{T}_{\max }\right)$ relative to top of geopressures in Point Thomson Unit-1 well. Solid curve, our analyses; dashed curve, analyses from Alaska Oil and Gas Conservation Commission well files. Cored intervals, indicated by crosshatching, are all oil stained. Shading indicates thermal maturity. above the depth of thermal maturity thought to represent the oil window $\left(\mathrm{R}_{\mathrm{o}}>0.6\right)$. However, uncertainties involved in relating vitrinite measurements to oil generation (see Bostick, 1979) suggest that the difference in depths may not be significant. Thus, the onset of oil generation and the transition to overpressuring could coincide. All cores from the Point Thomson Unit-1 well, which were collected below depths of about $3,260 \mathrm{~m}$ $(10,700 \mathrm{ft})$, display distinctive oil staining. These data permit the possibility that organic compounds have evolved from kerogen and are directly causing abnormally high pore-fluid pressures (see Meissner, 1978; Spencer, in press).

\section{Mineralogy}

$\mathrm{X}$-ray diffraction patterns for shales from the subject wells show that these rocks are primarily composed of quartz and feldspar (mainly plagioclase), with various amounts of phyllosilicates, calcite, siderite, pyrite, iron oxides (hematite and magnetite), mica (mainly discrete illite), and analcime. No distinctive trends are apparent in bulk mineralogy with depth in the intervals examined from either well. The 3,810- to $3,822-\mathrm{m}(12,500$ to $12,540 \mathrm{ft})$ sample of the Hue Shale from the Point Thomson Unit-2 well, however, contained a significant amount of analcime (fig. 13.4).

Analysis of the clay-size fractions $(<2 \mu \mathrm{m}$ and $<0.5 \mu \mathrm{m}$ ) indicates that discrete illite, $\mathrm{I} / \mathrm{S}$, chlorite, and kaolinite are present. Relative intensities of peaks suggest that the relative weight percent of $\mathrm{I} / \mathrm{S}$ in the $<2$ $\mu \mathrm{m}$ fraction of the Point Thomson Unit-2 samples increases with depth, whereas kaolin and chlorite decrease in both wells (fig. 13.5). Chlorite appears to be discrete, since the first-order reflection (14.4 $\AA$ ) does not shift upon glycolation (fig. 13.6).

Samples from both the Point Thomson Unit-1 and Unit-2 wells contain randomly interstratified $(\mathrm{R}=0)$ $\mathrm{I} / \mathrm{S}$ (fig. 13.6A-D). The first-order reflection for the chlorite peak shifts slightly to higher spacing upon glycolation, indicating either the presence of a swelling chlorite, or a mixed-layer chlorite/smectite. The $<0.5-\mu \mathrm{m}$ fraction of samples from both wells has the same mineralogy as the $<2-\mu \mathrm{m}$ fraction: $\mathrm{I} / \mathrm{S}$, discrete illite, chlorite, and kaolinite (fig. 13.6A-C).

The amount of smectite layers (S) in I/S was estimated in some $<0.5-\mu \mathrm{m}$ fractions by the methods of Reynolds and Hower (1970). The percentages of $S$ layers in I/S are listed in table 13.4 for those samples where estimates were possible. Samples from deeper than $3,353 \mathrm{~m}(11,000 \mathrm{ft})$ in both wells appear to contain $\mathrm{I} / \mathrm{S}$ with less $\mathrm{S}$ layers than do samples from above the $3,353-\mathrm{m}(11,000 \mathrm{ft})$ level. The $<0.5-\mu \mathrm{m}$ traces from the $3,627-$ to $3,642-\mathrm{m}(11,900$ to $11,950 \mathrm{ft})$ sample of the Point Thomson Unit-1 well and from the 3,551- to $3,566-\mathrm{m}(11,650$ to $11,700 \mathrm{ft}), 3,688-$ to $3,700-\mathrm{m}(12,100$ 
to $12,140 \mathrm{ft})$, and $3,871-$ to $3,886-\mathrm{m}(12,700$ to 12,750 $\mathrm{ft}$ ) samples of the Point Thomson Unit-2 well may contain short-range ordered $(R=1) \quad I / S$ as well as randomly interstratified $(R=0) I / S$. Ordering is suggested by first-order glycol peaks that are significantly less than $17 \AA$ thick (approx $14 \AA$ ) and by suggestions of superlattice reflections at very low $2 \theta$ angles.

However, the $3,810-$ to $3,822-\mathrm{m} \quad(12,500$ to $12,540 \mathrm{ft}$ ) sample from the Point Thomson Unit-2 well (fig. 13.6D) contains highly smectitic ( $>90$ percent S) I/S in the $<0.5-\mu \mathrm{m}$ fraction. This sample is mineralogically distinct in all X-ray diffractograms (figs. 13.4, 13.6D) and is interpreted to be an altered air-fall tuff bed. I/S in such beds is commonly regarded as a good indicator of temperature-related clay diagenesis (Pollastro and Martinez, 1985).

The transformation of smectite to illite and accompanying increases in crystal ordering with increas-

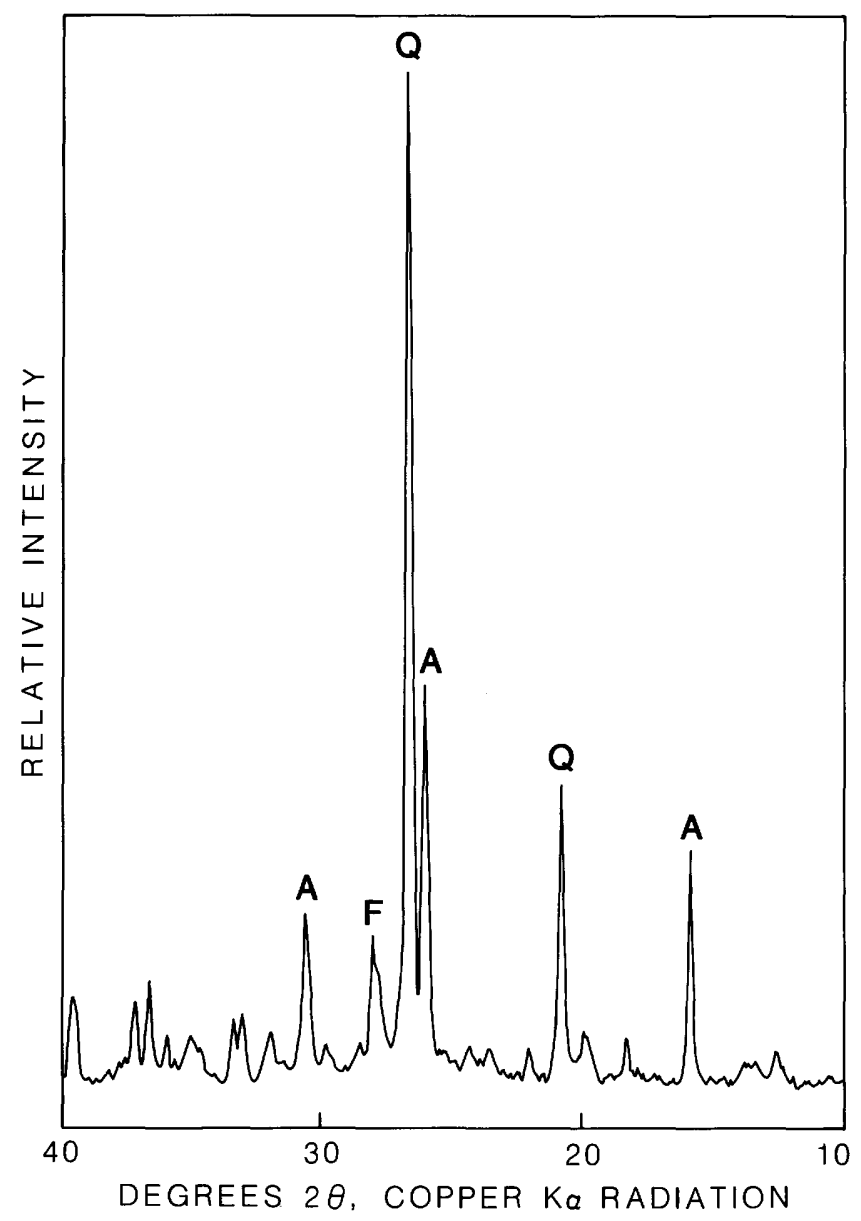

Figure 13.4. X-ray diffractogram of random powder whole-rock sample of tuff or tuffaceous shale from depth of 12,500 to $12,540 \mathrm{ft}$ in Point Thomson Unit-2 well. A, analcime; F, feldspar; $Q$, quartz. ing burial depth and temperature have been documented in sedimentary basins throughout the world (Foscolos and Kodama, 1974; Bruce, 1984; Pollastro, 1985). The coincidence of the smectite transformation with the onset of geopressures has also been documented (Kerr and Barrington, 1961; Freed, 1982; Pollastro, 1985). Expandability (smectite content) is considered by some to be a measure of the temperature to which rocks have been exposed (Hoffman and Hower, 1979; Pollastro and Barker, 1984), that is, the smectite component of mixedlayer illite/smectite is an indicator of the minimum temperature of reaction. Nadeau and Reynolds (1981) cautioned, however, that there is also a pore-fluid and clay compositional control on the smectite transformation.

The high smectite contents of shales at the top of the geopressure transition zone in the Point Thomson Unit-1 and Unit-2 wells and at the bottom of the Unit-2 well indicate both temperature and fluid composition controls on diagenesis in these sections. The presence of highly smectitic clays and analcime in volcanogenic material from the 3,810-m (12,500 ft) sample (fig. 13.4) from the Point Thomson Unit-2 well suggests that fluids with high $\mathrm{Na} / \mathrm{K}(160$; seawater $=27)$ or high $\mathrm{Ca} / \mathrm{K}$ ratios (Boles, 1977) may have inhibited illitization. The high smectite content and random interstratification of mixedlayer clays in shales above about $3,353 \mathrm{~m}(11,000 \mathrm{ft})$ and at the top of the geopressure zone suggest that the temperatures of these rocks have not exceeded $100{ }^{\circ} \mathrm{C}$ $\left(21{ }^{\circ} \mathrm{F}\right.$ ) (Hoffman and Hower, 1979). A decrease in smectite content with depth and a possible inset of ordering below the transition zone suggest slightly higher temperatures.

The apparent trend of decreasing smectite content with depth is similar to trends observed in the Gulf Coast region (for example, see Hower, 1981). The coincidence of the smectite decrease with the top of the geopressure zone is similar to trends observed in Texas (Freed, 1982) and Louisiana (Kerr and Barrington, 1961). However, randomly interstratified I/S may persist where there are high $\mathrm{Na}$ and (or) $\mathrm{Ca}$ concentrations to levels of relatively higher thermal maturity in the Point Thomson area.

\section{CONCLUSIONS}

Shales analyzed for this study are primarily terrigenous in their mineralogical and organic constituents. Like associated sandstones (chap. 9), the shales reflect a provenance in the complex tectonic terrane of the ancestral Brooks Range and a volcanogenic component of unknown provenance. General shifts in clay mineralogy with depth probably reflect changing provenance of the clay components. Changes in I/S ordering and composition may be diagenetic. The organic components of the Canning Formation display generally uniform composition 
throughout the sampled interval, with variations arising mainly from the increasing levels of thermal maturity that occur with depth. The Canning Formation displays a significant trend of increasing thermal maturity, as indicated by pyrolytic assay and vitrinite reflectance analysis, with the upper level of oil generation occurring at approximately $3,320 \mathrm{~m}(10,900 \mathrm{ft})$ in the Point Thomson Unit-1 (and Unit-2?) well. This increased thermal maturity is accompanied by oil staining in associated rocks. The depth at which significantly abnormal fluid pressures occur is about $3,000 \mathrm{~m}(10,000$ $\mathrm{ft}$ ), as indicated by acoustic logs and confirmed by mud weights used during drilling. The present-day temperature at $3,000 \mathrm{~m}(10,000 \mathrm{ft})$ is 66 to $73{ }^{\circ} \mathrm{C}(151$ to $163^{\circ} \mathrm{F}$ ). Although the depth to the top of geopressures and the top of the oil window could be in error by several hundred feet, there is a general coincidence of these parameters that suggests a genetic relationship between thermal maturity and geopressure development. A temperature-dependent trend of declining smectite layers in $\mathrm{I} / \mathrm{S}$ and increased ordering in $\mathrm{I} / \mathrm{S}$ from normally pressured shale to abnormally pressured shale is suggested but not proven by these data. However, randomly interstratified I/S persists to the so-called Lower Cretaceous unconformity deep within the geopressured section, suggesting that even at the base of the Cretaceous section, the shales have not yet been intensively heated. Present-day temperatures at the Lower Cretaceous unconformity, which range from 105 to $124{ }^{\circ} \mathrm{C}$ ( 221 to $256^{\circ} \mathrm{F}$ ) in the wells studied, may represent the maximum burial temperatures for these shales.

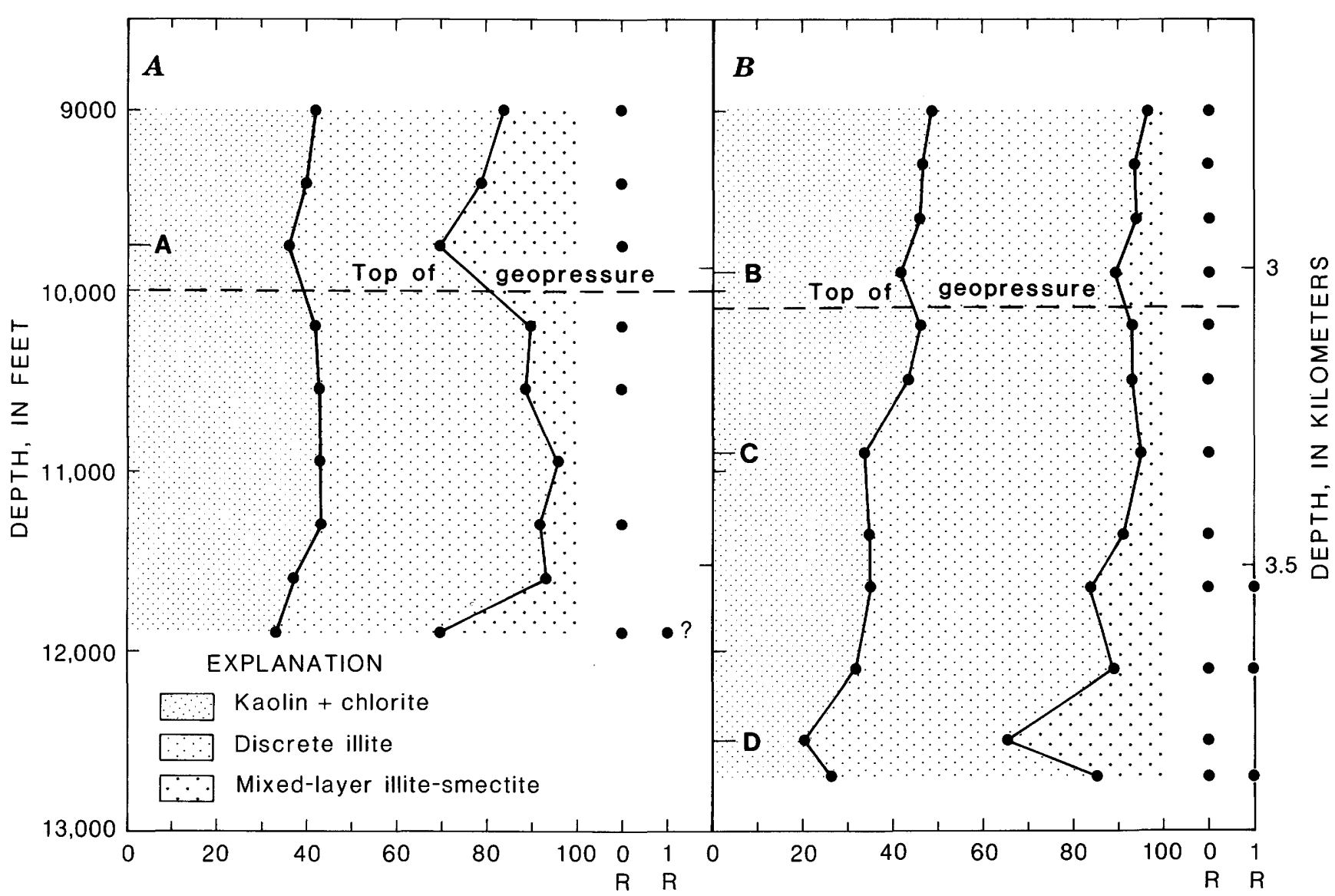

RELATIVE ABUNDANCE, IN WEIGHT PERCENT

Figure 13.5. Relative abundances of clay minerals in $<2-\mu \mathrm{m}$ fraction of samples from the Point Thomson Unit-1 $(A)$ and Unit-2 $(B)$ wells. Relative abundances were determined according to the methods of Schultz $(1964,1978)$ and are listed in table 13.4. Degree of ordering in mixed-layer illite-smectite is also shown. $R=0$ is random interstratification and $R=1$ is short ordering of illite and smectite layers. See figure 13.6 for X-ray diffractograms of samples A-D. 


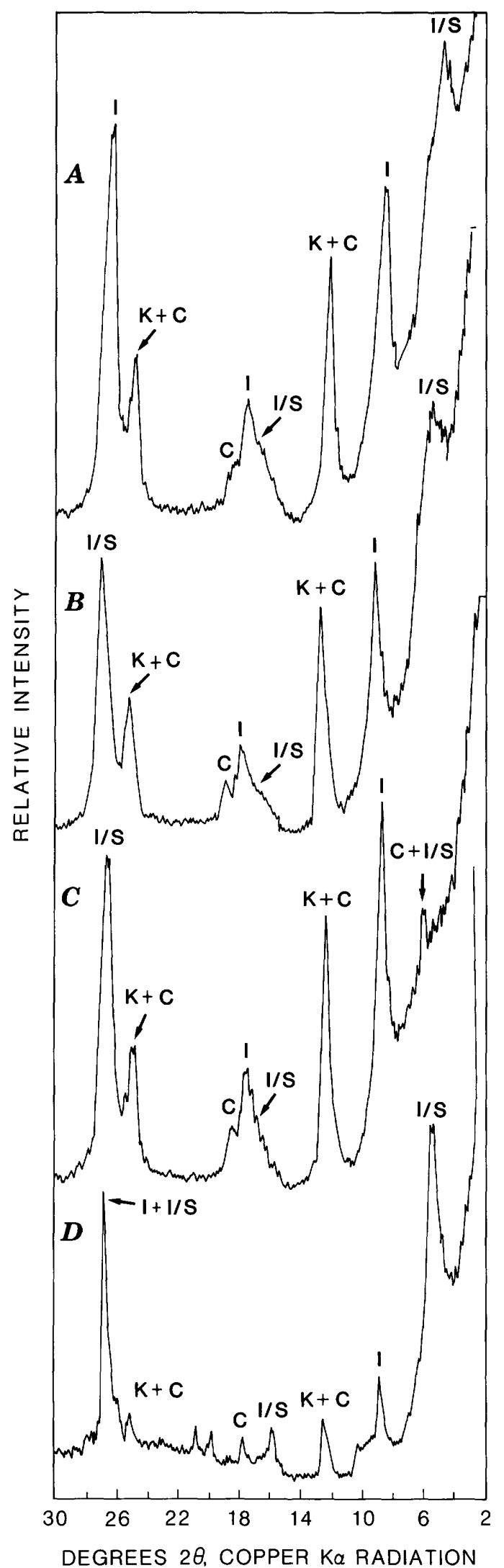

The results of this study, although preliminary, suggest that thermal maturation of organic matter sufficient for the onset of oil generation, mineralogical changes in $\mathrm{I} / \mathrm{S}$, and the development of overpressuring are coincident. Such coincidence suggests a genetic relationship and implies that overpressuring is to be expected in similar burial settings beneath the coastal plain of the ANWR. This, in turn, may provide some basis for optimism regarding porosity preservation in litharenite turbidites of the Canning Formation.
Figure 13.6. X-ray diffractograms of $<0.5-\mu \mathrm{m}$ fractions of selected shales from Point Thomson Unit-1 and Unit-2 wells and $<2-\mu \mathrm{m}$ fraction of one sample from Point Thomson Unit-2 well. All diffractograms are of oriented clay preparations after treatment with ethylene glycol vapor. I, discrete illite; $\mathrm{K}$, kaolinite; $\mathrm{C}$, chlorite; I/S, mixed-layer illite-smectite. $A$, Point Thomson Unit-1, 9,750- to $9,900-\mathrm{ft}$ depth, $<0.5 \mu \mathrm{m}$. B, Point Thomson Unit-2, 9,900- to 9,960-ft depth, $<0.5 \mu \mathrm{m}$. $C$, Point Thomson Unit-2, 10,900 - to $10,950-\mathrm{ft}$ depth, $<0.5 \mu \mathrm{m}$. $D$, Point Thomson Unit-2, 12,500 - to 12,540 - $\mathrm{ft}$ depth, $<2$ $\mu \mathrm{m}$. See figure 13.5 for locations of samples. 



\title{
Chapter 14.
}

\section{Horizontal-Gradient Magnetic and Helium Surveys}

\author{
By Kimberley I. Cunningham, ${ }^{1}$ Alan A. Roberts, ${ }^{2}$ and Terrence J. Donovan ${ }^{2}$
}

\section{INTRODUCTION}

Studies over part of the Arctic National Wildlife Refuge (ANWR) were conducted to detect and map near-surface manifestations of hydrocarbon microseepage. Vertical migration of these compounds through the sedimentary column initiates a complex chain of processes that involve pore-water chemistry, rock lithology, and microorganism interaction. Particularly significant are large changes in column eH and $\mathrm{pH}$ that affect the stability fields of minerals in this reducing environment. The mineralization and alteration processes commonly attributed to hydrocarbon microseepage include the precipitation of isotopically distinctive, pore-filling carbonate cement; the reduction, dissolution, and vertical redistribution of iron from ironbearing minerals; and the transformation of mineral phases by chemical reduction. While little fundamental research has been undertaken to elucidate the principal mechanisms and chemical pathways involved in hydrocarbon microseepage, existing data are combined with established principles in petroleum geology, geophysics, and geochemistry to support a qualitative model. This study integrates geophysical and geochemical data obtained over the ANWR coastal plain to support the existence of hydrocarbons in the subsurface.

\section{HORIZONTAL-GRADIENT MAGNETICS}

\section{Previous Work}

Earlier studies (Donovan and others, 1979, 1984; Reynolds and others, 1985) have suggested that nearsurface magnetic minerals may be formed in a reducing environment related to the presence of hydrocarbons and other petroleum-related compounds. The studies by Donovan and coworkers also demonstrated the feasibility of using low-level aeromagnetic surveys to detect magnetic minerals that occur at shallow depth $(<305 \mathrm{~m}$, $1,000 \mathrm{ft}$ ). A survey (fig. 14.1) was flown over the

\footnotetext{
${ }^{1}$ U.S. Geological Survey, Denver, Colo.

2 Comap Exploration Services, Inc., Lakewood, Colo.
}

ANWR coastal plain at an altitude of $91 \mathrm{~m}(300 \mathrm{ft})$ above mean ground level using a three-magnetometer airborne system (Donovan and others, 1984). Nearly simultaneous measurement of the Earth's magnetic field at three closely spaced positions within a horizontal plane allows the calculation of the magnitude of the horizontal gradient of the field, which is considered to be a sensitive indicator of the presence of near-surface magnetic minerals (Donovan and others, 1984) but is relatively insensitive to temporal variations in the magnetic field. Donovan and others (1984) have published a preliminary map of the horizontal magnetic gradient over the ANWR coastal plain. A magnetic tape of the raw data is available through the EROS data center in Sioux Falls, S. Dak.

\section{Source of the Magnetic Signal}

Thermodynamic arguments support the development of epigenetic magnetite $\left(\mathrm{Fe}^{2+} \mathrm{Fe}_{2}{ }^{3+} \mathrm{O}_{4}\right)$ through two different reaction mechanisms (Murray, 1979): (1) reduced iron in the sedimentary column may react with oxidized iron phases and water to produce magnetite via the reaction $\mathrm{Fe}^{2+}+\mathrm{Fe}_{2} \mathrm{O}_{3}+\mathrm{H}_{2} \mathrm{O}=\mathrm{Fe}_{3} \mathrm{O}_{4}$ $+2 \mathrm{H}^{+}$, and (2) reduced iron at depth may migrate upward in solution along a concentration gradient into the oxidizing zone, where the slow oxidation of $\mathrm{Fe}^{2+}$ eventually produces magnetite. While it is clear that magnetite is a stable phase under reducing conditions (Berner, 1971), it is not known if magnetite will be the dominant mineral causing detectable near-surface magnetic anomalies. Based on detailed petrographic and scanning electron microscope (SEM) analyses, Reynolds and others (1986) have determined that ferromagnetic griegite $\left(\mathrm{Fe}_{3} \mathrm{~S}_{4}\right)$ and pyrrhotite $\left(\mathrm{Fe}_{7} \mathrm{~S}_{8}\right)$ may be the actual sources of the surface signal in particular areas.

\section{Gradiometer System}

The airborne gradiometer system consists of a magnetometer mounted off each wingtip and a third sensor mounted in a tail stinger. The wingtip sensors produce considerably more variation in the magnetic 
signal than the one in the stinger. Because of the greater movement of the wingtip sensors relative to the airplane body, subtle variations in the horizontal magnetic gradient of the Earth's field may be obscured by noise, and in some instances false anomalies may be produced by unusual motions of the aircraft. Therefore, the gradient data in this report are calculated as the arithmetic difference between a given tail-stinger totalfield reading and a tail-stinger reading $2.2 \mathrm{~s}$ (approx 160 $\mathrm{m}, 520 \mathrm{ft}$ ) further along the flight path. The magnetic contrast between rocks having relatively low total magnetizations and those containing epigenetically derived magnetic minerals would result in highwavenumber total-field anomalies (Donovan and others, 1979), which are emphasized by this data treatment (Donovan and others, in press). Conversely, magnetic variations produced by deep subsurface magnetic materials are deemphasized. The horizontal-gradient values as calculated from measurements by the wingtip sensors were used both to identify periods within which variations in the tail-stinger data were caused by sources external to the Earth's magnetic field and to subsequently remove any such significant variations. The difference measurements are filtered and smoothed to produce an image (pl. 2) that shows locations and trends of nearsurface magnetic anomalies.

\section{Interpretation of the Magnetic Anomalies}

The most notable feature of the magnetic map is the trend of high values along and south of the Marsh
Creek structure, a northeasterly plunging asymmetrical anticline more than $49 \mathrm{~km}$ ( $30 \mathrm{mi}$ ) long and considered to be an obvious target for petroleum exploration on the coastal plain (Mull and Kososki, 1977; Grantz and Mull, 1978; Mast and others, 1980). A discussion of its stratigraphy can be found elsewhere in this bulletin (chap. 5). Regional deformation has involved at least Tertiary and younger sediments in the Marsh Creek area, and subsequent erosion has exposed Eocene and younger rocks.

A generalized map of the major thrust faults, synclines, and anticlines (chap. 19) identified in the Brookian sequence (Lower Cretaceous and younger rocks) from seismic-reflection data is superimposed on the map of the magnetic data (pl. 2). The major magnetic anomalies that are clearly greater than background noise $(>0.073 \mathrm{gamma} / \mathrm{ft})$ correspond closely with seismically identified faults within the Brookian sequence in the Marsh Creek anticline area. One theory to explain this observation is that these faults were more permeable to fluid migration than were surrounding unfaulted rocks. If ascending fluids had contained significant concentrations of hydrocarbons, and if sufficient quantities of iron were present in these rocks, then formation of magnetic minerals along the trace of the faults would produce this correspondence. Accordingly, the aeromagnetic data suggest that petroleum source rocks may exist in the subsurface in the Marsh Creek area and that hydrocarbons may have migrated to the near-surface or surface along these fault pathways. These data do not necessarily imply that

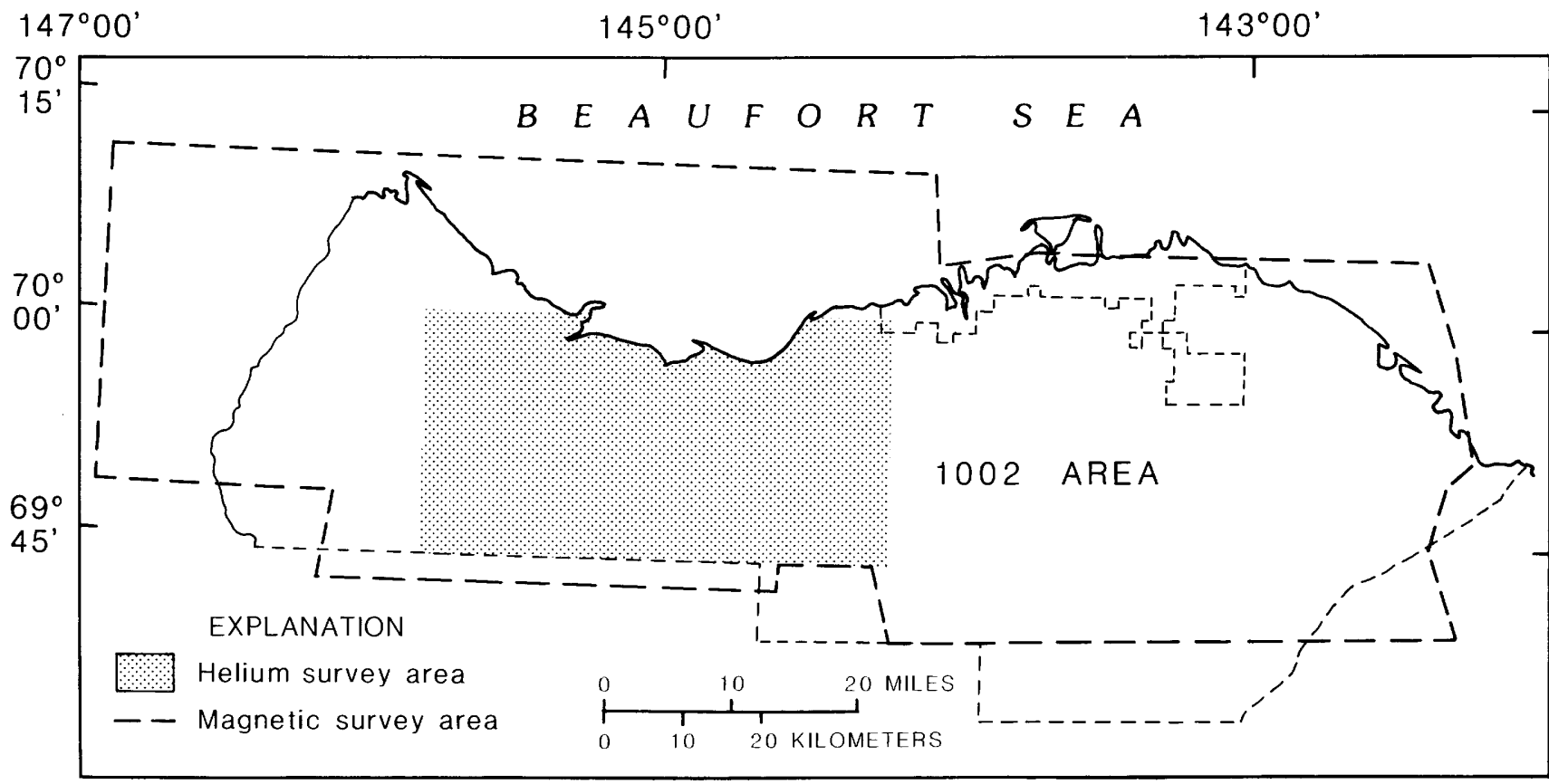

Figure 14.1. Index map showing areas of helium and magnetic surveys in 1002 area. 
hydrocarbons have accumulated, but they do suggest that hydrocarbons have been generated.

Another area of magnetic anomalies occurs immediately southeast of Barter Island (pl. 2). In this area a correlation is also observed with the locations of major mapped faults to the north of the area (marked as "Complex faulting and deformation trends-highly generalized" in pl. 2). The large area farther to the south is characterized by numerous thrust faults and much deformation of strata. The marked absence of magnetic anomalies may be due to the lack of generation and subsequent migration of hydrocarbons or to a deficiency of iron within the rocks from which to generate reduced magnetic minerals. No magnetic anomalies are observed in the northwest part of the coastal plain between the Canning River and the Marsh Creek anticline, where the rocks are relatively undeformed and unfaulted.

Most of the significant near-surface magnetic anomalies observed within the coastal plain are consistent with a model in which hydrocarbons have been generated at depth and have subsequently migrated upsection. These fluids tended to migrate along Brookian faults and produced a near-surface geochemical and biochemical environment in which magnetic minerals formed. Within the coastal plain, these magnetic anomalies are useful in interpreting general structural trends and can be used as supporting evidence that depositional and thermal conditions were suitable for the generation and subsequent migration of hydrocarbons. Lack of such magnetic anomalies may indicate that (1) no hydrocarbons have been generated, or (2) if hydrocarbons were generated, they have not migrated to the near-surface, or (3) quantities of iron in the rocks were insufficient to form magnetic minerals.

\section{HELIUM SURVEYS}

A helium survey was conducted in the area of the most intense magnetic anomalies associated with the Marsh Creek structure (figs. 14.1, 14.2). Helium has been shown to be an indicator for several different types of energy resources: petroleum and natural gas (Debnam, 1969; Ball and Snowdon, 1973; Roberts and others, 1976; Palacas and Roberts, 1980; Pogorski and Quirt, 1981; Roberts, 1981), geothermal reservoirs (Mazor, 1974; Roberts, 1975; Roberts and others, 1975; Hinkle, 1980), and uranium and thorium deposits (Clarke and Kugler, 1973; Dyck, 1976; Clarke and others, 1977; Reimer and Adkisson, 1977; Torgerson and Clarke, 1978). Helium has also proven to be effective in delineating faults and fracture zones (Ovchinnikov and others, 1972; Eremeev and others, 1973; Dikun and others, 1976; Jones and Drozd, 1983; Roberts and Roen, 1985).

\section{Technique}

The helium survey area (figs. 14.1, 14.2) is roughly rectangular in shape and covers approximately $1,820 \mathrm{~km}^{2}\left(700 \mathrm{mi}^{2}\right)$ south of Camden Bay centered over the Marsh Creek structure. Permafrost samples were collected on $1.62-\mathrm{km}(1 \mathrm{mi})$ centers that generally corresponded to section corners. The samples were obtained utilizing a helicopter-mounted, lightweight, permafrost-coring power auger and were hermetically sealed in aluminum containers. All samples were taken at a depth of $0.8 \mathrm{~m}(2.6 \mathrm{ft})$, which consistently penetrated permanently frozen soil. A total of 699 permafrost samples were collected for headspace analysis of the helium content, with a practical detection limit of 10 parts per billion (ppb) by volume (Pogorski and Quirt, 1981); these values were then used to back-calculate the helium concentration in the original sample. Air temperature, barometric pressure, sample depth, melt depth overlying the frozen sample, sediment description, and time of day were recorded at each locality. Samples of the permafrost in this area yielded a mixture of ice, silts, clays, sands, coarse pebbles, and peat. Subsequent to laboratory analyses, statistical correlations were performed to determine if the reported helium concentrations were dependent on weight/volume characteristics of the sample. Three methods of reporting helium concentrations are (1) the helium content relative to the total volume of ice (water) in the sample $\left(\mathrm{cm}^{3} \mathrm{He} / \mathrm{cm}^{3} \mathrm{H}_{2} \mathrm{O}\right)$, (2) the helium content relative to the total weight of wet sediment $\left(\mathrm{cm}^{3} \mathrm{He} / \mathrm{g}\right.$ wet sediment), and (3) the helium content relative to the total volume of soil, water, and pore space $\left(\mathrm{cm}^{3} \mathrm{He} / \mathrm{cm}^{3}\right.$ wet sediment). The reported helium concentrations were then regressed against the volume of water, the wet sediment weight, and the total sample volume. The three regression analyses returned nonsignificant correlations, which indicated that fluctuations in the reported helium concentrations were not due to variations in these three quantities. Additional support for this conclusion was obtained by comparing the helium concentration anomaly maps as calculated by each of the above methods. All three yielded the same surface anomaly trends, which indicated that the high helium areas are not an artifact of the calculation method but rather are an indication of strong subsurface helium sources.

All analytical results for this study are therefore reported as the volume of helium per unit volume of water, or equivalently as nanoliters of gas/liter of water, that is, nanoliters per liter ( $\mathrm{nL} / \mathrm{L}$; method 1). A background level for this survey was calculated from statistical procedures and found to be approximately 400 $\mathrm{nL} / \mathrm{L}$ (app. 14.1). The calculated helium values in permafrost ice greater than this background level indicate areas over the anticline where helium migration is occurring. 


\section{Uncorrected Helium Concentration Surface}

The contoured surface of helium concentrations in permafrost ice (fig. 14.3) represents a complex function of the amount of helium being contributed from various subsurface and atmospheric sources. Possible subsurface sources of helium include the following: (1) subsurface structural or stratigraphic traps, with or without petroleum, (2) radioactive, organic-carbon-rich shale packages, (3) faults or permeable fracture zones acting as concentrating pathways, (4) near-surface uranium/thorium deposits, and (5) geothermal circulation systems. In order to determine how much of this observed surface signal is related solely to microseepage from petroleum or natural-gas accumulations, all other sources must be normalized, discounted, or removed.

The ANWR coastal plain helium survey was designed to delineate broad anomalous microseepage features commonly associated with oil and gas accumulations. The survey sample density of one sample per $1.62 \mathrm{~km}^{2}\left(1 \mathrm{mi}^{2}\right)$ has been shown to be adequate for determining the gencral trend of anomalous helium soil gas concentrations (Roberts, 1981), but it is inadequate for showing fault and fracture systems for which closer sample spacing (3-67 $\mathrm{m}, 10-200 \mathrm{ft}$ ) is required (Roberts and Roen, 1985). However, samples may occur randomly on faults, given the large sample population over the study area and the high density of faults indicated by seismic data. Minor changes in the local soil microenvironment may also reduce either high or low values, which indicates that single-point highs or lows should be interpreted cautiously. For these reasons, helium surveying inherently requires a large sample population so that real anomalies can be distinguished from background, and so that spuriously high values not following the trend of nearest neighbors may be disregarded or further examined.

The map of the raw helium data (fig. 14.3) displays only those concentrations that are greater than 2.5 standard deviations above the $400 \mathrm{~nL} / \mathrm{L}$ background. This statistical level corresponds to approximately 800 $\mathrm{nL} / \mathrm{L}$. The values were contoured after appropriate digital projection and gridding procedures and indicate three broad classes of distribution: (1) a general helium low, at or near background, over the far eastern survey area; (2) a relative low (410 to $800 \mathrm{~nL} / \mathrm{L}$ ) over the axis and proximal flanks of the Marsh Creek anticline; and (3) a broad regional band of high values ( $>800 \mathrm{~nL} / \mathrm{L}$ ) that encircle the southwest (up-plunge) end of the Marsh Creek structure. This area is indicated by a heavy line which generally follows the $800-\mathrm{nL} / \mathrm{L}$ contour. Background levels of approximately $400 \mathrm{~nL} / \mathrm{L}$ are similar to those found in other surveys conducted on the western North Slope around Barrow and Cape Simpson (Roberts,

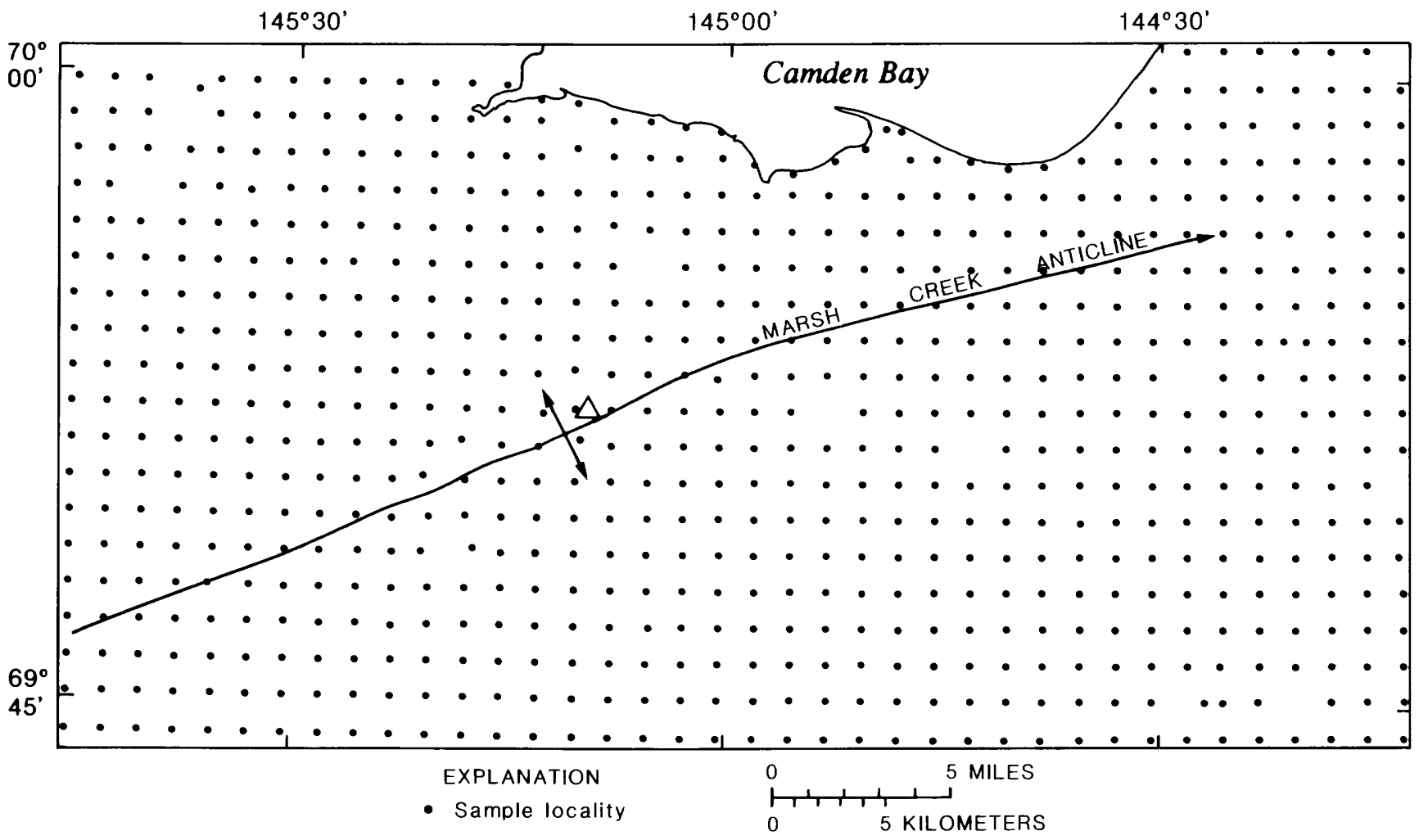

Figure 14.2. Sample localities for helium survey in the western 1002 area. Triangle represents oil-stained sandstone of the Canning Formation. 
1981). Helium anomalies observed over the ANWR coastal plain are of higher magnitude than those found in other North Slope surveys. Faults and zones of high fracture permeability can act as highly localized, preferential pathways for gas migrating to the surface. The raw helium data (fig. 14.3) were examined for highamplitude, single-point anomalies that characteristically identify probable fault locations. These anomalies have little or no agreement with adjoining sample values. Removal of these points and replacement by regionally calculated values does not effect the basic anomaly trends and results in a smoother concentration surface (fig. 14.4) from which a more reliable regional gradient can be abstracted.

\section{Regional Helium Gradient}

The regional helium gradient is the result of variation in the mean flux of helium to the Earth's surface derived collectively from all subsurface sources. Helium outgassing from the mantle and crystalline basement and helium production via radioactive decay in organic-carbon-rich sedimentary packages and via radioactive metals disseminated throughout the crust ultimately determine the magnitude of the regional gradient.

With the acquisition of seismic data in 1984 it was observed that the first-order trend of the faultcorrected helium surface (the regional gradient) correlated significantly with the trend of a pronounced seismic reflector beneath the helium survey area. Outcrop relationships on the north side of the Sadlerochit Mountains, where the sedimentary section is thrust over a basement high (chap. 20), confirmed this reflector as the Lower Cretaceous unconformity (LCU). It is not known whether Ellesmerian sequence rocks or preMississippian basement rocks underlie this regional unconformity in the helium survey area. Above the LCU is the pebble shale unit, an organic-carbon-rich shale averaging 61 to $91 \mathrm{~m} \mathrm{(200} \mathrm{to} 300 \mathrm{ft}$ ) in thickness deposited during Hauterivian to Barremian time (Early Cretaceous) on the northern flank of the Colville basin (chap. 5). Brookian sediments derived from a southem provenance conformably overlie this horizon. Above the pebble shale unit is the Hue Shale, a distal, condensed, organic-carbon-rich facies 61 to $305 \mathrm{~m} \mathrm{(200} \mathrm{to} 1,000 \mathrm{ft}$ ) in thickness. The basal 30 to $46 \mathrm{~m}(100$ to $150 \mathrm{ft})$ of this unit is referred to as the gamma-ray zone (GRZ) or the highly radioactive zone (HRZ) and is composed of

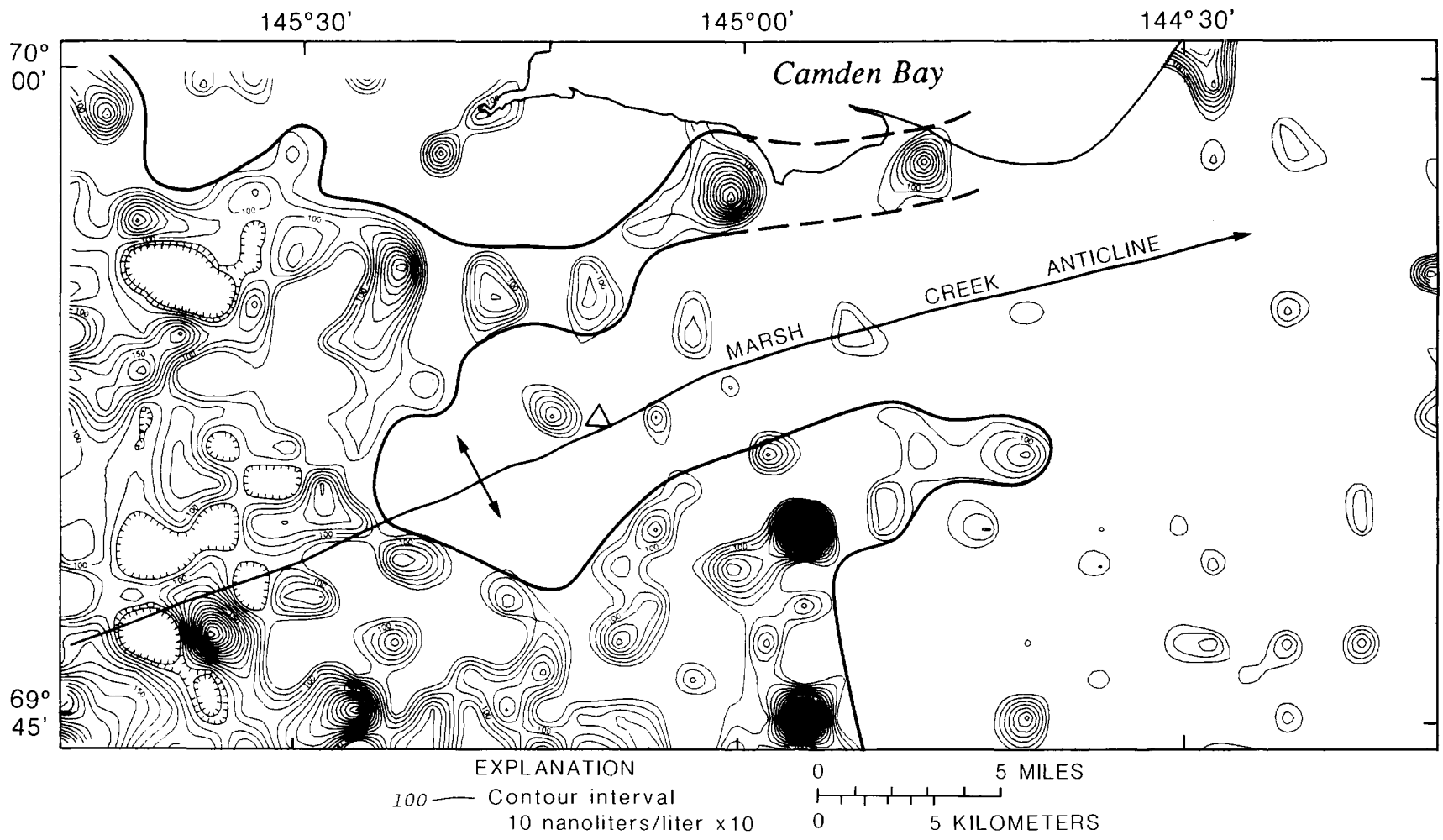

Figure 14.3. Contours of helium concentrations in permafrost greater than two standard deviations above background $(>800 \mathrm{~nL} / \mathrm{L}$ ) in the western 1002 area. Background, $400 \mathrm{~nL} / \mathrm{L}$. Heavy line indicates boundary of major helium anomalies; dashed where approximately located. Hachures indicate area of closed low. Triangle represents oil-stained sandstone of the Canning Formation. 
black, fissile, noncalcareous shale, with bentonite and tuff. Outcrop and well data depict the pebble shale unit and the GRZ as two discrete units throughout the North Slope (Molenaar and others, 1986).

Well logs from across the North Slope characterize the GRZ as a highly radioactive zone $(>100$ API units). Blanchard and Tailleur (1983) report about three times normal background concentrations of uranium and thorium in the GRZ in the Barrow area. Organic-carbon-rich shale packages are known to contain significant concentrations of uranium, thorium, and potassium where the $U, T h$, and daughters decay spontaneously through time to produce alpha particles that readily acquire two electrons to form the stable helium atom. The GRZ unit is a logical candidate to explain the high regional gradient observed in this area owing to its inherently high levels of radioactive emissions.

If the GRZ is coincident with the pronounced seismic reflector under the helium survey area and is a significant helium source, then regression tests between the measured surface helium concentration and the depth to the LCU should produce a significant correlation. Statistical correlation between the raw helium surface concentrations and seismic two-way reflection times to the LCU indicated that 5 percent of the variance in the helium data could be accounted for by proximity to the LCU at the 99.5 percent confidence level. Further treatment using the first-order trend (regional) of the same raw helium data indicated that nearly 35 percent of the variance was accounted for at the same confidence level, that is, one third of the variance in the regional helium data can be accounted for by proximity to this seismic horizon.

Since the thickness of the pebble shale unit and the GRZ are interpreted to be fairly constant and since the units are parallel or subparallel to the top of the basement throughout the area, a basement contribution must also be considered. However, the GRZ appears to be the predominant source of the regional helium gradient. A significant percentage of the regional gradient (fig. 14.5) appears to be a function of (1) the depth to these highly radioactive zones, or (2) the sediment stack thickness above the LCU.

\section{Helium Residuals After Subtraction of the Regional Gradient}

The residuals obtained from the subtraction of the regional gradient from the fault-corrected raw data

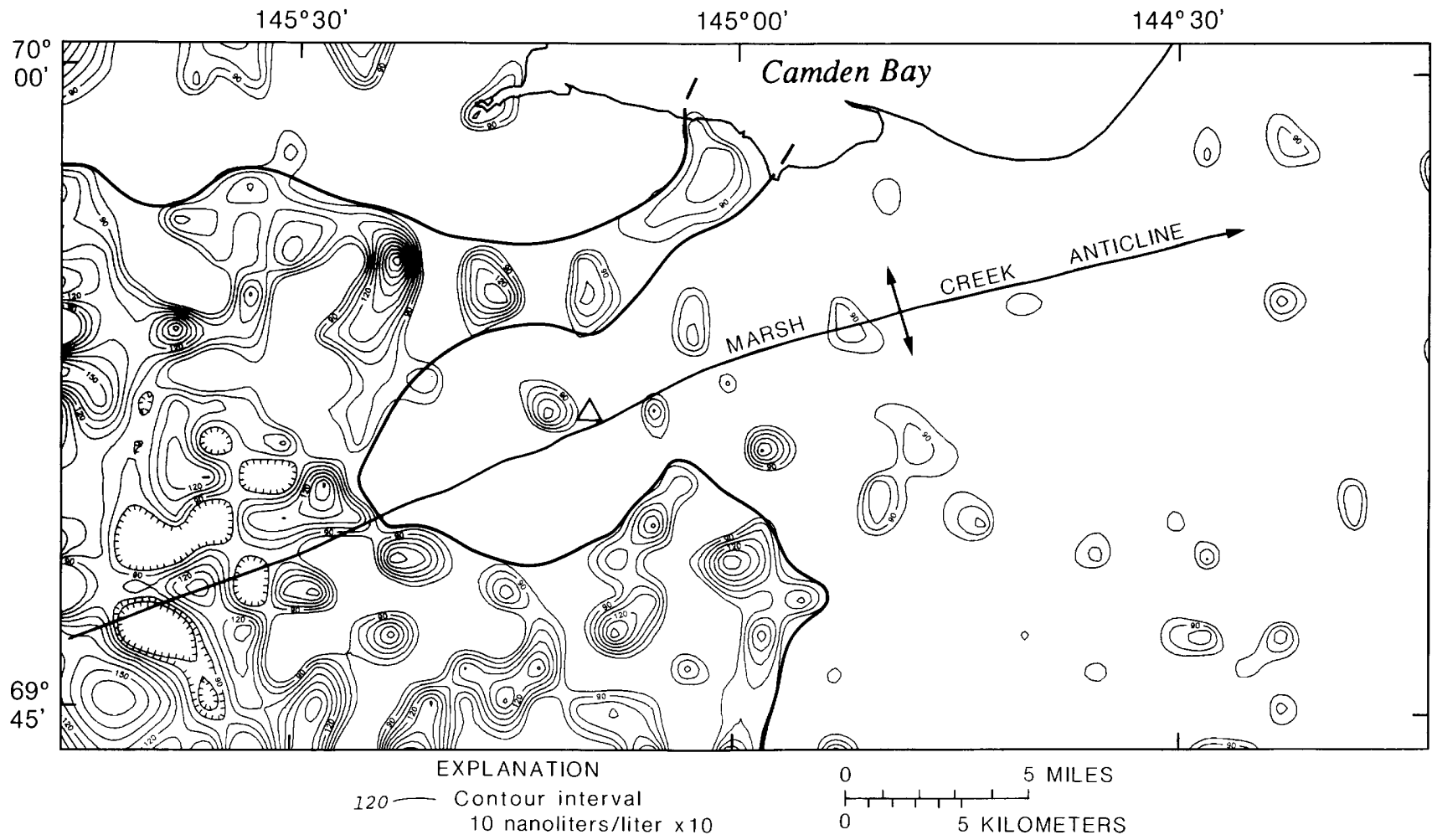

Figure 14.4. Contours of helium concentrations in permafrost in the western 1002 area from which possible fault anomalies were removed. Background, $400 \mathrm{~nL} / \mathrm{L}$. Heavy line indicates boundary of major helium anomalies; dashed where approximately located. Hachures indicate area of closed low. Triangle represents oil-stained sandstone of the Canning Formation. 
surface (fig. 14.6) are related to a subsurface flux that originates from local sources. Other deep-seated sources of helium, such as geothermal circulation systems that might carry waters high in helium into the survey area, can be discounted on the basis of current geologic knowledge of the study area. Several "thermal" springs $\left(4{ }^{\circ} \mathrm{C}, 40^{\circ} \mathrm{F}\right)$ have been documented on the east and west ends of the Sadlerochit Mountains (Bader and Bird, 1986), but there is no clear indication that these are circulation systems capable of significantly affecting the regional or residual helium patterns north of the range. Near-surface, local uranium/thorium deposits are also geologically uncharacteristic for this area. With the above sources of helium discounted, the residual anomalies are probably related to a combination of lithologic permeability, structure, or hydrocarbon accumulations. A helium anomaly has been documented over a structural trap that does not contain significant amounts of hydrocarbons (Roberts, 1981). This anomaly is related to structurally imposed controls on the helium as it passes upward through the sedimentary stack and encounters a barrier, which increases the residence time of the gas beneath the barrier. Ongoing vertical movement out of the trap will ultimately produce an apical anomaly. Helium emanometric techniques cannot determine the source of this particular anomaly.
However, if other near-surface manifestations of hydrocarbon microseepage can be documented in the area, such as (1) soil-color alteration zones, (2) light carbon-isotope, pore-filling carbonate cements, (3) anomalous levels of iron and manganese from mobilization in reducing ground waters, (4) epigenetic magnetic mineralization and accompanying highwavenumber, near-surface horizontal-gradient magnetic anomalies, or (5) thermal maturation anomalies such as elevated vitrinite reflectance values (Barker and Pawlewicz, 1986), then the helium anomaly is probably related to intrinsically high levels of helium in a hydrocarbon reservoir (Horvitz, 1969; Donovan and others, 1975; Dyck, 1976; Moore, 1976).

\section{OTHER INDICATIONS OF HYDROCARBON MICROSEEPAGE}

Oil staining is seen in fresh exposures of Canning Formation sandstones along the southern part of the Katakturuk River just south of the 1002 area and on the northern part of the Katakturuk River just north of the axis of the Marsh Creek anticline (Bader and Bird, 1986). The northern Katakturuk staining site is marked by an open triangle and appears immediately adjacent to

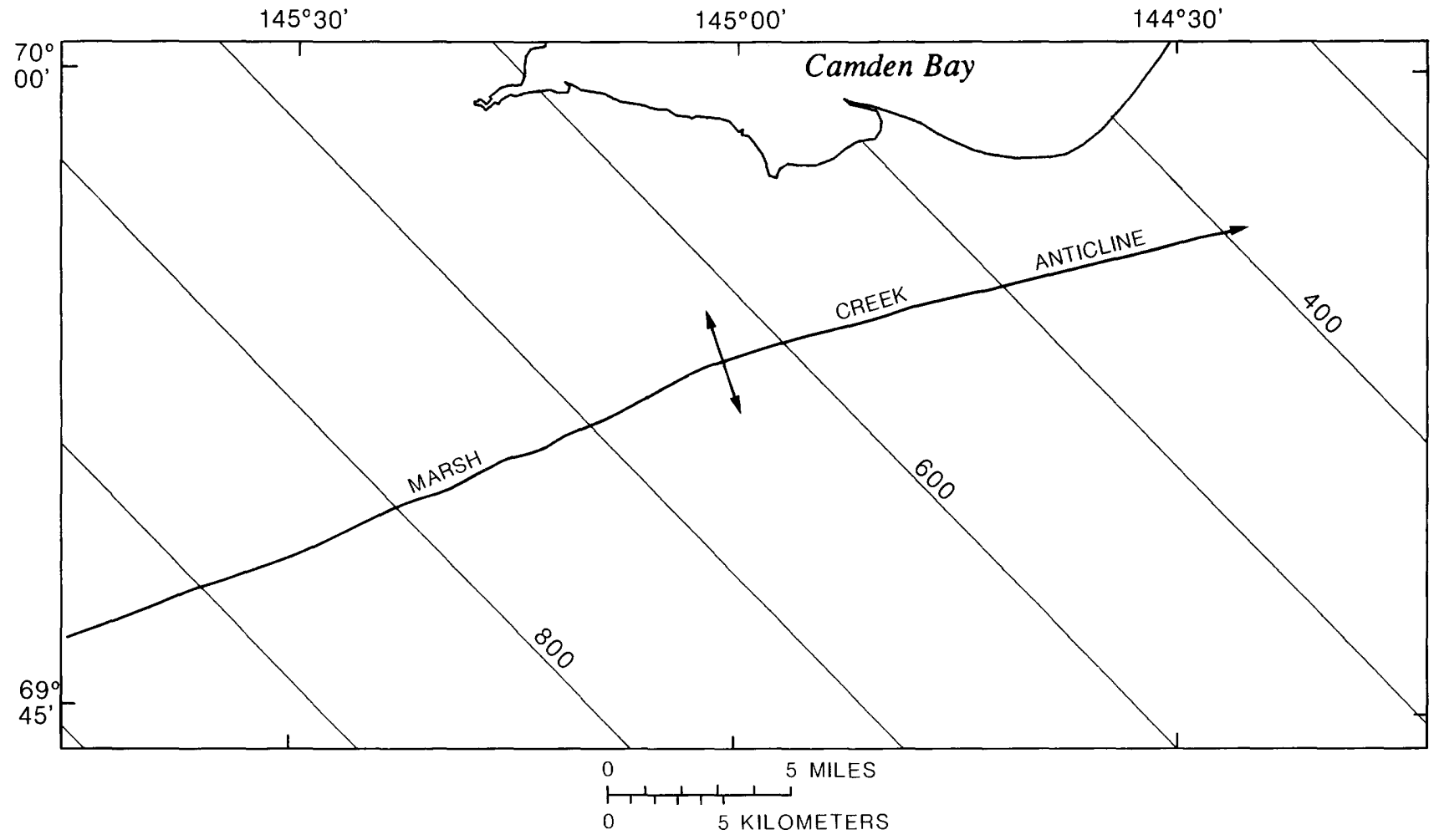

Figure 14.5. Contours showing regional helium gradient in the western 1002 area. See figure 14.1 for location. Contour interval, $100 \mathrm{~nL} / \mathrm{L}$; gradient, $20 \mathrm{~nL} / \mathrm{L}$ per mi. 
a high on all of the helium anomaly maps. The closest sample site to the outcrop was approximately $427 \mathrm{~m}$ $(1,400 \mathrm{ft})$ to the south of the exposure, so it is significant to note this macroseep can apparently be sensed by the helium sampling at a distance.

Data from a light-hydrocarbon survey over the Marsh Creek anticline display anomaly patterns similar to those for helium (Cunningham, in press) but are inconclusive without supporting isotope determinations. Methane, ethane, ethylene, and total $\mathrm{C}_{3}$ hydrocarbons were analyzed by headspace analysis from the same samples used in the helium analyses. The methane data are ambiguous owing to probable near-surface biogenic sourcing. Contour maps of ethane concentrations and ethane/methane ratios consistently indicate anomalies over the Marsh Creek structure, particularly in the area of the lower Katakturuk River seep. These hydrocarbon gases are presumed to follow the same preferential migration pathway (possibly a fault) as the helium that was detected at this locality.

The near-surface magnetic anomalies over the Marsh Creek anticline do not coincide with the residual helium anomalies; they fit, with minimal overlap, into the areally large relative helium low over the northeastern two-thirds of the anticlinal axis (fig. 14.7). From the previous discussion on horizontal-gradient magnetics, these anomalies suggest that there have been one or more periods of large-scale hydrocarbon or reducing ground-water movement through the axis of the anticline to produce the magnetic minerals. Close association of the magnetic anomalies and the mapped faults indicates that the magnetic mineralization is fault controlled and shows evidence of a preferred pathway for fluid transport.

Previous work has demonstrated that thermogenic hydrocarbons undergo biologically mediated oxidation in the near-surface $(<305 \mathrm{~m},<1,000 \mathrm{ft})$ to produce $\mathrm{HCO}_{3}^{-}$and $\mathrm{CO}_{2}$, which results in the precipitation of pore-filling carbonate cement (Donovan, 1974; Donovan and others, 1974, 1975; Donovan and Dalziel, 1977; Donovan and Roberts, 1980). The development of this carbonate cement, along with the epigenetic emplacement of various magnetic minerals that develop a magnetic anomaly, should produce a near-surface gravity anomaly over the Marsh Creek anticline by increasing the bulk density of the rocks in the shallow subsurface. The formation of these minerals through time should partially obstruct continued

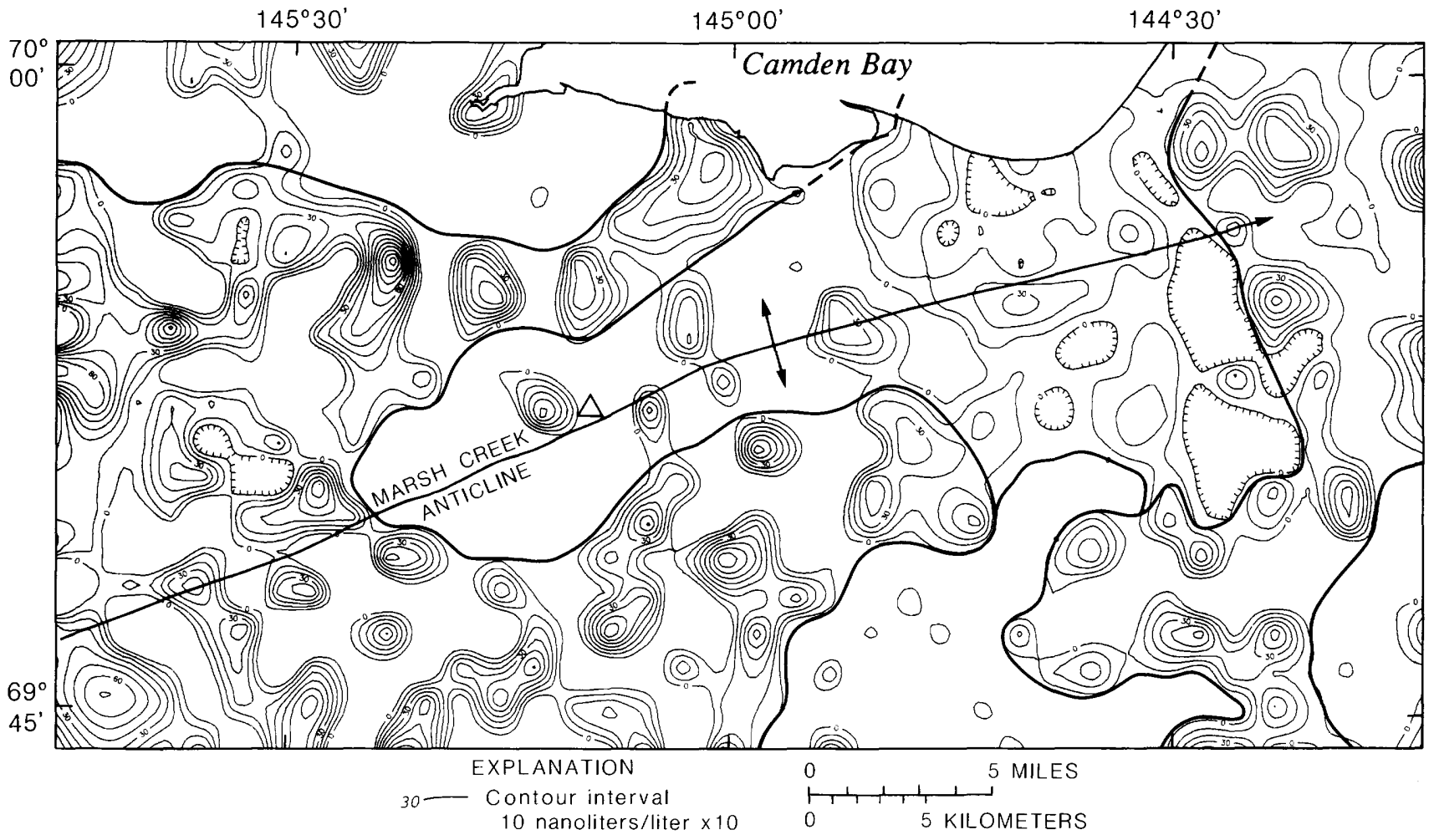

Figure 14.6. Contours of first-order residuals above regional helium gradient in the western 1002 area. Heavy line indicates boundary of major helium anomalies; dashed where approximately located. Hachures indicate area of closed low. Triangle represents oil-stained sandstone of the Canning Formation. 
migration of gases and fluids into the overlying sediments. The near-surface magnetic minerals and carbonate cement would be developed over the axis of the anticline and could explain the observed pattern of helium anomalies.

The ANWR gravity study by Robbins (chap. 15) has established the existence of a near-surface anomaly over the Marsh Creek anticline. Analysis of the residual Bouguer gravity surface indicates a sharply defined anomaly immediately over the anticlinal crest. Robbins utilized velocity curves from the Beli Unit-1 and West Staines State-2 checkshot surveys and determined that the anomaly exhibits a $0.27 \mathrm{~g} / \mathrm{cm}^{3}$ positive density contrast from the surrounding rocks, which are predominantly composed of mixed sandstones, siltstones, and shales. The anomaly is best modeled as a relatively dense block near the top of this 4,572-m -thick $(15,000$ $\mathrm{ft}$ ) sequence.

\section{CONCLUSIONS}

The Marsh Creek structure exhibits at least three characteristic signatures indicating that hydrocarbons have leaked or are leaking in the Marsh Creek area: horizontal-gradient magnetic, helium, and gravimetric anomalies. The geochemical and geophysical anomaly patterns detected over the Marsh Creek anticline cover a large area. Magnetic and gravity anomalies occur immediately above the anticlinal crest, and a halo of high helium concentrations rings the structure.

A model in which hydrocarbons migrate vertically and interact with the overlying rocks, fluids, and organisms to produce a complex diagenetically formed barrier is supported by the near-surface magnetic data, which suggest that significant reducing fluid movement has occurred through fault-controlled pathways within the Marsh Creek structure. If these

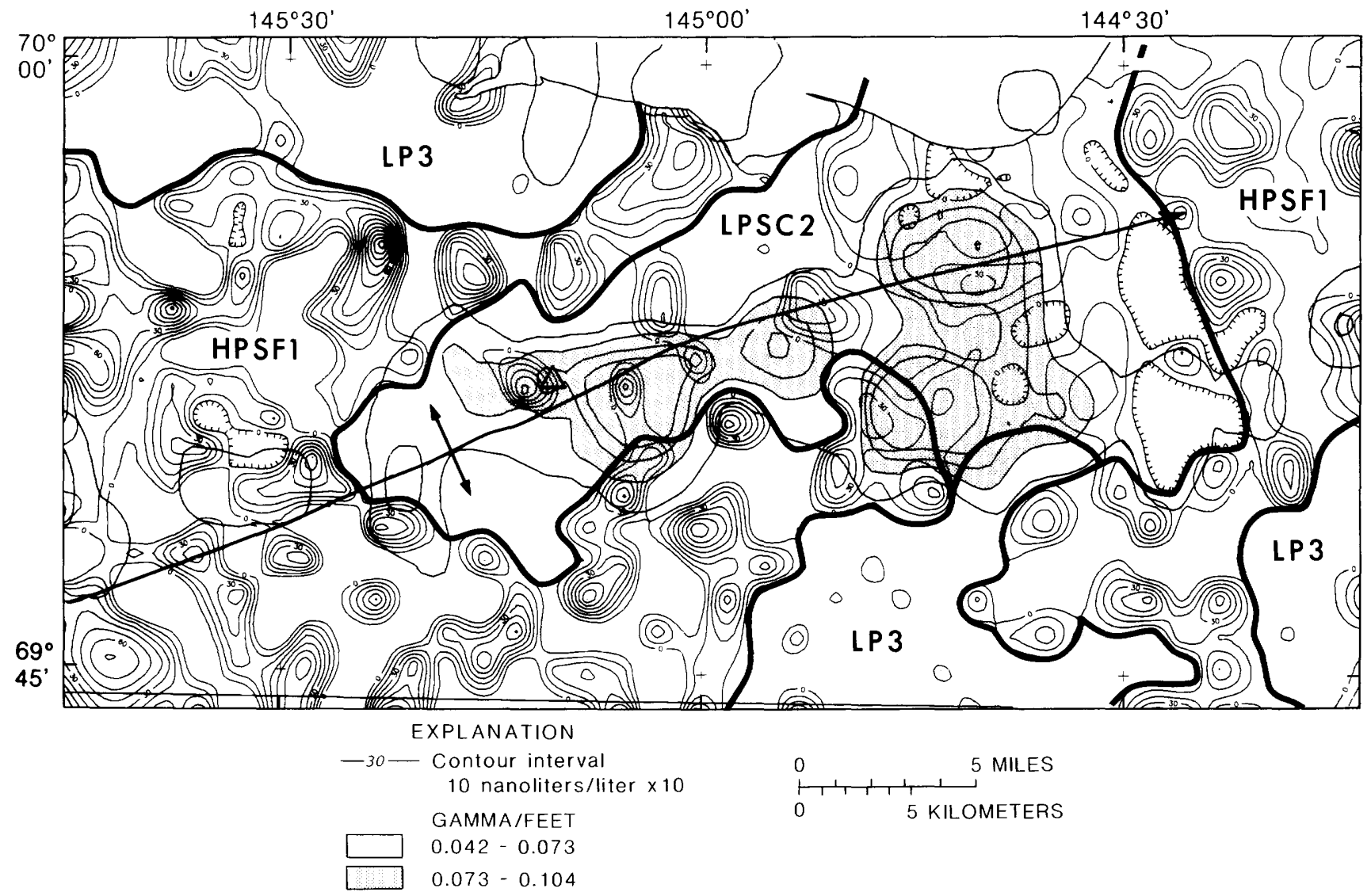

Figure 14.7. Comparison of first-order residual helium (numbered contour lines) with longitudinal-difference magnetic anomalies (unnumbered contour lines with pattern) in the western 1002 area. Helium contour interval is $100 \mathrm{~nL} / \mathrm{L}$ and hachures indicate area of closed helium lows. Magnetic contour interval, 0.031 gamma/ft. Northeasterly plunging structure is the Marsh
Creek anticline. Open triangle near anticlinal axis represents oil-stained sandstone of the Canning Formation. Abbreviations: HPSF1, high permeability structural flow in area 1; LPSC2, low permeability structural core in area 2; LP3, low permeability in area 3. 
fluids contained appreciable amounts of hydrocarbons and related compounds then subsequent interaction with microbial populations may produce pore-filling carbonate cement in the rock column, which would increase the bulk density of the overlying sediments in a tight, fluidcontrolled zone. Gas passage through this heavily modified column may be subject to the degree of cementation and postcementation fracture and fault development that would control the overall pattern and distribution of helium into the near-surface.

The ANWR coastal plain helium residual map (fig. 14.6) indicates an elongate, halolike anomaly pattern relative to the axis of the Marsh Creek anticline, in contrast to the raw data pattem of a horseshoe-shaped anomaly open to the northeast (fig. 14.3 or 14.4). Significant increases in anomaly magnitude are observed in the eastern survey area after all reported helium concentrations are normalized with respect to the regional gradient (fig. 14.5). The high regional gradient of $20 \mathrm{~nL} / \mathrm{L}$ per $1.6 \mathrm{~km}(20 \mathrm{~nL} / \mathrm{L}$ per mi) may be a reflection of proximity to a highly radioactive horizon under the survey area. We interpret this map of the helium residuals to be composed of three primary zones of significant gas distribution that reflect the probable paleodevelopment of a hydrocarbon-induced diagenetic chimney modified by late regional deformation.

(1) HPSF1 - a large area of abnormally high helium concentrations between 0 to $1,100 \mathrm{~nL} / \mathrm{L}$ He above the regional gradient. This zone exhibits widely varying concentration gradients indicative of differentially permeable sediments that are allowing relatively unrestricted gas migration. We characterize this zone as an area of high fracture density and high permeability.

(2) LPSC2 - an area directly over the Marsh Creek anticlinal crest with values generally below the regional gradient. Several multipoint anomalies have values from 0 to $600 \mathrm{~nL} / \mathrm{L} \mathrm{He}$ above the regional gradient and are probably related to discrete faulting perpendicular to structural strike. We interpret this zone as an area of high fracture density with reduced permeability due to diagenetic cementation, which is manifested by lower helium values.

(3) LP3 - small, discontinuous areas at or below the regional gradient that reflect zones of minimal helium flux and indicate low fracture density and low lithologic permeability.

\section{APPENDIX 14.1}

\section{Determination of Helium Background Level}

All measured helium concentrations were first sorted in ascending order $\left(X_{i}\right)$. The mean $\left(\bar{x}_{t}\right)$ was then calculated for the entire set of values (total population, table 14.1). The subset of data having values equal to or less than $\bar{x}_{t}$ was then defined as the background population. The mean and standard deviation for this subset were calculated and estimated to be the background mean $\left(\bar{x}_{b}\right)$ and background standard deviation $\left(\sigma_{b}\right)$. Anomalous values are those concentrations that exceed the background mean by more than one standard deviation of the background population (that is, values greater than $\bar{x}_{b}+\sigma_{b}$ were considered anomalous). The anomalous values are ordered into four categories according to the number of background standard deviations $\left(\sigma_{\mathrm{b}}\right)$ by which they exceeded the background mean (table 14.1).

Table 14.1 Population statistics for helium concentrations measured in the ANWR coastal plain helium survey area. See figure 14.1 for location

[Anomaly category: (1) $1-2 \sigma_{b}, 564-718$; (2) $2-3 \sigma_{b}, 718-872$; (3) 3-4 $\sigma_{b}, 872-1,026$; $(4)>4 \sigma_{b},>1,026$. All units are in nanoliters $\mathrm{He} /$ liter $\mathrm{H}_{2} \mathrm{O}$. N, population size]

\begin{tabular}{lccccc}
\hline & N & Mean Median & $\begin{array}{c}\text { Standard Variance } \\
\text { deviation }\end{array}$ \\
& & $(\overline{\mathrm{x}})$ & & $(\sigma)$ & $\left(\sigma^{2}\right)$ \\
\hline Total population & 699 & 675 & 574 & 398 & 158,404 \\
Background population & 405 & 410 & 419 & 154 & 23,716 \\
\hline
\end{tabular}




\title{
Chapter 15.
}

\section{Gravity Interpretation of the Coastal Plain}

\author{
By Stephen L. Robbins ${ }^{1}$
}

\section{INTRODUCTION}

The complete Bouguer gravity map for the Arctic National Wildlife Refuge (ANWR) region (pl. 2) is made up from six data sets: (1) 270 stations acquired by Photo-Gravity under contract to ITECH (stations are along north-northwest-south-southeast lines that are $2 \mathrm{mi}$ apart), (2) 1,002 stations acquired by Geophysical Service Inc. (GSI), in 1984 along eight of their reflection seismic lines (gravity stations are spaced $800 \mathrm{ft}$ apart), (3) 939 stations acquired by GSI in 1985 along 8 reflection seismic lines, (4) 180 USGS stations outside the coastal plain (Kososki and others, 1978; spacing is irregular and broad), (5) 289 stations south of the coastal plain obtained by T.R. Bruns and M.A. Fisher of the USGS in 1984 (spacing is irregular and broad), and (6) free-air contours from shipboard data north of the coastline (Boucher and others, 1977). ITECH and GSI data were processed by the USGS from the original field sheets, and all the land gravity data were terrain corrected by computer out to a distance of $167 \mathrm{~km}$ (104 $\mathrm{mi})$. The map was machine contoured at a scale of 1:250,000 with a 2 -mGal contour interval onshore and a 10 -mGal contour offshore, then reduced to publication scale of $1: 500,000$.

\section{MAJOR GRAVITY FEATURES}

The largest gravity feature on plate 2 is the -60 to $-70 \mathrm{mGal}$ negative anomaly (anomaly A) centered at the south end of Camden Bay. This feature corresponds with the thickest sedimentary section above the reflective horizon at the top of the pre-Mississippian basement complex (hereafter referred to as the TPM) as shown on seismic-reflection sections (chaps. 17, 19). This section, composed mostly of Tertiary sedimentary rocks, is more than $6,100 \mathrm{~m}(20,000 \mathrm{ft})$ thick southeast of Camden Bay, thus requiring a density average of less than $2.4 \mathrm{~g} / \mathrm{cm}^{3}$ to satisfy modeling of the gravity anomaly. The

\footnotetext{
${ }^{1}$ U.S. Geological Survey, Denver, Colo.
}

northwest-southeast trend of anomaly $\mathbf{A}$ is in general alignment with the offshore Dinkum graben (figs. 3.1, 21.1), a feature interpreted by Grantz and May (1983) to contain mainly Jurassic and Lower Cretaceous sedimentary rocks. The magnitude of anomaly $\mathrm{A}$ is compatible with a sediment-filled graben, although seismic sections in this area do not show such a feature. The southwest arm of anomaly A decreases in amplitude (-50 mGal contour) to the southwest, which suggests thinning of the sedimentary materials. However, modeling studies show that, at least in part, the anomaly decrease is more likely caused by a density decrease within the Tertiary section from west to east.

The east-trending relative positive gravity anomalies labeled B, shown in the west-central part of the map area, overlie the Sadlerochit and Shublik Mountains and are likely due to a southward decrease in depth to and ultimate surfacing of strata (Ellesmerian sequence and basement complex) that predate the Brookian sequence, as proposed by Kososki and others (1978). This apparent decrease in depth is probably due to northward thrusting of the older rocks. Between the positive gravity anomalies belt (B) and the southwestern arm of anomaly $A$ is a narrow northeast-trending positive anomaly (C) over the Marsh Creek anticline. This feature has a relief of 7-9 mGal on seismic line 84-14. Present in the northwest section of the map between two low anomaly flanks (A) is a positive gravity nose (D) that plunges east. This feature may represent the east end of the Barrow arch.

The large gravity low (E) located in the southcentral part of the mapped area is associated with a large, thick, low-density, granitic intrusive body. Preliminary modeling of the body using as much as -0.15 $\mathrm{g} / \mathrm{cm}^{3}$ density contrast with the surrounding rocks indicates a very thick root. However, even using these assumptions, the magnitude of the observed anomaly has not been duplicated (M.A. Fisher, oral commun., 1985).

A broad, somewhat circular positive anomaly (F), located just landward of the shore southeast of Barter Island, suggests a structurally uplifted basement platform (Kososki and others, 1978). Seismic-reflection data indicate that the TPM is as shallow as $3,000 \mathrm{~m}$ $(10,000 \mathrm{ft})$ and that several thrust faults are evident. The high, however, does not extend onto the Beaufort shelf, 
as Kososki and others (1978) proposed, which thus negates their analogies to the geology of Prudhoe Bay. Southeast of anomaly $F$ is a twin positive gravity anomaly (G), which may be structurally related to anomaly $\mathrm{F}$ or possibly to the east-trending anomaly belt (B) off to the west.

A narrow saddle $(\mathrm{H})$ separating anomalies $\mathrm{F}$ and $G$ also separates the eastern end of anomaly $A$, a basin on the west, from an offshore basin to the east located under anomaly $I$. The shape of the saddle suggests that anomaly $\mathrm{H}$ was part of these basins but now reflects anomalies from two sources: one from a very shallow depth causing anamolies $F$ and $G$, and the other from a much deeper depth causing anamolies A and I. This interpretation suggests a possible common origin for the two basins $A$ and $I$. If so, the positive anomaly (F) southeast of Barter Island may be related to thrusting or shale diapirism, as suggested by Grantz and Mull (1978) and Grantz and May (1983) and considered "plausible" by Hinds and others (1983).

\section{DENSITY}

Quantitative modeling requires good estimates of average density. Densities used in prior gravity studies (Kososki and others, 1978; Hinds and others, 1983) were determined from a small number of surface samples and mainly from rocks that are not widespread beneath the northeastern Alaska coastal plain. To obtain a more representative estimate for the units within the coastal plain, gamma-gamma density logs from 14 wells to the west were digitized and averaged over the various unit intervals (fig. 15.1). The values (deduced from fig. 15.1) used in the gravity models are shown in table 15.1.

Inspection of the density data reveals that (1) except for the Beli Unit-1 well, which contains anomalous values (fig. 15.1), density measurements were not made in the upper $607 \mathrm{~m}(2,000 \mathrm{ft})$ of the wells (the permafrost zone); (2) a density inversion occurs near the top of the Paleocene section or the Canning Formation, averaging about a $-0.05 \mathrm{~g} / \mathrm{cm}^{3}$ decrease; (3) the largest single-unit range in density occurs in the pebble shale unit, 2.22 to $2.62 \mathrm{~g} / \mathrm{cm}^{3}$, but it scarcely affects the surface gravity field because the pebble shale is so thin; and (4) the density averages for the Lisburne Group and older units (including the basement complex) are similar and are here treated as one unit.

\section{GRAVITY MODELING ALONG SEISMIC PROFILES}

Gravity models along profiles that include seismic lines 85-2, 85-8, 84-6, 84-14, 84-20, 84-24, and 84-30 are shown in figures 15.2 through 15.7. Depths and configurations of the unit horizons in figures 15.2 and 15.3, and of the TPM in all the figures, are based mainly on depth-converted seismic sections.

The regional gravity field is that part of the Bouguer anomaly caused by geologic features below the level of comprehension and (or) interest (longwavelength anomalies). Mantle-crust interface depth changes and different basement lithologies (carbonate rocks, argillites, and igneous intrusions) are common sources. Because the crust increases in thickness from a thin ocean border on the north (offshore) to a thick mountain root to the south, a linear 1 - to $2-\mathrm{mGal} / \mathrm{mi}$ decrease-to-the-south regional field, similar to that proposed by Kososki and others (1978), has been removed on each profile. More sophisticated forms of a regional field (that is, computer filtering, upward continuation, $n$ th-order polynominal fits, etc.) were not attempted; because so little is known about the basement, it was felt these regional fields would only complicate the interpretation without much real added benefit and might even introduce fictitious features.

The gravity models are more generalized and less accurate to the east, where well data are lacking. Exact fits between the observed and calculated gravity values were not attempted because small misfits can be attributed to lateral density inhomogeneities and structural complexities.

At the south end of most of the profiles, the observed gravity decreases sharply. This decrease is probably caused by the abrupt increase in crustal thickness beneath the Brooks Range, which is not compensated for in the linear regional gravity field and which has not been modeled.

The model for line $85-2$ (fig. 15.2), coordinated with data from nearby wells, shows a fair fit with the seismic-reflection data and the observed gravity. The small high within the large low (anomaly A) may be a zone of higher density (possibly about $+0.05 \mathrm{~g} / \mathrm{cm}^{3}$ ) caused by compaction from thrust faulting within the upper Tertiary section.

The depths in the model for line 84-6 and 85-8 (fig. 15.3A) are from a depth-converted seismic profile using velocity data from the West Staines State-2 well. The poor fit in the area of the thick Cenozoic section suggests a lower average density in part of the section, as postulated in figure $15.3 B$. The gravity high (C) over the Marsh Creek anticline is shown as being caused by uplift of the denser rocks that predate the TPM.

Correlation of unit horizons in line 84-14 (fig. 15.4) and in other lines to the east with lines 84-6, 85-8, and $85-2$ to the west is tentative enough that using only one density average $\left(2.37 \mathrm{~g} / \mathrm{cm}^{3}\right)$ for the entire section above the TPM is reasonable. The model shown requires a high-density $\left(2.62 \mathrm{~g} / \mathrm{cm}^{3}\right)$ body in the area of the Marsh Creek anticline. This body is not a separate lithologic unit but rather is a higher density zone resulting from compaction and (or) diagenesis within the 
thrust-faulted structure. So high an increase in density probably cannot be caused by compaction alone. Some other process may also be needed, such as precipitation of carbonate cement and various magnetic minerals by hydrocarbon seepage (chap. 14).
The model for line $84-20$ (fig. 15.5) provides a relatively good match between the gravity and seismic data, based on the assumed density average. The mismatch of the high at anomaly B may result from compaction due to thrusting in the Tertiary section.

DENSITY, IN GRAMS PER CUBIC CENTIMETER

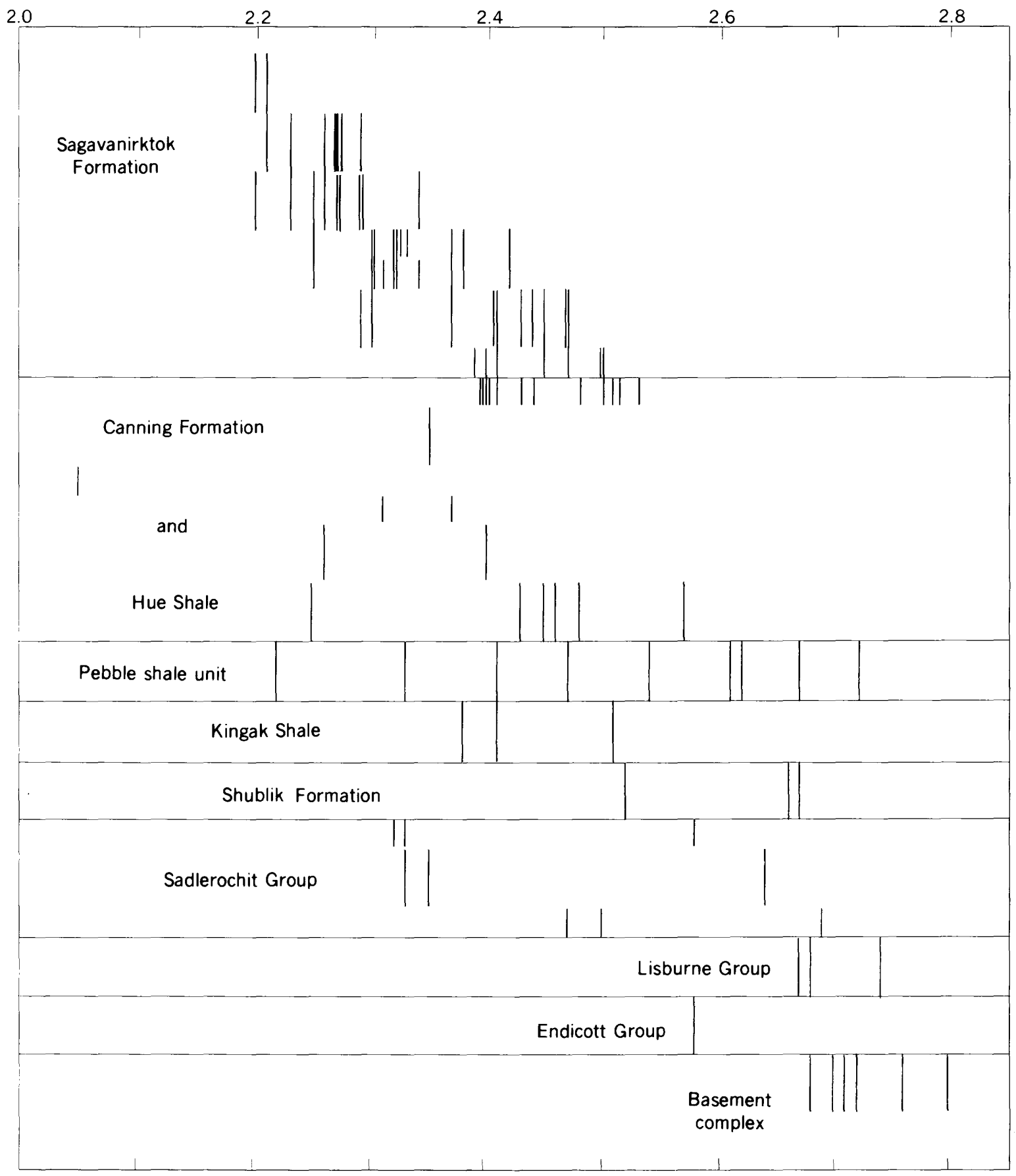

Figure 15.1. Distribution by stratigraphic unit of density averages from 14 gamma-gamma density well logs. Most of the observed minimum density values from the lower part of the Sagavanirktok Formation through the Sadlerochit Group are from the Beli Unit-1 well. Locations of analyzed wells are shown on plate 2. Average density values used in profile interpretations are shown in table 15.1. 
Table 15.1. Densities derived from gamma-gamma density well logs in 14 wells adjacent to the ANWR (pl. 2) that were used in modeling gravity profiles $A-A^{\prime}$ to $F-F^{\prime}$ (figs. 15.2-15.7) in the 1002 area

\begin{tabular}{lccc}
\hline \multicolumn{1}{c}{$\begin{array}{c}\text { Stratigraphic } \\
\text { unit }\end{array}$} & Age & \multicolumn{2}{c}{ Density } \\
\cline { 3 - 4 } & & $\begin{array}{c}\text { Range } \\
\left(\mathrm{g} / \mathrm{cm}^{3}\right)\end{array}$ & $\begin{array}{c}\text { Average } \\
\left(\mathrm{g} / \mathrm{cm}^{3}\right)\end{array}$ \\
\hline $\begin{array}{l}\text { Sagavanirktok Formation } \\
\quad \text { (upper part) }\end{array}$ & Plioc. - Oligoc. & $2.07-2.42$ & 2.27 \\
$\begin{array}{l}\text { Sagavanirktok Formation } \\
\quad \text { lower part) }\end{array}$ & Eoc. - Paleoc. & $2.29-2.53$ & 2.42 \\
& & & \\
Canning Formation & Oligo.(?) - Cret. & $2.05-2.57$ & 2.37 \\
Hue Shale & Paleoc.(?) - Cret. & $2.05-2.57$ & 2.37 \\
& & & \\
Kingak Shale & Cret. - Jur. & $2.32-2.69$ & 2.52 \\
Shublik Formation & Triassic & $2.32-2.69$ & 2.52 \\
Sadlerochit Group & Trias. - Perm. & $2.32-2.69$ & 2.52 \\
& & & \\
Lisbume Group & Penn. - Miss. & $2.57-2.80$ & 2.67 \\
Endicott Group & Miss. & $2.57-2.80$ & 2.67 \\
Basement complex & pre-Miss. & $2.57-2.80$ & 2.67 \\
& & & \\
Igneous intrusions & $?$ & $?$ & 2.62 \\
\hline
\end{tabular}
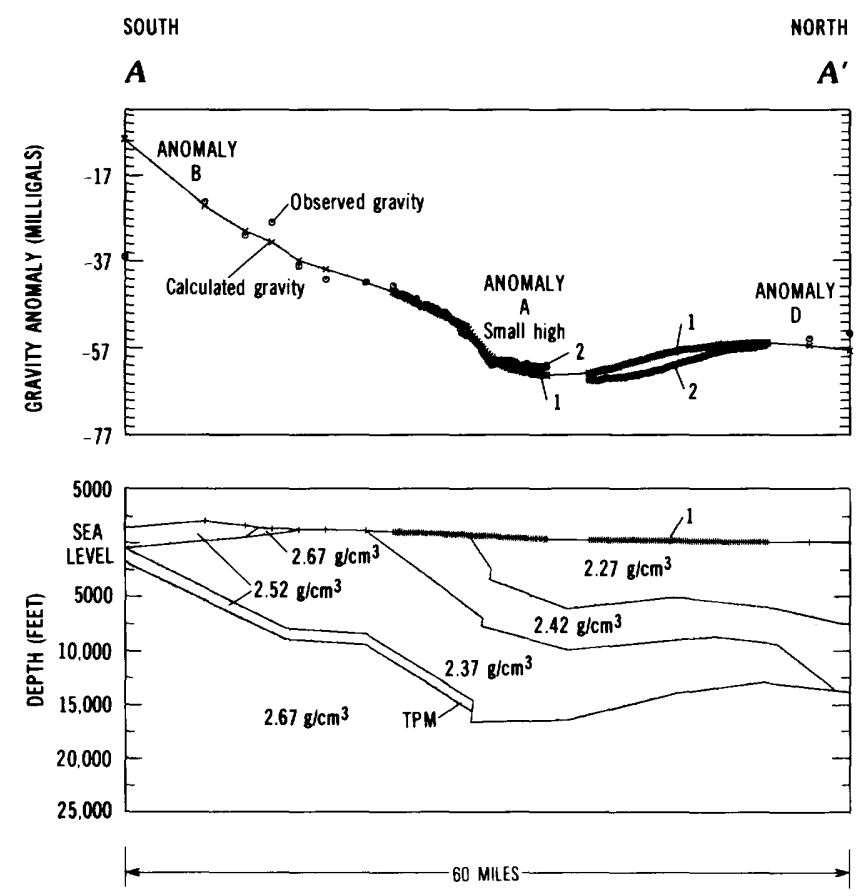

Figure 15.2. Gravity model showing observed and calculated values along profile $A-A^{\prime}$ (see pl. 2 for location). TPM, reflective horizon at top of preMississippian basement complex. Anomalies discussed in text. 1, observed gravity; 2 , calculated gravity.
The observed gravity profiles along lines $84-24$ and 84-30 (figs. 15.6, 15.7) contain more shortwavelength anomalies than do the profiles to the west. These anomalies result from density variations within the Cenozoic section and coincide with a more complex structural setting than for the area to the west. The
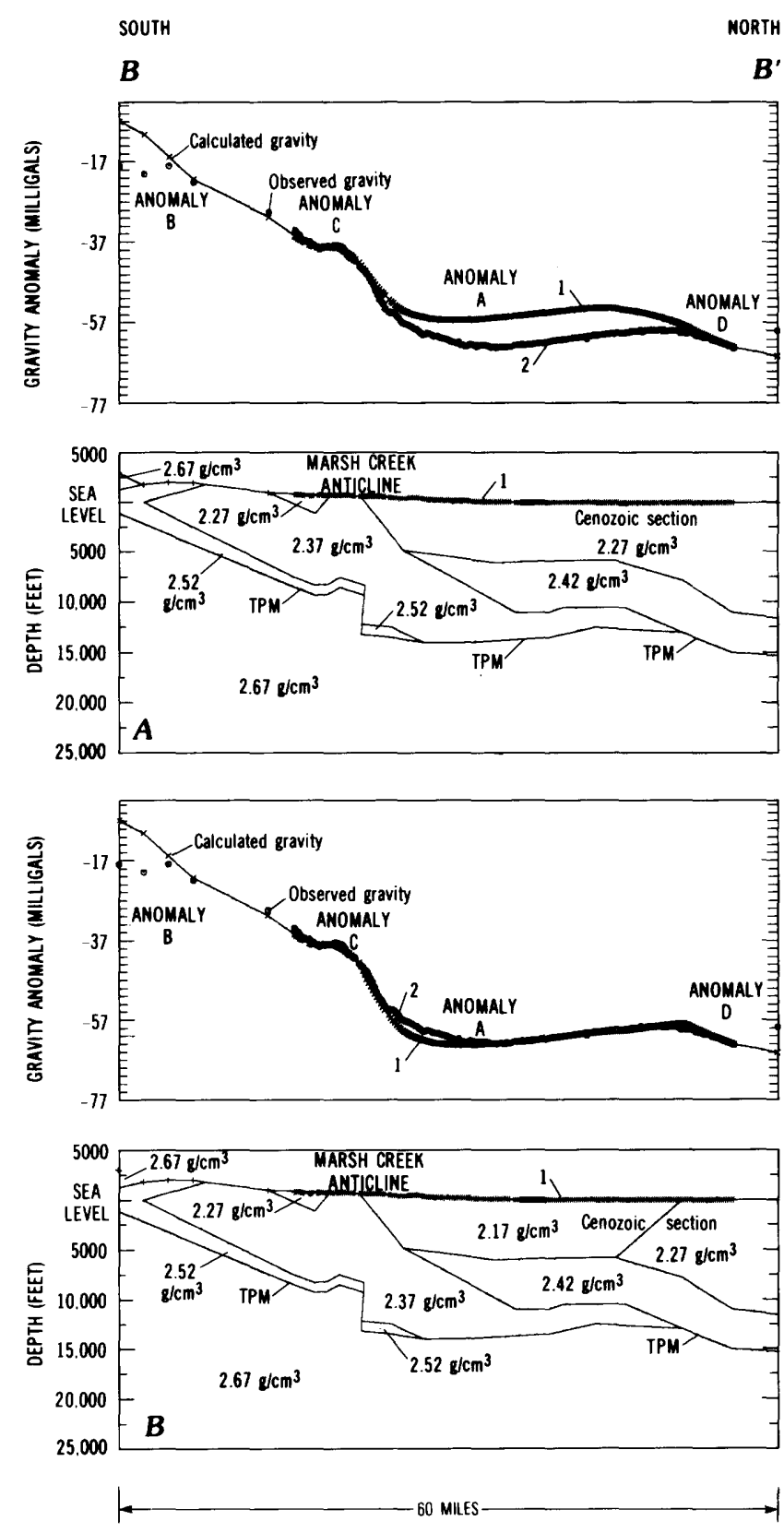

Figure 15.3. Gravity models showing observed and calculated values along profile $B-B^{\prime}$ (see pl. 2 for location). TPM, reflective horizon at top of preMississippian basement complex. Anomalies discussed in text. $A$, Gravity model. $B$, Gravity model that includes additional low-density body. 1, observed gravity; 2 , calculated gravity. 
shapes of the lows (a broad low with a steep-gradient low in the middle) on lines 84-24 (anomaly A) and 8430 (anomaly $\mathrm{H}$ ) indicate that both are the result of the same structural feature and appear to separate the area to the north (with the short-wavelength anomalies) from the area to the south (with no anomalies).

The western profiles (figs. 15.2-15.5) show relatively good correlation between the gravity data and models based on the seismic-reflection data. This suggests that older dense rocks had little or no involvement in the thrusting within the Cenozoic section. In the area of lines 84-24 and 84-30 (figs. 15.6, 15.7), Jurassic rocks crop out and probably cause at least some of the observed short-wavelength anomalies.

\section{CONCLUSIONS} follows.

The main results of the gravity study are as

(1) Gravity anomalies are dominantly controlled by the depth to the TPM. The lowest gravity is over the areas of the thickest sections of Cenozoic (post-TPM) sedimentary rocks, and the highest values are over areas of thin Cenozoic sediments.

(2) A narrow high-density unit is required over the Marsh Creek anticline to account for the positive gravity anomaly (C). This high is, in part, due to uplifting and thrusting of older dense rocks and to compaction of Tertiary sedimentary materials. However, gravity data along seismic line 84-14 show that the anomaly is large enough with steep enough gradients that another process is probable (perhaps cementation from hydrocarbon seepage).

(3) The Cenozoic coastal plain sedimentary materials appear to decrease in density from $2.27 \mathrm{~g} / \mathrm{cm}^{3}$ to $2.17 \mathrm{~g} / \mathrm{cm}^{3}$ in an easterly direction.

(4) The offshore Dinkum graben may possibly extend southeast onto the shore south of Barter Island. The graben apparently ends in this area, but the gravity data suggest it may have once been part of the offshore basin (anomaly I) to the east.

(5) The termination of the Barrow arch may be reflected in the gravity data by the positive gravity nose (D) at the northwest end of Camden Bay.

(6) The positive gravity anomaly (F) southeast of Barter Island is possibly due to a structurally uplifted basement platform, but it is also, at least in part, a result of thrusting. The short-wavelength anomalies in this area suggest complex deformation, with older denser rocks having been carried into the near-surface along the thrust faults.
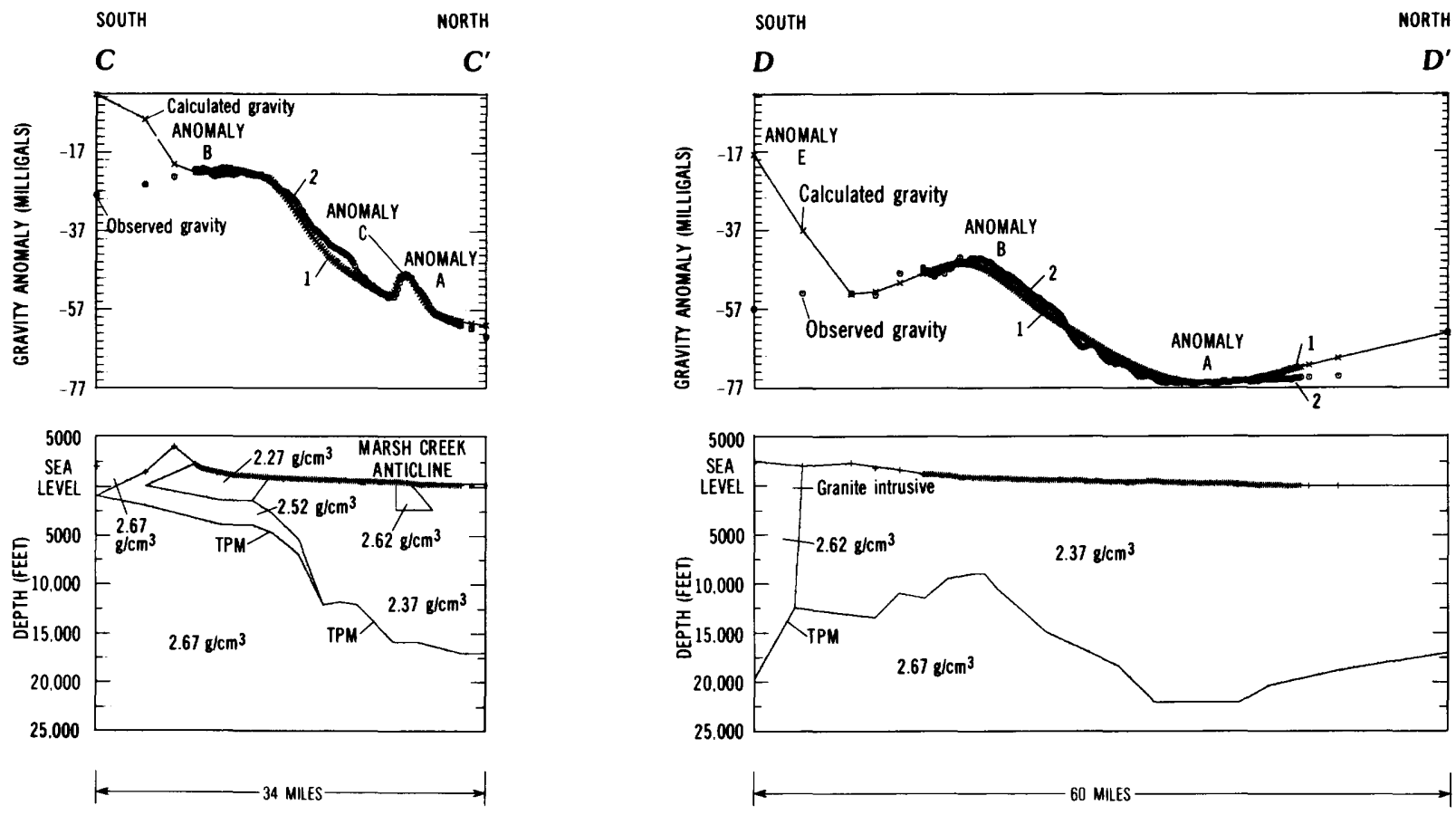

Figure 15.4. Gravity model with observed and calculated values along profile $C-C^{\prime}$ (see pl. 2 for location). TPM, reflective horizon at top of pre-Mississippian basement complex. Anomalies discussed in text. 1, observed gravity; 2 , calculated gravity.

Figure 15.5. Gravity model with observed and calculated values along profile $D-D^{\prime}$ (see pl. 2 for location). TPM, reflective horizon at top of pre-Mississippian basement complex. Anomalies discussed in text. 1, observed gravity; 2, calculated gravity. 

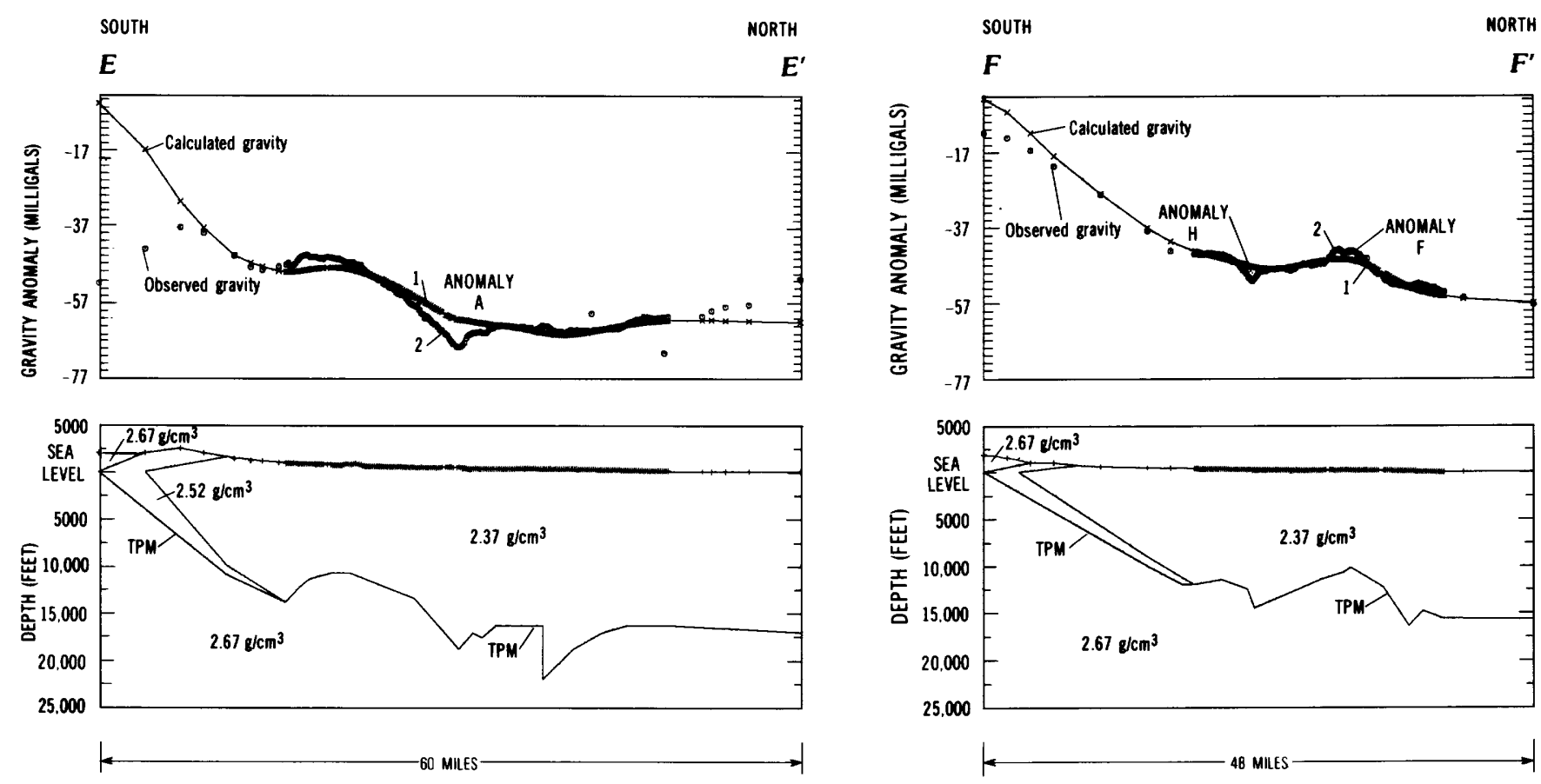

Figure 15.6. Gravity model with observed and calculated values along profile $E-E^{\prime}$ (see pl. 2 for location). TPM, reflective horizon at top of pre-Mississippian basement complex. Anomalies discussed in text. 1, observed gravity; 2 , calculated gravity.

Figure 15.7. Gravity model with observed and calculated values along profile $F-F^{\prime}$ (see pl. 2 for location). TPM, reflective horizon at top of pre-Mississippian basement complex. Anomalies discussed in text. 1, observed gravity; 2 , calculated gravity. 


\title{
Chapter 16.
}

\section{Seismic-Reflection Data Processing}

\author{
By W. James Leinbach, Jr., ${ }^{1}$ John J. Miller, ${ }^{2}$ and Myung W. Lee ${ }^{2}$
}

\section{INTRODUCTION}

In 1984 and $1985,2,351 \mathrm{~km}(1,451 \mathrm{mi})$ of digital, multichannel, seismic-reflection data were recorded on and adjacent to the Arctic National Wildlife Refuge (ANWR) as part of the resource evaluation study performed by the Fish and Wildlife Service (FWS), the Bureau of Land Management (BLM), and the U.S. Geological Survey (USGS). These data were collected by Geophysical Service Inc. (GSI), under contract to a consortium of petroleum exploration companies.

GSI processed all the seismic data and provided copies of the raw field-data tapes to the USGS. All lines that were recorded and processed by GSI during 1984 and 1985 are shown in table 16.1. Lines that were reprocessed by the USGS are indicated. The locations of the lines are shown in figure 17.1. Twenty-one percent $(500.69 \mathrm{~km}, 311.13 \mathrm{mi})$ of the data were reprocessed by the USGS at its seismic data-processing facility in Denver, Colorado.

Only those seismic data processed by the USGS are used as illustrations in this publication and in the report to Congress (Clough and others, 1987). This paper discusses the USGS processing of these data. Illustrations show the progression of data-processing results from initial testing on raw data through final, stacked record sections.

In $1984,982.76 \mathrm{~km}(606.64 \mathrm{mi})$ of dynamite data and $247.07 \mathrm{~km} \cdot(152.51 \mathrm{mi})$ of Vibroseis data were recorded. The Vibroseis lines were recorded along the coastline out onto the ice pack and were either overlapping extensions of the longer dynamite lines or independent short lines. Between the 1984 and 1985 field seasons, the FWS agreed with GSI that the Vibroseis data quality was comparable to that of the dynamite data. More importantly, data acquisition using Vibroseis is less distruptive of the surface environment Australia.

1 Flinders University of South Australia, Bedford Park, South

${ }^{2}$ U.S. Geological Survey, Denver, Colo. and is not as costly as using dynamite; hence, in 1985 , all $1,121.51 \mathrm{~km}(692.33 \mathrm{mi})$ of seismic lines were recorded using the Vibroseis method.

Table 16.1. Reflection seismic lines on and adjacent to the Arctic National Wildlife Refuge recorded and processed by GSI in 1984 and 1985

$\left[*\right.$, reprocessed by the USGS; ${ }^{* *}$, a registered trademark of Continental Oil Company]

\begin{tabular}{|c|c|c|}
\hline \multicolumn{2}{|c|}{1984} & \multirow{2}{*}{$\frac{1985}{\text { Vibroseis** }}$} \\
\hline Dynamite & Vibroseis** & \\
\hline AN84-1* & ANV84-1 & AN85-1* \\
\hline AN84-2 & ANV84-3 & AN85-2* \\
\hline AN84-3 & ANV84-7 & AN85-2A* \\
\hline AN84-2 & ANV84-3 & AN85-3 \\
\hline AN84-3A & ANV84-8 & AN85-7 \\
\hline AN84-3B & ANV84-10 & AN85-8* \\
\hline AN84-4 & ANV84-12 & AN85-10 \\
\hline AN84-5* & ANV84-14 & AN85-14 \\
\hline AN84-6* & ANV84-15 & AN85-15* \\
\hline AN84-7 & ANV84-16 & AN85-16* \\
\hline AN84-7A & ANV84-17 & AN85-17 \\
\hline AN84-8 & ANV84-18 & AN85-18 \\
\hline AN84-10* & ANV84-19 & AN85-19 \\
\hline AN84-11 & ANV84-30 & AN85-20 \\
\hline AN84-12 & ANV84-32 & AN85-21 \\
\hline AN84-13 & ANV84-34A & AN85-22 \\
\hline AN84-14* & ANV84-34B & AN85-24 \\
\hline AN84-16 & ANV84-36 & AN85-25 \\
\hline AN84-18 & ANV84-38 & AN85-26 \\
\hline AN84-2f* & ANV $84-40$ & AN85-28 \\
\hline AN84-22 & ANV84-48 & AN85-30 \\
\hline AN84-24* & ANV84-50 & AN85-32 \\
\hline AN84-26 & ANV84-52 & AN85-34 \\
\hline AN84-28 & ANV84-56 & AN85-36 \\
\hline AN84-30* & ANV84-58 & AN85-38 \\
\hline AN84-32 & ANV84-60 & AN85-42 \\
\hline AN84-34 & - & AN85-44 \\
\hline- & - & AN85-46 \\
\hline- & - & AN85-48 \\
\hline - & - & AN85-50* \\
\hline- & - & AN85-52 \\
\hline \multicolumn{3}{|l|}{ Mileage } \\
\hline 606.64 & 152.51 & 692.33 \\
\hline \multicolumn{2}{|c|}{ Total mileage } & $1,451.48$ \\
\hline \multicolumn{2}{|c|}{ Mileage reprocessed by USGS } & 311.13 \\
\hline \multicolumn{2}{|c|}{ Percent reprocessed by USGS } & 21.4 \\
\hline
\end{tabular}




\section{RECORDING FIELD PARAMETERS}

Dynamite and Vibroseis recording parameters are listed in tables 16.2 and 16.3, respectively. Note that the major differences between the 1984 and 1985 recording parameters are that (1) no dynamite data were recorded in 1985, (2) the sweep length was changed from 5 to $8 \mathrm{~s}$ in 1985 , and (3) the correlated record time was changed from 8 to $6 \mathrm{~s}$ in 1985 .

\section{PROCESSING FLOW}

The data were processed on a VAX $11 / 780$ computer using a Digicon, Inc., DISCO software package. The following steps were involved in the data processing (fig. 16.1).

Demultiplex.-The field tapes were reformatted from SEG B into VAX internal format. During this stage, a sampling of the raw field records was displayed. Typical dynamite and Vibroseis field records are shown in figure $16.2 A-C$ and $16.2 D$, respectively.

Gain correction.-When the dynamite charge is detonated within the permafrost layer, the ice is fractured and continues to fracture, which creates secondary sources that are sometimes called "ice breaks." These secondary sources can be especially bothersome when the amplitudes of the primary reflections are weak relative to the amplitudes of the ice breaks (fig. 16.2A).

On many of the lines, these ice breaks occur on almost every shot. One way to eliminate them is to inspect all of the shot records on the line and to set the amplitudes of the portion of each trace containing icebreak energy to zero, a process known as surgical muting. A dynamite field record surgically muted by the USGS is shown in figure $16.2 B$.

Table 16.2. Dynamite recording parameters for the 1984 GSI seismic survey on and adjacent to the Arctic National Wildlife Refuge

[SP, shotpoint]

$\begin{aligned} \text { Recording instrument } & \text { DFS V } \\ \text { Recording format } & \text { SEG B } \\ \text { Number of channels } & 120 \\ \text { Group interval } & 110 \mathrm{ft} \\ \text { Shot interval } & 220 \mathrm{ft} \\ \text { Fold coverage } & 30 \mathrm{fold} \\ \text { Spread configuration } & 2805-275-\mathrm{SP}-275-10725(\mathrm{ft}) \\ \text { Record length } & 8 \mathrm{~s} \\ \text { Sample rate } & 2 \mathrm{~ms} \\ \text { Size of charge } & 60 \mathrm{lb} \text { single hole } \\ \text { Recording filter } & 8 \mathrm{~Hz} 18 \text { db/octave low cut } \\ \text { Recording filter } & 128 \mathrm{~Hz} 72 \mathrm{db} / \mathrm{octave} \text { high cut } \\ \text { Geophone array } & \text { inline, 24 per group } \\ \text { Geophone type } & \text { GSC 200,10 Hz }\end{aligned}$

True amplitude processing can be performed on dynamite lines if surgical muting is used. Retaining true reflection amplitudes enables the interpreter to correlate the amplitudes of the waveform with the strength of the reflection coefficients at that boundary.

Because the USGS did not have the manpower to surgically mute out the ice breaks, gain tests were performed to find a function that would balance the reflection amplitudes with time and simultaneously suppress the high amplitudes of the ice breaks. First, a $\mathrm{T}^{2}$ curve was applied to each trace, where $\mathrm{T}$ is a twoway traveltime (in seconds). A time-varying scalar equal to $\mathrm{T}^{2}$ was multiplied by each data sample. Then a balance program with multiple, overlapping time gates of $1,000 \mathrm{~ms}$ was applied to each trace. A scalar was calculated in such a way that the average amplitude of each gate, when multiplied by the scalar, is equal. These scalars were applied at the midpoint of each gate and linearly interpolated for sample points in between.

A shot record with gain correction applied is shown in figure $16.2 C$. The ice breaks still remain, but their amplitudes are now nearly equal to that of the reflected signal. The stacking procedure after application of normal moveout (NMO, the variation in arrival time with offset) effectively eliminates the ice breaks.

CDP sort and datum statics.-Source and receiver geometries were coded into the trace headers so that traces could be rearranged into common-depth-point (CDP) gathers. Shot and receiver elevations were entered and datum-static values applied. The resulting time shifts reduced all traces to a datum of sea level. A dynamite CDP gather is illustrated in figure 16.3.

Table 16.3. Vibroseis recording parameters for the 1984 and 1985 GSI seismic surveys on and adjacent to the Arctic National Wildlife Refuge

[VP, vibrator point]

\begin{tabular}{|c|c|}
\hline Recording instrument & DFS V \\
\hline Recording format & SEG B \\
\hline Number of channels & 120 \\
\hline Group interval & $110 \mathrm{ft}$ \\
\hline VP interval & $110 \mathrm{ft}$ \\
\hline Fold coverage & 60 fold \\
\hline Spread configuration & 2805-275-VP-275-10725 (ft) \\
\hline Uncorrelated record length (1984) & $13 \mathrm{~s}$ \\
\hline Correlated record length (1984) & $8 \mathrm{~s}$ \\
\hline Sweep length (1984) & $5 \mathrm{~s}$ \\
\hline Uncorrelated record length (1985) & $14 \mathrm{~s}$ \\
\hline Correlated record length (1985) & $6 \mathrm{~s}$ \\
\hline Sweep length (1985) & $8 \mathrm{~s}$ \\
\hline Sample rate & $4 \mathrm{~ms}$ \\
\hline Sweep frequency & $10-80 \mathrm{~Hz}$ linear upsweep \\
\hline Source array & 4 VIBS in line \\
\hline Recording filter & $8 \mathrm{~Hz} 18 \mathrm{db} /$ octave low cut \\
\hline Recording filter & $128 \mathrm{~Hz} 72 \mathrm{db} /$ octave high cut \\
\hline Geophone array & inline, 24 per group \\
\hline Geophone type & GSC $200,10 \mathrm{~Hz}$ \\
\hline
\end{tabular}


Filter tests.--Various zero-phase bandpass filters were applied to the data to see if the signal-to-noise ratio could be improved. The frequencies of the signal and noise were similar enough so that no filter before stacking was necessary.

Deconvolution.-Spiking deconvolution was applied to both the dynamite and Vibroseis data. Stacked outputs from deconvolution tests showed that multiple gates were more effective than one large gate. Three 100-ms filters were designed and applied to gates of 0 to $2,000 \mathrm{~ms}, 2,200$ to $4,000 \mathrm{~ms}$, and 4,200 to 6,000 ms on each trace.

Gain correction.-After deconvolution, balance was again applied to equalize any amplitudes that might have been changed, using the same parameters as described above.

Velocity analysis.-A simple Earth model of a single flat reflector above which is an isotropic, homogeneous velocity medium is shown in figure 16.4A. Traces from multiple shots are sorted so that their source and receiver locations are equidistant from a common midpoint. This grouping is routinely called a CDP gather. During the NMO-mute-stack step of processing, each CDP gather is NMO corrected and muted, after which all traces in the gather are summed together. The remaining "stacked" trace is equivalent to one in which the source and receiver are coincident at the surface (zero-offset trace).

The NMO correction is based on an equation for the arrival time of a ray traveling from the source to reflector and returning to a receiver with some separation between the source and receiver. By inserting a raypath for a zero-offset trace at the midpoint (hypothetical stacked trace) and using the Pythagorean theorem, the NMO equation is derived:

$$
\mathrm{T}_{1}^{2}=\mathrm{T}_{\mathrm{o}}^{2}+\mathrm{X}^{2} / \mathrm{V}^{2}
$$

where

$\mathrm{T}_{1}=$ recorded two-way traveltime for the reflector,

$\mathrm{T}_{\mathrm{o}}=$ zero-offset, two-way traveltime at midpoint,

$\mathrm{V}=$ velocity above reflector, and

$\mathrm{X}=$ distance between source and receiver.

This equation defines a hyperbolic trajectory. The time shift applied to the data is the difference between $T_{0}$ (the traveltime to the reflector for a coincident source and receiver) and $\mathrm{T}_{1}$ (the traveltime for a source and receiver with some separation $\mathrm{X}$ ).

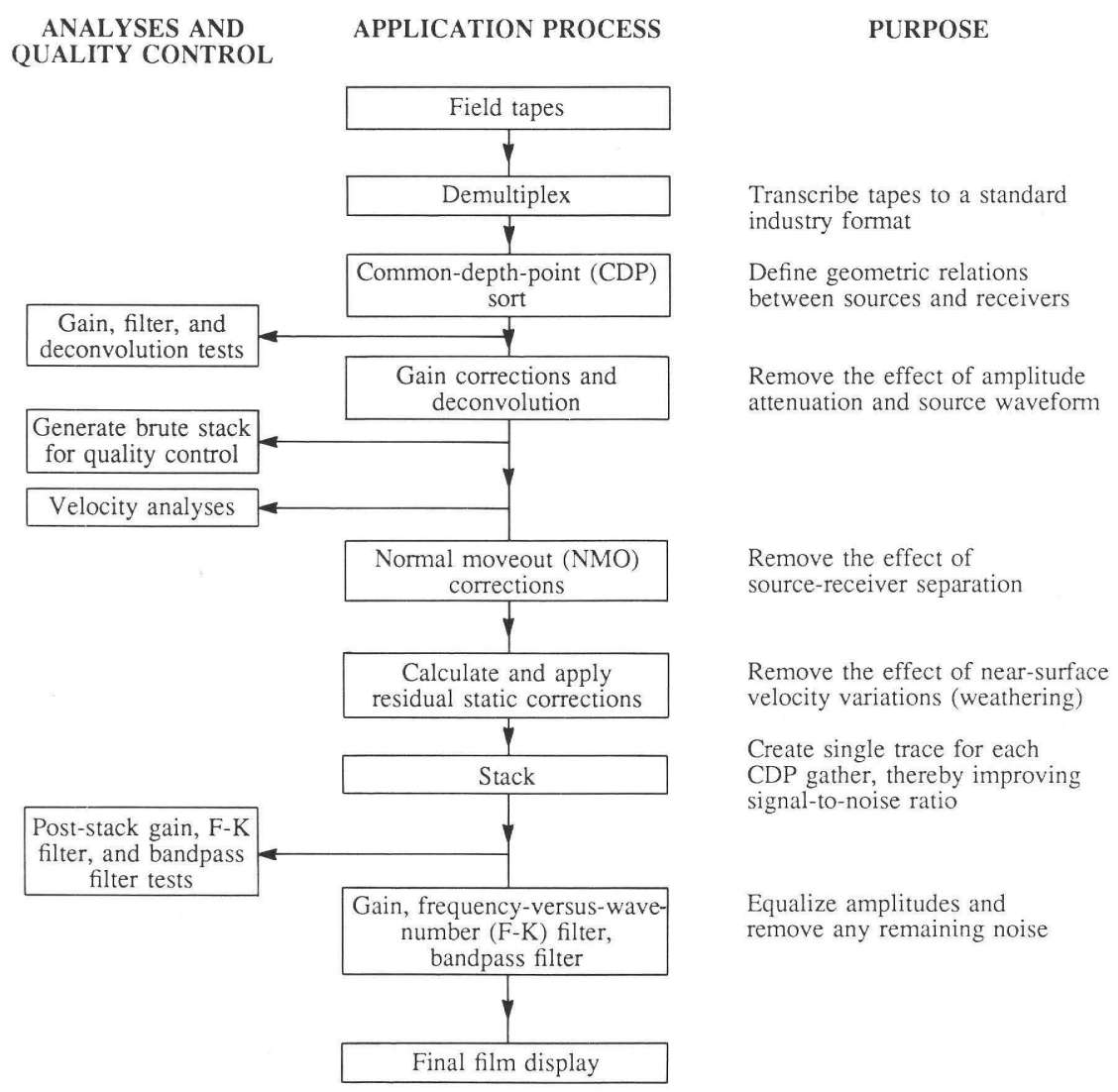

Figure 16.1. Flow chart of USGS processing of raw seismic field data from the Arctic National Wildlife Refuge. 

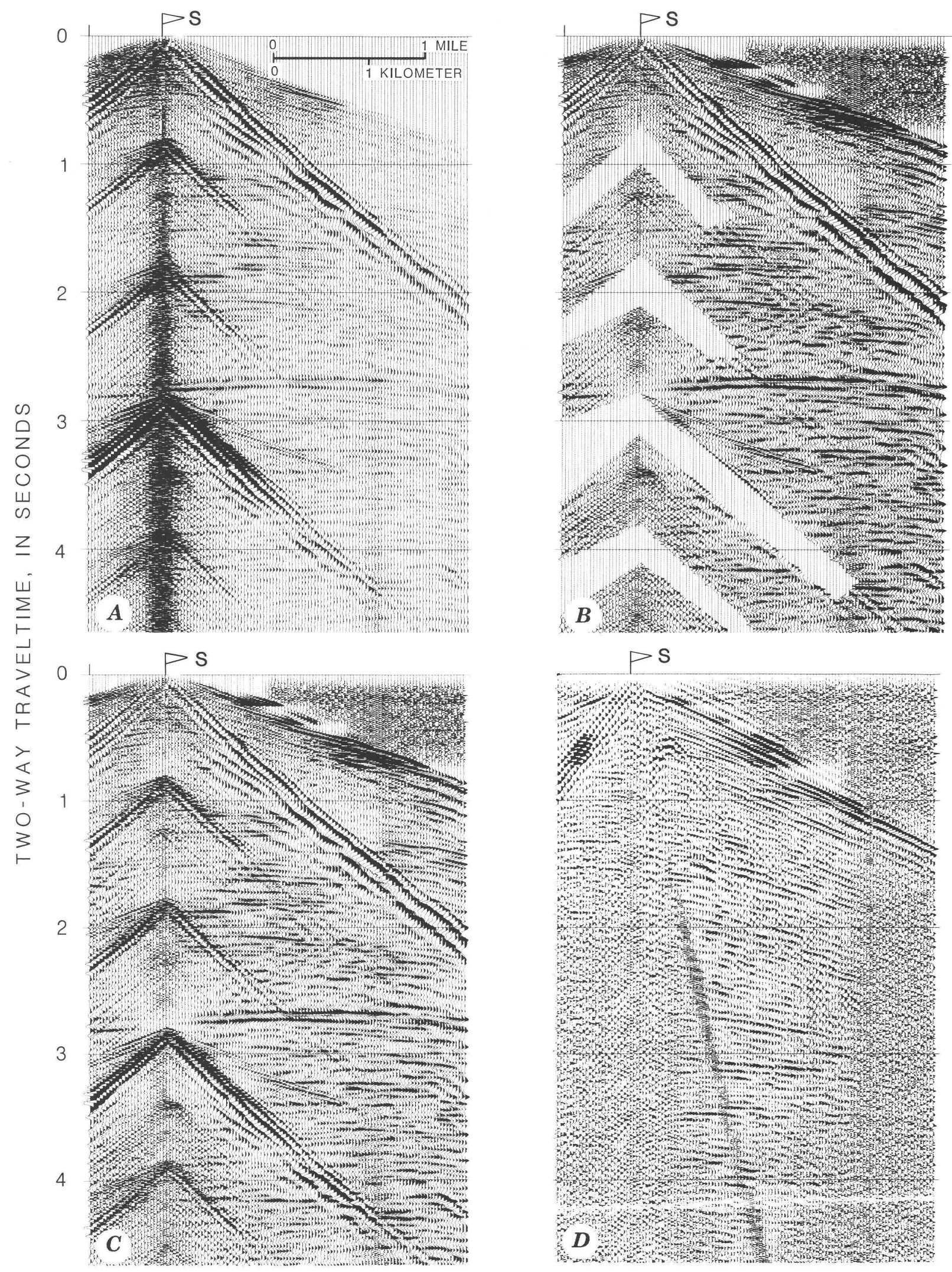

Figure 16.2. Typical seismic-reflection field records in the USGS data-set from ANWR. $A-C$, Dynamite records. $D$, Vibroseis record. $A$, Example of ice breaks overpowering primary reflections. $B$, Example of surgically muted record to compensate for ice breaks. $C$, Example of gain-corrected record to compensate for ice breaks. 
By applying an NMO correction, a trace is dynamically time shifted to remove the effect of the source-receiver separation. Hence, common reflectors on the various traces in a CDP are in alignment at the same time. After NMO, parts of the traces show distortion and need to be muted, after which the traces are then summed together to create a stacked, zero-offset trace.

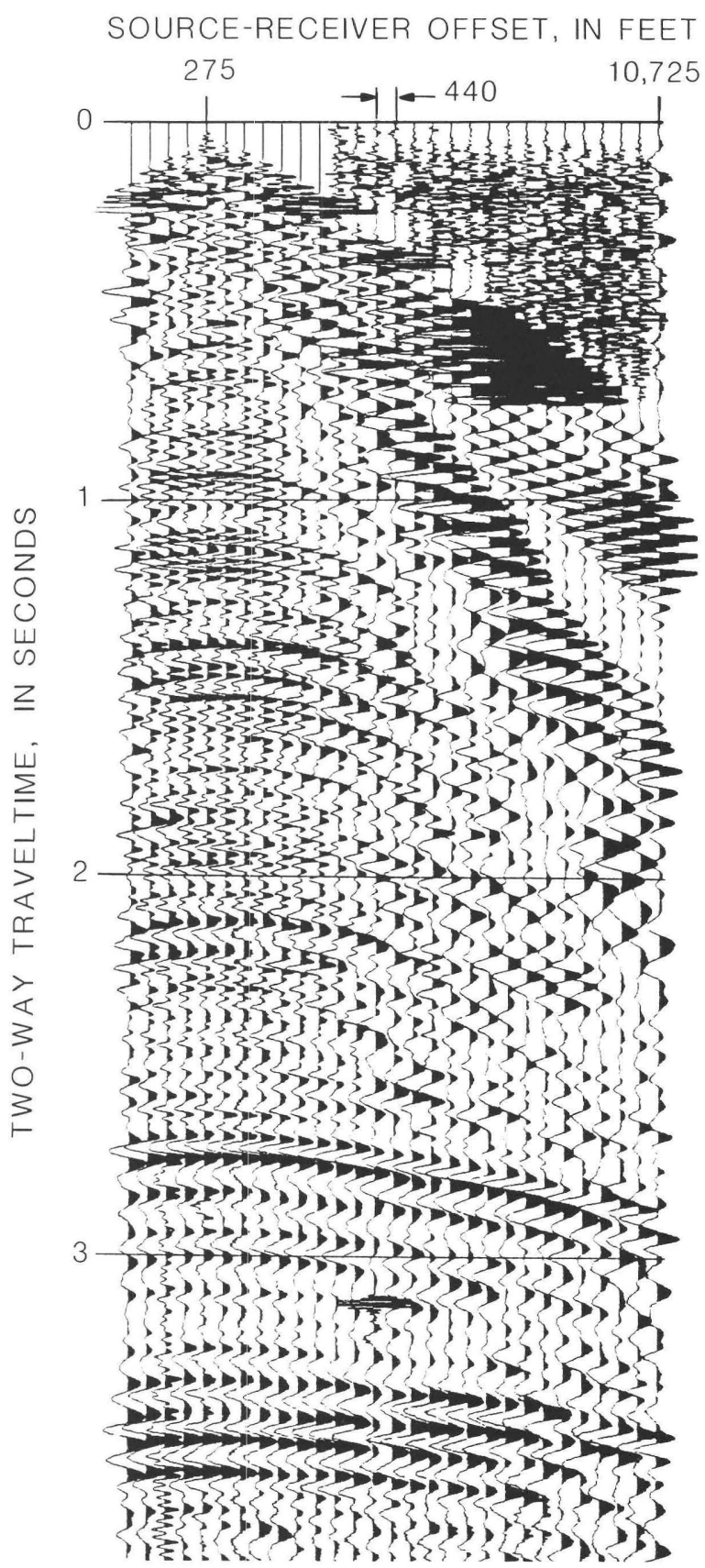

Figure 16.3. Illustration of common-depth-point (CDP) gather.
If a model with a dipping reflector is considered, the derivation of the traveltime equation becomes more complex. This model is illustrated in figure $16.4 B$. However, the velocity that stacks a dipping reflector is related to the velocity that stacks a flat reflector by $\mathrm{V}($ dip $)=\mathrm{V}($ flat $) / \cos \theta$, where $\theta$ is the cosine of the angle of dip. Holding other parameters constant and noting that the cosine of the angle of dip is always less than one, we observe that the velocity for a dipping reflector is greater than the velocity for a flat reflector.

The dipping reflector model shown in figure $16.4 B$ is similar to the type of geology found in the ANWR. This figure shows two different raypaths with common source and receiver; therefore, they are recorded on the same trace. Note that the normal-incidence,

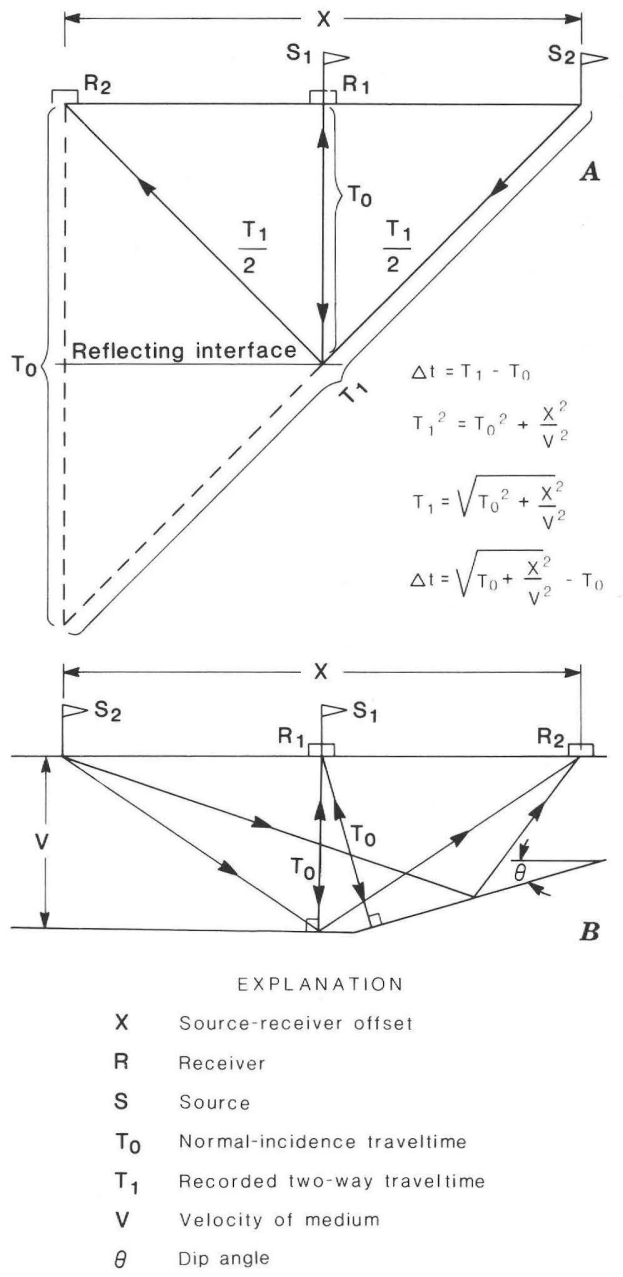

Figure 16.4. Earth models illustrating seismic velocity analysis. $A$, Flat reflector. $B$, Dipping reflector. 
zero-offset traveltimes for the two reflections are the same. From the previous discussion, we know that the velocity that stacks the reflection from the dipping reflector is faster than the velocity that stacks the reflection from the flat reflector. One or the other velocity function must be selected and the other ignored, a situation called multivalued velocity. In areas of complex geology, such as the ANWR area, multivalued velocity can present difficulties.
A comprehensive velocity-analysis program was employed as illustrated in figures 16.5 and 16.6. This program was used on groups of $10 \mathrm{CDP}$ 's at intervals of $838 \mathrm{~m}(2,750 \mathrm{ft})$ or $50 \mathrm{CDP}$ 's. The velocities tested ranged from 1,829 to $7,924 \mathrm{~m} / \mathrm{s}(6,000$ to $26,000 \mathrm{ft} / \mathrm{s})$ as a result of the large velocity variations encountered. The velocity-analysis program corrects for NMO on the input CDP gathers (figs. $16.5 A, 16.6 A$ ) by utilizing a usersupplied suite of time-variant velocity functions

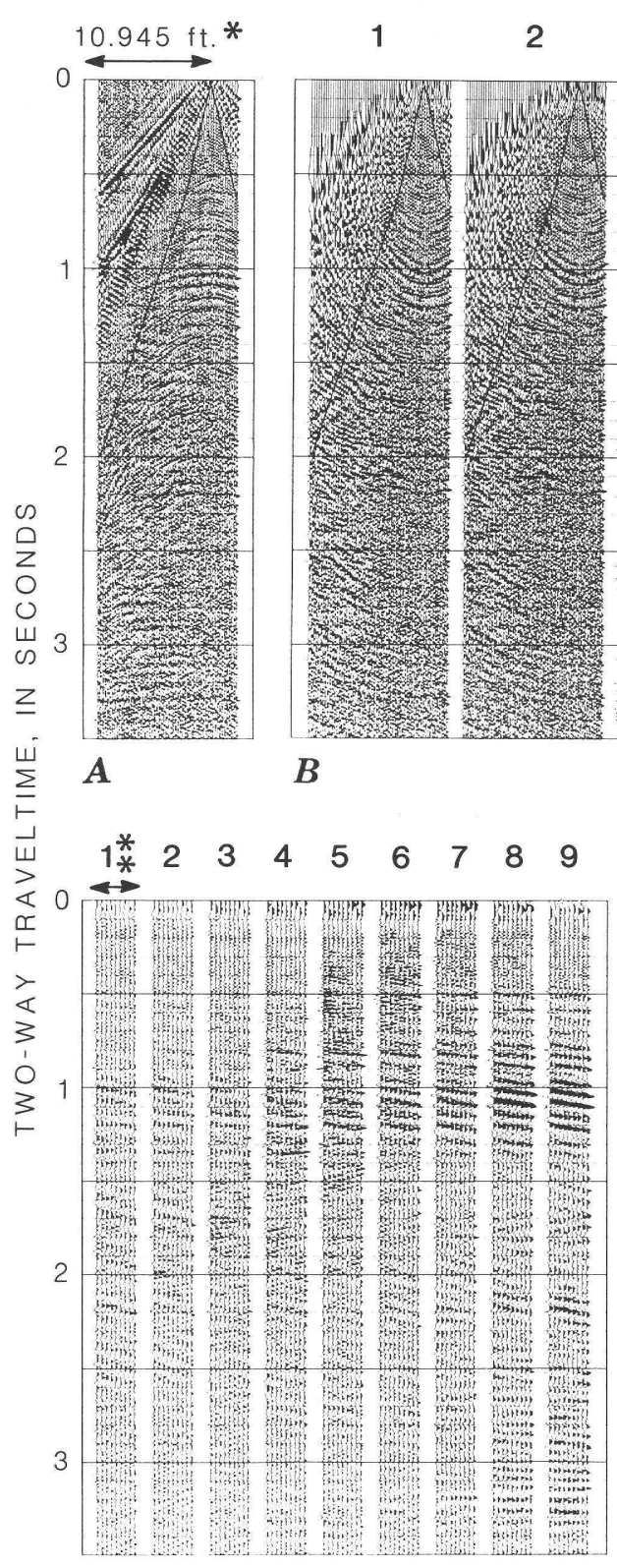

C
34

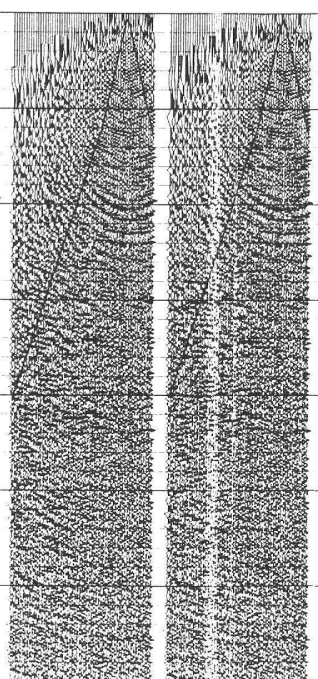

5

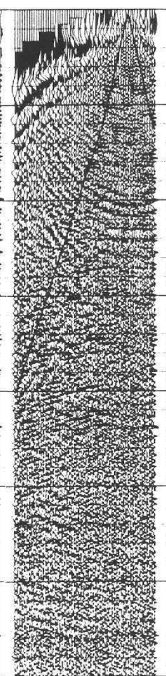

6

7

8

9
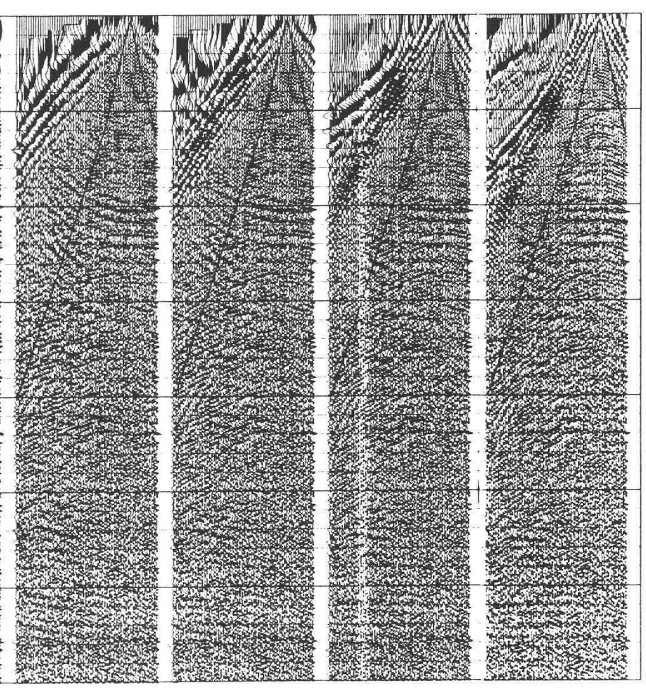

VELOCITY IN THOUSANDS OF FEET PER SECOND

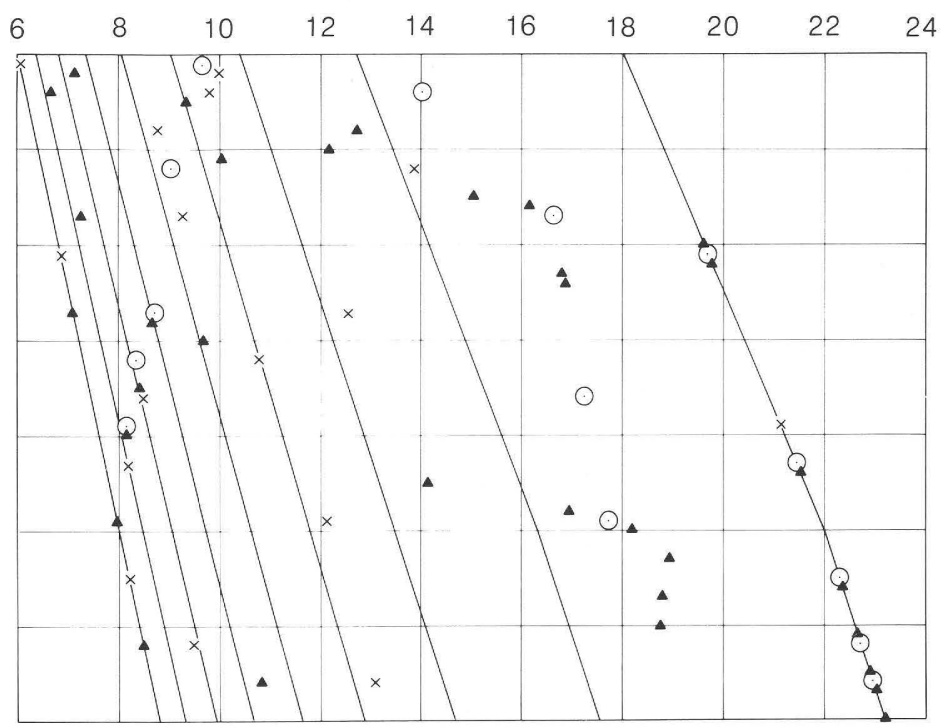

D

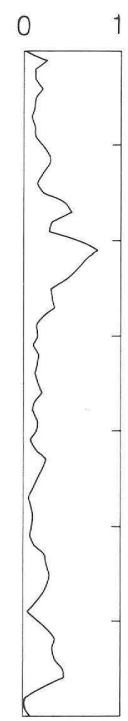

$\boldsymbol{E}$

Figure 16.5. Display of velocity analysis for multivalued velocity problem. $A$, Single, unstacked CDP gather without normal moveout (NMO) correction. $B, \mathrm{CDP}$ gather from $A$ corrected for NMO using velocity functions $1-9$. $C$, Consecutive CDP gathers (centered about $A$ ) stacked using velocity functions $1-9$. D, Stacking velocity picks made automatically by computer. Diagonal lines indicate velocity functions $(1-9)$ used for analysis. See figure 16.6 for explanation of symbols. E, Relative power of stacked CDP's at primary pick. 
(functions labeled $1-9$ on figs. $16.5 B$ and $16.6 B$ and shown as lines on figs. $16.5 D$ and $16.6 D$ ). The central gather of the group corrected at the various velocity functions is displayed before stacking (figs. 16.5B, $16.6 B)$, and then the group of CDP's is stacked at the various velocity functions (figs. $16.5 \mathrm{C}, 16.6 \mathrm{C}$ ). Finally, the program performs an automatic picking routine (figs. $16.5 D, 16.6 D)$. Because three types of analyses (NMO gathers, stack, and automatic velocity picks) are combined into one, the best velocities for stacking can usually be picked. The multivalued velocity problem described above is illustrated in figure 16.5. This analysis is difficult for the analyst to pick. An example of an extremely good velocity analysis is shown in figure 16.6.

Typically, the velocity analyses indicated surface velocities around 2,440 to $3,350 \mathrm{~m} / \mathrm{s}(8,000$ to $11,000 \mathrm{ft} / \mathrm{s})$, with a velocity inversion through the permafrost layer, after which the velocity began increasing with time (see figs. 16.5 and 16.6).

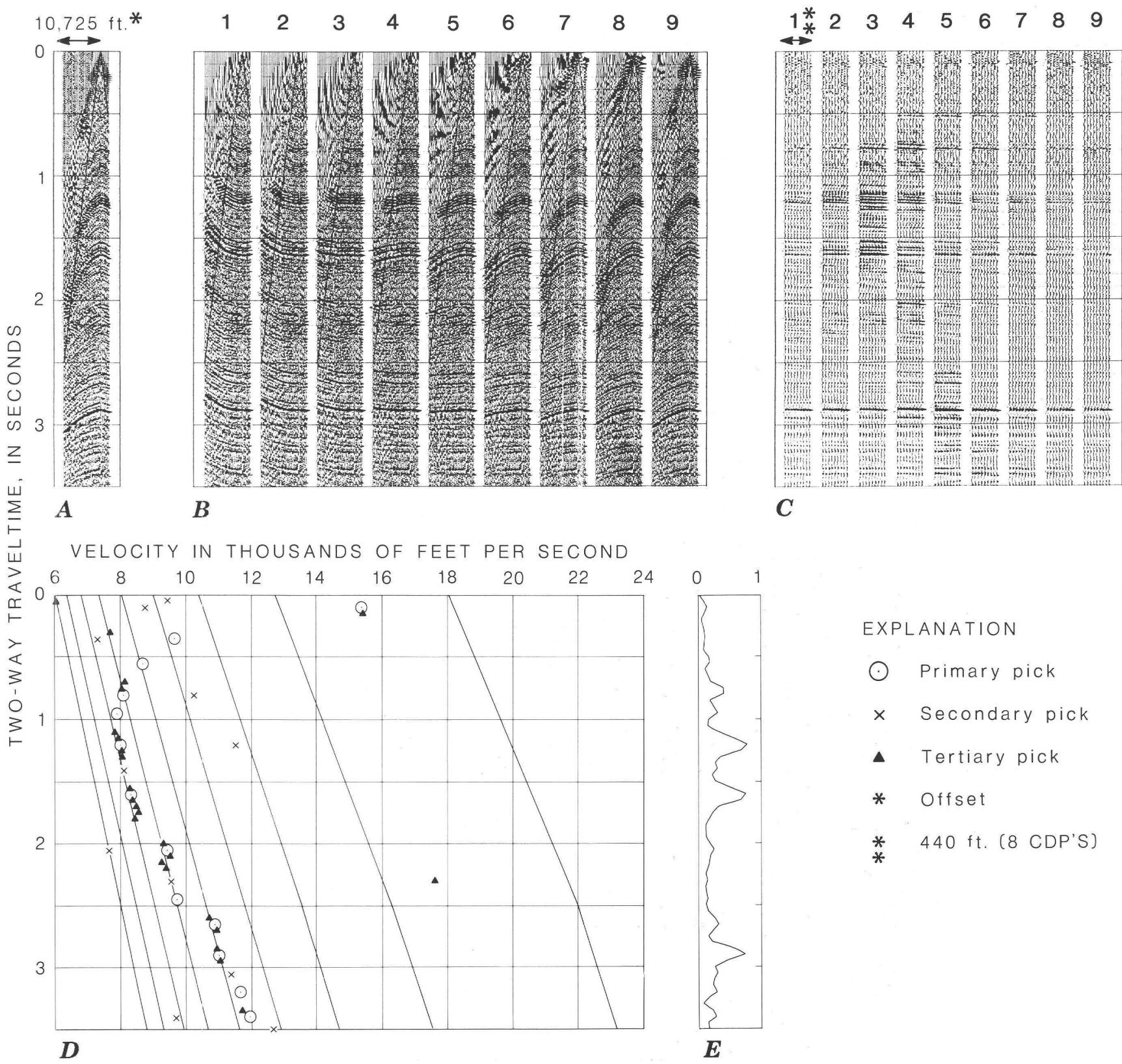

Figure 16.6. Display of velocity analysis for extremely good reflections. A, Single, unstacked CDP gather without normal moveout (NMO) correction. $B, \mathrm{CDP}$ gather from $A$ corrected for NMO using velocity functions $1-9$. $C$, Consecutive CDP gathers (centered about $A$ ) stacked using velocity functions $1-9$. D, Stacking velocity picks made automatically by computer. Diagonal lines indicate velocity functions $(1-9)$ used for analysis. $E$, Relative power of stacked CDP's at primary pick. 
Normal moveout corrections.-Normal-moveout corrections (NMO), based on the velocities defined from stacking velocity analysis, were applied to the data to prepare for residual-statics analysis.

Residual statics.-An automatic, surfaceconsistent, residual-statics program was run to compensate for any errors in datum-statics calculations. Residual-statics values in the general range of $\pm 16 \mathrm{~ms}$ were calculated and applied to the data, a process that aligned reflections for a better stacked section.

Mute and stack.-A mute was applied to set the high-amplitude first breaks and the NMO stretch to zero. Stacked traces were created by summing together all the traces in each CDP.
$F-K$ filter.-After stack, coherent noise trains are apparent across most of the lines. The noise is source generated and usually has a dip of between 8 and $20 \mathrm{~ms} /$ trace. A frequency-versus-wavenumber filter (F-K filter) discriminates between different dips and, depending on the structural dip present, can eliminate noise trains that dip more steeply than the structure. Illustrations of a stacked section before and after a F-K filter has eliminated events dipping at greater than 8 $\mathrm{ms} /$ trace are shown in figures $16.7 A$ and $16.7 B$.

Time-variant filter.-A final time-variant, bandpass filter was applied to the stacked section: between 0 and $1.7 \mathrm{~s}$, a bandpass of 18 to $70 \mathrm{~Hz}$ was used; between 2.2 and $6 \mathrm{~s}$, a bandpass of 12 to $50 \mathrm{~Hz}$

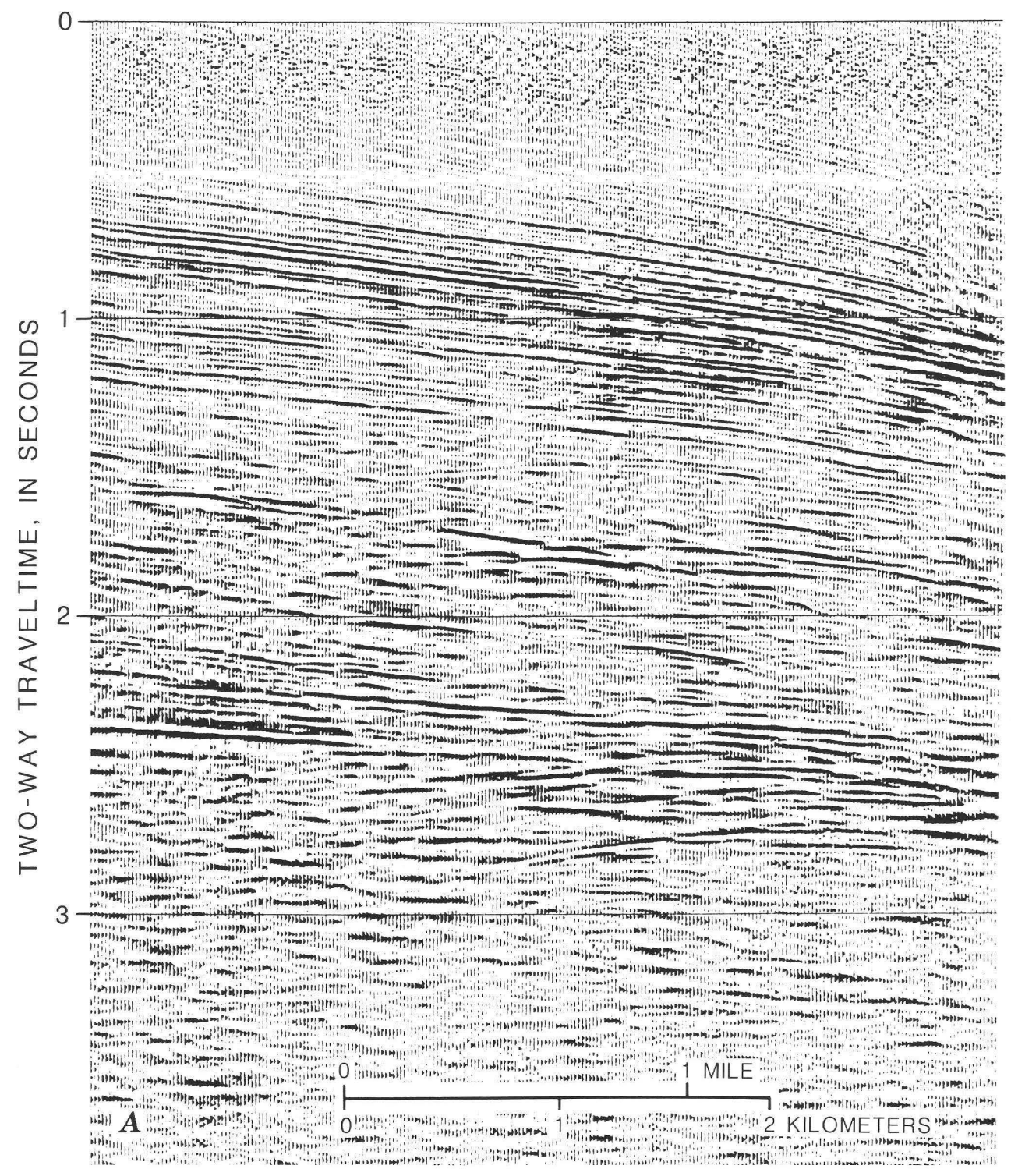

Figure 16.7. Displays of stacked section. $A$, Before frequency-versus-wavenumber (F$\mathrm{K}$ ) filter. $B$, Figure $16.7 A$ after events dipping at greater than $8 \mathrm{~ms} /$ trace are eliminated. 
was used; and between 1.7 and $2.2 \mathrm{~s}$, the bandpass was linearly interpolated.

Gain correction.-As a last step, a final-gain correction was applied in order to balance any amplitude variations.

\section{DISCUSSION}

The quality of the record sections processed by the USGS is variable. The variability results from seismic energy sources and geologic complexity. Because of constraints on manpower and time, the USGS equalized the amplitudes of the reflected signal and the dynamite source-generated noise. This procedure allowed the stacking process to attenuate the noise, created an appearance of amplitude homogeneity, but eliminated the possibility of amplitude and waveform analysis. The data recorded using Vibroseis sources effectively eliminated the "ice break" problem.

Examination of the data suggests that structural interpretations (and resource assessment) based on USGS-processed seismic data would be comparable to those based on GSI-processed data.

\section{CONCLUSIONS}

Twenty-one percent of the seismic reflection data recorded in the ANWR in 1984 and 1985 were processed by the USGS to the point of stacked record sections. The quality of these record sections was similar to those processed by GSI. The data were interpreted for regional geologic structure, and the findings were included in a mandatory report to Congress on the resource potential of the ANWR.

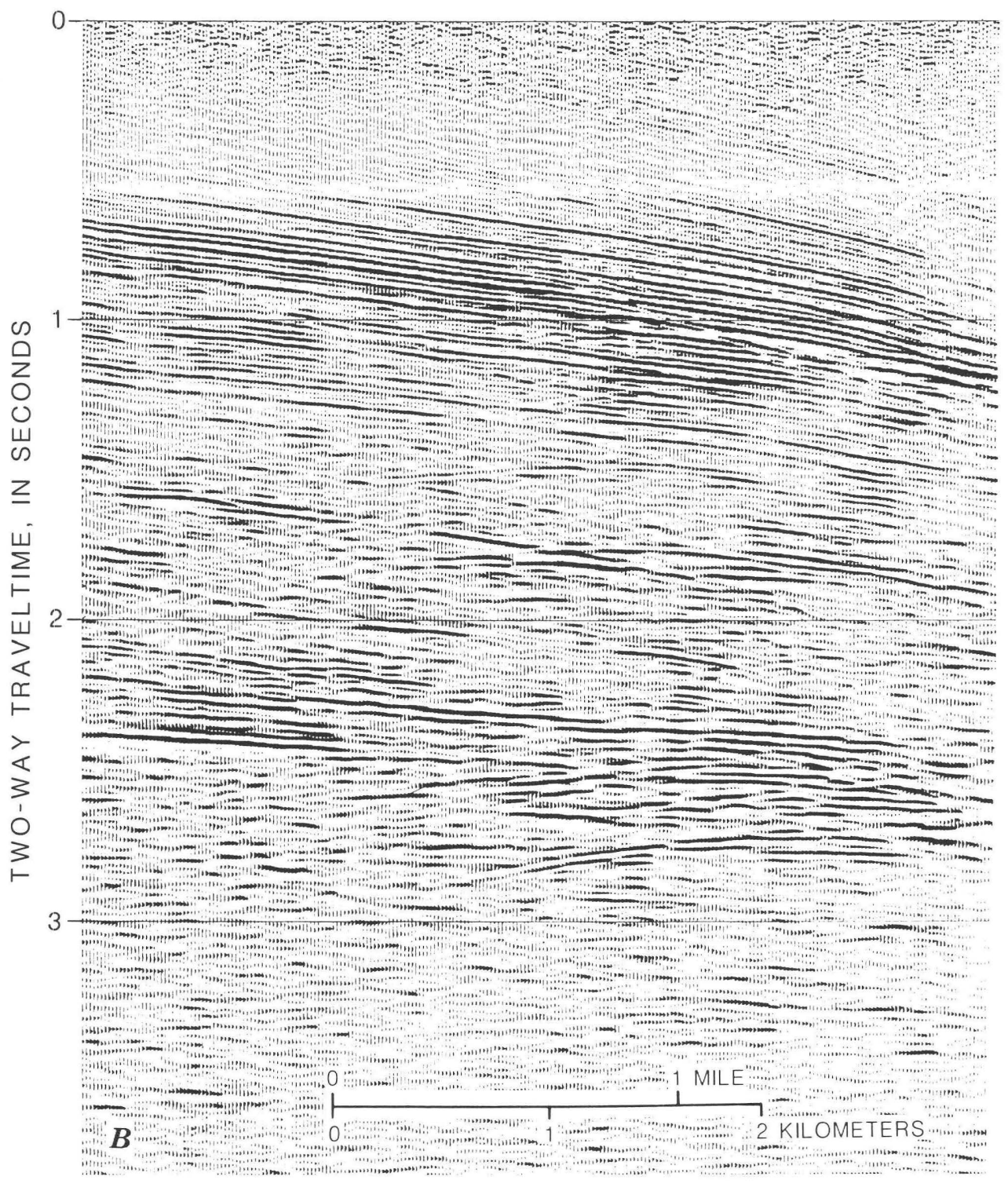

Figure 16.7. Continued. 



\title{
Chapter 17.
}

\section{Seismic-Reflection Data Acquisition, Processing, and Interpretation}

\author{
By Richard L. Foland ${ }^{1}$ and Douglas J. Lalla ${ }^{1}$
}

\section{INTRODUCTION}

The ensuing discussion describes, in succession, the acquisition, processing, and interpretation of seismic-reflection data as part of the process to assess the petroleum resource potential of the Arctic National Wildlife Refuge (ANWR) coastal plain.

\section{SEISMIC DATA ACQUISITION}

From January to April of 1984, Geophysical Service Inc. (GSI), acting on behalf of its oil company clients, acquired 982.7 line- $\mathrm{km}$ (606.6 line-mi) of dynamite source and 247.1 line-km (152.5 line-mi) of Vibroseis source, common-depth-point (CDP) seismicreflection data from the ANWR coastal plain and adjoining public lands (tables 16.1, 17.1). The dimensions of the resulting grid of seismic lines are roughly $10 \mathrm{~km}(6 \mathrm{mi})$ east-west by $16 \mathrm{~km}(10 \mathrm{mi})$ north-south (fig. 17.1). A second data acquisition season, from January to April 1985, allowed GSI (again acting for client companies) to infill the 1984 grid and acquire another 1121.5 line-km (692.3 line-mi) of CDP seismicreflection data on the ANWR coastal plain, contiguous lands, and coastal lagoons. These data and the 1984 seismic program totaled 2,351.3 line-km (1,451.5 line$\mathrm{mi}$ ) and produced an irregular seismic line spacing of about $4.8 \mathrm{~km}(3 \mathrm{mi})$ east-west by $12.8 \mathrm{~km}(8 \mathrm{mi})$ northsouth, which the Government deemed an adequate basis for the Congressional ANWR petroleum resource appraisal (fig. 17.1, table 17.1).

An adjoining area along the sea coast north of $70^{\circ} \mathrm{N}$ latitude, previously part of the ANWR but recently (1983) conveyed under the Alaska National Interest Lands Conservation Act (ANILCA) to the Kaktovik Inupiat Corporation (KIC) (fig. 17.1), was offlimits to both the Government and oil industry ANWR group and not explicitly evaluated in this assessment (see Bader and Bird, 1986, for KIC boundary).

Seismic noise tests using a dynamite energy source were conducted at several locations on the coastal plain in 1984. Analysis of the resulting noise profiles

\footnotetext{
${ }^{1}$ Bureau of Land Management, Anchorage, Alas.
}

and the anticipated steep subsurface dips helped determine the source-receiver parameters subsequently employed in data acquisition. Coherent noise

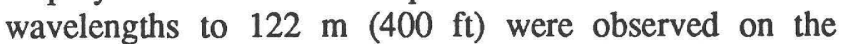
noise test records. Rather than attacking these surface waves in the field with long, unwieldy source-receiver arrays, which have the undesired side effect of being high-cut frequency and dip filters, a shorter receiver array $(34 \mathrm{~m}, 110 \mathrm{ft}$ ) was employed. This array removes about $7 \mathrm{~dB}$ from $122 \mathrm{~m}(400 \mathrm{ft})$ and $30 \mathrm{~dB}$ from $61 \mathrm{~m}$ (200 ft) apparent horizontal wavelength amplitudes and allows higher frequencies and steeper dips to be recorded. The residual coherent noise was reduced by data processing.

Large areas of the subsurface were poorly imaged by the 1984 seismic data. The resolution problem was largely attributed to three factors: (1) the convoluted layers of the highly deformed rock beneath much of the coastal plain violate key assumptions underlying the theoretical basis for the CDP seismicimaging process; (2) the unpredictable near-surface conditions, such as variable permafrost thickness and changing soils, cause statics problems and vary the amount of seismic energy transmitted into the Earth; and (3) some noise was ascribed to field methodology, that is, to the dynamite impulse source and associated secondary noise bursts. Accurate identification of potential hydrocarbon traps in the contorted ANWR subsurface required additional and more closely spaced seismic lines than provided by the 1984 survey. Altering field acquisition parameters-primarily by employing a Vibroseis energy source, by profiling in different locations, and by infilling the grid of 1984 seismic lines-appeared to offer a sound basis for improving the subsurface resolution by the acquisition of additional CDP seismic data.

Noise tests were again staged at several locations in 1985 to ascertain optimum source-receiver parameters for the Vibroseis system prior to collecting the CDP seismic data. The interference identified was similar to that observed on the 1984 noise profiles. Consequently, the geophone array and group interval were unchanged from 1984. Modifications in the 1985 Vibroseis effort, which generally focused on transmitting more energy into the Earth than was achieved with the 1984 Vibroseis program, included the following: the use 
of five rather than four vibrators; of a $67-\mathrm{m}$ (220 ft) rather than a 49- to $50-\mathrm{m}$ (160 to $164 \mathrm{ft}$ ) source array; of an $8 \mathrm{~s}, 8-90 \mathrm{~Hz}$ rather than a $5 \mathrm{~s}, 10-80 \mathrm{~Hz}$ vibrator sweep frequency spectrum; of a $34-\mathrm{m}(110 \mathrm{ft})$ rather than a $67-\mathrm{m}(220 \mathrm{ft})$ shot interval, resulting in 60 - instead of 30 -fold data; and of a slightly longer geophone cable (table 17.1). Long-wavelength noise was attenuated by the source-receiver array, including stack-array (Anstey, 1986), and residual coherent noise reduced by data processing.

\section{DATA PROCESSING}

The U.S. Geological Survey (USGS) processed selected lines from the 1984 data set to $8 \mathrm{~s}$ and from the 1985 data set to $6 \mathrm{~s}$ (chap. 16). The processing, excepting the poststack velocity filter, was routine and consisted of resampling, datum-statics application, CDP sort, bandpass filter, AGC (automatic gain control), deconvolution, velocity analysis and NMO (normalmoveout) correction, surface-consistent residual statics, mute, CDP stack, trace balance, bandpass filtering, and velocity-filtering. The record sections produced were velocity-filtered final stacks.
An unusual source of noise plagued the dynamite seismic data. As shown by shot records and seismic observer's notes, about 50 percent of the shots were associated with a suite of randomly delayed, secondary seismic energy sources, evidently caused by shallow stress-release fractures (fig. 17.2); these fractures presumably occurred in the underlying frozen ground or permafrost layer and are often called "ice breaks" (Specht and others, 1986). This fracturing superimposed a cascade (as many as 12 were identified on a single shot record) of secondary, often strong, seismic impulses on the primary reflection process. Direct arrivals on the geophone cable of such noise impulses are commonly of greater amplitude than reflected arrivals from the primary energy source, and thus they degrade the quality of the seismic records. These unwanted events are attenuated by receiver arrays, trace editing, frequency filters, and velocity filtering (fig. 17.2).

However, the ratio of the accompanying reflected secondary energy to the reflected primary energy is little changed by these noise-reduction procedures because the signal (reflected primary energy) and noise (reflected secondary energy) have similar attributes (see Sengbush, 1983, for a discussion of velocity filtering). Fortunately, the fracture-generated

Table 17.1. Parameters of seismic data acquisition in the ANWR area in 1984-1985

[*, 330-ft shot and 165-ft group interval; **, 61 percent and ***, 39 percent of the 1985 data; n.c., no change; n.a., not applicable]

\begin{tabular}{llll}
\hline \multicolumn{1}{c}{ Parameter } & \multicolumn{1}{c}{ Dynamite source } & & Vibroseis source \\
\cline { 2 - 4 } & 1984 & 1984 & 1985 \\
\hline Charge size & $60 \mathrm{lb}$ & n.a. & n.a. \\
Shot depth & $75 \mathrm{ft}$ & n.a. & n.a. \\
Shot interval & $220 \mathrm{ft}$ & n.a. & n.a. \\
& $330 \mathrm{ft}$ & n.a. & $110 \mathrm{ft}$ \\
Vibrator interval & n.a. & $110 \mathrm{ft}$ & $8 \mathrm{~s}$ \\
Sweep length & n.a. & $5 \mathrm{~s}$ & 4 or 5 \\
Vibrators/sweep & n.a. & 4 or 5 & $12 \mathrm{or} 8$ \\
Sweeps/VP & n.a. & 8 or 6 & $8-90 \mathrm{~Hz}$ \\
Sweep spectrum & n.a. & $10-80 \mathrm{~Hz}$ & $110 \mathrm{ft}$ \\
Group interval & $110 \mathrm{ft}, 165 \mathrm{ft}$ & $110 \mathrm{ft}$ & 120 \\
Groups & 120 & 120 & n.c. \\
Geophone array & linear, 24 geophones per group & n.c. & $220 \mathrm{ft}$ \\
Source array & point & $160 / 164 \mathrm{ft}$ & $3025-495-0-495-10945(\mathrm{ft})^{* *}$ \\
Spread geometry & $2805-275-0-275-10725(\mathrm{ft})$ & $2805-275-0-275-1075(\mathrm{ft})$ & $2915-385-0-385-10835(\mathrm{ft})^{* * *}$ \\
& $10065-330-0-33010065(\mathrm{ft})^{*}$ & & 60 \\
Fold & 30 & 60 & n.c. \\
Recorder & Texas Instruments DFS V & n.c. & $4 \mathrm{~ms}$ \\
Sample rate & $2 \mathrm{~ms}$ & $4 \mathrm{~ms}$ & $14 \mathrm{~s}$ \\
Record length & $8 \mathrm{~s}$ & $13 \mathrm{~s}$ & n.c. \\
Geophones & GSC 20D, 10-Hz resonance & n.c. & n.c. \\
High cut filter & $128-\mathrm{Hz} 72-\mathrm{dB} / \mathrm{octave}$ cutoff & n.c. & n.c. \\
Low cut filter & $8-\mathrm{Hz} \mathrm{18-dB/octave} \mathrm{cutoff}$ & n.c. & 692.3 \\
Miles of data & 606.6 & 152.5 & \\
\hline
\end{tabular}


noise bursts are expected to be temporally random. Thus, since each seismic trace contributing to a CDP stack represents a separate shot, the process of horizontal stacking (see Dobrin, 1976, for a discussion of horizontal stacking) reduces the random noise (including the reflected noise-burst arrivals) in the stacked trace measured against an unstacked trace by the square root of the number of traces summed. For the ANWR dynamite data, 30 traces are added, which effect a random noise reduction of $\sqrt{30}$, or a factor of 5.5 (15 $\mathrm{dB}$ ). At reflection times greater than about $2 \mathrm{~s}$, the interference is ordinarily less evident, apparently because of the effect of the tapered mute (applied in processing) on reducing the number of traces in the stack at earlier record times.

Although the Vibroseis method also triggers similar shallow noise bursts, albeit much less often in the ANWR than the dynamite source, the long Vibroseis signal is effectively separated from the reflected secondary impulsive noise by the required correlation of the input signal with the arrivals recorded in the field traces (see Waters, 1981, for a discussion of the Vibroseis method). Also, the Vibroseis data are 60 fold, and therefore random noise is reduced by $\sqrt{60}$, or a factor of $7.7(18 \mathrm{~dB})$. Thus, fracture-induced noise bursts were not a major problem with the Vibroseis method. In addition, the source-receiver array used in the ANWR Vibroseis programs meets stack-array criteria (Anstey, 1986), and thus it better rejects unwanted surface waves than does the ANWR dynamite sourcereceiver array, which did not satisfy the stack-array criteria.
The consensus among the Bureau of Land Management (BLM) and the USGS geophysicists is that the Vibroseis data better resolves the subsurface than the dynamite data. The enhanced resolution is especially visible above $2 \mathrm{~s}$, where the relative absence of noiseburst interference evidently contributes to the noticeable improvement in the Vibroseis data. However, substantial areas of poor data remain in the eastern half of the 1002 area.

GSI processed all seismic data to $6 \mathrm{~s}$. The processing flow, with the exception of velocity filtering, was routine. Comparison of seismic record sections processed by GSI with sections processed independently by the USGS and by individual oil companies suggests all processing techniques achieve similar results.

\section{INTERPRETATION}

\section{Data Base and Preliminary Interpretation}

Review of the processed record sections showed that the velocity-filtered sections generally have the best-resolved reflection events and constitute an optimum data base for regional horizon mapping. Thus, the seismic mapping was done on velocity-filtered sections. Migrated records were periodically used to verify fault locations.

Initial interpretation of the 1984 seismic data, prior to acquiring the 1985 seismic data, showed the subsurface structure of ANWR to be more complex than commonly expected. Four key observations were made.

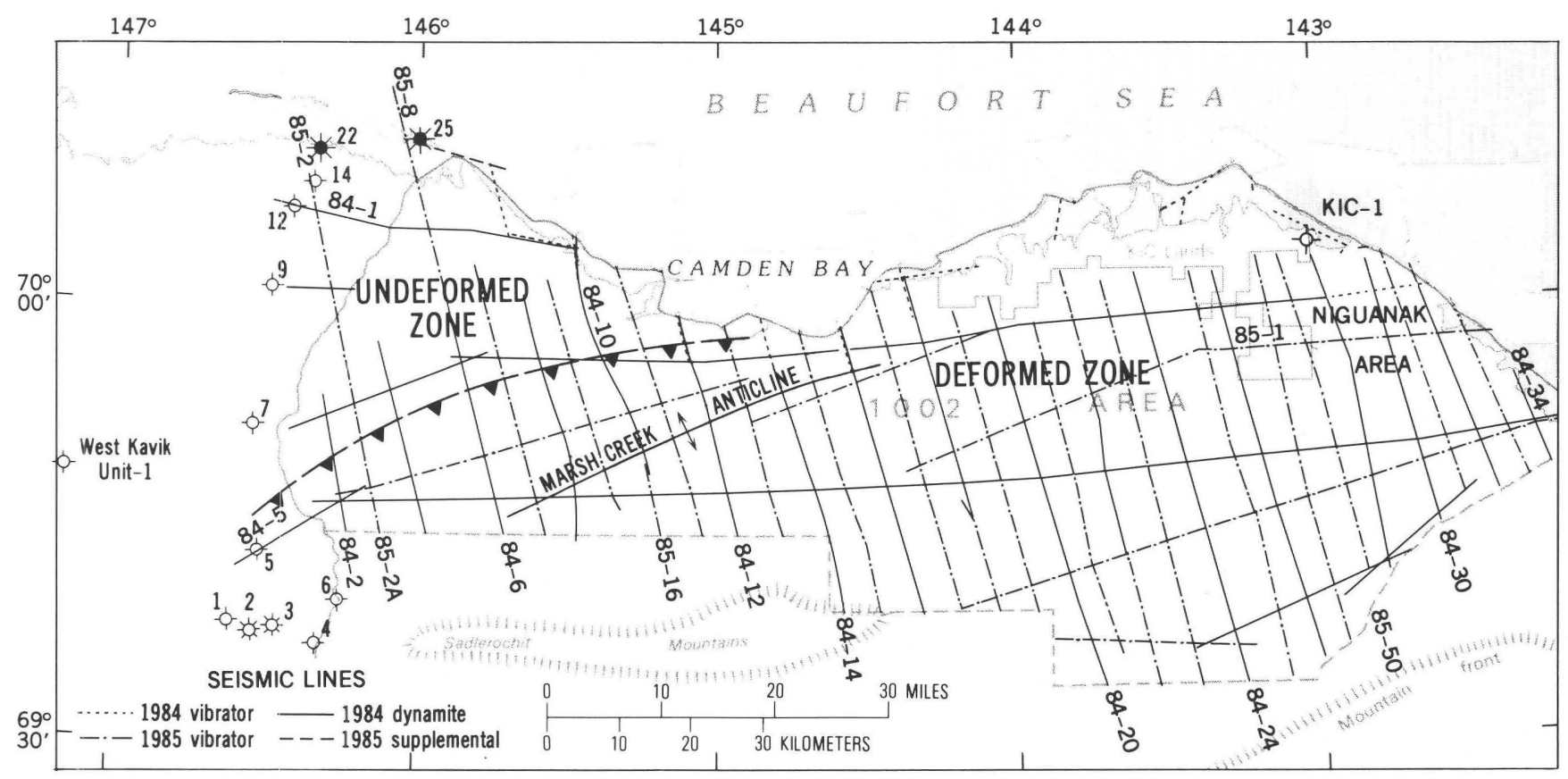

Figure 17.1. Locations of the ANWR seismic lines and exploratory wells (see table 1.1). Well symbols same as on figure 1.1B. Dashed line with barbs separates the undeformed zone from the deformed zone. 
(1) A foreland fold and thrust belt, which is part of the North American Cordillera and is partially exposed in the Sadlerochit Mountains, extends north beneath the ANWR coastal plain as an east-northeasttrending, north-verging imbricate fold and thrust fault system. It plunges approximately eastward from the east end of the Sadlerochit Mountains beneath the southeastern ANWR coastal plain (pl. 3, fig. 17.3).
(2) The Marsh Creek trend, previously considered a simple anticline and a likely exploration objective, was instead interpreted to be an intensely deformed anticlinorium or triangle zone (fig. 17.4), structurally similar to the disturbed zone west of Calgary in the foothills of the Canadian Rockies (Jones, 1982; Teal, 1983). By tectonic analogy (Harding and Lowell, 1979), this apparent structural complexity reduces the

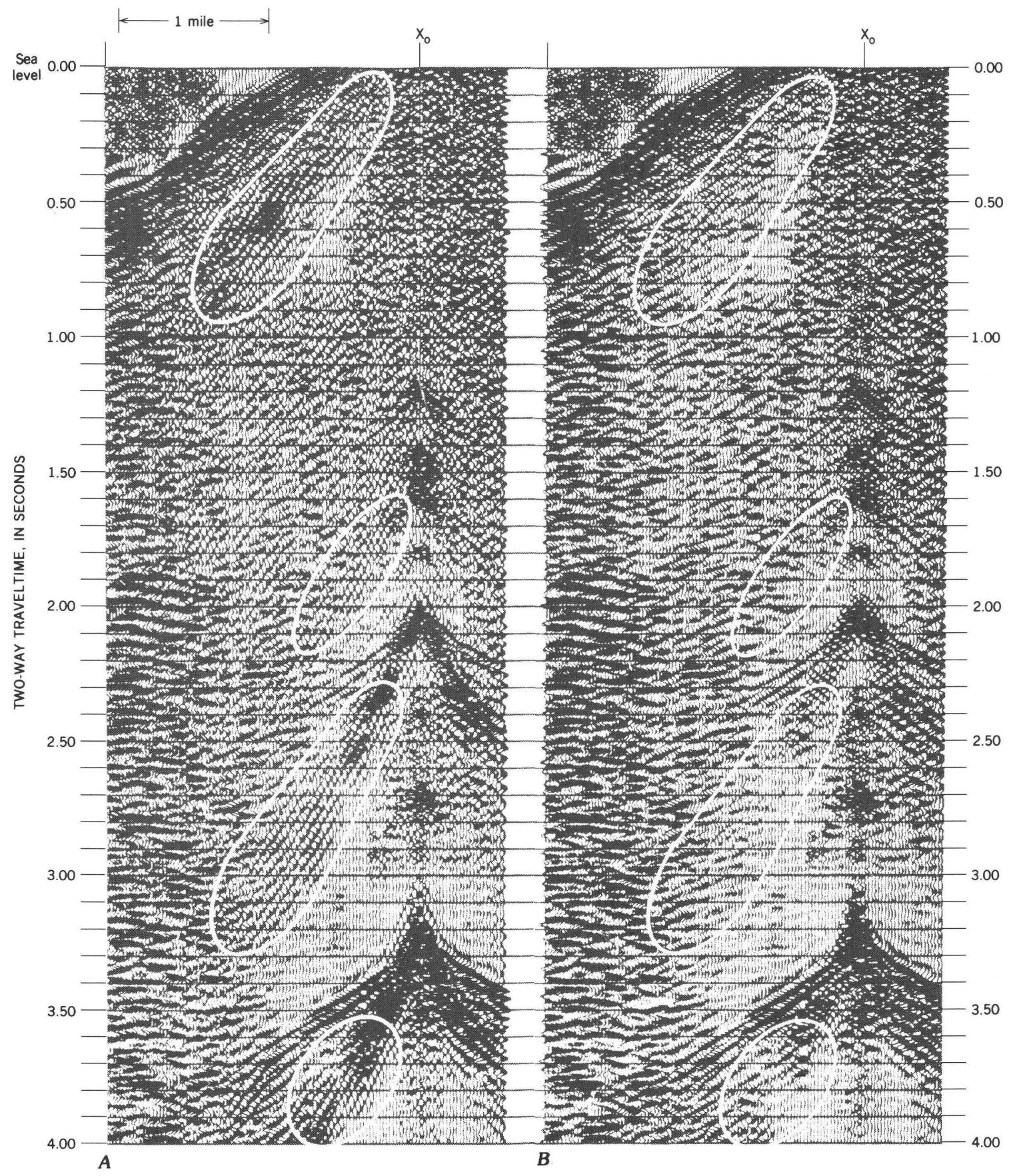

Figure 17.2. USGS processed shot records showing four noise bursts (circled) caused by stress-release fractures and noise suppression achieved by prestack velocity filtering. $\mathrm{X}_{\mathrm{o}}$, location of shotpoint. $A$, No velocity filter. $B$, Velocity filter ( $\pm 12 \mathrm{~ms} / \mathrm{tr}, 7$-tr window). 
probability that the Marsh Creek and similar detached structures contain large single-field petroleum reserves.

(3) Two large and previously undiscovered anticlines, possibly representing giant, Prudhoe Bay class, hydrocarbon accumulations, were mapped beneath the eastern coastal plain (fig. 23.2, structures 18 and 19; pl. 3).

(4) The eastern limit of the Endicott Group (Ellesmerian sequence) was interpreted to subcrop along a line trending southeast from just south of the West Staines State-2 well toward the west end of the Sadlerochit Mountains (fig. 17.5).

\section{Final Interpretation}

\section{Western ANWR Coastal Plain}

Seven exploratory wells west of the ANWR coastal plain along the Canning and Staines Rivers were tied or almost tied by 1984 and 1985 ANWR seismic lines. They are, from north to south, the Alaska State A-1, Point Thomson Unit-1, West Staines State 18-9-23, West Staines State-2, E. de K. Leffingwell-1, Alaska State J-1, and Beli Unit-1 wells (fig. 17.1). The E. de K. Leffingwell-1 and Alaska State J-1 wells are on state land, and their data are confidential and unavailable for consideration in this volume. Subsurface logs from the remaining five wells are public and constitute the basis for subsurface seismic control beneath the ANWR coastal plain. Acoustic logs from the Beli Unit-1 and the West Staines State-2 wells were merged and processed to create synthetic seismograms that helped tie seismic lines 84-5 and 84-1 to these wells (pl. 3).

An additional well, the KIC-1, located immediately north of the ANWR coastal plain on adjacent KIC lands near the Jago River (fig. 17.1), was

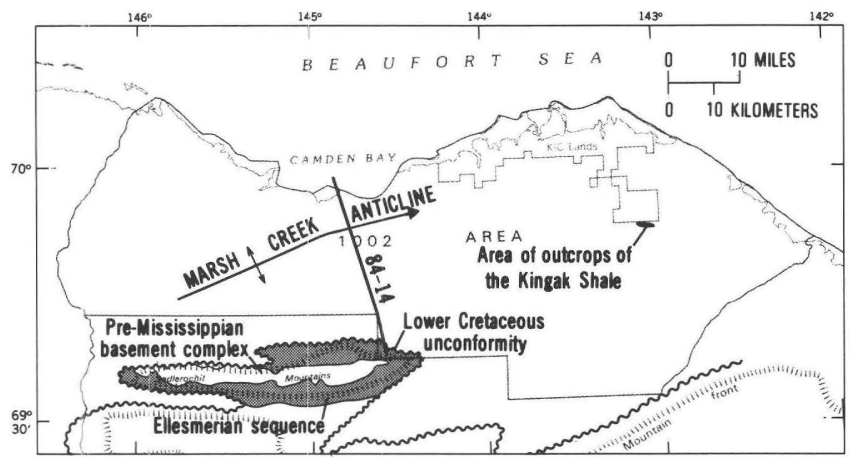

Figure 17.3. Generalized geologic map showing interpreted outcrop limits of the so-called Lower Cretaceous unconformity; outcrops of the preMississippian basement complex and Ellesmerian sequence in Sadlerochit Mountains; Jurassic Kingak Shale outcrops on coastal plain; Marsh Creek anticline; and location of seismic line 84-14 (see fig. 17.4). drilled to a depth of about $4,420 \mathrm{~m}(14,500 \mathrm{ft})$ during the 1985-1986 winter drilling seasons. This well appears to test a large mapped structure that extends beyond the KIC border and partially underlies the ANWR. Although rumors pertaining to this well abound, firsthand knowledge about the subsurface conditions sampled, although vital to the ANWR hydrocarbon resource assessment, is confidential and not available to the authors of this report.

\section{Ellesmerian Section}

A key issue to the resource assessment is the distribution beneath the ANWR coastal plain of that part of the Ellesmerian sequence that predates the pebble shale unit and consists of Prudhoe Bay-equivalent reservoir rocks. Considerable study was devoted to answering this question but with few conclusive results.
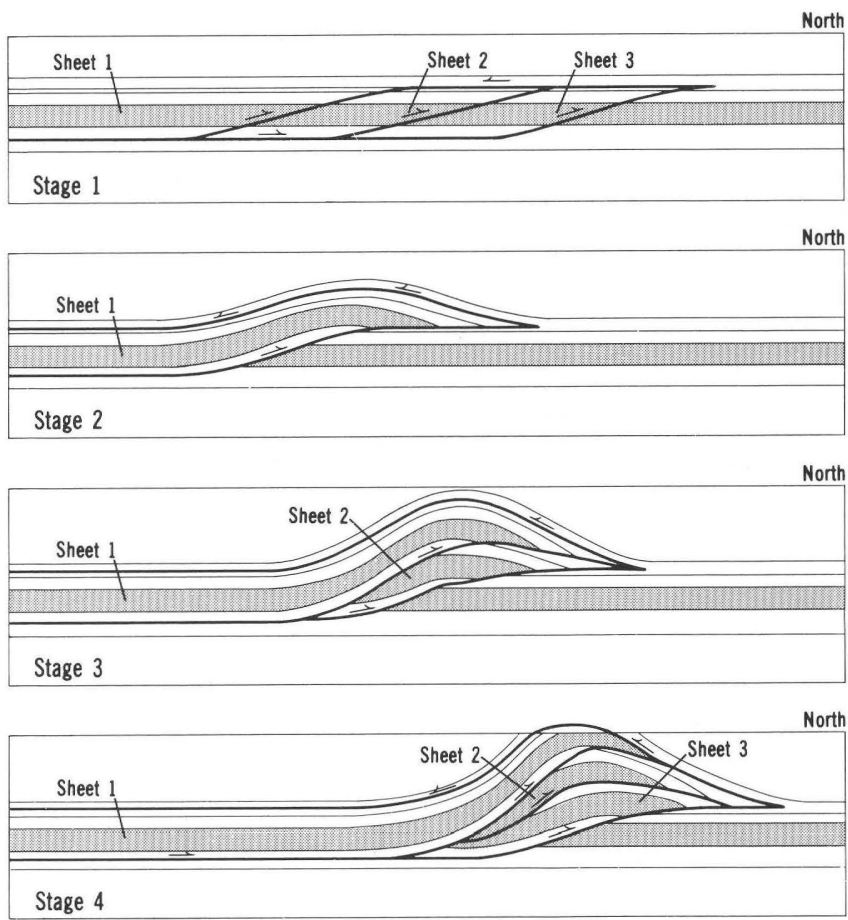

Stage 4

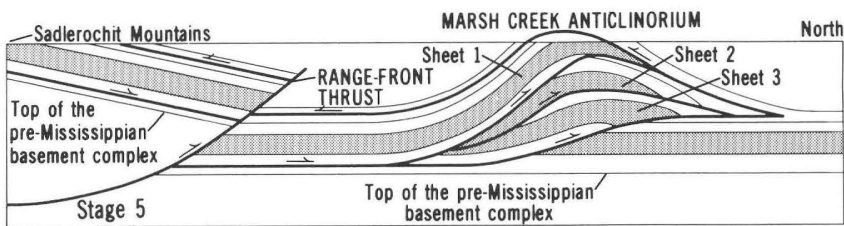

EXPLANATION

Marker bed

$\ldots$ Fault-Arrows indicate direction of movement

Figure 17.4. Simplified schematic drawing showing interpreted development of Marsh Creek triangle zone in relation to uplift of Sadlerochit Mountains (modified from Jones, 1982). Seismic line 84-14 (fig. 17.3), along which this cross section runs, shows two triangle zones (pl. 5); for simplicity only one is shown in this illustration. 
At the West Staines State-2 well (total depth (T.D.) $4,015 \mathrm{~m}, 13,171 \mathrm{ft}$ ), which is tied by seismic line 84-1, mappable reflections exist at the tops of Eocene, Paleocene, and Cretaceous strata, of the pebble shale unit, and of pre-Mississippian strata (fig. 17.1, pl. 3). The pebble shale unit is the only Ellesmerian rock unit described in this well and overlies pre-Mississippian argillite. The Beli Unit-1 well (T.D. 4,460 m, 14,632 ft) is tied by seismic line 84-5 (fig. 17.1, pl. 3) and encounters locally mappable reflecting horizons at the tops of the Paleocene and Cretaceous sections, the pebble shale unit, the Sag River Sandstone, the Ivishak Formation, the Lisburne and Endicott Groups, and, by projection, the pre-Mississippian basement complex.

Based on aeromagnetic data, on subsurface fault trends interpreted on seismic sections, and on well-log correlations, a large-displacement, north-verging Sadlerochit Mountains range-front thrust fault zone is inferred to displace the stratigraphic section of preMississippian and younger rocks between the Beli Unit-1 and West Staines State-2 wells. Tracing the Ellesmerian strata north from the Beli Unit-1 location across this zone is difficult, but well-log correlations (pl. 1) and seismic sections show that the Ellesmerian sequence (which predates the so-called Lower Cretaceous

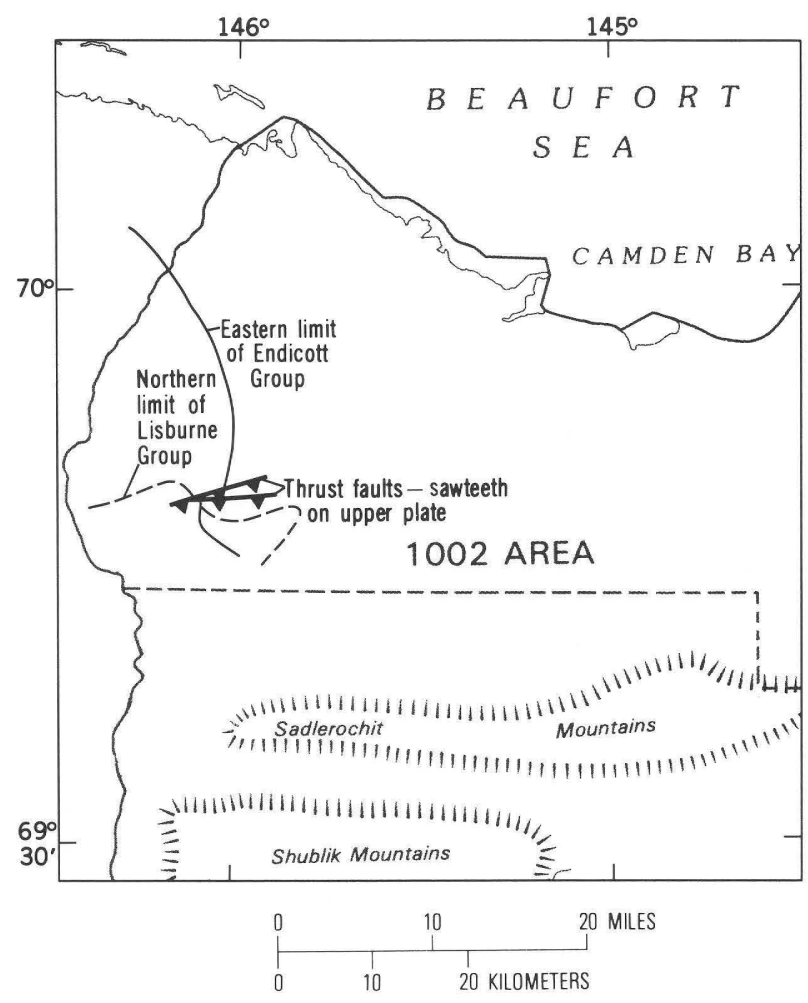

Figure 17.5. Interpreted truncation edges of strata of the Endicott and Lisburne Groups during Early Cretaceous time. unconformity) thins northward, is truncated by the Lower Cretaceous unconformity, and wedges out south of the West Staines State-2 well. Extending the truncation mapping eastward along seismic line 84-5 also discloses a thinning and apparently allochthonous Ellesmerian section (fig. 17.1, pl. 3). The zero edge of the subsurface Ellesmerian truncation is mapped with fair accuracy (fig. 17.5).

Whether Ellesmerian strata are present either continuously or as inliers beneath the Lower Cretaceous unconformity north of mapped Ellesmerian subcrops is unknown and controversial. Where the Lisburne Group, Ivishak Formation, Kingak Shale, Kemik Sandstone, and pebble shale unit rocks are exposed along the north flank of the Sadlerochit Mountains, they appear to be allochthonous (fig. 17.3). Thus, the probability of these rocks occurring autochthonously in the subsurface immediately north of the mountain front may not be increased by proximity to these mountain outcrops of Ellesmerian rocks.

Ellesmerian rocks crop out along, and are represented by reflection events on, the south end of seismic line 84-14 (fig. 17.3, pl. 5). However, a rangefront, northward-verging thrust fault with several thousand feet of vertical displacement, and apparently several miles of horizontal displacement, cuts this line and makes correlation of reflections corresponding to Ellesmerian strata across the fault and beneath the coastal plain dubious (see chap. 20). North of the range-front fault zone, however, seismic record sections generally look as if there are little or no Ellesmerian rocks represented (fig. 17.1, pl. 3, 5). Here, the most likely Ellesmerian representatives would appear to be isolated, relatively small outliers of the Endicott Group and the basal part of the Lisburne Group lying on the basement complex. Thus, excepting the pebble shale unit, Ellesmerian rocks appear to be largely absent beneath the western coastal plain.

\section{Seismically Mapped Horizons}

Two Tertiary horizons, characterized by monoclinal north dips, were mapped beneath part of the western coastal plain. They are the tops of the Eocene and Paleocene sections (pl. 3). A third horizon, located at the top of the pre-Mississippian basement complex, is mapped regionally beneath the entire ANWR coastal plain (pl. 3). A fourth horizon, the previously mentioned Ellesmerian truncation, was also mapped (fig. 17.5).

The horizon at the top of the pre-Mississippian basement complex (hereafter referred to as the TPM) is distinct on seismic records in the western half of the coastal plain, where it is usually characterized by a relatively strong and coherent reflection signature. The primary interpretive uncertainties generally are (1) fault correlations and (2) whether Ellesmerian rocks predating the Kingak Shale are locally present. 
The Eocene and Paleocene reflectors are fairly deep at the West Staines State-2 well $(1,646$ and 2,377 m $(5,400 \mathrm{ft}$ and $7,800 \mathrm{ft})$ beneath the surface, respectively), but owing to regional dip and range-front faulting they are found nearer the surface in the Beli Unit-1 well to the south, where the Eocene reflector bed crops out north of the well and the Paleocene reflector bed is at a depth

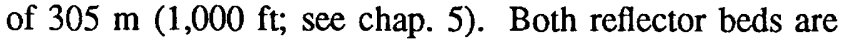
exposed along the north flank of the Sadlerochit Mountains and may also crop out along the axis of the Marsh Creek anticlinorium, interpreted to represent a triangle zone (fig. 17.4).

The Cretaceous and Paleocene section thickens south of the West Staines State-2 well toward source rocks belonging to the Brookian sequence. To the north these units thin, and the Cretaceous section (locally mapped) all but disappears.

\section{Eastern ANWR Coastal Plain}

Steeply dipping, tightly folded Cretaceous strata along with less deformed Paleocene and Eocene rocks, corresponding to the horizons mapped beneath the western coastal plain study area, crop out on the eastern coastal plain. The triangle-zone structural style, noted in the Marsh Creek feature (fig. 17.4), also seems a common result of the deformational kinematics beneath much of the eastern coastal plain. Typically, structural attitudes within these detached, imbricated, and folded rocks are only locally mappable with the seismic data.

Beneath the eastern coastal plain, the TPM is mapped with varying accuracy. Generally, the TPM is less distinct here than beneath the western coastal plain. In some areas, for example, where there are no coherent reflections on the record section, the position of the mapped horizon represents a constrained guess. In other locations, where the data quality is good the TPM seems distinct and looks much like it does on seismic lines from the western coastal plain. Elsewhere (beneath the Niguanak Ridge, for instance, which is characterized by relatively good seismic data) coherent reflections that possibly represent stratified pre-Mississippian rocks are present beneath the interpreted top of the preMississippian section; alternatively, the mapped TPM may actually be the Lower Cretaceous unconformity, and the underlying reflections possibly represent Ellesmerian strata.

The rationale used to pick the TPM reflector beneath substantial areas of the eastern coastal plain is based largely on the expected contrast in structural style between the relatively brittle, pre-Kingak Shale part of the Ellesmerian and older rocks, and the younger, shaley, more ductile Jurassic, Cretaceous, and Tertiary strata. The comparatively more plastic Jurassic and younger rocks are considered prone to deformation by developing short-wavelength folds, in contrast to the longer wavelength folds expected in the characteristically more brittle pre-Kingak part of the Ellesmerian and older strata. Thus, the TPM is generally chosen as the strongest reflector, in a sequence of relatively coherent reflections, located beneath the zone of discontinuous data associated with short-wavelength deformation (fig. 17.1, pl. 3).

There is potential for error with this scheme, particularly if the subsurface tectonic behavior routinely departs from the proposed model; additionally, similar Ellesmerian and pre-Mississippian carbonate sequences may produce correspondingly similar reflection patterns and thus be misidentified on seismic record sections. Finally, correlations based on relative seismic amplitudes are ambiguous, especially in regions such as the coastal plain that are marked by both widely varying nearsurface conditions and a highly structured subsurface. Fortunately, the major prospective features mapped beneath the eastern coastal plain are large (pl. 3) and their shapes relatively insensitive to the error considered probable in the TPM map.

The Jurassic part of the Kingak Shale crops out near the Niguanak Ridge (fig. 17.3). This occurrence is thought to be allochthonous, with the major structural detachment apparently located at or near the base of the Kingak. If this notion is correct, this Kingak exposure does not require the presence of older Ellesmerian rocks in the proximal subsurface. (Nondeposition of these strata or removal by erosion prior to Kingak deposition may also have occurred.) Whether Ellesmerian strata predating the Kingak occur autochthonously at depth in the large mapped subsurface structure is not known (fig. 17.1, pl. 3).

In an attempt to address this question, stackingvelocity analyses were studied and Dix interval velocities were calculated-with equivocal results. Even researchlevel velocity studies of the existing seismic data, however, are unlikely to satisfactorily indicate the type and age of rocks present, largely because of probable seismic-velocity similarities between carbonate rocks of the basement complex and the lower part of the Ellesmerian sequence. However, regional geologic and seismic information suggests that the eastern coastal plain may have substantial thicknesses of Ellesmerian reservoir rocks present in the subsurface. Ellesmerian rocks consisting of the Sadlerochit and Lisburne Groups crop out and plunge east beneath the coastal plain from the Sadlerochit Mountains. These same formations are exposed a few miles south of the coastal plain in the Romanzof Mountains foothills, where they generally dip north (Bader and Bird, 1986). Integrating this outcrop information with subsurface seismic analysis and interpretation indicates a greater probability of Ellesmerian reservoir rocks being present beneath the eastern coastal plain than the western coastal plain.

One possible direct hydrocarbon indicator, a gas chimney, was noted on a seismic line over a distance of about $2.7 \mathrm{~km}(1.7 \mathrm{mi})$. This zone of poor data occurs 
over one of the larger prospects identified on the ANWR coastal plain. Elsewhere (in the North Sea and Anadarko basin, for example), similar-appearing zones are often located above known gas fields. The deterioration of the seismic data is attributed to the presence of gas, leaking from below, in the stratigraphic column above the hydrocarbon reservoir.

\section{DEPTH DETERMINATIONS}

An estimate of interval velocities suitable for use in time-to-depth conversion of the ANWR seismic data was made from a survey of publically available acoustic $\operatorname{logs}$ from 10 wells located near the western boundary of the ANWR (tables 17.2, 17.3) and an analysis of stacking-velocity information from the ANWR 1984-1985 seismic data set. Over two-thirds of the coastal plain, however, interval velocities calculated via the Dix equation (Dix, 1955) are suspect because of complexly folded and faulted rocks in the subsurface. The tortuous ray paths generated by the contorted rocks violate the basic assumptions on which the Dix equation was derived (Taner and others, 1970; Blackburn, 1980).

The effect of a variable thickness of frozen ground directly beneath the coastal plain on the seismic time and depth maps was not explicitly addressed in the depth-conversion procedure. The following is a brief discussion of the probable effect of neglecting this variable on a depth map.

The coastal plain west of the ANWR is underlain by up to $610 \mathrm{~m}(2,000 \mathrm{ft})$ of frozen sediments that generally thins north to the sea coast and eventually zeros out offshore beneath the continental shelf (Osterkamp and Payne, 1981). Presumably a similar relation exists in the ANWR. The P-wave velocity through frozen sediments was found to vary from 2,999 to $4,999 \mathrm{~m} / \mathrm{s}(9,840$ to $16,400 \mathrm{ft} / \mathrm{s}$ ) (Timur, 1968) and to depend on the lithology, pressure, and temperature of the frozen material. P-wave velocities for similar unfrozen sediments range from 1,524 to $2,743 \mathrm{~m} / \mathrm{s}(5,000$ to 9,000 $\mathrm{ft} / \mathrm{s}$ ) (Press, 1966). Thus, a potential velocity differential

Table 17.2. Wells utilized in determining formation velocities in the 1002 area. See figure 17.1 for locations

\begin{tabular}{lc}
\hline \multicolumn{1}{c}{ Well } & Terminal depth (ft) \\
\hline Canning River Unit A-1 & 8,874 \\
Canning River Unit B-1 & 10,803 \\
Alaska State A-1 & 14,206 \\
Beli Unit-1 & 14,632 \\
West Staines State-2 & 13,171 \\
West Staines State 18-9-23 & 13,329 \\
West Kavik Unit-1 & 16,613 \\
Kavik-1 & 9,550 \\
Kavik Unit-2 & 7,500 \\
Kavik Unit-3 & 5,800 \\
\hline
\end{tabular}

of 1,475 to $2,256 \mathrm{~m} / \mathrm{s}(4,840$ to $7,400 \mathrm{ft} / \mathrm{s})$ exists in the interval from the surface to a depth of about $610 \mathrm{~m}$ $(2,000 \mathrm{ft})$. Spatial variation of the amount and kind of frozen material in this zone produces marked velocity gradients, thereby distorting the seismic time section (fig. 17.6). Unfortunately, the depth and velocity to the top and bottom of the frozen layer, information with which this aberration could be removed, is not readily calculable from the ANWR seismic data (see Justice and Zuba, 1986).

A potentially misleading and occasionally costly-when a well is mistakenly drilled (Specht and others, 1986)-distortion of the seismic record, caused by the rapid seaward thinning and eventual disappearance of the frozen-ground zone beneath the continental shelf, occurs along a strip centered about and roughly paralleling the coast. This velocity gradient, viewed in cross section with north on the right, rotates time horizons in a clockwise direction; thus north dips are steepened and south dips reduced (fig. 17.6). Only one prospective ANWR structure appears to be significantly skewed by disregarding the near-surface velocity gradient in the depth conversion, with the north-flank contours and possibly the crest being shifted southward. However, the crest of this structure is now mapped on KIC lands north of the coastal plain, and thus no substantial change in this prospect's ANWR resource value is likely to occur by considering the velocity gradient in the depth conversion and thereby moving the

Table 17.3. Formation velocities derived from analysis of acoustic logs from wells adjacent to the 1002 area (table 17.2)

[Velocity given is weighted average for each unit; $\sigma$, velocity difference for one standard deviation; $n$, number of wells]

\begin{tabular}{lcrr}
\hline \multicolumn{1}{c}{ Unit } & $\begin{array}{c}\text { Velocity } \\
(\mathrm{ft} / \mathrm{s})\end{array}$ & $\begin{array}{c}\sigma \\
(\mathrm{ft} / \mathrm{s})\end{array}$ & $\mathrm{n}$ \\
\hline Sagavanirktok Formation & 8,462 & 410 & 4 \\
Canning Formation and Hue Shale & 11,942 & 601 & 10 \\
Pebble shale unit & 10,563 & 588 & 9 \\
Kemik Sandstone & 13,389 & 1,712 & 6 \\
Kingak Shale & 10,626 & 1,053 & 5 \\
& & & \\
Sag River Sandstone & 13,683 & 1,185 & 6 \\
Shublik Formation & 15,544 & 769 & 5 \\
Ivishak Formation & 14,749 & 728 & 5 \\
Sadlerochit Group & 14,680 & 354 & 2 \\
Kavik Member & 13,927 & 204 & 3 \\
& & & \\
Echooka Formation & 14,933 & 1,650 & 2 \\
Lisburne Group & 19,709 & 1,247 & 6 \\
Pre-Mississippian carbonate rocks & 21,740 & 0 & 1 \\
Pre-Mississippian argillite & 15,535 & 697 & 3 \\
\hline
\end{tabular}

${ }^{1}$ of Ivishak Formation. 
seaward flank and possibly the crest north of their present positions. Furthermore, the shallow-velocity gradient is not readily determinable from the deep-focus ANWR seismic data (Justice and Zuba, 1986); thus, attempts to consider the shallow-velocity gradient in the depth computations produces, at best, ambiguous results.

Because of uncertainty in the velocity estimates, a simple time-to-depth conversion procedure was used that would hopefully minimize the creation of artificial structures solely as a result of the depth conversion and thus not over-represent the precision of the velocity data. The coastal plain was divided into two zones: the undeformed zone, which lies north of the crest of the Marsh Creek structural zone and encompasses about one third of the coastal plain; and the deformed zone, which covers the other two-thirds of the coastal plain (fig. 17.1). Three time horizons were converted to depths within the undeformed zone. They are the top of the Eocene section, the top of the Paleocene section, and the TPM. Within the undeformed zone, excepting a small area in the southwest corner near the Beli Unit-1 well (where Ellesmerian rocks are present), the following procedure was used:

(1) The depths to the tops of the Eocene and the Paleocene sections were determined from a two-way time-depth equation derived from fitting a polynomial to

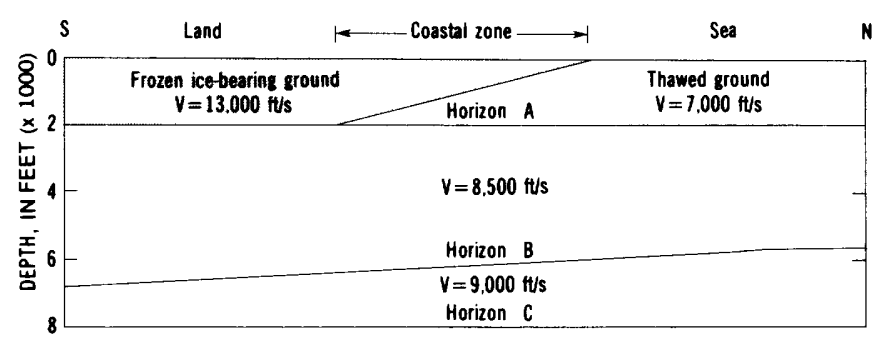

A

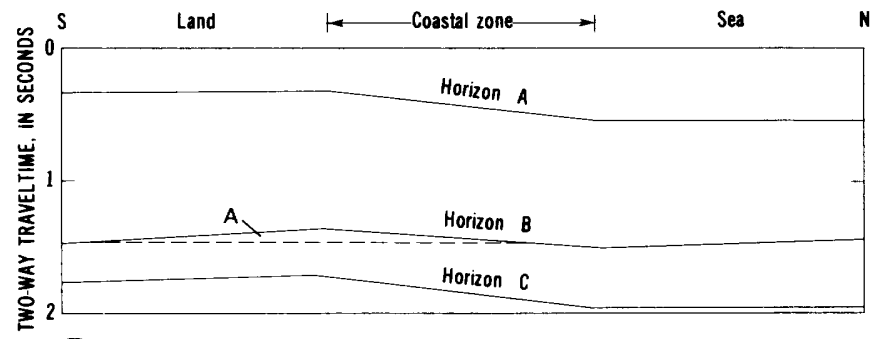

B

Figure 17.6. Simple geologic model of transition between frozen ground and thawed ground in shallow coastal zone $(A)$ and the simplified seismic response of the model $(B)$. Note distorting effects of coastal-zone velocity $(V)$ gradient on attitude of time horizons (A, B, $C)$, which produces an apparent hydrocarbon trap (A) on horizon $\mathrm{B}$. the checkshot-corrected West Staines State-2 well acoustic log (table 17.4).

(2) The depth to the TPM was calculated by first estimating the interval thickness from the top of the Paleocene section to the TPM and then adding this thickness to the depth to the top of the Paleocene section to obtain the total depth to the TPM. The thickness of the interval from the top of the Paleocene section to the TPM was determined by multiplying the interval time between the top of the Paleocene to the TPM by 3,640 $\mathrm{m} / \mathrm{s}(11,942 \mathrm{ft} / \mathrm{s})$. This velocity is the mean interval velocity for the Canning Formation and Hue Shale computed from the 10 adjacent wells (tables 17.2, 17.3).

(3) In the southwest corner of the coastal plain, near the Beli Unit-1 well (where Ellesmerian rocks are present), the Lisburne and Endicott Groups were each treated as separate velocity layers.

Within the deformed zone the average value for the interval velocity of the Canning Formation and Hue Shale $(3,640 \mathrm{~m} / \mathrm{s}, 11,942 \mathrm{ft} / \mathrm{s})$ was used to convert time to depth for the top of the pre-Mississippian section, the only seismic horizon mapped continuously in this zone. Selected velocity analyses indicate that the constantvelocity assumption limits the accuracy of depth resolution to \pm 15 percent.

\section{SUMMARY}

Approximately 1,450 line-mi of multifold seismic-reflection data were collected by GSI on and near the ANWR coastal plain for an oil-industry group and by statute for the United States Government during the 1984 and 1985 winter field seasons to help evaluate the hydrocarbon-resource potential of the coastal plain.

These data were processed to produce seismic record sections from which subsurface time maps were constructed of selected horizons. Finally, depth maps were produced using velocity information from seismic and well-log data. The interpretation shows the subsurface of the coastal plain to be complex, involving foreland fold and thrust belt structural and stratigraphic sequences with numerous large structures.

Table 17.4. Time-depth conversion equation

$[\mathrm{T}$, time; *, ft]

$$
\begin{aligned}
& \text { For } 0 \leq \mathrm{T}<2.6 \text { seconds, } \\
& \begin{array}{ll}
\text { Depth }(\mathrm{ft})=\mathrm{aT} & +\mathrm{bT}^{4}+\mathrm{cT}^{3}+\mathrm{dT}^{2}+\mathrm{eT}+\mathrm{f} \\
\text { Where: } & \mathrm{a}=193.929 \\
& \mathrm{~b}=-1772.062 \\
\mathrm{c}=5723.171 \\
\mathrm{~d}=-7310.368 \\
\mathrm{e}=7679.147 \\
\mathrm{f}=-11.458
\end{array}
\end{aligned}
$$

For $\mathrm{T} \geq 2.6$ seconds,

Depth $(\mathrm{ft})=13,190+11,924 *((\mathrm{~T}-2.6) / 2)$ 



\title{
Structure of Pre-Mississippian Rocks Beneath the Coastal Plain
}

\author{
By Michael A. Fisher ${ }^{1}$ and Terry R. Bruns ${ }^{1}$
}

\section{INTRODUCTION}

The structure of the pre-Mississippian rocks (also referred to by other workers as the basement complex) beneath the eastern part of the coastal plain of the Arctic National Wildlife Refuge (ANWR) is obscured in seismic-reflection data by the structural complexity of Cretaceous and Cenozoic rocks. Hence, only the area of the coastal plain lying between the Canning and Hulahula Rivers is of concern here (fig. 1.1).

Pre-Mississippian rocks in the Brooks Range and Sadlerochit Mountains, including some rocks as old as Precambrian, form the complexly deformed and regionally metamorphosed basement complex (see chap. 5). In this study, we suggest that the structure of the pre-Mississippian rocks beneath the coastal plain is much simpler than that of coeval rocks in the mountains.

The pre-Mississippian ages of the rocks discussed herein are based on a correlation of seismicreflection data with lithostratigraphic data from the Beli Unit-1 well (R. Foland, written commun., 1985). Although the base of the Mississippian rocks was not penetrated by this well, a strong reflection presumed to be from this base separates parallel, continuous reflections above from discontinuous events below. This strong reflection probably correlates with the regional unconformity at the top of Devonian or older rocks exposed in the mountains (see chap. 5). Beneath the southernmost part of the coastal plain, the unconformity at the top of the Devonian or older rocks merges with one at the base of the Cretaceous and younger rocks. This merged unconformity is mapped on plates 4 and 5 as the so-called Lower Cretaceous unconformity. This interpretation of the ages of the rocks below the top of the pre-Mississippian is supported by drilling in the Point Thomson area, where argillite, quartzite, and carbonate rocks, undated but presumed to be of Mississippian or more likely pre-Mississippian age (K.J. Bird, oral commun., 1985), were penetrated by wells drilled through the top of the pre-Mississippian.

\footnotetext{
${ }^{1}$ U.S. Geological Survey, Menlo Park, Calif.
}

\section{STRUCTURE OF PRE-MISSISSIPPIAN ROCKS}

General features of the geology of the preMississippian rocks are shown in this chapter by cross sections that were produced from unmigrated, stacked seismic sections. The use of unmigrated data means that dips depicted on the cross sections are less steep than true dips, and dipping events are shown downdip from their true positions.

Seismic traveltime through the Cretaceous and Cenozoic rocks of the coastal plain was converted to depth using a spatial interpolation of velocity information from the Beli Unit-1 and Alaska State A-1 wells (fig. 1.1). The acoustic velocity of the pre-Mississippian rocks was determined from three wells located near Point Thomson (Point Thomson Unit-2, Alaska State A-1, and East Mikkelsen Bay State-1). Although one thin $(50 \mathrm{~m}$, $150 \mathrm{ft}$ ) layer of carbonate rocks has an acoustic velocity of $6.1 \mathrm{~km} / \mathrm{s}(20,000 \mathrm{ft} / \mathrm{s})$, the velocities of all other preMississippian rocks (mostly argillite with minor amounts of carbonate rocks, chert, and quartzite) lie between 4.3 and $4.9 \mathrm{~km} / \mathrm{s}(14,000$ and $16,000 \mathrm{ft} / \mathrm{s})$, with an average of only $4.6 \mathrm{~km} / \mathrm{s}(15,000 \mathrm{ft} / \mathrm{s})$. Because the rate of change with depth of the velocity of the preMississippian rocks is unknown, a constant velocity of $4.6 \mathrm{~km} / \mathrm{s}(15,000 \mathrm{ft} / \mathrm{s})$ was used to convert traveltime through these rocks to depth. Hence, cross sections presented herein most likely show minimum thicknesses of the pre-Mississippian rocks.

A difficult problem in interpreting seismic reflections from below the top of the pre-Mississippian is to determine whether the reflections result from bedding or fault planes. For example, on north-south seismic lines, some prominent reflections from the preMississippian rocks are subparallel, whereas on east-west seismic lines, these same reflections converge and diverge in lenticular patterns. We assumed that the lenticular patterns represent rock bodies bounded by thrust faults.

The pre-Mississippian rocks can be grouped into southern and northern domains based on the reflector attitude of what are interpreted to be bedding planes. 
Bedding planes in the southern domain are subhorizontal or dip south (fig. 18.1). The south dip is similar to the regional dip of bedding in the pre-Mississippian rocks exposed south of the coastal plain, near Lake Peters (Reed, 1968) and in the Sadlerochit and Shublik Mountains and Fourth Range (Dutro, 1970). Rocks in this domain are cut by numerous thrust faults that are evidenced by the lenticular patterns of reflections on east-west seismic lines. The pre-Mississippian rocks in the northern domain consistently dip north. These rocks also have steeper dips and, in general, return more continuous reflections than do the rocks in the southern domain. Near and north of the coast of the ANWR, the rocks in the northern domain have variable dips (fig. 18.2).

The boundary separating the two domains of the pre-Mississippian rocks strikes nearly east-west, midway between the mountain front and the coast (fig. 1.1). This boundary commonly lies within a vertical zone of incoherent data and is marked chiefly by the transition from gently dipping rocks on the zone's south side to steeply north-dipping rocks on its north side.

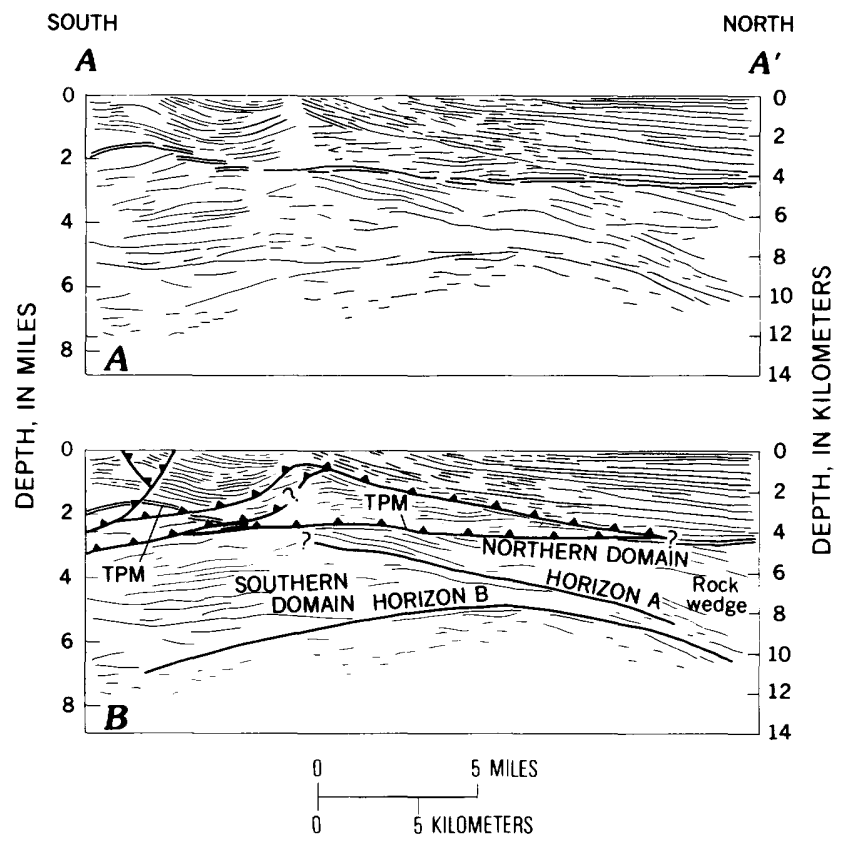

Figure 18.1. Cross section $A-A^{\prime}$, made from unmigrated seismic-reflection data, extends from near mountains to near coastline in western half of 1002 area. Barbed lines indicate thrust faults. $A$, Uninterpreted section. $B$, Interpreted section showing proposed regional structural relation between two domains of pre-Mississippian rocks. TPM, reflective horizon at the top of the preMississippian basement complex; horizon A, boundary between two domains; horizon $\mathrm{B}$, horizon at the base of reflective pre-Mississippian rocks.
Cross section $A-A^{\prime}$ (fig. $18.1 A, B$ ) strikes N. $15^{\circ} \mathrm{W}$. through the western part of the coastal plain, from near the mountain front to near the coast. This cross section shows that much of the stucture in the Cretaceous and Cenozoic rocks that overlie the top of pre-Mississippian rocks (TPM) results from thrust faults that begin at depth within the pre-Mississippian rocks and cut obliquely upward into younger rocks. The structure of these overlying rocks includes a triangle zone, within which rocks imbricated by thrust faults are bounded above and below by other thrust faults. On $A$ $A^{\prime}$ the zone's upper bounding thrust fault is interpreted to form the contact between rocks with discordant dips: along the northern flank of the triangle zone, rocks within the zone are subhorizontal or dip gently north, whereas rocks above and north of the zone dip more steeply and uniformly north. This zone's upper and lower bounding thrust faults converge $15 \mathrm{~km}(9 \mathrm{mi})$ north of the crest of the triangle zone. This convergence delimits on the north the thrust fault-related deformation.

At the southem end of cross section $A-A^{\prime}$, the pre-Mississippian rocks of the southern domain-below the top of the pre-Mississippian (TPM) - are horizontal or dip gently south. North-dipping rocks of the northern domain begin below the crest of the triangle zone and extend to the north end of $A-A^{\prime}$. The discordant dips of rocks in the two domains meet at horizon A (fig. 18.1), which is interpreted to be the boundary between the two

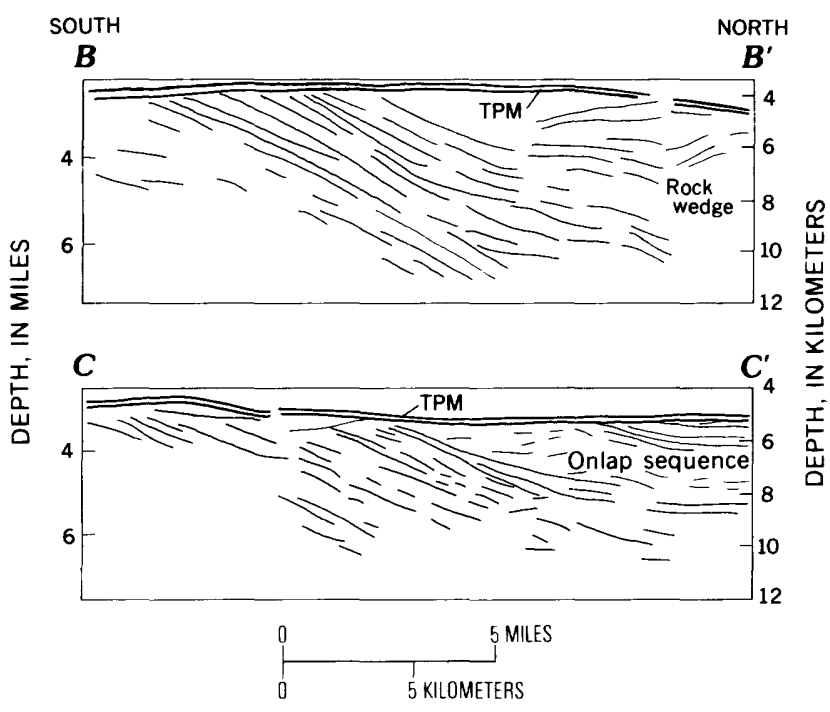

Figure 18.2. Cross sections $B-B^{\prime}$ and $C-C^{\prime}$ are made from unmigrated seismic-reflection data obtained near the coastline in the western half of 1002 area. Both sections show variable dips of rocks in northern domain of preMississippian rocks that suggest that these rocks retain their large-scale sedimentary structure. TPM, reflective horizon at top of the pre-Mississippian basement complex. 
domains. The seismic section on which $A-A^{\prime}$ is based is the only one in which this relationship between the domains is evident; elsewhere, the zone of poor data described above separates the domains.

At the northern and southern ends of cross section $A-A^{\prime}$, the reflective pre-Mississippian rocks extend in depth to about 10 or $12 \mathrm{~km}(6$ or $7 \mathrm{mi}$ ). Horizon B (fig. 18.1), the bottom of the reflective preMississippian rocks, is evident in seismic data and forms a broad arch that extends across the entire cross section. Below this horizon only faint, discontinuous reflections are evident. The base of the north-dipping rocks (horizon A) and the bottom of the reflective rocks (horizon B) converge near the northern end of the cross section. Rocks below the top of the pre-Mississippian near the northern end of cross section $A-A^{\prime}$ dip monoclinally north except for local flat horizons; these horizons suggest that a northward-thickening rock wedge is located there.

A similar wedge is evident in cross section $B$ $B^{\prime}$, and $C-C^{\prime}$ shows a wedge that includes an onlapping sequence (fig. 18.2). These cross sections were constructed from seismic data collected along north-south lines located in the western part of the ANWR. Data from rocks above the top of the pre-Mississippian have been omitted from these sections. Both cross sections show discordant dips that suggest large-scale sedimentary structure in the pre-Mississippian rocks. Section $B-B^{\prime}$ shows a wedge of rocks, nearly $2 \mathrm{~km}(1 \mathrm{mi})$ thick at the northern end of the section, that shallows and thins southward to where it is truncated at the top of the preMississippian rocks. The northern end of section $C-C^{\prime}$ shows a rock unit directly under the top of the preMississippian that laps to the south onto north-dipping rocks. These north-dipping rocks are 5 to $7 \mathrm{~km}$ (3 to 4 mi) thick and extend to depths of at least $10 \mathrm{~km}(6 \mathrm{mi})$. Section $B-B^{\prime}$ shows dipping events that may extend below $11 \mathrm{~km}(7 \mathrm{mi})$. Despite this great depth, the onlapping relationships between deep rocks and the north-dipping horizons suggest that the pre-Mississippian rocks are neither highly deformed nor metamorphosed but retain much of their large-scale sedimentary structure. All three cross sections show that preMississippian rocks, particularly those near the coast, are only mildly folded; these rocks, however, may be deformed along thrust faults. This apparently simple structure contrasts with the complex structure of coeval rocks exposed in the Brooks Range.

\section{DISCUSSION}

The regional structure of the pre-Mississippian rocks and the cause for their predominant north dip are still matters for speculation. The monocline formed by north-dipping rocks 5 to $7 \mathrm{~km}$ (3 to $4 \mathrm{mi}$ ) thick could have been caused by several processes: progradation into deep water; structural repetition of a relatively thin rock section along unrecognized, south-verging thrust faults; tilting and truncation of a thick rock sequence within a basin; or formation of a triangle zone during the pre-Cretaceous. Drummond (1974, fig. 5) has proposed a model of the development of the Arctic margin of North America in which the Late Proterozoic rocks in the Canadian Arctic Islands form a northward-prograding continental terrace and the Cambrian rocks there comprise a southward-prograding delta. Depending upon whether or not the coastal plain rotated away from Canada, one or the other of these prograding rock units could conceivably correlate with the north-dipping rocks described here. If so, the depth of water into which the coastal-plain rocks prograded would have had to be at least as great as the 5 to $7 \mathrm{~km}$ ( 3 to $4 \mathrm{mi}$ ) relief of the inferred foreset beds. This implied water depth is greater than most present ocean basins, and it does not even account for topset and bottomset beds, which are not evident in seismic data and must have been removed selectively by erosion or faulting. The north-dipping rocks, therefore, are unlikely to be forset beds associated with simple progradation.

Structural repetition of a relatively thin rock unit by unrecognized, south-verging thrust faults is also an unlikely explanation for the monoclinal dip, inasmuch as thrust faults would not have caused the very regular rock geometry, involving invariant north dip, that is present over tens of kilometers in the dip direction and over an even greater distance along strike. In fact, Reed (1968) has suggested that pre-Mississippian thrust faults in the Precambrian rocks near Lake Peters dip to the south, which implies a northward vergence.

Tilting and truncation of a basin could explain the north dip and the thinning units apparent below the top of the pre-Mississippian rocks in cross section $A-A^{\prime}$. In the Brooks Range, two unconformities lie within the pre-Mississippian rocks: one at the base of the Cambrian section, and the other at the top of the Middle Devonian (Brosgé and others, 1962; Dutro and others, 1970, 1972). Horizons A and B (fig. 18.1) could be unconformities within such a basin, and the north dip could have resulted from regional northward tilting of the basin.

Two of the proposed processes-those involving a tilted and truncated basin and the formation of a triangle zone-can be linked to provide a possible explanation for the predominant north dip. The sole basis for this hypothesis is the similarity in geometry of the rocks above and those below the top of pre-Mississippian rocks, as the following comparison suggests. Rocks above the top of the pre-Mississippian are deformed into a triangle zone that is bounded on the north by thrust faults that converge northward. Rocks within this zone are mainly subhorizontal, dipping discordantly to rocks north of the zone. Tilting and truncation of rocks above the top of the pre-Mississippian extends at least $20 \mathrm{~km}$ (12 mi) north of the zone's crest, which shows that the growth of even small zones can deform rocks over a 
large area within a basin. Below the top of the preMississippian, horizon A (the base of the north-dipping rocks) and horizon $B$ (the base of the reflective preMississippian rocks) converge, mimicking the convergence of thrust faults bounding the overlying triangle zone. Rocks between these horizons are subhorizontal, dipping discordantly to rocks between horizon $\mathrm{A}$ and the top of the pre-Mississippian. The absence from cross section $A-A^{\prime}$ of strongly divergent beds characteristic of proximal ends of some triangle zones may mean that these beds lie south of cross section $A-A^{\prime}$, perhaps within the mountains, where most of the pre-Mississippian rocks dip south.

In essence, two triangle zones may be stacked beneath the coastal plain. These zones would represent two generations of deformation because the deep zone formed during the pre-Cretaceous and was beveled flat by the top of the pre-Mississippian. The most likely time for the deformation of the pre-Mississippian rocks was during the Devonian orogeny that affected rocks in the Brooks Range (Brosgé and others, 1962; Brosgé and Dutro, 1973; Sable, 1977). Exact correspondence in location of two triangle zones may seem unlikely; however, thrust faults within the older zone may have been reactivated and thus controlled the location of faults bounding the younger one.

\section{CONCLUSIONS}

At least 5 to $7 \mathrm{~km}$ ( 3 to $4 \mathrm{mi}$ ) of reflective, preMississippian rocks lie below the top of the preMississippian. These rocks can be divided into two domains based on the attitude of bedding planes. The southern domain consists of rocks that are horizontal or dip gently south, whereas the northern domain contains rocks that dip monoclinally north except near the coastline, where their variable dip suggests that the rocks retain their large-scale sedimentary structures. The structure of the pre-Mississippian rocks underlying the coastal plain is simple, in contrast to the complex structure of coeval rocks in the mountains.

Whether these rocks contain hydrocarbons is a topic considered elsewhere (see chap. 7). However, few structures are present to attract explorers to the monoclinally dipping rocks of the northern domain. If hydrocarbons are contained in these rocks, the traps may be stratigraphic and probably will involve the unconformity at the top of pre-Mississippian rocks. Hydrocarbons might also be contained in carbonate rocks marked by fracture porosity or secondary porosity. Structures in the southern domain will be difficult to delineate because of the complex structure of the overlying Cretaceous and Cenozoic rocks. 


\title{
Chapter 19.
}

\section{Regional Structure of Rocks Beneath the Coastal Plain}

\author{
By Terry R. Bruns, ${ }^{1}$ Michael A. Fisher, ${ }^{1}$ W. James Leinbach, Jr., ${ }^{2}$ and John J. Miller ${ }^{2}$
}

\section{INTRODUCTION}

This chapter gives an overview of the regional structure of the Arctic National Wildlife Refuge (ANWR) coastal plain (fig. 19.1) as interpreted from seismic-reflection data and presents selected seismic lines that illustrate the major features (pl. 4). All seismic lines displayed in this report were processed by the U.S. Geological Survey from field data acquired by Geophysical Service Inc. in 1984 and 1985 (chaps. 16, 17).

Interpretation of the seismic-reflection data shows that the coastal plain is underlain in part by a foreland thrust belt. The structure has been largely controlled by the northward transport of basement (preMississippian) rocks and strata of the overlying Ellesmerian and Brookian sequences along thrust faults. Some of the kinds of features developed in such a tectonic setting are discussed by Kelly and Foland in chapter 20.

The coastal plain can be divided into two structural zones, the undeformed zone and the deformed zone (fig. 19.1), marked by increasingly complex deformation from west to east. Rocks in the undeformed zone in the northwest part of the coastal plain are characterized by nearly flat lying strata cut by normal faults with only small displacement. The deformed zone includes the remainder of the coastal plain. The boundary between the two zones lies on the flank of the Marsh Creek structural trend. This trend is mapped on surface geologic maps as the Marsh Creek anticline (fig. 19.1; Bader and Bird, 1986), but in the subsurface the structure consists of a set of subparallel thrust-faulted anticlines that trend northeastward from near the west end of the Sadlerochit Mountains to south of Barter Island. The rest of the deformed zone is similarly characterized by thrust-faulted basement highs overlain by northeast-trending complexly deformed structures.

\footnotetext{
${ }^{1}$ U.S. Geological Survey, Menlo Park, Calif.

2 U.S. Geological Survey, Denver, Colo.
}

\section{Seismic Stratigraphy}

A prominent seismic-reflection horizon, termed the top pre-Mississippian reflection horizon (hereafter referred to as the TPM), marks the top of the preMississippian basement complex and forms a regional stratigraphic marker on seismic-reflection records (pl. 4). The TPM is particularly well expressed as a continuous, strong seismic reflection in the western part of the coastal plain (the undeformed zone) and near the coast (see lines 85-2/85-2A, 84-6/85-8, and 84-10/85-16, pl. 4) In the deformed zone, the TPM is discontinuously present on seismic records because of structural complexity in the basement and overlying rocks.

Correlations of the seismic-reflection data with the stratigraphy in wells west of the coastal plain (lines $84-1,84-5$ and $84-6 / 85-8$, pl. 4) indicate that near the coast and probably throughout much of the coastal plain, the TPM corresponds to a regional Lower Cretaceous unconformity that developed as a result of rifting, uplift, and deep erosion of the Ellesmerian and basement complex rocks in Early Cretaceous time (see chap. 5). Thus, the prominent TPM reflection is likely caused by the velocity contrast between the low-velocity Hue Shale (at the base of the Brookian sequence) and pebble shale unit (at the top of the Ellesmerian sequence) and the underlying high-velocity rocks of the pre-Mississippian basement complex.

Ellesmerian rocks were penetrated in the Beli Unit-1 well, southwest of the coastal plain (line 84-5, pl. 4). In this region, the TPM lies below the Ellesmerian rocks and separates pre-Mississippian basement rocks from the Ellesmerian and younger rocks. The TPM reflection is not as prominent as in areas near the coast, since there is less of a velocity contrast between the basement and Ellesmerian rocks. The Ellesmerian rocks, about $1.2 \mathrm{~km}(4,000 \mathrm{ft})$ thick at the well, are progressively truncated to the northeast at the TPM (line 84-5, pl. 4). In wells near the coastline (lines 84-1 and 84-6/85-8, pl. 4), the Ellesmerian sequence is present only as the thin, 0 - to 120 -m-thick (0 to $400 \mathrm{ft}$ ) Kemik Sandstone equivalent (the Thomson sand of local usage) 
and pebble shale unit deposited during the Early Cretaceous marine transgression.

On the seismic-reflection data, the presence of Ellesmerian rocks in the subsurface can be inferred only by comparing the seismic-reflection character from beneath the coastal plain with the reflection character of the known Ellesmerian rocks in the Beli Unit-1 well. At the southwest end of line 84-5, the Ellesmerian rocks are marked by two prominent reflections at the top and bottom of the sequence, about 0.4 to $0.5 \mathrm{~s}$ apart. A similar pattern is observed on the Sabbath high, which is the eastward plunge of the Sadlerochit Mountains (pl. 3 and lines 84-20, 84-24, and 85-15, pl. 4). A second region having a similar but more discontinuous reflection pattern is the area beneath the Niguanak high (pl. 3), although the reflection character in this region could indicate instead the presence of fault-repeated sections (lines 85-50, 84-30, and 85-1, pl. 4). Elsewhere beneath the coastal plain, seismic-reflection patterns suggesting the presence of thick Ellesmerian rocks are uncommon. In these areas, it is likely that only a thin Ellesmerian sequence comprised of the Kemik Sandstone and pebble shale unit is present, as is seen in wells west of the coastal plain, or that Brookian rocks directly overlie the basement rocks.

Beneath the undeformed zone, and probably throughout much of the coastal plain, rocks above the TPM are predominantly Cenozoic in age. The Cretaceous rocks are primarily part of the Hue Shale, are thin in outcrops and wells, and are thin in the seismicreflection data as determined by correlating the reflection and well data (lines 84-1, 85-2/85-2A, and 84-6/85-8, pl. 4). The Cenozoic rocks consist of a northeastward- to eastward-prograding sequence of slope and shelf facies rocks (Canning Formation), overlain by shallow-marine and nonmarine facies rocks (Sagavanirktok Formation; Molenaar, 1983; chap. 5). These facies can be partly delineated on the seismic data in the undeformed zone, as for example on lines 84-6/85-8 and 84-1 (pl. 4). Eastward of the undeformed zone, stratigraphic relationships are probably similar but are obscured by the structural complexity.

\section{Time-to-Depth Conversion of Seismic-Reflection Data}

Velocity data from three wells west of the ANWR were used to calculate a simple curve for converting two-way traveltime on the seismic sections to depth for rocks above the TPM (fig. 19.2). In these wells, the rock velocity is similar in intervals at similar distances above the TPM, regardless of the depth. This relationship implies that the rock velocity depends mainly on the maximum burial depth, and that the velocity was maintained during subsequent uplift and erosion. Because the traveltime to the TPM ranges from about 2 to $4.5 \mathrm{~s}$, a time-to-depth conversion that applies

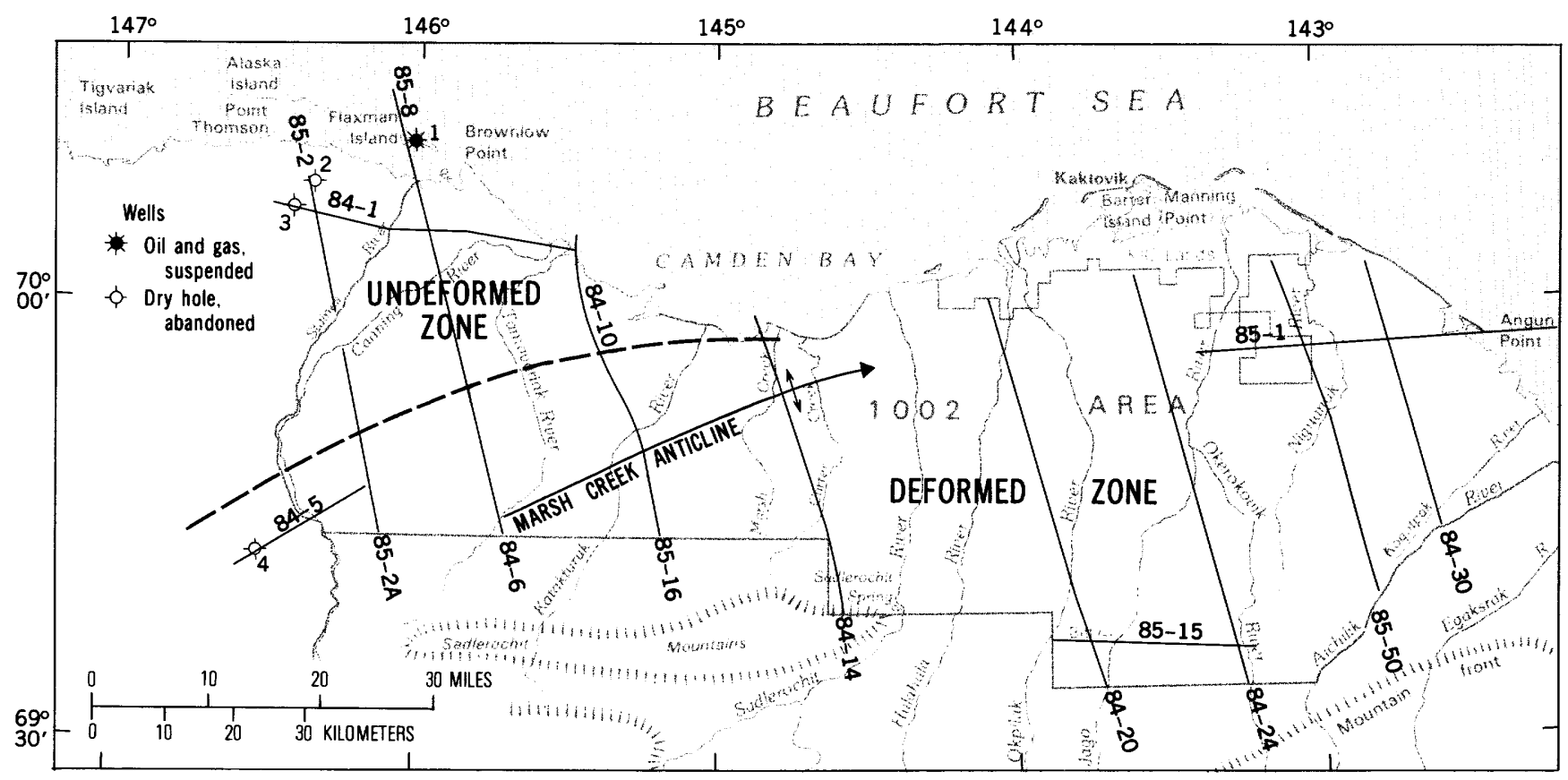

Figure 19.1. Index map of the ANWR coastal plain showing structural zones and locations of seismic lines processed by U.S. Geological Survey and illustrated in plate 4 . Numbered wells refer to plate 4 and are identified in table 1.1. 
the same velocity function everywhere from the surface to the TPM would be inaccurate. However, a function that is based on traveltime measured upward from the TPM (fig. 19.2) accounts for higher velocities in rocks near the TPM and gives a good correlation between the wells and the seismic data.

Wells near the coast give good rock-velocity data down to depths of about $4 \mathrm{~km}(13,000 \mathrm{ft})$. For greater depths a constant interval velocity of $4.0 \mathrm{~km} / \mathrm{s}$ (about 13,000 ft/s), as observed at the bottom of the wells, has been assumed. The resulting time-to-depth conversion curve is assumed to be valid throughout the coastal plain, although it is likely to be more in error in areas of complex structure than in the unstructured

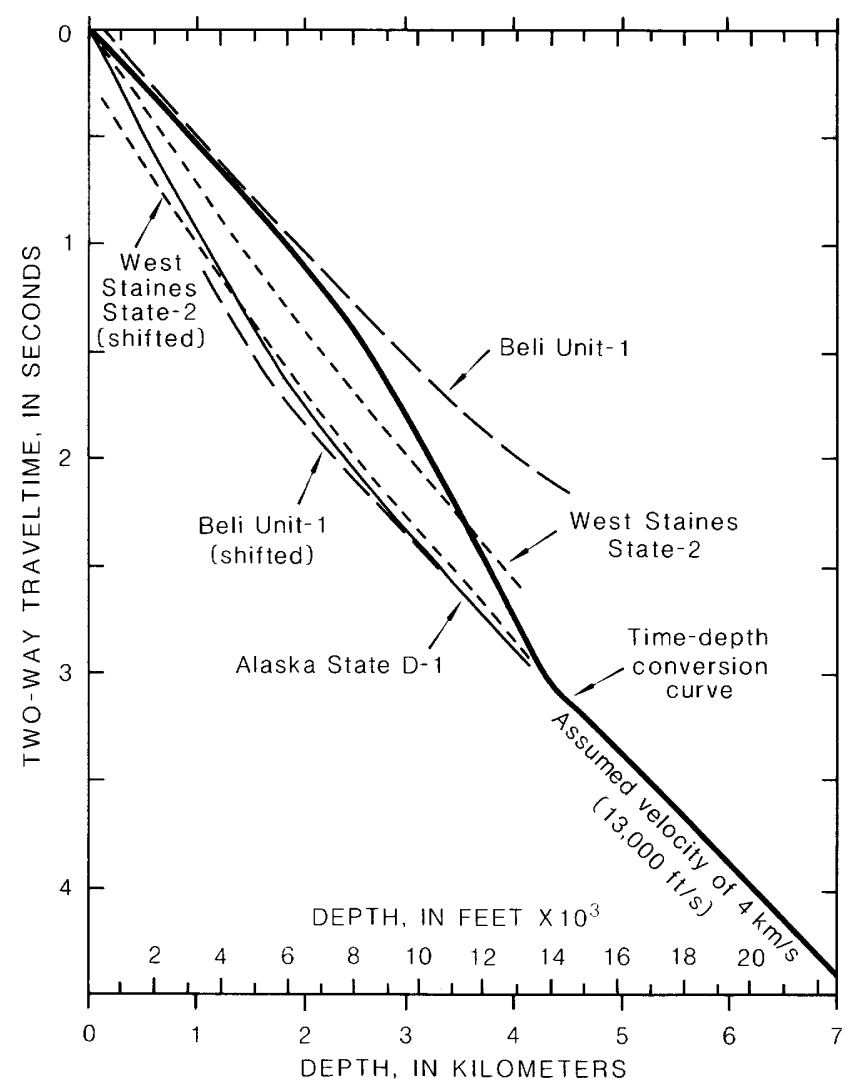

Figure 19.2. Time-depth conversion curve for seismicreflection data and velocity profiles of three wells adjacent to ANWR coastal plain. Beli Unit-1 and West Staines State-2 wells are plotted both as measured from surface and as shifted to match depth to the pebble shale unit in Alaska State D-1 well. Comparison of shifted curves indicates that velocities in wells are similar for same intervals above the pebble shale unit. Time-depth curve is constructed using this relation and assumes that times are measured up from the top pre-Mississippian seismic-reflection horizon at the top of the basement complex rather than down from surface. regions because of velocity changes caused by fracturing or tectonic compaction of the rocks during deformation. The curve is valid only for rocks above the TPM; for rocks below the TPM, a constant interval velocity of about $4.6 \mathrm{~km} / \mathrm{s}(15,000 \mathrm{ft} / \mathrm{s})$ gives an approximate thickness in the basement complex (see chap. 17). We present this curve here primarily to allow simple and rapid depth conversions of the seismic-reflection lines (pl. 4); a somewhat different and more detailed depthconversion process was used to map the structures on the TPM (pl. 3; see chap. 17).

\section{Structure}

The structure of the ANWR coastal plain is shown by structures on the TPM (pl. 3), by a trend map of structures or structural zones within the Brookian rocks (fig. 19.3), and by regional seismic lines (pl. 4). In highly deformed areas, such as on lines 84-20, 84-24, $85-50,84-30$, and 85-1 (pl. 4), the structure in the Brookian rocks is poorly defined on the seismic data owing to the prevailing structural complexity. The interpretation shown on the seismic lines must therefore be considered as partly to highly schematic.

Structures on the TPM (pl. 3) combined with generalized depth information (table 23.1) show the configuration of the top of the pre-Mississippian basement complex and the thickness of the overlying Ellesmerian and Brookian rocks between the TPM and sea level. Major structural features on the TPM are controlled by thrust faults, which cause northward transport and imbrication of the pre-Mississippian basement rocks. In turn, complex thrusting occurs in Brookian rocks in front of these basement faults as the thrust faults cut upward. On the seismic-reflection data (pl. 4), these basement thrust faults are the areas along which rocks below the TPM are thrust over the TPM (faults F1-F4, pls. 3, 4); the thrust faults then become bedding plane thrusts or cut upward through the overlying Brookian rocks.

Beneath the western part of the coastal plain, the TPM dips seaward from the Sadlerochit Mountains toward a deep low, termed herein the Hulahula low, southwest of Barter Island (pl. 3). Just north of the mountains, the TPM is disrupted by basement thrust faults in front of the mountains (faults F1 and F2, pl. 3; lines 85-2/85-2A, 84-6/85-8, 85-16/84-10, 84-14, and $84-20$, pl. 4). Thrust faults cutting upward from these basement faults along and through the Brookian section control deformation along the Marsh Creek structural zone.

East of the Hulahula low, the structure is dominated by four basement structural highs, herein termed from south to north the Sabbath, Aichilik, Niguanak, and Tapkaurak highs (pl. 3; lines 84-20, 84$24,85-50,84-30,85-15$, and 85-1, pl. 4). The first three of these structures are located on the south side and in 
the hanging wall of major basement thrust faults (faults F2-F4, pls. 3, 4). These structures may be underlain by fault-repeated rock units, as is suggested on dip lines $84-20,84-24,85-50$, and 84-30, and on line 85-1, a strike line across the Niguanak high (pl. 4). Both the Aichilik and Sabbath basement highs are associated with probable triangle zones (lines 84-24 and 84-30). The Tapkaurak high, present on the north end of line 84-30 in front of the Niguanak high, is not obviously fault controlled and may not be a thrust-faulted basement block.

The Sabbath high is on trend with the Sadlerochit Mountains and is the eastward-plunging nose of the mountains. The high has large north-south rollover (see lines 84-20 and 84-24) but little or no confirmed closure beneath the coastal plain (line 85-15).

The Tapkaurak and Niguanak highs are both dome-shaped structures having large closures. Other small areas of closure are present beneath the coastal plain, mainly along faults (pl. 3 ).

The small Aichilik high (line 84-30) has no large closure beneath the coastal plain, but it may be part of a much larger structure that lies largely east of the Aichilik River. Gravity data reflect the configuration of the TPM and show a major positive gravity anomaly trending parallel to the coast between the Canadian border and the Aichilik River (see chap. 15; pl. 2). This anomaly extends over the Aichilik high and suggests that the Aichilik structure extends eastward as a major structural feature.

Brookian rocks above the TPM are as thick as about $8 \mathrm{~km}(26,000 \mathrm{ft})$ in the deepest part of the coastal plain, the Hulahula low, and as thin as about $3 \mathrm{~km}$ $(10,000 \mathrm{ft})$ over major structural highs like the Niguanak high. These rocks are truncated by Holocene erosion at or near the surface just north of the Sadlerochit Mountains (pl. 3 and line 84-14, pl. 4). Structures within the Brookian rocks are detached along thrust faults and consist of long, northeast-trending, subparallel compressional anticlines and synclines (fig. 19.3). These structures result when the basement thrust faults break through the overlying Brookian rocks, causing complex thrust faulting, imbrication, and tectonic thickening within the Brookian section. The seismic lines (pl. 4) show these structural features and illustrate the changing structural style across the coastal plain.

Lines 85-2/85-2A, 84-6/85-8, 85-16/84-10, 8414 , and $84-20$ (pl. 4) show the structural variability on the Marsh Creek structural trend. The structure is controlled by thrust faults that cause imbrication within the basement complex along faults $F 1$ and F2 (pls. 3, 4); the northward motion of the block is in turn expressed by thrusting and imbrication in the overlying section. On lines $85-2 / 85-2 A$ and $84-6 / 85-8$, overthrusting of the

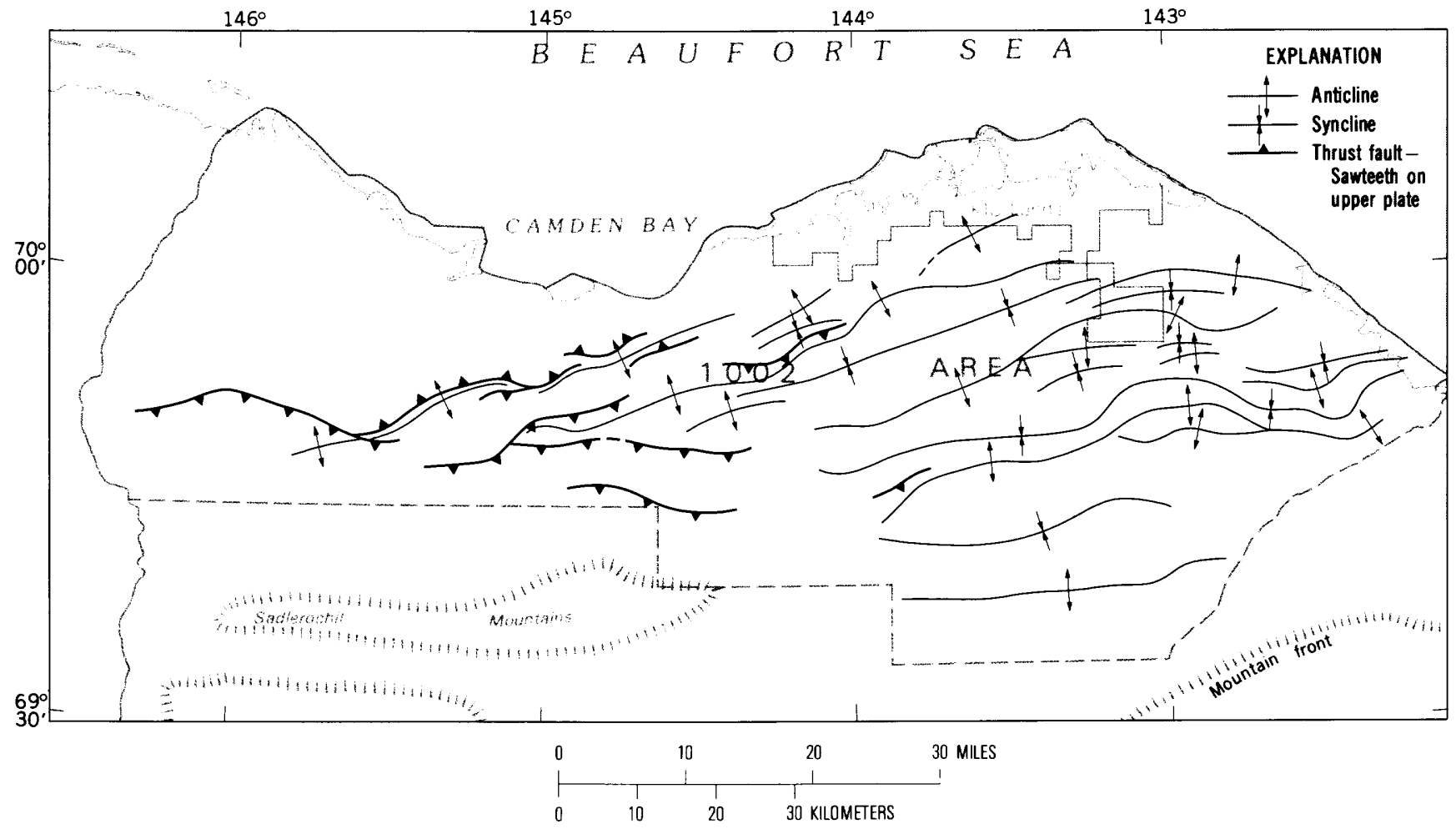

Figure 19.3. Generalized near-surface structural trends in the Brookian sequence. Because of structural complexity, not all features are shown, particularly in eastern half of coastal plain. 
rocks at the TPM is minor, the resulting structure in the overlying rocks is a monocline or anticline with the axis south of the end of seismic line 85-2/85-2A, and a gentle anticline on line $84-6 / 85-8$. On line $85-16 / 84-10$, more substantial basement displacement has resulted in imbrication within what is probably a small triangle zone (see chap. 20, especially figs. 20.8 and 20.11) formed between the upper and lower detachment surfaces. On line 84-14, further displacement along the bounding thrust faults has led to extensive imbrication within a large complex structure, probably also a triangle zone, in which the upper detachment has been partially removed by erosion. The triangle-zone deformation has created multiple near-surface and subsurface structural highs. Finally, on line 84-20, the large amounts of basement overthrusting seen on the previous two lines die out, and although thrust faults cut across the Brookian section, the structure appears to be simpler than on lines 85-16/84-10 and 84-14 without the development of a triangle zone.

The Sabbath and Niguanak basement highs (pls. 3 ,4) are overlain by highly deformed Ellesmerian and Brookian rocks, including some of the oldest rocks exposed on the coastal plain. The highs are probably overlain by a detachment surface near the TPM. Thrust faulting has caused substantial deformation of the Brookian rocks north of each high. Jurassic (Kingak Shale) and Lower Cretaceous (pebble shale unit) rocks crop out in the Niguanak high region and are probably scraps of the uppermost part of the Ellesmerian sequence transported northward and to the surface along the thrust faults.

In most of the structurally complex areas, the Brookian sequence has probably been multiply cut and deformed by thrust faults into a duplex structure, as suggested by the structural models presented in chapter 20 (see especially fig. 20.8). Even within the less complexly deformed regions, such as along the Marsh Creek structural trend, the structures within the anticlines probably include some degree of duplex structure that cannot be resolved using the seismic data.

\section{Structural Timing}

Major thrusting within the coastal plain began at least as early as Eocene time, and possibly earlier. West of the ANWR and offshore, thrusting reportedly began about middle Eocene time (Leiggi and Russell, 1985; Grantz and May, 1983). Deformation apparently also began about middle Eocene time in the coastal plain. An unconformity is present in seismic-reflection data along the shoreline between Barter Island and the Canadian border (north ends of lines 84-24, 85-50, and $84-30$, pl. 4). Outcrops and wells west of the coastal plain indicate that rocks above the unconformity are Eocene in age (see chap. 5 ; pl. 1), so the age of the unconformity must also be Eocene or older. This unconformity may be correlative with a well-developed offshore unconformity interpreted to be late Eocene in age (Grantz and May, 1983; see chap. 21). Because both the unconformity and the rocks below it are deformed, deformation within the ANWR region began before the late Eocene. In areas where the unconformity is present, this deformation was apparently largely complete by the time the unconformity was cut, because the rocks above the unconformity are not nearly so deformed as the rocks below it.

Deformation has continued to the present day beneath the coastal plain. In outcrops and on the seismic-reflection data, virtually all the rocks present, regardless of their ages, are involved in the deformation, including uplifted and tilted Quaternary beds along the Marsh Creek anticline (Grantz and May, 1983). Grantz and May (1983) have also noted that substantial earthquake activity is occurring just offshore of the ANWR and in the mountains south of the coastal plain. Deformed Pleistocene and Holocene deposits are also common in the adjacent offshore region (see chap. 21).

\section{Regional Structural Relationships}

Various tectonic elements found offshore of the ANWR can be related to onshore features or can be projected beneath the coastal plain. Offshore features described and illustrated by Grantz and May (1983) and Grantz and others (chap. 21) that have possible onshore counterparts are (1) the structure contours on a detachment fault surface, which are effectively a continuation of contours on the onshore TPM; (2) the Barter Island subbasin, which is continuous with the onshore region of thickest strata above the TPM (the Hulahula low); (3) the late Eocene unconformity east of longitude $144^{\circ} 15^{\prime}$ and on the Canadian Beaufort shelf, which continues onshore east of Barter Island; and (4) the Camden anticline, which is parallel to and may be a detachment fold similar to the Marsh Creek anticline. There is probably little difference between the stratigraphy and structural development history of the ANWR coastal plain and that of the immediately adjacent continental shelf.

\section{Major Controls on ANWR Stratigraphy and Structure}

The geology and structure of the coastal plain have been controlled by three main tectonic and geologic processes (Molenaar, 1983; chaps. 5, 21):

(1) Early Cretaceous uplift and erosion cut deeply into the Ellesmerian and older rocks in the ANWR region. Well and seismic-reflection data suggest that much of the Ellesmerian sequence has been removed beneath the coastal plain, except perhaps in the Niguanak 
and Sabbath high regions, and that the Kemik Sandstone, pebble shale unit, and Brookian sequence commonly directly overlie the basement rocks.

(2) Subsidence and marine transgression led to deposition of the Kemik Sandstone and pebble shale unit above the unconformity. Continuing subsidence and isolation from major sediment-source terrains led to deposition of a thin pelagic Cretaceous sequence (Hue Shale) in deep water. This section is overlain by eastward- and northeastward-prograding basin, slope, shelf, and nonmarine deposits of predominantly Cenozoic age. Seismic data confirm the eastward and northeastward progradation of the slope and shelf facies in the western coastal plain. However, structural complexity in the eastern part of the region could obscure other stratigraphic relationships.

(3) Northward-directed thrusting has been active during Eocene through Holocene time and was possibly active prior to the Eocene. This thrusting has led to marked deformation of the rocks beneath the coastal plain. Northward transport of basement blocks has led to the structural deformation observed on and above the TPM. At least locally, and probably regionally, uplift and eustatic sea-level changes during Eocene time created an unconformity throughout much of the nearshore coastal plain and adjacent offshore regions. 


\title{
Chapter 20.
}

\section{Structural Style and Framework Geology of the Coastal Plain and Adjacent Brooks Range}

\author{
By John S. Kelley ${ }^{1}$ and Richard L. Foland ${ }^{2}$
}

\section{INTRODUCTION}

This chapter describes the structural style and framework shown on two reflection seismic lines that transect the coastal plain, the adjacent Sadlerochit and Shublik Mountains, and parts of the northeastern Brooks Range in order to establish a structural geologic framework model for the 1002 area (fig. 20.1). In it, we integrate surface geologic studies in, south, and southeast of the 1002 area with seismic-reflection data from the 1002 area.

Structural style and a structural geologic framework model enhance interpretation of seismicreflection data, especially in structurally complex areas. They provide a template for structural pattern recognition in seismic data. Structural style and framework also provide a basis for projecting interpretations into areas of no data or for choosing an interpretation in an area where the data permit several alternative interpretations.

For a data base, this study relies on previous geologic mapping, field observations, and interpretation of two regional seismic lines that transect the 1002 area. Regional geologic mapping (Reiser and others, 1971, 1980) provides the context for structural geologic observations made during the 1984 (Kelley and Molenaar, 1985) and 1985 field seasons. Mapping in the Sadlerochit and Shublik Mountains (Reiser and others, 1970) and field observations are the basis for construction of a generalized tectonic map of the Sadlerochit and Shublik Mountains area (pl. 5). Interpretation of seismic line 84-14 (pl. 5) and five cross sections across the Sadlerochit and Shublik Mountains area (pl. 5, sections $A-A^{\prime}$ through $E-E^{\prime}$ ) shows the structural style and framework of much of the western 1002 area. Similarly, seismic line 84-24 (pl. 5) is the basis for the structural style and framework interpreted beneath the eastern 1002 area.

Structures in the 1002 area and adjacent mountains involve rocks ranging in age from Precambrian to Quaternary. Three regionally extensive

\footnotetext{
${ }_{2}^{1}$ U.S. Geological Survey, Anchorage, Alas.

2 Bureau of Land Management, Anchorage, Alas.
}

unconformities-a pre-Mississippian and an Early Cretaceous unconformity that locally merge, and an Eocene unconformity-are involved in thrust faulting and help date deformation. Structures present include thrust faults, a variety of rootless folds, large anticlines cored by pre-Mississippian rocks, duplexes, triangle zones, and complex structural thickening of mostly incompetent units.

Most thrust faults converge at basal sole thrust (BST) faults (Boyer and Elliott, 1982) that typically occur in easily deformable strata such as shale, along unconformities, and in zones of abrupt transition in mechanical properties. Although BST faults occur in particular strata over much of their extent, they generally tend to cut up-section in the direction of structural transport, as do subsidiary thrust faults that branch upward from them. Displacements along BST faults are commonly large relative to displacements on subsidiary thrust faults, in some cases orders of magnitude larger.

The structures in most of the coastal plain 1002 area and adjacent Sadlerochit and Shublik Mountains consist of east- and east-northeast-trending folds and thrust faults. The deformational style of much of the coastal plain and adjacent mountains is similar to that recognized by Dahlstrom (1970) and Bally and others (1966) in the Alberta Foothills and adjacent plains and recognized elsewhere in the Cordilleran fold belt (reviewed by Boyer and Elliott, 1982). Folds are asymmetrical, verge north and north-northwest in the direction of structural transport, and are typically floored by thrust faults. In general, the depth, intensity, and age of the rocks involved in deformation increase to the south toward the mountain belt. North-northwest structural shortening takes place through folding, thrust faulting of one sequence of strata over another, and imbrication of thrust blocks within thrust sheets.

The generalized tectonic map of the Sadlerochit and Shublik Mountains area comprises eight structuralstratigraphic domains (SSD's), with each domain made up of a particular stratigraphic sequence and structural style (p1. 5). These styles include (1) structural repetition of a characteristic stratigraphic sequence, or (2) no structural repetition in contrast to repetition of stratigraphic sequences in adjacent domains. 
Identifying and mapping SSD's accommodates some of the limitations in geologic mapping adjacent to the 1002 area. In much of the area adjacent to the Sadlerochit and Shublik Mountains, Jurassic and younger strata are too poorly exposed to allow thorough mapping. Many distinctive stratigraphic units are less than $90 \mathrm{~m}$ (300 ft) thick (Molenaar, 1983, p. 1074, fig. 6) especially Lower and lower Upper Cretaceous units, which are mostly recessive-weathering shale. In areas of continuous exposure, especially along streams that cross strike, SSD's can be identified by their repeated stratigraphic units. Extension of the domains across areas of poor exposure with the aid of scattered outcrops allows the generation of a structurally useful map without determining the detailed distribution of each stratigraphic unit. Some SSD's on plate 5 are identifiable thrust sheets; others are of uncertain character.

SSD's emphasize the location of BST faults for major thrust sheets. Subsidiary thrust faults sole into BST faults that bound the structural domains and repeat the characteristic stratigraphic sequence. The oldest stratigraphic unit in the SSD is especially important in identifying the BST underlying the domain, because major separation across a BST is rarely evident except where the BST perceptibly cuts up-section. Similarly, in the case of detachment folding, slip across a major décollement zone may be much greater than is suggested by observation of a single detachment fold.

The SSD's in the Sadlerochit and Shublik Mountains comprise six thrust sheets and two domains of uncertain character (fig. 20.2, pl. 5). Major thrust faults, including BST faults with upward-branching subsidiary thrust faults and roof thrusts with converging subsidiary thrusts, floor the thrust sheets recognized among the SSD's in the Sadlerochit and Shublik Mountains. SSD's of uncertain character include unrecognized thrust sheets, parts of thrust sheets, and (or) multiple thrust sheets.

\section{STRUCTURAL GEOLOGY OF THE SADLEROCHIT-SHUBLIK MOUNTAINS AREA AND SEISMIC LINE 84-14}

Outcrops in the Sadlerochit and Shublik Mountains at the south end of seismic lines in the

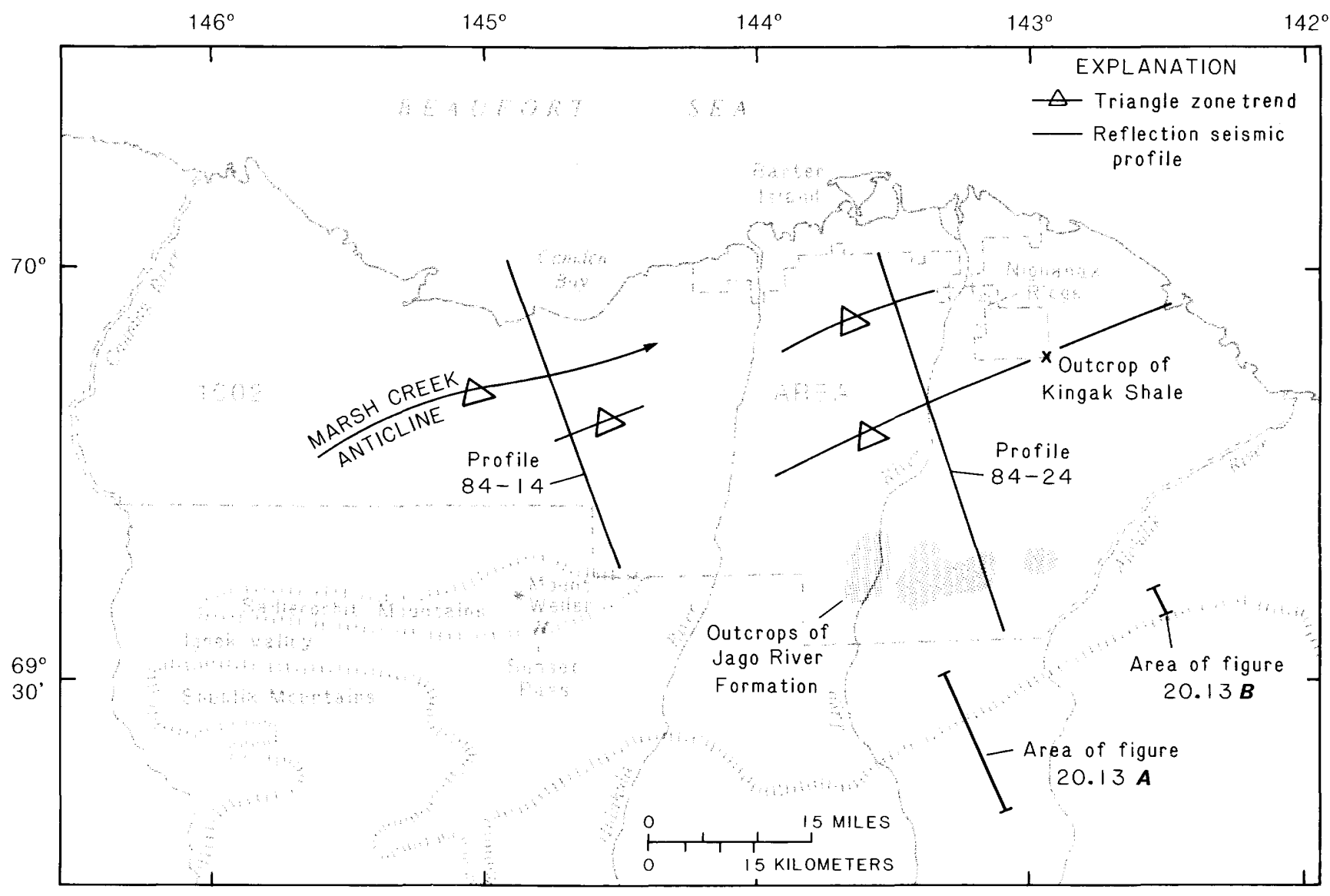

Figure 20.1. Location map of northeastern Alaska. 
western 1002 area make the geology of these mountain ranges important to interpretation of subsurface structure in the coastal plain (fig. 20.1). Structures exposed in the Sadlerochit Mountains continue north, downdip onto seismic line 84-14, and then plunge east apparently into the plane of seismic line 84-24. These mountain ranges are additionally important because the stratigraphy of the Sadlerochit and Shublik Mountains is better known than other areas adjacent to the coastal plain.

Six of the eight SSD's identified in the Sadlerochit and Shublik Mountains area (pl. 5, Domains I through VI) are thrust sheets that extend into the subsurface north of the Sadlerochit Mountains. Beneath the coastal plain, the ages of the oldest rocks in each thrust sheet probably become progressively younger northward because the BST faults flooring each sheet appear to cut up-section northward. Tracing each thrust sheet with seismic data provides a tentative means of

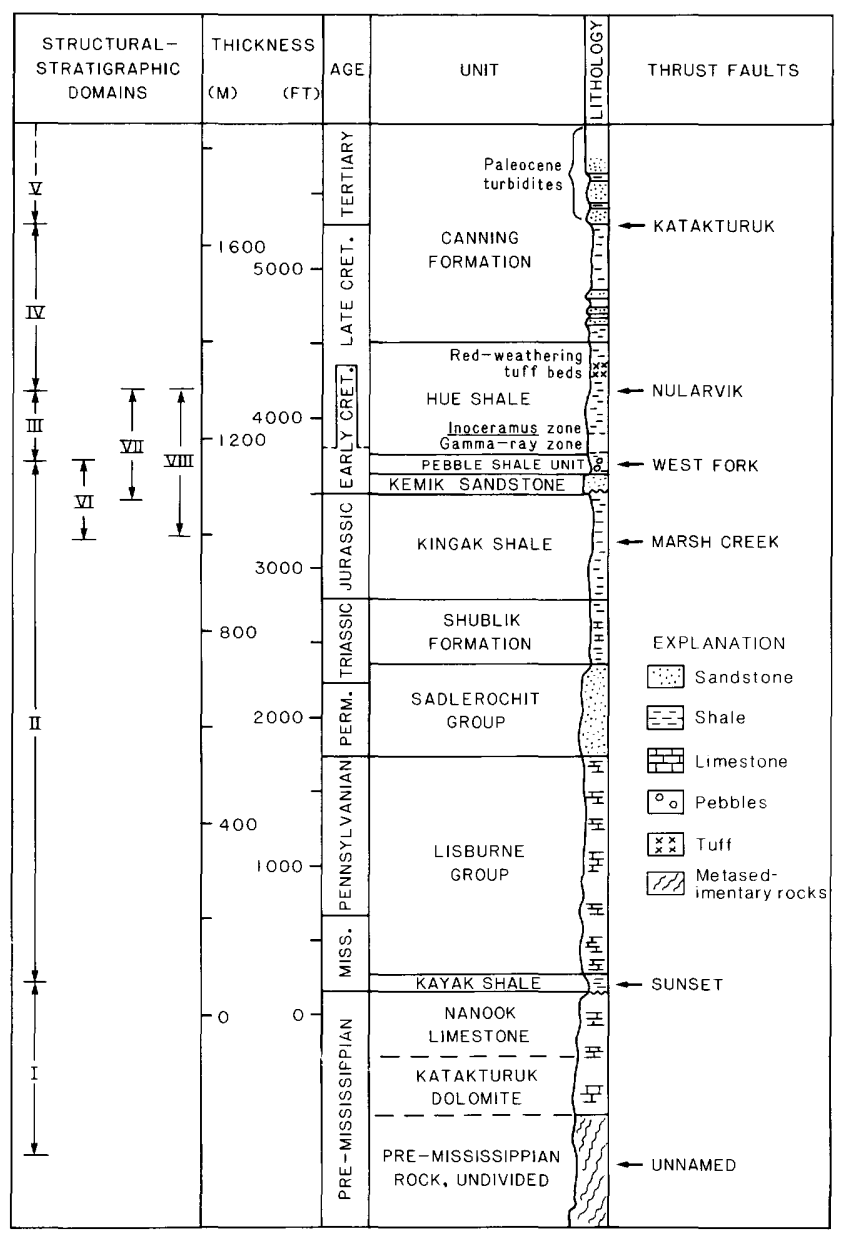

Figure 20.2. Stratigraphic location of major thrust faults underlying thrust sheets exposed in Sadlerochit and Shublik Mountains and adjacent foothills. assigning approximate ages and rock types under the coastal plain.

Thrust faults of regional extent floor the six thrust sheets that extend from the northeast flank of the Sadlerochit Mountains under the coastal plain and are present on line 84-14. In the Sadlerochit Mountains, five of the six BST faults crop out respectively along the pre-Mississippian unconformity, in the Kingak Shale, in the pebble shale unit, in the Hue Shale, and in or near the base of extensive turbidite sandstones in the Canning Formation. The sixth fault, in the pre-Mississippian rocks, is not exposed (fig. 20.2).

Two poorly known SSD's lie on the north and south flanks of the Sadlerochit Mountains. The domain on the north flank of the mountains (pl. 5, Domain VII) comprises a structurally simple sequence of Cretaceous strata in possible depositional contact with underlying strata. The other domain (pl. 5, Domain VIII) lies between the Sadlerochit and Shublik Mountains and consists of Jurassic and Cretaceous strata. The structural geology of this domain is largely unknown but seems mostly simple. The lower boundary of Domain VIII is a thrust fault on the southwestern flank of the Sadlerochit Mountains, where the domain overlies imbricate blocks of Jurassic and Cretaceous strata. Elsewhere, the lower boundary of Domain VIII is poorly known.

\section{Basal Thrust Fault in Pre-Mississippian Rocks}

High-angle reverse and thrust faults that involve pre-Mississippian rocks in the Sadlerochit and Shublik Mountains (pl. 5, Domain I) are probably subsidiary thrusts that sole into a BST fault in pre-Mississippian rocks. The faults trend eastward parallel to bedding, compositional layering, and cleavage in the preMississippian rocks and dip south. Some thrust faults subsidiary to the BST fault in pre-Mississippian rocks emplace imbricated pre-Mississippian rocks on strata as young as Late Cretaceous and Tertiary in age (for example, the Weller thrust in the western Sadlerochit Mountains and the Hue thrust in the Shublik Mountains). Most recognizable thrust faults in the pre-Mississippian rocks, however, do not appear to cut the overlying postMississippian strata. Instead, recognizable thrust faults in the pre-Mississippian rocks merge into a roof thrust fault, the Sunset thrust fault, along the pre-Mississippian unconformity (pl. 5, cross sections $A-A^{\prime}$ and $B-B^{\prime}$ ).

The amount of movement on the BST fault in pre-Mississippian rocks is uncertain, although movement on some of its subsidiary thrust faults is more than 3.2 $\mathrm{km}(2 \mathrm{mi})$. Limited knowledge of the dimensions of the thrust blocks of pre-Mississippian rocks and the depth to the BST fault preclude accurate estimation of total displacement.

The Itkilyariak and Weller thrust faults crop out on the north side of the Sadlerochit Mountains and 
probably sole into the BST fault in pre-Mississippian rocks. The Itkilyariak thrust trends eastward and extends from where it merges with the Weller thrust near the Katakturuk River eastward into the 1002 lands and across seismic line 84-14 (pl. 5, cross sections $B-B^{\prime}, C$ $\left.C^{\prime}, D-D^{\prime}, E-E^{\prime}\right)$.

The Weller thrust fault extends nearly the entire length of the Sadlerochit Mountains. West of the Katakturuk River, the Weller thrust is the frontal thrust fault for the Sadlerochit Mountains and emplaces preMississippian rocks on Upper Cretaceous and Paleocene strata. East of the Katakturuk River, the fault emplaces pre-Mississippian rocks on Mississippian through Triassic strata. East of Itkilyariak Creek, the offset of Mississippian and younger strata across the Weller thrust decreases to zero beneath a prominent fold in Mississippian to Triassic strata in the eastern Sadlerochit Mountains.

Seismic-reflection data suggest that thrust faults soling in pre-Mississippian rocks emplace preMississippian and younger Paleozoic rocks on strata above the so-called Lower Cretaceous unconformity (LCU). On seismic line 84-14 (pl. 5), reflectors interpreted to correspond to the downdip continuation of pre-Mississippian and overlying Paleozoic strata extend from the surface down to an abrupt termination marked by diffractions. Reflections corresponding to the LCU and overlying strata extend beneath reflections corresponding to overthrust pre-Mississippian and younger rocks.

Seismic data indicate that very large faultfloored anticlines, cored by pre-Mississippian rocks and similar to the anticlines in the Sadlerochit and Shublik Mountains, occur beneath the coastal plain (fig. 20.3). Structural culminations of the anticlines in the western 1002 area are right en échelon to the northeast and align with culminations in the Sadlerochit and Shublik Mountains. The culminations change trend to the east and extend beneath the Niguanak Ridge area and head offshore. The location of these anticlines probably reflects the distribution of detached pre-Mississippian rocks under the coastal plain.

\section{Sunset Thrust Fault and Overlying Thrust Sheet}

Structural discontinuity at the pre-Mississippian unconformity indicates detachment between the nearly homoclinal, south-dipping pre-Mississippian rocks and the concentrically folded overlying strata (pl. 5, Domain II). Above the unconformity, Mississippian and younger strata are locally deformed in north-vergent, locally overturned folds cored by commonly brecciated but not measurably rotated pre-Mississippian rocks (fig. 20.4). In order for the basement-cored structures to be emplaced without solution or flow folding, the basement rocks must slip parallel to bedding planes, compositional layering, and foliation into the cores of the folds; such slip indicates structural discontinuity between preMississippian and overlying rocks (fig. 20.4).

A thrust fault along the pre-Mississippian unconformity, herein referred to as the Sunset thrust, is probably a roof thrust, at least locally, for imbricate thrust faults in pre-Mississippian rocks. Some thrust faults in pre-Mississippian rocks merge with the Sunset thrust without recognizably offsetting Mississippian and younger rocks (pl. 5, cross sections $A-A^{\prime}, B-B^{\prime}, D-D^{\prime}$, and $\left.E-E^{\prime}\right)$. Transfer of movement from south-dipping thrust faults in the pre-Mississippian rocks to the Sunset thrust would produce a north sense of movement to Mississippian and younger strata unless there was complete decoupling across the Sunset thrust. A complete decoupling would allow imbrication of preMississippian rocks without appreciable transport of strata above the Sunset thrust. Imbrication of the preMississippian rocks is inferred from the recognition of thrust faults and probable repeated carbonate strata in the pre-Mississippian sequence without clear evidence of isoclinal folding in the homoclinal section. The stratigraphy and structure of the pre-Mississippian rocks are too poorly understood to confidently delineate imbrications.

The thrust sheet above the Sunset thrust fault consists of up to eight stratigraphic units (pl. 5, Domain II). The units range in overall age from Mississippian to Early Cretaceous; in ascending order, they are the Kekiktuk Conglomerate and Kayak Shale (Endicott Group), Lisburne Group, Sadlerochit Group, Shublik Formation, Kingak Shale, Kemik Sandstone, and pebble shale unit. Strata in the domain are unimbricated and little folded except where incorporated into the broad and compound anticlines that underlie the Sadlerochit and Shublik Mountains; the Sadlerochit, Itkilyariak, and Nularvik anticlines underlie the Sadlerochit Mountains.

Stratigraphic units exposed in the Sunset thrust sheet differ across the map area. Generally, the Triassic and Permian Sadlerochit Group and older strata underlie the present erosion surface. On the lower slopes of the mountains, especially in the Sadlerochit Mountains, post-Permian strata in the Sunset thrust sheet crop out.

In the northeastern foothills of the Sadlerochit Mountains, the Sunset thrust sheet includes strata as young as Early Cretaceous, the Kemik Sandstone and the lower part of the pebble shale unit (fig. 20.5). These Lower Cretaceous strata unconformably overlie the Sadlerochit Group; the Kingak Shale, Shublik Formation, and part of the Sadlerochit Group are missing because of erosion in Early Cretaceous time. Lower Cretaceous strata in the Sunset thrust sheet are undeformed, in marked contrast to imbricate blocks composed of the Jurassic Kingak Shale and Lower Cretaceous strata that make up the overlying Marsh Creek thrust sheet (Domain VI, fig. 20.5B). 
On the south flank of the Sadlerochit Mountains, the Kingak Shale and Shublik Formation in the Sunset thrust sheet occur under the LCU. Although field observations are inadequate to clearly identify a boundary with the overlying thrust sheet, the upper boundary of the Sunset thrust sheet is probably in the Kingak Shale because (1) strata below the Kingak Shale are well exposed and seem relatively undeformed, and (2) an overlying thrust sheet (pl. 5, Domain VI) on the north flank of the mountains includes the Kingak Shale, structurally transported to the north-northwest and probably derived from south of the Sadlerochit Mountains, where the Kingak Shale is present below the LCU. Additionally, the fault-repeated Kingak Shale (pl. 5 , Domain VI) probably occurs above the Sunset thrust sheet on the southwestern flank of the Sadlerochit
Mountains, which further suggests though does not prove that a regional thrust-fault boundary exists in the Kingak Shale along the southern foot of the Sadlerochit Mountains.

In the north-central Sadlerochit Mountain foothills, the Sunset thrust sheet possibly includes strata above the Lower Cretaceous pebble shale unit. An SSD (pl. 5, Domain VII) consisting of seemingly undisturbed Cretaceous strata above the pebble shale unit (including the Inoceramus zone, gamma-ray zone, and younger beds of the Hue Shale) occurs west of and adjacent to the Nularvik River. This sequence may be depositionally continuous with strata that make up the Sunset thrust sheet elsewhere on the north flank of the Sadlerochit Mountains, and hence it may be part of the Sunset thrust sheet. Along strike, strata that make up the domain east

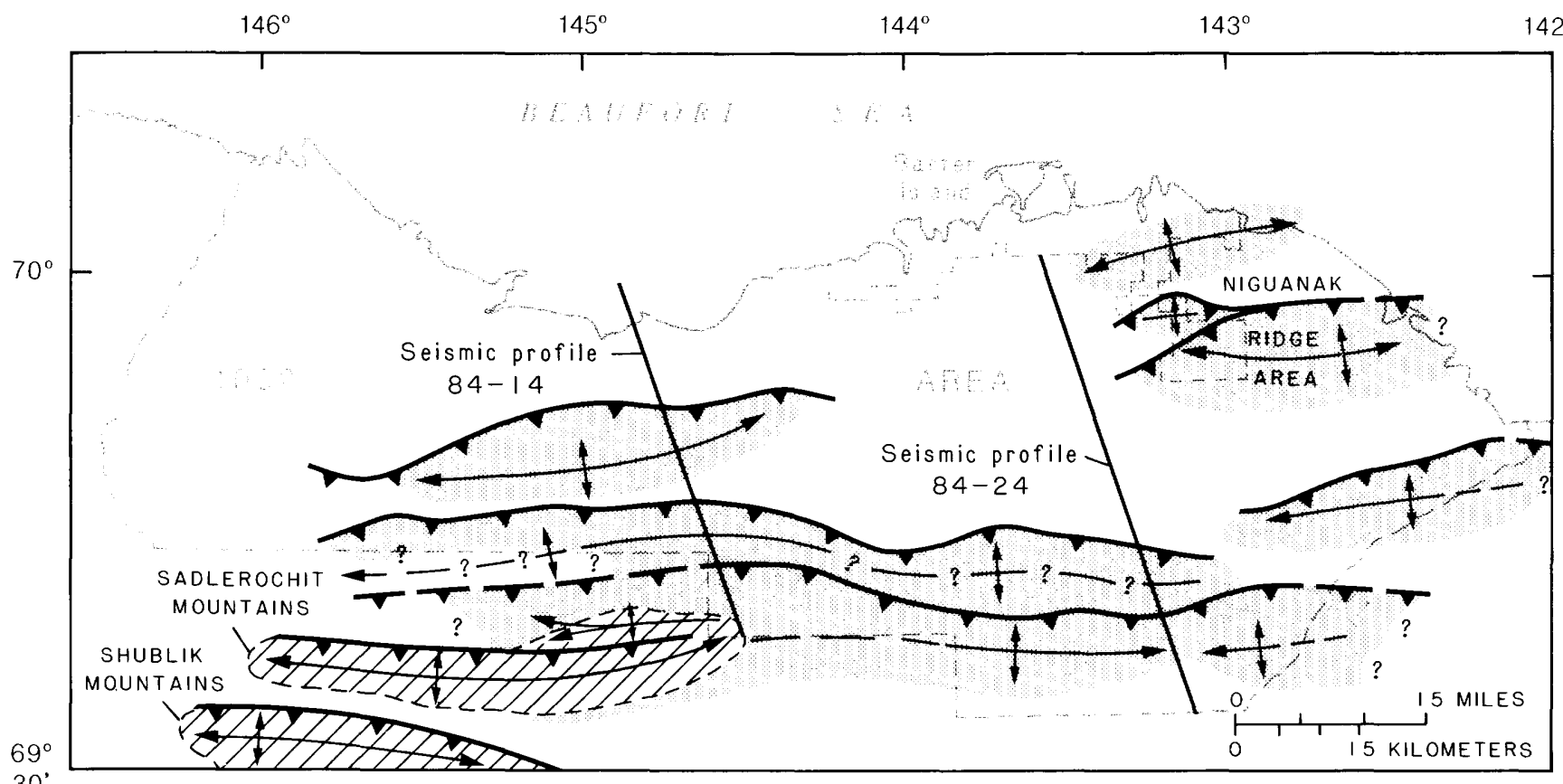

$30^{\circ}$

EXPLANATION

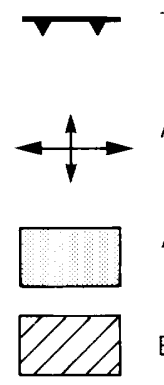

Thrust fault that emplaces anticline cored by pre-Mississippian rocks--Dashed where approximately located. Sawteeth on upper plate

Approximate location of axis of anticline cored by pre-Mississippian rocks, showing direction of plunge--Dashed where approximately located; queried where uncertain

Approximate and inferred part of anticline cored by pre-Mississippian rocks under Arctic coastal plain

Exposed part of anticline cored by pre-Mississippian rocks

Figure 20.3. Distribution of large anticlines cored by pre-Mississippian rocks in Sadlerochit and Shublik Mountains and under the 1002 area. 
of the Nularvik River (pl. 5, Domain VII) occur in the structurally complex thrust sheets above the Sunset thrust sheet.

Strata in the Sunset thrust sheet may now lie 24 $\mathrm{km}(15 \mathrm{mi})$ north-northwest of their prethrust position as reflected by the northward deviation of the truncation edge of the Kingak Shale under the LCU. Regionally, except for a fault-controlled excursion under Prudhoe Bay, the truncation edge of the Kingak Shale trends east-southeast across northern Alaska to the Sadlerochit Mountains, where its trend abruptly becomes easterly (fig. 20.6). The change in trend probably results from tectonic transport above the Sunset thrust. The deviation of the truncation edge from its regional trend appears to be about $24 \mathrm{~km}(15 \mathrm{mi})$ in the eastern Sadlerochit Mountains.

The maximum amount of transport of strata above the Sunset thrust is unclear from imbrication observed below the thrust. The number, dimension, and distribution of imbricate blocks of pre-Mississippian rocks below the Sunset thrust are unmapped, poorly recorded in the seismic records, and not well enough
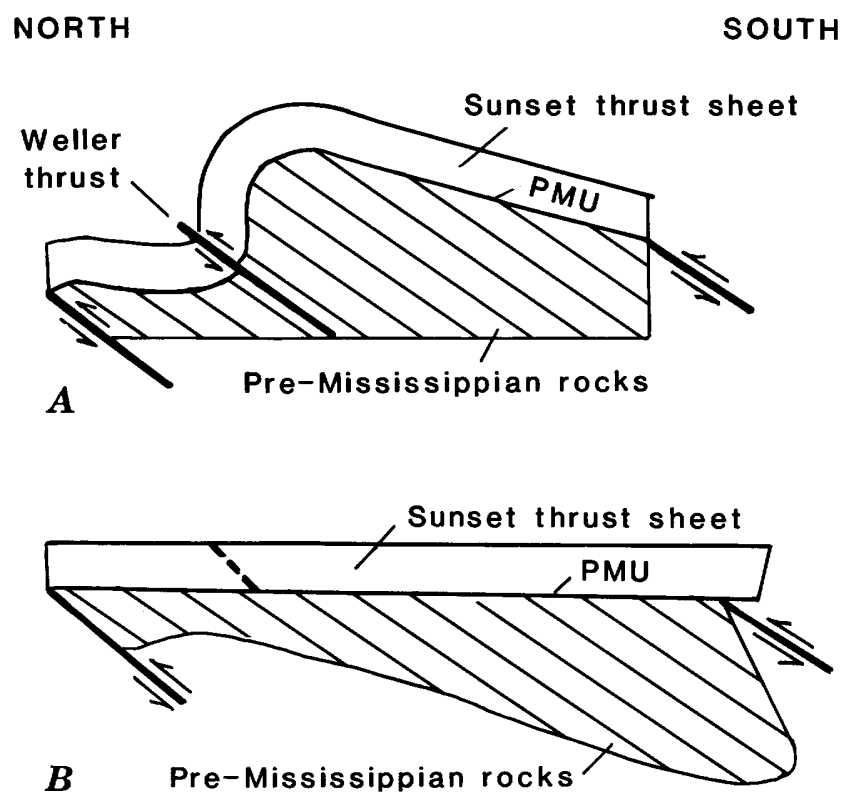

Figure 20.4. Structural discontinuity along preMississippian unconformity (PMU) in eastern Sadlerochit Mountains. Arrows indicate direction of relative movement. $A$, Displacement on Weller thrust dies out under anticline in Mississippian and younger strata. $B$, Retrodeformed section shows that Mississippian and younger strata are concentrically folded and preMississippian rocks slip into core of anticline on preexisting zones of weakness including bedding, compositional layering, and foliation. Dashed line indicates site of Weller thrust. known to constrain movement of the overlying Sunset thrust.

Transport above the Sunset thrust influences the distribution of pre-Cretaceous strata in the 1002 area. Tectonic transport of the Kingak Shale, Shublik Formation, Sadlerochit Group, Lisburne Group, and Endicott Group above the Sunset thrust causes these units to lie farther north (beneath the coastal plain) than predicted by regional trends between the Prudhoe Bay area and the western Sadlerochit Mountains.

\section{Marsh Creek Thrust Fault and Overlying Thrust Sheet}

Imbricate blocks composed of the Kingak Shale, Kemik Sandstone, and pebble shale unit (pl. 5, Domain VI) occur along the southwest, north-central, and
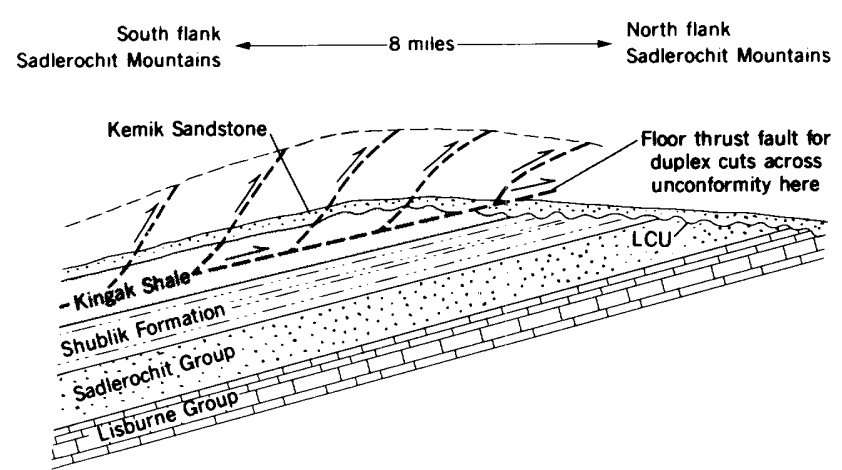

$\boldsymbol{A}$

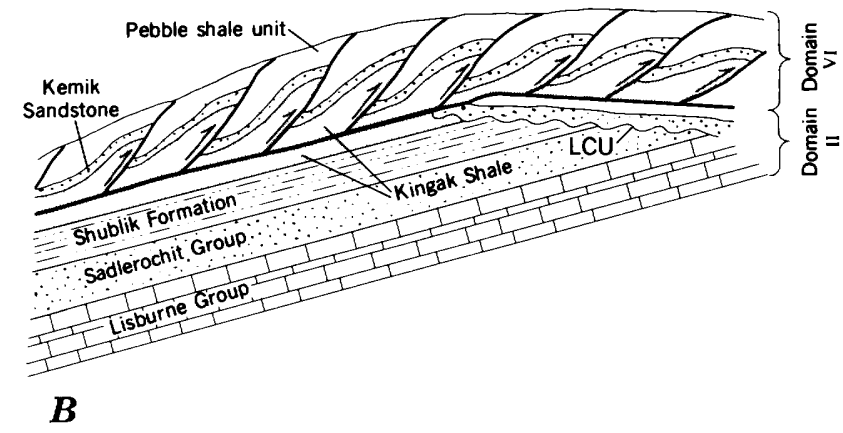

EXPLANATION

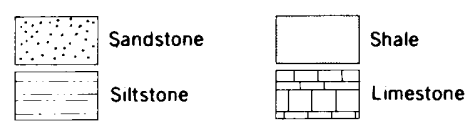

Figure 20.5. Marsh Creek and Sunset thrust sheets (domains VI and II, respectively) in western Sadlerochit Mountains. Arrows indicate direction of relative movement. $A$, Distribution of strata before thrusting. $B$, Generation of duplex (see fig. 20.8 for nomenclature) involving thrust transport of the Kingak Shale northward across truncation edge below Lower Cretaceous unconformity (LCU). 
northeast flanks (fig. 20.7) of the Sadlerochit Mountains. Because the Kingak Shale and Shublik Formation are missing below the LCU on the northeast side of the Sadlerochit Mountains, emplacement of the Kingak Shale on Lower Cretaceous strata north of the Sadlerochit Mountains apparently took place when the Marsh Creek thrust sheet was transported from a more southerly location where the Kingak Shale escaped complete erosional truncation prior to thrusting (fig. 20.5).

Along the south-central and southeastern flanks of the Sadlerochit Mountains, the Marsh Creek thrust fault probably separates unimbricated strata of the Sunset thrust sheet from poorly known, seemingly unimbricated Jurassic and younger strata (pl. 5, Domain VIII and cross section $\left.E-E^{\prime}\right)$. The location of the Marsh Creek thrust is uncertain and unmapped between outcrops of the Marsh Creek thrust sheet on the southwestern and southeastern flanks of the Sadlerochit Mountains.

Northeast of the Sadlerochit Mountains, the Marsh Creek thrust fault floors a duplex structure (fig. 20.8). Thrust faults producing prominent footwall cutoffs of the Kemik Sandstone on upper Marsh Creek (fig. 20.9) and elsewhere branch upward from the Marsh Creek thrust and are interpreted to ramp into a roof thrust fault, now removed by erosion. Strata overlying the pebble shale unit are not present in the imbricate blocks, and this indicates that the imbricate faults ramped into a roof thrust fault in the pebble shale unit.

An erosional remnant of the Marsh Creek thrust sheet occurs on the north-central flank of the Sadlerochit Mountains between the Katakturuk and Nularvik Rivers. The Marsh Creek thrust underlies exposures of structurally repeated Kemik Sandstone, and the Itkilyariak thrust cuts the Marsh Creek thrust. The thrust remnant is probably a small part of the leading edge of

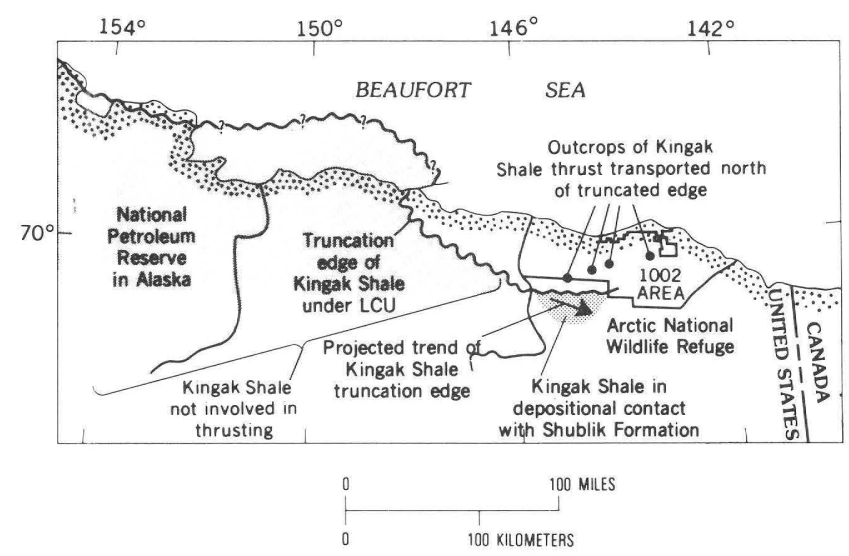

Figure 20.6. Areal distribution of the Kingak Shale, modified from Magoon and Bird (1985), showing eastsoutheast-trending truncation edge beneath Lower Cretaceous unconformity (LCU). the Marsh Creek thrust sheet because other remnants do not occur down-plunge to the west.

Repeated strata above the Marsh Creek thrust occur on the southwest flank of the Sadlerochit Mountains. The location of the Marsh Creek thrust east of these repeated strata is uncertain. The structural geology of the strata underlying Ignek Valley (pl. 5, Domain VIII) and the relation of these strata to the Marsh Creek thrust are not well known.

The duplex structure above the Marsh Creek thrust on the northeast flank of the Sadlerochit Mountains extends onto seismic line 84-14, although it is not clear in the reflection patterns. The duplex structure is an overthrust block that progressively lies on younger strata northward.

The amount of overthrusting of Jurassic strata is uncertain on line 84-14 (pl. 5), but it could be as much as $32 \mathrm{~km}$ (20 mi) east of line 84-14. The Jurassic Kingak Shale southeast of the Niguanak Ridge lies along trend with the structurally transported Kingak Shale above the Marsh Creek thrust in the Sadlerochit Mountains and is about $32 \mathrm{~km}(20 \mathrm{mi})$ north of the eastward-projected truncation edge of the Kingak Shale (fig. 20.6). Transport in the Sadlerochit Mountains area seems less because the erosional remnant of the Marsh Creek thrust sheet on the north-central flank of the mountains is probably near the leading edge of the sheet. Additionally, the present distribution of the structurally transported Kingak Shale north of the Sadlerochit Mountains does not require tens of miles of structural transport; the projected truncation edge of the Kingak Shale in the Sunset thrust sheet under the LCU is less than $8 \mathrm{~km}(5 \mathrm{mi})$ south of the outcrops of the thrusttransported Kingak Shale on the northeastern flank of the Sadlerochit Mountains.

\section{West Fork Thrust Fault and Overlying Thrust Sheet}

Repetition of stratigraphic units above and including part of the Cretaceous pebble shale unit in outcrops demonstrates a BST fault-the West Fork thrust fault-in the pebble shale unit (pl. 5, Domain III). The pebble shale unit and the gamma-ray zone and Inoceramus zone of the Hue Shale, exclusive of beds below the pebble shale unit and above the Inoceramus zone, are repeated above the West Fork thrust. Additionally, thickening of these mostly shale units to many times their aggregate depositional thickness of about $140 \mathrm{~m}(450 \mathrm{ft})$ above the West Fork thrust indicates substantial structural repetition. Although the Sunset and Marsh Creek thrust sheets also include the pebble shale unit, neither sheet includes repetition of strata above the pebble shale unit.

Structurally repeated strata above the West Fork thrust fault are poorly exposed. Dips in the most 
continuously exposed and least disrupted sections are south. Most folds verge approximately north. Superposition of stratigraphic units in the West Fork thrust sheet suggests that much of the section is rightside-up, but many zones appear chaotic. The structural repetition above the West Fork thrust has characteristics of a duplex fault zone (floor, roof, and connecting imbricate thrust faults), but the tight folding of strata suggests that structural thickening is not restricted to simple imbrication.
An unrepeated sequence of the stratigraphic units that make up the West Fork thrust sheet occurs north of the Sadlerochit Mountains (pl. 5, Domain VII). The stratigraphic sequence dips north and seems to be depositionally continuous with the sequence that makes up the underlying Sunset thrust sheet (pl. 5, Domain II); no prominent gouge zone was observed at the domain boundary, and strata in both domains appear to be in normal stratigraphic sequence.

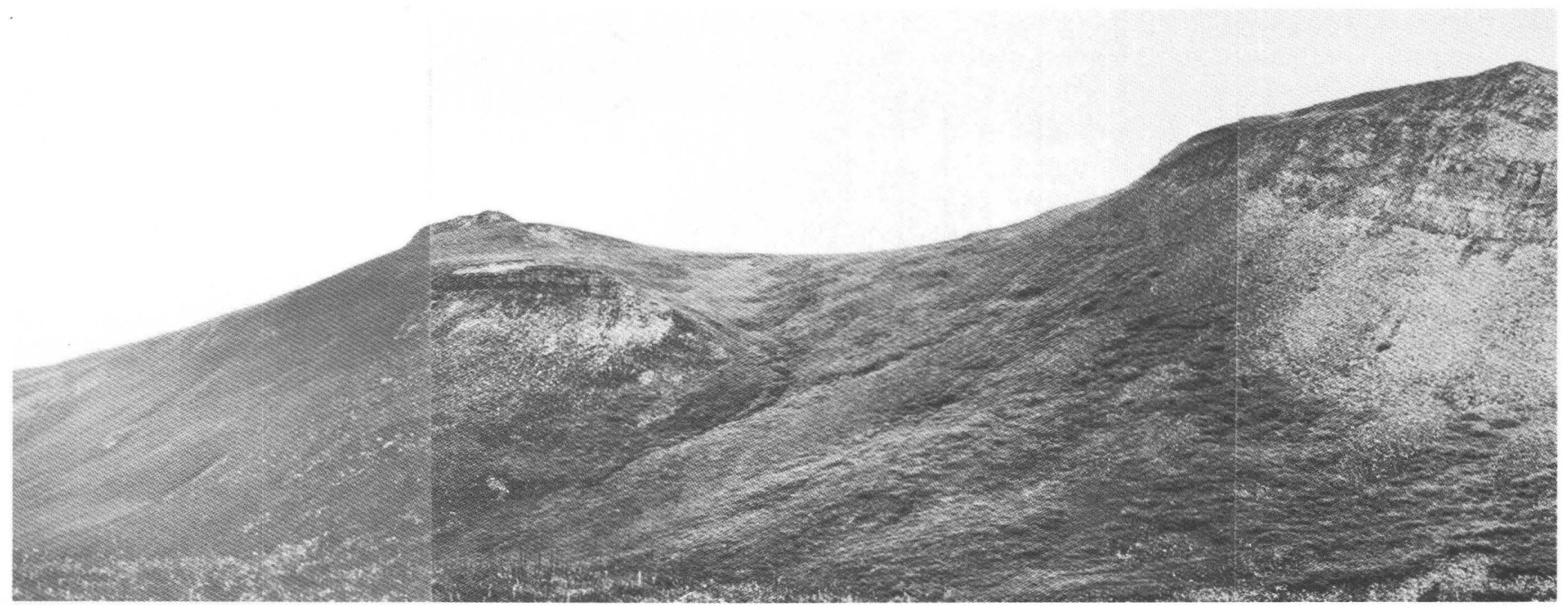

$\boldsymbol{A}$

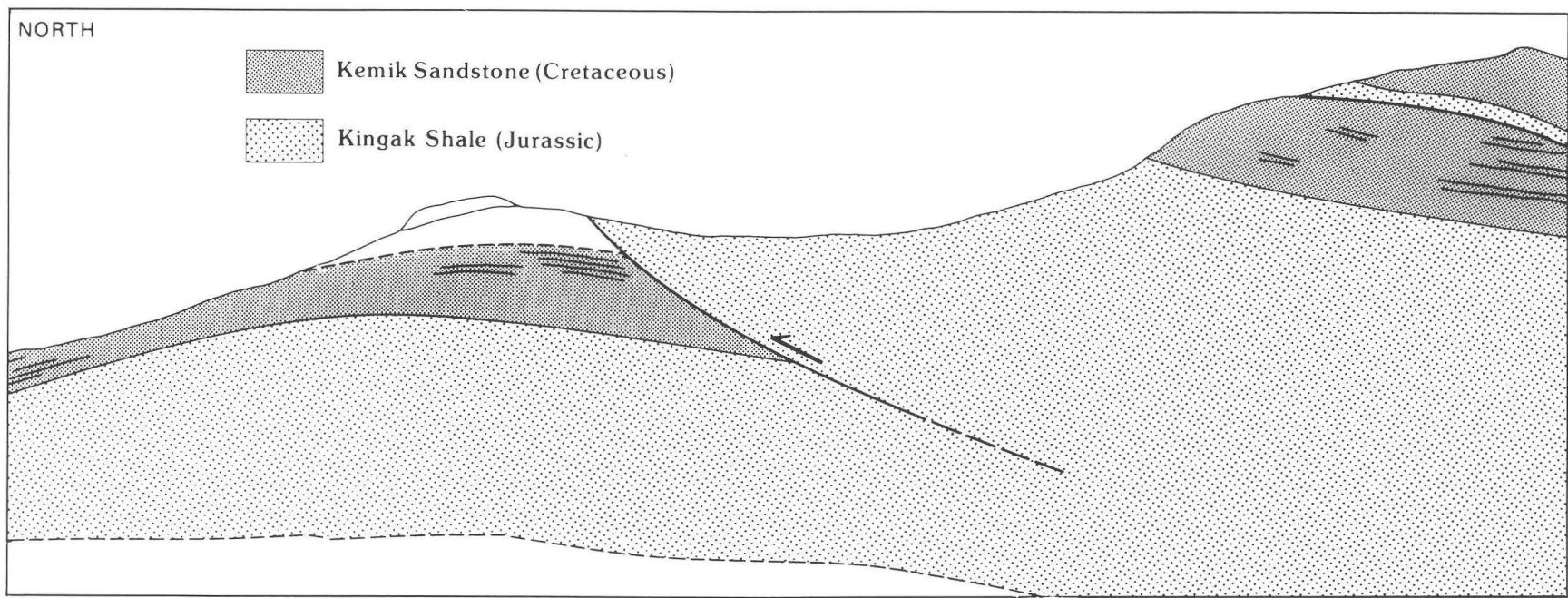

$\boldsymbol{B}$

Figure 20.7. Imbrication of the Kemik Sandstone above Marsh Creek thrust along upper Marsh Creek north of Sadlerochit Mountains. A, Panoramic photo-composite with view to the east. $B$, Sketch of geologic details shown in A. Arrows indicate direction of relative movement. 
The West Fork thrust fault probably separates the domain with the unrepeated sequence (pl. 5, Domain VII) from the overlying sequence (pl. 5, Domain IV). A fault does occur above the unrepeated stratigraphic section, since the overlying domain consists of repeated strata. No fault is recognized at the base of the domain containing the unrepeated Cretaceous strata (pl. 5, Domain VII), although an unrecognized fault could separate this domain from unrepeated strata of the Sunset thrust sheet. The West Fork thrust probably steps upsection by lateral ramping and thus separates the domain containing the unrepeated Cretaceous strata (pl. 5, Domain VII) from a thrust sheet consisting of the same strata in imbricate blocks. Lateral ramps are consistent with recognition of a fault at the top of, but not at the base of, the unrepeated strata.

The West Fork thrust fault and thrust sheet extend under the coastal plain. The structurally repeated
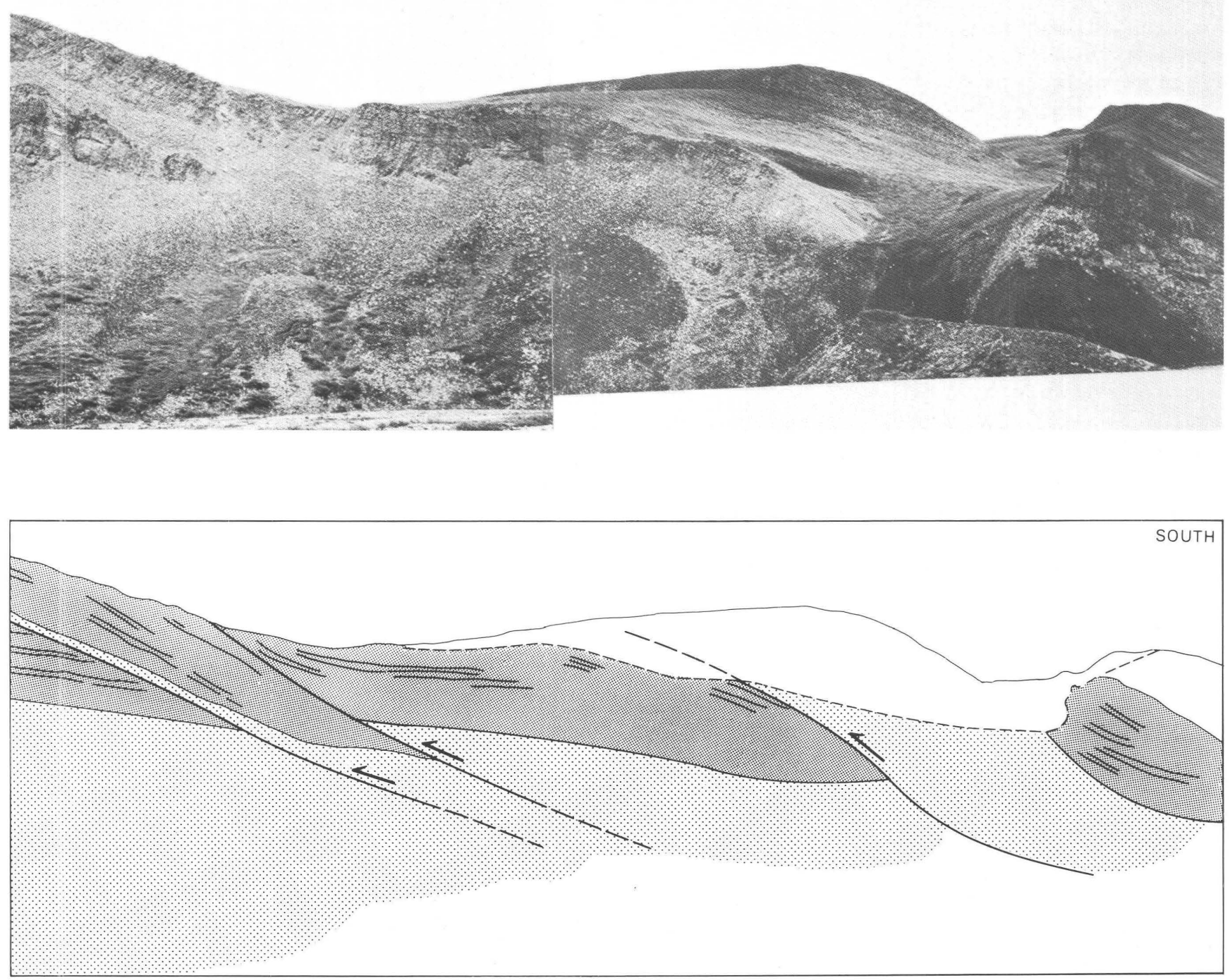
pebble shale unit and elements of the Hue Shale in the West Fork thrust sheet are transported north-northwest, probably over the unrepeated pebble shale unit in the Sunset thrust sheet and progressively younger strata.

\section{Nularvik Thrust Fault and Overlying Thrust Sheet}

Repetition of tuff, shale, and turbidite beds independent of underlying strata reflects repetition above a BST fault in the Hue Shale, here termed the Nularvik thrust fault. In the map area, the fault most likely lies in fissile, organic-carbon-rich, bentonite-bearing shale in the lower part of the Hue Shale. The thrust sheet overlying the Nularvik thrust fault (pl. 5, Domain IV) probably consists of repetitions of about $300 \mathrm{~m}(1,000 \mathrm{ft})$ of shale, discontinuous and scattered turbidite beds, and a prominent red-weathering tuff unit that occurs near the base of the repeated section.

The Nularvik thrust sheet (pl. 5, Domain IV) lies between two thrust faults, but the nature of the repetition in the thrust sheet is not clear from outcrop information. Poor and scarce outcrops with few marker beds limit evaluation of the roles of imbrication and folding in the structural thickening of the interval. Deformation observed in isolated outcrops includes chevron folds in tuff, steep dips, and local chaotic disruption of the repeated interval.

Seismic line 84-14 (pl. 5) transects the outcrop of the Nularvik thrust sheet. Reflection patterns from the thrust sheet suggest that fault-floored anticlines, much broader than those evident in surface observations, underlie the coastal plain. Several prominent reflectors on line 84-14 suggest that some south-dipping thrust faults splay up from the Nularvik thrust but do not seem to cut and offset the fault flooring the overlying thrust sheet (pl. 5, Domain V). The quality of the data on line

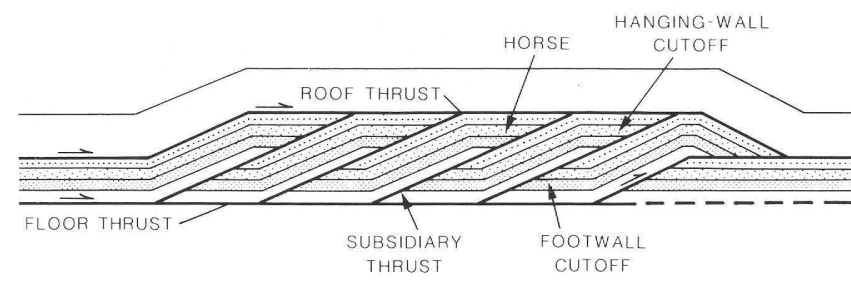

Figure 20.8. Relations and nomenclature of a duplex (modified from Boyer and Elliot, 1982, p. 1208, fig. 19). Subsidiary thrust faults connect floor thrusts to roof thrust and separate horses. Hanging-wall cutoffs occur where subsidiary thrusts crosscut strata in hanging wall, and footwall cutoffs occur where subsidiary thrusts form ramps in footwall. Note anticlines in horses. Arrows indicate direction of relative movement.
84-14 is inadequate to clearly identify the imbrication pattern expected in the Nularvik thrust sheet (pl. 5, Domain IV).

Structural thickening in the Nularvik thrust sheet is probably very great. Strata that make up the sheet have an undisturbed thickness of about $300 \mathrm{~m}(1,000 \mathrm{ft})$, but the thickness of the sheet ranges from about 1,000 to $3,900 \mathrm{~m}(3,300$ to $12,800 \mathrm{ft})$.

The lack of direct measurement of stratigraphic and thrust-sheet thicknesses, together with the locally poor quality of reflection data, limit confidence in interpreting the amounts of thickening and structural shortening in the Nularvik thrust sheet on line 84-14. The thickness estimates for the strata that make up the thrust sheet are from wells west of the 1002 area (pl. 1), and such thicknesses may not be representative of the 1002 area. Turbidite sandstone beds (pl. 5, Domain V) above the Nularvik thrust sheet (pl. 5, Domain IV) prograde northeast, which raises the possibility that the thickness of the principally shale section being repeated could increase to the north and east if the roof thrust to the Nularvik thrust sheet follows the sandstone and shale transition (fig. 20.10). In addition, interval velocities used to calculate depths on line 84-14 are from wells west of the 1002 area (chap. 17). Velocities in these wells may misrepresent the 1002 area subsurface seismic velocities, and thus they may not accurately represent the velocity field along line 84-14. If the subsurface velocities along line 84-14 are significantly lower than those found in the wells, the computed layer thicknesses will be too large.

\section{Katakturuk Thrust Fault and Overlying Thrust Sheet}

A striking contrast in structural style and degree of deformation between the Hue Shale and the overlying lower Paleocene turbidites of the Canning Formation in

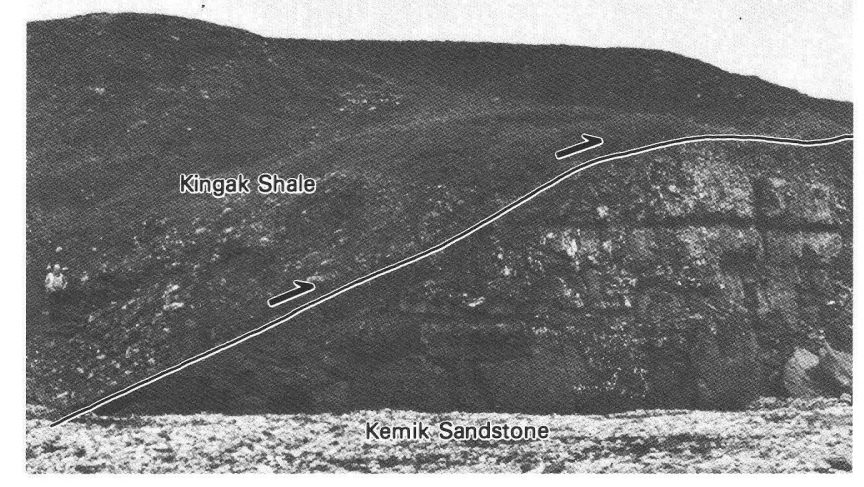

Figure 20.9. Footwall cutoff in the Kemik Sandstone on upper Marsh Creek north of Sadlerochit Mountains. View is to the west. Note man for scale. 
outcrops north of the Sadlerochit Mountains indicates detachment between the turbidites and the underlying Nularvik thrust sheet (pl. 5, Domain IV). This major fault, which is the structurally highest among those north of the Sadlerochit Mountains, is herein referred to as the Katakturuk thrust fault (pl. 5). Narrow, mappable, faultcored anticlines and broad, open synclines occur in these turbidite beds. The continuity and longer wavelength of the folds in the turbidites contrast sharply with the discontinuous, generally short-wavelength, complex structures in strata observed under the Katakturuk thrust.

The Katakturuk thrust sheet consists of Paleocene and latest Cretaceous turbidites of the Canning Formation and younger strata. The thrust sheet includes the Eocene unconformity as well as overlying Tertiary and Quaternary strata.

Seismic line 84-14 transects the Katakturuk thrust sheet. Under the coastal plain, the thrust sheet is recognizable at least as far north as the Marsh Creek triangle zone, where the sheet forms part of the south limb of this structure (pl. 5, line 84-14). Continuation of the thrust sheet (pl. 5, Domain V) north of the Marsh Creek structure is not clear on line 84-14. Reflection patterns from the turbidites along the base of the sheet are relatively continuous and simple, in contrast to complex reflection patterns from underlying structurally thickened strata. North of the Marsh Creek triangle zone, the contrast in reflection patterns diminishes across the thrust coincident with the declining deformational intensity of strata under the Katakturuk thrust sheet. On line 84-14, the Katakturuk thrust sheet is part of two triangle zones-the Marsh Creek triangle zone and a similar, unnamed triangle zone south of the Marsh Creek structure. These zones are produced by differential structural thickening of the Nularvik thrust sheet under the Katakturuk thrust sheet (pl. 5, fig. 20.11). A greater amount of structural shortening has taken place beneath the Katakturuk thrust fault than has taken place above it. Deformation above the thrust consists of broad synclines and asymmetrical triangle zones. Structural shortening, as inferred by structural thickening of the Nularvik thrust

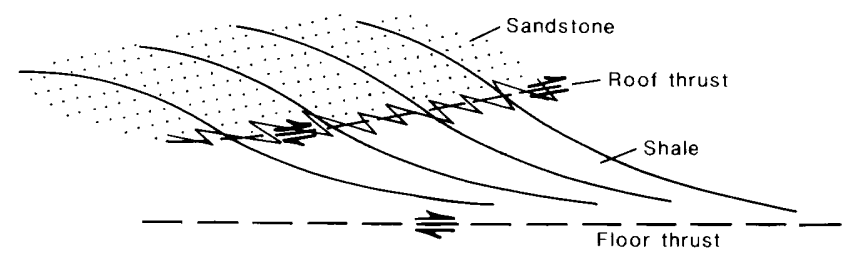

Figure 20.10. Roof thrust for Nularvik thrust sheet could cut up-section along sandstone-shale transition in prograding Late Cretaceous and Paleocene turbidites of the Canning Formation. Arrows indicate direction of relative movement. sheet, is greater than that reflected in folds and small faults above the Katakturuk thrust.

There seems to be little geometric discontinuity across thrust faults that sole into the Katakturuk thrust fault as well as limited beveling of hanging wall blocks and only slight truncation of reflectors against the Eocene unconformity; thus, displacements on these thrust faults are probably small. Some of the faults that sole into the Katakturuk thrust cut the Eocene unconformity, especially the one in the Marsh Creek triangle zone. This is consistent with outcrop observations of fault gouge and abundant slickensides in the core of the Marsh Creek triangle zone west of line 84-14.

\section{STRUCTURAL GEOLOGY OF THE EASTERN COASTAL PLAIN, NORTHEASTERN BROOKS RANGE, AND SEISMIC LINE 84-24}

The structural geology of the eastern part of the coastal plain in the Arctic National Wildlife Refuge (ANWR) is less understood than that of the western part. Structural trends involving the pre-Mississippian rocks plunge from the Sadlerochit Mountains and are clearly seen on seismic data beneath the southeastern coastal plain. East-west continuity, however, is less evident in younger strata.

Interpretation of reflection patterns on seismic line $84-24$ (pl. 5) and their apparent similarity to patterns on line $84-14$ is the basis for the provisional conclusions regarding the eastern part of the 1002 area. Poor-quality reflection data and a lack of 1:63,360-scale surface mapping along line 84-24 limit the certainty of interpretations, especially with regard to the identification of rock units under the coastal plain. Additionally, thrust

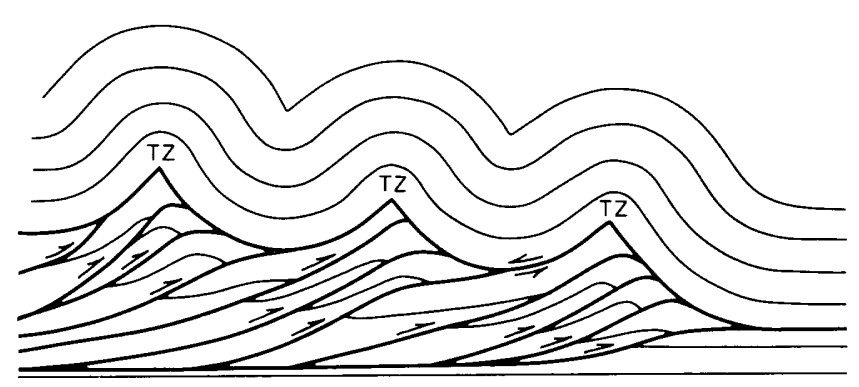

Figure 20.11. Triangle zones (TZ) produced by imbrication of strata under detachment at base of concentrically folded strata (modified from Jones, 1982, p. 73, fig. 25). Arrow above detachment between concentrically folded strata and imbricated strata represents relative movement; shortening below detachment is greater than shortening in concentrically folded strata above detachment. 
faulting and detachment folding in Mississippian through Triassic strata exposed in the northeastern Brooks Range may exist, but be unrecognized, beneath the eastern coastal plain.

\section{Seismic Line 84-24}

In order to facilitate discussion of line 84-24, the nomenclature introduced for the Sadlerochit and Shublik Mountains area and applied to line 84-14 is extended to line 84-24. In doing so, we are not stating, nor do we mean to imply, that individual faults are continuous between lines 84-14 and 84-24; rather, we consider the faults to be analogous in at least a structural-stratigraphic and kinematic sense.

Thrust faults interpreted in the pre-Mississippian rocks on line 84-24 appear similar to those in the Sadlerochit and Shublik Mountains area and the western coastal plain. Two south-dipping thrust faults, apparently analogous to the frontal thrusts of the Sadlerochit and Shublik Mountains (the Weller and Hue thrusts, respectively), underlie two anticlines cored by preMississippian rocks on seismic line 84-24 (fig. 20.3). The southernmost anticline is the down-plunge continuation of the Sadlerochit anticline. The anticline north of the Sadlerochit anticline corresponds in shape and position to an anticline in the subsurface north of the Sadlerochit Mountains on line 84-14. Both anticlines involving pre-Mississippian rocks on line 84-24 are fault floored and thrust over strata above the LCU.

Under the eastern coastal plain, faults that cut the pre-Mississippian rocks are similar to faults that cut the pre-Mississippian rocks in the Sadlerochit and Shublik Mountains and in the western coastal plain and that probably sole into a BST fault under the eastern coastal plain. South-dipping reflectors, similar in pattern to faults in the pre-Mississippian rocks under the Sadlerochit Mountains, occur under the Sadlerochit anticline on line 84-24 and seem to merge with a roof thrust, similar to the Sunset thrust fault below the LCU. The down-plunge continuation of the Sadlerochit anticline has a sole thrust analogous to the Itkilyariak thrust fault and probably emplaces Precambrian or lower Paleozoic rocks on Cretaceous strata. Sole thrusts under both anticlines that involve the pre-Mississippian rocks on line 84-24 and the imbricate faults under the downplunge continuation of the Sadlerochit anticline probably merge to a BST fault in the pre-Mississippian rocks.

A thrust fault, similar to the Sunset thrust fault in the Sadlerochit Mountains, probably occurs along the pre-Mississippian unconformity on line 84-24. The down-plunge continuation of the Sadlerochit Mountains anticline seems to include imbricate faults that merge with a roof thrust along the clearly visible LCU.

The northern extent of this Sunset thrust analog is uncertain. Record quality is too poor to confidently identify imbricate thrusts in the pre-Mississippian rocks north of the down-plunge continuation of the Sadlerochit Mountains anticline. Sole thrusts under anticlines cored by the pre-Mississippian rocks cut the pre-Mississippian and Lower Cretaceous unconformities in seismicreflection records under the coastal plain (pl. 5, line 8424) and indicate detachment. Although detachment of pre-Mississippian rocks is probably widespread under the coastal plain, the extent of the fault analogous to the Sunset thrust is uncertain, especially where the preMississippian and Lower Cretaceous unconformities merge.

Reflection patterns on line $84-24$ are similar to those present on line 84-14 that are interpreted to indicate subsurface continuation of a BST fault similar to the West Fork thrust fault in the Sadlerochit Mountains. Imbrication is interpreted from reflection patterns above reflections that are above and parallel to the clearly visible LCU, which in turn is above and north of the continuation of the Sadlerochit anticline on line 84-24. Poor seismic-record quality obscures definition of imbricate blocks above the BST; however, numerous footwall cutoffs are tentatively interpreted along the BST. The BST fault that is analogous to the West Fork thrust fault extends most of the length of line 84-24. Thrust sheets analogous to the Nularvik and Marsh Creek thrust sheets are not clear on line 84-24.

Strata on line 84-24 above the BST fault analogous to the BST immediately above the LCU on line 84-14 include Jurassic and possibly older rocks transported from the south-southeast, where Jurassic strata are inferred to occur below the LCU. This relationship is probably similar to that between the Marsh Creek thrust sheet and the truncation of the Kingak Shale beneath the LCU in the Sadlerochit Mountains (fig. 20.5). Southeast of the Niguanak Ridge and east of line 84-24, the Kingak Shale crops out about $32 \mathrm{~km}(20 \mathrm{mi})$ north of the presumed truncation edge of the Kingak Shale (fig. 20.6).

A BST fault, similar to the Marsh Creek thrust fault in the Sadlerochit Mountains, is not visible on line 84-24 but probably exists. A sole thrust for a prominent thrust block lying on strike between the Jurassic Kingak Shale outcrops southeast of Niguanak Ridge and the structurally transported Kingak Shale in the Sadlerochit Mountains is visible on line 84-24. The thrust block probably includes structurally transported Jurassic strata and may be part of an extensive overthrust sheet. The Jurassic strata probably overlie a thrust fault that soles into a BST fault on line 84-24 that is similar to the Marsh Creek thrust fault. This BST fault is in turn above the BST fault analogous to the West Fork or Nularvik thrust fault.

A major thrust fault, similar to the Katakturuk thrust fault in the Sadlerochit Mountains, occurs on line 84-24; the thrust fault and overlying thrust sheet are referred to as the "Katakturuk" thrust fault and thrust 
sheet for ease of description. The "Katakturuk" thrust fault separates underlying imbricated strata from little deformed strata that make up the flanks of triangle zones. Paleocene and younger strata make up the "Katakturuk" thrust sheet.

The "Katakturuk" thrust sheet differs from the Katakturuk thrust sheet in the Sadlerochit Mountains and along line 84-14. The Eocene unconformity truncates the "Katakturuk" thrust in a triangle zone along strike with Kingak Shale outcrops southeast of Niguanak Ridge. At least one thrust fault, soling below the "Katakturuk" thrust fault, cuts the "Katakturuk" thrust and the Eocene unconformity. Additionally, the "Katakturuk" thrust is locally the BST for structural telescoping.

At the south end of the interpreted part of line 84-24, the "Katakturuk" thrust sheet comprises a number of thrust imbrications. Subsidiary thrust faults branch upward from the "Katakturuk" thrust fault to produce the nearly threefold thickening of the Paleocene and Eocene(?) strata.

The amount of structural telescoping of Paleocene and Eocene(?) strata within the "Katakturuk" thrust sheet at the south end of line 84-24 is unknown. The Jago River Formation (chap. 5), a mostly nonmarine sandstone, occurs adjacent to and west of the telescoped Paleocene strata on line 84-24 (fig. 20.1). The Jago River Formation is anomalous in that it comprises the only nonmarine Upper Cretaceous and Paleocene strata recognized in the 1002 area. Transitional facies between the Jago River Formation and the coeval turbidite sandstone and marine shale are not seen in outcrop but may be obscured by structural complexity involving the "Katakturuk" thrust fault.

Although obscure, Paleocene strata on the southern part of line 84-24 and the "Katakturuk" thrust fault probably are part of a larger, compound thrust sheet floored by a BST below the "Katakturuk" thrust. Paleocene and younger strata, south of the triangle zone and along strike with outcrops of Kingak Shale southeast of the Niguanak Ridge structure on line 84-24 (including the imbricated Paleocene strata), are probably transported northward piggyback as part of a thrust sheet that includes Jurassic strata. Subsidiary thrust faults that probably sole into a BST, analogous to the Marsh Creek thrust fault in the Sadlerochit Mountains, cut the "Katakturuk" thrust. Hence, at least some movement on the Marsh Creek thrust fault analog postdates higher level thrusting because subsidiary thrust faults that presumably sole into the analog of the Marsh Creek thrust cut the "Katakturuk" thrust.

\section{Northeastern Brooks Range}

Detachment folding and faulting in strata equivalent to those in the Sunset thrust sheet is widespread in the northeastern Brooks Range, including the mountain ranges south of the Sadlerochit and Shublik Mountains (fig. 1.1B). In contrast, detachment folding and faulting is uncharacteristic of the Sunset thrust sheet in the Sadlerochit and Shublik Mountains, and it is unrecognized under the western coastal plain.

Detachment folding and faulting observed in the northeastern Brooks Range could result in greater apparent formation thicknesses in the southeastern 1002 area. Folding of the Lisburne Group is especially prominent in the Franklin Creek-Canning River area 58 $\mathrm{km}(36 \mathrm{mi})$ south of the western Sadlerochit Mountains, where detached concentric and chevron folds occur (fig. 20.12). Detachment folding and faulting also occurs in the Sadlerochit Group and is especially prominent along the upper Leffingwell Fork of the Aichilik River near Bathtub Ridge $(55 \mathrm{~km}, 34 \mathrm{mi}$ south of the eastern 1002 area, fig. $1.1 B$ ), where detachment folds and faults occur above a thrust fault near the base of the Sadlerochit Group.

Along the range front between the Hulahula and Jago Rivers (fig. 20.1), repetition of the upper part of the Sadlerochit Group results in an abrupt increase in the apparent thickness of the group. In this area an increase in structural complexity of the Sadlerochit Group roughly corresponds to an easterly decrease in the amount of sandstone and an increase in the amount of shale in the upper part of the Sadlerochit.

Similarly, the Kingak Shale south of the 1002 lands and east of the Sadlerochit River is structurally complex and poorly understood. An unknown thickness of Kingak Shale appears to be structurally repeated along the Aichilik River. Near the southern boundary of the 1002 lands, the Lower Jurassic part of the Kingak Shale is twice as thick as the same part of the unit in the Sadlerochit and Shublik Mountains area (Detterman and others, 1975, p. 18, fig. 7). Detterman and others (1975) incorporate only the lower part of the Kingak Shale along the Aichilik River into a composite stratigraphic section, and much of the section exposed on the Aichilik River includes evidence of disruption, including shear zones and disharmonic folding.

Anticlines cored by pre-Mississippian rocks along the mountain front east of the Hulahula River contrast with those in the Sadlerochit and Shublik Mountains. Such anticlines east of the Hulahula River are about $0.6 \mathrm{~km}$ (1 mi) across (fig. 20.13) and contrast with similar pre-Mississippian-rock-cored anticlines over $8 \mathrm{~km}(5 \mathrm{mi})$ across beneath the Sadlerochit and Shublik Mountains. Pre-Mississippian rocks in the cores of anticlines along the range front east of the Hulahula River are mostly metamorphosed clastic sedimentary rocks, rather than thick platform carbonate rocks, the principal rock type coring the anticlines under the Sadlerochit and Shublik Mountains. Additionally, some basement-cored anticlines east of the Hulahula River have limbs composed of Lisburne Group and Sadlerochit 
Group strata thrust over crests of adjacent anticlines (fig. 20.13); in contrast, the Sunset thrust sheet in the Sadlerochit and Shublik Mountains is structurally simple.

Contrasts between anticlines cored by preMississippian rocks along the northeastern Brooks Range front and those under the Sadlerochit and Shublik Mountains could result from the different mechanical properties of the rocks that make up the cores of the folds. The smaller and more complex anticlines in the northeastern Brooks Range could be related to the mechanical properties of the pre-Mississippian basement complex in the northeastern Brooks Range.

On line 84-24 (pl. 5), the anticline cored by pre-Mississippian rocks and lying at the south end of the line is, in contrast to anticlines in the northeastern Brooks Range, a broad smooth structure similar to the anticline under the Sadlerochit Mountains. Small anticlines similar to those along the range front southeast of line 84-24 are not evident on the down-plunge continuation of the Sadlerochit Mountains anticline on line 84-24. Anticlines that involve pre-Mississippian rocks and lie north of the continuation of the Sadlerochit Mountains are too obscure to confidently identify small structures superimposed on them.

\section{STRUCTURAL DEVELOPMENT AND TIMING}

Development of thrust faults and emplacement of thrust sheets in the Sadlerochit Mountains and adjacent coastal plain began between post-latest Cretaceous or Paleocene and Eocene time and continued into late Cenozoic time, although south of the area investigated, thrusting probably began earlier. Crosscutting relations among major thrust faults and unconformities in the Sadlerochit Mountains and interpretation of lines 84-14 and 84-24 (pl. 5) constrain the relative timing of the structural events. The termination of thrusting is constrained by the minimum age of the strata involved.

Thrusting in the Sadlerochit Mountains area began with emplacement of the structurally highest thrust sheet and progressed downward with the generation of successively lower BST faults. Thrusting probably began with the generation of the Katakturuk, Nularvik, and West Fork thrust faults; crosscutting relations among these thrust faults are not clear, and hence the relative sequence of generation of these three thrust sheets is unknown.

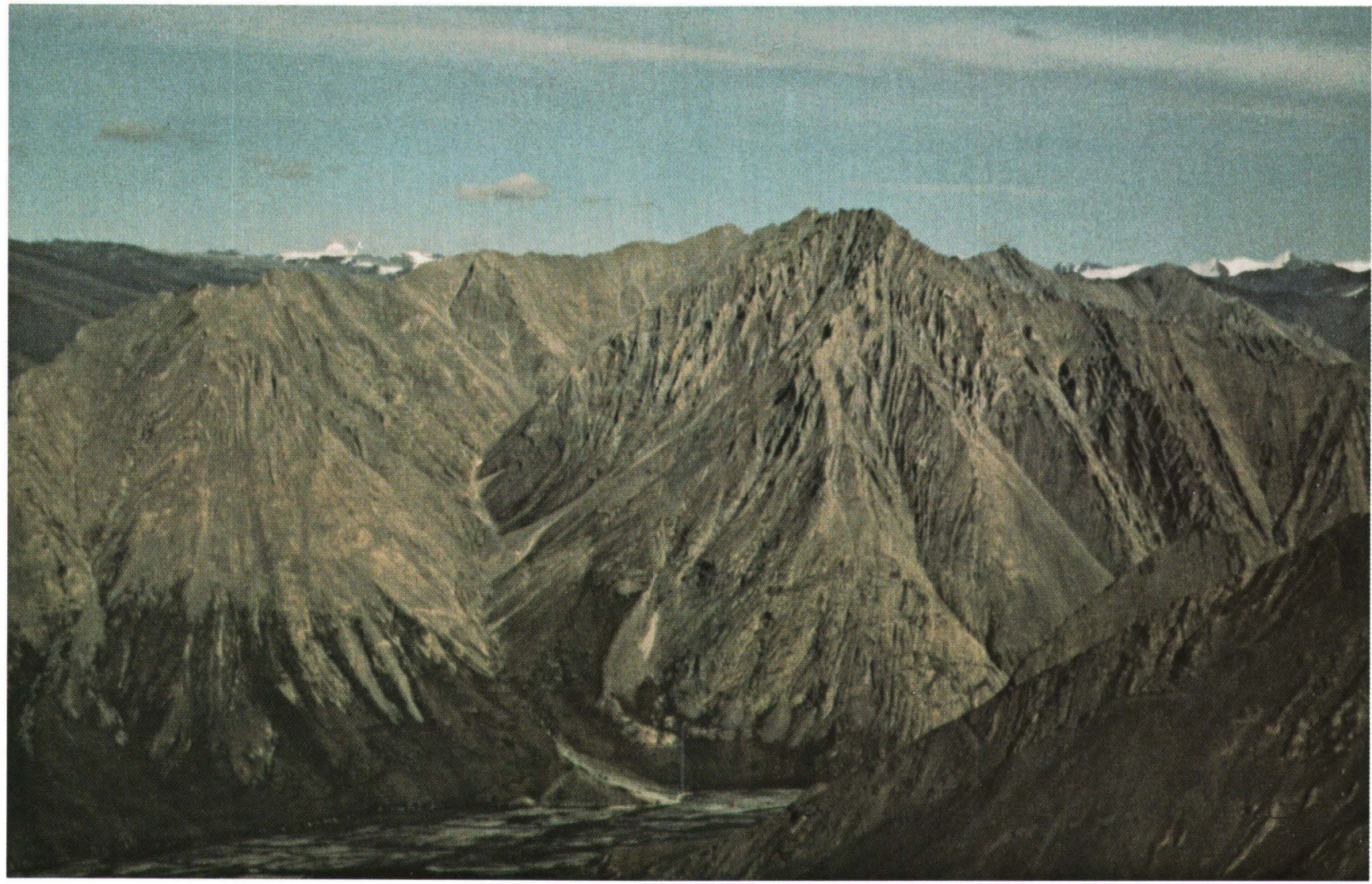

Figure 20.12. Detachment folds in the Lisburne Group in Franklin Creek-Canning River area, $58 \mathrm{~km}$ ( $36 \mathrm{mi})$ south of the western Sadlerochit Mountains. View is to east. 
The Marsh Creek thrust fault postdates the West Fork thrust fault and probably postdates generation of the Nularvik and Katakturuk thrust faults. The Marsh Creek thrust cuts the West Fork thrust and, by projection above the present erosion level, also seems to cut the Nularvik and Katakturuk thrusts.

Generation of the Sunset thrust fault and the BST fault in the pre-Mississippian rocks and emplacement of the large anticlines cored by the preMississippian rocks under the Sadlerochit Mountains are

SOUTH

NORTH
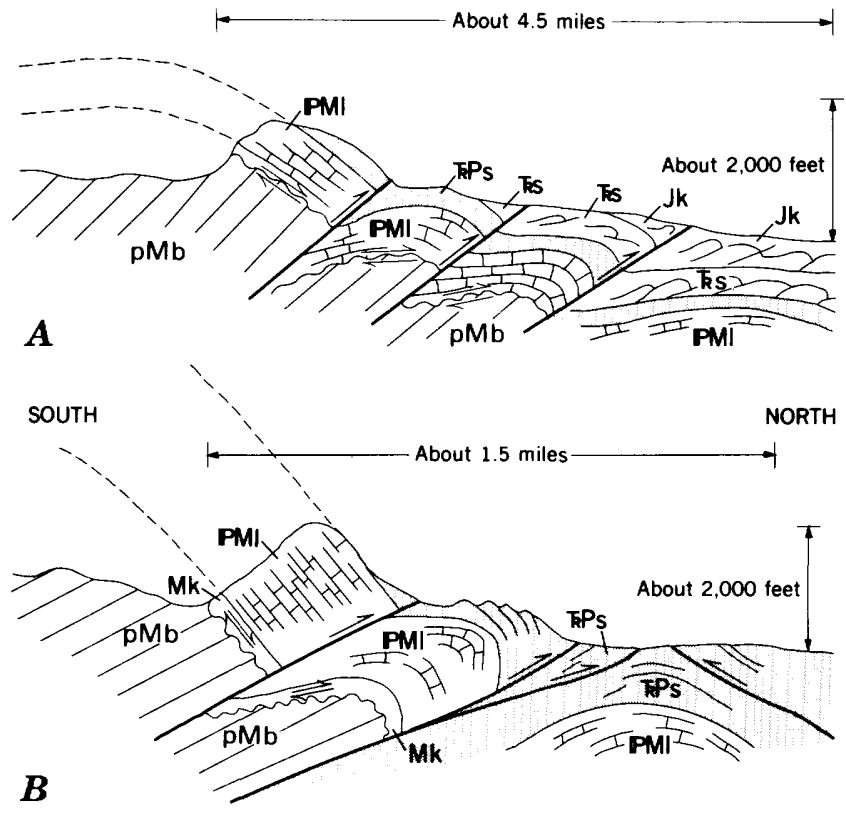

EXPLANATION

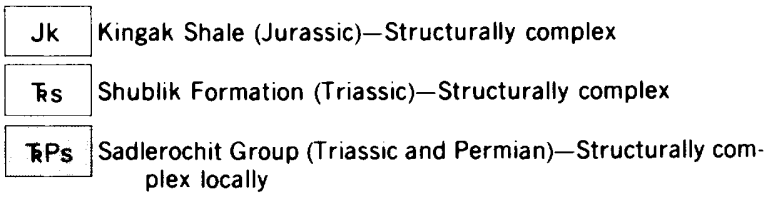

PMI Lisburne Group (Pennsylvanian and Mississippian)

Mk Kayak Shale (Mississippian)-Structurally complex

pMb-Basement complex (pre-Mississippian)-Line pattern shows general orientation of foliation and compositional layering

$\sim$ Pre-Mississippian unconformity-Arrows show sense of shear on fault that probably occurs along the un conformity-Analogous to Sunset thrust in Sadlerochit Mountains

$\rightleftharpoons$ Probable fault in Kayak Shale-Analogous to Sunset thrust in Sadlerochit Mountains

Figure 20.13. Geologic relations across mountain front $(A)$ southwest and $(B)$ east of southern termination of seismic profile $84-24$. See figure 20.1 for location. the final steps in the sequence of thrust faulting in the Sadlerochit Mountains area. A subsidiary thrust fault to the master sole thrust in the pre-Mississippian rocks, the Itkilyariak thrust fault, cuts the Marsh Creek thrust. Generation of the anticlines under the Sadlerochit Mountains, probably through imbrication of the preMississippian rocks under the Sunset thrust, deforms thrust faults above the Sunset thrust and produces northdipping thrust faults in the northern foothills of the Sadlerochit Mountains.

Thrusting under the coastal plain is coeval with thrusting in the Sadlerochit Mountains. Although thrusting probably progressed from south to north, emplacement of pre-Mississippian-rock-cored anticlines in the Sadlerochit Mountains coincides with continued thrusting beneath the coastal plain. On lines 84-14 and $84-24$, faults soling in anticlines cored by preMississippian rocks ramp up to merge with basal thrust faults above the LCU. Hence, subsidiary thrusts to the basal thrust faults above the LCU, which are obscure on the seismic lines, connect emplacement of the large anticlines cored by pre-Mississippian rocks to the most recent thrust faulting beneath the coastal plain.

Relations between deformation of Paleocene strata, the Eocene unconformity, and the LCU place constraints on initiation of thrust faulting in the northeastern Arctic coastal plain (including the 1002 area). The LCU does not perceptibly cut northnortheast-directed thrust-generated structures, whereas thrust faults do cut the LCU, which indicates that thrusting postdates the LCU. Initiation of thrusting is further constrained by the Katakturuk thrust fault near the base of the uppermost Cretaceous or Paleocene turbidites on line 84-14. The Katakturuk thrust acts chiefly as a roof thrust for repetition of the underlying Upper Cretaceous strata. Uppermost Cretaceous or Paleocene turbidites, little disturbed on line 84-14 in contrast to the highly imbricated Cretaceous strata below the Katakturuk thrust, were in place and probably lithified before imbrication of the underlying Upper Cretaceous strata. Hence, major tectonic shortening under the coastal plain is post-latest Cretaceous or Paleocene in age. Deformation of the Eocene unconformity, including partially beveled crests of triangle zones beneath the unconformity, probably reflects growth of the triangle zones during Eocene time and continued structural shortening during post-Eocene time. Also, the Eocene unconformity cuts structurally telescoped Paleocene strata that are probably part of the Jago River Formation on line 84-24, which further constrains initiation of thrusting to between late Paleocene and (or) Eocene time.

Thrusting continued into Miocene and Pliocene time and probably continues into the present day. In the core of the Marsh Creek triangle zone, faulted Eocene strata dip 60 to $70^{\circ}$, and onlapping Miocene and Pliocene strata, which form limbs of the structure, dip 15 to $20^{\circ}$. 
Morris (1957, p. 6) has noted the warping of early Pleistocene(?) gravels over the Marsh Creek anticline. Additionally, Pleistocene terraces on the Katakturuk River are deformed over the plunging crest of the Marsh Creek structure (L.D. Carter, U.S. Geological Survey, oral commun., 1986). Finally, the most recent focalplane solutions for offshore historical earthquakes, north and northeast of the Marsh Creek structure, suggest north-south or northwest-southeast horizontal compression (Biswas and others, 1986, p. 178), which is consistent with either thrusting or strike-slip faulting. The direction of thrust transport in the adjacent part of the 1002 area is north-northwest, consistent with the direction of compression in the focal-plane solutions.

\section{SUMMARY AND CONCLUSIONS}

Most of the coastal plain adjacent to the Sadlerochit and Shublik Mountains and the northeastern Brooks Range lies in a fold and thrust belt that spans northern Alaska. The fold and thrust belt underlies the Brooks Range and the adjacent foothills of northern Alaska and extends across all but the northwest corner of the 1002 area, northwest of the Marsh Creek anticline.

Structures in the Sadlerochit and Shublik Mountains, northeastern Brooks Range, and adjacent parts of the coastal plain are characteristic of detachment tectonics and include thrust faults, rootless folds, large anticlines cored by pre-Mississippian rocks, duplexes, triangle zones, and complex structural thickening of mostly incompetent units. Folds are generally asymmetrical, verge northward in the direction of structural transport, and are typically floored by thrust faults. The intensity and complexity of deformation and the age of the rocks involved in detachment structures increase toward the mountain belt.

Thrust transport is mostly to the northnorthwest. Thrust faulting of one thrust sheet over another, piggyback transport of one thrust sheet on another, later formed thrust sheet, and structural telescoping through imbricate faulting within thrust sheets contribute to structural transport. Thrust faults, triangle zones, and folds floored by thrust faults generally trend east-northeast where not influenced by preexisting structural grain. Thrust faults that cut the pre-Mississippian and younger rocks in the Sadlerochit and Shublik Mountains are typically concordant with structures in the pre-Mississippian rocks but discordant with structures involving younger strata.

The structural framework of the Sadlerochit Mountains and much of the coastal plain comprises six thrust sheets. The thrust sheets involve Precambrian through upper Cenozoic rocks and three regional unconformities. The thrust sheets are (1) an unnamed thrust sheet above a BST in pre-Mississippian rocks, (2) the Sunset thrust sheet, (3) the Marsh Creek thrust sheet,
(4) the West Fork thrust sheet, (5) the Nularvik thrust sheet, and (6) the Katakturuk thrust sheet. The regional unconformities are (1) the pre-Mississippian unconformity, (2) the Lower Cretaceous unconformity (LCU), and (3) the Eocene unconformity.

The poorly defined and unexposed BST fault in the pre-Mississippian rocks has subsidiary thrusts that branch up and emplace large blocks of the preMississippian rocks on strata as young as Paleocene. The large slabs of the pre-Mississippian rocks are probably internally imbricated. The pre-Mississippian rocks are detached under the Sadlerochit and Shublik Mountains and appear detached beneath much of the adjacent coastal plain.

The Sunset thrust sheet lies above a thrust fault along the pre-Mississippian unconformity. The sheet consists of Mississippian to Cretaceous strata that are not structurally complex in the Sadlerochit Mountains. The same strata are, however, structurally complex in the northeastern Brooks Range. Imbrication of the underlying pre-Mississippian rocks produces large anticlines in the Sunset thrust sheet.

The Marsh Creek thrust sheet consists of Jurassic and Cretaceous strata that have been thrust transported north-northeast across the LCU. The strata make up blocks in a duplex in the northeastern Sadlerochit Mountains. Jurassic strata exposed southeast of Niguanak Ridge are probably part of the Marsh Creek or an analogous thrust sheet.

The West Fork thrust sheet consists of Lower and Upper Cretaceous shales. The strata in the West Fork thrust sheet are complexly deformed and underlie the coastal plain adjacent to the Sadlerochit Mountains. The distribution of the same strata under the eastern 1002 lands is unknown.

The Nularvik thrust sheet consists of structurally repeated Upper Cretaceous strata, mostly shales but also including sandstone turbidites and red-weathering tuff beds. The thrust sheet probably underlies much of the 1002 lands.

The Katakturuk thrust sheet consists of Upper Cretaceous and Paleocene turbidites and younger strata and is a roof thrust for imbrication of underlying Upper Cretaceous strata. Structural shortening in the Katakturuk thrust sheet is small in comparison to that in the underlying Nularvik thrust sheet producing an underthrusting relation across the Katakturuk thrust. Mostly east-northeast-trending triangle zones are prominent features in the Katakturuk thrust sheet. The Katakturuk thrust sheet underlies much of the 1002 area.

Tectonic shortening in the Sadlerochit Mountains and coastal plain probably began during Paleocene to Eocene time. Thrusting probably continued into late Cenozoic time, possibly continued into Pleistocene time, and could still be ongoing if historic earthquakes along the Beaufort Sea coast indicate thrust rather than strike-slip faulting. 


\title{
Structure of the Continental Shelf North of the Arctic National
}

\section{Wildlife Refuge ${ }^{1}$}

\author{
By Arthur Grantz, ${ }^{2}$ David A. Dinter, ${ }^{2}$ and Raymond C. Culotta ${ }^{2}$
}

\section{INTRODUCTION}

U.S. Geological Survey seismic-reflection profiles at an average spacing of about $20 \mathrm{~km}(32 \mathrm{mi})$ (Grantz and Greenberg, 1981; Grantz and others, 1982) indicate that the geologic structure of the Beaufort continental shelf north of the Arctic National Wildlife Refuge (ANWR) has been shaped by the interplay of several tectonic features and geologic processes of regional extent or influence. These include (1) a continental margin and tectonic hinge line formed by rifting that was most active north of Alaska during late Early Cretaceous time, (2) the gravitational free face of the Late Cretaceous to Holocene continental slope, (3) northward-directed Eocene to Holocene thrust faulting rooted on the south side of the eastern Brooks Range, and (4) continental-margin collapse along north-dipping listric (curvilinear, concave upward) normal faults (figs. 21.1, 21.2, 21.3, and 21.4; Grantz and May, 1983).

The tectonic hinge line of the Beaufort shelf (fig. 21.1), beyond which prerift continental crust dips rather sharply seaward toward transitional and oceanic crust, strikes east-southeast from a position on the outer shelf near longitude $147^{\circ} \mathrm{W}$. toward the coast in Camden Bay. This trend suggests that part of the Beaufort shelf north of the ANWR is underlain by transitional crust, and it may account for the eastward thickening of Upper Cretaceous(?) and Tertiary clastic sedimentary rocks under the shelf in and east of the Camden Bay area. These eastward-thickening sedimentary rocks constitute the Kaktovik basin (fig. 21.1), which contains most of the strata and structures of interest for petroleum exploration on the shelf off the ANWR.

Large, roughly east trending detachment folds, faults, and basins in upper Mesozoic and Cenozoic rocks of the Beaufort shelf east of the Canning River (that is, off the ANWR) developed in a dominantly compressional setting above one or more extensive,

\footnotetext{
1 This paper also appears in the volume "Alaskan North Slope Geology" (Tailleur and Weimer, 1987).

${ }^{2}$ U.S. Geological Survey, Menlo Park, Calif.
}

south-rooted thrust faults that are inferred to extend northward beneath the entire shelf. The folded strata are also offset by listric normal faults. Some of these faults resulted from failure of the steepened north limb of the Camden detachment anticline toward the gravitational free face of the continental slope. Others resulted from gravity failures in the outer part of the sedimentary prism of the prograding continental terrace toward the same free face. Tectonic processes are still active in at least the western half of the area because (1) the western half of the ANWR and the adjacent shelf as far seaward as the core of the Camden anticline are generating shallow earthquakes (fig. 21.4; Grantz and others, 1983), and (2) Holocene deposits on the shelf off the ANWR are offset by faults (Dinter, 1985).

\section{STRATIGRAPHY}

Seismic interpretation, together with projection of geologic relationships using data from the northeast Brooks Range and test wells in the Canning River area, suggests that the basement complex of the continental shelf north of the ANWR consists of variously deformed and mildly metamorphosed Proterozoic to Devonian sedimentary and volcanic rocks. These rocks are inferred to be overlain unconformably by weakly deformed, dominantly fine-grained marine sedimentary rocks of Jurassic and Early Cretaceous age in the Dinkum graben (fig. 21.1) and beneath most of the eastern Beaufort shelf. Thicknesses locally exceed $4 \mathrm{~km}$ $(13,000 \mathrm{ft})$. The Jurassic and Lower Cretaceous rocks are succeeded locally by Upper Cretaceous coastal to deep-marine basinal shales and sandstones that may in places be as thick as $2 \mathrm{~km}(6,500 \mathrm{ft})$. Above these rocks is a stratigraphically complex section of Tertiary coastal, shelf, slope, and basinal shales and sandstones that is 4 to $7.2 \mathrm{~km}(13,000$ to $24,000 \mathrm{ft})$ thick, and in places probably thicker than $10 \mathrm{~km}(33,000 \mathrm{ft})$. A prominent angular unconformity dated as late Eocene on the Canadian Beaufort shelf (J. Dixon and J. Dietrich, written commun., 1985) lies in places within and in other places at the base of the Tertiary section off the eastern 
half of the ANWR. On the Beaufort shelf east of longitude $144^{\circ} 15^{\prime} \mathrm{W}$. this unconformity separates an uppermost Eocene or Oligocene to Quaternary sedimentary section from upper Eocene to Cretaceous beds below (fig. 21.3).

\section{STRUCTURE}

Between the Canning River and the Canadian border, the shallow geologic structure of the Beaufort shelf (figs. 21.2, 21.3) is dominated by long, arcuate, roughly parallel compressional detachment anticlines and synclines. Two of the synclines became sedimentary subbasins (Demarcation and Barter; fig. 21.3) that deepened contemporaneously with folding. To the west, the folds die out at the north end of the Canning displacement zone (CDZ) (Grantz and others, 1983), which is interpreted to be a broad, roughly linear zone in which northeast Brooks Range thrusting and related detachment folding die out by splaying and tear faulting (fig. 21.1). West of the $\mathrm{CDZ}$, the geologic structure of the shelf is dominated by flat to gently seaward-dipping strata that, on the middle and outer shelf, are offset by regional systems of north-dipping, west-northweststriking normal faults and listric growth faults. These growth faults were formed by gravitational failure of the sedimentary rocks of the continental terrace toward the free face of the continental slope. A large rollover anticline is developed on the seaward side (hanging wall) of the growth-fault system.

The growth-fault province is not bounded by the CDZ. The growth faults and associated rollover anticline extend eastward into the northern part of the offshore area with compressional detachment folds, where they drop the north flank of the Camden anticline down and thus contribute to the structural relief of its north flank.

All the compressional anticlines and intervening synclinal subbasins are inferred to overlie one or more low-angle detachment faults rooted in the Brooks Range, and they are tentatively inferred to terminate distally beneath a series of folds beneath the continental slope

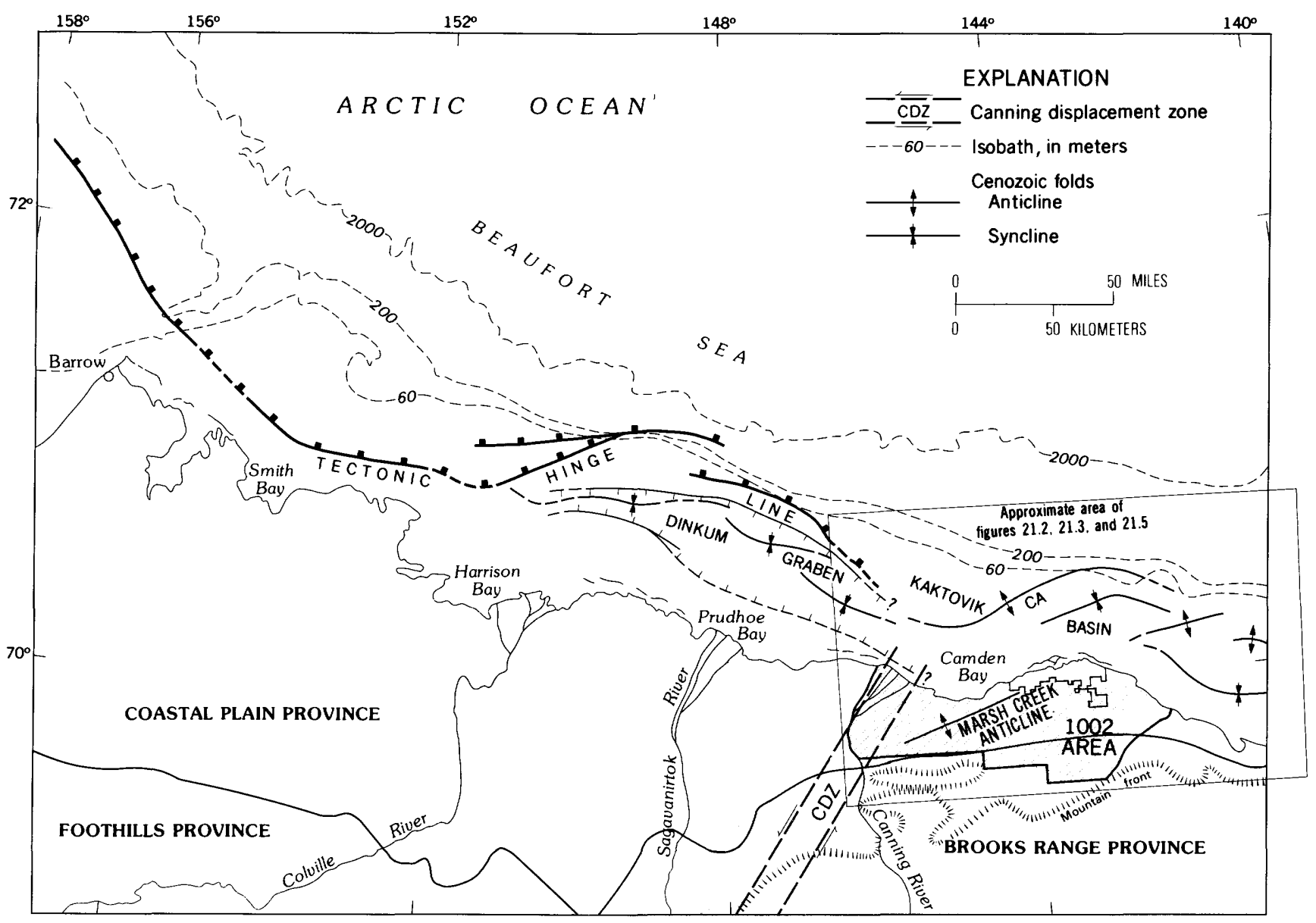

Figure 21.1. Index map of northern Alaska and Beaufort Sea showing major structural features. CA, Camden anticline. Teeth on tectonic hinge line indicate downwarped side. 
and rise (fig. 21.4; Eittreim and Grantz, 1979). Structure contours on the highest detachment fault that could be observed or inferred on the USGS seismic profiles are shown in figure 21.2. The contoured surface may be a composite of two or more thrust faults, and splay faults (which were not identified on the profiles) may merge into it from below.

Off the western ANWR the highest detachment-fault surface is interpreted to lie at depths of 4 to $5 \mathrm{~s}$ of two-way seismic-reflection time and is broadly warped. North of Camden Bay this surface appears to lie at the base of the Tertiary section (Grantz and May, 1983, fig. 13), and the overlying Camden anticline is developed mainly in Tertiary rocks. In this area the overall cross-sectional shape of the fold somewhat resembles an antiformal stack of thrust slices, and USGS seismic profiles suggest that splay faults may be present in the core. However, perhaps because of disruption by later listric normal faults, a complete pattern of imbricate thrust faults was not delineated. Farther east, near Barter Island, the Camden anticline becomes a simple detachment fold. Broad warping of
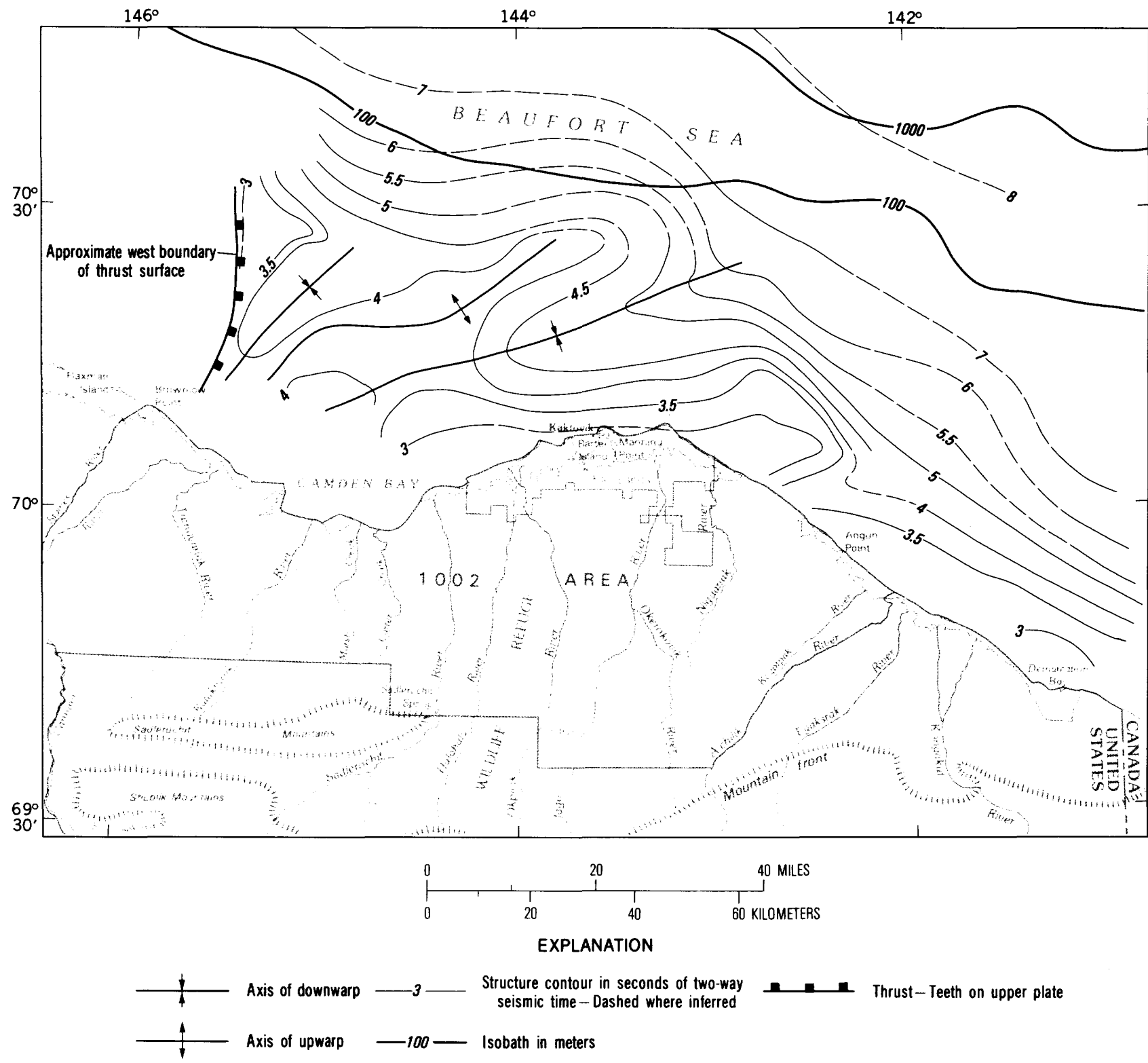

Figure 21.2. Structure contours, in two-way seismic-reflection time, on highest detachment-fault surface that could be either mapped or inferred from U.S. Geological Survey seismic profiles on Beaufort shelf. Contours east of long $142^{\circ}$ W. are speculative. Approximate equivalence of reflection time to depth given in figure 21.5. 
the detachment surface off the western ANWR suggests that this fault may be deformed above a deeper, younger thrust fault not identified on the seismic profiles.

The detachment-fault surface (fig. 21.2) deepens and its dip steepens eastward from Camden Bay. Concomitantly, the stratigraphic position of the fault apparently drops from the base of the Tertiary section to progressively deeper levels in the underlying bedded sequence, which is inferred to consist of mainly fine- grained Jurassic and Cretaceous marine clastic rocks. These changes correlate with changes in the structure of the overlying rocks. For example, the eastern part of the Camden anticline and the en echelon Herschel arch (fig. 21.3) are broader and less strongly faulted at the level of the Tertiary rocks than the west end of the Camden anticline; the late Eocene unconformity is best developed where the underlying detachment fault descends into beds of inferred pre-Late Cretaceous age; and, at least as
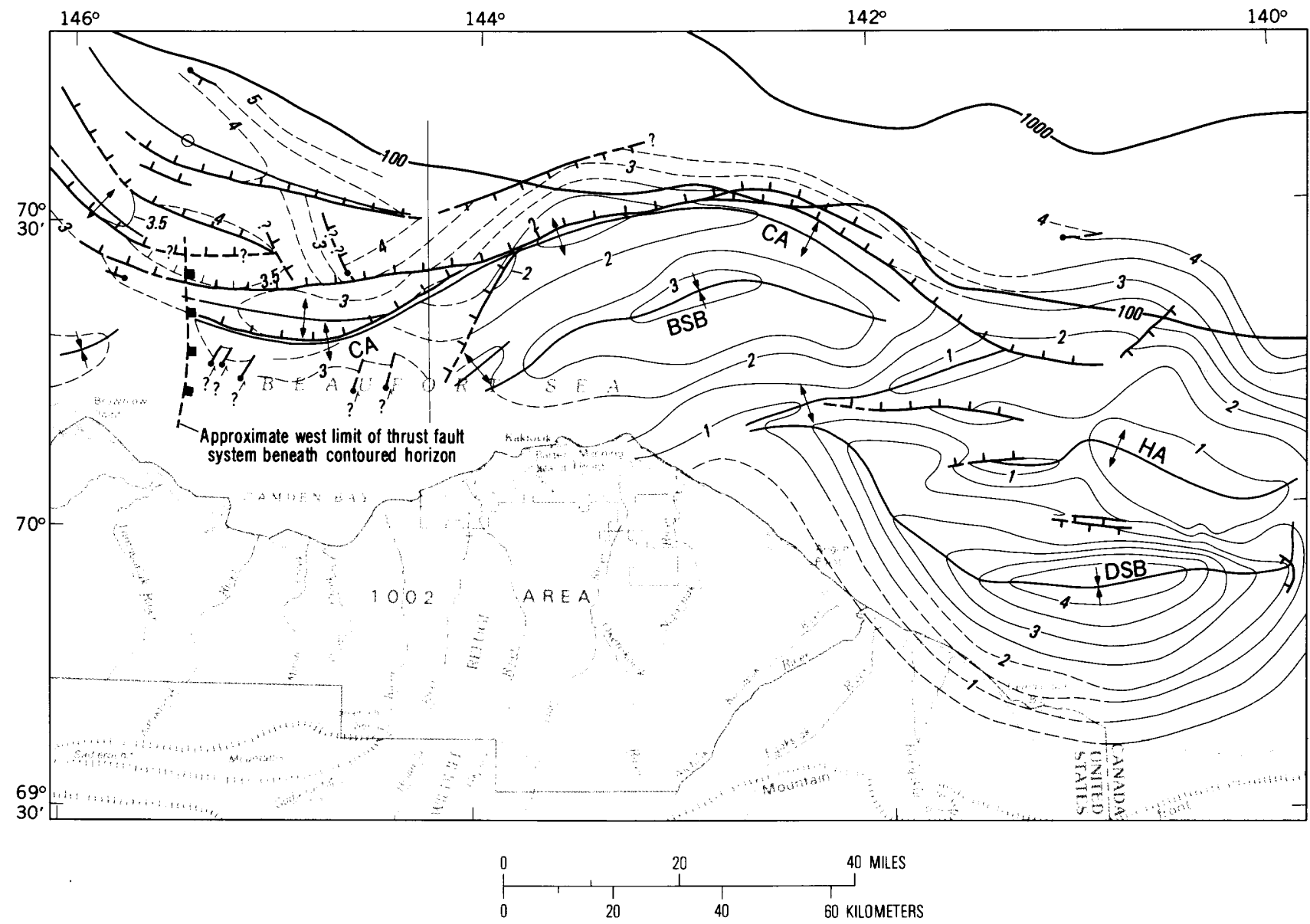

EXPLANATION
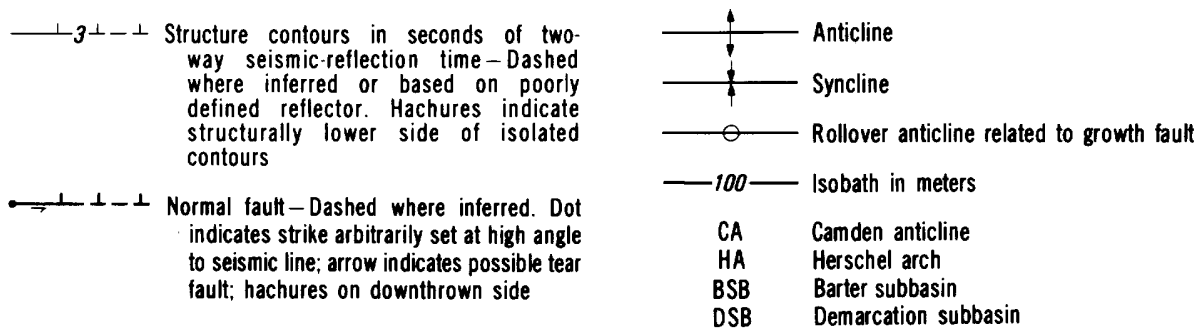

Figure 21.3. Structure contours, in two-way seismic-reflection time, on late Eocene unconformity to east and a middle Eocene horizon to west of long $144^{\circ} 15^{\prime} \mathrm{W}$. on Beaufort shelf. Contours east of long $141^{\circ} \mathrm{W}$. by James Dixon and James Dietrich, Geological Survey of Canada (written commun., 1985). Approximate equivalence of reflection time to depth given in figure 21.5. 
far east as longitude $143^{\circ} \mathrm{W}$., the detachment fault is more strongly warped. In addition, the thick upper Mesozoic section, which is broadly folded near Barter Island, is increasingly broken by moderately steep, south-dipping thrust faults to the east. The folds and thrusts are interpreted to overlie the detachment fault and to have been the structures that produced late Eocene relief on the Herschel arch and the eastern part of the Camden anticline.

Growth of the compressional folds off the eastern part of the ANWR was contemporaneous with the latest Eocene or Oligocene to Holocene filling of the Demarcation and Barter subbasins. The late Eocene unconformity on the crests of the eastern part of the Camden anticline and the Herschel arch shows erosional microrelief indicating structural uplift. The clastic strata overlying the unconformity buttress against, and thicken away from, the crests of these folds. Strata within each subbasin thicken toward the axis, and the basinal axes at progressively higher horizons have migrated landward, away from the anticlinal crests to the north. These features, plus local down-to-basin normal faults on the south flank of the Herschel arch, indicate that the folds were at least intermittently active from Eocene to Quaternary time.

The depths of the Demarcation and Barter subbasins, and the amplitudes of the bounding anticlines, appear to have been enhanced by diapiric flow driven by the accumulating weight of sediment deposited in the subbasins. The fill in the Demarcation subbasin, for example, constitutes a relatively local sedimentary load, $7 \mathrm{~km}(23,000 \mathrm{ft})$ thick, that may have mobilized some of the thick underlying sedimentary section and moved it into the adjacent Herschel arch. Sonobuoy velocities from the upper part of the underlying sedimentary section in the Herschel arch, probably of late Mesozoic age, range from 2.6 to $4.3 \mathrm{~km} / \mathrm{s}(8,500$ to $14,000 \mathrm{ft} / \mathrm{s})$. The generalized average seismic-reflection times as a function of depth for the Beaufort Sea are shown in figure 21.5. These low to moderate velocities indicate

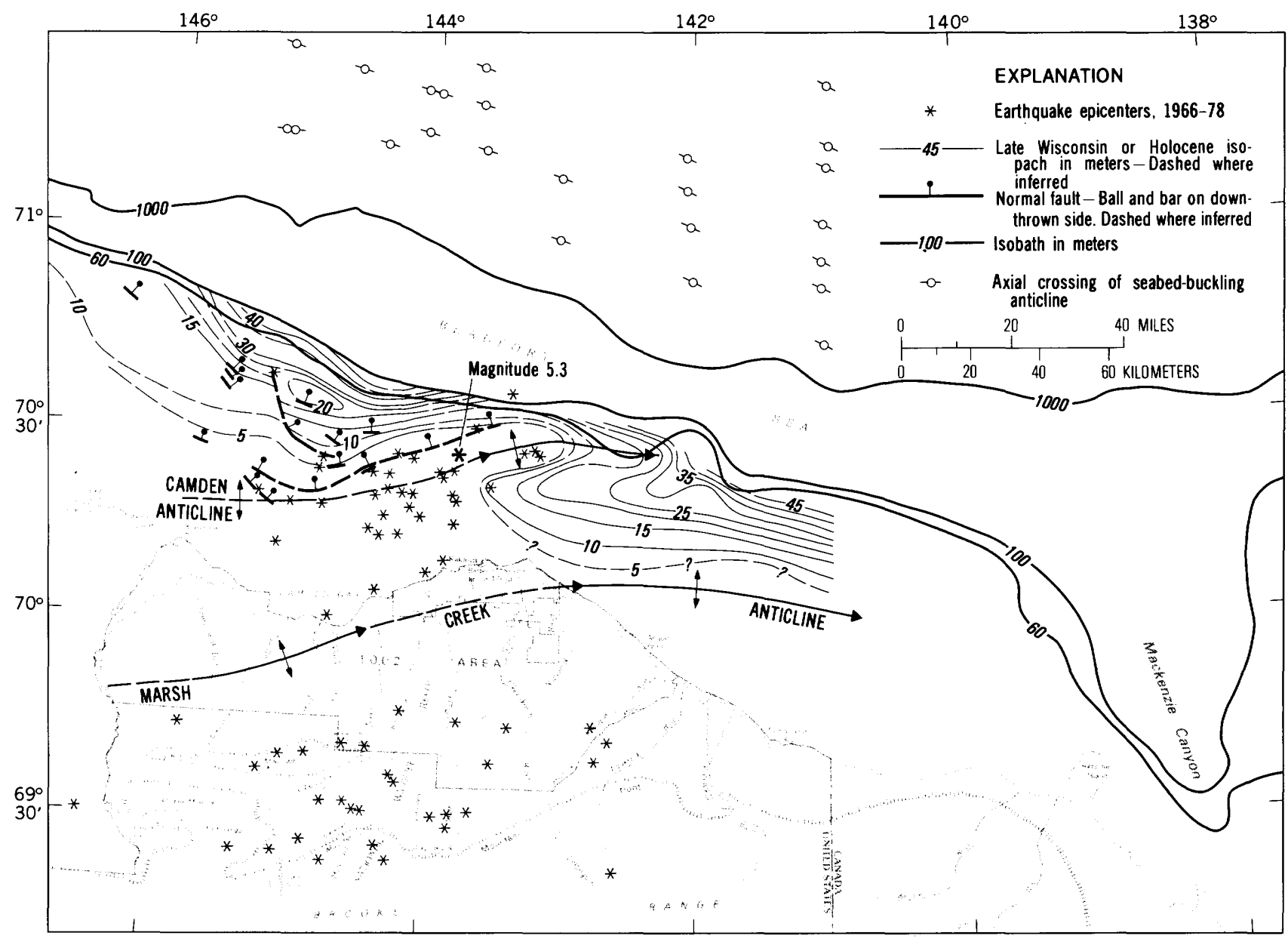

Figure 21.4. Isopachs of late Wisconsin or Holocene sedimentary prism and location of Quaternary fold axes, active normal and (or) tear faults, and earthquake epicenters in and adjacent to the 1002 area. Axial anticline crossings shown on continental rise include only those that buckle or offset seabed. 
that the thick sedimentary section in the core of the arch is not highly indurated, and that it might have been soft enough to flow diapirically when the folds and subbasins started to form in Eocene time.

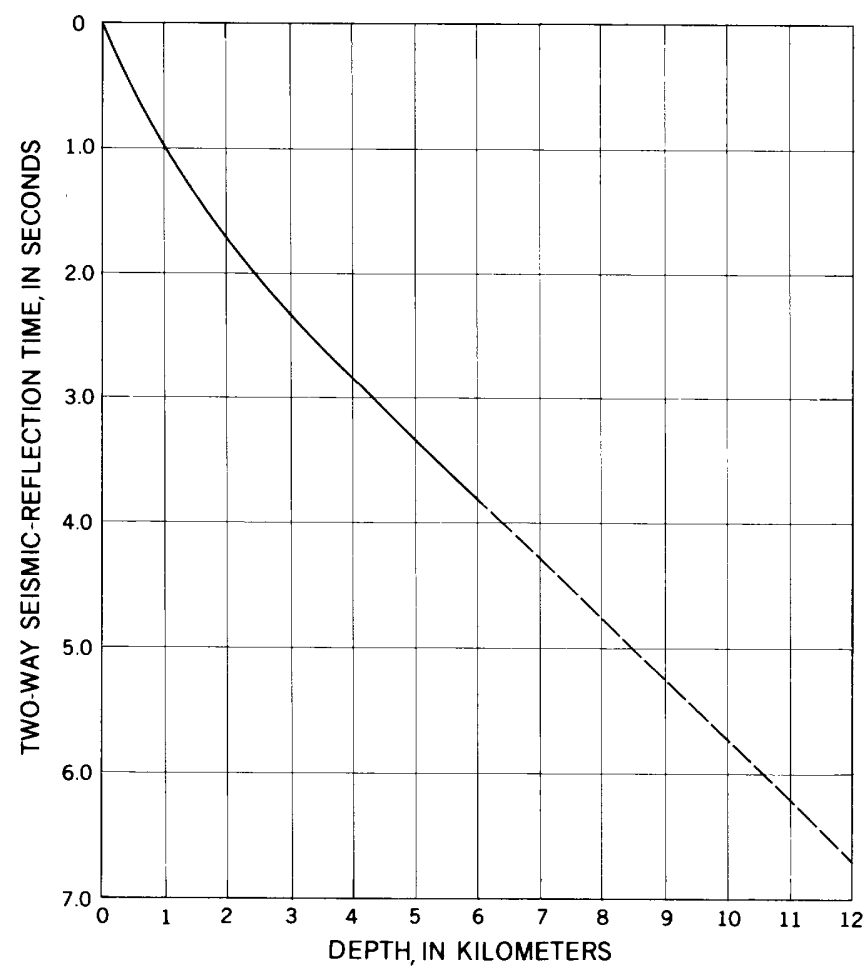

Figure 21.5. Generalized average seismic-reflection time as a function of depth for Beaufort shelf, derived from seismic-stacking-velocity measurements. Dashes indicate less certainty.

\section{QUATERNARY TECTONIC ACTIVITY}

The axes of the Camden anticline and the Barter subbasin (fig. 21.3) are also clearly delineated by isopachs drawn on a late Wisconsin or Holocene sedimentary prism (fig. 21.4). The Holocene axes, however, have migrated some 4 to $10 \mathrm{~km}(5,000$ to $33,000 \mathrm{ft}$ ) southeast from their earlier Cenozoic positions. A Quaternary high that developed over the south flank of the Herschel arch may be an extension of the Marsh Creek anticline, and the Quaternary sedimentary section is thickened near the axis of the Demarcation subbasin. The disconformity underlying the late Wisconsin or Holocene sedimentary prism could not be confidently identified over the subbasin, and therefore no contours are shown there.

Faults mapped on high-resolution seismicreflection profiles north of the Camden anticline offset

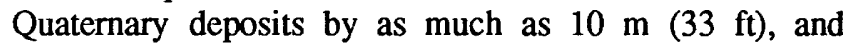
they must therefore be presumed active. Quaternary strata that are undeformed in the Barter subbasin are warped and truncated at the seafloor in the axial region of the Camden anticline, and thus the latter structure must be active as well. This is corroborated by the clustering of earthquake epicenters beneath its crest, with the largest so far recorded being of magnitude 5.3.

In addition to the active faults and folds evident beneath the Beaufort shelf north of the ANWR, numerous high-amplitude folds also deform the sediments of the continental slope and rise. Those that buckle or offset the seabed are shown in figure 21.4. These folds have previously been interpreted as diapiric folds induced by continental-margin slope failures (Grantz and others, 1979), but they are considered here to be related to thrust faults that underlie the entire shelf and root in the Brooks Range. 


\title{
Chapter 22.
}

\section{Assessment of In-Place Oil and Gas Resources}

\author{
By Gordon L. Dolton, ${ }^{1}$ Kenneth J. Bird, ${ }^{2}$ and Robert A. Crovelli ${ }^{1}$
}

\section{INTRODUCTION}

Oil and gas resources, in general, can be thought of in two principal ways: (1) in-place resources-that is, that amount of oil and gas that may exist in nature without reference to its recoverability, but from which some part may be extractable in a technological and (or) economic sense; and (2) recoverable resources-that is, the amount of the in-place resources that may be considered extractable under various present or future economic and technological assumptions. In this report, we present estimates of in-place oil and gas resources of the Arctic National Wildlife Refuge (ANWR) 1002 area, ${ }^{3}$ while in the following report (chap. 23), Callahan and others estimate the quantity of oil resources that may be recoverable. None of the gas resources in the 1002 area are considered to be economically recoverable in the near term (chap. 23).

As should be expected, recoverable resources constitute only a small part of the total in-place resources. The size threshold for economic deposits in this harsh environment varies, depending upon such parameters as reservoir properties, drilling depths, and location factors, but it is generally greater than 400 million barrels of recoverable oil (see chap. 23).

Separate methods were employed in estimating in-place and recoverable hydrocarbon resources in the ANWR. The in-place assessment utilized a "playanalysis" method whereby prospects (potential hydrocarbon accumulations) are grouped according to their geologic characteristics into "plays," or natural associations with common characteristics. In assessing recoverable resources, Callahan and others (chap. 23) employed a site-specific analysis of individual prospects in order to model the elements that determine recoverability (exploration, development, production, and transportation) at that level. Both assessment techniques were carried out independently of each other, even though both techniques utilized similar components of the extensive geologic data base. Each method depends

\footnotetext{
${ }^{1}$ U.S. Geological Survey, Denver, Colo.

2 U.S. Geological Survey, Menlo Park, Calif.

3 The 1002 area at the time of the assessment included what are now the KIC Lands south of approximately $70^{\circ} \mathrm{N}$. latitude.
}

fundamentally upon recognition of potential hydrocarbon traps (prospects) and description of their geologic and fluid characteristics. Particular care was taken to ensure consistent treatment of the geologic data in each assessment.

In general, the assessment of in-place resources by the play-analysis method deals with prospects in the aggregate, whereas the assessment of recoverable resources deals with separate assessments of the larger or selected prospects, which are then aggregated. Prospects of the in-place resource assessment consist of those identified and those estimated to exist on the basis of geologic setting-both structural and stratigraphic traps are included. However, estimation of recoverable resources was limited to those prospects (all structural) identified and delineated with a reasonable degree of certainty and physically large enough that they could reasonably be expected to contain commercial quantities of oil. These two related assessment techniques provide for a desirable verification of the precision of the results and allow a degree of confidence not attributable to either method alone.

\section{ACKNOWLEDGMENTS}

This assessment results from the considerable efforts of an interagency team composed of experts in the geology of the ANWR, petroleum geology, resource appraisal, probability theory, and computers. Bureau of Land Management personnel include A.C. Banet, Jr., R.J. Bascle, G.W. Brougham, J.E. Callahan, R.L. Foland, D.J. Lalla, and M.L. Menge. U.S. Geological Survey personnel include R.H. Balay, K.J. Bird, T.R. Bruns, R.R. Charpentier, R.A. Crovelli, K.I. Cunningham, G.L. Dolton, M.A. Fisher, D.L. Gautier, A. Grantz, J.S. Kelley, R.F. Mast, L.B. Magoon, H. McLean, C.M. Molenaar, R.B. Powers, A.A. Roberts, and S.L. Robbins.

\section{ASSESSMENT METHOD}

The method employed to estimate in-place oil and gas resources in the 1002 area is a modified version of the play-analysis technique developed by the Geological Survey of Canada to assess Canada's oil and 
gas resources (Canada Department of Energy, Mines and Resources, 1977) and used in earlier assessments of the National Petroleum Reserve in Alaska (NPRA) and the ANWR (U.S. Department of the Interior, Office of Minerals Policy and Research Analysis, 1979; Mast and others, 1980; Miller, 1981; Bird, 1986a). However, the present assessment is driven by a more efficient computer program, called Fast Appraisal System for Petroleum (FASP), that utilizes probability theory rather than Monte Carlo simulation (Crovelli, 1986; Crovelli and Balay, 1986).

In this method, geologic settings of oil and gas occurrence are modeled. Risks are assigned to geologic attributes of the model necessary for generation and accumulation of hydrocarbons, and ranges of values are assessed for the geologic characteristics of traps and reservoirs that control hydrocarbon volumes within the modeled accumulations of each play. The volume of hydrocarbons in the hypothetical traps is determined using reservoir-engineering formulas. The play is treated as a collection of prospects, which are conceived as having similar geologic characteristics and sharing common geologic elements. They are defined by a known or suspected trapping condition, which may be structural, stratigraphic, or a combination of both. The individual prospects, though conceptually similar to one another, have attributes and characteristics that vary.

In this appraisal method, geologists make judgments about the geologic factors necessary for the formation of an oil or gas deposit and quantitatively assess those geologic properties that determine its size. The computer program FASP then performs the resource calculation based on this information. This arrangement utilizes the geologist's expertise with geologic factors and the computer's facility in manipulation of numbers within the appraisal model. The method provides for a systematic analysis and integration of the geologic factors essential for the occurrence of oil and gas, a thorough documentation of the analysis, and an assessment that provides information on the size, distribution, and number of hydrocarbon accumulations as well as their sum.

In this assessment, seven plays were identified encompassing Precambrian to Cenozoic rocks (fig. 22.1) that underlie the 1002 area; for each play, in-place oil and gas resources were estimated. Estimates for each of the seven plays were aggregated using probability theory to produce the estimate of total resources for the 1002 area.

Figure 22.1. Generalized stratigraphic column for northern part of ANWR showing rock interval of each of seven plays (see figs. $22.2-22.8$ ) assessed in 1002 area. Hue Shale may range into the Paleocene in parts of this area.

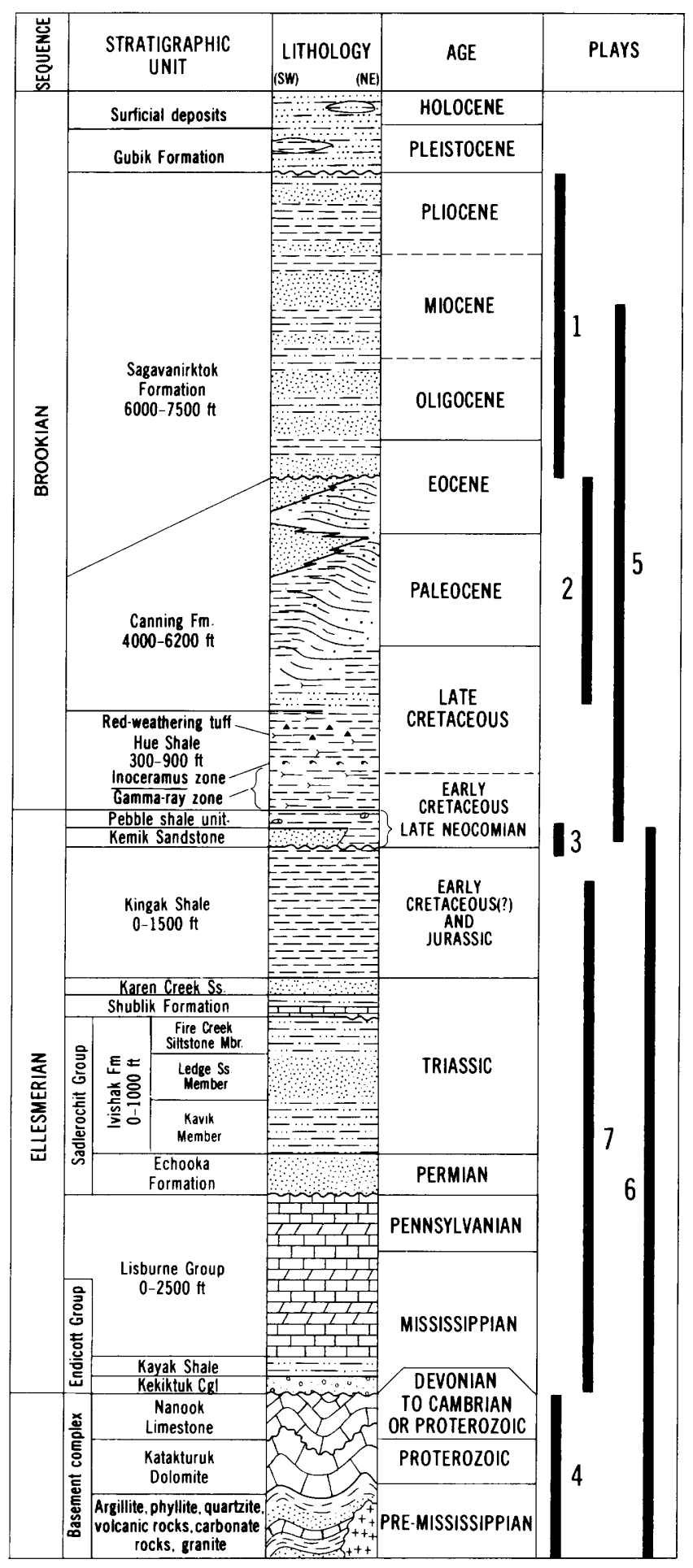

EXPLANATION

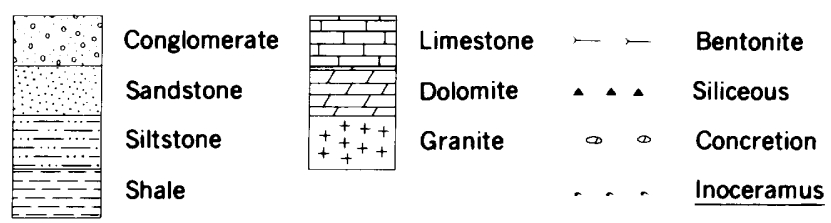




\section{DESCRIPTION OF PLAYS}

Brief narrative descriptions of each play follow. Illustrations accompanying these descriptions provide for each play a map and diagrammatic cross section showing play limits and geologic relations, the assessment data form, and the estimated in-place resources and pool sizes. Some plays are similar or equivalent to plays with known hydrocarbon accumulations in adjoining areas. The plays are presented in the order that they were assessed rather than by their estimated oil and gas potential. Definitions of terms on the assessment form are presented in appendix 22.1 at the end of this chapter.

\section{Topset Play}

The Topset play consists of stratigraphic traps in sandstone reservoirs of Tertiary age and includes those rocks represented on the seismic records in the topset position in a topset-foreset-bottomset sequence. This play is limited to the northwestern part of the 1002 area and is generally unaffected by Brooks Range folding and faulting (fig. 22.2). The southeastern boundary is selected as the line marking the north flank of the Marsh Creek anticline. These rocks, based on well penetrations immediately west of the ANWR, are assigned to the Sagavanirktok Formation and consist of marine and nonmarine deltaic sandstone, siltstone, shale, conglomerate, and minor amounts of coal. A maximum thickness of about $3,000 \mathrm{~m}(10,000 \mathrm{ft})$, estimated from the seismic records, occurs in the eastern part of the play; the sequence thins westward to about $2,130 \mathrm{~m}$ $(7,000 \mathrm{ft})$ in wells just west of the ANWR.

The reservoir rocks are composed of sandstone and conglomerate that may comprise as much as half the total thickness of the play interval, even though individual reservoir beds seldom exceed $15 \mathrm{~m}(50 \mathrm{ft})$. Fair to good reservoir continuity in sand bodies is expected parallel to depositional strike (northwestward), but marked changes may occur over short distances perpendicular to strike. Porosity of reservoir rocks is expected to be excellent, averaging 20 to 30 percent, and permeability is in the hundreds of millidarcies.

Potential source rocks immediately associated with the reservoirs are deltaic shales and mudstones, which are immature and probably biogenic gas prone. The underlying marine shales are both oil prone (Hue Shale) and gas prone (Canning Formation and pebble shale unit) and are mature below about 3,660 m (12,000 $\mathrm{ft}$ ) in the play area. As a consequence, oil accumulations in this play are likely to be the result of vertical migration along faults or inclined foreset beds in the underlying Canning Formation. Oil shows are reported in several wells in the Point Thomson area from the lower part of the rock sequence included in this play. The multibillion-barrel heavy oil and tar accumulations just west of the Prudhoe Bay field (West Sak and Ugnu) and the small oil accumulations in the northeastern NPRA (Simpson and Fish Creek) are considered to be analogs for potential accumulations in this play (see fig. 3.1, table 3.1).

Postulated traps in this play are mostly stratigraphic, related to facies changes, or combination structural and stratigraphic traps formed against smalldisplacement normal faults. Faults, interbedded shales, facies changes, permafrost, and asphaltic hydrocarbons are expected to provide only fair to poor seals. Poor seals - that is, barriers to hydrocarbon migration-may have allowed preferential escape of gas and thus left mostly oil accumulations in this play. Drilling depths range from 30 to $3,000 \mathrm{~m}$ (100 to $10,000 \mathrm{ft}$ ).

\section{Turbidite Play}

The Turbidite play consists of stratigraphic traps in deep-nrarine sandstone reservoirs of Late Cretaceous and Tertiary age that occur in the foreset and bottomset units of the Canning Formation as shown by seismic reflectors. The play is limited to the northwestern part of the 1002 area, which is generally unaffected by Brooks Range folding and faulting (fig. 22.3). The southeastern play boundary is a line marking the transition between folded and faulted rocks of the Marsh Creek anticline and the adjacent undeformed rocks. On the basis of well penetrations adjacent to the ANWR, these rocks consist of relatively deep marine shale, siltstone, and turbidite sandstone. A maximum thickness for rocks in this play is about $1,520 \mathrm{~m}(5,000 \mathrm{ft})$. Drilling depths range from 1,220 to $6,700 \mathrm{~m}(4,000$ to $22,000 \mathrm{ft})$.

Reservoir rocks, which are turbidite sandstones, may occur anywhere within the play interval, but in wells adjacent to the ANWR they are most frequently encountered in the lower third as toe-of-slope or basinplain turbidites. Sandstone bodies are expected to be laterally discontinuous and to have an aggregate thickness of several hundred feet, although individual beds are expected to be less than $15 \mathrm{~m}(50 \mathrm{ft})$ thick. Abnormally high fluid pressures are expected in the lower part of the play interval, since such pressures are found in wells west of the ANWR; thus, porosities should be better than those normally encountered for turbidite sandstone at these depths.

Potential source rocks include deep-marine shales adjacent to the reservoirs (Canning Formation) and below the reservoirs (Hue Shale and pebble shale unit). These shales are gas prone (Canning Formation and pebble shale unit) and oil prone (Hue Shale) and are mature below about $3,660 \mathrm{~m}(12,000 \mathrm{ft})$. Oil and gas have been recovered from turbidite reservoirs in several wells adjacent to the ANWR. The oil, generally $21^{\circ}$ to $27^{\circ}$ API gravity, but as high as $44^{\circ}$ API gravity in one 

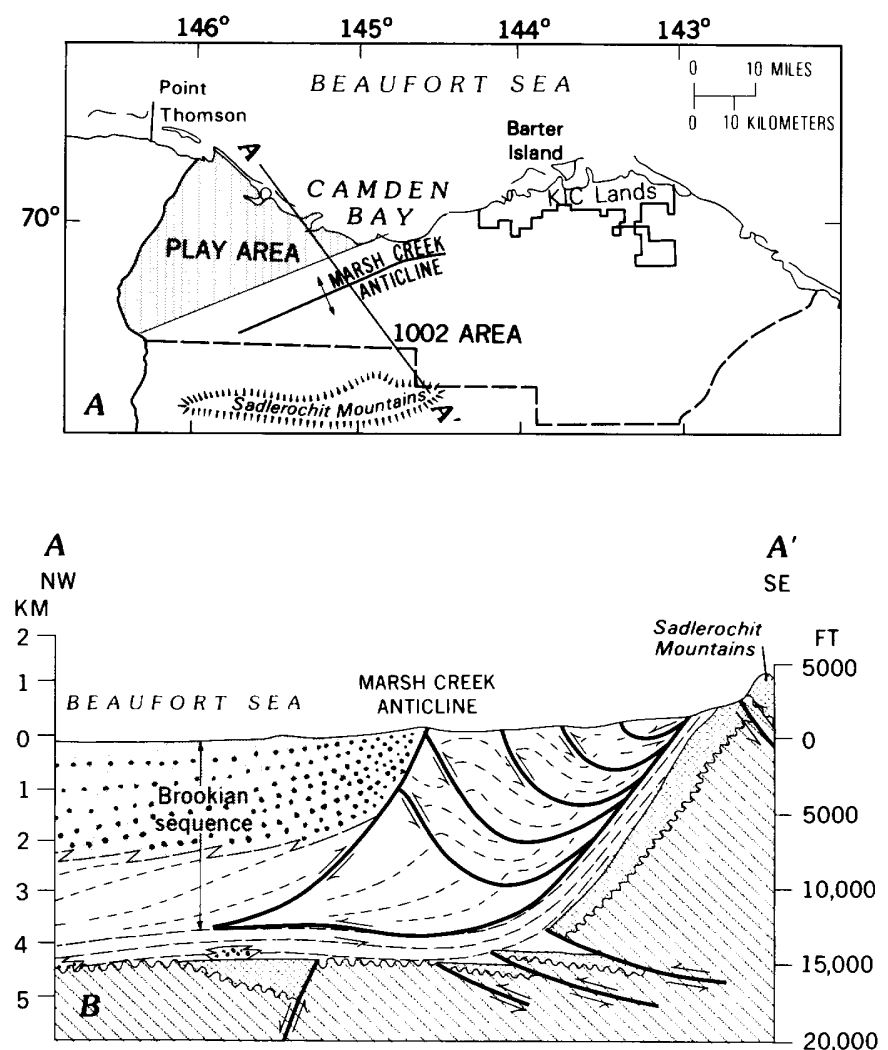

\begin{tabular}{|c|c|c|c|c|c|c|c|c|}
\hline \multicolumn{5}{|c|}{ ATTRIBUTE } & \multicolumn{4}{|c|}{$\begin{array}{l}\text { PROBABILITY } \\
\text { OF FAVORABLE }\end{array}$} \\
\hline \multirow{5}{*}{ 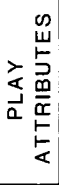 } & \multicolumn{4}{|c|}{ HYDROCARBON SOURCE (S) } & \multicolumn{4}{|c|}{1.0} \\
\hline & \multicolumn{4}{|l|}{ TIMING (T) } & \multicolumn{4}{|c|}{1.0} \\
\hline & \multicolumn{4}{|c|}{ MIGRATION (M) } & \multicolumn{4}{|c|}{1.0} \\
\hline & \multicolumn{4}{|c|}{ POTENTIAL RESERVOIR FACIES (R) } & \multicolumn{4}{|c|}{1.0} \\
\hline & \multicolumn{4}{|c|}{ MARGINAL PLAY PROBABILITY } & \multicolumn{4}{|c|}{1.0} \\
\hline \multirow{4}{*}{ 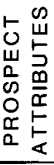 } & \multicolumn{4}{|c|}{ TRAP OCCURRENCE (TM) } & \multicolumn{4}{|c|}{0.3} \\
\hline & \multicolumn{4}{|c|}{ EFFECTIVE POROSITY ( } & \multicolumn{4}{|c|}{1.0} \\
\hline & \multicolumn{4}{|c|}{ HYDROCARBON ACCUMULATION (C) } & \multicolumn{4}{|c|}{0.2} \\
\hline & \multicolumn{4}{|c|}{$\begin{array}{l}\text { CONDITIONAL DEPOSIT } \\
\text { PROBABILITY }\end{array}$} & \multicolumn{4}{|c|}{0.06} \\
\hline \multirow{11}{*}{ 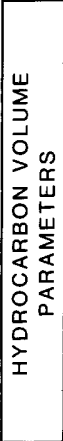 } & \multirow{2}{*}{ RESERVOIR LITHOLOGY } & \multicolumn{3}{|c|}{ SANDSTONE (a) } & \multicolumn{4}{|c|}{$v$} \\
\hline & & \multicolumn{3}{|c|}{ CARBONATE (b) } & & & & \\
\hline & \multirow{2}{*}{ HYDROCARBON MIX } & \multicolumn{3}{|c|}{ GAS } & \multicolumn{4}{|c|}{0.1} \\
\hline & & & OIL & & \multicolumn{4}{|c|}{$0 . \overline{9}$} \\
\hline & FRACTILES & \multicolumn{7}{|c|}{$\begin{array}{l}\text { PROBABILITY OF EQUAL TO OR } \\
\text { GREATER THAN }\end{array}$} \\
\hline & ATTRIBUTES & 100 & 95 & 75 & 50 & 25 & 5 & 0 \\
\hline & $\begin{array}{l}\text { AREA OF CLOSURE } \\
\left(\times 10^{3} \text { ACRES }\right)\end{array}$ & 0.6 & 2 & 8 & 17 & 30 & 45 & 90 \\
\hline & $\begin{array}{c}\text { RESERVOIR THICKNESS } \\
(\mathrm{FT})\end{array}$ & 50 & 75 & 100 & 200 & 300 & 500 & 750 \\
\hline & $\begin{array}{c}\text { EFFECTIVE POROSITY } \\
\text { (PCT) }\end{array}$ & 10 & 15 & 20 & 25 & 27 & 30 & 32 \\
\hline & TRAP FILL (PCT) & 1 & 5 & 15 & 25 & 40 & 75 & 100 \\
\hline & $\begin{array}{l}\text { RESERVOIR DEPTH } \\
\left(\times 10^{3} \mathrm{FT}\right)\end{array}$ & 0.1 & 2.1 & 4.5 & 6 & 7.3 & 8.7 & 10 \\
\hline & $\begin{array}{l}\text { NUMBER OF } \\
\text { RILLABLE PROSPECTS }\end{array}$ & 1 & 2 & 3 & 5 & 8 & 15 & 30 \\
\hline
\end{tabular}

C

EXPLANATION

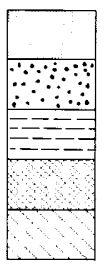

Play interval

Bed forms in sandstone and siltstone

Bed forms in shale and siltstone

Pre-Lower Cretaceous unconformity Ellesmerian-sequence rocks

Pre-Mississippian basement-complex rocks

Unconformity

$\leftrightharpoons$ Fault - Arrows indicate direction of relative movement

Probability

(equal to or

greater than)

0.95

.75

.50

.25

.05
Estimated in-place resources

Oil (millions of bbl)
0

.0

190.9

$3,108.4$

$1,995.6$

\begin{tabular}{lr}
\hline Mean value & 571.8 \\
Standard deviation & $1,995.6$ \\
\hline
\end{tabular}

Total gas (billions of $\mathrm{ft}^{3}$ )
.0

.0

96.3

$1,354.0$

264.1

$1,079.6$
Estimated oil pool size

(millions of bbl)

D

Figure 22.2. Topset play (no. 1, fig. 22.1). A, Map of play area. $B$, Diagrammatic cross section. $C$, Assessment data form. $D$, Estimated resources and pool sizes. 
occurrence, has been recovered on drillstem tests at calculated rates of as much as 2,500 barrels per day. Gas flows of 2.25 million $\mathrm{ft}^{3} /$ day were also measured in the Alaska State A-1 well (fig. 1.1B).

Most postulated traps in this play are stratigraphic and are related to facies changes, with structural traps also formed against small-displacement normal faults; three broad, low-amplitude structures have been identified seismically. Faults and the surrounding thick marine shales are expected to provide fair to good seals.
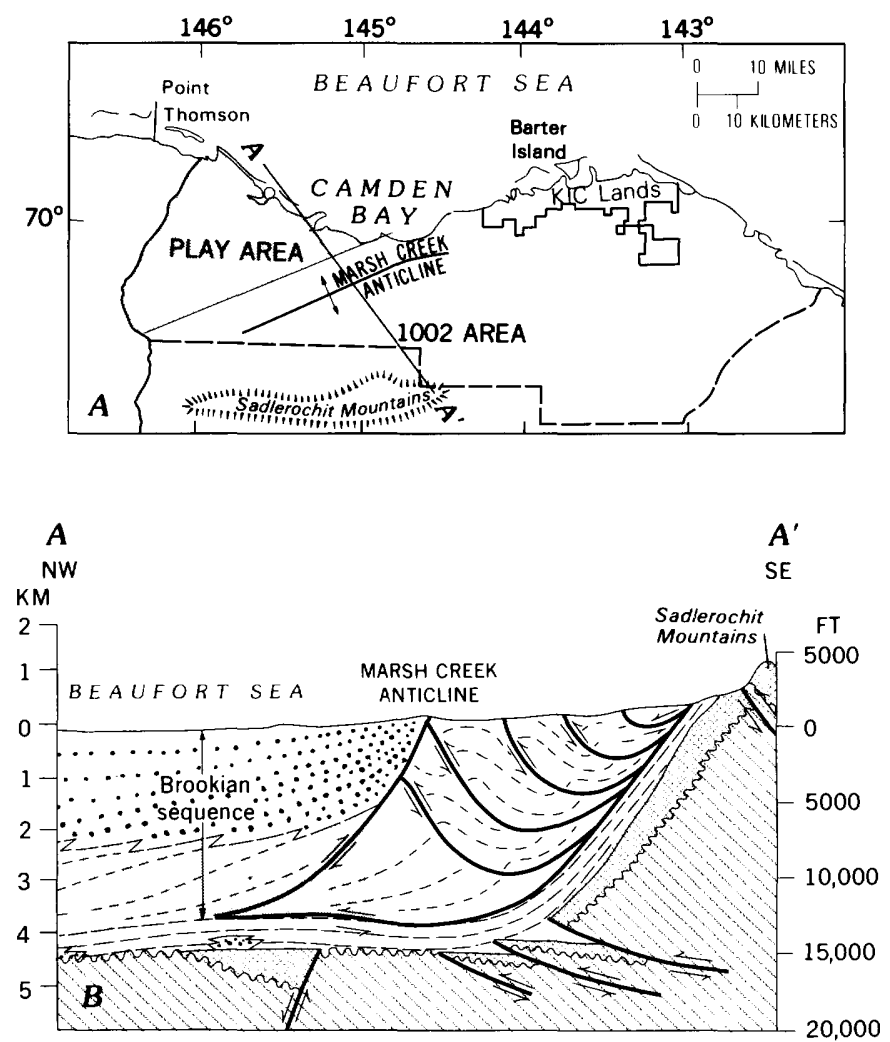

\section{Thomson/Kemik Play}

The Thomson/Kemik play consists of stratigraphic traps in sandstone reservoirs of Early Cretaceous (Neocomian) age in the Kemik Sandstone or the correlative Thomson sand of local usage. This play is limited to the northwestern part of the 1002 area, which is generally unaffected by Brooks Range folding and faulting (fig. 22.4).

The southeastern play boundary is a line marking the transition between folded and faulted rocks

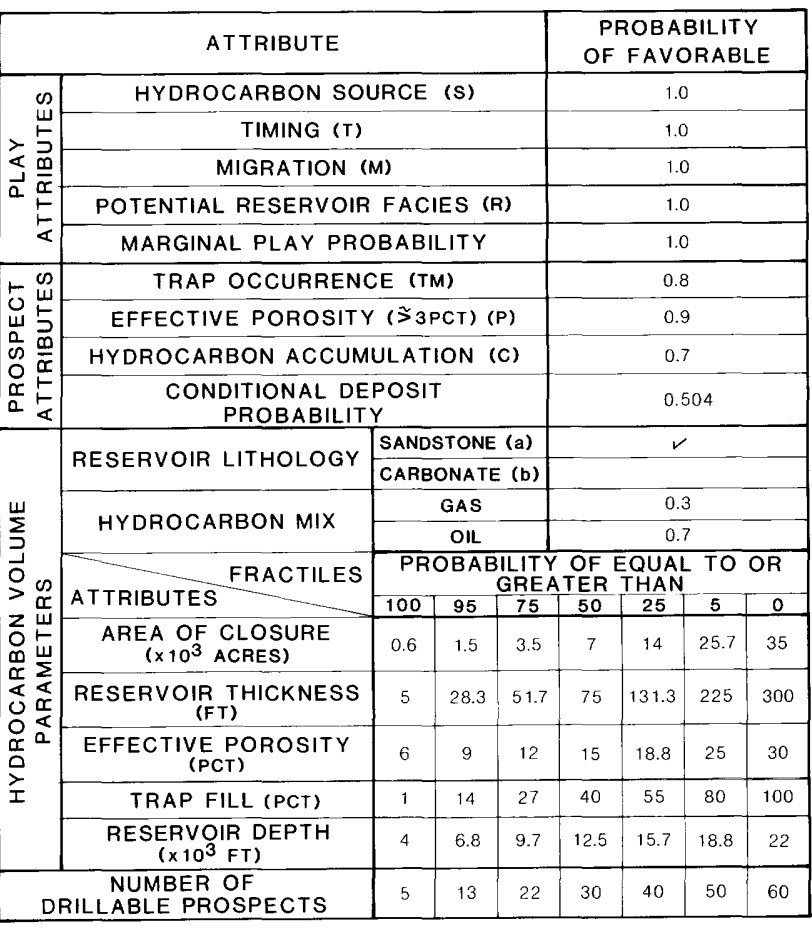

C

Probability (equal to or greater than)

0.95
.75
.50
.25
.05

0.95

.75

50

.05
Estimated in-place resources

Oil (millions of bbl)

713.9

$1,323.8$

$2,022.2$

$3,088.5$

$5,676.2$
Total gas (billions of $\mathrm{ft}^{3}$ )
$1,724.0$

$3,049.2$

$4,526.8$

$6,723.8$

$11,877.0$

$5,372.0$

$3,436.0$
Estimated oil pool size (millions of bbl)

53.4

116.7

255.3

787.3

288.8

386.0

Standard deviation

$1,707.5$

D

Figure 22.3. Turbidite play (no. 2, fig. 22.1). A, Map of play area. B, Diagrammatic cross section. See figure 22.2 for explanation. $C$, Assessment data form. $D$, Estimated resources and pool sizes. 
of the Marsh Creek anticline and the adjacent undeformed rocks. Sandstone in this play overlies the so-called Lower Cretaceous (regional) unconformity, was deposited in shallow-marine to possibly nonmarine depositional conditions, and is expected to be discontinuous. Drilling depths range from 3,660 to 7,620 $\mathrm{m}(12,000-25,000 \mathrm{ft})$.

The reservoir rock may range from a finegrained, well-sorted quartzose sandstone (Kemik) to a detrital dolomite and quartz conglomeratic sandstone

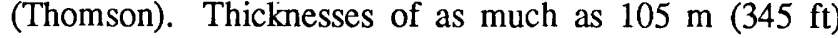

have been penetrated by wells, but the distribution of sandstone is unpredictable and appears to be seismically undetectable. Average porosity is expected to be about 12 percent. Abnormally high fluid pressures are expected in this play, as in wells west of the ANWR in these same units. Owing to abnormal pressures, porosities are expected to be better than normal for similar sandstone at these depths.

Potential source rocks consist of the Canning Formation, Hue Shale, and pebble shale unit, and possibly the Kingak Shale and Shublik Formation where
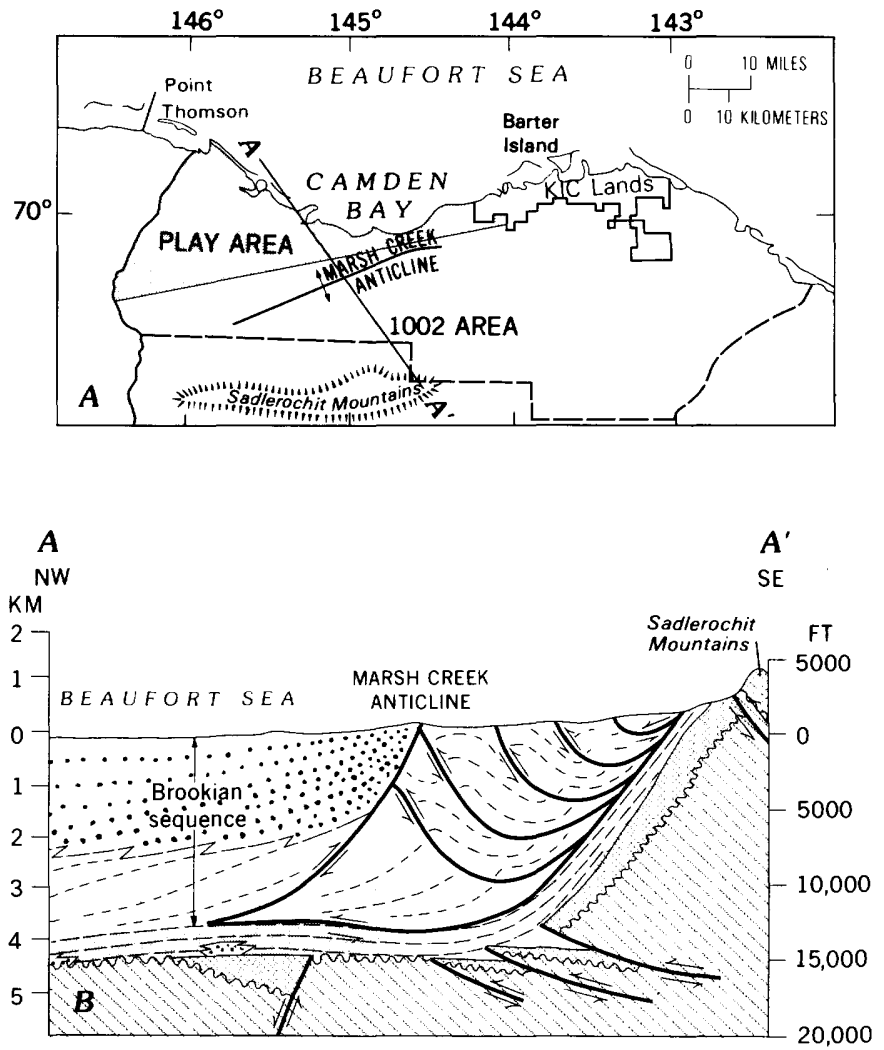

\begin{tabular}{|c|c|c|c|c|c|c|c|c|}
\hline \multicolumn{5}{|c|}{ ATTRIBUTE } & \multicolumn{4}{|c|}{$\begin{array}{l}\text { PROBABILITY } \\
\text { OF FAVORABLE }\end{array}$} \\
\hline \multirow{5}{*}{ を点 } & \multicolumn{4}{|c|}{ HYDROCARBON SOURCE (S) } & \multicolumn{4}{|c|}{1.0} \\
\hline & \multicolumn{4}{|l|}{ TIMING (T) } & \multicolumn{4}{|c|}{1.0} \\
\hline & \multicolumn{4}{|c|}{ MIGRATION (M) } & \multicolumn{4}{|c|}{1.0} \\
\hline & \multicolumn{4}{|c|}{ POTENTIAL RESERVOIR FACIES (R) } & \multicolumn{4}{|c|}{1.0} \\
\hline & \multicolumn{4}{|c|}{ MARGINAL PLAY PROBABILITY } & \multicolumn{4}{|c|}{1.0} \\
\hline \multirow{4}{*}{ 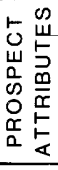 } & \multicolumn{4}{|c|}{ TRAP OCCURRENCE (TM) } & \multicolumn{4}{|c|}{0.3} \\
\hline & \multicolumn{4}{|c|}{ EFFECTIVE POROSITY ( } & \multicolumn{4}{|c|}{1.0} \\
\hline & \multicolumn{4}{|c|}{ HYDROCARBON ACCUMULATION (C) } & \multicolumn{4}{|c|}{0.8} \\
\hline & \multicolumn{4}{|c|}{$\begin{array}{l}\text { CONDITIONAL DEPOSIT } \\
\text { PROBABILITY }\end{array}$} & \multicolumn{4}{|c|}{0.24} \\
\hline \multirow{10}{*}{ 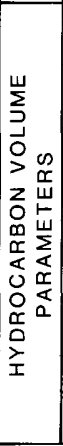 } & \multirow{2}{*}{ RESERVOIR LITHOLOGY } & \multicolumn{3}{|c|}{ SANDSTONE (a) } & \multicolumn{4}{|c|}{$\checkmark$} \\
\hline & & \multicolumn{3}{|c|}{ CARBONATE (b) } & & & & \\
\hline & \multirow{2}{*}{ HYDROCARBON MIX } & \multicolumn{3}{|c|}{ GAS } & \multicolumn{4}{|c|}{0.5} \\
\hline & & \multicolumn{3}{|c|}{ OIL } & \multicolumn{4}{|c|}{0.5} \\
\hline & ATTRIBUTES FRACTILES & PR & $\overline{\mathrm{OBAB}}$ & $\begin{array}{l}\text { ILITY } \\
\text { GREA }\end{array}$ & $\begin{array}{l}\text { OF } \\
\text { TER }\end{array}$ & QQUAL & TO & OR \\
\hline & $\begin{array}{c}\text { AREA OF CLOSURE } \\
\left(\times 10^{3} \text { ACRES }\right)\end{array}$ & 100 & 95 & 75 & 50 & 25 & 50 & 70 \\
\hline & $\underset{(F T)}{\operatorname{RESERVOIR}}$ THICKNESS & 5 & 36.7 & 68.3 & 100 & 175 & 300 & 400 \\
\hline & $\begin{array}{l}\text { EFFECTIVE POROSITY } \\
\text { (PCT) }\end{array}$ & 5 & 7.3 & 9.7 & 12 & 16.5 & 24 & 30 \\
\hline & TRAP FILL (PCT) & 1 & 17.3 & 33.7 & 50 & 66.7 & 83.3 & 100 \\
\hline & $\begin{array}{l}\text { RESERVOIR DEPTH } \\
\left(\times 10^{3} \mathrm{FT}\right)\end{array}$ & 12 & 13 & 14 & 15 & 17.5 & 21.7 & 25 \\
\hline & $\begin{array}{c}\text { NUMBER OF } \\
\text { RILLABLE PROSPECTS }\end{array}$ & 3 & 4 & 5 & 6 & 7 & 9 & 10 \\
\hline
\end{tabular}

Estimated oil pool size

Probability (equal to or Estimated in-place resources Oil (millions of bbl) greater than)
0.95
.75
.50
.25
.05

.0

.0

295.3

$1,296.9$
Total gas (billions of $\mathrm{ft}^{3}$ )

130.1

722.8

$1,813.0$

$5,785.9$

$1,542.1$

$2,804.8$ (millions of bbl)

\section{8}

93.2

210.7

476.3

$1,540.0$

437.7

796.9

Standard deviation

728.5

D

Figure 22.4. Thomson/Kemik play (no. 3, fig. 22.1). $A$, Map of play area. $B$, Diagrammatic cross section. See figure 22.2 for explanation. $C$, Assessment data form. $D$, Estimated resources and pool sizes. 
these formations are present beneath the regional unconformity. Geochemical data indicate that the Hue Shale is oil prone and the other units are gas prone, and that in the play area these deposits may be marginally mature to mature. Both oil and gas are present in the Thomson sand in the Point Thomson field, which is reported by the Exxon Corporation to contain reserves of 5 trillion $\mathrm{ft}^{3}$ (tcf) of gas and 375 million barrels of condensate. Flow rates are reported to be as much as 13 million $\mathrm{ft}^{3}$ of gas and 2,283 barrels of oil per day. Oil gravity generally ranges from $35^{\circ}$ to $45^{\circ}$ API, but some oil with gravity as low as $18^{\circ}$ API has been reported.

Postulated traps in this play are mostly stratigraphic and are related to facies changes, although structural traps may also occur against smalldisplacement normal faults; three broad, low-amplitude structures have also been identified seismically. Faults and the overlying thick marine shales are expected to provide fair to good seals. However, should a widespread basal lag deposit occur above the unconformity, it would make the occurrence of a purely stratigraphic trap less likely.

\section{Undeformed Pre-Mississippian Play}

The Undeformed Pre-Mississippian play consists of stratigraphic traps in carbonate or sandstone reservoirs in the pre-Mississippian basement complex. In this play, it is critical that the reservoir rocks be charged and sealed by source rocks in the overlying Ellesmerian or Brookian sequences. Pre-Mississippian rocks were metamorphosed, folded, faulted, uplifted, and eroded prior to the deposition of younger strata. The occurrence of reservoir rocks in the basement complex is unpredictable. This play is limited to the northwestern part of the 1002 area, which is unaffected by Brooks Range folding and faulting (fig. 22.5). The southeastern play boundary is a line marking the transition between folded and faulted rocks just north of the Marsh Creek anticline and the adjacent undeformed basement rocks. Drilling depths are expected to be 3,660 to $7,620 \mathrm{~m}$ $(12,000$ to $25,000 \mathrm{ft})$.

Potential reservoir rocks may be dolomite, limestone, and sandstone. Dolomites may be vuggy, as is observed in the Katakturuk Dolomite in outcrops. Sandstone may also be present. Under favorable conditions, leaching of calcareous cements may improve the reservoir character of the rocks. Although carbonate rocks may be thick and may locally have porosity as much as 25 percent, the average porosity for the entire unit is expected to be less than 10 percent. Fractures are expected in these rocks and should enhance the observed low-matrix permeabilities. Flow rates from basement rocks in the Alaska State F-1 well were about 3 million $\mathrm{ft}^{3}$ per day and 150 barrels of $35^{\circ}$ API gravity oil per day. Saltwater was recovered from the Alaska State A-1 well at a rate of 4,220 barrels per day, and freshwater was recovered from the Katakturuk Dolomite in the Canning River Unit A-1 well at a rate of 4,800 barrels per day. Abnormally high formation pressures were encountered in the basement rocks in some Point Thomson area wells.

Source rocks within the pre-Mississippian basement complex are unlikely because of the regional metamorphic character of these rocks. Hence, juxtaposition of younger (Cretaceous or Tertiary) source rocks with basement reservoir rocks is critical for hydrocarbon accumulations in this play. The Hue Shale is expected to be a mature oil-prone source rock, and the Canning Formation and pebble shale unit are expected to be gas-prone source rocks. Possible asphaltic hydrocarbons are described from the Katakturuk Dolomite in the Canning River Unit A-1 well, and oil and gas have been recovered from Point Thomson wells.

Postulated traps in this play are stratigraphic and are located in areas where truncation places Cretaceous or Tertiary source rocks in contact with reservoirs in the basement complex.

\section{Imbricate Fold Belt Play}

The Imbricate Fold Belt play consists primarily of structural traps in sandstone reservoirs of Cretaceous and Tertiary age. These traps are the result of Brooks Range folding and faulting. This play encompasses that part of the area southeast of a line marking the limit of deformation of rocks along the north flank of the Marsh Creek anticline (fig. 22.6). Rocks included in this play are bounded below by a major structural detachment zone; in the area of the Sadlerochit Mountains this zone lies within the Kingak Shale, and in the subsurface to the north it is believed to cut stratigraphically up-section and eventually to die out within rocks of the Marsh Creek anticline.

Sandstone reservoirs in this play may consist of the Kemik Sandstone, Canning Formation turbidites, and Sagavanirktok Formation deltaic deposits. Drilling depths in this play range from 30 to $7,920 \mathrm{~m}$ (100 to $26,000 \mathrm{ft}$ ). The turbidite reservoirs are expected to be most prospective in this play. Distribution of the Kemik is expected to be as unpredictable as it is in the Thomson/Kemik play. Deltaic sandstones are generally expected to have the same excellent reservoir qualities but poor sealing characteristics, as described in the Topset play; also included in this play are the very poor reservoir sandstones and conglomerates of the Jago River Formation in the southeastern part of the area. The distribution of this thick formation beyond the area of its surface exposure is unknown.

Potential source rocks consist of the Kingak Shale, pebble shale unit, Hue Shale, and Canning 
Formation. These shales may be present within this play or below the detachment zone in the subjacent Folded Ellesmerian/Pre-Mississippian play. The Canning Formation is expected to be a poor, submature source rock, whereas Jurassic and Cretaceous shales are expected to be fair to good source rocks in the submature to mature range. Oil seeps at Manning Point and Angun Point are thought to be from rocks assigned to this play. In addition, oil-stained sandstone is known from many surface exposures of these rocks.

Traps in this play are mainly structural and are expected to consist of relatively small but numerous fault-cored anticlines. Stratigraphic traps, such as updip pinchouts on the flanks of anticlines, may also be present. Shales within the play are expected to provide fair to good seals for these traps, although faulting and related fracturing may reduce their effectiveness.

\section{Folded Ellesmerian/Pre-Mississippian Play}

The Folded Ellesmerian/Pre-Mississippian play consists mostly of structural traps in sandstone or carbonate reservoirs of pre-Mississippian to earliest
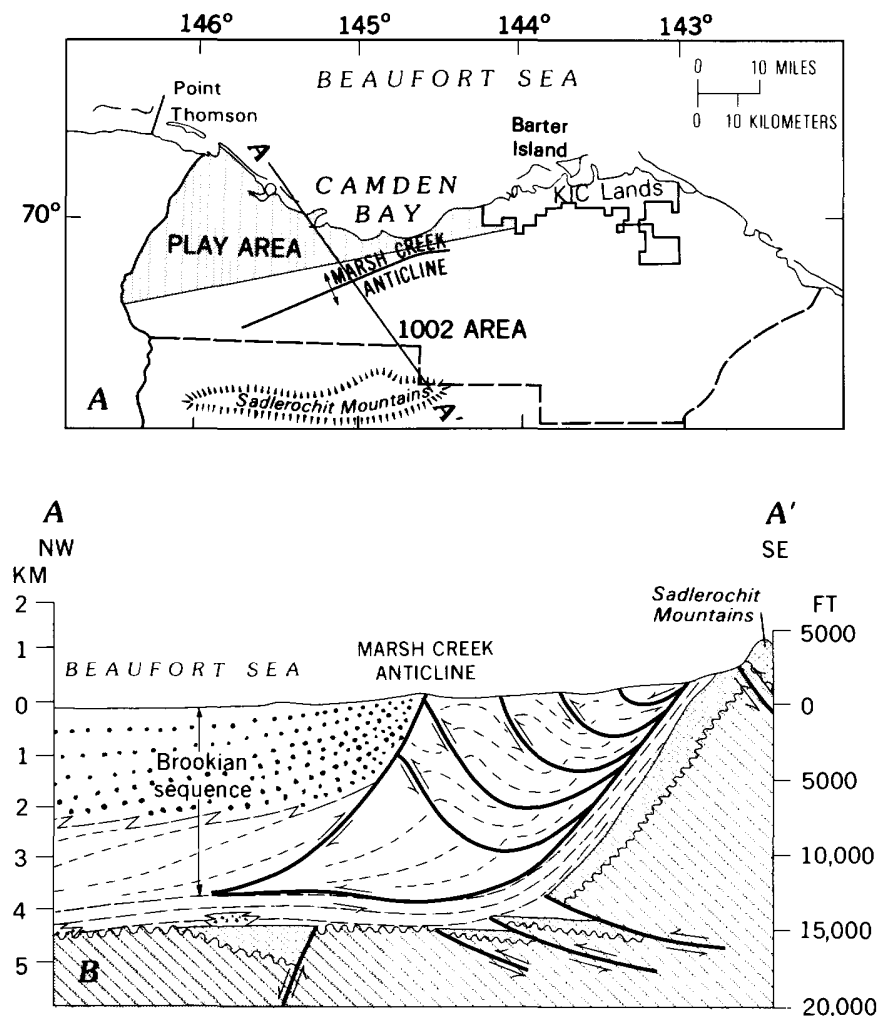

\begin{tabular}{|c|c|c|c|c|c|c|c|c|}
\hline \multicolumn{5}{|c|}{ ATTRIBUTE } & \multicolumn{4}{|c|}{$\begin{array}{l}\text { PROBABILITY } \\
\text { OF FAVORABLE }\end{array}$} \\
\hline \multirow{5}{*}{ 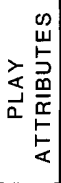 } & \multicolumn{4}{|c|}{ HYDROCARBON SOURCE (S) } & \multicolumn{4}{|c|}{1.0} \\
\hline & \multicolumn{4}{|l|}{ TIMING (T) } & \multicolumn{4}{|c|}{1.0} \\
\hline & \multicolumn{4}{|c|}{ MIGRATION (M) } & \multicolumn{4}{|c|}{1.0} \\
\hline & \multicolumn{4}{|c|}{ POTENTIAL RESERVOIR FACIES (R) } & \multicolumn{4}{|c|}{1.0} \\
\hline & \multicolumn{4}{|c|}{ MARGINAL PLAY PROBABILITY } & \multicolumn{4}{|c|}{1.0} \\
\hline \multirow{4}{*}{ 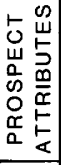 } & \multicolumn{4}{|c|}{ TRAP OCCURRENCE (TM) } & \multicolumn{4}{|c|}{0.3} \\
\hline & \multicolumn{4}{|c|}{ EFFECTIVE POROSITY (ラั3PCT) (P) } & \multicolumn{4}{|c|}{0.5} \\
\hline & \multicolumn{4}{|c|}{ HYDROCARBON ACCUMULATION (C) } & \multicolumn{4}{|c|}{0.8} \\
\hline & \multicolumn{4}{|c|}{$\begin{array}{c}\text { CONDITIONAL DEPOSIT } \\
\text { PROBABILITY }\end{array}$} & \multicolumn{4}{|c|}{0.12} \\
\hline \multirow{11}{*}{ 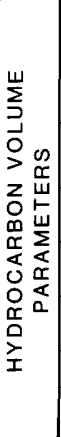 } & \multirow{2}{*}{ RESERVOIR LITHOLOGY } & \multicolumn{3}{|c|}{ SANDSTONE (a) } & & & & \\
\hline & & CARE & DNAT & (b) & \multicolumn{4}{|c|}{$\gamma$} \\
\hline & \multirow{2}{*}{ HYDROCARBON MIX } & \multicolumn{3}{|c|}{ GAS } & \multicolumn{4}{|c|}{0.5} \\
\hline & & & OIL & & \multicolumn{4}{|c|}{0.5} \\
\hline & FRACTILES & \multirow{2}{*}{\multicolumn{7}{|c|}{ 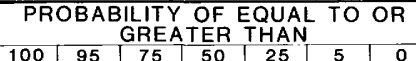 }} \\
\hline & ATTRIBUTES & 100 & & & & & & 0 \\
\hline & $\begin{array}{l}\text { AREA OF CLOSURE } \\
\left(\times 10^{3} \text { ACRES }\right)\end{array}$ & 0.6 & 3 & 7 & 10 & 13 & 20 & 50 \\
\hline & $\underset{(F T)}{\operatorname{RESERVOIR} T H I C K N E S S}$ & 5 & 20 & 35 & 50 & 162.5 & 350 & 500 \\
\hline & $\begin{array}{l}\text { EFFECTIVE POROSITY } \\
\text { (PCT) }\end{array}$ & 3 & 4 & 5 & 6 & 8 & 12 & 15 \\
\hline & TRAP FILL (PCT) & 1 & 7.3 & 13.7 & 20 & 40 & 73.3 & 100 \\
\hline & $\begin{array}{l}\text { RESERVOIR DEPTH } \\
\left(\times 10^{3} \mathrm{FT}\right)\end{array}$ & 12 & 13 & 14 & 15 & 17.5 & 21.7 & 25 \\
\hline $\mathrm{DF}$ & $\begin{array}{l}\text { NUMBER OF } \\
\text { RILLABLE PROSPECTS }\end{array}$ & 3 & 4 & 5 & 6 & 7 & 9 & 10 \\
\hline
\end{tabular}

C

\begin{tabular}{|c|c|c|c|}
\hline \multirow{2}{*}{$\begin{array}{l}\text { Probability } \\
\text { (equal to or } \\
\text { greater than) }\end{array}$} & \multicolumn{2}{|c|}{ Estimated in-place resources } & \multirow{2}{*}{$\begin{array}{l}\text { Estimated oil pool size } \\
\text { (millions of bbl) }\end{array}$} \\
\hline & $\begin{array}{c}\text { Oil } \\
\text { (millions of bbl) }\end{array}$ & $\begin{array}{c}\text { Total gas } \\
\text { (billions of } \mathrm{ft}^{3} \text { ) }\end{array}$ & \\
\hline 0.95 & 0.0 & 0.0 & 3.8 \\
\hline .75 & .0 & .0 & 13.7 \\
\hline .50 & .0 & 6.7 & 33.2 \\
\hline .25 & 8.7 & 125.5 & 80.4 \\
\hline .05 & 131.5 & 628.0 & 287.5 \\
\hline Mean value & 25.6 & 138.3 & 78.5 \\
\hline Standard deviation & 105.8 & 409.2 & 168.4 \\
\hline
\end{tabular}

$D$

Figure 22.5. Undeformed Pre-Mississippian play (no. 4, fig. 22.1). $A$, Map of play area. $B$, Diagrammatic cross section. See figure 22.2 for explanation. $C$, Assessment data form. $D$, Estimated resources and pool sizes. 
Cretaceous age. The structures are the result of Brooks Range folding and faulting. This play underlies nearly the same area as the Imbricate Fold Belt play. The play area lies southeast of a line marking the approximate northern limit of deep basement faulting, which lies just north of the surface trace of the Marsh Creek anticline (fig. 22.7). Rocks included in this play lie beneath the major structural detachment zone that marks the base of the overlying Imbricate Fold Belt play, and reservoirs consist mainly of Ellesmerian and pre-Ellesmerian rocks. Depending upon the stratigraphic level of the main structural detachment zone, some Brookian rocks may also be included.
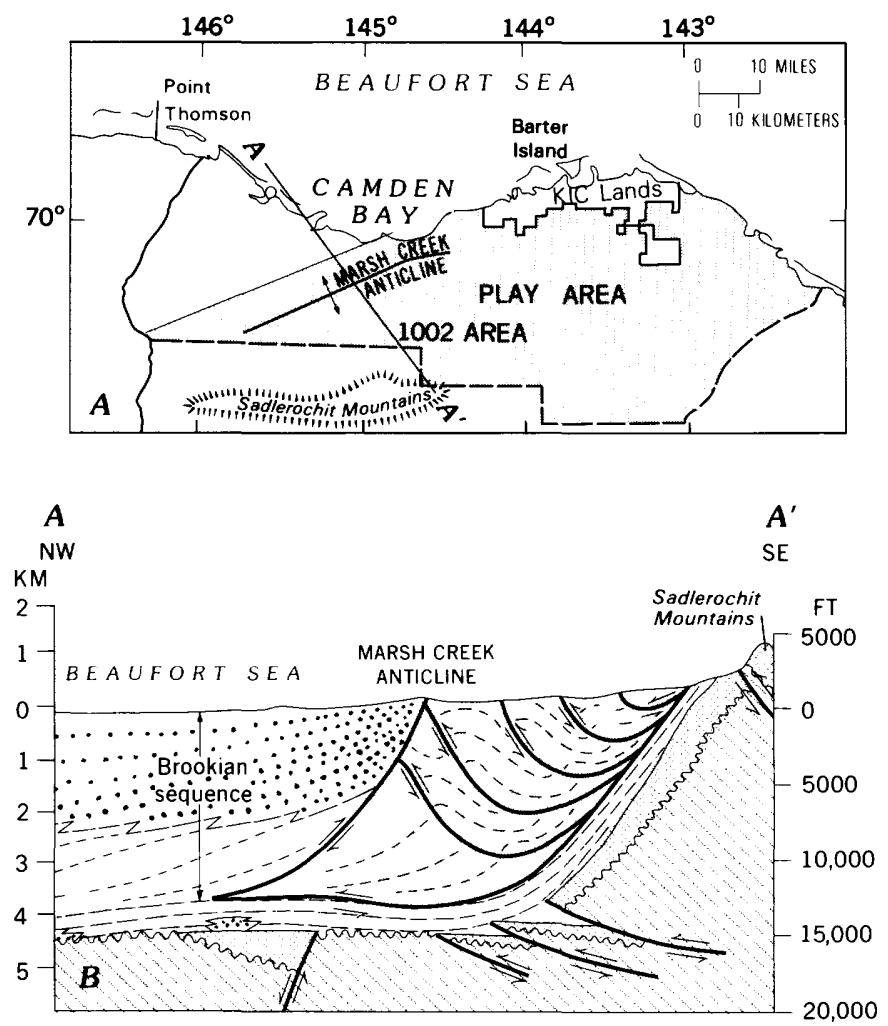

Reservoir rocks in this play consist of both carbonate rocks and sandstone. Potential carbonate reservoirs include the Katakturuk Dolomite, Nanook Limestone, other unnamed pre-Mississippian carbonate rock units, the Lisburne Group, and the Shublik Formation. Potential sandstone reservoirs consist of preMississippian sandstone, the Kekiktuk Conglomerate, Echooka Formation, Ivishak Formation, Karen Creek Sandstone, Kemik Sandstone, and possibly turbidite sandstones in the basal part of the Brookian sequence. The most important sandstone reservoir is expected to be the Ivishak Formation (Ledge Sandstone Member), and the most important carbonate reservoirs are expected to

\begin{tabular}{|c|c|c|c|c|c|c|c|c|}
\hline \multicolumn{5}{|c|}{ ATTRIBUTE } & \multicolumn{4}{|c|}{$\begin{array}{l}\text { PROBABILITY } \\
\text { OF FAVORABLE }\end{array}$} \\
\hline \multirow{5}{*}{ 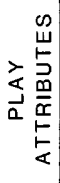 } & \multicolumn{4}{|c|}{ HYDROCARBON SOURCE (S) } & \multicolumn{4}{|c|}{1.0} \\
\hline & \multicolumn{4}{|l|}{ TIMING (T) } & \multicolumn{4}{|c|}{1.0} \\
\hline & \multicolumn{4}{|c|}{ MIGRATION (M) } & \multicolumn{4}{|c|}{1.0} \\
\hline & \multicolumn{4}{|c|}{ POTENTIAL RESERVOIR FACIES (R) } & \multicolumn{4}{|c|}{1.0} \\
\hline & \multicolumn{4}{|c|}{ MARGINAL PLAY PROBABILITY } & \multicolumn{4}{|c|}{1.0} \\
\hline \multirow{4}{*}{ 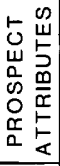 } & \multicolumn{4}{|c|}{ TRAP OCCURRENCE (TM) } & \multicolumn{4}{|c|}{0.6} \\
\hline & \multicolumn{4}{|c|}{ EFFECTIVE POROSITY ( } & \multicolumn{4}{|c|}{0.8} \\
\hline & \multicolumn{4}{|c|}{ HYDROCARBON ACCUMULATION (C) } & \multicolumn{4}{|c|}{0.9} \\
\hline & \multicolumn{4}{|c|}{$\begin{array}{l}\text { CONDITIONAL DEPOSIT } \\
\text { PROBABILITY }\end{array}$} & \multicolumn{4}{|c|}{0.432} \\
\hline \multirow{11}{*}{ 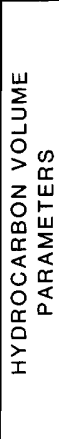 } & \multirow{2}{*}{ RESERVOIR LITHOLOGY } & \multicolumn{3}{|c|}{ SANDSTONE (a) } & \multicolumn{4}{|c|}{$\gamma$} \\
\hline & & \multicolumn{3}{|c|}{ CARBONATE (b) } & \\
\hline & \multirow{2}{*}{ HYDROCARBON MIX } & \multicolumn{3}{|c|}{ GAS } & \multicolumn{4}{|c|}{0.2} \\
\hline & & \multicolumn{3}{|c|}{ OIL } & \multicolumn{4}{|c|}{0.8} \\
\hline & \multirow{2}{*}{ ATTRIBUTES FRACTILES } & $\mathrm{PR}$ & $\overline{\mathrm{OBAE}}$ & $\begin{array}{l}\text { ILITY } \\
\text { GREA }\end{array}$ & & $\begin{array}{l}\text { EQUAL } \\
\text { THAN }\end{array}$ & TO & \\
\hline & & 100 & 95 & 75 & 50 & 25 & 5 & 0 \\
\hline & $\begin{array}{l}\text { AREA OF CLOSURE } \\
\left(\times 10^{3} \text { ACRES }\right)\end{array}$ & 0.6 & 0.8 & 1.3 & 2 & 4 & 7.3 & 10 \\
\hline & $\begin{array}{c}\text { RESERVOIR THICKNESS } \\
(\mathrm{FT})\end{array}$ & 5 & 28.3 & 51.7 & 75 & 181.3 & 358.3 & 500 \\
\hline & $\begin{array}{l}\text { EFFECTIVE POROSITY } \\
(\text { (PCT) }\end{array}$ & 3 & 7 & 11 & 15 & 19.3 & 26.3 & 32 \\
\hline & TRAP FILL (PCT) & 1 & 24 & 52.8 & 70 & 80 & 90 & 100 \\
\hline & $\begin{array}{c}\text { RESERVOIR DEPTH } \\
\left(\times 10^{3} \mathrm{FT}\right)\end{array}$ & 0.1 & 2.4 & 4.7 & 7 & 11.8 & 19.7 & 26 \\
\hline DF & $\begin{array}{c}\text { NUMBER OF } \\
\text { RILLABLE PROSPECTS }\end{array}$ & 10 & 23 & 37 & 50 & 75 & 117 & 150 \\
\hline
\end{tabular}

Probability (equal to or greater than) 0.95 .75 .50 .25 .05
Estimated in-place resources

\section{Oil} (millions of bbl)

$1,006.3$

$1,829.2$

$2,768.5$

$4,192.9$

$7,616.9$

$3,342.9$

$2,263.3$
Total gas (billions of $\mathrm{ft}^{3}$ )

$1,033.2$

$1,897.6$

$2,893.9$

$4,416.6$

$8,112.6$

$3,519.3$

$2,435.5$
Estimated oil pool size (millions of bbl)

12.0

37.8

84.0

186.8

589.9

169.5

296.9

D

Figure 22.6. Imbricate Fold Belt play (no. 5, fig. 22.1). $A$, Map of play area. $B$, Diagrammatic cross section. See figure 22.2 for explanation. $C$, Assessment data form. $D$, Estimated resources and pool sizes. 

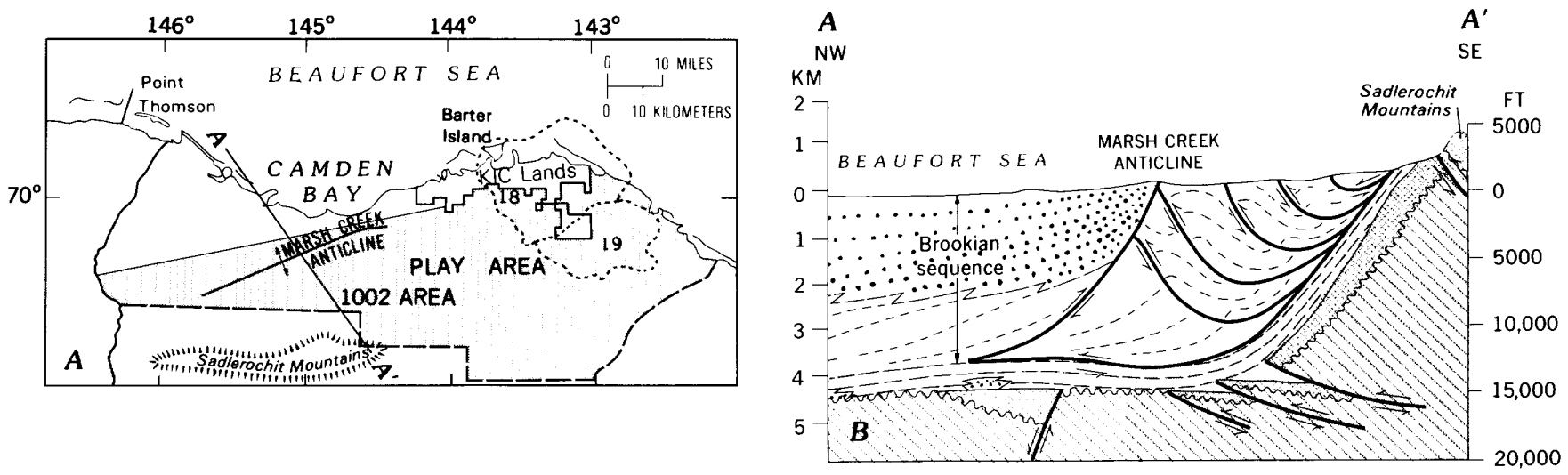

\begin{tabular}{|c|c|c|c|c|c|c|c|c|c|c|c|c|c|c|c|c|c|c|c|c|c|}
\hline \multicolumn{5}{|c|}{ ATTRIBUTE } & \multicolumn{4}{|c|}{$\begin{array}{l}\text { PROBABILITY } \\
\text { OF FAVORABLE }\end{array}$} & & & & \multicolumn{4}{|c|}{$\begin{array}{l}\text { PROBABILITY } \\
\text { OF FAVORABLE }\end{array}$} & & & & \multicolumn{3}{|c|}{$\begin{array}{l}\text { PROBABILITY } \\
\text { OF FAVORABL }\end{array}$} \\
\hline \multirow{5}{*}{ 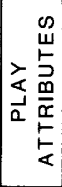 } & \multicolumn{4}{|c|}{ HYDROCARBON SOURCE (S) } & \multicolumn{4}{|c|}{1.0} & & & & \multicolumn{4}{|c|}{1.0} & & & & \multicolumn{3}{|c|}{1.0} \\
\hline & \multicolumn{4}{|c|}{ TIMING (T) } & \multicolumn{4}{|c|}{1.0} & & & & \multicolumn{4}{|c|}{1.0} & & & & \multicolumn{3}{|c|}{1.0} \\
\hline & \multicolumn{4}{|c|}{ MIGRATION (M) } & \multicolumn{4}{|c|}{1.0} & & & & \multicolumn{4}{|c|}{1.0} & & & & \multicolumn{3}{|c|}{1.0} \\
\hline & \multicolumn{4}{|c|}{ POTENTIAL RESERVOIR FACIES (R) } & \multicolumn{4}{|c|}{1.0} & & & & \multicolumn{4}{|c|}{1.0} & & & & \multicolumn{3}{|c|}{1.0} \\
\hline & MARGINAL PLAY PRO & $\mathrm{BABI}$ & LITY & & & 1.0 & & & & & & & 1.0 & & & & & & & 1.0 & \\
\hline$\vdash 8$ & TRAP OCCURRENC & EE (TN & & & & 0.8 & & & & & & & 1.0 & & & & & & & 1.0 & \\
\hline 足岁 & EFFECTIVE POROSITY & $1 \Sigma 3 p$ & CT) & & & $6 a /$ & $0.7 t$ & & & & & & 0.5 & & & & & & & 0.6 & \\
\hline$\infty$ & HYDROCARBON ACCUM & ULATI & ION & & & 0.6 & & & & & & & 0.8 & & & & & & & 0.7 & \\
\hline 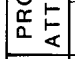 & $\begin{array}{r}\text { CONDITIONAL DE } \\
\text { PROBABILIT }\end{array}$ & $\begin{array}{l}\text { POSIT } \\
\text { POS }\end{array}$ & & & 0.28 & $38 \mathrm{a}$ & 0.33 & & & & & & 0.4 & & & & & & & 0.4 & .42 \\
\hline & RESERYOIR LTHOLOGY & SANDS & STONE & (a) & & $\gamma$ & & & SAND & STONE & $E$ (a) & & 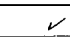 & & & SANDS & STONE & (a) & & $\sigma$ & \\
\hline & HESEAVUIR LIITULUG & CARBC & ONATI & $E(b)$ & 25 per & cent of & fpros & pects & CARE & SONATE & $E(b)$ & & r & & & CARB & ONAT & (b) & & 2 & \\
\hline & HYOROCARBON MIX & & GAS & & & 0.4 & & & & GAS & & & 0.3 & & & & GAS & & & 0.3 & \\
\hline 3 & HVURUCARBUIN MIX & & OIL & & & 0.6 & & & & OIL & & & 0.7 & & & & OIL & & & 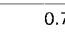 & \\
\hline$>0$ & ATTRIBUTES & PRC & $\overline{\mathrm{OBAE}}$ & $\begin{array}{l}\text { BILITY } \\
\text { GREA }\end{array}$ & ATER & $\begin{array}{l}\text { EQUAL } \\
\text { THAN }\end{array}$ & TO & $\mathrm{OR}$ & & OBAB & $\begin{array}{l}\text { BILITY } \\
\text { GREA }\end{array}$ & OF & $\begin{array}{l}\text { EQUAL } \\
\text { THAN }\end{array}$ & TO & & PR & $\overline{\mathrm{OBAE}}$ & $\begin{array}{l}\text { IILITY } \\
\text { GREA }\end{array}$ & ATER & $\begin{array}{l}\text { EQUAL } \\
\text { THAN }\end{array}$ & L TO \\
\hline z学 & AIIRIBUTES & 100 & 95 & 75 & 50 & 25 & 5 & 0 & 100 & 95 & 75 & 50 & 25 & 5 & 0 & 100 & 95 & 75 & 50 & 25 & 5 \\
\hline 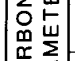 & $\begin{array}{c}\text { AREA OF CLOSURE } \\
\left(\times 10^{3} \text { ACRES }\right)\end{array}$ & 0.6 & 1 & 2 & 4.5 & 10 & 50 & 80 & 130 & 133.3 & 137.5 & 140 & 141.7 & 143.3 & 145 & 110 & 114 & H18 & 122 & 126 & 130 \\
\hline 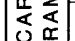 & RESERVOIR THICKNESS & (a) 5 & 86.7 & 168.3 & 250 & 337.5 & 483.3 & 600 & (a) 5 & 36.7 & 68.3 & 100 & 200 & 366.7 & 500 & (a) 5 & 70 & 135 & 200 & 325 & 533.3 \\
\hline $\mid \begin{array}{lll}0 & \frac{1}{8} \\
0 & 1\end{array}$ & (FT) & (b) 5 & 86.7 & 168.3 & 250 & 687.5 & 1417 & 2000 & (b) 5 & 20 & 35 & 50 & 162.5 & 350 & 500 & (b) 5 & 70 & 135 & 200 & 775 & 1733 \\
\hline$a^{a}$ & EFFECTIVE POROSITY & (a) 3 & 7 & 11 & 15 & 18.8 & 25 & 30 & (a) 3 & 6 & 9 & 12 & 16.5 & 24 & 30 & (a) 3 & 7 & 11 & 15 & 18.8 & 25 \\
\hline$\stackrel{0}{\succ}$ & $(\overline{P C T})$ & (b) 3 & 3.3 & 3.7 & 4 & 6.8 & 11.3 & 15 & (b) 3 & 4 & 5 & 6 & 8.3 & 12 & 15 & (b) 3 & 3.7 & 4.3 & 5 & 7.5 & 11.7 \\
\hline I & TRAP FILL (PCT) & 1 & 9 & 17 & 25 & 35 & 50 & 100 & 1 & 10 & 20 & 30 & 40 & 55 & 90 & 1 & 8 & 17 & 25 & 33 & 45 \\
\hline & $\begin{array}{l}\text { RESERVOIR DEPTH } \\
\left(\times 10^{3} \mathrm{FT}\right)\end{array}$ & 2 & 5.7 & 9.3 & 13 & 17 & 21 & 25 & 12.5 & 13.7 & 14.8 & 16 & 17.5 & 20 & 22 & 8 & 9.7 & 11.3 & 13 & 14.7 & 16.3 \\
\hline $\mathrm{DR}$ & $\begin{array}{c}\text { NUMBER OF } \\
\text { RILLABLE PROSPECTS }\end{array}$ & 20 & 21 & 23 & 25 & 27 & 32 & 40 & 1 & 1 & 1 & 1 & 1 & 1 & 1 & 1 & 1 & 1 & 1 & 1 & 1 \\
\hline$C_{1}$ & & & & & & & & & $C_{2}$ & & & & & & & $C_{3}$ & & & & & \\
\hline & Probability & & & & & Estin & mate & $\mathrm{d}$ in- & -plac & e res & sourc & & & & & & stim & ated & oil p & ool & size \\
\hline & $\begin{array}{l}\text { (equal to or } \\
\text { greater than) }\end{array}$ & & & & illior & $\begin{array}{l}\text { Oil } \\
\text { ns of }\end{array}$ & $\mathrm{f} \mathrm{bbl}$ & & & & $\begin{array}{r}\text { To } \\
\text { billio }\end{array}$ & $\begin{array}{l}\text { tal g } \\
\text { ns of }\end{array}$ & $\left.\mathrm{ft}^{3}\right)$ & & & & & illior & ns of & $\mathrm{bbl}$ & \\
\hline & 0.95 & & & & & 120. & & & & & & 305 . & & & & & & & 20.0 & & \\
\hline & .75 & & & & & 620. & & & & & & 871 . & & & & & & & 89.4 & & \\
\hline & .50 & & & & & 725 & & & & & & 660 . & & & & & & & 252.6 & & \\
\hline & .25 & & & & &, 531. & & & & & & 228. & & & & & & & 714.1 & & \\
\hline & .05 & & & & 19 & 953. & & & & & & 914. & & & & & & & 184.6 & & \\
\hline & Mean value & & & & & 922. & & & & & & 346. & & & & & & & 827.6 & & \\
\hline & Standard deviation & & & & & 413. & & & & & & 658. & & & & & & & 581.6 & & \\
\hline
\end{tabular}

D

Figure 22.7. Folded Ellesmerian/Pre-Mississippian play (no. 6, fig. 22.1). A, Map of play area including location of structures 18 and 19. $B$, Diagrammatic cross section. See figure 22.2 for explanation. $C_{l}$, Assessment data form for play exclusive of structures 18 and 19. $C_{2}$, Assessment data form for structure 18. $C_{3}$, Assessment data form for structure 19. $D$, Estimated resources and pool sizes for entire play including structures 18 and 19 . 
be the Lisburne Group and Katakturuk Dolomite. The areal distribution of reservoirs in this play is uncertain. This uncertainty is caused by the Lower Cretaceous regional unconformity in which erosion has removed an undetermined amount of underlying strata. The Ivishak Formation and Lisburne Group can be projected eastward from the Sadlerochit Mountians into the subsurface of the southernmost part of the 1002 area with a relatively high degree of confidence. North of this area, the character of seismic reflections offers the possibility of their presence. However, their northern extent is dependent upon a number of factors, such as the rate of truncation on the unconformity, the amount of northward transport by thrust faulting, and the possible existence of downdropped fault blocks north of the truncation edge, about which we have little direct information. Drilling depths range from 610 to $7,620 \mathrm{~m}(2,000$ to $25,000 \mathrm{ft})$.

Potential source rocks consist of marine shales in the Kayak Shale, Ivishak Formation, Shublik Formation, Kingak Shale, pebble shale unit, and possibly the Hue Shale. The Hue Shale is expected to be the best oil-prone source rock where it occurs above the thermal gas threshold (about $6,700 \mathrm{~m}$, or $22,000 \mathrm{ft}$ ). The other shales are all apparently gas-prone source rocks. They are generally mature to possibly overmature. As with reservoir rocks (described above), truncation is expected to reduce by an unknown amount the areal extent of all source rocks that predate the pebble shale unit.

Traps in this play are mostly structural and are expected to consist of a relatively few large, broad anticlines and fault traps. A significant number of structures smaller than the present $3 \times 6 \mathrm{mi}$ seismic grid are also expected to be present. Stratigraphic traps related to truncation by the Lower Cretaceous unconformity are also possible. The pebble shale unit and younger shales are expected to provide good to excellent seals. However, oil seeps and oil-stained sandstones in the play area indicate that leakage is occurring from traps in this play or the overlying Imbricate Fold Belt play.

Within this play area, two extremely large structures were seismically identified (structures 18 and 19, fig. 22.7). These structures were assessed independently from other structures composing this play, and special consideration was given both to their position relative to the Ellesmerian truncation edge and to the relationship of trap fill to hydrocarbon-column height (fig. 22.7).

\section{Undeformed Ellesmerian Play}

The Undeformed Ellesmerian play consists of stratigraphic traps in carbonate and sandstone reservoirs in the Ellesmerian sequence. The play is limited to the northwestern part of the 1002 area, which is unaffected by Brooks Range folding and faulting (fig. 22.8). The southeastern play boundary is a line marking the transition between folded and faulted rocks and adjacent undeformed Ellesmerian rocks. This boundary coincides with the northwest boundary of the Folded Ellesmerian/Pre-Mississippian play. A wedge of Ellesmerian rocks is seismically mapped beneath the Lower Cretaceous unconformity only in the southwesternmost corner of the play area. Elsewhere in the play area, there may be one or more fault-bounded, downdropped blocks that preserve Ellesmerian rocks. Such fault-bounded blocks are well known in the Prudhoe Bay area, but they have not been identified thus far on the seismic data in the ANWR. Drill depths to Ellesmerian rocks are 3,660 to $7,620 \mathrm{~m}(12,000$ to $25,000 \mathrm{ft}$ ).

Potential reservoirs consist of both sandstone and carbonate rocks. The most important reservoirs are expected to be dolomite in the Lisburne Group and sandstone in the Ledge Sandstone Member of the Ivishak Formation. Reservoir properties may be improved by proximity to the Lower Cretaceous unconformity, as at Prudhoe Bay. Average carbonate porosity is expected to be about 4 percent, and average sandstone porosity about 15 percent.

Potential source rocks consist of marine shales within the Ellesmerian sequence (Kayak Shale, Ivishak Formation, Shublik Formation, Kingak Shale) and the overlying pebble shale unit and Hue Shale. These shales are expected to be submature to mature. Only the Hue Shale is expected to be an oil-prone source rock.

Postulated traps in this play are stratigraphic and are dependent upon the pebble shale unit or younger shales for seals.

\section{ASSESSMENT MODEL}

The play-analysis method attempts to describe the natural occurrence of oil and gas and therefore is described as a model. The model divides the geologic characteristics and attributes of potential hydrocarbon accumulations into three classes: (1) play attributes, (2) prospect attributes, and (3) number of prospects and their reservoir and trap characteristics. Play and prospect attributes, which determine the presence of hydrocarbons, are assessed as to their probability of occurrence. Reservoir and trap characteristics, which determine hydrocarbon volumes, are assessed in terms of ranges of values (sizes). The number of prospects in a play is likewise assessed in terms of a range of values.

The geologist's judgments of these characteristics are recorded on a data form. An example of this form is annotated in figure 22.9 to show how this method addresses the two fundamental questions asked in any assessment: (1) are there oil or gas accumulations in the area, and (2) if so, how much oil and gas is present? 
To answer the first question, it is necessary to assess the play and prospect attributes. Play attributes are the geologic conditions or regional characteristics that apply to the play as a whole. They include the presence or favorability somewhere within the play area of hydrocarbon source, timing, and migration and of potential reservoir-rock facies. Jointly, they determine the favorability for the occurrence of oil or gas within the play. These play attributes are taken to be independent, and the product of their individually assessed probabilities of occurrence (the marginal play probability) is the probability that the play-level attributes necessary for occurrence of hydrocarbons are present. The existence of favorable play attributes is a necessary, but not sufficient, condition for the existence of hydrocarbon accumulations in the play; favorable prospect attributes are also required.

Prospect attributes are those geologic conditions concerning hydrocarbon occurrence that vary at the prospect level. They include the existence of a trapping mechanism, effective porosity, and hydrocarbon accumulation; the latter term refers to the probability of hydrocarbons being available to the individual prospect with proper timing relative to trap formation. Each attribute is assessed as to its probability of occurrence at a randomly selected prospect within the play, conditional
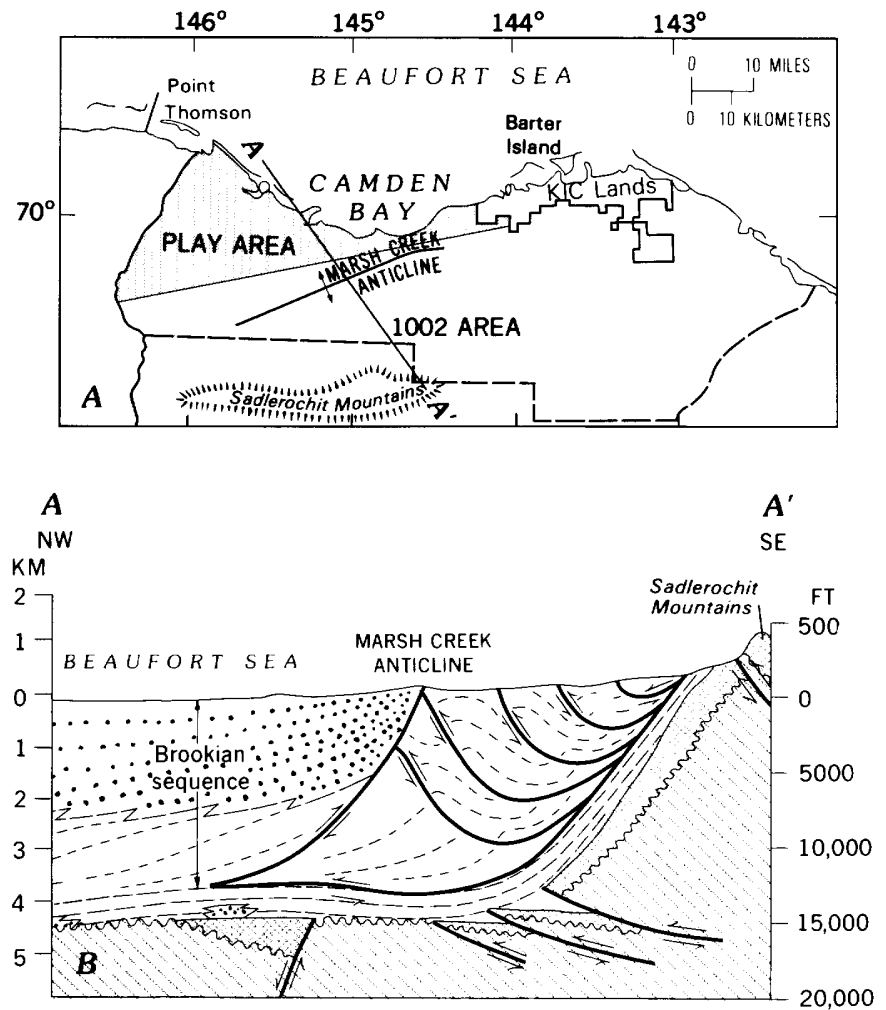

\begin{tabular}{|c|c|c|c|c|c|c|c|c|}
\hline \multicolumn{5}{|c|}{ ATTRIBUTE } & \multicolumn{4}{|c|}{$\begin{array}{l}\text { PROBABILITY } \\
\text { OF FAVORABLE }\end{array}$} \\
\hline \multirow{5}{*}{ 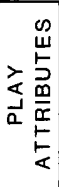 } & \multicolumn{4}{|c|}{ HYDROCARBON SOURCE (S) } & \multicolumn{4}{|c|}{1.0} \\
\hline & \multicolumn{4}{|l|}{ TIMING (T) } & \multicolumn{4}{|c|}{1.0} \\
\hline & \multicolumn{4}{|c|}{ MIGRATION (M) } & \multicolumn{4}{|c|}{1.0} \\
\hline & \multicolumn{4}{|c|}{ POTENTIAL RESERVOIR FACIES (R) } & \multicolumn{4}{|c|}{1.0} \\
\hline & \multicolumn{4}{|c|}{ MARGINAL PLAY PROBABILITY } & \multicolumn{4}{|c|}{1.0} \\
\hline \multirow{4}{*}{ 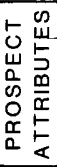 } & \multicolumn{4}{|c|}{ TRAP OCCURRENCE (TM) } & \multicolumn{4}{|c|}{0.6} \\
\hline & \multicolumn{4}{|c|}{ EFFECTIVE POROSITY ( } & \multicolumn{2}{|c|}{$0.6 a$} & \multicolumn{2}{|c|}{$0.5 \mathrm{~b}$} \\
\hline & \multicolumn{4}{|c|}{ HYDROCARBON ACCUMULATION (C) } & \multicolumn{4}{|c|}{0.8} \\
\hline & \multicolumn{4}{|c|}{$\begin{array}{c}\text { CONDITIONAL DEPOSIT } \\
\text { PROBABILITY }\end{array}$} & \multicolumn{4}{|c|}{$0.288 \mathrm{a} \quad 0.24 \mathrm{~b}$} \\
\hline \multirow{13}{*}{ 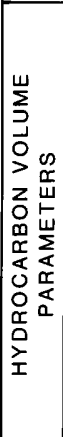 } & \multirow{2}{*}{ RESERVOIR LITHOLOGY } & \multicolumn{3}{|c|}{ SANDSTONE (a) } & \multicolumn{4}{|c|}{$r$} \\
\hline & & \multicolumn{3}{|c|}{ CARBONATE (b) } & \multicolumn{4}{|c|}{$\sigma$} \\
\hline & \multirow{2}{*}{ HYDROCARBON MIX } & \multicolumn{3}{|c|}{ GAS } & \multicolumn{4}{|c|}{0.5} \\
\hline & & \multicolumn{3}{|c|}{ OIL } & & 0 & & \\
\hline & FRACTILES & PRC & $\overline{\mathrm{BAB}}$ & $\begin{array}{l}\text { BILITY } \\
\text { GREA }\end{array}$ & $\begin{array}{l}\text { OF } \\
\text { TER }\end{array}$ & THUA & TO & OR \\
\hline & ATTRIBUTES & 100 & 95 & 75 & 50 & 25 & 5 & 0 \\
\hline & $\begin{array}{l}\text { AREA OF CLOSURE } \\
\left(\times 10^{3} \text { ACRES }\right)\end{array}$ & 0.6 & 3 & 7 & 10 & 13 & 20 & 40 \\
\hline & RESERVOIR THICKNESS & (a) 5 & 36.7 & 68.3 & 100 & 175 & 300 & 400 \\
\hline & (FT) & (b) 5 & 86.7 & 168.3 & 250 & 437.5 & 750 & 1000 \\
\hline & EFFECTIVE POROSITY & (a) 3 & 7 & 11 & 15 & 18.8 & 25 & 30 \\
\hline & ( $\mathrm{PCT})$ & (b) 3 & 3.3 & 3.7 & 4 & 6.8 & 11.3 & 15 \\
\hline & TRAP FILL (PCT) & 1 & 10.7 & 20.3 & 30 & 47.5 & 76.7 & 100 \\
\hline & $\begin{array}{c}\text { RESERVOIR DEPTH } \\
\left(\times 10^{3} \mathrm{FT}\right)\end{array}$ & 12 & 12.7 & 13.3 & 14 & 16.8 & 21.3 & 25 \\
\hline DF & $\begin{array}{l}\text { NUMBER OF } \\
\text { RILLABLE PROSPECTS }\end{array}$ & 2 & 3 & 3 & 4 & 5 & 5 & 6 \\
\hline
\end{tabular}

C
Probability

(equal to or greater than) 0.95 .75 .50 .25 .05
Estimated in-place resources

Oil (millions of bbl)

0.0

242.8

919.7

Mean value

217.6

Standard deviation

487.3

Total gas (billions of $\mathrm{ft}^{3}$ ) 0.0

178.0

570.1

$1,312.2$

$3,926.3$

$1,094.1$

$1,802.2$
Estimated oil pool size (millions of bbl)

128.4

289.6

933.3

\section{D}

Figure 22.8. Undeformed Ellesmerian play (no. 7, fig. 22.1). $A$, Map of play area. $B$, Diagrammatic cross section. See figure 22.2 for explanation. $C$, Assessment data form. $D$, Estimated resources and pool sizes. 
on the assumption that the play attributes are favorable. Prospect attributes are ordinarily treated as independent.

For a prospect to be an accumulation, the attributes of the play in which it exists must also be favorable. The conditional deposit probability, which describes the probability that a random prospect is a hydrocarbon accumulation given that the play is favorable, is simply their product. The probability that a hydrocarbon accumulation exists at a prospect is the product of the marginal play probability and the conditional deposit probability. The commonly used term "prospect risk" is simply 1 minus this product. Therefore, from the total number of prospects in a potentially productive play, some proportion will be hydrocarbon bearing and the remainder "dry"-a common situation in nature. Because of the small limiting values that are used for hydrocarbon volume parameters, prospects modeled as hydrocarbon accumulations will encompass deposits of all sizes, including very small deposits. This is one of the significant differences that must be recognized in comparing results between the in-place and recoverable resource estimates. The in-place estimate for each play includes the full range of accumulation sizes for each prospect containing hydrocarbons.

To answer the second question of how much oil and gas is present, it is necessary to assess the number of prospects and the hydrocarbon volume parameters-those characteristics that determine the number and size of oil or gas deposits within the play.

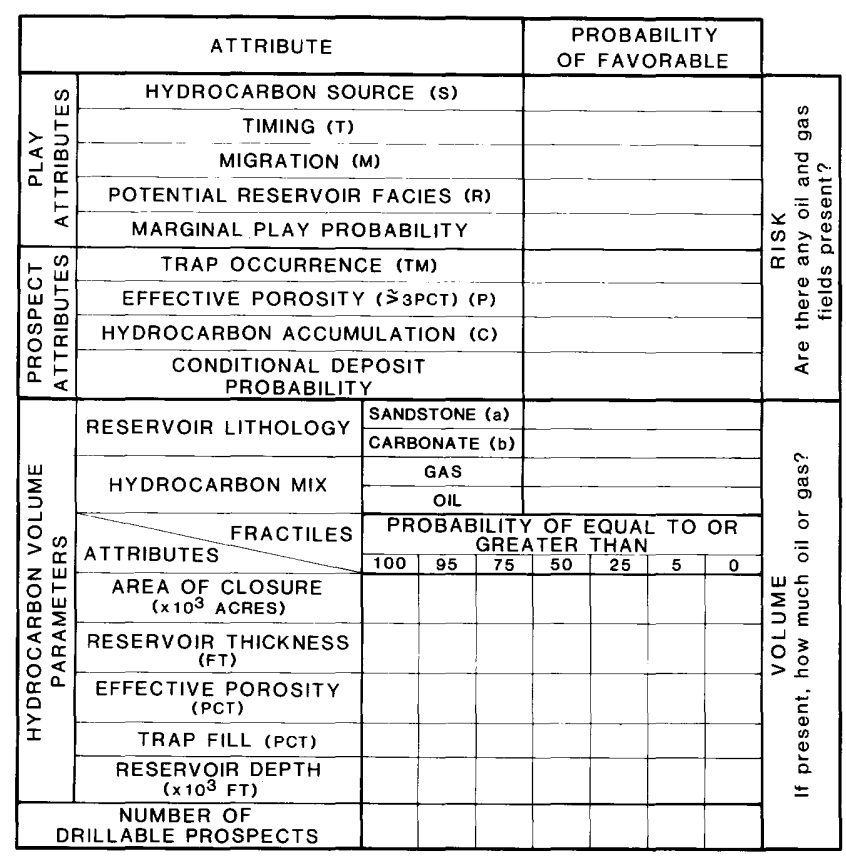

Figure 22.9. Example of play-analysis data form, annotated to show two fundamental questions asked in petroleum assessment.
The identification of all prospects within a play is generally impossible because of limitations on data quality, availability, or resolution. The number of prospects is therefore an uncertain quantity and is described by a distribution having a range of possible values. This distribution is derived largely from geophysical maps showing structural closures and anomalies tempered with an understanding of the geologic framework, which allows an estimation of unseen but suspected prospects, and is assessed in seven fractiles (probability levels).

The estimates of oil or gas volumes in deposits are functions of the probability distributions of five hydrocarbon volume parameters. These parameters are (1) area of the trap, (2) reservoir-rock thickness, (3) effective porosity, (4) trap fill, and (5) reservoir depth. They are treated as statistically independent. These five parameters are established by the assessment committee, whereas the sixth parameter is built into the computer program. The sixth parameter, water saturation, which is the complement of hydrocarbon saturation, is chosen from one of two distributions-one for sandstone and one for carbonate rock-developed by the Geological Survey of Canada, and is based on negative correlation $(r=-0.9)$ with effective porosity. These six parameters describe characteristics at randomly selected prospects within the play. They are uncertain quantities, described as distributions, and are assessed by seven fractiles. They are conditional on the prospect containing hydrocarbons.

Once the volume parameter values are estimated for a random deposit, and the tendency of accumulations in the play to be oil or nonassociated gas also estimated (hydrocarbon mix), it is possible to determine the oil or gas volume. Each deposit is either oil or nonassociated gas (that is, gas that exists free and independently of oil). The equations for in-place hydrocarbon resources are the standard volumetric expressions for the calculation of pore space occupied by fluid, expressed as barrels of liquid or cubic feet of gas.

$$
\begin{aligned}
\text { oil in place } & =7,758 \text { A F H } \phi\left(1-S_{w}\right) / B_{o}, \\
\text { gas in place } & =43,560 \text { A F H } \phi\left(1-S_{w}\right)\left(\mathrm{P}_{\mathrm{e}} / \mathrm{T}\right)(1 / \mathrm{Z})\left(\mathrm{T}_{\mathrm{sc}} / \mathrm{P}_{\mathrm{sc}}\right)
\end{aligned}
$$

where $\mathrm{A}=$ area of closure (acres),

$F=$ trap fill (decimal fraction),

$\mathrm{H}=$ reservoir thickness (feet),

$\phi=$ effective porosity (decimal fraction),

$S_{\mathrm{w}}=$ water saturation (decimal fraction),

$\mathrm{B}_{\mathrm{w}}=$ oil formation volume factor,

$\mathrm{P}_{0}=$ original reservoir pressure (psi),

$\dot{\mathrm{T}}=$ reservoir temperature (degrees Rankine),

$\mathrm{Z}=$ gas compressibility factor,

$\mathrm{T}_{\mathrm{sc}}=$ temperature, standard conditions (degrees Rankine),

$\mathrm{P}_{\mathrm{sc}}=$ pressure, standard conditions (psi). 
Those prospects in the play that are hydrocarbon bearing are represented in size by the conditional poolsize estimates, which are reported in the data output as "accumulation size," and their total is the oil or nonassociated gas resource for the play.

Dissolved gas (that is, gas in solution with the oil) is assumed to be at saturation and is calculated from the in-place oil by using an engineering equation (Crovelli and Balay, 1986). The assessment results include dissolved gas, nonassociated gas, and their combined totals; however in this report we generally give their sum.

In the geologic model, based on geochemical and geothermal studies in and adjacent to the ANWR, a floor for hydrocarbon liquids was assumed at $6,860 \mathrm{~m}$ $(22,500 \mathrm{ft})$, and all hydrocarbon-bearing prospects beneath it were calculated to be gas.

Plays were described to minimize dependencies between them and were treated as independent. Within each play, attributes and parameters were also generally treated as independent, except in special cases. Where dependency was assumed, as between the prospect attributes of trap mechanism and effective porosity in stratigraphic traps, the assessment was handled on a dependency basis. In both plays containing reservoirs of differing lithologies (Folded Ellesmerian/Pre-Mississippian and Undeformed Ellesmerian plays), the prospect attributes of trapping mechanism and hydrocarbon accumulation were considered shared between the reservoirs. Dependency problems are inherent in any analysis and affect the extreme values of derived resource distributions more than their central parts. Uncertainty attendant to assessment of a play's geologic characteristics generally appears to be more significant.

Although robust and flexible in its handling of uncertain events for frontier areas, the play-analysis method requires that all plays be identified and properly described when used for assessment of the total resource base. In the exploration process, unanticipated discoveries and failures occur often enough to warrant cautioning users of this report that as new data become available and play concepts are modified or revised, resource estimates will change.

The computer program FASP, which utilizes probability theory, processed the geologic input from the data forms. The specific structure of the probabilistic methodology used for calculation of individual play resources (Crovelli and Balay, 1986), shown in figure 22.10, can be considered in three basic components: (1) determination of the potential size of a deposit for the commodity being assessed in a random prospect; (2) determination of the number of prospects in the play that contain the commodity being assessed; and (3) derivation from (1) and (2) of the play resource potential. Each resource-that is, oil, nonassociated gas, and dissolved gas-is separately calculated. Finally, the estimated resources of each play and subplay are aggregated, using

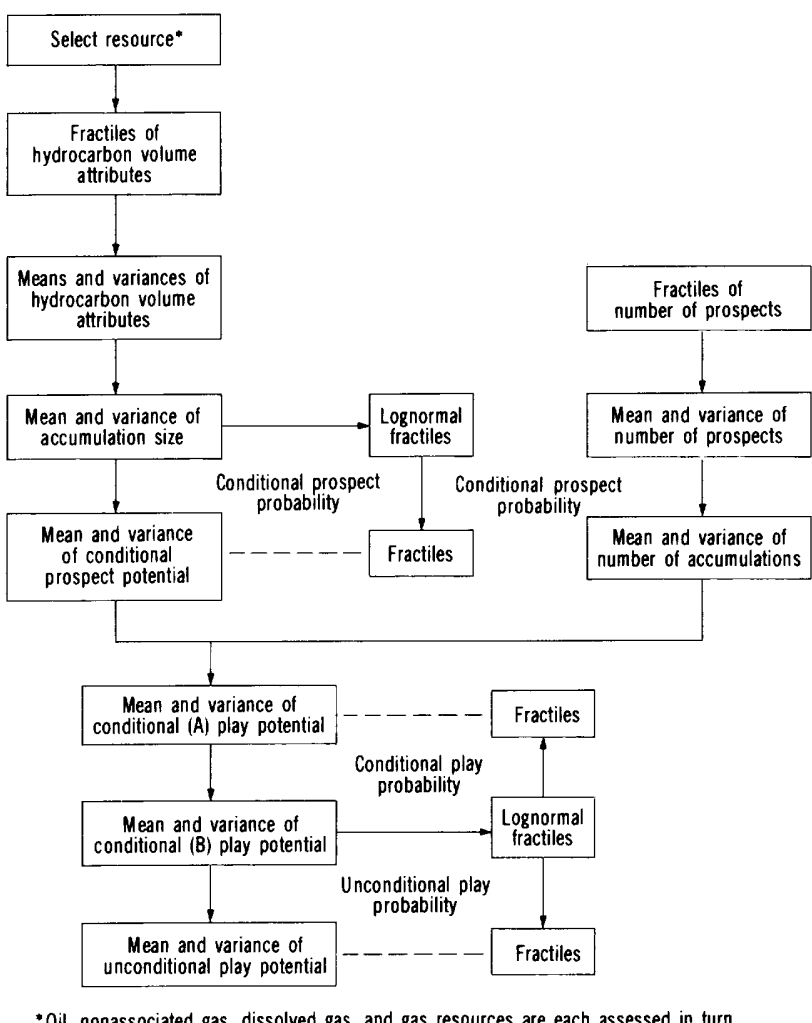

Figure 22.10. Flow chart of analytic method of play analysis.

probability theory, for the grand totals of oil and gas as reported for the various assessment areas.

\section{ASSESSMENT PROCEDURE}

The assessment of the oil and gas resources of the 1002 area was completed in several stages. The final assessment was accomplished in October 1985 and subsequently reviewed in April 1986. Two committees of USGS and BLM geologists, geophysicists, and appraisal specialists participated. The Geologic Assessment Committee was convened specifically to develop the initial geologic input required for the play analysis. The Assessment Review Committee functioned as a review panel whose purpose was to ensure completeness of geologic input, conformity with statistical and methodologic requirements of the assessment procedure, and adequate representation of plays, and to review the magnitude and distribution of possible resources. Observers from the BLM, USGS, and FWS attended.

The assessment was organized into three segments: (1) review of the geologic and geophysical data and identification of the plays and subplays (the units of assessment); (2) assessment of the geologic input parameters and computer generation of initial oil and gas 
resource estimates; and (3) review of the entire assessment.

In assessing each play, the assessment team reviewed and synthesized extensive data summaries and interpretations, representing many months of work by a team of geologists. A typical data summary for a play consists of several types of maps, cross sections, charts, and graphs, of which many are included in the preceeding chapters. Such comprehensive data summaries are essential for an efficient and reliable assessment and were based upon data derived from seismic, surface, geological, geochemical, aeromagnetic, gravity, and other studies, as well as subsurface data from contiguous or analog areas. Judgment values were elicited by consensus and entered on appraisal data forms. This included assignment of risk to the geologic attributes in each play and its prospects, and estimation of probability distributions using seven fractiles for such variables as effective porosity, reservoir thickness, and number of prospects. Graphic displays were generated for each input distribution to ensure valid input.

As the form for each play was completed, the information on the data form was entered into the computer and calculated by the play-analysis program FASP, which for each play resulted in initial resource estimates of in-place oil and gas and pool sizes. These initial estimates were analyzed by the committees, who ranked the plays and modified input where deemed necessary.

\section{ESTIMATES AS DISTRIBUTIONS}

The estimates of in-place oil and gas resources included in this report are in the form of complementary cumulative probability distributions, as shown in figure 22.11. These distributions summarize the range of estimates generated by the FASP computer program as a single probability curve in a "greater than" format. Because of the uncertainty attached to the many geologic variables, no single answer is possible to the question of how much oil and gas are present; instead, an infinite number of answers are possible, each with its own confidence level. In nature only one real value exists, and the curve is an expression of the uncertainty about its size. The degree of uncertainty is expressed in the "spread" or variance of the distribution. Larger quantities correspond to lower probabilities-that is, there is less confidence that greater than those quantities are present.

Our estimates are reported at the mean and at the $95^{\text {th }}$ and $5^{\text {th }}$ fractiles. In addition to the mean value, other central values are presented. We consider the $95^{\text {th }}$ and $5^{\text {th }}$ fractiles to be "reasonable" minimum and maximum values. Values exist beyond this nominal range, but estimates in those extreme parts of the probability distribution are highly sensitive to assumptions on the form of the statistical distribution and

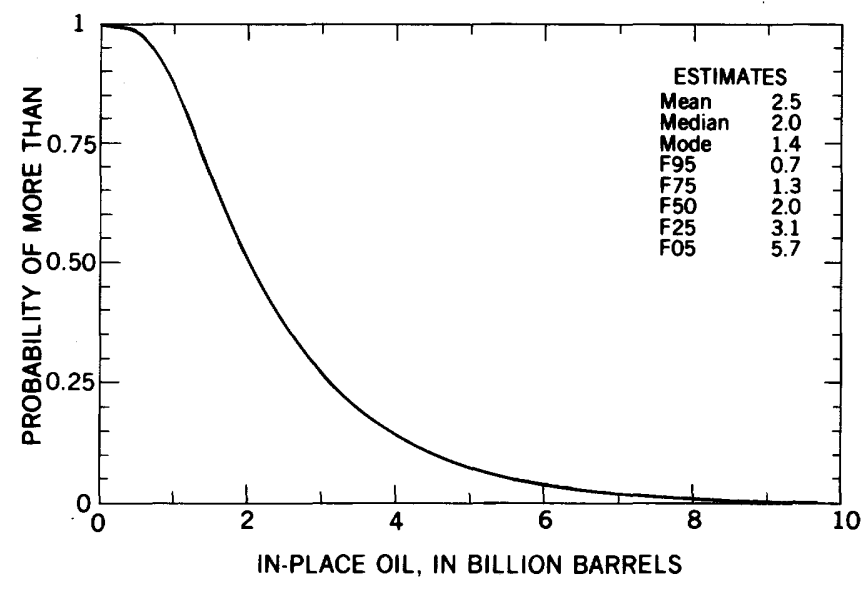

Figure 22.11. Typical cumulative probability curve showing decreasing probability associated with increasing amounts of resource. At a given probability, quantity of resource is greater than corresponding value shown. $\mathrm{F}$, fractile (probability) value. The curve is read as follows: there is a 50 percent chance that the resource potential is greater than 2.0 billion barrels, and there is a 5 percent chance that the resource is greater than 5.7 billion barrels.

assumptions and dependencies in the underlying assessment. Slight changes in these factors can produce large changes in resource quantities beyond the $95^{\text {th }}$ and $5^{\text {th }}$ fractiles, making them unreliable for planning purposes.

\section{ESTIMATES OF IN-PLACE RESOURCES}

In-place oil and gas resources within the 1002 area of the ANWR are estimated to range from 4.8 to 29.4 billion barrels of oil (bbo) and from 11.5 to 64.5 trillion $\mathrm{ft}^{3}$ of gas (tcfg), at the 0.95 and 0.05 probability levels, respectively (fig. 22.12, table 22.1). Although these ranges of values show a relatively high degree of uncertainty regarding the true value, they do indicate the potential for large quantities of oil and gas or the possibility that there may be no exploitable petroleum resources in the ANWR. Mean in-place values are calculated to be 13.8 bbo and $31.3 \mathrm{tcfg}$. The median (50th fractile) is 11.9 bbo and $27.3 \mathrm{tcfg}$ and the "most likely" (modal) values are $8.8 \mathrm{bbo}$ and $20.8 \mathrm{tcfg}$. The mean values are larger as a result of the resource distributions being positively skewed. For perspective, the Prudhoe Bay field is calculated to have initially contained in-place resources of about 23 bbo and more than $35 \mathrm{tcfg}$ in the Triassic reservoirs. Furthermore, an area similar in size and shape to the 1002 area, centered at Prudhoe Bay, encompasses 10 oil and gas 
accumulations, both economic and uneconomic, with inplace resources of nearly 60 bbo and $45 \mathrm{tcfg}$.

This assessment of in-place oil and gas represents those deposits that constitute the resource base without reference to recoverability. Included are accumulations estimated to range in size from very small (in-place reserves of far less than 1 million barrels of oil or equivalent) to very large (in-place reserves greater than 1 billion barrels). (See figs. 22.2 through 22.8 for tabulations of pool sizes.) The accumulations are made up of both stratigraphic traps and structural traps, and they include not only those traps that are unequivocally identified and measured by seismic data, but also those that are inferred to exist on the basis of framework geology. Clearly, these in-place resources include many deposits well below any economic size limit that may currently be assumed for the Arctic, as well as deposits that have reservoir characteristics that would preclude them from being economic (see chap. 23).
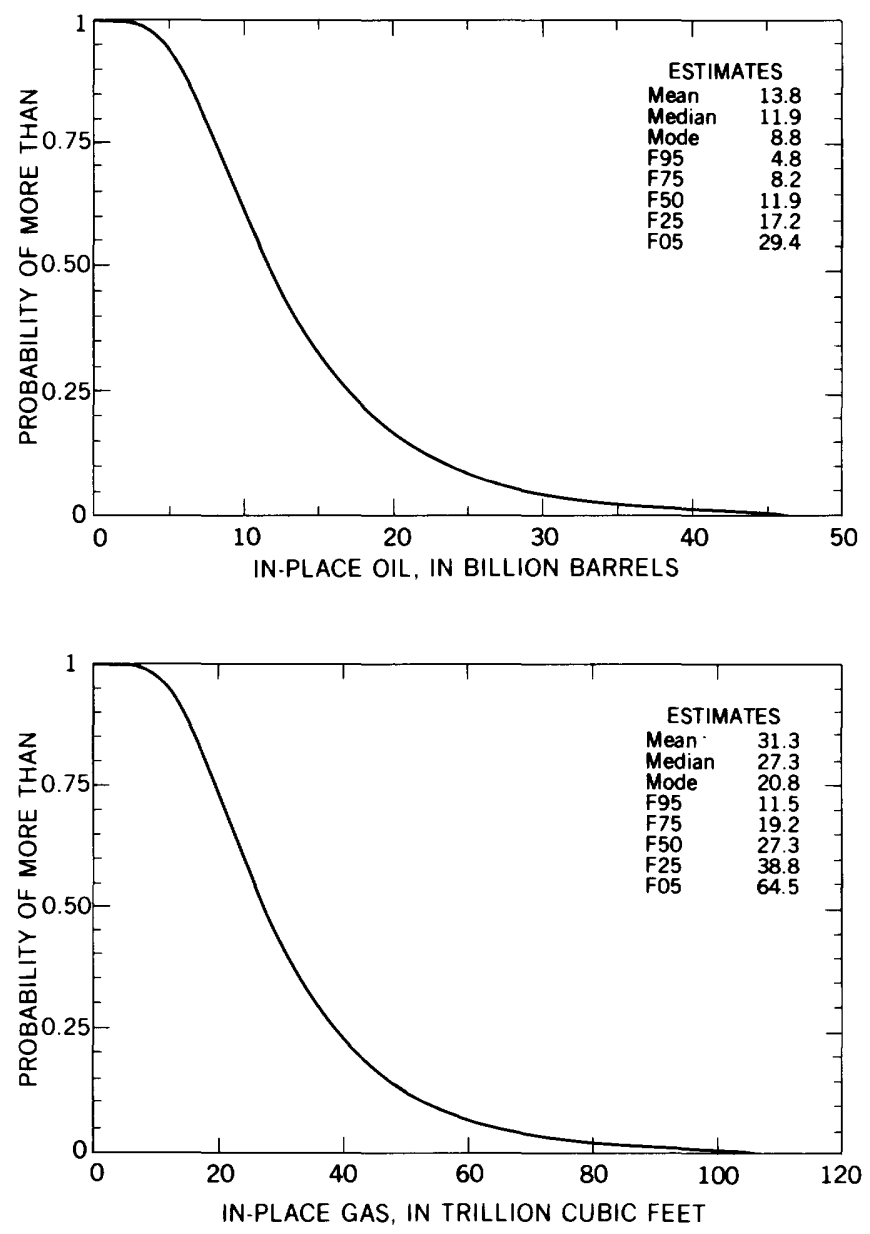

Figure 22.12. Probability curves showing estimated inplace oil and total gas resources of 1002 area. F, fractile (probability) value. See figure 22.11 for further explanation.
The seismic data show that the 1002 area consists of two distinct geologic provinces: (1) an area of little deformation showing very subtle structures, similar to the Prudhoe Bay-Point Thomson region, that comprises the northwestern one-third of the 1002 study area, and (2) an area of much deformation showing numerous structures, with some similarities to the Brooks Range foothills elsewhere on the North Slope, that comprises the southeastern two-thirds of the 1002 study area. The boundary between these two provinces is approximated by the axis of the Marsh Creek anticline. Five plays are located in the northwestern area and two in the southeastern area (refer to play area maps in figs. 22.2-22.8). The two distinct geologic provinces of the 1002 area have very different estimated resource values (table 22.1). Approximately 25 percent of the mean estimated in-place oil and gas is in the northwest sector, whereas 75 percent is in the southeast sector.

Estimated in-place resources of each of the seven plays are compared in figures 22.13 and 22.14 . The most significant play in terms of resource contribution is the Folded Ellesmerian/Pre-Mississippian play, containing approximately 50 percent of the area's estimated in-place oil and 60 percent of its estimated gas. This play has several unusually large structural prospects and is estimated to contain large accumulations. Following this play, in order of decreasing importance, are the Imbricate Fold Belt and the Turbidite plays. However, in these and several other plays, the estimated accumulation sizes, though perhaps substantial, are often of such size as to be of little or no current economic interest if occurring singly, and they are often mapped with great difficulty. If occurring

Table 22.1. Summary of 1985 USGS/BLM assessment of in-place oil and gas resources in the ANWR 1002 area

[F95, 95 th $^{\text {fractile; F05, }} 5^{\text {th }}$ fractile; oil in billions of barrels; gas in trillions of cubic feet; total gas represents dissolved gas plus nonassociated gas]

\begin{tabular}{|c|c|c|c|}
\hline & F95 & F05 & Mean \\
\hline \multicolumn{4}{|c|}{ Total ANWR 1002 area } \\
\hline Oil & 4.8 & 29.4 & 13.8 \\
\hline Nonassociated gas & 3.7 & 43.6 & 16.7 \\
\hline Total gas & 11.5 & 64.5 & 31.3 \\
\hline \multicolumn{4}{|c|}{ Northwest sector (plays $1-4,7$ ) } \\
\hline Oil & 0.9 & 8.7 & 3.6 \\
\hline Nonassociated gas & 1.0 & 11.9 & 4.6 \\
\hline Total gas & 3.0 & 17.8 & 8.4 \\
\hline \multicolumn{4}{|c|}{ Southeast sector (plays 5, 6) } \\
\hline Oil & 2.7 & 24.7 & 10.3 \\
\hline Nonassociated gas & 1.7 & 36.3 & 12.2 \\
\hline Total gas & 6.2 & 54.4 & 22.9 \\
\hline
\end{tabular}


above deeper and larger deposits or close to them, such accumulations may be of interest.

To facilitate weighing of land-use values within the 1002 area, the mean values of in-place oil and gas resources were assessed for four separate geographic land blocks, as shown in figure 22.15 .

\section{COMPARISON WITH 1980 ASSESSMENT}

The current assessment shows an overall increase of estimated in-place oil and gas resources and pool sizes when compared with the 1980 USGS assessment (Mast and others, 1980; table 22.2). The

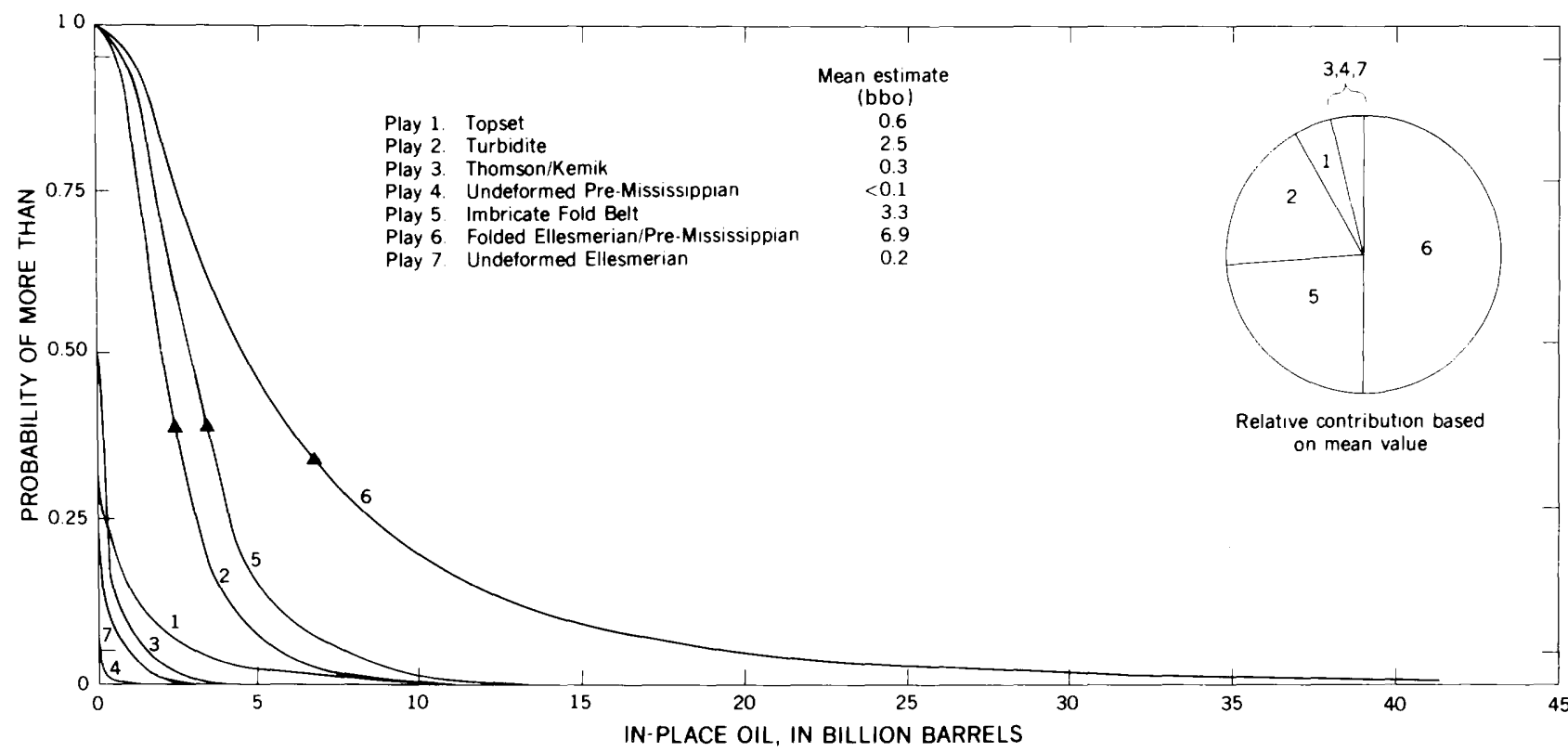

Figure 22.13. Estimated in-place oil for all plays in 1002 area. Individual probability curves show relative contribution of each play. Triangles show mean values on principal distribution curves.

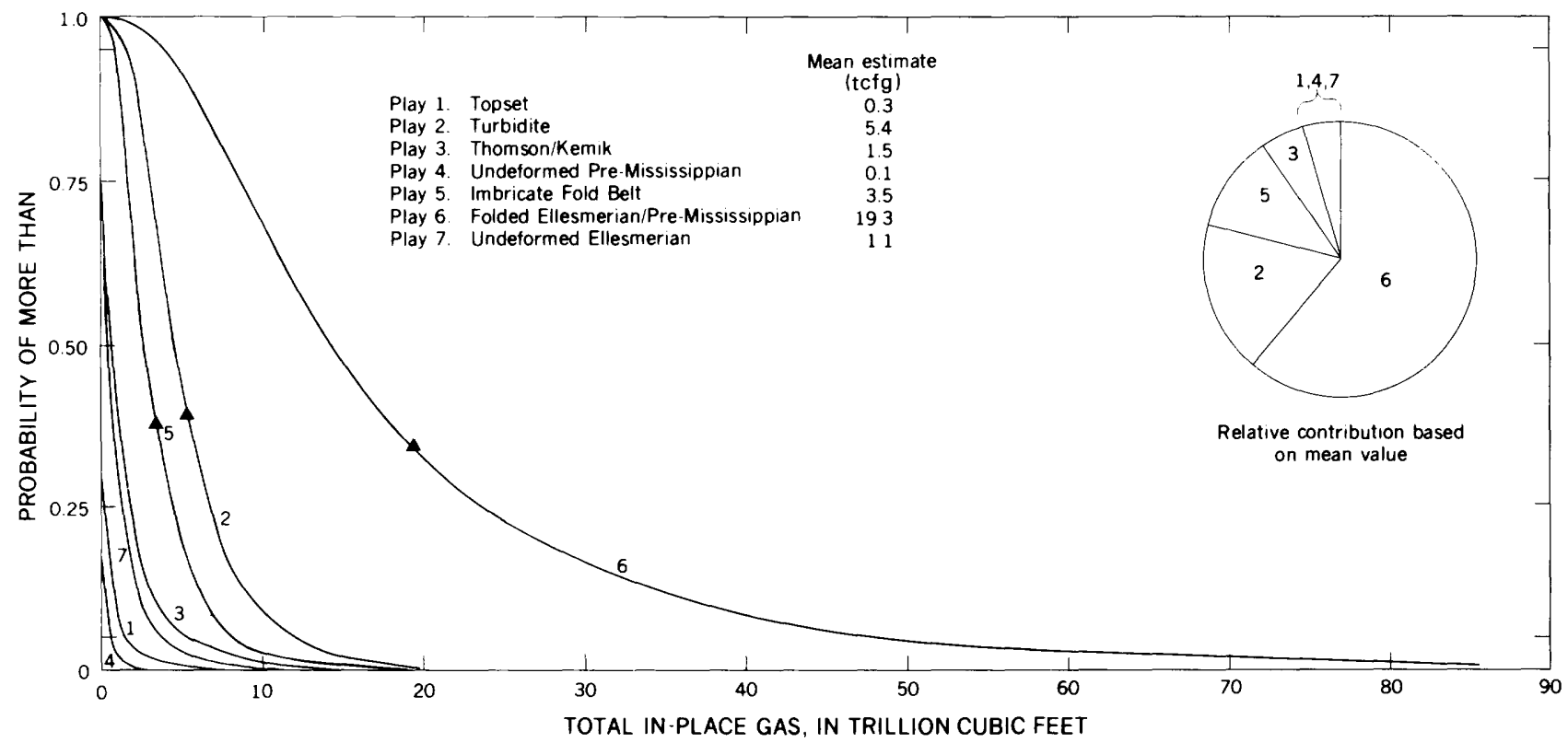

Figure 22.14. Estimated in-place gas for all plays in 1002 area. Individual probability curves show relative contribution of each play. Triangles show mean values on principal distribution curves. 
mean values show slightly less than a threefold increase in spite of a smaller assessment area in 1985. The area assessed in 1980 included all ANWR lands north of the mountain froni (about 2.4 million acres), an area 56 percent larger than the 1002 area (about 1.5 million acres).

Even though both assessments utilized the playanalysis technique, direct comparison is difficult because different geologic plays were defined for this assessment than were defined and employed in the 1980 assessment. In the 1980 assessment, all 10 plays were defined by stratigraphic reservoir interval and included both structural and stratigraphic prospects. The current assessment utilized five plays defined by stratigraphic reservoir interval, and two defined by structural interval that may include more than one reservoir. Furthermore, these two multiple-reservoir plays (Imbricate Fold Belt and Folded Ellesmerian/Pre-Mississippian plays) account for nearly two-thirds of the assessment area and about 75 percent (mean value) of the estimated in-place oil and gas resources.

The reasons for the almost threefold difference in the estimated in-place oil and gas resources are ultimately related to additions to the data set since 1980 . The most important addition is the 1,451 line-mi of seismic data, which provide information on number and
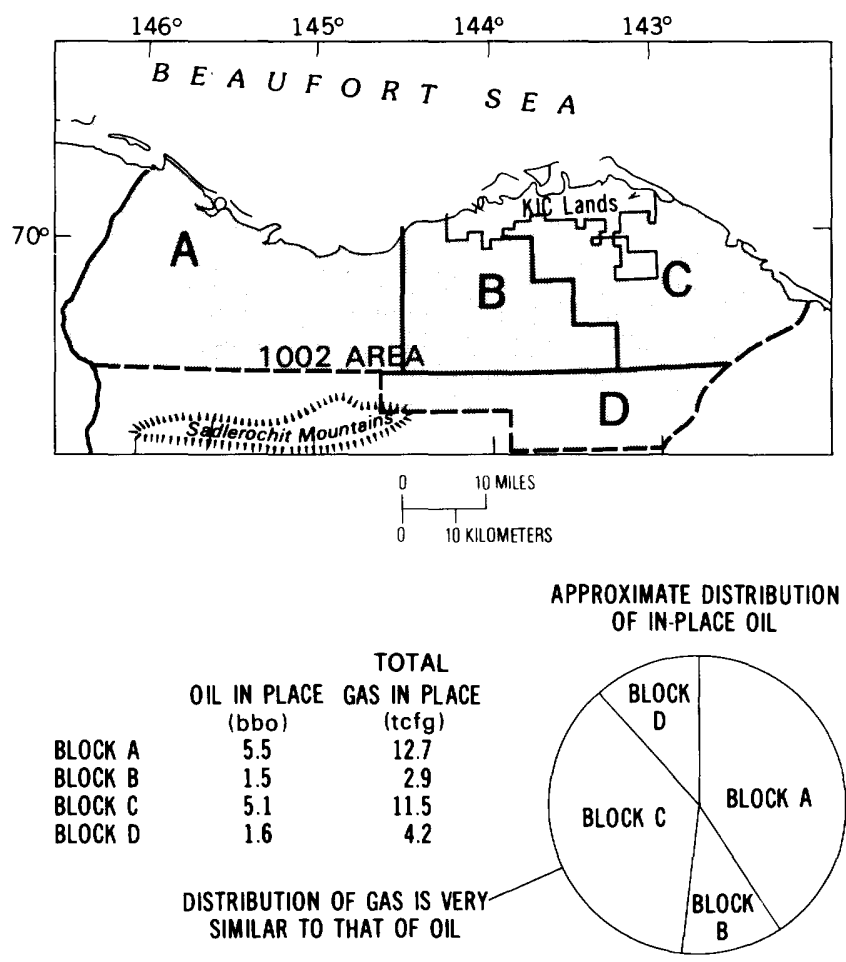

Figure 22.15. Land blocks A-D of 1002 area (shaded) and approximate distribution of in-place oil and total gas resources (mean values). bbo, billion barrels of oil; tcfg, trillion cubic feet of gas. size of prospects, structural style, timing, and reservoir depth. Also since 1980, a doubling of the number of wells (from 9 to 18) available for study immediately west of the ANWR has provided important information on subsurface temperature, pressure, stratigraphy, and reservoir and source rocks. Additionally, new field observations and samples provided improved information on structural style, ages of rocks, and source and reservoir potential. These new data had the effect of significantly changing estimates of (1) number and size of prospects, (2) depth range of oil generation, and (3) conditional deposit probability.

In the 1980 assessment, the number and size of prospects were guesses based on analogy with areas outside of the ANWR because of the scarcity of known structures in the ANWR. (Only the Marsh Creek anticline was known at the time.) The current assessment adds information not only on the number, size, and location of structures, but also about the distribution of reservoir and source rocks with respect to structures. This information shows that the average size of postulated drilling targets (prospects) is about one-half of our 1980 estimate, but that there are nearly twice as many prospects as we had thought.

An observation related to the comparison of prospects (above) is that most of the oil resources (95 percent at the mean value) were estimated to occur in younger (Cretaceous and Tertiary) rocks in the 1980 assessment. In the current assessment, the same rocks are estimated to contain only 50 percent of the oil, and the additional resources estimated by the 1985 assessment are largely in the older Ellesmerian sequence.

Table 22.2. Comparison of estimated in-place oil and gas resources and pool sizes in ANWR coastal plain by the USGS in 1980 (Mast and others, 1980) and 1985 (this report)

$\left[F 95,95^{\text {th }}\right.$ fractile; F05, $5^{\text {th }}$ fractile; oil and pool size in billions of barrels; total gas (dissolved and nonassociated) in trillions of cubic feet; size of accumulations in 1980 assessment may be somewhat understated because the possibility of stacking several reservoirs (plays) in a single prospect was not taken into consideration. Figures for 1985 are for oilpool sizes, whereas 1980 figures are for barrels-of-oil equivalent sizes]

\begin{tabular}{lcccc}
\hline & & F95 & F05 & Mean \\
\hline Oil in place & 1980 & 0.2 & 17.0 & 4.9 \\
& 1985 & 4.8 & 29.4 & 13.8 \\
& & & & \\
Gas in place & 1980 & 1.4 & 33.9 & 11.9 \\
& 1985 & 11.5 & 64.5 & 31.3 \\
Pool size & & & & \\
& 1980 & .01 & 3.81 & .89 \\
& 1985 & .01 & 1.31 & .34 \\
\hline
\end{tabular}


The reasons for this marked difference have to do with the nature and size of the prospects revealed by seismic data. Prospects identified in Cretaceous and Tertiary rocks in the 1985 assessment consist of a few low-relief structural or stratigraphic traps in the northwestern part of the coastal plain and many small, complexly folded and faulted structures in the southeastern area. Volumes of oil and gas estimated to occur in these rocks are matched by comparable or larger resource volumes estimated to occur in mostly pre-Cretaceous rocks within numerous large and relatively simple structures.

Present-day subsurface temperature profiles combined with geochemical studies suggest that the depth range of oil generation in the ANWR is 3,660 to $6,860 \mathrm{~m}(12,000$ to $22,500 \mathrm{ft})$. This compares with a depth of $4,570 \mathrm{~m}(15,000 \mathrm{ft})$ for the base of the oil window employed in the 1980 assessment. As a result, much of the section that was estimated to be gas bearing in 1980 is now estimated to be oil bearing.

The most significant change, one that depends on all factors mentioned above, is the assignment of higher probabilities to hydrocarbon occurrence and greater optimism in terms of trap fill. The average value of the conditional deposit probability for all geologic plays assessed in 1980 was 0.1 , whereas it was 0.3 for plays assessed in 1985. Marginal play probabilities in both assessments are mostly 1 . Most of the increase in estimated in-place oil and gas resources is probably caused by the changes in conditional deposit probability, which reflect an increased confidence in the favorable geologic setting as a result of data acquired since 1980 .

Hanson and Kornbrath (1986) have also reported estimates for the ANWR as prepared by the State of Alaska. Comparison of our estimates with theirs is difficult because the plays assessed are different than our own and because different assumptions apparently underlie the assessments. Nevertheless, there is great overlap in the range of estimates: $4.8-29.4$ bbo versus $0.1-26.5$ bbo and 11.5-64.5 tcfg versus 0.7-43.6 tcfg (our estimates versus State of Alaska). Both sets of estimates express great uncertainty as to the actual resources present, and both recognize the potential for large resources.

\section{APPENDIX 22.1-GLOSSARY FOR OIL AND GAS APPRAISAL DATA FORM}

This section consists of a glossary of terms used in the OIL AND GAS APPRAISAL DATA FORM, which was developed for the appraisal of the undiscovered hydrocarbon resources of large frontier areas. The terms are arranged according to their order on the data form (fig. 22.9). Terms printed in capitals indicate that their definitions are included in this section.

OIL AND GAS APPRAISAL DATA FORM: A form designed for systematic recording of geologic judgments pertaining to the occurrence of oil and gas. The form is organized by three main categories: (1) PLAY ATTRIBUTES, (2) PROSPECT ATTRIBUTES, and (3) HYDROCARBON VOLUME PARAMETERS. Judgments recorded on this form are used in a computer simulation of the petroleum geology of the PLAY under consideration, and this simulation yields a probabilistic resource appraisal and pool-size distribution of the play and, for multiple plays, of the region as a whole.

PLAY: An area consisting of one or more PROSPECTS in a common or relatively homogeneous geologic setting, the PROSPECTS of which can be explored by using geological, geochemical, and geophysical techniques.

PLAY ATTRIBUTES: Four regional characteristics that describe a given PLAY. They include (1) HYDROCARBON SOURCE (S), (2) TIMING (T), (3) MIGRATION (M), and (4) POTENTIAL RESERVOIR FACIES (R). These attributes determine whether conditions underlying the PLAY are favorable for occurrence of oil or gas within it.

HYDROCARBON SOURCE (S): This PLAY ATTRIBUTE estimates the probability of occurrence of a rock unit that has generated and expelled oil or gas. Evaluation of this attribute is accomplished by recording a single value between 0 (total certainty that the attribute is absent) and 1 (total certainty that the attribute is present) for the probability that oil or gas has been generated and expelled from source rocks in sufficient quantity to form an accumulation within the PLAY. Its evaluation is based on a set of minimum source-rock criteria that includes organic richness, kerogen type, and thermal maturity. As utilized in this study, minimum organic richness values are 0.5 weight percent for clastic source rocks and 0.35 weight percent for carbonate source rocks. Kerogen types favorable for oil are amorphous and herbaceous; for gas, herbaceous and coaly. Minimum requirements for thermal maturity are vitrinite reflectance values of 0.6 percent for oil and 1.2 percent for condensate and gas. When known HYDROCARBON ACCUMULATIONS occur in the PLAY, this PLAY ATTRIBUTE probability is 1.

TIMING (T): This PLAY ATTRIBUTE estimates the probability of occurrence of a suitable relationship between the time of trap formation and the time of hydrocarbon movement into or through the PLAY area. Evaluation of this attribute is accomplished by recording a single value between 0 (total certainty that the attribute is absent) and 1 (total certainty that the attribute is present) for the probability that favorable timing occurred somewhere in the PLAY. Its evaluation is based on knowledge of the time of trap formation and estimates of the time of maturity of source rocks. When known HYDROCARBON ACCUMULATIONS occur in the PLAY, this PLAY ATTRIBUTE probability is 1. 
MIGRATION (M): This PLAY ATTRIBUTE estimates the probability of effective movement of hydrocarbons through a conduit that may be a permeable clastic or carbonate rock, a joint, or a fault. Evaluation of this attribute is accomplished by recording a single value between 0 (total certainty that the attribute is absent) and 1 (total certainty that the attribute is present) for the probability that oil or gas has migrated in sufficient quantity to form an accumulation somewhere in the PLAY area. Its evaluation is based on structural and stratigraphic information from which inferences can be drawn concerning the presence of a geologically favorable conduit. When known HYDROCARBON ACCUMULATIONS occur in the PLAY, this PLAY ATTRIBUTE probability is 1 .

POTENTIAL RESERVOIR FACIES (R): This PLAY ATTRIBUTE estimates the probability of occurrence of a rock that may contain porosity and permeability capable of containing producible hydrocarbons. Evaluation of this attribute is accomplished by recording a single value between 0 (total certainty that the attribute is absent) and 1 (total certainty that the attribute is present) for the probability that favorable reservoir rocks occur somewhere in the PLAY area. Information used in the evaluation of this attribute may include reservoir data from the PLAY, projections from adjacent areas, or analog comparisons. When known HYDROCARBON ACCUMULATIONS occur in the PLAY, this PLAY ATTRIBUTE probability is 1 .

MARGINAL PLAY PROBABILITY (MP): This term expresses the probability that all of the first four PLAY ATTRIBUTES are concurrently favorable somewhere in the PLAY. Because each PLAY ATTRIBUTE is assumed to be statistically independent of the others, this probability is the product of the four separate PLAY ATTRIBUTE probabilities. A discovered oil or natural gas deposit in the PLAY is an indication that all four PLAY ATTRIBUTES are concurrently favorable, and therefore the marginal play probability is 1 .

PROSPECT: A geologically and (or) geophysically defined feature that may contain trapped hydrocarbons; in this assessment, prospects are limited to those of 600 acres or more in areal size.

PROSPECT ATTRIBUTES: Three local characteristics that determine the nature of PROSPECTS within a PLAY. They include TRAPPING MECHANISM (TM), EFFECTIVE POROSITY (P), and HYDROCARBON ACCUMULATION (A). Evaluation of these attributes is accomplished by recording a single value between 0 (total certainty that the attribute is absent) and 1 (total certainty that the attribute is present) for the probability that the attribute is generally favorable in a randomly selected prospect within the play area. When the prospect-attribute probability judgments are being made, it is assumed that all four components of the MARGINAL PLAY PROBABILITY are favorable. Thus the prospect attribute probability judgments are conditional upon the PLAY ATTRIBUTES being favorable. In a play for which all the regional characteristics are favorable, the existence of a HYDROCARBON ACCUMULATION at any particular PROSPECT is determined by the simultaneously favorable occurrence of the three prospect attributes.

TRAP OCCURRENCE (TM): This PROSPECT ATTRIBUTE estimates the probability of occurrence of a structural or stratigraphic configuration that provides a trap for migrating hydrocarbons. Evaluation of this attribute is accomplished by recording a single value between 0 (total certainty that the attribute is absent) and 1 (total certainty that the attribute is present) for the probability that a trap will be found to exist in a randomly selected PROSPECT within the PLAY. When evaluating this attribute, it is assumed that the PLAY ATTRIBUTES are favorable. Data used in the evaluation of this attribute are based on seismic or geologic mapping, projection from nearby areas, or analog comparison.

EFFECTIVE POROSITY (P): This PROSPECT ATTRIBUTE estimates the probability of significant interconnected void space of a POTENTIAL RESERVOIR FACIES (R) capable of holding hydrocarbons. Evaluation of this attribute is accomplished by recording a single value between 0 (total certainty that the attribute is absent) and 1 (total certainty that the attribute is present) for the probability that porosity equal to or greater than 3 percent will be found in any randomly selected PROSPECT within the PLAY. When evaluating this attribute, it is assumed that the PLAY ATTRIBUTES are favorable. In the special case of stratigraphic traps, which deal with the presence of a geometric configuration of a POTENTIAL RESERVOIR FACIES that may produce a trap, the assessment of EFFECTIVE POROSITY is made dependent upon the occurrence of the TRAP OCCURRENCE (TM) - that is, given the necessary trapping configuration of a potential reservoir, the probability of EFFECTIVE POROSITY within it is assessed. Data used in the evaluation of this parameter are based on the porosity of the potential reservoir rocks as estimated by measurement, calculation, projection, or analog comparison.

HYDROCARBON ACCUMULATION (C): This PROSPECT ATTRIBUTE estimates the probability of the combination of HYDROCARBON SOURCE (S), TIMING (T), and MIGRATION (M) necessary for the formation of HYDROCARBON ACCUMULATIONS. Evaluation of this attribute is accomplished by recording a single value between 0 (total certainty that the attribute 
is absent) and 1 (total certainty that the attribute is present) for the probability that hydrocarbons will be found adequate to fill at least 1 percent of any randomly selected PROSPECT within the PLAY. When evaluating this attribute, it is assumed that the PLAY ATTRIBUTES are favorable. In other words, this attribute deals primarily with the availability of hydrocarbons to a trap at a PROSPECT. Data used in the evaluation of this parameter are based on the structural, stratigraphic, and thermal history of the PLAY.

CONDITIONAL DEPOSIT PROBABILITY (CP): This term expresses the probability that any randomly selected PROSPECT is an accumulation, given that the PLAY ATTRIBUTES are favorable. This probability is the product of the three PROSPECT ATTRIBUTE probabilities.

RESERVOIR LITHOLOGY: This PLAY characteristic describes the most common reservoir rock type expected in the play. Evaluation of this attribute is accomplished by selecting either sandstone or carbonate rocks. No probabilities are expressed. Besides describing the reservoir rock type, the computer program is currently implemented so that RESERVOIR LITHOLOGY determines which of two distributions for water saturation will be selected. Values for water saturation are negatively correlated $(r=-0.9)$ with the estimated distribution for the HYDROCARBON VOLUME PARAMETER EFFECTIVE POROSITY ( $\geq 3$ percent).

HYDROCARBON MIX: This PLAY characteristic describes the tendency of accumulations in the play to be variously oil or nonassociated gas. The computer program employed in this method is set to consider HYDROCARBON ACCUMULATIONS to be either all oil (with solution gas) or all nonassociated gas; it is not set to simulate the mixture of oil and free gas (gas cap) that may occasionally occur in a single reservoir in nature. Evaluation of this attribute is accomplished by estimating two probabilities that sum to one. For example, a mix of 0.8 gas and 0.2 oil would indicate an 80 percent chance that a randomly selected accumulation in the PLAY would be nonassociated gas and a 20 percent chance that the accumulation would be oil. Data used in the evaluation of this parameter are based on concepts of thermal maturity, the type of organic material in the source rock, and the type of hydrocarbon observed in wells and seeps.

HYDROCARBON VOLUME PARAMETERS: These five parameters include (1) AREA OF CLOSURE, (2) RESERVOIR THICKNESS, (3) EFFECTIVE POROSITY, (4) TRAP FILL, and (5) RESERVOIR DEPTH. (The distribution for a sixth parameter, water saturation, is selected by the choice of RESERVOIR
LITHOLOGY.) They describe the range of possible values of the generic reservoir characteristics that determine the volume of hydrocarbons present in an individual accumulation within the PLAY. Evaluation of these parameters is accomplished by recording judgmental values at seven fractiles (probability levels) ranging from 100 percent (total certainty that at least this estimated value will be attained) to 0 percent (total certainty that this estimated value will not be exceeded). MINIMUM THRESHOLD VALUES may be recorded at the $100^{\text {th }}$ fractile. When the hydrocarbon volume parameters are being assessed, it is assumed that both the MARGINAL PLAY PROBABILITY and the CONDITIONAL DEPOSIT PROBABILITY are 1 . Thus, the hydrocarbon volume parameter judgments are conditional on the PLAY ATTRIBUTES and the PROSPECT ATTRIBUTES being favorable.

MINIMUM THRESHOLD VALUES: These minimum values apply to the five HYDROCARBON VOLUME PARAMETERS: AREA OF CLOSURE-600 acres; RESERVOIR THICKNESS- $5 \mathrm{ft}$; EFFECTIVE POROSITY - 3 percent; TRAP FILL-1 percent; RESERVOIR DEPTH $-100 \mathrm{ft}$. These minimum values are used at the $100^{\text {th }}$ fractile unless a higher value is selected. The probabilities that these threshold values are achieved are incorporated in the PROSPECT ATTRIBUTE judgments and the NUMBER OF DRILLABLE PROSPECTS distribution. The minimum threshold values are selected to be less than any reasonable economic limit in order to prevent economic considerations from influencing the evaluation procedure.

AREA OF CLOSURE ( $\times 10^{3}$ acres): This HYDROCARBON VOLUME PARAMETER estimates the possible range for the number of acres within a trap above the spill point. Evaluation of this parameter is accomplished by entering estimates for the size of closure at seven fractiles ranging from 100 percent (total certainty that at least this value will be attained) to 0 percent (total certainty that this value will not be exceeded). Intermediate fractiles indicate the relative confidence (subjective probability) that the area of closure is at least as large as the recorded fractile value. A MINIMUM THRESHOLD VALUE of at least 600 acres is required, and the probability that this minimum value is achieved is incorporated in the TRAP OCCURRENCE (TM) judgment (PROSPECT ATTRIBUTE). Data used in the evaluation of this parameter may include seismic mapping, surface geologic mapping, or analog comparison.

RESERVOIR THICKNESS ( $\mathrm{ft}$ ): This HYDROCARBON VOLUME PARAMETER estimates the possible range for the thickness of the reservoir, or the amount of vertical closure in the situation where structural amplitude is less than individual reservoir thickness. 
Evaluation of this parameter is accomplished by entering reservoir thickness or vertical closure estimates (whichever value is less) at seven fractiles ranging from 100 percent (total certainty that at least this value will be attained) to 0 percent (total certainty that this value will not be exceeded). Intermediate fractile values indicate the relative confidence that the reservoir thickness or vertical closure is at least as great as the recorded fractile value. Thickness values in the fractiles describe the maximum reservoir thickness for a single reservoir or stacked multiple reservoirs with EFFECTIVE POROSITY of 3 percent or more. Thus, these judgments assess the net thickness of the reservoir rather than the total thickness of the structure. A MINIMUM THRESHOLD VALUE of $5 \mathrm{ft}$ is used at the $100^{\text {th }}$ fractile. Data used in the evaluation of this parameter may include seismic mapping, surface and subsurface geologic measurements, projection from nearby areas, or analog comparison.

EFFECTIVE POROSITY ( $\geq 3$ percent): This HYDROCARBON VOLUME PARAMETER estimates the average value for the amount of interconnected void space of the reservoir rock at a randomly selected PROSPECT. Evaluation of this parameter is accomplished by entering porosity estimates at seven fractiles ranging from 100 percent (total certainty that at least this value will be attained) to 0 percent (total certainty that this value will not be exceeded). Intermediate fractiles indicate the relative confidence that the effective porosity is at least as large as the recorded fractile value. A MINIMUM THRESHOLD VALUE of 3 percent is used at the $100^{\text {th }}$ fractile, and the probability that this minimum value is achieved is incorporated into the EFFECTIVE POROSITY (P) judgment (PROSPECT ATTRIBUTE). Data used in the evaluation of this parameter are based on measurement, calculation, projection, or analog comparison.

TRAP FILL (percent): This HYDROCARBON VOLUME PARAMETER estimates the possible range for trapped hydrocarbon volume as a percentage of the porous volume under closure. Evaluation of this parameter is accomplished by recording percentage values at seven fractiles ranging from 100 percent (total certainty that at least this value will be attained) to 0 percent (total certainty that this value will not be exceeded). Intermediate fractile values indicate the relative confidence that the trap is at least as full as the recorded fractile value. A MINIMUM THRESHOLD VALUE of 1 percent is used at the $100^{\text {th }}$ fractile. The probability that this minimum value is achieved is incorporated into the HYDROCARBON ACCUMULATION (A) judgment (PROSPECT ATTRIBUTE). Evaluation of this parameter is based on (1) source-rock richness and thermal maturation, (2) hydrocarbon drainage area, (3) size of structure, (4) porosity and permeability of reservoir rock, or (5) analog comparison.

RESERVOIR DEPTH $\left(x 10^{3} \mathrm{ft}\right)$ : This HYDROCARBON VOLUME PARAMETER describes the possible range for the depth that must be drilled to penetrate the POTENTIAL RESERVOIR FACIES (R). Evaluation of this parameter is accomplished by entering depth estimates at seven fractiles ranging from 100 percent (total certainty that at least this value will be attained) to 0 percent (total certainty that this value will not be exceeded). Intermediate fractile values indicate the relative confidence that the reservoir is at least as deep as the recorded fractile value. 'A MINIMUM THRESHOLD VALUE of $100 \mathrm{ft}$ is used at the $100^{\text {th }}$ fractile. The probability that this minimum value is achieved is incorporated into the TRAP OCCURRENCE (TM) judgment (PROSPECT ATTRIBUTE). Data used in the evaluation of this parameter may include seismic mapping, projection from nearby areas, or analog comparison.

NUMBER OF DRILLABLE PROSPECTS: This PLAY characteristic describes the range of possible values for the number of valid targets that would be considered for drilling if the PLAY were to be fully explored. Evaluation of this attribute is accomplished by recording the estimated number of PROSPECTS at seven fractiles ranging from 100 percent (total certainty that at least this value will be attained) to 0 percent (total certainty this value will not be exceeded). Intermediate fractile values indicate the relative confidence that the number of drillable prospects is at least as great as the recorded fractile value. Only PROSPECTS of at least 600 acres (AREA OF CLOSURE) with RESERVOIR DEPTHS of at least $100 \mathrm{ft}$ are considered. The distribution of the number of drillable prospects also takes into account the probability that the reservoir formation may be absent in parts of the PLAY area. Data used in the evaluation of this parameter may include seismic mapping, surface and subsurface geologic mapping, and projection from nearby areas. Based on these data, additional PROSPECTS may be added to account for the existence of stratigraphic traps.

PROVED RESERVES: A compilation of all recoverable HYDROCARBON ACCUMULATIONS that have been found to date within a given PLAY. The presence of proved reserves indicates that at some time and place within the PLAY, all PLAY ATTRIBUTES were present. Therefore, the MARGINAL PLAY PROBABILITY is 1. Because no ANWR PLAY is yet productive of hydrocarbons, this item was deleted from the assessment form (fig. 22.9). 


\title{
Chapter 23.
}

\section{Economically Recoverable Oil Resources}

\author{
By James E. Callahan, ${ }^{1}$ Gary W. Brougham, ${ }^{1}$ and Robert J. Bascle ${ }^{1}$
}

\section{INTRODUCTION}

Amounts of economically recoverable oil resources in the Arctic National Wildlife Refuge (ANWR) coastal plain (1002 area) were estimated in order to indicate the relatively near-term (approx 40 years) production potential of the area. Because of the extremely high development, operating, and transportation costs in this area, economics of scale is an unavoidable consideration that limits the potential accumulations included in the recoverable resource estimates to those in excess of about 440 million barrels of technically recoverable oil, or upwards of 1 billion barrels of in-place oil. Natural gas from the 1002 area was not found to have economic potential for the time period considered.

\section{METHOD OF ASSESSMENT}

This estimate of economically recoverable oil resources for the 1002 area results from a prospectspecific analysis using the computer simulation model PRESTO II. PRESTO is an acronym for Probabilistic Resource Estimates-Offshore, developed and currently used by the U.S. Minerals Management Service for generating hydrocarbon resource estimates for Outer Continental Shelf Planning Areas.

PRESTO II uses prospect-specific hydrocarbon volumetric input data for identifiable prospects and produces prospect-specific and areawide resource estimates. Input data for this recoverable oil assessment were provided by the following individuals: A.C. Banet, Jr., R.J. Bascle, G.W. Brougham, J.E. Callahan, R.L. Foland, W.S. Hauser, D.J. Lalla, M.L. Menge, and J.S. Young. The uncertainty in a frontier area is addressed by allowing the user to input geologic risk factors and a range of values for each volumetric input parameter. Economic constraints are applied through the use of an economic field size cutoff, termed the minimum economic field size (MEFS).

The PRESTO model uses Monte Carlo simulation to calculate a range of possible hydrocarbon

\footnotetext{
${ }^{1}$ U.S. Bureau of Land Management, Anchorage, Alas.
}

volumes for each prospect considered and for the area as a whole. This technique involves repetitive calculations of resource volumes using random samples from each range of values for the volumetric parameters. Repeated many times, this process yields a range of estimated volumes representing many possible combinations of subsurface conditions. The arithmetic average of this range is the mean, or the expected volume of hydrocarbons in each prospect and the area. It cannot be emphasized too strongly that the mean or any other number in the range of values is neither the only answer nor the right answer. Resource values are presented at various probability levels, as well as at the mean, in order to illustrate the extent of the range of possible values.

\section{PRESTO MODEL INPUTS}

The PRESTO II model requires input of the following categories of information for the area or basin being modeled (see fig. 23.1):

Area characteristics:

Area dry risk (input geologic risk)

Number of prospects

Area minimum economic field size

Prospect characteristics:

Prospect dry risk (input geologic risk)

Number of reservoir zones

Prospect minimum economic field size

Zone charactertistics:

Zone dry risk

Hydrocarbon volume parameters:

Productive area

Zone pay thickness

Hydrocarbon recovery factors

\section{Risk Factors}

The PRESTO model requires an assessment of "dry-hole," or unconditional, geologic risk at the zone, prospect, and area levels. The unconditional risk is the 
probability that the zone, prospect, or area is barren of recoverable hydrocarbons.

At the zone and prospect levels, risk is assessed on the basis of confidence in the data, interpretations, and assumptions that determine a prospect; these include reliability of seismic data, confidence in projections of geologic data or trends from well control or outcrops, type of closure, existence of reservoir zones, source-rock richness, maturity, kerogen type, timing of hydrocarbon generation, and adequacy of seals. For the 1002 area, variations in geologic risk between individual prospects were assessed primarily on the basis of structural characteristics, type of trap, and confidence in the seismic interpretation. Reservoir and source-rock characteristics were generally considered from a regional perspective, common to all prospects, taking into account the attributes of equivalent geologic plays considered in the in-place resource assessment (chap. 22).

\section{PRESTO RESOURCE ESTIMATE INPUT FCRMAT}

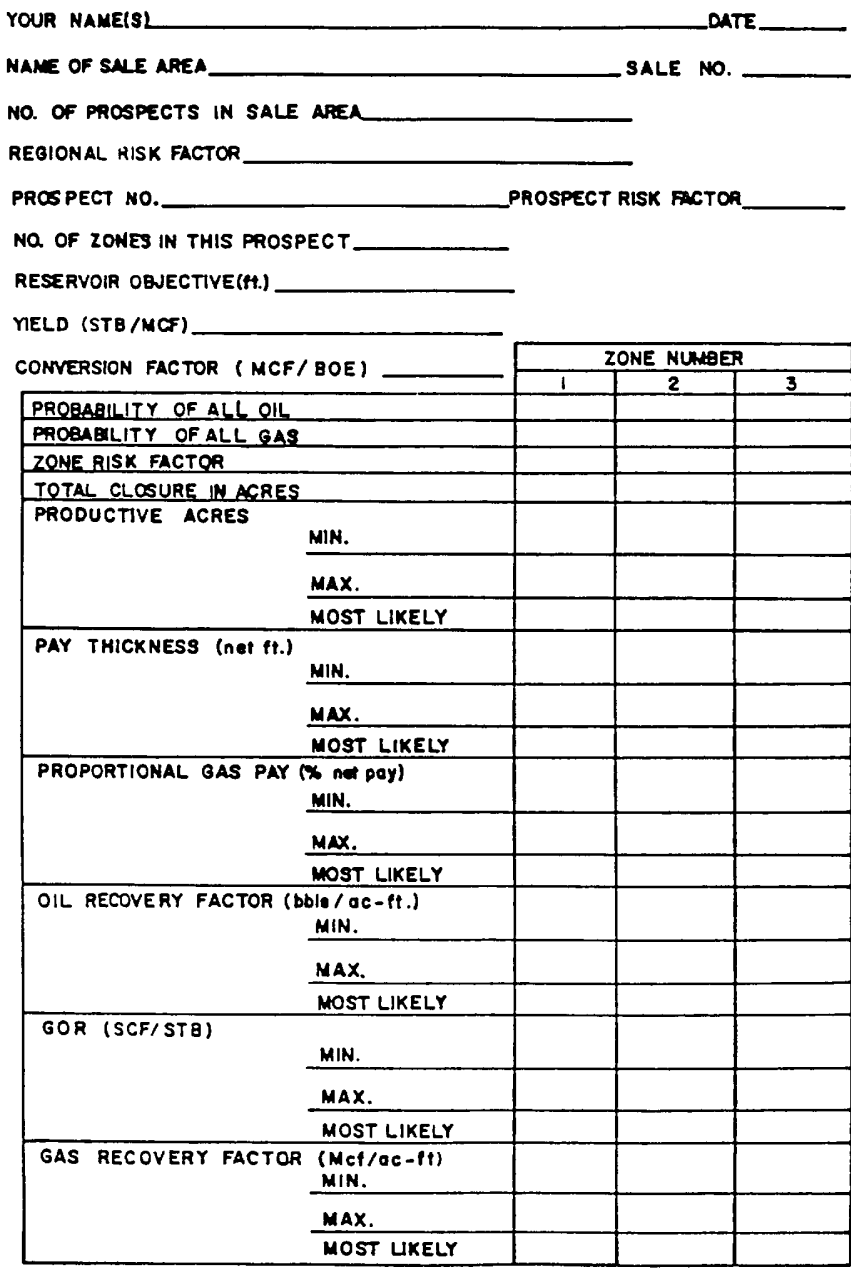

Figure 23.1. Input form for prospect-specific analysis using computer model PRESTO II.
At the area level, the dry risk reflects the probability that the whole area is barren of recoverable hydrocarbons. For purposes of this analysis, the area risk is derived by identifying the prospects that are physically large enough to be capable of containing commercially recoverable volumes of oil and then taking the combined product of the geologic risks of these prospects. In other words, the area risk is based on an assessment of the probability of occurrence of at least one economic field, taking into consideration the field size requirement for the area and the number of prospects that might be large enough to meet this requirement. This method for deriving the area risk presupposes no geologic dependencies among the large prospects used. The input area geologic risk should not be confused with the output marginal probability of occurrence of economically recoverable hydrocarbons for the area (described below), which incorporates economic as well as geologic risk.

In the PRESTO model, conditional prospect and zone dry-risk factors are calculated using the following relationships:

$$
\begin{aligned}
& C P R=(P R-A R) /(1-A R), \\
& C Z R=(Z R-P R) /(1-P R),
\end{aligned}
$$

where

$\mathrm{CPR}=$ conditional dry prospect risk,

$\mathrm{PR}=$ unconditional dry prospect risk,

$\mathrm{AR}=$ area dry risk,

$\mathrm{CZR}=$ conditional zone dry risk, and

$\mathrm{ZR}=$ unconditional zone dry risk.

These conditional risk factors are used by the model to control the frequency with which a given prospect or zone is sampled during the Monte Carlo simulation (see below). The sampling frequency, in turn, controls both the relative contribution of each prospect to the area conditional resource estimates and the relative contribution of each zone in a prospect to the prospect conditional resource estimates (Cooke, 1985, p. 9).

\section{Prospects}

Twenty-six structural prospects, identified and delineated as a result of interpretation of seismic data, were considered in the 1002 area recoverable resource assessment. The locations and areal extents of these prospects are shown in figure 23.2 , and their pertinent characteristics are listed in table 23.1. The minimum areal size of prospects that can be identified is a function of the seismic grid density and the resolution (quality) of the data on seismic record sections, which is variable in the area. Additional recoverable resources may be present in stratigraphic traps, and the seismic data indicate the probable presence of numerous small, complexly faulted structures that cannot be adequately mapped with the current seismic data set. 


\section{Zones}

Each prospect is modeled as having one or more prospective reservoir zones. For the purposes of the 1002 area recoverable resource assessment, the number and reservoir characteristics of zones within prospects were based on the areal distribution and characteristics of the equivalent geologic plays used in the in-place resource assessment (see chap. 22). Stratigraphic units modeled as zones in the various prospects are shown as "potential objectives" in table 23.1.

\section{Volumetric Inputs}

The basic unit for calculation of hydrocarbon volumes in the PRESTO model is the reservoir zone. The model accepts seven volumetric input parameters, which are described below. All nonzero parameters used in the 1002 area resource assessment were entered as ranges of values, with associated probability distributions. To the maximum extent possible, ranges and distributions were correlated with equivalent parameters in the equivalent play reservoirs used for the in-place resource assessment (chap. 22).
1. Productive Area-Estimates of productive acreage are based on the total structural closure for the prospect (area enclosed by lowest closing contour) and on estimates of trap fill for the zone, expressed as a percentage of the area of total closure. Trap-fill estimates are derived from an assessment of (1) the quantity and types of organic source material available in the vicinity of the prospect and (2) the occurrence of geologic events and subsurface conditions conducive to the generation and migration of hydrocarbon fluids into reservoir zones.

2. Pay Thickness-Estimates for pay thickness represent the aggregate thickness ( $\mathrm{ft}$ ) of intervals in the reservoir zone thought to have both sufficient porosity to hold significant quantities of fluids and sufficient permeability to allow movement of fluids to a wellbore.

3. Oil Recovery Factor-Oil recovery factors for the 1002 area assessment were derived from the standard volumetric equation for oil by setting the productive area and thickness equal to 1 :

$$
R F=7,758(\phi)\left(1-S_{w}\right)(R E) / B_{o}
$$

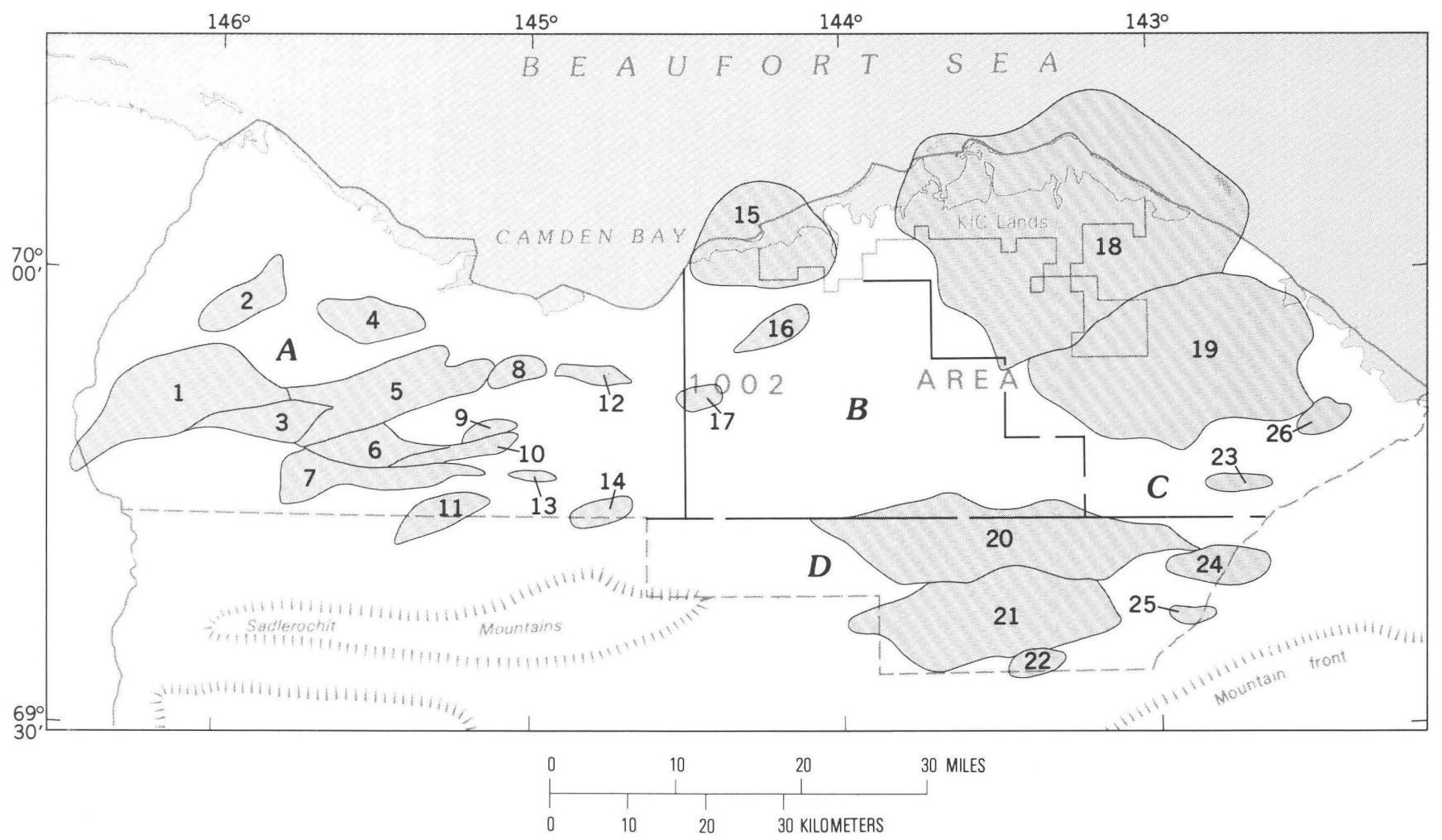

Figure 23.2. Seismically mapped prospects in the 1002 area. Numbers 1-26 refer to table 23.1. Blocks A-D refer to table 23.4 . 
where

$\mathrm{RF}=$ recovery in stock tank barrels per acre-ft of reservoir rock,

7,758 = number of 42-gal barrels in an acre-ft,

$\phi=$ reservoir rock porosity (decimal fraction),

$\mathrm{S}_{\mathrm{w}}=$ connate water saturation (decimal fraction),

$\mathrm{RE}=$ recovery efficiency (decimal fraction), and

$\mathrm{B}_{\mathrm{o}}=$ formation volume factor (shrinkage factor).

The input range of values for a zone recovery factor was calculated from the above equation by using the respective estimated ranges for porosity, hydrocarbon saturation $\left(1-S_{w}\right)$, and recovery efficiency, as well as the appropriate formation volume factor for the estimated depth of the zone in the prospect. Ranges of values for porosity, hydrocarbon saturation, and recovery efficiency used in the 1002 area recoverable resource assessment are shown in table 23.2, along with the resulting oil "yield" factor, which represents the volume of recoverable oil per acre-ft under reservoir conditions of pressure and temperature. The formation volume factor varies with depth. For this assessment, the following

Table 23.1. Data on petroleum prospects in the 1002 area

[Depths are below mean sea level. Potential objectives: 1, pre-Mississipian carbonate rocks; 2a, Ellesmerian sequence (clastic rocks); $2 \mathrm{~b}$, Ellesmerian sequence (carbonate rocks); 3, Thomson sand (of local usage) and Kemik Sandstone, undivided; 4, turbidites; 5, lower Neogene(?) topset beds; $\mathrm{x}$, objective with potential; -, no potential]

\begin{tabular}{|c|c|c|c|c|c|c|c|c|c|c|c|}
\hline \multirow[t]{2}{*}{ Prospect } & \multirow{2}{*}{$\begin{array}{c}\text { Area } \\
\text { (acres) }\end{array}$} & \multirow{2}{*}{$\begin{array}{l}\text { Size } \\
(\mathrm{mi})\end{array}$} & \multirow{2}{*}{$\begin{array}{c}\text { Crestal } \\
\text { depth } \\
(\mathrm{ft})\end{array}$} & \multirow{2}{*}{$\begin{array}{c}\text { Lowest } \\
\text { closing } \\
\text { contour } \\
(\mathrm{ft})\end{array}$} & \multicolumn{6}{|c|}{$\begin{array}{c}\text { Potential } \\
\text { objectives }\end{array}$} & \multirow{2}{*}{$\begin{array}{c}\text { Number } \\
\text { of } \\
\text { seismic } \\
\text { lines }\end{array}$} \\
\hline & & & & & 1 & $2 a$ & $2 b$ & 3 & 4 & 5 & \\
\hline 1 & ${ }^{1} 48,512$ & $18 \times 6$ & 14,000 & 15,000 & $\mathrm{x}$ & $\mathrm{x}$ & $\mathrm{x}$ & $\mathrm{x}$ & $\mathrm{x}$ & - & 5 \\
\hline 2 & 11,793 & $8 \times 3$ & 14,820 & 15,000 & $\mathrm{x}$ & $\mathrm{x}$ & - & $\mathrm{x}$ & $\mathrm{x}$ & - & 2 \\
\hline 3 & 13,120 & $12 \times 3$ & 13,000 & 14,000 & $\mathrm{x}$ & $\mathrm{x}$ & $\mathrm{x}$ & $\mathrm{x}$ & $\mathrm{x}$ & - & 3 \\
\hline 4 & 12,922 & $8 \times 3.5$ & 14,900 & 15,500 & $\mathrm{x}$ & - & - & $\mathrm{x}$ & $\mathrm{x}$ & - & 4 \\
\hline 5 & 34,234 & $16 \times 4$ & 12,700 & 15,000 & $\mathrm{x}$ & $\mathrm{x}$ & - & $\mathrm{x}$ & $\mathrm{x}$ & - & 6 \\
\hline 6 & 11,940 & $10 \times 3$ & 11,500 & 13,800 & $\mathrm{x}$ & - & - & $\mathrm{x}$ & $\mathrm{x}$ & - & 3 \\
\hline 7 & 18,970 & $16 \times 2$ & 8,500 & 10,500 & $\mathrm{x}$ & $\mathrm{x}$ & $\mathrm{x}$ & $\mathrm{x}$ & $\mathrm{x}$ & - & 6 \\
\hline 8 & 4,880 & $4 \times 2$ & 16,300 & 17,000 & $\mathrm{x}$ & - & - & $\mathrm{x}$ & $\mathrm{x}$ & - & 2 \\
\hline 9 & 2,200 & $4 \times 1$ & 12,500 & 13,200 & $\mathrm{x}$ & - & - & $\mathrm{x}$ & $\mathrm{x}$ & - & 1 \\
\hline 10 & 6,291 & $11 \times 1$ & 11,900 & 12,500 & $\mathrm{x}$ & - & - & $\mathrm{x}$ & $x$ & - & 3 \\
\hline 11 & ${ }^{1} 9,430$ & $8 \times 3$ & 5,200 & 6,000 & $\mathrm{x}$ & $\mathrm{x}$ & $\mathrm{x}$ & $\mathrm{x}$ & - & - & 2 \\
\hline 12 & 3,950 & $6 \times 1$ & 19,000 & 21,000 & $\mathrm{x}$ & - & - & $\mathrm{x}$ & $\mathrm{x}$ & - & 2 \\
\hline 13 & 1,344 & $4 \times 0.8$ & 10,900 & 11,500 & $\mathrm{x}$ & $\mathrm{x}$ & $\mathrm{x}$ & $\mathrm{x}$ & - & - & 1 \\
\hline 14 & ${ }^{1} 4,915$ & $5 \times 2$ & 5,640 & 6,000 & $\mathrm{x}$ & $\mathrm{x}$ & $\mathrm{x}$ & $\mathrm{x}$ & - & - & 1 \\
\hline 15 & ${ }^{1} 42,500$ & $13 \times 10$ & 22,500 & 23,000 & $\mathrm{x}$ & - & - & $\mathrm{x}$ & $\mathrm{x}$ & - & 6 \\
\hline 16 & 6,720 & $6.3 \times 2.4$ & 1,230 & 2,300 & - & - & - & - & $\mathrm{x}$ & $\mathrm{x}$ & 3 \\
\hline 17 & 3,170 & $3 \times 2$ & 21,600 & 22,000 & $\mathrm{x}$ & - & - & $\mathrm{x}$ & $\mathrm{x}$ & - & 1 \\
\hline 18 & ${ }^{1} 226,822$ & $27 \times 15$ & 13,500 & $>24,000$ & $\mathrm{x}$ & - & - & $\mathrm{x}$ & $\mathrm{x}$ & - & 16 \\
\hline 19 & 129,587 & $22 \times 13$ & 9,790 & 17,000 & $\mathrm{x}$ & $\mathrm{x}$ & $\mathrm{x}$ & $\mathrm{x}$ & $\mathrm{x}$ & - & 10 \\
\hline 20 & 79,738 & $30 \times 7$ & 11,900 & 17,500 & $\mathrm{x}$ & $\mathrm{x}$ & $\mathrm{x}$ & - & - & - & 10 \\
\hline 21 & ${ }^{1} 65,300$ & $21 \times 4$ & 7,500 & 14,500 & $\mathrm{x}$ & $\mathrm{x}$ & $\mathrm{x}$ & - & - & - & 7 \\
\hline 22 & ${ }^{14} 4,560$ & $5 \times 2$ & 11,600 & 12,000 & $\mathrm{x}$ & $\mathrm{x}$ & $\mathrm{x}$ & - & - & - & 1 \\
\hline 23 & 3,706 & $5 \times 1.5$ & 16,300 & 16,500 & $\mathrm{x}$ & $\mathrm{x}$ & $\mathrm{x}$ & - & - & - & 1 \\
\hline 24 & ${ }^{1} 11,872$ & $8 \times 3$ & 10,400 & 12,000 & $\mathrm{x}$ & $\mathrm{x}$ & $\mathrm{x}$ & - & - & - & 1 \\
\hline 25 & ${ }^{1} 2,360$ & $4 \times 1$ & 11,950 & 12,000 & $\mathrm{x}$ & $\mathrm{x}$ & $\mathrm{x}$ & - & - & - & 1 \\
\hline 26 & 4,954 & $5 \times 3$ & 16,500 & 17,000 & $\mathrm{x}$ & $\mathrm{x}$ & $\mathrm{x}$ & $\mathrm{x}$ & $\mathrm{x}$ & - & 2 \\
\hline
\end{tabular}

${ }^{1}$ Prospect area includes extensions or projections outside the 1002 area as shown in figure 23.2 . 
depth-dependent relationships were used in the calculation of formation volume factors:

Reservoir temperature $\left({ }^{\circ} \mathrm{F}\right)=35+$ depth $(\mathrm{ft}) \times 0.012$, Reservoir pressure $(\mathrm{psi})=$ depth $(\mathrm{ft}) \times 0.465$, API oil gravity $=$ depth $(\mathrm{ft}) \times 0.00182+7.473$.

These values result in formation volume factors ranging from about 1.05 at a depth of $3,000 \mathrm{ft}$ to 3.00 at $19,500 \mathrm{ft}$.

4. Gas Recovery Factor-Since natural gas was categorically determined to be noneconomic for purposes of this assessment, nonassociated gas recovery factors were set to zero.

Table 23.2. Reservoir volume parameters used in estimating recoverable oil in the 1002 area assessment

["Hydrocarbon saturation" range and probability distribution are based on equivalent range and distribution currently built into the USGS FASP Model for carbonate rock and sandstone reservoirs. "Recovery efficiency" is based on reported or projected estimates published for North Slope reservoirs in industry trade publications or State of Alaska reports: proven primary and enhanced recovery technology (water flood, gas injection) are considered implicit in these estimates. "Yield" is estimate of technically recoverable oil at reservoir conditions, not corrected for formation volume factor. Formation volume factor is depth dependent and, therefore, prospect specific. bbl, barrel of oil; acre- $\mathrm{ft}$, a volume of reservoir rock that covers one acre and is one $\mathrm{ft}$ thick]

\begin{tabular}{|c|c|c|c|c|c|}
\hline $\begin{array}{c}\text { Zone } \\
\text { equivalent }\end{array}$ & Range & $\begin{array}{c}\text { Porosity } \\
\text { (pct) }\end{array}$ & $\begin{array}{c}\text { Oil } \\
\text { saturation } \\
\text { (pct) }\end{array}$ & $\begin{array}{l}\text { Recovery } \\
\text { efficiency } \\
\text { (pct) }\end{array}$ & $\begin{array}{c}\text { Yield } \\
\text { (bbl/acre-ft) }\end{array}$ \\
\hline Topset beds & $\begin{array}{l}\text { Minimum } \\
\text { Most likely } \\
\text { Maximum }\end{array}$ & $\begin{array}{l}10 \\
25 \\
32\end{array}$ & $\begin{array}{l}35 \\
73 \\
95\end{array}$ & $\begin{array}{l}20 \\
25 \\
35\end{array}$ & $\begin{array}{r}54 \\
354 \\
825\end{array}$ \\
\hline Turbidites & $\begin{array}{l}\text { Minimum } \\
\text { Most likely } \\
\text { Maximum }\end{array}$ & $\begin{array}{l}3 \\
13.5 \\
30\end{array}$ & $\begin{array}{l}35 \\
73 \\
95\end{array}$ & $\begin{array}{l}25 \\
32 \\
40\end{array}$ & $\begin{array}{r}20 \\
245 \\
884\end{array}$ \\
\hline $\begin{array}{l}\text { Thomson sand } \\
\text { of local usage - } \\
\text { Kemik Sandstone }\end{array}$ & $\begin{array}{l}\text { Minimum } \\
\text { Most likely } \\
\text { Maximum }\end{array}$ & $\begin{array}{r}3 \\
11 \\
30\end{array}$ & $\begin{array}{l}35 \\
73 \\
95\end{array}$ & $\begin{array}{l}25 \\
32 \\
40\end{array}$ & $\begin{array}{r}20 \\
199 \\
884\end{array}$ \\
\hline $\begin{array}{l}\text { Ellesmerian } \\
\text { sequence } \\
\text { clastic rocks }\end{array}$ & $\begin{array}{l}\text { Minimum } \\
\text { Most likely } \\
\text { Maximum }\end{array}$ & $\begin{array}{r}3 \\
11 \\
30\end{array}$ & $\begin{array}{l}35 \\
73 \\
95\end{array}$ & $\begin{array}{l}25 \\
32 \\
40\end{array}$ & $\begin{array}{r}20 \\
199 \\
884\end{array}$ \\
\hline $\begin{array}{l}\text { Ellesmerian } \\
\text { sequence } \\
\text { carbonate rocks }\end{array}$ & $\begin{array}{l}\text { Minimum } \\
\text { Most likely } \\
\text { Maximum }\end{array}$ & $\begin{array}{l}3 \\
4.5 \\
15\end{array}$ & $\begin{array}{l}35 \\
75 \\
95\end{array}$ & $\begin{array}{l}10 \\
25 \\
35\end{array}$ & $\begin{array}{r}8 \\
65 \\
387\end{array}$ \\
\hline $\begin{array}{l}\text { Pre-Mississippian } \\
\text { carbonate rocks }\end{array}$ & $\begin{array}{l}\text { Minimum } \\
\text { Most likely } \\
\text { Maximum }\end{array}$ & $\begin{array}{l}3 \\
5.5 \\
15\end{array}$ & $\begin{array}{l}35 \\
75 \\
95\end{array}$ & $\begin{array}{l}10 \\
25 \\
35\end{array}$ & $\begin{array}{r}8 \\
80 \\
387\end{array}$ \\
\hline
\end{tabular}

5. Proportional Gas Pay-This is an estimate of the fraction of the total zone thickness occupied by free gas above the oil column. For this assessment, this parameter was set to zero. There are insufficient data to realistically quantify the probable proportions of gas and oil in a reservoir containing both oil and free gas in a gas cap.

6. Solution Gas/Oil Ratio-This ratio was set to zero for the 1002 area assessment.

7. Condensate Yield-This factor was set to zero for the 1002 area assessment.

\section{Economic Inputs}

In order to estimate economically recoverable resources, the PRESTO model uses a predetermined minimum economic field size for each prospect considered. The minimum field size for a prospect represents the minimum volume of hydrocarbons (oil only, in this case) that could be developed and marketed at a profit. While engineering costs and other economic factors are generally similar for all prospects within a given geographic area, each prospect has some unique geologic characteristics that effect development and production costs and, therefore, the per-barrel economic recoverability of the resource. In other words, different prospects may require different volumes to be economically viable. The methods, types of data, and assumptions used for deriving minimum economic field sizes (MEFS) for prospects are described by Young and Hauser (1986).

An important assumption in the economic aralyses of various prospects for the determination of MEFS is that unitized development is assumed among lessees and other interest holders at the prospect level, but that shared regional transportation and infrastructure costs are assumed among all interests at the area level. In other words, the economic analyses assume that development of the resource will take place in the most technically efficient and cost-effective manner regardless of ownership within the 1002 area. The same assumption is made for contiguous private, State, or outer continental shelf (OCS) lands for prospects that extend outside the 1002 area.

Under the "most likely case" economic scenario, the minimum economic field size for the 1002 area as a whole is about 440 million barrels. For the 1002 assessment, the area minimum resource size equals the lowest prospect minimum economic field size. For individual prospects, the MEFS varies, depending on prospect-specific characteristics such as depth, well spacing, and pipeline distance.

Minimum economic field sizes were also calculated using alternative, more optimistic economic 
assumptions. Under these assumptions, the areawide MEFS (that is, the least costly prospect) is about 155 million barrels of technically recoverable oil. This is referred to as the "optimistic case" economic scenario. The sensitivity of field-size economics to variations in economic parameters is discussed in more detail by Young and Hauser (1986).

\section{NATURAL GAS ECONOMICS}

Given (1) the projected high costs of North Slope natural gas at market, (2) uncertainties associated with development of a natural gas transportation system to a viable market for proven North Slope natural gas reserves located at Prudhoe Bay, (3) the additional costs of moving potential gas resources from the 1002 area to a major transportation system near Prudhoe Bay, and (4) the quantity of proven reserves likely to be developed prior to any gas reserves found in the 1002 area, it was assumed here that there would not be a demand for acquiring acreage in the area in the early to mid-1990's for the purposes of finding and producing natural gas in the 1002 area.

It was further assumed that any gas reserves discovered through oil exploration activities will remain undeveloped or will be used only locally. This is not to say that potential gas resources in the 1002 area are without value. At some future time, national or international economic conditions or technological advances may warrant exploration for, and development of, potential natural gas resources in the 1002 area. For a detailed discussion of the alternatives and issues affecting development of potential natural gas resources in the 1002 area, see Young and Hauser (1986).

\section{THE PRESTO MODEL}

The following is a brief description of the PRESTO II drilling simulation model. Schematic flowcharts for this model are shown in figures 23.3 and 23.4. For the purposes of the ANWR study, the terms "basin" and "area" are synonymous. Also, the term "productive" in the flowcharts means hydrocarbon bearing, not necessarily commercially productive. For a more detailed description of the PRESTO model, see Cooke (1985). Similar models and Monte Carlo simulation in general are described by Newendorp (1975).

From the user inputs described above, PRESTO first generates a random number to determine if the area contains hydrocarbons (fig. 23.3). If the random number is less than the area dry risk, then the area is considered to be dry, in which case the trial is not counted against the number of input trials. If the random number is greater than the area dry risk, then the area is considered to be hydrocarbon bearing.
If the area is found to contain hydrocarbons, then PRESTO proceeds to "drill" the prospects. The program generates a random number for the first prospect. If the random number is less than the prospect conditional dry risk, the prospect is considered to be dry and PRESTO proceeds to the second prospect, for which another random number is generated. If this prospect is dry, PRESTO proceeds to the third prospect, and so on, until all prospects have been tested. If all prospects are found to be dry, then the area is considered to be dry and the trial is not counted against the input number of trials. If the random number generated is greater than the prospect conditional dry risk, then the prospect is

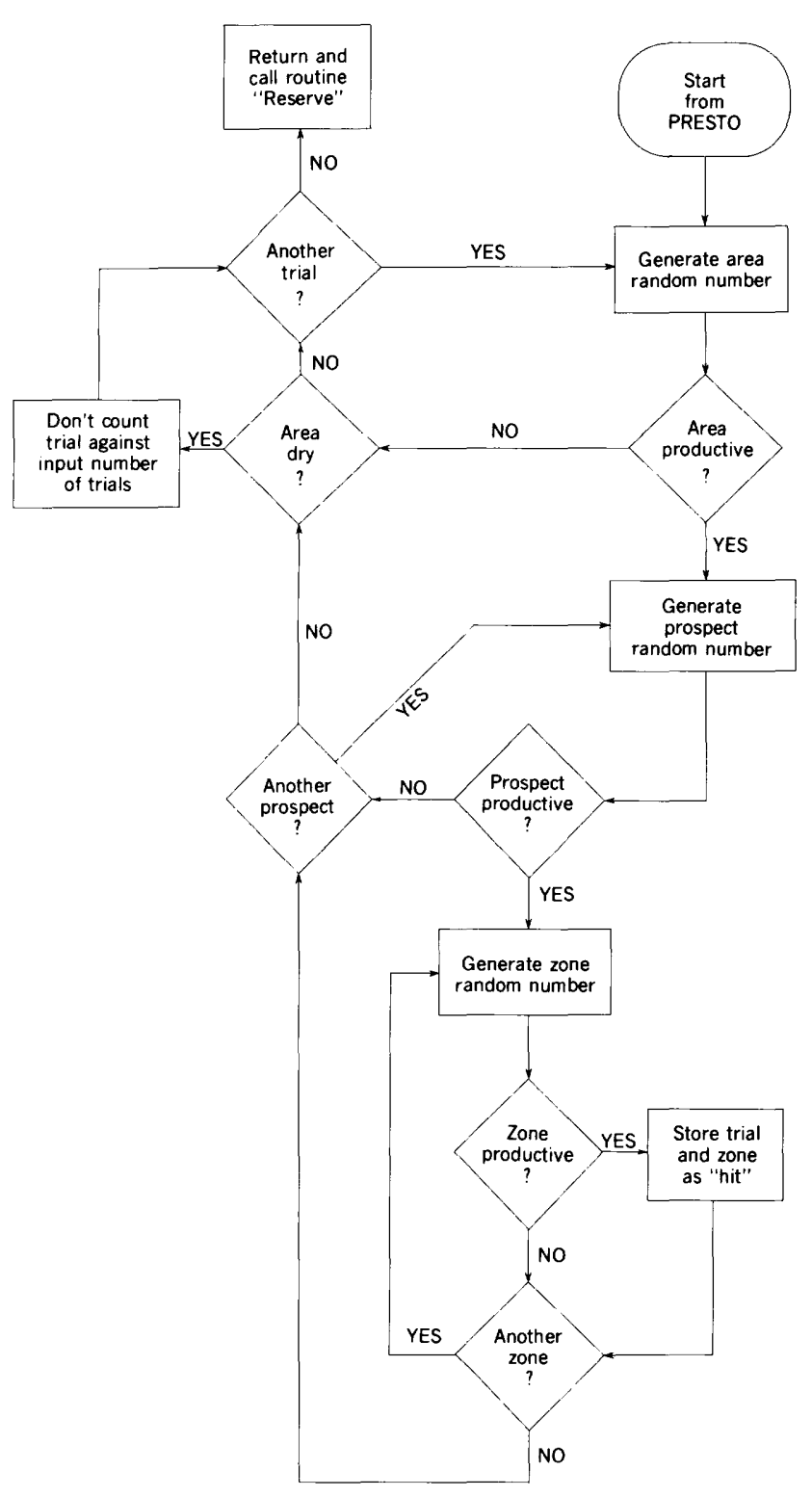

Figure 23.3. Routine for PRESTO drilling simulation. 
considered to be hydrocarbon bearing and PRESTO proceeds to test the individual zones within the prospect (if the prospect is modeled as having more than one zone). Another random number is generated for the first zone within the prospect. If the random number is less than the conditional zone risk, the zone is considered to be dry and PRESTO proceeds to the next zone. If all zones within the prospect are found to be dry, then the prospect is considered to be dry and PRESTO proceeds to the next prospect, where the process is repeated, until all prospects within the area have been tested. If the random number is greater than the conditional zone risk, then the zone is considered to be productive (not necessarily commercial) and the trial number, prospect number, and zone number are stored as a "hit." This process repeats until all prospects have been tested on the first trial, and then PRESTO returns to the area level and begins the second trial.

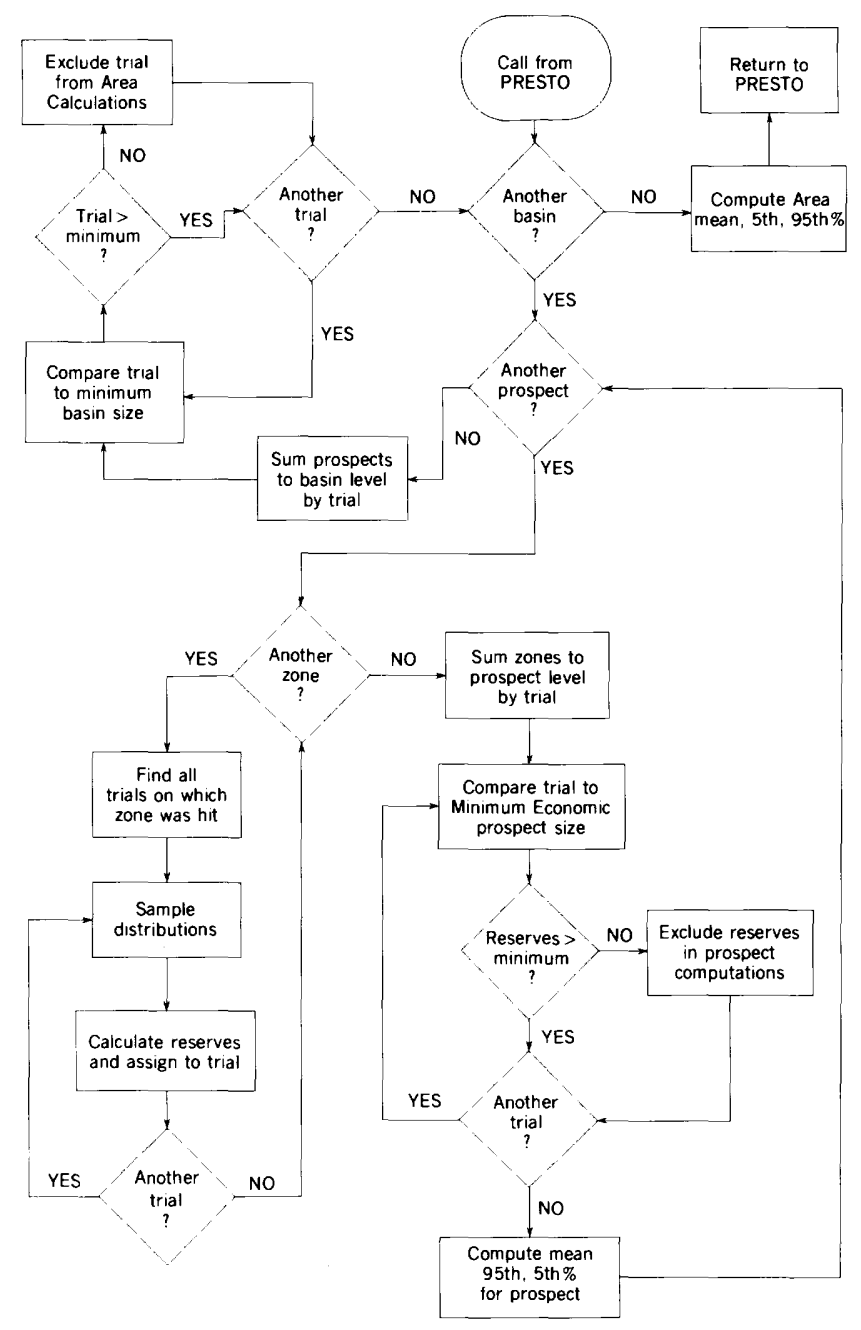

Figure 23.4. Routine for calculating resources using PRESTO.
After the area has been drilled, PRESTO starts the second phase, which is testing for economically recoverable resources (see fig. 23.4). The program finds all trials on which the first zone of the first prospect was hit, samples from the volumetric input distributions (productive acres, thickness, oil recovery) for that zone, and computes a value of oil resources for that trial. This is done for each trial on which the zone was hit. Then PRESTO does the same for the second and third (if necessary) zones of the first prospect. After all zones have been searched and resources computed for each trial of each zone, PRESTO sums the zones to the prospect level by trial. These summed resources are then compared with the prospect minimum economic field size, and all summed trials less than the minimum economic field size are excluded from the prospect resources. All summed trials remaining are averaged and reported as the prospect conditional economically recoverable resources-that is, given the condition that the prospect contains economically recoverable hydrocarbons, this would be the average value. This process is repeated for each prospect within the area. After all zones have been summed to the prospect level, PRESTO proceeds to sum the prospect results to the area level for each trial and compares area results for each trial with the area minimum economic field size. Any trial less than the area minimum economic field size is excluded. All remaining summed trials are then arranged in ascending order to produce a cumulative frequency distribution of the conditional area resources, and they are then averaged to give the area conditional mean resources. Because the PRESTO methodology sums prospects to the area level, individual prospect conditional resources cannot be added to give the area resources. Next, risked resources for each prospect and for the area are computed by averaging all trials, including dry, noneconomic (considered as zero), and economic trials. Finally, PRESTO recomputes the area dry risk to reflect the number of economic trials-that is, the input area dry risk determines the number of times the area is simulated as dry. The additional probability that the area contains noncommercial hydrocarbons is reflected in this recomputed area economic risk. The complement of the area economic risk (1 minus area economic risk) is reported as the marginal probability of occurrence of economically recoverable hydrocarbons.

\section{RESULTS}

Estimates of economically recoverable oil resources were calculated using two economic scenarios. The results are shown in table 23.3 along with the economic assumptions that most significantly affect the estimate of minimum economic field size for the "most likely" and "optimistic" cases. 
To provide a basis for assessing the consequences of resource management decisions in terms of the oil resource potential of the 1002 area, the unconditional resource potential for the area was allocated on a percentage basis to the blocks shown in figure 23.2. This allocation is based on the unconditional resource potential of the individual prospects contained in each block (table 23.4). A similar resource allocation, by percentage, was made to "activity areas" in the Sec. 105B Economic and Policy Analysis for the National Petroleum Reserve in Alaska.

The conditional mean resource is the expected volume for the area, given that economically recoverable resources occur somewhere in the area. By definition, this condition requires the existence of at least one field containing a sufficient volume of recoverable hydrocarbons to pay for the development, production, and transportation of the resource to market. As noted previously, the mean is simply the arithmetic average of a range of estimated values. The 5th and 95th percentiles are an indication of the extent of the range of possible values, given the uncertainty about the factors

Table 23.3. Undiscovered, conditional, economically recoverable oil resources in the 1002 area

[bbo, billion barrels of oil]

\begin{tabular}{|c|c|c|c|}
\hline & \multirow{2}{*}{$\begin{array}{c}\text { Greater } \\
\text { than } \\
\text { (pct) }\end{array}$} & \multicolumn{2}{|c|}{ Economic scenario } \\
\hline & & $\begin{array}{l}\text { Most likely } \\
\text { case }\end{array}$ & $\begin{array}{l}\text { Optimistic } \\
\text { case }\end{array}$ \\
\hline \multicolumn{4}{|c|}{ Conditional, economically recoverable oil } \\
\hline Probability & 99 & 0.49 bbo & $0.18 \mathrm{bbo}$ \\
\hline & 95 & $.59 \mathrm{bbo}$ & $.23 \mathrm{bbo}$ \\
\hline & 75 & $1.12 \mathrm{bbo}$ & $.67 \mathrm{bbo}$ \\
\hline & 50 & $2.21 \mathrm{bbo}$ & $1.49 \mathrm{bbo}$ \\
\hline & 25 & 4.24 bbo & $3.67 \mathrm{bbo}$ \\
\hline & 5 & $9.24 \mathrm{bbo}$ & 7.65 bbo \\
\hline & 1 & 17.19 bbo & $15.73 \mathrm{bbo}$ \\
\hline Maximum simulated oil & & 22.34 bbo & $22.34 \mathrm{bbo}$ \\
\hline Mean (arithmetic average) & & 3.23 & 2.66 \\
\hline Marginal probability ${ }^{1}$ & & $19.0 \%$ & $26.0 \%$ \\
\hline Minimum economic field & & $.44 \mathrm{bbo}$ & $.15 \mathrm{bbo}$ \\
\hline \multicolumn{4}{|c|}{ Significant economic assumptions } \\
\hline $\begin{array}{l}\text { Crude oil market price (1984 } \\
\text { dollars/barrel in year 2000) }\end{array}$ & & $\$ 33.00$ & $\$ 40.00$ \\
\hline Annual inflation rate (percent) & & 6.0 & 3.5 \\
\hline \multicolumn{4}{|l|}{ Discount rate (percent): } \\
\hline Real & & 10.0 & 8.0 \\
\hline Nominal & & 16.6 & 11.78 \\
\hline Federal royalty rate (percent) & & 16.67 & 12.5 \\
\hline Development cost multiplier & & 1.0 & .75 \\
\hline
\end{tabular}

${ }^{1}$ The marginal probability is the probability of occurrence of economically recoverable oil somewhere in the 1002 area. affecting hydrocarbon volumes and the geologic risk associated with individual prospects. The risked mean volume is an indicator of the relative recoverable resource potential of the area. It is the product of the conditional mean times the marginal probability that the area contains economically recoverable hydrocarbons (that is, the probability associated with the condition).

\section{Prospect Resources}

Under the "most likely" case, 18 of the 26 identified prospects in the 1002 area were modeled by PRESTO as being economic at least one time during the Monte Carlo simulation. For these 18 prospects, conditional mean resource estimates ranged from about 500 million to over 3.5 billion barrels of economically recoverable oil. For the five largest prospects, the conditional mean estimate exceeds 1.5 billion barrelsthe size of the Kuparuk River oil field. At the 5 percent probability level, the conditional, economically recoverable resource estimate for the largest prospect exceeds 10.5 billion barrels.

Under the "optimistic" case, 21 of the 26 prospects were simulated as economic on at least one Monte Carlo pass.

For both of these cases, the average number of prospects contributing to the area resource on any one Monte Carlo pass was two, and the maximum was five.

\section{SUMMARY AND CONCLUSIONS}

The effect of field-size economics on recoverability of hydrocarbons in a remote frontier area is obvious in the comparison between the in-place and the economically recoverable resource estimates in the 1002 area. Nevertheless, the occurrence of several very large structural closures, along with the potential occurrence of Ellesmerian reservoir rocks at depth, indicates a very large production potential for the 1002 area despite the extremely high costs associated with its remote and hostile environment.

Table 23.4. Distribution of estimated unconditional mean recoverable oil resources by blocks in the 1002 area

\begin{tabular}{llcc}
\hline Block & $\begin{array}{c}\text { Location in } \\
1002 \text { area }\end{array}$ & $\begin{array}{c}\text { Resource } \\
\text { distribution } \\
\text { (percent) }\end{array}$ & $\begin{array}{c}\text { Number of } \\
\text { prospects in } \\
\text { block }\end{array}$ \\
\hline A & West & 9 & 14 \\
B & Central & 3 & 3 \\
C & East & 63 & 4 \\
D & South & 25 & 5 \\
\hline
\end{tabular}


The conditional recoverable resource potentials of the eight largest prospects identified in the 1002 area are compared with those of several other large oil fields in the U.S. in figure 23.5. As noted above, five of the prospects have estimated conditional mean recoverable resources larger than the Kuparuk River field.

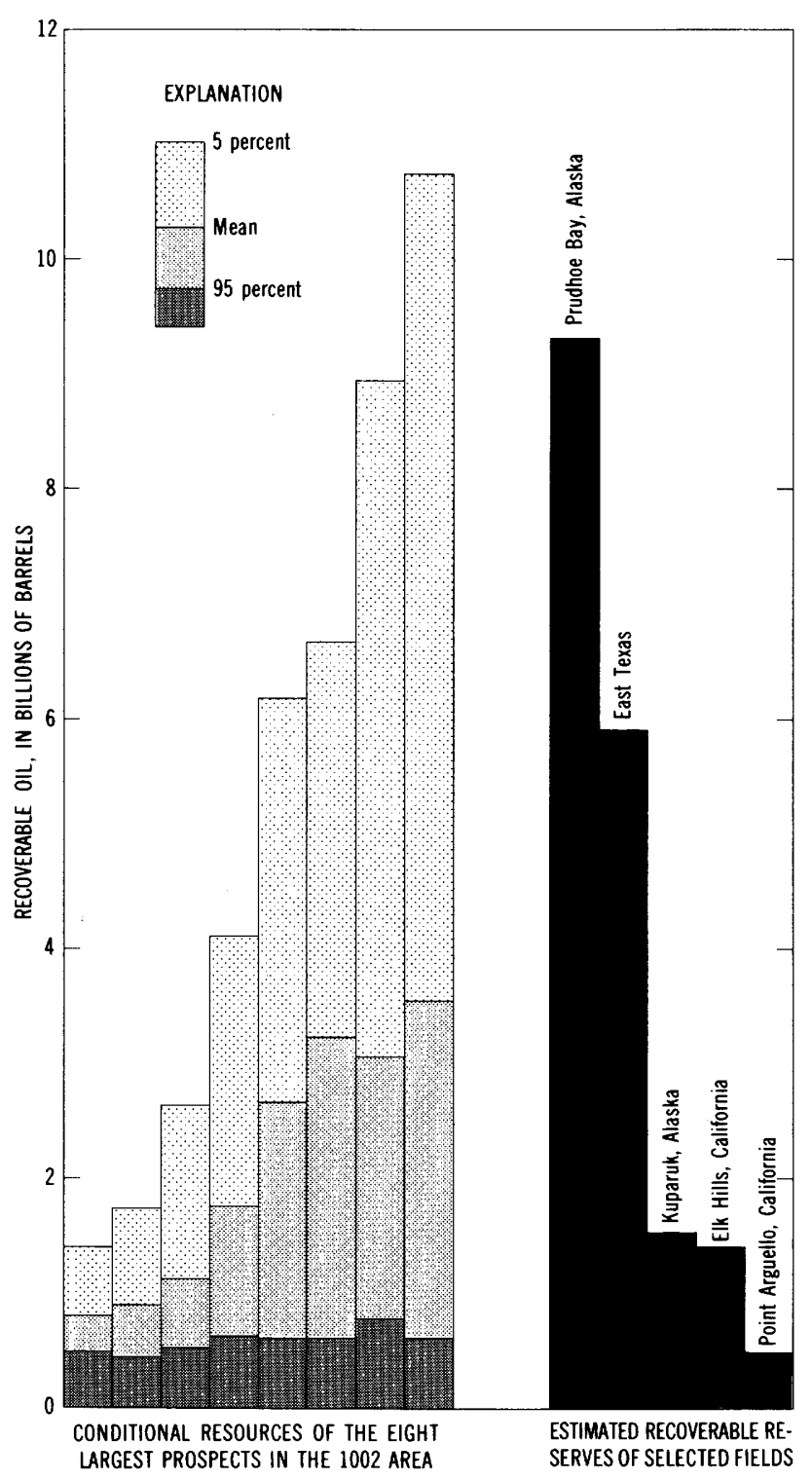

Figure 23.5. Conditional, economically recoverable oil resources of eight largest prospects in 1002 area compared with estimated recoverable reserves of five producing fields. Modified from McCaslin (1986, p. 318-319). 


\section{REFERENCES CITED}

Alaska Geological Society, 1972, Northwest to southeast stratigraphic correlation section, Prudhoe Bay to Ignek Valley, Arctic North Slope, Alaska: The Alaska Geological Society, Anchorage, Alaska, 1 sheet.

Alaska Oil and Gas Conservation Commission, 1984, Public hearing on Lisburne Field Rules, testimony by ARCO Alaska, Inc., November 29, 1984, Anchorage, Alaska, 87 p.

1985, 1984 Statistical Report: Alaska Oil and Gas Conservation Commission, Anchorage, Alaska, $187 \mathrm{p}$.

Anstey, N.A., 1982, Simple seismics: Boston, Mass., International Human Resource Development Corporation, $168 \mathrm{p}$.

1986, What happened to ground roll, Pt. 1: Geophysics: The Leading Edge, v. 5, no. 3, p. 40-45.

Armstrong, A.K., 1972, Pennsylvanian carbonates, paleoecology, and rugose colonial corals, north flank, eastern Brooks Range, Arctic Alaska: U.S. Geological Survey Professional Paper 747, $21 \mathrm{p}$.

Armstrong, A.K., and Mamet, B.L., 1974, Carboniferous biostratigraphy, Prudhoe Bay State 1, Arctic Alaska: American Association of Petroleum Geologists Bulletin, v. 58, no. 4, p. 646-660.

- 1975, Carboniferous biostratigraphy, northeastern Brooks Range, Arctic Alaska: U. S. Geological Survey Professional Paper 884, 29 p.

1977, Carboniferous microfacies, microfossils, and corals, Lisburne Group, Arctic Alaska: U.S. Geological Survey Professional Paper 849, 144 p.

Bader, J.W., and Bird, K.J., 1986, Geologic map of the Demarcation Point, Mt. Michelson, Flaxman Island, and Barter Island Quadrangles, Alaska: U.S. Geological Survey Miscellaneous Investigations Map I-1791, scale 1:250,000, 1 sheet.

Baker-10 SPE Applications Guide, 1982, Rapid separation of crude oil: Phillipsburg, N.J., J. T. Baker Chemical Co., 28 p.

Balkwill, H.R., Cook, D.G., Detterman, R.L., Embry, A.F., Hakansson, E., Miall, A.D., Poulton, T.P., and Young, F.G., 1983, Arctic North America and northern Greenland, in Nairn, A.E.M., and Moullade, A., eds., The Phanerozoic geology of the world, II: The Mesozoic, $B$ : The Netherlands, Elsevier Science Publishers, p. $1-31$.

Ball, N.L., and Snowdon, L.R., 1973, A preliminary evaluation of the applicability of the helium survey technique to prospecting for petroleum: Geological Survey of Canada Paper 73-1B, p. 199-202.

Bally, A.W., Gordy, P.L., and Stewart, G.A., 1966, Structure, seismic data, and orogenic evolution of the southern Canadian Rocky Mountains: Canadian Petroleum Geologists Bulletin, v. 14, p. 337-381.

Barker, C., 1974, Pyrolysis for source-rock evaluation: American Association of Petroleum Geologists Bulletin, v. 58, p. 2349-2361.

Barker, C.E., and Pawlewicz, M.J., 1986, A surface vitrinite anomaly related to the Bell Creek oil field, Montana, in Davidson, M.J., ed., Unconventional methods in exploration for petroleum and natural gas: Symposium IV, Institute for the Study of Earth and Man, May 1-2, 1985, Dallas, Tex., Southern Methodist University, p. 125-146.

Barnes, D.A., 1985, Sag River Formation, Prudhoe Bay, Alaska: Depositional environment and diagenesis [abs.]: American Association of Petroleum Geologists Bulletin, v. 69, no. 4, p. 656.

Barnes, P.W., Reimnitz, Erk, Kempema, E.W., Minkler, P., and Ross, C.R., 1980, Marine geologic studies in the Beaufort Sea, Alaska, 1979: data type, location, and records obtained: U.S. Geological Survey Open-File Report 80-603, 4 p.

Bartsch-Winkler, S., 1979, Textural and mineralogical study of some surface and subsurface sandstones from the Nanushuk Group, western North Slope, Alaska, in Ahlbrandt, T. S., ed., Preliminary geologic, petrologic, and paleontologic results of the study of Nanushuk Group rocks, North Slope, Alaska: U.S. Geological Survey Circular 794, p. 61-76.

Bayliss, G.S., and Magoon, L.B., in press, Organic facies and thermal maturity in the National Petroleum Reserve in Alaska-intercalibration of visual kerogen assessment, vitrinite reflectance, and C1-to-C4 hydrocarbons, in Gryc, George, ed., Geology of the National Petroleum Reserve in Alaska: U.S. Geological Survey Professional Paper 1399.

Behrman, P.G., Woidneck, R.K., Soule, C.H., and Wu, J.L., 1985, Reservoir description of Endicott field, Prudhoe Bay, Alaska [abs.]: American Association of Petroleum Geologists Bulletin, v. 69, no. 4, p. 656.

Berg, O.R., and Woolverton, D.G., eds., 1985, Seismic stratigraphy II: American Association of 
Petroleum Geologists Memoir 39, 276 p.

Berner, R.A., 1971, Principles of chemical sedimentology: New York, McGraw-Hill Book Co., $240 \mathrm{p}$.

1974, Iron sulfides in Pleistocene deep Black Sea sediments and their paleo-oceanographic significance, in Degens, E.T., and Ross, D.A., eds., The Black Sea, geology, chemistry, and biology: American Association of Petroleum Geologists Memoir 20, p. 524-531.

1978, Rate control of mineral dissolution under earth surface conditions: American Journal of Science, v. 278, p. 1235-1252.

1980, Early diagenesis, a theoretical approach: Princeton, New Jersey, Princeton University Press, $241 \mathrm{p}$.

1981a, Kinetics of weathering and diagenesis, in Lasaga, A.C., and Kirkpatrick, R.J., eds., Kinetics of geochemical processes: Mineralogical Society of America Short Course Notes, v. 8, p. 111-132.

$1981 \mathrm{~b}, \mathrm{~A}$ new geochemical classification of sedimentary environments: Journal of Sedimentary Petrology, v. 51, p. 359-365.

Berner, R.A., Baldwin, Timothy, and Holdren, G.R., Jr., 1979, Authigenic iron sulfides as paleosalinity indicators: Journal of Sedimentary Petrology, v. 49, p. 1345-1350.

Biddle, K.T., and Christie-Blick, Nicholas, eds., 1985, Strike-slip deformation, basin formation, and sedimentation: Society of Economic Paleontologists and Mineralogists Special Publication No. 37, 386 p.

Bird, K.J., 1978, New information on the Lisburne Group (Carboniferous and Permian) in the National Petroleum Reserve in Alaska (NPRA)[abs.]: American Asssociation of Petroleum Geologists Bulletin, v. 62, no. 5, p. 880 .

1981, Petroleum exploration of the North Slope, Alaska, in Mason, J.F., ed., Petroleum geology in China-principal lectures presented to the United Nations: Tulsa, Okla., PennWell Publishing Co., p. 233-248.

1982, Rock unit report of 228 wells drilled on the North Slope, Alaska: U.S. Geological Survey Open-File Report 82-278, 106 p.

1986a, A comparison of the play-analysis technique as applied in hydrocarbon resource assessments of the National Petroleum Reserve in Alaska and the Arctic National Wildlife Refuge, in Rice, D.D., ed., Oil and gas assessment-methods and applications: American Association of Petroleum Geologists Studies in Geology No. 21, p. 133-142.

1986b, The framework geology of the North Slope of Alaska as related to oil-source rock correlations, in Magoon, L.B., and Claypool,
G.E., eds., Alaska North Slope oil/rock correlation study: American Association of Petroleum Geologists Studies in Geology No. 20, p. 3-29.

Bird, K.J., and Jordan, C.F., 1977, Lisburne Group (Mississippian and Pennsylvanian), potential major hydrocarbon objective of Arctic Slope, Alaska: American Association of Petroleum Geologists Bulletin, v. 61, no. 9, p. 1493-1512.

Bischoff, J.L., and Ku, T.L., 1970, Pore fluids of recent marine sediments: I., oxidizing sediments of $20^{\circ}$ $\mathrm{N}$, continental rise to Mid-Atlantic Ridge: Journal of Sedimentary Petrology, v. 40, p. 960-972.

1971 , Pore fluids of recent marine sediments of $35^{\circ}$ to $45^{\circ} \mathrm{N}$, Gibraltor to Mid-Atlantic Ridge: Journal of Sedimentary Petrology, v. 41, p. 1008-1017.

Biswas, N.N., Aki, K., Pulpan, H., and Tytgat, G., 1986, Characteristics of regional stresses in Alaska and neighboring areas: Geophysical Research Letters, v. 13, no. 3, p. 177-180.

Black, R.F., 1954, Precipitation at Barrow, Alaska, greater than recorded: Transactions of the American Geophysical Union, v. 35, no, 2, p. 203-206.

Blackburn, G., 1980, Errors, stacking velocity-true velocity conversion over complex geologic situations: Geophysics, v. 45, p. 1465-1488.

Blanchard, D.C., and Tailleur, I.L., 1982, Temperatures and interval geothermal gradient determinations from wells in National Petroleum Reserve of Alaska: U.S. Geological Survey Open-File Report No. 82-391, 79 p.

1983, Pebble shale (Early Cretaceous) depositonal environments in National Petroleum Reserve in Alaska (NPRA) [abs.]: American Association of Petroleum Geologists Bulletin, v. 67 , no. 3 , p. $424-425$.

Blatt, Harvey, Middleton, G.V., and Murray, Raymond, 1980, Origin of sedimentary rocks (2nd ed.): Englewood Cliffs, N.J., Prentice-Hall Inc., 782 p.

Blodgett, R.B., Clough, J.G., Dutro, J.T., Jr., Ormiston, A.R., Palmer, A.R., and Taylor, M.E., 1986, Age revisions for the Nanook Limestone and Katakturuk Dolomite, northeastern Alaska, in Bartsch-Winkler, Susan, and Reed, K.M., eds., Geologic studies in Alaska by the U.S. Geological Survey during 1985: U.S. Geological Survey Circular 978, p. 5-10.

Boles, J.R., 1977, Zeolites in deep-sea sediments, in Mumpton, F. A., ed., Mineralogy and geology of natural zeolites: Mineralogical Society of America Short Course Notes, v. 4, p. 137-163.

1978, Active ankerite cementation in the subsurface Eocene of southwest Texas: 
Contributions to Mineralogy and Petrology, v. 68, p. 13-22.

Boles, J.R., and Franks, S.G., 1979, Clay diagenesis in Wilcox Sandstones of southwest Texas: implications of smectite diagenesis on sandstone cementation: Journal of Sedimentary Petrology, v. 49, p. $55-70$.

Bostick, N.H., 1979, Microscopic measurement of the level of catagenesis of solid organic matter in sedimentary rocks to aid exploration for petroleum and to determine former burial temperatures-a review, in Scholle, P.A., and Schluger, P.R., eds., Aspects of diagenesis: Society of Economic Paleontologists and Mineralogists Special Publication No. 26, p. $17-43$.

Boucher, Gary, Ruppel, B.D., Chiburis, E.F., and Dehlinger, Peter, 1977, Map showing free-air gravity anomalies in the southern Beaufort Sea: U.S. Geological Survey Miscellaneous Field Studies Map MF-851, scale 1:1,000,000.

Boyd, W.L., and Boyd, J.W., 1963, A bacteriological study of an arctic coastal lake: Ecology, v. 44, no. 4 , p. 705-710.

Boyer, S.E., and Elliott, David, 1982, Thrust systems: American Association of Petroleum Geologists Bulletin, v. 66, no. 9, p. 1196-1230.

Braunstein, Jules, ed., 1976, North American oil and gas fields: American Association of Petroleum Geologists Memoir 24, 426 p.

Brewer, M.C., 1955a, Preliminary interpretations of ice, water, and bottom temperature data in the Arctic Ocean near Barrow, Alaska [abs.]: Transactions of the American Geophysical Union, v. 36, no. 3 , p. 503 .

$1955 \mathrm{~b}$, Geothermal investigations of permafrost in northern Alaska [abs.]: Transactions of the American Geophysical Union, v. 36, no. 3, p. 503.

$1958 \mathrm{a}$, Some results of geothermal investigations of permafrost in northern Alaska: Transactions of the American Geophysical Union, v. 39, no. 1 , p. 19-26.

1958b, The thermal regime of an Arctic lake: Transactions of the American Geophysical Union, v. 39 , no. 2 , p. $278-284$.

1958c, Temperature measurement studies, p. 131-132, 142, 170-171, 197, in Collins, F. R., Test wells, Umiat area, Alaska: U.S. Geological Survey Professional Paper 305-B, p. 71-206.

1961, Temperature-measurement studies, South Barrow Test Well 1, p. 596, in Collins, F. R., Core tests and test wells, Barrow area, Alaska : U.S. Geological Survey Professional Paper 305-K, p. 569-644.

1974, Permafrost-its impact on development, in Man's impact on Arctic and subarctic environments: Washington, D.C., Arctic Institute of North America, p. 19-27.

1976, The seaward extension of permafrost off the northern Alaskan coast [expanded abs.], in International Conference on Port and Ocean Engineering under Arctic Conditions, 3rd, August, 1975, Proceedings: Fairbanks, University of Alaska, v. 2, p. 987-988.

Brosgé, W.P., and Dutro, J.T., Jr., 1973, Paleozoic rocks of northern and central Alaska, in Pitcher, M.G., ed., Arctic geology: American Association of Petroleum Geologists Memoir 19, p. 361-375.

Brosgé, W.P., Dutro, J.T., Jr., Mangus, M.D., and Reiser, H.N., 1962, Paleozoic sequence in eastern Brooks Range, Alaska: American Association of Petroleum Geologists Bulletin, v. 46, no. 2, p. 2174-2198.

Brosgé, W.P., Reiser, H.N., and Detterman, R.L., 1981, Organic geochemical data for Mesozoic and Paleozoic shales, central and eastern Brooks Range, Alaska: U.S. Geological Survey OpenFile Report 81-551, $18 \mathrm{p}$.

Brown, J., and Tedrow, J.C.F., 1964, Soils of the northern Brooks Range, Alaska-4, Welldrained soils of the glaciated valleys: Soil Science, v. 97, no. 3, p. 187-195.

Bruce, C.H. 1984, Smectite dehydration-its relation to structural development and hydrocarbon accumulation in northern Gulf of Mexico basin: American Association of Petroleum Geologists Bulletin, v. 68, p. 673-683.

Buckingham, M.L., 1985a, Stratigraphy, petrology, and depositional environments of Upper Cretaceous and lower Tertiary Sabbath Creek section, Arctic National Wildlife Refuge (ANWR), Alaska [abs.]: American Association of Petroleum Geologists Bulletin, v. 69, no. 4, p. 658.

1985b, Fluvio-deltaic sedimentation patterns of the Upper Cretaceous to lower Tertiary Sabbath Creek section, Arctic National Wildlife Refuge (ANWR), northeastern Alaska: Fairbanks, Alas., University of Alaska, M.S. thesis, $165 \mathrm{p}$.

1987, Fluvio-deltaic sedimentation patterns of the Upper Cretaceous to Lower Tertiary Jago River Formation, Arctic National Wildlife Refuge (ANWR), northeastern Alaska, in Tailleur, I.L., and Weimer, Paul, eds., Alaskan North Slope geology: Bakersfield, Calif., Pacific Section of Society of Economic Paleontologists and Mineralogists and the Alaska Geological Society, v. 50 [in press]

Burro, C., 1973, Want clean air? Barrow, Alaska, has purest in the nation: Seattle, Wash., The Seattle Times, August 31, 1973, p. 37

Burst, J.F., 1969, Diagenesis of Gulf Coast clayey sediments and its possible relation to petroleum 
migration: American Association of Petroleum Geologists Bulletin: v. 53, p. 73-93.

Butler, B.D., Pilger, R.H., Jr., and Nunn, J.A., 1985, Tectonic model of the central Brooks Range, Alaska [abs.]: Geological Society of America Abstracts with Program, v. 17, no. 7, p. 536.

Calvert, S.E., 1976, The mineralogy and geochemistry of near-shore sediments, in Riley, J.P., and Chester, R., eds., Chemical oceanography: New York, Academic Press, p. 187-280.

Canada Department of Energy, Mines and Resources, 1977, Oil and natural gas resources of Canada, 1976: Ottawa, Ontario, Canada Department of Energy, Mines and Resources Report EP 7-1, 76 p.

Carey, S.W., 1958, A tectonic approach to continental drift, in Carey, S.W., ed., Continental drift, a symposium: Hobart, Tasmania University, $p$. 177-355.

Carman, G.J., and Hardwick, Peter, 1983, Geology and regional setting of the Kuparuk oil field, Alaska: American Association of Petroleum Geologists Bulletin, v. 67, no. 6, p. 1014-1031.

Carpenter, A.B., Trout, M.L., and Pickett, E.E., 1974, Preliminary report on the origin and chemical evolution of lead- and zinc-rich oil field brines in central Mississippi: Economic Geology, v. 69, pp. 1191-1196.

Carter, Claire, and Laufeld, Sven, 1975, Ordovician and Silurian fossils in well cores from North Slope of Alaska: American Association of Petroleum Geologists Bulletin, v. 59, no. 3, p. 457-464.

Carter, L.D., Ferrians, O.J., Jr., and Galloway, J.P., 1986, Engineering-geologic maps of northern Alaska, coastal plain and foothills of the Arctic National Wildlife Refuge: U.S. Geological Survey OpenFile Report 86-334, scale 1:250,000.

Castaño, J.R., and Sparks, D.M., 1974, Interpretation of vitrinite reflectance measurements in sedimentary rocks and determination of burial history using vitrinite reflectance and authigenic minerals, in Dutcher, R.R., Hacquebard, P.A., Schopf, J.M., and Simon, J.A., eds., Carbonaceous materials as indicators of metamorphism: Geological Society of America Special Paper 153, p. 31-52.

Cavanagh, L.A., Schadt, C.F., and Robinson, Elmer, 1969, Atmospheric hydrocarbon and carbon monoxide measurements at Point Barrow, Alaska: Environmental Science and Technology, v. 3 , no. 3, p. 251-257.

Cederstrom, D.J., Johnston, P.M., and Subitsky, Seymour, 1953, Occurrence and development of ground water in permafrost regions: U.S. Geological Survey Circular 275, 49 p.

Churkin, Michael, Jr., and Trexler, J.H., Jr., 1980, Circum-Arctic plate accretion-isolating part of a Pacific plate to form the nucleus of the Arctic basin: Earth and Planetary Science Letters, v. 48 , p. 356-362.

Clarke, W.B., and Kugler, G., 1973, Dissolved helium in groundwater-A possible method for uranium and thorium prospecting: Economic Geology, v. 68 , p. $243-251$.

Clarke, W.B., Top, Z., Beavan, A.P., and Gandhi, S.S., 1977, Dissolved helium in lakes: Uranium prospecting in the Precambrian terrain of central Labrador: Economic Geology, v. 72, p. 233-242.

Clayton, J.L. and Swetland, P.J., 1976, Subaerial weathering of sedimentary organic matter $[a b s]$ : Geological Society of America Abstracts with Programs, v. 8, p. 815.

Clementz, D.M., Demaison, G.J., and Daly, A. R., 1979, Well site geochemistry by programmed pyrolysis: Offshore Technology Conference Proceedings, v. 1, Dallas, Tex., OTC 3410, p. 465-470.

Cloft, H.S., 1984, The sedimentology and stratigraphy of the Ledge Sandstone Member, Ivishak Formation, in the Arctic National Wildlife Refuge, northeastern Alaska: M.S. Thesis, Dallas, Tex., University of Texas at Dallas, 193 p.

Clough, N.K., Patton, P.C., and Christiansen, A.C., eds., 1987, Arctic National Wildlife Refuge, Alaska, coastal plain resource assessment-Report and recommendation to the Congress of the United States and final legislative environmental impact statement: Washington, D.C., U.S. Fish and Wildlife Service, U.S. Geological Survey, and Bureau of Land Management, v. 1 (Report)208 p., v. 2 (Appendix-Public comments and responses)-998 $\mathrm{p}$.

Coney, P.J., and Jones, D.L., 1985, Accretion tectonics and crustal structure in Alaska: Tectonophysics, v. 119 , p. $265-283$.

Connan, J., 1974, Time-temperature relation in oil genesis: American Association of Petroleum Geologists Bulletin, v. 58, no. 12, p. 2516-2521.

Cooke, L.W., 1985, Estimates of undiscovered, economically recoverable oil and gas resources for the Outer Continental Shelf as of July 1984: U.S. Minerals Management Service Offshore Resource Evaluation Division OCS Report MMS-85-0012, 45 p.

Craig, J.D., Sherwood, K.W., and Johnson, P.P., 1985, Geologic report for the Beaufort Sea planning area, Alaska: regional geology, petroleum geology, environmental geology: U.S. Minerals Management Service OCS Report MMS 850111, $192 \mathrm{p}$.

Craig, P.C., and McCart, P., 1974, Classification of streams in the Beaufort Sea and drainages 
between Prudhoe Bay, Alaska, and the Mackenzie delta: Canadian Arctic Gas Study Ltd. (CAGSL) and Alaskan Arctic Gas Study Company (AAGSC) Biological Report Series, v. 17, no. 1. [Quoted in U.S. Department of the Interior, 1976, Alaska natural gas transportation system-Final environmental impact statement, p. 102]

Crovelli, R.A., 1986, A comparison of analytical and simulation methods for petroleum play analysis and aggregation: U.S. Geological Survey OpenFile Report 86-97, 21 p.

Crovelli, R.A., and Balay, R.H., 1986, FASP, an analytical resource appraisal program for petroleum play analysis: Computers and Geosciences, v. 12, no. 4B, p. 423-475.

Cunningham, K.I., in press, Concentrations of helium, methane, and ethane in permafrost ice, Arctic National Wildlife Refuge, Alaska: U.S. Geological Survey Open-File Report.

Curtis, C.D., 1978, Possible links between sandstone diagenesis and depth-related geochemical reactions occurring in enclosing mudstones: Journal of the Geological Society of London, v. 135, p. 107-117.

Curtis, D.M., Dickerson, P.W., Gray, D.M., Klein, H.M., and Moody, E.W., 1981, How to (try to) find an oil field: Tulsa, Okla., PennWell Publishing Co., $94 \mathrm{p}$.

Dahlstrom, C.D.A., 1970, Structural geology in the eastern margin of the Canadian Rocky Mountains: Canadian Petroleum Geologists Bulletin, v. 18, p. 332-406.

Dapples, E.C., 1971, Physical classification of carbonate cement in quartzose sandstones: Journal of Sedimentary Petrology, v. 41, p. 196-204.

1979a, Diagenesis of sandstones, in Larsen, Gunner, and Chilinger, G.V. eds., Diagenesis in sediments and sedimentary rocks, v. 25A of Developments in Sedimentology: New York, Elsevier Scientific Publishing Co., p. 31-98.

$1979 \mathrm{~b}$, Silica as an agent in diagenesis, in Larsen, Gunner, and Chilinger, G.V., eds., Diagenesis in sediments and sedimentary rocks, v. 25A of Developments in Sedimentology: New York, Elsevier Scientific Publishing Co., p. 99-141.

Debnam, A.H., 1969, Geochemical prospecting for petroleum and natural gas in Canada: Geological Survey of Canada Bulletin, v. 177, p. $1-26$.

Deer, W.A., Howie, R.A., and Zussman, J., 1966, An introduction to the rock-forming minerals: London, Longman Group Ltd., 528 p.

Detterman, R.L., 1970, Sedimentary history of Sadlerochit and Shublik Formations in northeastern Alaska, in Adkison, W.L., and
Brosgé, M.M., eds., Proceedings of the geological seminar on the North Slope of Alaska: Los Angeles, Calif., American Association of Petroleum Geologists, Pacific Section, p. O1-O13.

1974, Fence diagram showing lithologic facies of the Sadlerochit Formation (Permian and Lower Triassic), northeastern Alaska: U.S. Geological Survey Miscellaneous Field Studies Map MF584,1 sheet.

1976, Lithofacies fence diagram of Sadlerochit Group for Philip Smith Mountains quadrangle and adjacent areas, northeastern Alaska: U.S. Geological Survey Miscellaneous Field Studies Map MF-744, 1 sheet.

1984a, Measured sections of Late Paleozoic and Mesozoic rocks, Mount Michelson quadrangle, Alaska: U.S. Geological Survey Open-File Report 84-331, 2 sheets.

-1984b, Measured sections of Upper Paleozioc to Early Tertiary rocks, Demarcation Point quadrangle, Alaska: U.S. Geological Survey Open-File Report 84-370, 1 sheet.

Detterman, R.L., Bickel, R.S., and Gryc, George, 1963, Geology of the Chandler River region, Alaska: U.S. Geological Survey Professional Paper 303E, p. 223-324.

Detterman, R.L., Reiser, H.N., Brosgé, W.P., and Dutro, J.T., Jr., 1975, Post-Carboniferous stratigraphy, northeastern Alaska: U.S. Geological Survey Professional Paper 886, $46 \mathrm{p}$.

Detterman, R.L., and Spicer, R.A., 1981, New stratigraphic assignment for rocks along Igilatvik (Sabbath) Creek, William O. Douglas Arctic Wildlife Range, Alaska, in Albert, N.R.D., and Hudson, Travis, eds., The United States Geological Survey in Alaska-Accomplishments during 1979: U.S. Geological Survey Circular 823-B, p. B11-B12.

Dickinson, W.R., 1970, Interpreting detrital modes of graywacke and arkose: Journal of Sedimentary Petrology, v. 40, p. 695-707.

1974, Plate tectonics and sedimentation, in Dickinson, W.R., ed., Tectonics and sedimentation: Society of Economic Paleontologists and Mineralogists Special Publication No. 22, p. 1-27.

Dickinson, W.R., and Suczek, C.A., 1979, Plate tectonics and sandstone composition: American Association of Petroleum Geologists Bulletin, v. 63, p. 2164-2182.

Dietrich, J.R., Dixon, J., and McNeil, D.H., 1985, Sequence analysis and nomenclature of Upper Cretaceous to Holocene strata in the BeaufortMackenzie basin, in Current research, part A: Geological Survey of Canada Paper 85-1A, p. 613-628. 
Dikun, A.V., Korobeynik, V.M., and Yanitskii, I.N., 1976, Some features of development of helium surveying: International Geology Review, v. 18, no. 1, p. $98-100$.

Dinter, D.A., 1985, Quaternary sedimentation of the Alaskan Beaufort shelf-influence of regional tectonics, fluctuating sea levels, and glacial sediment sources: Tectonophysics, v. 114, p. 133-161.

Dix, C.H., 1955, Seismic velocities from surface measurements: Geophysics, v. 20, p. 68-86.

Dixon, J., Dietrich, J.R., McNeil, D.H., McIntyre, D.J., Snowdon, L.R., and Brooks, P., 1985, Geology, biostratigraphy, and organic geochemistry of Jurassic to Pleistocene strata, BeaufortMackenzie area, northwest Canada: Course notes, Canadian Society of Petroleum Geologists, Calgary, Alberta, 64 p.

Dobrin, M.B., 1976, Introduction to geophysical prospecting (3rd ed.): New York, McGraw-Hill, $630 \mathrm{p}$.

Donovan, T.J., 1974, Petroleum microseepage at Cement, Oklahoma: evidence and mechanism: American Association of Petroleum Geologists Bulletin, v. 58 , no. 3 , p. $429-446$.

Donovan, T.J., and Dalziel, M.C., 1977, Late diagenetic indicators of buried oil and gas: U.S. Geological Survey Open-File Report 77-817, 44 p.

Donovan, T.J., Forgey, R.L., and Roberts, A.A., 1979, Aeromagnetic detection of diagenetic magnetite over oil fields: American Association of Petroleum Geologists Bulletin, v. 63, p. 245-248.

Donovan, T.J., Friedman, I., and Gleason, J.D., 1974, Recognition of petroleum-bearing traps by unusual isotopic compositions of carbonatecemented surface rocks: Geology, v. 2, p. 351-354.

Donovan, T.J., Hendricks, J.D., Roberts, A.A., and Eliason, P.T., 1984, Low-altitude aeromagnetic reconnaissance for petroleum in the Arctic National Wildlife Refuge, Alaska: Geophysics, v. 49 , no. 8 , p. $1338-1353$.

in press, Low-level aeromagnetic surveying for petroleum in Arctic Alaska, in Gryc, George, ed., Geology of the National Petroleum Reserve in Alaska: U.S. Geological Survey Professional Paper 1399.

Donovan, T.J., Noble, R.C., Friedman, I., and Gleason, J.D., 1975, A possible petroleum-related geochemical anomaly in surface rocks, Boulder and Weld Counties, Colorado: U.S. Geological Survey Open-File Report 75-47, 11 p.

Donovan, T.J., and Roberts, A.A., 1980, Stable isotope anomalies in surface rocks and helium anomalies in soil-gas over oil fields-causes and correlations [abs.]: American Chemical Society Meeting, Houston, Texas, March 23-28, 1980, Abstracts of Papers (GEOC), unpaged.

Dow, W.G., 1977, Kerogen studies and geological interpretations: Journal of Geochemical Exploration, v. 7, p. 79-99.

Dowdle, W.L., and Cobb, W.M., 1975, Static formation temperature from well logs-an empirical method: Journal of Petroleum Technology, v. 27 p. 1326-1330.

Drever, J.I., 1974, The magnesium problem, in Goldberg, E.D., ed., v. 5 of The Sea: New York, John Wiley and Sons, p. 337-357.

1982, The geochemistry of natural waters: Englewood Cliffs, N.J., Prentice-Hall Inc., 388 p.

Drummond, K.J., 1974, Paleozoic Arctic margin of North America, in Burk, C.A., and Drake, C.L., eds., The geology of continental margins: New York, Springer-Verlag, p. 797-810.

Duchart, Patricia, Calvert, S.E., and Price, N.B., 1973, Distribution of trace metals in the pore waters of shallow water marine sediments: Limnology and Oceanography, v. 18, p. 605-610.

Dutro, J.T., Jr., 1970, Pre-Carboniferous carbonate rocks, northeastern Alaska, in Adkison, W.L., and Brosgé, M.M., eds., Proceedings of the geological seminar on the North Slope of Alaska: Los Angeles, Calif., American Association of Petroleum Geologists, Pacific Section, p. M1-M8.

Dutro, J.T., Jr., Brosgé, W.P., and Reiser, H.N., 1972, Significance of recently discovered Cambrian fossils and reinterpretation of Neruokpuk Formation, northeastern Alaska: American Association of Petroleum Geologists Bulletin, v. 56 , no. 4 , p. $808-815$.

Dyck, W., 1976, The use of helium in mineral exploration: Journal of Geochemical Exploration, v. 5, p. 3-20.

Eisbacher, G.H., 1983, Devonian-Mississippian sinistral transcurrent faulting along the cratonic margin of western North America: a hypothesis: Geology, v. 11, p. 7-10.

Eittreim, Stephen, and Grantz, Arthur, 1979, CDP seismic sections of the western Beaufort continental margin: Tectonophysics, v. 59, p. 251-262.

Eremeev, A.N., Sokolov, V.A., Solovov, A.P., and Yanitskii, I.N., 1973, Application of helium surveying to structural mapping and ore deposit forecasting, in Jones, M.J., ed., Geochemical exploration, 1972: London, The Institute of Mining and Metallurgy, p. 183-193.

Espitalié, J., Laporte, J.L., Madec, M., Marquis, F., Leplat, P., Paulet, J., and Boutefeu, A., 1977a, Methode rapide de caractérisation des roches 
mères, de leur potentiel pétrolier et de leur degré d'évolution: Revue de L'Institut Francais Pétrole. v. 32, p. 23-42.

Espitalié, J., Madec, M., and Tissot, B., 1977b, Source rock characterization method for petroleum exploration: Offshore Technology Conference Proceedings, v. 3, Dallas, Tex., OTC 2935, p. 439-444.

Felix, Nancy, Jorgenson, M.T., Raynolds, M.K., Lipkin, R., Blank, D.L., and Lance, B. K., 1986, Snow distribution on the arctic coastal plain and its relationship to disturbance caused by winter seismic exploration, Arctic National Wildlife Refuge, in Garner, G.W., and Reynolds, P.E., eds., 1985 Update report, baseline study of the fish, wildlife, and their habitats, section 1002(c) of the Arctic National Interest Lands Conservation Act: Anchorage, Alaska, U.S. Fish and Wildlife Service, $46 \mathrm{p}$.

Ferrians, O.J., Jr., Kachadoorian, Reuben, and Greene, G.W., 1969, Permafrost and related engineering problems in Alaska: U.S. Geological Survey Professional Paper 678, 37 p.

Fertl, W. H., 1976, Abnormal formation pressures, v. 2 of Developments in Petroleum Science: Amsterdam, Elsevier Scientific Publishing Co., $382 \mathrm{p}$.

Folk, R.L., 1968, Petrology of sedimentary rocks: Austin, Tex., Hemphill's, 170 p.

Foscolos, A.E., and Kodama, H., 1974, Diagenesis of clay minerals from Lower Cretaceous shales of northeastern British Columbia: Clays and Clay Minerals, v. 22, p. 319-335.

Franks, S.G., and Forester, R.W., 1984, Relationships among secondary porosity, pore-fluid chemistry and carbon dioxide, Texas Gulf Coast sediments, in McDonald, D.A., and Surdam, R.C., eds., Clastic diagenesis: American Association of Petroleum Geologists Memoir 37, p. 63-80.

Freed, R. L., 1982, Clay mineralogy and depositional history of the Frio formation in two geopressured wells, Brazoria County, Texas: Gulf Coast Association of Geologic Societies Transactions, v. 32, p. 459-463.

Friedman, G.M., and Sanders, J.E., 1978, Principles of sedimentology: San Francisco, John Wiley \& Sons, $715 \mathrm{p}$.

Friedman, Irving, and O'Neil, J.R., 1977, Compilation of stable isotope fractionation factors of geochemical interest, in Fleischer, Michael, tech. ed., Data of geochemistry (6th ed.), chap. KK: U.S. Geological Survey Professional Paper 440, p. KK1-12.

Gardner, L.E., 1974, Organic versus inorganic trace metal complexes in sulfidic marine waters: some speculative calculations based on stability constants: Geochimica et Cosmochimica Acta, v. 38 , no. 8 , p. 1297-1302.

Gautier, D.L., and Claypool, G.E., 1984, Interpretation of methanic diagenesis in ancient sediments by analogy with processes in modern diagenetic environments, in McDonald, D.A., and Surdam, R.C., eds., Clastic diagenesis: American Association of Petroleum Geologists Memoir 37, p. 111-123.

Gautier, D.L., Kharaka, Y.W., and Surdam, R.C., 1985, Relationship of organic matter and mineral diagenesis: Society of Economic Paleontologists and Mineralogists Short Course Notes No. 28, $279 \mathrm{p}$.

Goldsmith, J.R., 1983, Phase relations of rhombohedral carbonates, in Reeder, R.J., ed., Carbonates: mineralogy and chemistry: Mineralogical Society of America Reviews in Mineralogy, $v$. 11, p. 49-96.

Grantz, Arthur, Dinter, D.A., and Biswas, N.N., 1983, Map, cross sections, and chart showing Late Quaternary faults, folds, and earthquake epicenters on the Alaskan Beaufort Shelf: U.S. Geological Survey Miscellaneous Investigations Map I-1182-C, scale 1:500,000, with text, cross sections, and correlation chart, 7 p., 3 map sheets.

Grantz, Arthur, Eittreim, Stephen, and Dinter, D.A., 1979, Geology and tectonic development of the continental margin north of Alaska: Tectonophysics, v. 59, p. 263-291.

Grantz, Arthur, and Greenberg, Jonathan, 1981, Map showing tracklines of high-resolution Uniboom seismic reflection profiles collected August 25 through October 5, 1977, on the Beaufort Sea: U.S. Geological Survey Open-File Report 810034, scale 1:500,000.

Grantz, Arthur, Holmes, M.L., and Kososki, B.A., 1975, Geologic framework of the Alaskan continental terrace in the Chukchi and Beaufort Seas, in Yorath, C.J., Parker, E.R., and Glass, D.J., eds., Canada's continental margins and offshore petroleum exploration: Canadian Society of Petroleum Geology Memoir 4, p. 669-700.

Grantz, Arthur, Mann, D.M., and May, S.D., 1982, Tracklines of multichannel seismic-reflection data collected by the U.S. Geological Survey in the Beaufort and Chukchi Seas in 1977 for which profiles and stack tapes are available: U.S. Geological Survey Open-File Report 82735, 1 map sheet with text.

Grantz, Arthur, and May, S. D., 1983, Rifting history and structural development of the continental margin north of Alaska, in Watkins, J. S., and Drake, C., eds., Studies in continental margin geology: American Association of Petroleum Geologists Memoir 34, p. 77-100. 
Grantz, Arthur, and Mull, C. G., 1978, Preliminary analysis of the petroleum potential of the Arctic National Wildlife Range, Alaska: U.S. Geological Survey Open-File Report 78-489, 21 p.

Graves, S.M., Reimnitz, Erk, and Barnes, P.W., 1984, A summary of U.S. Geological Survey geological data collected in the Beaufort Sea, Alaska, 1983: U.S. Geological Survey Open-File Report 84$117,13 \mathrm{p}$.

Green, A.R., Kaplan, A.A., and Vierbuchen, R.C., 1982, The evolution of sedimentary basins in the circum-Arctic, in Proceedings of the offshore northern seas conference and exhibition on the geological framework and hydrocarbon potential of basins in northern seas: Stavangar, Norway, p. E/1-1-E/1-53.

Gryc, George, 1985, The National Petroleum Reserve in Alaska-earth-science considerations: U.S. Geological Survey Professional Paper 1240-C, $94 \mathrm{p}$.

Gryc, George, Patton, W.W., Jr., and Payne, T.G., 1951, Present Cretaceous stratigraphic nomenclature in northern Alaska: Journal of the Washington Academy of Sciences, v. 41, no. 5, p. 159-167.

Halbouty, M.T., ed., 1970, Geology of giant petroleum fields: American Association of Petroleum Geologists Memoir 14, 575 p.

ed., 1981, Giant oil and gas fields of the decade 1968-1978: American Association of Petroleum Geologists Memoir 30, $596 \mathrm{p}$.

ed., 1982, The deliberate search for the subtle trap: American Association of Petroleum Geologists Memoir 32, 351 p.

Hansen, J.J., and Kornbrath, R.W., 1986, Resource appraisal simulation for petroleum in the Arctic National Wildlife Refuge, Alaska: Alaska Division of Geological and Geophysical Surveys Professional Report 90, $13 \mathrm{p}$.

Harding, T.P., and Lowell, J.D., 1979, Structural styles, their plate-tectonic habitats, and hydrocarbon traps in petroleum provinces: American Association of Petroleum Geologists Bulletin, v. 63 , no. 7 , p. 1016-1058.

Harper, J.R., and Penland, S., in press, Beaufort Sea sediment dynamics: Geological Survey of Canada Open-File Report.

Harris, A.G., Ellersieck, I.F., Mayfield, C.F., and Tailleur, I.L., 1983, Thermal maturation values (conodont color alteration indices) for Paleozoic and Triassic Rocks, Chandler Lake, De Long Mountains, and Point Hope quadrangles, northwest Alaska, and subsurface NPRA: U.S. Geological Survey Open-File Report 83-505, 15 p.

Haser, J., Eslinger, W.V., Hower, M., and Perry, E.A., 1976, Mechanism of burial metamorphism of argillaceous sediments-I. Mineralogical and chemical evidence: Geological Society of America Bulletin, v. 87, p. 725-737.

Heald, M.T., and Larese, R.E., 1974, Influence of coatings on quartz cementation: Journal of Sedimentary Petrology, v. 44., p. 1269-1274.

Hinds, G.W., Baumeister, Max, Sheldon, Richard, and Geyer, R.A., 1983, Gravity/photogeology interpretation report of the Arctic National Wildlife Refuge: PhotoGravity Co./International Technology Limited Administrative Report to the U.S. Fish and Wildlife Service, $25 \mathrm{p}$.

Hinkle, M.E., 1980, Survey of helium in soils and soil gases and mercury in soils at Roosevelt Hot Springs KGRA, Utah: U.S. Geological Survey Open-File Report 80-613, 31 p.

Hoffman, J., and Hower, J., 1979, Clay mineral assemblages as low grade metamorphic geothermometers-application to the thrust faulted disturbed belt of Montana, U.S.A., in Scholle, P.A., and Schluger, P.R., eds., Aspects of diagenesis: Society of Economic Paleontologists and Mineralogists Special Publication No. 26, p. 55-79.

Hood, A., Gutjahr, C.C.M., and Heacock, R.L., 1975, Organic metamorphism and petroleum generation: American Association of Petroleum Geologists Bulletin, v. 59, no. 6, p. 986-996.

Hopkins, D.M., Karlstrom, T.N.V., and others, 1955, Permafrost and ground water in Alaska: U.S. Geological Survey Professional Paper 264-F, p. 113-146.

Horner, D.R., 1951, Pressure buildup in wells: World Petroleum Congress, 3rd, The Hague, Section II, Proceedings, p. 503-521.

Horvitz, L., 1969, Hydrocarbon geochemical prospecting after thirty years, in Heroy, W.B., ed., Unconventional methods in exploration for petroleum and natural gas: Dallas, Tex., Southern Methodist University, p. 205-218.

Hower, John, 1981, Shale diagenesis, in Longstaffe, F.J., ed., Clays and the resource geologist: Mineralogical Association of Canada Short Course Handbook, v. 7, p. 60-80.

Hower, John, Eslinger, Eric, Hower, M.E., and Perry, E.A., 1976, Mechanism of burial metamorphism of argillaceous sediments: 1 . Mineralogical and chemical evidence: Geological Society of America Bulletin, v. 87, p. 725-737.

Huang, W.Y., and Meinschein, W.G., 1976, Sterols as ecological indicators: Geochimica et Cosmochimica Acta, v. 43, p. 739-745.

Hubbard, R.J., Edrich, S.P., and Rattey, R.P., 1987, Geologic evolution and hydrocarbon habitat of the 'Arctic Alaska microplate': Marine and Petroleum Geology, v. 4, p. 2-34.

Hunt, J.M., 1979, Petroleum geochemistry and geology: 
San Francisco, W.H. Freeman and Co., 617 p.

Hyne, N.J., 1984, Geology for petroleum exploration, drilling, and production: Tulsa, Okla., PennWell Publishing Co., 297 p.

Irwin, Hilary, 1980, Early diagenetic carbonate precipitation and pore fluid migration in the Kimmeridge Clay of Dorset, England: Sedimentology, v. 27, p. 577-591.

Jamison, H.C., Brockett, L.D., and McIntosh, R.A., 1980, Prudhoe Bay-A 10-year perspective, in Halbouty, M. T., ed., Giant oil and gas fields of the decade 1968-1978: American Association of Petroleum Geologists Memoir 30, p. 289-314.

Johnston, R.R., 1986, North American drilling activity in 1985: American Association of Petroleum Geologists Bulletin, v. 70, no. 10, p. 1195-1223.

Jones, H.P., and Speers, R.G., 1976, Permo-Triassic reservoirs of Prudhoe Bay field, North Slope, Alaska, in Braunstein, Jules, ed., North American oil and gas fields: American Association of Petroleum Geologists Memoir 24, p. $23-50$.

Jones, P.B., 1982, Oil and gas beneath east-dipping underthrust faults in the Alberta foothills, in Powers, R.B., ed., Geological Studies of the Cordilleran Thrust Belt: Rocky Mountain Association of Geologists, v. 1, p. 61-74.

Jones, V.T. and Drozd, R.J., 1983, Predictions of oil or gas potential by near-surface geochemistry: American Association of Petroleum Geologists Bulletin, v. 67, no. 6, p. 932-952.

Justice, J.H., and Zuba, C., 1986, Transition zone reflections and permafrost analysis: Geophysics, v. 51, p. 1075-1087.

Kaplan, I.R., Emery, K.O., and Rittenberg, S.C., 1963, The distribution and isotopic abundance of sulphur in recent marine sediments off southern California: Geochimica et Cosmochimica Acta, v. 27, p. $297-331$.

Keller, A.S., Morris, R.H., and Detterman, R.L., 1961, Geology of the Shaviovik and Sagavanirktok Rivers region, Alaska: U.S. Geological Survey Professional Paper 303-D, p. 169-222.

Kelley, J.J., Jr., and Weaver, D.F., 1966, Carbon dioxide and ozone in the arctic atmosphere, in Viereck, Eleanor, ed., Science in Alaska 1965-Selected papers of the 16th Alaskan Science Conference of the National Academy of Sciences, Proceedings: Fairbanks, Alas., University of Alaska, p. 151-167.

Kelley, J.S., and Molenaar, C.M., 1985, Detachment tectonics in Sadlerochit and Shublik Mountains and applications for exploration beneath coastal plain, Arctic National Wildlife Range, Alaska [abs.]: American Association of Petroleum Geologists Bulletin, v. 69, no. 4, p. 667.

Kempema, E.W., Barnes, P.W., Reimnitz, Erk, Asbury,
J.L., and Rearic, D.M., 1983, A summary of U.S. Geological Survey marine geological data collected in the Beaufort Sea, Alaska, 1982: U.S. Geological Survey Open-File Report 83493, 2 rolls microfilm, 9 p.

Kempema, E.W., Reimnitz, Erk, and Barnes, P.W., 1981, Marine geologic studies in the Beaufort Sea, Alaska, 1980: data type, location, records obtained, and their availability: U.S. Geological Survey Open-File Report 81-241, 4 p.

Kerr, P.E., and Barrington, J., 1961, Clays of deep shale zone, Caillou Island, Louisiana: American Association of Petroleum Geologists Bulletin, v. 45, p. $1697-1712$.

King, R.E., ed., 1972, Stratigraphic oil and gas fieldsclassification, exploration methods, and case histories: American Association of Petroleum Geologists Memoir 16, $687 \mathrm{p}$.

Kososki, B.A., Reiser, H.N., Cavit, C.D., and Detterman, R.L., 1978, A gravity study of the northern part of the Arctic National Wildlife Range, Alaska: U.S. Geological Survey Bulletin B-1440, 21 p.

Krauskopf, K.B., 1956, Dissolution and precipitation of silica at low temperatures: Geochimica et Cosmochimica Acta, v. 71, p. 145-152.

Krumbein, W.C., and Garrels, R.M., 1952, Origin and classification of chemical sediments in terms of $\mathrm{pH}$ and oxidation-reduction potentials: Journal of Geology, v. 60, p. 1-33.

Lachenbruch, A.H., Brewer, M.C., Greene, G.W., and Marshall, B.V., 1962, Temperature in permafrost, in Herzfeld, C.M., ed., Temperature-its measurement and control in science and industry, 4th Symposium on Temperature, 1961, Proceedings: New York, Reinhold Publishing Co., v. 3, no. 1, p. 791-803.

Lachenbruch, A.H., Sass, J.H., Lawver, L.A., Brewer, M.C., Marshall, B.V., Munroe, R.J., Kennelly, J.P., Jr., Galanis, S.P., Jr., and Moses, T.H., Jr., 1987, Temperature and depth of permafrost on the Alaskan North Slope, in Tailleur, I.L., and Weimer, Paul, eds., Alaskan North Slope Geology: Bakersfield, Calif., Pacific Section of Society of Economic Paleontologists and Mineralogists and the Alaska Geological Society, v. 50 [in press].

Lachenbuch, A.H., Sass, J.H., Marshall, B.V., and Moses, T.H., Jr., 1982, Permafrost, heat flow, and the geothermal regime at Prudhoe Bay, Alaska: Journal of Geophysical Research, v. 87, no. B11, p. 9301-9316.

Lawver, L.L., Grantz, Arthur, and Meinke, Linda, 1984, The tectonics of the Arctic Ocean, in Dyer, I., and Chryssosstomidis, C., eds., Arctic technology and policy: Proceedings of the 2nd annual MIT Sea Grant College Program Lecture 
and Seminar: Washington, DC, Hemisphere Publishing Corp., p. 147-158.

Lebedev, L.M., 1972, Modern growth of sphalerite in Cheleken Peninsula: International Geological Review, v. 14, no. 9, p. 959-965.

Leffingwell, E. de K., 1919, The Canning River region, northern Alaska: U.S. Geological Survey Professional Paper 109, $251 \mathrm{p}$.

Leiggi, P.A., and Russell, B.J., 1985, Style and age of tectonism of Sadlerochit Mountains to Franklin Mountains, Arctic National Wildlife Refuge (ANWR), Alaska [abs.]: American Association of Petroleum Geologists Bulletin, v. 69, no. 4, p. 668.

Lerand, Monti, 1973, Beaufort Sea, in McCrossan, R.G., ed., The future petroleum provinces of Canada-their geology and potential: Canadian Society of Petroleum Geologists Memoir 1, p. 315-386.

Leythaeuser, D., 1973, Effects of weathering on organic matter in shales: Geochimica et Cosmochimica Acta, v. 3, p. 1183-1194.

Link, P.K., 1982, Basic petroleum geology: Tulsa, Okla., PennWell Publishing Co., 235 p.

Lopatin, N.V., 1971, Temperature and geologic time as factors of coalification: Izvestiya Akademii Nauk SSSR Seriya Geologicheskaya, no. 3, p. 95-106 (in Russian) [English transl. by N.H. Bostick, Illinois State Geological Survey, 1972].

Lyle, W.M., Palmer, I.F., Bolm, J.G., and Maxey, L.R., 1980, Post-Early Triassic formations of northeastern Alaska and their petroleum reservoir and source-rock potential: Alaska Division of Geological and Geophysical Surveys Geologic Report 76, 100 p.

MacCarthy, G.R., 1953, Recent changes in the shoreline near Point Barrow, Alaska: Arctic, v. 6, no. 1, p. 44-51.

Mackenzie, A.S., 1984, Applications of biological markers in petroleum geochemistry: Advances in Petroleum Geochemistry v. 1, p. 116-213.

Maddren, A.G., 1912, Geologic investigations along the Canada-Alaska boundary: U.S. Geological Survey Bulletin 520, p. 297-314.

Magoon, L.B., and Bird, K.J., 1985, Alaskan North Slope petroleum geochemistry for the Shublik Formation, Kingak Shale, pebble shale unit and Torok Formation, in Magoon, L.B., and Claypool, G.E., eds., Alaska North Slope oil-rock correlation study: American Association of Petroleum Geologists Special Studies in Geology No. 20, p. 31-48.

Magoon, L.B., Bird, K.J., Claypool, G.E., Weitzman, D.E., and Thompson, R.H., in press, Organic geochemistry, hydrocarbon occurrence, and geology of government drilled wells, North Slope, Alaska, in Gryc, G., ed., Geology of the
National Petroleum Reserve in Alaska: U.S. Geological Survey Professional Paper 1399.

Magoon, L.B., and Claypool, G.E., 1981, Two oil types on North Slope of Alaska-Implications for exploration: American Association of Petroleum Geologists Bulletin, v. 65, no. 4, p. 644-652.

1984, The Kingak Shale of northern AlaskaRegional variations in organic geochemical properties and petroleum source rock quality, in Schenck, P.A., De Leeuw, J.W., and Lijmbach, G.W.M., eds., Advances in organic geochemistry 1983: Organic Geochemistry, v. 6, p. 533-542.

in press, Geochemistry of oils, National Petroleum Reserve in Alaska, in Gryc, G., ed., Geology of the National Petroleum Reserve in Alaska: U.S. Geological Survey Professional Paper 1399.

— eds., 1985, Alaska North Slope oil-rock correlation study: American Association of Petroleum Geologists Special Studies in Geology No. 20, 678 p.

Mast, R.F., McMullin, R.H., Bird, K.J., and Brosgé, W.P., 1980, Resource appraisal of undiscovered oil and gas resources in the William O. Douglas Arctic Wildlife Range [Alaska]: U.S. Geological Survey Open-File Report 80-916, 80 p.

Mayfield, C.F., Tailleur, I.L., and Ellersieck, Inyo, 1983, Stratigraphy, structure, and palinspastic synthesis of the western Brooks Range, northwestern Alaska: U.S. Geological Survey Open-File Report 83-779, $58 \mathrm{p}$.

Mazor, E., 1974, Atmospheric and radiogenic noble gases in thermal waters: their potential application to prospecting and steam production studies: United Nations Symposium on the Development and Use of Geothermal Resources, Proceedings, p. 793-802.

McCaslin, J.C., ed., 1986, International petroleum encyclopedia 1986 [v. 19]: Tulsa, Okla., PennWell Publishing Co., 408 p.

McDonald, D.A., and Surdam, R.C., eds., 1984, Clastic diagenesis: American Association of Petroleum Geologists Memoir 37, 434 p.

McWhae, J.R., 1986, Tectonic history of northern Alaska, Canadian Arctic, and Spitsbergen regions since early Cretaceous: American Association of Petroleum Geologists Bulletin, v. 70, no. 4, p. 430-450.

Meissner, F.F., 1978, Petroleum geology of the Bakken Formation, Williston basin, North Dakota and Montana, in Economic geology of the Williston basin, Williston Basin Symposium: Billings, Montana Geological Society, p. 207-227.

Melvin, John, and Knight, Angela, 1984, Lithofacies, diagenesis, and porosity of the Ivishak Formation, Prudhoe Bay area, Alaska, in 
McDonald, D.A., and Surdam, R.C., eds., Clastic diagenesis: American Association of Petroleum Geologists Memoir 37, p. 347-365.

Méring, J., 1949, L'Interférence des reayons X dans les systèms à stratification désondonnée: Acta Crystallographia, v. 2, p. 371-377.

Miall, A.W., 1984, Principles of sedimentary basin analysis: New York, Springer-Verlag, 490 p.

Miller, B.M., 1981, Methods of estimating potential hydrocarbon resources by the U.S. Geological Survey-Case studies in resource assessment in the National Petroleum Reserve in Alaska and the William O. Douglas Arctic Wildlife Range: Proceedings of the Southwestern Legal Foundation Exploration and Economics of the Petroleum Industry, v. 19, p. 57-96.

Minkler, P.W., Reimnitz, Erk, and Barnes, P.W., 1982, A summary of U.S. Geological Survey marine geologic data collected in the Beaufort Sea, Alaska, July-August 1981: U.S. Geological Survey Open-File Report 82-586, 9 p.

Molenaar, C.M., 1981, Depositional history and seismic stratigraphy of Lower Cretaceous rocks, National Petroleum Reserve in Alaska and adjacent areas: U.S. Geological Survey OpenFile Report 81-1084, 42 p.

1983, Depositional relations of Cretaceous and Lower Tertiary rocks, northeastern Alaska: American Association of Petroleum Geologists Bulletin, v. 67, no. 7, p. 1066-1080.

Molenaar, C.M., Bird, K.J., and Collett, T.S., 1986, Regional correlation sections across the North Slope of Alaska: U.S. Geological Survey Miscellaneous Field Studies Map MF-1907, 1 sheet.

Molenaar, C.M., Bird, K.J., and Kirk, A.R., 1987, Cretaceous and Tertiary stratigraphy of northeastern Alaska, in Tailleur, I.L., and Weimer, Paul, eds., Alaskan North Slope geology: Bakersfield, Calif., Pacific Section of Society of Economic Paleontologists and Mineralogists and the Alaska Geological Society, v. 50 [in press].

Molenaar, C.M., Huffman, A.C., and Kirk, A.R., 1982, Cretaceous-lower Tertiary depositional relations, northeastern Alaska, in Coonrad, W.L., ed., The United States Geological Survey in AlaskaAccomplishments during 1980: U.S. Geological Survey Circular 844, p. 33-35.

Molenaar, C.M., Kirk, A.R., Magoon, L.B., and Huffman, A.C., 1984, Twenty-two measured sections of Cretaceous-Lower Tertiary rocks, eastern North Slope, Alaska: U.S. Geological Survey Open-File Report 84-695, 4 pl., 19 p.

Moore, B.J., 1976, Analyses of natural gases: U.S. Bureau of Mines Computer Printout, $76 \mathrm{p}$.

Moore, T.E., Brosgé, W.P., Churkin, M., Jr., and
Wallace, W.K., 1985a, Pre-Mississippian accreted terranes of northeastern Brooks Range, Alaska [abs.]: American Association of Petroleum Geologists Bulletin, v. 69, no. 4, p. 670.

Moore, T.E., Whitney, J.W., and Wallace, W.K., 1985b, Cenozoic north-vergent tectonism in northeastern Alaska: indentor tectonics in Alaska? [abs.]: Eos, Transactions of the American Geophysical Union, v. 66, no. 46, p. 862.

Morgridge, D.L., and Smith, W.B., Jr., 1972, Geology and discovery of Prudhoe Bay field, eastern Arctic Slope, Alaska, in King, R.E., ed., Stratigraphic oil and gas fields-classification, exploration methods, and case histories: American Association of Petroleum Geologists Memoir 16, p. 489-501.

Morris, R.H., 1957, Reconnaissance study of the Marsh anticline, northern Alaska: U.S. Geological Survey Open-File Report 57-76, 6 p.

Mull, C.G., 1982, Tectonic evolution and structural style of the Brooks Range, Alaska: an illustrated summary, in Powers, R.B., ed., Geological studies of the Cordilleran thrust belt: Rocky Mountain Association of Geologists, v. 1, p. $1-45$.

Mull, C.G., and Kososki, B.A., 1977, Hydrocarbon assessment of the Arctic National Wildlife Range, eastern Arctic Slope, Alaska, in Blean, K.M., ed., The United States Geological Survey in Alaska-Accomplishments during 1976: U.S. Geological Survey Circular 751-B, p. B20-B22.

Mull, C.G., and Mangus, M.D., 1972, Itkilyariak Formation: new Mississippian formation of Endicott Group, Arctic Slope of Alaska: American Association of Petroleum Geologists Bulletin, v. 56, no. 8, p. 1364-1369.

Muller, S.W., 1947, Permafrost or permanently frozen ground and related engineering problems: Ann Arbor, Mich., Edwards Brothers, 230 p. [Original report in 1943 by U.S. Army Corps of Engineers].

Murray, J.W., 1979, Iron oxides, in Barns, R.G., ed., Marine minerals: Mineralogical Society of America Short Course Notes, v. 6, chap. 2, p. 47-98.

Nadeau, P., and Reynolds, R.C., Jr., 1981, Burial and contact metamorphism in the Mancos Shale: Clays and Clay Minerals, v. 29, p. 249-259.

Nagtegaal, P.J.C., 1978, Sandstone framework instability as a function of burial diagenesis: Journal of the Geological Society of London, v. 135, p. 101-105.

Nash, A.J., and Pittman, E.D., 1975, Ferro-magnesian calcite cement in sandstones: Journal of Sedimentary Petrology, v. 45, p. 258-265. 
National Oceanic and Atmospheric Administration, 1975, Geophysical monitoring for climatic change: National Oceanic and Atmospheric Administration, Summary Report No. 3, 107 p.

Newendorp, Paul, 1975, Decision analysis for petroleum exploration: Tulsa, Okla., Petroleum Publishing Co., $668 \mathrm{p}$.

Nilsen, T.H., 1981, Upper Devonian and Lower Mississippian redbeds, Brooks Range, Alaska, in Miall, A.D., ed., Sedimentation and tectonics in alluvial basins: Geological Association of Canada Special Paper 23, p. 187-219.

Nilsen, T.H., Moore, T.E., and Brosgé, W.P., 1980, Paleocurrent maps for the Upper Devonian and Lower Mississippian Endicott Group, Brooks Range, Alaska: U.S. Geological Survey OpenFile Report 80-1066, scale 1:1,000,000, 2 sheets.

Norris, D.K., 1984, Geology of the northern Yukon and northwestern District of Mackenzie: Geological Survey of Canada Map 1581A, scale 1:500,000.

1985a, Eastern Cordilleran foldbelt of northern Canada: Its structure, geometry, and hydrocarbon potential: American Association of Petroleum Geologists Bulletin, v. 69, no. 5, p. 788-808.

- 1985b, The Neruokpuk Formation, Yukon Territory and Alaska, in Current research, part B: Geological Survey of Canada Paper 85-1B, p. 223-229.

Nriagu, J.O., and Moore, P.B., eds., 1984, Phosphate minerals: New York, Springer-Verlag, 442 p.

Oil and Gas Journal, 1984, Exxon: N. Slope gas/condensate field is a giant: Oil and Gas Journal, v. 82 , no. 11 , p. 30 .

1986, Low oil prices dim Canadian Beaufort luster: Oil and Gas Journal, v. 84, no. 35, p. 30-31.

1987, Canadian Beaufort due first field development: Oil and Gas Journal, v. 85, no. 5, p. 20.

Osterkamp, T.E., and Harrison, W.D., 1985, Subsea permafrost-Probing, thermal regime and data analysis, 1975-81: Fairbanks, Alas., University of Alaska Geophysical Institute, 108 p.

Osterkamp, T.E., and Payne, M.W., 1981, Estimates of permafrost thickness from well logs in northern Alaska: Cold Regions Science and Technology, v. 5, p. 13-27.

Ovchinnikov, L.N., Sokolov, V.A., Freidman, A.I., and Yanitskii, I.N., 1972, Gaseous geochemical methods in structural mapping and prospecting for ore deposits, in Jones, M.J., ed., Geochemical exploration 1972: London, The Institute of Mining and Metallurgy, p. 177-182.

Page, R.A., Boore, D.M., Joyner, W.B., and Coulter, H.W., 1972, Ground motion values for use in the seismic design of the trans-Alaska pipeline system: U.S. Geological Survey Circular 672, 23

p.

Palacas, J.G., and Roberts, A.A., 1980, Helium anomaly in surficial deposits of south Florida-possible indicator of deep subsurface petroleum or shallow uranium-associated phosphate deposits: U.S. Geological Survey Open-File Report 80-91, $14 \mathrm{p}$.

Palmer, I.F., Bolm, J.R., Maxey, L.R., and Lyle, W.M., 1979, Petroleum source rock and reservoir quality data from outcrop samples, onshore North Slope of Alaska east of Prudhoe Bay: U.S. Geological Survey Open-File Report 79$1634,52 \mathrm{p}$.

Parrish, J.T., 1985, Lithological and geochemical facies of Shublik Formation (Triassic), North Slope, Alaska [abs.]: American Association of Petroleum Geologists Bulletin, v. 69, no. 4, p. 675.

Perrodon, Alain, 1983, Dynamics of oil and gas accumulations: Bulletin des Centres de Recherches Exploration-Production ElfAquitaine, Pau, France, Memoir 5, 368 p.

Pigott, J.D., 1985, Assessing source rock maturity in frontier basins: Importance of time, temperature, and tectonics: American Association of Petroleum Geologists Bulletin, v. 69, no. 8, p. 1269-1274.

Pogorski, L.A., and Quirt, G.S., 1981, Helium emanometry in exploring for hydrocarbons, part $\mathrm{I}$, in Gottlieb, B.M., ed., Unconventional methods in exploration for petroleum and natural gas II: Dallas, Tex., Southern Methodist University Press, p. 124-135.

Pollastro, R.M., 1985, Mineralogical and morphological evidence for the formation of illite at the expense of illite/smectite: Clays and Clay Minerals, v. 33, p. 265-274.

Pollastro, R.M., and Barker, C.E., 1984, Geothermometry from clay minerals, vitrinite reflectance, and fluid inclusions-applications to the thermal and burial history of rocks cored from the Wagon Wheel No. 1 well, Green River basin, Wyoming, in Law, B.E., ed., Geological characteristics of low-permeability Upper Cretaceous and Lower Tertiary rocks in the Pinedale anticline area, Sublette County, Wyoming: U.S. Geological Survey Open-File Report 84-753, p. 78-94.

Pollastro, R.M., and Martinez, C.J., 1985, Mineral, chemical, and textural relationships in rhythmic-bedded hydrocarbon-productive chalk of the Niobrara Formation, Denver basin, Colorado: The Mountain Geologist, v. 22, p. $55-63$.

Postma, Dieke, 1982, Pyrite and siderite formation in brackish and freshwater swamp sediments: 
American Journal of Science, v. 282, p. 1151-1183.

Poulton, T.P., 1982, Paleogeographic and tectonic implications of the Lower and Middle Jurassic facies patterns in northern Yukon Territory and adjacent Northwest Territories, in Embry, A.F., and Balkwill, H.R., eds., Arctic geology and geophysics: Canadian Society of Petroleum Geologists Memoir 8, p. 13-27.

Powers, M.C., 1967, Fluid-release mechanisms in compacting marine mudrocks and their importance in oil exploration: American Association of Petroleum Geologists Bulletin, v. 51, p. 1240-1254.

Press, F., 1966, Handbook of physical constants [rev. ed.]: Geological Society of America Memoir 97, $587 \mathrm{p}$.

Procter, R.M., Taylor, G.C., and Wade, J.A., 1984, Oil and natural gas resources of Canada 1983: Geological Survey of Canada Paper 83-31, 59 p.

Pye, K., 1984, SEM analysis of siderite cements in intertidal marsh sediments, Norfolk, England: Marine Geology, v. 56, p. 1-12.

Rattey, R.P., 1985, Northeastern Brooks Range, Alaska-new evidence for complex thin-skinned thrusting [abs.]: American Association of Petrolelum Geologists Bulletin, v. 69, no. 4, p. 676-677.

Reading, H.G., 1986, Sedimentary environments and facies (2nd ed.): Palo Alto, Calif., Blackwell Scientific Publications, $570 \mathrm{p}$.

Reed, B.L., 1968, Geology of the Lake Peters area, northeastern Brooks Range, Alaska: U.S. Geological Survey Bulletin 1236, 132 p.

Reed, B.L., and Hemley, J.J., 1966, Occurrence of pyrophyllite in the Kekiktuk Conglomerate, Brooks Range, northeastem Alaska: U.S. Geological Survey Professional Paper 550-C, p. C162-C166.

Reeder, R.J., 1983, Crystal chemistry of the rhombohedral carbonates, in Reeder, R.J., ed., Carbonates: mineralogy and chemistry: Mineralogical Society of America Reviews in Mineralogy, v. 11, p. 49-96.

Reimer, G.M., and Adkisson, C.W., 1977, Reconnaissance survey of the helium content of soil gas in Black Hawk, Eldorado Springs, Evergreen, Golden, Morrison, Ralston Buttes, and Squaw Pass quadrangles, Colorado: U.S. Geological Survey Open-File Report 77-464, 11 p.

Reimnitz, Erk, Barnes, P.W., Rearic, D.M., Minkler, P.W., Kempema, E.W., and Reiss, T.E., 1982, Marine geological investigations in the Beaufort Sea in 1981 and preliminary interpretation of the region from the Canning River to the Canadian Border: U.S. Geological Survey Open-File
Report 82-974, $64 \mathrm{p}$.

Reimnitz, Erk, and Maurer, D., 1978, Stamuki shoals of the Arctic-Some observations from the Beaufort Sea: U.S. Geological Survey Open-File Report 78-666, $17 \mathrm{p}$.

Reiser, H.N., 1970, Northeastern Brooks Range-a surface expression of the Prudhoe Bay section, in Adkison, W.L., and Brosgé, M.M., eds., Proceedings of the geological seminar on the North Slope of Alaska: Los Angeles, Calif., American Association of Petroleum Geologists, Pacific Section, p. K1-K14.

Reiser, H.N., Brosgé, W.P., Dutro, J.T., Jr., and Detterman, R.L., 1971, Preliminary geologic map, Mt. Michelson quadrangle, Alaska: U.S. Geological Survey Open-File Report 71-237, scale 1:200,000.

1980, Geologic map of the Demarcation Point quadrangle, Alaska: U.S. Geological Survey Miscellaneous Investigations Map I-1133, scale $1: 250,000$.

Reiser, H.N., Dutro, J.T., Jr., Brosgé, W.P., Armstrong, A.K., and Detterman, R.L., 1970, Progress map, geology of the Sadlerochit and Shublik Mountains, Mount Michelson C-1, C-2, C-3, and C-4 quadrangles, Alaska: U.S. Geological Survey Open-File Report 70-273, 5 sheets, scale $1: 63,360$.

Reynolds, R.C., and Hower, J., 1970, The nature of interlayering in mixed-layer illite-montmorillonites: Clays and Clay Minerals, v. 18, p. 25-36.

Reynolds, R.L., Fishman, N.S., Hudson, M.R., Karachewski, J.A., and Goldhaber, M.B., 1986, Magnetic minerals and hydrocarbon seepagepossibilities for magnetic detection of oil fields, in Carter, L.M.H., ed., USGS research on energy resources-1986, program and abstracts: U.S. Geological Survey Circular 974, p. 58-59.

Reynolds, R.L., Fishman, N.S., Karachewski, J.A., and Goldhaber, M.B., 1985, Magnetic minerals and hydrocarbon migration-Evidence from Cement (Oklahoma), North Slope (Alaska), and the Wyoming-Idaho-Utah thrust belt [abs.]: Eos, Transactions of the American Geophysical Union, v. 66, p. 867.

Rice, D.D., and Claypool, G.E., 1981, Significance of shallow gas in ancient marine sequences [abs.]: American Association of Petroleum Geologists Bulletin, v. 65, no. 5, p. 978.

Roberts, A.A., 1975, Helium surveys over known geothermal resource areas in the Imperial Valley, California: U.S. Geological Survey Open-File Report 75-427, 6 p.

1981, Helium emanometry in exploring for hydrocarbons, part II, in Gottlieb, B.M., ed., Unconventional methods in exploration for petroleum and natural gas II: Dallas, Tex., 
Southern Methodist University Press, p. 136-149.

Roberts, A.A., Dalziel, M.C., Pogorski, L.A., and Quirt, G.S., 1976, A possible petroleum-related helium anomaly in soil gas, Boulder and Weld Counties, Colorado: U.S. Geological Survey Open-File Report 76-544, 7 p.

Roberts, A.A., Friedman, I., Donovan, T.J., and Denton, E.H., 1975, Helium survey, a possible technique for locating geothermal reservoirs: Geophysical Research Letters, v. 2, p. 209-210.

Roberts, A.A., and Roen, J.B., 1985, Near-surface helium anomalies associated with faults and gas accumulations in western Pennsylvania: U.S. Geological Survey Open-File Report 85-546, 23 p.

Roehl, P.O., and Choquette, P.W., 1985, Carbonate petroleum reservoirs: New York, SpringerVerlag, $480 \mathrm{p}$.

Sable, E.G., 1977, Geology of the western Romanzof Mountains, Brooks Range, northeastern Alaska: U.S. Geological Survey Professional Paper 897, $84 \mathrm{p}$.

Sayles, F.L., 1981, The composition and diagenesis of interstitial solutions-II. Fluxes and diagenesis at the water-sediment interface in the high latitude North and South Atlantic: Geochimica et Cosmochimica Acta, v. 45, p. 1061-1086.

Schenk, C.J., and Richardson, R.W., 1985, Recognition of interstitial anhydrite dissolution-A cause of secondary porosity, San Andres Limestone, New Mexico, and Upper Minnelusa Formation, Wyoming: American Association of Petroleum Geologists Bulletin, v. 69, no. 7, p. 1064-1076.

Schmidt, Volkmar, and McDonald, D.A., 1979a, The role of secondary porosity in the course of sandstone diagenesis, in Scholle, P.A., and Schluger, P.R., eds., Aspects of diagenesis: Society of Economic Paleontologists and Mineralogists Special Publication No. 26, p. 175-208.

- 1979b, Texture and recognition of secondary porosity in sandstones, in Scholle, P.A., and Schluger, P.R. eds., Aspects of diagenesis: Society of Economic Paleontologists and Mineralogists Special Publication No. 26, p. 209-226.

Scholle, P.A., and Schluger, P.R., eds., 1979, Aspects of diagenesis: Society of Economic Paleontologists and Mineralogists Special Publication No. 26, $443 \mathrm{p}$.

Scholle, P.A., 1978, A color illustrated guide to carbonate rock constituents, textures, cements, and porosities: American Association of Petroleum Geologists Memoir 27, 248 p.

Scholle, P.A., 1979, A color illustrated guide to constituents, textures, cements, and porosities of sandstone and associated rocks: American
Association of Petroleum Geologists Memoir 28, $201 \mathrm{p}$.

Schultz, L.G., 1964, Quantitative interpretation of mineralogical composition from $\mathrm{X}$-ray and chemical data for the Pierre Shale: U.S. Geological Survey Professional Paper 391-C, p. C1-C31.

Schultz, L.G., 1978, Mixed-layer clay in the Pierre Shale and equivalent rocks, northern Great Plains region: U.S. Geological Survey Professional Paper 1064-A, $28 \mathrm{p}$.

Seifert, W.K., Moldowan, J.M., and Jones, J.W., 1979, Application of biological marker chemistry to petroleum exploration: World Petroleum Congress, 10th, Bucharest, Proceedings: London, Heyden and Son, Ltd., p. 425-440.

Selkregg, L.L., 1975, Alaska regional profiles-Arctic region: Anchorage, Alas., University of Alaska Arctic Environmental Information and Data Center, $218 \mathrm{p}$.

Selley, R.C., 1976, An introduction to sedimentology: London, Academic Press, 408 p.

1982, Petroleum geology for geophysicists and engineers: Boston, Mass., International Human Resources Development Corporation, 96 p.

Sengbush, R.L., 1983, Seismic exploration methods: Boston, Mass., International Human Resources Development Corporation, 296 p.

Shelton, J.W., 1964, Authigenic kaolinite in sandstone: Journal of Sedimentary Petrology, v. 34, p. $102-111$.

Sheriff, R.E., 1980, Seismic stratigraphy: Boston, Mass., International Human Resources Development Corporation, $227 \mathrm{p}$.

Siever, Raymond, 1983, Burial history and diagenetic reaction kinetics: American Association of Petroleum Geologists Bulletin, v. 67, p. 684-691.

Sofer, Zvi, 1984, Stable carbon isotope compositions of crude oils: application to source depositional environments and petroleum alteration: American Association of Petroleum Geologists Bulletin, v. 68, p. 31-49.

Specht, R.N., Brown, A.E., Selman, C.H., and Carlisle, J.H., 1986, Geophysical case history, Prudhoe Bay field: Geophysics, v. 51, p. 1039-1049.

Spencer, C.W., 1987, Hydrocarbon generation as a mechanism for overpressuring in the Rocky Mountain region: American Association of Petroleum Geologists Bulletin, v. 71, no. 4, p. 368-388.

Sredon, Jan, and Eberl, D.D., 1984, Illite, in Bailey, S.W., ed., Micas: Mineralogical Society of America Reviews in Mineralogy v. 13, p. 495-544.

Staplin, F.L., 1969, Sedimentary organic matter, organic metamorphism and oil and gas occurrence: 
Bulletin of Canadian Petroleum Geology, v. 17, p. $47-66$.

Stonecipher, S.A., 1977, Chemistry of deep-sea phillipsite, clinoptilolite, and lost sediment, in Sand, L.B., and Mumpton, F.A., eds., Natural zeolites-Occurrence, properties, use: Elmsford, N.Y., Pergamon Press, p. 221-234.

Surdam, R.C., Boese, S.W., and Crossey, L.J., 1984, The chemistry of secondary porosity, in McDonald, D.A., and Surdam, R.C., eds., Clastic diagenesis: American Association of Petroleum Geologists Memoir 37, p. 127-149.

Sweeney, J.F., 1982, Arctic-Alaska, a two-stage displaced terrane [abs.]: 33rd Alaska Science Conference, Proceedings, Fairbanks, Alas., American Association for the Advancement of Science, p. 146.

Tailleur, I.L., 1973, Probable rift origin of Canada basin, Arctic Ocean, in Pitcher, M.G., ed., Arctic geology: American Association of Petroleum Geologists Memoir 19, p. 526-535.

Tailleur, I.L., Pessel, G.H., and Engwicht, S.E., 1978, Subcrop map at Lower Cretaceous unconformity, and maps of Jurassic and Lower Cretaceous seismic horizons eastern North Slope petroleum province, Alaska: U.S. Geological Survey Miscellaneous Field Studies Map MF928I, scale 1:500,000, 1 sheet.

Tailleur, I.L., and Weimer, Paul, eds., 1987, Alaskan North Slope geology: Bakersfield, Calif., Pacific Section of Society of Economic Paleontologists and Mineralogists and the Alaska Geological Society, v. 50 [in press].

Taner, M.T., Cook, E.E., and Neidell, N.S., 1970, Limitations of the reflection seismic method, lessons from computer simulation: Geophysics, v. 35, p. 551-573.

Taylor, J.M., 1950, Pore-space reduction in sandstones: American Association of Petroleum Geologists Bulletin, v. 34, p. 701-716.

Teal, P.R., 1983, The triangle zone at Cabin Creek, Alberta, in Bally, A.W., ed., Seismic expression of structural styles-a picture and work atlas: American Association of Petroleum Geologists Studies in Geology No. 15, v. 3, p. 3.4.148-3.4.1-53.

Timur, A., 1968, Velocity of compressional waves in porous media at permafrost temperatures: Geophysics, v. 33, no. 4, p. 584-595.

Tissot, B.P. and Welte, D.H., 1978, Petroleum formation and occurrence-a new approach to oil and gas exploration: Berlin, Springer-Verlag, $538 \mathrm{p}$.

1984, Petroleum formation and occurrence (2nd ed.): Berlin, Springer-Verlag, 699 p.

Torgerson, T., and Clarke, W.B., 1978, Excess helium-4 in Teggan Lake: Possibilities for a uranium ore body: Science, v. 199, p. 769-771.
Tourtelot, H.A., and Tailleur, I.L., 1971, The Shublik Formation and adjacent strata in northeastern Alaska: description, minor elements, depositional environments and diagenesis: U.S. Geological Survey Open-File Report 462, 62 p.

U.S. Department of the Interior, 1976, Alaska natural gas transportation system-Final environmental impact statement: Washington, D.C., U.S. Government Printing Office, $778 \mathrm{p}$.

- 1986, Draft report on the Arctic National Wildlife Refuge, Alaska, coastal plain resource assessment: Washington, D.C., U.S. Government Printing Office, $172 \mathrm{p}$.

U.S. Department of the Interior, Office of Minerals Policy and Research Analysis, 1979, Final report of the 105(b) economic and policy analysis: Washington, D.C., U.S. Government Printing Office, $145 \mathrm{p}$.

U.S. Fish and Wildlife Service, 1982, Initial report, baseline study of the fish, wildlife, and their habitats, Section 1002(c) of the Alaska National Interest Lands Conservation Act: Anchorage, Alas., U.S. Fish and Wildlife Service, Region 7, $507 \mathrm{p}$.

U.S. Fish and Wildlife Service, U.S. Geological Survey, and Bureau of Land Management, 1983, Proposed oil and gas exploration within the coastal plain of the Arctic National Wildlife Refuge, Alaska-Final environmental impact statement and preliminary final regulations: Washington, D.C., U.S. Government Printing Office, chapters paginated separately.

Vail, P.R., Mitchum, R.M., Jr., Todd, R.G., Widmier, J.M., Thompson, S., III, Sangree, J.B., Bubb, J.N., and Hatlelid, W.G., 1977, Seismic stratigraphy and global changes in sea level in seismic stratigraphy, in Payton, C.E., ed., American Association of Petroleum Geologists Memoir 26, p. 49-212.

Van de Kamp, P.C., 1979, Stratigraphy and diagenetic alteration of Ellesmerian sequence siliciclastic rocks, North Slope, Alaska, 56 p. [Available from National Oceanic and Atmospheric Administration, EDIS/NGSDC (D-62), 325 Broadway, Boulder, CO 80303].

Van Dyke, W.D., 1980, Proven and probable oil and gas reserves, North Slope, Alaska: Anchorage, Alas., Alaska Department of Natural Resources, Division of Minerals and Energy Management, $11 \mathrm{p}$.

Vann, I.R., Graham, R.H., and Hayward, A.B., 1986, The structure of mountain fronts: Journal of Structural Geology, v. 8, nos. 3/4, p. 215-227.

Van Poollen and Associates and Alaska Division of Oil and Gas, 1974, In place volumetric determination of reservoir fluids, Sadlerochit Formation, Prudhoe Bay Field: Anchorage, 
Alas., Alaska Department of Natural Resources, Division of Oil and Gas, 41 p.

Vine, A.C., and Tourtelot, B.E., 1970, Hydrothermal alteration of arkosic sandstones in the Spanish Peaks region, Colorado [abs.]: Geological Society of America Abstracts, v. 2, no. 5, p. 352-353.

Wahrhaftig, Clyde, 1965, Physiographic divisions of Alaska: U.S. Geological Survey Professional Paper 482, $52 \mathrm{p}$.

Walker, D.A., Acevedo, W., Everett, K.R., Gados, L., Brown, J., and Webber, P.J., 1982, LANDSAT assisted environmental mapping in the Arctic National Wildlife Refuge, Alaska: Hanover, N. Hampshire, U.S. Cold Regions Research and Engineering Laboratory [U.S. Corps of Engineers], CRREL Special Report 82-27, 59 p.

Walker, H.J., 1973, Morphology of the North Slope, in Britton, M.E., ed., Alaskan Arctic tundra: Arctic Institute of North America Technical Paper 25, p. 49-92.

Walker, T.R., 1960, Carbonate replacement of detrital crystalline silicate minerals as a source of authigenic silica in sedimentary rocks: Geological Society of America Bulletin, v. 71, p. $145-152$.

Waples, D.W., 1980, Time and temperature in petroleum formation: applications of Lopatin's method to petroleum exploration: American Association of Petroleum Geologists Bulletin, v. 64, no. 6, p. 916-926.

1981, Organic geochemistry for exploration geologists: Boston, Mass., International Human Resources Development Corporation, 151 p.

Waters, K.H., 1981, Reflection seismology: a tool for energy resource exploration (2nd ed.): New York, John Wiley and Sons, $453 \mathrm{p}$.

Welte, D.H., 1965, Relation between petroleum and source rock: American Association of Petroleum Geologists Bulletin, v. 49, no. 12, p. 2246-2268.

Werner, M.R., 1984, Tertiary and Upper Cretaceous heavy oil sands, Kuparuk River Unit area, Alaska North Slope, in Meyer, R.F., and others, conveners, Exploration for heavy crude oil and bitumen: American Association of Petroleum Geologists Research Conference, Oct. 28-Nov. 2, 1984, Abstracts and Preprints, v. 2, 31 unnumbered pages.

1985, West Sak and Ugnu sands: Low-gravity oil zones of the Kuparuk River area, North Slope,
Alaska [abs.]: American Association of Petroleum Geologists Bulletin, v. 69, no. 4, p. 682.

Wescott, W.A., and Ethridge, F.G., 1980, Fan delta sedimentology and tectonic setting, Yallah Fan Delta, southeast Jamaica: American Association of Petroleum Geologists Bulletin, v. 64, no. 3, p. 374-399.

White, L.P., 1981, A play approach to hydrocarbon resource assessment and evaluation, in Ramsey, J.B., ed., The economics of exploration for energy resources: Greenwich, Conn., JAI Press, p. $51-68$.

Williams, J.R., 1970, Ground water in the permafrost regions of Alaska: U.S. Geological Survey Professional Paper 696, 83 p.

Wilson, M.D., and Pittman, E.D., 1977, Authigenic clays in sandstones: recognition and influence of reservoir properties and paleoenvironmental analysis: Journal of Sedimentary Petrology, v. 47, p. 3-31.

Wiseman, W.J., Jr., Coleman, J.M., Gregory, A., Hsu, S.A., and others, 1973, Alaskan arctic coastal processes and morphology: Baton Rouge, La., Louisiana State University Coastal Studies Institute Technical Report 149, 171 p.

Wolf, S.C., Reimnitz, Erk, and Barnes, P.W., 1985, Pleistocene and Holocene seismic stratigraphy between the Canning River and Prudhoe Bay, Beaufort Sea, Alaska: U.S. Geological Survey Open-File Report 85-549, 50 p.

Wood, G.V., and Armstrong, A.K., 1975, Diagenesis and stratigraphy of the Lisburne Group limestones of the Sadlerochit Mountains and adjacent areas, northeastern Alaska: U.S. Geological Survey Professional Paper 857, 47 p.

Wood, J.R., and Hewett, T.A., 1984, Reservoir diagenesis and convective fluid flow, in McDonald, D.A., and Surdam, R.C., eds., Clastic diagenesis: American Association of Petroleum Geologists Memoir 37, p. 99-110.

Young, J.S., and Hauser, W.S., 1986, Economics of oil and gas production from the Arctic Refuge (ANWR): Anchorage, Alas., U.S. Bureau of Land Management, unpublished report. [Available from BLM Alaska State Office, 701 C Street, Anchorage, AK 99513].

Zhijun, Yu, 1983, New method of oil prediction: American Association of Petroleum Geologists Bulletin, v. 67, no. 11, p. 2053-2056. 


\section{INDEX}

[Page numbers of major references are in boldface]

\section{A}

Abnormal fluid pressures (geopressures)

$.86,89-91,117,129$,

$199,204,206,282$

Acoustic anomalies (horizons $\mathrm{A}$ and $\mathrm{B}$ ).

...74-77

Acoustic reflectors

$65-73,76$

Aichilik high

....251

Aichilik River $27,46,101-103,252,267$

Air quality

.....36

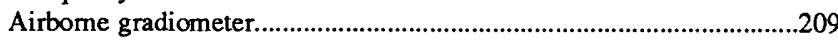

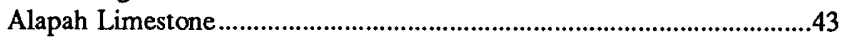

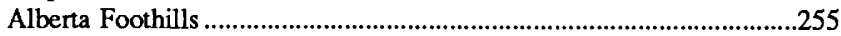

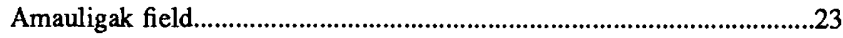

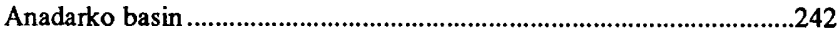

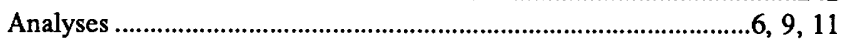

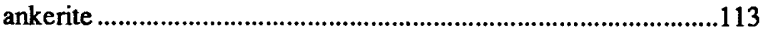

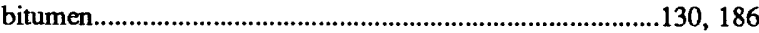

Canning Formation.......................................86, 141, 199-207, 215

carbon isotopes..........................................................................187

carbonate fluorapatite .................................................................11

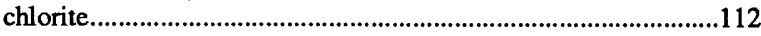

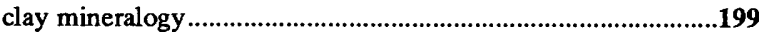

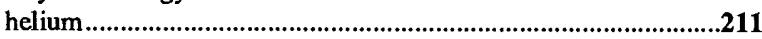

Hue Shale ..................................................................................136

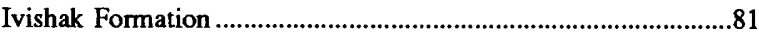

Jago River Formation .....................................................89, 123

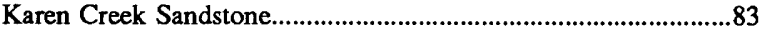

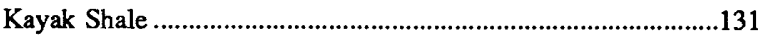

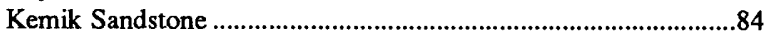

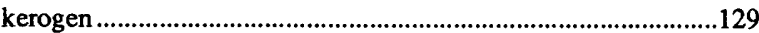

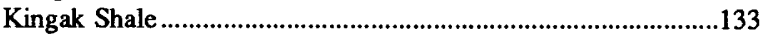

Ledge Sandstone Member, Ivishak Formation ...........................101

Lisbume Group....................................................................1, 132

methods ...............................................................................186

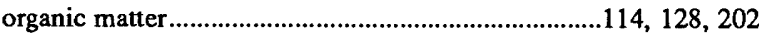

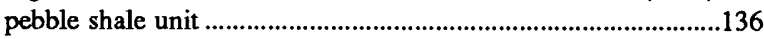

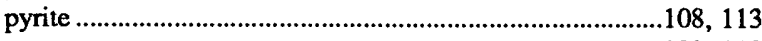

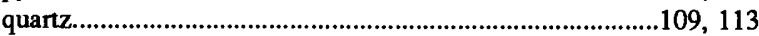

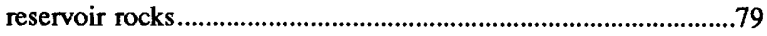

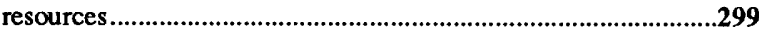

Sadlerochit Group ............................................................132

Sagavanirktok Formation..................................................89, 143

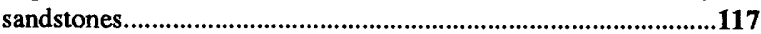

seismic data .................................................64, 74, 225, 235

Shublik Formation......................................................................132

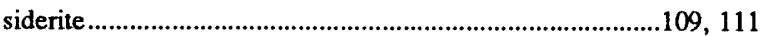

source rocks .....................................................127, 181, 277

sphalerite

.113

See also Ankerite, Apatite, Diagenesis, Gas-to-oil ratio, Hydrogen index, Illite, Lopatin diagram, Mass spectrometry, Multiple ion detection, Oil types, Oxygen index,

Petrology, Play-analysis technique, Pyrolysis, Rock

Eval analysis, Scanning electron microscope, Smectite,

Thermal maturity, Van Krevlen diagram, Vitrinite reflectance.

Angun Point

$27,181,192,198,284$

ANILCA (Alaska National Interest Lands Conservation Act)..........3, 235

Ankerite................................................102, 105-108, 111-115, 121

Apatite...

$102,105-108,111-115,121$

Appraisal data form.

$.295-298$

Arctic Alaska plate

$17,40,48$

Arctic Coastal Plain.

$27,61,76,249$
Arctic Creek facies.

47,55

Assessment, resource.

$.277,299$

\section{B}

Barrow

$22,30,36,181,212,214$

Barrow arch .............................................................20, 55, 219, 223

Barter Island, acoustic anomalies...................................................74-76

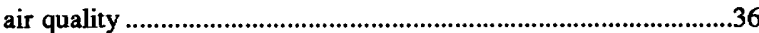

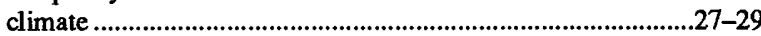

coastal plain ...................................................................61-67, 249

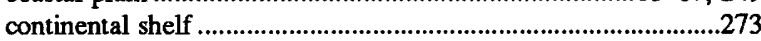

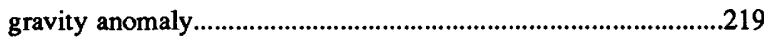

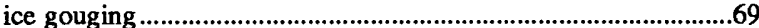

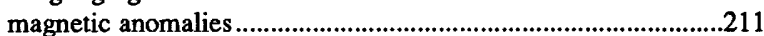

Barter subbasin ....................................................................253, 272

Basal sole thrust (BST) .............................255-258, 261, 264, 266-270

Bathtub Ridge....................................................................48, 181, 267

Beaufort continental shelf...................................................................271

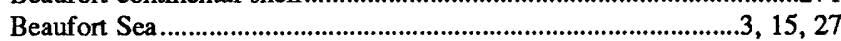

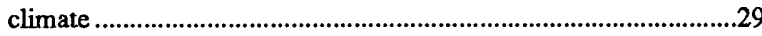

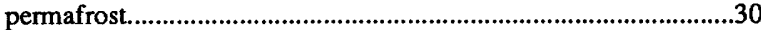

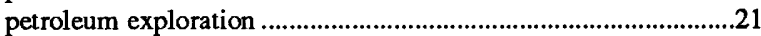

seismic data.........................................35, 59-61, 73-75, 270, 275

Biogenic gas (methane) ............................................................., 279

See also Hydrocarbons.

Biomarker ratios .

Bitumen. See Extractable organic matter.

Bouguer anomalies. See Gravity surveys.

British Mountains

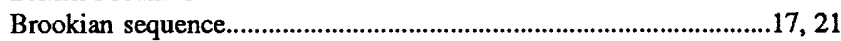

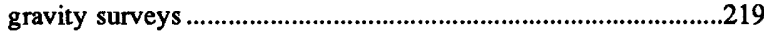

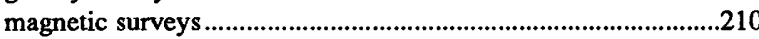

petrology ................................................................................117

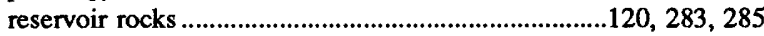

seismic data..............................................................241, 249

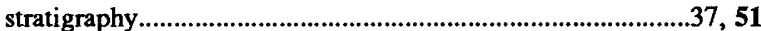

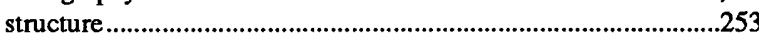

See also Arctic Creek facies, Canning Formation, Hue Shale, Jago

River Formation, Sagavanirktok Formation.

Brooks Range.

$17,37,245,255$

acoustic anomalies

$74-76$

Brookian sequence ....................................................................51

geochemistry ............................................................131-136, 181

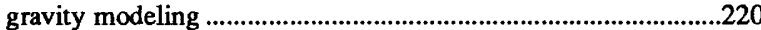

petroleum assessment .................................150-152, 279-287, 292

petrology ...............................................................123-126, 205

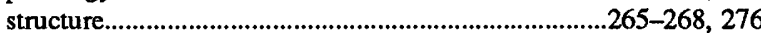

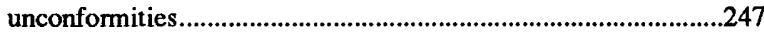

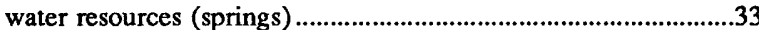

\section{C}

Camden anticline

$66,253,271-276$

Camden Bay

$.27,77$

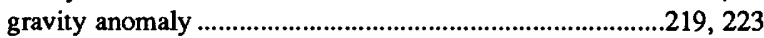

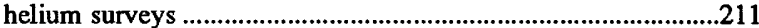

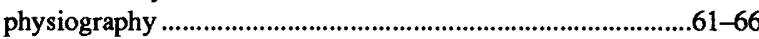

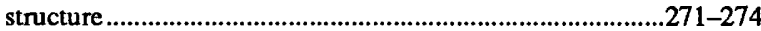

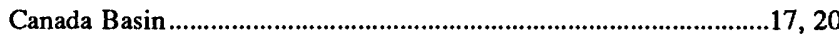

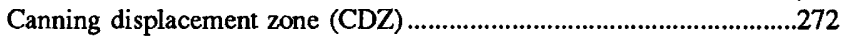


Canning Formation

$.51-53,55,184-186$

density data.

$131,141-143,188-198$

geochemistry

.1.............205-207

mineralogy.

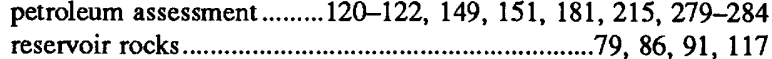

seismic data.................................................................243, 250

slope and shelf facies ...................................................57, 254

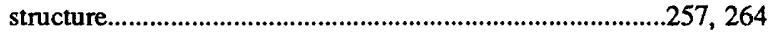

turbidite sandstone facies............................................57, 120

Canning River...............................................................27, 61, 79, 271

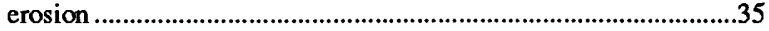

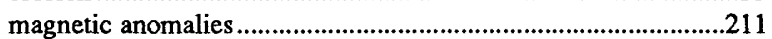

petroleum assessment ........................................181-183, 188, 283

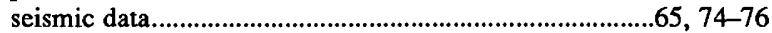

water resources..

Cape Simpson

181,193

Carbon isotopes

$81,186,192,195$

Carbonate fluorapatite

$105,109-111,115$

Catagenesis

$148,186-189,196$

Challenge Island

. .118

Chill factor. See Winds.

Chlorite.

Chukchi Sea

$. .32,81,86,105,112,121-124,204$

Clay mineralogy

198,205

Column chromatography ..................................................................186

Colville Basin........................................................................ 55, 213

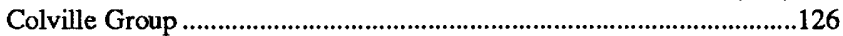

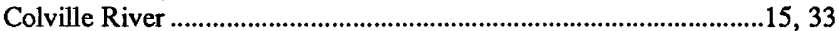

Common-depth-point (CDP) method .......................12, 226-232, 235-237

Compaction............10, 86, 89-91, 105-108, 117, 122, 126, 220-223, 251 See also Sedimentary rocks.

Cordilleran fold belt. .255

COST (Continental Offshore Stratigraphic Test) wells.. ...14

Crude oil. See Petroleum.

\section{D}

Deasphalting. . .189

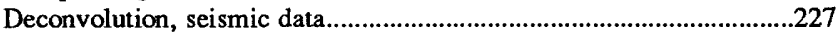

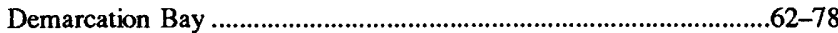

Demarcation Point .......................................................................... 58

Demarcation subbasin ..........................................................................272

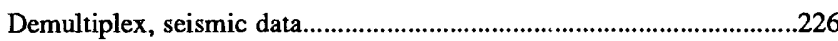

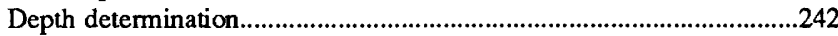

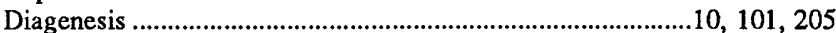

Canning Formation.................................................................121

Ledge Sandstone Member, Ivishak Formation ....................105-115

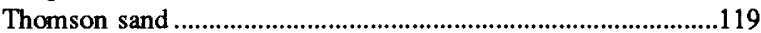

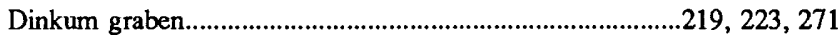

Duplex structure, thrust fault.

253,261

\section{$\mathbf{E}$}

Eagle River

.201

Earthquakes .....35

Echooka Formation

$.43,285$

Echooka River.

....48

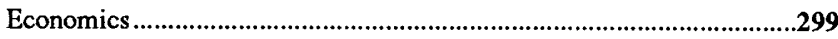

Electron Dispersion System (EDS).

102,111

Elemental analysis

.128

Ellesmere Island.

. .20

Ellesmerian sequence

$17,21,37,40,101$

gravity anomaly

.219

helium surveys

213

reservoir rocks

$79,117-122,149,283,287$

seismic data.

239-241, 249

structure.
See also Endicott Group, Karen Creek Sandstone, Kemik Sandstone, Kingak Shale, Lisbume Group, Pebble shale unit, Sadlerochit Group, Shublik Formation.

Endicott Group. $40,239,258,260$ See also Itkilyariak Formation, Kayak Shale, Kekiktuk Conglomerate.

Erosion.................... 7-10, 35, 40, 70, 91, 210, 247, 249, 253, 258, 287 See also Climate, Soils.

Extractable organic matter (EOM). $.81-83,186$

\section{$\mathbf{F}$}

Fan deltas .76

Fast Appraisal System for Petroleum (FASP) ….........................278, 290

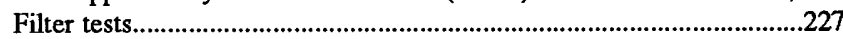

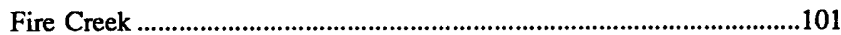

Fire Creek Siltstone Member, Ivishak Formation.......................43-45, 105

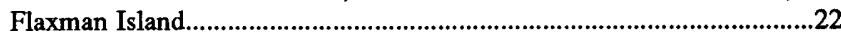

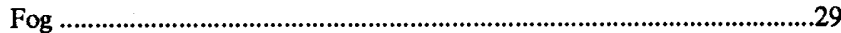

Fold and thrust belt.

$.20,25,238,243,270$

Fractures..................................................10, 80, 109, 115, 118, 236, 283 See also Permeability, Traps.

Franklin Mountains. .......3

Freezeup .29-34

\section{G}

Gain correction

226

Gamma-ray zone (GRZ)

Gas. See Hydrocarbons.

Gas chromatography..

Gas-to-oil ratio (GOR).

Geochemistry. See Analyses.

Geopressures.

$.189,192$

Geothermal gradient. .198, 204-206

Glaciers.

$113,126,146$

Gravel See also Erosion, Soils.

Gravity surveys .

$3,27,32$

Growth faults (listric)

$11,13,219-224$

$\ldots 3,30,32,35,61,72,76,126$ .272

\section{H}

Helium surveys

$.14,209-215$

Herschel arch 274-276

Highly radioactive zone (HRZ)

Horner cross plots 146,200

Hue Shale ....

$.51,53$

geochemistry.

-198

helium surveys

. .213

mineralogy.

petroleum assessment

. .204

reservoir rocks

..279-283, 287

seismic data

structure . .243

thermal maturity

Hulahula low..

Hulahula River

$147-152$

Hydrocarbons. accumulation ...251

discoveries.

geochemistry

helium surveys $249,254,257,261,264$

magnetic surveys

migration.

5, 267

petroleum assessmen

...7-10

..143-145

..21-25

See also Kerogen, Organic matter, Permeability, Petroleum, Hydrogen index (HI) 
Ice breaks

Ice gouging .236

Ice thickness

Ice wedges

Igilatvik Creek (Sabbath Creek)

Ignek Valley.

Illite.

Inoceramus (bivalve)

Itkilyariak Formation

Ivishak Formation

petroleum assessment.

reservoir rocks

$.69,74$

...29

.30-32

$.58,122,126$

$.47,53,129,133,183,187-189,261$

$.105,108,111,113,121,198,204$

$. .53,259,261$

$.42,43$

....43

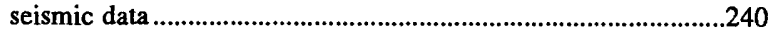

See also Fire Creek Siltstone Member, Kavik Member, Ledge Sandstone Member.

Jago River ................27, 57-59, 131, 133, 137, 183, 188, 192, 198, 239

Jago River Formation..........................................................48, 51,58

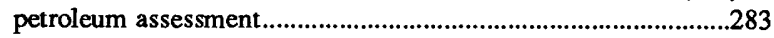

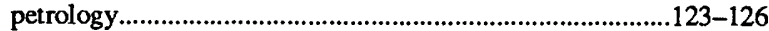

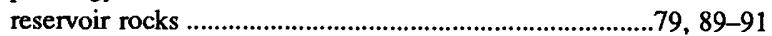

structure.

$.267,269$

\section{$\mathbf{K}$}

Kaktovik basin

. .271

Kaktovik Inupiat Corporation (KIC).

$3,22,235$

Kaolinite $.81,105,107,111,113,119-121,204$

Karen Creek Sandstone

.. .46

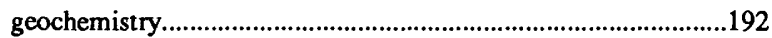

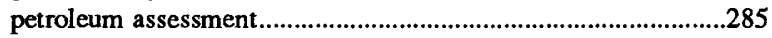

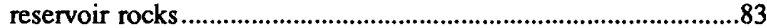

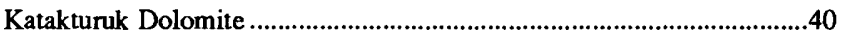

petroleum assessment.........................................................283-287

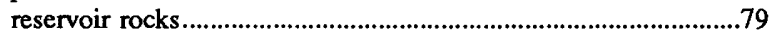

Katakturuk River ............................27, 35, 183, 192, 198, 215, 258, 270

Kavik.......................................................131-136, 141, 192, 196

Kavik gas field ......................................................................83, 183

Kavik Member, Ivishak Formation ........................................................43

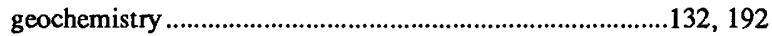

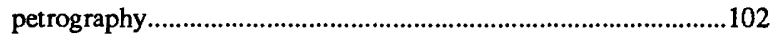

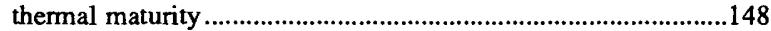

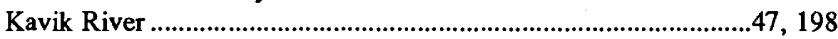

Kayak Shale …......................................................................40-42

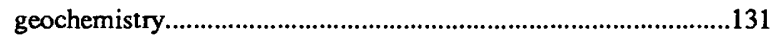

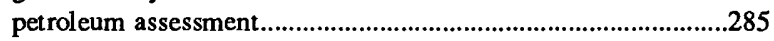

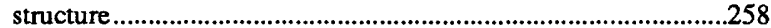

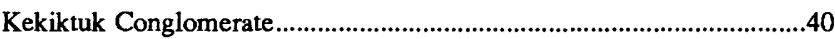

petroleum assessment...................................................................285

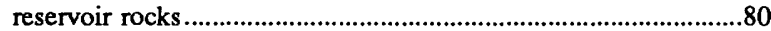

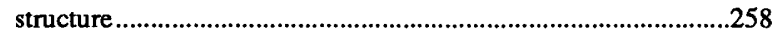

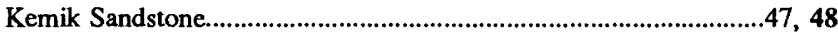

petroleum assessment........................................................281-283

reservoir rocks ........................................................79, 84-86, 91

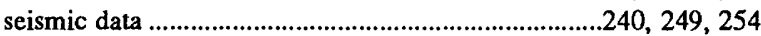

stratigraphy .......................................................55, 120, 258-261

Kerogen ..............................111, 127-129, 131-137, 143, 186-189, 203 petroleum assessment .....................................................295, 300

See also Hydrocarbons, Organic matter, Petroleum, Thermal maturity.

Kingak Shale.. geochemistry

$131,133-136$

petroleum assessment

282,287

seismic data.

240,266

structure.

$253,257-261$

thermal maturity

$150,183,187-196$

Kongakut Formation ....48

Kongakut River

....62

Kuparuk River oil field

$.22,306$
Lake Peters

$.42,246$

Ledge Sandstone Member, Ivishak Formation .........................................44

geochemistry.............................................................................192

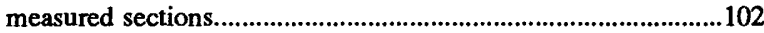

petroleum assessment........................................................285-287

petrography and diagenesis.........................................................101

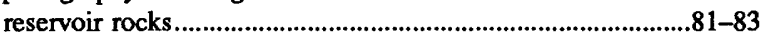

Lisbume Group........................................................................................43

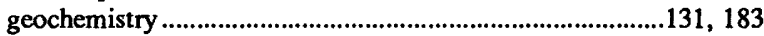

petroleum assessment....................................................................287

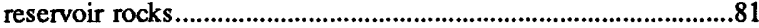

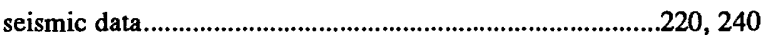

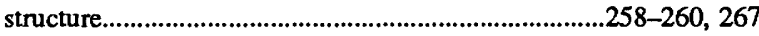

See also Alapah Limestone, Wahoo Limestone.

Lisburne oil field.

Lopatin diagram. .....81

Lower Cretaceous unconformity (LCU).....................40, 43, 45, 47, 79, 81, $83,91,102,111,115,120,131,150,184,188,206$, $213,240,245,249,258-261,266,269,282,287$

\section{$\mathbf{M}$}

Mackenzie Bay

Mackenzie Delta.

Magnetic surveys

Magnetite

Manning Point

Marsh Creek.

Marsh Creek anticline

$7,47,58,126,181$

..12-14, 209

204, 209

$27,181,192,198,284$

$27,32,35,47,101,111,115,210$

$. .57,59,67,131,149,151,183,188$, $210,215-219,223,238-241,243,249$, $253,270,276,279,282,285,292,294$

Mass spectrometry . .187

Milne Point field..

Minimum economic field size (MEFS)

$299,303-305$

Monte Carlo simulation.

$.278,304$

Moose Channel Formation.............................................................58, 126

Mount Chamberlin. 187

Multiple ion detection (MID)

\section{$\mathbf{N}$}

Nanook Limestone.

National Petroleum Reserve in Alaska (NPRA)..................22, 30, 43, 53 , $101,114,181,188,192,193,198,278$

Natural gas

$7,131,145$

discoveries.

.. .22

helium surveys

resource assessment.

$296,299,303$

See also Hydrocarbons, Organic matter, Petroleum, Thermal maturity.

Naval Arctic Research Laboratory (NARL) ...........................................36

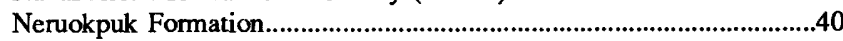

Niguanak.

$.150,184$

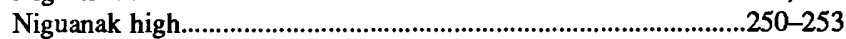

Niguanak Ridge...................131-137, 150, 189, 241, 258, 261, 266, 270

Niguanak River......................................27, 47, 51, 53, 57, 184, 187

Noise .

Normal moveout (NMO) ..............................................226-232, 236

North Slope.................................................................8, 17, 107, 123

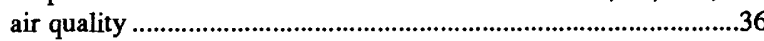

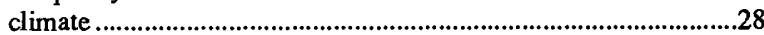

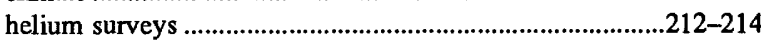

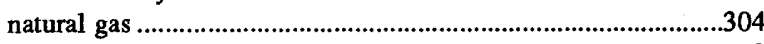

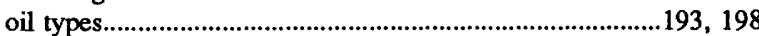

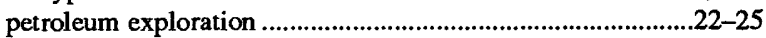

reservoir rocks .........................................79, 111, 120, 181, 184

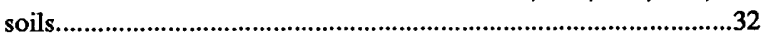

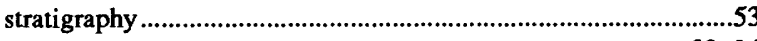

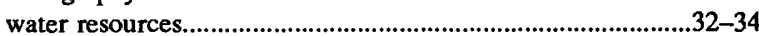


Pyrite

Pyrolysis
Prudhoe Bay field

$\ldots .10,22,44,48,51,83,105-107,114,133,291$

$.81,105-109,113,204$

\section{O}

Oil. See Hydrocarbons, Petroleum.

Oil seeps. $7,27,30,181,189,192,284,287$

Oil types. $181,189,192-198$

Okerokovik River $.51,55$

Okpilak River $.32,61$

Organic matter acoustic anomalies.. analyses. diagenesis. permafrost. reservoir rocks $128,147,152,188,201-207$ $107,113-115$ ....30-32 .....120, 126 See also Hydrocarbons, Permeability, Petroleum, Porosity, Thermal

Oxygen index (OI) maturity. .129

\section{$\mathbf{P}$}

Paragastroplites spiekeri (McLeam) (ammonite) .55

Pebble shale unit. $.43,48,102,118$ geochemistry $131,136,181,184$ gravity modeling .220 helium surveys . .213 petroleum assessment 279-287 seismic data. $239,249-254$ structure. 257-261, 264

thermal maturity $147-152,187-198$ Permafrost .................3, 5, 27, 30, 61, 200, 211, 220, 226, 231, 235, 279 Permeability...............10, 79-91, 107-115, 117-122, 123-126, 213-218, See also Fractures, Porosity, Traps.

$279,296,298,301$ Petroleum analytical methods .... $.3,7$ biodegradation $128-131,186$ economics.. $184,189-193$ exploration geochemistry ..................................................................128, 181 helium surveys .211 magnetic surveys migration 10,148

reservoir rocks $\ldots 9,37,40,43,47,59,79,101,111$, $117,122,126$

resource assessment . .277 seismic surveys. $.225,235,271-276$

See also Hydrocarbons, Kerogen, Oil seeps, Oil types, Organic matter, Permeability, Porosity, Resources, Sedimentary rocks, Thermal maturity, Traps, and individual formations by name.

Petrology. $102,117,287,290,294$

Physiography, offshore

Pingok Island

Play-analysis technique

$277,287,290-294$

Point Thomson........................22, 37, 40, 43, 45, 48, 53, 57, 79, 85-89, $117-122,128-131,136,141-143,146,149-152,181$, $188-192,196-198,201-206,239,245,279,283,292$

Point Thomson field.

d..................................................86, 149, 283

Porosity .....................................10, 37, 43, 57, 79-91, 101-112, 115,

$117-122,126,248,279,282,287-291,296-298,301$

See also Fractures, Permeability.

Precipitation

$.28,35$

Pre-Mississippian basement complex (TPM)................37, 201, 219-223, $241-243,246,249-254,268,283$

Probabilistic Resource Estimates-Offshore (PRESTO) ...............299-306

Probability theory 299-306

Prospect. $242,287-290,295-306$

Prudhoe Bay ...15, 17-25, 30, 35, 40-53, 59, 61, 74, 76, 81-84, 90, 101, $136,150,181,188,192,198,220,239,260,279,287,304$

\section{$\mathbf{Q}, \mathbf{R}$}

Quartz $.32,42,47,51-53,81-83,85-90,102$, $105-115,118-123,126,184,204,282$

Reservoir rocks See also individual formations by name.

Resources. See Petroleum.

Rifting

$20,25,249,271$

Rock Eval analysis . $128-137,143,186-189,201$

Romanzof Mountains $.3,241$

\section{S}

Sabbath Creek (Igilatvik Creek).

$58,122,123,126$

Sabbath high

Sadlerochit Group. $.251-253$ geochemistry.............................................................................131

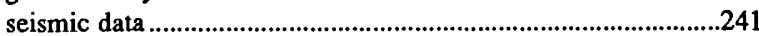
structure. $.258-260,267$ See also Echooka Formation, Ivishak Formation

Sadlerochit Mountains $3,5,37,40-62,79-85,90,102$, 181-184, 188, 198, 213, 215, 238-241, $245,250-252,255-262,265-270,283$

Sadlerochit Spring $.27,30,33$

Sag River Sandstone $. .47,83,240$

Sagavanirktok Formation $.51,55-57,59$ geochemistry $131,143,192$ petroleum assessment $.279,283$ $79,89-91,126$ seismic data 250 See also Staines Tongue.

Sandstone, composition ......................................79-91, 101-115, 117-122 Scanning electron microscope (SEM) ...............................102, 119, 209

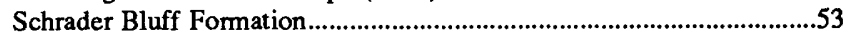

Scour saturation zone (SSZ)................................................................71

Seabee Formation ………........................................................................53

Seafloor gradient ...............................................................................62

Sedimentary rocks ...................................3, 8, 13, 22, 37, 40, 118, 131, $187,189,219,223,267,271$

Seismic surveys $11,15,61,225-243$

Seismicity. . .35

Shaviovik River

Shublik Formation $.43,45$ geochemistry 88,195 reservoir rocks ............................................................84, 111, 115

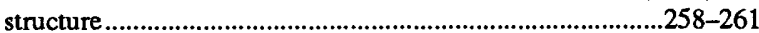
thermal maturity ...................................................................150

Shublik Mountains........... 4, 40, 44, 53, 79, 181, 184, 219, 246, 255-258, $266-268,270$

Side-scan sonar . .61

Siderite $.81-83,102-115,204$

Simbirskites (ammonite)

Smectite.

Snowfall

Soils .....

Sphalerite

Staines River.

Staines Tongue, Sagavanirktok Formation 108,111

Structural-stratigraphic domains (SSD's).

Subsidence reservoir rocks

Sedimentary basin ............................................................. 13, 205 petroleum assessment .................................................282, 285-287 See also Sedimentary basin. 


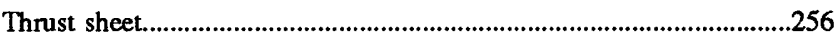

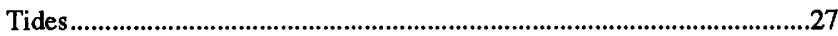

Tamayariak River.........................................................................27

Tapkaurak high ................................................................................251

Temperatures, subsurface...............108, 113, 118, 129, 145-147, 200-206

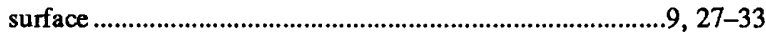

Terranes, tectonostratigraphic...........................................17, 37, 40, 121

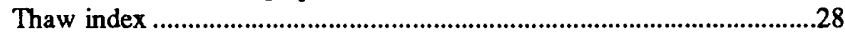

Thermal alteration index (TAD) ...............................................128-137

Thermal maturity ........9, 12, 127, 186-188, 195-198, 203-207, 295, 297

Thomson sand ....................................................................................51 geochemistry ..................................................189-192, 196

petroleum assessment..........................................................281-283

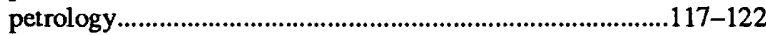

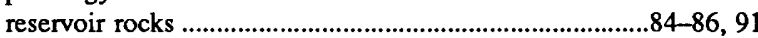

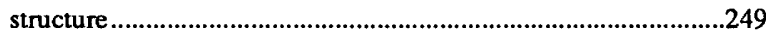

thermal maturity .................................................................................149

See also Kemik Sandstone.

Thrust faults

$48,59,240,246,269,274$

Itkilyariak ....................................................257, 261, 266, 269

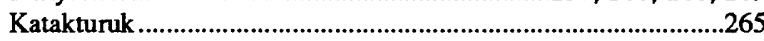

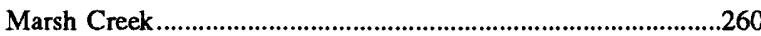

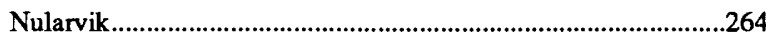

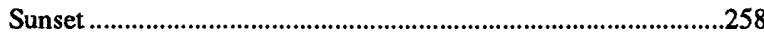

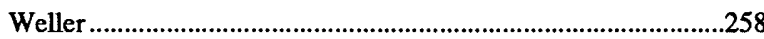

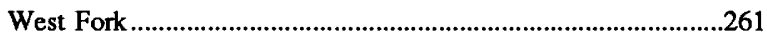

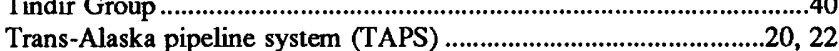

Traps ......................................10, 59, 151, 212, 235, 248, 277-298, 300

Triangle zone ............................................238, 246-248, 253, 265, 267

Tuktoyaktuk Peninsula ........................................................................22

\section{$\mathbf{U}, \mathbf{V}, \mathbf{W}$}

Umiat.. $. .27-30,55,181,193$

Unconformities ...................................37, 40, 48, 77, 255, 266, 268, 270

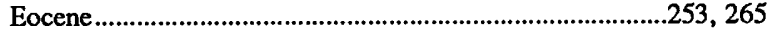

pre-Mississippian ....................................................246-248, 253

See also Lower Cretaceous unconformity.

Van Krevlen diagram ...........................................................................129

Velocity analysis ....................................................................227, 250

Vibrator (Vibroseis) .......................................12, 225-227, 233, 235-237

Vitrinite reflectance ........55, 120, 127-129, 131-133, 186, 206, 215, 295

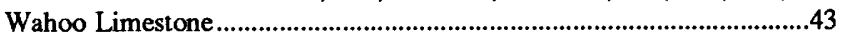

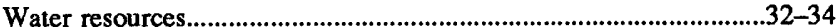

Well logs...........................................12, 15, 51, 79, 81, 154-178, 214

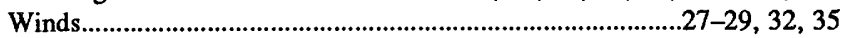





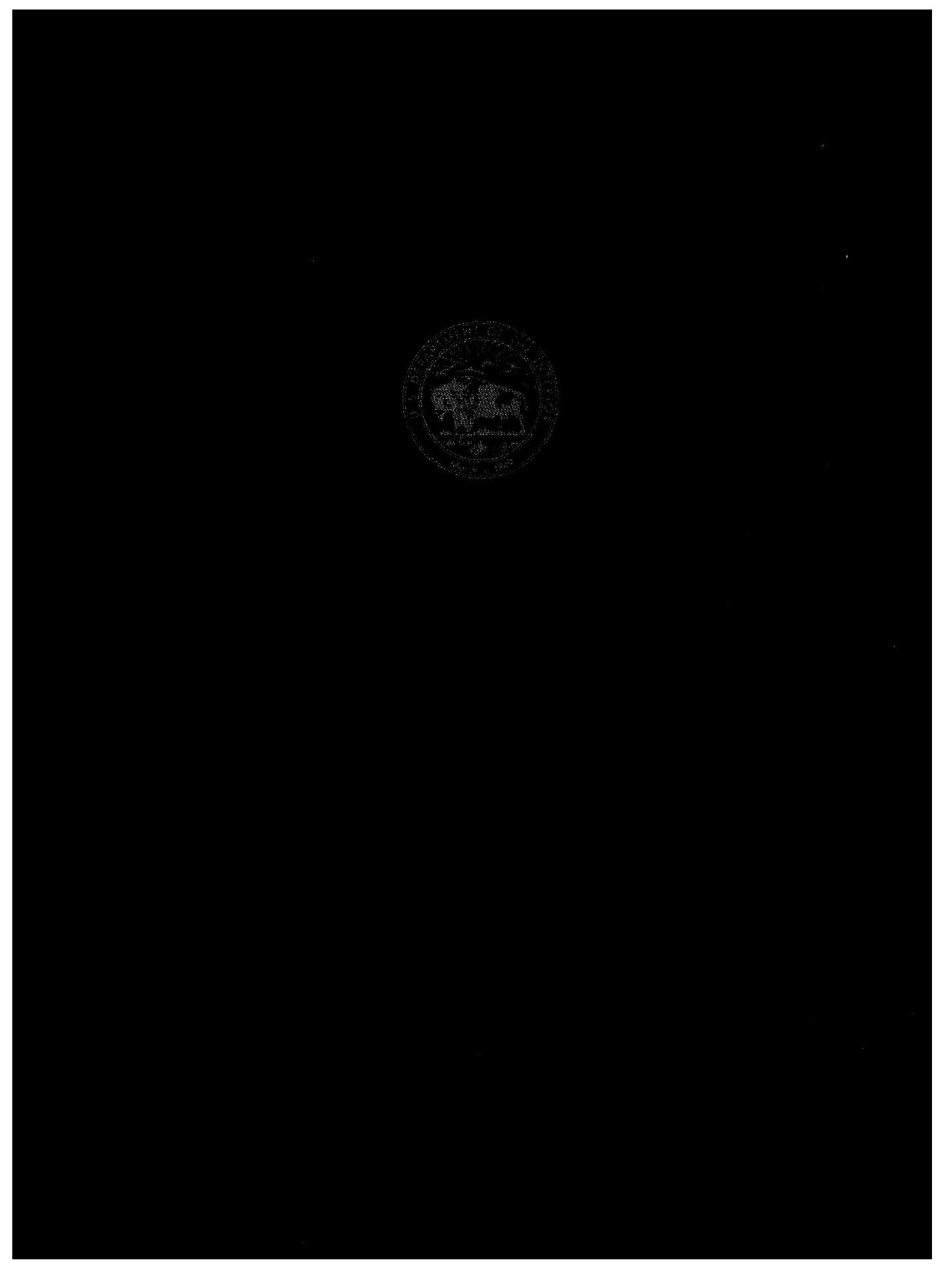

